





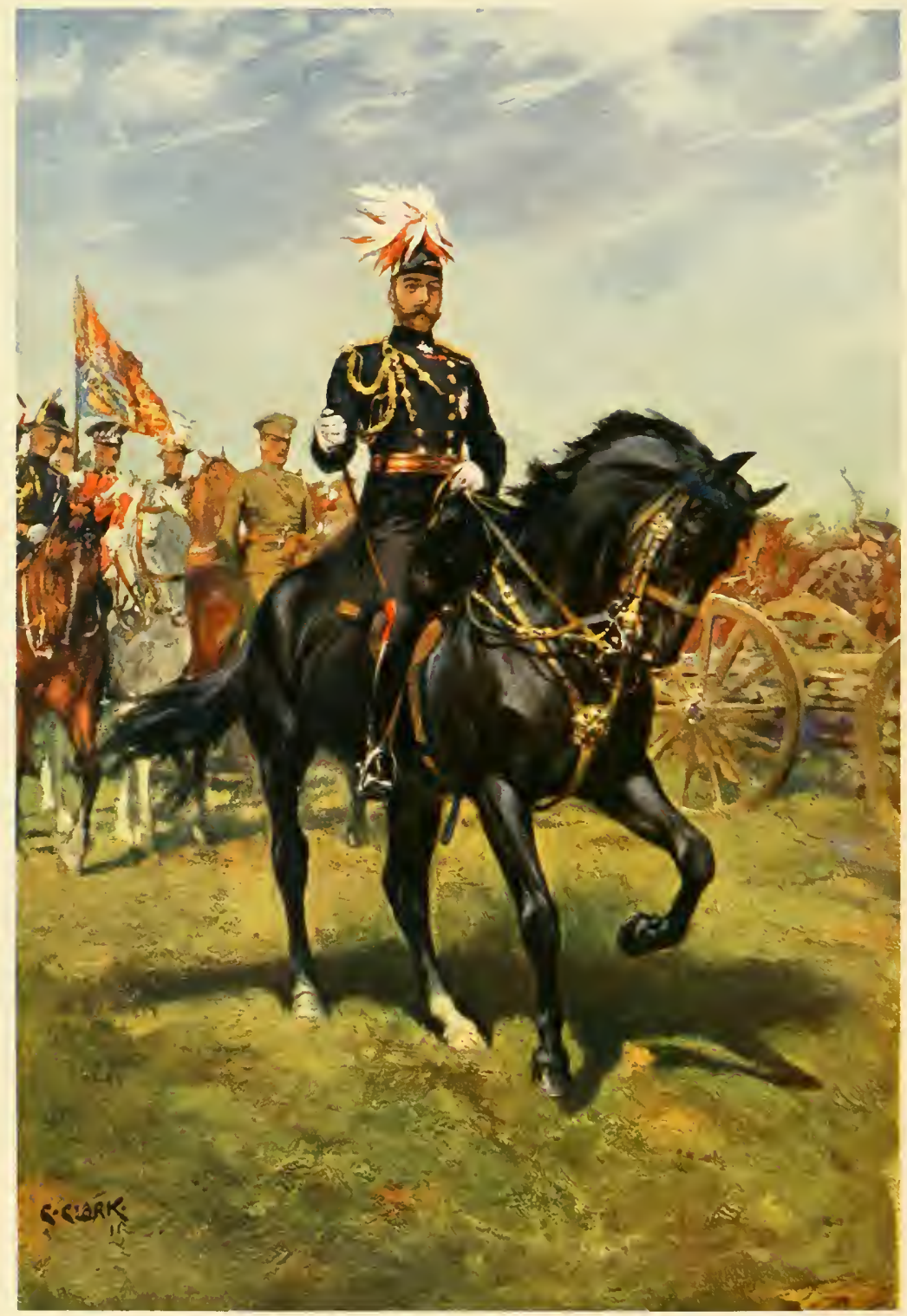

I1.M. KING GEORGE V. ON HIS CHARGER, RUPERT, From a puintise by Chutwephes Clask, R.I. 


\section{THE NEW}

\section{BOOK OF THE HORSE}

\section{BY \\ CHARLES RICHARDSON}

Hunting Editor of "The Field"

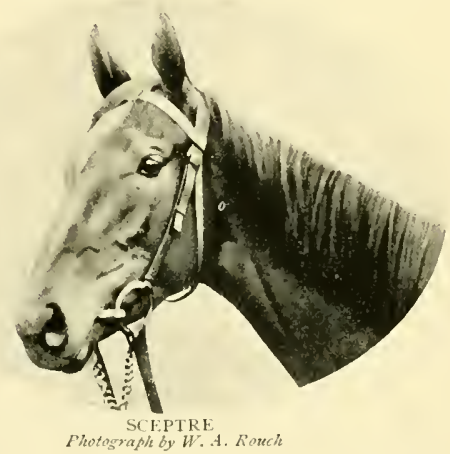

WITH TWENTY -NINE COLOURED PLATES AND NUMEROUS PHOTOGRAPHIC

ILLUSTRATIONS OF CELEBRATED HORSES

AND

AN EXTENSIVE VETERINARY SECTION

CASSELL AND COMPANY, LIMITED

LONDON, NEW YORK, TORONTO AND MELBOURNE 
ALL RIG RTS RESERved 


\section{INTRODUCTION}

$\mathrm{A}^{\mathrm{W}}$

L history teaches us that certain nations have been famous for their horses, and this most certainly applies to the British nation. Just as civilisation came from the East, so, too, did the best horses, or rather the best horse blood, but it is quite certain that in this country the horses bred from Eastern blood have been so greatly improved that an entirely different animal has been created.

The Arab, it may not be generally known, has stood still in his own country throughout the long period of time during which anything definite has been known about him. He has undoubtedly the same elegant outline, the same beautiful appearance, and the same wonderful stamina for which he has always been noted. But in his native state he is no bigger or heavier than he was when he was first introduced into this country something like 300 years ago, and this is probably due to the fact that he is bred in countries which do not possess such land as is to be found in many parts of the United Kingdon.

It may be urged that the Arab in his own country does not require the luxuriant grasses upon which English horses are reared, and to some extent that is true; but it may be pointed out that when Arabs, Barbs, and other Eastern sires were brought to this country with a view to improving our native breed, the size quickly increased, even in horses whose blood was almost entirely Eastern. The fact is that England, Ireland, and even parts of Scotland, are eminently suitable for horse-breeding, as are the blue grass plains of Kentucky, the Percheron district of France, certain parts also of the Northern Coast of France, and many districts of Australia and New Zealand.

If we go back to the earliest accounts of the English liorse we learn that the first horses of which there is any evidence in this country were exceedingly small-were ponies, in fact. Fossil remains in Essex yielded bones of a somewhat heavily built horse, which probably measured I 4 hands, but one gathers from the writings of Professor Ridgeway that a height of from $12 \frac{1}{2}$ to 13 hands was about the average.

One can easily understand that the development of the horse in this country was as gradual as the development of the land from an agricultural point of view. When husbandry had advanced far enough to allow of rich grass being grown, the horse quickly advanced in size and stature, and thus all through the Middle Ages we had the very heavy and almost colossal war-horse. It is true that this particular animal had a foundation of Noman blood, but it must be remembered that the Gauls were in advance of us in many things a thousand years ago, cliefly owing to our insular position.

What is certain is that if the country had not been eminently suitable for horse-breeding these war-horses could not have been the wonderful weight carriers which history teaches us they were. Granted a foundation of foreign blood, the fact remains that the war-horse 
gradually increased in size throughout the period of his existence, and that his descendants, the Shire horse, the Clydesdale, and probably to a great extent the Suffolk Punch, have also shown a tendency to become larger and heavier animals.

For hundreds of years two circumstances have been established in connection with the rarious breeds of British horses. One of these is that the semi-wild native breeds, such as those of the New Forest, Exmoor, and the Highlands, have, in spite of certain attempts to improve them by introducing fresh sire blood, made little progress, and are apparently not much larger than they were 500 years ago. The other circumstance is that when any breed of horses has been fostered and encouraged, the size and stature have increased.

It must not be forgotten that horses and ponies are not quite on the same plane, but would appear to be varieties of an original breed, for true ponies do not, for example, show much tendency to become larger even when most generously treated, and the Shetland of the show yard may be quoted as an example. On the other hand, the Arab horse probably does not at this day average more than $\mathrm{I}_{4}$ hands 2 inches in height, and yet in little more than 200 years he has in this country developed into a horse of I 6 hands and upwards, with only a very small admixture of purely English blood in his veins.

The fact is that certain land in the British Isles is endowed with bone promoting powers, and mention may be made of the various limestone districts, such as that which stretches right through the East Riding of Yorkshire, and that of the South of Ireland, about which so much lately has been heard in connection with recent Irish bred race winners, sired by imported English horses. The East Riding is not only a great district for raising thoroughbred stock, but it is almost the home of the hackney, and as great a hunter-raising district as any in the kingdom.

But horse-breeding districts are veiy variously distributed, as is proved by the fact that great horses have been bred in so many parts of the kingdom. The mighty Stockwell was bred in the inner suburbs of London; scores of good horses were bred in the Royal paddocks at Hampton Court between the days of Queen Anne and those of Queen Victoria, and, as two of the very last, before the stud was discontinued, La Flèche and her sister Memoir may be mentioned.

The late Sir Joseph Hawley, and the late Lord Falmouth, bred scores of good horses in Lient; St. Simon was foaled at Newmarket; Bend Or, Ormonde, Orme, Flying Fox, and Sceptre were reared in Cheshire; Barcaldine, Ard Patrick, and Galtee More in Ireland; Voltigeur, and the Derby winners owned by the late $\mathrm{Mr}$. John Bowes, in the county of Durham; and in fact one could extend the list to all the counties on the eastern side of the country.

In the following pages the horse is treated of from almost every point of view, but chief attention is paid to his position as far as the United Kingdom is concerned, and to the various uses to which he is put in this country at the present day. Thus racing, hunting, polo, driving, agricultural and heary work, are all taken into consideration, and the book includes a series of chapters on veterinary matters by one of the chief authorities of the day. The various English breeds are considered in detail, and in every case the articles are written by authorities or experts of the particular breed in question.

CHARLES RICHARDSON. 


\section{CONTENTS}

CHAPTER

PAGE

INTRODLCTION . . . . . . . . . . . . . iii

I. ENGI.ISH VARIETIES OF THE HORSE. BY ChaRles RichardsoN . . I

2. PRESENT POSITION OF THE HORSE IN THE LNITED KINGDOM. By Charles

RICHARDSON . . . . . . . . . . 9

3. THE THOROUGHBRED HORSE AND HIS ORIGIN. BY ChaRles RichardsoN 29

4. THE LINE OF EClipse. By Charles Richardsoy . . . . . 4

5. THE LINE OF ECLIPSE (continued! BY Charles Richarnson * . 6I

6. THE liNe OF HEROD. By Charles Richardson . . . . . . 73

7. THE l.INE OF MATCHEM. By Charles Richardson . . . 79

\&. THE FEMAle liNes. By Charles Richardson . . . . . . . . 84

9. THE Flidale liNes (continued). Br Charles Richardson . . . . 93

Io. THE TURF. By Charles Richardsox . . . . . . . . . g o

iI. NEWMARKET AND THE COLNTRY IEETINGS. BY Charles Richardon. I25

I2. FAilous HORSES. BY Charles Richardsox . . . . . . . I43

I3. FAMOLS HORSES (continud). By Charles Richardson . . . . 157

I4. STEEPlechasing. By Charles Richardson . . . . . . . ibg

I5. HUNTING AND HUNTERS. BY Charies Richardson . . . . . I 82

i6. HUNTING AND HUNTERS (continued). BY Charles Richardson * . . IS9

17. FON-HLNTiNG. By Charles Richardson . . . . . . . 209

is. HUNTERS AND THEIR BREEDiNG. By Charles Richardson . . . 219

I9. THE HACKNEY. By Vero Shaw . . . . . . . . . . 233

20. THE HACKNEY (continued). BY VERO SHAW . . . . . . 253

2I. THE HACKNEY PONY. BY V'ERO SHAW . . . . 25S 
CHAPTER PAGE

22. THE: CLEVELAND BAY. By IV. Scarth DixoN . 265

23. THE YORKSHIRE COACH HORSE. BY W. SCARTH DIXON 285

24. POlO AND polo ponies. By Charles Richardson . . . . . 293

25. PONIES: SHETLAND, HIGHL.IND, AND NEW FOREST, BY W. SCARTI DIXON 308 26. PONIES: WELSH, DARTHOOR, AND EXIIOOR. BY VERO SHAW. . . 3Ij 2\%. THE SHIRE HORSE. BY Charles Macdonald . . . . . . 326 28. The Clydesdale horse. By Charles Macdonald . . . . . 346 20. THE Clydesdale hORSE (continued). Br Charles Macdonald . . . 349 30. THE SUFFOLK HORSE. BY Charles MACDONald . . . . . . 355 3I. MANAgEMENT OF HEATY HORSES. By Charles Macdonald * * . 362 52. COACHiNg. By Charles Richardson . . . . . . . . . 37i

33. COACHING (contizued). BY Charles Richardson . . . . . 38I

34. DRIVING AND CARRIAGES. BY Charles Richardsox . . . 386

35. RIDING AND HORSE SHOWS. By ChaRles RichaRdSOX . . . . $39^{8}$

36. RIDING AND HORSE SHOWS (continued). By Charles Richardson • . 413

37. HORSE-BREEDING AND BREEDS ON THE CONTINENT. BY A. II. COATEN 420 38. HORSE-BREEDING AND BREEDS ON THE CONTINENT (continued). BYA. II. COATEN .

39. AMERICAN HURSES. By Charles Richardson . . . . . . $44^{8}$ 40. THE LAII AS REGARDS HORSES AND THEIR LSES. BY W. B. Woodgate 460

VETERINARY SECTION. By HAROLD LEENEY, M.R.C.V.S.

I. DISEASES OF THE BREATHING ORGANS . . . . . . . 473

2. DISEASES OF THE BREATHING ORGANS (continted) . . . . . 47;

3. DISEASES OF THE DIGESTIVE STSTEM * . . . . . . . 488

4. DISEASES OF THE URINARY AND GENITAL APPARATUS • . 509

5. DISEASES OF THE NERVOLS SISTENI . . . . . . . 5I5

6. DISEASES OF THE HEART AND BLOOD-VESSELS . . . * . 523

7. CONSTITLTIONAL DISEASES . . . . . . . . . . . 527 
CHAPTER

PAGE

8. CONTAGIOUS DISEASES . . . . . . . . . . . . . 53 r

9. DISEASES OF THE REPRODUCTIVE ORGANS . . . . . . . 538

IO. DISEASES OF THE EYE. . . . . . . . . . . . . . 544

II. DISEASES OF THE SKIN . . . . . . . . . . . . . . $54^{8}$

I2. PARASITIC DISEASES . . . . . . . . . . . . 55I

I3. DISEASES OF TIIE BONES AND JOINTS . * . . . . . . 556

If. DISLOCATIONS . . . . . . . . . . . . . . . 563

I5. DISEASES OF THE FEET . . . . . . . . . . . . . 567

I6. IVOUNDS . . . . . . . . . . . . . . . . . . . 577

17. FIRST-AID . . . . . . . . . . . . . . . . . . 582

I8. NURSING AND FOODS FOR THE SICK . . . . . . . . $\quad$. 885

I9. METHODS OF RESTRAINT: FIRING AND LLISTERING • • . . 58;

20. THE TEETH AND AGE OF HORSES . . . . . . . . 596

POISONS AND ANTIDOTES . . . . . . . . . . . . 594

TABLE OF DOSES . . . . . . . . . . . . . . . . . 596

APPENDIX 1.-LAWFUL STAKES, AND GAMING AND WAGERING IN RELATION TO HORSES. By W. B. WOODGATE . . . . . 598

APPENDIX II.-CARE OF THE HORSE'S FOOT, AND SOIE NOTES

oN Shoeing. By Captain Scratchley . . . . . . . 60z.

APPENDIX III.-HORSES FOR THE ARMY. By Charles Richardson . 607

EDITOR'S NOTE . . . . . . . . . . . . . 6II 



\section{INDEX TO ILLUSTRATIONS}

ARAB

Pasha .

\section{Cleveland Bays}

Beadlam

Cholderton Blossom

Favourite

Hawthorn Beanty with Foal.

Rosebery

Wonderful Lass

\section{Clydesdales}

At Work

Group,

Norris Team, The Famous

Novar .

Watering a Team

\section{CoAching}

Brocklebank's, Miss, Coach

Four-in-hand Club, A lleet of the, in Hyde Park

"Reliance, The" .

"Reynard" .

Road Coach, A Mlodern

Royal Mail Coaches at "The Angel," Islington

Vanderbilt's Coach, Mr., on the Brighton Road

"Venture, The" .

\section{Cobs}

Iron Duke

\section{DARTMOOR Ponies}

Group of, Grazing

"Derby DAY." From the Painting by W. P. Frith, R.A.

\section{Driving and Carriages}

Bath Horse Show, Single Harness Class . H.M. the King leaving the Park

Holyport Horace and Tissington Cock Robin

Loudwater Rob Roy and Diana Vernon .

My Lady and Anne of Austria

Radiant Champion

Rotten Row

Tissington Kit-Cat and Cock Robin
PAGE

5

277

280

272

260

265

273

$3+9$

$34^{\circ}$

348

370

353

386

381

$38+$

375

$37+$

355

$37 \mathrm{I}$

$2+$

320

105

419

398

396

380

386

It

$+60$

393
EXMOOR PONIES PAGE

Group of . . . . . . 325

\section{FOREIGN HORSES}

$\operatorname{Ajax} . \quad . \quad . \quad . \quad 426$

Barney F. and Fides Stanton . $45 \mathrm{I}$

Bonnie View . . . . . 454

Champion Coach Team . . . . 15

Drew, One of the Famous Mlorris Clydesdales . . . . 459

Haras de Jardy, At the . . . 422

Koheilan I. . . . . . . +38

Major de Bachant . . . . ttt

Norwegian Ponies . . . . . 477

Orloff Strain, Russian Horse of the . tf

Princell and Lake Erie. . . . $44^{8}$

Prussian Stud Farm, Young Mlares and Foals on a . . . 431

Ravissant . . . . . 427

Rève d'Or . . . . . $4+5$

St. I.o, Stables at the French Military Stallion Depot of . . . . . + +23

Troika Horse, A Russian . . . +43

Walkure, A Prussian Pony . . . +34

\section{HACKNEYS}

Adbolton St. Mary . . . . 253

Antonius . . . . 252

Berkeley Lily and Her Two Sons . . 260

Copmanthorpe Performer . . . 24I

Evanthus . . . . . . 256

Garton Duke of Connaught . . 2 $2+1$

Grand Viceroy and Grand Vulcan . . 233

Loudwater Gongelt and Grangelt . . $\quad 13$

Loudwater Rob Roy and Diana Vernon 389

Mathias Ar. . . . . 24t

Mel Valley's Mlaster . . . 26r

Polonius . . . . . . . 236

Rosador . . . . . . . 245

St. Thomas. . . . . . $2 f 1$

Towthorpe Iris and Foal . . 249

\section{Highland Ponies}

Group of, Grazing . . 28, 312

"Horse Falr, The." From the Painting by Rosa Bonheur. . . 420

\section{HUNTERS AND HUNTING}

Agricultural Hall Show, Judging at . fog 
Hunters AND HuNTING (contimeil)

Albrighton Hounds, The: A Meet at Stretton

An Awkward Corner

Belvoir Hounds: A llect in Croxton Park Blackmore Vale Foxhounds: A Ileet

Derwent

Devon and Somerset Staghounds: Waiting for the Hounds to come up

Jublin. Judging Hunter Geldings at

Fernie's, Mr., Hounds . . . . I03

Fitzwilliam's, Mr., Hunt: Going off to draw

Grafton Foxhounds, The: The Field eager to get away.

Golden Leaf.

Harrington's Foxhounds, Earl: Horsemen Crossing the Smite

Joker

Lord Leconfield's Foxhounds: Waiting at Covert Side

Olympia, Judging Riding Horses at

Patrician

Quorn Hunt, The

Well Over.

With the Warwickshire Hounds: Tho Hounds Arrive

Fork and Ainsty Hounds: A Weet at Aldborough

\section{JUMPING}

Bolla, Iieut., Jumping Display by t+o

Confidence Taking a High Jump . . fo4

Harriet, Lieut. Godfrey Brooks on . foI

Kitten, Lieut. IV. Macneill on . . t t3

Montebello, Lieut. Giorgio Bianchetti on $4_{5}$

\section{NEW FOREST PONIES}

Group of New Forest Ponies . . 3I3

In the New Forest . . . . I, 3I0

\section{Polo Ponies}

Hurlingham, Polo at . . . . 305

Saddle Room at Bisliop's Stortford . $5^{8}+$

Sapphire with Foal . . . . 300

Sandiway . . . . . . 297

Spanish Hero . . . . . 23

Stables at Bishop's Stortford . . 293

Stud at Bishop's Stortford . . . 307

White Vings . . . . . 30I

\section{RACE-COURSES}

Ascot, Royal Procession . . . I I 7

Chester Cup: The Parade . . . Ifo

Chester, Roodeye Race-course . . . 96

Doncaster Race-course . . . I I32

— A Start at . . . . 133

- St. Leger Day at . . . . I It2

Epsom Summer Meeting: Coaching up the Hill

Race-course.
RACE-COURSES (continued)-

PAGE

Goodwood, from Trundle Hill . . I 20

_- Race-course . . . . . IIO

Hurst Park Meeting: A Finish . . I 2 I

Iiempton Park: A Parade past the Stands. . . . Ios

Liverpool Race-course . . . . 139

Newbury, The Stewards' Stand . . I I 4

Newmarket High Street . . . 125

— Race-course in its Early Days . 127

- The Courses at . . . 128

- Exercising at . . . . I 20

Royal Ascot Race-course . . . IIG

Sandown Park Race-course . I09, 123

York Race-course . . . . IOO

\section{SHETLAND PoNies}

Group Grazing . . . . 308

Thoreau . . 25

\section{SHIRE HORSES}

Bardon Forest Princess . . 342

Barnfield's Forest Queen . . . 330

Calwich Marksman . . IO

Champions, A Group of . . 326

Lockinge Forest Jíng . . . . 334

Midland Railway Horse . 362

Tatton Dray King . . . 331

Team, A Fine . . . $3+5$

\section{STEEPLECHASING}

Aintree, Becher's Brook on Grand National Course at. . . . 175

- The Water Jump on Grand Sational Course at . . . . . 177

- Valentine's Brook on Grand National Course at . . . . . 176

Becher's Brook: Grand Tational Course at Aintree . . . . 175

"First Steeplechase on Record," The so-called. . . . . . . $\quad$ I69

Grand National of $18_{55}$, The . . 173

Valentine's Brook on Grand Vational Course at Aintrec. . . I77

Warwick, The Water Jump, National Hunt Steeplechase

I 80

\section{SUFFOLK HORSES}

Agricultural Work, A Team at . . 356

Boulge Mlaid . . . . . 36I

King of the Roses . . . . . 367

Rendlesham Sorcerer . . . . 357

\section{THOROUGHBREDS}

Alice Hawthorn . . . . . 93

Barcaldine . . . . . 81

Beeswing . . . . . . 89

Bend Or . . . . . . . 55

Birdcatcher . . . . . $5 \mathrm{I}$

Blacklock . . . . . I 45

Blink Bonny . . . . . 35 
THOROUGHBREDS (continued) -

Caller Ou

Challacombe.

Crucifix

Darley Arabian

Doncaster . . . . $5+$

Donovan . . $\quad$ I57

Flỵing Childers . . . $\quad 32$

Flying Dutchman v. Voltageur . . 76

Flying Fox . . . . . 59

Galopin . . . . . 63

Gimcrack . . . . 136

Hambletonian . . . Itt

Herod . . . . 38

Highflyer . . . . . . 73

Isinglass . . . . . I6I

liildare, King Edward V1I.'s Charger . Io

King Herod . . . . . 38

Lily Agnes . . . . . . 4

Narske . . . 33

Matchem . . . . . 39

Newminster, Winner of the St. Leger, 1851 I 49

Orme . . . . . . 60

Ormonde . . . . . 57

Persimmon . . $\quad 65$

Pot-8-Us . . . 4 4 47

Pretty Polly . . $\quad 165$

Queen Nlary . . . 84

Robert the Devil . . . . $\quad$ I53

St. Frusquin . . . . . 60

St. Gatien . . 156

St. Simon . . . . . 64

Sceptre . . . . . 164

Sir Hercules . . . . . 50

Stockwell . . . . . . 53

The Baron . . . . . 52

Thormanby . . . . . . 77

Volonel, Lord Roberts' Charger . . I I

Voltageur . . . . 148

Voltageur v. Flying Dutchman . . 76

VTaxy . . . . . . . . 49

West Australian . . . . . So

Whalebone. . . . . 49

VANNERS, Pair of . . . . . IS

\section{VETERINARY}

Bog Sparin Truss. . . . . 558

Bones of Horse's legs . . . . 560

Bronchial Tree of Horse . . 479

Capped Hock . . . . . 565

Catheter . . . . $51 \mathrm{I}$

Colic, Horse attacked with . . . 496

Dentition of the Adult Horse . . 508
VETERINARY (contintid) - PAGE

Elbow Pad . . . . . 564

Eye, Vertical Section of . . . $5+5$

False Quarter . . . . . 57.3

Firing lrons. . . . . . . 580

Fistulous Withers. . . . . . 580

Foot, Structure of . . . $57 \mathrm{I}$

Generation, Organs of, of a Mare . . $54^{\circ}$

Heart of Horse . . . . . 524

Hobbles, Leather . . . . . 588

Laminitis . . . . . $57 \mathrm{I}$

Lymphangitis . . . . . 528

Mlange, Sarcoptic . . . . 553

Nervous System of Horse . . . 519

Points of a Horse . . . . 49 I

Poll Evil . . . . . . . 580

Probang . . . . . . 492

Kingbone . . . . . . 557

Ringworm . . . . . 552

Sand Crack . . . . . . 569

Scars Caused by Brushing . . . 575

Section of Horse, Vertical . . . $4^{81}$

Scedy Toe . . . . . . 569

Side Bone . . . . . 573

Skelcton of a Horse . . . . . 485

Skull, Section of, Showing Brain . . 516

Slings . . . . . . . 598

Spavin . . . . . . . 558

Speedy Cut . $\quad . \quad$. $\quad . \quad$. 575

Splint . . . . . . 557

Stomach, Inner Face of Wall of Horse's. 495

Stringhalt . . . . . 575

Teeth as an Indication of Age . . 593

Tracheotomy Tube . . . 478

-_ -.. with Valve . . . 478

Twitch Applied . . . . 587

Udder, Section of a "Quarter" of a Mare's $5+2$

Umbilical Hernia, Colt with Truss fixed for 506

Urinary Organs . . . . . 512

Wagon Rope, Casting with a . . 587

Windgalls . . . . . . 566

WAR Horse, THE. From the Engraving by Albrecht Dürer . . . 327

\section{WELSH PONIES}

Greylight . . . . . . 317

Starlight . . . . . . $\quad 27$

\section{YORKSHIRE COACH-HORSES}

Josephine . $\quad . \quad$. $\quad 285$

Royal Carriage, Yorkshire Coach-horses in a . . . . . 289

Woodlands Brion. . . . 292 


\section{LIST OF COLOURED PLATES}

H.M. HING GEORGE V. (N HIS CHARGER, RUPERT. From the Painting by CHRISTOPHER ClaRk, R.I.

Frontispiece

PERsimiox. From a Photograph by Clarexce Halley d Co., lewmarket . Facing page 22 ECLIPSE. From the Painting by George Stubbs, A.R.A. . . . . . . .. .. 22

SPEARMint. From a Photograph by Clarence HaIleY \& Co., Newmarkct . . . . $3^{8}$

PERDITA WITH PERSIMAON. From the Painting by J. Haxson WaLkER, JUNR.

LA FLECHE BEATING SIR HIGO, ST. LEGER STAKES, 1892 . From the Drawing by $\mathrm{V}$. Loxge

DHAJIOND JUBILEe. From a Photograph by Clarexice Halley d Co., Newmarket

SIGNORINETTA. From the Painting by J. Haxsox Walker, Juxk.

MINORU. From the Painting ly J. HANSON WALKER, JUNR. .

THE CANAL TLRA: THE GRAND NATIONAI STEEPIECHASE. FrOM the Painting by G, D. GiLfes .

VIEWED BY THE RINAER. From the Painting by F. WHITING

MR. BUTTLE'S HACKNEY STALLION, KIRKBLRN TOREAI)R. Fron? the Painting by F. Whiting

SHR WALTER GILBEY'S HACISAEY STALLIOX, DANEGELT (IGOZ)

ON THE ROAD. From the Painting by F. Whitsa.

CLEVELAND BAY STALIION, SLLTAN

POLO PONIES, ROMANY ANI TITH, OWNED BY SHR J. BARhER.

From the Painting by F. Whitivg .

DUAL CHAMPION PONY STALLION, BERKELEY MODLI

COLT-HUNTING IN THE NEIV FOREST. From the Painting by Licr E. LIENP-WELCH .

SHIRE STALLION, HAROLD

SHIRE STALLION, HALSTEAD ROYAL DUKE. From the Painting by J. Hanson Walker, Junr.

CLYDESDALE STALLION, PRINCE OF ALBION

A TYPICAL CLYDESDALE. From the Painting by F. Whitsis .

SUFFOLK SIRE, PRINCE WEDGEIVOOD .

SUFF()LK HURSes. From the Painting by Christopher Clark, R.I. .

A TANDEMI TEAM. From the Painting by F. Whiting

THE MLSCCIAR SYSTEM

STOMLTITIS ERLPTIONS

A MAL-PRESENTATHN

THE FETLOCK, NORMAL AND OVERSHOT

220

228

$25^{8}$

.6. 2

$28+$

292

316

$32+$

$3+8$

$35^{6}$

380

$3 \mathrm{sS}$

$+12$

$+44$

47

+8S

538

564 


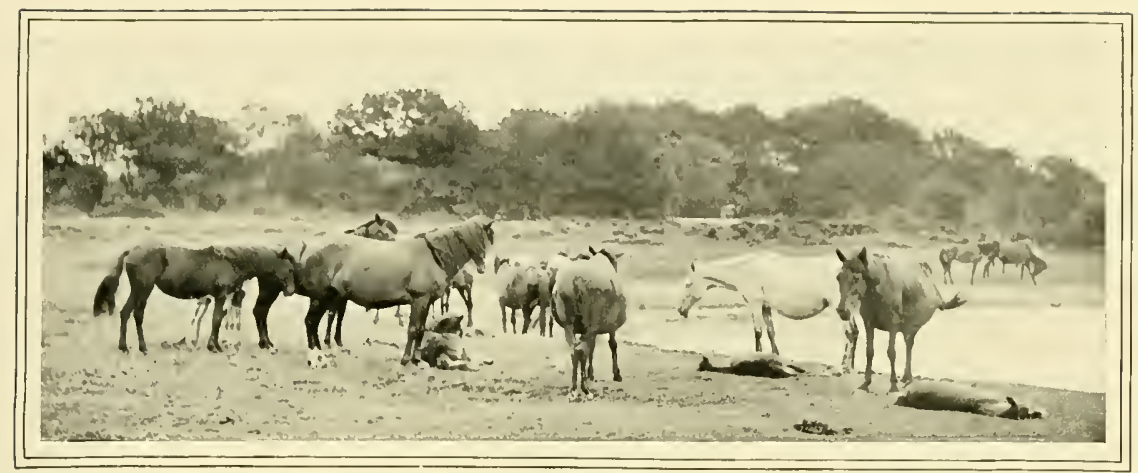
IN THE NEW FOREST.

Photografk by C. Rctid, Hishaw, $A: B$.

\section{THE NEW \\ BOOK OF THE HORSE}

CHAP'TER I

ENGLISH VARIETIES OF THE HORSE

$\mathrm{T}$ HOLGH doubtless every sort of English horse can claim a common ancestor, there are at the present time many distinct breeds of horses and ponies, nearly all of which owe their position to the fact that for some hundreds of years their breeding has been closely attended to by the inhabitants of Great Britain.

As to what the exact origin of the earliest British horses may be there is still considerable doubt, and though many opinions have been formed, and much evidence put forward to confirm these opinions, it is difficult to form really funal conclusions. According to Professor Ridgeway in "The Origin and Influence of the Thoroughbred Horse," Cæsar, when he invaded Britain, found the Belgic tribes, who occupied the South-
Eastern portion of the Island, employing not only cavalry like the Gauls, but also war chariots. Yet, writing in the sixth century A.D., Procopius describes a war between the Angli [settled in Britain] and the Varni, and states that the former tribe did not even know what a horse was like because they had never seen one, nor even a representation of one.

That Procopius was mistaken there is plenty of evidence to prove, chiefly derived from fossil remains and so forth; but we take it that a setting out of the arguments as to what manner of horses were first found in Britain would be uninteresting to the average reader, and we shall mercly state that the English horses at the time of the Roman invasion were most certainly very much smaller than those of the present 
day. Professor Ridgeway, indeed, is of opinion that they were small ponies, rather than horses, and he cites as proof the iron horseshoes found at Silchester and elsewhere, which are possibly to be ascribed to Roman times.

\section{The Norman Invasion}

It is extremely probable that during the period which intervened between the departure of the Romans from Britain and the arrival of the Normans the cult of the horse was to some extent pursued, for civilisation was gradually advancing, and there liad been considerable intercourse between this country and several of the European States. Anthorities, however, have not very much to say concerning English horses until the Norman invasion, when the heary horse was introduced, which for centuries was used as a charger, and which became the ancestor of the Shire, the Clydesdale, the Suffolk Punch, and, in fact, of all the powerful draught horses of the present day.

\section{Distinct English Breeds}

At present there are many breeds of English horses, some of which have been pure for more than a liundred years, while others can show several generations of pure blood. But the average horse is in nineteen cases out of twenty of no regular breed, as we shall show. The following are the distinct breeds:-

I. The Thoroughired, by which is meant the RACE-HORSE.

2. The Hackney, which may be simply described as the best type of CARRIAGE HORSE, with showy action and good manners.

3. The Polo Pony.-As a distinct breed this type of horse has an existence of barely a dozen years.

4. The Shrire Horse Clydesdale $\left\{\begin{array}{l}\text { The biggest and } \\ \text { strongest DraY- } \\ \text { Horses, such as } \\ \text { are used for the } \\ \text { heaviest vehicles. }\end{array}\right.$

6. The Suffoli Punchi-Also a Cart HoRse, but of rather lighter make than the Shires and Clydesdales. A local breed, greatly used by the maltsters and brewers of the Eastern Counties.

7. The Stud Book Hunter.

8. The Yorkshire COACH Horse and Cleveland Bar.

9. The General Utility NaG, of no particular breed, but by which is meant the ordinary, every-day light horse, such as is seen in cabs, omnibuses, and tradesmen's carts.

It is, as will be understood, almost inpossible to say exactly where each of these breeds diverged from the ordinary English horse of the Middle Ages, but as regards the formation of the breed known as the thoroughbred there is plenty of evidence, and for more than two hundred years his history can be traced with absolute certainty.

\section{The Pony Tribes}

It should here be mentioned that besides the distinct breeds which have been enumcrated, there are many varieties of English and Scottish ponies, and the inference is that some of these pony tribes-especially those from the far north-have remained small because they have been allowed to live in a semi-wild condition, while horses generally have increased in size because they have been the objects of extraordinary care and attention on the part of their breeders and owners.

It is hardly necessary to point out that the love of horses is strongly developed in the Anglo-Saxon race. In no country in the world, of anything like the same size as the United Kingdom, are there so many valuable horses, and no nation in the world, with the possible exception of the Arabs, has paid so much attention to horses since civilisation became a pronounced reality.

The evidence of the oldest writings, of sculptures, of frescoes, and so forth, goes to show that horses were driven long before they were ridden; Professor Ridgeway states that men employed the horse for draught before they habitually rode upon his back, not because they were afraid to mount him, but because he was rather too small to be 
effectively used as a charger, or because, where he was of sufficient size to carry a nran, it took a long time before weapons and methods of warfare were devised suitable for mounted men.

\section{Early Horse-Races}

In England the horse was probably used first for war purposes, and donbtless he was bred, and gradually improved, with the same idea. But all old writings teach us that he was also quickly brought into general use, as a means for hastening a journey. It is not necessary to go into such evidence as is forthcoming, but it may be brietly stated that throughout the Middle Ages, for travelling from one spot to another, horses were utilised. They were at this period used principally as chargers, but the hackney or roadster-in those days a riding horse, and not a trapper-was to be found in the stables of all the nobles and knights throughout the Tudor and Stuart periods, and even much earlier. There is, in fact, plenty of evidence that horses were used for other purposes than carrying men-at-arms as far back as the time of Henry II., for it was during this reign that the tournament was introduced into England, while it can be further gathered from the writings of William Stephanides, a monk of Canterbury, that horse-racing was a Sunday amusement of the Londoners of the day.

According to this writer every Sunday in Lent young men rode out into the fields on horses which were fit for war and excellent for their speed. The learned monk then relates how they practised for tournaments, and trained themselves for battle, and finishes his remarks on the subject as follows :

"At times two or three boys are set on horseback to ride a race and push their horses to their utmost speed, sparing neither whip nor spur."

Here is proof that the horse tournament and the horse-race were known in England as far back as the twelfth century. Nearly two hundred years later there is mention of some six or eight different sorts of horses which were in daily use, and thus we may take it as certain that by the middle of the fourteenth century, riding for pleasure was one of the principal pastimes of the great nobles and their families. It is also certain that in every great establishment mounted retainers were kept, who acted as soldiers when necessary, and whose lives were in great part spent in the saddle.

\section{In the 15th Century}

But it was a good deal later that the horse became the general servant of the AngloSaxon race, for in parts of the fifteenth century there was a certain amount of retrogression, for which the Wars of the Roses were chiefly responsible. The continuous strife, over so long a period, had a most injurious effect upon agriculture and lorse breeding, for all horses were liable to be seized for military purposes, and therefore many breeders discontinued their breeding, and turned their attention to other kinds of stock.

\section{"Protection" of Horses}

When Henry VII. came to the throne in I 495 he found the supply of horses so smail, and the prices so high, that he forbade the export of any horse without royal permission, on pain of forfeiture, and of any mare whose value exceeded six shillings and eightpence. He made other stipulations, too, with regard to export, and in fact he seems to have been possessed of the idea that we were in danger of losing the best of our breed.

Henry VIII. continued the "protection" of horses, for he absolutely forbade all export, not only from England but from Scotiand as well, and stipulated that all prelates and nobles of a certain degree-to be ascertained by the richness of their wives' dress-should maintain stallions of a given stature. He made horse-stealing a capital offence, and deprived persons convicted of it of the benefit of chergy. He also, as Sir Walter Gilbey explains in "Ponies Past and Present," made a vigorous attempt to weed out the ponies whose small size rendered them useless. It may be added 
that during this reign armour reached its maximum weight, and that in consequence war-horses had to carry the weight of, broadly speaking, two men instead of one.

Here we may break off for a moment to note that the fact of exportation of horses being compulsorily stopped in the reign of Henry VIII. shows, or perhaps only suggests, restrictions may be placed upon exportation. The subject has been mentioned in both Houses of Parliament, and in all probability some legislation with a view to stopping the leakage will be effected.

By the time of Henry VIII. horses were used in England for agriculture and for the state chariots of noblemen, but the ordinary

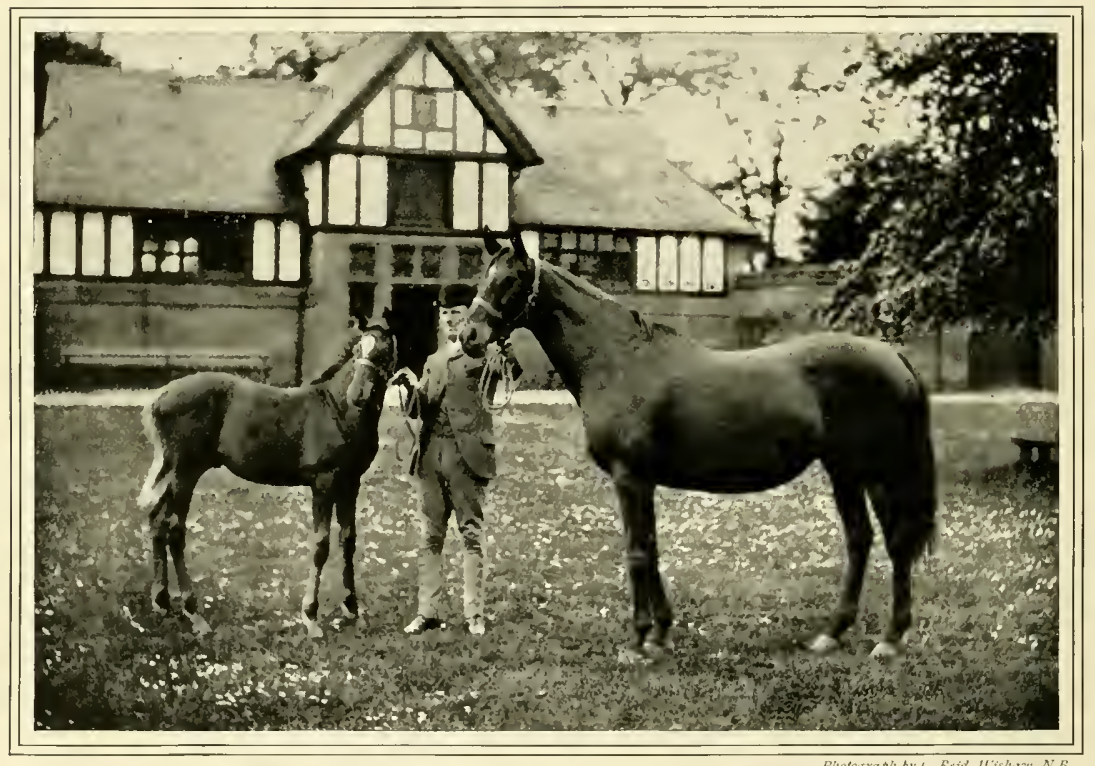

THE DUKE OF WESTMINSTER'S THOROUGHBRED MARE, LILY AGNES.

that even at that day there was a demand for British horses on the part of Continental buyers. No doubt it had been ascertained that bigger and stronger horses could be grown in the United Kingdom than elsewhere, and that in fact careful breeding gave better results. This is, of course, to a certain extent conjecture, but had there been no demand from the Continent there would have been no need for the protectionist measures.

Another reflection à propos the same subject is to the effect that at the present day there is a demand for some form of protection, but this time it is the War Office and English breeders of horses who are alarmed, and who are clamouring that some carriage had hardly come into existence. The fact is that there were practically no roads except horse tracks, until the earliest of the coaching days. The appearance of the stage wagons caused gradual improvement in the roads, and as the roads became better the coach replaced the wagon, and the speed quickly increased.

Travelling by carriage-if a stage wagon can be called a carriage-was not general, however, until the seventeenth century was well advanced, and for some four or five hundred years all journeys in this country were undertaken, on horseback by the rich, and on foot by the poor. In the reign of Henry VIII. the state coach was known, but except in and near London, and 


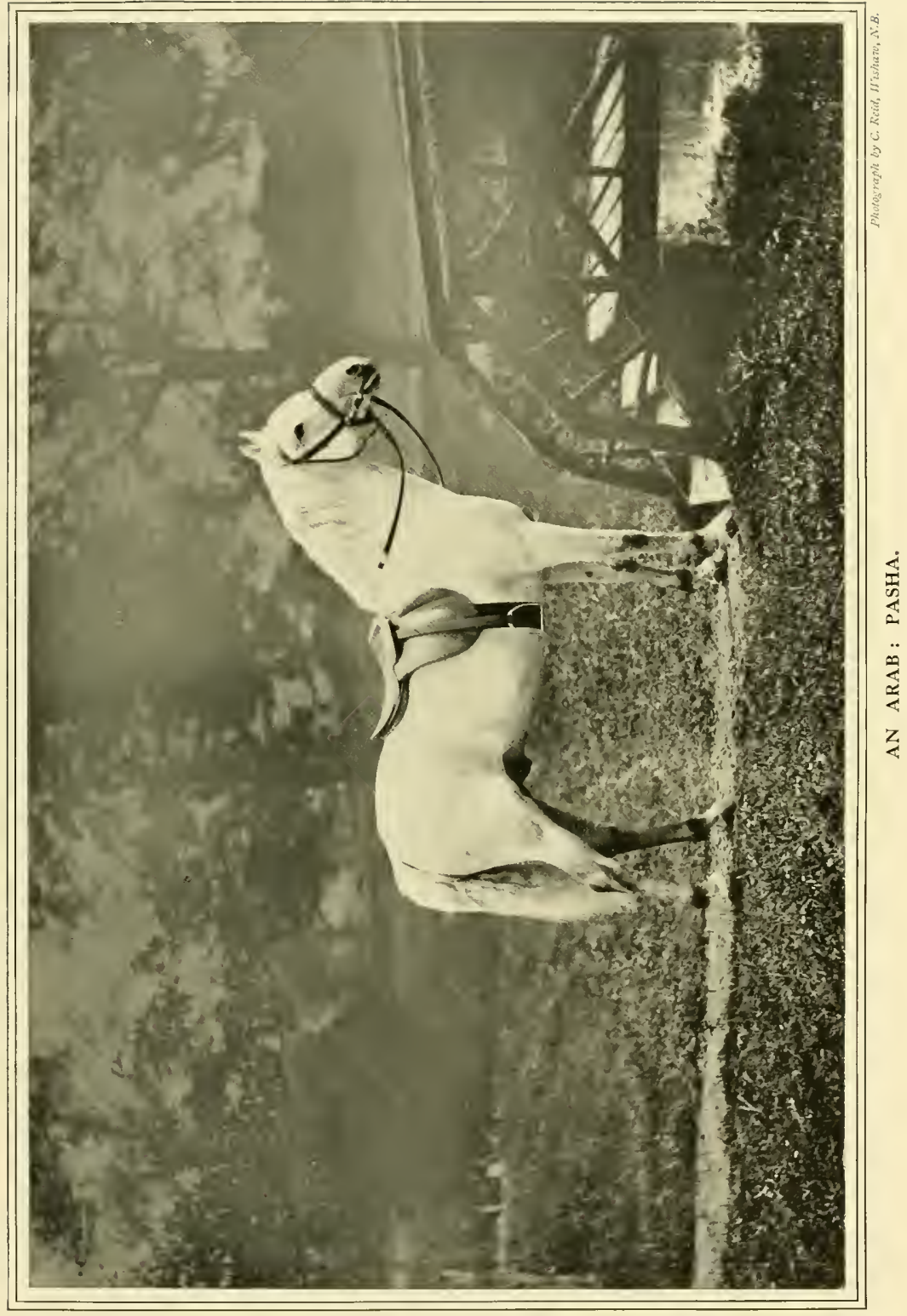


on one or two of the oldest main roads, such rehicles were never used.

\section{A 16th Century Stable}

Sir Walter Gilbey, whose researches into all matters connected with driving and harness horses have been very thorough, quotes a passage from "The Regulations of the Establishment of Algernon Percy, Fifth Earl of Northumberland," in the year 15 I2, which gives a detailed account of the stables, and therein appears the following :

"Item, chariot hors to stand in my lorde's stable yerely. Seven great trottynge horsys to draw in the chariott, and a nag for the chariott man to ride-eight. Again, hors for his lordship's son and heir. A gret doble trottynge hors called a curtal, for his lordship to ride out on out of towns, another trottynge gambaldyn hors for his lordship to ride on when he comes into towns. An amblynge hors for his lordship to journeye on daily. A proper amblynge little nag for his lordship when he goeth on hunting and hawking. A gret amblynge gelding, or trotting gelding to carry his male."

The above is rastly interesting, for it shows what the position of the horse was in this country almost four hundred years ago. We have not quoted the tally of "gentall horsys, saddell horsys, and palfreys," nor have we mentioned the " hobys and nags" which were also sheltered in the great establishment, but the record in its entirety proves that every description of the then existing English horse was used, that the "chariott" involved the yoking of eight horses, and that for ordinary riding a different horse was used from that requisitioned for hmoting and hawking.

No doubt in the royal stables the tally would be an even larger one, but the Earl of Northumberland was one of the greatest and most influential peers of the day, and his establishment would probably be one of the largest in the Kingdom. Unfortunately the numbers of retainers' horses are not given, but in all thirty horses are spoken of as being kept for the use of the earl, my lady, and the son and heir, and thus it appears that the number was proportionately greater than it would be at this day, except in the matter of hunters.

\section{A "Gambaldyn" Horse}

It is rather curious that only one horse, and that a little one, should be mentioned in connection with sport, while different horses for riding out of town and into towns are named. A "curtal" was in all probability a docked horse, and as far as we know this is the first historical mention of the practice of docking. What a "gambaldyn" horse was we can only guess. Sir Walter Gilbey supposes it was a horse of high and showy action, but we cannot find the word in the old dictionaries of sport. It is, however, probable that it signified a gambolling or galloping horse, but the fact is that 400 years ago there were subtle differentiations between horses, the meaning of which can only be guesswork.

\section{Edward VI and Horses}

There is suggestion, if not actual evidence, that the action of Henry VII. and Henry VIII. had the desired effect of restoring the deficit in horseflesh, for in the reign of Edward V'I. an act was passed to sanction the export of mares worth not more than ten shillings, and Henry V1lI.'s law about the benefit of clergy for horse-stealers was altered in some degree. Still, it is certain that horse-stealing was quite one of the "liberal professions " of the day, for during the reign of Queen Mary an act was passed which aimed at its suppression. This involved a plan for registering all sales of horses, and caused the property in a stolen horse not to be diverted from the lawful owner, under certain conditions.

Queen Mary also legislated with a riew to making it obligatory on the upper and middle classes that they should licep horses in the interests of the defences of the Kingdom. Queen Elizabeth also laid the horse question very much to heart, and made all sorts of laws and proclamations with the object of encouraging breeding, and increasing the supply of horses. 


\section{ENGLISH VARIETIES OF THE HORSE}

\section{A Royal Horsewoman}

It was at the end of Queen Mary's reign that carriages came into use, and a little later gumpowder was discorered, and the slow and very gradual disappearance of the war-horse began. But the demand for horses of all sorts was now steadily, and even rapidly, increasing. The big horses which were not required for the royal service were gradually requisitioned as draught horses, both for road work and agricultural purposes, and the middle class of people, which was quickly coming into existence, rode here, there, and everywhere, as a matter of course. Indeed, it is probable that a big majority of country folk were able to ride, and that a very large percentage of town-bred folk learnt to ride at the earliest opportunity. Coaches were introduced in the reign of Queen Elizabeth, and the importation of Arabs, Barbs, and Spanish horses set in, witl a view to improving the native breeds. Queen Elizibeth herself kept race-horses, and was a horsewoman until she was nearly seventy years of age. She usually rode on a pillion behind her Master of the Horse, but it is said that when hunting or hawking she rode her own palfrey on a side saddle.

\section{Eastern Stallions}

Though there is no doubt that there had been many importations of foreign horses previous to the advent of the seventeenth century, details concerning them are ratler vague, and it is not until the reign of James $\mathbf{I}$. that we have really definite statements. The modern thoroughbred had its earliest foundations during the latter part of this century, but it may here be pointed out that there must have been a rare foundation of English blood to cross with the Eastern stallions which from this time forward were brought to the country, and in this connection a quotation from Gervase Markham is $\dot{a}$ propos, because of the strong proof it affords as to the excellence of the then existing English horse.

Gervase Markham wrote an exceedingly valuable book on horses, which was published in 1616 or 1617 , and in this book there is distinct eridence that the author had travelled abroad, almost certainly with a view to buying and studying the various European breeds of lorses. Markham wrote :-

"I do daily finde in mine experience, that the rirtue, goodness, boldness, swiftness and endurance of our true English bred horses is equal with any race of horses whatsoever. Some former writers, whether out of want of experience, or to flatter novelties, have concluded that the English horse is a great strong jade, deep ribbed, sid-bellied, with strong legges and good hoofes, yet fitter for the cart thain either saddle or any working employment. How false this is all English horsemen knowe. The true English horse, him I mean that is bred under a good clime, on firme ground, in a pure temperature, is of tall stature and large proportions; his head, though not so fine as either the Barbarie's or the Turke's, yet is lean. long, and well fashioned; his crest is hie, only subject to thickness if he be stoned, but if he be gelded then it is firm and strong; his chyne is straight and broad; and all his limbs large, leane, flat, and excellently pointed. For their endurance I have seen them suffer and execute as much and more than ever I noted of any foraine creation. I have heard it reported that at the massacre of Paris (St. Bartholomew), IIontgomerie, taking an English mare in the night, first swam over the river Seine, and after ran her so many leagues as I fear to nominate, less misconstruction might tax me of too lavish a report. Again for swiftness. What nation hath brought forth that horse which hath exceeded the English? When the best Barbaries that were ever in their prime. I saw them overrunne by a black hobbie at Salisbury ; yet that hobbie was more overrunne by a horse called Valentine, which Valentine neither in hunting or running was ever equalled, yet was a plain bred English horse both by syze and dam? Again for infinite labour and long endurance, which is to be desired in our hunting matches, I have not seen any horse to compare with the English. $\mathrm{He}$ is of tolerable shape, strong, valiant, and durable."

\section{The "Hobby"}

In spite of the allusion to the race at Salisbury, this was written when the English turf was in its infancy, and when-as far as we can judge-lunting matches were as 
important as actual racing. The "hobby" was either a pony or a very small horse; the word is derived from the French hobbin, which signifies a pony, and one is much inclined to think that by this time there must have been a breed of light horses in the comntry which were begiming to assert themselves as both speedy and enduring. Gervase Warkham's horse which we have described was certainly not a great or warhorse, and Valentine, who beat the "hobby," must also have been a "light" horse.

It will be noticed that in Markham's description there is no mention whatever of suitability to carry a man-at-arms, but rather the full description encourages the idea of a superior horse which was bred for hunting or racing, probably for both.

\section{The Pack-Horse}

Three liundred years ago most of the ploughing was done by oxen, but the packhorse had come into existence, and no doubt lnorses of a much lighter description than those used for war were bred for this purpose. The pack-horse, as a special tribe, liad a life of probably rather less than 200 years, for long after wagons and coaches were running on the main roads much of the merchandise was still carried on horseback. The pack-horse tracks were in many places not easily converted into sound roads, because they went straight ahead, and many of the bridges over small streams were not more than four feet wide.

When the stage wagon and the goods wagon were first used their routes were, of course, from town to town, a majority having their headquarters in London. The pack-horse, however, was used to carry minerals from certain mines to the coasts, and he was therefore not greatly interfered with by the increase of wheeled traffic. For example, all the lead which was mined in the dales of the moorland districts of Northumberland, Durham, and
Cumberland, was carried on donkeys, or small horses, to the seacoast by tracks which led straight across the moorlands, and some of which to this day have been left in their original state. At Riding Millon-Tyne there is a perfect specimen of the narrow pack-horse bridge; it does not span the Tyne itself, but a tributary thereof, which is some twenty feet wide.

\section{The Rise of the Light Horse}

The pack-horse was probably to a great extent the progenitor of many of the modern light horses of no particular breed. He was, it has been surmised, the ancestor of the "Dale" pony, which is by far the biggest and strongest horse of pony type in the kingdom. The best mares of the packhorses were undoubtedly bred from, for the Devonshire pack-horse was, less than a hundred years ago, one of the boasts of the county. But by this period of the history of our own country horses were being sorted out. The line of demarcation was in fact being gradually drawn, and quietly the light horse was ousting the heary horse from first position. The light horse, as has been stated, went to found the breed of race-horses, and of hunters; the heary horse, no longer wanted to carry enormous weights in times of war, developed into the highest class of draught horse which the world has ever known.

\section{The Unchanging Pony}

The ponies of the wilder parts of the country alone showed no change; even their size and height did not increase, because of the poor quality of their food. They had, moreover, been through times of neglect, being despised because of their want of size, but when a whole nation was using the horse as a means of locomotion, even the ponies became useful, and after a while they were cared for, and, indeed, came to be highly regarded. 


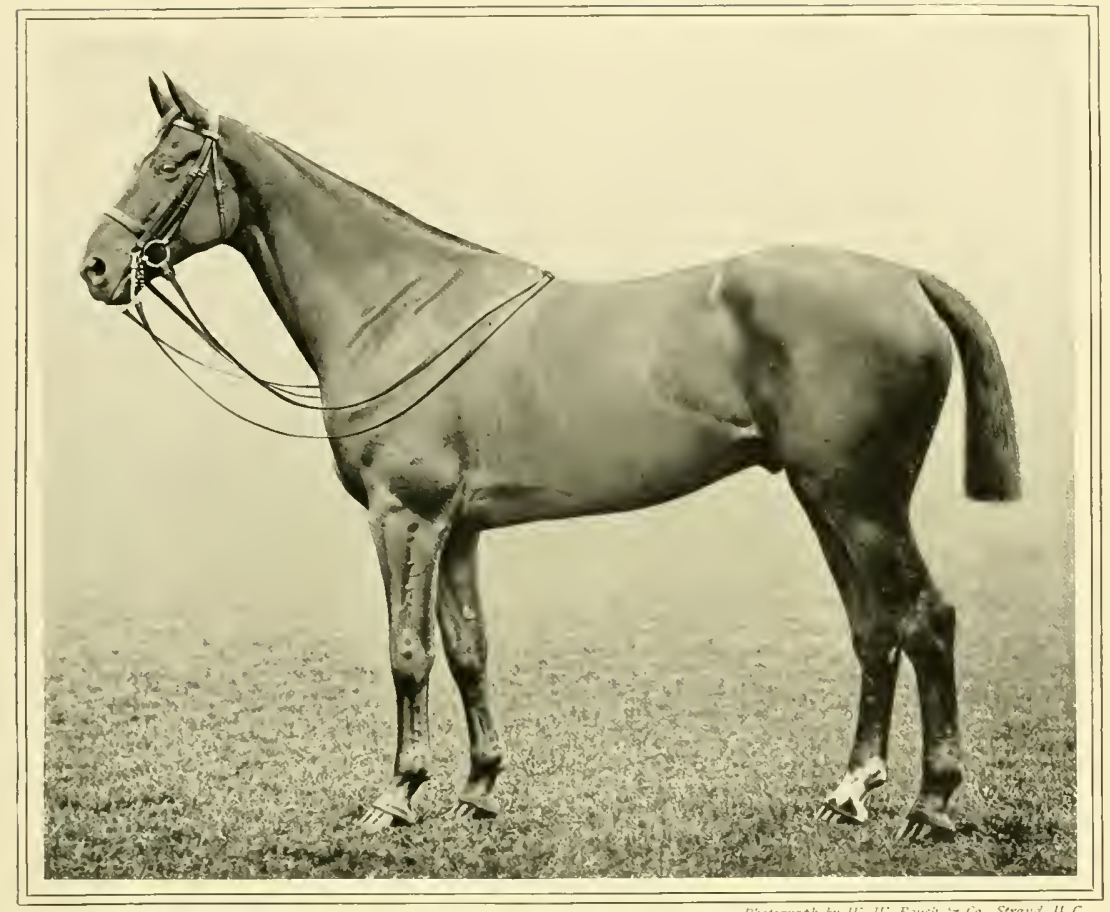

A NOTED HUNTER: PATRICIAN.

\section{CHAPTER II}

\section{PRESENT POSITION OF THE HORSE IN THE UNITED KINGDOM}

$\mathrm{T}$

HAT the horse always has been and always will be one of the most important of domestic animals is a fact which cannot be disputed. Indeed, many who have considered such questions are inclined to award first place to the horse, being of opinion that his usefulness as a beast of burden-whether carrying a man or drawing a load-has been of greater consequence to the human race than have the food-giving properties of the sheep and the ox.

Into such questions there is no need to enter-nor, for that matter, would it be at all easy to decide such a point-but as an animal whose existence does not greatly influence the food supply in this country it is practically certain that the horse stands alone.

As examples of the extraordinary importance which the horse has acquired in our own times it may be mentioned that-

An English thoroughbred racer has been sold at public auction for 37,500 guineas.

An English thoroughbred brood mare has been sold at public auction for 12,500 guineas.

An English thoroughbred yearling filiy 
has been sold at public auction for ro,ooo guineas.

A young hunter has been sold (privately) at the Dublin Horse Show for $f \mathrm{r}, 25^{\circ}$.

A team of four ponies or cobs was sold at the Olympia Show of rgos for-as wheeled traffic (as a matter of fact the motor movement was in its infancy when Flying Fox and Sceptre were sold), because they were race-horses, and race-horses have an extraordinary value beyond their intrinsic value as horses.

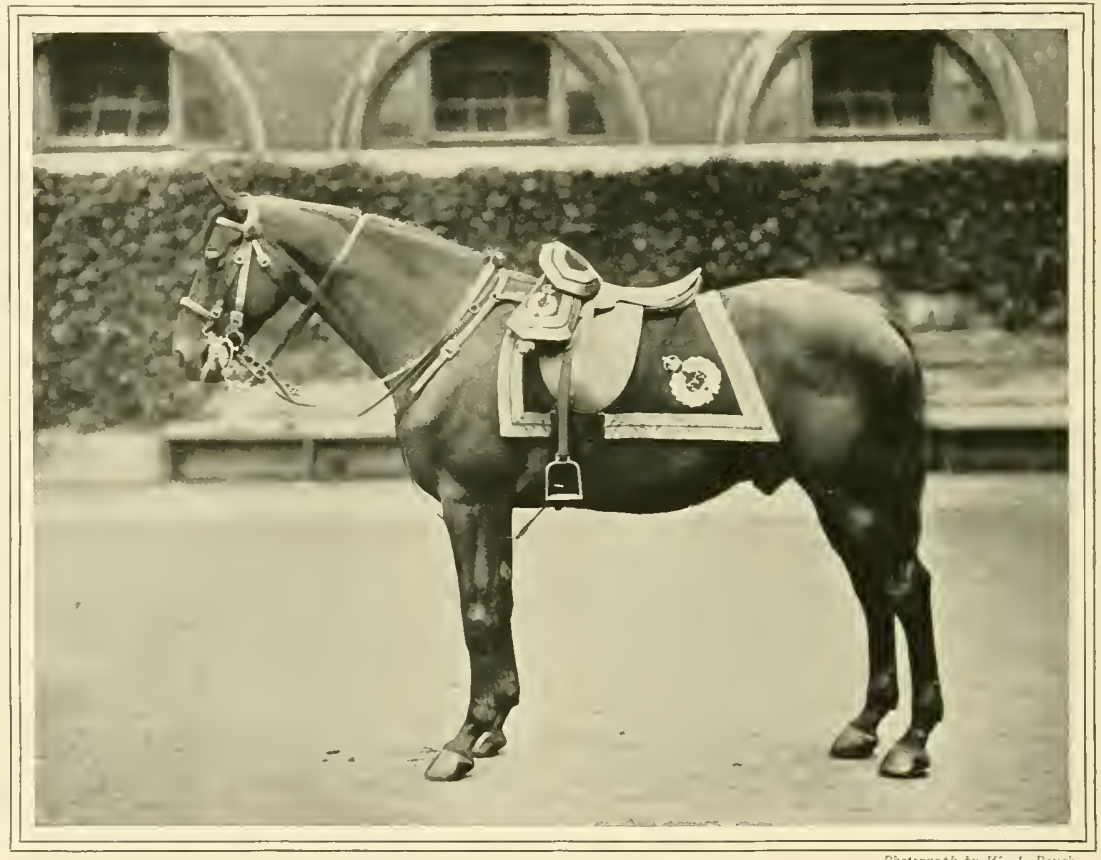

H.M. THE KING'S CHARGER, KILDARE.

was currently reported- $\underset{\sim}{f} 5,000$. That this amount was actually correct we do not assert, but the on dit which gave the price named was never contradicted. A year before, a pair of celebrated tandem ponies changed hands, it was said, at 2,000 guineas.

Many other instances of high prices could be given, but there is no need to quote further, and the few later examples which have been cited are merely put forward as proof of the fact that in these days of much mechanical traffic the value of horses has shown few signs of decrease. The thoroughbreds referred to-Flying Fox, La Flèche, and Sceptre-do not come into any argument which bears upon mechanical,
But the cobs sold at the Olympia Show were harness horses, the four which formed the team being geldings, while of the tandem pair one was a gelding and the other a mare. Thus five of the six were unfitted for breeding purposes; but, on the other hand, all of these cobs had an enhanced value because of the prizes they were likely to win in the show ring.

As far as mechanical traffic is concerned, we may take it that a very serions rival to horse industry has come into being, yet we are not of opinion that because many road journeys are now made without the employment of horses, and great quantities of goods are being delivered through the agency 
of motor vans, the horse is therefore doomed to extinction. We think, rather, that the demand for certain classes of horses is likely to increase, though at the same time there is no disputing the fact that omnibus horses, carriage horses, and light vanners are being in a great degree replaced by motor traction.

Seventy years ago, at the beginning of the railway era, the same cry was raised, it being a general opinion of the day that when the coach and the postchaise were no longer to be seen on the country roads the horse must of necessity be much less required. But the fact is that railways, because they opened out the country, caused the demand for horses to increase-in spite of their not buing required for posting. And in these days there is the fact that, up to the arrival of the motor car, horses of sorts were in continually increasing demand, chiefly because of the increase of population, and because there is so much more going about than there used to be.

Not long ago we met with an example of the increase in horseflesh, and though it occurred in a goahead district which does not depend entirely on agriculture, it will serve to explain our meaning. We may say, then, that more than a quarter of a century ago we resided for some time in a village which was in a somewhat primitive condition. Everyone knew everyone else, and it was a simple matter to count all the horses in the parish. There were four or five residents who kept two and three harness horses, one who kept hunters, and some half-dozen farmers who had two or four horses, according to the size of their holdings. Then two doctors had a couple of horses each, the

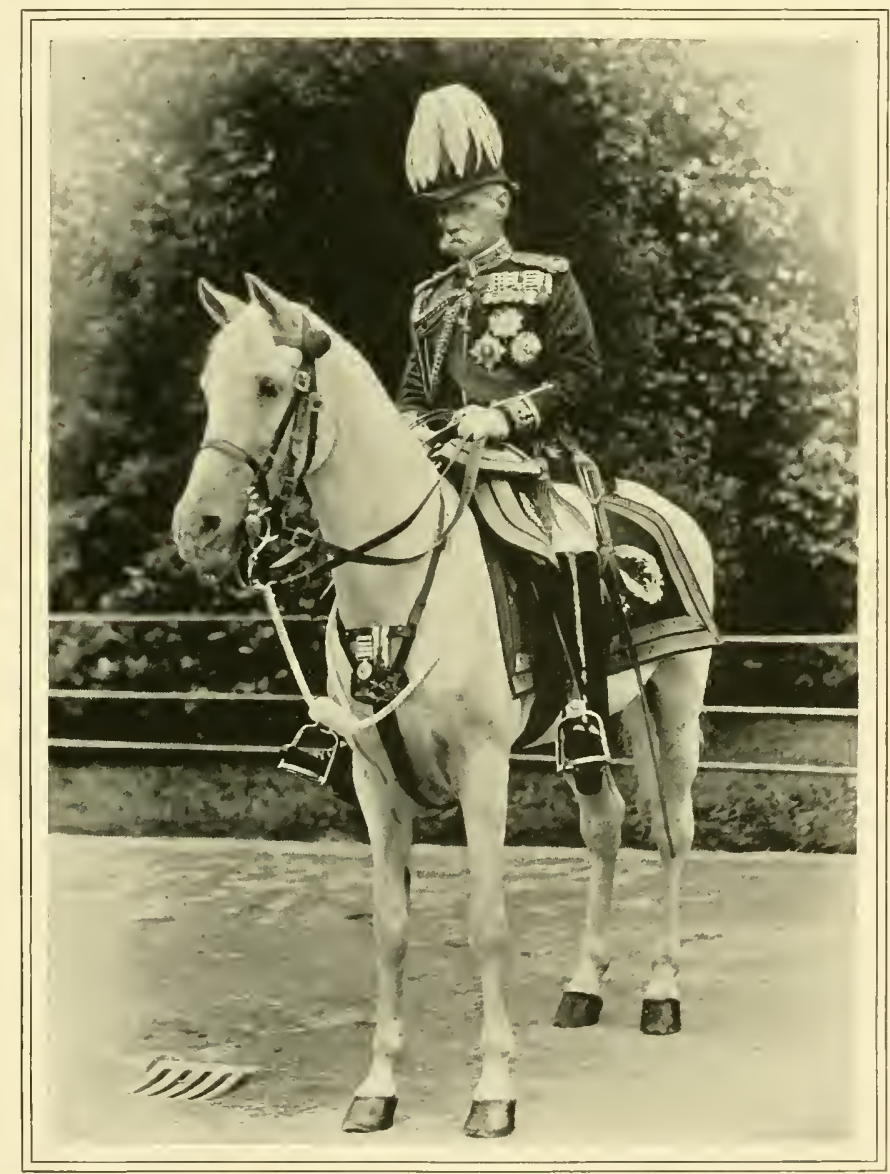

LORD ROBERTS' CHARGER, YOLONEL. 
landlord of the imn had three or four which he let out on hire, but only two of the tradesmen had a single horse apiece-one of the two butchers, and the grocer.

Quite latery we revisited the place, and, though the village was not appreciably larger, it should be mentioned that the surrounding district had become much more populous, owing to the fact that coal mines had been opened up not many miles away. The country-side had, in fact, become a prosperous one, and though it was not quite so easy to ascertain the number of horses in the parish, it was at once evident that they had greatly increased.

\section{Increase of Horses}

Of carriage horses for double harness there were probably rather more than there had been, and there was a considerable increase in the number of governess cars, Ralli carts, and so forth ; and in and about the village were also some thirty hunters, whereas at the earlier date there had never been more than half a dozen. But it was with regard to tradesmen's horses that the great increase was chiefly visible. Instead of there being two to the whole community, there were from forty to fifty (including those for the farmers' milk carts) in and near to the village, while every day the place was visited by brewers' drays, mineral-water vans, and carts of all sorts from the nearest townsall these rehicles being horse-drawn.

The local anthority had become horseusers for the watering and cleaning of the streets, and every tradesman in the place had taken to sending his goods out, this being an innoration (in this particular district) of comparatively recent date. In fact, when we first knew the village only two tradesmen delivered goods, and their rounds were only bi-weekly-when they practically took part of their stock-in-trade with them, and sold from the cart.

On the whole we came to the conclusion that there were twice the number of horses in the parish that there had been at the time of our former residence, and yet many of the wealthy residents used motor cars -but kept horses as well. This brings one to the opinion that, no matter how much motors may be used, they cannot altogether supersede the horse in the comtry districts. It the moment we do not concern ourselvis with sport, but may state with confidence that for years past the increase in the number of horses required by country tradesmen has been a steady one.

\section{The Sporting Instinct}

It is, moreover, somewhat unlikely that motor vans will ever be greatly used by the smaller tradesmen. Not only is the initial cost much greater than the cost of a horse and trap, but it has to be considered that the Enghish are still to a great extent a horsey nation, and that probably a majority of country-bred tradesmen would sooner own a smart business cart and cob than a motor van. Butchers, for example, are nearly always sportsmen, and the same may be said of innkeepers, auctioneers, and many others. The sporting instinct inclines to something smart in the way of horseflesh, and thus it happens that in many country neighbourhoods there will be quite a ligh standard of excellence amongst the tradesmen's turn-outs.

\section{Tramway v. Horse}

Neither are we inclined to think that electric tramways have interfered very much with horses, except where they have driven umnibuses off the road. The tramway carries no luggage or goods, and can only be utilised for going from one fixed point to another. It is not exactly popular for long journeys, because the frequent stoppages cause such numerous delays, but it is exceedingly popular with the man or woman who wishes to travel a short distance. That tramways carry more passengers than the horse 'buses did we feel fairly certain, but what we wish to point out is that the very fact of there being a tramway from one point to another has caused all sorts of people to use the tram, who would lave walked had there been no tram available.

At the same time it must be admitted that in London and other big towns horses have been greatly superseded by mechanical 


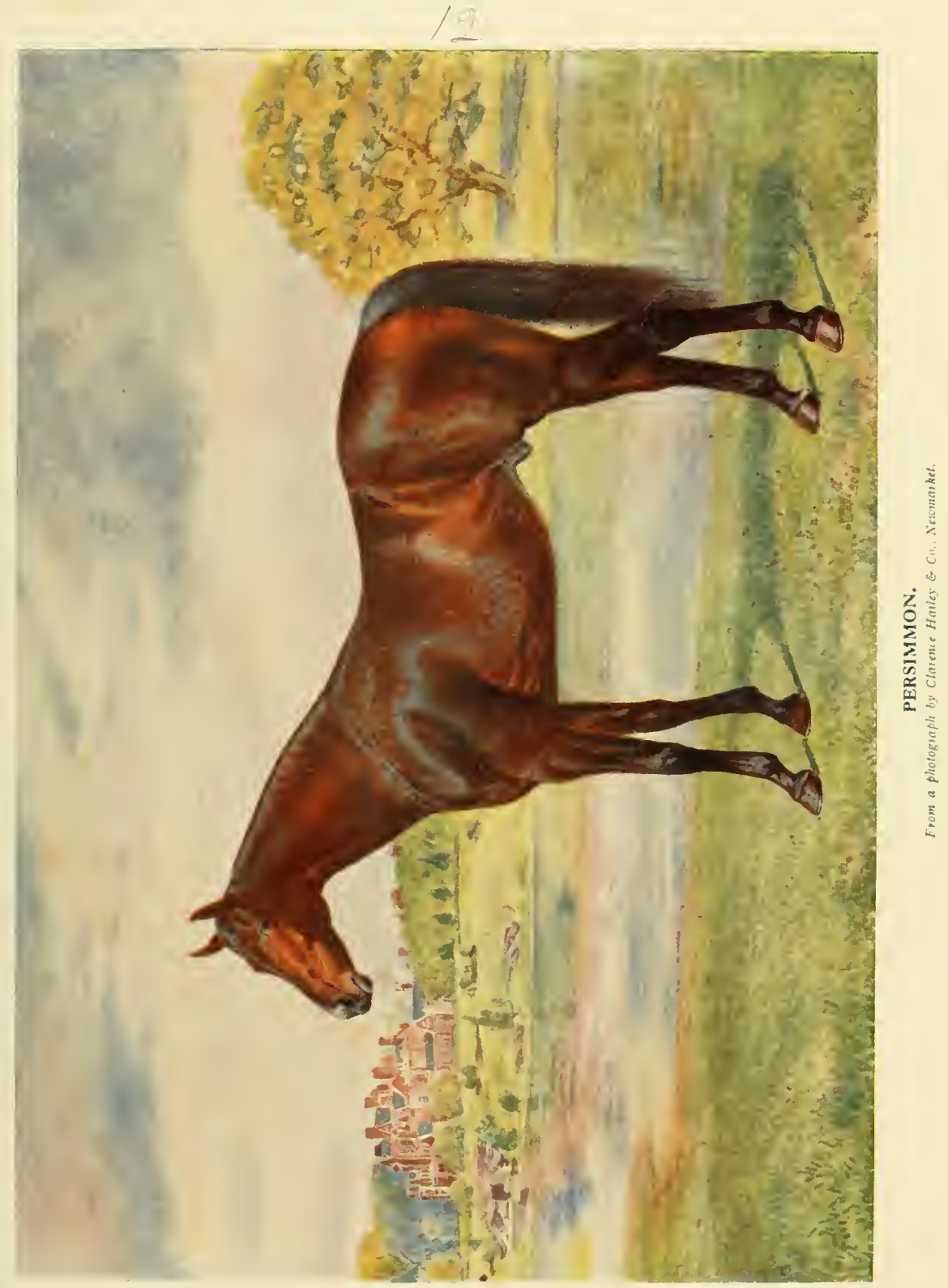



traffic, and that a certain number of people have replaced their carriage horses by motor cars. We are, however, inclined to think that the damage to what may be called the horse industry is not so great as it has been represented to be, and in confirmation of this opinion we may point ont that an enormous
It is also a fact that there is a falling off in the horse birth-rate, for on July 6th, 1908 , Lord Carrington (Minister of Agriculture) stated in the House of Lords that there were 10,000 fewer foals in Igo6 than in 1905. His lordship also stated that the known number of horses in the country was

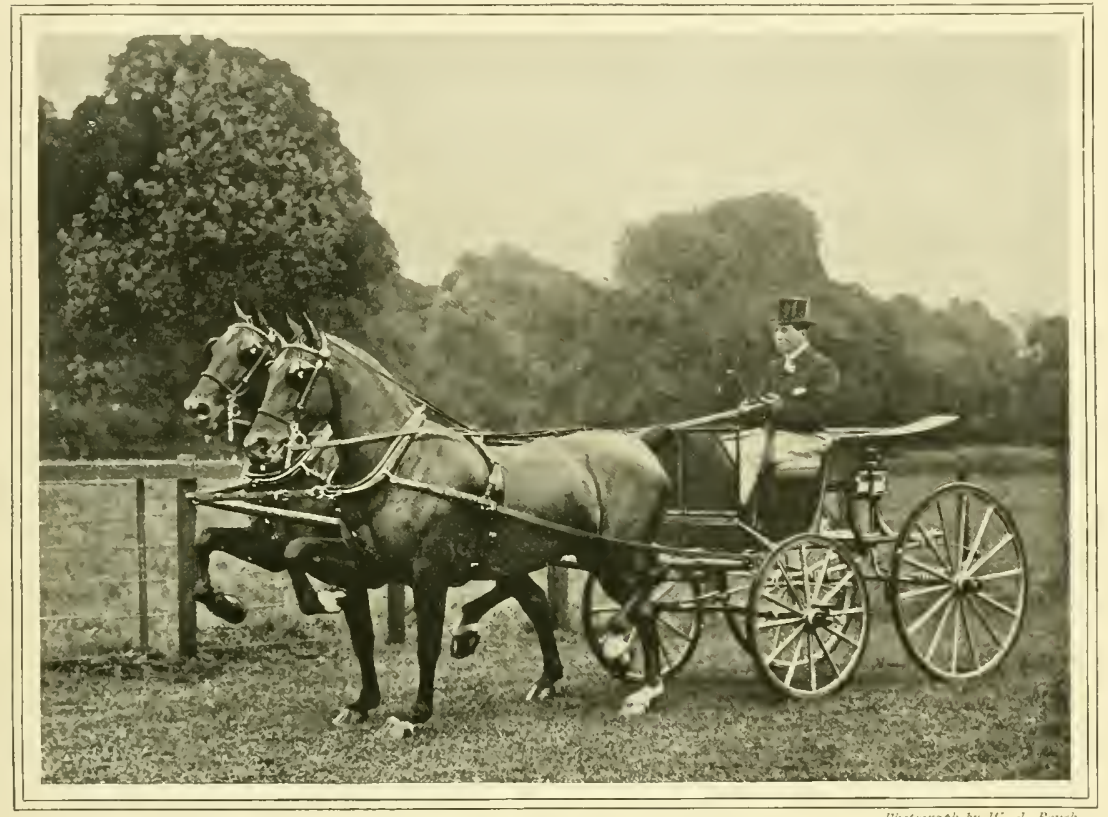

MR. JOHN KERR'S CHAMPION PAIR, LOUDWATER GONGELT AND GRANGELT.

number of motor-car owners (who keep no horses or carriages in addition to their motor cars) began their road-driving only after the introduction of motor cars, and had previously never kept horses at all.

As to what the future may have in store with regard to the horse it is impossible to say, but the best and worst of the present state of affairs can be briefly put forward.

To begin with the darker side of the question, there is absolutely no doubt that for street work of almost every kind the horse is being superseded in London and the big towns, but not yet in suburban districts and the smaller country towns.
2,089,000 of agricultural and young horses, but the horses in the towns were not included, and apparently no notice had been taken of working horses in the country, other than farm liorses and young stock.

The decline in the number bred is probably due in some degree to the adrance of mechanical traffic, but not entirely so, for the cost of rearing is heavier than it used to be, and only poor prices are forthoming for the many moderate animals which are from time to time put on the market. To this subject we shall refer a little later.

Looking at the brighter side of the question, it may be stated, firstly, that good horses of every particular breed are at the present 
time (in all probability) better than they have ever been before.

Secondly, that for the best horses of every variety an all-round higher price than has ever been known is now obtainable.

Thirdly, that the demand for the best sorts, for what may be called extraordinary would be artillery horses, and the others would be heavy draught horses necessary for the Army Service Corps and the wagons. The total of $17+, 000$ includes the horses for the Territorial force.

This was the state of affairs with regard to Army requirements in July, Igo8, and

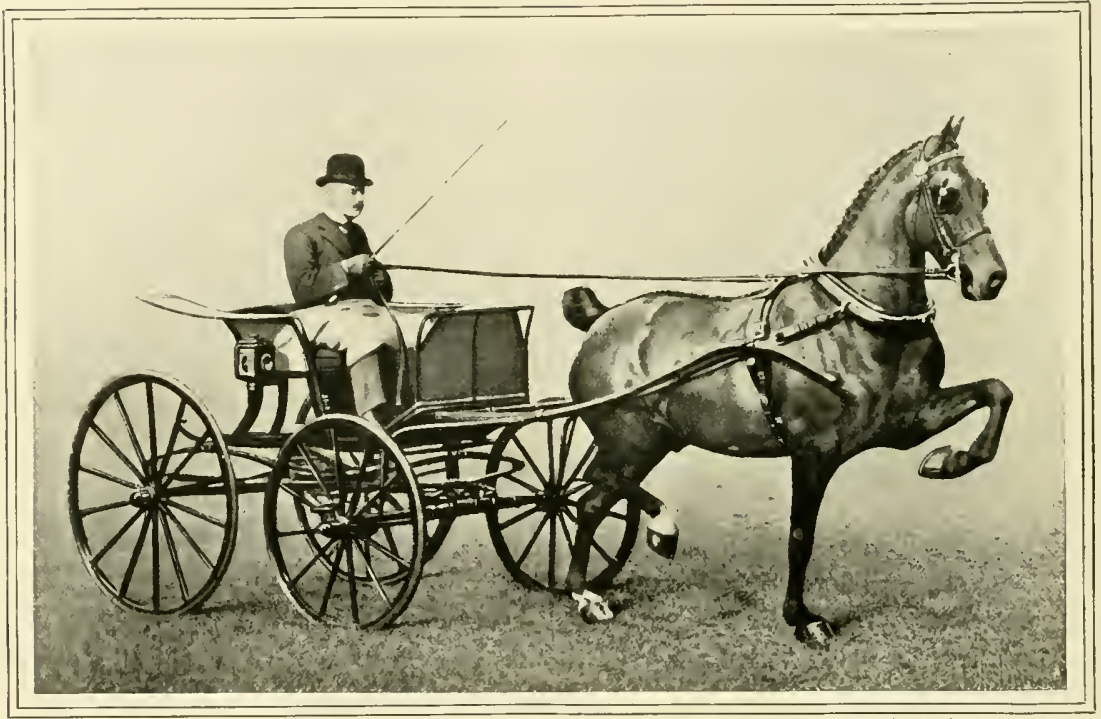

MR. GERALD JURGENS' CHAMPION HARNESS HORSE. RADIANT

purposes, is bigger than it ever was, that it still shows an increase, and that such increase is likely to continue.

We may now briefly consider the principal uses to which horses are put in this country; and, beginning with Government needs, there are the Army horses to be considered. The number required for this purpose in times of peace is not really great, but it is an imperative demand, for so far there is no immediate sign of the horse being superseded in warfare. The Army buys 2.500 horses annually in times of peace; 70,000 would be required on mobilisation of the Expeditionary force, and the total number of horses required to bring the units up to war establishment is 174,$000 ; 59,000$ of these would be cavalry horses, a certain number we may take it that there has been no great change since that date. But whereas the Government of the day has hitherto done nothing towards ensuring a supply of horses for itself, a scheme has now been formulated which has for its objects, firstly, the making certain that horses for Army use will always be on hand when wanted, and, secondly, the keeping in the comtry of a large number of mares and stallions which might otherwise be sold to foreign buyers.

Here it may be as well to explain that the Government has never, until quite recently, concerned itself with the horse question, and that its present action is the result of agitation on the part of two sets of people, the military authorities, and the country residents-landlords, tenants, and 


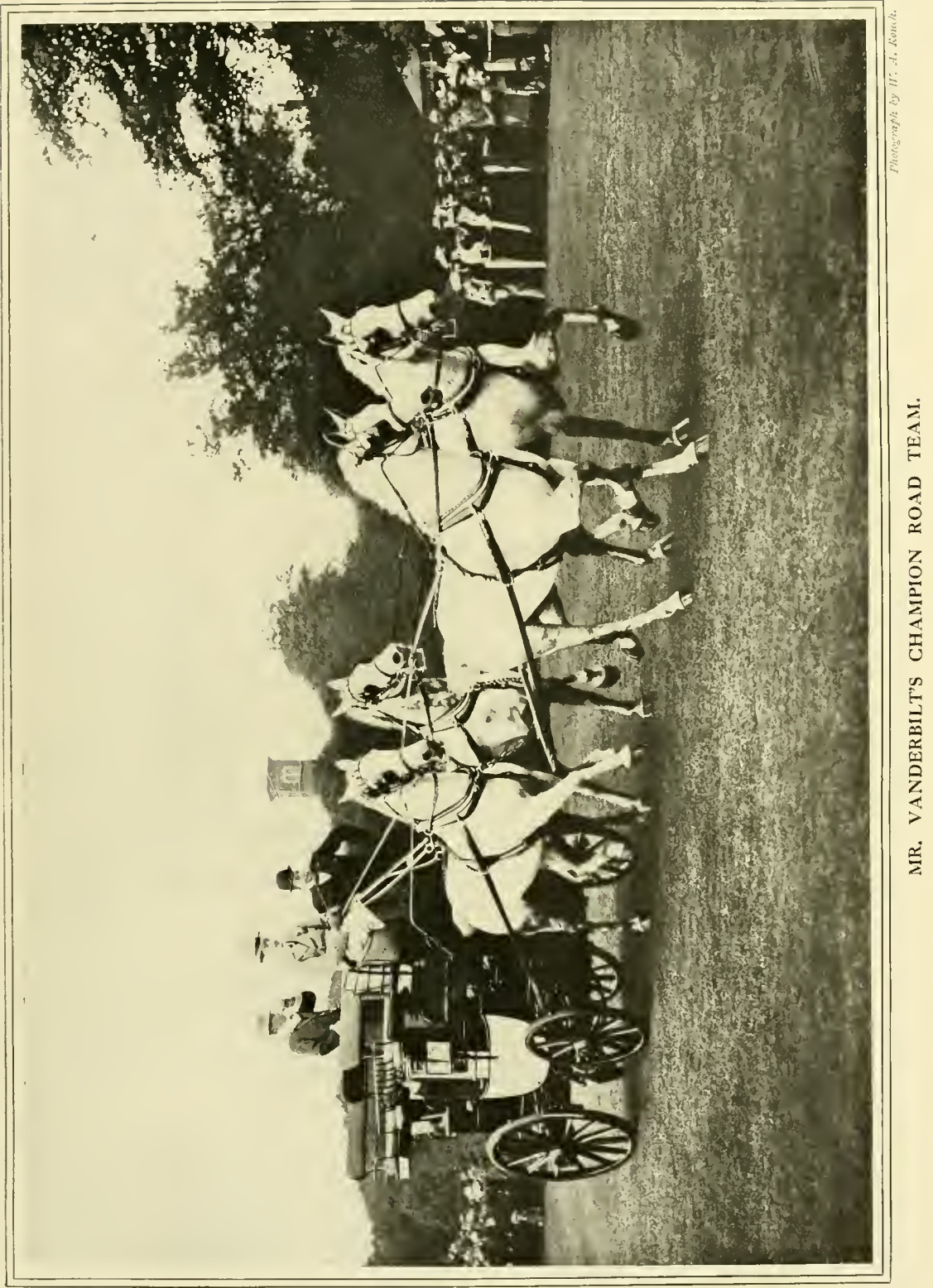


others-who were interested in the lorse industry, and who could not help seeing that the continual selling of breeding stock to the foreigners was having a serious effect upon the native supply.

\section{The King's Plates}

For a period of over a hundred years the King's or Queen's Plates comprised the only sums which were given by the State to linise-breeders, and these amounted to about $£ 5,000$ in England, and rather under $£ 2,000$ in Ireland. The money was split uj inte amounts of $f r o o$, and was run for, as a rule. at the old-fashioned race meetings, being given for long-distance races, so that stamina in loorses might be encouraged. In England the establishment of the enclosed park race neeting, and the Jockey Club rule that no flat race should be of less than froo in rolue, caused the King's Plates fther were Quecn's Plates then) to become of exceedingly minor importance.

There were two reasons for the collapse, one being that the froo rule caused scveril country fixtures, at which King's Plites were rum, to disappear from the list of mectings, and the other that the competition of the gate-money courses led to an allround increase in the prize lists of the most important meetings, and this. naturally cnongh, caused the froo weight for age plate to become much more insignificant than it had been.

\section{Decline of "Platers"}

Such a horse as Fisherman, and such mares as Caller Ou and Lilian, had in their day farmed the plates, but even the winning of a great number by one and the same horse wats---provided the horse was a really good "ne--of less consequence than having these races contested by " platers." A little carlier it had been worth while to keep good horses for the King's Plates, but the all-ronnd increase in money prizes altered this very greatly. At the present day there are scores of races which are not worth more than fioo, but they are not contested, as a rule, by valuable horses, and certainly not by the sort which are likely to improve the breed.
We need not go further inte the reasons why the King's Plates disappeared, but it may be mentioned that they are still run for in Ireland, where there is no froo rule. What happened with the money - which, by the way, is an annual grant from the Privy Purse-is that it was diverted from racing to horse-breeding, and became a small subsidy to be divided amongst the owners of thoroughbred stallions.

\section{Premium Stallions}

A Royal Commission on Horse-breeding was appointed, and this Commission found itself with a clear sum of $f+200$ to give away. The amount was divided into twentyeight preminms of $f \mathrm{r} 5 \mathrm{O}$, and these have been awarded every year since. The awards have been made by carefully selected judges at a show lield at the Agricultural Hall, Islington, in March, and the greatest care has been taken that no horses suffering from hereditary or other unsoundness should be found in the prize lists. Every competitor for a King's Premium has, in point of fact, to be clear of roaring (or whistling), ringbone, unsound feet, navicular disease, bone sparin, and cataract; and to ensure this, careful reterinary examinations of all the candidates are made by some of the greatest experts of the day.

The prizes lave been offered for thoroughbred stallions between four years old and twenty, on the condition that each stallion should surve not fewer than fifty half-bred mares (if required) during the season, and to stand or travel, as the Comnissioners might direct. The fee in every case has been $£ 2$, and $2 s$. $6 d$. for the groom, and the country has been parcelled out into districts, and the horses divided accordingly. Thus, Yorkshire has had three sires, three have stood or travelled in the Home Counties, thrce have been located in the Midlands, and four in the ten counties ranging from Kent on the east 10 Cornwall in the west. Four have also be'n established in the western Midlands and south Wales, three in Cheshire, lancashise, and North Wales, and three in Cumberland, Westmorland, Northumberland, and Durlaum; while five have 


\section{THE HORSE IN THE UNITED KINGDOM}

been apportioned to the various districts of Scotland.

\section{Inequality of Distribution}

The division has been as equal as the circumstances would admit of, but from the very commencement the funds have not allowed of anything like a sufficient number of stallions being placed up and down the conntry; and how easily this can be shown is proved by the fact that all along the nearly foo miles of southern seaboard only four horses are allotted, while an enormous colmty like Lincolnshire, where some of the best horse's in the kingdom have been bred from time immemorial. actually has to share a horse with Notts. Yorkshire, still the greatest liorse-breeding comnty in England, is as badly served as Lincolnshire; and to sum up, there should be at least Ioo frovernment stallions, instead of twentyeight, to make sure of a majority of small breeders being in a position to avail themselves of the clance of a sound horse at a reasinable fee.

\section{An Admirable Result}

At the same time it must be conceded that t]e plan adopted by the Commissioners has answered admirably, as far as it lias gone. Not every breeder, not even every loorsebreeding district has profited by the placing of these stallions-simply because there have not been enough to go round-but where the stallions have been arailable the results have been most satisfactory : each of the favoured districts is now in a position to show allround improrement in its locally-bred horses.

In proof of this assertion we may quote from the Eleventh Report of the Royal Commission on Horse-breeding, in which the following passage occurs :-

"That the young stock is turning out well is proved by the fact that during I905, at the different summer meetings at which medals are awarded by the Hunters' Improvement Society, 446 awards, ranging fr m Champion Prizes, Gold and Silver Meda!s, etc., down to fifth prizes, were gained by animals sired by Premium stallions; whilst in I906, 329 similar awards were secured by the produce of the Premium stallions."
This is rery conclusive proof as to the efficacy of the system, and the fact that the Premium sires have played a strong part in the improvement of the ordinary English horse-the animal which is liunted, ridden, or driven, according to his fitness, and which in ninety-nine cases out of a hundred is of no particular breed, by which is meant that it is not eligible for any of the recognised Stud Books. More evidence on this head conld be produced if it were necessary, but we have submitted quite enough to show that the system adopted by the Royal Commission on Horse-breeding of spending the small amount of money at their command has been an admirable one.

\section{Horse in Agriculture}

If it is allowed that horses for military purposes are the most important equine requirement of the nation, the agricultural horse must be considered to rome next, and at present there seems to be little reason to think that motor traction will be a serions rival to lorseflesh in this connection. The steam plough has been in use for nearly two generations at least, and one sces it here and there in work, especially in flat, level countries. But it has never seriously rivalled the horse, and we have known farmers who gave it a fair trial and then decided that horse ploughing was cheaper. For many years most of the threshing of corn has been done by steam, all orer the country, but eren the old-fashioned plan of working the threshing machine by horse power is not yet extinct, and during the autumn of rgos we saw one of these machines at work, at a farm which is situated near the village of Littleton in Middlesex, and not more than seventeen or eighteen miles from London.

Four years ago we saw a motor plough in operation near Biggleswade, and it appeared to work well, but motor ploughing has made little or no adrance since then; and in point of fact the motor is not much used for farm work, and at present no great amount of agricultural produce is carried by motor wagons. In undulating countries the steam plough is always at a disadrantage, and it is probable that if motor ploughs ever 


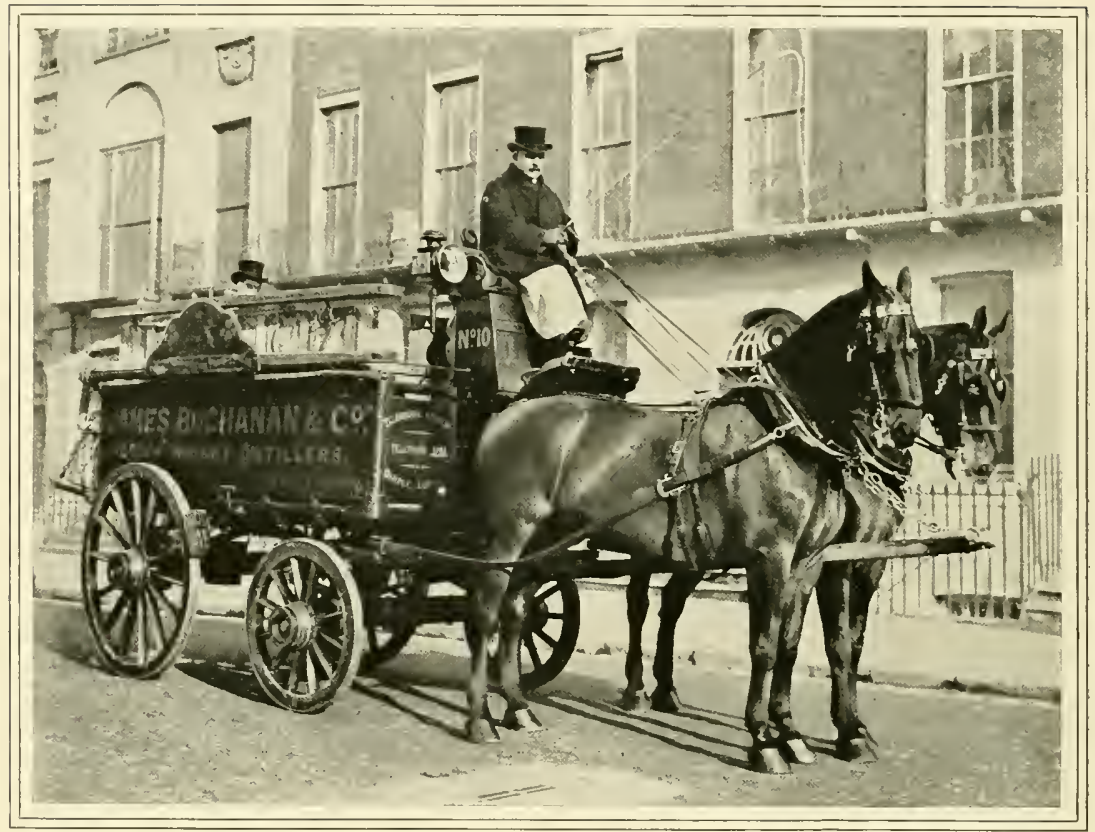

A PAIR OF VANNERS.

become common they will be mostly used in flat countries.

Supposing that motor traction in various forms becomes common, or fairly common, for agricultural purposes within the next few years, it will probably be very greatly localised. That is to say, in certain districts where the land is fairly level, where there are good roads, and where there are many and good markets, motors of sorts may replace horses in some considerable degree, but this will only take place in such farming districts as are comparatively rich, where the holdings are large, and where the tenant farmers are possessed of capital.

The small farmer, who exists in thousands all over the country, but more especially in those districts which are high-lving, wild, and remote, will most certainly stick to the horse, if only because he can breed stock from his working nags. Nares which do slow work on a farm can be used for ploughing, harrowing, sowing, or any cart work until they are almost due to foal, and even after foaling they are quickly at work again, the foal often being taken to the fields where the dam is working, in order that its natural sustenance may be administered. Moreover, the average farmer, who is a working man, and not merely an overseer and director, such as many a large farmer is, would never take the trouble to concern himself with learning all about the machinery of the motor. Horses he understands, and of course he knows the value of the manure which he obtains from them, but machinery as a rule he dislikes, though he is glad enough to avail himself of the services of the threshing machine when they are available.

The return in manure alone is enough to ensure the horse being kept everywhere in this country for agricultural purposes, and it may also be borne in mind that the occupation roads on many farms are totally unfit for any machinery but the very roughest, while in the hill countries it is often 


\section{THE HORSE IN THE UNITED KINGDOM}

impossible to bring a steam threshing machine to the onstead. Indeed, one has known frequently of corn crops bcing stacked close to the public road, merely so that there should be no difficulty about bringing the threslsing machine into action.

We may now go on to what we have called the extraordinary uses to which the lorse is put in this country. Tlese may be enumerated as follows: racing, hunting, polo, and such fancy work as breeding liorses for show purposes, and to supply a small but very lively market for high-actioned harness horses.

We shall not at the moment attempt to go into details, but may state that racehorse breeding is carried on as a hobby and as a business, and that there are, as a rule, between 6,000 and 7,000 brood mares at the stud. The breed not only prospers, but grows gradually larger, and it tends to improve the blood of nearly every other breed in the kingdom, except the heary horses, such as Shires, Clydesdales, Punches, etc. Nor is it used for breeding Stud Bonk hackneys, but all hackney blood came originally from thoroughbred blood, and even now there are breeders who at times resort to the thoroughbred cross, while really trying to breed harness horses of the highest class.

The thoroughbred must not, however, be considered from a numerical point of view, but because it is his blood which is used in making the liunter, the polo pony, and the general utility nag. In addition to the King's Premitum horses there are scores (but nevertheless not enough) of thoroughbred sires scattered about the country, which are privately owned, and which are mated with light mares of every description, from the cob of $\mathrm{r}_{f}$ hands or so, to the cart mare who is fairly clean about the legs. 1reland, too, lhas 400 of these thoroughbred sires.

If all of them were chosen with as much care as is taken in choosing the King's Premium stallions, the average half-bred and quarter-bred horse would be far better than it is, but unfortunately many of these

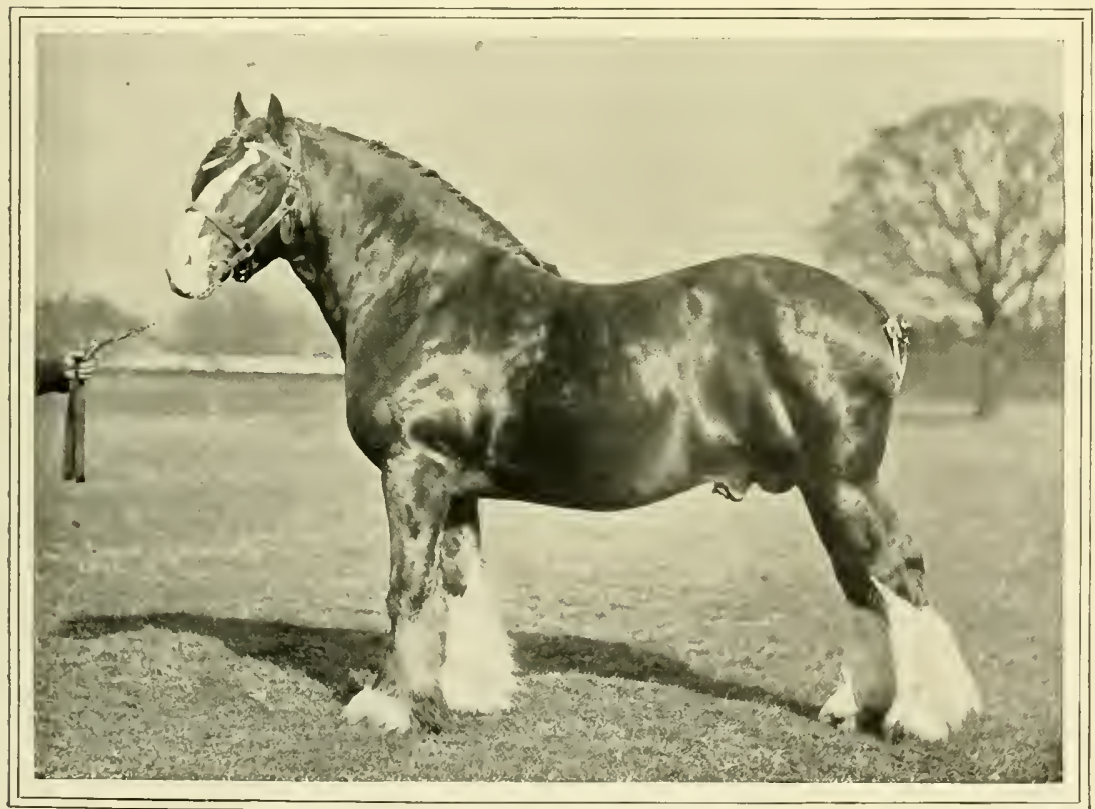

MIR. EDGAR BAXTER'S SHIRE HORSE, CALWICH MARKSMAN.

Prows rapht by $1 r^{\prime}$ A. Fouch. 
privately-owned comtry sires are of little value, and a good many of them are a fflicted with hereditary unsoundness of some sort or other. In certain districts the privatelyormed local sires are quite as good as the King's Premium horses, and this is especially the case where masters of hounds or hunt committees kecp stallions for the use of the firmers within the confines of their hunt.

\section{Lord Middleton's Stallions}

We may instance Lord Middleton, who is master of a pack of hounds which launts over a large district in the East Riding of Forkshire. At Birdsall, near Malton, where the kennels are situatcd, hunter breeding is also carried on on a large scale, and several stallions are kept for the nse of the tenants of the estate and the farmers of the hunt. These horses are chosen with consummate judgment, and are as good as could be procured unless really great race-horses were chosen. Great race-horses can, however, command a big fee for thoroughbred mares, whereas the stamp of liorse which Lord Middleton and other masters of hounds keep is the second-best sort of race-horse, the animal whose breeding and general appearance are equal to those of the classic winners, but whose performances on the race-course were not quite good enough to ensure him a profitable supply of thoroughbred mares.

\section{Speed Consideration}

In breeding race-horses, speed must be largely considered; therefore it is that all the really big winners are given a chance of making a name for themselves. "By making a name one means siring horses which in turn are good enongh to win races. If a stallion, after he has left the course, begins to furnish an output of winners, his success is assured, for some years at least; but if his progeny run without distinguishing themselves, the horse ceases to command patronage, and then very often becomes a half-bred stallion, and is used for lumter mares.

To give an instance of what we mean. A horse named Macgregor won the Two Thuusand in $187^{\circ}$, and started an exceedingly loot fasourite for the Derby. In that race, however, he broke down. After a time he went to the stud in the North of England, and though he sired a great number of small-race winners, and was actually responsible for the Two Thousand winner, Scot Free, he was not altogether a stud success, and, as it happened, he was allowed to cover a few half-bred mares. From these he sircd light-weight hunters of a very elegant type. Ther were, for the most part, rather short of bone, and were not built on a large scale, but they could jump like stags, and no day was too long for them.

Nacgregor of course had absolutely firstclass speed, but in the average hunter sire of the present day size, bone, soundness, and good looks are sought for. and breeders will be contented with what may be called secondary speed. In hunters, speed is of course necessary, but not quite in the same way that it is for racing, and the arerage thoroughbred liunter sire can give his progeny quite enough speed, provided that the mare he is mated with has a certain amount of blood on her side, and is not built in too heary a mould.

\section{Racing and Hunting}

This, however, is a digression, and, returning for a moment to our original statement, it may be emphasised that racing is the chief horse sport of the British people, and that it is never likely to lose its hold on the nation. We may take it that horses will always be bred for racing in England and Ireland, and a few in Scotland, and tlat, as at present, the cast-offs from the turf will be used as hunters, harness horses, hacks, and so forth.

As regards hunting, and the demand for horseflesh which it entails, it mat at once be said that there are at the present day more people following hounds regularly on horseback than ever there were before, and this, of course. means that there are more hunters kept than at any previons period of the sport. It is, of course, no easy matter to get thoroughly reliable statistics as to the exact number of hunters which are being constantly maintained in the United King- 
dom, but certain figures were prepared some ten vears ago br an accepted authority, and there is every reason to belicre that these figures give a rather low estimate.

\section{Number of Hunters}

The authority in question is Mr. Richard Ord, at one time IIaster of the South Durham Foxhounds, and for many years secretary of the same pack. IIr. Ord reckoned that a total of something like 200,000 hunters wats being constantly maintained, and that the actual value of these hunters was $f$ ro, 000,000 . Is to the value, it will be seen that an allround average of $f 50$ for each horse is taken, and if we follow the sales of hunters which are being constantly held at Tattersall's in London, at Leicester, and other places, it will be seen that $£ 5^{\circ}$ is anything but a high figure. In point of fart, hundreds of hunters are sold by auction every year at prices ranging between froo and $f_{5} 500$ (at times for (xen more money), though the rank and file of hunters in a provincial comtry may not average more than $f 50$.

Is for the total of 200,000 , there is little reason to doubt it, as there are (broadly) about 300 packs of hounds in the kingdom which are ridden to. If we allow an average of roo regular riders to every pack, we have a total of 30,000 hunting men and women, but it is probable that there are far more, because of the countless number of penple who do not hunt regularly, but have odd days when the chance allows. In many of the Midland and other fashionable districts, fields will be seldom less than 200, and at times will be as high as 500 , and in scores of good but not quite so fashionable countries the average will be well over roo per day. Then it must be considered that a few packs hunt six days a week, one or two are out on five, and about threescore hunt on four of the six available days, while no pack does less than two days a week.

\section{The Change of Mount}

If an average is struck, it will be found that during the season about roo packs of hounds, which are followed on horseback, are ont on each of the six days of the week. .1l over the Midlands, in Meath and Kildare, in Cheshire, the Blackmore Vale, in the principal Yorkshire hunts, and in such northem countries as the Trnedale, Norpeth, and Lord Percy's, second horses are in very general use, and eren in provincial hunts which are more remote, and less fashionable, a certain percentage will be used.

In all the crack countries, master, huntsman, first and sometimes the second whipperin will have two horses out on every hunting day, and in some cases a third. And with every foxhound pack, master, huntsman, and some of the ficld will have a change of nounts. In the Shires-and elsewhere to some extent-ladies will also have two horses out, and though there are still many hunting folk who stick to a single horse, and go home when it has had enough, the custom of using two horses is most certainly becoming more common every day.

\section{Two Horses Necessary}

Where hounds travel fast-and they generally do in grass countries-two horses are an absolute necessity, mless the rider is content in the aftemon with a rearward position when the pace is good. Many packs, too, are taken from one covert to the next, when drawing, at a high rate of speed, and in point of fact the one-horse man is on many days unable to see all the sport properly. Only last season we were at some trouble to count the horses out on one particular day with one of the best of the provincial packs, which possesses a fine grass country.

At the meet and on the way to the first covert we counted 139 riders; afterwards fresh arrivals were constantly seen, but, on the other hand. one or two groups of schoolgirls, and a few others, quickly dropped out and went home. About two o'clock the field had dwindled to about eighty, and we gathered that some five-and-thirty second horses were being ridden. We also discovered that half-a-dozen riders had a third horse out, and one man-who at times does a little amateur dealing-had no fewer than five in the field. In the moming a majority of the field had driven 
to the meet, or had ridden their hunters on. some seventeen carriages and dogcarts of sorts had been seen (in addition half-a-dozen motor cars), but this did not include all the carriages used, for we were at some trouble to inquire, and found that quite a fair number of people had driven so far on their road to covert, and had got on to their liunters a mile or two short of the fixture.

On the whole. we were of opinion that about thirty horses had been used, a few in double but more in single harness, to bring people to the meet, and that not more than half-a-dozen of the field had used a liack. (One who had come a long distance had not only a hack to ride to covert, but a a second, carefully "placed," to help him on his homeward journey, but he was rather of the old school.)

We also considered that about ninety of the 139 riders in the neighbourhood of the meet were legitimate, or regular hunting men and women, the forty-nine being casual riders out, girls who had to be in the schoolroom after luncheon, stud grooms, and the rarious "irresponsibles" who always cast up at every easily-reached meet of every popular pack.

\section{Second-Horse Men}

The second-horse men, except an odd one or two who had brought their masters' first horse as well, were not to be seen at the meet; and for the benefit of readers who are not conversant with all the details of hunting it may be explained that the second-horse men as a rule follow on in a body after hounds, keeping as much as possible to the roads, and not attempting to gallop across country.

\section{Horses, One Hunt}

Making a grand total for the day, we came to the conclusion that, including hunters, the horses of the casual meet attenders, and the hacks and the harness horses, at least 200 animals had been used in this one day's hunting. Over and over again we went through the calculation; we actually -in conjunction with a friend-made a list of those who were present, marked out tine regular hunting men and women, ascertained almost exactly who had second lorses out, and so forth. We were, in fact, practically certain that 200 horses for the day was a low estimate. On other occasions we made rough attempts at counting, and these always confirmed, to a great extent, our previous figures.

\section{Feminine Majority}

It is, then, our opinion that, except in some few isolated and extremely provincial hunts, the arerage number of horses used each day for lunting, hacking to the meets, driving either way-and in this connection it must be remembered that on all fine days in good countries there are many driving parties who follow hounds as near as they can, for a considerable part of the day - may be put down at about double the number of the regular hunting men and women. For confimation figures have been taken in a much smaller hunt, in a very outof-the-way district, and, of a field of twentyfive, eleven had second horses and nine drove to the meet, while in addition several carriages of lookers-on were present. Indeed in this particular case one made out that fifty-seven horses were being used for a field which consisted of master (his own huntsman), two whippers-in, twelve lindies, and ten men. It may be rather a revelation to some of our readers that more women than men were present, but for several seasons we hunted one day in each week with a pack in which the sexes were just about equally balanced, and where at times there were more ladies than men from the beginning to the end of the day.

The above has been written as proof that a very large number of horses is required for lnunting in the United Kingdom; and now mention must be made of two or three little matters in connection with hunters, which go to substantiate the fact that there must always be a huge reserve.

First, it must be stated that in scores, nay, hundreds of cases, the average hunter only comes out on one single day in each week. 


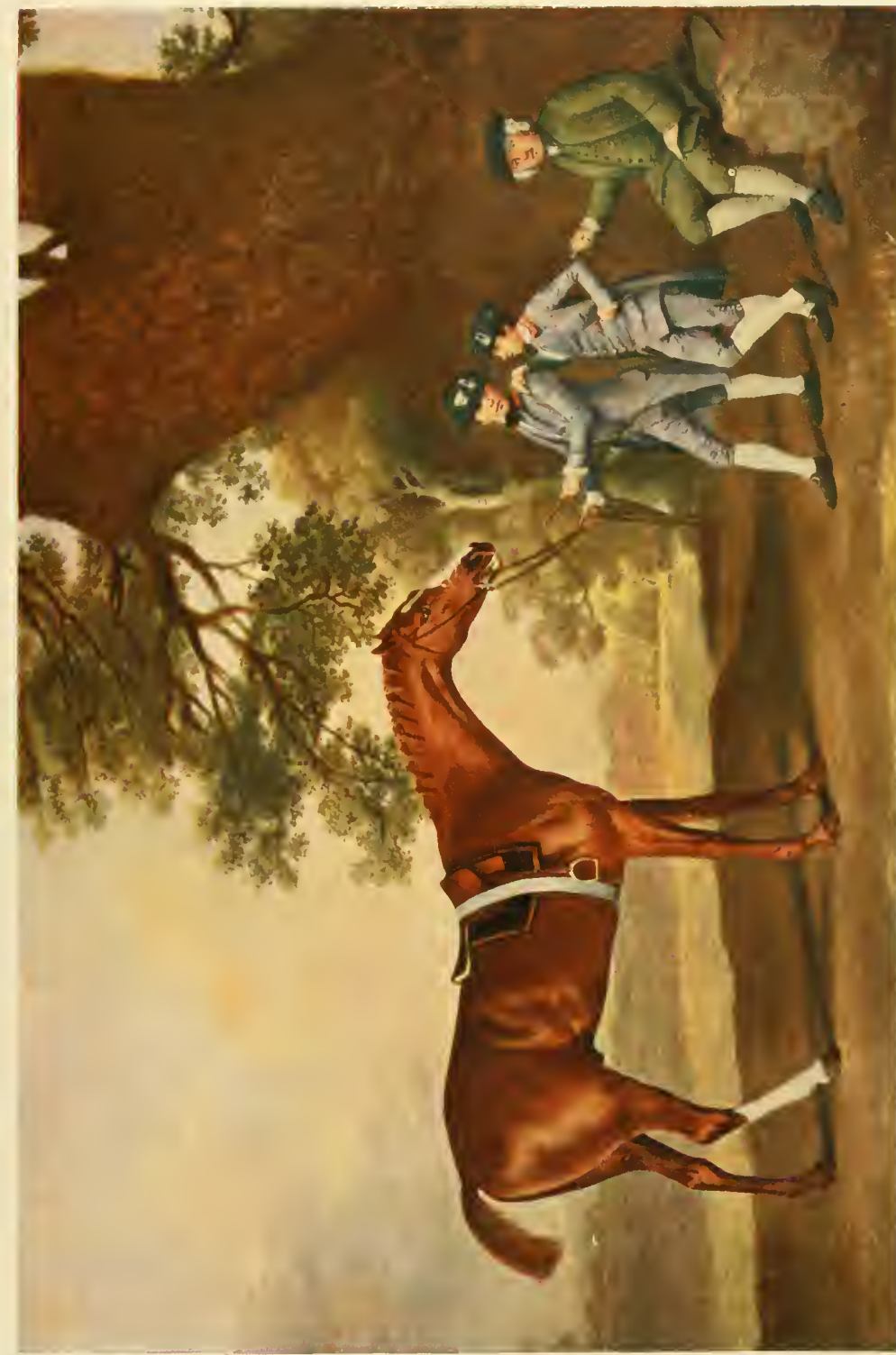

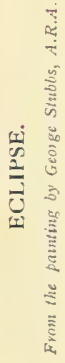





\section{THE HORSE IN THE UNITED KINGDOM}

Secondly, that hunters are constantly amiss from coughing, limeness caused by accident, or by unsoundness, temporary or otherwise.

Thirdly, that the stock of hunters on active service all over the country must of necessity be continually replenished. seasons entered in a htunting diary the names of all horses out on each day of huntingnot only those he rode himself, but thrse ridden by his huntsman and whippers-in, and by his friends. From these statistics it is easily gathered that the average liunter hardly does twenty days a season, and

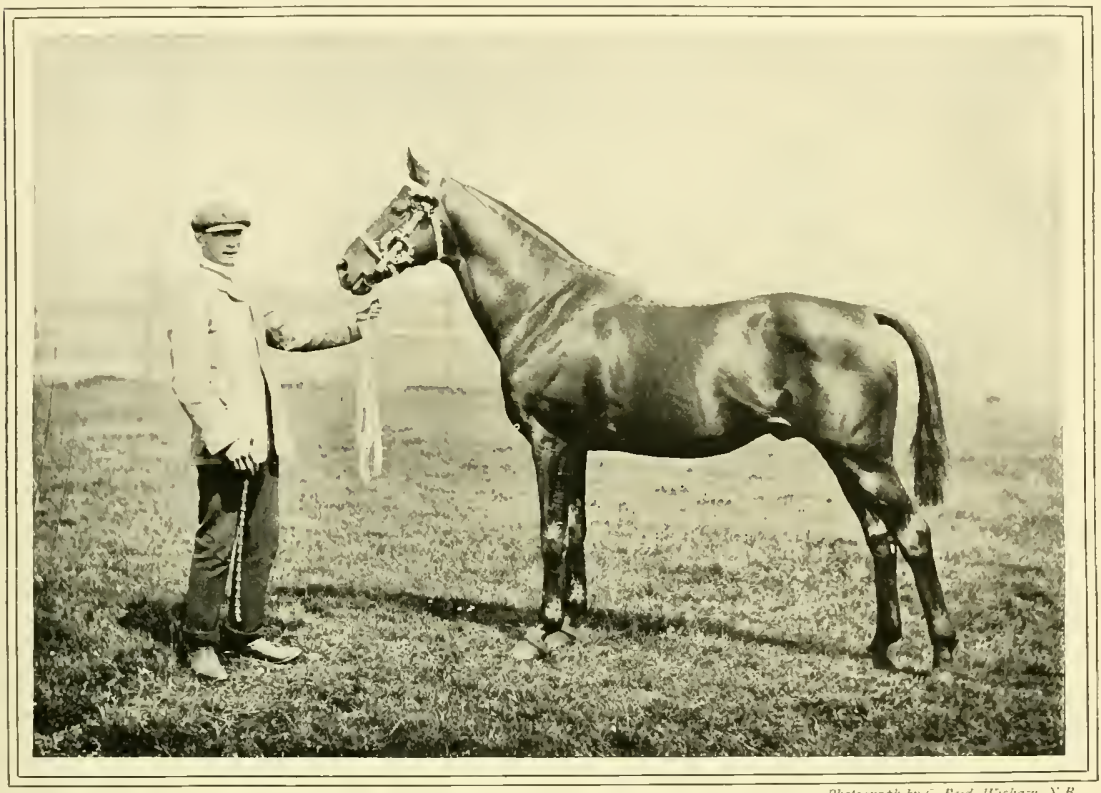

MR. STEPHEN MUMFORD'S POLO STALLION, SPANISH HERO.

Dealing briefly with these three statements, it is true that many hunters while in good health and condition are brought out for two half-days in each week; and that another considerable number do five and even six full days in a month, these being generally the property of men who only keep one or two hunters. But, on the other hand, only a small majority of hunters go through a season without being "off" work for some period of either long or short duration.

In this connection we have had the opportunity of looking over certain statistics which have been got together by a master of hounds of many years' standing. 'This gentleman had over a perjod of twenty that he lasts about three seasons and a half.

In point of fact, some number between seventy and eighty days would appear to be the average life of a hunter. It is true that many horses last eight, ten, and even a dozen seasons, but these are exceptional horses, and what has to be borne in mind is that many horses break down, others go wrong in their wind, and others again are drafted to less ambitious work. simply becanse they have been found to be short of pace or of jumping ability.

IIoreover, it is quite certain that in every large establishment, such as those maintained by masters of hounds, and by men who hunt constantly and also provide 
mounts for their friends, there are at any period of the season quite a large percentage of horses which are temporarily out of work.

We have known of a big hunt establish- seasons, it will be understood that the hunting community is constantly being refitted. And about this there can be no dispute. In every large stud there is a certain proportion of fresh horses every season, and as

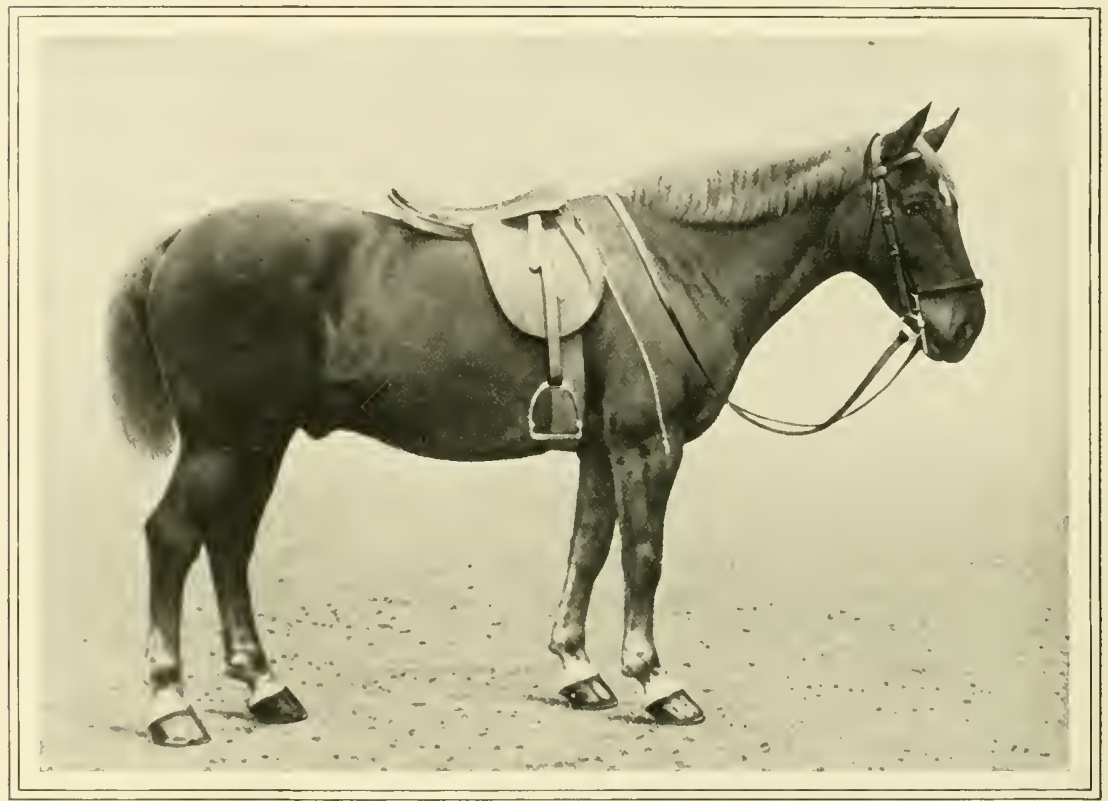

H.M. THE KING'S SHOOTING COB, IRON DUKE.

ment, in which from forty to fifty horses were kept, being only able to send a dozen out with hounds in the last week of the season, and we have known of a private stud of half-a-dozen horses, all of which were hors de combat when the season was only half completed. There is also a case of a hunt establishment which was visited by a severe influenza epidenic, when practically the whole stud was thrown out of work, and the hunt had to be carried on with borrowed horses. Further instances could be given, but our point is that many more horses are really required for hunting than would be supposed by those who have not gone into the subject.

As for the renewals, if the life of a hunter be taken at not more than three and a half a rule, unless there is a total absence of bad luck, additions have to be made during the actual season.

Looking for a moment again at Mr. Ord's figures, we have it stated that 200,000 hunters, which have cost their owners some fro,000,000, are always kept in the United Fingdom for hunting alone. To this it may be added that the supply is changed once in four years (to give a slightly better average of hunter life than what has been suggested above), and therefore, by dividing $f 10,000,000$ by four, we have it set forth with a tolerable degree of plainness that 50,000 fresh horses are required every year, for a sum which amounts to $£ 2,500,000$.

It would appear, then, that on the score of hunting alone the reign of the horse is 
not quite over in this country as yet, and it may be further pointed nut that hunting every year demands a lirger aggregate supply of horses-firstly, because there is almost certainly a steady increase in the number of people who hunt; and secondly, because hunting luxury is also on the increase, and far more horses are now used than was the case a generation or two ago. In other words, well-to-do hunting men and women maintain considerably larger studs than did the hunting men and women of a generation or two ago, for about the same amount of hunting.

As for polo and its requirements in the matter of horseflesh, the increase in the number of ponies kept is rapid and con- polo has advanced by leaps and bounds, and whereas it was at first only played in London and a few military centres, it is now exceedingly popular all over the country, and every year one learns of fresh centres of play. In and about London alone there are no fewer than seven polo grounds, and all through the provinces the number is steadily increasing, there being at present a total of eighty-four clubs in the United Kingdom.

In fact, during the last few years the demand for polo ponies has been very great indeed, and now breeding, and dealing in polo ponies have become important industries. There is in these days a Polo and Riding Pony Society.

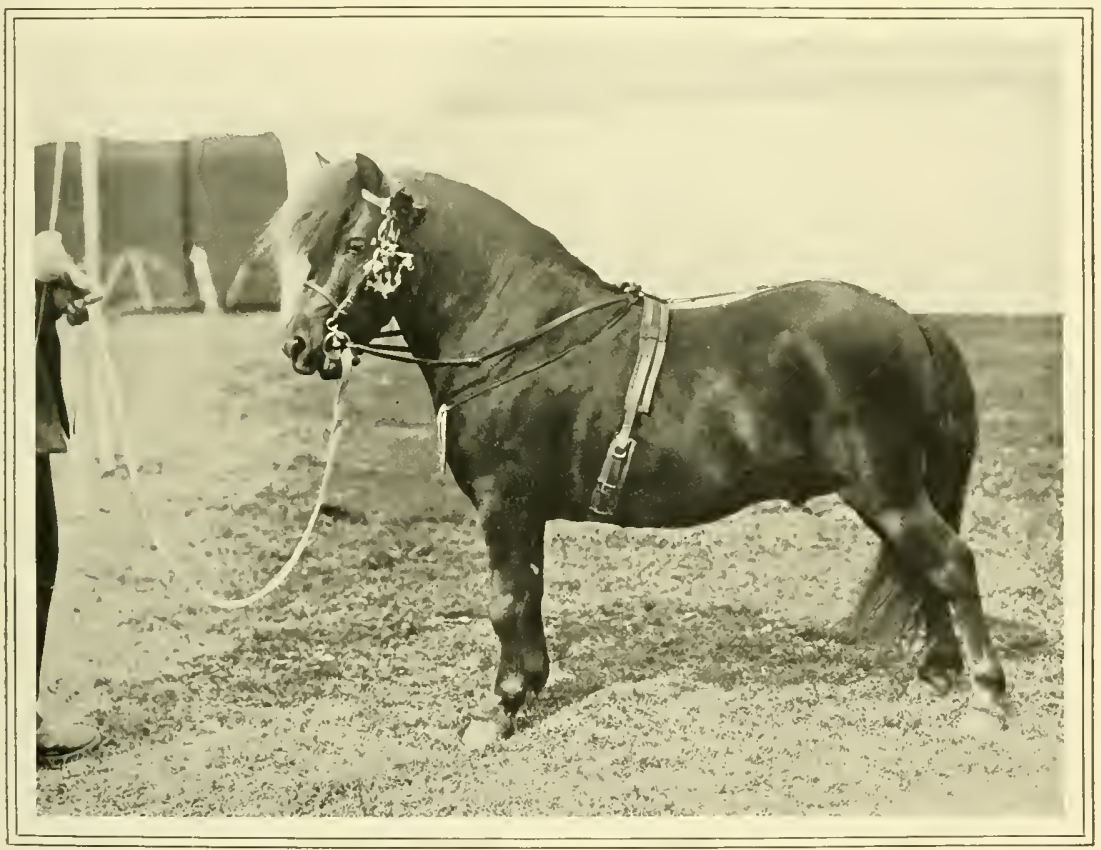

THE LADIES G. AND D. HOPE'S SHETLAND PONY, THOREAU.

tinuous. Practically, the life of polo in this country is only a little over thirty years, and for nearly half that period the growth of the gane was by no means rapid. During the last twelve or fifteen years, however, which holds an annual show at the Agricultural Hall, Islington, and of these shows, up to the present year, ten have been held. The show is continued over two days, and not only are there prizes 
for breeding stock of every age, but also for ponies which have been trained for polo, and for ponies which have been played.

How many polo ponies there may be in the kingdom one cannot say with eertainty, but it is the case that the game has become a much faster affair than it was a few years ago, the chief result of this increase of pace being that more ponies are now required. Very large studs are owned by all the principal players, and the tendency is to increase the numbers. Two and three ponies are used by every player in every important game, and even at the provincial grounds when ordinary club games are played there will be -at a rough average-from thirty to fiveand-thirty ponies on the ground when about ten players are taking part in the game.

\section{Polo Pony Stud Book}

There are, moreover, breeding studs where polo ponies alone are bred, and other studs where they share the farm with horses of some other breed. The Polo and Riding Pony Society has a Stud Book of its own, and the socjety has a big membership. At present, however, only a small proportion of the ponies regularly used for the game are Stud Book ponies, and it is of those which are not entered that it is difficult to form an estimate. The subject need not further be pursued here, as polo ponies will be treated of in due course, but it may be pointed out that the number of polo ponies is steadily increasing, and that probably there are in the United Kingdom not far short of 10,000 ponies which are being bred for or used in the game. The question of reserves, too, must, as with the hunters, be taken into account.

Lastly, we come to the sliow horses of fancy breed, and in this connection hunters need not be taken into account, for it is probable that the demand for hunters is in only a small degree affected by the horse show. Hunters are wanted because of the sport for which they are used, and polo ponies are wanted for the game. In either case the horse show encourages the breeder and sets the type, but hunting and polo would go on just the same if there were no shows.

\section{The Modern Hackney}

On the other hand, it is probable that the modern hackney would drop out if it were not for the shows, for the modern hackney is a fancy horse which is not actually required. He is, as a matter of fact, the finest harness horse in the world, but it is not absolutely necessary that he should be used, and he is to a certain extent sustained by the horse show. For the benefit of the minitiated it may be explained that the modern hackney is the beautiful harness horse of high action, arched neek, and fast pace who wins the driving prizes at the Agricultural Hall, at Olympia, Richmond, and at all the big shows of the kingdom. As far as pedigree goes, he comes originaliy from thoroughbred stock (on the side of the horse at least), and he is an almost perfect horse of his kind. He is oecasionally ridden, but is out of place under the saddle, and most thoroughly in place in the shafts, or alongside another of his species in double hamess.

\section{Importance of the Hackney}

The hackney will be treated of in his proper place, and he is only mentioned now in order that his intense importance to a certain section of the horsey world may be realised. It is perhaps not going too far to state that the horse show as an institution could hardly be sustained as it now is if it were not for the hackney. Shire horses, hunters, and polo ponies have, like the latkney, a breed show every spring, where the classes are confined exclusively to horses of each particular breed, and there are some few local shows of Shire or hunter breeding stock. But at the all-round show, where there are classes for all sorts of horses, the part played by the hackney is a truly important one.

It does not quite follow that every horse or pony which is shown in harness is a pedigree hackney, but probably nine out of every ten horses which come in to contest the driving elasses at the best shows are in the Hackney Stud Book, unless, indeed, they are American trotters or tradesmen's lorses. 


\section{THE HORSE IN THE UNITED KINGDOM}

This means that all the single and double hamess classes which are seen at such a show as Olympia are placed on the programme in the interests of the hackney, and it need hardly be sitid that if there were no harness classes there would, in all prob- is not exactly an old one. Some breeders have always been interested in producing a high-class stepping horse, and the East Riding of Forkshire and Norfolk especially concerned themsclves with this class of animal. But at one time trotting pace

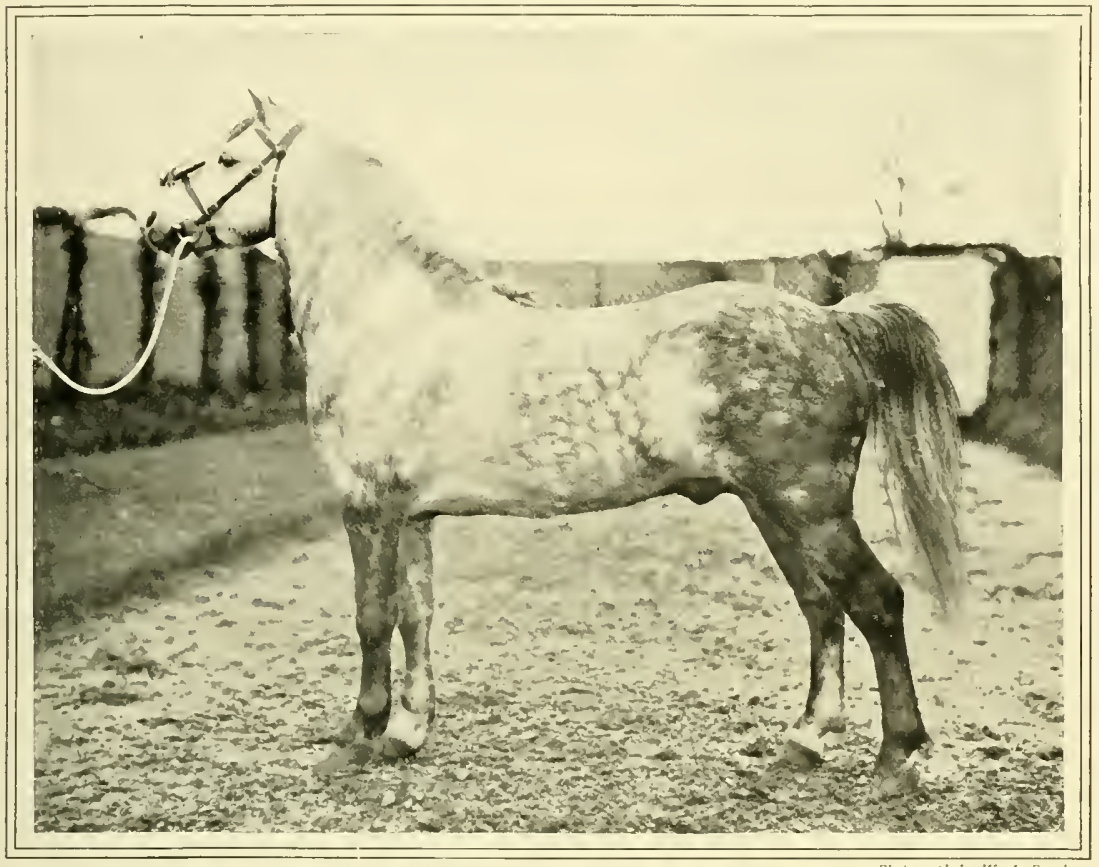

SIR WALTER GILEEY'S WELSH PONY, STARLIGHT,

ability, be a great falling off in interest on the part of the public. The crowd dearly love to see the high-stepping, quick-actioned harness horses flying round the ring, and in proof of this statement it may be mentioned that year after year the Hackney Show at Islington attracts much larger afternoon attendances than do the hunter and polo pony shows in the following week. During the afternoons of the Hackney Show, when harness classes are being judged, the crowd is always a large one, and the popularity of this particular breed of horse is invariably proved by the enthusiasm which is displayed.

It must be understood, too, that the hackney industry, as at present conducted, appeared to be the great desideratum, and it was only when it began to be recognised that there was practically no market in this country for the home-bred trotter, that more attention was paid to elegance of outline, showy appearance, and fine knee and hock action.

Trotters were never wanted for ordinary harness purposes in the United Kingdom, but when high-class harness horses with grand action were forthcoming, a demand for such horses for park work quickly arose, and this demand extended to Paris, to ltaly, and in some degree to all parts of the European continent. Then about a quarter of a century ago came the Hackney 
Society-which held its twenty-fifth annual show this year - and since then huge sums of money have been invested in stud farms, and the hackney has gradually come to be recognised as the highest class of harness horse, as apart from a trotter, in the world.

\section{Triumph of the Hackney}

For long enough there was a certain amount of prejudice against the hackney, his enemies affirming that he knocked limself to bits and was of little use for a long journey. The hackney, indeed, had to struggle against a great deal of unfair opposition. There were those who said that he was of too artificial a breed, and that his pronominced action would never stand work. but the hackney has lived down all that sort of thing, and during the last eight or ten years even the coaching men have not only been reconciled to him, but have in many cases become his warmest admirers.

Of the meets of the Four-in-Hand and Coaching Clubs held during Igo8, it can truly be said that about half the teams which put in appearance were either purebred hackneys or horses of hackney type, which if not actually in the Stud Book had been sired by a hackney, and had, at all events, hackney appearance and action. Certain members of either of the clubs drive hackneys over the matching of which much care must have been taken, and Sir Henry Ewart. Sir Lindsay Hogg, and Mr. E. Colston may be quoted as admirers of the type, whose teams are to all appearances the same sort of horses that are seen in the harness classes of the Hackney Society's Show at Islington.

\section{The Hackney Pony}

Closely akin to the hackney is the hackney pony, or hackney in miniatire, a distinctly modern type of little harness nag, which is seen to advantage in a Ralli car. This pony has attracted the attention of breeders since the larger hackney became fashionable, and not only is much money spent on breeding him, but at times the outlay is well repaid, certain of these ponies having recently been sold for enormous sums.

Other breeds of ponies there are--some, indeed, may almost be called fancy breeds -but these will be treated of in their proper order, and mention is only made of them here in order that the many and varied branches of the horse industry may be realised and understood.

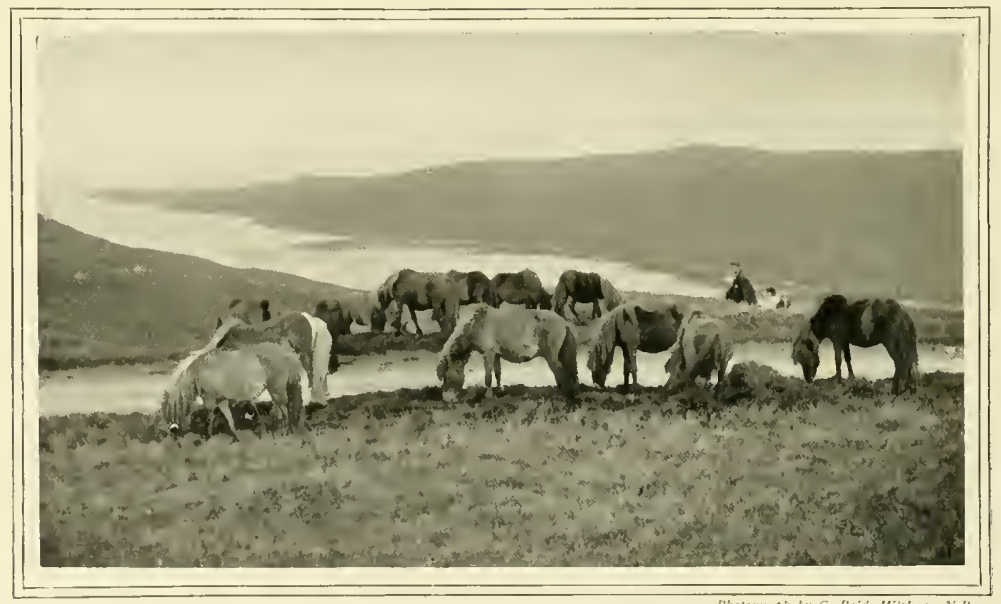

HIGHLAND PONIES FEEDING. 


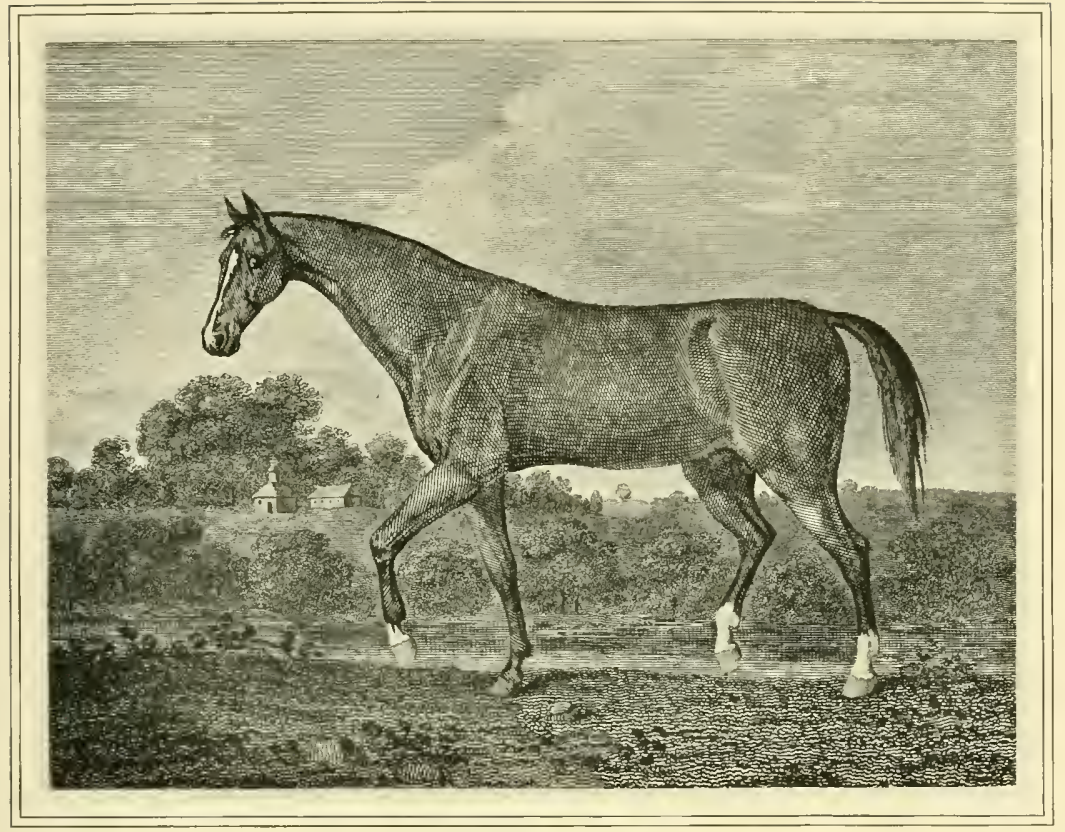

THE DARLEY ARABIAN.

From the engraving by $J$. Wictob.

\section{CHAPTER III}

\section{THE THOROUGHBRED HORSE AND HIS ORIGIN}

$\mathrm{A}^{\mathrm{T}}$ the present moment there is no horse in the world which can compare with the thoroughbred as far as speed is concerned, and the thoroughbred, though now to be found in many parts of the world, is of British origin, or perhaps it would be more correct to say of British manufacture.

To describe in the simplest possible manner from what breed of horses the thoroughbred is derived is an easy matter so far as the sire line is concerned, but rather more difficult with regard to the mares from which the breed originally came. Briefly, every thoroughbred horse now living traces to one of three Eastern sires which were imported into Great Britain in the eighteenth century. In like manner, nearly every thoroughbred traces to one of some fifty-more or less-mares, but whereas the evidence is conclusive and complete with regard to the sires, it is not always clear with regard to the mares.

The sires to which reference has been made are the Darley Arabian, the Godolphin Barb, and the Byerly Turk, and about these three horses all particulars have been well preserved. On the other hand there is a considerable doubt surrounding the origin of several of the mares, and whilst it is certain that some of them were Eastern 
importations, it is possible that others dated back to English ancestors.

It will, perhaps, be the best plan to treat of the sires first, and to begin with it should be stated that the thoroughbred horse is, in common English, the race-horse. He is thoroughbred because his name is to be found in the General Stud Book, and this means that his ancestors can be traced back to the various Eastern sources of which brief mention has just been made.

\section{The Stud Book}

The Gencral Stud Book, it may be cxplained, covers the ground for a period which may be broadly reckoned as 200 years, and for the latter three-fourths of that period details as to the breeding of every horse or mare in the book are very concise. With regard to the earlier entries, elements of doubt are occasionally met with, but for all practical purposes a pedigree of I5o years is long enough for anything. especially when it is borne in mind that as regards the sire lines the records are remarkably clear.

That racing was carried on in England for hundreds of years, during which no records of the sport were kept, is a fact of which there is plenty of proof. Indeed, the names of various early race-horses are to be found in certain historical writings, but there is no reliable evidence which connects them with the thoroughbred of the present day, and it is by no means certain whether such horses were British bred, cross bred, or importations from foreign countries.

We know that Normandy horses were brought into this country in considerable numbers aiter the Norman conquest, and we also know that during that period which is generally known as the "Middle Ages," there was it breed of big English horses which were used as chargers or war-horses, and which were of great size and strength, able to carry men, who, when fully accoutred in armour, weighed well over twenty stone. These, however, there is reason to belicve, were not the same horses which were used for racing, and as a matter of fict there wcre, four or five hundred vears ago, as many varieties of the breed as there are to be found at the present day.

\section{Early Race-Horses}

In Sir Walter Gilbey's "Horses Past and Present," it is stated that in the reign of Edward 1II. (I327-I377) there were, in England, in addition to war-horses, palfreys, hachneys, hengests, somers, coursers, trotters, hobbies, nags, and genets. Sir Walter is of opinion that the distinction between some of these was evidently very slight, but it is reasonable to assume that the "courser" was the fleetest of the lot, and that he was used for such racing as then took place. So much, however, with regard to the history of the earlier British race-horses is in doubt that it is best to go on to where the evidence is really reliable, and though it is broadly known that many Eastern sires had been previously imported, the first of which there is any real knowledge is the Markham Arabian, brought to this country by a Mr. Markham, and paid for by King James I., on December 2oth, I6I6. The actual price paid, according to the records of the Exchequer, was $f_{5} 54$, and fII "to a man that bought the same Arabian horse and kept him." This is fairly conclusive evidence, but the pity of it is that the Markham Arabian was not only a failure on the race-course, but also at the stud, for he has left no line which can be traced.

\section{Royal Turf Patrons}

King James I. was a great patron of the turf, and is generally credited with having caused the first race-course at Newmarket to be laid out, but the breeding of racehorses made greater strides during the reign of his son Charles I., and practically every race-horse of the present day can be traced back (not in tail male) to the Buckingham or Helmsley Turk (generally known by the latter name), who was imported by Henry Villiers, Duke of Buckingham. This horse, about whom rery little has becn handed down, was the sire of Hutton's Royal Colt, from whom was descended the 
unnamed dam of Marske-who was himself the sire of Eclipse. Moreover, Spiletta, the dam of Eclipse, traced on her dam's side to Bustler, another son of the Helmsley Turk, so that Eclipse was inbred to this importation.

\section{The Helmsley Turk}

Writers on the earliest known blood from which the British thoroughbred has been evolved, have had nothing particular to say about this Helmsley Turk, probably because little or nothing was handed down, but as every thoroughbred in the kingdom has the blood of Eclipse in lis veins, and because the Helmsley Turk is the first of the ancestors of Eclipse of which historical mention is made, the horse in question is really entitled to far greater prominence than has ever been accorded to him. Unfortunately no picture of the Helmsley Turk can be traced.

\section{The Byerly Turk}

Place's White Turk, the property of Mr. Place, who was stud master to Oliver Cromwell, was the next important horse to be brought to this country, and his name is to be found in the pedigrees of all horses who have a single strain of Natchem blood in their reins. Still, like the Helmsley Turk, he is not to be found in any tail male line, and, as a matter of fact, the first of the three Eastern horses, from whom a line of blood has been directly handed down, was the Byerly Turk, who was ridden by Captain Byerly as a charger throughout the whole of the Irish campaigns of William III. At the battle of the Boyne the Byerly Turk narrowly escaped capture, and this was lucky, as he became one of the three Eastern sires from which all race-horses are descended in tail male.

It is hardly necessary to go through the list of all the Eastern horses which were imported into this country during the seventeenth and eighteenth centuries, though as a matter of course the blood of very many of them is to be found in the pedigrees of all race-horses, if only these same pedigrees are taken right back to their earliest sources.
The Stud book shows that no fewer than r7f Eastern sires were brought into this country, eighty-nine of which have been classified as Arabians, forty-seven as Barbs, thirty-two as Turkish horses, four as Persian, and two as "foreign" horses-which really means that they could not be more definitely classified.

\section{Eastern Sires}

The names of many of these-the Markham Arabian, for example, cannot be found in the pedigrees, but there are others, to a considerable number, which figure on the female side of the pedigree of various great horses, as will be shown later. Keeping the list of sires for our subject, the Byerly Turk (as has been stated) is one of the three horses which survive in tail male, the second being the Darley Arabian, brought to this country in 1705 , and the third the Godolphin, sometimes called an Arabian, and sometimes a. Barb, who was imported about the year r728.

It is curious to think that out of the great number of Eastern sires brought to England, only three survive in the male line, but it is none the less a fact. No doubt all of the $\mathrm{I} 7+$ which were noticed in the first volume of the Stud Book were brought to this country expressly with a view to improving the breed of English horses. They would therefore be afforded every chance of reproducing themselves, yet in a period of not more than a hundred years all but three had died out in the male line-truly a wonderful example of "the survival of the fittest."

It follows, of course, that every thoroughbred of the present day goes back in direct male line to the Byerly Turk, the Darley Arabian, or the Godolphin, and as "thoroughbreds " all over the world are descended from English race-horses, the same thing applies to them, whether they be European, American, or Colonial.

To go a little more into detail concerning the famous trio, who may fairly be called the fathers of the turf, it may at once be said that the descendants of the Darley Arabian disputed the supremacy for many 
years with those of the Byerly Turk, and that the descendants of the Godolphin were always in a rather subordinate posi- from her original Arabian (or Barb) male ancestor.

Because of its being so much the strongest,

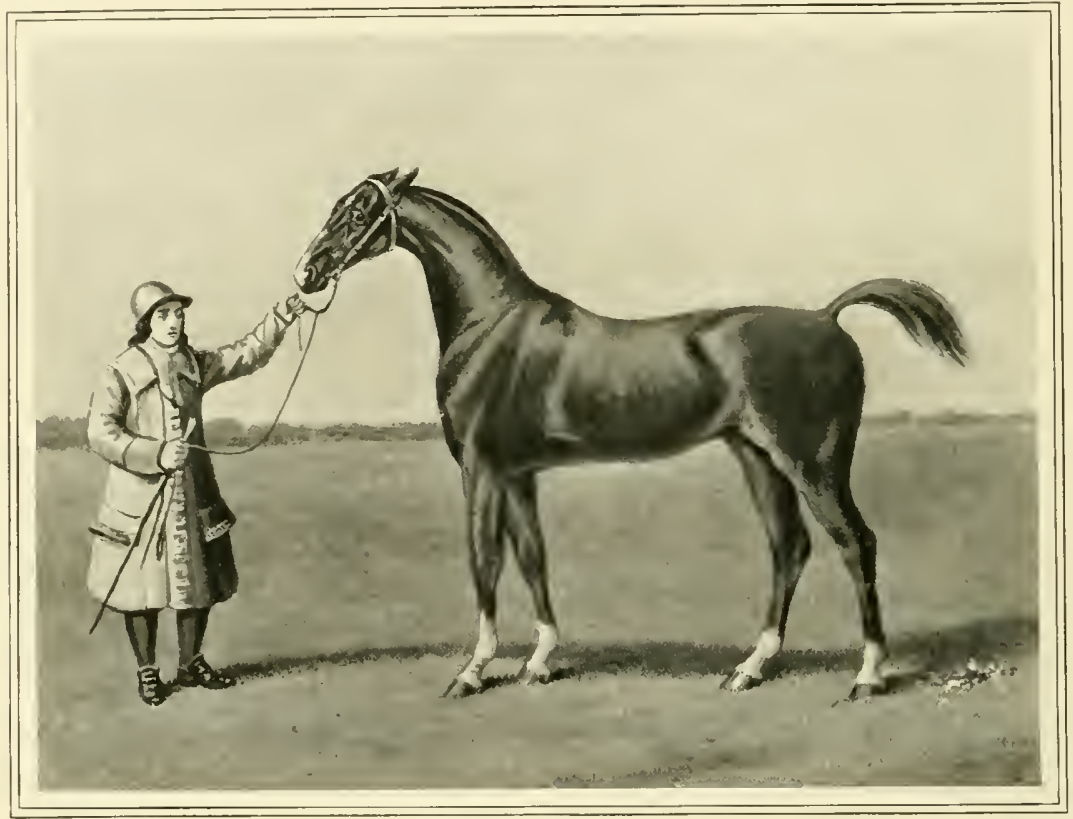

FLYING CHILDERS.

After the painitig by Seymour.

tion, despite the fact that the Godolphin was himself the most famous of all the Eastern stallions which were imported. But towards the middle of the nineteenth century-or even a little earlier-the descendants of the Darley Arabian parted company with the horses descended from the Byerly Turk, and since then the gap has gradually been so widened that Darley Arabian horses are now in an enormous majority, not only numerically, but as regards the amount of stake money and the number of great races which have been won by their descendants.

The line of the Godolphin is, on the other hand, rather stronger than it was some years ago, and its latest representative is the rgo8 Derby and Oaks winner, Signorinetta-who is fourteenth in descent the line of the Darley Arabian shall be first discussed. This horse was imported early in I706, as the following extract from a letter written by Mr. Thomas Darley, his importer, proves.

"The colt, bought about a year and a half ago, with a design to send him to my father at the very first opportunity $\mathrm{He}$ comes four years old the latter end of March or beginning of April next. His colour is bay, and his nea: forefoot before, with his hind feet, has white upon them. He has a blaze down his face. something of the largest. He is about fifteen hands high, of the most esteemed race among the Arabs, both by sire and dam, and the name is called Mannicka. Shall send him over by an intimate friend of mine, the Hon, and Rev. Henry Brydges, son to Lord Chandos, who embarks in the Ipswich, Captain IV. Waklin. Hope he will not be much disliked; for he is 


\section{THE THOROUGHBRED HORSE AND HIS ORIGIN}

highly esteemed here, where I conld have sold him at a very considerable price, if I had not designed hin for England.

"I have desired Mr. Brydges to deliver him to my brother John, or my cousin Charles Waite, who he can find (sic), and they are to follow niy father's orders in sending him into the country.

"(Signed) Thomas Darley, Aleppo, Dec. 2 Sth, I705.

"Freight, one hundred pounds and upwards."

There was at this period considerable rivalry amongst the Yorkshire nobles and gentry as to horseflesh, and one form which the rivalry took was the importation or purchase of horses of Eastern blood. It was being realised in England that the native horses were inclined to be somewhat heary of build, and short of speed. They than war, and all the evidence shows that Yorkshiremen were of horsey tastes, and that they were amongst the earliest to recognise how the English breed could be improved by the introduction of Eastern blood.

If one compares the portraits of the Arabs, or other Eastern horses which were imported two hundred years ago-or for that matter the living Arabs of to-daywith the horses depicted in old drawings of Cavaliers of the same date, it will at once be noticed that whereas the Arab was (and still is), neat and elegant, the war-horse of two hundred years ago was a heavily built, cumbrous animal, not in the least likely to go fast, or travel far. He was, indeed, what we at the present day would call an underbred brute, and thus it can be easily understood that there

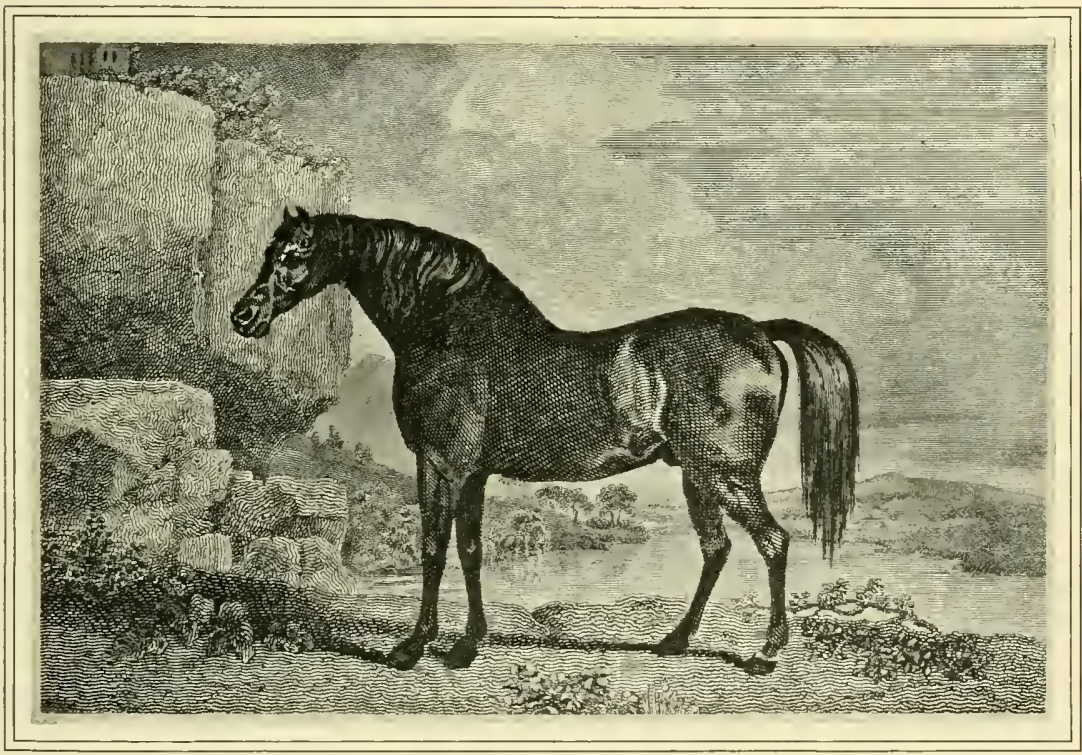

MARSKE.

From the engraving by $J$. Scott after the painting by G. Stubbs, A.R.A.

liad, doubtless, been bred so for hundreds of years, solely that they might become the most powerful war-horses in the world, but as civilisation advanced it was found that horses were required for other purposes would be a desire on the part of horse experts to improve him by crossing his blood with that of the more graceful and elegant Arab.

Some amount of conjecture is perliaps 
allowed in these matters, and it is probable that English breeders recognised the fact that size was absolutely necessary in horses required for certain purposes. They had size and to spare in England, but throughout the Middle Ages there must have been a sad lack of quality, and this was corrected by the admixture of Arab blood.

Here it may be interposed that the imported Eastern horses would almost certainly be mated with the best, and bestlooking mares which could be found near the location of each indiridual stallion. Not every Eastern horse, however, would have the picked mares, such as were to be found in the Royal stud, or in the studs of the great noblemen who interested themselves in breeding. These chances would be given to some few of the importationsmuch depending upon what part of the country they were sent to-and the others would be mated with country mares, and thus from these would be descended hundreds and thousands of what may be called light horses, which were never good enough for racing, and which were not included in the earlier volumes of the Stud Book.

\section{Influence of Eastern Sires}

In fact, we are justified in believing that the Eastern sires, imported in the serenteenth and eighteenth centuries, were not only instrumental in the formation of the breed known as thoroughbred, but had also a great deal to do with establishing the breed of the general utility horse, which exists all over the kingdom, and from which the hunter and the average hamess horse are drawn. The general utility horse-which will be treated of in its proper place-is in these diys generally sired by a thoroughbred, but no doubt scores of the so-called half-bred light mares and geldings go back through their dams to Eastern blood-even apart from that which they now obtain througin their sires.

Just as there are now far more thoroughbred stallions than are required for sireing race-horses, so there were two hundred years ago more Eastern sires than could be mated with the Royal and other racing mares of that day." And as the present day surplus stallions are used all over the country for mating with half-bred stock it is only reasonable to assume that the surplus Eastern sires in their day were mated with scores of country mares.

\section{The Darley Arabian}

The Darley Arabian stood at Aldby Park, or Buttercrambe, a few miles west of Nalton, in a country which has always been famous for horse-breeding. What his fee was we do not know, but Mr. John Brewster Darley, to whom he was consigned, had a stud of mares, and one of these, known as the (Old) Hautboy mare, bred in ryir and I7I3 respectively Aleppo and Almanzor to the Darley Arabian. Aleppo and Almanzor were race-horses, not of the highest caste, but they ran with sufficient prominence to draw attention to their sire, and the upshot was that a mare named Betty Leedes was sent to the Darley Arabian, and she produced in I7I5 a bay colt named Flying (or Deronshire) Childers, and (no date given in Stud Book) a bay colt named Bartlett's, or Bleeding Childers.

\section{Betty Leedes}

Betty Leedes is to be found in the more recent editions of the first volume of the General Stud Book, the information concerning her having been doubtless gathered from the earlier Stud Book of William Pick. In this it is stated that Betty Leedes was by Old Careless, out of Sister to Leedes, by the Leedes Arabian, her dam by Spanker out of the Old Morocco mare that was the dam of Spanker. We have given this pedigree at some length, because it shows two things: firstly, that the most thought of mares in the country had pedigrees of some length as long ago as the time of the Darley Arabian-almost exactly two centuries ago - and secondly, because it is clear, through the double mention of Spanker's name-that inbreeding was already being resorted to. Indeed Betty Leedes was very closely inbred, and later on we shall show how much more closely inbred are all the modern race-horses. 
There was once an opinion to the effect that Flying Childers and Bartlett's Childers were one and the same horse, and even now there is a certain amount of vagueness about the matter, but the weight of evidence farours the idea that the two horses named were brothers. Pick says that Bartlett's Childers was bred by Mr. Leonard Childers, and sold to Mr. Bartlett of Nuttle Court, near Masham (in the North Riding of Yorkshire), and that he was own brother to Flying Childers, and was first distinguished by the name of Bleeding Childers, because of his tendency to bleed at the nose (to break blood-ressels it would be called in those days). He (l'ick) also goes on to say that "there was formerly an opinion that Betty Leedes never produced any other foal than Flying Childers, except one that was cloked, when very young, when eating chaff, or hulls, at Mr. Childers' barn-door, but Mr. Cheney says he has heard the contrary from so many gentlemen of worth and honour, that he cannot but be of opinion that he weas own brother to lim."

\section{Flying Childers}

It is to be noted that Flying Childers is entered as having been foaled in I7 I5, but no date is given to the entry of Bartlett's Childers.

Pick's Stud Book was first published in I786, and a reprint in $\mathrm{I} 803$, and his chief authorities were some "fifty or sixty volumes of Racing Calendars, by Cheney, Heber, Tuting, Fawconer, etc."

Our readers will see the point raised by this question of whether Betty Leedes bred one or two own brothers to the Darley Arabian. It is merely this, that Flying Childers was a great race-horse, and was never beaten, whereas, according to Pick, Bartlett's Childers was never trained for racing, but kept as a stallion in Yorkshire. As far as the line of blood is concerned, it is immaterial whether these two sons of the Darley Arabian and Betty Leedes were one and the same horse, or different individuals, but there is no reason to doubt the statement that Flying Childers was a great race-horse, and that being so, it is curious that he should not have done better at the stud than he did.

\section{Flying Childers' Record}

"Flying Childers started several times at Newmarket, against the best horses of his time, and was never beat," says Pick, and it is also recorded of him that he ran a trial over the Round Course at that place against Almanzor and the Duke of Rutland's Brown Betty, carrying nine stone two pounds, in six minutes and forty seconds; "and it was thought that he moved eighty.two feet and a half in one sccond of time, which is nearly at the rate of one mile in a minute, a degree of velocity which no horse has been known to exceed; he likewise ran over the Beacon Course in seven minutes and thirty seconds, and it was supposed that he covered at every bound a space of twenty-five feet-he also leaped ten yards on level ground with his rider."

According to Pick, the Round Course was at the time 3 miles, 6 furlongs, and 93 yards, and the Beacon Course + miles, I furlong, and $I_{3} 8$ yards. At the present day the Round Course is 3 miles, $\&$ furlongs, and $\mathrm{r}_{3} 8$ yards, and the Beacon Course + miles, I furlong, and $I 77$ yards, and it is perhaps hardly necessary to add that such times are altogether unreliable, and have never been accepted by experts of racing.

\section{Bartlett's Childers}

Leaving Flying Childers, and assuming that Bartlett's Childers was a different horse-though it is curious that none of the carly authorities can give the exact year in which he was foaled-Pick says of the latter "he got so many good horses that he is justly ranked with the first-rate stallions." Whereas there are two portraits of Flying Childers, both of which have been reproduced, there is not one of Bartlett's Childers, nor do we know what colour he was-the colour of Flying Childers has, by the way, been disputed, owing to the original pictures having faded. Pick calls him a chestnut, but other authorities are of opinion that he was bay, or brown. 


\section{THE NEW BOOK OF THE HORSE}

The fact is that Flying Childers was a great celebrity on account of his performances, while it is only reasonable to assume that Bartlett's Childers was practically unknown. He never ran a race, but went to the stud in Torkslive, and of course it could not wen be guessed then that he was to be the connecting link between the Darley Arabian and the greatest male line of racehorses which the world has ever known.

\section{The Childers Mystery}

Mr. Osborne, who carefully sifted all the evidence which was forthcoming regarding the produce of Betty Leedes, dismisses the Childers question very briefly, having evidently accepted the general opinion to the effect that Flying Childers and Bartlett's Childers were own brothers. He even assigns a date to the last-named in the following passage:

"Mr. Childers sent to the Darley Arabian his favourite mare Betty Leedes by Careless, who was almost incestuously bred to Spanker, with the result of breeding in I7I5, The Flying or Devonshire Childers, generally esteemed to be the fleetest horse ever trained. In the following year" (the italics are ours) "Betty Leedes, having again been sent to the Darley Arabian, she produced Bartlett's Childers, who was never trained, but nevertheless he became a popular sire, and rendered great service to the British stud."

It is a great pity that Mr. Osborne did not give his authority for this statement, which cannot be accepted without corroborative evidence. For as it is, there will always remain a slight doubt as to whether Flying Childers and Bartlett's Childers were not one and the sane horse, and there will always be those to think that it was the first-named who was the stud success, after his running days were over.

\section{Tragedy of Squirt}

But no matter whether Bartlett's or Flying Childers slrould figure in the direct line which connects the modern race-horse with the Darley Arabian, it is the case that this same line very nearly came to an end in the next gencration, for Squirt, the connecting link between Bartlett's Childers and Marske, was ordered to be shot when in Sir Harry Harpur's stud. We are told that "when Miles Thistlewaite was leading lim to the dog kennel, he was begged off by Sir Harry's groom, after which he got Marsk (sic), etc." Squirt was bred by a Mr. Metcalfe, near Beverley, and was a fair race-horse, who won races at Newmarket, Epsom, Stamford, Winchester, and Salisbury, but not mucli can have been thought of him when he went to the stud, for it is on record that he was mated with very few well-bred mares.

\section{Marske's Birthplace}

No picture of Squirt has been handed down, but Marske was painted by Stubbs, and curiously enough "The Jruid" blumdered over this picture when he wrote of Marske as "drawn as standing among the rocks on the sea coast, in honour of the mansion from which he was named." "The Druid " of course, had in his mind llarskeby-the-Sea, a big village situated on the Forkshire coast, midway between Redcar and Saltburn; but there are two Marskes in Yorkshire, and the sire of Eclipse was foaled in I $75^{\circ}$ at Marske, near Richmond, and something like fifty miles from the seaside Narske.

The evidence concerning this horse is as clear as noonday, for Pick gives an extract from Mr. Hutton's Stud Book, which is as follows :-

"Nlarsk was got by Squirt, out of the Ruby mare, she was from a daughter of Bay Bolton, and Mr. Hutton's Blackleg; grand-dam by Foxcub; great grand-dam by Coneyskins; great great grand-dam by Mr. Hutton's Grey Barb, a daughter of Mr. Hutton's Royal colt, a daughter of the Byerly Turk from a Bustler mare. In the year 1750 , His Royal Highness the Duke of Cumberland gave me (John Hutton) a chestuut Arabian, in exchange for a brown colt, got by Squirt, bred from the Ruby mare, and which His Royal Highness afterwards called Mlarsk. My Blacklegs was got by the Mulso Bay Turk; his dam by Coneyskins; his grand-dam was the Oid Clubfoot mare, got by Mr. Wilke's Old Hautboy.

"The above are true copies from Mr. Hutton's Stud Book." 
The picture to which "The Druid" referred, was by Stubbs, and if one studies it carefully, it will be seen that "The Druid's" sea coast is in reality a pond or lake, and that there is a background of hills, such as are to be found right behind the Richmond Marske, whereas Marske-bythe-Sea is on a flat plain, the Cleveland Hills being some distance away.

\section{Marske at Stud}

Marske does not appear to have been a great race-horse, nor even a frequent rumner. He was twice successful in $175+$, and lie was beaten three times in the following year. He then went to the stud, and was sold for a trifling sum after the death of the Duke of Cumberland, his purchaser being a farmer, for whom he covered country mares at a half-guinea fee in Dorsetshire. After a while Mr. Wildman bought the horse for twenty guineas, and according to Pick the seller was highly pleased at having got rid of what he thought was a bad bargain.

What had really happened was that Mr. Wildman had probably found out the merits of Eclipse, who was a son of Marske, and who had also been sold at the death of the Duke of Cumberland. This induced him (Mr. Wildman) to acquire Marske, whose fee rose to three, five, ten, and thirty guineas in a few years, the horse being subsequently sold to Lord Abingdon for I,000 guineas. He then stood at Rycot in Oxfordshire, at roo guineas-being, as a matter of fact, the first stallion, who ever commanded a three-figure fee.

And in spite of his quiet beginnings it can fairly be said that Marske justified the money asked for his services, for he was certainly the greatest stud success which the turf had ever known, up to that particular date. In twenty-two years he sired I5t winners of $£ 7 r, 806$, an enormous sum for those days, when stakes were not a tenth the value of what they are in the present generation. Curiously enough Pick concluded his account of Marske with the remark that there may have been yet other winners of his, but that they were unkwown to the publisher.
A remarkable thing about Marske, if Stubbs's portrait was true to life, was his extraordinary crest, and that has been handed down, and at times is exceedingly pronounced in horses of Blacklock-Voltigeur descent-which in these days generally means the line of St. Simon and his sons.

\section{The Great Eclipse}

Eclipse was foaled in $\mathrm{I} 764$, and was so named because he was born during a great eclipse. His breeder was the Duke of Cumberland, but as his Royal Highness died in the following year, he had no opportunity of ever knowing what an equine wonder he had bred. It may, however, be stated, that though Eclipse's running days were nearly rfo years ago, the horse may still be called the greatest celebrity of the English turf.

It was not only because he was never beaten that he achieved such an extraordinary reputation, for many good horses can be mentioned which never met with defeat, and even in our own times St. Simon, Ormonde, and Barcaldine were each undefeated. But none of the trio named showed the complete superiority to all opponents that Eclipse did, for we are told that as a rule he distanced his opponents, and won running away. In only one of his races, a match against Bucephalus, which took place at Newmarket in April, I770, was thereaccording to early turf historians- the slightest appearance of equality in an opponent, but it is not stated by how much Eclipse won, though as regards Bucephalus we are told that he never afterwards regained his form, so severe and heart-rending were the efforts he made.

\section{Eclipse at Stud}

In all, Eclipse won or walked over for some six-and-twenty races and matches, amongst which were included eleven King's Plates. He was undoubtedly so far in front of all his contemporaries that he-naturaliy enough-created a great furore, but at the moment we are concerned more with what he did at the stud, and at once it may be mentioned that he more than doubled his 
sire's record, both as regards the number of actual winners he sired, and as regards the amount of money won by his sons and daughters.

In twenty-three years Eclipse sired 344 winners of $f 158,0+7$ I2s., to say nothing of certain cups, whips, bowls, and other prizes
Eclipse haid to compete against Herod, who was at the time an even greater stud success - though he liad not been so great a runner.

Having traced the line of the Darley Arabian down to Eclipse, and having made mention of Herod, we must refer back to the Byerly Turk, from whom Herod came in direct tail male. The Eastern horse just mentioned was, as has been stated, ridden as a charger in Ireland in I689, etc. Of his subsequent history we have practically no particulars ; neither have we ever heard of any portrait of the horse. Nor is it known where exactly he came from, but he "afterwards proved a most excellent stallion, though he did not cover many well-bred mares."

Thus scantily is the early history of the Byerly Turk dismissed, and concerning his son Jigg the information is equally meagre. Pick, indeed, merely states that Jigg, a son of the Byerly Turk, was a common stallion in Lincolnshire till Partner was six years old, after which he came into note, and was sire of Robinson Crusoe, Shock, Saucebox, etc.

Partner-he is called "Old Partner" by some of the authorities - was foaled in I 7 I 8 , being bred by Mr. Charles Pelham of Brocklesby, Lincolnshire, and was sold by him to IIr. Crofts of Barforth, Yorkwhich were not in specie. In modern times these records have been frequently beaten, but it must be remembered that the value of the principal prizes has been enormously increased, and that there are in these days far more chances for a successful stallion, than there were $\mathrm{I}_{40}$ years ago.

Eclipse's stud fee varied between twenty and fifty guineas, but never reached three figures, as did that of his sire Narske, and the reason for this was, we imagine, that whereas Mlarske had no very great rival, shire. His dam was by the Curwen Bay Barb, who was a present from the King of Morocco to Louis the Fourteenth of France, and was brought into England by Mr. Curwen of Workington. It is stated that this horse did not cover many mares except those of Mr. Curwen and Mr. Pelham.

Partner is said to have been a horse of great strength, fine shape, and beauty, and to have been the best racer of his time at Newmarket. It is also stated that "he 


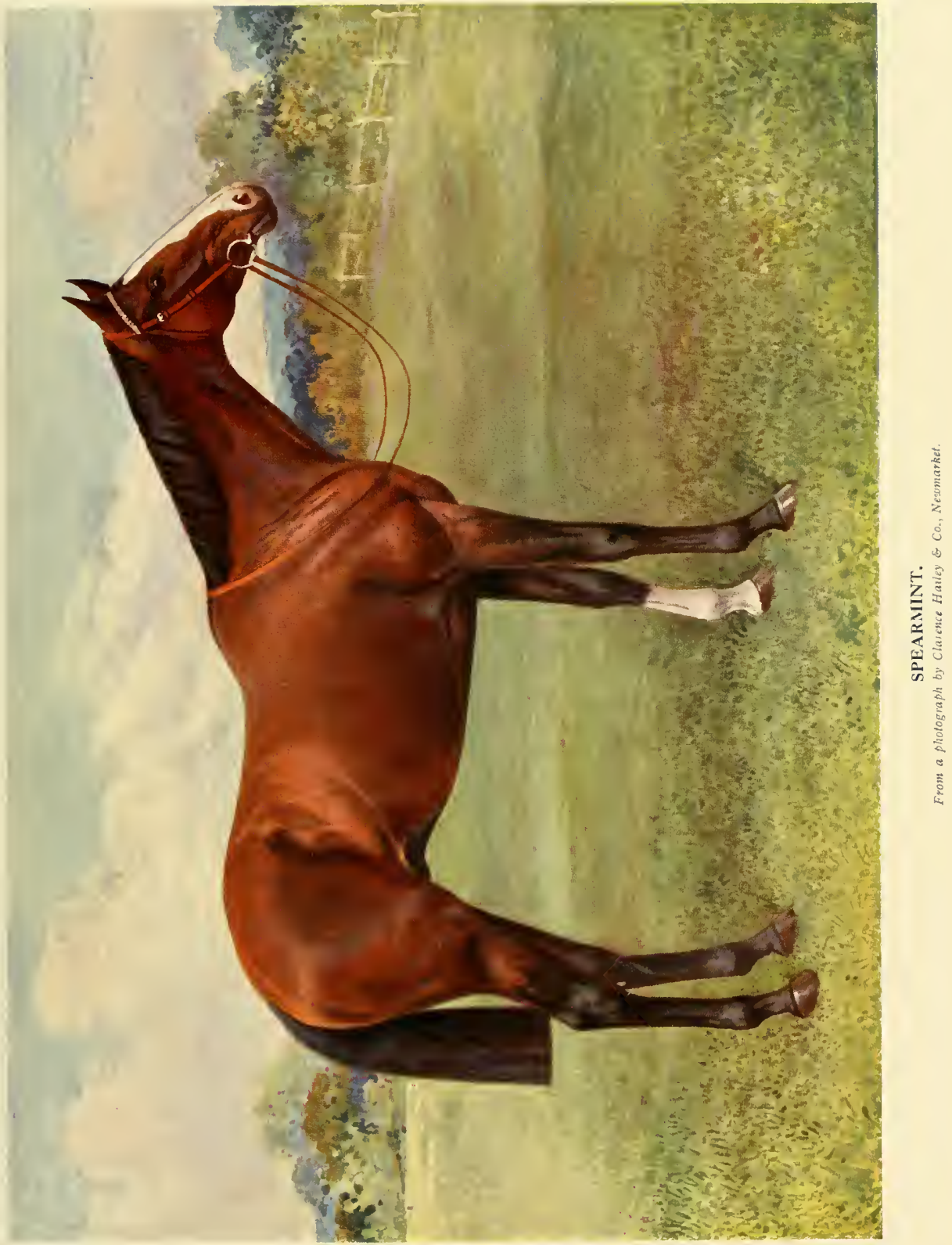



was allowed to be as fine a stallion as any ever bred in this kingdom, and not inferior to any foreign one. He covered in public only four years, when he served most of the best bred mares in the North, after which he covered very few except those of Mr. Crofts. Partner died the latter end of the year 1747 , aged twenty-nine." great runner, and it is worthy of note that his fee was never higher than five guineas, whereas, as has been shown, Marske, the sire of Eclipse, stood at twenty times that amount.

Herod, like Eclipse, was bred by the Duke of Cumberland; he was foaled in I758, and was sold after the duke's death

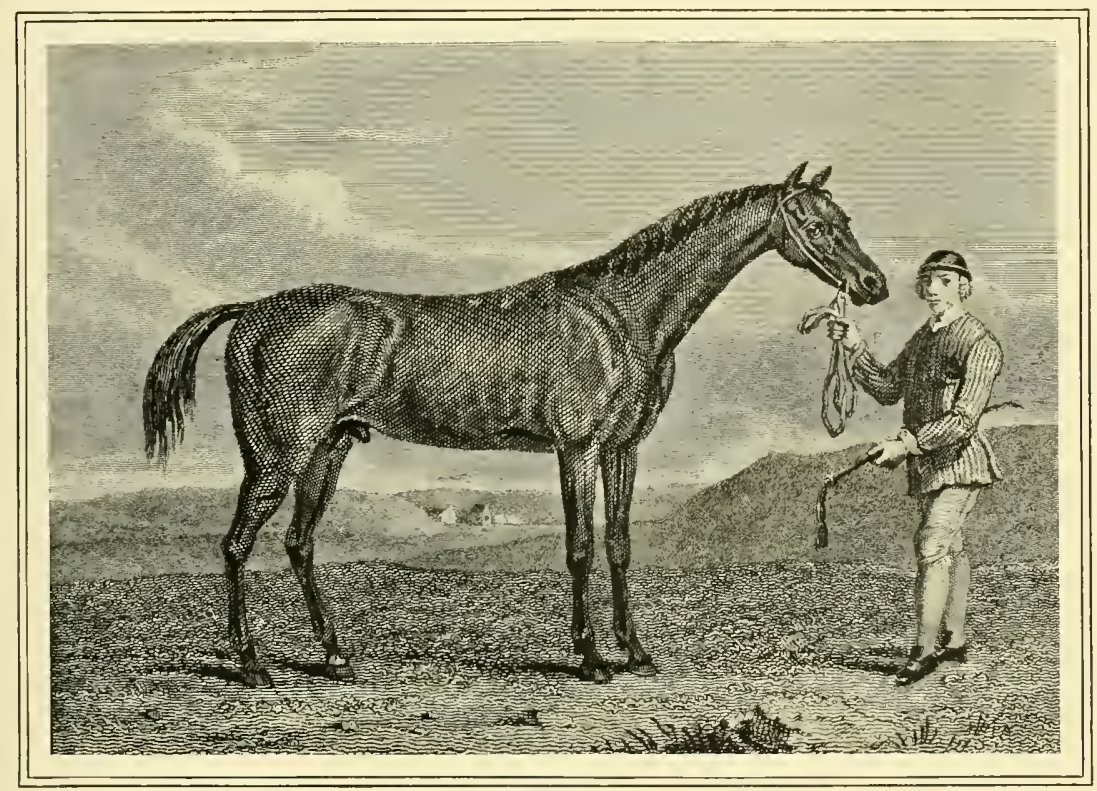

MATCHEM.

Fron the engraving by $J$. Scolf after the painting by Wr. Wheb.

Next in the line of tail male descent from the Byerly Turk comes Tartar, by Partner, out of Meliora, by Fox. He was bred in I $7+3$ by Mr. Edward Leedes of North Milforth, Yorkshire, and as Partner was foaled in I7I8, it follows that the last-named was twenty-four years old when he sired the horse who was to carry the line down to the horses of the present day. Tartar (it is stated) was nearly fifteen hands high, of great power and strength, and was esteemed to be as fine a horse as any in England. He ran chiefly in the North of England, and was a good winner, but he is better known as the sire of Herod than as a in I765 to Sir John Moore. Got by Tartar, he was out of Cypron by Blaze (a son of Flying Childers), and it is worthy of note that his dam was never trained for racing. As a race-horse Herod, or "King Herod" as he was called in his running days, did very well, winning many important races. He was, says Pick, a fine horse with uncommon power, and was looked upon as one of the best-bred horses this kingdom ever produced, and as a stallion inferior to none, being sire of a larger number of racers, stallions, and brood mares than any other horse before him. His descendants have always been famous for quality. 


\section{Herod's Great Record}

The praise awarded by Pick was in no way ton high, for, as a matter of fact, Herod had a stallion's record which in those days was simply marrellous. It has been stated that Eclipse sired $34+$ winners of $£$ I58,047 I2s., but his stud life lasted twenty-three years. Herod on the other hand had a stud career which was shorter by four years than that of Eclipse, and his figures show that in nineteen years he was responsible for 497 winners of $f_{201.505}$.

When we reflect that in Herod's day the classic races had only just been instituted, and that there were no really large money prizes to be won, these figures stand out as most remarkable. In the year 1778 , fortyfive sons and daughters of Herod won $\{23,046$, which is only $\{2,000$ above the total which stands to the name of St. Frusquin, the highest winning sire of rgo7. It may be urged that 1907 was not a good year because no sire stood out from the others, and that Herod in his day did stand out, but I30 years ago Herod had Eclipse to fight against, and as Eclipse had much the best racing record, it is only reasonable to assume that he would have as much patronage as his great stud rival Herod.

\section{The Godolphin Line}

Leaving Herod and Eclipse for a moment, we must show the third line of male blood which has come from the Godolphin. This horse was foaled, according to Pick, in $\mathrm{I}_{72} 4$, and was long thought to be an Arabian; "but his points more resemble the highest breeds of Barbs." The Godolphin was a brown horse, standing about fifteen hands, who was brought to England by Mr. Coke. It was said that he was discovered in Paris, in or about 1828 , where he was working in a water cart. How this story arose we have never discovered. There is no mention of it in Pick's Turf Register, but the story has been handed down, and such an authority as Mir. Joseph Osborne makes special mention of the circumstance in ail his tabulated pedigrees where the name of the Godolphin occurs.

At this day it is of little consequence whether the horse ever drew a cart or not, for the fact remains that he did immense good to the breed of English race-horses. He was the last of the three great Eastern sires to reach this country, but he quickly proved his worth at the stud, and whilst he established a tail male line through his son Cade, he also sired Regulus, whose daughter, Spiletta, was the dam of Eclipse. Though his early history will probably always remain a mystery, there is no doubt about the English career of the Godolphin, for he was given by Mr. Coke to Mr. Roger Williams, a coffee-house keeper in St. James's, and by him was presented to the Earl of Godolphin, who owned him throughout his stud career. He died at Gog Magog in Cambridgeshire in $x 753$, being then in his twenty-ninth year.

\section{Cade and His Offspring}

From Roxana by the Bald Galloway, the Godolphin sired a bay horse named Cade, who was foaled in $\mathrm{I} 734$. Cade does not appear to have run until $\mathrm{I} 74^{\circ}$, when he won the King's Plate at Newmarket; his turf career was, however, an uneventful one, and at the end of it he was sold to Mr. Thos. Neredith, of Easby, Yorkshire, where he became a favourite stallion.

In $x 7+8$ a daughter of Partner, who came of a line of unnamed mares on her dam's side, foaled to Cade a bay horse which was afterwards called Ifatchem. He was bred by Mr. John Holme of Carlisle, but was sold to Mr. William Fenwick, of Bywell, Northumberland, and under lis colours he won several important events, including the Subscription Purse for five-year-olds at York, and the IThip at Newmarket. His stud career was a most successful one, for in twenty-three years he sired $35+$ winners of $\underset{\sim}{f} 5 \mathrm{r}, 097$, and he founded a tail male line, which exists to the present day, and of which the rgo8 Derby and Oaks winner, Signorinetta, is at the moment the most recently conspicuous ornament.

Iie have now shown the descent on the male side of the house of the three famous horses, Eclipse, Herod, and Matchem, and have explained that each of the three came 


\section{PEDIGREE OF ECIIPSE}

\begin{tabular}{|c|c|c|c|c|c|}
\hline & & & 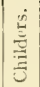 & Darley Arab. & $\begin{array}{l}\text { Was imported by Mr. Darley, brother of Mr. Darley, of Buttercrambe } \\
\text { (now called Aldby Park), a manor long in the possession of the } \\
\text { Darley family, midway between York and Mlalton. }\end{array}$ \\
\hline & & $\frac{\dot{m}}{\stackrel{2}{m}}+\frac{1}{i}$ & 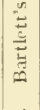 & Betty Leedes. & $\begin{array}{l}\text { Careless by Spanker (D'Arcy Yellow Turk-Old Morocco mare, her dam } \\
\text { Old Bald Peg by an Arabian out of a Barb mare)-a Barb mare. } \\
\text { Sis. to Leedes by the Leedes Arabian-dau. of Spanker (D'. Ircy Iellow } \\
\text { Turk) -dau. of the Morocco Barb mare-Spanker's dam. }\end{array}$ \\
\hline & in & 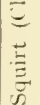 & $\stackrel{\sum}{2}$ & Snake. & $\begin{array}{l}\text { The Lister TuRk, brought into England in the reign of James II., was } \\
\text { purchased by Mr. Lister, and covered in Lincolnshire. } \\
\text { Dan. of Hautboy (D'Arcy White Turk-a Royal mare). There is no } \\
\text { record of Snake's grand-dam. }\end{array}$ \\
\hline & $\stackrel{\overrightarrow{1}}{\tilde{L}}$ & & $\begin{array}{l}\dot{0} \\
3 \\
\dot{m} \\
\dot{n}\end{array}$ & Grey Wilkes. & $\begin{array}{l}\text { Hautboy by the D'Arcy White Turk-a Royal mare. } \\
\text { Miss D'Arey's Pet mare - daughter of a Sedbury Royal mare. The } \\
\text { name of Pet mare's sire not preserved. }\end{array}$ \\
\hline & 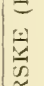 & & 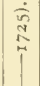 & $\begin{array}{l}\text { Hutton's } \\
\text { Bay Barb. }\end{array}$ & $\begin{array}{l}\text { This Eastern horse was imported about } 1720 \text { by Mr. Hutton, of Marske, } \\
\text { near Richmond, Yorks, and besides being the sire of Blacklegs, got } \\
\text { Black Chance, the best rumer of his day at high weights. }\end{array}$ \\
\hline & $=$ & $\frac{1}{3}$ & $\frac{1}{c}$ & Daughter of & $\begin{array}{l}\text { Coneyskins by the LISTER TURK was a grey horse bred in } 1712 \text { by the } \\
\text { Duke of Rutland; his breeding not preserved. } \\
\text { The Old Clubfoot mare by Hautboy. The further breeding of this mare } \\
\text { (in the stud of Mr. Crofts) las not been preserved. }\end{array}$ \\
\hline & & 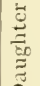 & 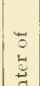 & $\begin{array}{l}\text { Bay Bolton } \\
\text { (B.-1;05). }\end{array}$ & $\begin{array}{l}\text { Grey Hautboy by Hautboy. Further breeding not preserved. } \\
\text { Dau. of Makeless (Oglethorpe Arabian)-dau. of Brimmer (D'Arcy } \\
\text { Yellow Turk-Royal mare)-dau. of Diamond-sis. to Merlin's dan. }\end{array}$ \\
\hline 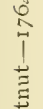 & & & 焉 & Daughter of & $\begin{array}{l}\text { Fox Cub by Clumsy (Hautboy-Miss D'Arcy's Pet mare)-dau. of the } \\
\text { Dau. of Coneyshins (Lister TuRk)-dau. of Hutton's Grey Barb-dau. } \\
\text { of Hutton's Royal colt (Helmsley T.- Royal mare)-dau. of Byerly } \\
\text { Turk, etc. }\end{array}$ \\
\hline 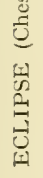 & & $\underset{\substack{\hat{m} \\
i}}{i}$ & 运 & & $\begin{array}{l}\text { The Godolphin-the most celebrated of all the Eastern sires, about whom } \\
\text { opinions are divided as to whether he was an Arabian or a Barb, the } \\
\text { best judges inclining to the latter beliel-was picked up in Paris } \\
\text { about } 1728 \text { (where it is said he had actually drawn a water cart) by } \\
\text { Mr. Coke, of Norfolk, who gave him to Mr. R. Williams, by whom he } \\
\text { was presented to the Earl of Godolphin. A brown bay, with some } \\
\text { white on off hind heel : about fifteen hands. Died } 1753 \text {. }\end{array}$ \\
\hline & & 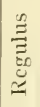 & $\begin{array}{l}\dot{\Xi} \\
\dot{\Xi} \\
\stackrel{\Xi}{c}\end{array}$ & $\begin{array}{l}\text { Bald } \\
\text { Galloway } \\
(--)\end{array}$ & $\begin{array}{l}\text { St. Victor's Barb was imported into France by MI. St. Victor, from whom } \\
\text { he was purchased by Captain Rider, of Whittlebury Forest, Northamp- } \\
\text { tonshire, and attached to his stud. } \\
\text { Dau. of Why Not (son of Fenwick Barb)-her dam a Royal mare. }\end{array}$ \\
\hline & $\frac{0}{9}$ & & 永 & $\begin{array}{l}\text { Sis. to Old } \\
\text { Country W. }\end{array}$ & $\begin{array}{l}\text { Snake by the LISTER TuRk-dau. of the Hautboy (D'Arcy White } \\
\text { 'Turk-Royal mare). Further breeding not preserved. } \\
\text { Grey Wilkes by Hautboy (D'Arcy White Turk-Royal mare)-Miss } \\
\text { D'Arcy's Pet mare-dau. Sedbury Royal mare. }\end{array}$ \\
\hline & 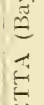 & $\dot{1}$ & $\begin{array}{l}4 \\
b \\
0 \\
5\end{array}$ & Snake. & $\begin{array}{l}\text { The LISTER TURK was brought into England by the Duke of Berwick, } \\
\text { from whom he was purchased by Mr. Lister. } \\
\text { Daw. of Hautboy (D'Arcy White Turk-Royal mare). There is no } \\
\text { record of Snake's grand-dam. }\end{array}$ \\
\hline & $\overline{\omega_{n}}$ & z & 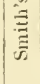 & -). & $\begin{array}{l}\text { The Stud Book gives no account of the dam of Smith's son of Snake, } \\
\text { although he begat W'illiams' Squirrel in } 1719 .\end{array}$ \\
\hline & & 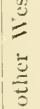 & 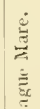 & $\begin{array}{l}\text { Woodcock } \\
(-17 \text { I } 5)\end{array}$ & $\begin{array}{l}\text { Merlin by Bustler (Helmsley Turk). Further breeding unknown. } \\
\text { Sis. to Ruffler by son of Brimmer (D'Arcy Yellow Turk Royal mare)- } \\
\text { dau. of Chesterfield Arabian-dau. of Hutton's Grey Barb-dau. of } \\
\text { Why Not (Fenwick Barb)-Wilkinson's Turk mare. }\end{array}$ \\
\hline & & $=$ & $\underset{\Xi}{\stackrel{\Xi}{\Xi}}$ & $\begin{array}{l}\text { Daughter of } \\
(\stackrel{-}{(-})\end{array}$ & $\begin{array}{l}\text { Hautboy by the D'Arcy White Turk-his dam a Royal mare. This sire } \\
\text { was in the stud of Lord D'Arcy at Sedbury, Yorks. } \\
\text { Dau. of Brimmer (D'Arcy Yellow Turk-his dan a Royal mare). } \\
\text { Brimmer was in the stud of Lord D'Arcy, of Sedbury, Yorks. }\end{array}$ \\
\hline
\end{tabular}


from a different Eastern horse. We have also stated that no other tail male line from the Arab has existed in this country for about a hundred years. So far then, it is proved that the English thoroughbred is of Eastern descent in the male line, but there are many difficulties in the way of proving all the female descent, and a brief glance at the full pedigrees of the three horses will take us some way towards explanation.

\section{Pedigree of Eclipse}

As it is the most important, we first give the full pedigree of Eclipse. It will be noticed that on his sire's side of the house Eclipse was fourth in descent from the Darley Arabian. His great grandsire Bartlett's Childers was out of Betty Leedes by Careless out of Sister to Leedes by the Leedes Arabian (an imported horse) out of a daughter of Spanker, whose dam was the Morocco Barb mare-Spanker's dam. Spanker was himself by the D'Arcy Yellow Turk (an imported horse) out of the old Morocco mare, who was by Lord Fairfax's MIorocco Barb out of Old Bald Peg, who was said to be by an Arabian horse out of a Barb mare. What particular Arabian horse, and what Barb mare these were there is no evidence to prove, and it must be admitted that the bare statement to be found in Pick, and repeated in the first volume of the Stud Book is unsatisfactory. It is generally allowed, however, that Bartlett's Childers was entirely of Eastern blood, and there it must be left.

Turning now to Squirt, the son of Bartlett's Childers, and the grandsire of Eclipse, he was out of Sister to Country IVench by Snake out of Grey Wilkes. Snake was by the Lister Turk (imported) out of a daughter of Hautboy - who was by the D'Arcy White Turk out of a Royal mare, and in this direction the pedigree ends, there being no evidence as to the dam of the daughter of Hautboy.

Grey Wilkes again goes to two Royal mares, one being the dam of Miss D'Arcy's Pet mare, whose sire is unknown to this day. Here there are two blanks in Eclipse's pedigree. Again the dam of Blacklegs
(Marske's maternal grandsire) traces to Coneyskins and the Old Clubfoot mare, and in both cases the dam is unknown. Bay Bolton again was by Grey Hautboy, of whose dam nothing was known.

\section{Royal Mares}

There is no need to analyse the pedigree further, but there are in all thirteen blanks which cannot be traced, and it has been urged by some of those who made great study of the matter that some of the original and muknown female lines were of English blood. It is generally understood that the Royal mares were imported by Charles II. The story goes that the Fing sent abroad Sir John Fenwick, Master of the Horse, and a prominent turfite of the day, to procure a number of high-bred stallions and mares for breeding purposes. There is no account extant of the countries to which Sir John Fenwick went, but whether the horses imported were Arabs, Barbs, or Turks, it is a fact that improvement in the breed quickly followed their arrival in this country. The mares then procured were called Royal mares, and as far as can be judged the term Royal was applied to many of their offspring.

But after all, the evidence which is forthcoming with regard to the Royal mares is hardly conclusive, except in one particular instance. It is well known that Arabs are not inclined to part with their mares, and no Eastern mares are mentioned by name until after Sir John Fenwick's visit to the East. Shortly after this comes mention of Dodsworth's dam, and in Pick's Register we find the following:-

"Dodsworth, though foaled in England, was a natural Barb-His dam (a Barb mare) was brought over in the time of King Charles the Second, and was styled a Royal mare-She was sold by the stud master, about or soon after the King's death, for to guineas, at 20 years old, when in foal of Vixen-Dodsworth, was a stallion and covered several well-bred mares, as will appear in various pedigrees."

This is conclusive enough, and suggests that the original Royal mares were Barbs ratler than Arabs, and that under any 
PEDIGREE OF HEROD

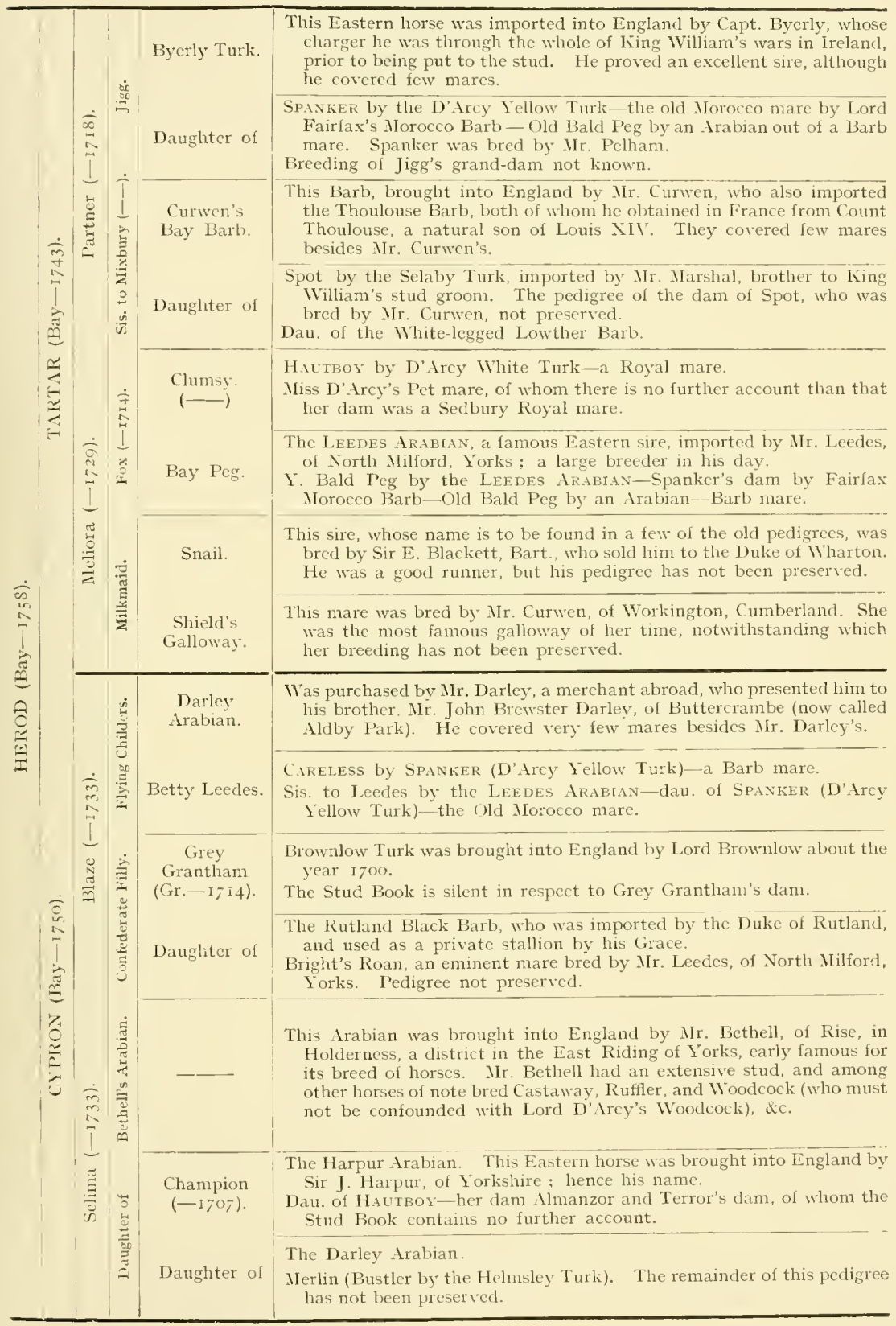


circumstances they were of Eastern origin. But the very fact of the names of several Royal mares being given in the pedigree of Eclipse, and of there still being so many blanks which have never been filled up, leads one to think that some, at least, of these blanks may have referred to native blood. All the records of the imported blood, from the time of Charles II. onwards, have, apparently, been well kept, and therefore it is perhaps reasonable to assume that where there is no mention of Eastern horses by name in a pedigree the blood was native. This is merely presumption, but it is presumption for which there is some foundation, and here it may be pointed out that in the reign of Charles 11 . there was already in this country a breed of light horses, which had probably been used for all the racing which took place, and which (breed) had been constantly recruited throughout the Middle Ages.

It is not as if the imported Eastern sires were brought to this country in order that they might be crossed with horses of the cart horse type, but rather it is practically certain that they were brought here especially for the best light mares which the country possessed.

\section{Foreign Stock}

According to Blundeville, not only Barbary and Turkish, but Spanish, Neapolitan, and Sardinian horses were known in England in 1580 , and all this has been carefully explained by Professor Ridgeway, in his "Origin and Influence of the Thoroughbred Horse," a work which has gone deeply into the subject, and which sets ont a mass of evidence on every disputed point in connection with the thoroughbred. But in one little matter we hardly agree with Professor Ridgeway, for he says "it is now practically admitted that our racing stock is purely foreign in origin, etc." We need not go further into the question, but we have shown that there is some room for the belief that the blanks in the early pedigrees were native, and there we must leave it - for at this day no further evidence is likely to be forthcoming.
Returning for a moment to the pedigree of Eclipse, it may be mentioned that he had nine strains of Hautboy, who represents the blood of D'Arcy's White Turk, five of the Lister Turk, six of Spanker, who was by the D'Arcy Yellow Turk, and two of the Leedes Arabian. In all, Eclipse can be traced to other Eastern stallions than the Darley Arabian through twenty-two channels. The Stud Book does not give the date of the importation of the D'Arcy White Turk, or the D'Arcy Yellow Turk, but they were brought to England by Lord D'Arcy more than two hundred years ago, and were located at the Sedbury stud, and it is because records of that stud appear to have been carefully kept where Eastern sires had been used that we can assume that where no Eastern sire or dam is named the blank implies something of English origin. And if the pedigree is referred to it will be seen that the sire of Miss D'Arcy's Pet mare is not given, which suggests the probability of her having been the daughter of an English horse.

\section{Pedigree of Herod}

We now give the pedigree of Herod of the line of the Byerly Turk, and here we have much the same want of completeness that there is in the pedigree of Eclipse. The name of Miss D'Arcy's Pet mare occurs in this pedigree, as it does in that of Eclipse, but there are two exceedingly weak points in the lineage of Herod, where the information is most meagre.

One of them is the breeding of Meliora, the dam of Tartar, who was Herod's sire. Meliora was by Fox, whose sire Clumsy has one blank, but whose dam Bay Peg was of Eastem origin. Meliora's dam was Milkmaid by Snail, and all that is known about Snail is that he was bred by Sir Edward Blackett, and sold to the Duke of Wharton. What he was by, or how his dam was bred is not known, but as he was bred in a remote part of Northumberland it is quite likely that he was of English blood. Milkmaid's dam was the Shield's Galloway, who was bred by Mr. Curwen (the owner of Curwen's Bay Barb) of Workington, and was the 
PEDIGREE OF MATCHEM

\begin{tabular}{|c|c|c|c|c|c|}
\hline & $\dot{\vec{\ddagger}}$ & $\frac{\frac{E}{\Xi}}{\frac{E}{0}}$ & I & & $\begin{array}{l}\text { The Godolphin - the most celebrated of all the Eastern sires, about } \\
\text { whom opinions are divided as to whether he was an Arabian or a } \\
\text { Barb, the best judges inclining to the latter belief was picked up in } \\
\text { Paris about } 1728 \text { (where it is said he had actually drawn a water cart) } \\
\text { by Mr. Coke, of Norfolk. This gentleman gave him to Nr. R. Willians, } \\
\text { keeper of the St. James's Coffee House, by whom he was presented to } \\
\text { the Earl of Godolphin, to whose stud he was attached for many years. } \\
\text { He was a brown bay, with sone white on his off hind heel, and was } \\
\text { about fifteen hands high. He died in I753, supposed to be twenty- } \\
\text { nine years old. }\end{array}$ \\
\hline & $\underset{1}{2}$ & & $\stackrel{3}{3}$ & $\begin{array}{l}\text { St. Victor's } \\
\text { Barb. }\end{array}$ & $\begin{array}{l}\text { This Eastern sire was brought into France by } 11 \text {. St. Victor, a gentleman } \\
\text { well known to sportsmen, and he was subsequently attached to the } \\
\text { stud of Capt. Rider, at Whittlebury Forest, Northamptonshire. }\end{array}$ \\
\hline & & $\underset{⿱ 亠 䒑}{\stackrel{\infty}{1}}$ & $\frac{3}{3}$ & Daughter of & $\begin{array}{l}\text { Why Not by the Fenwick Barb. Why Not is to be found in several of } \\
\text { the old pedigrees, but his further breeding has not been preserved. } \\
\text { Royal mare. }\end{array}$ \\
\hline $\bar{\sigma}$ & & 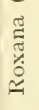 & 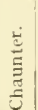 & Akaster Turk. & $\begin{array}{l}\text { By whom this famous Eastern sire was brought over there is no } \\
\text { record. He covered very few mares, but nevertheless his blood comes } \\
\text { down to our time through Cade, Molly Long Legs, Squirrel, and } \\
\text { Thwaites Dun mare. }\end{array}$ \\
\hline $\overrightarrow{1}$ & & & $\begin{array}{c}2 \\
\frac{m}{s}\end{array}$ & Daughter of & $\begin{array}{l}\text { Leedes Arabian-imported by Mr. Leedes, of North Milford, Yorks. } \\
\text { next to Lord D'Arcy the largest breeder of his time. } \\
\text { Dau. of Spanker, her breeding not preserved. }\end{array}$ \\
\hline$\underset{0}{=}$ & & & $\dot{\theta 0}$ & Byerly Turk. & $\begin{array}{l}\text { Was imported by Capt. Byerly, whose charger he was through the } \\
\text { whole of King William's wars in Ireland, prior to being put to the } \\
\text { stud. }\end{array}$ \\
\hline$\underset{I}{J}$ & & $\underset{\hat{x}}{0}$ & $=$ & Daughter of & $\begin{array}{l}\text { Spanker by the D'Arcy Iellow Turk-dau. of Lord Fairfax's Morocco } \\
\text { Barb-Old Bald Peg by an Arabian horse out of a Barb mare. } \\
\text { Nothing is known of Jigg's grand-dam. }\end{array}$ \\
\hline & $\stackrel{i}{m}$ & 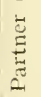 & $\stackrel{\hat{E}}{\underline{E}}$ & $\begin{array}{l}\text { Curwen's } \\
\text { Bay Barb. }\end{array}$ & $\begin{array}{l}\text { Was brought into England by Mr. Curwen, of Workington, Cumberiand. } \\
\text { He covered very few mares besides Mr. Curwen's and Mr. Pelham's, } \\
\text { and was a most valuable sire. }\end{array}$ \\
\hline & 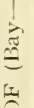 & & 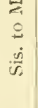 & Daughter of & $\begin{array}{l}\text { Spot by the Selaby Turk. Of Spot, who was bred by Mr. Curwen, of } \\
\text { WVorkington, nothing more is known. } \\
\text { Dau. of the White-legged Lowther Barb-the Old Vintner mare, greatly } \\
\text { celebrated, but whose breeding was not preserved. }\end{array}$ \\
\hline & $\underset{\Xi}{\check{E}}$ & & $\frac{n}{2}$ & $\begin{array}{l}\text { Oglethorpe } \\
\text { Arabian. }\end{array}$ & $\begin{array}{l}\text { This Arabian was imported into England by Sir Thomas Oglethorpe, of } \\
\text { Scotland, and, besides Makeless, was the sire of Bald Frampton, and } \\
\text { the famous Scotch galloway who beat the Duke of Devonshire's } \\
\text { Dimple at Newmarket. }\end{array}$ \\
\hline & $=$ & $\begin{array}{l}\overline{0} \\
\dot{b}\end{array}$ & $\frac{\sqrt{3}}{2}$ & $(\longrightarrow)$ & $\begin{array}{l}\text { Nothing authentic is known of the breeding of the dam of that dis- } \\
\text { tinguished performer on the turi and favourite sire, Iakeless, whose } \\
\text { name is to be found in several of the best old pedigrees. }\end{array}$ \\
\hline & & 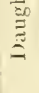 & $\mid \begin{array}{l}\overrightarrow{5} \\
\vec{\Xi}\end{array}$ & Brimmer & 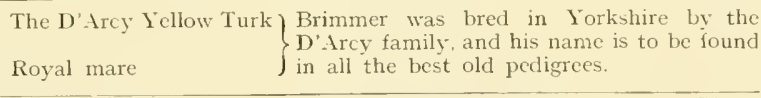 \\
\hline & & & $\frac{5}{2}$ & Daughter of & $\begin{array}{l}\text { Place's White Turk, a famous sire, brought into England by Mr. Place, } \\
\text { stud groom to ()hiver Cromwell when Protector. } \\
\text { Dodsworth (a natural Barb, though foaled in England)-the Layton } \\
\text { Barb mare. }\end{array}$ \\
\hline
\end{tabular}


most famous racing pony of her time. Fet there is no trace of her breeding in any of the old records, and no trace of her having been imported. Then Herod's dam Cypron was by Blaze, a son of Flying Childers and the Confederate filly, and the last-named was by Grey Grantham out of an unnamed mare, who was by the Rutland Black Barb out of a danghter of Bright's Roan. Grey Grantham was by the Brownlow Turk, but his dam is unknown. Bright's Roan was bred by Mr. Leedes, owner of the Leedes Arabian, but neither her sire nor dam are known, and thus in one sixteenth of Herod's pedigree there are actually three blank spaces. Further down there are even more, and as a matter of fact the pedigree is no more perfect than that of Eclipse, but it takes in two strains of the Darley Arabian, and about twenty others of known Eastern blood. At this date there is no likelihood that the mystery of these many blanlss will ever be explained.

\section{Pedigree of Matchem}

Lastly we give the pedigree of Natchem, which differs slightly from the other two because, whereas Eclipse and Herod were the great-great-grandsons of the Darley Arabian and the Byerly Turk respectively, Natchem was the grandson of the Godolphin, and therefore two degrees nearer to his tail male ancestor. But Matchem's grand-dam Roxana had two flaws in her pedigree, and Iatchem's own dam had one absolute blank only three generations away, and several further back. The dam of Matchem was never named, but was by Partner out of a daughter of Makeless, and Makeless was by the Oglethorpe Arabian ont of a mare of whom nothing whatever is known. Thus, though Matchem was nearer to the Eastern horse than either of his great stud rivals, he too cannot show anything like a clean sheet, and it is quite as fair to assume that some at least of the blanks in his pedigree were British as that they were Eastern.

The pedigrees given in this chapter were compiled by Mr. Joseph Osborne for the "Horse Breeder's Hand-Book," and were revised for the "Horse Breeder" newspaper (I890-I-2) by Mr. Osborne and the present Author, who, over the signature of "Blacklock," wrote on breeding in every number of the "Horse Breeder" during its nearly three years of existence. 


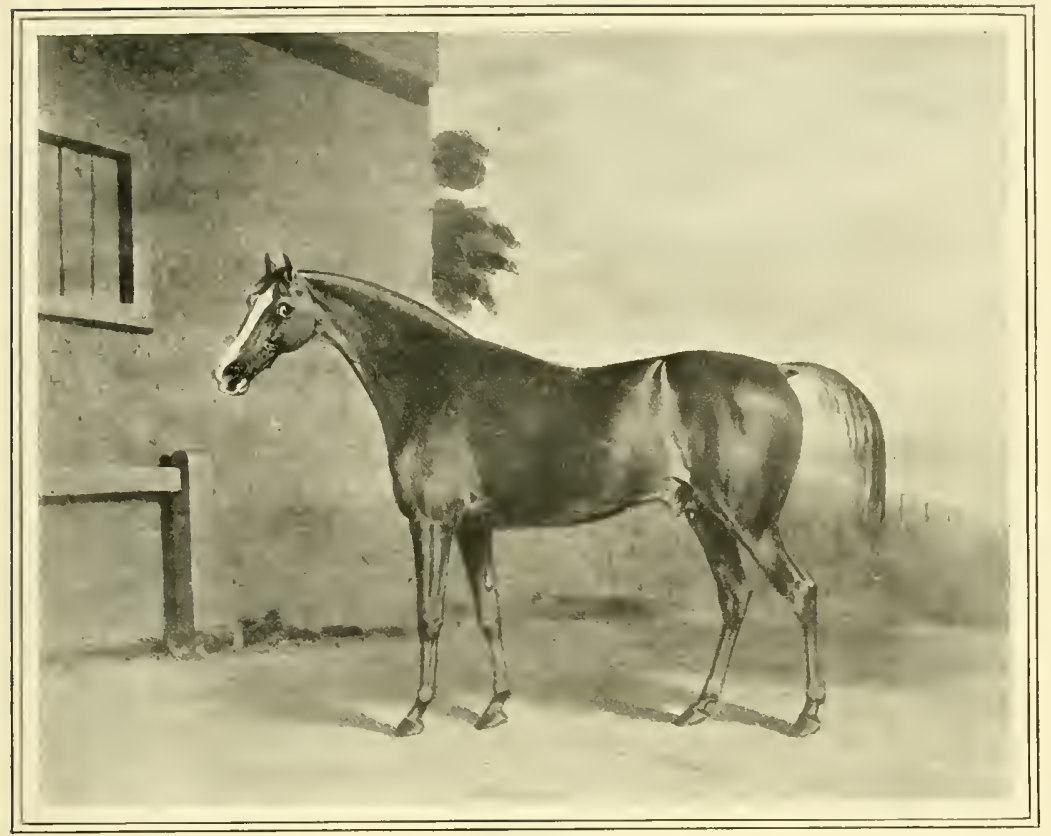

POT.8.0S.

From the pantmg by George Stubbs, A.R.A.

\section{CHAPTER IV}

\section{THE LINE OF ECLIPSE}

$\mathrm{T}$ the horse himself was distancing his com petitors at Epsom, for the tail male descendants of Eclipse have lately been winning about nine-tenths of the stake money which is run for in the United Kingdom. For many years it was a great struggle between the lines of Eclipse and Herod, while Matchem was alway's in a subordinate position, but Herod has-in this country-beat a rapid retreat during the present generation, and now in the male line he is doing nothing like so well as Matchem, whose fortunes have been revived by the stud successes of Barcaldine and his descendants.

To show the descent in tail male will be the simplest plan, and dealing first with Eclipse, his blood has come down in male descent through more than one channel. Eclipse's greatest son was a horse named Pot-8-os, who was bred in 1773 by Lord Abingdon, and sold four years later to Lord Grosvenor. He ran for seven seasons with much success, and was then sent to the stud, where he made a great name for himself. There is no need to go at length into his performances, but he is responsible 
for several existing lines of Eclipse, as the following tables will show.

Eclipse

Pot-8-os

Waxy

Whalebone

Sir Hercules

Birdcatcher

The Baron

Stockwell-

Doncaster

Bend or

\begin{tabular}{cll} 
& \multicolumn{1}{|l}{$\mid$} \\
$\begin{array}{l}\text { Kendal } \\
\text { Galtec Iore }\end{array}$ & $\begin{array}{l}\text { Ormonde } \\
\text { Orme } \\
\text { Flying Fox }\end{array}$ & $\begin{array}{l}\text { Bonavista } \\
\text { Cyllene }\end{array}$ \\
Cicero
\end{tabular}

The line we have shown is perhaps the best known, but there are others which are well to the fore, so that we may give some further variations of the family, as follows:-

Eclipse

Pot-8-os

Waxy

Whalebone

Sir Hercules

Birdcatcher

The Baron

Stockwell

Lord Ronald

Master Kildare

Melton

Blair Athol
Craigmillar
Bread Knife

$\begin{array}{ll}\text { The Duke } & \text { Lord'Lyon } \\ \text { Bertram } & \text { Minting } \\ \text { Robert the Devil } & \text { Minstcad }\end{array}$

Chittabob

The above lines all come through Sir Hercules, and at one time were generally known as branches of the Sir Hercules family. Then for a time much mention was made of Birdcatcher blood, and it will be seen that every example we have given does not leave the parent line until after Birdcatcher lias been included. Nore latterly one hears of the Oxford line of Birdcatcher, for which Gallinule has done so much, and of the Bend Or family, from whom come the Ormonde-Orme-Flying Fox line, the Bonavista-Cyllene-Cicero family, and such sires as Martagon, Orvieto, and many others.

A pectliar feature of the Bend Or line is that many of its chief winners have been bred from very young parents. Thus Doncaster won the Ierby in 1873 , and during the 1908 season a two-year-old named Jackson was running in England who is by French Fox, a son of Flying Fox. This youngster is therefore sixth in descent from Doncaster, so that in his case the last halfmerit. dozen generations of his pedigree have averaged less than six years.
Or, if we look at it in another way, Jackson, or any other grandson of Flying Fox, is nineteenth in descent from the Darley Arabian, while the still rumning sons and

daughters of St. Simon are fourteenth in descent from the same horse, and the sons and daughters of IIarco, or any other Barcaldine horse, only thirteen generations from the Godolphin.

It is no easy matter to decide which line of Birdcatcher is the strongest, for whilst Flying Fox and his immediate ancestors monopolised all the attention a few years ago, just lately Gallinule has beaten all the Stockwell horses, having been for several years past one of the highest placed and most consistent of stallions. At the same time the Doncaster family has been productive of more brilliant performers, and notably Ormonde and Flying Fox were quite exceptional horses, while Bend Or and Orme were a very long way beyond the average race-horse in point of all-round

In this connection it is hardly necessary to go right back, and discuss each of the lines scriatim, but Birdcatcher must have been an extraordinary horse, for he founded 


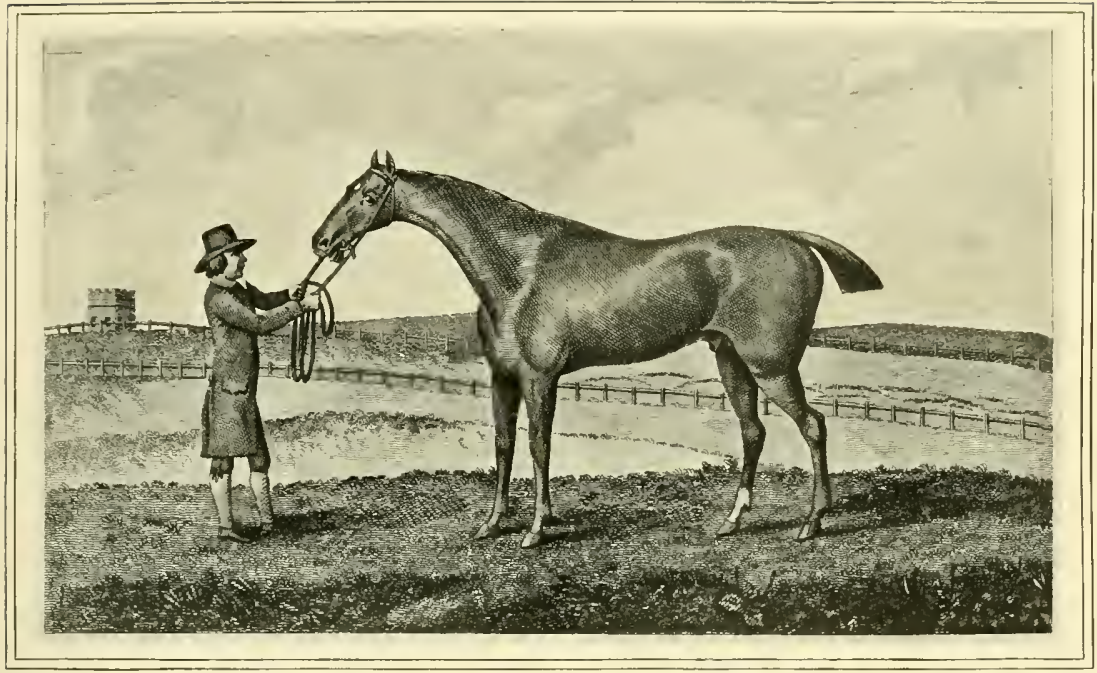

WAXY.

From the engraving by Cook

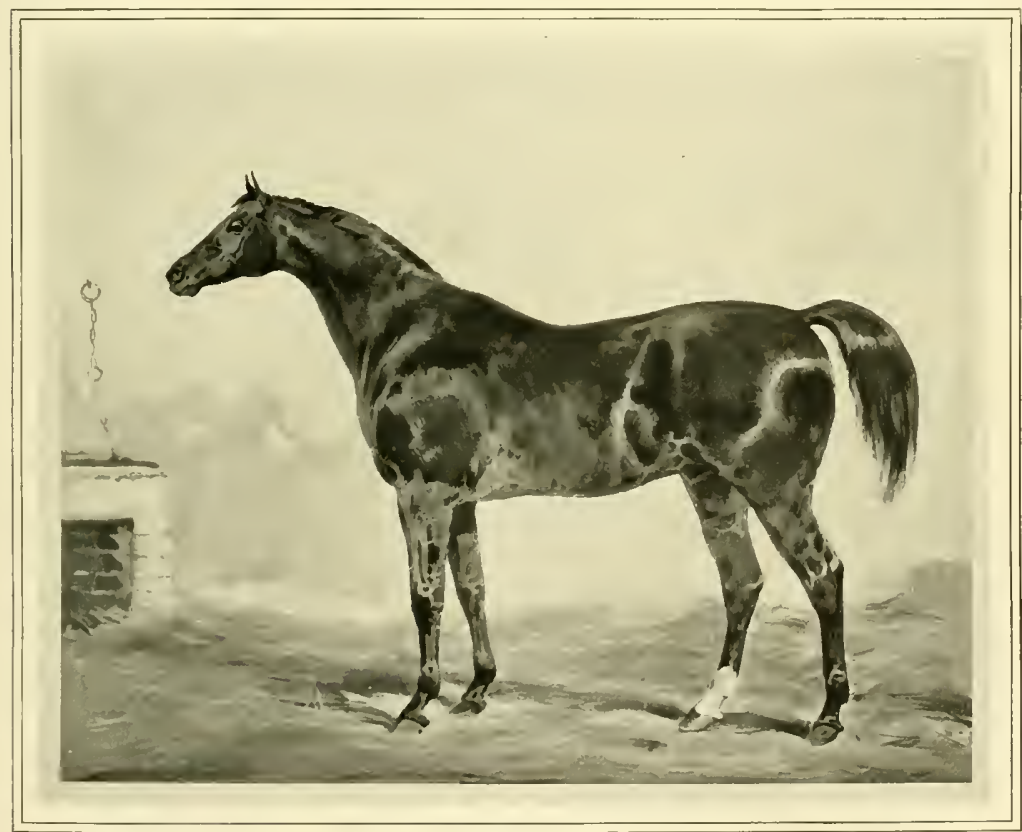

WHALEBONE.

From the painting by J. F, Horring. 
the Stockwell, and also the Oxford line, just as his grandsire Whalebone had been responsible for the Sir Hercules and the Camel families. Birdcatcher was bred in Ireland, where his sire Sir Hercules had been sent, and was raced in Ireland, where he very often played second fiddle to Harkaway. He does not seem to have been a horse of the highest class when in training, for he was beaten oftener than he won, but he sired The Baron, a chestnut horse who was foaled in $18_{42}$, his breeder being a Dublin veterinary surgeon named Watts.

During his three-year-old career The Baron was sent to England to be trained by John Scott at Malton, and he not only won the St. Leger, but carried a ten pound penalty to victory in the Cesarewitch. He was in fact a high class horse, and he sired the brothers Stockwell and Rataplan, both of whom live in tail male to this
day-Stockwell in half a dozen different lines.

Stockwell was bred by Mr. Theobald in I849, and was named after the district of South London in which he was foaled. He also was a chestnut, and was built on very massive lines, great substance being his strongest point. His breeder and other good judges-says "The Druid "-thought him to be on too large a scale, but Lord Exeter was persuaded to buy him, and got him for $£$ r8o, with a contingency of $f 500$ if he won the Derby. Lord Exeter was only just in time, as $\mathrm{M}_{\mathrm{r}}$. Theobald died within a month of Stockwell reaching Burleigh.

Stockwell was not a beauty to look at, and not a good goer, and he was beaten in both his two-year-old efforts, while he also suffered defeat as a three-year-old at the Craven meeting of 1852 . He then won the Two Thousand Gumeas, and the New-

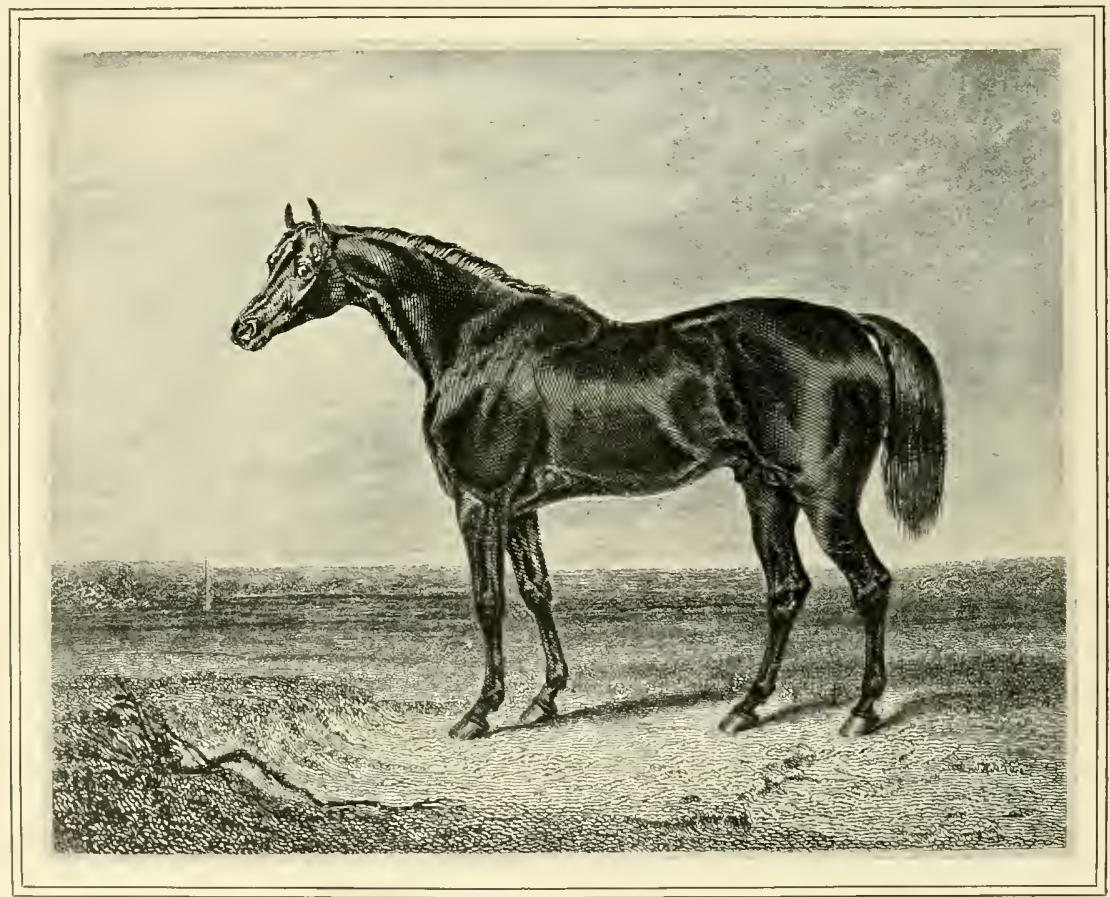

SIR HERCULES.

From the engraving by Pain after the pointing by Hatcock. 


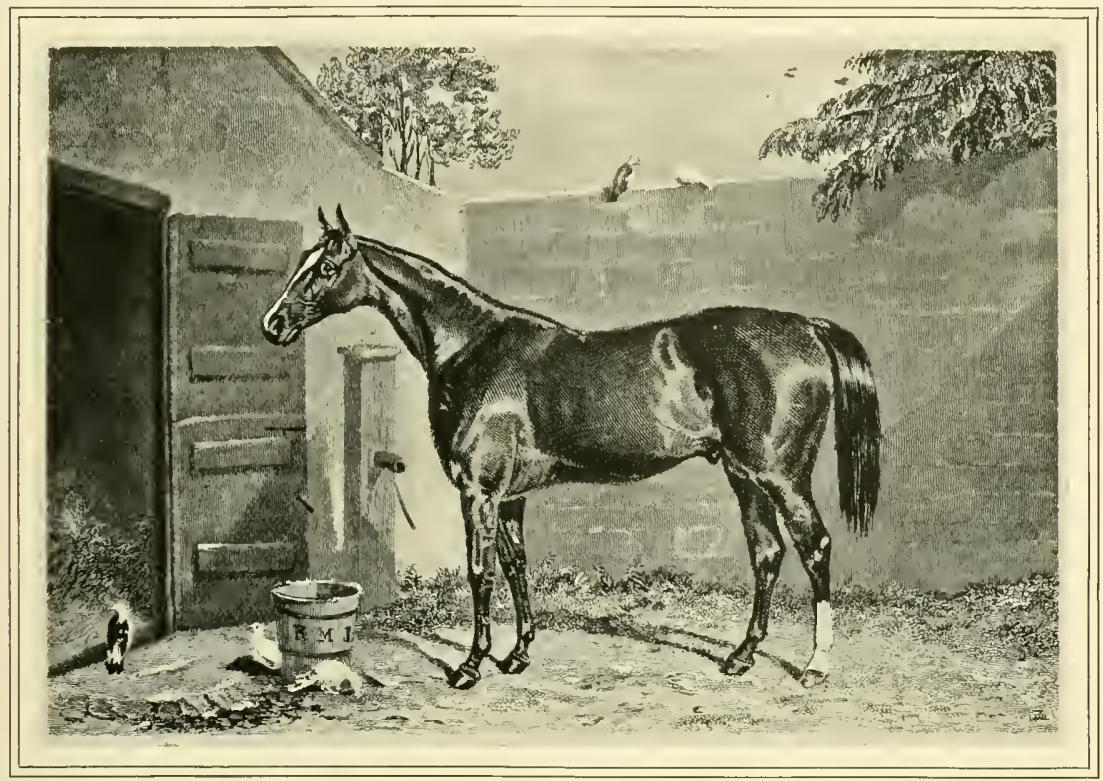

BIRDCATCHER.

Flom the englaring by E. Hacker after the paining by Harry Hall.

market Stakes, but was unplaced in the Derby won by Daniel O'Rourke. He took up the winning thread again, however, at Goodwood, where he was twice successful, and he afterwards won the Great Yorkshire Stakes, and the Doncaster St. Leger, in which latter race he turned the tables on his Epsom conqueror, I aniel O'Rourke.

That Stockwell would have won the Derby had he been all right is practically certain, but the horse was out of form, and ought not to have been started. As a fouryear-old Stockwell was beaten by a head by the five-year-old Teddington for the Emperor's Plate at Ascot; he then went amiss, and did not run again for a year and a half, when he beat Kingston for the Whip. At the stud his successes were quite remarkable, and he justly earned the title of "Emperor of Stallions." Year after year he headed the wimning sire list, and in I866 his stock won $£ 66,39 \mathrm{r}$ in stake money, a sum which has not since been exceeded.

His sons won three Derbys, six St. Legers, four Two Thousands, three One Thousands, and one Oaks. It would take a full page to enumerate all the good horses for which he was responsible, but mention may be made of Blair Athol, Lord Lyon, and Doncaster, and of St. Albans, Lord Ronald, and Uncas, for all of these live in tail male. Blair Athol was undoubtedly the greatest race-horse sired by Stockwell, and at the stud he too was a great success, heading the sire list year after year, as his sire had done, but not with such great amounts to his name. Blair Athol was the sire of many good horses, including the Derby winner Silvio, but his line has not lived in tail male as one expected it to do, and at the moment it has no better representative in this country than Bread Knife.

Doncaster came nine years later than Blair Athol, and if he never created the furore which the "pale-faced chestnut" had done, he was nevertheless at very sterling performer, and the sire of Bend Or. The last-named was a brilliant performer up to 
a mile and a half, and was always seen to the greatest advantage at Epsom, where he won the Derby, the Epsom Cup, and the City and Suburban under nine stone. His many struggles with Robert the Devil (a great-grandson of Stockwell through The the unbeaten St. Simon, and there are others who have some pretensions to be far beyond the ordinary good race-horse in point of merit, but we are concerned with Ormonde at the moment, and it may be said that proof of his great class was afforded by the excellent

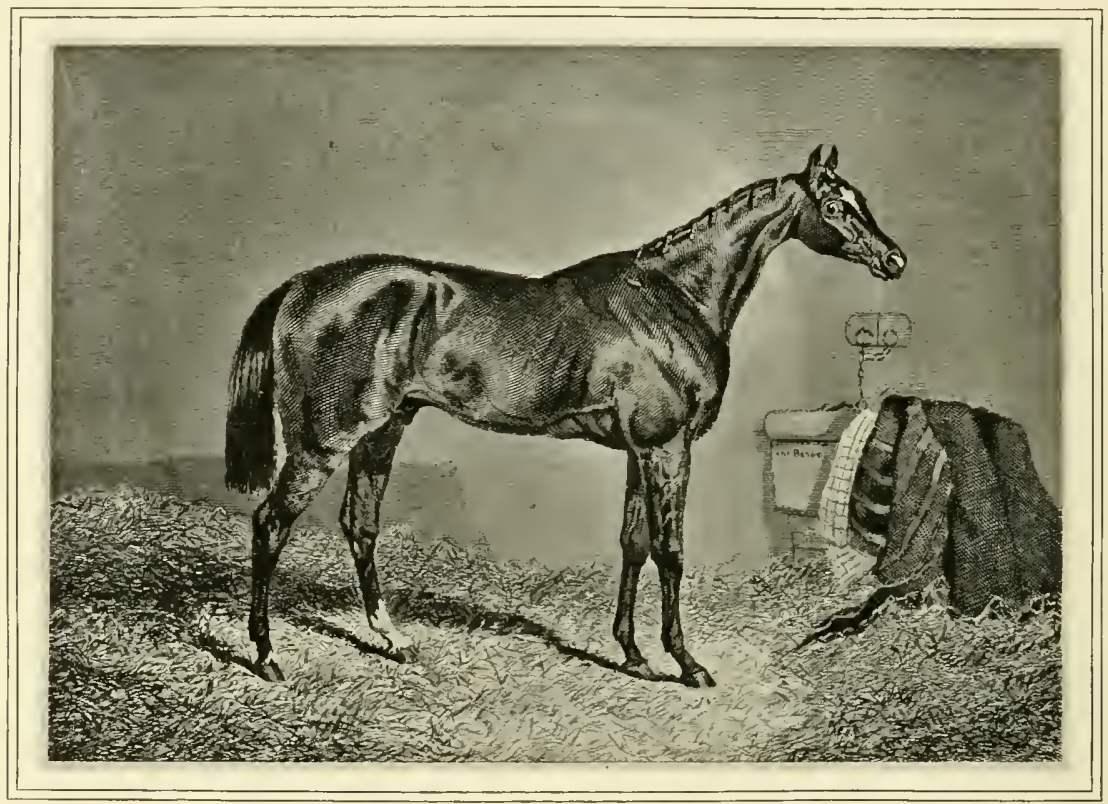

THE BARON.

From the engrating by $E$. Hacker after the painting by J. F. Herring.

Duke and Bertram) were a great feature of the racing of that particular period, but Bend Or's fame as a sire was quite as great as that which he earned on the race-course, for he not only got Ormonde, but continued sireing winners until he was a great age.

Indeed, the I908 Goodwood Cup winner, Radium, is actually a son of Bend Or, whereas Jackson, the son of French Fox, to whom reference was made a page or two back, claims the famous r 880 Derby winner as his great-great-great-grandsire.

Ormonde was unbeaten as a race-horse, and is one of two or three horses for each of which it is claimed that it is "the horse of the century." The title is also claimed for performances put up, at other times, by the horses he beat. Minting, for example, succumbed to Ormonde in the Two Thousand, and again in the Hardwicke Stakes at Ascot, when both were four-year-olds, but Minting was good enough to win the Grand Prix de Paris, and to take the Jubilee Handicap at Kempton Park with the huge weight of ten stone in the saddle. Minting, a very big and somewhat angular horse, it should be stated, was a grandson of Stockwell. sired by the Derby winner Lord Lyon, and though he has not been a great stud success himself, it is probable that Minting mares will always be valuable, and it is quite certain that Minting was a great race-horse. 
There is no need to go very deeply into Ornonde's performances, nor to enumerate all the good horses he beat, but, besides Minting, the Bard, Saraband, and St. Mirin were really fine performers, and, in fact, Ormonde's year was one of the best which the modern turf has known. What was chiefly remarkable about Ormonde was his brilliance, and this quality was undoubtedly transmitted to Orme, who had, however, a somewhat chequered career, and was unable to run in the Derby, while in the St. Leger he was ridden in butcher-boy fashion and never had much chance of winning. Orme was seen at his best at Sandown Park, where he won the Eclipse Stakes two years in suc- during his one season at the stud in this country, and yet he sired Orme, Goldfinch, and other good horses. He was sold to go abroad because the late Duke of Westminster, who bred him and raced him, did not care about sending a roarer to the stud. Orme, on the other hand, has always stood at Eaton, in Cheshire, but his stud career has not been exactly even, and though he began with Flying Fox, and in 1907 was responsible for a second Derby winner, exactly ten years later, in Orby, there was an intervening period when very little was heard concerning him. It is said that he suffered from indifferent health during some of this time, but he has done his duty towards the particular line of blood

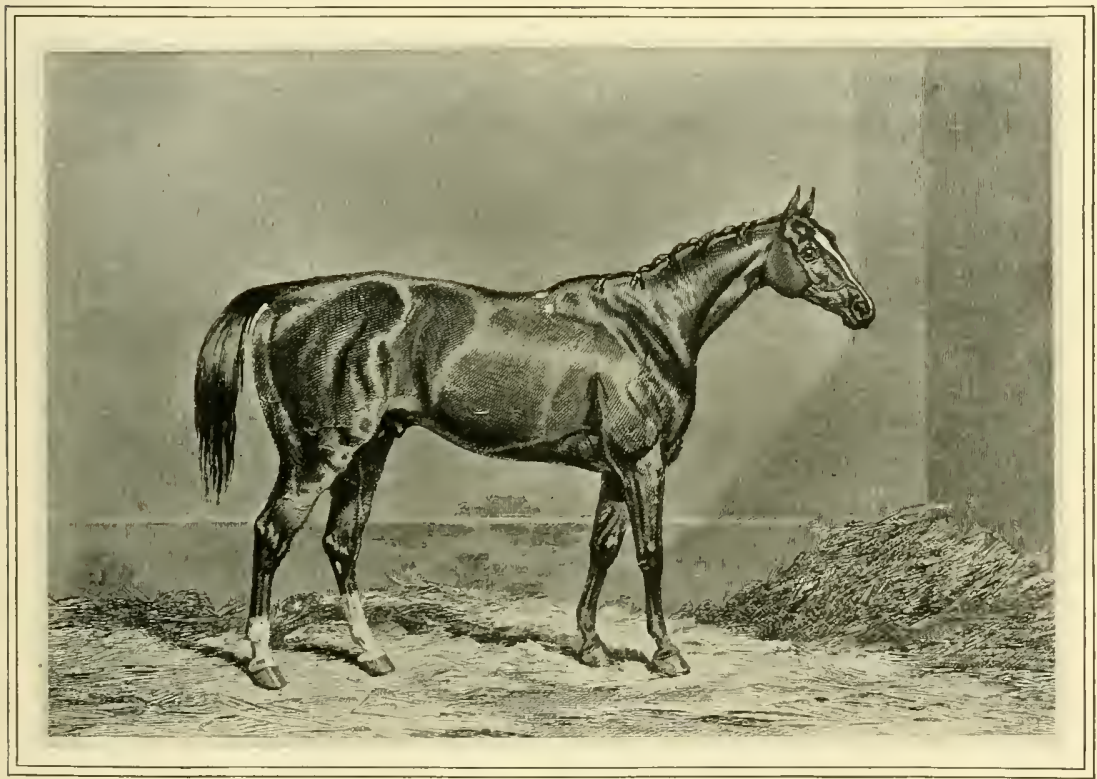

STOCKWEL1.

From the engraving by E. Hacker after the panting by Hawy Hall.

cession, and those who saw it will never forget his grand performance at Goodwood, when he defeated his stable companion La Flèche, the horse having the worst of the weights.

Ormonde suffered from serious illness he comes from, for Flying Fox was one of the most brilliant performers of the present generation, and was also the sire of so many good horses in his first season at the stud that there is little chance of the line dying out. But Flying Fox has been located in 
France ever since he was sold for 37,500 guineas at the famous Kingsclere sale in March, I90o, and all the good horses for which he has, so far, been responsible have been bred in France, and are located there, or have been sold to be sent to America.

Curiously enough, no English breeders who have sent mares to Flying Fox have bred anything of much value as yet, and it is really beginning to look as if this particular line of Stockwell might not be carried on, through this particular channel, in this country.

Orme may, in the future, have to rely upon Orby, as far as the United Kingdom is concerned, or on Missel Thrush, and his son Thrush-a very brilliant short distance runner-but this is a matter of conjecture, and there is nothing to be gained by attempting to probe the future of the various lines of blood. Going back to Bend Or, the horse in question established another line, through Bonavista, and Cyllene, which last named horse has already been responsible for the Derby winner Cicero.

Then Kiendal by Bend Or was the sire of the Derby winner Galtee More (now in Russia), and Martagon, also by Bend Or, is a useful sire, most of whose stock are long distance runners. It will thus be seen that even if Flying Fox fails us in this country, there are many other members of his particular line who are likely to keep it alive.

From Birdcatcher, in addition to The Baron, came Oxford, and though he was not a brilliant race-horse, he sired the great miler Sterling, who in turn, was responsible for Isonomy. The two last-named were far beyond the average in point of merit, and wonderful horse as Sterling was, he

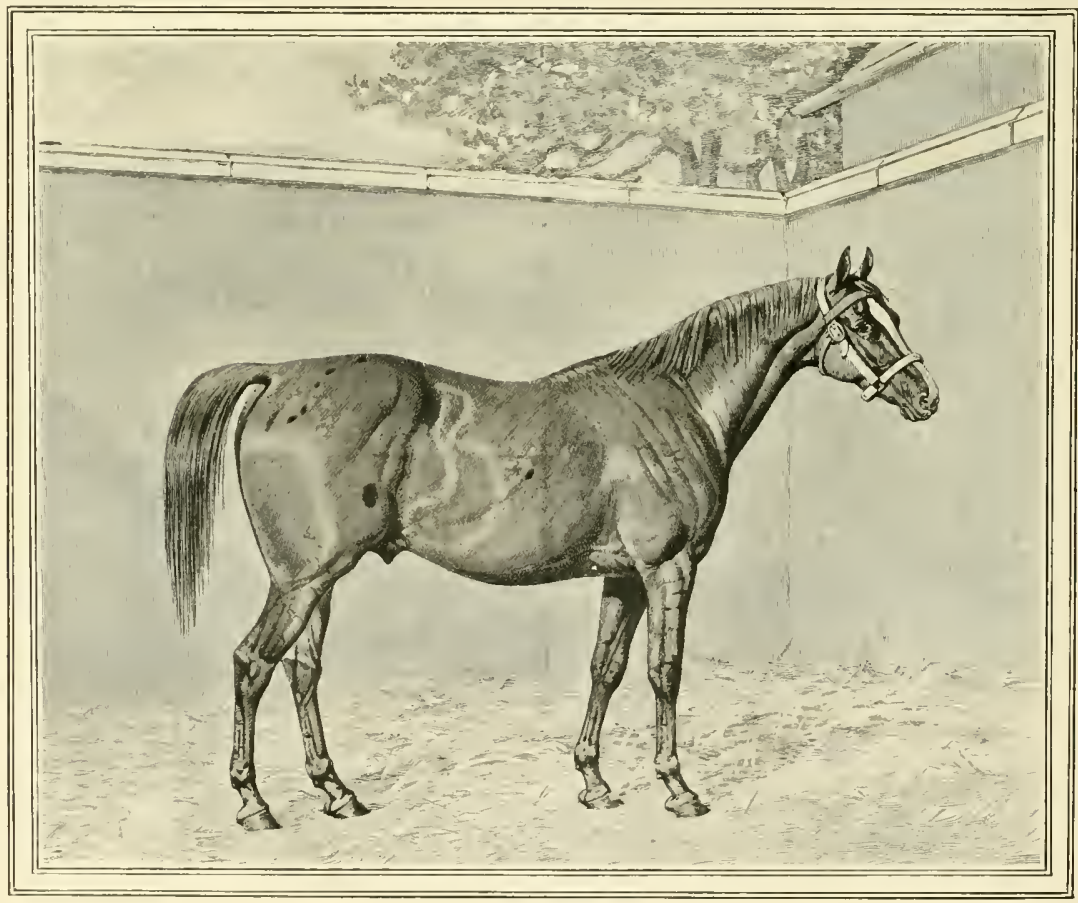

DONCASTER.

From the dhaving by $P$. Palirey 


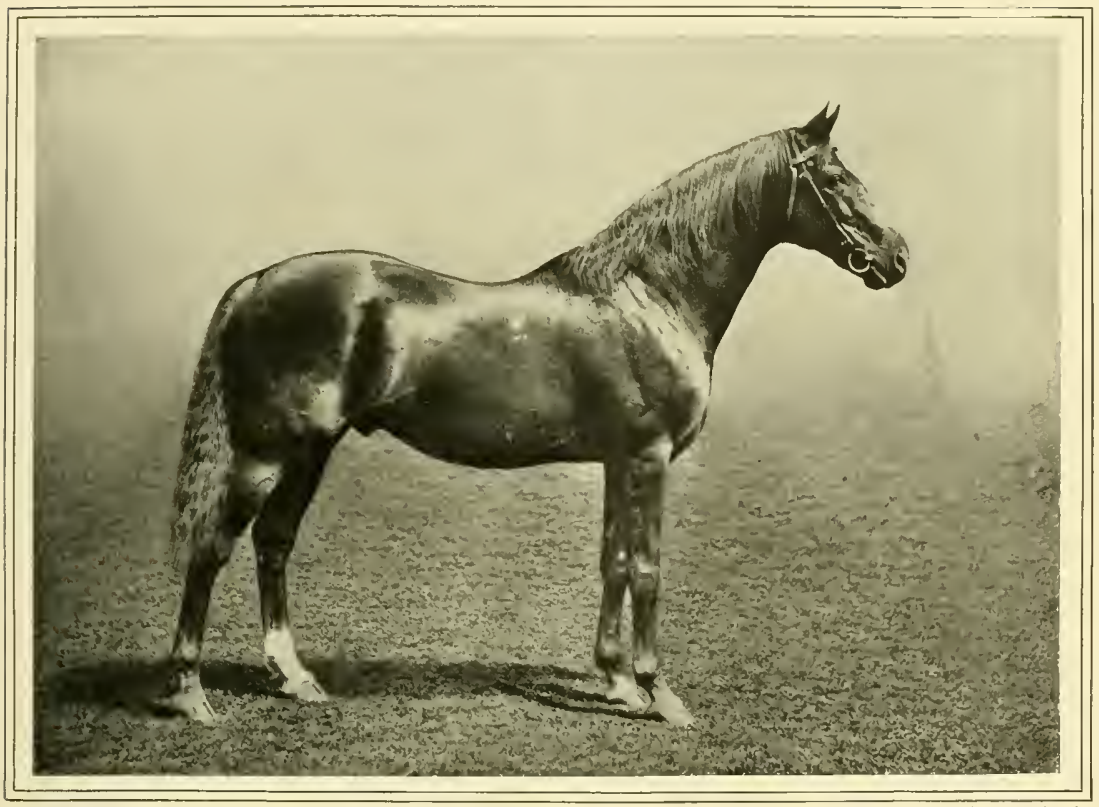

BEND OR.

sired an even better than himself in Isonomy, who was a great stayer, a great weight carrier, and, in fact, a horse of the very highest class. He did not run in the classic races, because he was owned by a man who preferred to win a big stake in a handicap, and thus Isonomy was exploited in the Cambridgeshire, which he won in $I 878$. He also won the Ascot Cup twice, the Goodwood Cup, the Doncaster Cup, the Ebor Handicap under nine stone eight pounds, and the Manchester Cup with nine stone twelve pounds in the sadcle, and at the stud he sired many great horses, including the Derby winners Common and Isinglass (both of these won the Two Thousand and St. Leger as well as the Derby), Janissary, who sired a Derby winner in Jeddah, and Gallinule. The last-named has not yet sired a Derby winner, but has earned future reputation as the sire of Pretty Polly, who won the One Thousand, Oaks, and St. Leger.

Another St. Leger winner by Gallinule was Wildfowler, and though Slieve Gallion -a Two Thousand winner, and one of Gallinule's most brilliant sons-has left the country, it is probable that the line will be continued in tail male.

Isinglass took high rank as a race-horsewhich Gallinule never did-but at the stud the former has not quite fulfilled expectations, and though he has been credited with two Oaks winners and one winner of the One Thousand, he has not yet sired a colt who has been successful in any of the classic races.

The line of Stockwell which has come through Lord Ronald, Master Kildare and Melton is at the moment doing little, but there are young sons of Melton at the stud who may bring about a revival, and it is on the cards that the I 885 Derby winner, who is still alive and well, may yet sire a horse as good as he himself was. Then there is Best Man, a son of Melton, who has been responsible for more than one useful winner. 
As for that line of Stockwell which has come down through St. Albans, Springfield and Sanfoin, the best representative of it, from the point of view of racing merit, is Rock Sand, who won the Derby in I903. This horse was sold for something like $£ 20,000$, and, unfortunately, is now in America, and therefore it is to be hoped that Sanfoin will sire something equally good.

\section{The Camel Line}

We must now go back to the parent line of Eclipse again, and we find that from Whalebone, great-grandson of Eclipse, there came Camel as well as Sir Hercules. Camel was founder of the line which was first spoken of in connection with Touchstone, and afterwards of Newminster. Now it is best known through the descendants of Hampton, though twenty years ago it was Hermit who kept the family in position. Camel had no great career as a race-horse; he was in training for two seasons, and for part of a third, but he never ran except at Newmarket, and yet he made a great name for himself at the stud. Indeed, "The Druid " wrote of him that "he was as good as an amnuity of $£ 800$ to Mr. Theobald (the breeder of Stockwell) for several seasons after the performance of Touchstone had brought lim promineutly into notice."

An American agent bid 5,000 guineas for him (a big price in those days), which was relused.

He was a short-backed horse with a grand fore-liand, and very powerful quarters, so powerful in fact, that he has been spoken of as "the cart-horse quartered Camel." The picture of lim, which is given in Taunton's "Portraits of Celebrated Race-horses," bears out this idea, and the same quarters are even now a characteristic of the line. Hampton had them, though he was probably on not quite so large a scale as Camel, and, to quote a recent instance, Forfarshire is possessed of very grand, extraordinarily powerful quarters, though there is absolutely 110 suspicion of carthorse coarseness to be noticed in Mrr. Brice's stallion.

\section{Touchstone's Performances}

But Touclistone takes an even better position than Camel, for he was a great performer on the race-course, and a most successful sire to boot. He was not a big horse, for lie onjy stood fifteen hands two inches, and he was a hard puller. But he had extraordinary action. He did not run in the Derby, but he won the St. Leger with the greatest ease, and as a four-year-old, the Doncaster Cup, and many events of lesser importance, while he took the Ascot Cup in two successive years (in 1836 and 1837 ), and he also won a second Doncaster Cup. He had wonderful speed, as well as pronounced stamina, and at the stud he sired, among others, Cotherstone, Orlando, and Surplice, all winners of the Derby; Flatcatcher, Nunnykirk, and Lord of the Isles, all of them Two Thousand winners; Blue Bonnet, Surplice, and Newminster, winners of the St. Leger,

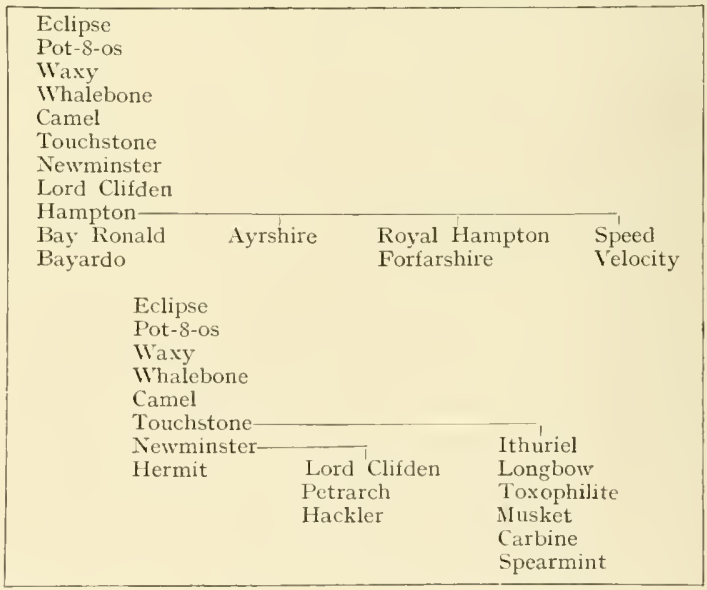

and Mlendicant, wimner of the One Thousand and Oaks. We give above the line from Eclipse throngh Camel, in order to 


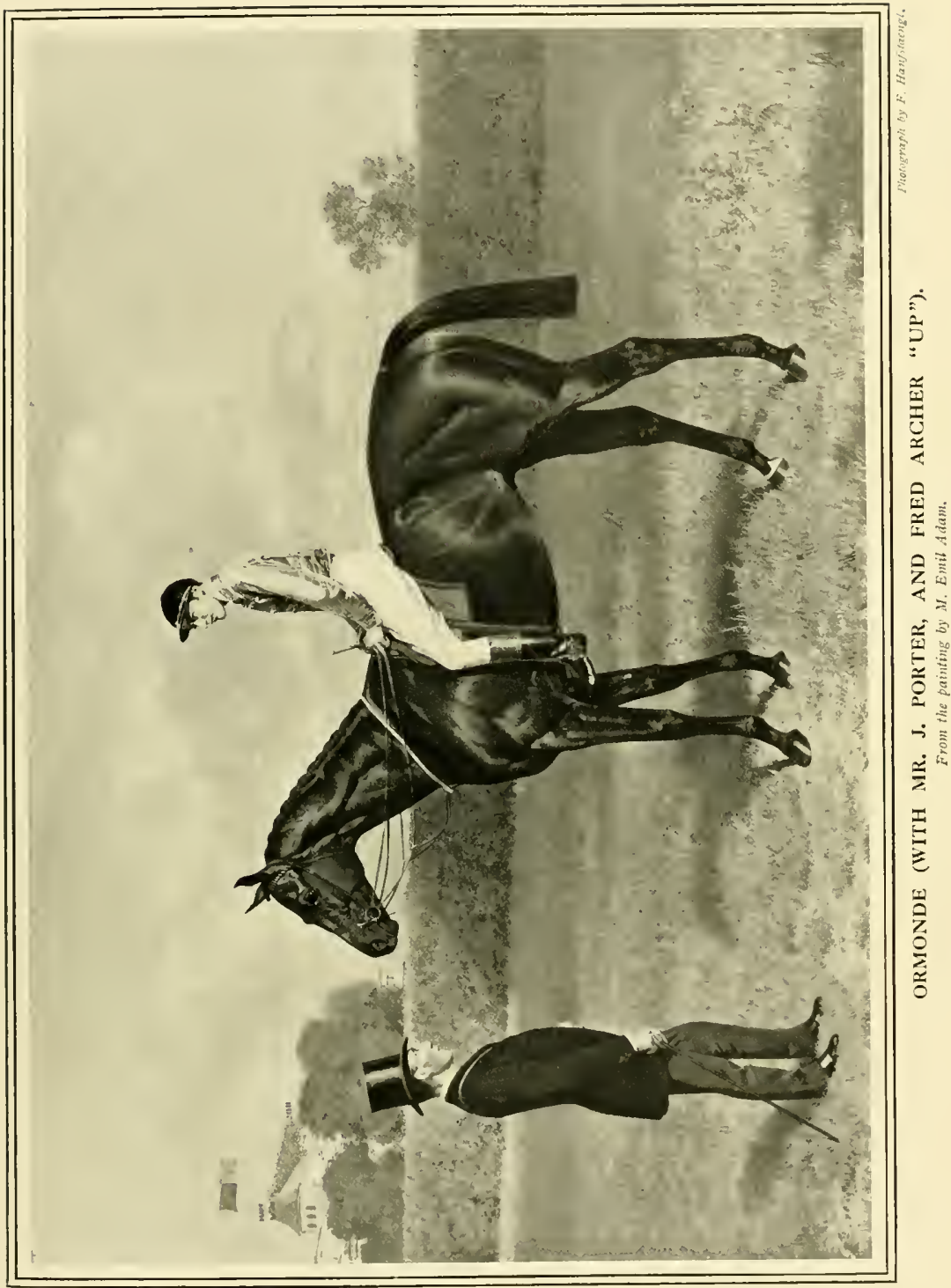


show exactly how the descent lias come to race-horses of the present day.

\section{Newminster at Stud}

Newminster was foaled in $18+8$, being bred in Northumberland by Mr. Ord. He was not Touchstone's best son from a racing point of view, but he was a wonderful stud horse, and for many years was the only real rival of Stockwell. He headed the list of winning stallions more than once, and left behind him such horses as Hermit and Hampton to carry on his line. Like Touchstone, he was a St. Leger winner, but he was amiss when he ran in the Derby, and he must have been difficult to train, for John Scott-the greatest trainer of that day-could never get him quite to his liking.

Hermit was the first horse to bring the line of Newminster into real prominence, but Hermit was a delicate horse, rather given to breaking blood-ressels, and, marvellously successful as he was at the stud, his line has already almost dropped out in tail male, though certain sons of his, such as the now defunct Ascetic and Tacitus, have done and are still doing great things in Ireland with their cross-country descendants. Whilst Hermit was living his stock carried all before them, their winnings in stake money being over $f_{3} 300,000$, and amongst them were Derby winners in the filly Shotover and St. Blaise, two winners of the One Thousand, two winners of the Oaks, and a single winner of the Two Thousand.

\section{Hermit's Descendants}

Hermit never sired a St. Leger winner, and only one of his classic successes was scored by a colt, and this is partial evidence to the effect that he did better with his female than with his male stock. St. Blaise, it should be mentioned, has been successful at the stud in America, but in this country there are few horses of Hermit descent at the stud just now, whereas the Calendar was full of them some twenty years ago. Still the line may be revived, and there are those who think highly of the stud chances of the Cesarewitch winner,
Black Sand, a son of Melanion, and a grandson of the $\mathrm{I} 867$ Derby winner.

In Ascetic Hermit was responsible for a horse who has had no equal as a sire of crosscountry horses. Cloister, the most famous steeplechaser of all time, was one of his sons, and he was only one of scores who have won over a country in every part of the Kingdom.

\section{Hampton as Racer}

Hermit mares have been, and mares descended from Hermit are, of immense value, but as far as the tail male line is concerned the Newminster family is doing much better through Hampton. The lastnamed was not a classic horse, and in point of fact he began life as a selling plater, his first win being scored on the old Hampton race-course-now Hurst Park-and from this victory he obtained his name.

After a while Hampton passed into the clever hands of the late Mr. Robert Peck, and gradually leaving the platers, he became a high class handicap horse, and lastly a Cup horse of sterling merit. He won such liandicaps as the Goodwood Stakes, the Great Metropolitan Stakes, and the Northumberland Plate, and also the Goodwood and Doncaster Cups, and it must be remembered that in those days the handicaps mentioned were of vastly greater importance than they now are. Park racing had not come into fashion, and valuable prizes were not of everyday occurrence, and, for example, such races as the Goodwood Stakes and the Northumberland Plate were mediums of speculation for many weeks before they were run, and were productive of far better class fields than they now are.

Hampton's two strongest points were gameness and stamina. He could fight out a long contested funish as well as any racehorse of modern times, and the longer the course the better he ran. Not being a classic winner he had to make lis way at the stud against the feeling which exists with regard to breeding from handicap horses, but he was in capable hands, and he soon made a mark. Three winners of the Derby -Merry Hampton, Ayrshire and Ladas- 


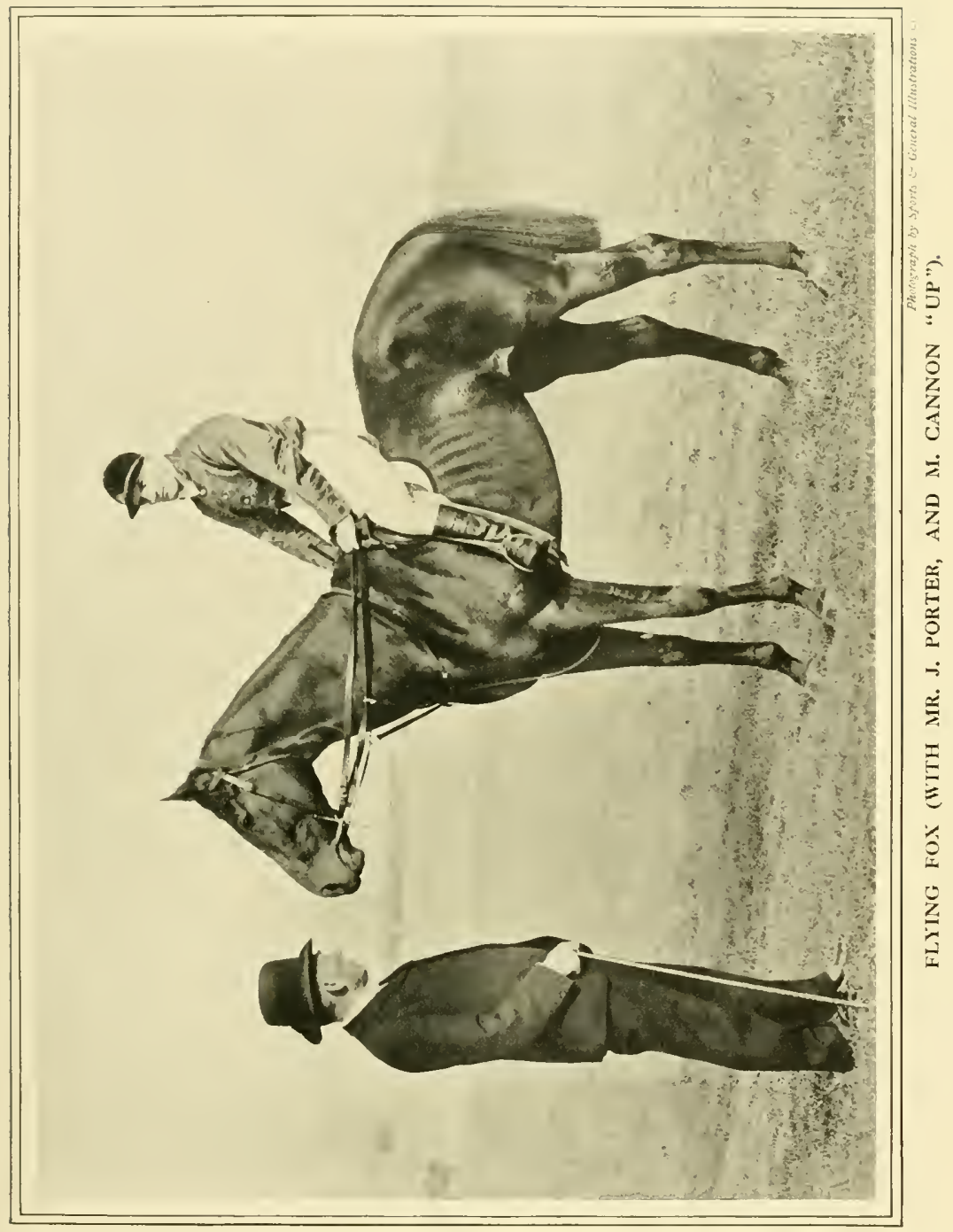


claim him as sire, and it may be added that Perdita II. - the dam of Persimmon, Diamond Jubilee, and Florizel II.-is a daughter of Hampton.

As so many of this family are now at the stud there can be little chance at present of its dying out, and, in addition to the three Derby winners which have been named, mention may be made of Speed (by Hampton) the sire of Velocity; of Bay Ronald, the sire of Bayardo, of Bushey Park ; of the beautiful Robert le Diable (by Ayrshire); of Forfarshire, and a host of others, who are likely to reproduce themselves at the stud.

The line of Lord Clifden through Petrarch is at present best represented by Hackler, the sire of Hackler's Pride and Ebor, and then we have another line of Touchstone, which comes through Ithuriel, Longbow, Toxophilite and Musket, and which had practically died out in this country until Carbine was brought from Australia. Like the Hamptons, the Carbines are great stayers, and doubtless this attribute is derived chiefly from Touchstone, who was probably as stout a horse as the race-course has ever known.

Carbine, it will be remembered, is the sire of the Derby winner Spearmint, who was doubtless a very great horse when he won the Derby. His performances will be alluded to in a later chapter, but here it may be stated that he alone was good enough to justify the bringing to England of his sire, and that though Carbine has not been quite the success at the English stud that was anticipated, he has, nevertheless, done fairly well. It is, too, extremely probable that his blood will, in the future, be of great value through females, for it is undoubtedly the stoutest line which has come from Touchstone. Many horses and mares of Hampton descent have been fine stayers, but, on the other hand, others, apparently just as well bred, have been milers, or merely sprinters. It is, however, most certainly the case that when an English bred son or daughter of Carbine runs, no matter what his class may be, he is almost certainly a stayer.

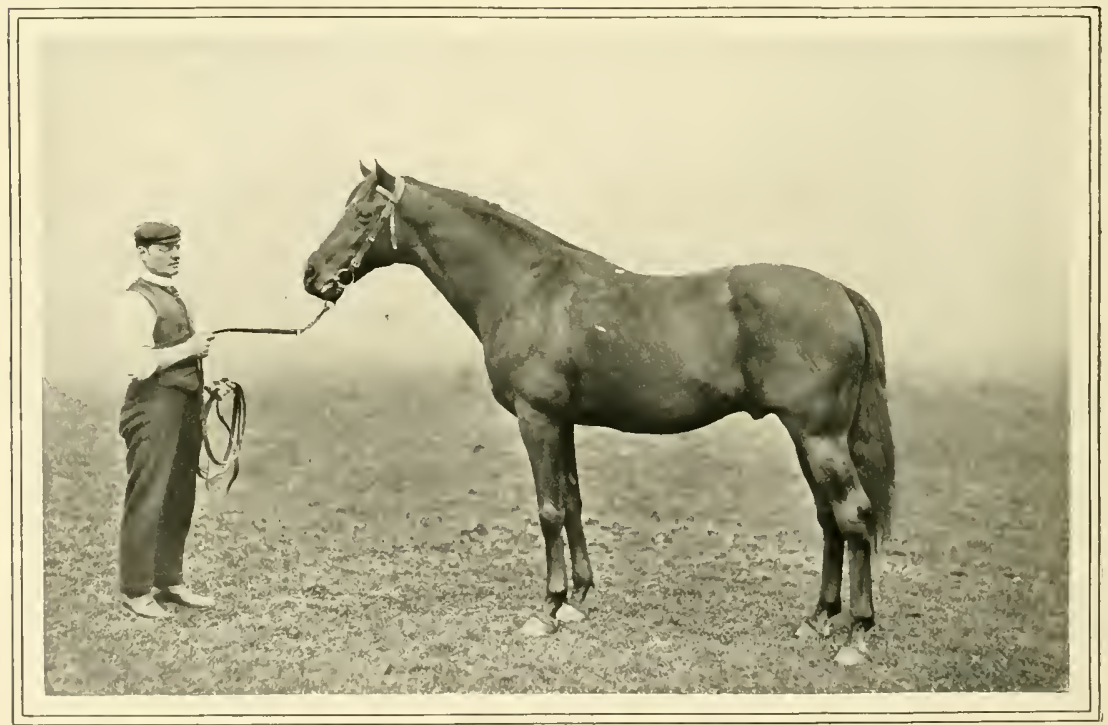

ORME. 


\section{CHAPTER V}

\section{THE LINE OF ECLIPSE (continued)}

T HE next line of Eclipse to be considered is generally known as the line of Blacklock, and it practically means the line of Galopin, St. Simon and his sons, which family, it need hardly be said, are at the moment beating, not only the other lines of Eclipse, but all the existing male lines of thotoughbred stock.

The descent from Eclipse in tail male is as follows:- and after that again he stood at Shipton, some few miles from York, where he sired Hambletonian and Beningborough - the names of both being taken from places in this particular neighbourlıood. King Fergus, however, seemed to know very little rest, for he was afterwards heard of at Maidenhead, Egham, Turnford in Herts, (rog Magog in Cambridgeshire, and finally was brought back to Yorkshire, and died at Boroughbridge in I8or, being then twent $y$-six years old.

Eclipse
King Fergus
Hambletonian
Whitelock
Blacklock
Voltaire
Voltigeur
$\begin{aligned} & \text { Vedette } \\ & \text { Galopin }\end{aligned}$
$\begin{array}{llll}\text { St. Simon } & & & \\ \text { Persimmon } & \text { St. Frusquin } & \text { Florizel II. } & \text { St. Florian } \\ & \text { St. Amant } & \text { Volodyorski } & \text { Ard Patrick }\end{array}$

\section{Hambletonian}

Hambletonian was bred at Shipton, near York, and was a great race-horse, being only once beaten in his seventeen starts, and then, it is said, he jumped the rails and

\section{King Fergus}

King Fergus was no great race-lorse, but in after life a pronounced stud success. $\mathrm{He}$ is described as laving been a very handsome chestnut of sixteen hands (a great height for those days, when as far as can be judged the best race-horses averaged about fifteen hands two inches), with immense bone and free from blemish. He was foaled in 1775 , and was in training until I78I, but he was only successful eight times in four years, and his early stud career, in Ireland, was apparently a failure, for he was put into training again when nine years old, and was second in a Lord Lieutenant's Plate at the Curragh, in I 784 .

Not long after this he was sent back to England, and stood for a season at some livery stables near Park Lane. He next was located at Catterick in the North Riding, ran out of the course. He is described as having been rather harness-like in appearance, but whether that be true or not he was undoubtedly the best race-horse of his day, and he will always bear a great name in turf history, because of his 3,000-guinea match with Diamond. Sir Harry Vane Tempest bred Hambletonian, who was seven years old when he ran his great match over the Beacon Course at Newmarket. It is recorded that he won by a head only, and opinions have been given to the effect that Diamond was the better horse of the two, but as the races of those days were not reported, and as Diamond was several times beaten, and made no such stud mark as Hambletonian did, we are greatly inclined to think that the winner of the matcl must have been the superior horse.

Hambletonian was out of a Highflyer (Herod) mare, and he and lis opponent 
were, on the sire's side, two degrees from Eclipse and two from Herod respectively. "The Druid" tells us it was a saying of the day that the Eclipses were speedy and jady, and the Herods hard and stout; and there was talk of a second match, but it came to nothing.

\section{Characteristics of the "Herods"}

It is curious in this connection how things have changed, for stoutness has been for many generations the peculiar characteristic of the male line which Hambletonian carried on, whereas the Herods-though the line was at one time prolific of fine stayers - has in recent years been productive-in this countryof sprinters rather than stayers.

In proof of this it need only be mentioned that such recent Ascot Cup winners as The White Knight, Zinfandel, William the Third, Persimmon, La Flèche, and St. Simon are all in direct male descent from Hambletonian, whereas, though the Herod line is doing fairly well in France, it has in this country few good representatives at present, and unless some new winning strain quickly appears, it will shortly be a thing of the past. Moreover, such horses of Herod descent as are left in this country are, in nine cases out of ten, sprinters, such as the sons of Grey Leg, Bentworth, and a few other very moderately successful sires which could be mentioned.

"The Druid" also tells us that Hambletonian did not get (in his stock) size, so much as speed, and that his stock were principally browns. He adds that Hambletonian was a fine and lengthy, but rather a blotchy skinned lorse, a trait which botl Stubbs and Sartorius brought out in their pictures of him. Brown is still the prevailing colour of the line, as those who have noticed the general appearance of the many good horses and mares by St. Simon will know, but now there is a combination of speed and stamina in most of the family, and just lately there have been more good horses of this than of any other line.

\section{Whitelock's Descendants}

Whitelock, who comes next in the descent, was not a distinguished horse, and spent most of lis life as a country stallion. He was nothing wonderful to look at, but he had not many chances of distinguishing limself, and as a matter of fact he only ran twice, winning a f6o plate at Kinutsford, and losing the final for the Cup, after having run a dead heat with the Cheshire mare Duchess.

Amongst the few thoroughbred mares put to Whitelock was an unnamed mare by Coriander out of Wildgoose by Highflyer, and this conjunction of the Eclipse and Herod blood resulted in the breeding of Blacklock-the horse who subsequently gave his name to the line of blood now best represented by the St. Simon family. Coriander was a son of Pot-8-os, therefore a grandson of Eclipse, and thus the name of that famous horse appears in the two top removes of Blacklock's pedigree. Moreover, Rosalind, the dam of Whitelock, and Wildgoose, the dam of the Coriander mare, were both by sons of Herod, so that in Blacklock we get Eclipse and Herod in exactly equal proportions, there being four strains of each horse in the pedigree.

\section{A Lucky Fluke}

From the evidence of the pedigree it would in fact be thought that the mating of the Coriander mare with Whitelock was the result of careful study, but in all probability the whole thing was a fluke, firstly because Mr. Moss, the breeder of Blacklock, purchased the Coriander mare for $f 3$ (so the story has been handed down), and secondly because the mare was brought to York, in which neighbourhood Whitelock was standing at a low fee. The evidence, it will be seen, is rather vague, but, if our suggestion as to the fluke be a correct one, the most curious part of it is that the wonderfully successful line of the St. Simon family should have come into existence because of a $£ 3$ deal in blood stock between ninety and a hundred years ago.

"The Druid" gives a description of Blacklock, which he can only have gathered 
from other people, but which is generally accepted as correct. It is to the effect that he was "a great black-brown, with a stride which required half a mile to settle itself in, a head like a half moon, with eyes appears to have been unluckily beaten. Blacklock had only a short stud career, but he left an indelible mark on the turf, as he was the sire of a host of gand horses, of which Voltaire and Velocipede did most at

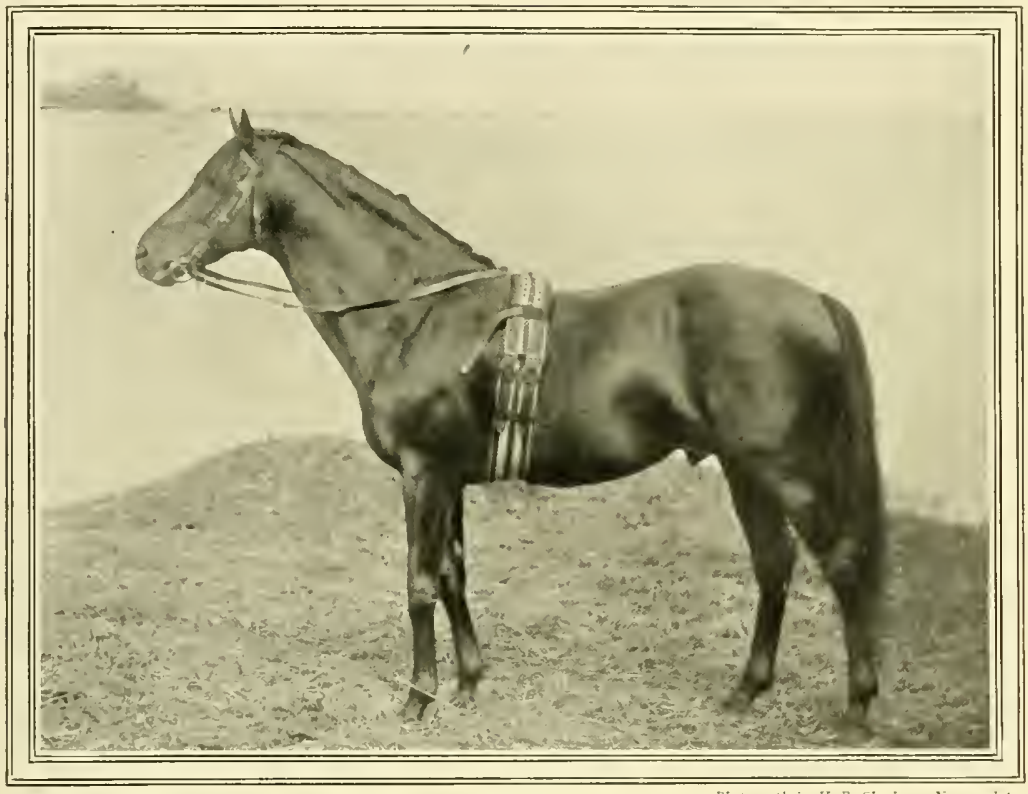

GALOPIN.

quite in lis cheeks, and quarters and shoulders as fine as horse could wear. Perlaps to the eje he might be rather light in the fore-ribs, though the tape told a different tale, and the hocks of his stock generally stood well away from them, a formation which requires great strength in the loins to support."

On the whole it is pretty certain that Blacklock was something quite out of the common, both as regards his general appearance and his performances. Authorities differ as to whether Mr. Watt gave forty guineas for Blacklock as a yearling, or 400 guineas for him after he had won as a two-year-old at York and Doncaster. What is certain is that he was sent to Sykes of Malton (Mr. Watt's trainer) to be trained, and that he ran in Mr. Watt's colours for the St. Leger of $18 \mathrm{I} 7$-in which race he the stud, the first-named being the fifth link in the clain which connects Eclipse with the St. Simon horses of the present day.

Nuch more could be written concerning Blacklock, but his actual history can hardly roncern us now, though it is perhaps interesting to note that the horse had a wonderful crest as well as a rather clumsy head. This crest seems to crop up every now and then in the Darley Arabian male lines. Marske had it almost to deformity; five generations later the "Blacklock crest "was a household word amongst breeders of blood stock, and Voltigeur was described as having been a heavy necked horse.

Between Blacklock and Voltigeur came Voltaire, who, like his sire, was second in the St. Leger, but who was nevertheless a high-class race-horse, and a stud success. 
He only ran six times, and was just beaten by a neck in the St. Leger, while he won the Gold Cup at the same Doncaster meeting, but he lit lis leg in the race, and was sent to the stud not long afterwards. It is worthy of note that Voltaire failed to reach a froo reserve at the Doncaster sales. At the stud Voltaire's most famous son, by heaped upon him was undeserved. Quite lately one read of a certain horse having been the greatest stud failure since Voltigeur's day, and yet Voltigeur was the grandsire of Galopin, the great-grandsire of St. Simon, and the great-great-grandsire of Persimmon, St. Frusquin, and countless thoroughbreds of the very highest class.

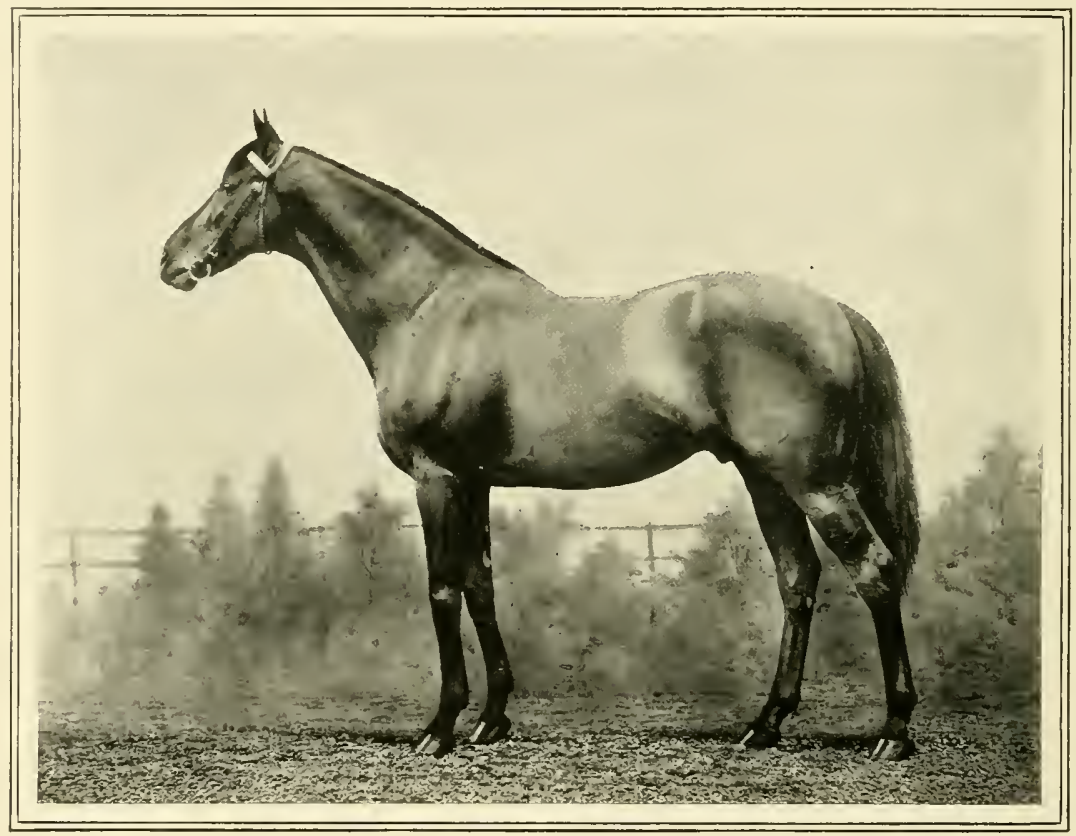

ST. SINION.

whom the line has been handed down, was Voltigeur, who was bred in $\mathrm{I} \&+7$ by $\mathrm{Mr}$. Stephenson, of Hart in the county of Durham. This horse had twenty-three strains of Herod blood against fifteen of his direct paternal ancestor Eclipse, and was undoubtedly a very fine horse.

Voltigeur, like Hambletonian and Blacklock, was another of the celebrities of this particular line of Eclipse. He is probably best remembered because of his great match at York with the Flying Dutchman, but he was not altogether a success at the stud, though some of the abuse which was
As a yearling Voltigeur was reserved at 300 guineas, and as only two-thirds of this amount was bid he was sent back to Hart. As a two-year-old he won the Wright Stakes at the now defunct Richmond (Yorkshire) meeting, and then he was purchased by the late Lord Zetland for $£ \mathbf{r}, 000$, and certain contingencies. There is no need to go through his whole career, but it may be stated that he won the Derby, and the St. Leger after a dead heat with Russborough. At the same meeting he also won the Doncaster Gold Cup, upsetting long odds which were laid on the Flying Dutchman. 
It was this race that gave rise to the match between these two horses in the following spring, and this time Voltigeur was beaten by half a length (sce p. 76 .)

Voltigeur, like most of the family, was a brown, standing fifteen hands three inches. handed down. The muscular neck is a distinct feature of the St. Simon family now, though the coarse head has in a great measure disappeared. But the "powerful quarters, drooping towards the tail" "(the italics are ours) have in late years been a marked

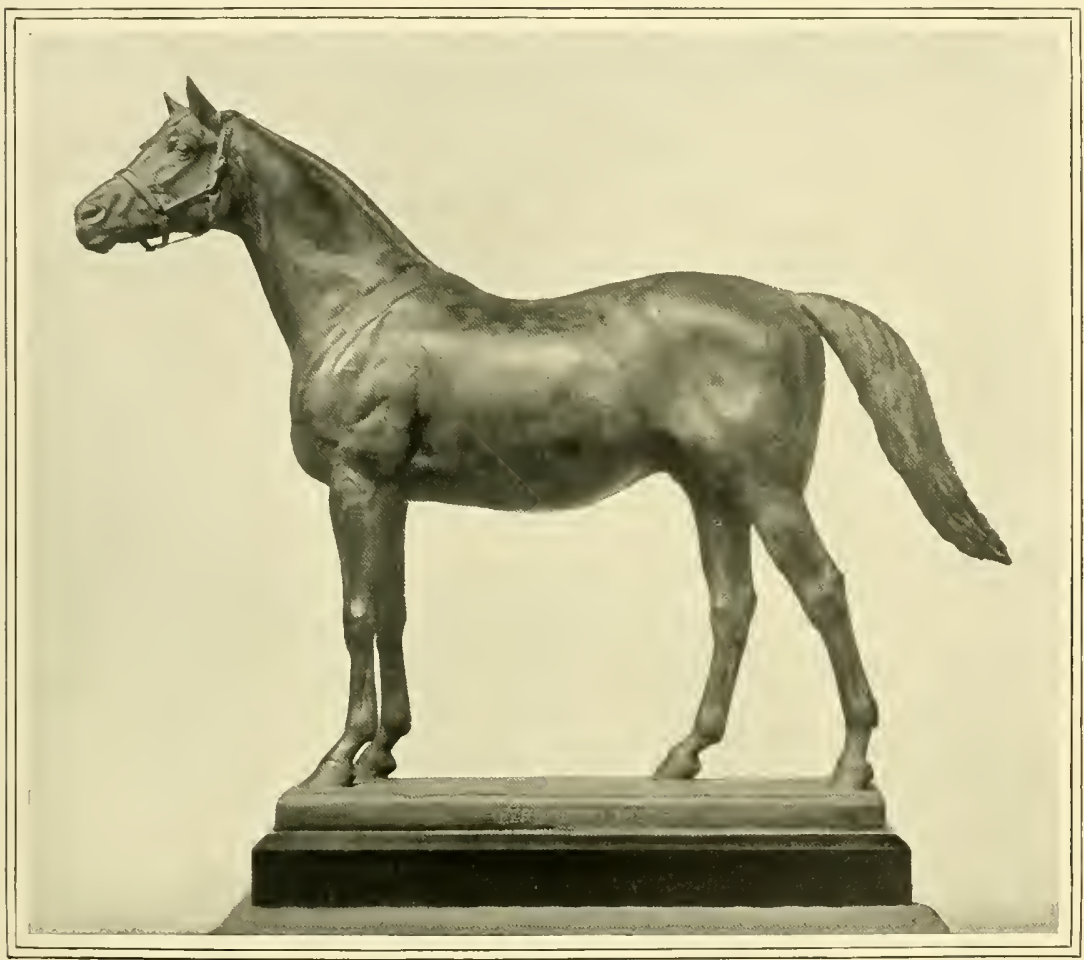

PERSIMMON.

Front the statue by Capt. Adian Jones. By permission of the sculptor.

He had a somewhat coarse head, a strong muscular neck, and fine oblique shoulders, with good depth of girth; he had rather a light middle, with a good back, and powerful quarters drooping towards the tail, muscular thighs, and good hocks, and knees with plenty of bone; docile, quiet temper, and excellent action.

We have quoted this description of the horse, which was written when he was in training, because it is proof of how family traits of character and appearance are characteristic of many of the best performers of the family, and the earlier stock of St. Simon showed this attribute in very distinct fashion. Several Oaks winners could be named who had the drooping quarters, La Flèche, Amiable, and Mrs. Butterwick, to wit, and, indeed, very many of the best fillies by the famous Welbeck horse have this appearance to a great extent.

To return to Voltigeur, he sired Vedette, who was bred in 1854 by Mr. Chilton, who lived at Billingham in the county of Durham. 
He (Vedette) was out of Mrs. Ridgway by Birdcatcher, and therefore combined the two strongest lines of Eclipse. According to "The Druid" he had that thickness of neck which made him rather uneven to the eye, but his action was very beautiful. He also went into Lord Zetland's stable, and was a high-class race-horse, who won the Two Thousand (the only classic race in which he took part) and two Doncaster Cups. At the stud Vedette did not do particularly well, but he sired Galopin, who was bred by Mr. Wr. Taylor Sharpe at Baumber in Lincolnshire, in I $8 ; 2$.

\section{A Galopin Legend}

From time to time a story crops up that Galopin was sired, not by Vedette, but by a horse named Delight, but we made ample investigation of all the facts of the case some years ago, and lad the personal evidence of Mr. Taylor Sharpe on the question, and that gentleman has no doubt whatever but that Vedette was the sire of Galopin. There is also the strong confirmatory evidence which Galopin afforded in his appearance. He had the colour of Vedette, the rather lieavy crest, and his tail was set on rather low. Indeed, he was undoubtedly of Vedette-Voltigeur descent to look at, and in his stock were reproduced many of the characteristics of his own male ancestors.

But where Galopin went ahead of or diverged from the Blacklock line was in the extreme quality which he showed. Great strength and power, combined with a certain amount of coarseness, had been manifest in Blacklock and the horses which maintained the male line down to Calopin. In Galopin quality asserted itself in very marked fashion, and at times the I875 Derby winner suggested the Arab type very forcibly.

Galopin in his running days was rather round barrelled, and heavy in his crest, his quarters very powerful and slightly sloping, and his tail set on rather low. He was a wonderful combination of power and quality, but he was a rather irritable horse, and this irritability has been inherited by many of his descendants.

\section{The Galopin Temper}

Where exactly it came from it is impossible to say, for many of his ancestors were quiet enough, and many of his sons and grandsons are of very even temperament, but on the other hand there have been some of the breed who were very difficult to manage when in training.

Curiously enough, recent eridence as to the irritability of the Galopin tribe has come from Australia, published in The Sportsman, on August 26th, Igo8. The subject of this communication is the starting gate, and as usual the old country is accused of being behind the times and reactionary, but the point is that horses of Galopin descent are liable for all the bad starts which take place in Australia. The writer refers to the scant consideration with which the starter treats the outlaws (badly behaved horses), and states that all clubs reserve the right to refuse the entry of a fractious horse. He then tells us that even this precaution was not deemed necessary until the descendants of Galopin and one or two other English sires became so numerous on the Australian turf. Later on in the same letter is the following :-

"But the fact remains that the major portion of our vicious race-horses trace back to Galopin and other latter-day English sires. The presence of these savages is greatly detrimental to the interests of Australian racing, since they also teach our own horses bad manners, with a probability that in time the present starting gate will be just as inefficient here as it apparently is in England. If this ever comes to pass we will blame such sires as Grafton, Positano, and Gallinule, in view of the fact that they first infused vice and bad temper into our racing stock. It cannot be gainsaid that the Galopin blood is fiery to a remarkable degree. Though the great horse's Australian descendants are full of brilliancy, courage, and stamina, they are, almost without exception, of a nervous and excitable temperament, and where such is not the case we find it is due to a cross of some exceedingly sober strain, such as Musket, Traducer, or Fisherman." 


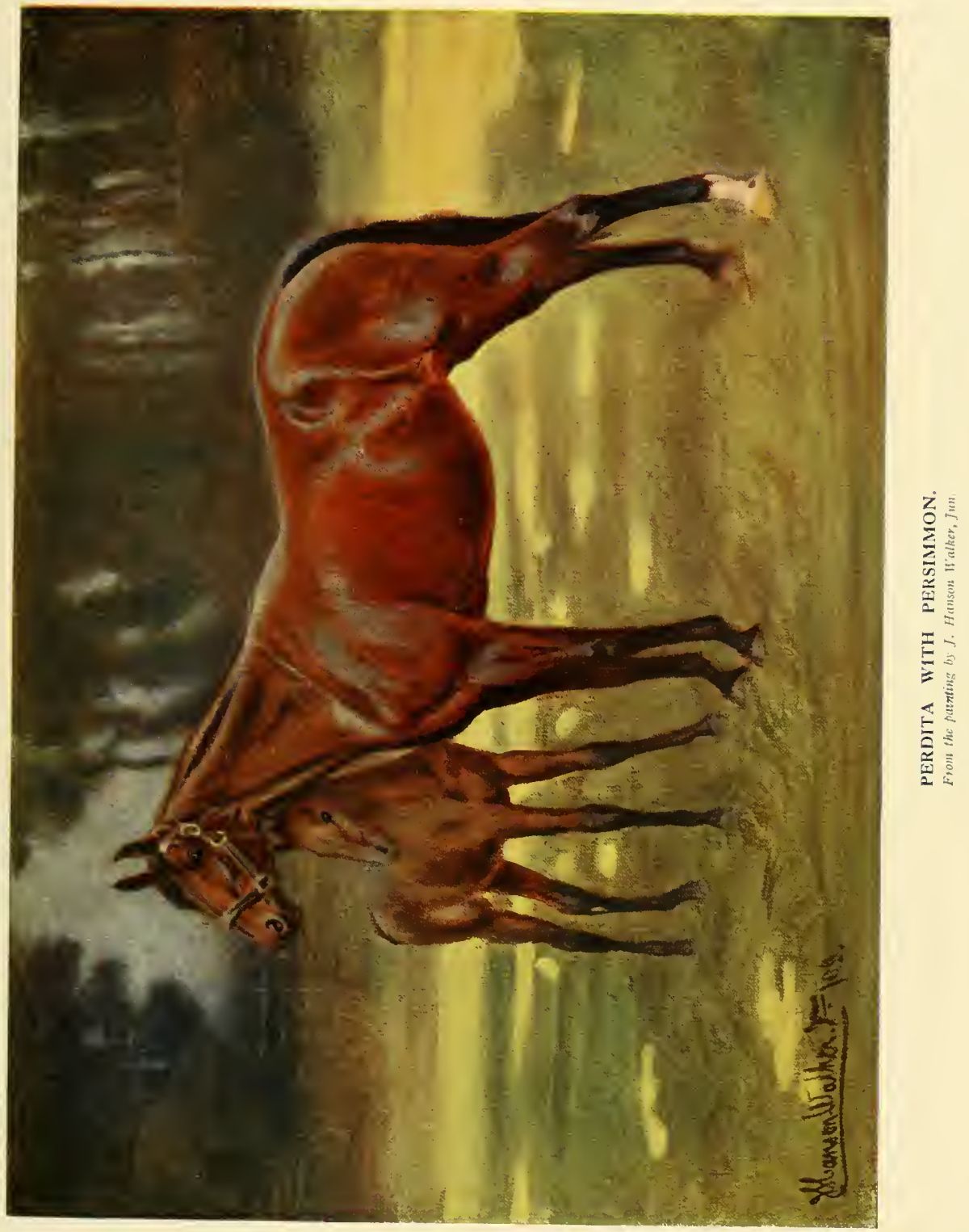





\section{THE LINE OF ECLIPSE}

\section{A Highly-strung Family}

This is a very serious charge to make against the breed, and most certainly no such broad accusation can be put forth against the Galopin family in England, though there is no denying the fact that some of them are lighly strung. It is probably the extraordinary vitality of the family which has caused so many of its members to be brilliant race-horses, but on the other hand it does not follow that all the tail male descendants of Galopin should be bad tempered. It may be pointed out that Gallinule is not of the Galopin family.

The worst of the family we ever noticed on a race-course was Galloping Dick, and the Two Thousand winner Disraeli appeared to be an irritable customer, but one is inclined to think that the St. Simon family-in England at all events-are just as well behaved as any other family; notably Persimmon had perfect race-course manners, and these have been repeated in most of his stock.

Indeed, in the autumn of Igo8, we saw three big colts all by Persimmon in one race, for which there were eight starters: a fourth was by Florizel II., a fifth by Collar, a sixth by St. Frusquin, and a serenth by William the Third, while the eighth was by Ladas. Now as Florizel II., Collar, St. Frusquin and William the Third were all sons of St. Simon, it resulted that seven of the eight runners were of the "vicious" Galopin breed. Yet these eight horses went quietly round a walking enclosure in a racecourse paddock for half an hour, and cantered soberly to the post. After the white flag went up there was a delay of fifty odd seconds and then the race began with a first-rate start, and ended smoothly enough.

\section{Treatment of Vicious Horses}

Probably it will be considered that a single letter to a sporting newspaper is not conclusive evidence as to the suggestion that Galopin blood is greatly detrimental to the interests of Australian racing, but it may be pointed out that in this country vicious race-horses-no matter of what particular breed-are in a small minority, and that the really incorrigible ones are seldom seen on a race-course. If a horse is found to be a regular savage in this country be is, almost always, made a gelding, and in ninety-nine cases out of a hundred he becomes quict enough for all practical purposes. All horses are not of sheeplike character, and all horses, even many of those which have beautiful manners, will not stand quictly at the gate. Some are excitable without being vicious; others are only timid and shy, but these cannot be lumped together and condemned.

On the other hand, the horse which stands like a sheep may possibly be a surly customer, and his apparent quietness may conceal a fair amount of obstinacy. We do not say that this is even common, but as far as the starting gate is concerned, it is quite likely that the horse who plays the fool may be a generous rumer, and the horse who stands still be a bit of a cur. There can be no fixed rule on the subject, and certain it is that vicious horses have appeared at times in any and every line of blood, but at present-in this country at all eventsbad-tempered horses of Galopin descent are on the decline, and whereas they were irritable two generations back, they are only excitable now, and the veritable savage is seldom heard of, and even less frequently seen in public.

\section{St. Simon's Record}

Galopin had a wonderful career both on the course and at the stud. He died in June, I899, being twenty-seven years old at the time, and only in the preceding year be had headed the list of winning sires. But even his prowess fails before that of St. Simon, who was not only an unbeaten horse, but whose stock has already won over half a million in stake money, and whose sons and daughters are carrying on all the prominent features of the line. In Igos five out of the first eight places in the winning sire list were held by St. Simon and four of his sons, and two of the latter-Persimmon and St. Frusquin-were actually first and second in the winning sire list. In Igog he had seven sons in the first eighteen winning sires, but the highest of 
them was only fifth, and therefore his record was not quite so good.

\section{The Great St. Simon}

St. Simon was bred by the late Prince Batthyany in I88I, and was by Galopin out of St. Angela by King Tom (of another direct line of Eclipse). He (St. Simon) had three crosses of Blacklock from his sire, and one from his dam, and he was a much more outbred horse than many of the successful sires of modern times. He was a big horse, standing sixteen hands one inch, and with a girth of six feet six inches; he measured below the knee eight and a half inches - a very big measurement for a thoroughbred. He was a bigger horse all over than his sire Galopin; grander looking in every way, and possibly with less of the Arab character in his general appearance.

He had wonderful action for so big a horse, and this action is generally reproduced in the best of his sons and daughters. As a race-horse he was never beaten, but he could not contest the classic events, owing to his not having been entered for some, while for others he suffered disqualification owing to the death of his nominator. As it was, however, he won the Halnaker, and a maiden stake at Goodwood, and then took the chief Nursery at the Derby September meeting under eight stone twelve pounds. This was a big performance, but it was eclipsed a week later, when he won the Prince of Wales Nursery at Doncaster, giving a stone to the lighest weighted of his twenty-one opponents, and a great deal more to the others. The Prince of Wales Nursery is decided on a course of a mile, and it is usually considered the most important handicap of the season for two-year-olds. In it St. Simon achieved what is undoubtedly the biggest nursery performance on record.

As a three-year-old St. Simon won the Trial Stakes at Newmarket, the Epsom Gold Cup, the Ascot Gold Cup, the Gold Cup at Gosforth Park, and the Goodwood Cup (in which he beat the St. Leger winner of the previous year by twenty lengths), and then was sent to the stud, where his success was instantancous.
We need not go farther in this direction, as though Persimmon is dead, many of St. Simon's best sons and daughters are still living, and their stud work is by no means at an end. Nor is it necessary to discuss the question of whether Persimmon or St. Frusquin was the better race-horse.

\section{The St. Simon Type}

But it may be pointed out that St. Simon in some degree remlutionised the breed of thoroughbreds, for lie sired a type of horse which was little even if it was at all known before his day. It is not an easy matter to define exactly what the change made by St. Simon was, and possibly such change can only be appreciated by those who were really conversant with the appearance of the best thoroughbreds before St. Simon came on the scene.

By such people it will, however (probably), be admitted that a fair number of the sons and daughters-especially the sons- of St. Simon were much higher on the leg and shorter in the back than the average racehorse of other breeds. There never has been, as a matter of course, any fixed rule in the matter, but the average St. Simon colt could be fairly described as a high, short-coupled horse, who showed a great deal of daylight under lim. No doubt the type was to be met with before St. Simon's day, but that it has greatly increased since the famous horse became the most powerful stallion of the present generation is a fact which hardly admits of doubt, and it is (in all probability) evidence as to the extraordinary individuality of the horse himself.

There are other lines of Eclipse besides those of Birdeatcher, Newminster, and Blacklock, but they are not doing so well in tail male, and therefore remarks concerning them may be very brief. The Tramp family for example. This line came through Joe Andrews, who spent most of his stud life as a hunter sire in the W'est of England, and his son Dick Andrews, who gained fame as the sire of the St. Leger wimner Altisidora ( $18 \mathrm{I}_{3}$ ), and of Tramp, a great winner of four-mile heats.

Tramp sired two winners of the Derby in 
St. Giles and Dangerous, and the St. Leger winner Barefoot, but the line came down through Lottery, who was said to be a very bad-tempered lorse. He ran with some success, and when at the stud sired Sheet Anchor, who was foaled in I832, and is sired the Derby winner Blue Gown, and the St. Leger winner Pero Gomez. He was also responsible for a very grand horse in Rosicrucian, and it is from him that the presentday sire Tyrant is descended, Beauclerc being the intervening link. There is an-

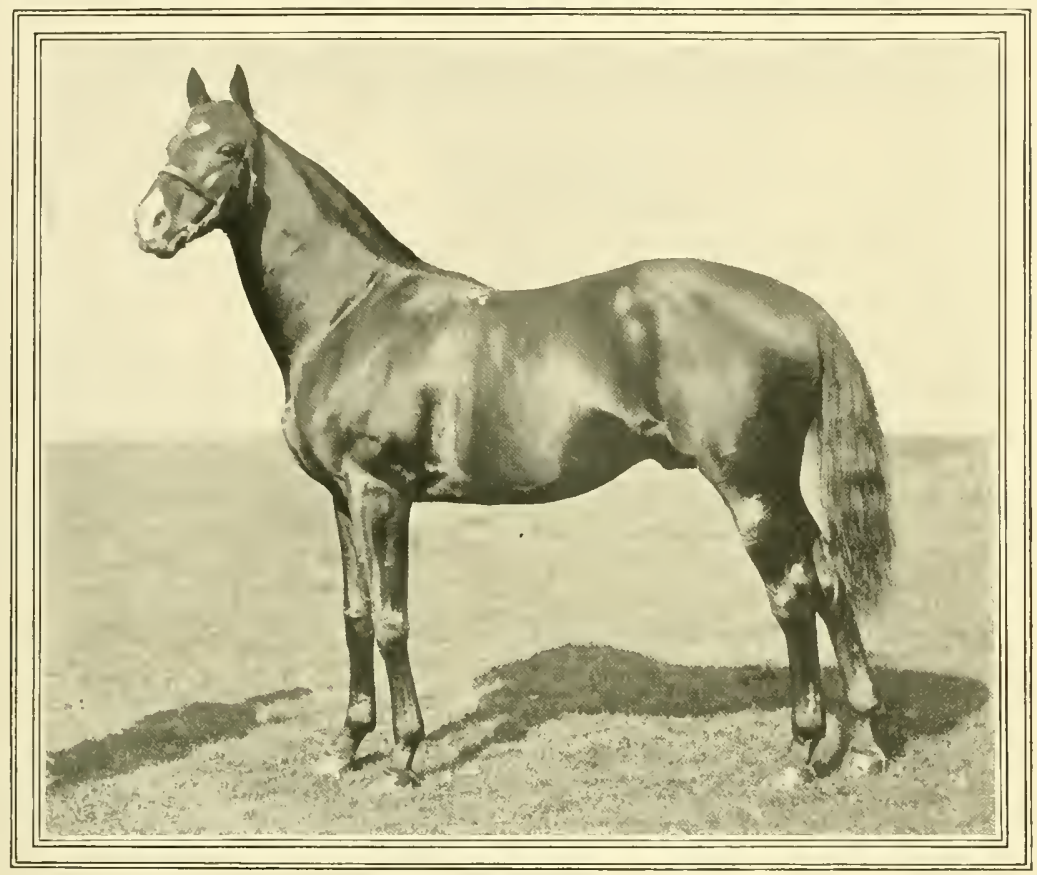

ST. FRUSQUIN.

described as having been a big horse of great bone and power, though heavy in the shoulder, and common to look at.

Sheet Anchor in turn sired. Weatherbitborn just ten years after his sire-who was a moderate performer but a fine stayer. He sired a fair horse in Brown Bread, and a better in Beadsman, who was out of Mendicant (Oaks winner in I8,6) by Touchstone, her dam Lady Moore by Tramp, the grandsire of Sheet Anchor. This was much the same sort of inbreeding that took place with regard to Flying Fox at a later date, and it was successful.

Beadsman won the Derby in 1858 , and other line of Beadsman through Coeruleus and Blue Green, but little is heard of it in these days, and at present the family, in the male line, is in very low water.

Another line of Eclipse came through Whisker, a son of Waxy, and thence through Economist, Harkaway, and King Tom to Kingcraft. Harkaway was a great horse, and King Tom was not only far above the average as a race-horse, but he sired a Derby winner in Kingcraft, and three winners of the Oaks-Tormentor, Hippia, and Hannah, to wit. But somehow the male line has practically died out in this country, though the blood has done better 
in Australia and America, and that great horse Foxlall-who, like Kingcraft, was a stud failure-came from it.

\section{Features of the Eclipse Lines}

At the present day there are in this country three lines of Eclipse which are a great deal more prominent than the other lines of the same horse, these being the line of Blacklock, which we may now call the line of Galopin; the line of Sir Hercules, which may still be called the Birdcatcher line; and the line of Camel, which may, as heretofore, be called the line of Newminster -though it looks like becoming the line of Hampton before long. Broadly speaking, the chief feature of the Stockwell family is massive substance, the chief feature of the Newminster family extreme quality, and the chief feature of the Galopin family an inclination to legginess-to being in point of fact high and short. There have, of course, been scores of variations from type, and such as St. Serf and Persimmon may be instanced as horses which had a great deal of daylight under them, and with many of Persimmon's sons the same formation can be noticed.

Curiously enough the high, short horse seems to be an extraordinary galloping machine, even if he does not fill the eye from the point of view of perfect symmetry, and St. Simon got his stock of two different types. Quite early in his stud days St. Serf, Simonian and Raeburn may be quoted, the first-named a sixteen hands three inches horse, who, to the ordinary eye, was terribly on the leg, Simonian and Raeburn, probably a hand lower, with more length in proportion to their size, and endowed with extraordinary quality. Then a few years later we had Persimmon and St. Frusquin, the former sixteen hands two inches, and St. Frusquin fifteen hands three inches, and a far smaller horse in every way. It may be that the shortbacked appearance of such horses as Persimmon and St. Serf was due in some measure to the fact that they were big all over, and a good deal on the leg, but as far as general symmetry is concerned St. Frusquin was a handsomer horse than his great rival, and to some extent the same remark can be applied to his stock, when comparea with the stock of Persimmon.

\section{The St. Simon Fillies}

Then, again, though many of the best St. Simon fillies were rather on the leg, and decidedly short coupled, they were seldom very big, and La Flèche may be quoted as almost mean looking when in training, while Semolina was undersized and jumped up when she won the One Thousand. On the other hand, Signorina was a beautiful mare in every respect, and Sceptre, a daughter of Persimmon, was bigger and grander than any St. Simon mare we can think of. Another very grand mare by the King's horse is Keystone II., who won the Oaks in I9o6, and this mare and Sceptre are, we are inclined to think, fair examples of a rather new type of mare. They have as much length as the best looking mares who are nearer the ground, but they are higher on the leg, and yet symmetrical, and are by no means deficient in quality. One sees elegance of outline, perfect symmetry and extreme quality in mares of more than one type, but Sceptre and Keystone II. have all these attributes and the great height of the modern race-horse as well.

\section{The Height of Racers}

Perhaps in no respect has there been a more consistent advance than in the height of race-horses. What height exactly the Arabs and other Eastern horses were at the beginning of all the pedigrees is not known, simply because the old records seldom make any mention of height. Nor is it known exactly what height the average English light horse of two hundred years ago was. We may take it that the imported Arabs would probably average about fourteen hands two inches, and the imported Royal mares may have been rather smaller. Most certainly the average Eastern horse of good pedigree is at the present day no bigger, and scores of good Arabs are merely ponies of fourteen hands.

It is vaguely stated that the Godolphin was about fifteen hands, but there is no 
mention of the exact height of the Darley Arabian, or of the Byerly Turk. Indeed, we are very much in the dark as to the height of the sons and daughters of the three famous horses who founded the male families, and we can only conjecture that Bartlett's Childers and other horses of his time were mere ponies as compared with the racehorses of the present day. In a recent work Baron Von Oettingen states that the Darley and Godolphin Arabians were each fifteen hands, but we do not know on what authority these heights are given. In $I 7+5$ there was bred a race-horse named Sampson, who was by Blaze (a son of Flying Childers) out of a mare by Hip, her dam by Spark out of a daughter of Mr. Lister's Snake, who was a son of the Lister Turk. This horse was about four generations from the Eastern blood in sereral directions, and lis measurements are given-probably because he was a giant compared with the various horses of his day.

\section{The 18th Century Giant}

Sampson stood-we are told-just fifteen hands and two inches high, and was at that time the largest boned horse ever bred for a racer. This is very strong evidence on two points: first, that the average racer of that day was very much smaller than Sampson; and secondly, that there were in the country horses which were bigger than racers. Indeed, the sentence "largest boned horse ever bred for a racer" implies that Sampson was an exceptional horse with regard to his size, and it is no doubt on this account that his dimensions have been preserved. It is said also that from the hair of his hoof to his fetlock joint he was four inches; from the fetlock joint to the bend of the knee, eleven inches; from the bend of the knee to the elbow, nineteen inches; round the narrowest part of the leg below the knee eight and a half inches; and round the narrowest part of the hind leg nine inches. The name Sampson also implies that the horse was extraordinarily big and powerful.

Matchem is said to have stood about fifteen hands one inch; the famous turf pony Gimcrack ( 1760 ), in whose honour the Gimcrack Stakes at York were established, "measured about fourteen hands one-fourth of an inch." We may take it that Gimcrack's height was as much below the average as that of Sampson was above it, for in the records of a number of contemporary runners there is no mention whatever of height.

\section{The Height of Eclipse}

The height of Eclipse must unfortunately for ever be a matter of conjecture. The whole subject has been so thoroughly thrashed out by Mr. T. A. Cook in his "Eclipse and O' Kelly" that there is no need to labour the point, but we may record an opinion to the effect that the measurement arrived at by M. Vial de Saint Bel, which made the horse sixteen hands two inches, must have been an exaggerated one. It is certain that in Eclipse's day the average race-horse did not exceed fifteen hands, and had Eclipse been of abnormal proportions, there would have been any amount of reliable evidence on the subject. That the horse was short in the fore-hand and high in the hips we know, and it is possible that he was very high at the withers, too, and that in consequence he was when measured a higher horse than his general conformation suggested, but even this is not quite clear.

Mr. Cook thinks that fifteen hands two inches is much nearer Eclipse's real height than the figure given by Saint Bel, and we are of opinion that this is in no way too low an estimate. If fifteen hands two inches was abnormal in $175^{\circ}$ - when Sampson was running-it would probably have been still remarkable when Eclipse commenced his rumning career only nineteen years later, and because there is no reliable information on the subject it is reasonable to assume that the great horse was of the normal height of those days. Baron V'on Oettingen also gives Eclipse's height as fifteen hands two inches.

Some few years later, in I 790 to be precise, a horse named Gohanna was bred by the Earl of Egremont, and writing of him in "Silk and Scarlet," "The Druid" said, "No two horses could be more different to look at 
or more dissimilar in character than were Waxy and Gohanna. Indeed, very high quality came into English stock with Waxy (he won the Derby in I793); whereas Gohanna was a plain, powerful, hunter-like style of horse to look at. He was put to all kinds of mares, and got his stock with great power, on short legs; and if they exceeded fifteen-one, it was beyond the average."

Gohanna was second in W'axy's Derby, and it may be taken from "The Druid's" description that the average race-horse of that date-sily the last ten years of the eighteenth century - was fifteen hands one inch, or thereabouts.

\section{The First Big Race-Horse}

The first really big race-horse of which there is a reliable account, was Sorcerer, who was bred by Sir Charles Bumbury in 1796 . He is in the direct male line which connects the sons of Barcaldine with their Eastern ancestor the Godolphin, and it is said that he was a black horse, standing sixteen hands one and a half inches high, and possessed of very great power. We are also told that Sorcerer's great size and substance may originally have been derived from Babraham, sire of the dam of Giantess, but this is conjecture, and what is evident is that Sorcerer was a great deal taller than any of the horses of his day-just as in these days an occasional thoroughbred appears which is nearly eighteen hands-Ambergris, to wit.

Another big horse, who was three years younger than Sorcerer, was Orville by Beningborough out of Evelina by Highflyer, but he was said to be rather coarse-though a very powerful horse. Of Whalebone, who won the Derby in ISro, "The Druid" said, "The standard could never make him more than fifteen hands and half an inch." Tramp, bred in $18 \mathrm{IO}$, and founder of a line of Eclipse which has come down through Lottery, Sheet Anchor, Weatherbit, Beadsman, Rosicrucian, and Beauclerc, to the present-day stallion Tyrant, was a nice level horse, standing just fifteen hands and two inches high, and Partisan, who figures in the Sweetmeat line of Herod, was exactly the same height. Doctor Syntax, a very frequent winner in the North of England about the same period, was barely fifteen hands high, and yet he had ten seasons in training, and won a great number of cups.

Again the famous Filho-Da-Puta, who was beaten in a great match by Sir Joshua (ISI6) was "fully sixteen hands high," and it is plain enough that by this time rather big horses were beginning to be fairly numerous. Also it is the case that the exceptionally big ones were, generally, highclass performers.

\section{The Modern Tendency}

Taking a leap to the middle of the nineteenth century, such great performers as The Flying Dutchman, Voltigeur, and Teddington were all about sixteen hands high, while Daniel O'Rourke was onJy fourteen hands three inches when he won the Derby in $\mathrm{I}_{5 \mathbf{5}}$, but it is said of him that he grew very nearly a hand between the middle of his three-year-old career and his being sent to the stud. He was doubtless exceptionaliy small, as were Little Wonder and Amato, the Derby winners of ${ }_{1} \delta_{3} S$ and IS fo. Neither of these horses was a fraction over fifteen hands, and in more recent times the Bard, who ran second in Ormonde's Derby, was only fifteen hands one inch.

Ormonde was sixteen hands and a quarter of an inch, without his shoes, and in all probability the average height of the best class of modern race-horse is sixteen hands. The small horse is not often seen, while on the other hand it is quite possible to find a big field of three-year-olds, towards the end of the season, in which more than half the horses are well over sixteen hands. Horses of sixteen hands two inches are common enongh, and the tendency still seems to be towards an increase of height. 


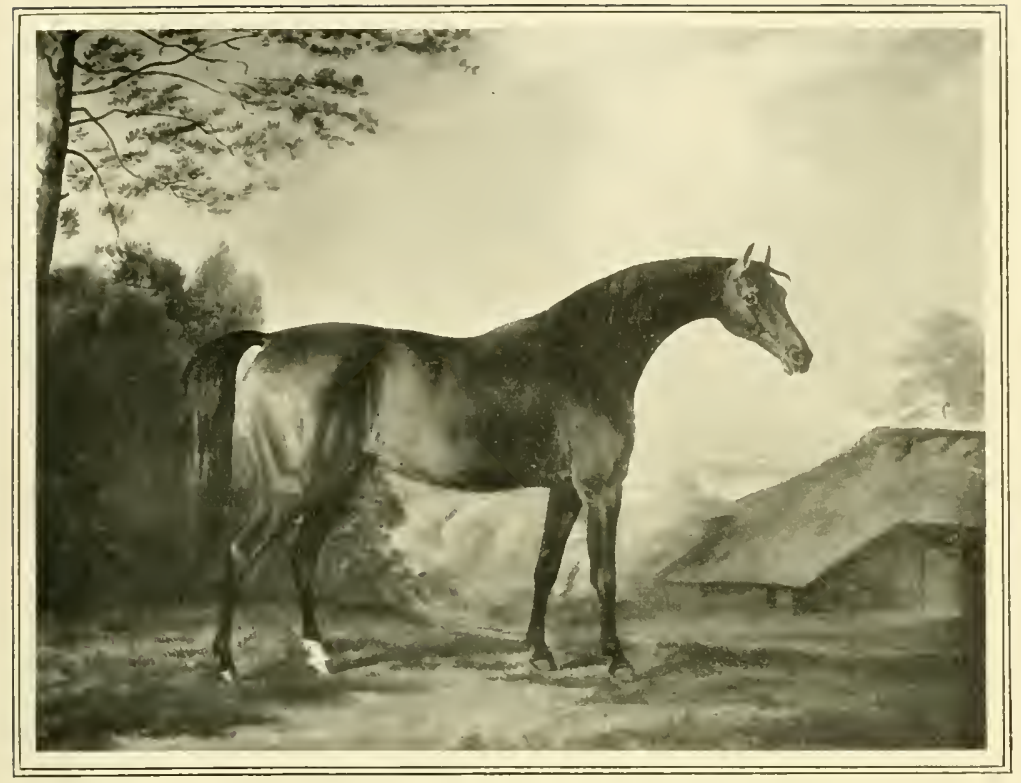

HIGHFLYER.

From the painttng by Gilfin in the pussesston of Messys. Tattersall, Knightsbidge.

\section{CHAPTER VI}

\section{THE LINE OF HEROD}

IV

E must now hark back to Herod, and show the descent to horses of the present day, but as the male lines have become exceedingly feeble in this country we shall be very brief. We have already explained what a great horse Herod was, and what wonderful success he had at the stud. It may be added that for the best part of a century his line disputed supremacy with the line of Eclipse, but in the last thirty years the two lines have parted company, and though the Herods are still to the fore in France and the United States, they are in a condition of partial collapse in the United Kingdom, and unless one or more successful stud horses come quickly to the rescue, the line will be defunct altogether.
Highflyer and Woodpecker were Herod's best sons ; the first named was never beaten in his running days, and was a great racehorse, and a great sire to boot. $\mathrm{He}$ was immortalised in picture and song, and was so named because of his having been foaled in a paddock in which there were several high-flyer walnut trees. Highflyer was foaled as far back as I774, and was out of Rachel by Blank, her dam a mare by Regulus, who was a son of the Godolphin. Indeed, Highflyer was inbred to the Godolphin and also to the Byerly Turk, while he had one strain of the Darley Arabian through Herod's dam Cypron, who was a granddaughter of Flying Childers. There are, of course, many blanks in Highflyer's pedigree, but none of the horses of his 
day could show pure blood in each quarter of their pedigree, and, as a matter of fact, the breed of thoroughbred was only in its infancy, and was being built up from a number of sources which were becoming clearer in each succeeding generation. Highflyer's stock won $f_{\mathrm{r}} \mathrm{yo}, 407$ odd.

It will simplify matters to tabulate the best known male lines of Herod blood, which are as follows :- in the Derby, but he won in spite of his lack of experience. At Ascot he also won an important race, and at Newmarket, not long afterwards, he took a sweepstakes of $£ r, 400$ - a very big prize in those days. He won three other events at Newmarket during the autumn of $\mathrm{r}_{7} 87$, and was unbeaten as a three-year-old. As a four-year-old he took the Jockey Club Stakes, the Claret Stakes of $\mathrm{r}, 200$ guineas, and two other events, all

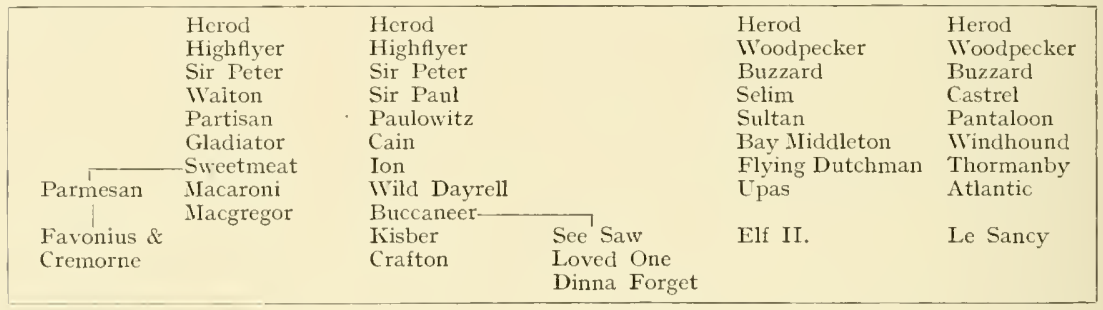

From the above it will be seen that two distinct lines of Herod are doing well in France, whereas the reverse is the case in this country. Elf II. (he is Elf in France) won the Ascot Cup in 1898 , and he represents what was, through two-thirds of the nineteenth century, a remarkably strong line in this country.

\section{Sir Peter Teazle}

It is very difficult to find really sound reasons for the decline of Herod blood, but we may go briefly through some of the lines which have been enumerated, and, to begin with, Sir Peter-his real name was Sir Peter Teazle, but this was shortened more than a century ago-who won the Derby in 1787 , and was one of the most important racehorses of all time. His height has not been recorded, but the prints of the day suggest that he was a big horse of rather the lunnter type, very symmetrical, very powerful, and altogether good looking. His shoulders appear to have been very good; he had a strong middle-piece, and was well knit together, while he was high at the withers, and also at the croup. P'erhaps he was rather long in the cannon-bones, and it is quite possible that he may have been rather leggy when he was in training.

Sir Peter did not run before he took part four races being decided at Newmarket. He was, however, beaten by Dash, a horse of his own age, to whom he was attempting to give thirty-five pounds. Other races besides those specified were won by this great horse, and lie also received forfeit in several matches.

We have mentioned Sir Peter's performances at length, because they indicate that he must have been a great horse. Any horse who runs in the best company, and who has an unbeaten three-year-old career, is probably a great horse, and if Sir Peter lad come a few generations later he would most likely have remained unbeaten, for he would have been confined to cup contests when a four-year-old, and would hardly have been asked to give two stone and a half to a horse of his own age.

\section{Sir Peter's Characteristics}

But another thing may be written of this horse, and that is that he appears to have been of rather a different type from many of his predecessors. It was said at a later date that Waxy revolutionised the thoroughbred as far as quality is concerned, and of Sir Peter it may be said thatalways provided that his and the portraits of lits predecessors are true likenesses - he was the first great horse who looked 
exactly like the best medium-sized racers which the present and the past generation have known. For example, of his own line Macaroni, Nacgregor, Favonius, and Cremorne, may all be cited as fine specimens of the medium-sized, fine-quality race-horse. None of thum had the massive substance of the Stockwell-Birdcatcher horses, and the St. Simon family, with its peculiarities which have been mentioned, had not appeared in the 'seventies-during which decade no fewer than four Derbies were won by direct descendants in the male line from Herod.

\section{"Cobby-Looking" Walton}

Walton, by Sir Peter, was foaled in 1799 , and, judging from his picture, was much more Arab-like than his sire. He is described as having been "cobby-looking," and according to "The Druid" his stock had no great character about them; but he played a big part at the stud, for he not only carried on the line of Herod, which has generally been connected with the name of Sweetmeat, but he also sired the dam of Voltaire (the sire of Voltigeur), and the dams of Ishmael and Bay Middleton, to say nothing of Phantom, who won the Derby in $\mathrm{r} S \mathrm{I}$.

\section{Partisan at Stud}

Partisan, however, was Walton's greatest hit, though he was not quite in the first rank as a race-horse, and his fame was really acquired at the stud rather than on the course. His best sons were Gladiator and Venison, from the first-named of which came Sweetmeat, who in turn was the sire of Macaroni, and also Parmesan. Sweetmeat was bred in $\mathrm{I} 8_{42}$, and was out of Lollypop by Voltaire, whose dam, Phantom, was-as we have just shown-by Walton, the great-grandsire of Sweetmeat. The last-named was therefore closely inbred to Highflyer, having, indeed, no fewer than twelve crosses of Mr. Tattersall's famous horse. Lollypop, on the other hand, was closely inbred to Blacklock, and had eleven strains of Eclipse all told, while Gladiator had six strains of the same horse.
It is therefore patent that Sweetmeat was a greatly inbred horse, and this may account for the fact that he suddenly went blind, losing the sight of both eyes within a fortnight, when he was at the Neasham Stud, near Darlington. He was a very fine performer in his running days; and though Mr. Joseph Osborne always said of him that his form and general appearance suggested speed rather than stamina, the fact is that he had both. He won, amongst other races, the Gold Vase at Ascot and the Doncaster Cup, and must, therefore have been a stayer. To look at he was a very taking and showy horse, but he was of light build, and had no great amount of bone; his son Macaroni was of much the same type, though perhaps a trifle heavier.

\section{The Line of Sweetmeat}

Yet curiously enough many of Sweetmeat's colts were big, and unable to stand strong preparations; but his fillies were very good, and two of them, Mincemeat and Mincepie, won the Oaks. "The Druid" wrote of Sweetmeat that he was essentially a fillygetter; and this is curious, because in spite of the fact that his male line was carried on for two generations, it has now practically died out, and this "The Druid" did not live to realise. Indeed, five-and-thirty years ago the line of Sweetmeat was going really well, for Macaroni won the Derby in $\mathrm{I} 86_{3}$, and in $\mathrm{I} 87 \mathrm{I}$ and $\mathrm{I} 872$ the winners were Favonius and Cremorne, both sons of Parmesan and grandsons of Sweetmeat.

Macaroni only stood fifteen hands three inches, and was a remarkably strongly-built horse, but had upright pasterns, and these were inherited by his son Nacgregor. The former was above the average Derby winner in point of merit, but it is probable that Macgregor was a much more brilliant race-horse, although his pasterns did not stand work on the hard ground, and he broke down in the Derby. He had won the Two Thousand in a canter, and had taken the Biennial at Bath, in which he proved himself some three stone better than the subsequent Oaks winner, Gamos. The upshot was that he started 


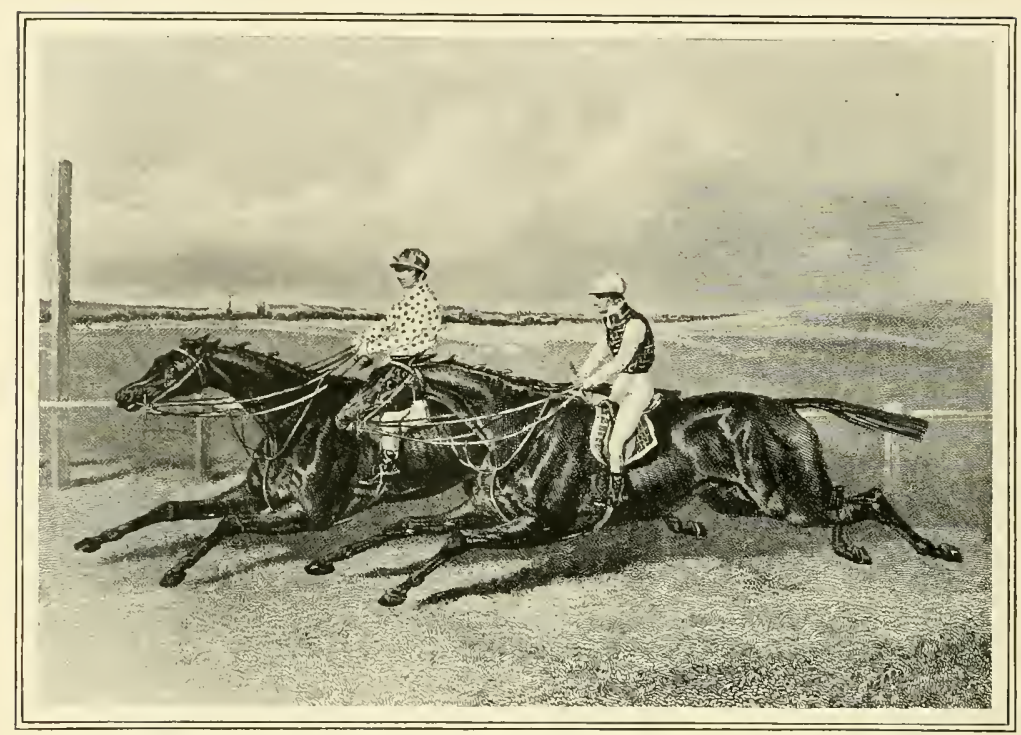

THE GREAT MATCH AT YORK BETWEEN FLYING DUTCHMAN AND VOLTIGEUR. From the engraiting by. $E$. Hacker after the paintung by $H$. Nesbit.

the hottest favourite that had then ever been known for the Derby, but a leg gave way, and he was never really sound again. At the stud he sired Scot Free, a Two Thousand winner NacMahon, and a great number of minor winners, but no son of his own quality.

Parmesan was foaled in I857, and was out of Gruyere by Verulam, Gruyere being much inbred to Eclipse. The horse did not greatly distinguish himself, but he sired the Derby winners Favonius and Cremorne, and Favo, a son of Favouius, has had many winners in Ireland.

The Britisl male line of Herod through Ion and Wild Dayrell is also doing badly, for brilliant as Kisber was he liks left nothing in this country anything like as good as limself, and the same thing applies to the Thormanby family, which has done well in France. Indeed, reference to the tabulated lines will show Le Sancy and Elf II, at the bottom of two lines of Herod through Woodpecker, and it may be added that a French-bred son of Le Sancy named Nabot was at the stud in England during the season of Igo8.
There are, too, certain male lines of Herod still producing winners in this country, such as the branch of the Wild Dayrell family which lives through See Saw and Loved One to Dinna Forget, the sire of Dinneford, and other recent winners. From Wild Dayrell also came Pepper and Salt, the sire of Grey Leg, who is in the Duke of Westminster's stud at Eaton, and, in fact, there are about a dozen Herod stallions at the stud just now, but all the evidence goes to show that much of the stamina for which the family was at one time remarkable has disappeared as regards the male line in this country.

Whether there will ever be a revival or not one cannot even guess; but as Elf II. won the Ascot Cup in Igo6, and as the line is much livelier in America, in Australia, and in France, it is always on the cards that it may come into fashion again. There are those who think that as every race-lorse is full of Herod blood it matters little whether they have it in tail male or throngh females; but if one reflects for a moment it becomes obvious that if there are no good horses to 
sire the female stock the blood must fade and become more remote with every succceding generation. It seems curious that the line should have played such an extraordinary part over such a long period, and then, in a comparatively short space of time, should have almost disitppeared.

IIr. II. Allison, in his book "The British Thoroughbred Horse," which goes deeply into the science of breeding, has furnished some interesting tables on the subject, which were compiled by a French writer. From these we learn that of the Englisin classic winners for the twenty years between $I_{7 / 7} 8$ and $I_{797}$, the Herod tine had an average of $+8 \cdot 2 \mathrm{I}$ per cent. to the $39 \cdot 28$ per cent. of Eclipse and the I2.5 per cent. of llatchem. In the next twenty years there was a reversal of the placings, Eclipse standing first with 45.69 per cent, to the 38.88 per cent. of Herod and the 15.27 per cent. of Matchem.

In the period between I8I8 and I837 Herod gained on his rival considerably, the figures being Eclipse 46 per cent., Herod 42 per cent., and IIatchem I 2 per cent.; but between $\mathrm{r}_{3} 8$ and $\mathrm{I}_{57}$ Ectipse rose and Herod declined, the figures being Eclipse 64 per cent., Herod 2I per cent., and Matchem I5 per cent. In the next twenty years, from ${ }^{18} 5_{5} \mathrm{to}$ to 877 , Herod recovered his position a little and Hatchem fell off badly, the figures being Eclipse $72 \cdot 28$ per cent., Herod 23.76 per cent, and Iatchem 3.96 per cent.; while in the last twenty years with which the figures deal, to the end of 1897 , Eclipse had 88.II per cent. of the winners, and Herod and Matchem 5.9t per cent. apiece. Since I897 things have gone even worse with Herod, and Hatchem has improved a little, owing to the many successes achieved by the sons of Barcaldine.

IIr. Allison and other authorities are of opinion that fashion has had a good deal to do with the decline of Herod blood. and that the final straw was the coming of the Galopin-St. Simon family-which, curiously enough, did not interfere so much with the chief lines of Eclipse-Stockwell and Newminster, to wit-as it did with the various Herod lines. It is argued that because Herod has not been sent to the

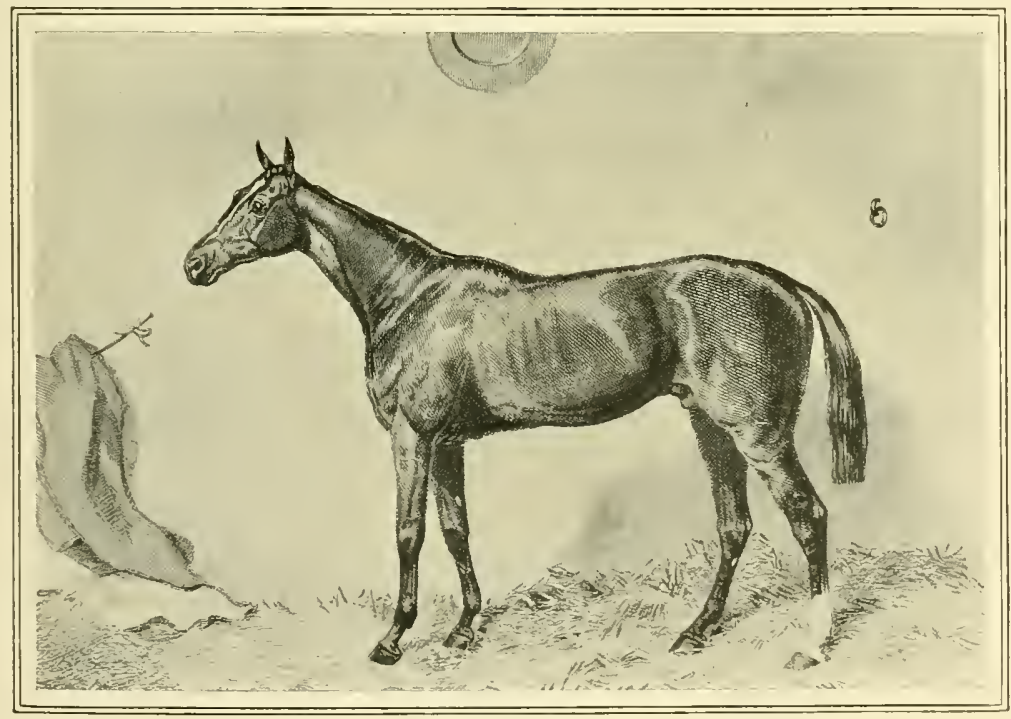

THORMANBY. 
wall in other countries his failure to maintain his position in Britain was due to the caprice of breeders.

\section{Eclipse v. Herod}

There may be a certain amount of truth in this, but one is more inclined to think that it is a case of survival of the fittest, dne mainly to the fact that Eclipse was a stronger sire individually than Herod. This one can judge by the tables we have quoted, which prove that whilst Herod began by sireing many good horses, which in turn became sires of other good horses, and so forth, the line did not maintain its position, but gradually dropped lower and lower.

Eclipse, on the other hand, was behind Herod at first, but gradually passed him, and then for a while the two ran a neckand-neck race. Afterwards Eclipse drew away, and quite lately he has had matters all his own way. But the strongest argument against the idea that the coming of the Galopin-St. Simon line is to be blamed for the collapse of the line of Herod is supplied by the figures themselves. From these we learn that in the forty years previous to $\mathrm{I} 877$ Eclipse had risen from 46 per cent. to $72 \cdot 28$ per cent., and Herod had fallen from 42 per cent. to $23 \cdot 76$ per cent. Now, as Galopin did not win the Derby until I875 his stock had not appeared in 1877 , and therefore for this gradual but certain collapse the Galopin-St. Simon line cannot be blamed.
It may be that the rather greater falling off between $\mathrm{I}_{777}$ and $\mathrm{I} \mathrm{S}_{97}$ was in some degree influenced by the fact that breeders were patronising the most successful lines of the day; but even this is not certain. Want of sire vitality was more than suggested, when such horses as Favonius, Cremorne, and Nacgregor, all failed to repeat themselves, and when Herod stallions began to sire better females than males.

It may be mentioned, though, that when any line of blood begins to fail, breeders, or at least a considerable majority of them, will neglect it altogether. Public breeders, for example, will not send their mares to horses which are not sireing a fair number of good winners, because they know that the produce of such sires will not bring much money. Private breeders are on rather a different plane, and any who hase hobbies in the way of mating may patronise sires which are not of the ultra-fashionable type. There are small men, too, who look to the fee rather than to the breeding of the horse they use, and such men at times have the luck to breed a good horse on what may be termed unorthodox lines; but one swallow does not make a summer, and the sire which has to trust to such pieces of luck is not likely to make much headway. One would like to see the male line of Herod revived, but at present the chances of such a reviral seem to be rather remote. 


\section{CHAPTER VII}

\section{THE LINE OF MATCHEM}

$\mathrm{T}$ HE line of Matchen has always held a stibordinate position, as the tables to which we have referred in the previous chapter show. But there is some reason to believe that it may, in the future, take a better place than it has done-owing to the present vitality of the Barcaldine family. Matchem, it has been explained, had the Godolphin for his grandsire, his own sire being Cade. From Natchem the descent is as follows:-
Trumpator, who was foaled in I782. This Brunette was a wonderfully fine brood mare, whose name is to be found in many pedigrees, and Trumpator was her best son from the stud point of view, for lijs stock won $f_{6} 65.7+\mathrm{I}$, and amongst them was Sorcerer, who carried on the male line. Sorcerer was a black-brown, a very big horse for those days, and he is said to have transmitted a fatal unsoundness to his stock. What this unsomindness was history does not relate,

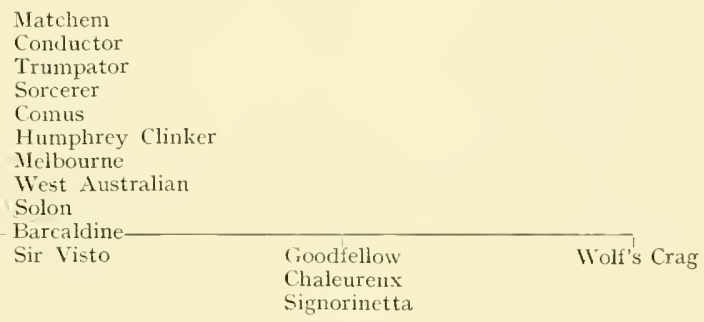

Matchem was foaled as long ago as $\mathbf{I} 7+8$, and was a really good wimner in his day. He was out of a daughter of Partner (second in descent from the Byerly Turk), whose dam was the unnamed daughter of Makeless, and he was for many years the leading sire in the North of England. He began stud life at a five guinea fee, and this was gradually raised to fifty guineas, and it is said that he could command this price when he was twenty-seven years old. He must have sired wonderful stock, for his owner cleared fir,000 in stud fees, and the progeny of the horse won fi5I,097.

About Conductor, who carried on the male line, not much seems to be known. He was a chestnut, foaled in $1>67$, and was ont of a mare by Snap, and he won fourteen races, including two King's Plates. He was, howerer, an undoubtedly successful stallion, and from Brunette by squirrel he sired but it may have been the wind infirmities which troubled some of the family some seventy or eighty vears later, and which it may be said have ahnost entirely disappeared, the present generation not having known clearer winded horses than Barcaldine and Bachelor's Button.

Sorcerersired a Derby winner in Smolensko, but it was his son Comus who carried on the line, and this horse, a chestnut, was profusely marked with both black and white spots. He stood at Sledmere for a longish period, and " filled the pastures with dozens of white-legged chestnuts," and he also sired Grey IInmus, for whom Lord George Bentinck gave 500 guineas when a yearling-a very big yearling price for those days. From Comus Humphrey Clinker was bred, a biggish horse, who, according to the records of the day, was a speedy roarer. He was a golden-yellow bay, 
and according to some of the trainers of that time "as splendid a horse as ever was seen." From a mare by Cervantes-a descendant of Eclipse in a line which has not lived-he sired Melbourne, who may safely be spoken of as one of the great stud horses of that particular day.

Melbourne was bred by Mr. H. Robinson in ${ }^{2} 834$, and was so knuckle-kneed that great race, and the very best older horses of the day were accustomed to compete for it. Melbourne must, then, by that time have acquired a great reputation; otherwise he would not have been so highly weighted. As a handicap horse and not a classic winner he would begin stud life at some disadvantage; but breeders appear to have given him a fair chance, and he was responsible for no

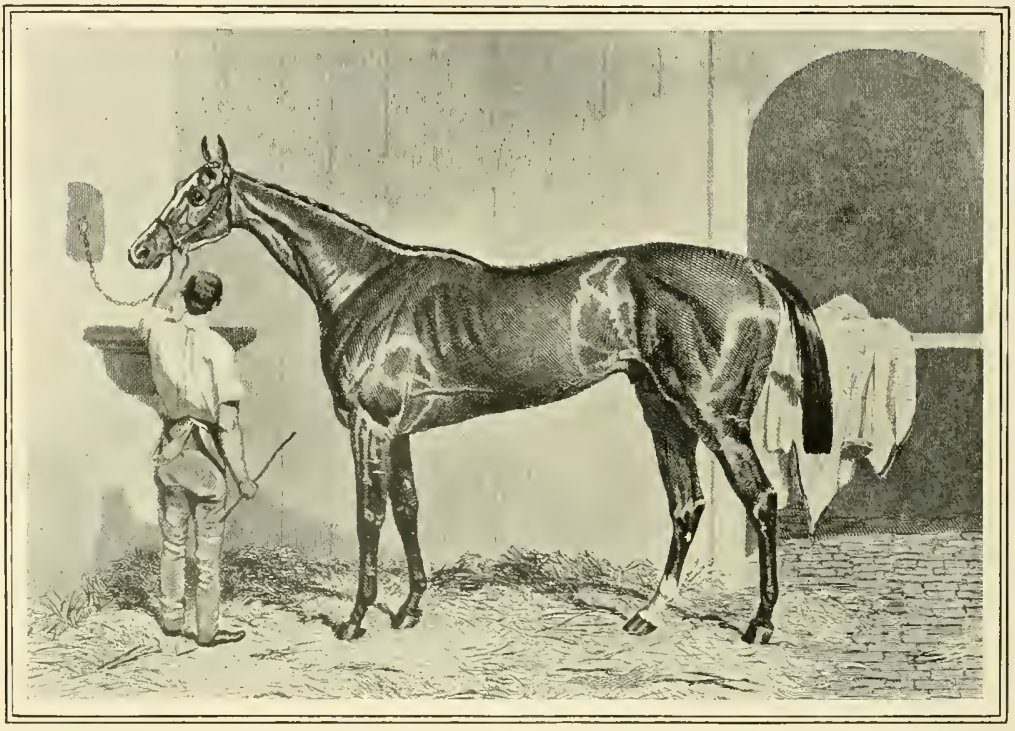

WEST AUSTRALLAN

From the engraving by E. Hacker aiter the painting by Harry Hall.

it was no easy matter to train him. The upshot was that he only ran once as a threeyear-old, and took no part in any classic race. As he grew older he became sounder, and became a rare stayer, winning many good races all over the country, including the three miles Lincoln Cup. His best performance, however, was to run second for the Chester Cup to Dey of Algiers, when carrying nine stone four pounds, and attempting to give one stone four pounds to the winner. The field was a large one, and of the highest class, Lanercost being one of the runners. It may be added that at the period of turf history wherein Nelbourne flourished, the Chester Cup had become a fewer than seven winners of eleven classic races, amongst which were West Australian, the first horse to complete the treble event of Two Thousand, Derby, and St. Leger, and Blink Bonny, winner of the Derby and Oaks, and herself the dam of a great Durby winner in Blair Athol.

West Australian was not only the greatest horse sired by Melbourne, but he shares with Barcaldine the distinction of bcing the "swell" of the line. He was, in fact, a very high class performer, and many of the last generation of Yorkshiremen used to swear by him as the best horse they had ever known, even when the names of St. Simon and Ormonde cropped up. He was bred 
in I85o by the late Mr. John Bowes, of Streatlam in the county of Durham, and was out of Mowerina by Touchstone, her dam Emma by Whisker out of Gibside Fairy by Hermes-a grandson of Eclipse through Mercury. West Australian had eight strains of Matchem, eleven of Eclipse, and no lewer than fourteen of Herod, so that although mitted that the holders of this opinion had very strong grounds for their belief. Indeed, Barcaldine is one of the few horses which were never beaten; but he took no part in the classic races, and though he beat some of the best horses of his day, it cannot be granted that he fairly established his claim. Still, he was undoubtedly a great horse.

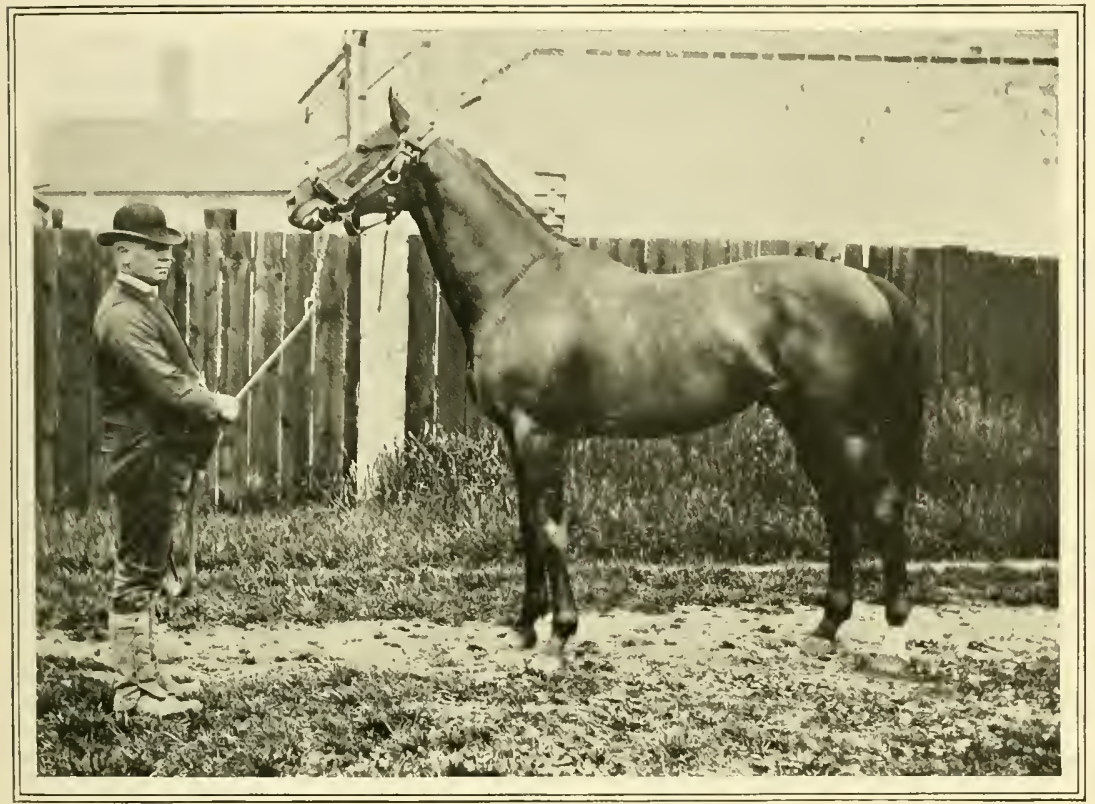

BARCALDINE.

he was of Matchem descent in tail male, he had an even greater supply of the blood of Matchem's two great rivals.

Yet in spite of his bri]liant race-course performances Mest Australian can hardly be called a stud success; but he sired a horse named Solon, who was bred in Ireland, and was a fair second-class performer in his day; the latter sired many fair horses, and one or two very good ones, of which Barcaldine and Arbitrator (the sire of Kilwarlin) have both carried on the line.

As for Barcaldine, there are, or, rather, there were, those who thought him a horse of the century, and it must be ad-
To begin with, he was about as fine a specimen of the thoroughbred as ever was foaled. He was a very big horse, though we never heard his exact height. Mr. Joseph Osborne, w. lo rated him very highly, wrote of him as being upwards of sixteen hands, with an eighty-six-inch girth, and an eight and threequarter-inch measurement below the knee. This girth is simply extraordinary, as will be understood when it is explained that according to the same authority (Mr. Osborne's "Horse Breeder's Hand-Book") the girth of St. Simon is given as seventy-eight inches, that of Orme seventy-six and a half inches, and that of Persimmon seventy-five inches. 
Mr. Osborne took the greatest pains to procure correct measurements, and there is no reason to question the eighty-six inches placed against the name of Barcaldine.

We may even go further, and state that Barcaldine was probably nearer sixteen hands two inches than sixteen hands. He certainly lnoked it when he was in training, and he was, as a matter of fact, a bigger horse all over than St. Simon or even Persimmon. He had extraordinary substance, immense bone, and muscle in keeping with his gigantic frame, and yet he was well off for quality, most symmetrical, and, for such a big one, elegantly turned. He was, in point of fact, the grandest, very big horse we ever saw, and we can quite believe that had he been able to compete he would have won the classic races of his year.

\section{Barcaldine's Greatness}

As it was, he remained in Ireland (he was bred by Mr. G. Lowe in County Roscommon) until he was five years old, As a two-yearold he made a clean sweep of all the most important two-year-old races at the Curragh, and a year later he won the Baldoyle Derby, and three miles Queen's Plates, and, in fact, continued his victorious career. As a fouryear-old he never ran; not because he was in any way hors de combat, but because his owner was mixed up in certain disputes, which caused the horse to remain in his stable. The circumstances are regrettable, because Barcaldine would surely have had a big year; but as it was, he appeared in England in $\mathrm{ISS}_{3}$, and began by beating Tristan and two others for the Westminster Cup at Kempton Park. Now Tristan, in the previous year, had won the Gold Vase (two miles) and the Hardwicke Stakes at Ascut, while in the same year he won the Gold Cup at Ascot, and took the Hardwicke Stakes for the second time. As a matter of fact, Tristan won the Hardwicke Stakes three years in succession, and though there liave doubtless been many better Ascot Cup winners, he was a good horse, a hard horse, and a most consistent performer.

let he had no chance whatever with Barcaldine, who showed clear superiority at a difference of only three pounds in weight.
The Irish horse next won the Epsom Stakes of a mile and a half in a conter, and at Ascrit he beat Faugh-a-Ballagh in relentless fashion for the three miles Orange Cup, and Faugh-a-Ballagh was good enough to win the Alexandra Plate on the last day of the meeting.

\section{Barcaldine's Last Performance}

But it was Barcaldine's last performance which was his best, for he won the Northumberland Plate of two miles with the extraordinary weight of nine stone ten pounds in the saddle-not having done a gallop for a week. There was a good handicap horse in the race named Shrewsbury, and so well had this borse run on previous occasions that his success was generally anticipated. It was thought by those in a position to judge that no horse in the world could give Shrewsbury seventeen pounds (he was weighted at eight stone seven pounds), but Barcaldine accomplished the feat with little effort, to the general surprise. It ought to have been discovered when Barcaldine defeated Tristan that the former was an extraordinary horse, but the cleverest of turfites took a long time thoroughly to realise the merits of the great Irish horse, and even now few will admit that he was entitled to the high position assigned to him by Mr. Osborne and one or two contemporary writers.

Barcaldine's dam was Ballyroe, by Belladrum (this horse became a bad roarer after beginning a turf career in brilliant fashion) out of Bon Accord by Adventurer (son of Newminster) out of Darling's dam by Birdcatcher. This Darling's dam was also the dam of Solon, the sire of Barcaldine, and probably inbreeding to her was greatly responsible for the excellence of Barcaldine.

\section{Barcaldine at Stud}

At the stud Barcaldine was an undoubted success, but it is practically certain that he never sired anything that was of his own class, and this is a result which frequently happens where what may be called an unfashionably bred horse makes a really big mark on the turf. Derby winners, and, 


\section{THE LINE OF MATCHEM}

indeed, a very big percentage of the most important wimners, are fashionably bred, which means that they are sired by a stallion whose stock are doing well, and who stands at a big fee. Every now and then, however, a horse makes its appearance who is by some little known or neglected sire, and who, nevertheless, takes very high rank as a race-horse.

Barcaldine was a horse of this character ; he was well enough bred if his pedigree had been analysed, but he came from Ireland, and five-and-twenty years ago Irish horses were not in such demand as they have been lately. Irish Birdcatcher and Harkaway had done great things, especially at the stud, but they belonged to a period of turf history which had long since passed away, and when Balcaldine made his wonderfully successful appearance in this country, Irish horses were rather at a discount as far as the English turf was concerned - saving, of course, the cross-country runners, for which Ireland was then as famous as it now is.

\section{Barcaldine's Descendants}

At the stud Barcaldine was responsible for the winners of well over f 100,000 , but he died somewhat early. He began by sireing Winkfield and Morion, the lastnamed a winner of the Hunt Cup in I89o, and of the Ascot Gold Cup in the following year, and quite early in his stud career he was represented by Mimi, who won the One Thousand and Oaks, and altogether about $£ 20,000$ in stake money. In I895 he had the winner of the Derby and the St. Leger in Lord Rosebery's Sir risto, and in the same year his son Marco won the Cambridgeshire in a canter, and was very probably the best three-year-old of the year. Wolf's Crag was another good horse by Barcaldine, and in I906 his grandson Bachelor's Button, won the Ascot Cup, and the Jockey Club Cup three months later. Moreover, Bachelor's Button was the only horse in this country who succeeded in defeating the famous mare Pretty Polly, and it may be added that he is one of the most beautiful horses of modern times.

\section{Revival of the Melbourne Line}

We have gone at some length into the performances of Barcaldine, because it is quite possible that through him there may be a revival of the Mlelbourne line of Matchem. No winner of the Derby has been of Herod descent since Sir Berys won thirty-one years ago, whereas since then Sir Visto has done the trick for Natchem, and in Inos Signorinetta-who is by Chaleureux, a son of the Barcaldine horse Goodfellowfollowed suit, while Neil Gow, a son of Marco, was the most brilliant two-yearold performer of Igog. It is, in point of fact, the case that in the male line several sons and grandsons of Barcaldine are doing very well, and such stallions as Marco, Winkfield's Pride, Bachelor's Button, or Neil Gow, might easily sire horses of the very first class.

Then again whereas nine-tenths of the horses of Herod descent left in this country are merely sprinters, the exact opposite is the case with horses of Barcaldine descent, stamina being the rule and not the exception in the family. They have also got size and substance, and the best of them, such as Bachelor's Button, extreme quality. That they will ever approach the Eclipse family as stake winners is exceedingly unlikely; but the best of them are worthy of the best patronage, and they should be used as a corrective where there is a superfluity of Eclipse blood in the top line.

The mares of the family shonld be especially cherished; of that we feel very sure. Mimi has bred such a great performer as St. Maclou, to say nothing of the stallion St. Simonmimi, and Nimic; Signorinetta is another female of the line. liany others could be mentioned, but these two perhaps stand out, and as lar as can be judged at present both are likely to have influence on the race-horses of the future. 


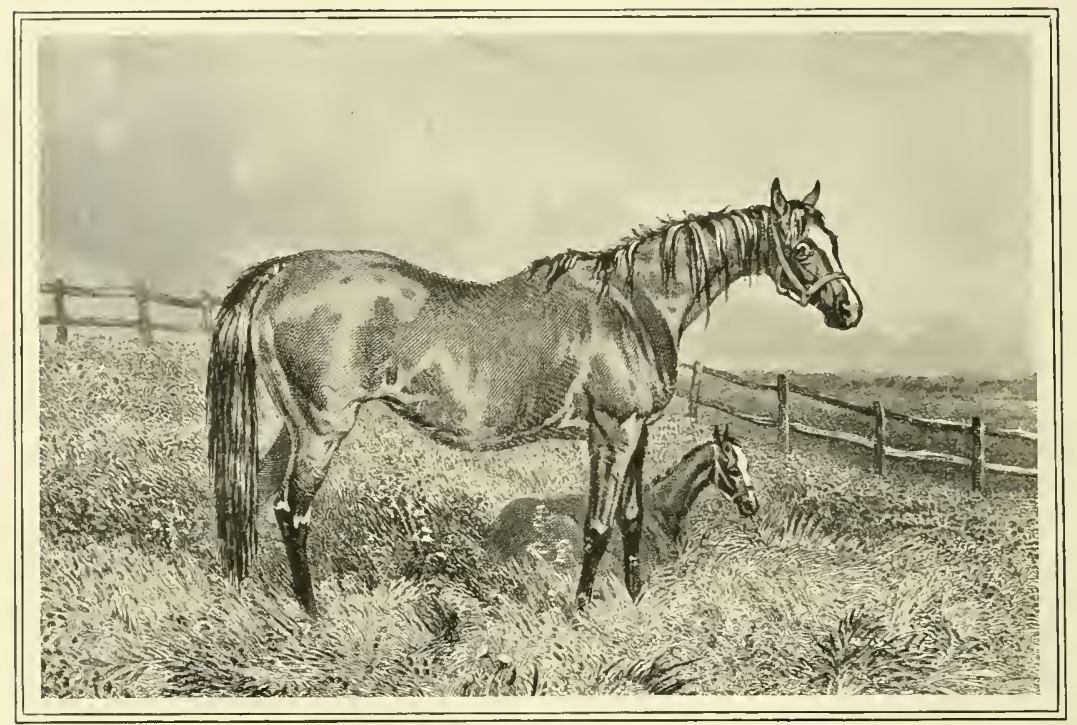

QUEEN MARY,

From the engraing by E. Hacker after the paisting by Harry Hall.

\section{CHAPTER VIII}

THE FEMALE LINES

T HOUGH great brood mares have always been almost as highly thought of by their breeders and owners as stallions, they have not until quite recently attracted anything like so much general interest. Successful brood mares have, as a matter of course, been awarded their full due of praise, but their origin in tail female (and for that matter the origin of all race-horses in tail female) was almost entirely ignored until the late Mr. Bruce Lowe, an Australian, was at the trouble to classify all the female families of which there are existing descendants at the present day.

Mr. Bruce Lowe's work drew attention to the fact that the original females and the part they played towards building up the breed of thoroughbreds had been to a great extent ignored, but one cannot help thinking that he went too far in the opposite direction, and was inclined to the idea that the male played a somewhat small part in breeding. Mr. Lowe wrote in the Introduction of his book: "While admitting the important part a sire plays in the introduction of a race-horse, it will be conceded generally that the dam exercises a greater influence upon his constitution and temper . . . and that a successful sire derives his excellence principally from the combination of certain temale lines in his pedigree tables."

That the above statements are by no means conclusive need hardly be said, and a somewhat general opinion is to the effect that where there is great individuality in either horse or mare, similar characteristics will be reproduced in the stock. This individuality must have been exceedingly conspicuous in such famous stud matrons 
as Giantess, Beeswing, Alice Hawthorn, Martha Lynn, Pocahontas, and more recently in Morganette and Perdita II. (to name only half-a-dozen famous breeders), and in like manner such sires as Eclipse, Herod, Pot-8-os, Whalebone, Stockwell, Newminster, and more lately Galopin, Bend Or, and St. Simon, have been the possessors of extraordinary individuality. As for constitution and temper these attributes will be found in some cases to follow the sire and in others the dam, though it is generally conceded that the male animal gives the external, and the female the internal organs.

It is not necessary to argue at length either for or against this rather disputed point, for it may safely be said that there is no fixed rule on the subject. Indeed, there is so little that is decisively known concerning the breeding of thoroughbreds, and so much that is still obscure, that a strong opinion, either one way or the other, must be injudicious. One can think of dozens, nay hundreds of good horses which have been bred from dams of the most moderate character, and one is inclined to think that really first-rate race-horses whose dams have been moderate platers are far more common than horses of similar calibre whose sires had been third-rate performers in their running days.

Morganette, the dam of the Derby winners Galtee More and Ard Patrick, was a very ordinary selling plater and a roarer to boot, and Pocaliontas, the dam of Stockwell, Rataplan and King Tom in three succeeding years, was described by one who was interested in her fortunes as "a bad roarer and indifferent performer on the turf."

It is our object, however, to show the female descent as we have the male, so that the origin of the British thoroughbred may be made clear. It may be stated at once that whereas all the evidence with regard to the males is fairly clear, the origin of many of the earlier females is wrapped in mysteries which will never be thoroughly solved. There is, for example, that matter of the Royal mares to which reference has already been made, and the further matter of the blanks in the pedigrees of Eclipse, Herod and IIatchem.

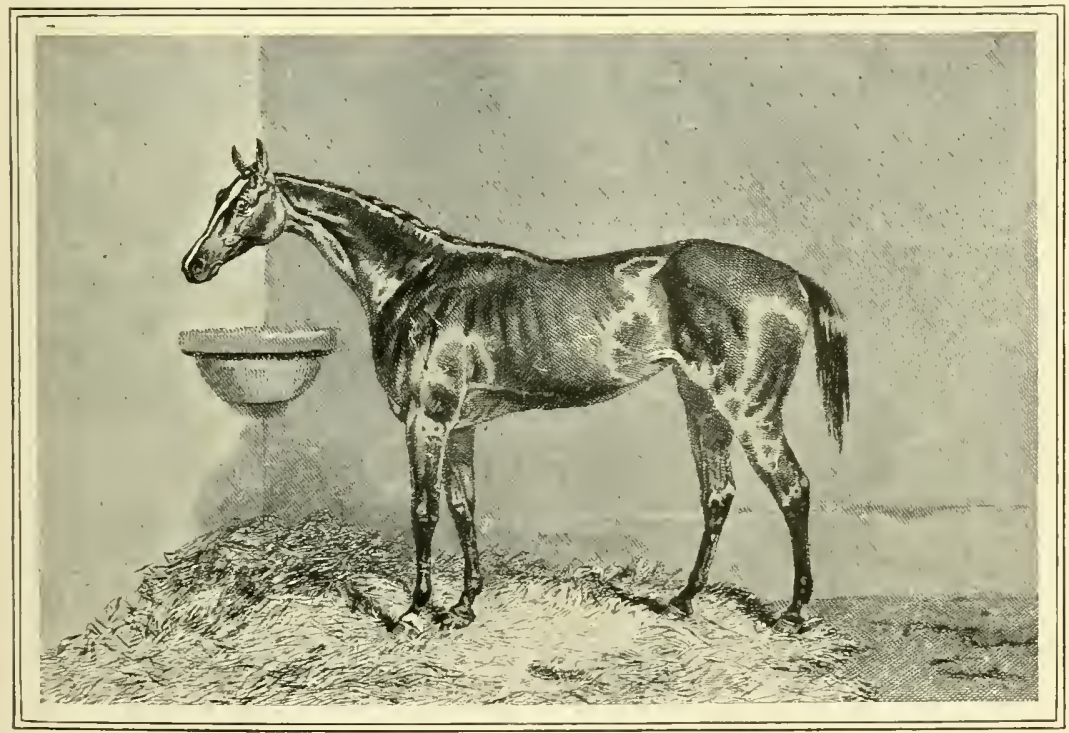

BLINK BONNY. 
To sum up this part of the question we cannot say for certain whether the Royal mares were all of Eastern origin-because it is possible that the term Royal was applied to all mares at the Royal studnor can we decide whether the blanks in the pedigrees were of Eastern or English origin. We ourselves incline strongly to the idea of a large amount of British foundation in the composition of the thoroughbred, but that is only because of the fact that the records of Eastern horses-both sires and mares-seem to have been fairly well kept, while there are no accounts extant of English sires or mares - except one or two, the line of which has not been continued.

\section{First Stud Book Mares}

When the English Stud Book was furst compiled it contained about one hundred original mares-which Mr. Lowe designated tap roots. Of these fifty, more or less, are still represented, so that there has been nothing like so much "survival of the fittest" as there has been with the sires. Mr. Lowe, by the way, was strongly of opinion that effeminacy in sires or sire lines was derived from Barb origin, and that the great sires of the English stud mostly trace their descent to Royal and English nativebred mares.

It will be seen that Mr. Lowe does not differentiate between Royal and native-bred (the italics are his) mares, and it may be here stated that his opinions on this subject are entitled to the fullest consideration, because he made so much research into the matter.

Now going on to the evidence of the Stud Book, we find on page 388 , of the $189 \mathrm{r}$ edition of the first volume, that Charles 1 . had at Tutbury, Staffordshire, in $16+3$, a number of mares and stallions described as race-horses, a list of which from the records includes three Morocco mares. Of the issue (if any) of these mares nothing has been handed down, and whether their offspring became Royal mares we do not know. We can, however, trace the modern racehorse back in the bottom remove of his pedigree to a female ancestor, as we can in the top line to one of the three Eastern stallions.

This tracing Mr. Lowe applied to all the winners of classic races about sixteen years ago, and having sorted them out he apportioned the mares in the order of their winning descendants, writing of them as No. I family, No. 2 family, and so on.

\section{Persimmon's Descent in Tail Female}

Perhaps it will be the simplest method of explaining if we take a well-known horse of the present day, and show his descent in tail female, as we have already done in tail male. For example Persimmon traces back to D'Arcy's Black Legged Royal mare. Thus :-

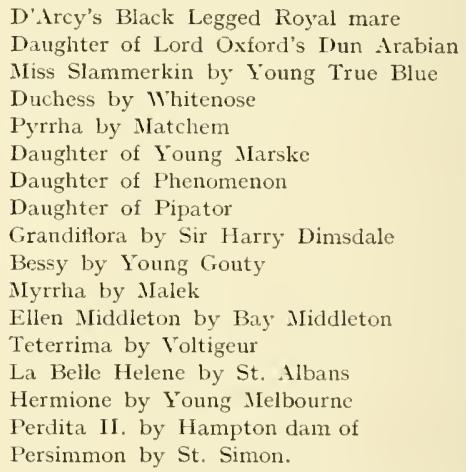

Persimmon, it will be seen, is sixteenth in descent from his earliest known female ancestor, just as he is fifteenth from the Darley Arabian in his sire line. As to what D'Arcy's Black Legged Royal mare really was, or how she was bred, the Stud Book is completely at sea. The entry is as follows: "Lord D'Arcy's Black Legged Royal mare, probably a daughter of one of the Royal mares at Hampton Court, and removed to Sedbury, near Richmond (in Yorkshire), on the death of Queen Anne." This, it will be seen, is almost entirely conjecture, and therefore it can only be said that horses descended from this particular root go back to a certain "Royal mare" which was (presumably) living 
just after Queen Anne died. Such wellknown horses as Donovan, Wild Dayrell, and West Australian trace back to this same mare.

It will, however, be best to glance at these original mares or tap roots in the order of their placing by Mr. Bruce Lowe. For the "families" have since been known in that particular way, and as regards merit the numbers as chosen sixteen years ago are still in the foremost positions, though there have been, and always will be, changes of individual positions.

\section{The "Natural Barb Mare"}

The first place was assigned by Mr. Lowe to a "natural Barb mare" owned by Mr. Tregonwell, and about whom the particulars are singularly vague. Indeed, she is only incidentally mentioned in the Stud Book as the great-grand-dam of Sir Wr. Ramsden's Byerly Turk mare, who, in 1704 , bred Grey Ramsden, and a year or two later had a filly by the Darley Arabian, who was in turn the direct matemal ancestress of such recent classic winners at Ladas, Canterbury Pilgrim, Bend Or, Robert the Devil, and Lord Lyon.

What was the date of this natural Barb mare's importation we do not know, but she was mated with l'lace's White Turk, an Eastern stallion imported by Mr. Place, Haster of the Horse to Oliver Cromwell, and the result of this alliance was a filly which was mated with the Taffolet or Norocco Barb, about whom no particulars are forthcoming beyond the fact that "he got the Honeycomb Punch about r692." of this family have not been numerous during the last ten years.

\section{Burton's Barb Mare}

No. 2 family is known as that of Burton's Barb mare, of whom there are no particulars in the Stud Book beyond the bare mention of such a mare having bred a filly to Dodsworth, and another filly to Dicky Pierson, a son of Dodsworth. These fillies were bred at the Royal stud at Hampton Court, and from the Dodsworth filly came a brother and sister by the Helmsley Turk, of which the latter bred a filly by Hautboy, while from the Dicky Pierson filly came Old Thomton by Brimmer, and a sister to her, Old Thornton being the dam of Chestnut Thornton by Makeless, from whom a whole host of good horses are descended. Vol. I. of the Stud Book mentions Whitelock, Blacklock, Sir Hercules, Harkaway, Voltigeur, Teddington, and Lord Clifden, amongst others, as being descendants of the Burton Barb mare, and if the lines of this blood are carefully examined it will be found to have had great influence on the breed of thoroughbreds.

\section{Byerly Turk Mare}

Family No. 3 comes from a mare which is described in the Stud Book as Byerly Turk mare, and about which reliable information is greatly wanting. The Stud Book says: "A celebrated mare belonging to Mr. Bowes of Streatlam, and conjectured to have been the same as the above mare." The above mare to which reference is made is described as follows:-

\section{BIERLY TLRI MARE.}

"Her dam by the Selaby Turk, grand-dam by Hautboy out of Sister to Morgan's Dun, by a son of Helmsley Turk-Dodsworth-Burton Barb.

$\left.\begin{array}{l}\text { f. Bowes by Hutton's Grey Barb } \\ \text { I } 703 \mathrm{gr} \text {. c. Surley by ditto } \\ \text { ch. c. Whitefoot by ditto (sold to the Duke of Rutland) }\end{array}\right\}$ Mr. Hutton.

Again the result was a filly which was the dam of the Byerly Turk mare, and from this point downwards the line can be traced to the celebrities which have just been mentioned, and to many other great horsesthough it may be stated that classic winners
The entry then goes on to give information concernmg Bowes and Surley, and it must be admitted that the entry, though clear enough as to the mare herself, is very hazy as to whether she can be identified with the Byerly Turk mare which forms the next 
entry in the book, and of which we have just made mention.

\section{Dam of the Two True Blues}

This second Byerly Turk mare was the dam of two grey colts by Honeywood's Arabian (also known as Williams' Turk and Sir Charles Turner's Turk). These grey colts were foaled in $r>I O$ and $r>r S$, and it has lately been the custom to describe their dam as the dam of the two True Blues, the colts having been known as True Blue and Foung True Blue respectively.

Between Iyro and IjIS (the exact dates not being given) the dam of the two True Blues foaled two grey fillies to Honeywood's Arabian, and in turn the elder of these fillies bred two fillies to Bartlett's Childers, and from her many of the best known race-horses are descended. There is no need to give a full list, but the names of the Flying Dutchman, of Stockwell, Rataplan, and King Tom, of Galopin. Isinglass, and of the famous fillies Memoji and La Flèche may be mentioned.

\section{The Layton Barb Mare}

Family No. + is known as the family of the Layton Barb mare, who, according to the Stud Book. was owned by Lord D'Arcy in the early day's of the eighteenth century. She appears to have bred fillies to Dodsworth, to Brimmer, and about I7I5 to D'Arcy's Chestnut Arabian. From the Dodsworth filly came Natchem, from whom all the Barcaldine family are descended in tail male, but the line has been more prolific of great mares than of great horses, and in recent days Throstle, Sibola, Rêve d'Or, Seabreeze, Thebais, st. Marguerite, and Apology are descended from it, while Virago-thought by some to be the greatest female performer of all time-is also one of the line, as is the Derby winner Rock Sand.

Apropos this Layton Barb mare, a mare named Anticipation was foaled in 1802 , who is described in Vol. III. of the stud Book as by Beningborough out of Expectation out of sister to Telemachus by Herod out of Skim. This Skim mare belonged to Mr.
Fernon.- and there is a note in the Stud Book to the effect that Mr. Vernon's own Stud Book gave the Skim mare as out of Foung Country Wench, by James out of Crab, and Telemachus was entered and advertised as dam by Skim-James-Crab, which is right of both pedigrees. It is thought, however, that Mr. Vernon's entry is not a correct one, and the Weatherby Stud Book pedigree has always been accepted. It may be added that many of the best mares of the family trace back to Expectation.

\section{Massey's Barb Mare}

Family Xo. 5 goes back to a mare by Mr. Massey's Black Barb, which mare was possibly of English descent. About Massey's Black Barb there are no particulars, but the mare sired by this horse bred Old Ebony to Basto (by the Byerly Turk), and she in turn bred several colts and a mare named Ebony to Flying Childers. Ebony bred a mare named Hag to Crab; she in turn bred Young Hag to Skim, and her daughter by Herod bred a mare known as Silver's dam, who foaled Grey Skim to Herod. This is the main line of the family which came down to the r867 Derby winner Hermit. Nore recently Galtee More and Ard Patrick are of this family, and other nembers thereof are Doncaster and IIarie Stuart, stable companions who ran such a great race for the St. Leger, Gladiaterr, and Florizel ( $r>68)$, the sire of the first Derby winner, Diomed, from whom many of the best American race-horses are descended.

Family No. 6 comes, according to Mr. Bruce Lowe, from Old Bald Peg, but this Old Bald Peg was, according to the stud Book, got by an Arabian out of a Barb mare, and was therefore of Eastern descent. The information is very vague, and the name of the owner of the Barb mare is not given, but old Bald l'eg was the dam of Spanker by the D'Arcy Yellow Turk, and later she herself foaled to her own son Spanker a filly from whom Betty Leedes (see the pedigree of Eclipse) was descended. The Stud Book adds that "the same (the 
pedigree) is written on the fly-leaf of MIr. Buller's copy of the first edition of IIr. Fairfax's 'Compleat Sportsman.'" This Mr. Fairfax died in I774. Spanker is said to have been the best horse at Newmarket in Charles II.'s reign; he afterwards covered in the family one may look for its more than holding its owm in the future.

Family No. 8 is known as that of "the mare by Bustler" (son of the Helmsley Turk), who bred a mare to the Byerly Turk, she in turn breeding a mare to Hutton's

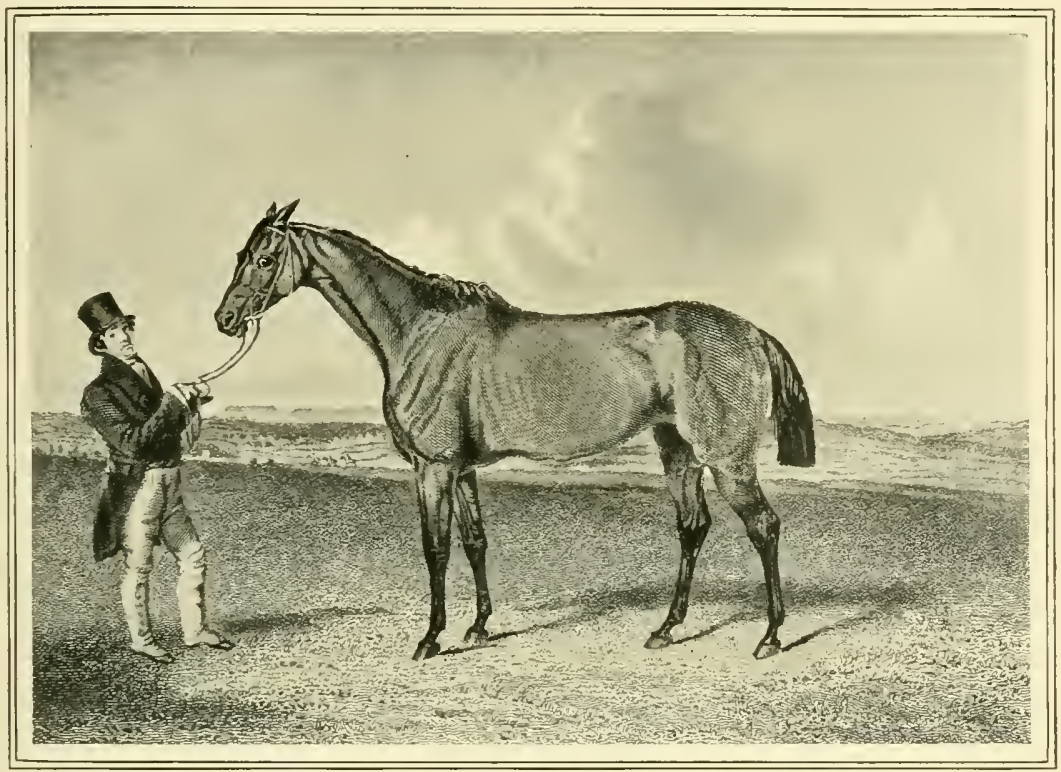

BEESWING

From the engraving by Hacker ajter the painting by Martin.

at Brocklesby in Lincolnshire, and has sometimes been described as Mr. Pelham's Bay Arabian. From this family are descended King Fergus, Sorcerer, Priam, Plenipotentiary, and several famous lights of other days, but of late years the line has been stagnant as regards classic winners, and it looks like going farther back.

Family No. 7 , that of the Black Legged Royal mare, has already been mentioned in explanation of the table which traces Persimmon to his female tap-root. It need only be added that Flying Fox, Donovan, Wildfowler, and of course Florizel II. and Diamond Jubilee, are also of the line, and that as there have been many recent big winners
Royal colt, and she again breeding a mare to Hutton's Grey Barb, which was known as the Coneyskins mare. All this is very vague, but there is presumptive evidence that the original Bustler mare was English, as there is no mention of her dam, which there would surely have been had she been a foreign importation. The Coneyskins mare bred four fillies, one of whom was by Fox Cub, and this filly in turn bred to Bay Bolton a filly who was the grand-dam of Marske and the great-grand-dam of Eclipse. Ayrshire, St. Serf, Melton, and Newminster are some of the good horses of this line.

Family No. 9 is that of the Old Vintner mare, about whom the Stud Book has the following: "All that is known of this mare 
is from a memorandum of Mr. Crofts to the effect that he had himself seen lser, that she was the property of Mr. Curwen of Morkington, and was the best bred as well as the best runner of her day in the North. She was a brood mare before running. As Mr. Crofts does not say so she was probably not a natural Barb or Arabian, but very likely from the Lowther stud, the Lowther family having for many generations imported Eastern blood, and many good horses." The origin of this mare is, then, just as great a mystery as is the origin of any and every other original mare which cannot be traced to Eastern ancestors on both sides of the house. It will be noticed that the remark about the mare having possibly come from the Lowther stud is pure suggestion, and we are much more inclined to think that if she had any foreign blood in her veins such blood came from some of Mr. Curwen's own importations, as he brought two rather famous Barbs from France, one of which had been a present from the ling of Norocco to Louis the Fourteenth.

After all, however, the presumption is that the Vintner mare in some degree, if not altogether, was of British blood. She was mated with the White Legged Lowther Barb, and again with Pulliene's Arabian -about neither of which horses is there any information-and she bred a filly to each, and they in turn were mated with Curwen (or Pelham Old Spot) and Blossom (a son of the Curwen Bay Barb) respectively. From the first-mentioned union came sister to Mixbury, who went mated with Jigg, by the Byerly Turk bred Partner, the sire of Tartar and the grandsire of Herod. Many big wimners came from this tap-root at one time, but just lately there has been a falling off, though La Sagesse and Kilwarlin may be mentioned as descendants in tail female of the Old Vintner mare.

\section{The Snap Mare}

Family No. ro is that of "the Snap mare, her dam an unnamed mare by the Gower stallion, grand-dam by Childers (probably the Grey Childers mare-Fair Helen)."
This is delightfully vague, and if we turn to an earlier entry in the Stud Book we find "Grey Childers mare, bred by Lord Gower in $\mathrm{r} 7+\mathrm{r}$, got by Grey Childers (brother to Fleece 'Em), her dam Fair Helen, by Williams' Squirrel out of an Osysterfoot mare." It can be conjectured that the two mares were identical, but the evidence is unreliable. It is a pity that the records are not clearer, as from the Snap mare are descended such celebrities as Blair Athol, Blink Bonny, and Caller Ou, to say nothing of later high class horses in Hampton, Tristan, and the Oaks winner La Roche. As there is doubt as to identity one cannot help thinking that the Snap mare should give its name to the family rather than the daughter of the Gower stallion.

\section{The Sedbury Royal Mare}

Family No. II is that of the Sedbury Royal mare, but should most certainly be called that of Miss D'Arcy's Pet mare, as it is absolutely impossible to say for certain whether the Pet mare was out of a Sedbury Royal mare or not. The Stud Book says of the Pet mare, "she was the daughter either of Grey Royal or of a Sedbury Royal mare," and Grey Royal was "bred at Hampton Court or Sedbury, got by D'Arcy's White Turk, dam by D'Arcy's Yellow Turk -a Royal mare. Grey Royal (or rather her dam) has a family of her own, and it is quite possible that this family and that of Miss D'Arcy's Pet mare were identical. We shall not attempt to solve the mystery, but may mention that Birdcatcher, St. Simon, and Orme are members of the line which has come from the Pet mare, and that No. II (the Pet mare) is doing much better than No. I3 (the dam of Grey Royal).

\section{Brimmer Mare}

Family No. 12 is known as the family of a Royal mare (dam of Brimmer mare). From the Brimmer mare came a mare by Hautboy, and she again bred to Old Montagu a mare, who, in Vol. I. of the Stud Book, is recorded as having bred five fillies, one of whom, by Smith's son of Snake, was Nother Westem, the dam of Spiletta, and grand-dam 


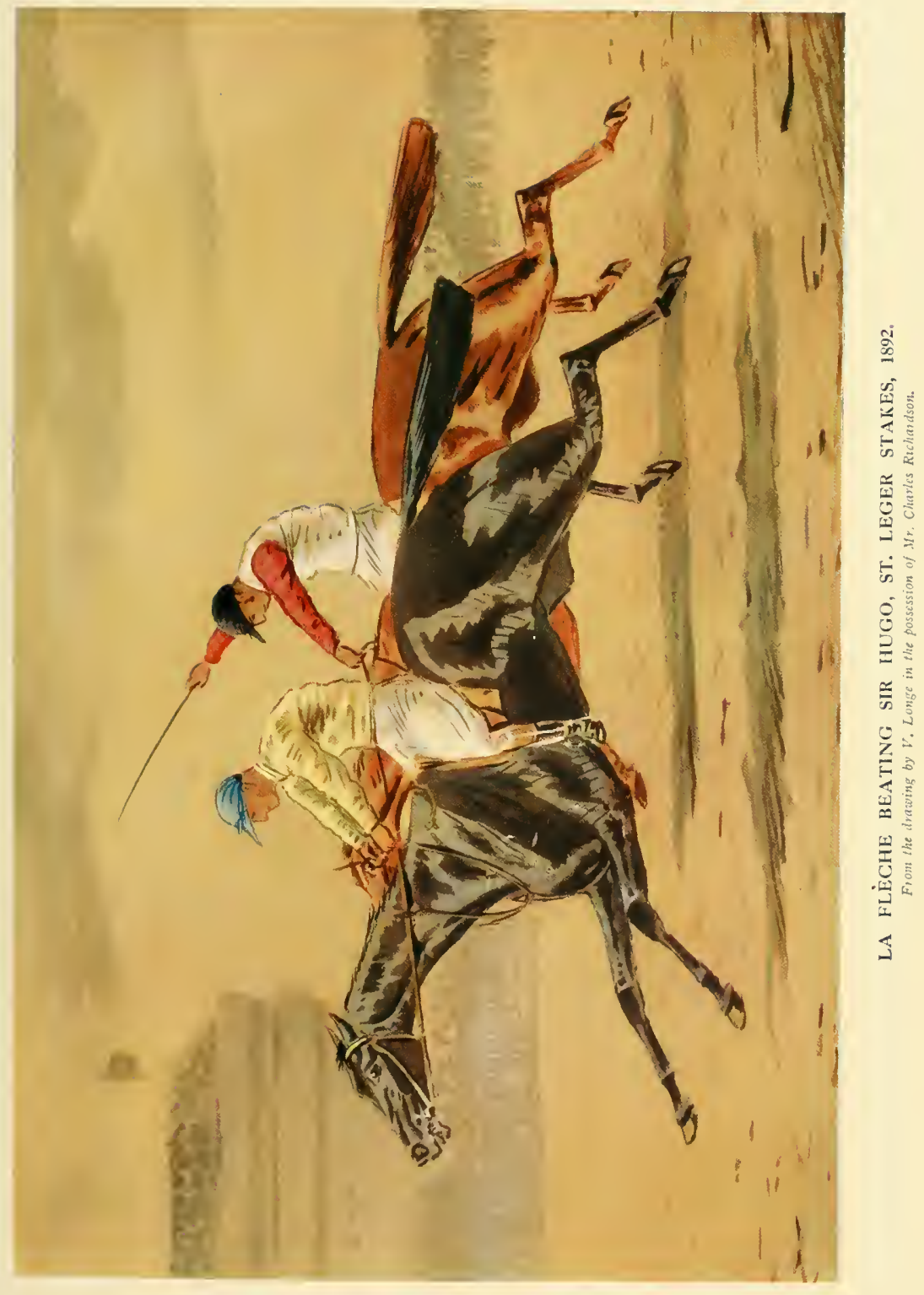



of Echipse. This then is the family to which Eclipse belongs, but beyond Spiletta and her sire Regulus (by the Godolphin) no dates in Eclipse's pedigree are given, so that, as has already been suggested, the earlier part of the pedigree is indefinite and vague. The family has never been a particularly strong one, and this is evidence in a way to the extraordinary vitality of Eclipse, who was able to assert himself in spite of the fact that his relatives on the lemale side of the house were never doing much towards bringing the family into prominence.

\section{The Oldfield Mare}

No further reference to Family No. I3, that of the Royal mare (dam of Grey Royal), is needed, but Family No. If is that of the Oldfield mare, "of which nothing is known, but she was described as 'highly bred.", The real Stud Book entry refers to "Lady Mare" got by (Old) Pert (son of the Ely Turk), her dam by St. Martin, grand-dam by Sir E. Hale's Turk out of the Oldfietd mare. The Stud Book is blank as to the Ely Turk and Sir E. Hale's Turk, their names only being mentioned, but the Lady mare bred Driver and two fillies, one by the Newton Arabian and one by Merlin, and the former bred in 173 I Look at the Lads by Grasshopper, a son of the Byerly Turk, while the other bred the dam of Naylor's Sally and a sister to Sally. From the daughter of Grasshopper came I)ove, the dam of Brunette and grand-dam of Trumpator, and others in the descent are Touchstone, Buccaneer, Touchet, and Saraband, while quite lately such celebrities as Pretty Polly, and the Derby wimers Volodyorski and St. Amant, have brought the family into a prominent position.

Family No. $\mathrm{I}_{5}$ is that of the Royal mare who bred Grey Why Not to Old Why Not, a son of the Fenwick Barb. Grey Why Not bred fillies to St. Victor Barb, and from these some nine or ten classic winners have been bred, but with the exception of Harvester most of them won their races a long time ago, and when Harvester sliared the Derby with St. Gatien he was the first of his family to win a classic race for forty-two years.

\section{"Young Marske" Mare}

Family No. I6 is one of the vaguest as to its origin. In the Stud Book there is an entry of "Young Marske mare, bred by Mr. Hutton, her dam by brother to Silvio, grand-dam (sister to Stripling) by Hutton's Spot." There is also a footnote that Mr. Hutton's ch. h. Stripling was running in I75I, but no further pedigree of him is known. Hutton's Spot was by Hartley's Blind Horse out of a mare by Surley, her dam by Coneyskins out of a mare by Hautboy, and Hartley's Blind Horse was by the Holderness Turk, who was brought from Constantinople by Queen Anme's ambassador about r704. We need not go through all the line of this family to the present day, but whereas the last lamily we have mentioned began well, and has done badly in recent years, so No. I6 has been a good deal to the front just lately, having had the winners of no fewer than twelve classic races since $I 88_{3}$. Its latest great representative is Sceptre, and it can also claim Ormonde, St. Gatien, Bonny Jean, L'Abbesse de Jouarre, Farewell, and Trontbeck, who won the St. Leger in roo6. It is likely that this family will take a higher place in the immediate future.

Family No. I7 is that of the dam or grand-dam (the Stud Book is not quite clear on the subject) by the Byerly Turk of the Wharton mare, who was herself a daughter of Lord Carlisle's Turk. The only classic winner the family has had in this country was Regalia, by Stockwell, who won the Oaks in 1865 .

\section{Old Woodcock}

Family No. IS comes from a daughter of Old Woodcock, about whom there seems to be some doubt. Pick mentions "a mare of Mr. Wikinson's called Old Wroodcock by the Wavey Woodcock," while Vol. I. of the Stud Book merely states that a Bartlett's Childers mare, "bred by Sir M. Wyvill in I 720 , her dam by the Devonshire Turk out of sister to Westbury by the Curwen Bay 
Barb-Curwen Old Spot-Old Woodcock," was the dam of certain fillies by Young Belgrade, whose descendants are still to be found. Probably the origin was British, but the evidence is terribly vague. Waxy, the sire of four Derby winners in Whalebone, Blucher, Whisker, and Pope (or Waxy Pope), was the greatest horse of the line, and if the blood of the Old Woodcock mare is not doing great things now in direct tail female, it lives through all the descendants of Whalebone, so that every horse of Birdcatcher or Newminster descent has some of it.

Fanuily No. I9 is supposed to come from a daughter of Davill's Old Woodcock, but whether there was any connection between this Old Woodcock and the mare of the same name who founded family No. Is it is impossible to say. The Stud Book assumes two different mares, but no dates are given, and we only know in connection with the second of the two that she was the great-grand-dam of a mare, who figures as "Counsellor (Woods) mare, sister to gr. h. Thunderbolt, who was foaled in 1723 . Her dam by Snake-Luggs-Davill's Old Woodcock." Of the Counsellor mare full particulars are given; she had numerous issue, and from her that great horse Isonomy was descended, and also his son Gallinule. The line is therefore doing pretty well, though its total of classic winners is not large.

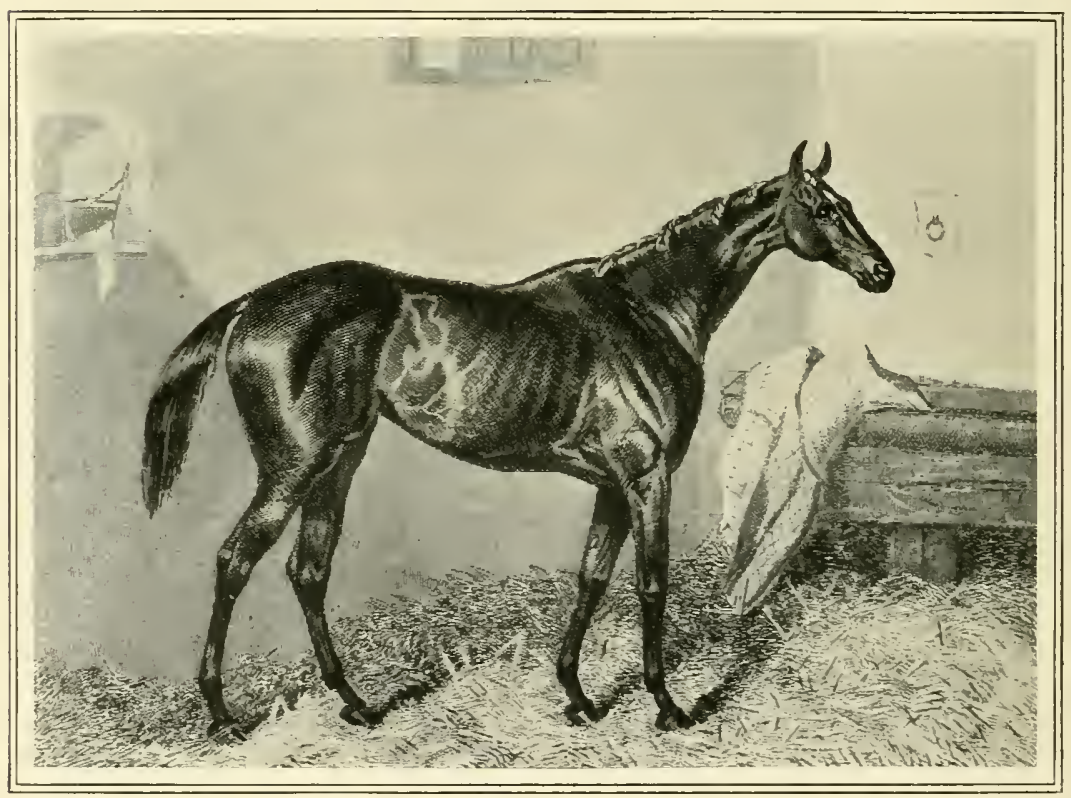

CALLER OU.

From the engraving by E. Hacker after the painting by Harry Hall. 


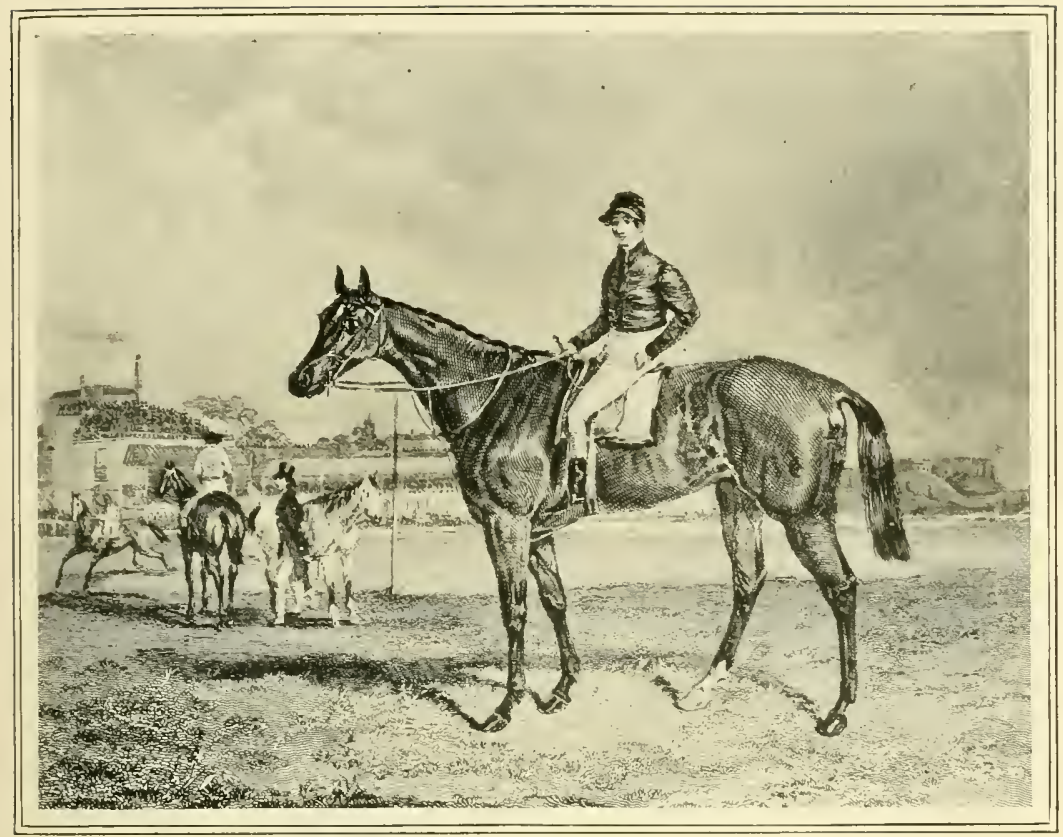

ILICE HAWTHORN

From the engraving by $I . H$. Englehent. After the original by W. Tasket.

\section{CHAPTER IX}

THE FEMALE LINES (continued)

F

AMILY No. 20, called by Bruce Lowe

1 that of the Daughter of Gascoigne's

Foreign horse, begins in the Stud Book with (grey) Favourite, bred by Mr. Durham in $\mathrm{r}_{7} 28$, got by a son of the Bald Galloway, her dam by Sir T. Gascoigne's Foreign horse. Some nine or ten classic winners are descended from Favourite, who was lately represented by Doricles, winner of the St. Leger in Igor.

Family No. 2 I comes from the Iloonah Barb mare who was owned by Queen Anne, and was located at the Hampton Court stud. Sweetmeat is probably the best known horse of this line, which is not an illustrious one.

Family No. 22 traces back to a mare by the Belgrade Turk, whose daughter by Bay Bolton had a filly to Bartlett's Childers, she in turn foaling Flora to Regulus. Flora was a most prolific mare, and from her are descended two comparatively recent Derby winners in St. Blaise and Merry Hampton, a much more famous horse than either in St. Frusquin, and the I9o3 Oaks winner, Our Lassie.

Family No. 23 is that of Piping Peg, the dam of the Hobby mare, who was by Lister's Turk. From the Hobby mare came the line of Brocklesby Betty, Brocklesby, Grey Brocklesby, Bay Brocklesby, and a numerous family, which has lately been in 
evidence through the Derby and Oaks victories of Signorinetta in Igos. From the Hobby mare were also descended Bob Booty, and more recently Solon, Barcaldine, Ossim, and Hagioscope.

Family No. 24 comes from the Helinsley Turk mare, who was the grand-dam of the Duke of Bolton's Old Lady. Camel, the sire of Touchstone, is of this family, as also is the Baron, the sire of Stockwell.

Family No. 25 is that of an unnamed mare by Brimmer, who was the dam of the (Old) Scarboro' mare by Makeless. From her are descended Young Melbourne, and the Derby winners, Azor and Sefton, but the family is not much lieard of in these days.

Family No. 26 is that of a daughter of Merlin, who was the dam of a mare by the Darley Arabian; and she in turn was the great grand-dam of Salome (or Selima), whose daughter Cypron by Blaze was the dam of Herod. The great horse just named is the most illustrious of the family, from which, however, nine classic winners have sprung, the last of which was Promised Land, successful in the Two Thousand of $185 \mathrm{I}$.

Family No. 27 is called by Bruce Lowe a Spanker mare, dam of a Byerly Turk mare. In the Stud Book it commences with Farmer mare, got by King William's White Chillaby-Byerly Turk-Spankervague enough in all conscience. Many good horses have come of this line, and Pero Gomez, Energy, Doubloon, Discord, and Arbitrator may be mentioned as some of the most recent.

Family No. 28 is that of a daughter of Place's White Turk, who bred the Coppin or Coffin mare to the Selaby Turk. Pick and the Stud Book hold different opinions as to whether there was a dual individuality, and though the Stud Book takes the view that the two mares were confused in old pedigrees we have failed to discover why Pick's story should not have been correct. Anyhow, from the Coppin or Coffin mare came a filly by Commoner, and from her certain winners of a bygone generation were descended.

Family No. 29 is that of a Natural Barb mare, dam of a mare by the Bassett Arabian, from whom the St. Leger winners Ashton and Rowton were descended, and Family No. 30 is that of the daughter of the Duke de Chartres' Hawker, who was the granddam of Golden Locks, and from whom came two early Derby winners, Archduke and Paris.

Beyond the above thirty original mares there are twenty others whose blood is still to be found. Their families are, however, inconspicuous, and it will be sufficient if we enumerate them as they were placed by Bruce Lowe.

Family No. 3I, Dick Burton's Barb mare: representative, Fazzolet to (Two Thousand Guineas, I856).

Family No. 32, Barb mare, dam of Dodsworth: representative, Challacombe (St. Leger, I905).

Family No. 33, Sister to Honeycomb. Punch: representative, Sargeant (Derby, I784).

Family No. 34, Daughter of Hautboy: representative, Birmingham (St. Leger, I830).

Family No. 35, Daughter of Bustler: representative, Haphazard.

Family No. 36, Daughter of Curwen's Bay Barb: representative, Economist.

Family No. 37, Sister to Old Merlin: representative, Bourbon (St. Leger, I777).

Family No. 38, Thwaites dun mare: representative, Pot-8-os.

Family No. 39, Bonny Black, her dam by a Persian horse.

Fanily No. 4o, A Royal mare, dam of Brimmer mare.

Family No. fI, Grasshopper mare, dam of Traveller nare.

Family No. 42, Spanker mare, dam of mare by Pulleine's Arabian Oiseau.

Family No. 43, Natural Barb mare, great grand-dam of Cardigan colt mare: representative, Underhand.

To Mr. Bruce Lowe's list of original mares, Mr. W. Allison, who edited Mr. Bruce Lowe's book, has added:-

Family No. 44, Bustler mare: representative, Joe Miller.

Family No. 45, Young Cade mare: representative, Barcarolle. 
Family No. $4^{6}$, Babraham mare: representative, Young Gouty.

Family No. 47 , Spectator mare.

Family No. 48, Shields Galloway mare: representative, Tartar.

Family No. 49, Whitenose mare: representatives, Chiselhampton, Orzil.

Family No. 50, Miss Euston : representative, Bryan O'Lynn.

It has been explained that a majority of the best race-horses come from the families with the lowest numbers, and this is proved by the fact that a very large proportion of all the greatest races in this and in other countries are won by horses which have low numerals. But there is no infallible rule in the matter, and every now and then a big winner will be found to belong to an outside family, as Challacombe (32), Signorinetta (23), or St. Gatien, Ormonde, Troutbeck and Sceptre, all of whom come from family No. I6.

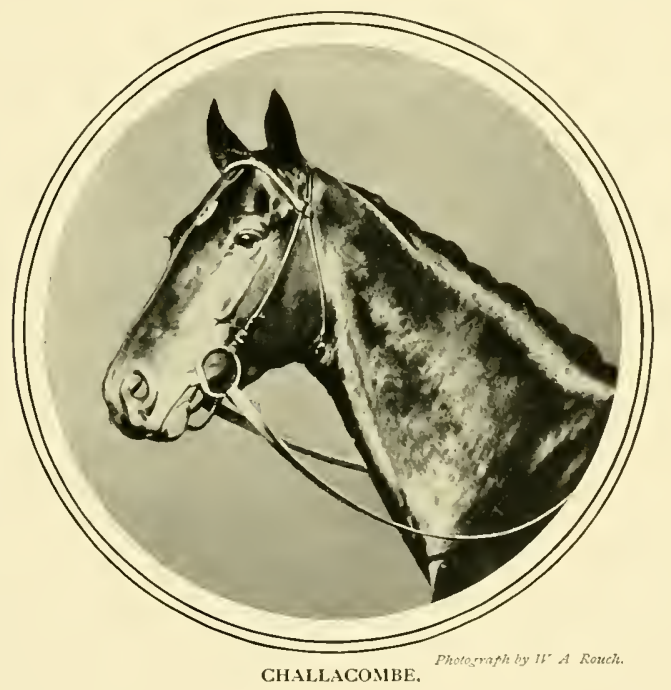




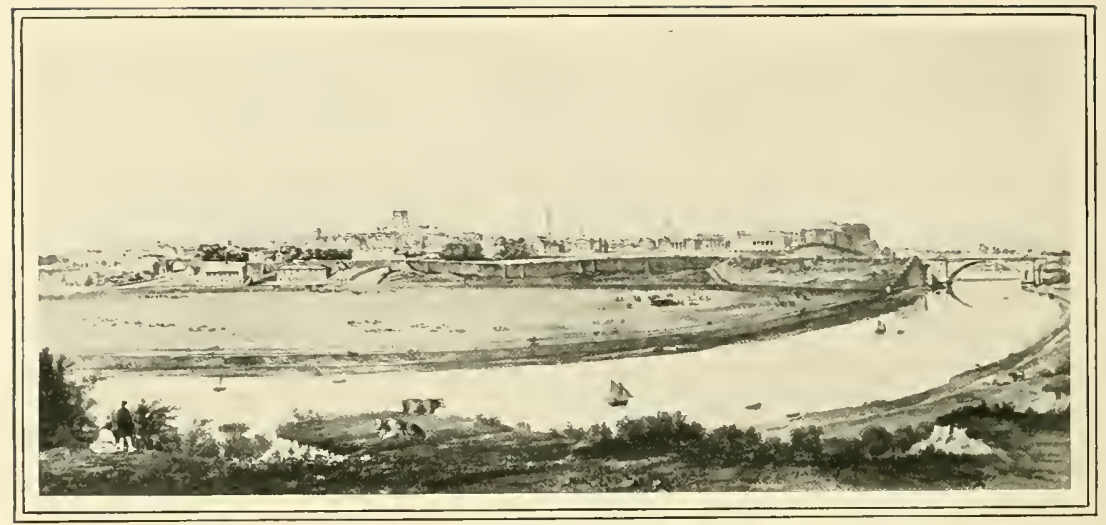

THE ROODEYE, CHESTER: THE OLDEST RACE.COURSE IN THE KINGDOM.

From an old lithograph. After a diawing by Alfret Sumnz.

\section{CHAPTER X}

THE TURF

$\mathrm{I}^{\mathrm{T}}$ T has been very truly stated that horses existed in Great Britain before histories, and it is also exceedingly probable that horse-races took place at a period when there could be no chance whatever of their being recorded. That the English are a horsy nation, or rather that they were once a horsy nation, is a fact which can hardly be disputed, and that being so it is probable that tests of speed were tried at a very early period of English history.

But it is also probable that during the earlier part of what is now known as the Middle Ages the toumament and the warhorse or charger claimed more consideration than the horse whose speed was his chief characteristic, and who was too lightly built to carry a fully equipped knight in armour. There is, however, no need to speculate on a question concerning which there are not many reliable historical details, and about which there is so much doubt, and therefore we may turn to such evidence as is forthcoming. The first usually cited reference to racing, or rather to running horses, occurs as early as the ninth century, when Hugh Capet, who was a suitor for the hand of the sister of Athelstan, sent over as a present to that prince several running horses (equos cursores), caparisoned with saddles and bridles ornamented with gold. It has been concluded by various writers and commentators on the original Latin from which the story is derived, that these running horses were race-horses, and that there probably was some use for such horses in this country.

Strutt, who wrote an important work on "The Sports and Pastimes of the English People" more than one hundred years ago, evidently took the view that Hugh Capet's horses were race-horses, and he argues the fact of this gift proves that horse-racing was known and practised by the AngloSaxons, "but most probably confined to persons of rank and opulence, and practised only for amusement sake." Strutt's opinion has not been generally accepted, however, and in James Rice's "History of the Turf," published in 1879 , the writer takes the view that the gift of running horses " does not establish the existence of the practice of horse-racing among the Anglo-Saxons; 
on the contrary, the rumning horses of Hugh Capet were, it is sufficiently proved, animals swift in the chase, and called running horses on account of their superior speed."

Is to which conjecture-for the views of strutt and Rice were really only conjectures - is the right one we shall not attempt definitely to decide, but it seems to us that the Latin words used by the original writer afford a very correct definition of a racehorse, and we are inclined to think that at the time referred to there was no hunting on horseback of sufficient importance to demand a special sort of horse. Indeed, all horses were primarily chargers at this period of the world's history, and that chargers were occasionally raced is extremely probable. It is also possible that as the chargers were bred bigger and bigger, in order that they might be able to carry the fully accoutred man-at-arms, it was found that they were too clumsy for racing, and that in consequence horses built in lighter mould were requisitioned. This might possibly account for the fact that there is no mention of horse-racing between the story of Hugh Capet in the ninth century, and the races which took place at smithfield in the reign of Henry II., who reigned betrieen II5t and I189.

It is just possible, as has been suggested, that during the period referred to the war-horse was too big to race, and that by the middle of the twelfth century lighter horses were being bred, which had more speed, and were not quite so chumsy as the charger accustomed to carry twenty stone.

\section{The Earliest Racers}

But there is further and earlier reference to racing in England which was made use of in Hore's " History of Newmarket," and which is derived from Bruce's "Roman Wall." This makes mention of imported Arabs of famous speed and stamina (in the reign of the Emperor Severus Alexander, A.D. 210) at Netherby (? Wetherby), in Yorkshire, which were so unsuitable to this climate that their owners were obliged to construct an enclosed training ground in order to prepare them for their engagements. It is also thought by some antiquaries that during the Roman occupation there were race-courses at Rushborough, Carleon, Silchester, and Dorchester.

\section{Anglo-Saxon Racing}

There is, moreover, a mention of horseracing in the works of the Venerable Bede, who lived in the seventh century, in the midst of the Anglo-Saxon era. One of Bede's characters describes how a party on a journey came to a spacious plain adapted to a race-course. The young men were anxious to prove their horses in the greater course, or, as the Saxon translator expresses it, that "we might run and try wlich had the swiftest horse; an individual joined them, but his animated horse, attempting to clear a cavity in the way, by a violent leap, the youth was thrown senseless against a stone, and with difficulty brought to life." Hore concludes that this probably occurred at Newmarket, within the domain of East Anglia, but there seems to be no proof of this suggestion, and the occurrence is just as likely to have taken place in the North of England, where Bede resided, and where there had been not long before many important Roman camps.

Passing over the Smithfield racing in the time of Henry II., it may be mentioned that a horse-race took place in 1377 , between horses owned by the Prince of Wales (afterwards Richard II.) and the Earl of Arundel, which was described by the Marquis de Saluces in a manuscript formerly preserved in the Royal library at Paris. This match was " owners up," but it is not recorded where the race took place, what the distance was, or what weights were carried.

\section{The Oldest Race-Course}

In all probability Chester was the first town at which horse-races were regularly held, and anyhow it is quite certain that the Roodeye is the oldest race-course in the kingdom about which there is any distinct account. They may have raced at 
Newmarket at an earlier date, but racing is known to have taken place at Chester in the reign of Henry VIII., while the first mention of Newmarket in this connection was at the latter end of the reign of Charles I.

\section{The Chester Bell}

Racing, it appears, was in its earliest days held upon public holidays, and thus an antiquary writing of Chester said, in an ancient IIS., attributed to the elder Randel Holme, "it had been customary, time out of mind, upon Shrove Tuesday, for the Company of Saddlers belonging to the City of Chester, to present to the drapers a wooden ball, embellished with flowers, and placed upon the point of a lance; this ceremony was performed in the presence of the Mayor, at the Cross in the Rodhee, or Roody, an open place near the City ; but this year (the 3 Ist of Henry VIII.) the ball was changed into a bell of silver, valued at three shillings and sixpence, or more, to be given to him who shall run the best, and the farthest on horseback, before them upon the same day." These bells were often denominated St. George's Bells-so says Strutt in his "Sports and Pastimes" -and it is said that in the last year of James I., John Bredeton, innkeeper, Mayor of Chester, first caused the horses entered for this race, then called St. George's race, to start from the point, beyond the new tower, and appointed them to rmn "five times round the Roody, and he who won the last course or trayne, received the bell, of a good value, of eight or ten pounds or thereabouts, and to have it for ever, which moneyes were collected of the citizens, to a sum for that purpose."

Strutt conjectures that the sentence about the winner having the bell for ever implies that it had formerly been used as a temporary mark of honour, and doubtless this was so, but the "temporary mark of honour" may be more definitely construed into " Challenge Cup," for that is what it would be called at the present day. The date of this alteration was I624, the last year but one of the reign of James $I$.
But the Chester antiquary's writing seems rather to suggest that the race was run in heats of a mile, for the winner was the horse who "won the last cours or trayne." This may either mean that no notice was to be taken as to which horse was leading at the end of the first four circuits of the course, or it may mean, as has been suggested, that the race was run in heats. The point will never be solved now, but racing in heats was common enough not so very long afterwards, so that one is inclined to adopt the idea that this is the first mention of such a competition.

\section{Early Disqualifications}

Forty-six years later there is another mention of Chester races in the IIS. of Randel Holme, and this time there was grave trouble because some of the competitors did not fulfil the conditions of the race. The passage is as follows: the Sheriffs of Chester "would have no calves-head feast, but put the charge of it into a piece of plate, to be run for on that day, Shrove Tuesday; and the High Sheriff borrowed a Barbary horse of Sir Thos. Middleton, which won him the plate; and being master of the race, he would not suffer the horses of Master Massey, of Puddington, and of Sir Philip Egerton of Oulton, to run because they came the day after the time prefixed for the horses to be brought, and kept in the city; which thing caused all the gentry to relinquish our races ever since."

From the above it is evident that in 1665 racing at Chester was conducted with a certain amount of business-like regulation. It is evident that "conditions" had been drawn up, and it is also evident that disqualification ensued when the conditions were not properly observed. There is, however, no record as to the actual runners, nor is it known what weights they carried. At the same time the reference to the gentry relinquishing the races suggests that those same races had already acquired a certain amount of popularity; and that they were important enough to be considered by the authorities of the City, there being a 
reference to the Hayor in the earlier account, and to the Sheriffs in the later one.

\section{Henry V'III. as a Race Patron}

It has been stated that racing took place at Chester in the reign of Henry VIIL, but there is also plenty of evidence to show that the King himself was a patron of the sport, for in his Privy Purse expenses mention is made of various sums of money given in reward to grooms and servants by whom horses were brought to Eltham, Windsor, and elsewhere, to compete on the race-course with those belonging to the King. Mr. Hore in his " History of Newmarket" ferreted out a whole host of particulars in connection with the King's stud, and amongst other things he told us that "in the spring of 1530 , the King's watermen received 2 Is. and $f d$. for waiting on the day the King's horses ran. The jockey, if he won, received $24 \mathrm{~s}$. and $8 \mathrm{~d}$., while Thomas Ogle, the 'Gentleman Rider of the Stables,' got a gratuity of 20s. by the King's special grace and favour." It also appears that it was no easy matter to procure jockeys in those days, for there is an item of $f 36 \mathrm{~s}$. 8d. for the expenses of sending one from the borders of Scotland. There is plenty of evidence also to prove that the jockeys wore distinguishing colours, as in these Privy Purse expenses mention is made of " riding boys," of clothes " bought for the boys that ride the running horses," and also of riding caps for these same boys. It is then extremely probable that distinguishing colours were worn at this early date of racing history.

\section{Elizabeth's Racing Stud}

From the time of Henry VIII. onward racing gradually became one of the national sports of the country. Pages of evidence to this effect could be given, but it will be sufficient if one or two more important landmarks are noted. It is a fact, then, that Queen Elizabeth maintained a racing stud, and in Nichols' " Progress of Qucen Elizabeth" it is mentioned that in ${ }_{5} 85$ the Queen, accompanied by a brilliant retinue, attended the races at Croydon, when 34 s. was expended on a stand for the use of her Majesty. She was also present in 1587 and ${ }_{5} 58$, there being references to similar expenses in these two years.

It is, perhaps, rather curious that whilst the money accounts of Henry VIII., Elizabeth, and later sovereigns, are so definite in respect to these petty details, there is so little reference to the horses, or to the actual races in which they took part. The five-mile race at Chester seems to be the only event in these early days of the turf of which there is any sort of description, and this description, as has been shown, is exceedingly vague.

\section{Other Early Race-Courses}

Another place of early racing was Doncaster, for a race-course on "Wheatley Iore" is noticed in old deeds, dated I60o, and there is further reference to it in connection with certain other deeds of the Corporation. "Wheatley More" was probably the Doncaster Town Moor of the present day, for Wheatley Park is situated almost adjoining the course-beyond the Red House-and has been for long years the residence of the Cooke family, of which Sir William Cooke, Baronet, and Master of Foxhounds, is the present head.

There is record of a horse-race at Sapley, near Huntingdon, in $\mathrm{I} 602$, when one bearing the great name of Oliver Cromwell won the silver bell. This Oliver Cromwell was not, however, the afterwards famous Protector, but according to some authorities, his uncle, and it is also said that he was knighted by Queen Elizabeth in ${ }_{5} 598$, and created K.B. at the coronation of King James. The one thing probable about him is that he was a sportsman, for he won this race, and, in the words of the chronicler, "had the glory of the day."

Christopher Clarkson, who wrote a history of Richmond, in the County of York, says that in the reign of Queen Elizabeth racing was carried on to such an excess as to injure the fortunes of many individuals, private matches being made between gentlemen who were generally their own jockeys and 
tryers. At Carlisle the Corporation gave silver bells to be run for in I599, and it is said that there was an annual horse-race at Haddington in Scotland as early as I552, the prize being as usual a silver bell.

The race-course at Newmarket was, it is generally conceded, made in the reign of bringing in of a peece of plate for a hunting prize, to be ridden for at Woodham Stowpes yearely, upon the Tuesday next before Palme Sunday, and soe to be contynued."

It is on record, too, that in $\mathrm{I} 6 \mathrm{I} 7 \mathrm{King}$ James I. came to the castle at Durham on the roth of April, and " on Monday the next following the King travelled from the

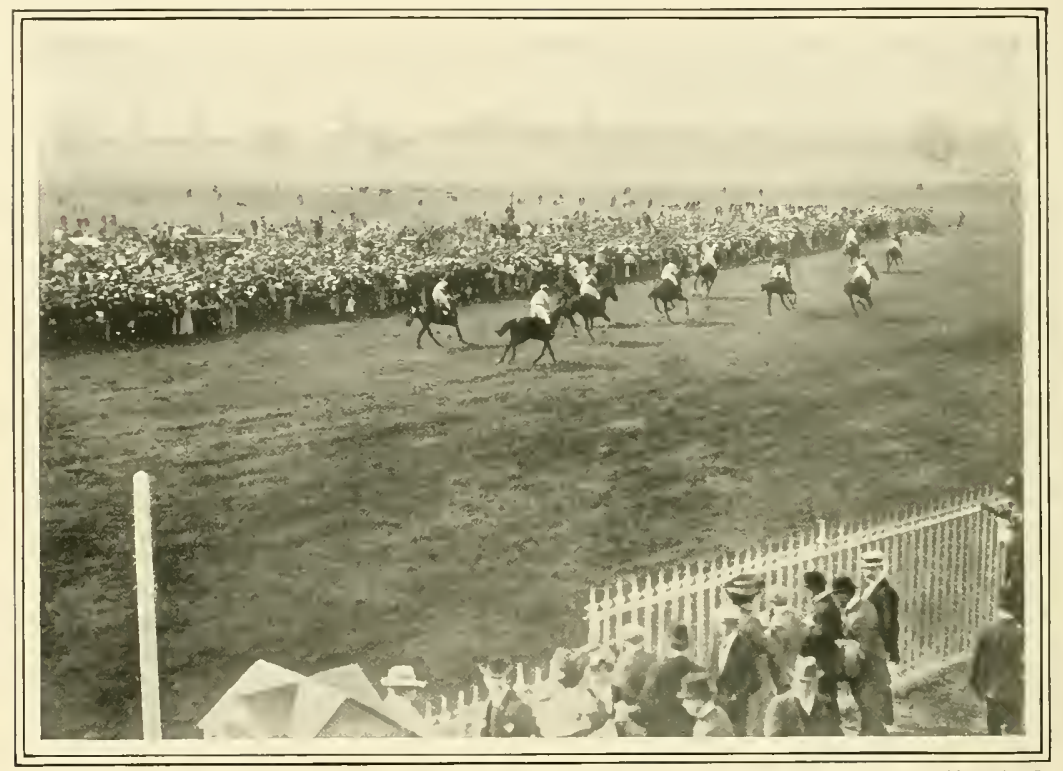

YORK RACE-COURSE.

James I., on land which had been a favourite hunting-ground of that particular King, for quite a lengthy period. But there is reason to believe that racing did not actually take place at what was afterwards to be the headquarters of the Turf, until the following reign. Though James $I$. kept race-horses, he seems to have cared quite as much for hunting, whereas Charles I. encouraged racing-which in his day also took place in Hyde Park. In I6II "Great Horse Racing" came off at Croydon during the Easter holidays, and in 1617 there was racing at Woodham Moor, in the county of Durham, when " the sum of fiftie pounds was collected and provided for the yearely
Castle to Woodham Moor, to a horse-race, which was run by the horses of William Salvin and Master Maddocks, for a gold purse." The Salvin family still own much property within a few miles of Durham, but the name of Maddocks is hardly known in the district at the present day.

Gatherley Moor in Yorkshire, some few miles north of Richmond, on one of the great North roads, was another scene of early racing, and in Clarkson's " History of Richmond " there is a description of the race for the cup, run for on May I6th, 1622 , and as this is the earliest description of a race that the present writer can find, it is here reproduced. 
"A new maid race upon Rychmond Mloor of iiii myles, sett forth and measured by MIr. James Raine, Alderman, and Mr. John Metcalfe, and many other gentlemen and good fellowes the vith of May. And further the said James Raine, Alderman, with his brethren, hath made up a sume of xii poundes for to buy a free cupp for those knights, gentlemen, or good fellowes that have horses or mares to run, learvng the cupp free to their own disposition, must make upp the value of the said cupp, to renue the same for the next yeare.

"Whereas the names in order as they came this present year 1622 , was as followeth, John llagget onely the starter.

Impunius Sir George Bowes . . his horse, I.

Mir. Humplarey Wyvell, his tryer.

Mr. Thomas Bowyer . . . his horse, 2.

Mr. Christ. Bollmer, his tryer.

Ir. Francis Broughe . . his horse, 3 .

Mr. Matt. Rymer, his tryer.

Mr. Wausforde . . his mare, 4 .

Ir. Anthony Franckland, his tryer.

Mr. Loftus . . his horse, 5 .

Mr. Francis Wickliffe, his tryer.

Mr. Gilbert Wharton, the last and the 6 th.

Mr. Thomas Wharton, his tryer.

-So every party putting $\mathrm{xl}$ shillings, hath maid upp the stake of xii pounds, for the buying of another cupp for the next year following."

\section{7th Century Race-Meetings}

There is record of races having been held at Langworthy in Cumberland in 1612 , and at Salisbury in 1616 , while in the following year horse-races are mentioned as having occurred in Lancashire at Whalley Abbey, Liverpool, and Walton. There were races at Thetford in 1620 , and there is mention of a horse-race at Linton in Cambridgeshire, in the reign of James I., of which the exact date is not forthcoming, and of a match between two gentlemen at Brackley in Northants, in I612. Then, again, in one of Beaumont and Fletcher's plays called "Ionsieur Thomas," and which was acted about $162 \mathrm{I}$, there is mention of a horserace at Derby. There is also evidence to show that York, Paisley, and Peebles had races about this period, and there is in point of fact ample proof, forthcoming from a variety of trustworthy sources, to the effect that racing was, during the reign of James I., rapidly becoming a popular amusement.

\section{The Rise of Newmarket}

It has now been shown that the Turf in England is, practically, about 300 years old. Neetings, or rather individual races, were common enough in the early days of the seventeenth century, but according to some authorities there is no reliable mention of racing at Newmarket until I6 fo, which seems rather curious, because -as has been stated-the course is supposed to have been made in the previous reign.

It is, perhaps, a question of no great inportance, but Hore, whose writings show great historical research, was of opinion that racing took place on the famous heath during the reign of James I. In Vol, I. of the "History of Newmarket," p. 327. he wrote: "Our summary introduction to the ammals of the turf in the reign of James I., commences with Newmarket, where horseraces and hunting matches were instituted under the auspices of royalty." On P. 215. quoting from Camden's "Annals," or Birch's MS.- it is not quite clear whichhe says "there was a horse-race at Newmarket, at which the King, tarrying too long, in his return from Newmarket, was forced to put in at an inn at Wichfordbridge, by reason of his being indisposed, and came very late in the night to Rayston " (probably Royston). The date of the occurrence referred to was March Igth, I6I9, and the passage affords strong evidence as to the correctness of Mr. Hore's date. There is further evidence on the subject in the MS. of Sir Richard Graham, a gentleman of the horse to the Duke of Buckingham. This makes mention of the Duke losing froo to Lord Salisbury, in a race at Newmarket, in I622, and though particulars of the race or races in question are wanting, there is no reason to distrust the accuracy of the 115 .

In Mr. T. C. Whyte's "History of the British Turf," published in 18 fo, the author boldly states: "The first races which were held in Newmarket, took place in the reign 
of Charles I., in the year I6 40 , although the Round Course was not made until I666."

\section{Cromwell and Racing}

Charles 1. lived in unsettled times, but he was a horseman, and encouraged legitimate sport of all kinds. Oliver Cromwell was too busy a man to devote time to racing, but he did his best towards improving the breed of horses, and continued the importation of Eastern sires, which had now been going on at intervals for a considerable period of time. References to Place's White Turk have been made in connection with the descent of the modern race-horse, and all the evidence points to the fact that "Oliver" was fond of horses, and that he did not discourage racing. Indeed it is on record that the Puritans interfered with nearly every sport of the day except racing, and that they doubtless left alone, because of the need for encouraging the breed of horses.

After the Restoration came a general development of racing, under the auspices of Charles II., who was a great patron of Newmarket, and who instituted the meetings on Datchet Mead. He also patronised Burford (in Oxfordshire) races in I68I. James II. was only hing for three years, but William III. took personal interest in racing, and maintained a stud, which was under the charge of one Tregonwell Frampton (wno has been named the Father of the English Turf), who also filled the office under Queen Anne, George I. and George 11. The Byerly Turk was brought to this country during this reign, and in 1706 , the fourth year of the reign of Queen Anne, the equally famous Darley Arabian made his appearance.

\section{Parliament Intervenes}

At this period of history racing was firmly established as one of the national sports of the country, and it appears to have progressed smoothly until i7fo (George II.), when an Act to restrain excessive racing was passed by Parliament, which had for its object the putting an end to a number of country meetings by raising the stakes run for. The new law provided that every horse entered for a race must be bona fide the property of the person entering it, and that one person might only enter one horse for a race on pain of forfeiture. It was further enacted that no plate should be run for of less value than $£ 50$-the penalty for transgression of the law being $£ 200$. Parliament also settled the weights which horses had to carry, as follows:-

Five-year-olds to carry Io stone.

Six , , , , II stone.

Seven ," , , I2 stone.

The penalty inflicted upon the owner of any horse carrying less than these weights was the forfeiture of the horse, and the payment of a fine of $£ 200$ besides. It will be seen that in those days there were no races for young horses, but as a majority of the races were of four miles in length-very often four-mile heats-one can quite understand

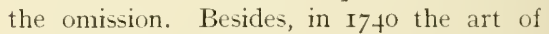
training was probably not understood as it is at the present day, and most certainly thoroughbreds were not forced, almost from foalhood, as they are now.

\section{The Jockey Club}

The Act also declared that matches might be run for a stake of under $f 5^{\circ}$, only at Newmarket, and at Black Hambleton, in Yorkshire, under a penalty of $£ 200$ for disobedience. Everywhere else the lowest prize was to be $\underset{ \pm}{\circ}$, and entrance money was to go to the second horse. Unfortunately there is no record of all the meetings which had been held prior to $\mathrm{I} 74 \mathrm{O}$, so that it is impossible to know accurately which of them disappeared as a consequence of this Act. The law, however, was altered five years later, both as regards money and the weights to be carried, and since then there has been very little State interference with racing, and promoters of the sport have been allowed to make their own rules. The Jockey Club was founded in $175^{\circ}$, or $\mathrm{I} 75^{\mathrm{I}}$, and for a long period it only concerned itself with racing at Newmarket, but gradually it took charge 


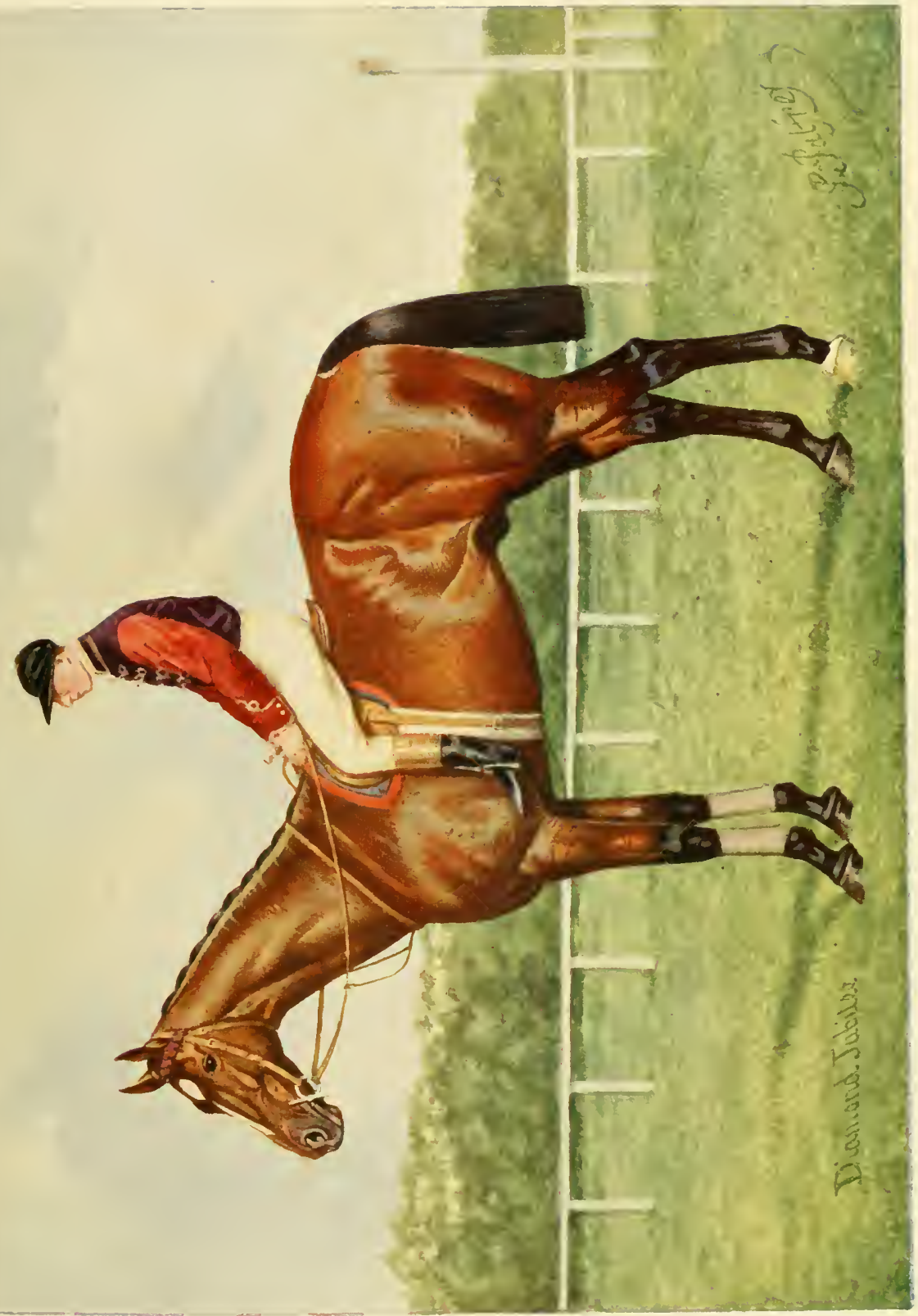

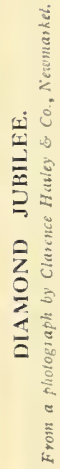



of the sport altogether, and for at least two generations has managed everything.

As this is not a history of the British Turf, it is unnecessary to trace the development of racing through the eighteenth and nineteenth centuries. Some account of the early begimnings of the sport has been given, in order that the origin of racing should be explained, but after the appearance of calendars and records of meetings, incidents followed each other so quickly that it is impossible to do more than note brietly certain landmarks of the Turf.

\section{8th Century Fixtures}

Orton's " Turf Annals" begins with mention of a race for a Gold Cup which took place at York on September I 3 th, I jog, and in which there-were three heats of four miles each. Forty-three years later (in I752), meetings were held at something like seventy different places, ten of which were in Yorkshire, four in Cambridgeshire, four in Suffolk, three in Berks, Chester, Durham, Lincoln, Middlesex, and Northumberland, two in Bucks, Cumberland, Derby, Gloucester, Hants, Hereford, Leicester, Northampton, Nottingham, Oxford, Kent, Surrey, Warwick and Wilts, while in Dorset, Essex, Hants, Lancaster, Norfolk, Somerset, and Sussex, there was a single meeting.

At the time referred to races were held at many of the most important county towns, and already the early fashion of having contests decided on remote heaths and moorlands was beginning to disappear.

In $\mathrm{I}-\mathrm{SQ}$ racing took place at seventy-two places in England, at three places in Wales, at six in Scotland, and at fifteen in Ireland. At many of these places there were more than one meeting, however, and notably there were ten fixtures at Newmarket, two at Preston, four at Malton, two at York, and the same number at Edinburgh, but Gatherley-or Gaterly as it was sometimes called-had disappeared from the list, nor is there any mention of Hambleton in the Calendar for that year, and doubtless it was being felt that it was extremely inconvenient to have meetings in out-of-the-may districts, which can only have been reached by making long journeys over very rough country roads. Hambleton in pre-railway days had no towns nearer to it than Thirsk, Helmsley, Malton, and York, the firstnamed a very small market town, while lork must be quite twenty miles away. Even at the present day Hambleton can only be approached by road, and the highways which lead to it from the plain of Sork are still terribly steep-even for a motor-car. The galloping on the moor above the plain is about as perfect as any that can be found, but the place always was, and still is, to a great extent, inaccessible.

Gatherley, too, is very wide of centres of population, and entailed a long drive from such places as Richmond and Darlington, but on the other hand the races at KiplingCoates were mentioned in the Calendar of 1789 , and these were held on the wolds, between Beverley and Market Weighton. In 1780 the race is spoken of as "The Annual Plate for horses carrying Io stonefour miles," but all mention of KiplingCoates has been absent from the Calendar for many generations. And yet the race or races have not wholly disappeared, but in these days they are not under Jockey Club rules, and may be placed in much the same category as the Newmarket Town Plate, which is run for annually, over a four-mile course.

\section{Cathedral City Courses}

A feature of the 1789 Calendar is forthcoming in the number of race meetings which were held at the cathedral cities. The list includes Chester, Carlisle, Durham, Hereford, Canterbury, Lincoln, Peterborough, Wells, Lichfield, Oxford, Salisbury, Worcester, Ninchester, and York, and even in this day, when racing has become centralised and park meetings have taken the place of the country fixtures, we find that races are still held in the immediate vicinity of several cathedral cities. In the list which has just been given fourteen such cities are named where the sport flourished in $I_{7} 89$. At six of the fourteen-Chester, Carlisle, Lincoln, 
Salisbury, Worcester, and York-racing still takes place, while it now flomishes in two cathedral cities which were not included in the $I 789$ list. The two places to which reference is made are $B$ ath and Ripon, and to these may perhaps be added Manchester, Liverpool, and Newcastle-on-Tyne, which have received the ecclesiastical dignity in recent years.

\section{The Increase of Meetings}

In $\mathrm{I} \mathrm{S} 9$ the sport was far more widely distributed than it is at the present day, for whereas at the earlier date there were eighty-one places in England and Scotland at which these race meetings were held, there were in Igos only forty-seven. At the same time the number of meetings is vastly larger than it was, as many of the enclosed park race-courses have five and six flat race fixtures during the season, whereas a hundred years ago only at Newmarket, Malton, Carlisle, York, Preston, and Edinburgh, was there more than one meeting, and at York, Preston, Carlisle, and Edinburgh the fixtures were only two in number, while Malton had four dates.

In all there were ninety-nine meetings of which particulars are given in the Racing Calendar of $x>84$, whereas in Igos there were one hundred and thirty-three, with a far greater number of races to each day than was the case at the earlier date.

The increased interest in racing may be shown in another way. In I827 I,I66 horses ran in flat races; in $I 867$ the number had risen to 2,458 ; in $I S_{77}$ it had dropped to 2,057 ; in IS87 the numbers were 2,045 ; in $\mathrm{I} S 97$ there was an increase of about $\mathrm{I}, 500$, the actual number of runners being 3,506 ; and in 1907 the number was 3,465 ; which shows that matters remained stationary in this respect during that ten years.

In Igor the number reached 4,0 org, and this is the biggest total which the British Turf has known. Moreover, unless there is some radical change-and there are no signs of any such change at present-there is not likely to be any material increase or decrease of these figures. The numbers will, of course, vary from year to year, but as long as there is a close time of sixteen or seventeen weeks during the winter months, and as long as the Jockey Club keep the number of meetings much as it is at present, there is little likelihood of any great increase. If many more American race-horses are sent to this country in the immediate future there will, naturally, be an increase in the size of the fields, but hitherto the chief law which has governed the number of runners for each race has been the state of the going. The year Igor was rather a wet one, there being a good deal of rain in July, and this doubtless allowed of larger fields than usual during what is generally the dry season.

\section{Changes in Racing Methods}

Certain radical changes in racing have taken place, most of which were rather gradual. The first of these to be noted was with regard to the running of young horses, instead of keeping them until they were five years old. In Orton's "Turf Annals," which begins with the year ryog, there is no mention of four-year-olds until $\mathrm{I} y+3$, when a plate of $f_{50}$ was run for by horses of that age, at York, on Friday, August 12 th. In all the previous years of which a record is given the various races seem to have been for five- and six-year-olds, or for aged horses. The usual distance, too, was four miles outright, or heats of four miles, whereas in this four-year-old race " twomile heats" were the conditions. Fouryear-olds appear to have run at Doncaster in $\mathrm{I} 75 \mathrm{I}$, and they may have competed at an earlier date, for the returns of several years are missing.

Orton's first mention of three-year-old racing is in $177^{\circ}$, when the Stand Plate of $f_{50}$ was run for horses of that age, over a two-mile course. From this time onwards there was almost invariably a race or races for young horses at the more important meetings. Ten years later, in I 7 So, the first Derby was rum, but it had been preceded by the St. Leger and the Oaks, of which the first-named race was first decided in 1776 , and the Oaks in 1779 .

One is much inclined to think that previous to the institution of the Derby, Oaks, and 


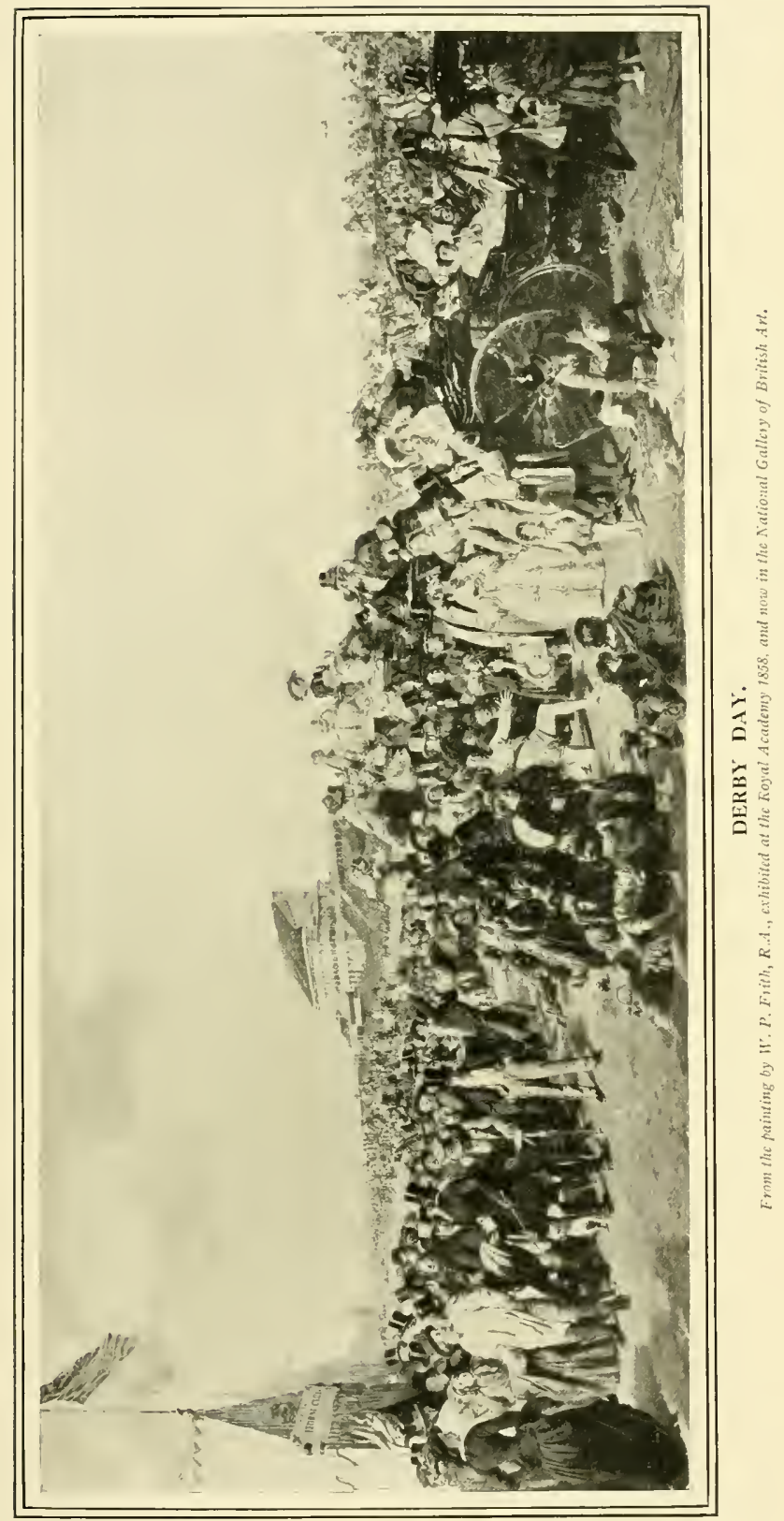


St. Leger, York had for some years been quite as important with regard to its meetings as Newmarket or Epsom, and much more important than Doncaster. For a long period of years the series of "Great Subscription Stakes" at York appear to have been the greatest events of the year, and such horses as Matchem and Eclipse were amongst the York performers of their day. The Doncaster meetings were certainly smaller affairs than those of York, but the St. Leger made a great deal of difference, and one camnot help thinking that lork lust a chance when it did not instantly start a rival race. As it was the St. Leger began as a sweepstakes of $f 25$ each for threeyear-olds, while the Derby, four years later, began as a sweepstakes of $f_{50}$ each, the stake for the Oaks being the same.

The result of the founding of these races was that in a very short period of time they became the most important races of the year, and in consequence Epsom and Doncaster became also the most important race meetings. The Two Thousand and One Thousand Guineas were instituted in ISon and IsIt respectively, but they never seriously rivalled the Derby and Oaks, and were to some extent looked upon as trial stakes for the more important events which were decided at Epsom foul or five weeks later.

\section{Centralisation of Racing}

There is no need to treat of each race meeting-whether it is defunct or otherwise-in detail, but it may be mentioned that one or two changes, which were brought about uwing to a combination of circumstances, have caused racing to become greatly centralised. In its infancy, as has been shown, the sport was scattered over the country, and one hundred years ago there was more of it in Yorkshire and the Midlands than there was in the neighbourhood of London-in spite of the fact that Epsom and Ascot were even then extremely fashionable. The fact is that racing in its early days was most popular in the horse-breeding districts, and the Calendars of the period between I 800 and $\mathrm{IS}_{25}$ show that in Yorkshire alone there were about twenty meetings, while in Surrey, Epsom, Guildford, Egham, and Reigate were the only centres of the sport. The Midlands, and especially the Western Midlands, were at about the same period very well off for meetings, Staffordshire and Worcestershire being particularly well supplied. Indeed there were more individual meetings eighty years ago than at any uther period of Turf history, but very few of them had more than one fixture in the twelve months, whereas in these days most of the enclosures summon their patrons about once a month.

\section{Influence of Railways}

Just before railways made their appearance all these country meetings depended -as a matter of course-on local support. The promoters of the meetings and the nobility and landed gentry of the neighbourhood rery often worked together, and the runners were frequently trained not far from where the meetings were held. The stakes were of small value, and unless there was a King's Plate on the programme very few horses from a distance were present. To a certain extent each group of country meetings formed a circuit, round which various horses travelled, their trainers often galloping them on the race-course only, for a certain period of time, and walking them from one meeting to another.

The alteration was brought about by the coming in of the railway period, which soon allowed of race-horses being boxed from one end of the kingdom to the other. This, of course, meant that when a good prize was offered, the local horses no longer had it all their own way, for strange horses were brought from Newmarket, and from the down countries of Hants, Wilts, and Dorset, where many horses were trained, and few meetings were held-and very quickly the sport became much more cosmopolitan in character.

Then, indeed, the smaller and more remotely placed meetings began to disappear from the Calendar, and it can be noticed that the fixtures which survived were for the most part so placed that ther could 
command plenty of patronage. Thus meetings which were located in the environs of a big town held their own, while those meetings which could not command much money to be given in prizes, or which were a long distance from any training quarters, disappeared. Still, throughout the middle of the last century the sport flourished, and whilst Newmarket, Epsom, Ascot, Goodwood, York, Doncaster, Chester, IIanchester, Shrewsbury, Newcastle-on-Tyne, and Liverpool were the most important racing centres, a fair number of minor meetings just held their own.

\section{Modern Meetings}

The next great change was the introduction of the gate-money meeting in 1875 . Previous to the establishing of Sandown Park race meetings were managed by Corporations-as Doncaster still is-by private individuals (who never made much out of their ventures), or by syndicates of local folk. Many of them had always a hard struggle to live, and had not there been well supported subscription lists in nearly every district, there would have been much less racing than there was. The nobility, the neighbouring gentrs, the County and Borough Members, were all expected to subscribe to the race fund, and thus such items as the "Lord Lientenant's Plite," the "Borough Member's Plate," and so forth, can be noted in old numbers of the Calendar. The innkeepers and prosperous tradesmen of the country town were subscribers to the fund, and the money was wanted, because with the exception of the grand stands and the enclosures, all parts of the course were free to the public.

\section{The $£ 100$ Rule}

The gate-money meeting completely revolutionised the Turf, and in so doing it was greatly assisted by a rule of the Jockey Club which insisted that no stake of less value than $\underset{\sim}{f}$ Ioo to the winner should be run for under their rules. The Jockey Club had by this time complete control of all the important flat racing, and what little sport there was in the country which was not under their rules was quite insignificant. Rumners at meetings which were not held under Jockey Club rules were-and are still-perpetually dispualified from rumning at meetings controlled by the Club. This, it can easily be understood, has had the effect of liniting such other flat racing as there is to tenth-rate obscurity. No one would think of running a really valuable horse at what is often called a "flapping" meeting, and thus it remains that such equine support as is forthcoming for the meetings which are not under rules is provided, in great part, by the patched-up selling platers, which are not good enough to win under the proper rules of racing.

\section{The Extinct Country Meetings}

The $f$ Ioo rule finished off another large batch of country meetings, perhaps more specially in the north of England, where Morpeth, Durham, Richmond, Northallerton, Scarborough, and Malton all disappeared within a year or two. In the south some of the smaller fixtures struggled against fate for a longer period, but it was impossible for meetings held on an open common to make headway against rivals who could charge admittance to their courses, and thus within the last few years such meetings as Lichfield, Huntingdon, and Northampton-the last named at one time a really important fixturehave gone to the wall.

But the advent of the gate-money enclosure was gradual, and it took at least fifteen years to set the new style of racing thoroughly on its legs. At first a great deal of prejudice had to be overcome, and there were also the vested interests of sundry folk who had worked hard in the interests of racing to be considered. Thus Sandown came into existence as a racing place in 1875 , and four years were allowed to elapse before Kemptom Park made its appearance. After this again there was another lull, but racing officials had by this time recognised the fact that the park meeting was more likely to prosper than the open affair-except indeed in such cases as those of Newmarket. Epsom, Ascot, and 
Goodwood, where there were special attractions in the way of popular races, or special patronage of the magnates of the racing world.

But from about I888 to I895 there was a rapid increase in the number of gate-money fixtures, and in several instances old meetings were altered to conform to the new conditions. Hurst Park, which began as a steeplechase course, and which was used
It will be appreciated that the advent of the gate-money meeting completely altered the racing which had previously taken part in many neighbourhoods. The London district, for example, had shortly before the advent of the enclosed gate-money meeting, racing at Epsom, Ascot, Bromley, Egham, Hampton, Harpenden, Kingsbury, West Drayton, and Windsor, but except at Epsom

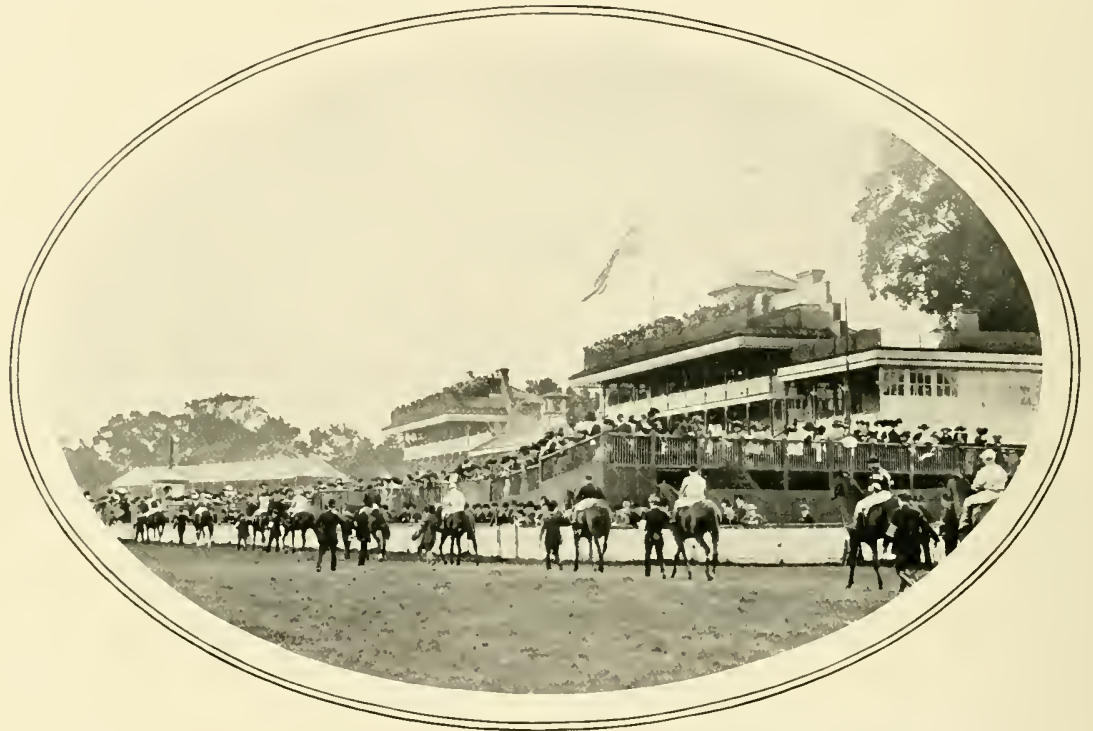

A PARADE PAST THE STANDS AT KEMPTON PARK.

for pony and galloway racing before the Jockey Club licence was granted, was one of the earlier ones, and Gatwick and Lingfield were inaugurated much about the same time, Lingfield having at first, like Hurst Park, a good deal of trouble about its licence, then came Four Oaks Park (which no longer exists), Colwick Park to take the place of the old Nottingham racecourse, and shortly afterwards Bromford Bridge, Birmingham. The first of the country enclosures, however, was Gosforth Park, which took the place of the old Newcastle-on-Tyne race-course, and probably the second was Dunstall Park, close to the town of Wolverhampton. and Ascot the sport was second or third rate, and, except on public holidays, there was practically no great attendance beyond the professional element of every description. In place of such plating fixtures as "'Appy 'Ampton," Kingsbury, and Bromley, London now has Sandown, Kempton, Hurst Park, Gatwick, Lingfield, and the modernised Windsor and Alexandra Park, and instead of catering for the platers as their predecessors did, the meetings just named attract-some of them always, others at times-all the equine celebrities of the day.

It should be mentioned that the froo rule to which reference has been made had 
already finished off several of the old suburban fixtures, but the curious part of the new style is that a high standard of class is now maintained at all the gate-money meetings round London, whereas a reference to old Calendars will show that under the old system nearly all the racing was of the plating order, with the same lot of horses going the treadmill round of the fixtures. somehow or other made their living out of so doing. The boxing booths, the gambling tents, the exhibitions of sorts, found no accommodation reserved for them at Sandown Park, or its successors, and the result of this has been that even at Epsom there is very much less "fun of the fair" than there used to be.

Everyone who has paid a single visit to

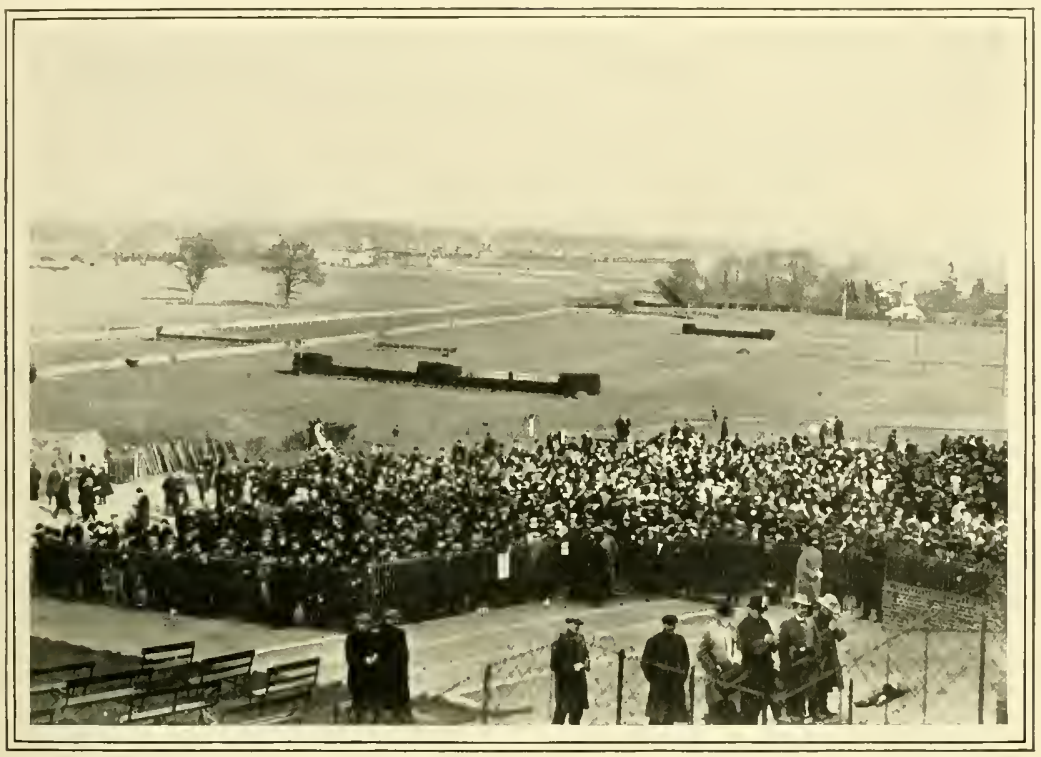

SANDOWN PARK, LOOKING FROM THE STANDS OVER TATTERSALL'S AND THE COURSE.

But the gate-money meeting did more than improve the sport. By having a fixed charge-without the payment of which entry was impossible - the standard of visitor was raised. It is not for a moment suggested that no one who is not honest and respectable ever goes to a place like Sandown or Kempton, but the money to be paid for entrance has undoubtedly been the means of keeping away a whole host of undesirables, and this remark, of course, applies more strongly where the charge for admission to the course is 2s. 6d. than where it is a shilling. Then, again, the old, open courseswere always visited by thousands of loafers, gipsies and vagrants of all sorts, who followed the meetings, and any of the modern race-courses-to Sandown Park or Kempton for example-must be aware that within the course there is absolutely nothing beyond the racing to attract the visitor. The upshot is that an enormous majority of those who attend the meetings must do so because of love of racing. As regards the betting little need be said. English people will bet, and that betting is greatly associated with racing is as true as that it is associated with football, or that people gamble on the Stock Exchange.

But there always has been, and there always will be, a large section of race-goers who are attracted by love of the horse, 
and who, practically, never bet. There always has been, and there always will be, another section who are attracted in the first place by love of the horse, and only in a minor degree by a love of speculation. There is, also, a section of the community which goes racing purely for betting purposes, but eren this section may be divided, and of regular racing men who bet only a small moiety do so recklessly and foolishly. There are white and black sheep in every fold, and when considered in its entirety race-course betters, whether they be backers of horses or layers of the odds, are a singularly honest Iot.

To those who do not go racing it may not be generally known that on the race-course all sorts of sums are wagered between man and man, and as regularly paid by the loser -whether he be backer or layer-without any formal contract, often without any real evidence which could be brought forward in case of a dispute, but merely on a verbal arrangement made in a matter of seconds, and in an ordinary way not even confirmed, as a bet made a week or two in advance may be.

\section{The Betting System}

For the benefit of the uninitiated it may be explained that the numbers go up for a race, and the layers of odds offer certain prices against certain horses. The backer inclines to the chance of one of these, and asks the price, or hears it shouted. He accepts the offer of, let us say, Ioo to Io, the bet is entered, and when the time of settlement arrives it is not Ioo to Io but $I, 000$ to $I$ on the fact that the two parties are agreed, and that the loser discharges his liability.

In such a case as has just been quoted, it is of course supposed that the two parties to the bet know each other, but if the wouldbe backer is a stranger he has merely to be introduced-in some cases to give a reference is sufficient, or to stake his money, and in the latter case he will be paid immediately after the "all right" has been shouted. There is in these days no place in the world except a race-course in which what may be called a "friendly understanding" allows of constant financial exchanges, involving at times thousands of pounds.

There is no contract note. If the bookmaker has no clerk, there is often no witness of a really big bet, and yet repudiation is seldom heard of, and disputes are of infrequent occurrence. Indeed, betting men, whether they be backers or layers, are for the most part exceedingly honest in their transactions, and it is this honesty which allows of turf matters proceeding with such regularity from day to day and week to week. It is not necessary to pursue the subject further, but before leaving it an emphatic statement may be made to the effect that honesty on the turf is extremely pronounced, and that proof of this is always forthcoming in the fact that turf scandals are few and far between, and that racing is always conducted in the strictest business-like fashion.

\section{The Club Enclosures}

To return for a moment to the changes which the modern system brought about, mention may be made of the club enclosures, which gradually induced ladies to go racing in great numbers. In the old days Ascot was the one great ladies' meeting. A good many ladies attended Newmarket-where some of them rode on the course; Goodwood, with its lawn and other attractions, was fairly well attended, but at the mass of meetings which were held all over the country ladies were conspicuous by their absence, though a few were at times to be seen in the stewards' stands, and at the country meetings, or in carriages on the far side of the course. There was an idea once that the Epsom Friday, on which the Oaks is run, was a "Ladies' Day," but there was really little reason for the sobriquet, for there never was a club at Epsom into which ladies had the entrée, and only a limited number of boxes in the grand stand. At the present day a fair number of ladies attend Epsom, but most of them are habituées of the club fixtures also, whereas before enclosed racing came into fashion, there was no regular contingent of racing ladies. 
The club system brought into existence by the modern enclosure, had also the effect of making racing a much simpler affair than it was. The new race-courses were always placed close by a railway line, and where there was none, a special station and platforms were made for them. At Kempton Park, for example, there are three or four corered passages from the railway platforms to the stand, and thus on a wet day not only the club members but the general public can walk under cover from the train to the various enclosures. At Gatwick the station is immediately behind the stands, and the same is the case at Newbury, whilst at Sandown the station adjoins the course, but the stands are on the far side of the park. At Hurst and Lingfield there is rather farther to go, especially at the first-named place, but on a fine day the private walk from the Lingfield station to the stands is enjoy. able enough, and the distance is barely half a mile.

\section{Modern Facilities for Race-Goers}

Club trains - commonly called " members' specials"- -and restaurant luncheons have made the average race-goers' lot an easy one, and to attend any of the various London enclosed meetings it is not necessary to start before twelve o'clock, or even later. In the summer racing at these places rarely commences before two o'clock, and thus Londoners have time for business and so. forth before they start; and as a rule they are in town again by six o'clock. In point of fact the enclosures near London provide an abundance of sport, which only involves half-day journeys. Thus racing is far less expensive than it used to be, and this is all owing to the change from the oldfashioned country meeting to the modern enclosure.

Previous to the present style becoming general, any Londoner who wished to see the best of the sport had to travel great distances, to put up with third-rate accommodation at more than first-rate prices, and had, in addition, to waste a great deal of time, for the mornings hung heavily at the old country fixtures, and there was little to do at night. It may be said that as some of these old country fixtures still exist there must be the same state of affairs in connection with visiting them. But in reality this is not altogether the case, as will be shown.

\section{The Newmarket Meeting}

To begin with, Newmarket is outside the argument, firstly, because except on two or three big days it does not attract many occasional race-goers, but only the regular habitués. These are, for the most part, people who make racing the business of their lives during the summer months. They include owners of horses, a large proportion of whom have their horses trained at Newmarket, professionals of every sort, as trainers, jockeys, bookmakers, backers, and a certain contingent who, without actually owning horses, are the friends of owners, and who follow the meetings. There is, practically, no hotel life at Newmarket, but hundreds of private houses are used during the race weeks, and almost all who attend regularly either own or rent houses, or have rooms taken by the year. Then, again, the early morning on the heath, where more tiran a thousand horses are being trained, entirely militates against any dullness, and in addition the full strength of the regular visitors is broken up into groups of friends. Lastly, there is an admirable train service from London, which allows of people going down for the racing, and returning to town in time for dinner. To be precise on this point, one can leave Liverpool Street at I I a.m., or

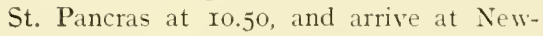
market with an hour in which to have luncheon and drive to the course; and if that is too early one can leave st. Pancras at a few minutes after I 2 o'clock, leave the train at Dullingham, and drive on to the course in time to see the second race.

Newmarket, then, need not be considered in this connection; nor need Goodwood, for it has a special charm of its own, which has for generations been powerful enough to 
counteract the troubles involved by the fact that the place is isolated. And if Newmarket and Goodwood are put out of the question, there are left as really important country racing centres, Chester, Liverpool, Manchester, Gosforth Park (Newcastle-onTyne), York, Derby, and Doncaster. These, it will be noted, are all important towns, where good hotel accommodation may be secured, and it may be added that in these days of very complete railway service-to say nothing of motor-cars-visitors to the races can stay at all sorts of places which are within a short distance from the course. Further mention of this will be made when the various racing centres are described, but here it may be added that the club system prevails at all the meetings which have just been enumerated.

It is the case, in fact, that the crowding and the trouble involved on the part of the race-goer of a full generation ago have given way before the club system and the modern enclosure. Now brief reference may be made to the places at which racing takes place. These may be divided into groups, as Southern, Northern, and Midlands, but it must be understood that to a very great extent the best races decided either in the South, the North, or the Midlands, call upon the same class of horse, and it is only amongst the platers who compete in the less important events that the sport is in any way local.

\section{Southern Racing}

The Southern group may be taken first, and in this are placed-merely in order to explain the position-all the meetings which race-goers may comfortably " do" from London, without staying from home, or for that matter without even being late for dinner. First, there is Epsom, the most important fixture of all, because the Derby is run there, and, curiously enough, a fixture which has more than held its own, in spite of the fact that it has not been in a position to go with the times, and is therefore old-fashioned and out of date.

\section{Popular Epsom}

It is not an easy matter to state why Epsom should be so popular, but the probable reason is that the course is an easy one. There are more speedy non-staying horses in training than there are nags possessed of pronounced stamina, and at Epsom speed is unduly served, compared with what it is on most other race-courses. This doubtless helps to swell the fields, but in addition the fact of Epsom being a classic meeting, where the greatest race of the year is run, causes an éclat to hang round it. Thus nearly every owner likes to run at Epsom, and the upshot is that all through the programmes of the two meetings a very high standard of class amongst the horses is reached.

The place is inconvenient, as compared with the enclosures, for the Downs station is a mile from the stands, the town station about two miles, and the station at Tattenham Corner has not yet become popular, because of the somewhat roundabout route which the line takes after it leaves the Brighton main line at Coulsdon. There may be a future before this route, for the station is half as near again to the stands as the Downs station, and there is no toilsome climb, the terminus being on a level with the grand stand. The lastnamed structure can certainly accommodate a great number of people, but it is a good deal out of date, and it is placed a considerable distance below the winning post, so that even from the Jockey Club portion of it it is at times very difficult to be able to know which horse has won in a close finish. But the greatest trouble in connection with Epsom is the situation of the paddock-quite a quarter of a mile from the stands - which can only be reached by a dusty walk through the crowd, either along the course, or at the back of the stands.

There is a club at Epsom, but it is confined to men, and is by no means large. The average race-goer has to mix with the betting crowd in the public enclosures, and thus it results that a huge number of the visitors still see the racing from vehicles drawn up immediately opposite the stands, 
between them and Tattenham Corner, or on the hill, which is opposite the stands a quarter of a mile away. Year after year thousands of race-goers of both sexes see the Derby from "outside." Many of these visit no other race meeting, and are in no sense of the word regular racing folk, but make a point of seeing the Derby, and perhaps Ascot as well. that in five years out of six the weather is fine throughout the Derby week, and that there is very seldom more than one day of bad or even doubtful weather during the Summer Meeting.

A great charm of Epsom is provided by the situation of the course. From the level of the stands, the ground slopes downwards to the south, and thus the course

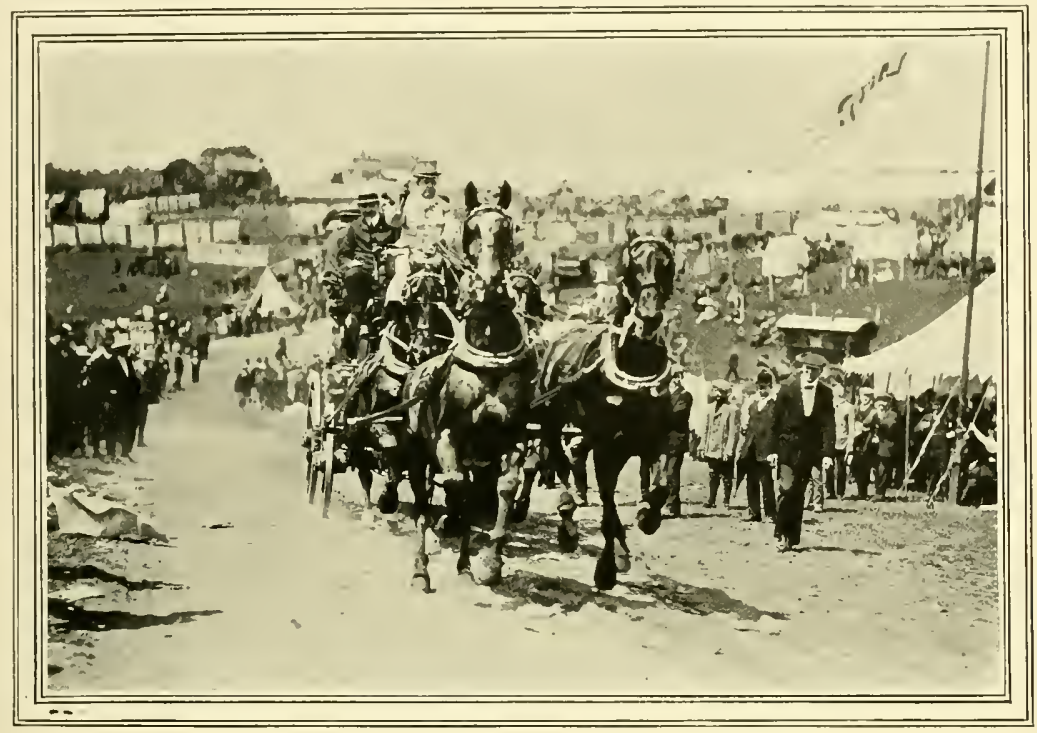

EPSOM SUMMER MEETING. COACHING UP THE HILL.

Epsom on a wet day is a most uncomfortable place, for there is not sufficient shelter to accommodate a twentieth of the visitors, and at such times the passages of the stands become congested, and it is no easy matter to go from one part of the course to another. But not one of the drawbacks which have been mentioned is powerful enough to counteract the popularity of the place, and thus year after year the attendances seem to be on the Derby day each larger than the last, unless the weather is really bad. As a rule, however, it is fine in the early days of June, and though St. Amant and Common each won on a day of terrible storm-to say nothing of Hermit more than forty years ago-it may safely be said itself is below the enclosures, and a much better view of the racing is possible than when the course is on a plain, as at Doncaster, Kempton Park, Lincoln, and a host of other places. Sandown is probably the best course in the kingdom from this point of view, but Epsom runs it close, and at both places it is possible to find coigns of vantage where the ground slopes sufficiently for spectators to see over each others' heads.

There are in these days two meetings at Epsom every year-the Spring lleeting, which takes place in April, and the Derby meeting, which is held at the extreme end of May or the very beginning of June. At the Spring Meeting the City and Suburban 


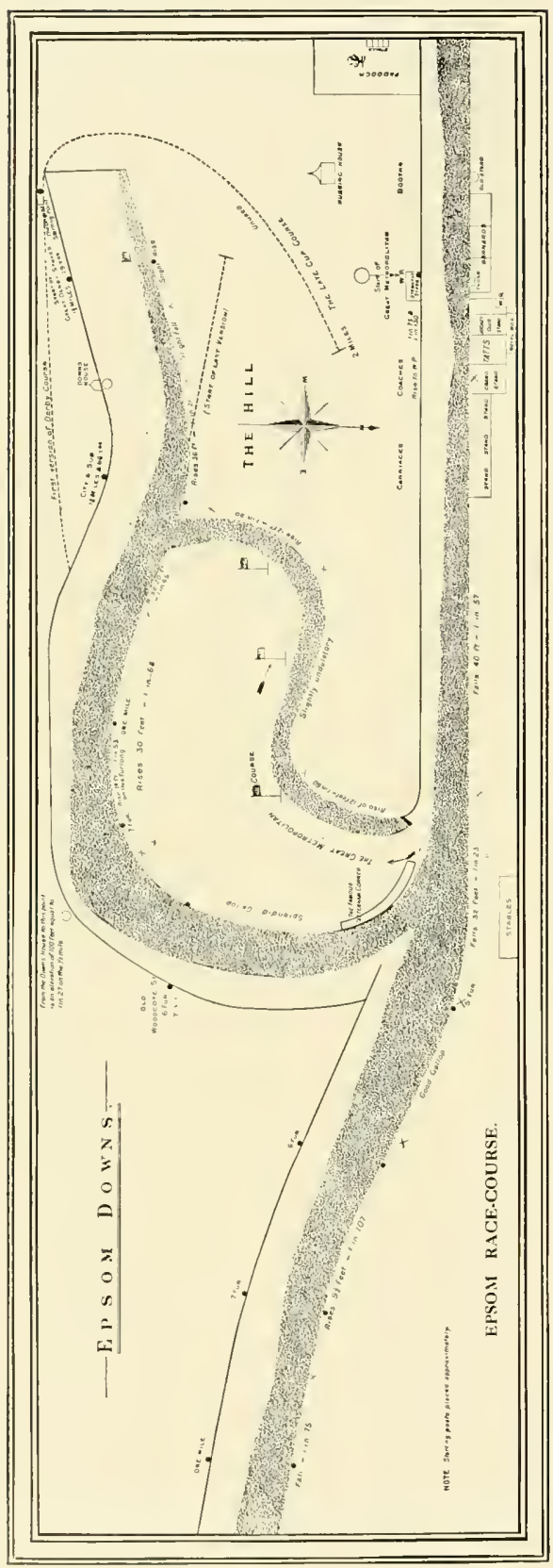

and the Great Metropolitan are the chief events, both of these being handicaps, one of a mile and a quarter, and the other of two miles and a quarter. The City and Suburban is one of some eight or ten handicaps which attract the very best class of handicap horses, and not infrequently some of the classic horses of the last year or two, and if the Metropolitan is not quite so prolific of class it is one of the prettiest races of the year to watch, as the horses are started opposite the stands, and go down the reverse way of the course to Tattenham Corner. They then turn and wind up the hill to the Derby course, which they reach near the mile post, afterwards going through the Furzes, and down the hill as in the Derby. The City and Suburban is run on the last mile and a quarter of the Derby course; there is also what is called a straight course of nearly a mile, on which five, six, and seven furlongs are also run, which begins near the new South Eastern Railway station, and joins the old, or round course at Tattenham Corner.

Popular as the Epsom Spring Meeting is, it is altogether eclipsed by the fixture which follows it six weeks later. This Epsom Summer Meeting is one of the greatest meetings of the year. One cannot call it the greatest, because the Ascot programme is from an all-round point of view a more powerful one; but even the Gold Cup at Ascot is not so important a race as the Derby; and the Derby is not the only classic event which is decided at Epsom, for the Oaks is also an item of the Epsom Summer Neeting.

Here it may be mentioned that there are five classic races, all of which are contested by three-year-olds. These are the Two Thousand and the One Thousand Guineas run for at the Newmarket First Spring Meeting, the Derby and Oaks, decided at the Epsom Summer Neeting, and the St. 
Leger, which is included in the programme of the Doncaster September Meeting.

\section{Epsom Summer Meeting}

The Epsom Summer Meeting begins on a Tuesday, and on that day the Woodcote stakes for two-year-olds is the most important race. The Woodcote is the first race of the season in which two-year-olds run a six-furlong course, and it is worthy of note that this particular race is decided on the last six furlongs of the Derby course and not on part of the straighter new mile. This involves the start taking place on a descent, but as a rule the best horse wins, and the Woodcote is, as a matter of fact, about the earliest two-year-old race to attract the class of horse that may play a prominent part in the classics of the following season. It has in very recent years been won by such celebrities as Cicero, Rock Sand, and Sceptre.

\section{The Derby}

On the Wednesday the Derby is the great attraction, and the crowd on the outside portions of the course is probably ten times as large as it is on any other day of the meeting. In the enclosures, too, there is a vast accession of strength, and it has often been roughly estimated that the number of those present on the Downs very nearly, if not quite, reaches a million. It need hardly be said that the figure must be guess-work, but it is the guess-work of those who may be considered experts in the matter of estimating crowds, and certain figures are available, as for example the numbers of those who travel by the three lines of railway in hundreds of special trains. Then, too, the road traffic has been counted at certain spots, as so many cars, so many omnibuses, coaches, cabs, carriages, motors, and so forth. Giving an average of a certain number of passengers to each vehicle which travels by any of the most popular roads out of London, a fair estimate has been arrived at, and to this London traffic and the railway passengers must be added the traffic that does not arrive by the main roads, and the thousands and thousands who have reached the Downs by walking.

The Derby course at present in vogue has only been used since 1872 , when the High Level Starting Post was made. In former times the start took place in what is known locally as Langley Bottom, and the first half-mile was on a much steeper ascent than it now is. The new or present course joins the old one at the mile post, and a very full view of all the race is obtainable from the stands, though just between the mile post and the top of the hill-which descends to Tattenham Corner-the jackets are better seen than the horses, the latter being rather hidden by the furze. Tattenham Corner is rather abrupt, and at times horses run very wide, but long experience of Epson has amply confirmed one's opinion to the effect that the Derby course is a true test of merit, and that in nine years out of ten the running comes out correctly afterwards. There are, at times, unlooked for results, and the race of I908, when Signorinetta so unexpectedly won, will probably always remain something of a mystery, but on the other hand the average Derby winner almost invariably distinguishes himself in the future-as the pages of the "Racing Calendar" amply proves.

\section{The Coronation Cup}

On the Epsom Thursday the Cupformerly called the Gold Cup, more recently the Coronation Cup-is the greatest attraction, though there are also two handicaps of $f \mathrm{I}, 000$ each on the card. The Coronation Cup, as a rule, draws the best four- and fiveyear-olds in training, but it is run on the Derby course, and is therefore not so great a test of stamina as is the race for the Ascot Cup, a fortnight later. The event in consequence hardly takes such high rank as it should do, and there are those who think that it would gain in prestige if the Metropolitan course of two miles and a quarter was used instead of the Derby course of a mile and a half. On the other hand, it is the case that there are many horses which can slow great form up to a mile and a half, and yet are not genuine stayers, and this 
class of horse has in many years a fair chance of winning the Cup at Epsom, but would be hopelessly out-stayed at Ascot. On the last day of the Epsom Meeting the principal events are for fillies, these being the Oaks for three-year-olds, and the Acorn Stakes for two-year-olds. The Oaks is just a fair draw, but does not attract anything like the crowd which goes to see the Derby.

It has been implied that Ascot is the greatest meeting of the year, and though no classic race is decided there, few will dispute the implication. To begin with, the celebrity, has no Ascot engagement, and it may also be the case that one or two of the best Epsom performers have been stumped up by hard ground, but in an average year nine-tenths of the best horses of every age are to be seen during the four days. Highly tried, well-bred two-year-olds are, as a matter of course, kept for Ascot; even youngsters which are only well thought of, and have not been actually tried, make their début on the famous Berkshire heath, and there is comparatively no rank and file of mediocre quality, though, as is only

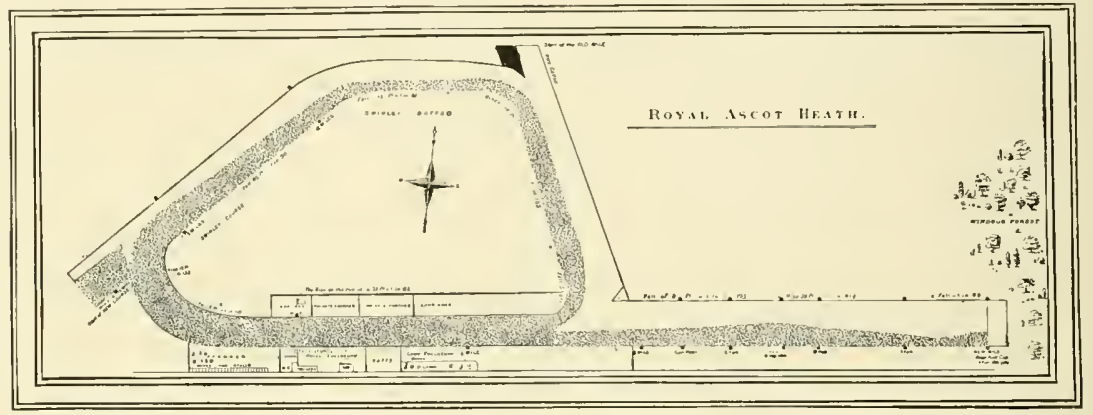

ROYAL ASCOT RACE-COURSE.

programmes for the four days are for the most valuable races of the year, about $f, 0,000$ being run for during the meeting, which gives an average of $£_{10,000}$ a day, or, as there are seven races a day, an average of over $£ I, 400$ as the value of each race. Moreover, the added money at Ascot is far beyond what is given elsewhere, amounting to well over $£ 20,000$. There are many valuable prizes for second and third horses also, and, to take 1909 as an example, one finds that on the Tuesday the seven winners took $£ 9,680$ Ios. ; on the Wednesday, $£ 9,793$ Ios. ; on the Thursday, $£$ II,I68 Ios. ; and on the

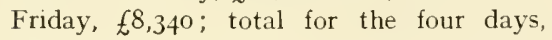
$£ 38,997$ Ios. This amount is exclusive of second and third prizes, which make the full total well over $£ 40,000$.

No other race-course in the kingdom offers such prizes as Ascot, and the result is that all the best horses in training are kept for the meeting. It may happen, of course, that the Derby winner, or sume other classic natural, some of the youngsters of which a great deal is expected do not always fulfil expectations.

There are prizes enough to tempt all the best three-year-olds in training, but whereas the Coronation Stakes for fillies more often than not brings out the Oaks and One Thousand winners, and most of the best filly form of the year, there are so many races for three-year-olds of either sex that it is often uncertain which of four or five events may produce the most important race. In 1909, for example, the Prince of Wales Stakes, won by Bayardo, was worth $£^{2}$, I 50 ; the Biennial, won by Telbedde, was worth $£ \mathbf{I}, 095$; the Ascot Derby, won by William the Fourth, was worth $£$ I, 475 ; the St. James's Palace Stakes, won by Minoru, was worth $£ I, 95^{\circ}$; and the Triennial, won by Louviers, was worth $£ 79 \mathrm{r}$. It is worthy of note that the first and second in the Derby were among the Ascot winners, but the Oaks winner had no engagement, and in the 


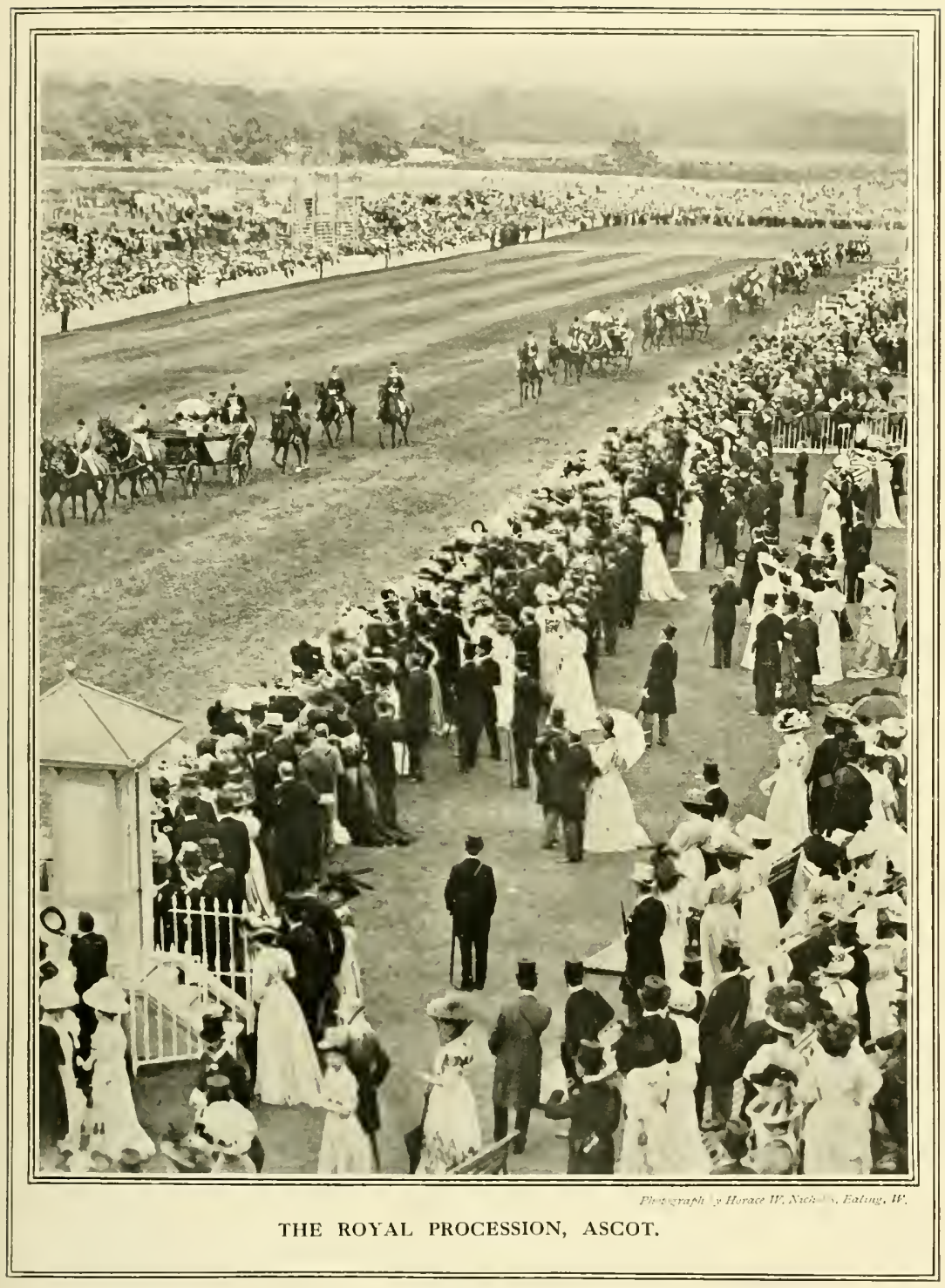


valuable prize for three-year-old fillies the second in the One Thousand, with a pull in the weights of 7 lbs., turned the tables on her Newmarket conqueror.

\section{Other Ascot Races}

For the older horses (and for threeyear-olds also) there are the Trial Stakes and the Rous Memorial Stakes, each of a mile, the Hardwicke Stakes of a mile and a half, the Gold Vase of two miles, the Gold Cup of two miles and a half, and the Alexandra Plate of a little over two miles and three-quarters. Three-year-olds frequently run for the Vase, the Hardwicke Stakes, and the Rous Memorial, but in these days they seldom contest the Gold Cup or Alexandra Plate, and this is not to be wondered at seeing that the programme gives then so many chances of distinguishing themselves in easier races, or in events which are confined to three-year-olds. The winner of the Gold Cup for Igog, Mr. James de Rothschild's Bomba, was, by the way, a three-year-old.

Of selling races the Ascot programmes are innocent, and only five handicaps are decided on the four days, these being the Ascot Stakes, the Hunt Cup, the Visitors' Handicap, the High Weight Stakes, and the Wokingham Stakes. The Ascot Stakes is, like the Vase, decided on a two-mile course, and in this connection it may be mentioned that the Ascot executive do a great deal toward encouraging long-distance racing. They have the only flat race of the year (the Alexandra Plate) which is over two miles and a half, and there are also during the four days one race of two and a half miles, three of two miles, one of a mile and five furlongs, four of a mile and a half, eight of a mile, one of six furlongs, and nine of five furlongs, five of which are for two-year-olds.

At Epsom, on the other hand, not a single race decided at the summer meeting is of greater length than a mile and a half. There are four races of that length during the week, one of a mile and a quarter, three of a mile, two of seven furlongs, five of six furlongs, and no fewer than ten of five furlongs. At a glance then it can be seen that the Epsom programme is likely to attract all the speedy non-stayers of fair class, and that the Ascot programme appeals to the most stout-hearted horses in training.

\section{Social Ascot}

There is no need to go into the social side of Ascot, for it may at once be said that in this particular respect no other meeting can in any way compare with it. Sandown and Kempton draw most of the aristocratic racing people who may happen to be in town when there is racing at either of those places. The Eclipse Stakes, at Sandown, the Grand Military Gold Cup (generally run at the same place), and the Jubilee Stakes, at Kempton, are individual draws of great magnitude, but no whole four-day meeting attracts to the same degree as Ascot, and causes hundreds of parties to be made up, and hundreds of houses to be rented for the week. The meeting is under Royal patronage, and as a rule there are state processions on the Tuesday and Thursday; there is also the Royal Enclosure, accommodating some 3,000 people, but as a matter of fact hundreds who have the entréc into this coveted place are not racing people, except for Ascot week. The regular turfites of either sex, whether they be of the aristocracy or of some lower rank in the racing world, are present as a matter of course, but so, too, is the occasional race-goer, and just as the Royal Enclosure contains numbers of people who are unknown in the racing world, so do the Grand Stand and the lawn. Ascot is in point of fact a holiday gathering, visited every year by thousands of people who are not in the habit of following the meetings.

\section{Goodwood}

After Epsom and Ascot the greatest of the Sonthern meetings is Goodwood, which possesses what is in the opinion of many race-goers the best course in the world. It need hardly be said, however, that in this connection Goodwood has a great rival in Newmarket; there is no need to compare the two courses at the moment, but it may be pointed out that Goodwood as a race meeting is unique in more ways than one. 
Goodwood is in a degree a survivalalmost the only survival of the old-fashioned, remote country meeting. It came into existence before the railway era, and, after racing was no longer held on the Danebury course near Stockbridge, it was practically the only meeting situated at a long distance from a railway which did not go to the introduced, the journey from Drayton or Chichester stations occupied at least an hour. Even now the bulk of the traffic is horse-drawn, but doubtless the motors will gradually increase.

Once the top of the hill at Goodwood is reached the marvellous beauty of the place is discovered at a glance, for the race-course

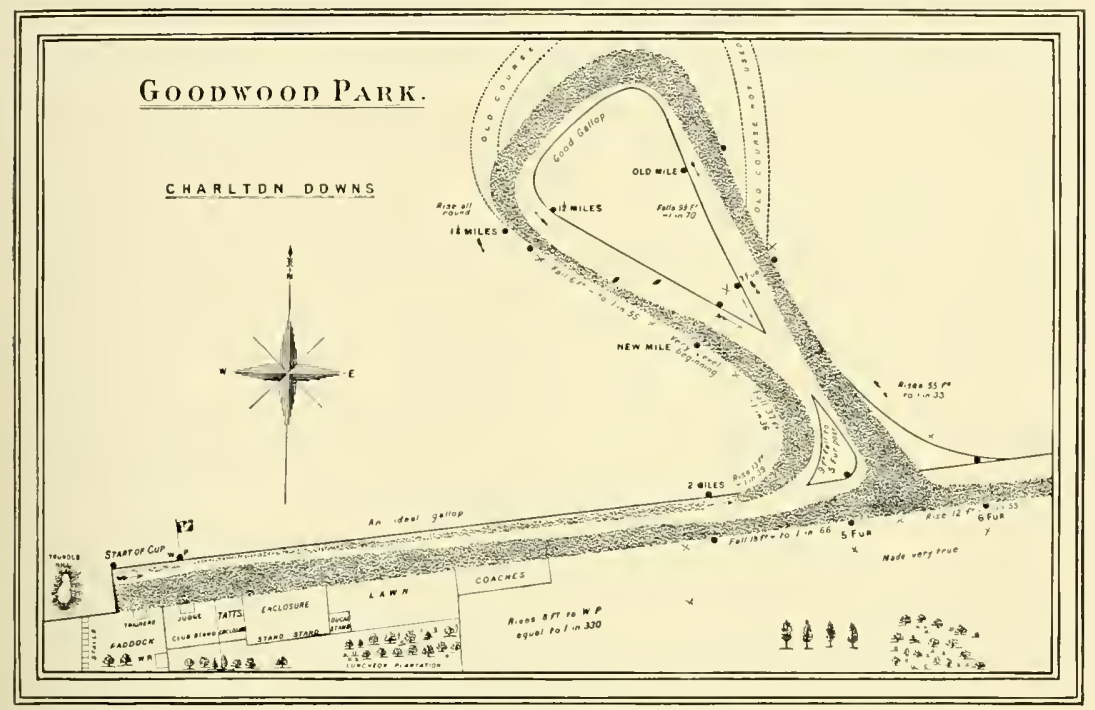

GOODWOOD RACE-COURSE.

wall. There is one other similar fixture, by the way, viz. Croxton Park, in Leicestershire, but Croxton Park is only a one-day affair with a mixed programme, under both sets of rules, and of purely local interest. There had been horse-racing at Up Park in Sussex (not many miles from Goodwood), long before Goodwood was heard of, and that place is about the same distance from the main Portsmouth and London road as Goodwood is from the town of Chichester. The actual distance between Chichester and the Goodwood race-course is just about five miles, but Chichester is placed at sea level, and the Goodwood course stands some 700 feet higher. The result is that there are a couple of miles of very steep ascent to be surmounted before the course is reached, and before motor-cars were is situated on the backbone or ridge of a range of hills, and the eye can travel to the sea on one side, and over range upon range of wooded hills to the north. New stands have lately been built, but it is the lawn and the grove behind it, where the tents and luncheon tables are placed, that give so much charm to the place, for the meeting is really a monster picnic with much firstrate racing thrown in.

But whereas at Ascot three-year-old racing plays such an important part, horses of that age are not so much in evidence at Goodwood. The best are often being kept for the St. Leger, and the prizes for threeyear-olds are not so valuable as those divided amongst the two-year-olds. At times, of course, the best three-year-olds are sent to the meeting, and one has lively recollections of 


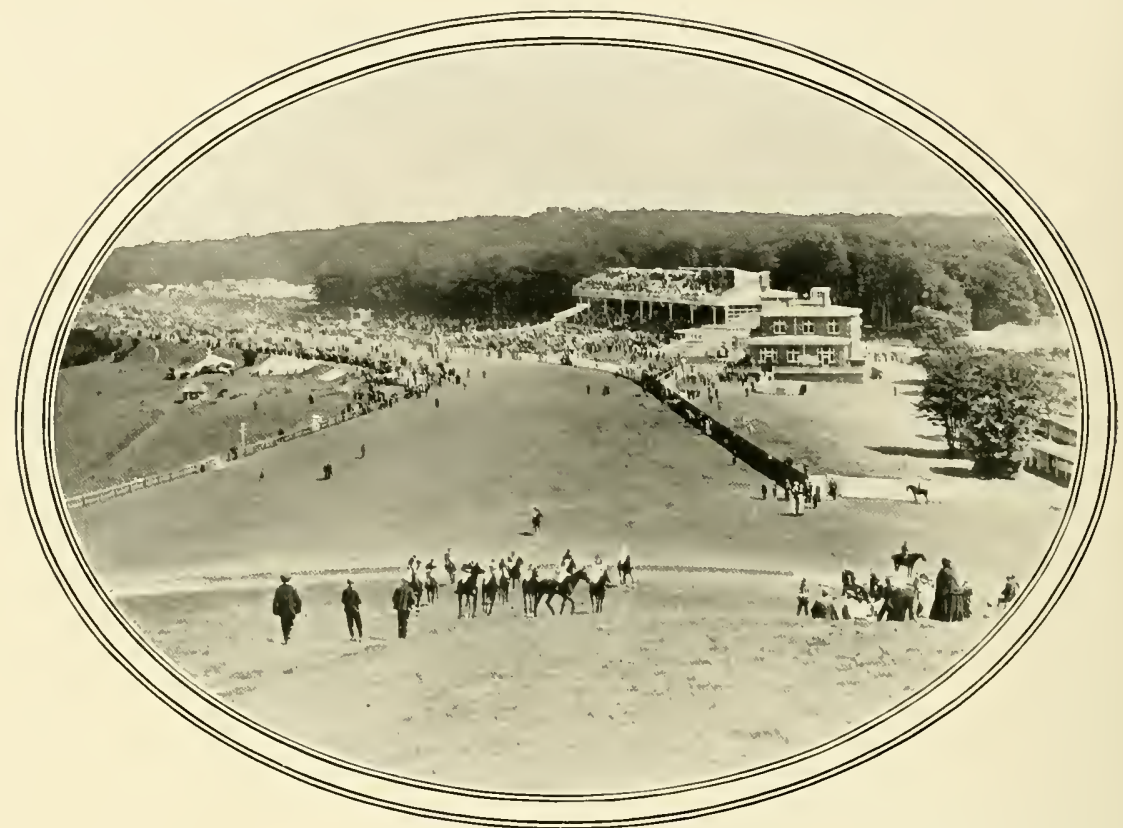

GOODWOOD: FROM TRUNDLE HILL.

a stirring duel between Orme and La Flèche for the Sussex Stakes, but race-goers hardly look for much three-year-old racing at Goodwood. There are on the other hand many important two-year-old prizes, and as a rule one sees a fair number of the very best youngsters of the season at the ducal meeting. The Cup, too, stands as the second most important long-distance, weightfor-age race of the year, but long-distance running is not a great feature of Goodwood, there being only the Cup of two and a half miles and the Plate (a handicap) of two miles which are longer than one mile and a half.

There are, moreover, an immense number of five and six furlong races on the four days of the meeting, of which the Stewards' Cup (six furlongs) is about the most important sprint handicap of the year. Unfortunately, horses which are drawn on the stand side in this race are at a disadvantage, and therefore a good deal depends upon the position which each horse draws, but in spite of this the race is exceedingly popular. Another important handicap decided at Goodwood is the Chesterfield Cup, run on the Craven course of a mile and a quarter, and though this race is of no great monetary value, it invariably attracts horses of high class, and in it was achieved one of the greatest handicap performances of all time, viz., when Vespasian won in 1869 , with no less than ro stone $4 \mathrm{lb}$. in the saddle.

Much of the success of Goodwood is due to the fact that owners whose racing is conducted on the highest lines, and who are not always scheming how to win a good stake with a leniently handicapped horse, like to win at Goodwood. In this respect Goodwood stands out, with Epsom and Ascot, and the upshot is that good class horses are put on one side and specially prepared for the meeting, whereas they might, in many cases, compete for more valuable stakes elsewhere.

The Goodwood course has been mentioned, and now it may be explained that the going 


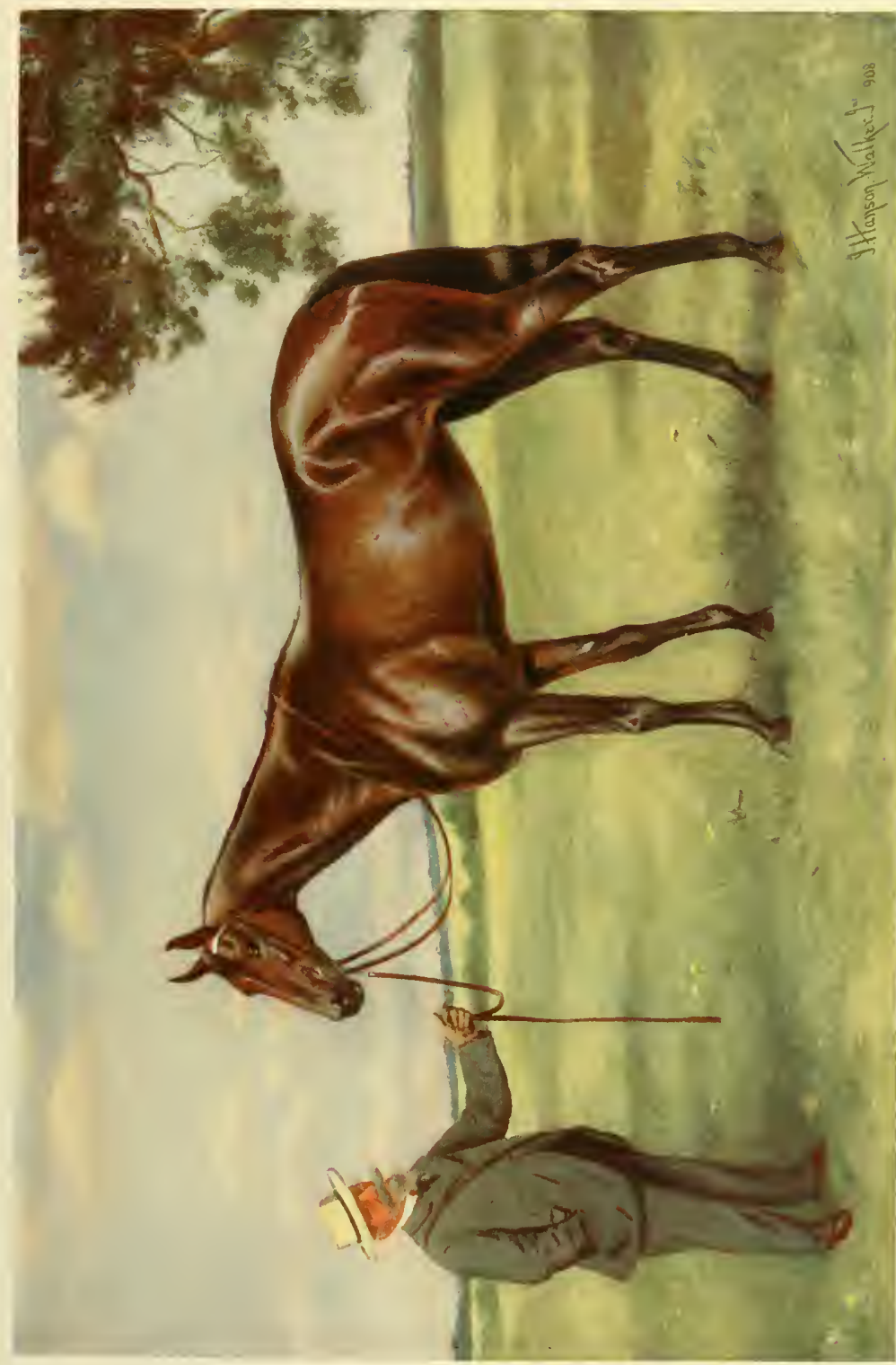

1
0 

is always exceptionally good. The course was made by the famous Lord George Bentinck in the early part of the nineteenth century, but there was never any question of new ground which had to be sown, for old turf of the very best sort was there in abundance, and the making consisted of levelling and so forth, and in no way concerned the top of the ground-which was replaced, and quickly settled under a course of rolling. The meeting is held at the very end of July, at a period when many horses have in a dry season become rather stumped up. But even in times of the greatest drought the Goodwood track is springy and resilient, so that horses can stride out freely, with little fear of breaking down.

Pages could be written about Goodwood, but lack of space forbids any further description, and, to go on with the southern meetings, Brighton and Lewes are also survivors of the old order of things, and both are popular racing places, though the sport is of the medium kind, attracting a fair number of good second-rate horses, but not the cracks of the year. Both courses are, like Goodwood, on down-land, but both are in exposed positions, and though fairly good going is generally to be found neither course can compare with Goodwood-which, by the way, is a good deal sheltered. Indeed the Stewards' Cup track is alongside a plantation, and nearly all the course can boast of a certain amount of protection.

The Brighton course has a steep descent, not far from home, which comes into every race, and Lewes has a certain amount of switchback. Both courses are, in fact, of the give and take order, and at Lewes a good number of races for gentlemen riders-under the auspices of the Southdown Club-are included in the programmes. Another south country meeting which still holds its own is Salisbury, now the headquarters of the Bibury Club. Two meetings are held every year, and, as at Lewes, races for gentlemen riders are strongly encouraged. The Bibury Club is, indeed, the chief institution of its

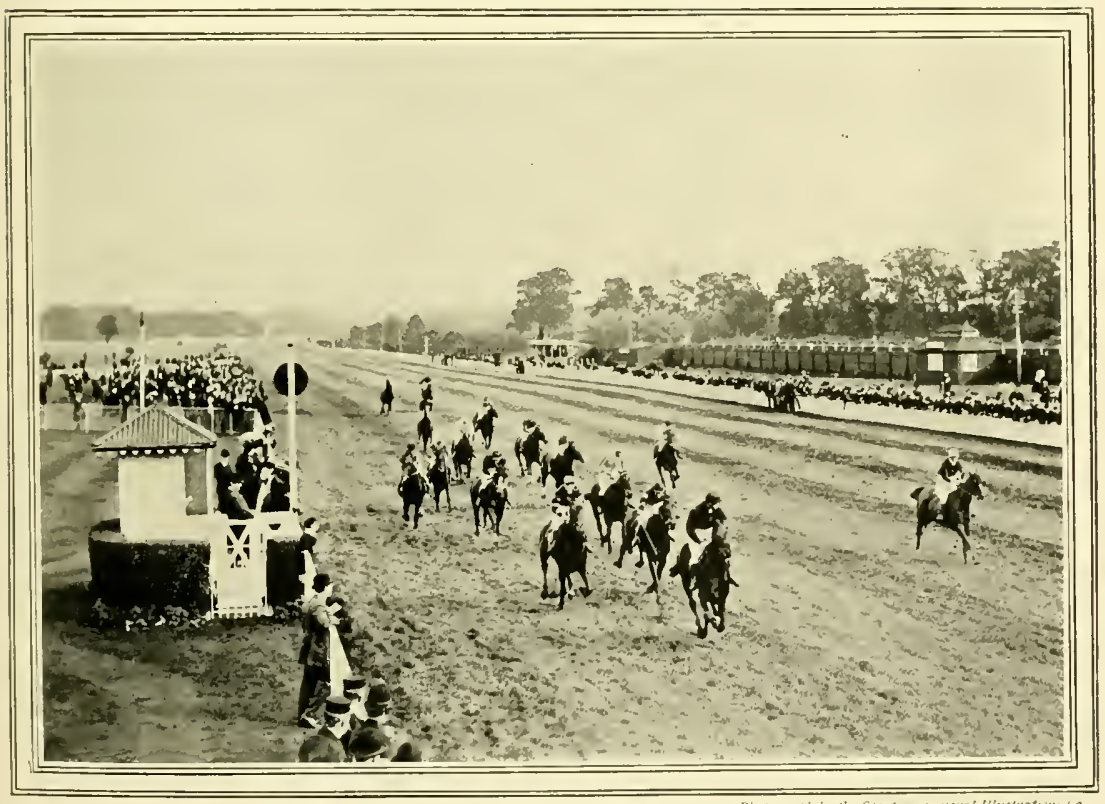

HURST PARK MEETING: A FINISH. 
kind in the kingdom, and membership is only granted to those of a good social position. The meetings are very enjoyable, but they do not attract very great numbers.

\section{Other Southern Meetings}

The only remaining south country fixture, run on the old lines, is Bath, where there is a capital down-land course, high above the town on what is called the Lansdown. Certain vested interests, and a great deal of local popularity, keep the Bath meetings going, but they are nothing like so important as they were in the pre-enclosure period, and probably such a sight as the Derby favourite beating the subsequent Oaks winner by a hundred yards (as occurred in IS70 when Macgregor who had won the Two Thousand ran right away from Gamos) will never be seen on the Lansdown again.

It is, by the way, very satisfactory that such meetings as Goodwood, Brighton, Bath and Salisbury have been able to hold their own, for it cannot be doubted that too much centralisation in racing is not good for the sport. Even now there is actually no flat racing further west than Bath and Salisbury. Dorset, Devon, and Cornwall have no meetings at all, Wilts has only Salisbury, and Somerset only Bath, while in the western midlands Gloucestershire, Herefordshire, Monmouthshire, and Shropshire are all without a meeting. Worcestershire has two neetings, at Worcester itself, and there are meetings at Birmingham and Warwick, but the West and South-West of the kingdom, including the whole of Wales, have to depend for their racing on cross country sport.

In the interests of horse-breeding racing is desirable in every corner of the kingdom, for from the point of view of blood there is no horse like the race-horse, and where there is no flat racing the small breeder has no chance of seeing the great performers, or even of studying the type in its running days and this is matter for extreme regret.

\section{Gate-money Enclosures}

The balance of south country racingand in this case the balance means far the greater part-takes place at the gatemoney enclosures, of which there are nine in the southern group. These are Alexandra Park, Folkestone, Gatwick, Hurst Park, Kempton Park, Lingfield, Newbury, Sandown Park, and Windsor, and as Sandown Park is the oldest it claims first attention.

\section{Sandown Park}

At once it may be said that Sandown yields in popularity to no other enclosed course in the kingdom, and that its meetings are excellently managed. Its course, however, is not an ideal one, for there is a long bend or elbow round the bottom of the course on which all races beyond five furlongs in distance are run, and this in some degree favours the speedy non-stayer, because there must be a slight easing up while the curve is being negotiated. It should be explained that the run in, when horses are fairly in the straight, is of a full half-mile in length, and up hill all the way. This to some extent equalises matters, but on the other hand one has seen results at Sandown which probably would not have been confirmed elsewhere, and the mind reverts to the victory of the speedy, nonstaying Surefoot in the Eclipse Stakes of I89I. The horse in question came with a tremendous burst of speed from the botton of the hill, and though he was tiring to nothing as the post was reached he just managed to hold his own.

The Sandown five-furlong course is right across the centre of the park, and though on the rise is nothing like so steep as the finish of the oval course. The winning post for this course is a quarter of a mile from the stands, but so well placed are the stands -on sloping ground above the coursesthat it is quite possible to see the five-furlong races without crossing the park-but not an easy matter to judge a close finish between two or three horses which are running wide of each other.

There is no need to go into the Sandown programmes at any length, but it may be mentioned that the mammoth stake, often spoken of as a ten thousand pounder, was 
inaugurated there, and that the Eclipse Stakes, established as long ago as 1886 , is still one of the greatest events of the year, which is hardly ever won by a bad horse. On the day following (the meeting is held in the third week of July) the National Breeders' like those of Sandown Park, draw upon the best class of horses-though as a matter of fact handicaps are the most important races on the Kempton programme. The two principal meetings are held in Mlay and October, and at the May meeting the Jubilee

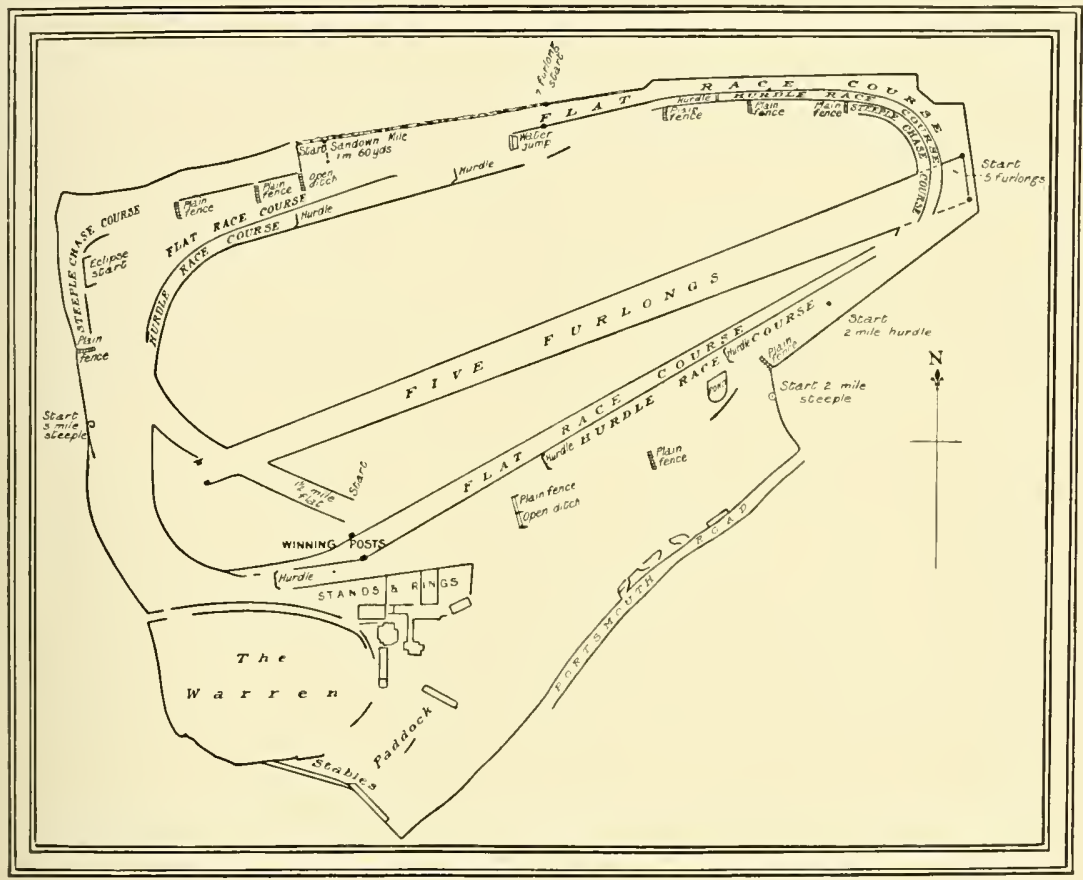

SANDOWN PARK RACE.COURSE.

Produce Stakes is the most valuable twoyear-old race of the year, and these are not the only important races decided at the Esher enclosure, for every programme of every meeting provides high-class sport, the ranks of the very best horses in training being drawn upon to provide the runners for all the more important events.

Kempton Park is on a dead flat, and has a round course, a straight six furlongs, and a course of a mile and a quarter, with a considerable bend or elbow, rather more than a quarter of a mile from home. The stands can be reached from the railway by a series of roofed passages, and the meetings,
Handicap is, as far as class is concerned, the most important "spring" handicap of the season, while at the October meeting the Duke of York Stakes ranks as inferior to the Cesarewitch and Cambridgeshire only, when autumn handicaps are considered.

Gatwick, midway between London and Brighton, is also very flat, though as a matter of fact the ground is rather deceptive, and there is more give and take up the straight mile than is apparent to the casual observer. The round course is only one furlong short of two miles, and is eminently adapted for long-distance racing. The stands and enclosures are spacious, 
and well laid out, and the programmes are attractive enough, but the meetings are not quite so well supported from the class point of view as are those of Sandown and Kempton Parks. Lingfield, a few miles east of Gatwick, has a straight mile which is slightly downhill, and a round course, and the place attracts enormous fields of platers of every sort. The course is the prettiest of all the enclosures, and the gardens in summer time a dream of loveliness, and at times there are valuable races which bring the better sort of nags.

Hurst Park always goes with the times, and is full of enterprise. It has a straight seven furlongs, and a round or oval course of a mile and three furlongs, so that races of any distance can be run. All sorts of stakes are decided during the year, and all sorts of horses, from Derby nags to selling platers, take part in them. Windsor, Folkestone, and Alexandra Park are all popular, and all provide interesting racing, but do not attempt big stakes, and therefore do not draw upon the best class of horse. Newbury, the latest and most up-to-date of all the meetings, caters, on the other hand, for the best sort of nags, and has good programmes, in which weight-for-age races and handicaps of considerable value are included. The courses are on the flat, with very slight undulations.

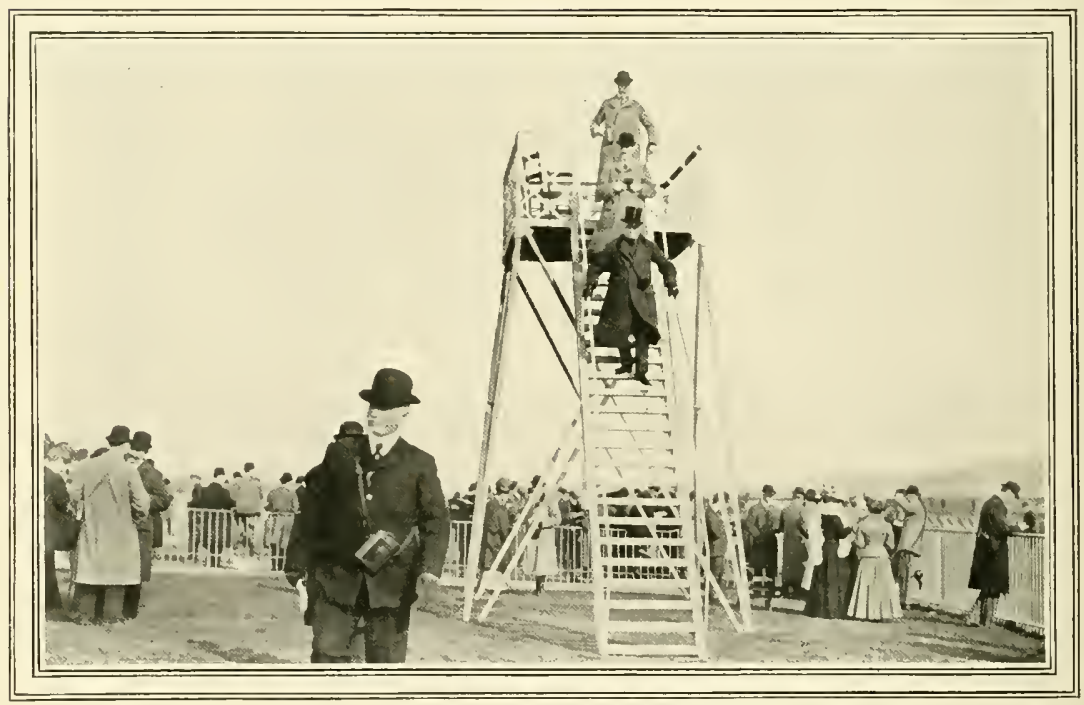

THE STEWARDS STAND, NEWBURY. 


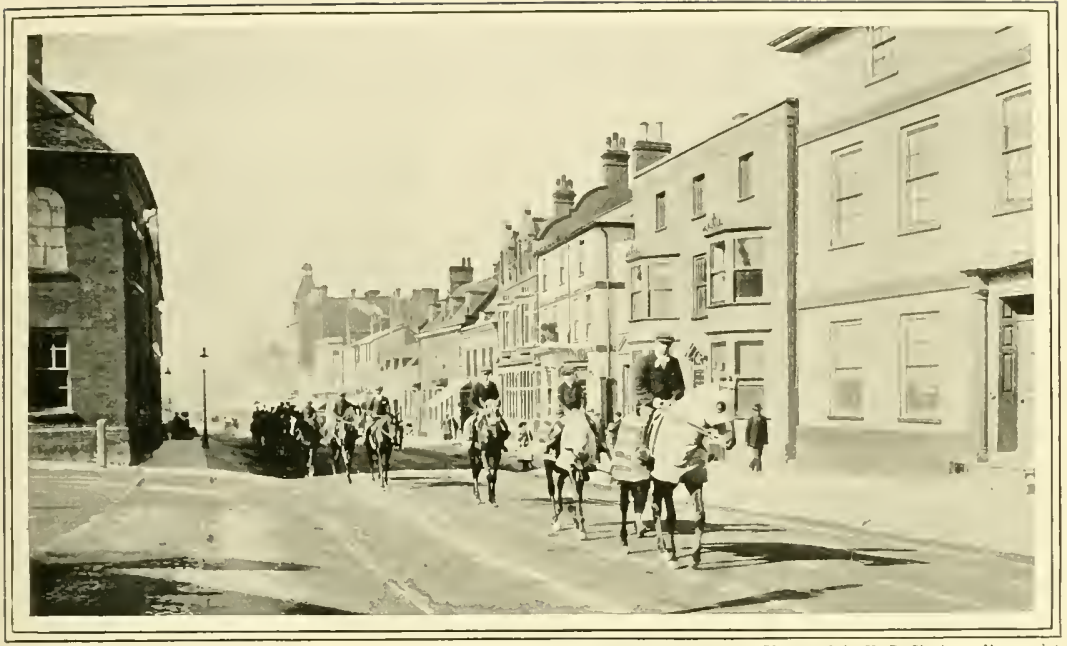

HIGH STREET, NEWMARKET.

\section{CHAPTER XI \\ NEWMARKET AND THE COUNTRY MEETINGS}

$I^{1}$ has been mentioned that the centralisation of racing has in a great measure brought the sport into a narrow compass, because it is grouped in certain dis. tricts, while many other districts are entirely neglected. The southern group is doubtless the most important, and the midland group the least important of the three, but outside each of these groups there is Newmarket, which, as a racing centre, stands alone, and which some description must now be given.

Newmarket is emphatically the headquarters of the turf, and practically it exists for no other purpose than to provide every variety of race-course, and to allow of an enormous number of horses being trained on the heath. It is true that the place lies in the midst of a great agricultural district, but even its advantages in this respect would avail it little, if there were no racing, for it is situated almost midway between Cambridge and Bury St. Edmund's, and therefore its market is really unimportant.

Racing is in stern reality the be-all and end-all of Newmarket. How many horses in training are kept there, how many training establishments there are, and how many jockeys reside there are questions not easily answered, because the numbers are always changing. But when the last edition of Ruff's "Guide" was published, the names and addresses of forty-six Newmarket trainers were given, and it is practically certain that the number was a fair average one. It may also be taken for granted that there are never less than a thousand racehorses being trained in and about the town, but here again there are constant fluctuations of the numbers, and doubtless the stables are fullest in October and November, when long strings of vearlings have just arrived, and the December sales have not yet been held. As regards the jockeys it may at once be said that about four-fifths 
of those who are in regular work live there, during the racing season at all events, while, as a matter of course, many of the apprentices are also located in the place.

\section{The Jockey Club}

Newmarket is the headquarters of the Jockey Club, who have an official residence, known as "The Rooms" in the High Street, and where by far the larger portion of their business is transacted, though the annual meeting of the club is generally held in London. The eight race meetings-comprising in recent years twenty-nine days of running - are entirely managed by the Jockey Club, and so too are the various race-courses and the huge tract of ground available for training. As the meetings are of such frequent occurrence, and so many horses are trained on the heath it has long been the custom for members of the Jockey Club and other prominent owners of race-horses to maintain an establishment at Newmarket, and thus not only in the town itself, but amidst its environs on every side are private houses owned or rented by racing people. These are primarily used for the meetings, but are frequently visited at other times, in order that owners of horses may be present at private trials, or be able to witness the gallops of particular horses.

Then, again, the air at Newmarket is so invigorating that the place is resorted to on this account, and thus some of those who own or rent houses will stay out each series of meetings, without rushing back to London by the first special which departs after the conclusion of any individual meeting. The upshot of all this is that though many of the houses are only temporarily occupied, the periods of occupation are in a great number of cases very frequent, and of fairly long duration, and therefore the place flourishes, and ahways has a prosperous appearance.

It is, however, with the horses and the racing which is provided for them at the headquarters of the turf that we are concerned, and we have merely referred to the prosperity of Newmarket in order to show how great a thing racing is, and what huge interests the sport involves.

\section{Newmarket Meetings}

Eight meetings are now held on the heath, viz., the Craven in April, the First and Second Spring meetings in May, the First and Second July meetings in the first and third weeks of the month after which they are named, the First October, which almost invariably begins in September, the Second October and the Houghton. All of these meetings extend over four days, except the Craven, the Second Spring, and the Second July, which are three-day fixtures, and all the spring and autumn meetings are held on parts of the original Beacon Course, the stands at the end of the Rowley Mile being used, while the July celebrations take place behind the Ditch.

\section{Courses at Newmarket}

A great charm of Newmarket is to be found in the fact that the courses vary in no small degree. There are four finishing posts on the Rowley Mile (a part of the Beacon Course) and two on the July course (behind the Ditch), and these afford every variety of finish, so that an owner can enter his horse for that race which finishes on the course likely to suit him best. The Beacon Course is four miles one furlong 177 yards in length, and has its starting post about half a mile east of the NewmarketCambridge road, at a spot which is three miles and a half, in a straight line, from where the Portland stands were, until they were pulled down some five or six years ago.

This allows of the various bends in the Beacon Course making a total of over half a mile, but as a matter of fact the first two miles and a quarter are practically straight -i.e. from the starting point to the Ditch. From the Ditch to the turn of the lands (beyond the Rowley Mile finishing post) the course bends away from the direct line, and at the turn of the lands there is another bend. But it is little use writing of the Beacon Course, for the whole length of it is only used when there is a contest for the Whip, and since they discontinued racing on 
the Ancaster . Vile, and the Old Cambridgeshire Course, all the contests are confined to various parts of the Cesarewitch Course.

The Cesarewitch Course is two miles and a quarter in length, commencing about a mile and a quarter beyond the Ditch. The programmes, and this is matter for regret, because the Cesarewitch Course is, on the whole, superior to any other cup course in the kingdom. To begin with it nearly always affords good going. It is used in April and Ilay, and again in October, so

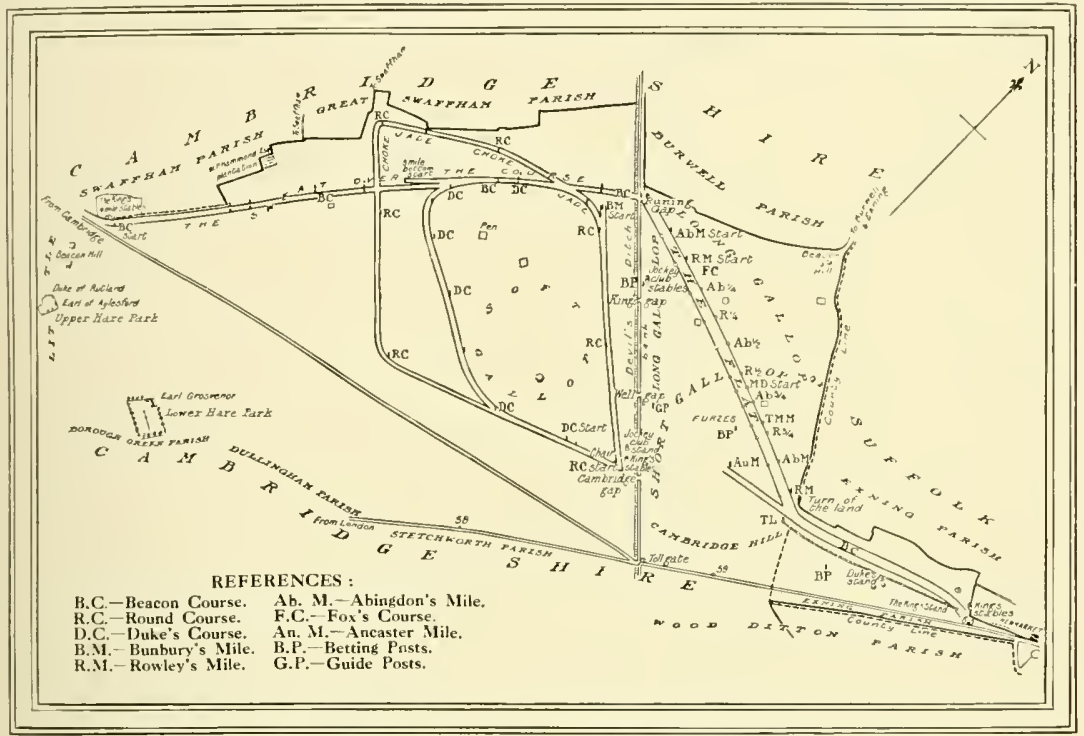

NEWMARKET RACE.COURSE IN ITS EARLY DAYS.

From an old map of "Newmarket Heath" in the possession of the Jockey Clsbb, Newurarket.

Gap through which the horses come is practically just half way between the start and the finish, and about nine-tenths of the racing which takes place at the six meetings held at Newmarket during spring and autumn is decided on this mile and a quarter. There are certain races run on the full length of the Cesarewitch Course, certain others on the "two middle miles," which means the two middle miles of the Beacon Course, and which begins at the Cesarewitch starting post, and ends at the Ditch Mile winning post-and a fair number over the last mile and a half of the Cesarewitch Course, the start for which takes place about a quarter of a mile behind the Ditch.

But, as a matter of fact, there are not a great number of long races on the Newmarket that it lies idle during all the summer months, and therefore the chances of having to race on it when it is very hard are somewhat remote. Moreover the land on Newmarket Heath is light and friable, and apparently free from stony clay. This means that when there is a long period of droughty weather the top becomes to some extent pulverised instead of caking as a clay soil will do. It may be added that the courses are all kept in the best possible order. They are manured, mown, when it is necessary, and constantly rolled, and bush harrowed. Indeed, it is almost impossible to visit the race-course on non-racing days without noticing that some work is being done on the running track. Lastly the turf, though not quite like down-land, is very similar in character, and as unlike an ordinary pasture 
or meadow field as it well can be. Close, short herbage with a thick bottom is to be found everywhere, and if it happens to be dry-say at the First October meetingand dust is seen to rise behind the horses, that dust is almost certainly caused by the proper, and at the two meetings which are held on the July course.

A year or two ago 198 races were decided during the year at Newmarket, and no fewer than 76 of these were less than six furlongs. (There are two-year-old courses on the race-

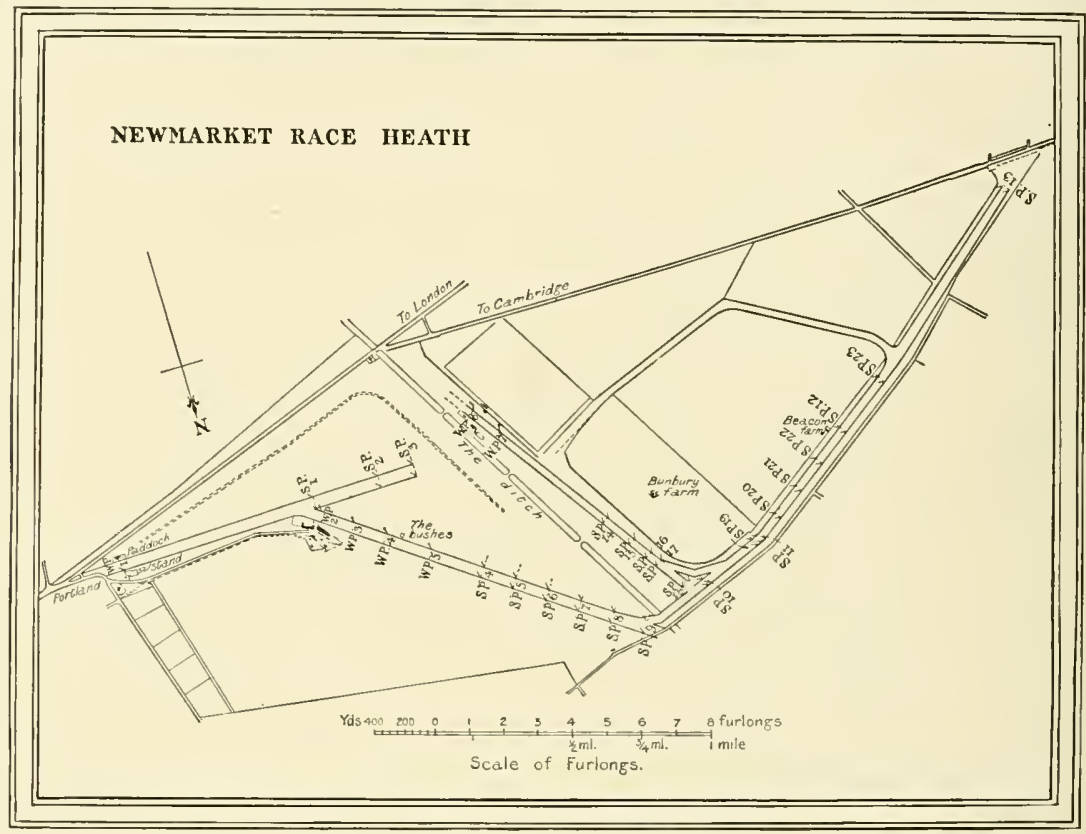

THE COURSES AT NEWMARKET.

moss litter or kindred matter which has been used, and is not raised because the ground is bare. If, on the other hand, there is heavy rain during a race meeting, and the going becomes soft, the softness is nothing like so bad as it would be in the same circumstances at many other courses. The heath can stand a great deal of rain, for the water is quickly absorbed by the light soil, and very seldom forms pools as would be the case were the subsoil clay.

Besides the Cesarewitch only the Jockey Club Cup is run on the two miles and a quarter course, and a little study of the programmes reveals the fact that in an average year sprint races are in an enormous majority both on the race-course course, and behind the Ditch, the distances of which are five furlongs 134 yards, and five furlongs $\mathrm{I}$ to yards, and all the races decided on either of these courses are included in the 76 .) Thirty-one of six furlongs, I I of seven furlongs, 29 of a mile, 2 of nine furlongs, 9 of a mile and a quarter, 2 of a mile and three furlongs, 27 of a mile and a half, 2 of a mile and six furlongs, 2 of two miles, and 2 of two miles and a quarter.

It will be seen then that at their own meetings the Jockey Club favour shortdistance racing, and one would like to see some of their programmes with more long races such as there are at Ascot. There is, however, no necessity to write anything of a controversial nature, our mission being to 


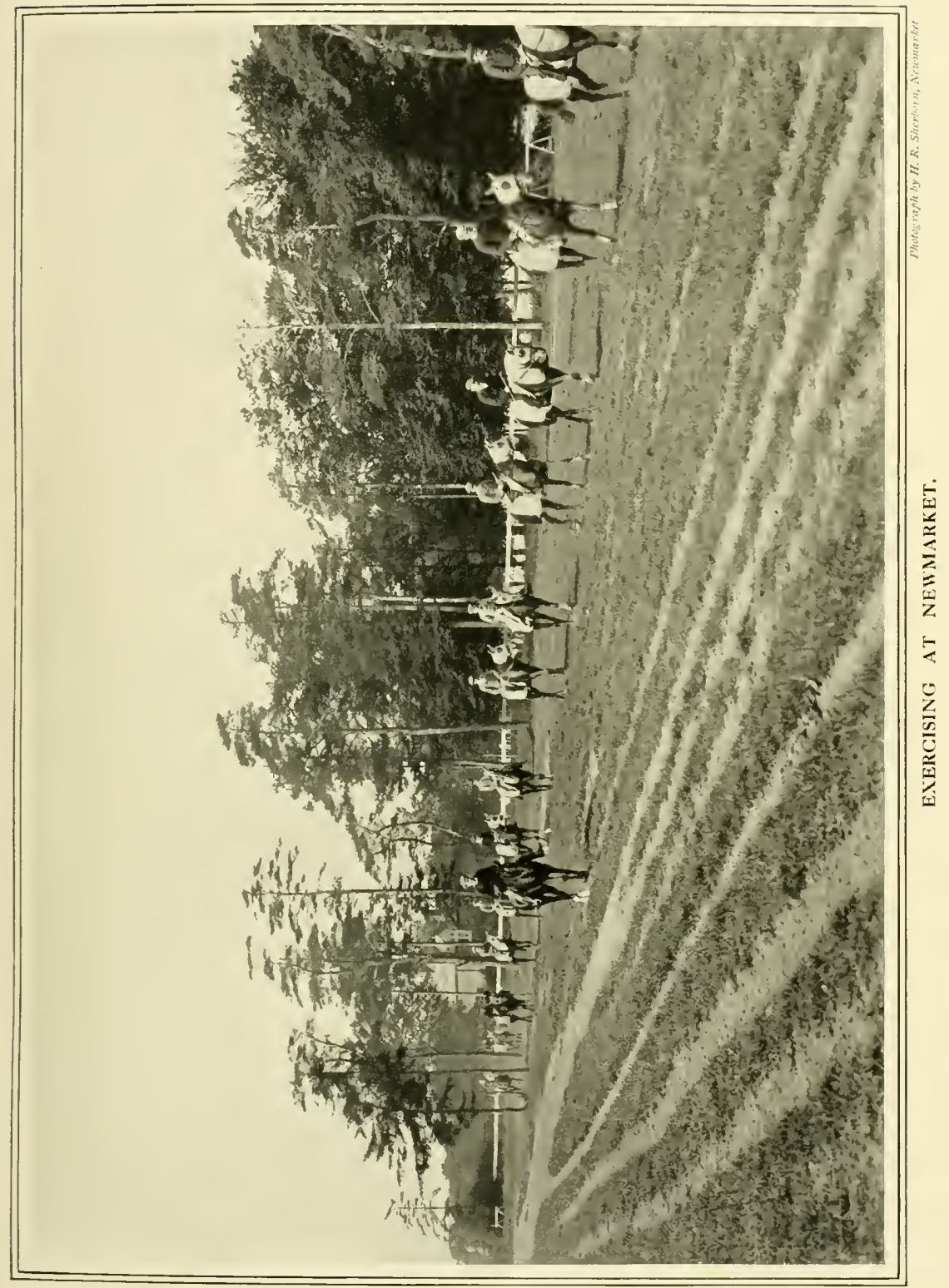


describe the racing as it actually is. At the Craven meeting then there are no stakes of the first importance, though several of the three-year-old stakes-the Biennial, the Column Produce Stakes, and the Craven Stakes to wit-give the would-be classic horses the chance of a public trial. And it may be added that these races are on the whole terrible pitfalls, for year after year some of them are won by horses which become false favourites (not necessarily first favourites) for certain classic races, and which afterwards turn out most disappointingly. The Biennial in particular has a most unenviable reputation, but as a matter of fact there is little to choose between this race and the Craven Stakes.

\section{The First Spring Meeting}

The First Spring Meeting is by far the most important of the three Newmarket fixtures which are held in the early part of the season, for at it are decided two of the five classics of the season, viz. the Two Thousand, and the One Thousand Guineas. At this meeting, too, certain fairly well-tried two-year-olds may make their appearance, and there is also such an important weight-for-age contest as the March Stakes on the programme. The Second Spring Meeting, held a fortnight after the First Spring fixture, has nothing more important, or of greater money value than the Newmarket Stakes on its three days' programme, but the Newmarket Handicap is, in its revived state, an interesting race, and again there are several two-year-old stakes which may bring out good class youngsters-especially such as happen to be trained on the heath, and who can therefore be indulged with a public gallop even if they are a long way from being thoroughly wound up.

\section{The July Meetings}

The July meetings at headquarters are very generally considered the best of the year from the general point of view; though as regards the all-round quality of the horses, and the character of the races decided they cannot be honestly put on the same level as the Second October or the Houghton meet- ings. But the course "behind the Ditch" is in July a charming place, and the racing is quite good enough to attract the attention of the enthusiast. Though the weather is often very hot, a long plantation, behind the paddock and private stands, affords plenty of shelter, and there is no crowd, no bustle, and nothing whatever to distract the attention from the business of the moment.

The Round Course behind the Ditch is in these times never used in its entirety, but the last two miles of it, called the Summer Course, is used for the Summer Handicap at the Second July meeting. Other parts of it provide the courses for all the racing behind the Ditch, and the last mile-called the Bunbury Mile-is quite straight. There are two finishing posts, a furlong apart, of which that farthest away is just where a sharp ascent begins, while the other is at the top of the same sharp ascent, and is therefore more severe. At the earlier of the two meetings, the July Stakes for two-year-olds, the Princess of Wales's Plate and the July Cup, a sprint race for horses of all ages, are the most important events, while at the later fixture the Chesterfield Stakes for twoyear-olds, and the Summer Handicap take fairly high rank.

\section{The Autumn Season}

The autumn season at Newmarket begins as a rule on the last two or three days of September, the three four-day meetings being each separated by a week. The first of the three fixtures is the least important and only draws a small attendance, but the programme has been strengthened in late years by the inclusion of the Jockey Club Stakes, and the two-year-old racing is nearly always good. The Second October is perhaps the best of all the Newmarket meetings. The Cesarewitch and the Middle Park Plate are its best known races, but the programmes are full of important events, and as a rule all the best horses in training, except those which have been retired for the season, run at the meeting. The Clearwell for two-year-olds, and the Champion Stakes are the big events on the first day. The Cesarewitch is backed up by such races as 
the Chieveley Park Stakes, the Select Stakes, and the Second October Nursery on the Wednesday. Thursday has the Challenge, the Lowther, and the Prendergast Stakes, and Friday is big with the fate of the Middle Park Plate, the most important two-yearold contest of the season.

The Houghton meeting, being held at the very end of October, sometimes comes in for bad weather, and in $\mathrm{ISS}_{2}$ - when Hackler won-the race for the Cambridgeshire had to be postponed until the following day. The handicap just named is the greatest event of the Houghton meeting, but the whole programme is a strong one, such races as the Criterion, the Dewhurst Plate (for two-year-olds), the Jockey Club Cup, and the Free Handicaps for two- and for three-year-olds being some of the most important events.

\section{Early Morning at Newmarket}

Besides the racing at Newmarket there are other attractions, the chief of which is the early morning visit to the heath, when hundreds of horses can be seen doing their daily work, and at times two or three trials. These semi-private gallops are of frequent occurrence in the race week, because so many owners are on the spot, and therefore trainers grasp the opportunity of trying their nags in the presence of those to whom they belong. In these days there is very little secrecy about the trials. Of course the weights cannot even be guessed at by the casual onlooker, and if he be a visitor he may be quite in the dark as to the individuality of the runners. On the other hand he may have easily acquired the information from one of the many horse-watchers who will be present, for it is the business of these men to know every horse by sight, and some of them will reel off the names of hundreds without making a single mistake.

The charms of Newmarket Heath before breakfast can hardly be appreciated until they have been experienced, but to the lover of horses, who is able to understand something of what is going forward the daily scene is one of the greatest attractions which the racing season affords, and in race weeks the same men are to be seen day after day, and year after year, watching the work. At the July meetings there are sales of yearlings, both before and after racing. and additional sales are held on various mornings of the Spring and Autumn meetings.

\section{The Midland Meetings}

The midland meetings are not of such great importance as some of the southern or northern fixtures. In the group may be included Birmingham, Croxton Park, Derby, Leicester, Lincoln, Nottingham, Warwick, and Wolverhampton, and of these Derby and Lincoln are the most important. At each place three meetings are now held during the season, and at Derby the Autumm meeting in November has the Derby Gold Cup on its programme, and one or two very important nurseries. Lincoln has the honour of being the first flat race meeting of the season, and on this account it has acquired greater prominence than is really its due. As a matter of fact there is only one race of really good class on the three days' programme, viz, the Lincolnshire Handicap. The Brocklesby Stakes for two-year-olds used to be an event of some magnitude, but since the value of all two-rear-old stakes (in the early part of the season) was cut down the prestige of this race has in a great measure departed. At all the other places which have been enumerated the racing is mostly of the plating order, but at Leicester large fields are the rule, and the give and take course is exceedingly popular with trainers.

The northern group of race meetings is large and important, and may in a sense be divided into separate groups of east and west. In the eastern section may be included all the Yorkslire meetings, Stockton, and Gosforth Park, and in the western, Manchester, Liverpool, Chester, Haydock Park, and Carlisle. To go a little more into detail there are now in Yorkshire ten courses on which flat race meetings are held, viz. Beverley, Catterick Bridge, Doncaster, Hull, Pontefract, Redcar, Ripon, Stockton (the town of Stockton-on-Tees is in Durliam, but the race-course is on the south side of 
the river, and consequently in Yorkshire), Thirsk and York.

It need hardly be stated that the Doncaster September meeting is far ahead of all other Iorkshire fixtures. It not only has the St. Leger, the last classic race of the season, on its programme, but it caters on every women who spend the day outside the enclosures, and who are holiday-making, after a somewhat serious fashion of their own, the object being to see the St. Leger at all costs, and if possible to back the winner. From a social point of view the meeting is only second to Ascot, the State

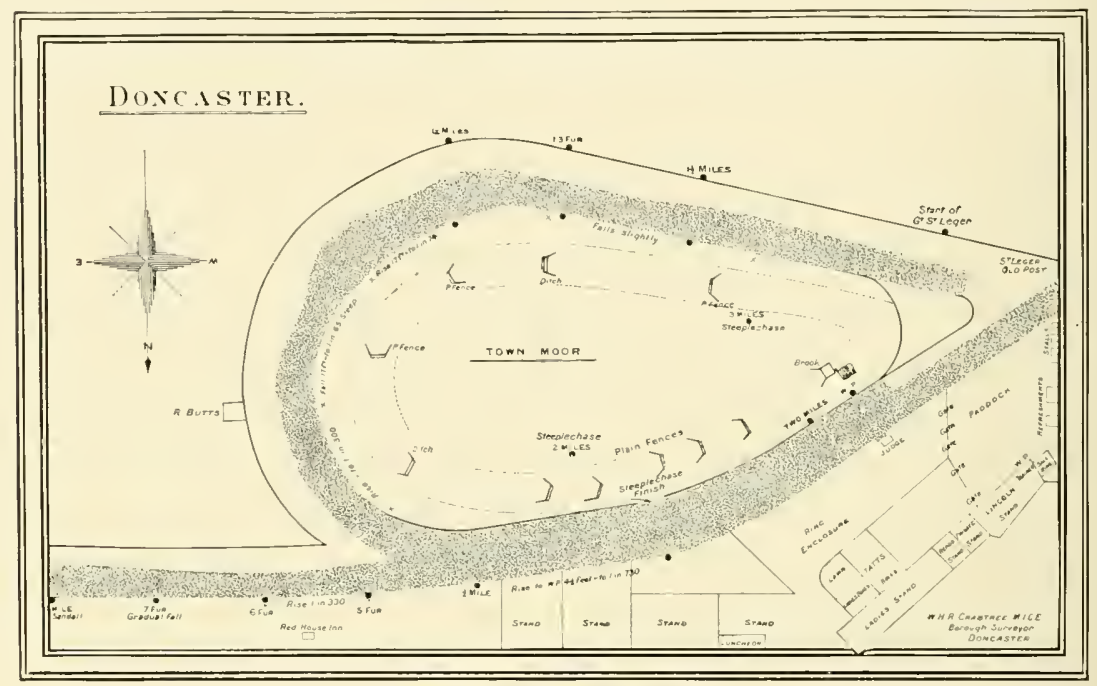

DONCASTER RACE-COURSE.

day of the meeting for the best class of horse. Indeed Doncaster is one of the four great meetings of the year (the other three being Epsom, Ascot, and Goodwood), and in some ways it is the greatest of all. For example it is quite possible that the attendance at Doncaster is actually the biggest of the year, that at Epsom on the Derby Day alone excepted. But whereas an enormous number of the visitors to Epsom care little for the actual racing, the Doncaster crowd is almost entirely attracted by the sport itself. the horse-loving Yorkshiremen eagerly welcoming the chance of seeing the best threeyear-olds of the year perform.

It results then that whilst the attendance of all the racing notabilities is very large indeed on every day of the meeting, the numbers on the St. Leger Day are supplemented by a rast concourse of men and procession and the Royal enclosure placing the last named meeting in a class of its own, but whereas Ascot has a unique position in this respect, Doncaster runs it far closer than does any other meeting, chiefly because of the fact that it attracts just as many of the magnates of the racing world as Ascot, and perhaps more than Epsom. Some racing folk who do not happen to be members of the Epsom club never visit the Downs; others similarly placed go to see the Derby, and perhaps the Oaks. Ladies again are there in very small numbers, because of there being so little accommodation for them, and, in fact, big as the general crowd at Epsom is the mecting is not exactly a social function.

At Doncaster on the other hand there are half a dozen private stands included in the long range of buildings, and ladies are 
adnitted to nearly all of these. As everyone who has been at the September neeting will agree, the paddock is crowded with ladies between the races, and it must be added that this part of the attendance is not local, but is drawn from every part of the kingdom. The local magnates do a great deal of entertaining, and throughout a circuit of fifty miles house parties are brought together for the meeting. The king is almost invariably present-generally coning from Rufford Abbey with Lord sivile-and his presence doubtless has much to do with the success of the meetings socially, but in addition to the King every important personage of the turf world is present, and thousands of occasional turfites, who do not exactly make a business of racing, but in the kingdom, and the turf is always in capital order. This turf is kept almost like a tennis lawn, and is not only beautiful to look at, but affords excellent going; but there is one fault to the course, and one often wonders that it has not been remedied long ago. Reference is made to the bend or long elbow, not much more than a quarter of a mile from the winning post. This bend is known as the "Intake Turn" (it is just opposite the Intake Farm), and though not very pronounced it at times causes a good deal of scrimmaging. But that is not exactly the worst of it, for it must be understood that when a course bends-either way-so near the end of a race the positions nearest to the rails are far more valuable than the outside places, and thus it happens that in the sprint

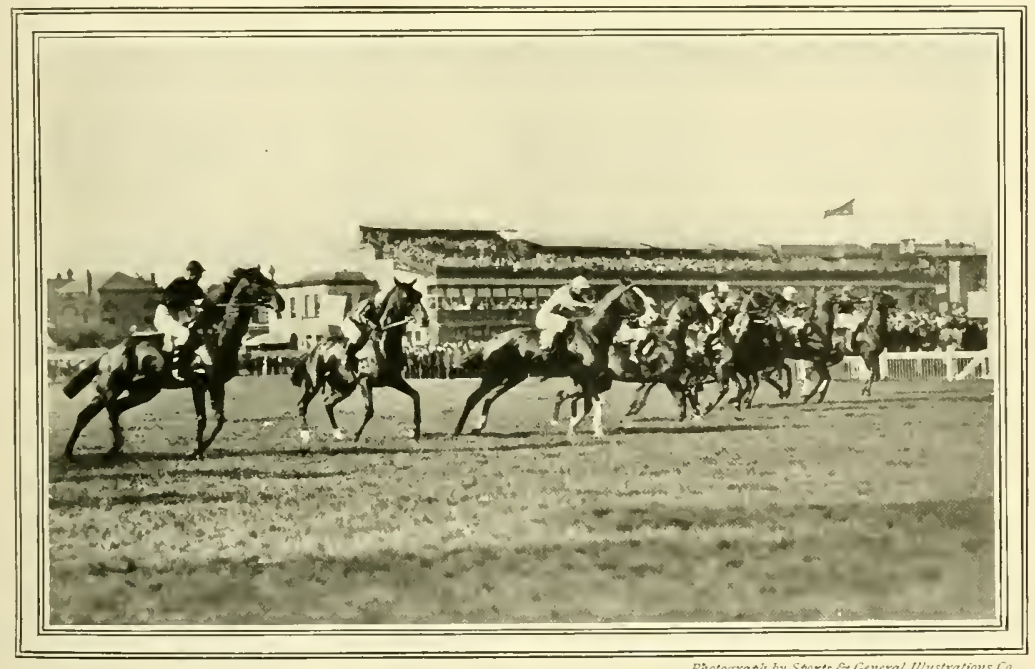

A START AT DONCASTER.

who make a point of never missing Doncaster. Besides the racing there are the sales to attract. These are held, at no great distance from the course, between the hours of ten and one o'clock on each of the four racing days, and the business chiefly concerns yearlings, of which (broadly) one hundred thousand pounds' worth are disposed of every year.

The course at Doncaster is one of the best 18 races at Doncaster one often sees horses shut in at this place, and others unduly favoured. There is in fact too much racing from the start in order to secure the coveted position on the rails, and this in a measure alters some of the races, and often interferes with the result. It is stated that the course is to be altered and the turn straightened out.

This Intake Turn seldom has any effect upon the race for the St. Leger, for by the 
time it is reached the lorses have come a mile and a half, and are somewhat strung out. Indeed, if there is trouble in the St. Leger-as there was in Memoir's year-such trouble generally occurs at the Red House, where the round course joins the so-called straight mile, and not at the Intake Turn.

\section{The Doncaster Course}

The Doncaster course is almost a dead flat, though there is a very slight rise and fall on the round course about a mile and a quarter from home. The round courseon which the St. Leger is run-is one mile six furlongs and $I 32$ yards, and as the horses start just in front of the paddock, and only a few yards from the stands there is as good a view of the start as there is of the finish. In addition to the round course there is the Sandall Mile, on which all the sprinting events are decided, and this joins the round course rather more than five furlongs from home.

The races are managed by the Corporation of Doncaster, who make a big profit out of the meetings, and who are by no means free with added money. Indeed, the full anount of prizes for the four days of the September meeting does not reach much more than fi7,000, and this compares very unfavourably with what is given, for example, at Ascot. Probably the average racing man, unless he owns horses, never inquires much into the actual value of races. It does not affect him whether owners are running for their own, or for someone else's money, and the result of this is that-owners being a longsuffering class-very little is heard of the subject. There are, as a rule, two meetings during the year (there were three in rgog), but only the St. Leger meeting, held at the beginning of September, is a really important fixture.

\section{The Doncaster Fixtures}

On the Tuesday of the great week the Champagne Stakes for two-year-olds is the most important event of its kind which is decided in the north of England. As in the Coventry Stakes at Ascot, there are no penalties or allowances, and in five years out of -six the very best form of the year is represented. Pretty Polly, RockSand, Ladas and $\mathrm{La}$ Flèche are amongst the recent winners, for example, and briefly the race is one of half a dozen which have claims to be the most important two-year-old events of the season. The other big race on Tuesday is the Great Yorkshire Handicap, run on the St. Leger course of a mile and six furlongs, and this again attracts some of the best long-distance handicap horses.

\section{The Doncaster Cup}

On Wednesday, there are, besides the St. Leger, the Tattersall Sale Stakes for two-year-olds, and the Rufford Abbey Plate, a two-mile handicap. On Thursday the Portland Plate, a handicap sprint of five and a half furlongs, is second only to the Goodwood Stewards' Cup amongst races of this kind, but the card is the weakest of the four, while that of Friday is perhaps the strongest all round. On this day the Doncaster Cup, the Prince of Wales Nursery, the Park Hill Stakes, and the Doncaster Stakes are all of them races of note, and the Cup stands on an equality with that given at Goodwood, the two being inferior to the Ascot Cup only, amongst long-distance weight-for-age races. And the inferiority is more imaginary than real, for as a matter of fact the same class of horse contests both races, and in very recent times, in support of this argument, it may be stated that William the Third and Bachelor's Button won both trophies, while The White Kinight won a brace of Ascot Cups, and in each year was beaten when he attempted to add Doncaster honours to those gained at Epsom and Ascot.

The Prince of Wales Nursery is the first mile nursery of the season, and so good is the class it attracts that it is looked upon as the most difficult two-year-old handicap of the season. St. Simon won it with 9 stone in the saddle, and won by so great a margin that some of the field appeared to be hardly beyond the Intake Turn when he was passing the winning post, and a recent example of a good winner may be quoted in Radium, who three years later was also successful 
in the Doncaster Cup. The Park Hill Stakes is for three-year-old fillies, and the Doncaster Stakes is also a three-year-old race; both bring out good class, and notably the firstnamed often shows confirmation, or an upset, of One Thousand and Oaks form.

\section{York August Fixture}

After Doncaster the York August fixture is the greatest meeting of the year in the north of England. It is held a fortnight before Doncaster, and when many racing people are in Scotland, or abroad, but it is of great local importance, and in spite of its rather awkward date it attracts a big number of strangers to the place, and the sport, without being quite up to the Doncaster standard, is of fairly high class. In these days there is no York Cup, and the Ebor Handicap seems lately to have rather lost its hold on the public, while the Great Yorkshire Stakes - in which The Iiner beat Blair Atlol, and Trent disposed of Apology, each of the beaten horses winning the St. Leger a fortnight later-has also declined in importance. But on the other hand the two-year-old racing at this meeting has steadily improved, and the Gimcrack Stakes has gradually become one of the great twoyear-old contests of the season. It is now a thousand pound race, with penalties and allowances, and as far as its conditions go is much like many other races of the present day, but it has outside importance, because of the annual dinner of the Gimcrack Clubheld in Iork during December.

\section{The Gimcrack Stakes}

The Gimcrack Stakes was founded in honour of a grey horse named Gimcrack, who was by Cripple out of a mare by Grisewood's Partner. He was foaled in 1760 , and though only a little (a quarter of an inch to be precise) over fourteen hands high, won a great number of races, and in fact made a very big mark on the turf. He began his running career when four years old, and won races when he was eleven, and his victories were very greatly in excess of his defeats, though as a matter of fact he was beaten some half-dozen times during his career. Curiously enough two of his defeats were sustained at York. In $\tau_{7} 68$ he was unplaced to Pilgrim, Chatsworth, and Tortoise, in the Great Subscription Plate, and a year later in the same race he was third to Chatsworth and Tortoise. It is thus rather singular that the York folk should have recognised his great merit when he was twice defeated over their course. They did so, however, and the Gimcrack Club has not only lasted to the present day, but has during the last five-and-twenty years obtained an importance which did not belong to it at an earlier date.

\section{The Gimcrack Club.}

At first indeed the membership and influence of the club were only local, but gradually it became the custom to exercise a good deal of hospitality at the annual dinner. Invitations were sent to prominent turfites, stewards of the Jockey Club, and others, and then the inevitable thing happened, and what had once been merely a social gathering became to some extent a meeting of turf politicians, with a long programme of after-dinner speeches, all of which were reported, at length, on the following day. At one time the dinner was looked to to clear the turf horizon, and from one particular speech came a cause célébre which is hardly yet forgotten. Hore recently no great importance has been attached to the utterances of the speakers-probably because several who have spoken out on the subject of turf reform and so forth have been merely private individuals, with no mandate from the stewards of the Jockey Club. Besides giving the turf world something to talk about every year the members of the Gimcrack Club endow the race with $f_{500}$ of added money, and it may be added that the desire to win it is, amongst owners of race-horses, very great.

None of the other Yorkshire meetings is of really first-class importance. Stockton has a three-day fixture in August, in the week inmediately preceding York, and other meetings of much less general interest. The August meeting does not lack for patronage, and supplies capital racing of 
not quite the best class, but which is not far removed from it. There are several good stakes for two- and three-year-olds, and the course is a good one, though not quite so good as York. Nor is Stockton quite so handy for southern visitors, but of late years the train service to the meetings has been greatly improved, and it is not the other. The programmes include Biennial; and Foal Stakes, and so forth, and were it not that the meetings are never allowed a clear date they would be a far bigger draw than they actually are. This applies both to Redcar and Stockton, of which the former is generally opposed by Kempton Park, while Stockton has, as a rule, the

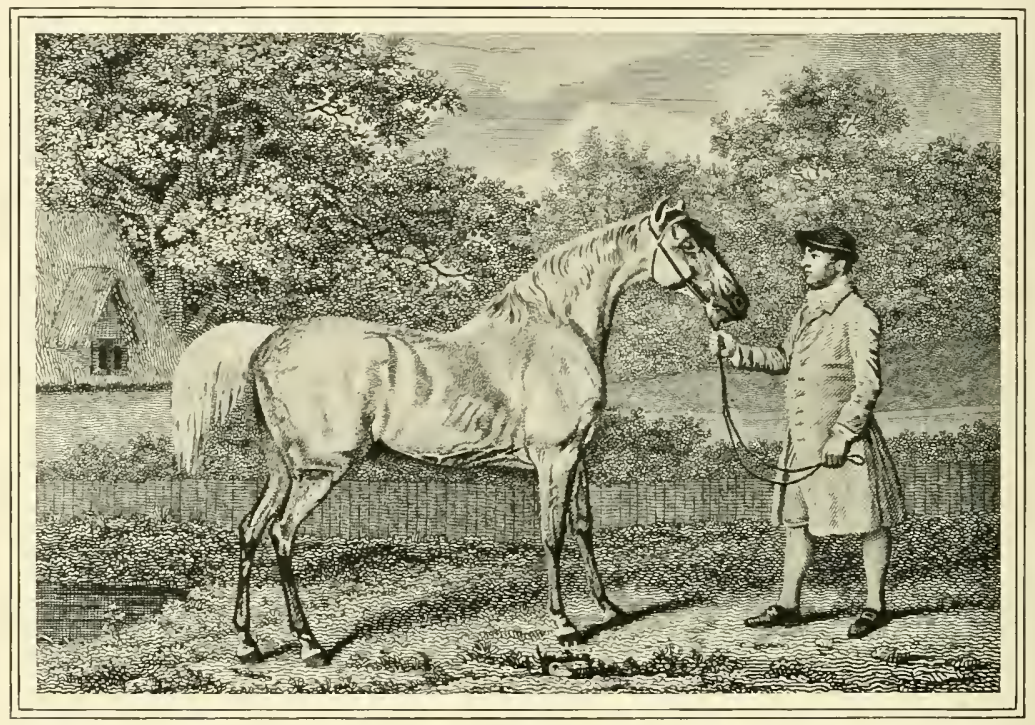

GIMCRACK

From the engrawing by J. Scott, after the painting by George Stubbs, A.R.A.

necessary to stay at Stockton-where the hotel accommodation is of rather a limited character-because Redcar and Saltburn are close at hand, and at either place there are many good hotels.

Redcar, half an hour by train from Stockton, has one of the best courses in the kingdom. and its August meeting, though of only two days' duration, is much on a par with that of Stockton as regards the class of competitor which is found in the more important races. Though drawing largely on the northern stables, both Redcar and Stockton always attract a very strong contingent of Newmarket trained horses at their Angust meetings, and as Stockton follows Redcar many horses stay on from one meeting to opposition of Folkestone and Wolverhampton.

Redcar would be a first-class meeting, or something very like one, were a clear date allowed. It is an older meeting than Kempton, and it had a fair standing-.. which was improving every year-before any racing took place in the Sunbury Vale. Of late the opposition in the south has tended to injure Redcar, however, and this is matter for extreme regret, as the real sporting spirit is far stronger in the North Riding of Yorkshire than it is in the neighbourhood of London. Moreover, there is in the early days of August a great exodus of racing people from the London district to the north of England. 
$\mathrm{By}$ this time of year the summer is well advanced, and professional race-goers have been hard at it in the south for not far short of six months. In many years the weather has become very hot, and the ground considerably dried up. Then come a series of northern meetings, Redcar, Stockton, and York, in successive weeks, with Derby sandwiched in between York and Doncaster. Here then is the chance of a change to crisper air, a good deal less heat, and courses with which the average southern enclosure cannot compare. Scores of racing folk go north, and many stay in the north until York is over, while a fair number do not come south again until after Doncaster, but all the time there are meetings in the south, and even if these are ignored by many, they put trainers and jockeys to a great deal of trouble.

\section{Racing in August}

In August only a moiety of the horses in training are fit to run. Many of the spring performers are being rested until the autumn, and many others have in most years shown signs of feeling the effects of hard ground. There is then a difficulty about filling the fields, for as a matter of fact there is at this time of year more racing than either before or afterwards, there being a continuous clashing between northern and southern meetings. Jockeys in August spend their days in the saddle and their nights in the train, and to some extent this is also the lot of those trainers who happen to have horses fit to fulfil August engagements. Instead of being a slack month-which it is to the race-goer who is not a professional, and whose attendance is optional-it is one of the busiest months of the year, and yet it is a time of disappointments, because the supply of good jockeys is so limited that if the forces are about equally divided there are not enough at either fixture. How many horses one has heard of which have been sent to some of these August meetings, and home again without running because the owner or trainer could not find a suitable jockey, one does not know, but it is quite certain that the jockey question often becomes acute at this period of the season, and it is probable that most difficulties occur during the Redcar-Kiempton week.

\section{Pontefract and Hull}

Such Yorkshire meetings as Beverlev, Catterick, Pontefract, Thirsk, and Ripon, are unambitious in their programmes, and are chiefly of local interest. Pontefract secures a fair number of Newmarket trained horses, and is the best of the five, but it cannot be called a first-rate meeting. What sort of racing the new fixture at Hull will provide remains to be seen, it being at present far too early to speak with real conviction. The course is a good one, and well adapted for long-distance racing, but much depends upon the attitude of the North Eastern Railway Company, who have it in their power to make or mar the fixture. So far a promise of fair class sport conducted on very sound lines is given.

\section{Gosforth Park}

In the north-eastern district Gosforth Park is the only other racing centre, and at this place there is the best enclosed course in the country. The straight mile is probably the widest to be found at any enclosure, and on the round course of a mile and three quarters the turns are so gentle that there is seldom any shutting out, or much crowding. Indeed one hardly knows a better course for two-mile races, and were Gosforth Park close to Londion, instead of being in the country, at a distance of five miles from Newcastle-on-Tyne, it would have a very much greater reputation than it has.

But like Redcar and Stockton the fixtures never have a clear date. The spring and autumn meetings are not of great importance, their programmes being of a modest nature, but the summer fixture alnost attains the dignity of a great meeting, and yet it is always opposed by a meeting of some considerable importance in the south of England. Gatwick and Newbury are the meetings which generally clash with Gosforth Park in June, but in this case it 
is probably the southern meeting which suffers, for the racing up north is in this particular week almost of higher class than that which takes place at its southern rival.

Though Gosforth Park is a modern enclosed course of some twenty-five years of existence the meeting (held in June) is one of the oldest of existing fixtures, and its removal from the Newcastle Town Moor to the present site was compulsory. The result was that all the old features of the racing were continued, and though Gosforth Park is farther away from the town, the change was all for the best, for it allowed of the course being kept in perfect order, whereas the Town Moor is a public common, used by the freemen of Newcastle-on-Tyne for grazing purposes, and it was not always an easy matter to keep the race track in really good galloping condition.

\section{The Northumberland Plate}

Turf history is replete with stories of what happened at Newcastle in old days, when the Newcastle Gold Cup was of greater importance than the Northumberland Plate, and when such horses as $\mathbb{X}$ Y Z , Beeswing, Doctor Syntax, and others were the heroes of northern racing, but as the Cup declined the Northumberland Plate gathered inportance year by year, and for a considerable period, during the middle part of last century the race was one of the greatest two-mile handicaps of the year. The famous Underhand won it three years in succession, the St. Leger winner Caller Ou was successful as a five-, and again as a six-year-old, and in later days Lily Agnes, the dam of Ormonde, Hampton, who afterwards sired three Derby winners, and the mighty Barcaldine, who won under 9 stone Io lb., and who never knew defeat during his racing career, are to be found amongst the list of winners. Nore recently the race has suffered because of the extraordinary number of new $f_{\mathrm{I}}, \mathrm{OoO}$ handicaps which the enclosures lave provided, but even now it is of considerable importance generally, and as the "Pitman's Derby" has a local standing which is almost unique.

Besides the Northumberland Plate the
North- Derby for three-year-olds, and the Seaton Delaval Stakes for two-year-olds are trump cards of the Gosforth programme, and even the minor events at the June meeting bring out horses of fair class. Indeed, Gosforth Park is in many respects an ideal racing place, but as its principal meeting is held in the height of the London season it is not a big social function, though well supported locally.

\section{The Liverpool Meeting}

There are two, and sometimes three, meetings every year at Carlisle, and at the fixture which follows Gosforth Park in June (or the first week of July) the sport is pretty good, but the place as a racing venue is the least important of the north-western group, and pride of place must certainly be given to Liverpool, while Chester stands next, for its one meeting in May takes higher social rank than any of the meetings held at Manchester during the racing year.

Liverpool has three fixtures, one towards the end of March, the second in July, and the last in November, and all three come into the category of first-class meetings. The spring races are the most important, because the Grand National Steeplechase is included in the programme, and this race is undoubtedly the most famous cross-country event in the world. Further reference will be made to it when steeplechasing is being discussed, and it will be enough if it is here mentioned that the race draws such a crowd as is never seen on any other course in the kingdom. In actual numbers the Derby and the St. Leger crowds are much larger, but at Liverpool it is the attendance inside the stands and paddock which is so extraordinary, for it includes not only all the racing world, and all the steeplechase world, but hundreds, nay thousands of hunting folk from all parts of the kingdom, many of whom are in no sense of the word regular racing folk. From Ireland, too, it draws an enormous number, and when an Irish trained horse wins the demonstration is most pronounced.

At the Spring meeting, and again at the Nosember fixture the Liverpool programmes 
include races under both sets of rules, but there is also a Liverpool Cup (handicap of a mile and three furlongs) at each meeting, and though the Spring Cup does not take very high rank, the Summer Cup is one of the most important handicaps of the mid season, and the Autumn Cup usually attracts some of the best handicap nags in training, and is often a sort of second edition of the Cambridgeshire. In addition to the cups there are good class two- and three-year-old races, and at the Summer meeting the programme is one of the richest of the year, the St. George's Stakes, the Lancashire Breeders' Produce Stakes, and the Atlantic Stakes being each of $£ 2,000$ in value, while the Cup is worth over $£ \mathrm{I}, 000$, and the Molyneux Plate and the Knowsley Dinner Stakes $f_{\mathrm{I}, \mathrm{O} 00}$ apiece. The flatracing course is not the best in the world, for there is a long elbow to the Cup course, and horses at times run very wide when coming into the straight. There is a straight six furlongs, and the super-excellence of the steeplechase course quite makes up for the rather poor quality of the flat-race course.

Chester has only one meeting, in Nay, and in many respects the course is about the worst in the kingdom. "Twice round the frying pan, and once up the handle" has been descriptive of the course on which the Cup is run any time during the last fifty years, and it cannot be said that the description is in any way inapt. The races are run on the Roodeye, and their antiquity has been explained in an earlier chapter of this work. But in spite of the poor course there are always plenty of runners, and the meeting has extraordinary popularity amongst all sections of racing folk. The Chester Cup, a two-mile handicap, is the great draw, attracting such a crowd that the narrow streets of the town are congested with pedestrian traffic from quite an early hour in the forenoon until quite late in the evening, and long after the sport of the day is over. Nor is the crowd composed entirely of the

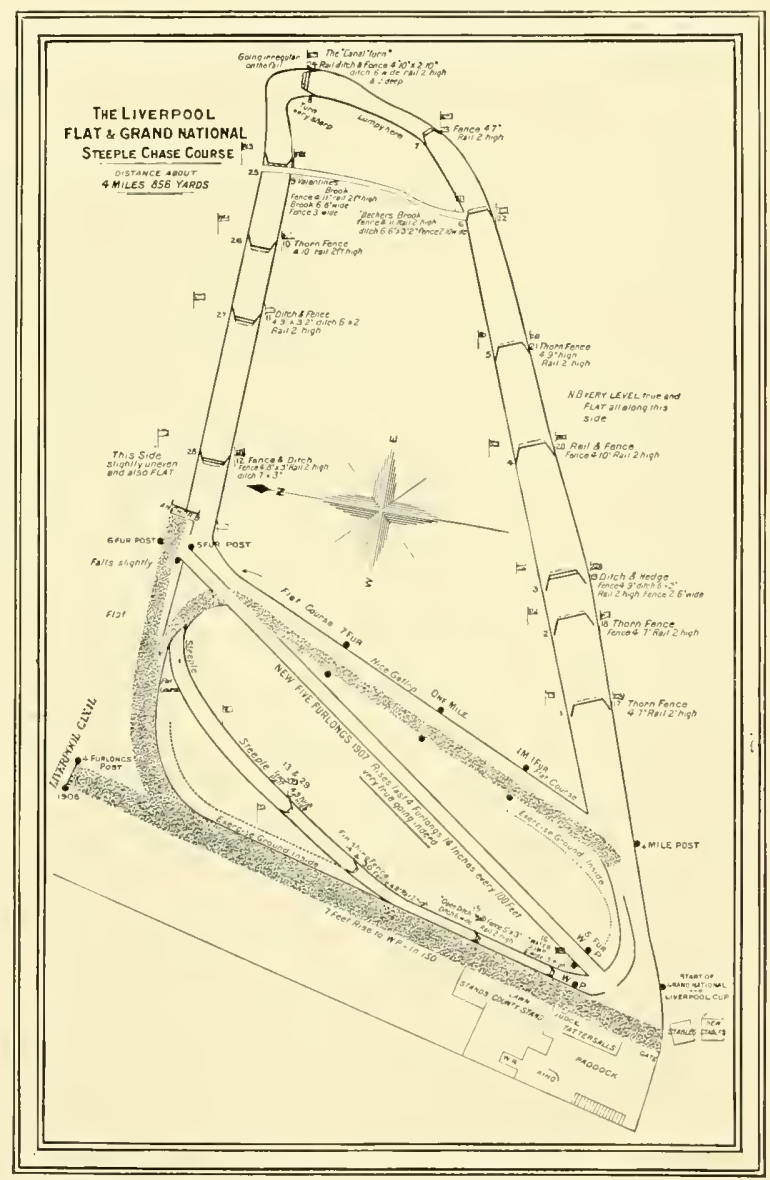

LIVERPOOL RACE.COURSE. 
local " bob-a-nob" element, for the fact is that the meeting is just as popular with the aristocracy of the racing world as it is with the poorer race-goers, and house parties by the hundred are made up, for this particular meeting, not only in Cheshire, but in Shropshire, North Wales, North Staffordshire, case. But except in the two or three most important events it is good second class, rather than first class which is to be found, and this could hardly be otherwise, considering that selling plates and minor handicaps are to be found on the programmes of each of the three days' racing.

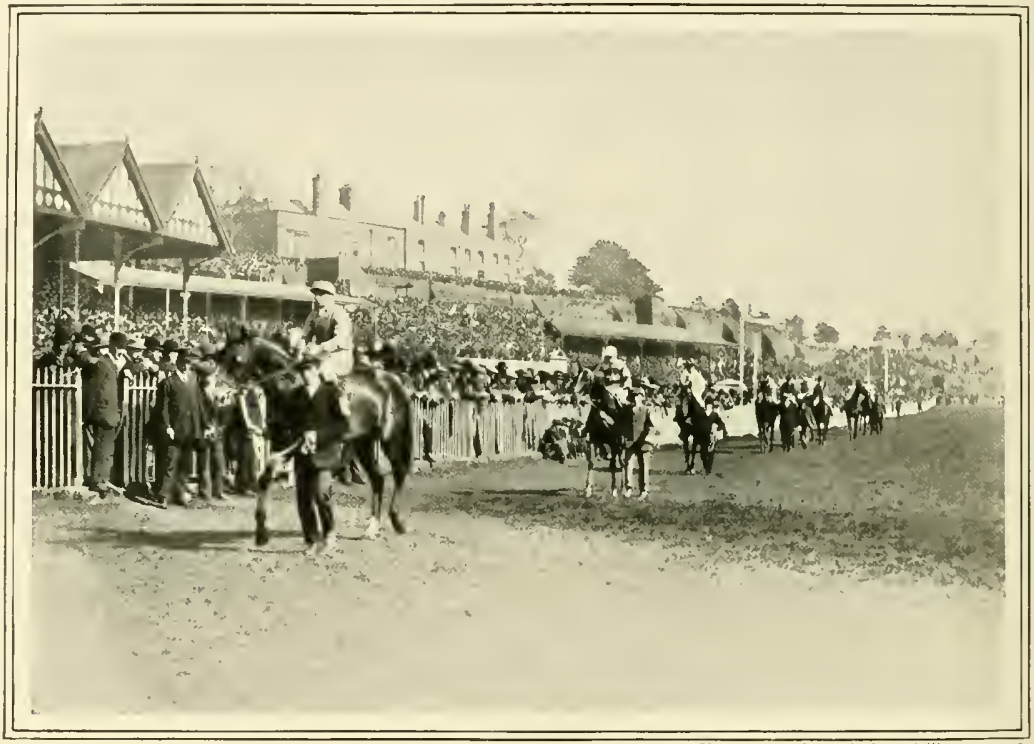

CHESTER GUP: THE PARADE.

and from every part of the Manchester and Liverpool districts.

On the first day the greatest attraction is now the Chester Vase of $£ 2,000$; on the second day the Cup takes precedence, and on the last day the Dee Stakes for threeyear-olds, and the Great Cheshire Handicap. There are, in addition, several two-year-old stakes which are well worth winning, and minor handicaps of some importance. Horses are sent to the meeting from all parts of the kingdom, and the King is a fairly frequent visitor. In every respect the meeting is a pleasant one, and from a social point of view it perhaps takes higher rank than is warranted by the class of horse mostly in evidence. By this it must not be understood that class is poor, for this is not the
Manchester is a great racing centre, and has three meetings every year, one in May or June, one in September, and one at the end of November, this third fixture being in fact the last flat-race meeting of the year. The new course at Castle Irwell is by no means a bad one, and the going improves year by year. There is a round course of a mile and six furlongs, with a straight run in of five furlongs, and a straight course of six furlongs, but there are two drawbacks to Manchester, one being that the programmes frequently contain one big race, and a lot of third-rate events, and the other that the light is often very bad, owing to the lowlying position of the course, which allows of fog and mist hanging about when the atmosphere is not dry. 


\section{Manchester Meetings}

At the Spring meeting of three days there were (in Igos and held in June) the Whitsuntide Plate of $f_{s} 1,000$ for two-year-olds, and the Castle Irwell Handicap of $£ 500$ on the first day, while each of the four other races was of less than $£ 200$ in value; on the second diy there were two handicaps of less than $f_{500}$ eacls to the winners, and five races of less than $\$ 200$ apiece, and on the third day the Manchester Cup of $£ 2,570$ to the winner, with four races of fioo each, and one worth just under f20o. Thus it will be seen that whilst the Cup was bound -on account of its value-to attract horses of good class, the balance of the programme catered for platers, and there are those who think that there is far too much plating, in proportion to good class racing, at all the IIanchester meetings.

In September the fixture is now of two days duration, and on the first day it has a t500 nursery, and the Autumn Breeders' Foal Plate for two-year-olds (this was worth f8S8 to the winner in I908), and the usual four races of less than f20o. On the second day there was the Prince Edward Handicap of $f_{1}, 670$ to the winner, four minor races, and the Michaelmas Plate for two-year-olds, worth $\underset{\sim}{f 52}$. At the November meeting there was a $f_{5}$ oo handicap and six minor events on the first day, a $f_{5}$ oo nursery and six minor events on the second day, and the Manchester November Handicap of $f_{\sim}, 500$, and five little races on the third day. One cannot help thinking that more money should be provided, for the meetings have great pretensions, and are well favoured in the matter of dates.

\section{Racing in Scotland}

The only flat-race meetings which are heing held in Scotland just now are Ayr, Eglinton, Lanark, and Edinburgh, and of these Ayr is quite the most important. The new course is an oval of a mile and five furlongs, and the principal meeting is held in September, and is of three days' duration. The West of Scotland Foal Stakes for twoyear-olds, the Ayrshire Handicap, and the Ayr Gold Cup are the principal races, and the meeting takes rank as good secondclitss, and has very powerful locil support. Eglinton, Lanark, and Edinburgh appeal chiefly to the Scottish and north of England stables, but each has a popularity of its own, and the Caledonian Hunt Cup, and Edinburgh Gold Cup, both decided at Edinburgh, are the most important events on the programmes.

\section{The Irish Meetings}

In Ireland there are about forty courses on which flat-racing takes place, but a very large majority of them are of minor importance. The rule with regard to the value of stakes allows of smaller prizes being given than in England and Scotland, and thus a host of small local meetings are held, which are of quite different type to those known in England. No doubt the horsebreeding industry is encouraged by the multiplicity of small meetings, for small breeders have the chance of running their young stock at comparatively small expense, and all country folk are enabled to have sight of thoroughbreds other than those bred or trained in their immediate locality. It says a great deal for the horse-loving qualities of the Irish that in a country of which the population is a great deal less than that of London (inner and outer London) there should be nearly as many racing places as there are in Great Britain. There were, as a matter of fact, forty-one places in Ireland where race meetings were held in 1907 , to the forty-seven on this side of St. George's Channel.

Ireland, is, however, better known in connection with the breeding of race-horses than great race meetings, and when an Irish thoroughbred of more than average merit puts in an appearance, he is very frequently sold to an English owner. In breeding, Ireland does remarkably well, more especially perhaps with English stallions and mares which have been sent to the country after their rumning days are over. Much of the land is undoubtedly suituble for rearing horses, and though hunters have been the chief industry for two or three gencrations, there has been during the last 
few years a great increase in the number of thoroughbreds, and certain English breeders of race-horses have actually taken stud farms in Ireland and placed there their English stud matrons-many of which are sent every spring to England to be mated, and are then sent back to Ireland, to be kept, so that the foal may have the benefit of the bone-making limestone pastures.

As regards the actual flat racing which takes place in the Sister Isle it may be said that Baldoyle, the Curragh, Cork Park, Leopardstown and Phonix Park are the principal centres, where the best class horses are to be seen, and between them these five places have no fewer than twenty-four flatrace meetings in the course of the year. The sport is probably even more popular than it is in England, but the comparatively small population does not allow of anything very great being done in the matter of prize money, and thus the programmes are on a small scale, even at the best meetings. At times prizes of $£ \mathrm{I}, 000$ are forthcoming, but the good Irish race-horse has only a small chance of winning any very big sum, unless he is sent over to England. And this is what happens with regard to the best of the breed. If they have distinguished themselves in the country of their birth, and have failed to find an English purchaser at a longish price, they are sent to some English trainer, and unless they turn out to have been sadly overrated Ireland knows them no more. Many good judges in England are always on the lookout for Irish nags of class, and the result is that early or late-either because they have been sold or sent to run in England-a huge majority of the best find their way to this country.

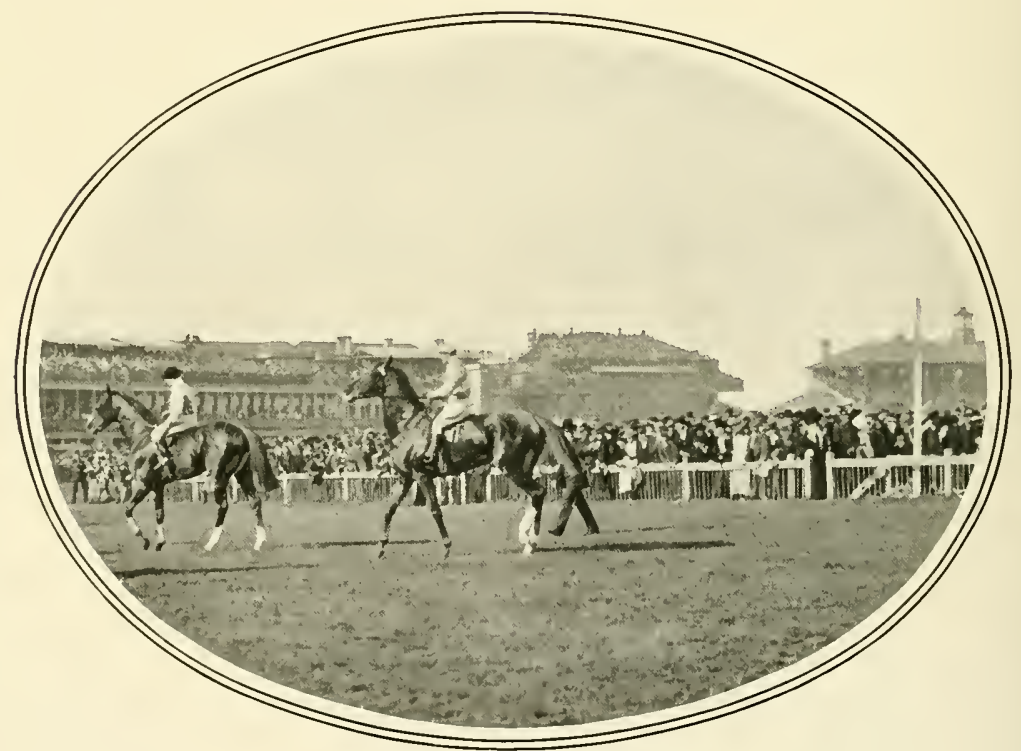

ST. LEGER DAY AT DONCASTER. 


\section{CHAP'TER XII}

\section{FAMOUS HORSES}

$\mathrm{T}$

MOUGH there have been liundredsprobably thousands - of race-horses which were far above the ordinary in point of merit, it has not fallen to the lot of all such horses to have becone really famous. Some of the best ran so seldom that their good qualities were never properly appreciated by the public; others came in a good year, when something just a little better would beat them two or three times, and thus prevent them from taking the high position in turf history which they might otherwise have achieved. Then, again, accident has frequently interrupted a career which could hardly have failed to have been great, and lastly certain horses have become famous more because they were popular idols with the race-going crowd than because of their superlative merits.

To quote an example or two, such horses as Minting, The Bard, and Saraband, were overshadowed by the mighty Ormonde, as Ravensbury was by Isinglass a few years later. Such a horse as Spearmint never reached the high position-in the estimation of the general public - to which he was probably entitled, because he never ran again after winning the Grand Prix de Paris, and because he only ran five times altogether, and showed no particular form as a two-year-old. Again, such horses as Bendigo and Victor IVild attained extraordinary race-course popularity because of the big performances they gave in handicaps, and yet when Bendigo ran against Ormonde and Minting in the Hardwicke Stakes at Ascot he was beaten by fifty yards, and when Victor Wild attempted to add the Ascot Cup to his handicap honours he also was beaten off.

Instances of lucky and unlucky horses, of horses with great reputations thoroughly deserved, and of horses with great reputations rather easily come by, could be given by the dozen, but space will only allow of a very cursory glance at some of the greatest performers which the turf has known, and those whose doings are within the recollection of many of our readers-and who can be written of from personal observationwill receive more attention than the early celebrities.

Mention of many famous horses from a stud point of view, has already been made, and as a general rule the great horses of every period of turf history have followed up their race-course victories by a successful stud career. There have, as a matter of course, been exceptions, and, for example, such a horse as Gladiateur-thought by some good judges to have been one of the best runners of all time-was a complete failure at the stud. Dozens of instances could be quoted, in point of fact, of firstrate runners who have been unable to reproduce themselves in their progeny, whereas, on the other hand, the lines of blood which have been given in an earlier part of the present work, show the names of certain horses who did nothing on the turf, and yet whose blood lives, and is strongly represented at the present day. It may be, of course, that such an animal as Whitelock (to quote a single example), the sire of Blacklock, and from whom all the St. Simon family are descended in direct tail male, might have done better in other circumstances. It may be that the quality and merit were there, but that he was badly managed and not properly trained. It is possible that he ought to have been as good as his sire Hambletonian, or his son Blacklock, but this is an abstruse turf problem, which it is almost impossible to solve, and it is only 


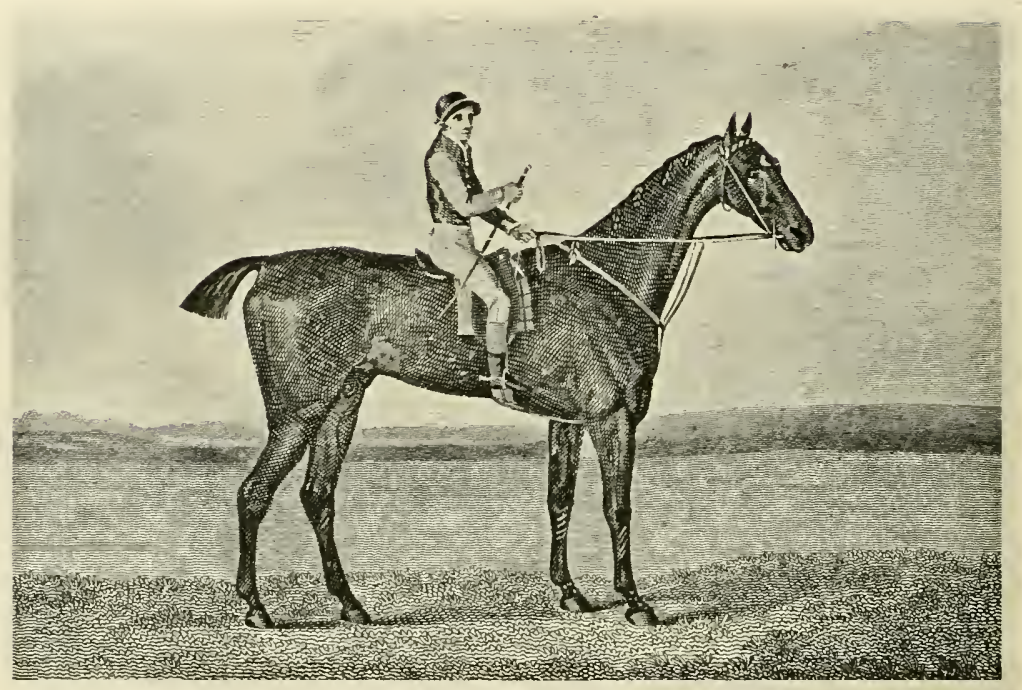

HAMBLETONIAN

From the engraung by $J$. Scott, after the painting by Francis Sartorius.

mentioned because in the line from Eclipse to Persimmon, Whitelock is the only sire who was not a race-horse of far more than average merit.

The first great runner of whom there is any reliable account was Flying Childers, and of this horse, who, according to turf historians, was never beaten, sufficient account has already been given. The next real celebrity, from the racing point of view, was Eclipse, who was foaled in 1764 , and this horse made by far the greatest name of all the old-time racers. He was the Ormonde of his day, and, as has been already explained, he won, or walked over for all the six-and-twenty races and matches which are credited to his name, and retired from the turf with a reputation which has never been equalled in the turf history of all the world. In only one of his races, a match against Bucephalus, decided at Newmarket in 1770 , was there any appearance of his having at last met an opponent really worthy of him, but we are left quite in the dark as to how far the great horse won, and all that is known in connection with the race is that
Bucephalus was so distressed by his efforts that he was never able to run again.

It is extraordinary that Eclipse should have been such a Triton amongst the minnows in his running days, for Herod, who was foaled six years earlier, had a better stud record, and though the line of Eclipse in later years has completely dominated the line of Herod, there is no getting away from the fact that Herod sired 497 winners against the 344 sired by Eclipse, although the last-named was four years longer at the stud. It is evident, then, that in his own time Eclipse had a stud rival who actually beat him, but as regards racing, whilst Herod won many good races he was also often beaten, and on the course he showed none of that marked superiority to (practically) all his opponents that Eclipse did.

Matchem, foaled in 1748 , was also a greater horse at the stud than he was on the course, and Pot-8-os, foaled in 1773 , was in training for eight seasons, and yet sired Waxy, through whom two different lines of Eclipse have been handed down. Waxy won the Derby (his first onting) and 


$$
\text { A }
$$



many other races, and was afterwards a great sire. Whalebone, who carried on the ine, also won the Derby, and was a good, if not an exceptional, race-horse. Another son of Eclipse, King Fergus by name ( 1775 ). was a fair runner, winning nine or ten good races, but his son Hambletonian (I792) was a more famous horse, and much of his fame was due to the fact that he beat Diamond in a match for 3,000 guineas, run on the Beacon Course at Newmarket, at the Craven meeting of 1799 . This match was one of the most famous of all time, and is said to have drawn together a greater concourse of people than Newmarket had ever known before. It was supposed that between two and three hundred thousand pounds changed hands on the race.

Hambletonian won many other races, and was a great stayer, and it is rather remarkable that in 1797 , two years before he won his great match, he was advertised as a sire, but his subscription not having filled he was put into training again. He was a good, but not exactly a great horse, and as far as one can judge, it was the prestige of winning so important a match which gave him the high place he undoubtedly holds in turf history. Herod's best son, Highflyer, was undoubtedly a great horse, both as a runner and at the stud. He was bred by Sir Charles Bunbury, and was foaled in 1774 , and according to Pick he was never beaten and never paid a forfeit, "though it has been asserted to the contrary." He was undoubtedly the best horse of his day in England, and though he only ran once as a three-year-old, five times (and received one forfeit) as a fouryear-old, and six times as a five-year-old (including two walks over), his winnings in stakes amounted to $f_{0} 9,336$ Ios., an enormous sum of money for those days, when mammoth stakes had never been heard of and the bigger subscription races only received a dozen or so of entries.

A great horse also was Highflyer's son, Sir Peter Teazle, commonly called Sir Peter. As a three-year-old he was unbeaten, winning the Derby and five other races,

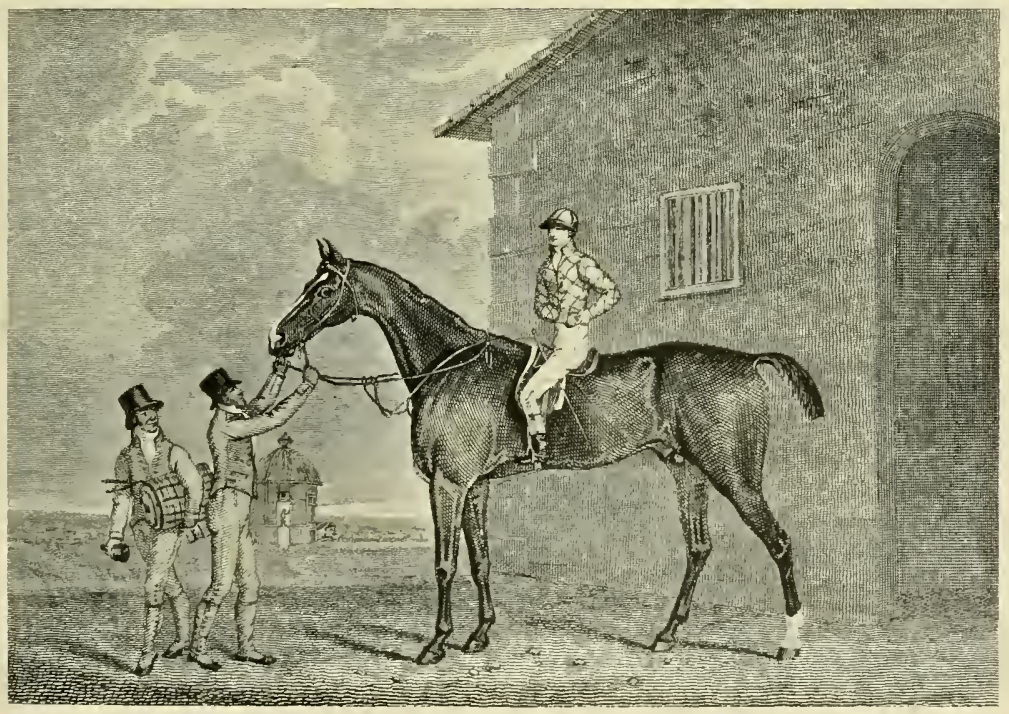


while he walked over for two other events. As a four-year-old he won four races and received two forfeits, as a five-year-old he won twice and he was twice beaten, and paid two forfeits when six years old. It will be seen that he carried all before him in his first two seasons, and he certainly has claims to be considered a great horse. He was also a great sire, and it is worthy of note that the American line of blood which has lately been in evidence through Emperor of Norfolk, Americus, and Americus Girl, comes from him in the direct male line.

\section{Doctor Syntax}

Whisker, by Waxy, who won the Derby in $I_{S} 5_{5}$, came very near to being a great horse, and Doctor Syntax, one year older, was a great celebrity and a very frequent winner, though he was essentially a northern horse in pre-railway days, when racing in the north and south was much more divided than it now is. Doctor Syntax was by Paynator, of the line of IIatchen, and he fell in his first race as a three-year-old, and was beaten in two succeeding events. He then took up a winning vein, and won at Preston, Morpeth, and twice at Richmond in Yorkshire. He started as a four-year-old by winning twice at Catterick and once at Iriddleham. He then won the Cup at Lancaster and the Cup at Preston, but was beaten for the Richnond Cup by the famous Filho-da-Puta, but at the same meeting he was successful in an f8o stake, in three mile heats.

As a five-year-old he won at Catterick, again took the Cups at Lancaster and Preston, having in the last-named race his revenge on Filho-da-Puta, who had beaten him at Richmond in the previous year. As a sixyear-old he won the Cup at Preston for the third year in succession, but was beaten into second place for the Richmond Cup by The Duchess. In the following year he took a third Lancaster Cup, a fourth Preston Cup, and a second Richinond Cup, and a year later (in I8I0) he was successful for the fourth time in the Lancaster Cup and for the fifth time in the Preston Cup, but was once more defeated in the Richmond Cup.
In I820 he won a fifth Lancaster and a sixth Preston Cup, beating the St. Leger winner Antonio in the first-named race. He also won the Richmond Cup again, and other races. In $I 8 \geq \mathbf{I}$ he was beaten by Reveller in the Lancaster Cup, but he won a seventh Preston Cup and another Richnoond Cup, while in $\mathrm{I} 822$ he sustained his first defeat in the Preston Cup, but won Cups at Richmond and Northallerton. In I823, being now twelve years old, he won at Newcastle, Pontefract, and the Richmond Cup again, but was beaten at Doncaster. One is inclined to think that the record of seven Cups in seven years (at Preston) has never been equalled by any other horse, and Doctor Syntax was such a farourite throughout the north of England that his portrait can be found to this day, as the sign of an inn, in many a country district. "The Doctor," as he was always called, was barely fifteen hands, with a high drooping rump and short quarters. He was mouse coloured, and, according to "The Druid," a slight canter would bring out his veins so strongly that he looked as if he was covered with network. He had splendid legs, and a strong, muscular head, but could never bear either whip or spur. One of his jockeys, Rob Johnson, always got every ounce out of him by merely stroking and talking to him, while when Bill Scott rode him he used to hiss at him furiously.

\section{A Great Race}

Two horses who came in for more notoriety than was perhaps their due ran a great match in I8I6. These were Filho-da-Puta and Sir Joshua. The first-named won the St. Leger, but in the following spring he was beaten by a neck by Sir Joshua in the great match, and according to the turf historians of the day the loser was unlucky. "The Druid" says that Filho-da-Puta faiked owing to his rearing suddenly at the post and losing some length which he could never quite make up again, while, according to the late Mr. Prince of Newmarket, who was an eye-witness of the match, "Filho" slipped and nearly fell, coming down Bushes Hill. The race was run in Mlarch, during a heary 
fall of snow. Both horses were of the line of Herod, and Sir Joshua died whilst he was still a four-year-old, owing to an accident caused by slipping up in his box.

Blacklock (ISI 4 ), though he was beaten by a fluke in the St. Leger, was a fine specimen of the big race-horse, and quite the best of his day. He was a great sire, too, but he was not quite an exceptional race-horse, and, indeed, we may pass over the next fifteen years or so in search for something quite out of the common, but may pause at the name of Plenipotentiary, who was foaled in $I_{3} \mathrm{I}$, and was by Emilius out of Harriet.

\section{Wonderful Plenipotentiary}

Plenipotentiary was a fair specimen of the great race-horse who made no name at the stud, and at the moment he does not figure in the tail male pedigree of any living horse, but his name is to be found in the pedigree of Lord Lyon and Minting, as the sire of the dam of Ellen Horne. Yet he must have been an extraordinary performer, for Wildrake in his "Cracks of the Day," published in $18+3$, begins his description as follows: "Here stands the crack of his day, as well as of every other, a horse such as we shall ne'er look upon the like of again, the wonderful and the unequalled, the ill-used "Plenipo'!' Taunton, writing some thirty years later, says this may appear a somewhat extravagant summing up of the transcendent merits of Plenipo, as a race-horse, but if we take public opinion we find from contemporary testimony that Plenipo occupied a station of prominence never before attained by any of his predecessors. Childers, doubtless, was a phenomenon, and the wonders of Eclipse have come down to us with higher claims to authenticity; but if speed be the test of superiority in a racer, then we are bound to draw the conclusion that when such distances as four and six miles were the tests of excellence, power and substance were necessary elements, which do not enter into the breeding arrangements of more recent times. l'lenipo, however, was an exception, for he had bone and size enough to go be- tween the shafts of a cabriolet. We have not quoted Taunton's words exactly, but have given the conclusion he arrived at, and this accords with all that was written concerning Plenipotentiary, who was a large horse of snch ponderous muscle, and who carried so much tlesh that he looked like a fat bullock when in training. Still, it is silid that he was greatly admired for his beauty and racing points.

Plenipotentiary won the Derby, but was beaten so far in the St. Leger that he was generally supposed to have been the victim of foul play. It is said, moreover, that his constitution was ruined for all time, and it may be that his want of success at the stud was due to his Doncaster experience. Touchstone was a high-class horse and a great stud success. Bay Middleton, who won the Derby in 1836 , was another very high-class horse, and surplice, who took both the Derby and St. Leger in 1848 , was probably much above the average classic three-year-old in point of merit, but he was followed in the next two years by horses which were of even better class, in The Flying Dutchman, Voltigeur, and Teddington.

\section{The Flying Dutchman and Voltigeur}

The first-named of the trio won the Derby and St. Leger in $\mathrm{I}_{49}$, and a year later Voltigeur did the same. Two days after Voltigeur's St. Leger victory he beat The Flying Dutchman in the Doncaster Cup, and this defeat gave rise to the great match which was run between the pair, at York, in the spring of $185 \mathrm{I}$. In this The Flying Dutckman turned the tables on his Doncaster conqueror, but both were great horses, and whilst Voltigeur did not appear to be a success at the stud for long enough, he eventually became the sire of Vedette, from whom comes St. Simon and his family. The Flying Dutchman's blood has done better in France than it has in this comntry, but it is worthy of note that Flying Duchess, the dam of Galopin (sire of St. Simon), was by The Flying Dutchman, so that all the great horses of the St. Simon family come in the first place from the union of a son 
and daughter of the two great match performers of $18 \bar{I}$.

Voltigeur rather lost his form after the match, but he was a great horse when at his best, and so, ton, was Teddington, who follows him in the list of Derby winners, and who, like The Flying Dutchman, was successful in the Ascot Cup. West Australian, in 1853 , was the first horse to win the named was unlucky, because he went amiss before the Derby (won by Teddington), and did the same thing before he took part in the Ebor St. Leger at York. Still, he was a fair horse, and a great stud success, having carried on the line of Touchstone by siring Lord Clifden, Hermit, and others. Stockwell was a greater race-horse than Newminster, and won two of the three classic events in

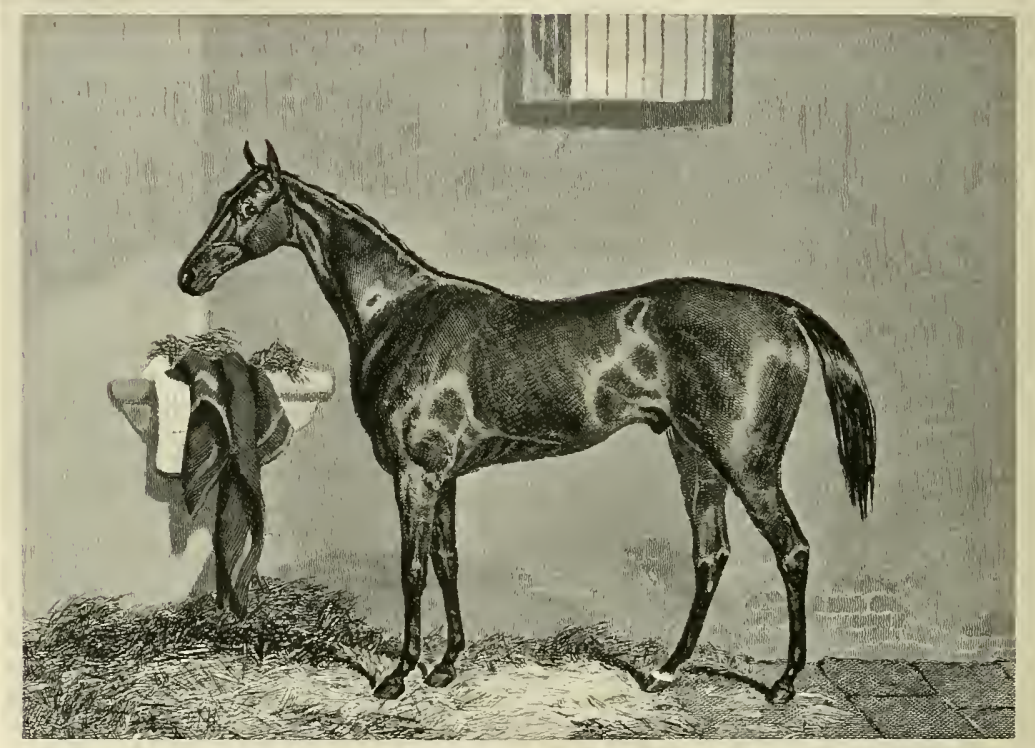

VOLTIGEUR.

From the engraving by E. Hacker, after the painting by Harry Hall.

treble event of Two Thousand Guineas, Derby, and St. Leger, and as the grandsire of Barcaldine his male line lives to this day, in Signorinetta, Bachelor's Button, Marco, and Neil Gow. He was undoubtedly a great horse, and even when St. Simon and Ormonde were astonishing the world by their great performances, there were dozens of Yorkshiremen who still swore by "The West."

Mention must be made also of the two St. Leger winners which preceded West Australian, for each played a big part in turf history. The horses in question were Newminster and Stockwell, of which the first- which colts can take part, whilst at the stud he was the greatest success of all time with the single exception of St. Simon, and it will always be matter of controversy which of these two is deserving of the higher honour.

Stockwell was not a handsome horse in the ordinary acceptance of the term, but he was an immensely powerful one, and he did not come very readily to hand, proof of which is forthcoming in the fact that he was beaten in both his two-year-old efforts. He also suffered defeat at the Newmarket Craven meeting when a three-year-old, but shortly afterwards won the Two 
Thousand Guineas and the Newmarket Stakes, and then was beaten in the Derby, being amiss at the time, indeed, he ought never to have run; at Goodwood he won twice, at York he took the Great Yorkshire Stakes, and he won the St. Leger by ten lengths, the Derby winner, David O'Rourke, being only a moderate third, while the Oaks winner, Songstress, was unplaced. The Newmarket successful sire of modern days, died within the same week, West Australian on Monday the 2nd, and Stockwell on Thursday, the $5^{\text {th }}$ of May, I870.

Stockwell's great merit as a race-horse was proved during the autumn of his threeyear-old career, when he was head and shoulders in front of all the three-yearold form of the day. He was ton big and heavy to stand a great deal of work, but

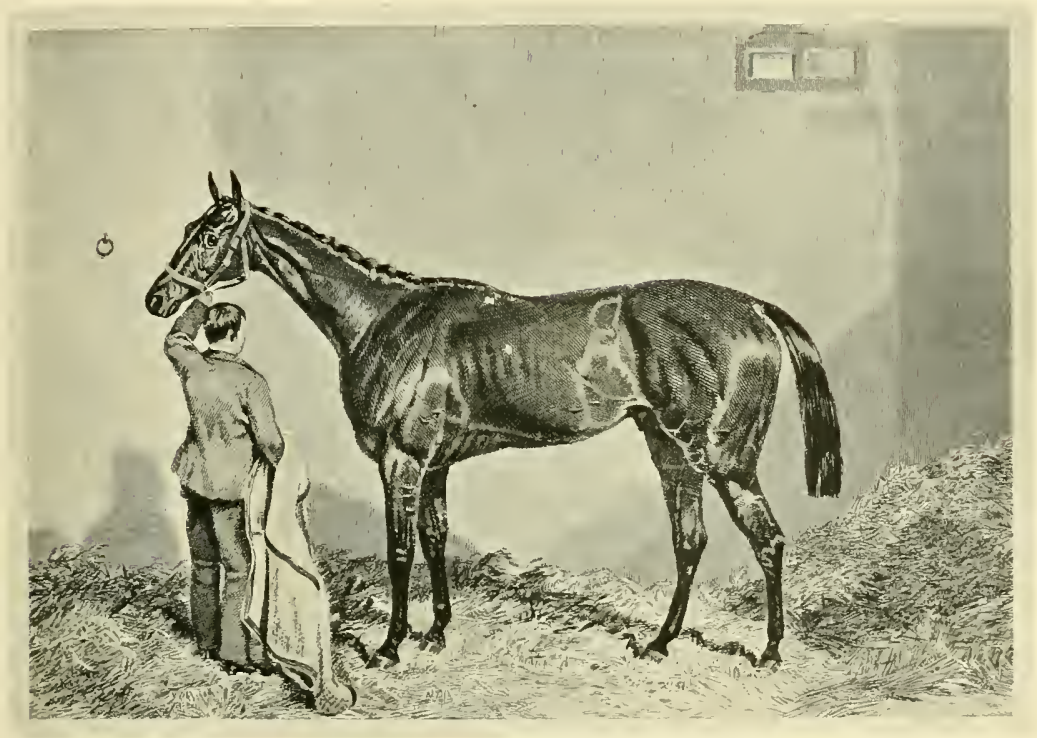

NEWMINSTER, WINNER OF THE ST. LEGER, 1851.

From the englaving by E. Hacker, after the painting by Hatry Hall.

St. Leger, and the Grand Duke Nichael Stakes-then an important race-were added to his three-year-old score, but at Ascot in the following year Teddington beat him by a head in the Emperor's Plate (Ascot Cup), after which the loser went amiss. In the following year he beat Kingston for the Whip, and this was his last appearance.

As proof of the great estimation in which West Australian and Stockwell were held. it may be mentioned that they both died in the same week, when it was written by a great authority of the day, "The best racehorse the world ever saw, and the most that he was a great horse when he won the St. Leger there can be no doubt, and from the stud point of view it may be said that he and his descendants literally dominated the position until the stock of St. Simon began to be so much in evidence. Earlier, the stock of Newminster had in a rather mild way disputed supremacy with the line started by the " Emperor of Stallions" (Stockwell), but they could never really hold their own, in spite of the stud successes achieved by the Hermit and Hampton lines, and to this day the Stockwells have the best of it. 
Thormanby, who won the Derby in IS60 and the Ascot Cup in the following year, was a horse of ligh class, and so, too, was St. Albans, who beat Thormanby for the St. Leger, while Blair Athol and Gladiateur, foaled in IS6I and I862 respectively, were also far above the average Dcrby winner in point of merit. Blair Athol never ran until he took part in the Derby, which he won readily enough. He was beaten by Vermout in the Grand Prix de Paris, but he had done little or no work between the Derby and the Paris race, and probably he ought to have won. Anyhow the gallop must have done him good, for he beat a high-class horse in Ely at Ascot, and he won again at Goodwood. At York he sustained a most unexpected defeat, being beaten by a length by The Miner in the Great Yorkshire Stakes, when attempting to give $6 \mathrm{lbs}$. This race has always been looked upon as one which it was impossible to explain, but two suggestions may be made concerning it, one being the opinion of William Ianson, the Malton trainer, whose father owned and trained Blair Athol, and the other that of John Osborne, the ex-jockey, who rode The Miner in his York race.

\section{Why Blair Athol Lost}

William Ianson told the present writer, when discussing the race many years ago, that Blair Athol was a horse who always wanted one or two rather strong winding-up gallops, and that before the York race he had hardly had sufficient strong work. It was expected that Ely would be the best he would be likely to meet, and he had beaten Ely so far at Ascot (and also in the Derby) that he went to the post just a little short of being fully wound up, and this, in the opinion of his own party, lost him the race. John Osborne, on the other hand, maintains that there was no fluke about the race, and that on that particular day The Miner was a great horse.

Blair Athol never ran again, which is a matter for regret, but he was a fair stud success, not so good perhaps as was expected, however. It is true that he headed the list of winning stallions on several occasions, and that he sired a Derby and St. Leger winner in Silvio, and another St. Leger winner in Craig Millar, but bis line has not lived on as it onglit to have done, and at present it looks like going out altogether.

\section{Gladiateur's Record}

Gladiateur had probably more racing merit than Blair Athol, though the French horse did not fall in so good a year. He (Gladiateur) was bred in France, but was trained in England, and the greater portion of his victories were scored in this country. He was big, angular and plain, but was a wonderful galloper and a fine stayer, and had he not suffered a good deal from navicular disease he would probably have won even more great races than he did. As a two-year-old he won one race and was twice beaten, but he was coughing badly on the occasion of his second defeat and ought not to have run. He had only a short preparation for the Two Tlousand Guineas, and there were four better favourites at the start, but he won cleverly, and afterwards was successful in the Derby, for which the field was that year a very poor one.

After the Derby, Gladiateur went to Paris and won the Grand Prix, and later he was twice successful at Goodwood, and then won the St. Leger, though he had been very lame only a day or two before. He was thus the second horse to secure "the triple crown," of the Two Thousand Guineas, Derby, and St. Leger. He won a second race at that same Doncaster meeting, won again after that in Paris, came back to England and won the Newmarket Derby, with 9 stone iz lbs. in the saddle, but failed in very heavy going to secure a place in the Cambridgeshire. In this race he ran remarkably well, however, and it was thought by his trainer, that if Grimshaw-whose sight was very badhad come along a little earlier than he did the horse would certainly have finished in the first three.

As a four-year-old Gladiateur won the Ascot Cup, and a big event in Paris, besides taking minor races at Newmarket. 


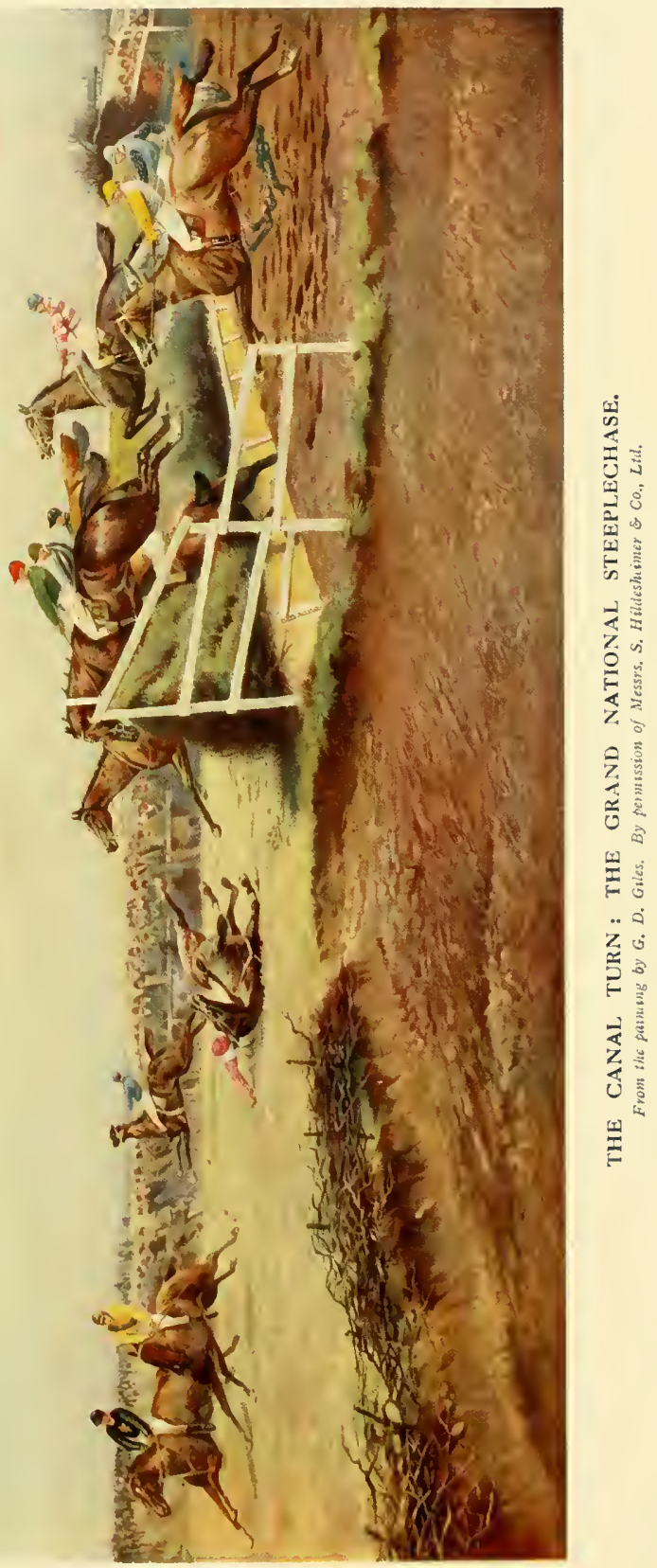



He was only beaten three times, twice as a two-year-old, and in the Cambridgeshire, and it may be added that in many of his races he showed very great superiority to all his opponents. At the stud he was a failure, and, like Plenipotentiary and other great runners, he evidently had not the power to transmit his own good qualities to his stock.

\section{The Famous Hermit}

Lord Lyon and Blue Gown were average Derby winners, but Hermit, who came in between, was a somewhat famous horse, who, for various reasons, attained a celebrity to which he was hardly entitled on his actual running. He was beaton in the St. Leger and other races, but he was a great sire, his stock winning immense sums of money. In tail male, howerer, he has been nothing like so successful as he has through his female descendants, except as regards crosscountry horses. Here his line has done wonderfully well, and Ascetic, the sire of Cloister, may be quoted as quite an exceptional horse as regards his steeplechasing sons and daughters. Nor was Ascetic the only son of Hermit to sire high-class jumpers, for as a matter of fact the calendars of the last five-and-twenty years are brimfull of the names of steeplechase winners who can claim Hermit as their grandsire or great-grandsire.

\section{Doncaster's Victories}

Pretender and Kingcraft were moderate Derby winners, and though Cremorne, who won the Derby in $18 ; 2$, took the Ascot Cup as a four-year-old, he was not a really great horse, and he did very little at the stud. Doncaster, who followed Cremorne in the bead-roll of Derby winners, was, if not quite a great horse, a very famous one. He was bred by Sir Tatton Sykes at Sledmere, and was sent to the Doncaster rearling sales, named in the catalogue All Heart and No Peel. There the late Mr. Merry bought him for $95^{\circ}$ guineas, but he was backward as a two-year-old and could not be trained.

His first outing was in the Two Thousand Guineas, when he failed to run into a place, but he won the Derby-turning the tables on his Newmarket conqueror, after having started at the long price of 45 to $\mathrm{I}$. He was beaten ten days later in the cirand Prix de Paris, and in the St. Leger he succumbed by a head to the Oaks winner, his stible companion, Marie Stuart, after a desperate race. He then temporarily lost his form, and was easily beaten at Newmarket by horses which he had defeated in the Derby and St. Leger. As a four-year-old he succumbed to Boiard, his Grand Prix conqueror of the previous year, in the Ascot Cup, but had Marie Stuart behind him. He afterwards won the Goodwood Cup, and in the following year he took the Ascot Cup and Alexandra Plate, being afterwards sold for $f \mathrm{I} 0,000$, and resold for fI 4,000 , his last purchaser being the late Duke of Viestminster.

Doncaster was a great stayer and a horse who improved with age. At the stud he sired Bend Or (the sire of Ormonde), and though there are those who think that Blair Athol was Stockwell's best son, Doncaster has strong claims to the position, and if the after stud career of both is taken into consideration, he has the best of it, as his male line is exceedingly vignrous at the present day. Indeed six Derby winners are his direct descendants, and he was the grandsire of the horse who is by many thought to have been the best of modern times.

\section{Galopin's Derby}

Two years after Doncaster came another very famous horse, who made a great mark as a three-year-old, and an even greater mark at the stud. Refercnce is made to Galopin, who won the Derby in 1875 , and who in time became the sire of st. Simon and the grandsire of all the wonderful colts and fillies which have done such great things on the turf almost within the present generation.

Galopin was bred by Mr. Taylor Sharpe, at Baumber in Lincolnshire, and was by Vedette, a county Durham bred son of Voltigeur, who won the Two Thousand Guineas in I 857. Galopin's dam was Flying Duchess by The Flying Dutchman, and it may be here stated that in after days doubts were thrown on the authenticity of Galopin's parentage, 
it being very freely alleged that the colt was by Delight, and not by Vedette. The two horses stood at the Diss stud in Norfolk, and it is unquestionable that matters were managed in very haphazard fashion at this stud, but IIr. Taylor Sharpe explained the whole position, and stated exactly what occurred, to the present writer, not once but several times, and as a matter of fact the breeder of Galopin does not entertain a shadow of doubt but that Vedette was the sire.

Perhaps, however, the strongest argument in favour of Vedette liaving becn the sire of Galopin is that the last named horse favoured the Blacklock family. He had the Voltigeur crest, and reproduced the same peculiarity in many of his stock. He had also the family colour, being a dark brown, and a generation later his son St. Simon sired a great number of colts and fillies-more especially fillies - whose quarters drooped towards the tail. Mention is made of this circumstance because a description of Voltigeur, written in his running days, describes how his quarters drooped towards the tail.

\section{Galopin's Defeats}

Galopin on the day he won the Derby was just a fraction under sixteen hands. He was well knit together, rather roundbarrelled and heary of neck, with sloping, powerful quarters, and his tail set on rather low. He presented a combination of great power with extreme quality, and he always - to us-rather suggested the Arab, as did his son Disraeli, winner of the Two Thousand Guineas in ISgS. As a yearling Galopin brought 520 guineas, being bought by Prince Batthyany, and he began his racing career with a defeat from a filly named Cachmere, who was, however, promptly disqualified for boring. At Ascot he won twice, and though he was just beaten for the Middle Park Plate he ought to have won that race also, and would have done so readily enough had he not been nearly knocked down when less than a furlong from home. As it was he was catching the leaders hand over hand from the Abingdon Dip to the winning post, but there was not quite enough room, and he was beaten by two heads.

At the Houghton meeting a fortnight later he won two races, and as a three-yearold he began by giving Io lbs. to Stray Shot in a $f 500$ match, over the Rowley Mile, at the Second Spring meeting. After this he won the Derby very easily indeed-though Claremont finished only a length behind him-and was again successful at Ascot; he next beat Lowlander in a thousand guinea match over the Rowley Mile, and he finished the season by easily defeating the St. Leger winner. Craig Nlillar, in the Newnarket Derby.

Though Galopin did not achieve the stud celebrity of his son St. Simon, he was a great sire, and was responsible for such classic winners as Donovan, Galliard, Disraeli, Galleottia, and Aida, and also for Atalanta, Corrie Roy, Galeazzo, Gantlet, Grafton, Modwena, Pioneer, and a host of others.

\section{Kisber's Failure}

Kisber followed Galopin as a Derby winner and it has often been asserted that he was a great horse. His form in this country, however, does not bear out this idea, for though he won the Dewhurst Plate and the Derby, he was easily beaten in the St. Leger, which was won by Petrarch, and as this horse also won the Two Thousand Guineas, he has strong claims to be considered the best three-year-old of $18 ; 6$.

\section{Isonomy's Great Performances}

Isonomy was the next great horse; he took no part in the classic races, being the property of a turfite to whom big handicaps appealed more than Derbys and St. Legers. Isonomy was by Sterling out of a Stockwell mare, and was bred by the Messrs. Graham at the Yardley stud near Birmingham. He was a big, upstanding horse, who showed enormous power and strength, and had fair quality. At the same time he had not the elegance of outline which such a horse as Petrarch showed, and which was so plain in Bachelor's Button a year or two 
ago. He was nevertheless a really great performer, and one of the most genuine stayers of modern times. As a two-year-old he won a single Nursery in three attempts. As a three-year-old he only ran once, winning the Cambridgeshire under 7 st. I $\mathrm{lb}$.
As a five-year-old Isonomy won the Ascot Cup a second time, and at the stud he sired, amongst a host of other good ones, Seabreeze, Isinglass, Ravensbury, and Gallinule, so that his blood is doing well at the present day. In other hands Isonomy

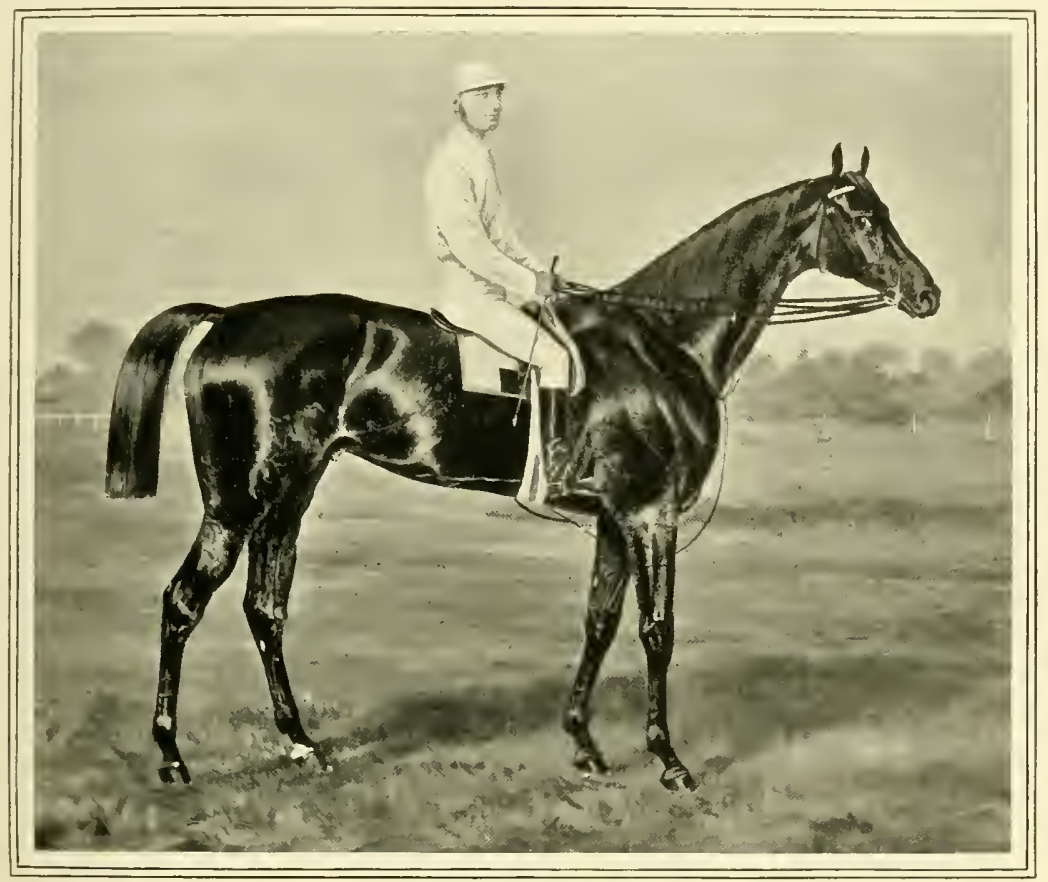

ROBERT THE DEVIL.

From a paintirg by Harry Hall. Photograph by H. R. Sherborn, Newmarket.

As a four-year-old he just failed to give 8 1bs. to the American Parole in the Newmarket Handicap, but he afterwards won the Gold Vase, and the Gold Cup at Ascot, and in the last-named race he beat all the best long-distance form of the day, including the French horse Verneuil, who had won in the previous year, the St. Leger winner Janette, Touchet, Insulaire, and others. He next won the Goodwood Cup, and in the following spring he was successful in the Manchester Cup, with the bumper weight of 9 st. I2 lbs. in the saddle, this being one of the greatest handicap performances of all time. would doubtless have won the classics of his year; as it was, he proved himself, when four and five years old, to be an exceptional horse in Cup contests.

It is impossible in such a work as this to go into full details of the careers of the great horses of comparatively recent timeshorses whose performances have been witnessed by the older generations of race-goers, and whose names are household words to the younger turfites. It will be understood that much more space than can be afforded would be necessary, even if we attempted to set forth the more important facts in 
comnection with the best of the latter-day celebrities. As it is we have to pass over a great number of high-class horses, and we have also to condense the accounts of those to whose doings we may refer.

The Derby winners silvio, Sefton, and Sir Berys were moderate, but in I8so Bend Or and Robert the Devil were probably a good deal out of the common; and Bend Or not only won the Derby and other important races, but gained great distinction as the sire of Ormonde. Mention of this has already been made when treating of the line of Eclipse, but it may be added that Bend Or and Robert the Devil were a well-matched pair of antagonists, and that whilst Bend Or beat " Robert" by a head in the Derby, the last named had his revenge in the St. Leger, and also beat his Epsom conqueror in the Great Foal Stakes, and again in the Champion Stakes at Newmarket.

\section{Robert the Devil and Bend Or}

Probably, by a majority of those who witnessed the race, it was thought that Robert the Devil, and not Bend Or, should have won the Derby. Below the distance post Robert the Devil had a lead of quite two lengths, and for a moment looked like rumning home alone. But when Archer, on Bend Or, took second place, he set to work at once, and quickly began to overhaul the leader. A jockey named Rossiter was riding Robert the Devil, and as far as jockeyship was concerned Bend Or had much the better of it. . Rossiter was undoubtedly flurried, and Bend Or just got up as the post was reached, and won by a head. With the opinion that Robert the Devil should have won we never altogether agreed. We admit the superior jockeyship, but it must be remembered that Robert the Devil was out by himself, that Bend Or challenged, and in his final rim made up a couple of lengths. The winner had not held so good a place as Robert the Devil in the early part of the race, but was travelling much the faster of the two in the last furlong. Moreover, in the following year Bend Or won the City and Suburban with 9 stone in the saddle, and six weeks later beat Robert the Devil by a neck for the Epsom Cup.

Robert the Devil and Bend Or met five times, and whereas Bend Or won the first and the last of the five races, he could not stay the St. Leger distance, and most certainly "Robert" was his superior as an autumn three-year-old. "Robert" was undoubtedly the better stayer of the two, but both were good horses, and Bend Or finished his career by winning the Champion Stakes at Newmarket (in which he had succumbed to Robert the Devil a year before) as a four-year-old, beating, amongst others, Iroquois, the Derby winner of I $88 \mathrm{I}$. Robert the Devil, on the other hand, won the Ascot Gold Cup and Alexandra Plate, after losing the Epsom Cup to Bend Or, but whereasas has been shown in a previous chapterBend Or became a great stallion, Robert the Devil was not a stud success, though his son Chittabob would probably have proved himself a great horse had it been possible to train him.

\section{Foxhall's Wins}

The American-bred Foxhall, to whom Bend Or gave 35 lbs, in the City and Suburban, was another great horse, but he did not come to hand very early as a three-year-old. In the autumn, however, he won the Cesarewitch under 7 stone I2 lbs., and a fortnight later took the Cambridgeshire with 9 stone in the saddle, this being the most wonderful performance ever achieved by a three-year-old in the race. Foxhall also won the Ascot Cup as a four-year-old, but, like Robert the Devil, he made no great mark at the stud.

\section{St. Simon and St. Gatien}

In $\mathrm{ISS}_{3}$ two great horses made their appearance, St. Simon and St. Gatien to wit. St. Simon has been dealt with in connection with one of the lines of Eclipse, but St. Gatien is deserving of some little description. This horse was bred by Major Brace, and as a two-year-old he won three rather unimportant races. He did not run again until he took part in the Derby, when he "dead heated" with Sir John Willoughby's Harvester-the stakes being divided. St. 
Gatien next beat that good mare Corrie Roy in the Gold Vase at Ascot, and in the following October he carried 8 stone ro lbs. to victory in the Cesarewitch, while a fortnight later he took the Free Handicap for threeyear-olds with 8 stone 12 lbs. in the saddle, and the Jockey Club Cup, run over the Cesarewitch course.

As a four-year-old St. Gatien won the Ascot Cup, but he did little good at the stud, being a "single speech Hamilton" style of horse. His only progeny of real worth was IIeddler, a colt bred from Busybody by the late Lord Falmouth, who won the Oaks in I88 f for Mr. "Abington" Baird, on whose death he (Meddler) was sold to go to America.

\section{Celebrities of 1886}

The still living Melton, who won the $188_{5}$ Derby, was a fair horse, but not exactly a great one. In I886, on the other hand, celebrities were numerous enough, as Ormonde was supported by Minting. The Bard, Saraband, St. Mirin, and Mephisto. Of these great horses Ormonde was the greatest, and his successes have already been alluded to in connection with the lines of blood. It may now be added that one constantly sees it stated in print that "Kendal was the only horse which ever beat Ormonde." This is a matter which should be explained, for the statement, in the form in which it is usually made, is very misleading.

\section{The Unbeaten Ormonde}

That Ormonde was never beaten in a race need hardly be repeated, but upon one occasion Kendal did finish in front of him in a home trial at Kingsclere, when both were two-year-olds, and Kendal had been already a most successful one. Ormonde, on the other hand, had not run in public, nor had he ever been previously tried, but according to " Kingsclere," by John Porter, Kendal came in a length in front of Ormonde, and the report adds that the great horse was stripped for the first time on this occasion, and was not very fit.

So far so good, but there is also written in "Kingsclere" the following significant remark, "and yet the story of Ormonde's magnificent career may be written in two sentences. He won all his engagements, and he ran practically untried." This, it must be remembered, is the statement of the man who had charge of Ormonde throughout his racing career, and it is difficult to reconcile it with the tabulated account of the trial, in which the names of the horses which took part in it, and the weights they carried, are given. As a matter of fact Porter's statement that Ormonde ran practically untried, and the account of the trial which is to be found in following pages of " Kingsclere," are contradictory, and it is a pity that no clear explanation was given.

\section{Ormonde's "Yorkshire Gallop"}

But John Porter in discussing the subject afterwards explained that the trial was only a "rough up" - what used to be called " a Yorkshire gallop" - that Ormonde had his clothes off for the first time, and that the spin was merely intended to wake him up, and not to ascertain his merits to a pound or two. In these circumstances we are of opinion that those who wrote of Ormonde having been beaten by Kendal are not altogether correct, more especially because Ormonde was not ridden out. Kendal was not, apparently, the trial horse, either, for Whipper In took part in the gallop, and Whipper In was the stable tell-tale, and absolutely reliable. In this often-referred-to gallop, Ormonde, a twoyear-old, finished in front of the six-year-old Whipper In at I $_{3}$ lbs., and this he did without being bustled.

The second sentence of the famous summing-up by the master of Kingsclere was absolutely true, for Ormonde won everything for which he started, including the three classic races of his year. About the time he won the St. Leger his trainer had discovered that he was undoubtedly going wrong in his wind, and as a fouryear-old he was a roarer. Still he did not lose his form, for he beat his old opponent Minting in the Hardwicke Stakes at Ascot, and Mlinting was a winner of the Grand Prix 
de Paris, and the hero of the greatest handicap performance of modern times-when he, as a five-year-old, was successful in the Jubilee Stakes at Kempton Park with Io stone in the saddle. This weight is the biggest which has been carried successfully in any first-class handicap of the last or the present generation. Vespasian won the Chesterfield Cup at Goodwood in I869. with ro stone + lbs. in the saddle, but the class he beat-as far as can be judged- was nothing like so good as that which Minting defeated at Kempton Park; and whereas Minting was inferior only to Ormonde, Vespasian was often beaten by horses which met him on level terms.

Minting won the Hardwicke Stakes as a five-year-old, and was undoubtedly a great horse, but was a comparative failure at the stud, whereas Ormonde sired Orme, Goldfinch, and one or two others, before suffering from serious illness.

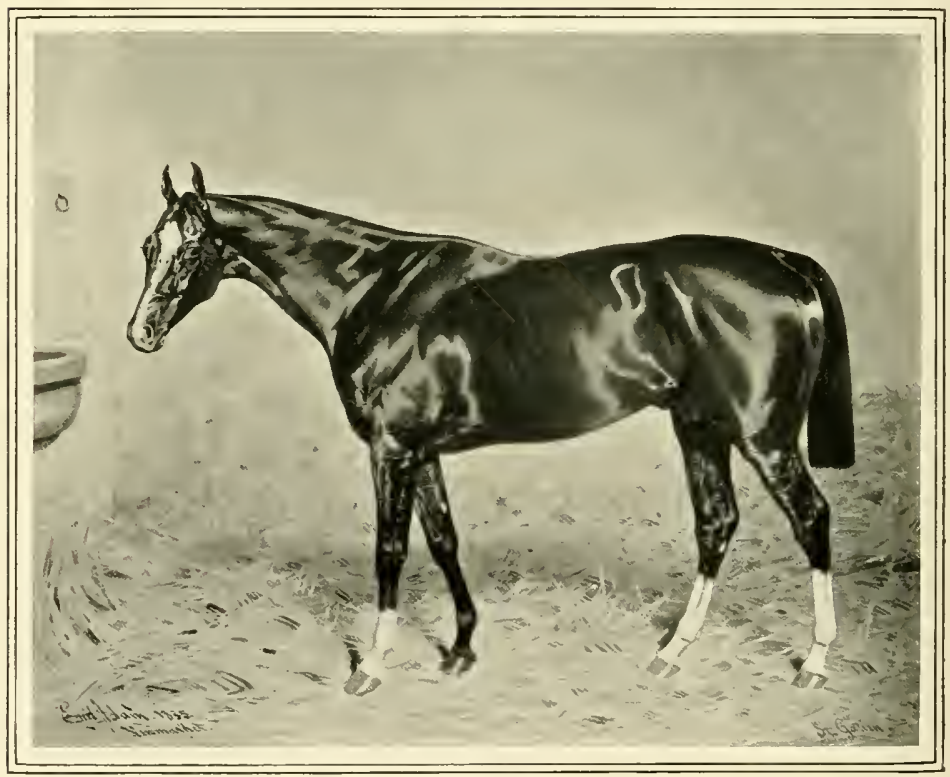

ST. GATIEN.

After the painting by Prof. Emil Adam, in the posscssion of Join Hammond, Esq, Niwnarket. Photografl by $H$. $R$. Sherborn, . Veatmonkt. 


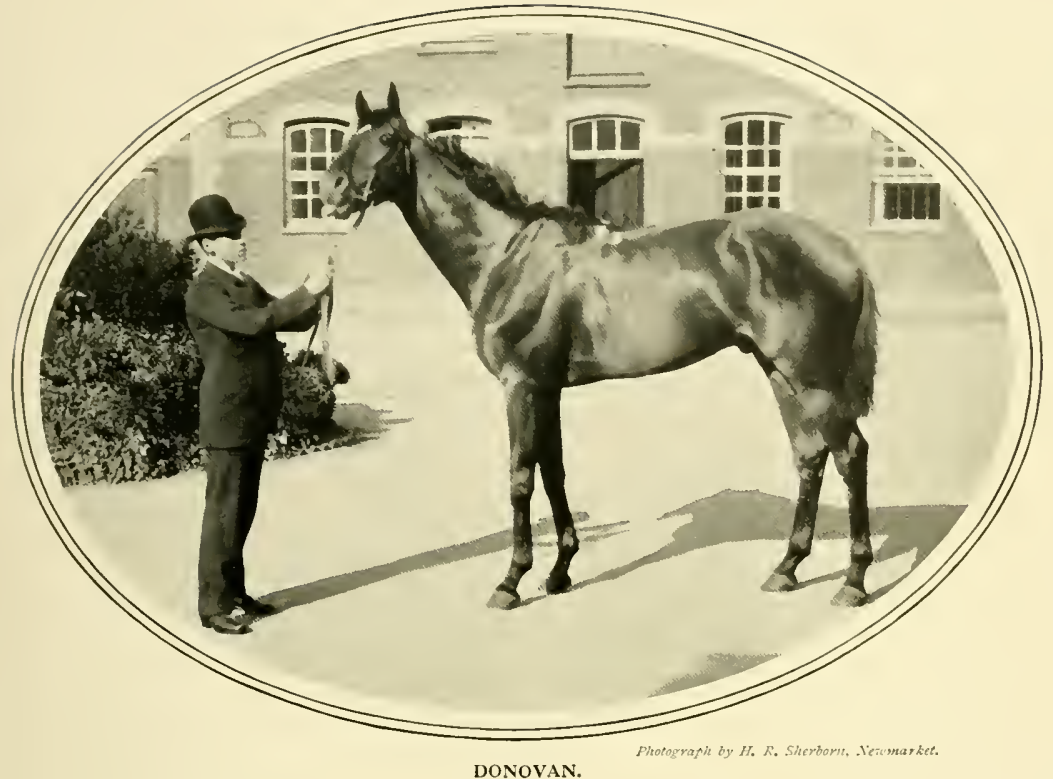

\section{CHAPTER XIII}

\section{FAMOUS HORSES (continued)}

$I^{T}$

has been mentioned in connection with the lines of blood that Ormonde and St. Simon have both been spoken of as horses of the century; which was the better no one can say. Neither of the pair was ever beaten, but whereas Ormonde came in a great year, and won the treble events of the Derby, St. Leger, and Two Thousand, St. Simon, owing to the death of his breeder, was unable to compete in the classics. Ormonde was a brilliant performer up to a mile and a half, but he went wrong in his wind and never attempted a cup course. St. Simon, on the other hand, was a great stayer, who won the Ascot and Goodwood Cup when a three-year-old, and at the stud he was the greatest success since Stockwell. On the score that he did most good to the turf St. Simon is entitled to even more posthumous merit than Ormonde, but the form of the latter was greatly enhanced because of the style in which he defeated such horses as Minting and Bendigo.

Bendigo himself was no bad representative of class. He won, amongst other races, the Cambridgeshire, the Lincolnshire Handicap, the Hardwicke Stakes at Ascot, the Eclipse Stakes, the Champion Stakes at Newmarket, and the Jubilee Handicap at Kempton, in which he carried 9 stone $7 \mathrm{lb}$. He was belored of the people throughout his racing career, and yet in that memorable Hardwicke Stakes, in which Ormonde and Minting were first and second, he was beaten by nearly fifty yards for second place. It was indeed their form with Bendigo which placed Ormonde and Minting on so high a plane, and probably if the turf world of the period had 
been polled in their running days, public opinion would have put Ormonde in front of St. Simon.

\section{Donovan's Winnings}

After these great celebrities there was -naturally enough-a drop in class, which extended over some years. Merry Hampton, who won the Derby for the late Mr. "Abington" Baird in IS87, was an exceedingly moderate horse, and his successor in Epsom honours, the Duke of Portland's Ayrshire, was just a useful sort, who has done pretty well at the stud and is still living. Donovan, who gave the Duke of Portland a second Derby in two years, was a good, but not a great horse. He is, however, celebrated because of the amount of stake money he won whilst he was in training. As a two-year-old he won eleven races worth $f_{1} 6, f^{8} S_{7} I_{5} \mathrm{~s}$, as a three-year-old he won seren races worth

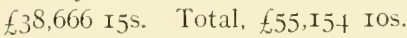

Up to this period of turf history no racehorse had ever won so much. The record did not stand long, however, for Isinglass, who won the Derby in 1893 , beat the amount by $f 2,300$ IOs., and to this day that sum stands as a record for winnings achieved by a single horse.

Donovan had a doughty opponent in Chittabob, who beat him once, but suffered so much from rheumatism that he could not be properly trained. Sainfoin was a common Derby winner in a somewhat moderate year, and Sir Hugo, who won for the late Lord Bradford in IS92, was not of the same class as Orme and La Flèche, though he beat La Flèche in the Derby, and finished well in front of Orme in the St. Leger.

\section{Orme's Bad Luck}

Orme was an unlucky horse, but a good one. He won the Eclipse Stakes twice, but was unable to run for the Derby, having been poisoned in his stable at Kingsclere. The mystery-for such it was-was never elucidated, but that the horse was poisoned is almost beyond doubt, on the evidence of his trainer, John Porter, who set out the full particulars in his book
"Kingsclere." In the St. Leger Orme was ridden contrary to orders, being raced away at the head of his field, with the result that he was done with at the final bend.

\section{A Great Mare}

As a four-year-old he beat La Flèche in the Eclipse Stakes, but the last-named was a great mare, who won, amongst other races, the One Thousand, the Oaks, the St. Leger, the Ascot Cup, the Cambridgeshire, as a three-year-old, under 8 stone Io $\mathrm{lb}$., and the Liverpool Cup as a four-year-old under 9 stone $6 \mathrm{lb}$. La Flèche also won the Lancashire Plate at Manchester, a ten-thousandpound stake which had a somewhat short life, and when sold by auction at the end of her career she brought 12,500 guineas, her purchaser being Sir Tatton Sykes. At the stud she soon recouped her purchase money, but she was hardly the great success which had been expected, though her son John O'Gaunt ran second for the Derby in Igot, and at the moment has excellent stallion prospects.

\section{The Lazy Isinglass}

Isinglass and Ravensbury, who were first and second in the Derby of I893, were good horses, especially the first-named, who, as has been explained, won more money than any other horse in turf history. He was a fine stayer, and won the Ascot Cup when a five-year-old, but he was not an attractive runner, being a very lazy horse who required to be very vigorously ridden before he would do his best. Ravensbury would have won more than he did had there been no Isinglass, but he was a good horse all the same, and the day after La Flèche had won the Ascot Cup he beat her in the Hardwicke Stakes, over the last mile and a half of the Cup course. The famous mare had her Cisp race in her, and had just been trained for a much longer course, but all the same the form places Ravensbury in a high position, and to this he was doubtless entitled.

Ladas (IS94) was a beautiful horse, and most likely a good deal the best of the three Derby winners sired by Hampton, but he was not a great horse, and the 
following year was a moderate one, when the Derby winner Sir Visto was probably not so good as Marco or Whittier. In 1806 the two best three-year-olds were exceptionally good. These were Persimmon and St. Frusquin, a well-matched pair, who were both sired by St. Simon.

\section{Persimmon's Record}

Persimmon was bred and owned by King Edward VII., and as a two-year-old won the Coventry Stakes at Ascot and the Richmond Stakes at Goodwood, but was beaten in the Middle Park Plate, the race going to St. Frusquin, while Persimmon was only a moderate third. He had gone amiss prior to the race, and this was not his true form.

In the following spring St. Frusquin won the Two Thousand, for which Persimmon did not run, and in the Derby the two drew clean away from their field, and after a desperate race Persimmon won by a neck, the victory of the Royal colours being received with the greatest enthusiasm. The two met again at Newmarket in July, when St. Frusquin, in receipt of $3 \mathrm{lb}$., beat his mighty opponent by half a length. The race was run on the Bunbury mile, and though it is quite probable that St. Frusquin was a good stayer, he never had the chance of proving his stamina, and as the record stands, the short course favoured the smaller horse. After this St. Frusquin won the Eclipse Stakes, and then, unfortunately, broke down, while Persimmon took the St. Leger with apparently a stone or more in hand, and then beat Sir Visto-the Derby winner of the previous year-most decisively in the Jockey Club Stakes.

St. Frusquin never ran again after winuing the Eclipse Stalies, but Persimmon won the Ascot Gold Cup very easily indeed, beating Love Wisely (who had won the same race in the previous year), Winkfield's Pride, and the Oaks winner Limasol. It was an electrifying performance on the part of his late Majesty's horse, and it was supplenented a month later by success in the Eclipse Stakes at Sandown Park, after which the course was exchanged for the paddock. That Persimmon was a great horse is proved by the fact that he made everything he met, except St. Frusquin, to look like a plater, and that St. Frusquin was his equal is proved by the fact that although he succumbed in the Derby he turned the tables when the terms were only three pounds in his favour. Because he won the Derby and the Ascot Cup, Persimmon should take higher rank than his great rival in days to come, for St. Frusquin had no more important races to his credit than the Two Thousand and the Eclipse Stakes.

\section{"The Horse of the Century"}

Few racing men had a longer experience than the late Mr. Joseph Osborne, who in his later days wrote very learnedly on the science of breeding. Mr. Osborne was elected a member of the Irish Turf Club when he was only just of age, and when eighty years old he edited the Horsebreder, a weekly newspaper, written chiefly in the interests of breeders, and at the same time was reproducing every second or third year a fresh edition of the "Horse Breeder's Handbook." He had owned and trained racehorses-chiefly in Ireland-had won the Grand National with Abd-el-Kader, and his opinions were to the last exceedingly valuable. The last edition of his "Handbook" was published in $\mathrm{I} 898$, and in it he wrote that Persimmon " may fairly claim to be the horse of the century, if we except Harkaway ; for, great horse as Ormonde undoubtedly was, he never ran a cup course, and it may be questioned if at any time he beat such good horses as Winkfield's Pride and Love Wisely."

\section{Harkaway's Greatness}

Mr. Osborne's belief in Harkaway never faltered. Years before he had written of him that he considered him the grandest and best horse he had seen during his (Mr. Osborne's) long career on the turf. Yet Harkaway only won twenty-five of the thirtyeight races in which he took part, and most of his victories were achieved in Ireland. He was, however, a great stayer, who constantly improved; he won the Goodwood Cup as a four-year-old, and again in the 
following year, and in England he was also successful in several minor cup races which have long since disappeared from the calendar. Mr. Osborne knew Harkaway from foalhood, and was perhaps rather biassed in his favour. But the fact is that horses which did not win any of the great cup contests, or in some other way prove themselves genuine stayers, did not altogether appeal to him, and thus to a certain extent he ignored Ormonde, because Minting, Saraband, The Bard, and others, beaten by the mighty bay, were horses which did all their big things over distances of from a mile to a mile and a half, and which never won a cup race. Love Wisely and Winkfield's Pride, on the other hand, were proved stayers, the first-named being actually that rara aris in these days, a winner of the Ascot Cup at three years old. Mr. Osborne often told the present writer that he thought St. Simon was possibly (his own word) "the best horse of all time," but that the opinion could only be a presumptive one, because he beat nothing better than Tristan, whom Mr. Osborne considered to be much below the average Ascot Cup winner, and not quite a genuine stayer. It may be that too low a view was taken of this horse, who won the Hardwicke Stakes in three successive years, but critics generally will admit that the high place assigned by " Beacon " to Persimnon was thoroughly warranted.

Following Persimmon and St. Frusquin, another very grand horse appeared in Galtee More, who won the triple crown in 1897 , and who was sold to the Russian Government for 20,000 guineas. He was a beautiful horse, but he never ran after he was three years old, and in the St. Leger he got home less than a length in front of the Oaks winner Chelandry. He failed in the Cambridgeshire, but ran well up, under the enormous weight of 9 stone $6 \mathrm{lb}$., and he is now doing well at the stud in Russia. He was a good horse, and possibly a great one, but had no real chance of proving it.

\section{Flying Fox's Close Race}

Flying Fox was the next great horse to appear, and he also secured the Two
Thousand, Derby, and St. Leger of his year, but like Galtee More he never ran after his three-year-old career was at an end. As a two-year-old he suffered two defeats, but in each case he was beaten by what may be called the force of circumstances, rather than superiority on the part of his opponents. His first defeat was administered by St. Gris in the Imperial Produce Stakes at Kempton Park, when St. Gris, in receipt of $5 \mathrm{lb}$., won by a head. The pair ran very wide of each other, and M. Cannon-who was riding Flying Fox-was on the stand side nearest the judge's box, and thought he had won. He afterwards stated that he conld have got more out of his horse had he thought it necessary, but being of opinion that he was a good head in front during the last fifty yards he did not push his mount as he might otherwise have done. The late Duke of Westminster, who bred and owned Flying Fox, entertained no doubt that he had actually won, and one can sifely say that if the number of the Kingsclere colt had gone up instead of that of St. Gris, no one would have been much surprised.

At the same time it may be stated that where two horses are finishing very wide of each other, and yet close together on a broad course, no one except the judge can say with certainty which of the two is actually in front when the post is passed.

Less than a week later the Middle Park Plate was decided, and there was a terribly strong wind blowing right up the course. As soon as the flag fell Sloan, on Caiman, dashed away with the lead, and it is to be noted that at that day the English jockeys had not by any means made it a general custom to come right through, as they now do in most short races. The upshot was that the American colt secured far too long a lead, whereas Flying Fox never attempted to go after him until the race was more than half over. Coming down the hill, when apparently nearly a dozen lengths behind, Flying Fox made a tremendous eftort, which carried him to within a length and a half of Caiman, but the challenge came too late, there being too much ground to make up. 
No pluckier race than this Middle Park Plate was ever seen, and it may be added on the testimony of John Porter, who trained Flying Fox, that the horse was not himself either at Kempton Park or Newmarket. Porter did not wish to run him in either race, and had his advice been taken it is quite be particularly well ridden in the Derby, and no doubt an element of danger was removed when the French horse Holocauste fell and broke his leg, but for all that he was practically unchallenged in the last furlong.

In the Two Thousand, M. Cannon made running with Flying Fox, and as a matter

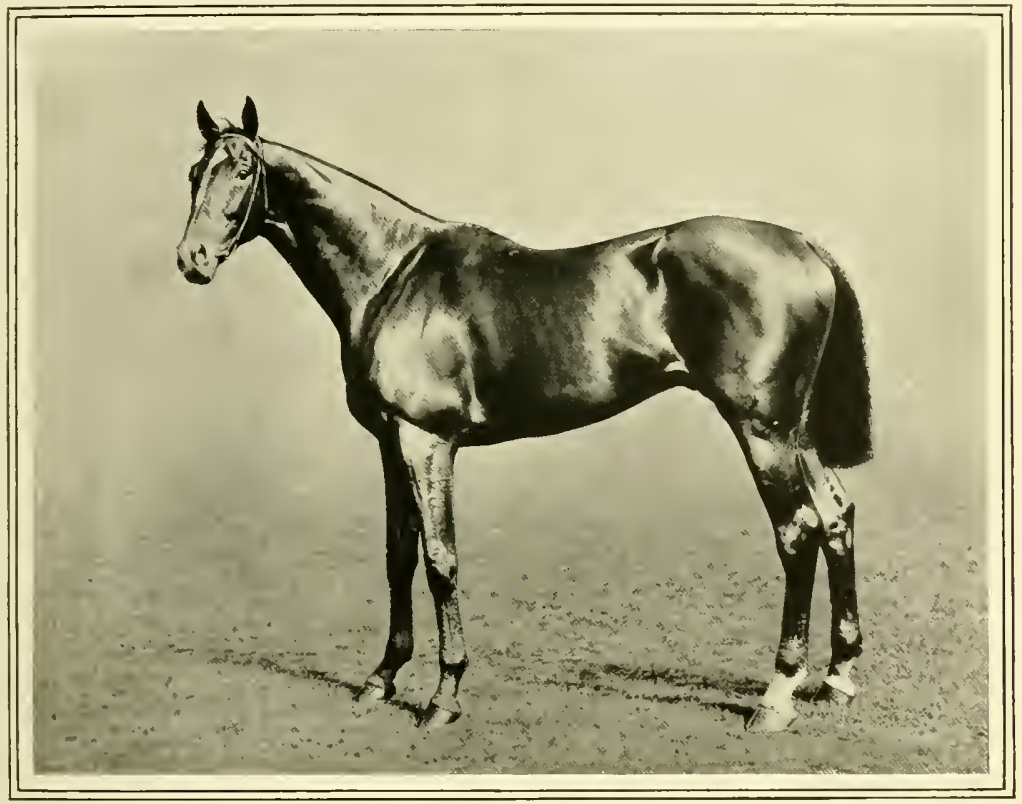

ISINGLASS IN TRAINING.

Phorograph by II: A. Rouch.

certain that Flying Fox would have retired from the turf an unbeaten horse, like his grandsire Ormonde.

Errors of judgment on the part of his jockey were, as has been explained, to a great extent accountable for Flying Fox's two-year-old defeats, but after his Middle Park race no more attempts to win by a short head were seen, and to begin with, the Kempton Park defeat was proved to be entirely wrong when the Kingsclere colt beat St. Gris - his conqueror in the Sunbury Valeby very many lengths at Newmarket. During the following season Flying Fox was out half a dozen times, and won all his races with consummate ease. He did not appear to of fact, the Kingsclere jockey, no doubt bearing in mind what had occurred in the previous year, always adopted a forcing policy with this particular horse during his three-year-old career. The upshot was that he showed extraordinary superiority to all opponents which could be brought against him. In the Princess of Wales Stakes (at that time a ten-thousand-pound race) he won so far that he was eased almost a furlong from home. He had in this race his field dead settled before they had covered half a mile, and yet he had much the worst of the weights with everything except the Oaks winner Musa. In the Jockey Club Stakes he beat Jeddah, who had won 
the Derby in the previous year, pointless, and in the following spring he was sold by public auction, at Kingsclere, for the enormous sum of 37,500 guineas, his purchaser being a French breeder, M. Blanc.

\section{Cyllene v. Flying Fox}

There has lately been a discussion as to which of the recent Derby winners was the best, and as lack of space will not allow of each of them being very fully discussed, we may pass over those whose form was obriously moderate. It must be explained, too, that during the last few years certain horses which did not take classic honours were nevertheless of very superior class, and amongst these may be named Cyllene, who won the Ascot Cup in I899, but did not run in the Derby or St. Leger. It was at one time hoped that a meeting between this horse and Flying Fox would take place, but Cyllene went amiss, and thus the mich debated question as to which was the better was never settled. Cyllene won the Gold Cup in great style, and was undoubtedly a very high-class horse, but he hardly showed the great superiority over all his opponents that Flying Fox did throughout his threeyear-old career. The Derby winners Cicero, Ninoru and Lemberg are sons of Cyllene.

Diamond Jubilee, who won for the late King (then Prince of Wales) his second Derby in I900, was a handsome big horse, and a triple crown hero; but the next really high-class horse to take Epsom honours was the Irishbred Ard Patrick, by St. Florian (a son of St. Simon), and this horse's great worth is proved by the fact that he showed himself better than Sceptre, first in the Derby, and then as a four-year-old in the Eclipse Stakes.

\section{Sceptre the Extraordinary}

Sceptre was an extraordinary mare; she won four of the five classic races-both the Guineas contests, the Oaks, and the St. Leger to wit-but she missed the Derby. Fillies in the Derby week are by no means always trustworthy, and it is quite certain that Sceptre's rumning in this particular race was all wrong, but the Eclipse stakes of the following year suggested that Ard
Patrick had fairly won the Epsom race on his merits, and it need only be added that this horse and Sceptre were both (in their year) far above the average three-year-old in point of merit. In the Eclipse Stakes of I 903 these two drew right away from Rock Sand-the Derby winner of that year-and though the official verdict was to the effect that there were only three lengths between the second and third-Sceptre and Rock Sand -the distance was in reality far greater. Indeed this was fully proved by the instantaneous photographs of the finish which were taken at the time.

"A length" in this connection is generally estimated at from nine to ten feet, and as the Sandown course is guarded with posts and rails of equal length between it was a simple matter to prove that the official verdict was very wide of the mark. As a matter of fact when the point was being arguedsome time after the race-we, being in the neighbourhood of Sandown Park, measured the rails, and having reckoned up the number of uprights in the photograph, came to the conclusion that Ard Patrick and Sceptre finished eight lengths in front of Rock Sand. The last named was an honest little horse and a consistent performer, but he was outclassed by the longer striding Ard Patrick, and by Sceptre-when she was at her best.

\section{Pretty Polly's Success}

The best horse in Volodyovski's year was William the Third, who won the Ascot Cup and Alexandra Plate in Igoo, and the next really good one was Pretty Polly, who won the One Thousand, Oaks, and St. Leger in Igot. This mare was a veritable champion, but she was twice beaten, viz. in the Grand Prix de Paris, and in the Ascot Cup as a five-year-old, by Bachelor's Button. Otherwise she went through her racing career in exceptional style, and it will be remembered of her that when she made her début at Sandown Park, she so quickly established an extraordinary lead that nine people out of ten thought she had broken the tapes and come away by herself in a false start. Though a most consistent performer, and, 
except in the two races referred to, a very gallant winner, it is open to doubt whether Pretty Polly was any better than Sceptre. One cannot fairly compare horses of one day with those of another, and as far as consistent running is concerued, Pretty Polly has much the best of the argument, but lier lines were cast in easier places than those of Sceptre, and she was (probably) never opposed by such a horse as Ard Patrick.

Sceptre was one of those fillies whose correct form can only be gauged on her very hest rumning, whereas Pretty Polly can be judged on all her form. Sceptre was extremely brilliant at times, and yet occasionally performed almost indifferently. Pretty Polly was a quiet, sleepy-looking, and apparently almost a sluggish mare, while Sceptre was full of vitality, all on pin-wire, and when really at her best almost an clectrifying performer. In point of fact her runuing was more attractive than that of Pretty Polly, and there we may leave it.

Since Pretty Polly's day the only othes. classic wimner of really high class (to the end of IgoS) was Spearmint, who won the Derby and Grand Prix de Paris in Igo6. This horse has claims to be considered one of the very best of the recent Derby winners, and yet it is quite possible that he has been a little overrated in some quarters.

\section{Spearmint's Derby}

Spearnint was on the book a moderate two-year-old, who only won a single race in three atteinpts. He began his career by winning the Great Foal Stakes at Lingfield, and after that Black Arrow gave him 3 lb., and beat him in a canter by three lengths at Derby. His last outing as a youngster was in the Richmond Nursery at the Newmarket Houghton Nleeting, and in this race he could only finish fourth to Farasi, Queen Camilla, and Chiltern. It is true that he was giving weight away, but Farasi had not more than i7 lb., and Queen Camilla is lb., the best of the terms, and to such horses a tuture Derby winner should have given stones instead of pounds. As a three-yearold, Spearmint only ran in the Derby and in the Grand Prix, and his clains to greatness are chiefly because he beat, in the Derby many horses who greatly distinguished themselves later.

As a matter of fact the field for the Derby of Igo6 was a very good one, when judged from the only possible point of view, viz. the number of previous and of future good winners which it contrined. It included Gorgos, who had previously won the Two Thousand; Lally, who had beaten Gorgos in the Newmarket Stakes, and who in the following year won the Eclipse Stakes and Hunt Cup at Ascot under 8 stone; Troutbeck, who subsequently won the St. Leger; The White Knight, who afterwards won the Gold Vase, two Ascot Gold Cups, the Goodwood Cup, and two Coronation Cups at Epsom; Radium, who subsequently won the Goodwood, Doncaster, and Jockey Club Cups; and Beppo, who won the Hardwicke Stakes at Ascot when a four-year-old.

\section{Troutbeck and the St. Leger}

There can be no disputing the strength of this field, but if we look into the form it is possible that all of them have been overrated. A horse nained Picton was second to Spearmint in the Derby, beaten by a length and a half, and he in turn finished two lengths in front of Troutbeck. Picton never ran again, and Spearmint only took part in the Grand Prix, and then retired from the turf. Thus the two first in the Derby were unable to contest the St. Leger, and Troutbeck, who had finished third in the Derby, easily pulled off the Doncaster race, in which neither Radium nor The White Irnight took part, while the Oaks winner, Keystone II. was decidedly short of work. In this st. Leger Troutbeck got home a head in front of a horse named Prince IVilliam, who in turn beat Beppo by a head, with lieystone II. close up fourth. Troutbeck and Keystone II. did not meet again, but in the Jockey Club Stakes-three weeks after the St. Leger - Keystone II. gave Beppo I 2 lb., and ran him to a length, while Polymelus, a great exponent of handicap form, was unplaced. A few weeks later Kieystone II. and Prince William (who had only lost the St. Leger by a head) met in the Sandown Produce Stakes 
of a mile and five furlongs, and Keystone II. won very casily, finishing, according to the official verdict, five and a half lengths in front of Prince William. This was fairly conclusive proof that Troutbeck was an exceedingly lucky St. Leger winner, and few will gainsay the suggestion that Keystone II. was really the best of the St. Leger field, or that she would have won had she not been stopped in her work for a time very shortly before the race.

Now we come to 1907 , and it may at once be stated that Keystone II. could not be properly trained, and never reproduced her two-year-old form. The first and second in the Derby were now out of training; the winner of the Oaks had gone off, and there were very few five-year-olds of much class. But all the usual weight-for-age races were still on the programmes, and something had to win each of them as they came on for decision.

It happened then that The White Knight was the successful cup horse of the year. He won the March Stakes at Newmarket. and in the Coronation Cup at Epsom he very easily defeated Troutbeck, the only winner of the previous year who was then in a position to defend the classic form. Polymelus was also beaten in this race, but his good form was for the most part slown in handicaps and not in weight-forage races against the best of the year. At Ascot The White Knight won the Gold Cup only after a dead heat with the French horse Eider; and Troutbeck and Prince William-first and second for the previous St. Leger-were the two last to finish in a

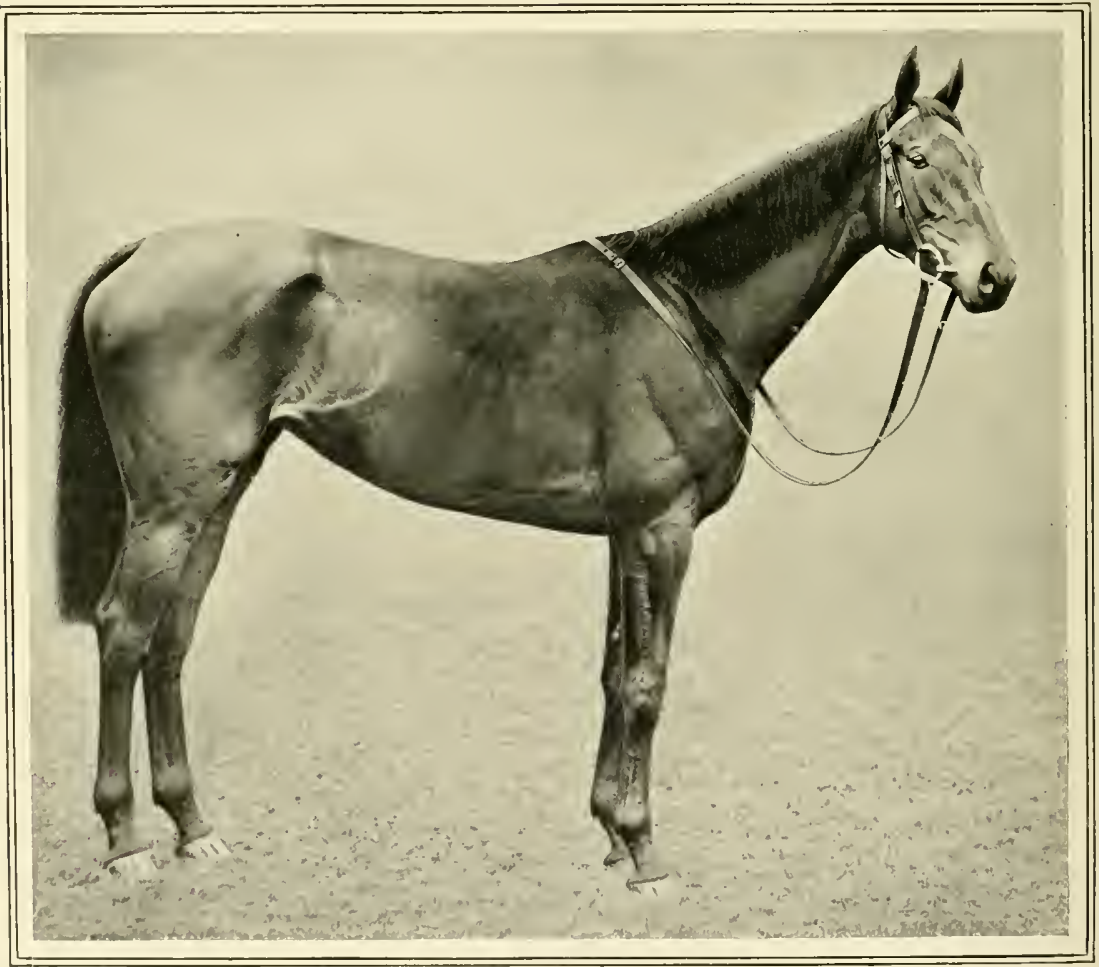




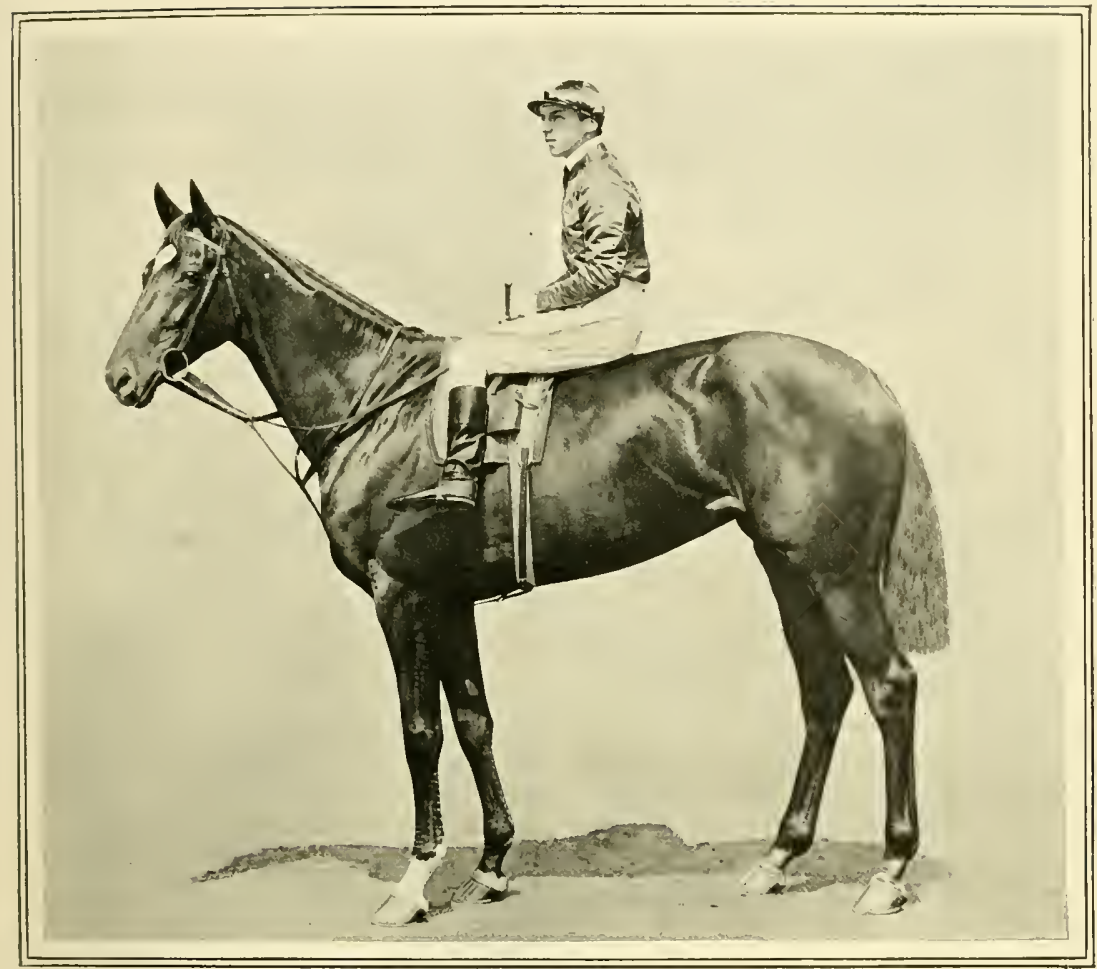

PRETTY POLLY.

field of eight. At Goodwood The White Knight also won the cup, but in the Doncaster Cup he could do no better than finish third to Velocity, another handicap horse, but all the same an exceptionally good one. Radium was unplaced in this race, but six weeks later he won the Jockey Club Cup, beating The White Knight. There was no Velocity in this field, however, and in point of fact another handicap nag and ex-selling plater, by name Torpoint, was the only other runner.

In Igo8 The White Knight carried all before him up to the middle of the season, beating Radium at Epsom and Ascot, but at Goodwood, where Radium had a big pull in the weights, he was the better of the pair, and again at Doncaster. Careful analysis of all the races in which the horses beaten by Spearmint in the Derby took part reveals the fact that there was no very strong opposition. The cup races of the following year had to be won, and as the first and second in the Derby were out of training, and the Oaks and St. Leger winners had trained off, it was only natural that horses which had hardly been in the front rank when three-year-olds should come to the front. It may be added that the best three-year-olds of 1907 were, from one cause and another, unable to contest the cup contests of the following season. Orby broke down within a few weeks of winning the Derby, Slieve Gallion had been sold out of the country, while Witch Elm and Glass Doll, respectively winners of the One Thousand and Oaks, had both joined the ranks of the unemployed. The one big three-year-old winner of the year, Woolwinder, ran very early in IgoS, when 
half prepared, but that was his only appearance of the season, for, unfortunately, he could not be properly trained. Therefore, as The Ihite linight and Radium were still sound and in training, and as Velocity was no longer a possible opponent, the two horses just referred to had a second year of cup ruming, and between them farmed all the most important weight-for-age, long distance contests of the season. Spearmint, of course, won the Grand Prix de Paris, but it is not an easy matter to get at the real value of the horses he beat, and we are assured by a well-known French turfite that they were not a very high-class lot.

\section{Spearmint's Position}

That Spearmint was much above the average Derby winner in point of merit there is every reason to believe, but he hardly did enough to prove that he was an exceptional horse. He was beaten twice in his three starts as a two-year-old, and he won two races in the following spring, but he only beat Brisecreur by half a length in the Grand Prix, and Storm, who finished two lengths behind him, made no show whatever in the St. Leger. Neither was there anything electrifying about his defeat of Picton and Troutbeck in the Derby, and Picton, who ran second to him in that race, had just previously been beaten by Sarcelle at Newmarket. Neither was this same Picton thought to be a great lorse by his connections, proof of which is afforded by the fact that he was quoted at a long price before the flag fell at Epsom. It is true that Spearmint has the credit of haring beaten Pretty Polly in a trial, but it is possible that Pretty Pully as a five-year-old was not so good as she had been, for she was beaten shortly afterwards by Bachelor's Button in the Ascot Cup.

\section{Flying Fox's Record Price}

Flying Fox, on the other hand, showed himself about a stone in front of anything of his age, and in one or two of his racesfor instance in the Princess of Wales Stakes at Newmarket-he had his field utterly demoralised before half the distance of the race was covered. Ard Patrick has claims to be considered almost on a level with the best Derby winners of the last ten years, more particularly because of what he did with Sceptre and Rock Sand; but, as has been suggested, Sceptre was a peculiar mare, and even now it is open to doubt whether she was anything like at her best on either occasion of her being defeated by the Irish horse. But perhaps the strongest argument in favour of Flying Fox is the fact that he was sold for the greatest price which has ever been given for a horse. Ard Patrick was sold, too, but his price was not much over $\{20,000$, whereas Flying Fox made nearly double the amount. This, it must be acknowledged, is very strong evidence that Flying Fox stood higher in the public estimation than did Ard Patrick for after all " money speaks," and in the case of the Kingsclere horse it spoke much more volubly than it did concerning the Irish horse. Flying Fox is, in our opinion, fairly entitled to be considered the best Derby winner since Persimmon, and Ard Patrick may hold a rather higher place than Spearmint, because the first-named horse beat the brilliant Sceptre, while Spearmint never, in his short career, met any horse or mare of anything like such class.

\section{Signorinetta's Surprise}

Other recent Derby winners hardly demand recognition, and Signorinetta in wimning the race in Igo8 afforded one of the greatest turf surprises which has ever been known. The Chevalier Ginistrelli's filly had, as a two-year-old, been four times beaten, and had won a solitary nursery with no more than 6 stone $3 \mathrm{lb}$. in the saddle. The average racing man probably considered ler a plater: and not even a plater of very high class, but she won the Derby and Oaks, and in the first-named event fairly wore down horses who turned the tables on hel a little later in the season. The victories of Signorinetta have ince been regarded as flukes by many critics of racing, and at the present time of writing it rather looks as if the contention was true, but it is possible that such a fine stayer may assert 
herself at the stud; and anyhow the Epsom sucesses of the mare are a very direct encouragement to the small breeder. The success of the late King's Minoru in Igog was most satisfactory, but it is too early to state with confidence whether the colt is a really great horse or not, and already some of the subsequent running suggests that the three-year-olds of Igog were not much above the average.

\section{Famous Mares}

There is no space in which to discuss the doings of many of the horses whose principal victories were achieved in cups and handicaps. Even the more modern ones, such as Bendigo, Victor Wild, Ypsilanti, and so forth, must be passed over, and only the briefest mention can be made of the famous mares which have not been referred to hitherto. Mares of the highest class as runners are not quite so plentiful as horses. When a really good mare does appear she is as a rule almost unbeatable, but it should always be borne in mind that the average mare is more difficult to keep in perfect health, or rather to keep in perfect condition for running, than the average horse. It is no easy matter to have mares at their best in the spring, and for that reason very few of them are ever to be found in the Derby field. Such races as the One Thousand and Oaks, being confined to mares, will, as a rule, bring out large fields, but the owners of good fillies are shy of running them against colts in April, May, and June, as they may very easily be upset and lose their form in consequence.

Only four fillies have won the Derby, and one of these, Shotover, was beaten by another filly, Dutch Oven to wit, in the St. Leger. Yet I 882 was essentially a filly's year, for Shotover won the Two Thousand as well as the Derby, and in the St. Leger the first three places were filled by the fillies, Dutch Oven, Geheimnis, and Shotover. Eleanor won the Derby and Oaks in ISoI, and though one cannot find much written in her praise, it is only fair to assume that she was an exceptional mare. Fleur de Lis, who won the Goodwood Cup in 1829 and 1830 , was, accurding to such evidence as is witlin reach, a very grand performer, and so too was dice Hawthorn, who was successful in the same race in $I 8+4$, and who afterwards founded a most successful family of racehorses. Queen of Trumps, winner of the Oaks in 1835 , was a useful mare, whose name figures in the pedigree of many good horses, and Crucifix, who won the Two Thousand, One Thousand, and Oaks in I $84^{\circ}$, and afterwards bred the Derby winner Surplice to Touchstone, was a very great mare, being not only a brilliant but a most consistent runner.

\section{Virago's Successes}

About Virago, who won the City and Suburban and the Metropolitan in the same afternoon in $185+$, much has been written, and there are turfites still living who remember her well. She was a cheap mare to begin with, but a great runner, and besides the races already mentioned, she won the Doncaster Cup, the Great Northern Handicap, and the Yorkshire Oaks at York, the Nassau Stakes at Goodwood, and other. events. Mr. George Hodgman, in his " Sixty Years on the Turf," wrote: "If my opinion were asked I should, after careful thought of all the magnificent fillies I have watched seek turf honours, unreservedly place Virago on the highest pedestal." This was written some years before Sceptre and Pretty Polly had appeared, and was the opinion of a consummate judge who all his life has closely watched the running. Nor has the advent of the two celebrities which have just been named in any way altered Mr. Hodgman's ickeas, for he is still strongly of opinion that Virago was the best of her sex which has appeared within the last sixty years.

Another great mare was Achierement, whose three-year-old form was especially good, in spite of the fact that she was beaten by Hippia in the Oaks. She won, however, the Great Iorkshire Stakes, the St. Leger, and the Doncaster Cup within a fortnight, and in each of the two last-named races she beat the Derby winner Hermit. Marie Stuart, who beat the Derby winner Doncaster 
for the St. Leger of 1873 , was an exceptional mare, and so too was Apology, the Oaks and St. Leger winner of the following year. Then there was Wheel of Fortune, who won the One Thousand and Oaks in 1879 , but broke down before the St. Leger of her year, and Seabreeze, who beat the Derby winner Ayrshire in 1889. But a probably better filly than either of these St. Leger winners was La Flèche, who won the St. Leger in 1892 , and to whom previous reference has been made. Since La Flèche's day Pretty Polly and Sceptre have been the greatest fillies, but there is no need to go at length into their performances, which have been treated of a few pages back.

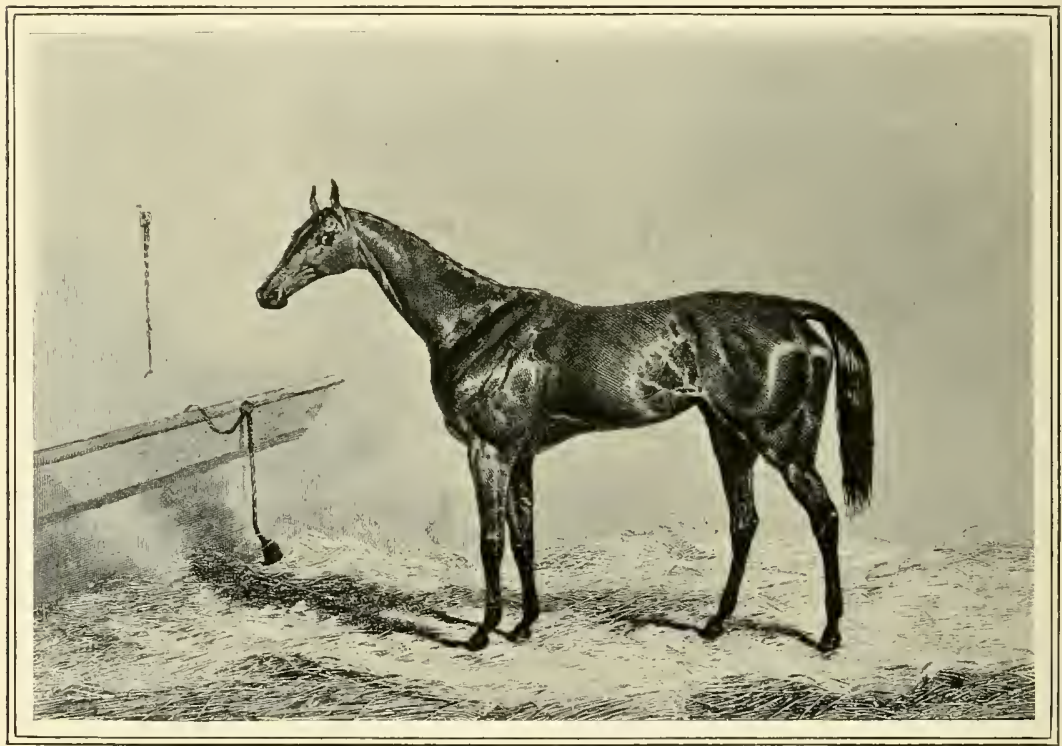

CRUCIFIX:

From the engraving by $J$. $R$. Scott after the original by $H$. Hall. 


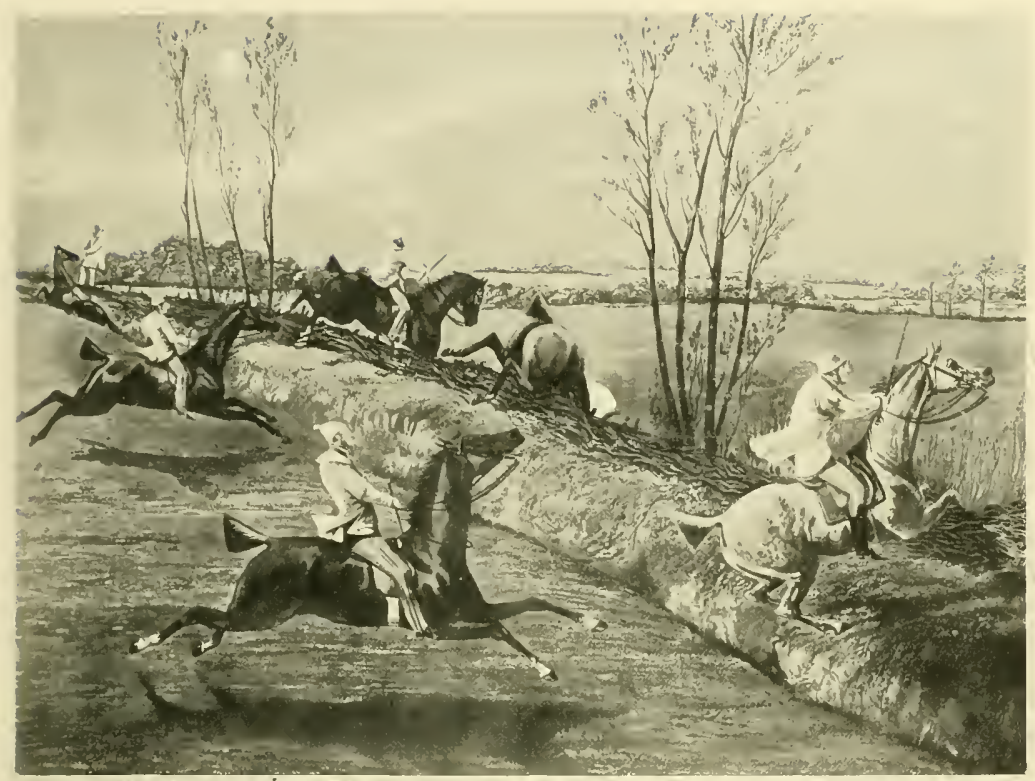

THE SO.CALLED "FIRST STEEPLECHASE ON RECORD : THE LARGE FIELD NEAR BILES'S CORNER." After the drawing by $H$. Alken.

\section{CHAPTER XIV}

STEE P L E C H A S I N

$S^{\mathrm{i}}$ TEEPLECHASING is a much more modern sport than flat-racing, being little more than a hundred years old-though there is a well-founded tradition that a race across country was held in Ireland as long ago as I752. In the family of O'Brien of Dromoland, there is, or was some time ago, an interesting document which gave particulars of a match over four and a half miles of country. The parties to the match were Mr. O'Callaghan and Mr. Edmund Blake, and the course was from Buttevant Church to St. Leger Church. As to what was the amount of the stake or how the race was won no particulars are given, nor is it even known which of the two opponents was the actual winner.
Mr. Hore, who wrote a valuable history of Newmarket, says that steeplechasing was known in the time of James I., but there is no really reliable evidence to this effect, and the Irish race referred to-if it actually took place-can fairly claim to be the first of its kind of which there is any record. The course of this Irish race, be it noted, was from one church to another church, and certain it is that the word "steeplechase" was derived from the fact thatno matter where the start might be-the finish of these early cross-country races was in the immediate neighbourhood of a church steeple.

If one thinks of it it is no easy matter to descry an object something like four miles away, and as all the early steeplechases were 
run from one point to another it can be easily understood that a church steeple would be scen-especially if the church were placed upon high ground-when other objects would be hidden from view. It is plain enough that flags to mark out the course were not used at first, but it is also reasonable to assume that some at least of those who took part in very early steeplechases would have some knowledge of the country they rode over.

\section{"The First Steeplechase" Myth}

The late Mr. W. C. A. Blew made considerable research into the records of the past with a view to ascertaining when and where the first steeplechase was rum. He was inclined to think that "the first steeplechase on record " as depicted by Alken, and constantly reproduced at the present day, was a myth, or a joke on the part of the painter. Reference is made to the set of pictures which show a number of soldiers, with nightshirts over their regimental clothes, and with nightcaps on their heads, riding across country by moonlight. It has in more recent times been claimed that this steeplechase took place in many districts where cavalry were quartered, and Mr. Blew gave the date-if there ever was a date - as I803, but the newspapers and magazines of that day are silent as to the affair, and the only reference to it in older sporting literature appeared in the Sporting Magazine many years later.

This account was to the effect that the steeplechase was originated during mess at the Ipswich barracks, but the name of the cavalry regiment quartered there at the time was not given. There is, however, a graphic account of the circumstances which led up to the race, but it is quite certain that when the account appeared, the race, if it ever did take place, was a thing of many years before, and the conversation which took place before it, and which was recorded at length, can hardly have been remembered so that it could be set forth as it appeared in the Sporting Magazine.

The evidence, or rather the want of evi- dence, favours Mr. Blew's idea that the whole thing was a myth, and anyhow there had been many cross-country races before $\mathrm{I} 803$, though most of them were matches. The fact is that in the early part of the eighteenth century, riding across country was not much indulged in. Everyone rode, however, and hunting was taken seriously in hand after hawking began to die out. But for long enough the horse was looked upon as a means of allowing the hunter to keep near his hounds, and the pleasures of riding across country were perhaps not thoroughly realised. The country was far more open than it is now, and for hawking an open country where there were no small enclosures was preferred. But throughout the eighteenth century great advances in farming were being made, and many thousands of acres of open country were enclosed -which means that they were laid out in fields, large or small as the case might be.

\section{Change in Hunting Conditions}

Hunting folk, in those days the noblemen, squires, parsons, and probably a few of the well-to-do farmers, soon found out that in an enclosed country it was impossible to follow hounds unless the fences were jumped. About this time, too, there began to be a great improvement in the native breeds of lighter horses, owing to the importation of a great number of Arabian and other Eastern stallions. The average country horse with a strain or two of Eastern blood gradually took the place of the heavier sort which had been used for hunting in its very earliest days, and these horses of lighter breed were quickly found to be more suitable for following hounds. They had not only much more pace than the heavy horse, but they were more easily taught to jump, and were able to spread themselves, and so negotiate a brook, or any sort of wide jump, in a manner which was probably unknown before the introduction to the country of Eastern blood.

It is a fact that the better bred a horse the better jumper he is likely, with proper schooling, to become. An underbred horse, who is not necessarily a cart borse, but who 
is not far renosed from it, will often jump a fair height, but as a rule he cannot cover any great distance of ground when he jumps. Many heavily built, half-bred horses will jump timber, a wall, or anything which merely requires an up and down jump, well enough, but will fail at a fence and ditch, which is wide rather than bigh, or at a brook which is anything like ten feet across.

But once the horses were good enough to cross an enclosed country at a fair pace, and jump all the fences as they camse, the spirit of rivalry entered into their owners, and cross-country, or steeplechase matches were made.

\section{Early Steeplechases}

The first steeplechase which was not a match between two horses of which there is any record took place in Leicestershire in 1792 , the competitors being Lord Forester, Sir Gilbert Heathcote, and Mr. C. Mernell, a son of the famous Hugo Meynell who hunted what is now the Quorn country for a period of about fifty years. The course was from Barkby Holt to Billesdon Coplow and back, a distance of about eight miles, and Mr. Meynell won, while Lord Forester beat Sir Gilbert Heathcote for second place.

In the same year (I792) there was a thousand-pound match in Leicestershire, from near Melton Mowbray to Dalby. Wood, between horses owned by Mr. L. Hardy, and Mr. Willoughby (afterwards Lord Middleton), and at the time hunting what is now known as Lord Middleton's country. Mr. Hardy put up his valet, and Mr. Willoughby his whipper-in, and the valet won, owing, it is said, to his wonderful knowledge of the country.

The next important record refers to Ireland in 1793, when there was a steeplechase at Ballyshamon on the 3rd of January. It is said that the stake was $f 25$ each, that four horses started, and that one of the conditions was that there should be a six-foot wall in the course. One of the horses - so the account says-was ridden by a light boy, who when he came to the wall jumped off, got his horse to go oser the wall riderless, remounted on the far side, and eventually won. Of the other three one cleared the wall, and two refused, and there was an appeal to the Irish Turf Club as to whether the horse which went over riderless was entitled to the stake-but history does not state which way the decision went. The story may or may not be true, but the height of the wall must, under any circumstances be taken cum grano salis, for though a high jump of over seven feet has been cleared at Olympia several times, a slanting slow jump obstacle of that height would hardly be more formidable than a six-foot wall in the open country, especially when such a jump was encountered in the middle of a race.

\section{The First Course Steeplechase}

At Bedford, in $18 \mathrm{ro}$, there was decided what was probably the first steeplechase over a made course of three miles, in which there were eight fences, built up four feet six inches high, with a strong bar on the top. The race was rum in heats, but of the eleven subscribers only two went to the post, the winner being Fugitive, who was ridden by her owner, Mr. Spence. It is worthy of note that Fugitive, and Cecilia, whom she beat, each had a certificate gained by being in at the death of three foxes in Leicestershire. It is said that this race took place in the presence of a crowd of fo, $^{\circ}$ oo people.

Three years later there was a weight-forage steeplechase in County Roscommon, for a stake of $f r o o$, and in the course of six miles were six walls, each five feet high, and several wide ditches. There were half a dozen runners, and a four-year-old named Young Blacklegs was the wimner.

\section{The St. Albans Steeplechase}

Organised steeplechase meetings were first held near st. Albans, the organiser being Ir. Thomas Coleman, innkeeper and farmer, who before that had been a race-hrorse trainer, who had met with a fair amount of success at the country meetings. He still liad horses under his care, when he built the Turf Hotel (at St. Albans), on the site of the 
olcler "Chequers," which he pulled down. Coleman was also a stage-coach proprietor, and the Hertfordshire Hunt Club had its headquarters at his hotel, so that all things considered he was in a good position to secure the patronage of turfites.

There is, however, no need to go further into the history of the St. Albans trainer, and it can now be stated that some officers of the Ist Life Guards, when dining at the Turf Hotel one day, conceived the idea of a steeplechase meeting and left all the details to Coleman. The race duly came off in 1830 , a field of sixteen doing duty over a course which began near Harlington Church, and ended at the Obelisk in Wrest Park, the winner being Lord Ranelagh's grey horse Wonder, ridden by Captain MacDowall, while Lord Clanricarde's Nailer, steered by his owner, was second.

\section{The Grand National}

The St. Albans steeplechases set the fashion, and a year or two later cross-country races took place in many parts of the country. Steeplechase jockeys, both amateur and professional, quickly came into being, and throughout the 'thirties the sport took strong hold of the people. At Liverpool two steeplechases were decided on the $29^{\text {th }}$ of February, 1836 , and three years later the First Grand National took place over the Aintree Course, the winner being the famous Lottery, ridden by the even more famous Jem Mason. There were seventeen runners, and all the horses carried the same weight. In IS fo there was a high stone wall in front of the stands, and this is shown in the first set of pictures of the Grand National -dated I855-but curiously enough the artist has made the peculiar mistake of making the lawns between the stand and the course quite empty. The stands are represented as crowded, and on the flat-race course between the steeplechase course and the lawn is a solitary old gentleman, very probably the clerk of the course, on a white cob; but the intervening space, which, during the race, would have been black with people, is de- picted as a green sward, with not a living creature on it.

In ${ }^{8} 8_{3}$ the race became a handicap, and was won by Lord Chesterfield's Vanguard, with Tom Oliver in the saddle, and in $I \delta_{4} 8$ the race was won by Captain Little's The Chandler, who carried II stone I $2 \mathrm{lb}$., and was ridden by his owner. The Chandler was almost as famolis a horse as Lottery had been a few years before; he won races all over the country, and in the Warwick Hunt Cup of $18+6$, he cleared a distance of thirty-seven feet, the jump being considered to the present day to be the biggest of which there is any authentic record.

Peter Simple, who won in $18+9$, and again in 1853 , was the first double winner of the race, but he had only accomplished one half of his double event when Abd-el-Kader came on the scene, and this little horse won two years in succession-I850 and $18_{5} \mathrm{I}$ so that he actually completed his double before Peter Simple. When Abd-el-Kader gained his first victory the starters numbered thirty-two, and this number was never equalled until I909, when the French horse Lutteur III. finished at the head of an equally large field. Abd-el-Kader only carried 9 stone $\mathrm{I} 2 \mathrm{lb}$., and ro stone $+\mathrm{lb}$., on the two occasions of his winning, respectively, and thus it is evident that a different system of handicapping to that which prevails at the present day was then adopted.

\section{The "Little Abd-el-Kader"}

Any horse who wins with a low weight at the present time is quite certain to be put up a stone, or even more, and even horses which are placed, or who finish well up with the placed horses are often raised. Tet Abd-el-Kader was only weighted $6 \mathrm{lb}$. higher in the race which followed his first victory. He was a little horse, standing under $15^{-2}$ hands, and his breeder and owner was the late Mr. Joseph Osborne, of whom mention has been made in an earlier number as a great authority on breeding and pedigrees. Mr. Osborne bought the dam of the double Grand National winner, out of a Shrewsbury coach, for 50 guineas; she was only a half-bred mare, but she won 
steeplechases and bred an exceptionally good little horse, who, if not orer-weighted, could stay for ever, and who always jumped like a stag. On the second occasion of his winning, Abd-el-Kader only got home by "half a neck" in front of Maria Day, and a rear later he looked very dangerous until he fell when leading between Becher's and Valentine's Brooks.
They had to jump out of heavy ploughed land, over a rail beyond which was a hedge, and beyond that again a brook six feet in width.

Conrad crashed through the timber, and fell into the water, and Captain Becher lay quiet under the fence as the other horses jumped. When all danger was at an end he crept out, remounted, and went on in

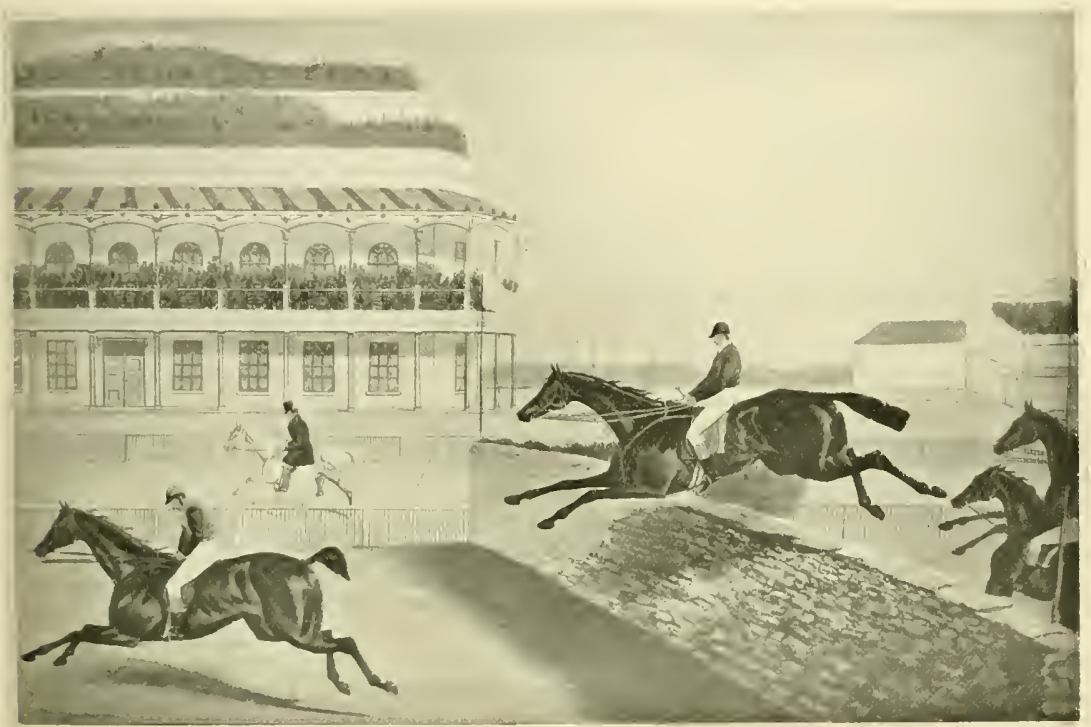

THE GRAND NATIONAL OF 1855.

From an engrating, stowing the wall in front of the Grand Stand.

The question is often asked why the obstacles which have just been referred to were so named, and it may be explained that Becher's Brook was named after Captain Becher, the most famous steeplechase rider of his day, who had an extraordinary escape at this particular fence. Captain Becher won the first Liverpool Steeplechase on The Duke in 1836 , but the race was not then called the Grand National; three years later, in the first actual year of the race, he had the mount on Conrad, and made running over the first half-dozen obstacles. His mount was, however, a rushing brute, and at the particular fence which has since been called "Becher's" he came to grief pursuit of his field, but the brook has been known as "Becher's" ever since. In these days Becher's Brook is innocent of water, because the water is carried in a pipe underneath, but it is still a most formidable obstacle, which in every succeeding Grand National brings a certain number of horses to grief. Valentine's Brook is probably so called after a horse named Valentine, who ran third to Jerry, and Arthur, in I8,40, and whose owner betted a large amount that he would be first at the wall. The upshot was that in this race the pace was a cracker during the first round, and so many horses were blown that no fewer than four-including the famous Lottery-came down at the wall. 
In I853, Peter Simple won his second Grand National, and on this occasion Abdel-Kacler finished fifth. "Peter" was an honest horse, and it is worth noting that in this race he beat Miss Mowbray, who had been successful in 1852 . Peter Simple ran again in 1854 . when the race was won by Bourbon, who carried II stone I2 lb. - one of the eight highest weights ever carried by the winners since it was a handicap. In I 858 Little Charlie, who won, was ridden by William Archer, the father of the great jockey, Fred Archer, and of the present day Newmarket trainer Charles Archer, and in I 860 Mr. Capel, the owmer of Little Charlie, was again successful, this time with Anatis, who was ridden by Mr. "Thomas "- the still living $\mathrm{Mr}$. Tom Pickernell.

\section{Alcibiade's Wonderful Win}

In $\mathrm{I}_{86}$ and the following year Lord Coventry won with Emblem and Emblematic respectively, each being ridden by the late George Stevens, and in I 865 another member of the Coventry family rode the wimner, a French bred five-year-old named Alcibiade, who carried II stone $+\mathrm{lb}$., and was the first of his age to be successful in this particular race. Alcibiade, though foaled in France, was brought to England at a very early age, and was owned by one Englishman, trained by a second, and ridden by a third. It is perhaps worth mentioning that twenty-three ran in this particular event, but there were so many falls and refusals that only five finished the course. Alcibiade, on account of his age when he won, must certainly be written down as one of the greatest of Grand National winners.

\section{The Lamb's First Win}

In I 866 the race was run during a snowstorm, and Salamander won from Cortolvin, while Alcibiade failed under a heavy weight. This Cortolvin was undoubtedly a very fine chaser, and in 1867 -the horse having since the previous Grand National been purchased by the late Duke of Hamilton-he won under II stone I3 lb. In I868 Lord Poulett's The Lamb, ridden by Mr. George Ede, fought out the finish with another somewhat famous chaser, Pearl Diver by name. Alcibiacle finishing third, under i s stone ro lb., and of Mr. Ede it may be said that he had a wonderful career as an amateur jockey. He began to ride in 1856 , was second for the Grand National on the Marquis Talon's Weathercock in 1858 , and ten years later won the great race on The Lamb. In I870 he was killed when riding a horse named Chippenham in the Stortford Steeplechase at Liverpool. In all he won 306 races in fourteen years, and he was also a fine rider to hounds, and an excellent cricketer.

\section{The Colonel}

In I 869 and I 870 The Colonel was successful with io stone $7 \mathrm{lb}$, , and II stone I2 lb., respectively, and it is worthy of note that in his first race Alcibiade only just lost fourth place, while in his second race The Doctor was second, only beaten a neck, and this same horse afterwards became a famous hunter, and a few years later was ridden by the ex-jockey Custance in the celebrated "Waterloo" run with the Pytchley hounds. The Doctor carried only $5 \mathrm{lb}$. less than The Colonel at Aintree, and most certainly this was a big year. George Stevens who had the mount on The Colonel on either occasion of his winning, had previously won the Grand National on Freetrader and Emblem and Emblematic, and is the only jockey who has been successful in the race more than four times. He was killed in June, I87I, near Prestbury, in Gloucestershire, through being thrown on to a heap of stones, but he was merely riding from Cheltenham to his home on Cleeve Hill, and the accident was in no way connected with steeplechasing.

\section{The Lamb's Double Event}

In I87I The Lamb completed his double event, the first half of which had been achieved in I868-he had not run for the race in the two previous years - and in $I 872$ when Casse Tete won he was fourth, carrying I 2 stone $7 \mathrm{lb}$. He was a little horse for Aintree, who had been bred in Ireland, and it is said that he once changed hands for £3oo. This may or may not be true, but 
Mr. Joseph Doyle of Dublin gave $£ 300$ for him, and leased him for his racing career to Lord Poulett, who won the '6s Grand National with him at the first time of asking.

After his second Liverpool victory The Lamb was sold to Baron Oppenheim, and sent to Germany, and his career was abruptly a while another horse came down the hill in pursuit. He was a long way behind, but his rider was hustling him along for all he was worth, and at first it looked as if the jockey of The Lamb was not aware of what was taking place.

When he did see the other horse, though

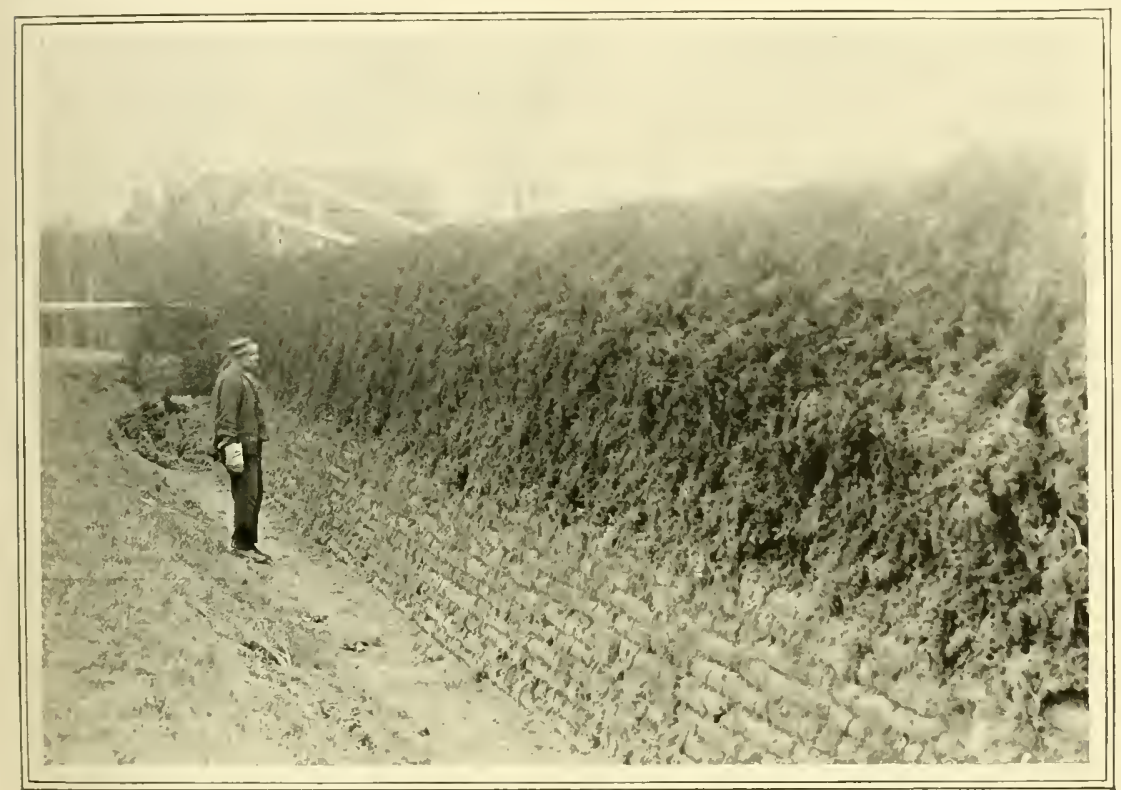

BECHER'S BROOK: THE GRAND NATIONAL COURSE AT AINTREE.

ended in August, I872, when he broke his leg during the process of the Grand Steeplechase at Baden-Baden. Of this race the present writer was a witness, and it may be explained that The Lamb, who was ridden by an Austrian (or Hungarian) nobleman, was winning in a canter, when he came to grief. The Baden-Baden course was in those days a peculiar one, and the steeplechase finished round the top of the loop beyond the stands -the reverse way to the finish of the flat races. To reach the race-course the horses came down a short, very steep hill from a higher lying tableland above the flat-race course, and The Lamb was actually alone when he reached the flat. His rider eased him up round the rather long loop, and after still a long way in front, the rider of The Lamb instantly set about his own horse, and as he happened to be passing through a boggy bit of ground The Lamb's leg snapped like a carrot, and he, limping in on three legs, was just beaten on the post. The present writer has not been able to find any account of the race to refer to, but if memory serves the winner was a horse named Monarch, and anyhow the whole thing was a terrible fiasco. The bit of boggy ground was far beyond the flat-race finishing post ; and was a narrow strip close to the rails. The horse should have been taken round it, and not through it, and even if his rider had not suddenly urged him he could not possibly have lost the race. As it was he travelled 


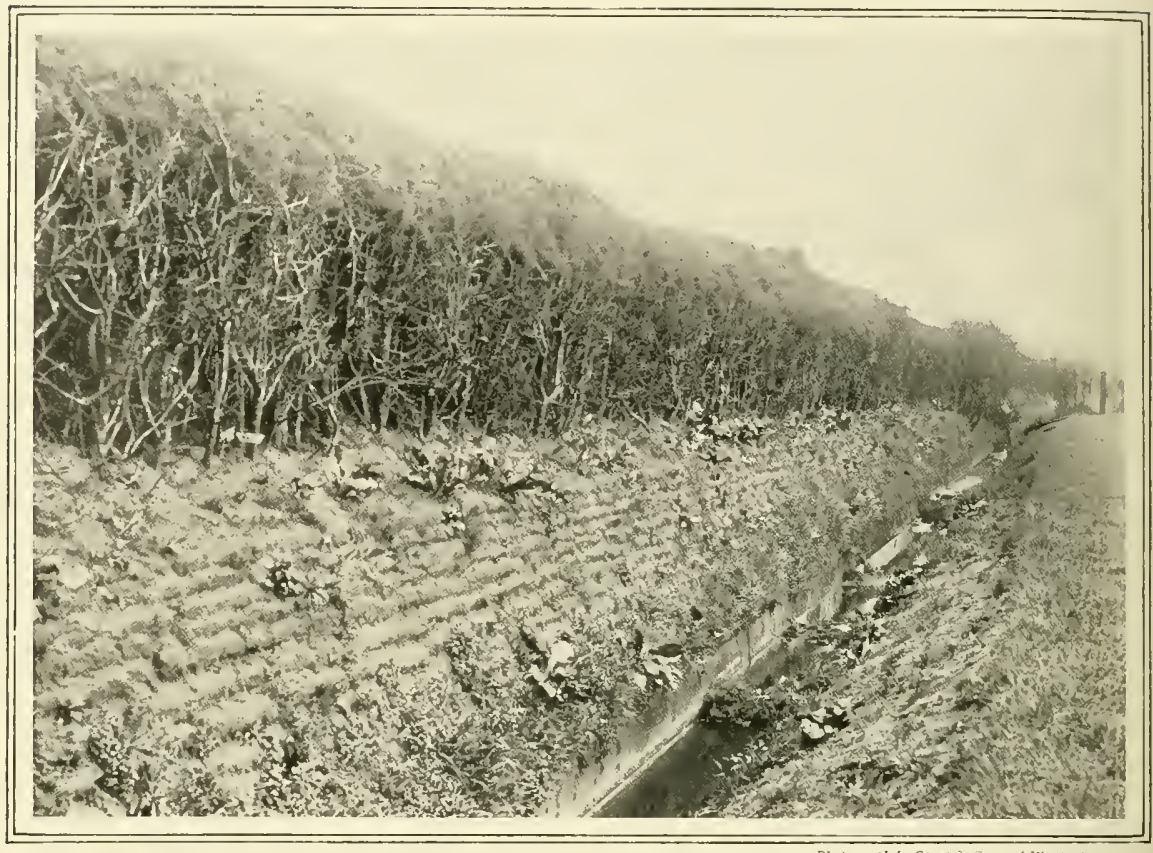

VALENTINE'S BROOK: THE GRAND NATIONAL COURSE AT AINTREE.

probably more than a hundred vards on three legs, and then was only just beaten. There were no "slings" in those days, or if they had been invented they were not to be found at Iffezheim, so The Lamb stood on three legs all night, and ice and various other things were tried to reduce the swelling; on the following morning it was thoroughly realised that the leg was broken, and the horse was shot.

Casse Tete who won when The Lamb was fourth, under I 2 stone $7 \mathrm{lb}$., was a common weedy mare, and far below the average Grand National winner in point of merit; but Disturbance, who won for the late Captain Machell in IS73, was a sixyear-old who carried the heavy weight of II stone II $\mathrm{lb}$., and was ridden by Mr. J. Maunsell Richardson, who, a year later, won again on Reugny, Captain Machell being again the lucky owner. A cast-off from the flat named Rhysworth (trained in the same stable as Disturbance) was backed at a much shorter price than the winner, but Disturbance actually beat him for speed in the run home, the pair finishing first and second, and victory going to the regular steeplechaser of hunter cut rather than to the ex-flat racer.

In 1876 Captain Machell won a third Grand National with the five-year-old Regal, ridden by the present day Newmarket trainer, Joseph Cannon, and in the following year another five-year-old, by name Austerlitz, was successful, ridden by his owner, the late Mr. F. G. Hobson, who threw up his arm-in the hunting fashion of the MidVictorian period-at every fence. In both the last mentioned years Congress was second, in 1876 , with is stone $8 \mathrm{lb}$. in the saddle, and in the following year under I 2 stone $7 \mathrm{lb}$. These were notable performances achieved by a horse that was a great performer over the Liverpool country, though his name is not included in the list of winners. Shifnal, who won in $\mathbf{1} 878$, was 
ridden by the late "Jack" Jones, father of the late King's jockey Herbert, or "Jubilee" Jones, and in I879, the late Mr. Garrett Moore won on The Liberator, who had finished third to Austerlitz and Congress in 1877 .

Another five-year-old, Mr. Ducrot's Empress won in I880, The Liberator being only beaten by a couple of lengths with the top weight of 12 stone $7 \mathrm{lb}$, and in $\mathrm{I} 887$ Captain Kirkwood, recently assuciated with the victories at Ascot and elsewhere of The White Knight, was successful with Woodbrook, Regal this time ruming second with II stone I $2 \mathrm{lb}$. in the saddle. A year later Lord Manners won the race on his own horse Seaman, and it is worthy of note that in Woodbrook's year there were only thirteen, and in Seaman's only twelve runners. Seaman beat Cyrus by a head, and as his owner-who has since been Master of the Quorn-had had very little experience of race riding, the victory, like that of Mr. Hobson, on Austerlitz, was a notable one.
Another amateur, Count C. Kunsky, won in 1883 on his own mare Zoedone, and in I88+ Voluptuary was successful, and this horse afterwards appeared on the stage of Drury Lane Theatre, being ridden by $\mathrm{Mr}$. Leonard Boyne, in a play called "The Prodigal's Daughter." After that again he was in the stables of a Newmarket trainer, who used him as a hack on the heath, and the writer rode him frequently some years later, when he was an old horse but a charming hack with perfect manners. Roquefort, the winner in 1885, was, like Voluptuary, steered by Mr. E. P. Wilson, and Old Joe, who took the prize in I886, was a Cumberland horse, who had been hunted, driven in harness, jumped at horse shows, and had been in fact a general utility nag. Gamecock who won in 1887 , is celebrated because he was winning steeplechases until he was fifteen or sixteen years old, but Playfair, successful in I888, was a cast-off from the flat. To him the Irish mare Frigate was

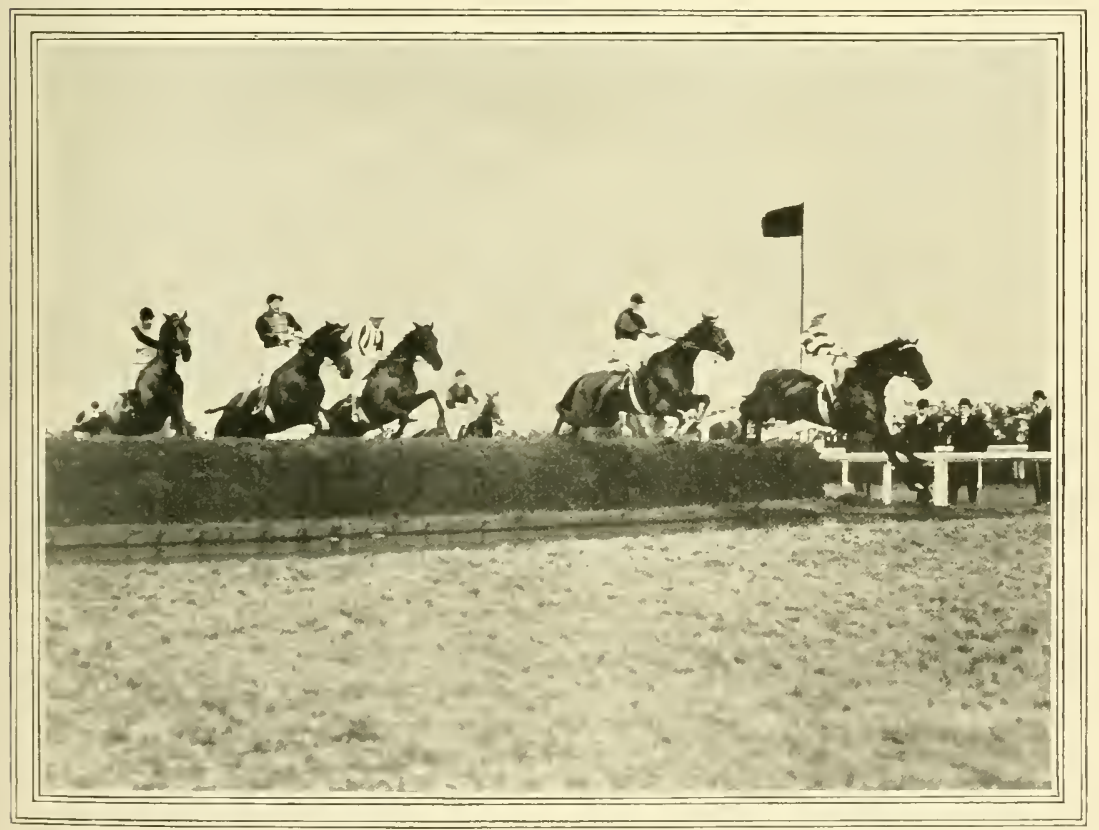

THE WATER JUMP: THE GRAND NATIONAL COURSE AT AINTREE. 
second (she had alsu been second to Voluptuary in I88f), and in $I 889$ this mare won, having made three previous unsuccessful attempts. A good horse named Ilex, who hailed from Epsom, was the winner in ISgo, and in ISoI Come Away, ridden by Mr. H Beasly, just defeated Cloister, by half a length.

\section{Come Away's Victory}

This was one of the greatest struggles ever seen at Aintree, and the field was probably one of the best which the race has known. It included previous winners of the race in Ilex, Voluptuary, Roquefort, and Ganecock, and subsequent wimners in Cloister and Why Not. In fact, of the twenty-one who did duty, exactly one third are now to be found in the bead roll of Grand National wimners, yet curiously enough only six of the twenty-one runners completed the course, and Come Away-Irisli bred and Irish trained-got home half a length to the good, and was stopping fast at the finish. The winner carried II stone I $2 \mathrm{lb}$. to the II stone $7 \mathrm{Ib}$. of Cloister, and good as Captain Owen (he rode Cloister) was as a jockey, he appeared to be more beaten than his horse in the run home. Though one does not grudge the victory of a good and heavily weighted horse like Come Away it is probable that Cloister was unlucky to lose, because one understands that the decision to run him at Liverpool was only arrived at a week or ten days before the race, after his stable companion Royal Mea1h had broken down. That Cloister was short of a gallop or two was well known at the time, but even then he was only just beaten, and Come Away was probably the best tried animal which had ever been sent from Ireland for the race.

\section{Cloister's Great Race}

In I8n2 Cloister carried I2 stone $3 \mathrm{lb}$, and ridden by Mr. J. C. Dormer-now Mr. J. Upton - beat everything, but Father O'Flynn, ridden by the late Captain Owen; and in IS93 the most extraordinary sight was witnessed, when Cloister put all previous performances into the shade by winning with the top weight of
I2 stone $7 \mathrm{lb}$. in the saddle. But it was the style in which this great horse won that was so impressive. He took up the rumning almost inmediately, and after passing Becher's brook in the first round was well clear of his field. From that point he sailed away in front, never being approached, much less headed at any subsequent part of the race. He was eight or ten lengths ahead of his nearest pursuer when they jumped the water, and afterwards he went right away, finally winning by forty lengths. This was a long way the greatest performance which the race has known, and it is probable that on that particular day another stone would not have stopped the winner.

Cloister never ran again for the Grand National, but at the Liverpool November meeting of $\mathrm{IS}_{94}$ he won the Sefton Steeplechase under I3 stone $3 \mathrm{lb}$, and on this occasion a rerdict of twenty lengths was recorded in his favour by the judge. This performance has often been quoted as the biggest thing ever done in steeplechasing, but the field which contested the Sefton of I89t was nothing like so good as the field which Cloister had beaten in the Grand National of the previous year, and, for example, Mr. Duff's great horse gave Why Not $9 \mathrm{lb}$., and beat him by about a lundred yards in the Grand National, and that same Why Not was good enough in I894-when Cloister was not in the field, to win the great race with II stone $I_{3} \mathrm{Ib}$. in the saddle-a weight which has only been twice beaten in the history of the race.

\section{Manifesto's Feat}

Wild Man From Borneo and The Soarer, who won in 1896 and 1897 , were of poor class when compared with the best winners of the great steeplechase, but Manifesto, who won in 1897 , and again in 1899 , was a veritable giant who disputes with Cloister what may be called the championship of the cross-country world. Manifesto carried II stone $3 \mathrm{lb}$. on the first occasion of his victory, and in 1899 equalled the Cloister's record by wiming with 12 stone $7 \mathrm{lb}$. in the saddle. He also did wonderfully well in 
subsequent Grand Nationals, when he carried an even heavier weight, but he did not string wut his field as Cloister had done, and one is inclined to think that the horses he beat when he carried the top weight were not so good as those defeated by Cloister.

There is, however, no reason why one should attempt to decide between the merits of Cloister and Manifesto. Both were great horses, magnificent fencers, and wonderful stayers. There were at times training difficulties in connection with each of the pair, and though they ran on until they were well up in years each in turn had to undergo temporary retirement.

\section{Ambush II.}

In Manifesto's last year he had a great struggle with a young horse named Ambush II., who carried the colours of the then Prince of Wales (King Edward VII.). The horse in question was only five years old at the time, and he was not ridden out when it was found that he could not beat IIanifesto. But in the following year Ambush II. won, and had it been possible to keep him in training he would most likely have taken very high rank. It was in I 890 that the royal colours were successful at Liverpool, and in the same year the purple, scarlet, and gold was in first place, on Diamond Jubilee, for the Derby, thus completing a double, which was then, and still is absolutely unique.

\section{Recent Grand Nationals}

Grudon, an entire horse, who has since got good hunting stock in the Midlands, won in a snowstorm in IgOI, and in IgO4 a Colonial bred horse named Moifaa was successful, while in Igo6 an American bred horse named Rubio took first honours. This Rubio only cost $f_{5} \mathrm{I}_{5}$ as a yearling, and was bought for a lunter, but he won the Grand National, after starting at 66 to I, and when a stable companion-who finished second-started at a much shorter price. The winner of rgog, Lutteur III, was a French bred horse, and only a five-year-old, and one is inclined to think that if he stands training he should make a great name for himself, but this seems to be doubtful.
Little has been said about very 10cent Grand Nationals, because there lave been no real champions since Cloister and Manifesto, and perhaps the most singular feature of the last few years is to be found in what has just been stated-viz., that the race has been won by a Colonial bred, an American bred, and a French bred horse, within the space of half a dozen years.

\section{Age of Winners}

Though the Grand National is much the most important cross-country race in the Kingdom it is seldom won by an entire horse, and therefore the names of Grand National winners are very rarely found in race-horse pedigrees. The fact is that it is difficult to keep entire horses in training until they are eight or nine years old; they are more difficult to train than mares and geldings, and more liable to go wrong-not necessarily from unsoundness of limb, but in a variety of ways. Another fact in connection with this race is that the arerage winner is from eight to nine years old, and there are instances of the race having been won by much older horses. Why Not, for example, was thirteen years old when he won in 1894 . He had won the National Hunt Steeplechase when five years old, in I886, and eight years later lie secured the blue riband of cross-country racing, being then very much over at the knees. It is also to be noted that the successes of Irish bred horses have been very numerous, whilst a fair number of Irish trained ones have also won. It is the custom with certain Irish breeders to put likely looking young horses aside for steeplechasing, and these horses benefit greatly by not being hurried while they are in an unfinished and immature state, and the result is that when they are put into training they are more likely to stand a lot of work than the nags who have been at it since the altumn of their yearling days.

All this means that the cast-off from the flat can seldom be made into a high class steeplechaser. There have been exceptions, of course, Congress and Voluptuary to wit, and there will be again, but the best cross- 
country nags have beer steeplechasers pure and simple.

Other important steeplechases at the present day are not very numerous, though there is an enormous amount of cross-country racing throughout the winter months. Indeed on the regulation courses at the park meetings, there is hardly a day between the is the running over the faster and easier courses always to be relied upon as far as Liverpool is concerned, for scores of nags have done well in the Grand National, who were much too slow for the park racing. In Igog for instance, a horse named Caubeen was unplaced-beaten a hundred yards in a little race at $1 \mathrm{Windsor}$, in the middle of

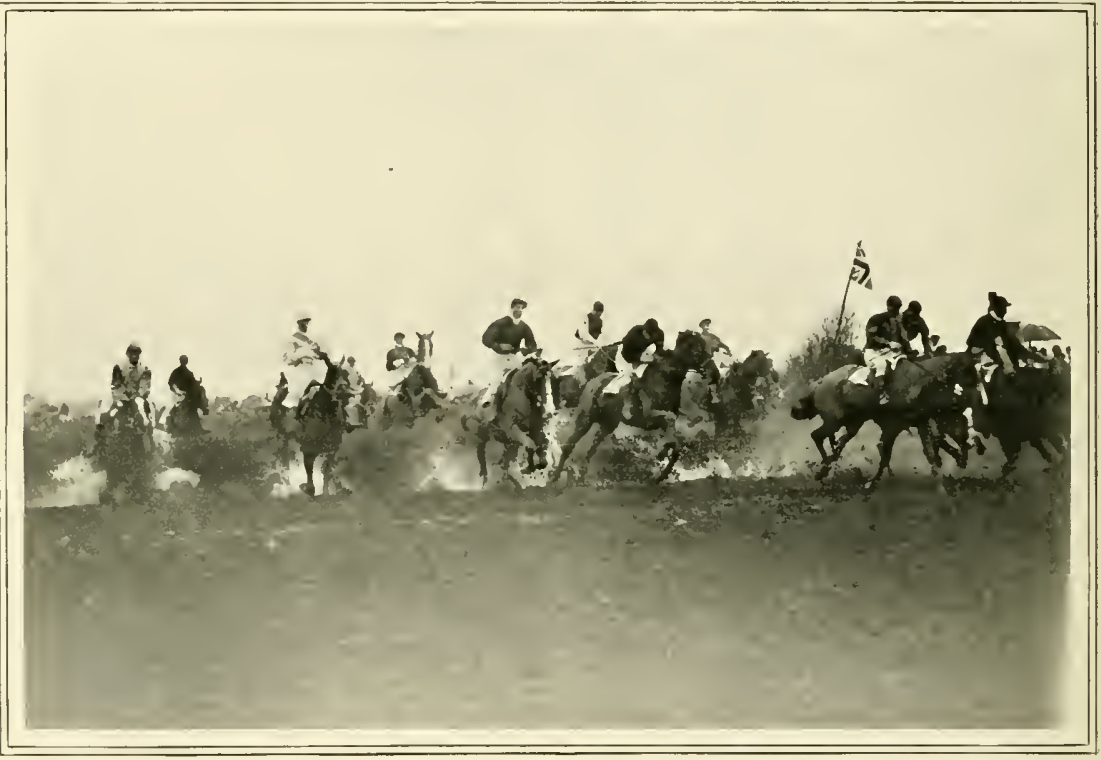

THE WATER JUMP, NATIONAL HUNT STEEPLECHASE, WARWICK.

finish of one flat-racing season and the commencement of the next, which is not appropriated. But the names of the races do not live in memory, as did the old "Grand Aunuals" and "Grand Aristocratics" of a couple of generations ago, and truth to tell the interest of the general public is almost entirely centred on the Grand National. From the moment the weights for the big race are published in January until the eve of the race itself the Grand National absorbs more attention than all the other cross-country races put together, and people go to the parks in February and March merely to see how the horses which are likely to run at Liverpool perform. Nor
February, who in the Grand National of a month later finished third to Lutteur III. and Judas, in a field of thirty-two for the great Aintree race.

Besides the park meetings there are a great number of liunt steeplechases, chiefly decided in the spring of the year, and many of these are most flourishing afiairs, though, as a matter of course, the interest is almost entirely local. There are, too, certain military meetings, of which the "Grand Military," usually held at Sandown Park in the first week of March, is the most important. The great race at this fixture is the Grand Military Gold Cup, which was first run for at Aintree in 1867 . The meeting was after- 
wards held at Rugby, IVindsor, Aylesbury, and Aldershot, but for the last twenty years it has been a fixture at Sandown Park, and no doubt the place is most suitable, because of the enormous crowds which witness the race every year. The Grand Nilitary Gold Cup has been won by many good horses, but, curiously enough, there is not a single Grand National winner in the list of successful nags.

Another rather important race is the National Hunt Steeplechase-at one time called the Grand National Hunt Steepleclase. Though of late years decided at Warwick this race is a movable feast, which was first run for at Market Harborough in I860. It is a maiden race, for horses which have never won any sort of race before the day of starting, and this does not allow of the class being very grand. Indeed, Why Not is the only horse who has completed the double event of this race and the Grand National, and it is a quite common saying that horses who win the National Hunt Steeplechase are rarely heard of again. In 1909 there was a very curious circumstance in connection with the race. Twenty-six started, and
Wychwood was an easy winner. It has been stated that the race is for maidens, and Wychwond was a maiden according to the rules of the National Hunt. But for all that when running as Cheap Jack two years before he had come in first for four races. It was not known by his then owner how he was bred, but after he had won these four races it transpired that he was an American bred horse, who had been sold as a yearling (at the same sale as the Grand National winner Rubio) to Blackwell, the Newmarket trainer for I fo guineas, and he was disqualified for all four races. He had run on the flat as Wychwood, without success, and being drafted out of Blackwell's stable had passed through several hands, before he was bought at a Leicester auction by the man who won races with him as Cheap Jack. There was no suspicion of fraud in the matter, and the curious part of it is that the horse who had come in first in four races was able to win a steeplechase, worth a thousand pounds-this being the value of the National Hunt Steeplechase. After this victory Wychwood was again objected to on the grounds that he was not qualified, but the objection was overruled.

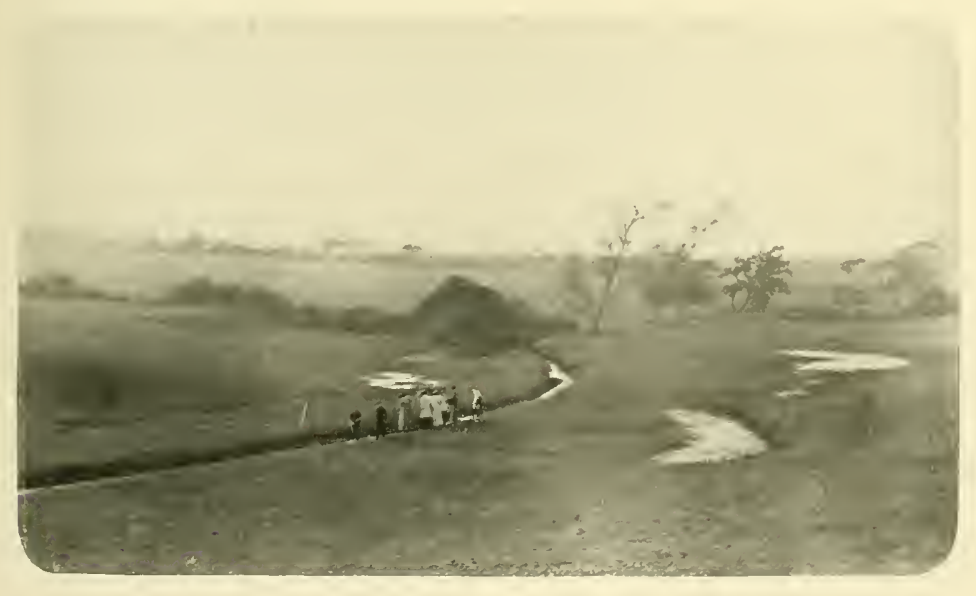




\section{CHAPTER XV \\ HUNTING AND HUNTERS}

$\mathrm{H}$

ORSES in this country are used for pleasure as well as for genuine work. The draught horse, whether he be Shire, Clydesdale, Punch, or of nondescript breed, is essentially a utility horse. He is used to draw heavy wagons, to haul goods about, and for every sort of agricultural purpose. He is, as a matter of fact, with the exception of the Army horse, the most useful horse in the Kingdom, and the best of his species are very valuable from a stud point of view. But there are other horses which are almost entirely used for pleasure, and chief amongst these is the hunter. The race-horse camnot be considered altogether a pleasure horse, for from him thousands of general utility horses are bred, but hunters, polo ponies, and, to a certain extent, hackneys are pleasure horses, and there are probably ten times as many hunters as there are hackneys and polo ponies, even when the two lastnamed varieties of the British horse are added together.

In the opening chapters of this book it has been stated that 200,000 hunters are being constantly maintained. It is not necessary, therefore, to go over this ground again, but to get on to hunting it may be explained that hunters are used for foxhunting, stag-hunting, to some extent for lare-hunting, for the drag, and for point to point racing, which last-named sport is an outcome of hunting.

Of these three or four varieties of lrunting which entail riding over, or across-as it is usually called-the country, stag- and hare-lunting are far older than fox-hunting, but the last-named has in the last two hundred years taken so strong a lead of the other two that it is now, and indeed has been for nearly half-a-dozen generations, the most important of all field sports in which horses are employed.

There are at the present time in the United Kingdom 208 foxhound packs, of which I73 are English, 24 Irish, and II Scottish; I30 harrier packs, of which 89 are English and 4 Irish; I9 staghound packs, of which I6 are English and 3 Irish, and I3 draghound packs, all of which are located in England. This makes a total of 370 packs of hounds with which horses are ridden, and if the deductions on page $2 \mathbf{I}$ are fairly correct, it is plain enough that the demand for hunters is very large. It has also been explained how the supply must be constantly replenished, and, in fact, it is indisputable that the hunter industry is a very large one.

Hunters are bred in England, Ireland, a few in Sonth Wales, and a few in the lowlands of Scotland, and from every district good horses are forthcoming. But in more recent times the best have come from Ireland, and the number bred there, and sent to this country, is, proportionately, much larger than the number bred in England. No doubt the limestone pastures of the South and South-West of Ireland are eminently suitable for luunter breeding, and thus it is that there is a fair supply always forthcoming from these districts, while in England hunter breeding is carried on vicariously and does not absorb anything like so much attention as it ought to do. There are, of course, English breeders of hunters who take the greatest pains, and whose operations are attended with firstrate results, but hunter breeding in England is not-except, perhaps, in a few specially favoured places-helped by the climate and the land as it is in Ireland.

The proof of this statement is forthcoming 
in the fart that a majority of the highest priced hunters to be found at any time in the stables of the great Midland dealers have been bought in Ireland and brought over to England to be sold. This is one piece of evidence which favours the Irish hunter, but another proof is even of greater consequence, and this is to be found in what occurs at the Agricultural Hall in every succeeding March. But first it must be explained that there is a Hunters Improvement Society, a very valuable institution, which has done, and is doing, good work in the interests of the breed. The society is nothing like so large as it ought to be, because it is not sufficiently supported by hunting men and women, but with that we are not concerned at the moment. It must be stated, however, that in March of every year the Hunters Improvement Society hold; a show of made hunters and young hunting stock, at the Agricultural Hall, Islington, in connection with the show of stallions which compete for the King's Premiums.

\section{Prizes for Hunters}

There are at this hunter show two sets of prizes, one set for breeding stock, the other for made hunters, which are ridden in the ring. In the first series yearlings, two-year-olds, and three-year-olds, of either sex are shown singly, and in groups, and it is a fact that nearly all the prizes are won every year by English-bred animals. On the other hand, something like three-fourths of the winners in the riding classes (for "made" hunters) have come from Ireland. This is remarkably convincing, more especially when it is explained that practically no Irish young stock are shown. The Irish breeder will not be at the trouble and great expense of sending two- and three-yearolds to this country for competition. He will send young stock to an Irish show, held towards the end of the summer, but he will not get young animals ready for showing in England so early in the year as the second week of March, and in all probability it would hardly pay him to do so, even if he were to secure a fair proportion of the prizes.
Neither, for that matter, is the Irish exhibitor much to the fore in the riding classes. A small number of the horses shown may have come from Ireland directly for the show, but the greater number of winning exhibits, which were bred on the other side of St. George's Chamel, have already been disposed of to English buyers, and are shown by them or by the persons to whom they have been sold. The fact is that the big English dealers buy up all the promising Irish hunters when they are four or five years old, and immediately bring them to their stud farms in the Midlands. Many of them are only half made; others are scarcely made at all, and a considerable number have been fed on "soft" food and are in no sort of condition. The dealer, or his agent in Ireland, picks out the likely ones on their make, shape, pedigree, and general appearance, and having got them safely to this country proceeds to turn them into the finished article. Many dealers, some of then amateurs, exhibit the best of their Irish purchases at the shows, and just lately-tliat is to say, during the last ten years-Mr. Stokes, of Great Bowden, near Market Harborough, and Mr. Drage of Chapel Brampton, near Northampton, have practically farmed the hunter prizes at all the great shows-and when both are beaten the horse which beats them has generally been sold by one of these two dealers to a customer who is inclined to strive for show-ring fame.

\section{English Bred Hunters}

Some Irish dealers there are who import strings of hunters on their own account, and have special sales of them in this country, but as a rule the highest priced Irish hunters are bought by the English customer from an English dealer who, through his agents, acts as the intermediary between the breeder and the man, or woman, who eventually rides the horse to hounds. With regard to English-bred hunters there is no such method of putting them on the market. In the North and East Ridings of Yorkshire, parts of Lincolnshire, Shropshire, and the Midlands generally a fair number are bred, 
and Northumberland is also fairly well to the fore as a hunter county, but the average breeder seldom has more than one or two to dispose of at a time, and he finds his market here, there and anywhere. Sometimes he sells to a neighbour, at other times to a local dealer, and occasionally he disposes of his horse whilst he is riding it to hounds. Much depends upon the breeder himself; if he happens to be a hunting man, and has a reputation for turning out good horses. he has no trouble in disposing of all he breeds; but such a man is a rara avis, and, as it happens, many of the most successful English breeders of hunters do not actually follow hounds themselves. When this happens a very long price is often asked for a horse which is thoroughly schooled, and when such price is not forthcoming from the local hunting man a much smaller figure is often accepted from the local dealer.

\section{Direct Buying $v$. Dealers}

It is regrettable, but none the less a fact, that there is not anything like so much buying of horses by the hunting man direct from the farmer as there ought to be, and both buyers and sellers are in some degree to blame. The breeder when first he puts his horse on the market is apt to take a somewhat over-sanguine view of its merits, and to ask a longer figure than the horse appears to be worth. The horse's schooling may not have been perfect, and the wouldbe buyer is of opinion that if he buys from the average farmer-breeder he should bily cheaply, because he is buying what may be called a raw horse, who will require a lot of time before he is in good enough condition to stand a very long day. The two attempt to deal, but the difierence between them is too big to be smoothed away, and in course of time the farmer sells either to a local dealer or to the agent of a big dealer-if he has bred a horse which is really a hunter, and not merely a ride-and-drive nag.

The buyer, on the other hand, knows that he will have to pay more for what he requires when he goes to a dealer in a big way of business, but if he is a regular customer he can very bikely have his horses on trial for a week or two, or if he buys one out and out and does not like it, his dealer will often excliange it for another. If he buys the farmer's horse and it does not answer expectations there is generally nothing for it but to sell at a loss, and it is the chance of doing this that often prevents the man in need of a horse from buying locally.

\section{A Curious Case}

It has just been said that there is not enough disposition on the part of hunting people to buy from the farmers in their own district, and one has known of cases which were almost ludicrous. One farmer of the writer's acquaintance brought out two four-year-olds of his own breeding about Christmas time, a brown and a grey, and rode them with the local hounds. Both were fine jumpers, well-bred, and up to a good deal of weight, and he asked $f_{100}$ apiece. Several men niggled at the pair, but no one offered more than $£_{5}$ or $\underset{\sim}{i} 60$, and at the end of the season the two were bought by the local agent of one of the big dealers, and were taken out of the country.

In the following March the writer saw one of these colts (the grey) in a five-year-old class at the Agricultural Hall, where he secured a reserve, or a highly commended rosette. He was shown by a dealer, and he was shown again at one or two of the early summer shows. The brown was not shown, but during the summer the two were bought from the dealer for the price of $£ 350$ for the two, or an average of $\$ 175$, and their buyer was one of the men who had tried to buy from the breeder eightee. months before. And, moreover, the purchaser was justified in giving the extra money, for, as he stated, the horses were eighteen months older, and more matured than when he had first tried to buy them, whilst in addition they had been carefully kept, had not been knocked about, and had only " played at a little hunting during the previous winter."

The farmer cannot afford to keep his young horses long enough, and many farmers hardly realise that a horse rising six years old, who has done little or no work, must 


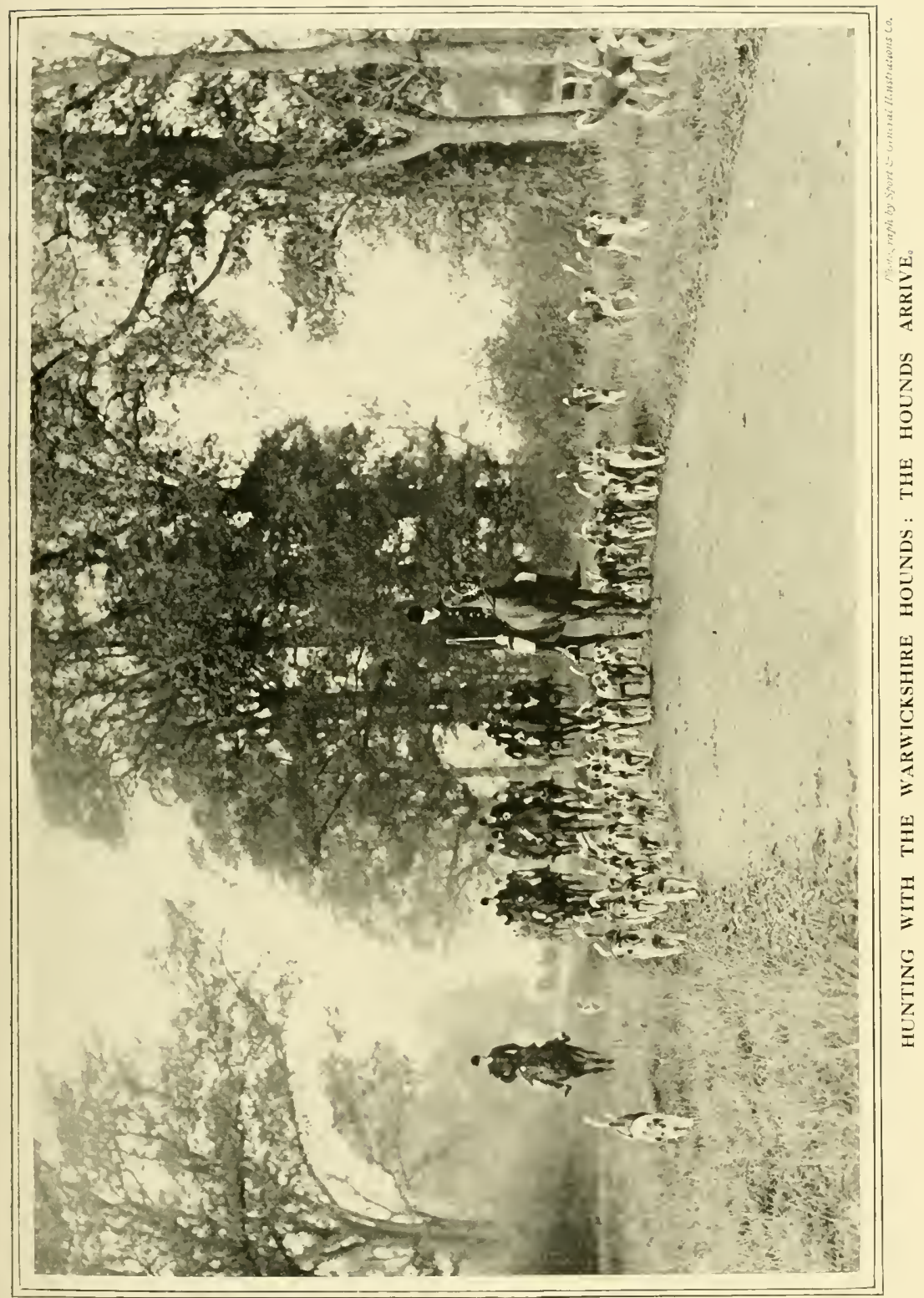


have a far greater value than a four-yearold who is his equal in appearance.

Just at the present time the air is full of schemes which are to benefit the farmer, and-incidentally - to improve the breed of hunters, but these cannot be discussed here, and we may take leave of this part of the subject by remarking that even in these days of depression with regard to horsebreeding there are still far more good hunters than there were-say, a couple of generations ago.

\section{Fox-Hunting}

Fox-hunting with a pack of hounds, and the followers on horseback, is not much more than two hundred years old in this country, and it is probable that at the beginning of the eighteenth century only an odd pack hunted the fox, in preference to the deer or the hare. Also it is extremely probable -nay, almost certain-that fox-hunting, as we know it, was little indulged in before the middle of the eighteentl century. Indeed the sport came into being so gradually and so quietly, and was at first so much confined to certain parts of the country, that it did not for some time command the services of any historian, and thus nearly all the early history of the sport is still, to an extent, shrouded in oblivion. Books there are concerning stagor buck-hunting, and, in earlier days, manuscripts, but these writers on sport do not include any authorities on fox-hunting, until Beckford wrote his "Thoughts on Hunting," in $178 \mathrm{I}$. It is true that an "Essay on Hunting" was published in I733, and two copies of this of rather different dates are in possession of the present writer, but the author-whose name was never made public-treats only of the sport from the technical point of view and deals chiefly with hare-hunting.

The early history of fox-hunting will, in all probability, remain very hazy unless, indeed, such a thing as the manuscript diary of a very early master should be unearthed. This is extremely improbable, and if we take the existing evidence which is really reliable, and do not trust to "state- ments of claim " which have been vaguely asserted, it is pretty clear that some halfdozen packs of hounds are at the present day hunting country which was used for fox-hunting very nearly, if not quite, two hundred years ago. Further back we cannot go, nor can it be said with truth that any of the present day packs can show any continuity of history from the original pack which first hunted in their country.

\section{The Oldest Packs}

It is possible, but exceedingly improbable, that there were older foxhound packs than those we are about to mention. On the other hand it is well known that certain hunts, such as the Royal Hunt are several hundred years old. This and other old hunts were originated for the purpose of liunting buck, stag, or deer, and in the case of the Royal Hunt the quarry never changed. This is specially mentioned because quite lately a book entitled "England's Oldest Hunt " has been published, which deals with the Bilsdale Hunt in the North Riding of Yorkshire. The book is an interesting one, and shows an extraordinary amount of research on the part of the author, Mr. I. Fairfax Blakeborough, but it seems more than probable that in the hunt of which the Bilsdale was in part a successor, and which was established by the famous Duke of Buckingham in "I680 or thereabouts," stag or buck was at first the quarry.

\section{The Sinnington}

The Sinnington, which joins the Bilsdale on the south-east, and probably the country between Malton and Scarborough, which has lately been taken by the Hon. H. C. Vane, and which was for generations in the Hill and, afterwards, the Harcourt Johnstone families, were, as far as can be judged, within the territory hunted by the Duke of Buckingham; and another Yorkshire pack, the Goathland, whose country lies inland of IVhitby, goes back to a remote time, " the hunt being mentioned in records, dating back to 1650 , which are preserved at Pickering." Each of these hunts can claim 


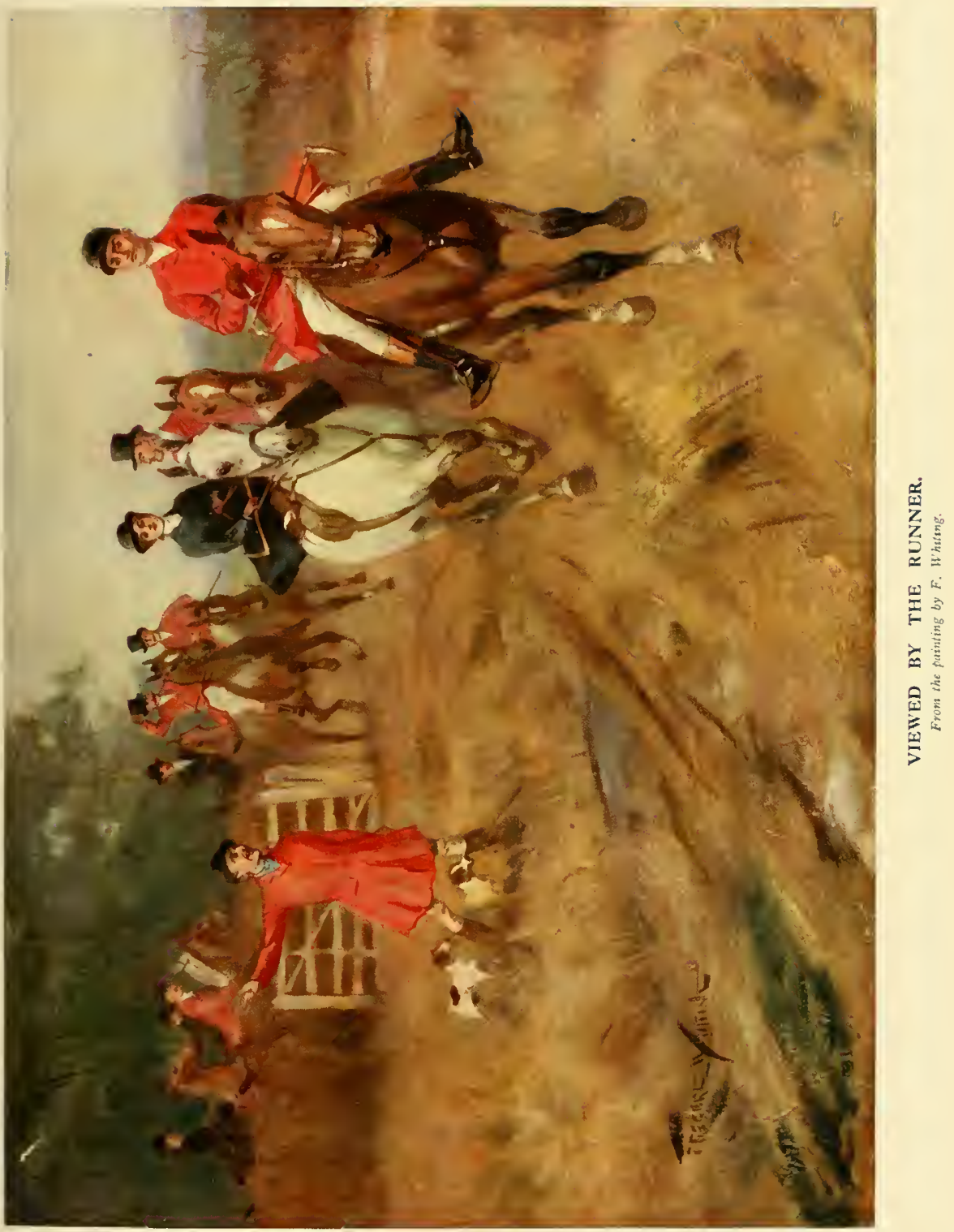



great antiquity, and so too can the Stainton Dale, whose country lies along the coastline between Scarborough and Whitby.

\section{The Stainton Dale Hunt}

The local tradition which survives to the present day is to the effect that the Stainton Dale Hunt was created by Royal Charter in the days of King Stephen, but the Record Office was searched for information, and no light was thrown upon the subject. Mr. IV. Scarth Dixon has suggested in "The Foxhounds of Great Britain" that the charter was probably a permission from someone in authority, something like a right of Free Warren. As to whether this solution of the tradition is true there would appear to be mo means of ascertaining, but if the Stainton Dale Hunt came into existence in the reign of King Stephen it is quite certain that some other animal than the fox was the original quarry, and this was probably buck. In the opinion of the writer this group of Yorkshire hunts have claim to considerable antiquity, but there is no definite information to the effect that any one of them is the oldest in the Kingdom.

It is true, no doubt, that the Bilsdale, the Sinnington, and probably Mr. Vane's hounds lunt over country which was hunted by the Duke of Buckingham, and it is also true that the Bilsdale can show a greater continuity than either of the other two packs. The Goathland and the Stainton Dale claim antiquity on other grounds than that their country was part of the Duke's country, but there is a complete lack of really reliable evidence, and local tradition cannot be considered proof.

\section{The Royal Hunt}

To go farther south the oldest pack of hounds was undoubtedly the Royal Buckhounds, which was disbanded at the beginning of King Edward VII.'s reign. About the antiquity of this hunt there can be no doubt, as the State records give information concerning it which dates from 1362 . Iuch of this information was gathered into a volume by MIr. Hore, who also gave a complete list of masters of the pack, and from this their history can be followed from the reign of Edward III. It is certain that no other hunt of any description can show half so long a pedigree, or one-tenth the amount of evidence as to early days as is forthcoming with regard to the Royal Hunt, but the quarry was never changed, and to the end deer was the object of pursuit. When wild deer became extinct in the near neighbourhood of London, the "carted" deer replaced the wild species, but until comparatively recent times hounds were taken to the New Forest for wild deer hunting, and here it may be mentioned that at the present day only wild deer are hunted by the New Forest staghounds, by the Devon and Somerset staghounds, by Sir John Amory's staghounds, and in the north by the Ribblesdale buckhounds. In the case of the last-named, however, the deer were taken to Ribblesdale and turned down, three or four years ago, whereas in Devon and Somerset, and in the New Forest, the breed has never been allowed to lapse, and is indigenous to the country.

\section{The Penistone}

There is a harrier pack called the Penistone, whose country lies in a moorland part of the West Riding of Yorkshire, west and rather north of Sheffield, and it is claimed for this pack that it has existed since 1260 , in which year Sir Elias de Midhope was master. This information appears every year in Bailey's "Hunting Directory," but after the date given the information is very meagre, and we are only told that in the fourteenth, seventeenth and eighteenth centuries masters were furnished from the families of Wilson of Broomhead Hall, Wortley of Wortley Hall, Riches of Bullhouse Hall, and Fruton of Underbank Hall. The roll is very incomplete, so much so indeed, that the Royal Hunt, of which particulars are known for a period of over five hundred years, must take precedence as the oldest.

Dealing with foxhound packs only, it is on record, the authority being the "Sussex Archieological Collections," that a Kentish gentleman named Roper managed a pack 
of hounds for the Duke of Nonmouth and Earl Grey in I689. The details as to the early histury of this hunt are rather vague, but it has always been understood, and accepted by authorities, that the pack was kept to hunt fox alone. Vyner, in "Nottia Venatica," stated broadly that foxhunting became an amusement in England at the end of the seventeenth century, but there is little doubt that a majority of the earlier packs formed especially to hunt foxes were family packs, which came to an end in due course. The comntry over which many of these family packs hunted is, of course, hunted by foxhounds at the present day, but in very few cases has the continuity been preserved right through. The Charlton Hunt, however, continued for a long period, and not long after it ceased to exist Lord Egremont established a pack in the same country. This was in I773, and since that time the country has been hunted by the family of the Duke of Richmond, or by nembers of the Iyndham family, whose representative at the present day is Lord Leconfield.

When Lord March, the present Duke of Richmond hunted much of the Charlton country with the "Goodwood" hounds, but he gave up about fourteen years ago, and since then Lord Leconfield has hunted an immense tract of country which includes most of what was the " Groodwood " country, as riall as the country about Petworth, and further north to the Chiddingfold border. At times, especially during the early part of the last century, there were hounds both at Petworth (Lord Leconfield's), and Goodwood (the Duke of Richmond's), and it is possible that the country of the old Charlton Hunt included country to the north and east of Chichester, which is now hunted by the Crawley and Horsham hounds, and country to the west (north of Portsmouth), which is now a part of the Hambledon Hunt. Charlton, it should be explained, is a little Sussex village, situated within a couple of miles of the Goodwood race-course.

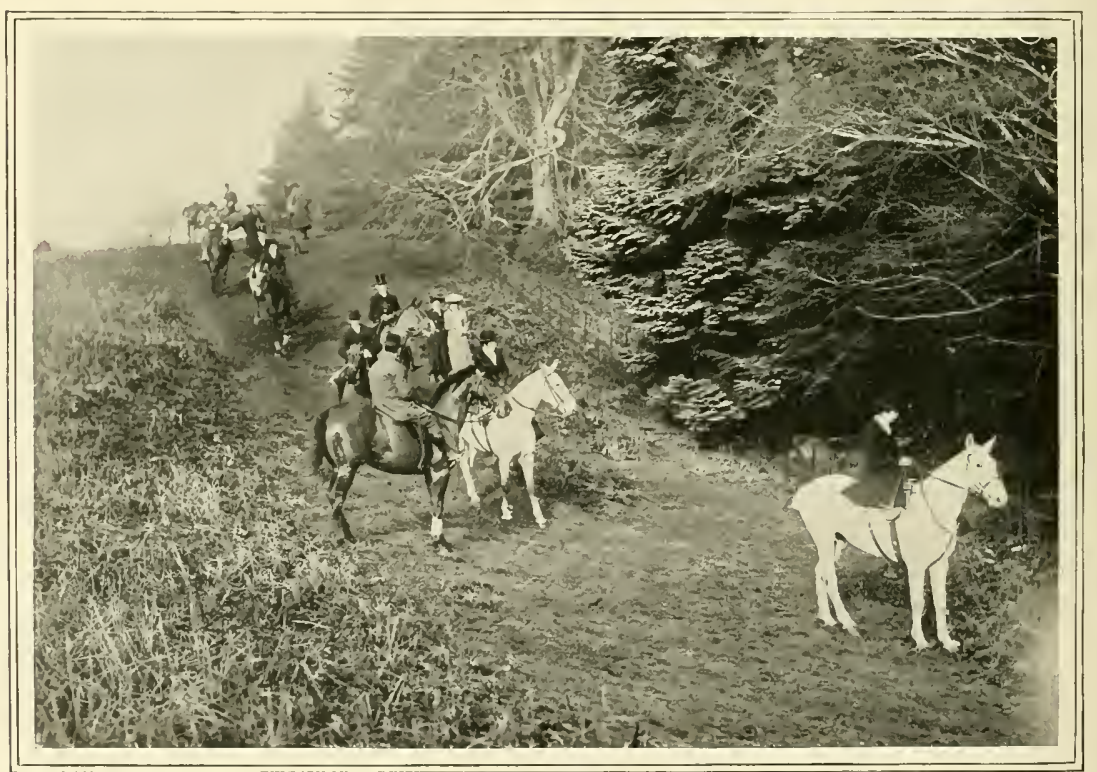

MEET OF LORD LECONFIELD'S FONHOUNDS AT LYTIE HILL, NEAR HASLEMERE: WAITING AT COVERT SIDE. 


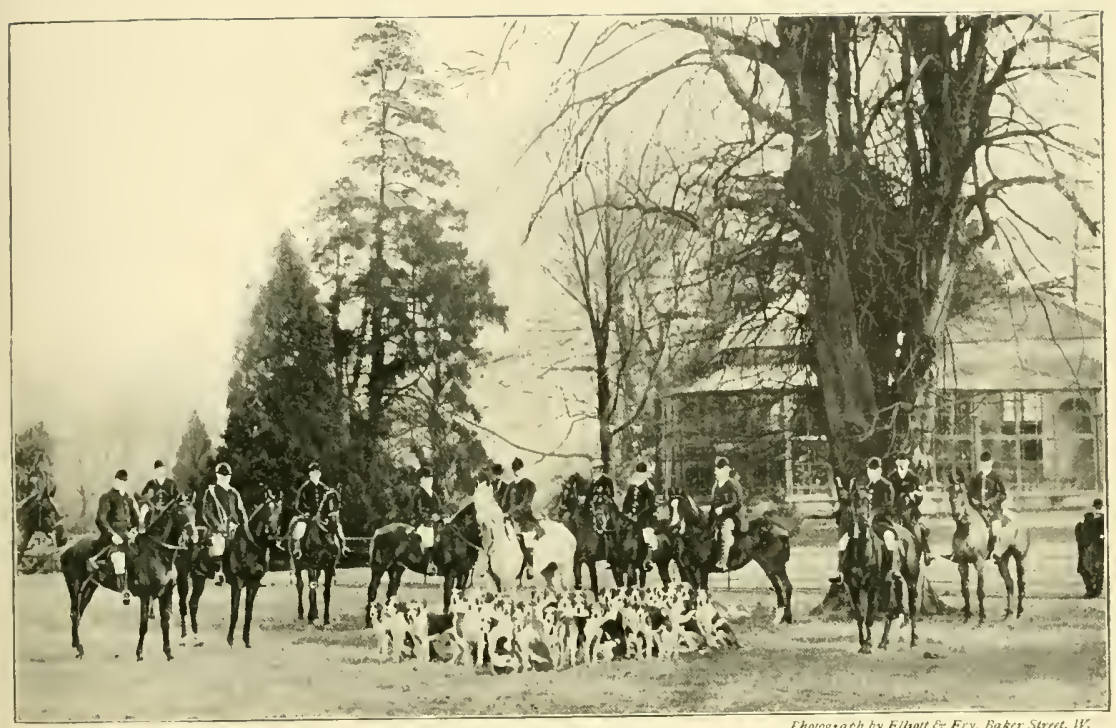

THE QUORN HUNT.

\section{CHAPTER XVI}

\section{HUNTING AND HUNTERS (continued)}

NOTHER hunt which has even
stronger claims to be considered kingdom is the Quorn, whose operations are wholly confined to Leicestershire. The Quorn claim rests chiefly on the evidence of the famous Mr. Boothby's hunting horn, an engraving of which was published in The Field in the early 'eighties. The inscription on the plate is as follows:--

Thos. Boothву, EsQ., Tooley Park, Leicester. With this horn he hunted the first pack of foxhounds then in England 55 years. Born I677, died 17.52 .

In Bailey's "Hunting Directory," I6os is given as the first year of Mr. Boothby's mastership, and it is practically certain that whether this date is right, or a year or two early, Mr. Boothby hunted fox, and fox alone. In 1698 he would just have attained his majority, and this would be a very natural time for him to establish a pack of hounds. In any circumstances the history of the Quorn is quite complete, for on Mr. Boothby's death the even more famous Hugo Meynell took the hounds, and maintained them until I80o. Thus two men hunted what is generally conceded to be the best country in the world for a period of over a hundred years - truly a wonderful record.

For the Cranborne Chase-much of whose original country is now hunted by the Blackmore Vale hounds--claims have been made that it was the first country in which hounds were kept to hunt fox to the exclusion of other quarry, but as far as the present writer has investigated it would appear that the Cranborne Chase hounds 
were established by Mr. Thomas Fownes of Stapleton about $173^{\circ}$, or more than thirty years after Mr. Boothby began to hunt Leicestershire. This gives the Leicestershire sportsman a big advantage, and until something is proved to the contrary one is inclined to consider that Mr. Boothby had the first foxhound pack of which there is any reliable record.

There is no need to go further into this question, for at the present day it is of little consequence which is the oldest pack. But it may be stated that in one of the earliest volumes of the old Sporting Magazine there is an account of a fox-hunt with Sir Charles Newcomen's hounds, which took place as long ago as $175^{\circ}$, in what are now the Hurworth and Cleveland countries. The Sir Charles Newcomen referred to lived at Kirkleatham, near Redcar, and this rum was from the neighbourhood of Hurworth - four or five miles south of Darlingtonto the neighbourhood of Skelton in Cleveland, where Mr. Wharton, the present master of the Cleveland, resides. The point must have been at least five-and-twenty miles, and not only is a very graphic account of the hunt given, but one actually learns that Mr. Colling, great-great-great-grandfather of the trainer, and ex-jockey of that name, was the only one who got to the end.

\section{Family Packs}

In older days of the sport, and more especially during the latter half of the eighteenth century, family packs were very numerous, not only amongst the nobility, but amongst the more important and wealthier members of the squirearchy. Some few of these family packs remain, and at their head are the three celebrated " B" packs, of Belvoir, Brocklesby, and Badminton. All three have been especially famous for their hounds, and at this date Belvoir blood is reckoned-and justly soto be the most valuable in the world. The Belvoir Hunt goes back to I750, and there is evidence to the effect that it has been purely a foxhound pack since 1762 . The pack has alway's been owned by the Dukes of Rutland, and though the present master,
Sir Gilbert Greenall, is not a member of the Manners family, the pack is lent to him during his mastership. There was one previous "foreign" mastership, between I 830 and I 857 , when Lord Forester was in command, but at all other times members of the ducal family have been at the head of affairs.

\section{Belvoir Influence}

It is almost impossible to state exactly what extraordinary influence Belvoir blood has had upon fox-hunting generally, but one is probably correct in stating that there is hardly a modern pack of hounds which has not some of it, and at many kennels the entire pack has been built on a Belvoir foundation. Indeed it is probable that some of the Welsh packs, and several of the "Fell" packs which hunt in the mountainous districts of Cumberland and Westmorland, are the only packs in the kingdom which are without it, and even some of these have in comparatively recent times tried crosses from other (lowland) packs which would most likely contain strains of Belvoir.

It is also quite certain that to Belvoir blood much of the excellence of the modern foxhound is due. For generations the Belvoir kennel has set the fashion, not only in outward conformation, but in size, colour, and general all-round character. There are other kennels which contain excellent packs of hounds, and as the Belvoir does not enter at the annual Peterborough show of hounds there is not much opportunity to make comparison, but in all probability the Belvoir pack in its entirety is superior to any other pack, and one has no doubt that if it were put up for saleluckily there is no chance of such an occurrence-it would double the record price made by any individual pack.

\section{The Brocklesby}

The Brocklesby (Lord Yarborough's), whose country is in the north-east of Lincolnshire, claims to date from 1700 , or a little earlier, and its hound lists go back to 1746 , while it is also an article of faith 
amongst those interested in such matters that the country has existed as it is at present since I7If, when a triumvirate of masters, Messrs. Viner, Tyrwhitt, and Pelham (Pelham is the family name of the Earls of Yarborough), hunted it conjointly. It will thus be seen that the Brocklesby is older than the Belvoir, and it has been in the hands of the Pelham family from some date, which is not exactly traceable, between the years I7It and $I 75^{\circ}$. It is, therefore, the oldest family pack which still exists, and as Brocklesby blood was used to a considerable extent in the formation of the Belvoir pack we may take it that the kemnel is the probable fons et origo from which a majority of the other packs have sprung-in spite of the fact that during the last two or three generations Belvoir blood has held the first place in the estimation of those qualified to give an opinion on such matters. The Belvoir hounds were also largely bred from the packs of Mr. Heron and Mr. Calcraft, but these packs have long ceased to exist, and one can only learn of them from old records.

\section{The Badminton}

The Badminton pack is also of great antiquity, and it is extremely probable that hounds were kept there much earlier than the period of which there is any reliable account. It is known that the fifth Duke of Beaufort was hunting a pack of hounds in $1>86$, and since that date the pack has descended regularly from father to son, and is at the present day one of the most important in the kingdom. The original country of the Dukes of Beaufort included what has since been known as the Heythrop country in Oxfordshire, but this was given up in 1836 , and has since that date been a separate hunt. Meantime the Dukes of Beaufort continued hunting a vast extent of country in Gloucestershire, Somerset, and Wilts, the total area of which reaches 760 square miles. At times outlying portions of the country have been lent, and at present that part of it which has occasionally been known as the Avon Vale country is lent to Mr. H. WV. Nell, of Chipping Sodbury.

\section{The Williams-Wynn Pack}

Another family pack is that of the Williams-Wynn family, whose country lies in Cheshire, Shropshire, and parts of North Wales. The first baronet of the family was killed when hunting in $17 f^{9}$, and since that date a pack has been generally maintained at Wynnstay, but the history of it from a foxhound point of view is only clear since I793, the earlier packs being said to have hunted hares quite as often as foxes.

\section{The Berkeley Hunt}

Lord Fitzhardinge's pack in Gloucestershire is another very old one, though the country, as at present constituted, dates from 1807 only. The original date of the hunt is given as $\mathrm{I}_{6} \mathrm{I}_{3}$, and if hounds were kept by the Berkeley family, as no doubt they were, at that date it is almost certain that they were staghounds or harriers, for fox-hunting as it is now practised was unknown at that day. It is the case, however, that during the eighteenth century the Berkeley Hunt was about the most powerful in the kingdom, for its country extended here, there, and everywhere, and in Grantley Berkeley's "Reminiscences of a Huntsman," published in 1854 , the author boldly stated that his father used to hunt all the country from Kensington Gardens to Berkeley Castle in Gloncestershire. He also gives an account of a run with a fox found at Scratch Wood-supposed to have been somewhere near Wornwood Scrubbsand lost in the rough covert of Kensington Gardens. That Grantley Berkeley's statement. was a vague one is quite evident, for the length of country he mentions would cut clean throngh a good deal of the districts hunted at that day by the Dukes of Beaufort. It is certain, however, that the original Berkeley Hunt had two distinct beginnings or ends, one at Cranford, in Middlesex, and the other at Berkeley Castle. There was, too, for a considerable period a kennel at Nettlebed in Oxfordshire, some five miles north-west of Henley-on-Thames, and near a point where the South Berks and South Oxfordshire countries march with each other at the present day. 
The principal family packs have now been mentioned, and it has been explained that many of the best-known existing packs have countries which were originally hunted by some particular family. The subscrip- records of the pack in Thomas Noel's "Book of Hounds," dated I732. The Noel family gave up lunting the country in 1788 , the hounds being sold to Sir William Lowther, ancestor of Lord Lonsdale, who is the master

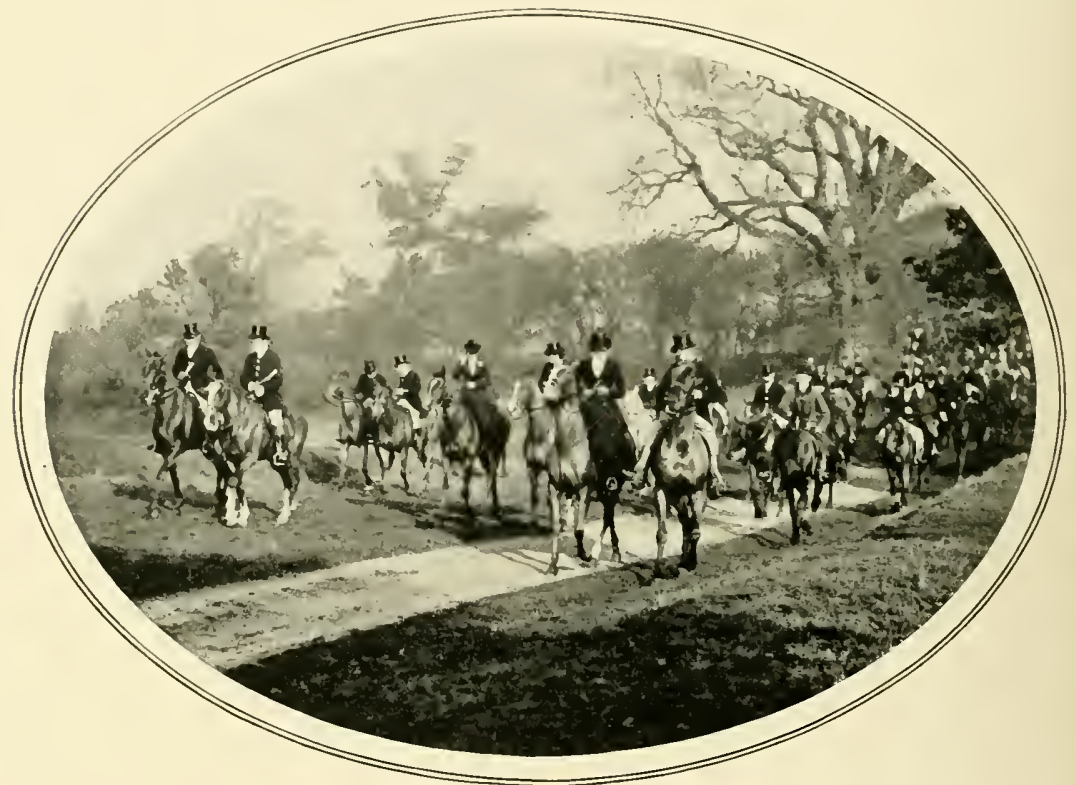

THE BELTOIR HOUNDS: MEET IN CROXTON PARK.

tion pack came into existence more than a hundred years ago, however, and since that date subscription packs have almost everywhere succeeded the private hunt, while a great number have been formed where foxhunting had not been previously carried on. Of the "Shire" packs-Quorn, Belvoir, Cottesmore, Mr. Fernie's, Pytchley, and Woodland Pytchley-the Quorn country was hunted by Mr. Boothby, and afterwards by Mr. Hugo Meynell, as has been explained. The last-named was followed by Lord Sefton in $I S o o$, and since that date (when the hunt was placed on a business-like footing) there have been over a score of masters. Mr. Fernie's Hunt was originally part of the Quorn country, and only dates from 1856 , but the Cottesmore country was formerly hunted by the Noel family, and there are of the pack to-day. The Pytchley was founded by the Lord Spencer of that day, about I750, with a Hunt Club, and this suggests that it has always been a subscription pack. In $I 782$ the club had a membership of twenty-eight, and since the hunt came into being over thirty men have held the mastership, or have been joint masters of the pack. The Woodland Pytchley is part of the Pytchley proper, but the country has been to all intents and purposes divided since $I 87+$.

Almost every part of the kingdom where riding is possible-and certain districts where hounds can only be followed on foot -is hunted by one or more packs of hounds. Foxhounds, as a matter of course, predominate, but staghounds and harriers are very popular in some districts, and there are 
large districts of Lancashire where there are no foxhounds, but quite a number of staghound and harrier packs.

It is the case that throughout the greater part of the kingdom the best hunting is to be found in localities which are not generally picturesque, and that where the country is really pretty, where there are steep hills, deep valleys, big woodlands, and so forth, the district is not so good for the sport. This partly explains itself, for where the of the sport, and this can be best achieved in an open country where hounds can be kept in sight by those who follow them field by field. As regards the hounds themselves, if they are staunch and true they hunt as well in a rough wooded country as they do in an open plain, but it is often a matter of extreme difficulty for followers to keep thoroughly in touch where woodlands and steep hills are abundant, whereas it is just the reverse in the open country.

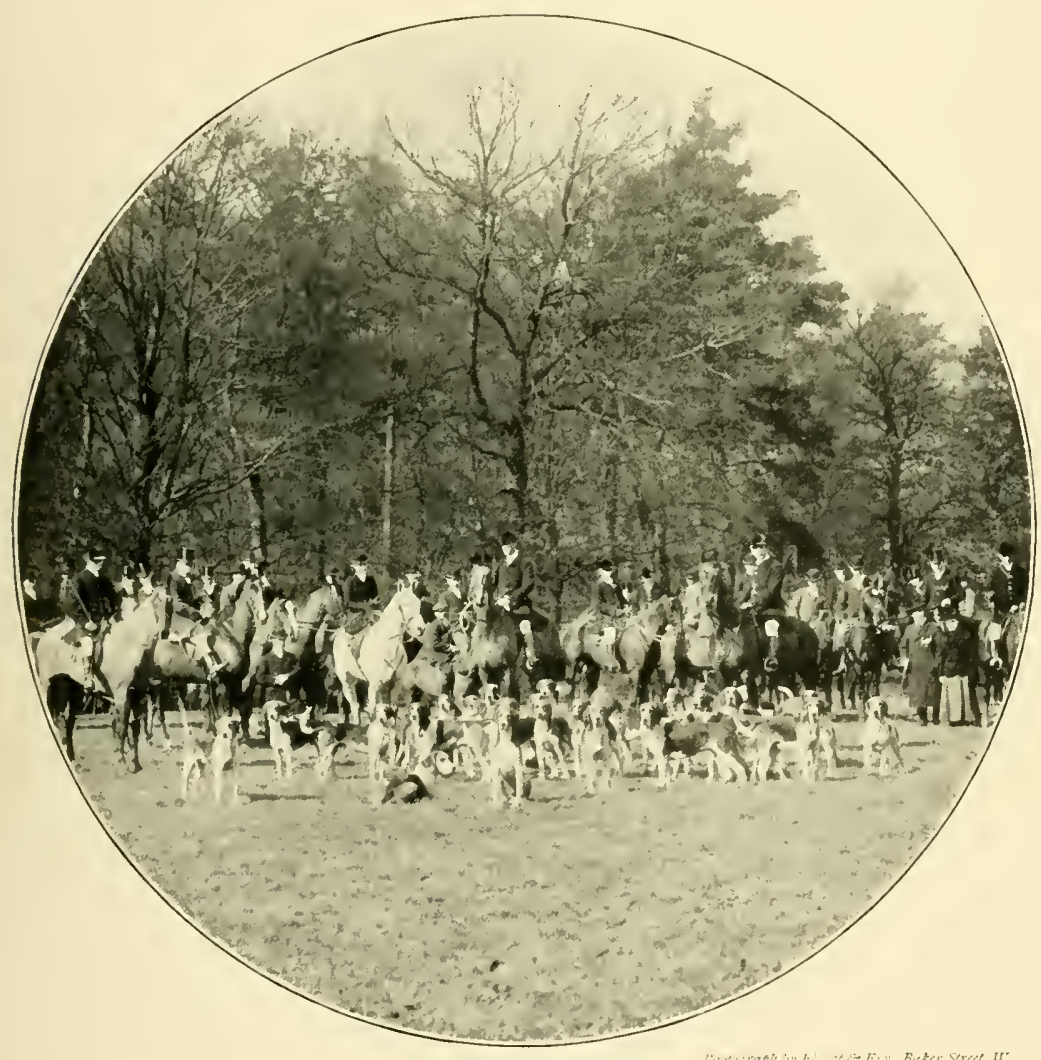

MR. FERNIE'S HOUNDS.

land is flat, or gently undulating, the riding must be better than where there are constant declivities. In fox-hunting it is, of course, necessary to be very near hounds if one is thoroughly to enjoy all the niceties
This difference of country it is which causes one hunt to be fashionable, and another to be very different. Every country that presents few riding difficulties-except the ordinary fences dividing the fields--is 
in these days attractive from a hunting point of view, while the hilly and woodland countries leave a good deal to be desired as far as the riding is concerned. Thus it is that the Midlands generally are looked upon as the best hunting grounds, and are visited by more strangers than are to be found elsewhere. All who have travelled from London by any of the three or four main line routes to the north must know that there is no scenery worth talking about until the Midlands are left behind. Passengers on the Great Northern, indeed, hardly reach anything that is really picturesque until the train has crossed the Scottish border, but this particular railway runs through a dozen hunting countries, some of which are first-rate, some fairly good, and very few of them only moderate. It is the same with the Midland, the London and North Western, and the Great Central main lines, but possibly a traveller on the Midland can form the best idea of what is a good hunting country, as their main line north intersects the very best of the Shire countries.

On the other hand some of the southern railways, notably the Brighton line, and the line from Waterloo to Portsmouth, pass through picturesque, hilly, and well wooded country, and though every inch of it is thoroughly hunted by foxhounds, the packs which are there located are more local in character than those on the north of the metropolis, and the hunting is in a great measure confined to the residents.

\section{Midland Hunts}

In the Midlands, and certain other districts, it should be explained that scores of the residents have chosen a neighbourhood to live in chiefly because the hunting is good, whereas in the unfashionable hunting countries, the new-comers are seldom influenced by hunting possibilities.

Leicestershire, Northamptonshire and Rutlandshire are generally conceded to be the best hunting counties, and in them are located the Shire packs which have already been mentioned. That some of the luunting countries in these two counties overlap is a fact, and this part of the Belvoir and
Cottesmore hunts extend into Lincolnshire, but their best country is in Leicestershire, and this is formed of grazing ground, on which thousands of cattle are fed during the summer months. It is because there is so much more grass than plough, because the country is mostly open, with few big woodlands, and because there is little population, and not much industrialism in the more rural districts, that the Shires are such a famous hunting ground. The hills are molehills in comparison with those farther north, or in parts of the south of England, and therefore it is generally possible to keep close to hounds, whilst riding over sound grass, and jumping fences which are for the most part practicable to a wellschooled horse. The advantages of these Shire countries were quickly detected when fox-hunting became fashionable, and for a good deal more than a hundred years the Shires have stood first of all districts in the hunting man's estimation, and Melton Mowbray in Leicestershire has been the metropolis of the hunting world. All sorts and conditions of hunting enthusiasts have looked upon Melton as a veritable Mecca, and ever since the sport became really popular the town has attraced hosts of strangers, who reside in its neighbourhood throughout the winter months.

\section{Improvement of Provincial Hunts}

A little south of Melton Mowbray is Market Harborough, also a fashionable hunting quarter, and west of this place is Rugby, where several hunts join, and which now accommodates scores of hunting folk who are not natives of the district. There are many other places in the Midlands which also attract strangers for the hunting, and mention may be made of Grantham, Lutterworth, Loughborough, Weedon, Oakham, and Uppingham. Round about the Shire countries the hunting is not very much inferior to that which takes place in Leicestershire and Northants, and in the matter of equipment of the hunts there is really nothing to choose.

Indeed, the great improvement which has taken place in nearly all the front rank of 
provincial hunts is one of the most remarkable things in connection with modern hunting. Time was when it was a case of "The Shires first and the rest nowhere," but in these days, although the Shires are still first, "the rest" are very much to the fore, and in many ways some of the so-called provineial packs more than hold their own.

\section{Increase of Subscription Packs}

The fact is that during the last hundred vears many of the countries away from the Shires have become much better from every point of view. In a great number of places nuch land has been laid down to grass since the repeal of the corn laws. This has made the riding better than it was, but this is not all, for curerts have been made where they were wanted, foxes have been carefully preserved, and in point of fact the conditions surrounding the sport have been altered for the better in all sorts of ways. Then, too, the country hunts are conducted on a higher and more expansive scale than was formerly the case. Many of the larger countries have been divided, several what may be called auxiliary countries have been ereated, and, in fact, there are about three times as many subscription packs as there were seventy or eighty years ago. In proof of this it may be mentioned that when Mr. Vyner compiled the first Foxhound Stud Book in $18 f 1$, he could only give a list of forty-six packs, and of the Royal Buckhounds. Particulars of about half-a-dozen other early packs were furnished by Mr. Cecil Legard in the lately published Vol I. of the new series of the Foxhound Stud Book, but in the last volume one finds the lists of over $15^{\circ}$ packs, and this is conclusive evidence that not only are there more packs, but that the kennel records are much better kept than they used to be.

\section{Influence of Peterborough Show}

But where the provincial packs-and all packs except the half-dozen Shire packs are "provincial" in the technical sense of the term-have gone so much ahead is as regards the scale on which they are turned ont.
Hound breeding has engrossed the attention of a majority of masters in recent yearsthanks in a great measure to the institution of the Peterborough Show, and as hounds have improved a better class of horse has been used to ride up to them. The Belvoir do not show at Peterborough, but when other Shire packs are represented the best of the provincials fairly hold their own. In the matter of hounds, then, there is nothing to choose, and as a natural sequitu: it is the case that much the same state of affairs exists with regard to the horses. A very large dealer recently told the writer that if all the best horses in any hunt, from the stables of the master and from those of the principal subseribers were to be put up to auction he would expect to see the horses from the Meynell bring more money than the horses of any other hunt. The man who said this was in a position to speak, and he appeared to be very firm in his opinion.

\section{Increased Popularity of Hunting}

At the present day the Meynell is not the only hunt which is not in the Shires but which has nevertheless a very high place among modern hunting establishments. But before mentioning other (what may fairly be called) great hunts, it may be explained that not only do hounds and horses show marvellous improvement in many of the provincial hunts, but that the number of followers has so greatly increased that the subscription has risen, and the hunting is carried on on a far larger seale than it used to be. In several countries where hounds hunted two days a week the number of days has been increased to three and four, and many of the old county packs are now in two sections, such as the Shropshire, the Durham, the V.W.H., and so forth. As an instance of a very great increase the Ledbury (in Herefordshire) may be quoted. In the early 'screntics the writer hunted for the best part of a couple of seasons in this country, and the establishment was a very small one, hounds being out only two days a week regularly, though after Christmas there was often a third day. In the rgo8-9 season the Ledbury proper hunted four days a week, the 
North Ledbury (on the north side of the original Ledbury country) two days, and Mr. Gordon Canning had a private two-daysa-week pack on the Gloucestershire side of the country, which for the most part had its operations in country lent by the Ledbury Hunt.

\section{Smartening-up of Hunts}

And even in many remote countries there has been a general smartening up, as regards horses, hounds, and turn-ont generally ; and where the hunt establishment has been modernised and generally improved, the improvement has, as a rule, extended to the field. Some of the very provincial hunts are now turned out in exceptional fashion, with horses and hounds which would pass muster anywhere, and with the men dressed by London tailors and bootmakers, just as they are in the fashionable countries. Second horses, too, have become common all over the country, and the upshot of this in the provincial hunts is that more country is now drawn in an average day than was formerly the custom, and that operations generally are conducted considerably faster than they once were. There has, in fact, been a levelling up, and though there still exist certain packs of hounds whose turn-out can only be described as primitive, these packs are now in a minority, and there has been no change because they are located in out of the way districts, where the following is very small, and where-in many cases - the neighbourhood is not a rich one. It may be added that, as regards improvement, the best results have been obtained in those parts of the country which are not very far away from large industrial districts, and which, for this reason, have been chosen by sporting and wealthy commercial families for their recreation.

\section{The Fitzwilliam}

It has been said that many other packs in the Midlands are of great importance in addition to the Shire packs. Several of these are only at a disadvantage where the country is concerned. Such packs have plenty of good open country, and a fair share of grass, but not the continuous grass of Leicestershire and Northants, and for this reason they are a little less fashionable, and do not attract so many strangers. One such hunt is the Fitzwilliam, which is mostly in Northamptonshire, but at the wrong end of the county as far as grass is concerned, plough and pasture being about equally distributed throughout the hunt. Still, the Fitzwilliam is essentially a great hunt, and its kennel one of the most famous which the history of fox-hunting has known. Fitzwillian hounds, though greatly allied in blood to Belvoir, are for the most part lighter in colour, and at the present day they are one of the two or three packs which are most successful at Peterborough. The blood is generally known as Milton-Milton Park being the residence of Mr. George Fitzwilliam, the master-and it is to be found in nearly all the best kennels of the day. The Fitzwilliam march with two Shire packs, the Woodland Pytchley and the Cottesmore to wit.

\section{Other Midland Hunts}

The Grafton, to the direct south of the Pytchley, is also an important four-daysa-week hunt, and the sime can be said of the Bicester, which touches the Pytchley on the latter's south-west border. North and west of the Bicester lies the Warwickshire country, which is almost as fashionable as the Shires, the country having in recent years attracted scores of people as residents, solely on account of the hunting. The Warwickshire as regards area claims to be the biggest hunt in the kingdom, and until quite recently hounds were out on five and six days of the week. From a riding point of view, however, Warwickshire in its entirety cannot be compared with Leicestershire and Northants; much of it is very heavy and frequently flooded, and there are one or two very steep hills in the southem part. The North Warwickshire, hunting three and four days, according to the season, lies between the Warwickshire and Atherstone, and is one of the several hunts which is within convenient reach of Rugby: 


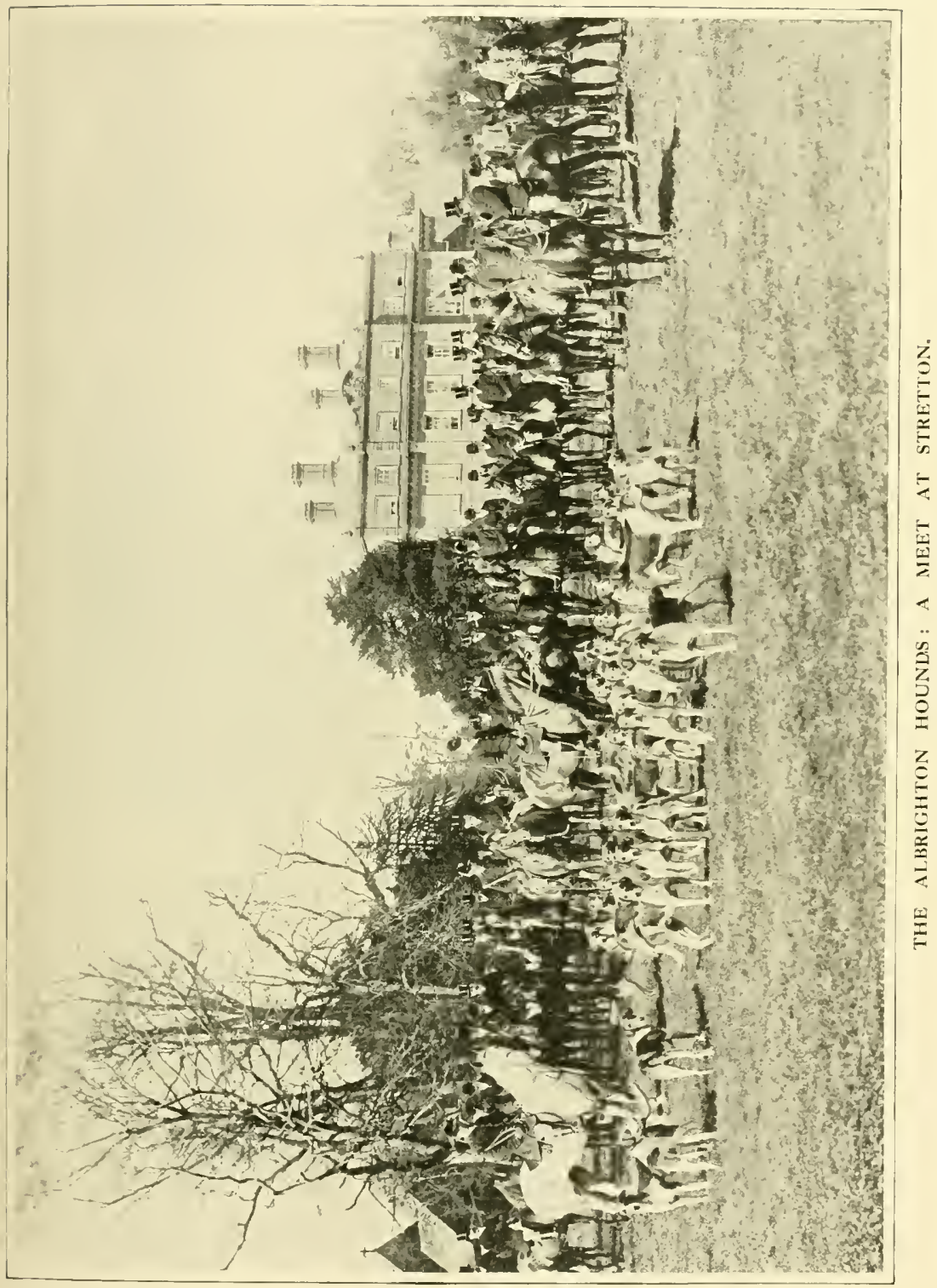




\section{The Atherstone and Others}

The Itherstone, west of the Quorn and south of the Meynell, is almost a shire pack, mucl of its best country being in Leicestershire, and on certain days attracting a section of the Quorn field, and the Mernell, which has already been mentioned, is also a famous pack, possessing a capital country, which joins the Quorn on the south-west, and contains a large area of grass. The Meynell has one of the best packs of hounds in the kingdom, and altogether the hunt is a very smart one. The North Staffordshire, hming four days a week, and possessing a fair mixed country, borders the Mernell on the north-west, and north of that again is the Cheshire country, which is nearly all grass, and includes an excellent vale country. The Cheshire is one of some three or four packs which hunt six days a week, and at all the more popular meets the "fields" are very liurge. Indeed, there are those who think that the Cheshire has as big a following as any pack in the country, and at a recent ordinary meet over five hundred riders were comnted.

\section{Western Midlands Hunts}

Throughout the western Vidlands there are many well-nunaged hunts, several of which not only show capital sport, but lave good country to ride over. The North and South Shropshire between them hunt five, and sometimes six times a week, The Wheatland is ont twice (and sometimes thrice), and the Ludlow has three regular ditys, and an occasional by-day. Then there are the Cotswold, the North Cotswold, the Worcestershire, the Croome, the Ledbury and its auxiliaries, which have been mentioned, the North and South Herefordshire. the Mommouthshire, and Mr. Curre's, all of which may be termed sporting hunts, and which have a fair following. The countries are, perhaps, not so good on the whole as those farther north and east, nor are the fields so large, and. in fact, the followers are, as a rule, local residents, but each one of those mentioned has some good cotintry, and the Cotswold and the Ledbury, which hunt the Cheltenham and Malvern districts, at times attract many strangers.

\section{Berks and Oxfordshire Hunts}

Going westward from London much good country is to be found. Nearest town on this side of the country there is the Old Berkeley West, which, with the exception of a small slice of the Vale of Arlesbury, is only a moderate country, but contains a well-managed hunt. There is so much game preservation, so many enclosed parks, and so much woodland that at times it is difficult to follow hounds, and much of the country is what is known as cold scenting land. All the same the hunt is well supported and popular, and this description applies to its southern neighbour, the Garth Hunt, in Berks. The Garth has a very varied country, with good bits here and there, and a very large following, which is easily understood, because the district is largely populated, and such towns as Windsor, Maidenhead, and Reading are on its boundaries. West of the Girth lies the four-dars-a-week South Berks country, and north-west of the last-named the Old Berks, which has a fine vale country west of Didcot, and a great deal of grass, as well as down-land on its southern border. North of the Thames lies the South Oxfordshire country, which includes in its area the most southern part of the Vale of Arlesbury, and north of the South Oxfordshire is the Bicester, which has already been mentioned, and the Whaddon Chase, the last-named a two-days-a-week pack, which shares with Lord Rothschild's staghounds the greater part of the Vale of Arlesbury, one of the most famous grass vates in the kingdom.

\section{Duke of Beaufort's}

But west and south of these Berkshire and Oxfordshire hunts are some three or four others which take very high rank, all of them possessing much good country, big establishments, and each liaving a lirge and important establishment. Reference is made to the Hey throp, the Duke of Beaufort's (Badminton) country, the $\mathrm{V} . \mathrm{W}$. H, and the 
Berkeley. The Heythrop hunts on four day's a week, most of its country being in Oxfordshire, and though there is a good deal of plough land in certain parts of the liunt, much of it is light plough, and the country from an all-round point of view is a very good one. The Duke of Beaufort's country is about the largest in the kingdom-though it is claimed that the Warwickshire have a greater acreage-and includes every form of land. Much of the best of it is grass, but considerable areas of plough are also to be found, and parts of the country are high lying with large fields intersected by stone walls. But what is most remarkable about the Duke of Beaufort's Hunt is that hounds hunt regularly six days a week. There are one or two other packs who will hunt six days for a season or two, and then go back to four or five days. But the Duke of Beaufort's, and the Cheshire since the North and South Cheshire were reunited, maintain the same order of things year after year. At times two packs of hounds are out in the Badminton country on the same day-this custom also obtains occasionally in Cheshire, in different parts of the country-and at other times hunting is commenced very early in the day with one pack, and somewhere about noon fresh horses and hounds are brought out.

In point of fact the Duke of Beaufort's is about the most complete and most important hunting establishment in the kingdom. The kennel is quite one of the most famous in the world, and the country is so large that, as has already been explained, a portion of it is nearly alway's lent to some individual or to some other hunt. As a matter of course many strangers visit the Duke of Beaufort's country every year, and scores of hunting people reside there merely because the sport is so attractive

\section{Vale of Bcrkeley}

The Vale of White Horse country, lying north-east of that of the Duke, was formerly a single country, but was divided into two sections, Cirencester and Cricklade, in 1886. There is more grass than plough throughout the whole district, and hounds are out on five or six days of the week in the two countries. The Berkeley has been mentioned as one of the old family packs. The country hunted now is all in Gloucestershire, the best of it being in the valley of the Severn, commonly called the Vale of Berkeley, and it is believed that seventy per cent. of the whole area is grass, and that there is not more than fifteen per cent. of plough, the balance being woodland.

\section{Blackmore Vale and Cattistock}

South of the hunts which have been mentioned are many well-known countries, but with two exceptions-the Blackmore Vale and the Cattistock-none of them takes such high rank as the countries already described. The Blackmore Vale and Cattistock are mostly in Dorsetshire, though both packs hunt a little in Somersetshire, and most of their operations are conducted in country which is given over to dairy farming. This means that most of the riding is on grass, and as a matter of fact both countries are described as "chiefly pasture with a little light plough." The Blackmore Vale is a four-days-a-week country, and the Cattistock through the roo8-9 season adrertised for five days a week, but the number of these days has varied considerably in recent years, and at times they have been out on the full six days a week.

\section{Devonshire Hunts}

In Devonshire there are some eleven packs of foxhounds, and every incly of the county is hunted, but as most of the country is hilly the riding is somewhat rough, and "fields" are for the most part local. Still Devonshire is a wonderfully sporting county, and on the whole it contains more packs of hounds-staghounds, otter-hounds, harriers and beagles being included-than any other county in the kingdom. Without doubt the residents in Devon encourage hunting in all its forms, and though there are many moorlands in the country, and a great number of densely wooded combes, hounds show great sport. The premier pack is undoubtedly that of the Devon and somerset Staghounds, to which some further 


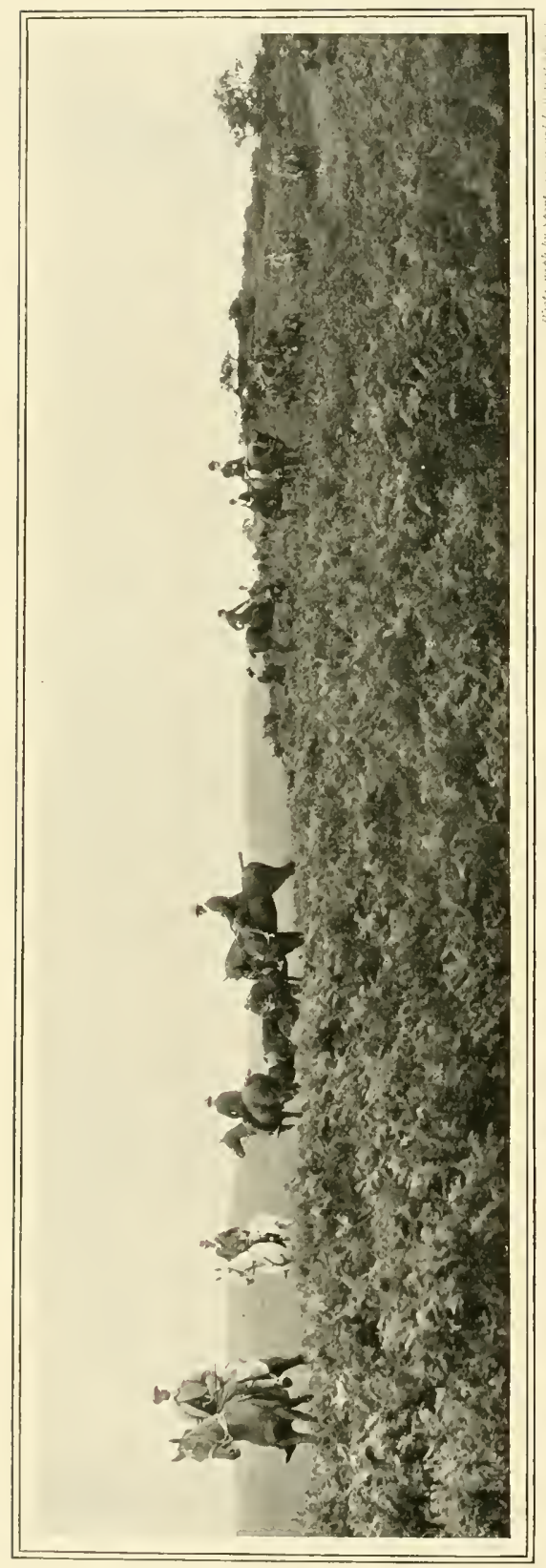

reference will be made, but foxhounds also hunt the same ground, and notably the Exmoor, the West Somerset, the Dulverton, and the Tiverton. Nuch of the riding in these countries is on moorlands, but the moorlands of Devon and Somerset are rideable, especially to those who know them well, whereas when hounds in some of the north of England countries reach the moors, it is at times impossible to follow them, and the writer has seen a northern pack go clean away from everyone, and be lost for half a day. This was due to the fact that tracks across the moor were few and far between, that because hounds so seldom went there none of the field had a real knowledge of the moor, and because the various allotments were divided by wire fencing.

Two or three years ago there was for a time a supplementary pack to the Bedale, belonging to MIr. Scrope of Danby, but it was found so difficult to follow hounds that they were given up. The fact is that many north of England hunts have country which borders the moorlands, but these particular moors are mostly steep and rugged, and of vast extent, whereas Exmoor and Dartmoor are isolated patches of moor, with open country all round them, and at times the staghounds run right across Exmoor in a single hunt. Moreover, there are a fair number of roads which divide the moor ; but in the north the line of moors extends for more than a hundred miles, and is practically unfit for riding. Cornwall has some three or four packs, of which the Four Burrow has far the largest country; and if we look at the south coast from Dover to the Land's End we shall, as a matter of fact, find that there are hounds everywhere.

In Kent there are the East and West Kent, the Tickham, and the Eridge; in Sussex are to be found the East Sussex, the Eastbourne, the Southdown, and the Crawley and Horsham, 
which packs amongst them cover every inch of the country. Kent and Sussex hunting is conducted to a considerable extent among wooklands, but here and there are nice pieces of open country, and all the packs are popular and well supported. Further down the coast, almost entirely in Sussex, but going a little inte Hants, is Lord Leconfield's Hunt, one of the largest establishments in the kingdom, as three distinct packs of hounds are kept, and hunting takes place almost every day. This country includes a great deal of what was originally the Charlton, and afterwards the Goodwood Hunt, and though it is very hilly, and well wooded in places, it also contains some strongly fenced vale. Being rather more remote than some of the Sussex and Hampshire countries, and well away from centres of population, Lord Leconfield's is, to a great extent, a very wild country, and possibly in no other hunt of this particular part of England can hound-work be so thoronghly appreciated, because fields are seldom large.

\section{The Hants Hunts}

In Hants there are the H. H. (Hampshire Hunt), a four-days-a-week pack, in the northern part of the county, the Hambledon and the Hursley, and in the New Forest there are both foxhounds and staghounds. Other hunts touch the county, and much of the Vine country is in Hants, but the county as a whole is a good deal covered with woodlands, and where the country is open there is more plough than grass. In Wilts and Dorset there are the South and West Wilts, the Tedworth, the Wilton, Lord Portman's and the South Dorsetall to the east of the already-mentioned Blackmore Vale and Cattistock, and in Berks, Hants, and Wilts, there is the Craven Hunt, sonth of the Old Berks and V. W. H., and due north of the Vine country.

\section{Home Counties Hunts}

All round London there are packs of hounds at no very great distance from town, and probably those who have not studied such matters would be greatly surprised if ther knew how very near to population some of the hunting comes. The writer, for example, has seen, within the last eight or ten years, the Old Berkeley West at Denham, just beyond Uxbridge, the Surrey Union at Worcester Park, not more than eleven or twelve miles from Hyde Park Corner; and he has also seen the same pack run a fox right across the Epsom racecourse, leaving it at Tattenham Corner, and going on to the Nork Park coverts, which lie between Tattenham Corner and Banstead. He has seen a run with the now defunct West Surrey Staghounds have its finish in the goods yard of Surbiton Station, and he has seen the Old Surrey hunting within three or four miles of Croydon. On the north side, too, Mr. Smith Bosanquet's hounds, the Essex, the Essex Union, the Old Berkeley, and the Hertfordshire, all are at times within easy riding distance of the northern suburbs, and on the west side the Garth hounds meet constantly within a mile or two of Chertsey or Maidenhead.

\section{Hunting for Londoners}

That all these hunts which come so near London are supported by Londoners is an actual fact. One does not imply that men and women ride out of London to hunt with them, but the fields are for the most part formed by people who have occupation or business in town, but who reside within the boundaries of the particular hunt they affect, and who are in town on the nonhunting days. Indeed, there are many other packs beyond those named which draw largely on London business men for their support, and in this connection may be mentioned the Burstow in Surrev, the Puckeridge in East Herts, the Whaddon Chase in Bucks, the Garth and South Berks, the Bicester to some extent, and in fact every pack which is located within what may be called residential reach of London. With some of these Home Counties packs fields are very large indeed, especially at the popular meets, and 300 riders is by no means an uncommon field within a thirty to forty mile radins of the metropolis. As a matter of fact the 
popularity of all these packs varies with the quality of the sport that is shown, and, perhaps even to a greater extent, is dependent on the fox supply. Much of the country near London is heavily wooded, and on the southern side it is hilly as well. On the north and east, however, there is a great deal of open country, the greater part of which is arable land, this applying particularly to Herts and Essex.

But even in the hilly districts there are at intervals nice bits of vale country, and to the north-west, notably in the Vale of Aylesbury, it is practically all grass, and much the best riding country near town. In Herts and Essex the stubbles are good riding during the autumn months, and if the winter is a wet one scent lies well on the ploughs, but, as has been suggested, the greatest drawback to sport near London is the fact that foxes are not preserved everywhere as they are in the Midlands, and that in consequence sport is not so continuous. One is inclined to think that there has been an improvement in late years, and during the r $908-9$ season a certain pack reported that it had had no blank day, whereas about a dozen seasons ago the writer had five full days with the same pack, when only two foxes were found.

\section{Eastern County Hunts}

In the Eastern Counties also there is considerable difficulty in keeping the fox supply up to the mark, and though all the country is hunted, except a part of Norfolk, most of the huntable area is arable land, and nearly everywhere game preservation is carried on to what, from the fox-hunter's point of view, amounts to excess. But nevertheless there is in every district of the kingdom a certain section of the community who will hunt if there is anything which can be hunted, and there is also an inner section of hunting folk who prefer to do their hunting on horseback. The upshot of this is that hounds which can be ridden to are to be found even where the galloping is all plough, and where the district is celebrated for its shooting rather than the sport which is forthcoming from packs of hounds. The Eastern Counties maintain many packs ; several of those hunting in Essex have been mentioned, but there are, in addition, the East Essex, the Essex and Suffolk, the Newmarket and Thurlow, the Suffolk, and the West Norfolk, the lastnamed hunting, amongst other places, the coverts connected with the Royal residence at Sandringham.

\section{Lincolnshire Hunts}

Going farther north, and still dealing with the eastern side of the kingdom, Lincolnshire is a very fair hunting county, and is to some extent a good horse-breeding district also. Very much of the country is under plough, but there are certain grass districts, and notably a fine vale in the Blankney country. The inhabitants are a horsy and sporting community, and as much of the hunting is on the light plough of the wolds, and as the Lincolnshire packs are all famous ones, it follows that the sport reaches a pretty high standard. The most important pack in the county is the Belvoir, whose best country as regards riding is in Leicestershire, but who have their larger district in Lincolnshire. North of the Belvoir there is the Blankney, and north of that the Burton, of which the last-named is the parent hunt, the Blankney, which came into being in $187 \mathrm{I}$, being the southern half of the original Burton country, which was made famous by Lord Monson in the eighteenth century, and has since had such masters as "Squire" Osbaldiston, Mr. Assheton Smith, Sir Richard Sutton, and Lord Henry Bentinck-to say nothing of Mr. Henry Chaplin, who was master from I865 to $\mathrm{I} 87 \mathrm{I}$, and afterwards held office with the Blankney for eiglet seasons.

The Brocklesby country, which has already been mentioned, is north and east of the Burton, and the Southwold south of the Brocklesby and east of the Burton and Blankney. The last-named contains more plough than pasture, but is a fine sporting country, very open, and little troubled by population, railways or industrialism. All the Lincolnshire packs have fine kennels of hounds, and throughout the county the 
various hunts are well supported not only by the landowners and squirearchy generally, but by a class of large yeomen and farmers who are almost peculiar to the county. Such a class is also to be found in the East Riding of Yorkshire, and both there and in Lincolnshire these men-many of whom farm 2,000 acres or more-are a great backbone of the sport. They are for the most part breeders of horses, and though they have had the rivalry of Ireland to contend with in the hunter market during the last two or three generations, they still produce many high-class animals.

\section{Notts Hunts}

Another very sporting county is Notts, which maintains Lord Harrington's hounds (formerly the South Notts), the Ruffordpart of whose country is in Derbyshireand Lord Fitzwilliam's (who go a little way into South Yorkshire), known for many years as Lord Galway's. Lord Harrington also hunts at present a strip of country between Loughborough and Leicester, which has been lent to him by the committee of the Quorn, and his hounds are often out on all six day's of the week. His proper country varies a good deal, and it contains more population than is to be found in the Lincolnshire hunts, but some of the vale land is capital, and many good hunters are bred and reared within the confines of the hunt. Indeed, thronghout the northern and eastern Midlands the local horses, and the local classes at the more important shows, are wonderfully well supported, and it is a fact that the breeders in Notts are extremely particular as to the quality and breeding of the sires they patronise. It may be that because the breeding of thoroughbreds has been immensely successful in Notts, the breeders of hunters have a better chance of procuring good sires than many other men who have the same object in riew. Anyhow, it is a fact that at the Welbeck Abbey stud, where the Duke of Portland has bred two Derby winners, and a host of other good horses, first-rate hunter sires are at the service of the tenants and other neighbours. And at Sir John Robinson's Worksop Manor stnd much the same state of affairs prevails, and the Duke of Portland and Sir John are not the only breeders of thoronghbreds in the county of Notts.

"I always pay particular attention to the young horses bred in Notts," said a well-known dealer to the present writer at the last Peterborough Show. "There is a fine choice of good sires, and the Nottinghamshire farmers are as a rule excellent judges." This was sound evidence as to the value of Notts as a horse-breeding country, and it may be added that it is the hunting which makes the market for these and other horses, and that if there were no hunting the industry would collapse. As a matter of fact, all the very best of the half-bred stock which is reared in Notts, Lincolnshire, all over the Midlands, in the North and East Ridings of Yorkshire, and to a lesser extent in many other parts of the kingdom, find their way into the lunting field, and only the poorer specimens-the mistits they are nsually called - go to harness work, or become Army horses or general utility nags. Hunting it is which keeps up the price of the top rank, and the hunting which goes on around him it is which stimulates the tenant farmer in his endeavours to breed a highclass cross-country nag.

\section{Earl Fitzwilliam's}

Derbyshire has the already-mentioned Meynell Hunt, part of the Rufford, and the Barlow, the last-named lying north of the Rufford and including a good deal of hilly country almost in the centre of England. Yorkshire supports some thirteen packs of foxhounds, and supplies half the country of a fourteenth pack, and a small district of Lord Fitzwilliam's (Grove) hounds. It may be explained that Lord Fitzwilliam is at present master of two packs, both of which are known as "Earl Fitzwilliam's," but there are two distinct establishments, one at Wentworth in lorkshire, and the other at Barnby Hoor in North Notts, the firstnamed being known as the "Wentworth," and the other as the "Grove" division of the hunt. The Grove hunt fonr days a week, and though they go into Derbyshire 
and the West Riding, most of their country is in Notts. The Wentworth hunt chiefly in Yorkshire, but go over the Derbyshire border. They liave a good deal of population to contend with in places, and a fair amount of woodland country, but grass and plough are about equally divided, and this is the case in either district of the hunt.

\section{The Badsworth}

North of Lord Fitzwilliam's Yorkshire hunt lies the Badsworth country, which can be well located by the traveller who jouney's north on the Great Northern line, as he enters it soon after leaving Doncaster and is in it until he crosses the Ouse into the York and Ainsty country at Selby. On the eastern side of the country there is a delta of strong arable land, stiffly fenced, and with many big ditches to be crossed. On the western side the country is hilly, mostly grass, intersected with stone walls, and a good deal cut up by collieries and railway lines. The Badsworth dates back to 1730 , and at the present day hounds are out four times a week.

\section{The York and Ainsty}

North of the Badsworth three Yorkshire lunts cover the country from east to west, the Holderness being nearest the sea, the York and Ainsty in the centre, and the Bramlam Moor farthest inland. All three are large and important four-davi-a-week countries, well supported, and followed by very large fields. The Holderness is situated in what is perhaps the greatest horse-breeding country in the kingdom, for not only are thoroughbreds and hunters bred in great numbers, but the East Riding is almost the home of the hackney-and in a smaller degree of the Yorkshire coach horse. Curiously enough there is far more plough than grass land in the hunt, but wherever grass is to be found horse-breeding of sume sort is carried on, and it would take pages to enumerate only the celebrated horses that lave been reared within the confines of the Holdemess Hunt. The York and Ainsty is, geograplically, the most curious liunt in the kingdom, being of great length from north to south, thicker at either end, and with a long piece of country on the north-west which dovetails between the Bramham Moor and the Bedale. It extends from Selby to Thirsk, and in the neighbourhood of York is little more than half a dozen miles wide, the Bramham Ioor coming to Rufforth on the western side of the city, while Lord Middleton's hounds meet at the fourth mile-stone from lork on the road to Malton.

The York and Ainsty country was at one time divided into northern and southern districts, but the hunt is now reunited, and being of such great length it draws upon two widely separated parts of the county. Having York for its centre, it attracts large fields at all the more popular meets, and it is all fair country with a good deal of grass in that part known as the Ainsty, and a great deal of flat arable land in the sonthern part of the liunt.

\section{Other Yorkshire Hunts}

The Bramham Moor has on the whole more grass than the York country, especially on the Harrogate side, but probably its most popular district is that which lies between York and Wetherby, and the Friday meets in this particular bit of country are very largely attended. North of the Holderness lies an equally important fourdays-a-week country, long known as Lord Middleton's. Most of the hunting of this pack takes place on the wolds, but there is a strongly fenced vale through which the River Derwent runs, and a famous pack of hounds at the Birdsall kennels. Lord Middleton is a great and successful breeder of botls horses and hounds, and maintains it large establishment for the breeding of humters, while he owns many sires, the progeny of which are extremely successful in the show ring. Immediately north of Lord Middleton's country is a group of small hunts-the Sinnington, Mr. Tane's (late Sir William Cooke's), and the Stainton Dale, and north of them again the Bilsdale, the Farndale, and the Goathland. The three packs last named are moorland hunts of small importance, but the Sinnington 


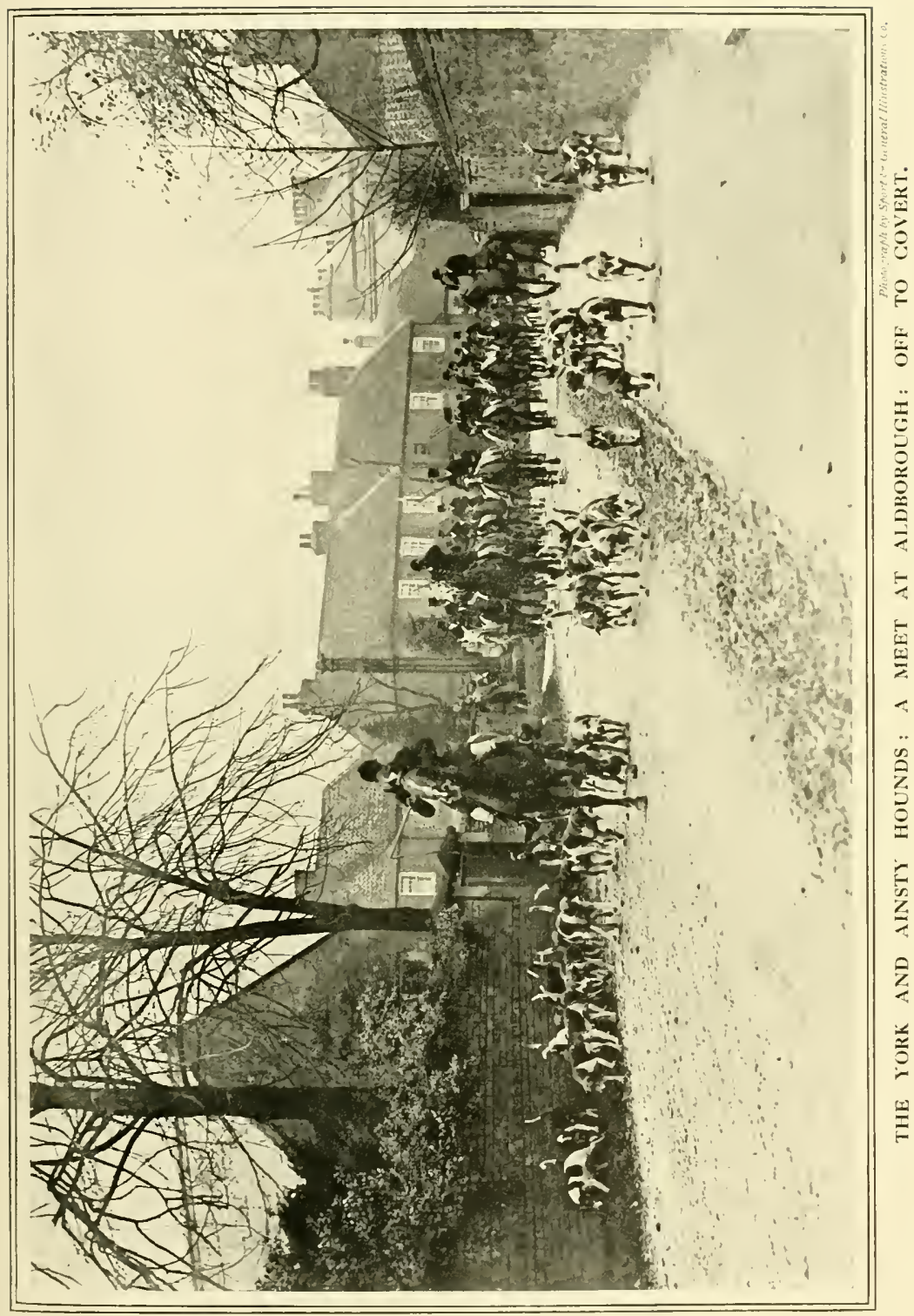


have a small but excellent bit of grass country, and Mr. Vane's the northern side of the Vale of Derwent, between Malton and Ayton, which is fair riding country. These have all been mentioned in connection with the claims as to which is the oldest hunt.

The Cleveland, a three- or four-days-a-week pack, confine their operations to the country north and east of Whitby, and though their country is a hilly one, horses are bred in the valleys, especially the Cleveland bay, so well known in connection with state carriages. Thoroughbreds and hunters, too, are reared in Cleveland, and no less a celebrity than the Flying Dutchman was foaled at Kirkleatham some sixty years ago. Though there is a lot of moorland in Cleveland most of it is rideable, and in this respect the Cleveland district is a good deal better than certain other countries where some of the hunting takes place on the moors.

\section{The Bedale Country}

Going to the western side of Yorkshire, the Bedale country is north of the York and Ainsty, and almost fills up the northwestern part of the North Riding, hounds going west to the moors, so that they have no neighbour on that side of the country. The Bedile is a three-days-a-weel pack, and much of the comntry is somewhat wild, and very remote from any great centre of population. The River Tees, dividing Lorkshire and Durlom, is hunted between Darlington and Barnard Castle by Lord Zetland's hounds, and east of Darlington by the Hurworth. Each of these packs has country in both Durham and Yorkshire, and the Zetland in its entirety is one of the best of provincial countries. On the Yorkshire side of the Tees, where two of the four days in each week are spent, the land is rather flit, but a fine riding country, with fiying fences, small corerts, and more grass than plough. There are no towns, no big villages, no industrialism, and only a single line of railway-which forms the Bedale boundary. The fields are as a rule very large, especially on Thursday, when the meets are within easy reach of Croft and Darlington. On the Durham side of the Tees the country is flat near Darlington, but more undulating farther north and west, and about threefourths of it is grass. There are two or three collieries in the extreme north of the hunt, but these are somewliat remote, and hounds are not very often near them. The Zetland is a particularly smart hunt, and extraordinarily popular. The Hurworth has a flattish country, but there is a good deal of plough in all the best parts. Like its neighbour it is not situated in a populous district, and few humts in the north have a more sporting record, long hunts having at one time been very common in this country.

\section{Other Durham Hunts}

Besides the Zetland and the Hurworth, lounting the extreme south of the country, there are in Durham the North and South Durham, and the Braes of Derwent, which last-named pack liunts a part of South Northumberland as well. The Durham hunts were divided in 1870 , and since then the North Durham country has been greatly cut up by the increased number of coal mines. It has at the present day a small country south and east of Durham, and a larger and much wilder country which goes right up to the moorlands in the north-west of the county. This bit of country is all grass, with small coverts, and carries on the whule the best scent of any country which the writer has ever visited. The South Durham country is much flatter than the North, and offers a lot of fine riding lines, while there is a good deal more grass than plough, and a beautiful pack of hounds. Sedgefield, near where the kennels are situated. was, during the first half of the nineteenth century, a great hunting centre. There was a hunt club, and scores of hunting folk had stabling, or even took houses in the village. The place was then spoken of as "the Melton of the nurth," but the advent of a railway caused great alterations, and though the Sedgefield district has not changed very much, it is not the residential lunting centre it once 
was. The Braes of Derwent country is hilly, and contains some immense woodlands, but many of the coverts are wide apart, and the country between is all grass. Indeed, one may hunt there for a month without riding across a ploughed field, and as a rule the foxes are very strong.

\section{Foxes and Mange}

These Durham countries, however, have lately undergone a terrible visitation of mange among the foxes, and for many seasons the sport in all of them was greatly interfered with. The disease was of the most virulent stamp; foxes which were nothing but skin and bone, with no hair on their bodies, and their brushes looking like sticks, were found lying dead all over the country, and litters of cubs that were apparently healthy and clean in the early autumn died off like rotten sheep before the end of the year. The disease reached the country gradually from the south, and though it was very bad in some of the Forkshire countries first, it seemed to reach its culminating point in Durham. Indeed, a few seasons ago the master of the Nurth Durham reported that he had only killed three sound foxes during the full season, and thus it followed that it was almost impossible to give hounds a fox to eat which they had killed. During this period there were not only many blank days in all the Durham hunts, but a huge majority of the foxes hunted were more or less mangy, and some of the worst afflicted could only run for a few fields. It was a terrible time for all hunting people, and, to show how bad the disease was, a whipper-in's horse has been known to catch mange from contact with a fox's mask which was humg from the saddle, and which, until very carefully examined, appeared to be clean enough. Luckily the disease is nothing like so bad as it was. It has not quite disappeared, but it is much less common, and the mangy fox is now the exception rather than the rule. The trouble is that the supply of foxes was greatly reduced everywhere, but just lately there has been great improvement, and during the autumn of Igog some wonderfully good hunts fell to the lot of the Braes of Derwent hounds. Unfortunately, too, about I007-8 the disease crossed the River Tyne, and the Northumberland hunts accordingly suffered nearly to the same extent as those of the neighbouring county.

\section{The Tynedale and Morpeth}

The southern part of Northumberland contains one of the finest hunting countries in the kingdom, for nowhere away from the Shires are there two adjoining hunts, such as the Tynedale and Morpeth, where there is such an area of the best sort of grass. The Tynedale is practically a grass country, and the Morpeth divide their country into seventy per cent. of grass, only five per cent of plough, fifteen per cent. of woodlands, and ten per cent. of moorland. This moorland extends along the north-western boundary of either hunt, but hounds seldom rum on to it, and as a matter of fact a very large proportion of the hunting with either pack takes place in a somewhat isolated grass country, which is not very easy to reach. Moreover, the pastures are of large extent, and for the most part are very sound going, and except in one or two places there is an absence of the ridge and furrow which is so conspicuous in many parts of the Midlands. Railways and population, except on the extreme east of the two countries, are not to be found either. and in the Tynedale district there is a plateau of high lying grass country, which is a most delectable hunting district. There is, moreover, no town, and hardly a village of more than hamlet size in the Tynedale country, but the best of it is all within reach of the Tyne valley, between Newcastle and Hexham, and in this district a majority of the regular followers reside. The Morpeth country is more easily reached, because the main line from Newcastle to Edinburgh goes through it, but all the best country lies many miles to the west of the railway, and away from the population. The Tynedale have woodlands on the south side of the Trme, but hounds are only taken there for cub-hunting, and in the late spring; the 
Morpeth woodlands consist chiefly of the wooded banks of the Rivers Blyth, Font, and Wansbeck.

\section{Other Northumberland Hunts}

North of the Morpeth lies the Percy country, which also contains a very considerable area of grass land, and is a well organised and important hunt, situated near the coast between Warkworth and Berwick. Northumberland also supplies country for the Haydon, the North Tyne, the Coquetdale, the Border, and the North Northumberland hunts, and, with the exception of the last mentioned, all these have their hunting grounds in remote, ont-of-the-way districts, and hounds are constantly on the moors. The Haydon come down to the South Tyne valley, west of Hexham, and have some fair grass country, but they have enormous woodlands also, where it is difficult to keep close to hounds. The Border have an extraordinary reputation for killing foxes, and as a matter of fact show wonderful sport. There are no woodlands in this country, and nearly all the hunting takes place on the moors, but these moors are rideable to those who know them, and as the following is purely local, it results that the field is able to get about everywhere. In all probability the Border is the most successful moorland pack in the kingdom.

\section{Scottish Hunts}

In Scotland there are eleven packs of foxhounds, rather widely scattered, and of these the Duke of Buccleuch's, in Selkirk, Roxburghshire and Berwickshire, and the Earl of Eglinton's, in Ayrshire, are the most important, each being a four-days-a-week pack, and Lord Eglint on's hounds having a great deal of grass to hunt over. Other Scottish packs are the Dumfriesshire, the Liddesdale, the Eskdale, the Jed Forest, Mr. Scott Plummer's, and the Berwickslire, all of them not very far from the border, the Lanark and Renfrewshire and the Linlithgow and Stirlingshire farther north, and the Fife, which is now the most northern pack in the kingdom.

\section{Irish Hunts}

In Ireland the number of packs rather varies from year to year, but the average number is from twenty-two to twenty-four. There is practically no fox-hunting in the north and north-west of the island, the Louth being the most northerly hunt, but along the south coast there are hounds everywhere. As a whole Ireland is a grand hunting country, and in these days a large majority of the best hunters in the kingdom are bred there, chiefly in the south and south-west. The Meath and the Kildare, which draw largely on Dublin for their fields, are the most important hunts, and like the other countries farther south, they have a plenitude of grass, and nothing like so much bog as is to be found elsewhere. The Irish bank is a formidable obstacle to those who see it for the first time, but Irish horses go on and off in great style, and these fences look more difficult than they really are-to the visiting stranger. Other important Irish hunts are the County Galway, the Island, the Kilkenny, the Carlow, the Duhallow-which has an excellent country north of Cork - the Limerick (where many ligh-class hunters are bred), the Tipperary, and the Waterford. Nearly every Irish hunt attracts at times English visitors, and many of the masterships are frequently held by Englishmen, some of whom serve an apprenticeship to mastership in Ireland with a view to taking important English packs later on. Ireland is, in fact, a nursery for hunters, and a nursery for masters, and one often wonders why more English hunting people do not go there. Nany are to be found in the countries which are easily reached from Dublin, but farther south there is room for far more than now visit the country. 


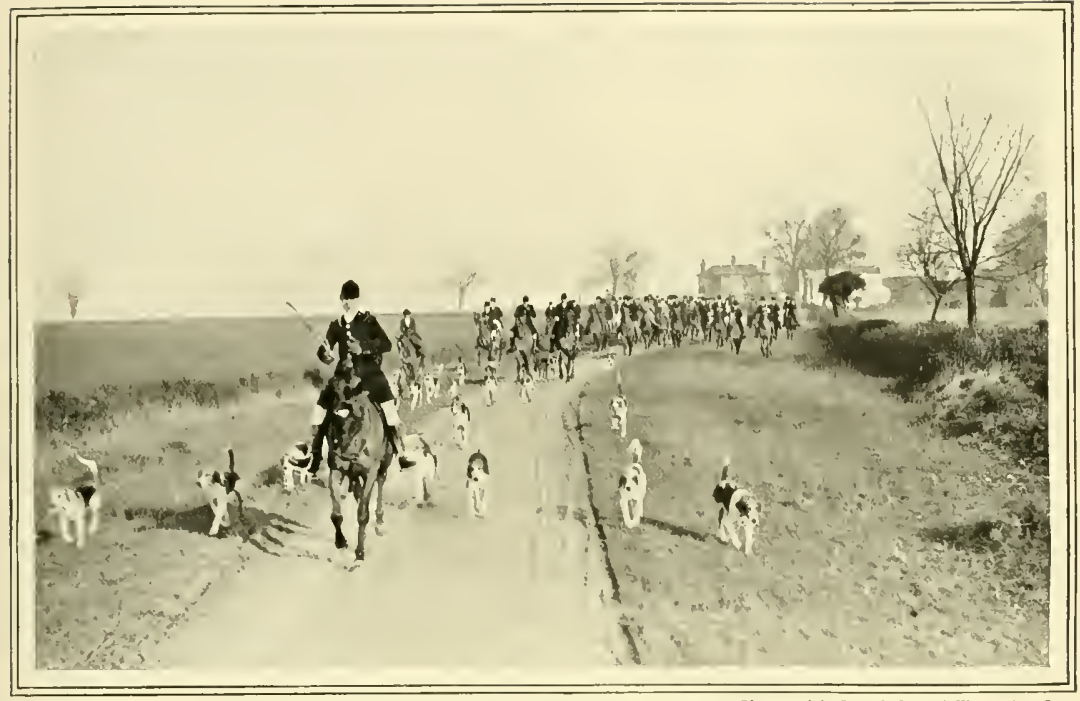

MR. FITZWILLIAM'S HUNT: GOING OFF TO DRAW,

\section{CHAPTER XVII}

\section{FOX-HUNTING}

$\mathrm{I}^{\mathrm{T}}$ $T$ is probable that some readers of this book may never have had the chance of acquiring correct knowledge as to how hunting is conducted in this country, and that being so, a brief description may be given. In all essentials the various kinds of hunting are conducted in the same manner. Whether the fox, the hare, the stag, or the drag is the quarry, hounds are used for the pursuit, and the "field "-which means the people who participate in the sport-are for the most part mounted on liorseback, except in the case of slower and smaller hounds, such as beagles and basset-hounds, when the following is on foot. Foot hunting, however, is not within our province, and we may therefore turn at once to fox-hunting, which attracts probably two or three dozen riders for every one who follows harriers (on horseback), stag-hounds, or the drag.
Fox-hunting, it has been explained, is the greatest of all sports in which horses and hounds are concerned. It attracts thousands of men and women on every day of the autumn, the winter, and the early spring, and its influence on British and Irish country life is enormous. Millions are spent over it every year, and it is open to everyone who is in a position to take part in it. That the British people are a nation of riders (though at the present day there are thousands who have never been on a horse), is in a great measure due to the fact that when riding became unnecessary as far as travelling was concerned, hunting was daily gathering strength, and as a natural consequence riding was indulged in all over the country in a way that has always been practically unknown in most other civilised countries.

There are, of course, other countries besides 
England where riding is common. The Arabs still ride. In Australia and New Zealand every man on any of the stock farms must be a horseman. The same thing occurs in the Argentine Republic, in $\mathrm{La}$ Plata, in many districts of the United States, and, in fact, everywhere where ranching is in progress; but in all these places the riding is for the most part limited to a certain number of individuals. Then in all the capitals of Europe there is a certain amount of hack-riding, just as there is in London, but on the European continent generally the riding is shared by the wealthy class, by the soldiery, and by the country farmers in remote districts, who still ride in order that they may get about the country. In the United Kingdom we have also riders who rice ior business, and some who ride for pleasure, but we also have, and in this respect we are almost unique, the before-mentioned thousands who ride as often as possible in pursuit of a pack of hounds, which are employed in hunting.

\section{Foreign Hunts}

Hunting with a pack of hounds, and a mounted following, is not entirely monopolised by the United Kingdom, but whereas the sport in the British Isles is a veritable business, which gives pleasure to many thousands, and affords employment to many other thousands, and is universal all over the country, it is in other climes pursued vicariously, with here and there a hunting establishment conducted on British lines. In no other country but our own is hunting, as we know it, the sport of a people, attracting all classes of society, and causing enormous sums of money to be spent. Of European countries beyond the United Kingdom only France, Spain, and Italy can claim packs of hounds. France has the Pau Hounds, who almost invariably have the serrices of an English master, and a great number of private and semi-private packs, which for the most part hunt buck or hare, though some of them turn their attention to foxes at times. In a majority of cases the followers are mounted, but there is practically no " field," drawn from almost every class of society, as there is in the United Kingdom. Spain has the Royal Calpe, which hunt the country lying inland from Gibraltar, and Italy has the Roman Hunt, whose operations are conducted on the Campagna. These packs all hunt foxes, and the style of hunting is much the same as that seen in this country, though the "country" differs from ours very considerably. In India there are seven or eight packs of hounds, hunting jackal as a rule, but foxes occasionally, and in Australia there are the Adelaide, Helbourne, and Oaklands Hunt Clubs, hunting foxes, hares, carted deer, and, in the case of the Adelaide Club, a drag. In New Zealand there are at least eight packs of harriers; in Canada there are the Lundon (Ontario) Hounds, which now run a drag, and the Nontreal Hounds, which hunt foxes; while in the States there are a fair number of hunts, the horses from some of which have been seen at recent Olympia shows.

\section{Haunts of the Fox}

In this country foxes are found wild in the woodlands, and in all smaller coverts where there is a thick undergrowth. To gorse-or whin, as it is called in the north of England-they are particularly partial, and this having been realised in the early days of fox-hunting gorse coverts have been planted by the dozen, at some time or other, in nearly every hunting district, but more particularly, of course, where there is a scarcity of woodland. Foxes also frequent dry drains, and "earths," which are, as a rule, rabbit burrows, enlarged by foxes. Where the soil is very light loam, or sandy, and where rabbits are numerous, one occasionally finds a big set of holes which are frequented not only by foxes and rabbits, but by badgers as well. It is a curious thing in natural history that the fox and the rabbit are often close neighbours; the fact is that the fox seldom burrows for his food, but catches it outside, during the hours of darkness. Where the foxes lie mostly at earth-which means underground - the earths are stopped during the night previous to hounds coming to the district, 
and the fox who finds his home closed to hin, will, as a rule, lie up in the nearest covert. Foxes are fond of lying out altogether, and many are bred in the open where there is thick gorse, or in those coverts which have a luxurious undergrowth of hazel, thorns, and so forth. These are frequently called stub-bred foxes, and very seldon do such lie at earth in the day-time, while, when hunted, they go to ground far less frequently than those foses which liave been bred under the surface.

\section{How Foxes are Secured}

It must be understood that in a wellorganised country, where hounds are about to visit a certain district, everything is, or should be, done which is likely to cause foxes to be in the way when wanted. The earths will have been carefully stopped, the coverts will have been kept quiet, and terriers will have been run through any dry drains there may be on the property; such places will in many places be made safe by having a grating placed over the entrance; all these precautions having been taken, it is practically certain that any foxes there may be in the district will be discovered by the hounds. The above applies to a country which in hunting vernacular is "well looked after" by individuals who have fox preservation at heart, and the thing is easily done if the coverts are not too large. But if there are big woodlands in the neighbourhood of the meet it is impossible to make a certainty of finding in any particular place, except in the early day's of cub-hunting. No matter how well the eartlis of a big woodland may be stopped the foxes will stray considerable distances as long as they are in shelter. They may be found close by the earths which they generally use, or they may be miles away, and where there is a chain of woodlands it is no uncommon thing to draw a wellfoxed country for an hour or two without finding, and then to come upon three or four foxes close together.

Fox-hunting begins in August in the south of England, and in September in countries farther north, while in some of the districts near the border there is often no hunting until October is well advanced. The beginning depends greatly upon the harvest, for no hunting takes place until the corn has been carried. Foxes, by the way, lie in the standing corn a great deal during the few weeks before the harvest.

\section{Cub-Hunting}

The earliest hunting of the season is called cub-humting, and at the commencement of this schooling time for young hounds the meets take place shortly after daybreak. The dual object of cub-hunting is to teach the young hounds which are joining the pack for the first time how to hunt, and the young foxes to fly at the approach of hounds, and so get into the way of trying to save themselves when hunted. All early cub-hunting is confined to such woodlands as there may be in any hunt, and, if it is possible, hounds are prevented from following foxes into the open country, but, of course, this cannot always be helped. The writer once saw a seven mile point in the first week of September, between seven and eight o'clock in the morning, after an old fox which slipped away, followed by hounds. The pace at first was so good that the huntsman and whippers-in were unable to get anywhere near the pack, and the fences being absolutely " blind," and the land as hard as iron, they resigned themselves to following on quietly, and came up with the hounds when they were eating their fox.

\section{"Holding-up" Cubs}

In some countries the young foxes, found after the earliest cub-hunting meets, are "held up," when it is possible, in order that the young hounds may be quickly blooded. Holding up cubs does not meet with entire approval, there being many hunting folk who object to it on the grounds that it is not fair play-just as some otter hunters object to the forming of a "stickle," which means that the otter is, if possible, kept in one particular pool owing to a line of people taking up their position at the shallows at the head and tail of the pool, and doing all they can to prevent 
the otter passing to the water above, or the water below.

In principle the holding up of cubs is effected in similar manmer, and the modus operandi is as follows. The covert to be drawn must of recessity be a small one, standing by itself in open country. If such a covert is known to hold cubs, the "field" will-if holding up is decided on-surround it, each individual rider or man on foot standing out in the open about a hundred yards frum the covert fence. When a cub appears whips will be cracked in his face, and he will, if pussible, be turned-.- "headed" it is called--back to covert. Another strong argument in favour of holding up has been mentioned-viz. that rerv early in the autumn it is undesirable that hounds should run in the open, because of the difficulty of foilowing them. One inclines to the idea that where there are no big woodlands, or rather where there are many cubs in small spinneys, or gorse coverts of no great size, it is absolutely necessary to take toll of the cubs; but in the earliest days of the sport cubs camnot travel far, and if allowed to go they seldom cover more than a mile or so before they are rum into. As for stopping hounds from following an old fox on these early cub-hunting mornings, this should always be done, if possible, but there are parks in which the cub-hunting is conducted just as the later hunting is, where hounds are allowed to hunt the first fox they find.

\section{Hours of Meets}

These packs are, as a rule, very late in beginning their sport, and the only difference they make is that they meet at an earlier hour before November than they do afterwards. In one or two odd counties even the hour of meeting in always the same, and to give chapter and verse the writer a few years ago travelled to Exmoor on the Saturday of Doncaster week-probably between the Ioth and $5_{5}$ th of September-and on the Monday morning following went--the staghounds being too far away-to a meet of the Exmoor foxhounds. during the mastership of the late Sir William Williams. The meet was at i I a.m., just as if the regular season had begun, and during the day there were two runs of over an hour each, in which a great deal of comntry was covered.

\section{Cub-Hunting as it Was}

At the cub-hunting fixtures all over the country full hunting costume is not worn, but mufti of every description. Time was when cub-hunting was only attended by the master, hunt servants, possibly by the owners and tenants of the coverts which were to be drawn, and occasionally by a few farmers. One even remembers long hours of cubhunting which were conducted by huntsmen and whippers-in, without the master, or a single member of the field, the writer, and another schoolboy on a pony, being the only others present. This was, of course, many years ago, and in big woodlands which were very remote. One can also remember at a rather late period cubhunting with both the Quorn and Cottesmore packs, when not more than a dozen people on horseback were present, and two or three of those were grooms. Again in the Ledbury country in the early 'seventies, fields in September wouk not average more than half a dozen. Now, however, everything has been changed for many years past, and during the 'nineties one counted over a hundred riders after a five o'clock meet in the first week of September. Not each one of the hundred was present when hounds went to the first covert, but by 7 a.m. the number given was counted, and the country was not quite a fashionable one.

The fact is, that almost within the present generation cub-lunting has been changed from a private affair, nearly entirely confined to the officials of the hunt, to a very complete rehearsal of what is to occur when the season proper commences. The great differences between cub-hunting and regular humting are that the former takes place much earlier in the day, the meets varying from 4 or 5 a.m. at the end of August to Io o'elock or 10.30 in the last week of October; that cubs are, if possible, hunted, and all the old foxes allowed, if possible, to go free; and that everyone dresses as he likes, in anything but orthodox hunting costume. 
After the first of November, or that particular day in early November which is fixed for the opening meet of the season proper, orthodox hunting costume should always be worn, and hounds, instead of being kept to covert work, are allowed to follow eacls and every tox they find into the open country. There is no more holding up, and no further attempts at cub-hunting, though in these days it often happens that hounds
Fields have increased very much in recent years, and whereas the big crowd was at one time only to be found in the Shires, and a few other good and fashionable countries, it is now in evidence in from fifty to a hundred hunts, many of which had no claim to fashion until quite lately. Many of the provincial countries have been greatly improved, owing to the care and forethought which have been bestowed upon

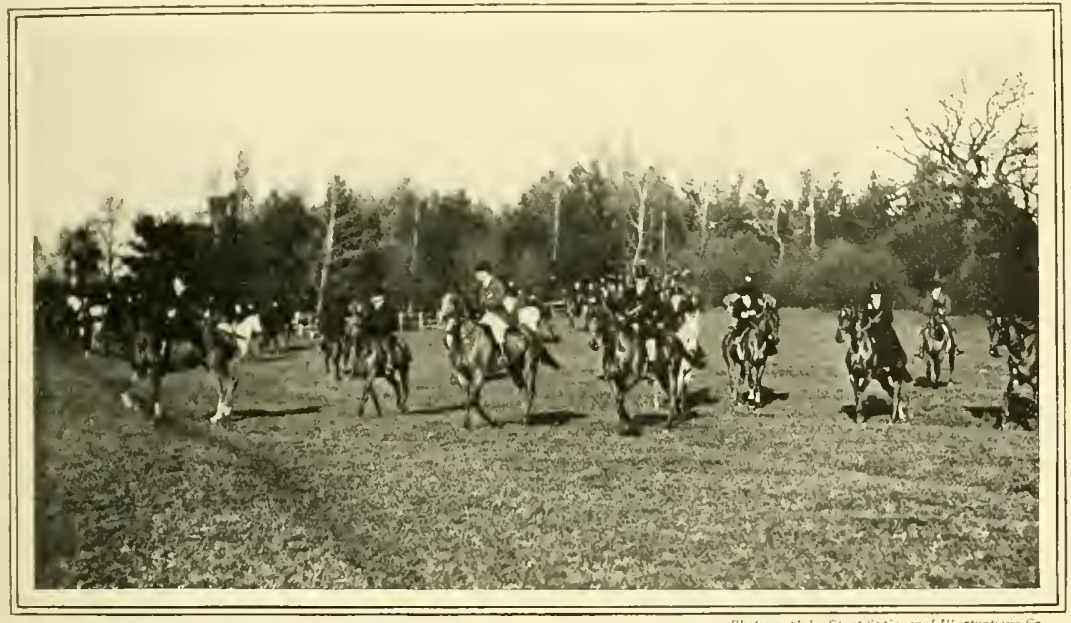

THE GRAFTON FOXHOUNDS: THE FIELD EAGER TO GET AWAY.

have not been in all the coverts (on account of shooting interests) during the cub-hunting periods, and that they may in November, or even later in the season, come upon foxes which have not previously been hunted, which know no extent of country, and which are unable to afford much sport. Before dismissing cub-hunting it may be mentioned that in many open countries the hunting in October is often on the same lines as the later sport, hounds being allowed to follow foxes where they like. In this connection, however, much depends upon whether the ground is hard or soft, whether, in fact, it is a wet or a dry autumn. In times of great drought cub-hunting is often stopped for a t.me, and one has known of fashionable packs postponing their opening day for a week, or even longer, to give the rain a chance of falling. them, and because there is more grass to ride over than there was before the repeal of the Corn Laws. But the chief reason for the improved condition of a large number of provincial hunts is that there has been a huge increase in the number of hunting people, and this means that the subscription list is (on the whole) much larger than it was, say, fifty years ago.

It is true that the old-fashioned squirearchy and the farmers are not represented in the field as they were in the Early and Mid-Victorian period, but there are twenty hunting men who have been successful in business, or have inherited money made in trade, for every one there was at the earlier date, and this accounts in a great measure for the increase in the size of the fields. But not altogether, as in these days about 
a third of every field is composed of ladies, and fifty years ago-and even much more recently-ladies formed hardly a tenth of the fashionable fields, while in the provincial districts there would be not more than two or three in every hunt who regularly followed hounds. The modern hunting woman rides just as hard as the modern hunting man, has two horses ont, and makes as much a business of it as does the enthusiast of the stemer sex. She may ride to a leader in preference to picking out her own line, but there are women who, if they can, go right in front, and depend on no pilot whatever ; there are good men riders to hounds, also, who must follow some one, and are quite unable to pick their own line.

\section{Troublesome Riders}

It follows, then, that in a great many, perhaps in a majority of countries, the field requires more looking after than was formerly the case, firstly on account of its size, and secondly because a big field ahmost invariably includes a certain proportion of horsemen and horsewomen whose ideas concerning hunting are somewhat vague. There is always, where the numbers are large, a new school of riders, many of whom have more pluck than real knowledge of the sport, and such peopie at times give the master an infinity of trouble. Instinctive knowledge of hunting is a gift. Some people, of both sexes, have it, and will pick up sufficient information in two or three days of hunting to make them exceedingly unlikety to do anything wrong. Others, again, though giving it their very best attention, are a little dense, and cannot understand why they must not go here, there, or exactly where they like. When a master is capable, tactful, and has the happy knack of making himself popular, matters seldom go wrong. The old hands know exactly what to do, and where to go, and the beginners quickly adapt themselves to their surroundings. But where the master is impatient, careless, or always behind-this is unusual, but instances have been known-his field is very apt to get out of hand, and then the hunting is very often spoilt.
The beginner should not be above asking for explanations of what he does not thoroughly understand, especially if he has taken to hunting late in life, and has had no real opportunity of acquiring knowledge of the sport. Hunting folk who have begun as boys and girls have the best chance, for most of them live in the cuuntry when at home, and probably are the children of hunting parents. Such children are initiated into hunting very early in life, and as a rule see a good deal of sport during their school holidays. As they grow up they gradually become possessed of all sorts of knowledge in connection with hunting, and if they offend afterwards, it is not because they are ignorant, but because they choose to ignore the unwritten laws with which hunting is surrounded, and without the observance of which it would be impossible to carry on the sport in an orderly manner.

\section{"Give them room, please!"}

Here it must be made plain that hunting in many countries is greatly interfered with by a certain section of the followers who habitually ricle too near the hounds. Who, of those who have hunted in the Midlands, has not heard the cry of "Give them room, please!" either from master or huntsman? And who is there who has not at times seen all warnings disregarded, and hounds in all sorts of difficulties, entirely due to the fact that the foremost of the field were giving them no room in which to do their work?

\section{The "Scent"}

All sorts of hounds, it need hardly be said, follow their game by scent. When a fox is found and hounds get a view they may run by sight for a few hundred yards, but the average fox travels much faster at first than hounds do, and after he has gone through the first fence he is probably seen no more by hounds, until he is being run into. One has often watched a fox (which has been viewed by hounds at the start) in an open country, and been able to follow him with the eye for half a dozen fields or more, but hounds will have ceased to run him by sight almost immediately, and, no matter how 
fast they may be going, will be following the scent which the fox has left. Scent varies greatly, being governed by the state of the land, by the state of the atmosphere, and, to some extent, by the fox himself. Foses differ very much in the amount of scent they throw off. How much it is impossible to say, but vixens with cubs probably throw oft less scent than at other times, and foxes which live most of their lives underground seem to have more scent than the stub-bred variety, who always lie in the open. These opinions are the writer's own, and are given with all diffidence, being merely the result of observations spread over a great number of years.

To go back to the over-riding, it must be understood that as scent varies so does the pace of foxhounds. When there is a really good scent-“" a ravishing perfume" as it was called on one memorable occasionhounds will follow it at their best speed, because they can catch the scent as they gallop. But if scent is lying poorly, the hound has to stoop for it, and pick it out, this effort, naturally enough, reducing his pace. On the good scenting days hounds travel so fast that they have no difficulty in keeping in front of the riders, but on tlee days of bad scent, when hounds can only work slowly, certain riders will frequently keep far too near the pack, and this usually ends in hounds being driven " beyond their noses," and losing the scent altogether. That such conduct greatly interferes with the sport can be readily understood. Overriding is due to conceit, to jealousy, to the absence of consideration of anyone elseand sometimes to ignorance, and when it is not checked there is always trouble.

\section{Remedies for Over-riding}

It is not worth while to go at length into the reasons why so much over-riding takes place, but it is a fact that the worst offenders in every country are very often the people for whom there is no excuse. If a hardriding novice comes out, and gallops too near the pack, he is probably doing so because he is ignorant of where he ought to be, but when people who have hunted regularly for many seasons habitually offend, they must do so with complete knowledge that they are disregarding the laws of the sport, and spoiling the fun of other people.

What is to be done with the persistent over-rider is a problem which has puzzled the hunting folk of many countries. On two or three occasions a firm master has taken hounds home in the middle of the day by way of protest, but masters generally are extremely desirous of awoiding such a last resort, and yet it is the only real remedy, short of singling out the offenders, and asking them not to come out with hounds again. We have, perhaps, written rather strongly on this subject, but it is a matter of paramount importance at the moment, and it is possible that our words may be read by some of the culprits-or even by beginuers who are inclined to press on. No matter where the hunt is located hounds must be allowed plenty of room in which to work for the scent, and to cast themselves when they have lost it, and even on the good scenting days no one except the huntsman should ride within a hundred yards of the pack in an open country, while if scent is catchy and uncertain, the field should give them much more room.

\section{Drawing the Covert}

From the meet hounds are taken to the covert which has been chosen by the master as his first draw, and into that covert the huntsman goes with his hounds, who proceed to hunt the undergrowth for a fox. The field in every well ordered hunt will be drawn up in one particular place, where it is not desired that the fox should breakin other words, leave the covert. One whole side of the covert may possibly be given to the field, but in no circumstances should any ordinary member of the hunt leave the crowd, as he may easily "head" a fox by doing so. In the smaller hunts where the same group of people are hunting every day there is never any trouble about this part of the business; everyone knows where to go, and what to do, and when foxes are "headed," the culprits are usually foot people, people in carriages, or people who 
are not there for hunting, such as men at work in the fields. Supposing, however, that a fox breaks where he is wanted to break, and hounds come quickly out of the covert, then the hunt begins in a satisfactory manner, and if the fox is a bold one, if scent is good, and if a nice line of country is taken, then first-rate sport will naturally follow.

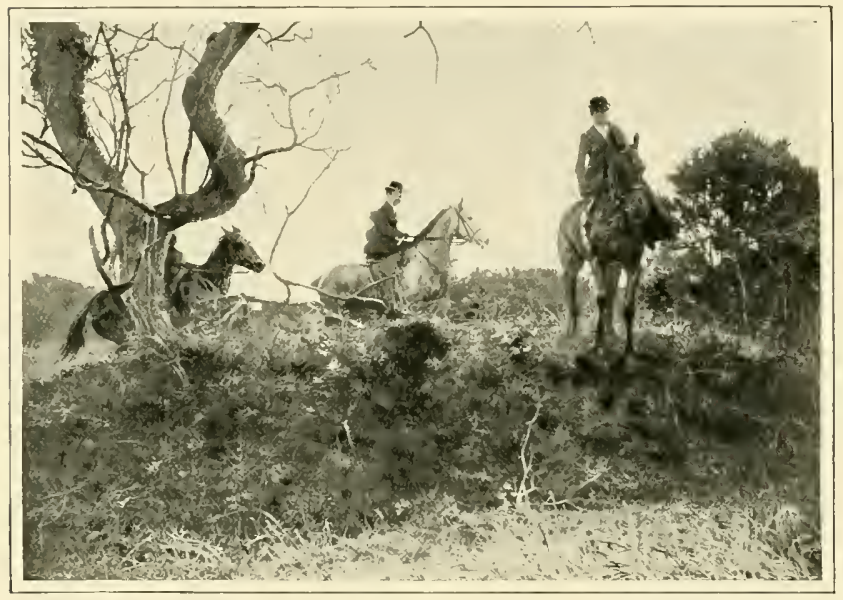

AN AWKWARD CORNER.

But there are many " ifs " in fox-hunting, and the unexpected is ahays happening. What the beginner-and for that matter the experienced hunting man or woman-should first of all remember is that it is no use attempting to hunt a fox without hounds, and yet one constantly sees or hears of people galloping on immediately the fox has left covert. This is done very often designedly, with a view to obtaining a good start, and the culprits are very often men who ought to be ashamed of themselves for so doing. Only the season before last the writer saw hounds thrown into a six acre gorse, about one acre of which was dense with hollies and thorns. Honnds were hardly inside the covert fence before a good-looking fox broke across the centre of a grass field, and at the same time there was a vociferous chorus from the pack, who were still in covert. Parallel with the fox's line of departure was a high thorn fence, and one by one sundry scarlet-coated members of the field-ladies with them-stole quietly along the fence, disappearing over a fall in the ground two hundred yards away. There were at least twenty of these triers for an unfair start, but as they got to the lower ground they could not see the covert, except the tops of the hollies, and what happened was that the hounds slipped away on the far side with another fox, which, going immediately straight through a biggish spinney and round the corner of a little hill, took the hunt clean out of sight. There was a capital half hour over grass before this fox was run to ground, and meantime those who had stolen away on the line of the first fox waited quite five minutes before they dared to venture back-no doubt thinking that if the field was still drawn up alongside the covert they would of course be spotted. The master who had observed the whole proceedings, and who at times suffers a good deal from over-riding, was much pleased, and when the delinquents did join hounds much later in the day they had to run a veritable gauntlet of chaff.

It must, then, be understood that fox first, hounds second, and the field third is the right order of procedure. It is not so always, however, and one remembers a rather clever poem, descriptive of a hunt, which began-

\section{"First came Mr. \\ And then came the fox."}

This was, of course, a hit at a man who habitually over-rode, and who never seemed to realise what mischief he caused. He was a good fellow, and according to his lights 
a cipital sportsman, but he only took to hunting in middle life, and having a very lirge heart he would go anywhere and everywhere where hounds went, and no matter how much he was reprimanded he continued to offend. The "poem," however, caused him to realise his position, and after its publication he ceased to be such a thorn in the master's side.

\section{Hints for Riders}

Nor is it right for the field to follow the first few hounds which leave the covert; they should wait until the bulk of the pack has gone. When this happy state of affairs is arrived at then horsemen and horsewomen can follow, but beginners should bear in mind that people should not race against each other in hunting, and that those who drive their horses at top speed in the first part of a run will probably find that at the end of ten minutes their nags are pumped out, and unable to raise a gallop. When a run begins it may be going to last five minutes, or any greater period of time up to two or three hours, or even longer. This is a thing which it is impossible for anyone to know, and therefore it is absolutely necessary that horses should not be allowed to extend themselves fully all the time, but should be saved as much as possible. A carefully ridden hunter in good condition will go on far longer than a horse which is allowed to gallop at top speed in the early part of a run, and though the latter may be in a better place -that is to say, nearer hounds-for a few minutes, he will not, unless he is eased, remain there if scent is good and hounds continue to run hard for a considerable period of time. The men and women who see far the most sport in the long run are those who know how to save their horses, and in this connection it may be explained that "saving" does not mean dropping some distance behind, and avoiding the fences, but riding with judgment, so that, while going well in the front rank, the horse is never allowed to exert his greatest galloping powers, but is always going "within himself," as the racing people express it.
A horse which is ridden so that he goes within himself will last three times as long as a horse which is allowed to gallop as fast as he can, and this is a point which should never be lost sight of. One man will go in front, or very near the front, all day on the same horse, while another, to the eye an equally good rider, will get through two or three horses in the same space of time, and yet be, on the whole, no nearer to hounds.

\section{The Careful Rider}

The careful rider who understands his horse must necessarily get more fun at a less cost than the careless horseman, who either rides with a slack rein, or pushes his horse when it is blown. Those who have seen good steeplechasing must be aware that the fastest gallopers and best jumpers cannot go on at anything iike full pressure for more than three or four miles, and, therefore, it can easily be understood that if hunters are ridden as if they were rumning in a steeplechase they are likely to be quite done with at the end of ten minutes or so, and do not require more of the same sort of galloping until they have had a long rest. Luckily for the spurting rider hounds do not go fast enough for steeplechase pace except at odd times of exceptional scent. If one of those remarkable scurries, for which the grass countries are famous, does occur, let those go at top speed who know that they have another horse to take the place of the blown one, but the one-horse man or woman who attempts this sort of game must, after the initial scurry; be a looker-on for the rest of the day.

One or two instances of the careful rider may be quoted. A certain hunting man was with a southern pack many years ago when they had the biggest day that is known in the annals of the hunt. Hounds began by crossing some six miles of a fine, but strongly fenced country of more grass than plough, and did not check for forty-tive minutes. They hit it off again, and killed their fox in the open one hour and fifteen minutes from the original find, having made a nine mile point. Half the field (which numbered quite two hundred 
at the start) went home, but hounds were taken right back into the country they had come from, and were not put into covert again until about 3.30. Finding at once, they ran for ten minutes in covert, and then went away, going in the opposite direction to the morning run. This time the pace was not so fast, but hounds ran on with great determination after a travelling fox (it was at the end of February) until twenty minutes to six, when they killed in a hedgerow. No one was really near them but the huntsman and the careful hunting man, and the two had exchanged horses two minutes before hounds killed, the huntsman's naga second horse-being done to a turn. Within five minutes three other men, and a single lady arrived, and by the time the fox was broken up it was quite dark, and the party were altogether lost, hounds having come many miles into the neighbouring hunt. It was a great day's sport, and what is remarkable about it is that the careful rider rode the same horse all day long (and rode him again a week later), while all the five who struggled on to the end of the second run had procured fresh horses just before the second covert was drawn, quite late in the afternoon.

This same careful rider fifteen years later rode a single horse through a great run of three hours and a half in the north of England, being one of six who saw the end, and on this occasion he had the freshest horse of the six at the end, though four of the others were on second horses. Instances of this kind could be given by the score, but there is no need to write anything more on the subject, as it has been made plain enough that the man who saves his horse has the best of it in the long run.

Nor, perhaps, is it necessary to explain that in an ordinary day's lumting the rest of the procedure is in accordance with the morning's doings. After the first fox is killed, put to ground, or lost, hounds are taken to another covert, and there they draw for a second fox. In many countries the afternoon sport is often the best, especially where fields are very large, for in these days a big percentage of either sex go home early, and thus in the afternoon hounds have more room to work. Moreover, wherever hounds meet in the morning the whole country-side is alive with people, and foxes are often headed, while others are scared away from the small coverts before hounds have had time to draw. In the afternoon hounds are probably some distance from where they have met in the morning, and the country is almost certain to be perfectly quiet. This means that there is small chance of foxes being headed, and therefore better sport will be obtained. A hunting man of good memory, who can recollect nearly all the best days of a long experience in many countries, stated recently that a large majority of the best hunts he had seen did not commence until towards the afternoon.

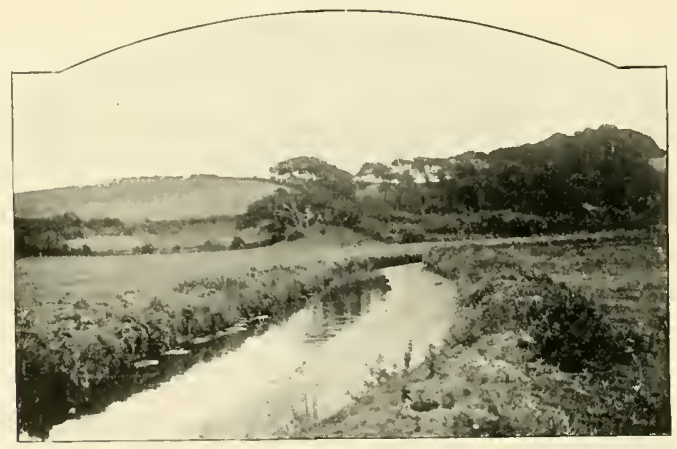




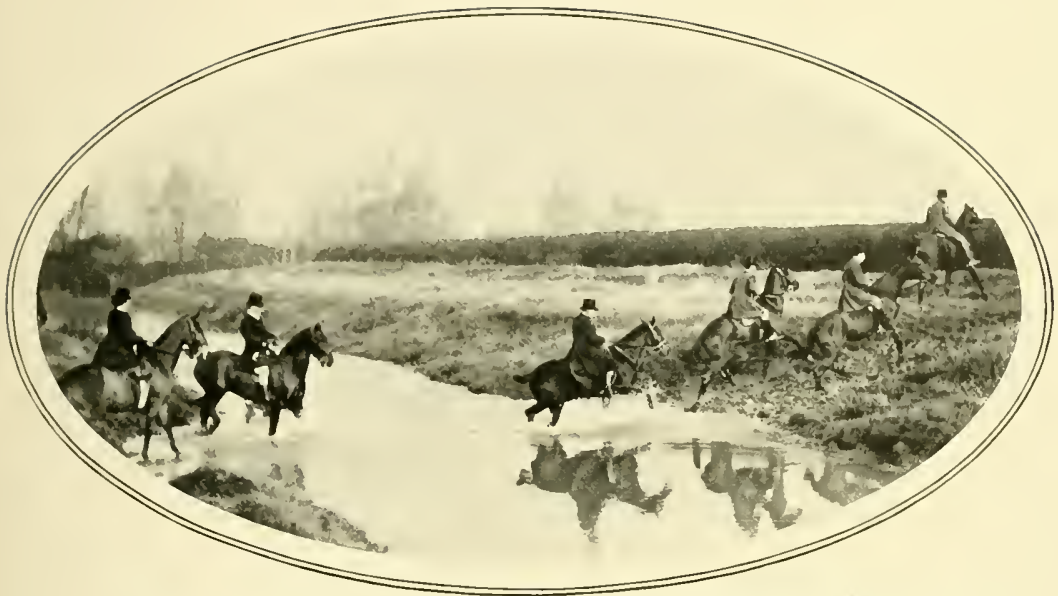

EARL HARRINGTON'S FONHOUNDS: HORSEMEN CROSSING THE SHITE.

\section{CHAPTER XVIII}

\section{HUNTERS AND THEIR BREEDING}

T

DHERE is not sufficient space in the present work to go at very great length into the breeding of hunters, but certain facts may be given, so that readers may be able to form an opinion as to what sort of horse is likely to turn out a good hunter. Briefly, then, it may be stated that the average horse to be seen in every hunting-field is the produce of a thoroughbred stallion, and what is generally spoken of as a half-bred mare. But it is also the case that the animals upon which people go hunting take the very widest range, every sort of " light " horse being impressed into the service at times. Thoroughbreds-very often cast-offs from the race-course-are often used in the grass countries, especially by men and women whose riding weight is not more than twelve or thirteen stone. Weight carriers are seldom actually thoroughbred, but the best of them have several crosses of pure blood, and have combined much of the quality and vital force of the blood horse with the strength and power which has doubtless come through the mare from a heavier strain. And beyond thoroughbreds and high-class weight-carriers of considerable breeding and quality there comes a slightly lower class, with pure blood on one side, and perhaps a sprinkling of it on the other. Such horses are to be found by the hundred in every hunting district, for on them are mounted the rank and file of every ordinary hunt. In the Shires, and in certain other hunts where there is a good deal of grass, the standard of hunters is higher than it is in the provincial hunts, but there are now certain men and women hunting in every part of the kingdom who pay long prices for their hunters, and procure a fair 1 roportion of the best which may be on the market, and in fact the Shires, though they have a greater number of the good ones, no longer have a monopoly of the best. Indeed, one of the biggest Midland dealers lately stated that a majority of his most valuable horses went into the provinces, and that he had amongst his customers provincial masters of hounds and provincial 
hunting men and women who were just as keen on acquiring the very best as were his neighbours in Leicestershire and Northamptonshire.

It must be understood that horses which are short of speed are of little use in a grass country, and thus it follows that common, underbred horses are rarely seen in Leicestershire. Screws one may see, and horses which are not of great intrinsic value even in the most fashionable hunts, but all are able to gallop, or else they would not be there.

\section{“Jumpers"}

In the average provincial hunt, on the other hand, there is usually a small group of well-mounted men and women, but when one comes to look at how the hunt in its entirety is mounted, clumsy-looking, common horses will be seen also: horses short of quality, short of length and liberty, thick about the neck and shoulder, and looking as if they would be more at home in a tradesman's cart than carrying a man to hounds. These are the cheaper lunters of the less wealthy hunting folk, and many of them (the hunters) are really far better than a first glance suggests. It is a fact that all sorts of horses can jump. Nany hackneys are excellent jumpers, especially where height is concerned, and many of what are, perhaps, best described as "common" horses are really good fencers. They will not, as a rule, cover a wide jump like a well-bred horse, but they can jump up and down. To give an instance, the best jumper of high stone walls the writer ever saw was out of a cart mare, and had favoured his dam in appearance.

\section{Short-Legged Hunters}

In a hill countı". Where there is not much fast galloping, a sulort-legged horse, which has little quality but is clever, will go on for many seasons if carefully ridden, but the short-legged sort are not much good when galloping on the level at top speed, being very often deficient in pace. It results, then, that men and women choose their horses with a view to their being of the right sort for the country they are intended to hunt in, and scores of people who hunt in less fashionable countries never through a lifetime of sport possess the sort that could live through a fast thing in the Shires.

At times one sees in a rough country horses of the highest class which are wasted by being hunted where they are, but as a rule, wherever one goes the horse is appropriate to the country in which he is hunted.

\section{Thoroughbreds as Hunters}

The thoroughbred who has been raced may make a good hunter, but as a rule he requires not only a great deal of schooling, but a lot of experience before he settles down and becomes a tractable cross-country horse. Racing very often teaches horses to fret and pull, to race against anything which comes alongside them. Then again the average race-horse when turned out of training is wanted for the stud if he has been a good winner, and if a gelding is often of small value. There are men who always ride thoroughbreds, and are seen to the greatest advantage on them, but such men have made a study of the business, and know where to find the sort of animals they require. They are also prepared to take chances while making the race-horses into hunters, and will take the greatest pains with their purchases. Some people even buy young thoroughbreds which have never seen the inside of a training stable, and keep them to be made into hunters in due course.

Then, too, there is the odd thoroughbred who has almost perfect manners, and is what may be called a natural hunter. This rara avis, when he is discovered, is a gem of the first water, and if he continues sound will do an enormous amount of work. Where the thoroughbred horse that has become a perfect hunter beats the half-bred is in the matter of pace and stamina. In an ordinary hunt of medium pace he will not have to exert himself so much as the horses of less breeding, and at the end of a very big day his blood will keep him going long after the average half-bred horse has had enough. 


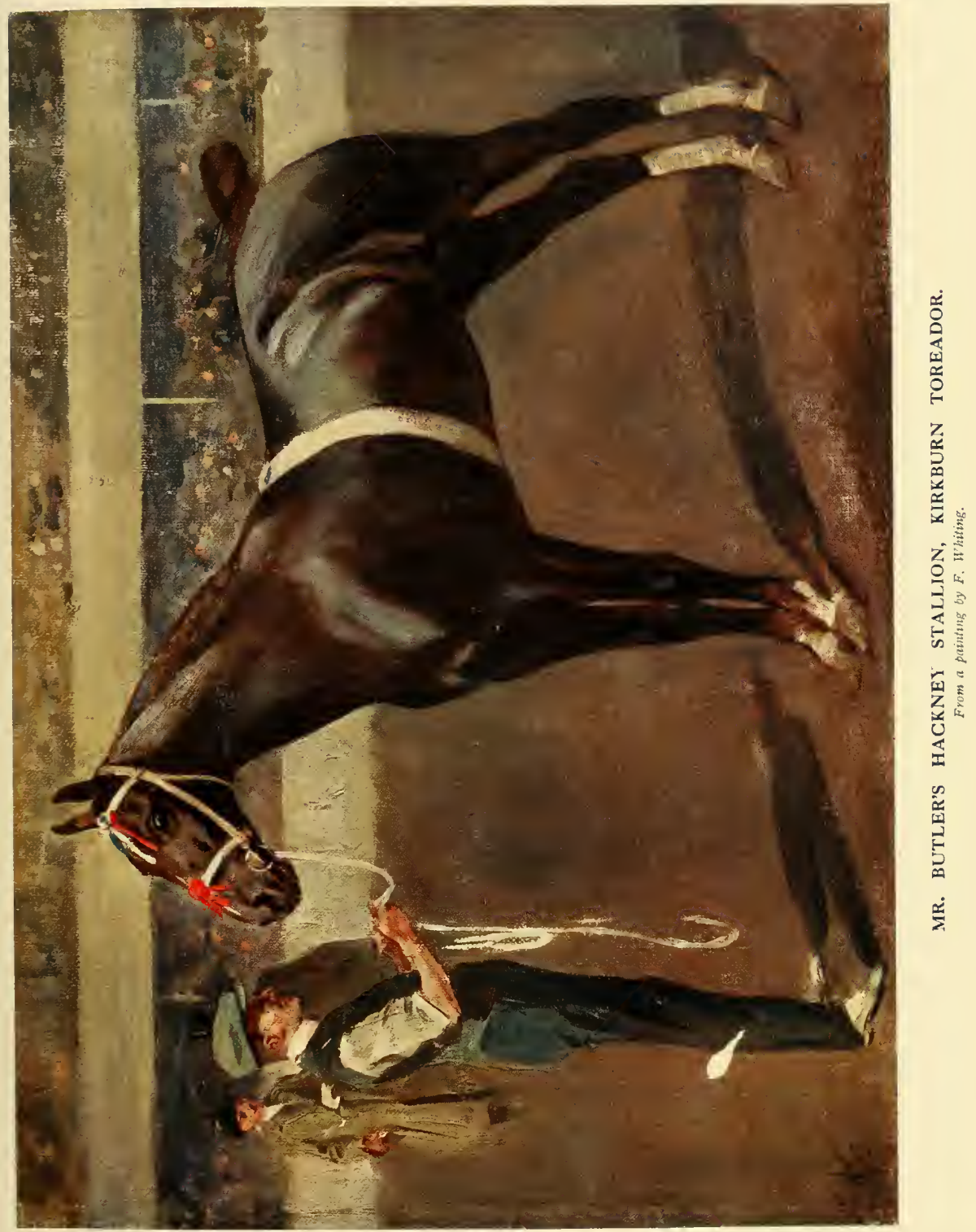



There are, as a matter of course, hunters of every possible description. Some thoroughbreds, even if they have won races, and are good mannered, are of little use in the hunting-field, whereas there have been, and are still, countless hunters, other than thoroughbred, for whom no day appears to be too long, and no distance too far. There are, in point of fact, exceptions to every rule, and though the good-looking, wellbred horse is in nine cases out of ten the good hunter, there are flatcatchers of this type, too, whereas one occasinnally meets with what is to all appearances a common horse, but who can nevertheless gallop and jump all day, and recover from a severe bucketing just as quickly as the horse of purer blood. These are the sort of things which experience alone can teach, and which the quick and correct eye for a horse cannot always discover.

To give an example: a man who kept harriers, who rode a nice light weight, and who never gave a big sum for his horses, bought a grey cob mare out of a butcher's cart for $£_{15}$. She was It hands 3 inches, but was quite good looking, though somewhat coarse. A year or two afterwards she was mated with a King's Premium stallion, and in due course she produced a brown foal, which was quickly made a gelding, and which in his early days ran out summer and winter, and had only the smallest modicum of corn. He was, in fact, reared on the rough and ready principle, and when four years old he was still unbroken. But he had acquired size, and when brought up and groomed it was soon evident that he had the makings of a very fine horse. Not being sent to the breaker until he was four years old, he took a great deal of "making," but towards the autumn of that year he stood out a very fine horse. Curiously, because his dam was a cob and his sire barely i6 hands, he was, nevertheless, a very big horse, at least I6 hands $I \frac{1}{2}$ inches in height, and with a body and frame that were in keeping with his height. He had apparently inherited all the good points of his dam, with none of the bad ones, and had also reproduced in himself much of the quality of his sire. His owner and breeder at once set about making him into a hunter, and though he was very impetuous, and a hard puller at

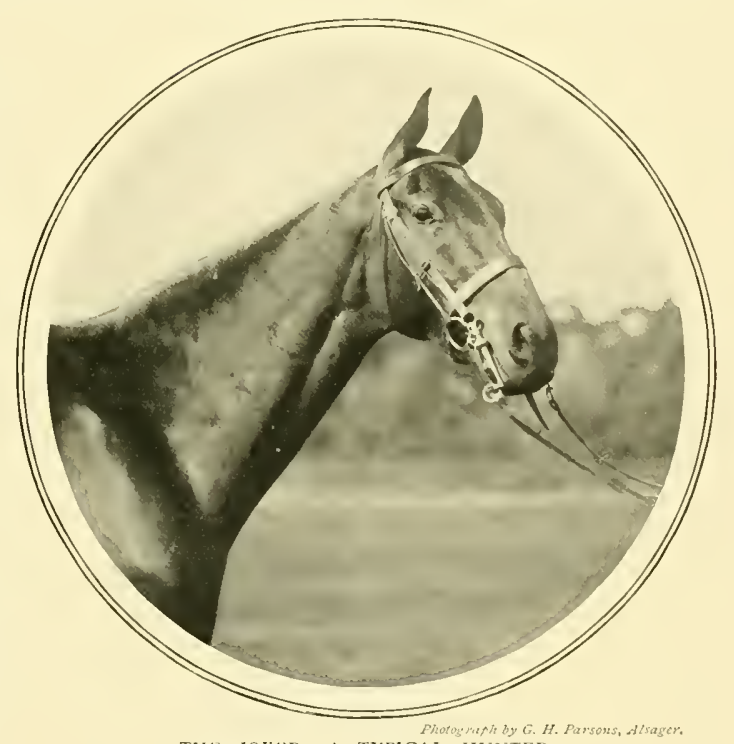

THE JOKER: A TYPICAL HUNTER.

first, he settled down at length. During his first season, owing to buck jumping and pulling proclivities, he was a rough ride, and a big handful, but all the same he was a great hunter, and never sick or sorry after the longest day. He galloped fast, and went on, was a fine bold fencer, whilst he did not rush in the least. fI50 was paid for him locally; for his new owner he has done thirteen seasons, and is still fresh and well. Like all other horses with a long career, he has had spells of idleness, owing to accidents and so forth, but when 
information concerning him reached the writer he had done two hundred and fifty full days' hunting with various packs of hounds, and was still doing one day a reek.

No doubt there have been other horses bred in similar fashion who have done equally well, but it is a fact that this horse's sire and dam were mated again for several years, and the cob mare never again bred anything like a hunter, or even a harness horse. All her after-produce were commonlooking, underbred, and very misshapen. Some of them had plenty of size, but their points were all wrong; straight shoulders, unsightly limbs, and a general absence of symmetry being their invariable characteristics.

\section{Hunters as Harness Horses}

Good hunters have been fashioned out of all sorts of material, but the horse with straight shoulders should always be avoided. As a rule he can neither gallop nor jump, and his conformation makes him much better suited for harness work than for hunting. As a rule, too, it is not a good plan to attempt to make a hamess horse into a hunter. It is done sometimes successfully enough, but when it happens it is good odds that the horse has the cut of a hunter, that he is not in his right place in a carriage, and that someone with a good eye for a horse has detected this, and given him a trial. There are, of course, many good general utility horses, who will pull a trap on five days of the week, and do a fair day's hunting on the sixth, but the fact is that nearly all hunters will go fairly well in harness, while it is only the exceptional harness horse that can be made into a good hunter. The general utility nag to which reference is made is, in nineteen cases out of twenty, of hunter cut, and he is only driven in harness because his owner (probably) cannot afford to keep horses specially for hunting. Many years ago a well-known light-weight hunting man, who has since been master of the Ledbury Foxhounds, was hunting in the north of England. He lived very wide of the meets of the pack with which he hunted, and for two or three seasons it was his almost invariable practice to drive a pair of well-bred cobs, tandem fashion, to the meets, taking a saddle in his cart, and to hunt one, sometimes both, during the day, and drive them home again at night.

\section{Hunters at Coach-Work}

Another hunting man, for a long period of years, gave his hunters about six weeks' rest at the end of the season, and then brought them up and drove them in a coach all the summer. And in this coach he did not merely exercise his horses with a few miles two or three times a week, but went touring all over the country, often doing as much as forty miles a day with the same team, and a fairly heavy load on the coach. One horse he hunted for ten or eleven seasons, and drove as a leader every summer, and a better hunter never stepped. He was by Homceopathist, and though he was a curious-tempered horse, very difficult to get to a meet, he was so good when hounds were running that $f f 00$ was once offered for him. As it happens, he would not pass the ret.'s examination, and no deal took place, but the horse was only half-way through his career then, and, as a matter of fact, he was as sound as a bell of brass, in spite of some technical objection on the part of the veterinary surgeon.

\section{Breeding Difficulties}

There is possibly a royal road to breeding hunters, but even if horses of the highest class are aimed at, and only very valuable mares are used-of the sort which are nearly thoroughbred, good looking, lengthy, and of fair size-it is nevertheless no easy matter to find such mares as have proved their ability in the hunting-field, and here comes a very difficult problem. The difficulty is as follows: all hunting men understand that where a good-class thoroughbred is mated with a well-made, roomy mare, who has quality and size, and who has been a good hunter herself, there should be every chance of breeding a hunter, but wherever there is a strain of base blood there is a 
likelihood of the foal throwing back to it, and thus-as has been explained-a halfbred mare may breed a hunter, or she may produce an animal that is almost useless.

This is one difficulty, but the better bred the mare is the less chance there is of its occurring. There is, however, a nother difficulty, which is as follows: if a man owns a mare who is a first-rate hunter he is loth to leave off hunting her as long as she can gallop, jump, and go through a big day in satisfactory fashion. He thinks he will breed from her when he has done hunting her, and he puts her to the horse when she is thirteen or fourteen years old, and is to a great extent worn out. She may possibly breed a good one, or even two or three, but unless she is a mare of extraordinary vitality, with a great deal of good, pure blood in her veins, she is more likely to be a failure than a success at the stud.

\section{Successful Irish Method}

Very many of the good race-horses have been bred from young mares. It is true that race-horses are forced in their early days, but a huge majority of the mares are sent to the stud not later than when five or six years old, whereas the average good hunter mare is not bred from until she is twelve or even older, and after she has gone through an enormons amount of hard work. This it is which causes the average English hunter breeder to turn up so few trumps during his period of breeding, and, probably because many of them are bred from comparatively young mares, the hunter average is higher in Ireland than it is in this country. By this, we mean, that, as far as can be judged, there are, comparatively, more successful matings in Ireland than there are in this country, where hunter breeding is concerned.

To breed, and to continue breeding, good hunters, mares which are not too old must be kept. An observant hunting man ought to be able to acquire these without much difficulty. He should always be on the look-out for young mares which come to grief and cannot be hunted regularly again, and also for young mares whose value has been lessened by a bad blemish. Such mares, if without hereditary unsoundness, are more likely to breed good stock than older mares who have been kept to hunting until they are twelve and upwards. Our opinion is also to the effect that a thoroughbred sire should be used in preference to the sire bred on the lines of the Hunter Stud Book, unless, indeed, the mare is very light and small, thoroughbred herself, or so nearly thoroughbred as to have sufficient quality to counteract the lack of it which must be present in any hunter sire who is not in the General Stud Book. This, however, is only an individual opinion, and one knows that there is a certain amount of controversy on the subject.

\section{The Thoroughbred as Sire}

It is said by those who favour the hunterbred sire, who has three or four crosses of blood, but is not thoroughbred, that many thoroughbred sires are apt to get stock which are too light all over, and unequal to carrying weight, and that the heavier halfbred will give additional weight and size. This may be so, but one must speak from experience, and we have seen many big hunters which were bred from light mares, and were by a thoroughbred horse-a good deal smaller than they were. All these horses we have in mind may have been exceptions to the rule, but it is an undoubted fact that scores, nay hundreds, of the best geldings one sees in the hunting-field are bigger all over than either of their parents were. Indeed, it would almost appear that many average size mares of not pure blood will, when mated with a medium sized thoroughbred horse, breed stock that, if given every chance to mature, will be larger all over than their parents.

The point need not be laboured, but we have in mind a chestmut gelding by the famous hurdle-racer Hesper (Capt. Machell's) out of a mare that was little more than a pony - a mare who did ride and drive work for a country doctor. She had some quality, and was quite a well-made mare, but barely It hands 2 inches high. The doctor had bought her for $f 20$ at a fair, and had no idea 
how she was bred. To Hesper she bred a chestnut colt, which the doctor sold to a hunting man, and which was made a gelding. The young horse's new owner was careless about horses, and this one was allowed to run out until he was four years old, living entirely on grass in the summer, and never having more than a single feed of com a day in the winter. Yet he gradually grew until he was 16 hands 2 inches, and, when broken, was found to be a really great performer. He won the first point-topoint steeplechase of four miles ever run in the north of England, by 150 yards, and carried seven pounds more than his opponents as the conditions insisted upon horses ridden by anyone who was not the owner carrying extra weight. Later he won between the flags, and for nine seasons he carried a master of hounds or his kennel huntsman, and the former told the present writer that he had never owned a horse which did a greater amount of work. "Nothing very wonderful in this," the reader may say, but the fact may be emphasised that here was an exceptionally grand hunter, a big horse all over, up to quite 15 stone, possessed of great jumping ability, with a very fine turn of speed, who was out of a little, weedy mare which never stood more than $I$. hands 2 inches, and could not under any conditions be described as a hunter.

\section{Schooling for Hunters}

The making of hunters-by which is meant the conversion of the raw animal into the finished performer-is a matter which should only be attempted by the skilled horseman, for it is attended with many risks, and is seldom a very simple job. There are horses who are of such placid temperament that the rider's task is a comparatively easy one, but the rank and file require a considerable amount of schooling, and many of the Irish-bred inportations are only half broken when they arrive.

And here it may be mentioned that it is only the really horsy man-the expert, in fact - who should buy Irish hunters direct. The average hunting man or woman will do far better to procure such animals from the dealer of standing, even though the price be a good deal higher. The dealer has probably had his Irish nags for some months before he attempts to selt them to his regular customers. He has schooled them, and got them into some sort of condition, whereas when they first arrive they are as a rule not only short of schooling, but by no means ready to be put into strong work. Some of them have hard or one-sided mouths, and nearly all have been fattened for sale on soft food, and require very gentle treatment as to their corn and so forth

A man who knows a horse, who is prepared to keep him for some months before he wishes to hunt him, and who is a sufficiently skilful horseman to remedy the effects of too little or very careless breaking, should not go far wrong in buying raw Irish nags, but those who wish to hunt the horses as soon as they have hought them should not dream of adopting this plan.

\section{An Experience With Irish Horses}

Some years ago a hunting man who was an enthusiast in horseflesh, but a timid rider, built himself a new large range of stabling, and having done so determined to buy raw Irish horses and make them into hunters. It must be understood that several nembers of his family hunted, and what with attendant grooms and second horses, he generally had from six to eight or nine horses out on every hunting day. With his stud groom he proceeded to visit several fairs in the south-west of Ireland, and after about a month in the country he came home with a string of twenty young horses. Several of them were very good looking, and, curious to relate, an English veterinary surgeon passed the lot as sound a few days after their arrival. The horses were all fat, and were put on to a corn and hay diet, and ridden about the country by grooms. For a week or two all went well; but they were probably unaccustomed to a liberal supply of corn, and at the end of a month half of them were sick, while the others were almost unmanageable. Moreover, those of 
weaker constitution became hopelessly wrong. Their legs swelled, they developed a kind of fever, and wasted a way to shadows. Neither did they come right after the fever had abated, for it seemed to leave behind it all sorts of ailments, and even unsoundness. Several were sold for what they would fetch without having done a single day's work, huntsman of a well-known pack for many seasons. It is possible that the stud groom did not understand his business, and gave these horses too much corn at first, but the fact remains that only two horses from a consignment of twenty turned out well, and the owner-who used to tell the story against himself-was the loser of over a thousand

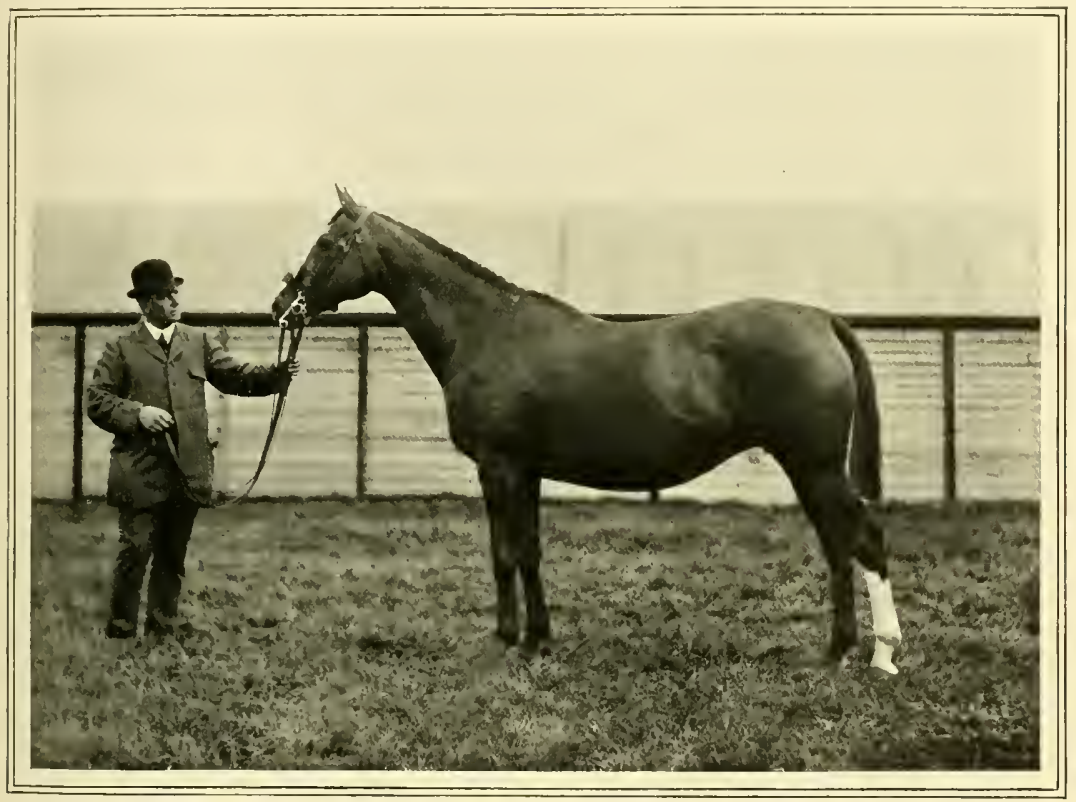

CHAMPION HUNTER MARE, GOLDEN IEAF.

but the hardier lot were persevered with, and in due course half a dozen of them appeared at a lawn meet, all being ridden by grooms. It is probable they had never seen hounds before, for they began to be most unruly before hounds left the meet, and on the way to the covert they all bolted. To cut a long story short, only two of the twenty were ever made into hunters, and for a season or two this pair could only be ridden by a strong, resolute man. Not a single horse of the lot was ever used by the owner or his family, for, finding the two horses just referred to too much for him, he gave them to the hunt, and they were ridden by the pounds on the full transaction, and that in spite of the fact that he had bought all the horses cheaply enough.

The English hunter bought direct from the breeder is generally better schooled and in better condition than the Irish horse bought in the same way, and all hunting men should, if possible, buy their horses from the farmer-breeder. At times this is difficult, because the farmer is apt to take too exalted a view of the horse of his own breeding, and ask a longer price than the animal is worth. But-and this is a curious fact-one has known of not one but many horses which had failed to secure the price 
asked by the breeder of members of the local hunt being sold to a dealer at a lower figure, and afterwards bought back into the country in which they were bred at a price which allowed of a fair profit to the dealer. One knows, too, of hunting farmers who never look for a eustomer at home for horses they have bred, but invariably submit them to dealers after they have been schooled.

\section{Home-Schooling a Necessity}

Time was when great numbers of young hunters did nearly all their schooling in the hunting-field, but in these days fields are so large that the practice is in many hunts greatly discouraged, especially when dealers' horses are sent out in charge of rough-riding grooms. The fact is, that in the modern hunting-field there is little room for any except regular subscribers to the pack, and regular hunting folk now seldom bring out horses which have not been properly schooled. The farmer does not like to see grooms riding half-made horses across country, boring a hole in a fence which they have refused half a dozen times, and the master does not care about the hunting-field being utilised in such a manner. Where fences are damaged by members of the hunt it is quite customary ior someone appointed by the hunt to repair them within a day or two, but a groom schooling a horse is apt to ride wide of the line of the hunt, and can do a lot of mischief which may not be noticed by the hunt authorities.

All this means that horses are now schoold at home. Every dealer in hunters has a schooling ground, and the farmer or amateur breeder can take his nags on to his own land, where it does not matter if he breaks the fences. Schooling a hunter is often very pleasant work to the real horseman, but there are many ways of doing it, and while some have horses "lunged," or led over obstacles, others will never allow them to learn to jump except when mounted. Nuch depends on the horse himself. One horse will take to jumping at once, while another will require weeks of practice. What is quite certain is that every horse can jump if he tries, and that every hunter can clear a fair-sized fence, if ne has been properly taught, and properly ridden at it.

\section{A Natural Jumper}

The most natural jumper we ever saw was a thick-set thoroughbred, owned by a racing man who was also a hunting enthusiast. This horse was slow for the flat; but he did win a little race as a three-year-old, and througlout the following season he was employed at leading work. When he was nearing five years old his owner thought he might be the sort of horse to win a country steeplechase, and had him brought from Newmarket to his hunting quarters. A day or two afterwards he was taken into a field where there were all sorts of jumps. To a little hurdle less than two feet high he was trotted up-it must be understood that he had never seen a fence in his life-when he stopped short, put his head down, and being gently encouraged by his rider, jumped it from a stand. After five minutes of walking about he was again taken to the hurdle, and this time he jumped twice as high as was necessary. Before he was taken back to his stable he had jumped a higher fence, and a day or two later he could be ridden over the natural fences on the farm.

\section{How Jumping is Taught}

When a horse is first taught unridden, and with the lunging rein or rope, he appears very often to take longer to learn his husiness than when he is ridden, and therr have been cases in which horses have jumped well with the rope, but have refused badly for a time when ridden at the same obstacles. The fammer who can ride his horse about his farm and has the chance of making him handy at gates is more likely to teach a hunter his business than the inan who puts his colt or filly through a course of lunging: but that is perhaps a matter of opinion, and though a great deal depends upon the temperament of the horse, doubtless even more depends upon the man who attempts the training of raw material. There are people who prefer to teacl horses to jump in a riding school; but if the horses are afterwards required to 
jump the natural fences of the hunting-field, and are not being schooled with a view to Olympia, and such kindred places, the country education is undoubtedly the better. One of the greatest difficulties the schoolmaster has to contend with is rushing. Horses quickly beeome very fond of jumping. and many of the highest-couraged are inclined to rush. One has, when schooling horses, seen dozens of them quicken up the moment they saw the fence, and attempt to take it at top speed. When this happens everything depends upon the horsemanship of the rider. If he is possessed of good hands and can hold his horse, rushing ought not to be difficult to cure; but when the horse happens to be a hard puller the case is very different, and there have been many hunters who have gone through a long period of service, and have always had this fault. Such horses can only be ridden with comfort by a strong and resolute man, and are of little value to ladies, or, in faft, to anyone whose nerves are not of the strongest.

\section{The Red-Ribbon Horse}

In the hunting-field one sees many horses who rush their fences, and occasionally an odd one who will rush an open gate as well. In these days such horses are distinctly out of place, and those who own them, if unable to bring about any improvement, should send their nags to a rough-rider ; if that fails they should put them to some lower walk of horse enterprise. The fact is, that all or nearly all hunting-fields are now too large for the unruly horse, for in the crowds which come out such horses are dangerous. The confirmed rusher is almost as bad as the confirmed kicker, and though the last-named may be ridden with the warning red ribbon twisted through his tail, he should not be seen in the field unless his rider is prepared to keep wide of the crowd. The hunting man or woman who goes into a crowd of horses riding a red-ribbon decorated nag is apt to think that he or she has done all that is required, and that, having flown the danger signal, it is the business of everyone else to give the kicker a wide berth. But in a big crowd, especially at a gate, a canal bridge, or in the narrow ride of a covert, this is impossible, for at such times there is alway's congestion, and many find themselves immediately behind a supposed kicker, but unable to pull back because of those who are pressing on behind. It may be added tliat the fashion of riding a horse with a red ribbon in its tail is sometimes abused, for some people will fly the signal merely in order that they may secure more room at gates and gaps. The present writer knows of a horse which has worn a red ribbon for seven or eight seasons, and has never been known to kick since the first day he came out, when only a four-year-old. Frequently this horse has been seen hustled and jostled in a erowd, but kept perfectly quiet all the time; yet lis rider sticks religiously to the warning badge. Horses there are, by the way, who will never kick other horses, and yet will lash out at a small pony, or a donkey. Some horses, too, are hound kickers, and certain of these it has been found almost impossible to cure. One first-rate little horse, who earried a whipper-in for several seasons, suddenly became untrustworthy with hounds, and did considerable damage before it was realised that he had lost his manners. It afterwards transpired that when leaving certain stables a terrier had bitten one of his fore fetlocks, and after that he lashed out at any dog (whether a hound or not) which came near him.

\section{Working Life of a Hunter}

It is not an easy matter to say what is the average working life of a hunter, for horses vary greatly, and illness and aecident have to be taken into consideration. Then, again, so much depends upon the rider. This man is always "saving" his horses, while his neighbour is always pushing them beyond their pace, or overworking them. Grooms, too, vary in their knowledge and capability. One man will keep a horse which is laardly sound on his legs going for a whole season, while in the hands of another the same horse will not last a week. There are hard riders whose horses seldom get through a season without an aceident, and there are careful 
riders who do not have an accident in half a dozen years. Some horses, moreover, have inherited unsoundness which does not develop until they are put to hard work; some, again, have wonderful constitutions, and can come out twice a week, while others take longer to recover from the effects of a hard day, and can only be kept going if not worked too often, or too long at a time.

Horses there are who thrive on hard work, who gradually grow firmer and

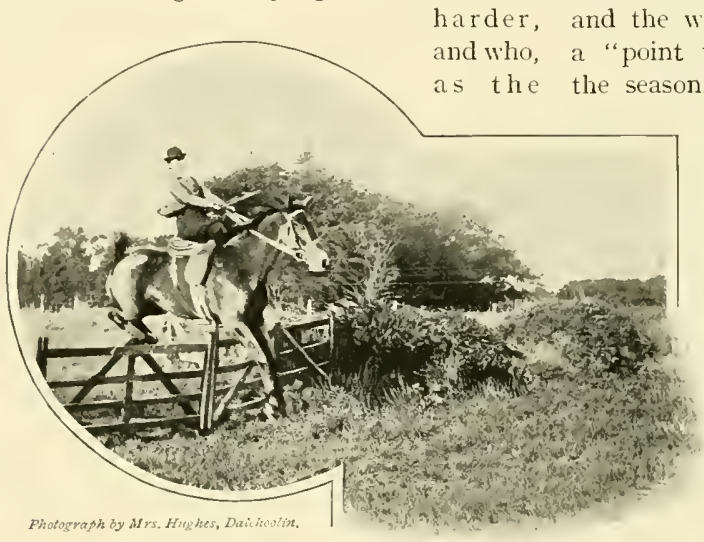

"WELL OVER."

years wear on, become a veritable mass of muscle. Such animals, if well done by, do not lose much of their condition in the summer, and are quickly got ready in the autumn, but these are what Surtees called the "good tickets," and it is probable that in the long run they are outnumbered by the "bad tickets." Indeed, it is most likely the case that about one-half of the horses which begin life as hunters do little or nothing to repay their owner. A certain percentage of them go wrong almost immediately; others are so constantly ailing that they can do little work, and others, again, are found to be much more moderate than had been anticipated. A horse may look well in a dealer's yard, may jump well over the fences he is accustomed to, but may nevertheless be a shocking bad hunter. There are, in fact, flatcatchers innumerable amongst so-called hunters, and personal experience may be quoted.

A very good-looking and powerful fiveyear-old went the round of certain shows one summer, and won almost everywhere. He was generally first in his class, never lower than second, and his ring-paces were admirable, in spite of the fact that he was a big, rather heavily made horse. He was bought by a heavy weight who had little time for hunting, but the horse was out regularly with hounds, and the writer was asked to ride him in a "point to point," towards the end of the season. Then came a question as to whether the horse was fast enough, and whether he could stay a four-mile course, and the upshot was that he was sent to a meet where we got on him just as hounds found. The lunt was in a good galloping country, and as there was a strong scent hounds immediately began to run hard. For a few fields the big horse went well, but before two miles had been covered he was completely pumped out, and yet he had been galloping on sound, old pasture all the way, and had only jumped some half-dozen ordinary fences. In this case it was probably base blood on the dam's side that accounted for the collapse, but the point is, that here was a grand hunter to look at, who was a flatcatcher of the deepest dye.

It must be understood, then, that everyone who buys a fair number of hunters must buy amongst the lot a certain number of flatcatchers, and also a considerable number of horses which, owing to one of many causes, do no good. Wishing for other experience than our own on this subject we applied to a master of hounds, who is huntsman of his own pack, and who keeps a full record of all the work done by his horses. This gentleman has supplied a statement of what his experiences were between the years ISgI and I908, and he begins by saying that during that period he had, for his own 

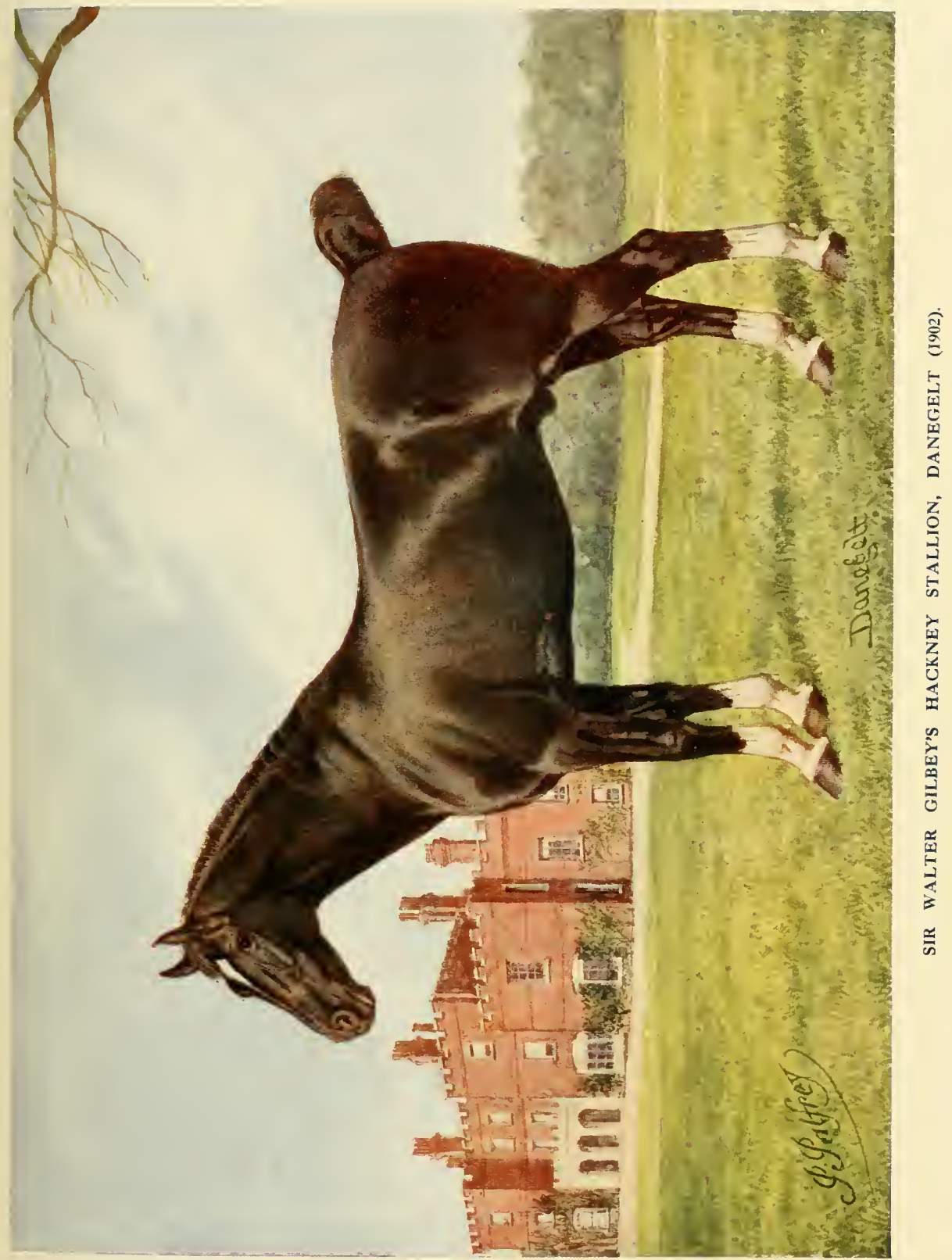



\section{HUNTERS AND THEIR BREEDING}

riding. some thirty horses, of which about twenty "were not worth their leep, and had to be disposed of anyhow:" The remaining ten all turned out well, as the following table will show:-

$$
\text { Horse. }
$$

Dick . 69 I 50 Fell dead when hunting.

Dazzle . Io $6 \mathbf{1 1} 7$ Finished life on farm.

Darlight $0 \quad 3 \quad 33$ Shot. badly sparined.

Anthony 68 II6 Finished life on farm.

Darid . 5 Io ras Finished life on farm.

Derwent. 5 It $2 \mathbf{I} 2$ Still at work.

Derby - $65+7$ Sold.

Duke . $6 \quad 6 \quad 85$ Finished life on farm.

Durban . 6 Io I 16 Still at work.

Duchess $0 \quad 8$ I 43 Still alive, has had two foals.

From the above table one may judge that the average hunting life of these ten horses was about eight seasons, that they worked (with the owner who has supplied the record) an average of $\mathrm{I} 2 \mathrm{2}$ days apiece, that the average life of those which were never hunted except by this particular owner and his friends - viz. Dick, Daylight, Anthony, David, Duke and Duchess-was about a hundred and five hunting days.

But we are able to give much fuller particulirs, and taking the horses as they stand, Dick was a very thick-set bay horse, up to a great deal of weight, but rather short of quality to look at. He pulled hard, was very seldom sick or sorry, and died from internal rupture at the beginning of a good run, when he was fifteen years old. On one occasion this horse was put into a coach team as a leader, but he had them all galloping in a moment, and when his head was fastened down with side reins he still pulled so hard that the experiment of driving him was not again attempted. Dazzle was bought at the sale of the late Lord Chesham's horses when he (Lord Chesham) gave up the Bicester country. He then cust fI50, and he had probably done about five seasons' hunting. He was an extraordinary jumper, and when sent to the farm to end his days

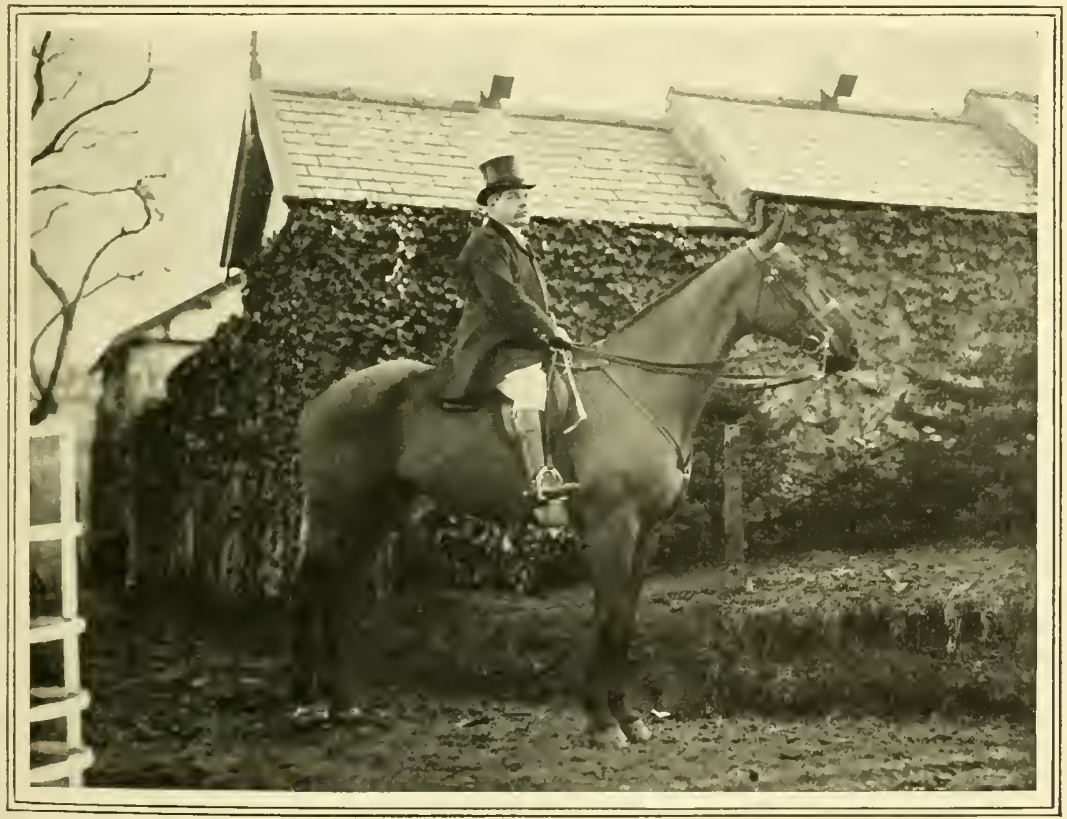


in peace he could still win jumping prizes at the local shows. It is quite probable that he had done a hundred days before he passed into the hands of our record keeper. Daylight was also a brilliant hunter, but an unlucky horse, who frequently caught cold and was confined to stables, either by that or a slight accident. His thirty-three days reduce the average of the others, but when all right he was so good that he had to be included. He was bought from a dealer, was nearly thoroughbred, and cost f.I $5^{\circ}$. Anthony was a weight carrier of great quality, and very fast. He was a strong, resolute goer, who would run away if ridden by anyone not possessed of good nerve, but he was a great stayer, and occasionally he was worked in a coach team during the summer.

\section{David and Derwent}

David was a common horse compared to most of the others. He was a big horse, up to a lot of weight, and a big jumper, but he had to be ridden carefully. If, however, his rider really understood him he could go on for ever, and he was one of three at the end of one of the best and longest hunts the present writer ever saw. Before he became a hunter David was one of a carriage pair, but he was a better hunter than he was carriage horse, for he was bold, lion-hearted, and always carried extraordinary condition. In his ten seasons he only fell once at a fence, and once over a manure heap, when badly jostled by another horse. Derwent, however, is the wonder of the lot. He is a big $I 6$ hands $I_{2}^{1}$ inches brown, by the King's Premium horse Even, out of a little mare, who stood less than $I_{5}$ hands. He was not hunted until he was five, but his breeder rode him for a whole season before the record begins, and as he did a full season in $1908-9$, and a lot of work in the succeeding winter, it is certain that he accomplished at least 250 full day's. He was difficult to ride for some years, owing to exuberance of spirits, which induced a fair amount of buck jumping. He also took a strong hold, and once when he was waiting as second horse for his master, he ran away with a whipper-in, and was not seen for a couple of hours. When the man returned and was interrogated, he merely remarked: "I suppose the horse thought he was being ridden by a butterfly, and might take liberties." This Derwent has had his portrait in the Royal Academy, and as far as the writer's inquiries have gone he stands out as having done the most work of any hunter he has ever heard of. It must be understood, too, that he has never been spared, has done a great part of his work when carrying a man riding over I $_{5}$ stone, and hunting a pack of hounds, and that he has seldom been hors de combat from accident or illness since he was six years old.

\section{Derby, Duke, Durban and Duchess}

Derby was a dealer's horse, who cost fi6o, a strong, bold horse, and very fast, but a big handful when fresh. Duke was another great hunter, but he went wrong in his wind when about twelve years old, and did gentle work on a farm afterwards. Durban, another dealer's horse, bought at the same figure, is still going, having now done eleven seasons, and Duchess was an extraordinary mare, for she only cost $f_{\sim} 5^{\circ}$, being bought from a farmer who worked her in harness. She was an upstanding mare, of $\mathrm{x} 6$ hands 2 inches, a great fencer, and with a fine turn of speed, and since her retirement she has done well at the stud.

\section{A Low Average}

Here we have the history of ten horses out of thirty, bought by one man over a period of seventeen years, and if we take the "bad tickets" into account, the average life of a hunter in this stud works out at less than three seasons. As these horses were all ridden by a heavy man, hunting his own hounds, and ridden freely at every description of fence, it may be that the average is lower than it would be in the private stud of a careful man, for it must be remembered that a huntsman's horse has to go and return from hunting at a far slower pace than the horse of the ordinary hunting man, that it is always at work when other horses 
are standing quietly by the covert side, and that it can never shirk, but must be taken wherever hounds go. A huntsman's horse is probably out of his stable from one to two hours longer than the liorse of the average member of the field, and it is quite certain that in every hunting day it covers more ground. It must be understood that in the statement which we have given all the days are full days-i.e. that when any of the horses were worked half days two of these were taken as one full day.

\section{Points of a Hunter}

Opinions differ in some degree as to what a good hunter should be like, and most certainly horses have themselves changed very considerably during the last hundred years. The best modern hunters are extremely blood-like, and the coarseness of the horses used by our great-grandfathers has almost disappeared. Men are much inclined to judge hunters by their own standard of weight, which, by the way, is very natural. Thus a really big man has little use for a light-weight hunter, and a little or a spare man can see no virtue in a horse which looks like being master of sixteen stone or more. Probably, too, the handsomest hunters are not always the best performers, and several who have taken the highest honours in the ring have been of little value in the field. On the other hand there have been big prize winners who were excellent hunters, and notably the famous Whiskey was said to be a first-rate crosscountry performer, though mutch inclined to pull hard when lounds were rumning. Apropos this showing question, Dazzle, one of the horses mentioned in the above statement, was once sent to a show along with a stable companion, who was one of the "bad tickets," and is not included in the statement. Dazzle at the time was quite the greatest performer in two hunts, but the judges awarded first prize to the "bad ticket," a goodish-looking bay, who could not gallop over half a dozen fields without being distressed.

Still, all hunting folk are agreed on certain pomts, such as that a sloping shoulder is better than a straight one, that a horse must have bone equal to carrying his weight, that he should be sound in wind and eyesight, and have good feet, clean hocks, and should not stand back at the knees. As a rule the best hunters are high at the withers, and are truly made. One likes a blood-like, and not too large a head, but a Roman nose (thongh it may be an eyesore to some) often gives a horse a sporting appearance, as does a rat tail. Back, loins, and quarters should all be long, and firmly welded together, while the tail perhaps looks best when squared not very far below the dock. Dock tails—or bob tails, as they were once calledare out of fashion just now ; they were a device of the dealer for showing off a horse's quarters, but they are gradually disappearing, and no doubt the horse himself infinitely prefers to have his tail left long. At the same time a long tail left on a half-bred horse which lacks quality is ridiculous. Another thing to be avoided is too much length in a gelding, or perhaps one might say too long a back. A mare may stand over more ground than a gelding, but she, as a rule, is rather differently built, and a well-made mare has sufficient strength of back and loin. A long backed gelding, on the other hand, is often weak behind the saddle; a cobby-made big horse is generally slow, and heavy in his paces; in fact, there should always be length in proportion to height and bulk, and it is only pronounced length that is to be avoided.

\section{The Question of Height}

Height is largely a matter of individual choice. One does not like the look of a very small man on a very big horse, and when such a one does appear he is likely to be compared to a "tom-tit on a rail," or a "robin on a round of beef," according to whether he is riding a very tall horse, or a very massive one. Men and women should get horses to fit them, if possible; but quite little horses can jump as well as the very tall ones, and when one falls from the former the distance to the ground is not so far. But there are good and bad hunters of every height, and the best we ever rode to hounds 
stood half an inch over 17 hands, and was thoroughbred, though so ungainly in his juvenile days that he was never raced. As for colour, that also is a matter of choice, but duns and roans are not frequently seen in the hunting-field, and one is inclined to think there are not so many blacks as there were some years ago. Bay, brown, and chestnut, are the prevailing colours, and skewbald and piebald the rarest. Greys are not very numerous, and our individual experience does not favour them, but still they are showy and smart. The greatest difficulty in buying hunters is that it is almost impossible to judge from appearance what a horse's constitution may be, and constitution is, after all, the most important quality in the perfect hunter. A softlooking horse generally has a weak spot somewhere, while a horse of good constitution usually carries a strong chest, and is very fully dereloped everywhere. Young horses which have fared poorly will often grow into hardy animals when a change for the better of stables is made. We knew of an imported Irish horse who was brought to this country a perfect bag of bones. For a whole year he was constantly ailing, and when at length he did begin to pick up it took him the best part of another year to acquire condition. After that, he never looked behind him, and he is now in his tenth season as a hunter, and very hard to beat when hounds are running.

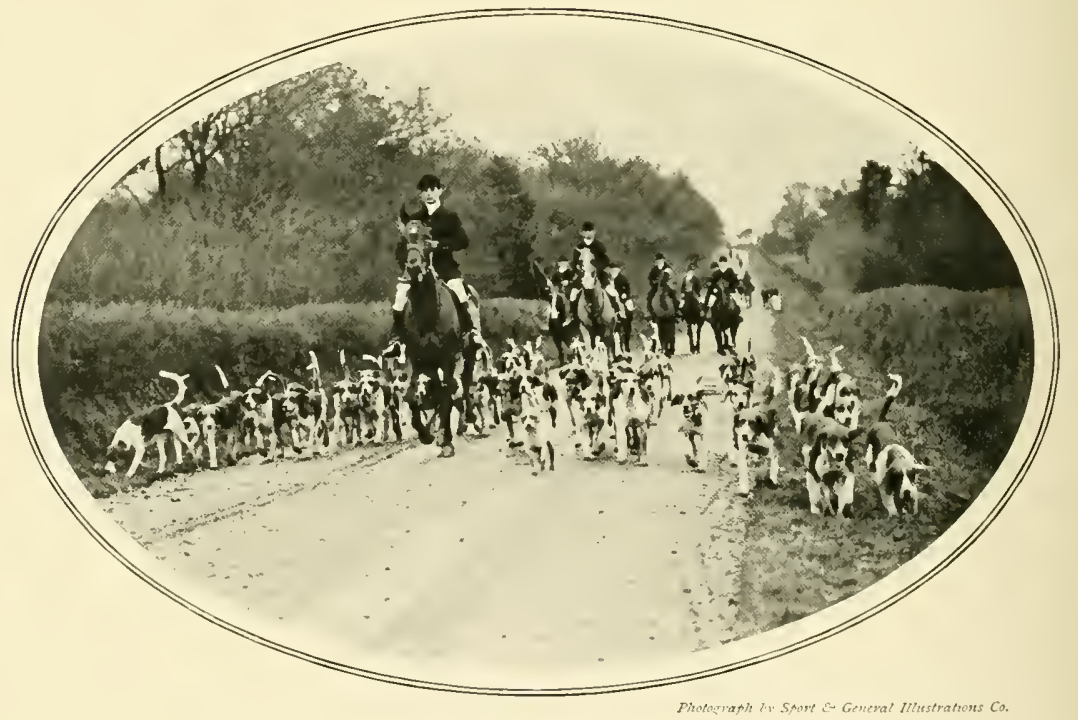

THE BLACKMORE VALE FOXHOUNDS: A MEET AT HOLNESS POUND. 


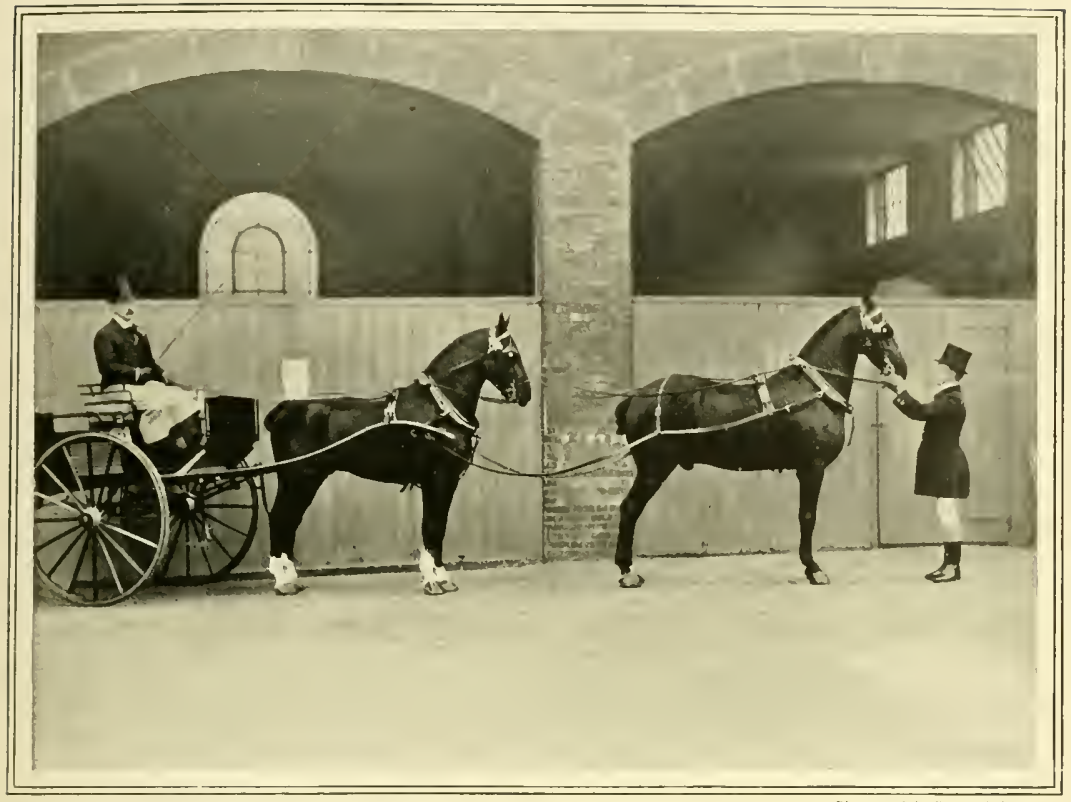

MISS ELLA ROSS'S TANDEM TEAM, GRAND VICEROY AND GRAND VULCAN.

\section{CHAPTER XIX}

\section{THE HACKNEY}

$\mathrm{A}^{\mathrm{t}}$

LTHOLGH the Hackney cannot aspire to be regarded by the public with the same amount of sentimental interest that is attached to the Arab, or to be accepted as a national asset as valuable as the thoroughbred, there can be no denying the fact that the variety has earned for itself the respect of every horse-breeding nation in the world. It can also be claimed for the Hackney that he belongs to one of the very oldest varieties of British horse, though it is freely conceded that he, in common with other breeds, has been the subject of many modifications of type from time to time.

The Hackney, in fact, has played many parts in the course of the centuries which have elapsed since he first was recognised by writers on equine subjects, for he was at one time, in the capacity of the leading trotting breed, regarded as a valuable cavalry horse; whilst in the olden times his merits as a speedy trotter were so highly appreciated, that his services were resorted to by American breeders to improve their strains of light horses. Then he became recognised as the heavy-weight riding horse of this country; but when railways came upon the scene and his services in this connection were no longer in request, the skill and patience of his owners combined to transform him into the animal he at present is, namely the finest actioned harness horse in all the world.

All these facts concerning the Hackney of the past and present will be duly entered into in the following pages, but the 
opportunity which now presents itself may be utilised to emphasise a point to which the writer attaches considerable importance as indicative of the value and prepotency of the breed, nanely, that the connection between the Hackneys and the thoroughbreds of a hundred and fifty years ago was very much closer than many people imagine. There are, of course, proofs positive in almost countless instances of modern Hackneys straining back directly in the male line to Flying Childers, himself a son of the Darley Arabian; but, as is only natural, the ancient mare pedigrees were very badly kept, and hence one is driven back upon inference when offering the suggestion that in all probability the dams of many Hackneys of the middle 'seventies were closely related to mares which were producing cornerstones of the General Stud Book. At all events, there is no denying the existence of both galloping and trotting mares at that period of the world's history, and doubtless the blood horse came ont of the former, and the Hackney or trotting breed from the latter, by sires, if not identical, at all events bred upon very similar lines. Upon this point there can be very little reasonable doubt, if any, the only difficulty that exists being the tracing of the connection which may be expected to have existed between the mares before the time came for the thoroughbred and Hackney to branch out into different lines.

The evolution of the Hackney will, however, be a subject for consideration later on, therefore the theory above propounded need not be further proceeded with here. It, nevertheless, appeared desirable to disclose at the earliest possible opportunity the opinion the writer, after many years of research, has formed upon the subject.

\section{Derivation of "Hackney"}

The derivation of the word "Hackney" provides ample evidence to prove the antiquity of the breed, as it comes from the Anglo-Saxon word hncgan, to neigh, which at a later period of England's history was merged in the Norman word haquence, which, by some stretch of imagination, may be accepted as having been derived from the Latin word cquus.

\section{Early History}

It would be an umprofitable waste of time to go farther back than the time of the Roman invaders, as there would have to be a good deal taken on trust, as it were; but from their time to the present the references to the Hackney, both by name and in his position as the riding horse of the period, are plentiful, and in many instances authoritative. The Romans, it may be pointed out, recognised two varieties of the saddle-horse, namely those which trotted, known as Itincrarii, and the amblers or Ambulaturarii. The Hackney doubtless was included to a greater or less extent in both categories, but the existence of some very superior trotting horses in those parts of the country which had been invaded by the Danes suggests that the latter had recognised the value of the trotting action, and devoted some attention to its encouragement. King Stephen, whatever his failings may have been, was clearly a believer in the trotting horse, as the great seal of England during his reign represented a man riding a horse moving at this gait; but his immediate successors appear to have devoted most of their attention to the improvement of the heavy horse. By the commencement of the fourteenth century, however, the term Hackney, spelled in various ways, was in general use in England.

\section{"The Trotting Stallion"}

King Henry VIII., amongst several wise ordinances issued by him for the improvement of horseflesh, included one under which every archbishop and duke was compelled to keep seven trotting saddlehorses; every bishop, marquis, and earl five ; and other persons of high degree from three to one, according to their station. The inclusion of the expression "trotting stallion" in the above Act of Henry VIII. tends to show that the word "trotter" had already occupied a position in the vocabulary of Englishmen sufficiently long for the meaning of the word to be generally under- 
stood. In East Anglia, however, it was in use long before the days of bluff King $\mathrm{Hal}$, as the wife of Sir John Paston, writing to her husband about the year $\mathrm{I}_{4} 6_{5}$, makes allusion to the recent purchase of three horses at St. Faith's Fair, adding the information that "all be trotters, right fair horses, God save them, and they be well keeped." In the days of Queen Elizabeth the merits of the trotter as a cavalry remount were fully recognised, as every demilance and light horseman was compelled to join his regiment mounted on a trotting stallion or gelding.

\section{Blundeville on Trotting Horses}

When Blunderille, the first English writer who dealt exclusively with equine subjects, wrote in 1609 , the trotter's position as a cavalry horse appears to have been thoroughly established, for he alludes to the fact that " some man would perchance have a breed of great trotting horses meete for the warre, and to serve in the field," whilst he adds later on that " the plaine countryman would perchance have a breed only for draught or burden." Blundeville, be it noted, was a Norfolk man, residing at Newton Flotman, and his allusions to " some carriers that go with cartes" who were " so exquisite in their choice of horses as unlesse they had been as comely to the eye as good in their work, they would not buy them," speaks volumes for the East Anglian horse of that remote period. That Blundeville was deeply imbued with a sense of admiration for the trotter is made obrious by the following quotation from another of his writings, which referred to the subject of brood mares. In this he expresses the opinion that these mares should be " of a high stature, strongly made, large and faire, and have a trotting pase. . . For it is not meet for divers respects that horses for service should amble."

\section{De Grey as Prophet}

A writer of the name of Thomas de Grey, who appeared as the author of "The Compleat Horseman and Expert Farrier," during the reign of James I., was as warm an admirer of the harness horse as he was a denouncer of the thoroughbred and hunter of the period. De Grey, in fact, appears to have been a good deal exercised in his mind on the question of desirable cavalry remounts, as he entertained but a poor opinion of the value of the race horse of his day for that sort of work. Most strongly did he deplore the prevailing disposition to neglect the breeding of the class of animal which supported "the most ancient honour of horsemanship peculiar to the Kingdom," and adds that "were we pressed with thoughts of defence we should be forced to pull horses from the coach or cart to fill up our troop." The application of the latter quotation to the events of more recent times at least entitles De Grey to the honour attaching to a true prophet, even if it may not, in the opinion of everybody, constitute him a good judge of a horse. Many of the ideas which he committed to writing are, however, perfectly sound, as he describes the horse to be "esteemed " in the following terms: "Good and serviceable, wellmettled, bold and hardy, of a gentle condition, of a round and comely trot and pace, and well born, obedient mouthed, sure on foot, tough, strong and easie." His idea of a desirable cavalry remount was, in his own words, as follows: "If you design him for war, then the lofty trot is most to be esteemed, and to know that he is cleaner therein take these observations-in the taking up his legs and cross moving his limbs, as when the far hinder leg and the near fore leg move and go forward, and in the same manner the other two legs in good order and equal distance." Of course, the cavalry of those far-off days were differently equipped from those of modern times, and consequently De Grey's opinions regarding the selection of remounts count for very little; but the quotation above is valuable as proving that such a form of action as the lofty trot was in existence when he wrote.

\section{7th Century Breeding}

By the time the seventeenth century was reached the chief attention of horse-breeders 
appears to have been directed towards discovering the best class of stallion to put to their mares, the character of which was very high, thanks to the successful efforts of their forefathers. In fact, the Duke of Newcastle, in his famous and very lengthy titled work, asserts "For English mares there are none were considerably decreased, as they found the materials at hand, and had only to exercise a wise discretion in thinking out their crosses. How well they succeeded the records of the present most amply testify, and in no case is a greater tribute to the skill of the breeders of the eighteenth

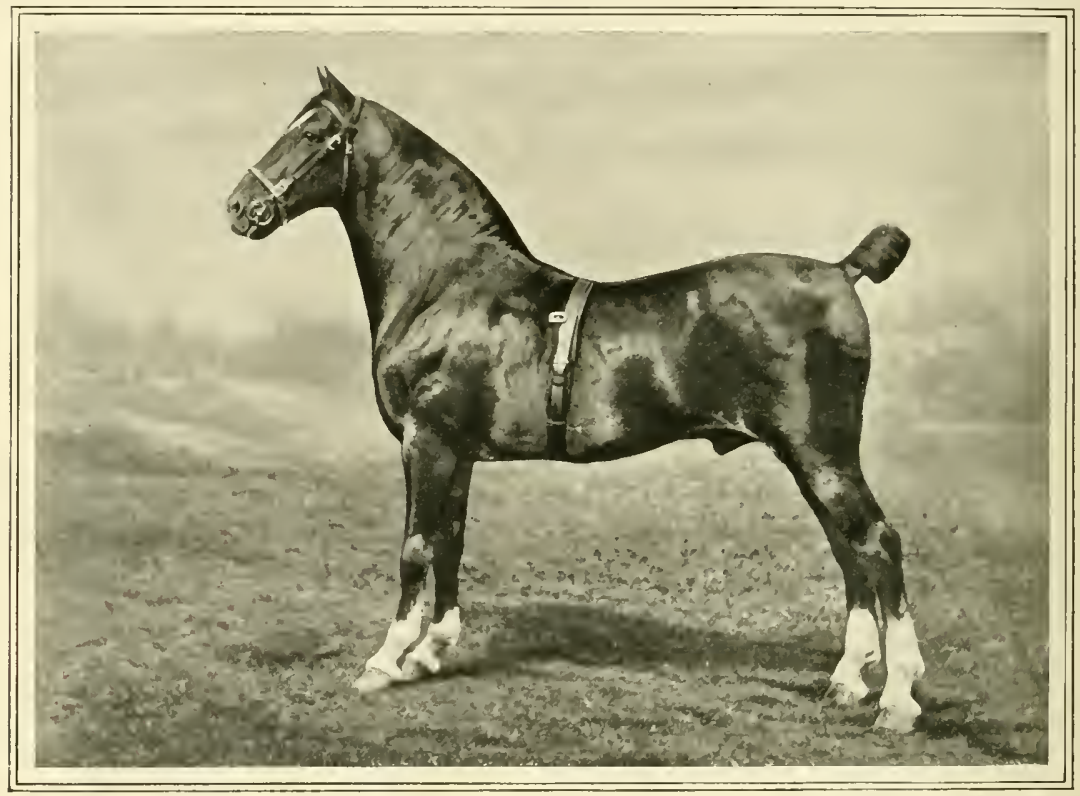

MR. R. WHITHORTH HALIFAX'S HACKNEY STALLION, POLONIUS.

like them in the world to breed on: but then you must choose them fit for such horses as you would breed." It is almost to be feared that such golden words of wisdom have been lost sight of by some modern breeders who regulate their operations upon the haphazard principle of crossing prizewinners with prize-winners, and hoping for the best; but the injunction of the Duke appears to have been laid to heart by his contemporaries.

At all events, by the middle of the eighteenth century the foundations of most of the leading British breeds had been well and truly laid, the result being that the labours of those whose object it was still further to improve the horses of this island century forthcoming than that provided by the Hackney.

The ancestry of the Hackney in tail male is unquestionably the thoroughbred of the Darley Arabian line, the blood horse most entitled to the credit of having established the breed as it now exists being the famous little Flying Childers, who, in spite of the smallness of his stature, distinguished himself immensely both upon the turf and at the stud. It was his son Blaze who got Shales-now referred to as "the original," as many horses of the same name have appeared since his day-who in turn sired Driver out of a mare by Foxhunter, a son of the thoroughbred Sampson, and Scot Shales, out of "a well-bred hunter," which 
two horses may be regarded as veritable pillars of the Hackney Stud Book. Of course, a good deal of doubt will always prevail regarding the class of mare upon which the modern Hackney was built up, but the opinion expressed in the opening sentence, to the effect that they were of the trotting character, may be repeated. This theory is strengthened, as will be shown later on, by the fact that a century ago, more or less, the spert of trotting was very extensively indulged in in England, and consequently there is little room for doubting that good mares possessed of this action were highly prized. It is extremely probable, too, that mares of the pack horsealso known as the chapman's horsevariety were largely used by Hackney breeders of the period, for the pack horse, whose chief strongholds were Devon and Yorkshire, was unquestionably a most valuable breed, and hence regret must be expressed that it was ever permitted to become extinct.

\section{Famous Stallions}

Reverting for a moment to the blood horses which bore an honourable share in the establishment of the modern Hackney, allusion ought in justice to be made to a stallion named Jalap, a grandson on his sire's side of the Godolphin Arabian, as he was by a horse named Regulus, and on his dam's side of Flying Childers blood. Jalap stood for some time in Yorkshire, and earned for himself a great reputation amongst the farmers there who were interested in breeding roadsters. Doubtless, therefore, many of his stock were subsequently used for breeding Hackneys from, a fact which should be borne in mind when the subject of Hackney sires imported from Norfolk to the northern county is being dealt with.

Undoubtedly to Blaze, foaled in $\mathrm{I} 733$, belongs the credit of having sired Shales, the original tap-root from which all the best Hackneys past and present trace back, through his two great sons Scot Shales and Driver. The latter of these was foaled in $I_{7} 6_{5}$, and earned the gratitude of every Hackney breeder by getting the famous 31
Fireaway (Jenkinson's), out of a mare by the thoroughbred Joseph Andrews. Scot Shales, who was foaled three years previously, sired several very useful horses, but none of them attained the eminence of Fireaway, aforesaid. Blaze, moreover, sired another horse who has assisted in making equine history on both sides of the Atlantic, as he was the sire of Engineer, and grandsire of Mambrino, the sire of Messenger, who was exported to America, where he contributed in no small measure to the establishment of the race of trotters which is so highly prized in the United States at the present day. The other horse sired by Blaze was Sampson, a coachy looking black, standing 15 hands 2 inches in height, and who was regarded as being one of the most powerfully built horses of his day; interest, consequently, attaches to his measurements which were: Elbow to knee I9 inches, knee to fetlock II inches, round the fore cannon bone at its narrowest part $8 \frac{1}{2}$ inches, round the hind cannon bone at its narrowest part 9 inches. These figures read well even when compared with modern measurements, and it may be added that though Sampson is recognised as having been a thoroughbred, there were many people who were absolutely convinced that there was a bar sinister in the pedigree of his dam which did not entitle him to claim the distinction. It may be remarked, too, of his grandson Mambrino that "he went in a remarkably good trotting form," and that his owner, Lord Grosvenor, had many excellent coach horses from him. Hence, probably, the success that attended his son Mlessenger when crossed with American trotting mares.

\section{The Hackney as Riding Horse}

A digression may be permitted here to point out that the Hackney was principally a riding horse during the end of the eighteenth and first half of the nineteenth centuries. No doubt there were exceptions, such as a mare called Smart, owned by Mr. Samuel Dyball, of Alby, who, in 1767 , was referred to as being "very famous for hunting, ploughing and travelling the road." 
About this time owners of stallions began to indulge in the habit of advertising the merits of their horses as a general thing, the thirst for publicity not being confined, as formerly, to a few. No doubt the eulogies of such interested parties must be accepted with some degree of reserve, but they are in a measure useful as providing evidence to show the purposes for which the animals were fitted.

\section{Jenkinson's Fireaway}

Somewhere about the year I780, Fireaway (Jenkinson's) was foaled, and this bright chestnut was destined to contribute greatly to the improvement of the Hackney, as amongst his sons were Fireaway (West's), who came out of a trotting mare by the blood horse Pagan, and Pretender (Wroot's), who, assuming that the chroniclers of the period and the Hackney Stud Book are correct, must have been a very closely bred horse, as his dam was the same mare that threw his sire, so Wroot's Pretender was the result of a son and mother being mated. This fact, however, does not appear to have affected his merits as a sire - rather the reverse-as amongst his numerous progeny may be mentioned Performer (Ramsdale's), and Bellfounder (Stevens's), the latter horse being the sire of Bellfounder (Jary's), who being expatriated to America, completed the work which had previously been commenced by Messenger in the way of establishing the national breed of trotters upon a firm basis.

\section{Jary's Bellfounder}

The horse in question, generally known as Jary's Bellfounder, was a bay foaled in $18 \mathrm{I} 6$, his sire, as already mentioned, being Stevens's liellfounder, and his dam a well-known trotting mare named Velocity. He was not a big horse, his height being stated to have been a trifle over $\mathrm{I}_{5}$ hands, but it is not wise to attach great importance to) the accuracy of the measurements of a hundred years ago. There can be no doubt, however, that he was exported to America when he was six years old, and the success which attended him there as a sire has become a matter of history. Jenkinson's Fireaway, the great-grandsire of Jay's Bellfounder, was himself an undoubtedly speedy horse; indeed, he is stated to have covered two miles on the Oxford Road in five minutes. This statement is probably an exaggeration, but there is evidence of a more trustworthy nature to show that his fee when he stood in London was five guineas, and there is no reason to doubt the statement that he at one time was sold for one thousand guineas, which was a long figure for a horse foaled in $r 780$. His son, Wroot's Pretender, was undoubtedly a very good horse indeed, and he is stated to have trotted sixteen miles in the hour when a five-year-old. He was a black horse, standing on short legs and showing a good deal of quality, whilst it may be added that he was a very long-lived horse, as he was serving mares in the north of England long after he had passed the age of thirty years.

\section{Ramsdale's Performer}

Wroot's Pretender in tum begat Performer (Ramsdale's), whose name is to be found in many a Hackney pedigree. He was foaled somewhere about the year I8Io; that is about-it is unfortunate that these "abouts" should exist in so many Hackney pedigrees of a hundred years ago, but it must be remembered that there was no Stud Book in those remote days-the same year in which was produced Leake's Performer, a horse which came out of a nameless Hackney mare, and which is credited with a win at the Wharfedale Agricultural Society's show in I8I6. Ramsdale's Performer was the sire of Merrylegs (Lund's), a horse which can claim the high distinction of being the great-grandsire on both sides of Denmark. one of the three great stallions-Fireaway (Triffit's), and Lord Derby 1I. are the other two-to which the modern Hackney is indebted for most of his excellence.

\section{Norfolk Cob}

In the year I8I5 there was foaled the I5 hands I inch chestnut roan Fireaway (Burgess's), a horse which sired the famous Norfolk Cob, also known by the name of 
Norfolk Phenomenon, whose dam was by IIarshland shales, a grandson of Scot Shales. Norfolk cob succeeded his sire in the stud of Mr. Theobald, of Stockwell, the breeder of the fimous thoronghbred of that name, and it was he who altered his name to that of Norfolk Phenomenon. He is described as having been up to 20 stones, and was a bay of $I 5$ hands $I$ inch, his best points being lis beautiful head, first rate shoulders, and excellent limbs. In turn he sired The Norfolk Phenomenon-ihe prefix "The" is distinctive-whose dam was a roan granddaughter of Wroot's Phenomenon. The name of this horse is to be found in many a good Hackney's pedigree in the present day, and it may be added that he eventually found his way to Edinburgh, where he died. This horse's blood also ran in the veins of such pillars of the Hackney Stud Book as Fireaway (Triffit's) and Lord Derby II., who share with Denmark the honour of being the three main sources from which all the best Hackneys of the day have sprung.

Confidence (Doyley's), another most successful sire - though his services were more in the direction of pony-breeding-was also a descendant of The Norfolk Phenomenon, who sired a number of other must valuable horses. The date of this horse's birth was 1824 , and of him it may be remarked that he was amongst the last of the old race of Hackney stallions which contributed towards the establishment of the breed.

\section{In Defence of the Hackney}

At this point it may be regarded as permissible temporarily to discontinue a consideration of the breeding question in order to discuss the position occupied by the Hackney as a trotting horse during the latter part of the eighteenth century and the earlier portion of the nineteenth. Before proceeding to do so, the opportunity which presents itself may be utilised to protest against the imputation which is so often directed against the Hackney by his enemies, who assert, without the remotest justification, that he is soft and a non-stayer. The whole record of the breed proves the contrary to be the case, and though it is freely admitted that there are bad Hackners as well as good ones, it is as unfair to brand the whole breed with the reproach of cowardice as it is unjust and unchivalrous to blame the entire race of thoroughbreds for the ignomin ous display with which the publis are far too often indulged by a faint-hearted race-horse of irreproachable pedigree. The whole history of the Hackney provides one continuous refutation of this baseless slander, as the relation of past performances of bygone trotting Hackneys proves conclusively, whilst of the modern Hackney; it may be observed that for years the longdistance road championship of America, the land of the trotting horse, was held by a British bred Hackney, namely County nember Junior, who had won a few minor prizes in this country before his expatriation to the United States.

\section{The Hackney as Trotter}

Beyond all doubt the Hackneys of a hundred years ago were largely used by their admirers for trotting purposes, and were, in consequence, as highly valued for their speed as they were admired for their action. There were no scientifically prepared tracks in those days as there are now, and therefore the horses were compelled to give their performances on the high road. This circumstance not unnaturally gives rise to suspicion regarding the exact distances which are reported to have been covered, and it is not unreasonable to give expression to the belief that the timing might not invariably have been correct; on the other hand, it may be pointed out that by far the most of the matches here referred to were for very heavy stakes or wagers as the case might be, and therefore it is morally certain that the loser satisfied himself that the distance covered and the timing were both correct before he paid. For this reason, if for no other, it may be assumed that the records of the past are entitled to recognition, and hence they are likely to be perused with interest by those interested in the history of the Hackney. 


\section{Early Trotting Matches}

Anongst the earliest reports of trotting matches is one that deals with the performance of a mare which at the age of eighteen years trotted sixteen miles in fifty-six minutes and a few seconds, in I79I. This performance is recorded in the Sporting Magazine for I iyt, and it may be added that the reports of several other of the performances noted are taken from the same authority. The Sporting Magazine also refers to a one-eyed blach stallion which trotted the last mile of a two-mile match on the Clapham Road in well under three minutes, whilst in I $78_{t}$ a horse named Archer, earrying I I st. $7 \mathrm{lb}$., covered sixteen miles in fifty-four and a half minutes. Ten years later the Sporting Magazine alludes to a mare which, under the burden of I8 st., trotted forty miles in three hours, thirty miles in two hours, and ten miles in thirty-two minutes.

\section{The Wonderful Phenomenon}

All contemporary performances, however, pale before those of the wonderful little cob mare Phenomenon, who stood only $I_{f} \frac{1}{2}$ hands high. The list of her performances is a very lengthy one, and includes the covering of seventeen miles in fifty-six minutes, on the Huntingdon Road, in the year I 800. Another match was made on the same terms, and a month later, that is to say in July, I800, Phenomenon proved the correctness of her former performance by completing the distance in a little under fifty-three minutes.

After this she was matched to trot nineteen and a quarter miles in the hour for a stake of 2,000 guineas, but her owner received forfeit when it became known that upon the occasion of her last performance she had covered four miles under eleven minutes. At the age of twenty-three, this extraordinary mare trotted nine miles in twentyeight and a half minutes. Phenomenom died suddenly at the age of twenty-six years, her only descendant whose name appears in the Hackney Stud Boxk being a grandson, Phenomenon (Jones's), by a grandson of The Norfolk Phenomenon, who, by the way, stood $I_{5}$ hands 3 inches at the shoulder. Phenomenon, it may be observed, came of good trotting parents, as her dam was a Norfolk Hackney of some repute, whilst her sire, Othello, distinguished himself by covering seventeen miles in fiftyeight minutes forty seconds, on the Highgate Road, in 1798 , at which time his illustrious daughter was ten years old.

\section{Other Records}

In the year last mentioned a mare be longing to Mr. John Wiers trotted fifty miles in two seconds over four and a half hours, covering the last mile in four minutes three seconds, which does not look as if the Hackney was a soft horse.

Coming to more recent dates, it may be mentioned that one Dixon, of Knightsbridge, in April, I832, matched his mare Nonpareil to trot one hundred miles inside ten hours in harness. She was driven the first twenty miles in two seconds less than two hours, and forty miles within four hours, eventually winning by three minutes three seconds; a rather narrow unargin, certainly, but the mare was not in the least degree distressed at the finish, and therefore might have been capable of a better performance had she been pressed.

The above references to a few of the many recorded performances of the Hackneys of the early part of the last century justify the suggestion that the breed was at that time in a flourishing condition, and with a still more prosperous future before it.

\section{“The Equine Jack-of-all-Trades"}

The Hackney was, in fact, the equine Jack-of-all-trades, as in addition to the support he received from sportsmen, the agricultural community found him to be a very useful horse, who could not only be utilised for riding purposes, such as taking his master, often accompanied by his spouse, seated in a pillion behind him, to market, but was also equal to putting in a goud day's work on the farm should emergencies arise. This satisfactory state of affairs continued to exist until the advent of railways, when the fortunes of the Hackney 


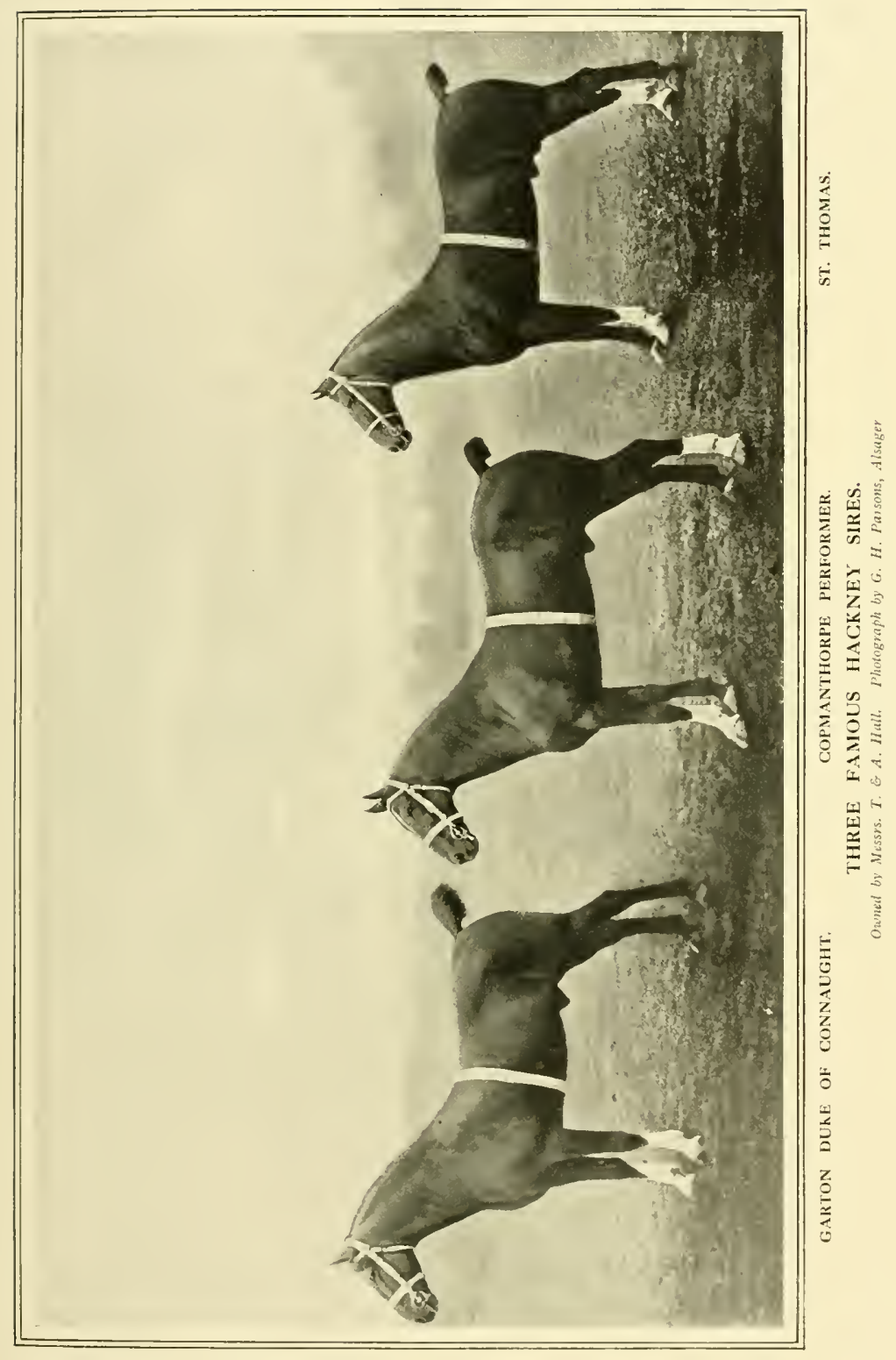


underwent a change for the worse in most parts of the country.

\section{The Cult of the Hackney}

It may here be observed that admirers of the breed were to be found in many districts beyond the limits of East Anglia, the home of the Hackney. Burgess's Fireaway and his illustrious son Norfolk Cob have already been shown to have occupied boxes at Mr. Theobald's stud farm at Stockwell, and as their services were beyond all doubt in great request, it must be assumed that there were plenty of Hackney breeders in the county of Surrey in the early part of the nineteenth century. Burgess's Fireaway also stood in Middlesex for a short time after he left the Stockwell stud, his headquarters being at Mattam's Livery Stables in Down Street, Piccadilly. In 1825 he found his way to Yorkshire, his name having been changed by his then owner, Mr. T. Kirby, of York, to Mildfire, and two years after he travelled in Essex, but returned later on to lorkshire. A famous descendant of his namely, Norfolk Phenomenon, by Norfolk Cob, foaled in I824, was another Norfolk - bred horse which saw a good deal of the world, as he travelled in Yorkshire for several vears, and also served in Lincolnshire, Cambridgeshire, and Norfolk, before going to Scotland, where he died. Merrylegs (Lund's) by Ramsdale's Performer, who was foaled in I 830 , is yet another Hackney stallion whose name appears in many of the leading pedigrees, and who travelled all the breeding districts of East Anglia and Yorkshire.

\section{The Hackney in Scotland}

Meanwhile Scottish breeders had not been backward in recognising the value of the Hackney, as, in addition to Norfolk Phenomenon, some very useful stallions of the breed found their way across the Tweed. Reports, moreover, are to hand regarding the existence of a mysterious sire named Sportsman, who travelled the Fife district about the year I\$25, and left a good supply of sound coloured and otherwise valuable stock behind him. Unfortunately no definite particulars are forthcoming as regards the breeding of this horse, but he was confidently reported to be Yorkshire bred, and doubtless was so.

The horses mentioned do not, of course, represent the entire list of successful Hackney sires of the early nineteenth century, but there are few modern pedigrees which do not include some of their names, and therefore sufficient has been written to throw light upon the breeding of most of the modern prize-winners. Unfortunately the Georgian and early Victorian race of Hackney breeders were extremely careless in respect to the way they kept up the records of their breeding operations. There was at the time no Stud Book for them in which to enter the pedigrees of their Hackneys, and hence a good deal of the information thit is forthcoming regarding the horses of the past has come down by word of mouth - statements directly or indirectly conveyed to someone who wrote them down.

\section{The Pedigree Difficulty}

This unfortunately has been a particularly common occurrence in the case of mares, and hence, though it is not a very difficult matter to trace out the pedigree of a Hackney in tail male, the breeding of the animals on the nare's side of the table soon becomes lost in obscurity. This is particularly annoying to modern breeders possessed of a disposition for working out pedigrees, but it is not unreasonable to assume that a very considerable number of the dams of Hackners whose names appear in the Stud Book of the breed were bred in a similar manner to the horses whose pedigrees are given, as there must have been as many fillies as there were colts raised, and the former must naturally have been used for breeding purposes. No doubt a good ceal of discredit is attached to Hackney pedigrees of the past by opponents of the breed owing to the non-existence-nutil some thirty years ago-of a Stud Book of the breed; but it appears to be going too far when all Hackney ped grees are denounced as having been either intentionally or unintentionally fabricated. The breeding of 
their horses was doubtless handed down from father to son by the Hackney admirers of the past, with exactly the same care as though the information were being supplied to the compiler of a Stud Book; and it may be pointed out that in the days when there were fewer facilities for getting about than there are now, neighbours knew a great deal more about each other's business, and hence it would have been a difficult thing to fabricate a pedigree. This is an important matter in the opinion of Hackney breeders, who are naturally as jealous of the reputations of their ancestors as they are proud of the breeding of their horses; and it may be added that there could have been no guarantee forthcoming to satisfy a doubter that all the information supplied by early breeders of the thoroughbred for publication in the General Stud Book was unimpeachably correct.

\section{Influence of the Railway}

Allusion has already been made to the disastrous effects of the railway movement upon the Hackney; indeed, it would be difficult to over-estimate the damage inflicted upon breeders, many of whom completely lost their heads, as they imagined that the era of equine supremacy had departed, never to return. Of course, farmers soon realised that it was easier to go to market by train than on horseback, and hence, no doubt, the cause of the prevailing scare which caused many breeders to break up their studs. This was a very serious matter for the breed, for as there were no horse shows-such as are known nowadays-to produce a market for goodlooking horses, the majority of Hackney raisers arrived at the conclusion that their occupation was absolutely gone. Happily, however, a few of their number were true to the horse of their affections, and in due course they reaped the reward of their constancy, but the relief came from a rather unexpected quarter, as will presently be seen.

\section{The Hackney as Harness Horse}

Up to this time the Hackney had been practically a riding horse of a very sub- stintial type, otherwise he would not have been able to dispose of such duties as carrying welter-weight farmers, and very often their wives as well, to market on his back. A change, however, came over the spirit of the age as regarded the qualifications of a saddle hack when the railways were built; but simultaneously there arose an increased admiration for the high-stepping harness horse possessed of good looks, and the wisest of the breeders who had Hackneys left on their hands set themselves to work to supply the demand. The result of their efforts to do so must assuredly have ex ceeded their most sanguine expectations, as really high-class harness horses were never more sought for than now, and the fame of the British Hackney has extended to every part of the world.

\section{'Triffit's Fireaway}

Passing over the period that elapsed between the introduction of railways and the time when the merits of the Hackney once again commenced to be recugnised outside the circle of his immediate supporters, which period had been one of great anxiety and trial to the latter, we arrive at the end of the 'fifties, when the fortunes of the breed revived, and since which period they have steadily advanced. The year I 859 will long be remembered by Hackney breeders as the one in which the dark brown Fireaway, known as Triffit's, was foaled, as he was one of the great trio of stallions which practically built up the breed again. He was a Yorkshire-bred horse, standing 15 hands 2 inches high, and strained back to Norfolk Phenomenon on both sides, whilst his great grandsire on the male side was Ramsdale's Fireaway. Such a combination of blood could not possibly fail to produce excellent results when crossed with almust any sort of mare, and undoubtedly Triffit's Fireaway was the beau ideal of all that a harness horse sire should be, and the neglect of Hackney breeders to treasure this blood as it deserved has undoubtedly resulted in serious loss to the breed. Horse shows were not such events as they are nowadays when Triffit's Fireaway was in the 


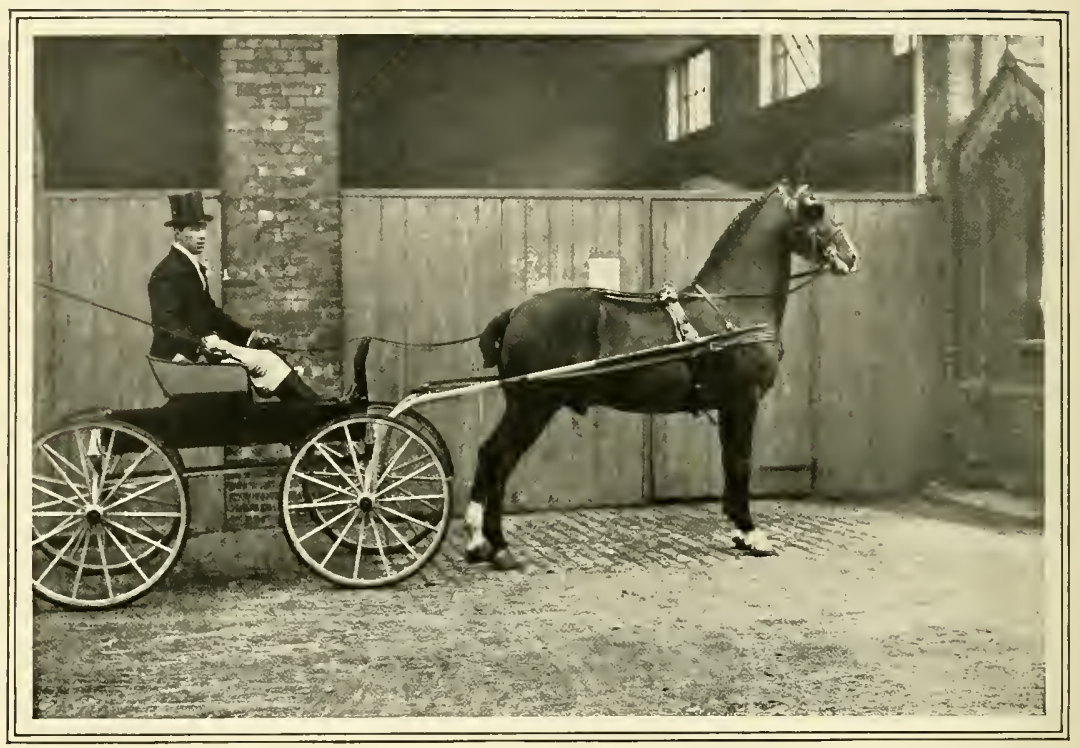

DR. A. BOWIE'S HACKNEY STALlion, MATHIAS Al.

zenith of his fame as an exhibition horse, but they were judged by practical breeders, who understood, not merely what sort of horse was wanted, but how to produce it, and hence fewer mistakes were made than there are in these modern times. Amongst his victories were some very important ones, secured at the Royal Agricultural Society's and great Yorkshire shows, but successes which may appear to have been easily gained at minor exhibitions were in reality nothing of the sort, for in those days many a great Hackney competed at little gatherings held in country lanes.

Fireaway's great rival was the chestnut Denmark, foaled in 1862, and likewise a Yorkshire-bred horse. His pedigree contains a quite remarkable amount of the blood of Merrylegs (Lund's), as he is inbred ciosely to that horse, from which doubtless he derived much of his excellence. Denmark, like Fireaway, was a successful competitor in the show ring, but Mr. Triffit's horse beat him when they met at Bridlington in 1872 . Comparisons between two horses such as those just referred to must always be invidious, but the opinion must be expressed that Hackney breeders during the past few years have been guilty of great unwisdom in blindly rushing after the blood of Denmark and entirely neglecting that of Fireaway, which is now practically lost. Apart entirely from the question of colour-all Fireaways being mostly brown, and the Denmarks chestnuts, which will be duly referred to later on-the mistake of allowing the Fireaway blood to become lost was that it almost invariably crossed well with the Denmark strain. If an illustration of the correctness of this assertion is required the cases of Mr. Henry Moore's Princess, Countess, Sunbeam, Sweetbriar, Primrose, and Snowdrop, who were all by Denmark out of the Fireaway mare Empress, may be quoted. The last-named was of the long, low, heavyboned, old-fashioned type of brood mare, possessed of good all-round action, and, in fact - as were her daughters that we have named -of exactly the stamp that could not fail to produce harness horses of the very highest class.

The third great Yorkshire-bred sire of 
Hackneys was Lord Derby II. He was foaled much later than either of the others, as he did not see the light until I87I. Fireaway's sire, Achilles, was his grandsire on the dam's side, and like Mr. Triffit's horse, he almost always threw good coloured stock, his young ones being generally browns; and they crossed well with the Denmarks, though the craze for the latter blood caused the Lord Derbys to be neglected.

As we have observed, the three great Hackney stallions of recent days were all Yorkshire-bred, but they all possessed a strain of the old Norfolk blood in their veins, Fireaway through Burgess's Fireaway on his sire's side, and Norfolk Phenomenon on his dam's; Denmark through one cross of Burgess's Fireaway and two crosses of Lund's Merrylegs on his sire's, and one each of the same blood on his dam's side; whilst Lord Derby showed a double cross of Burgess's Fireaway, and a single one of Norfolk Phenomenon in his pedigree. It must not be imagined, how- ever, that East Anglia, the ancient home of the Hackney, has been left entirely destitute of good blood by the removal of so many of its best sons and daughters to the North and elsewhere. Norfolk had still left to it the Great Gun family of which Rufus, the champion stallion at the fifth. London Show, and, in the opinion of many, the best Hackney of modern times, was a distinguished representative, the Great Guns figuring prominently on the sire's side of his pedigree table, whilst on that of his dam the names of Prickwillow (Cobbin's) and Norfolk Cob are prominent. The Great Guns were responsible for the Shot family which has a good deal to do with many a recent Norfolk pedigree; and in addition to these Confidence (Doyley's) who was full of Norfolk Cob blood, and who also traced back to the expatriated Bellfounder on both sides-sired some very good specimens of the breed, including Reality, three times champion in London. But Confidence's successes were mostly

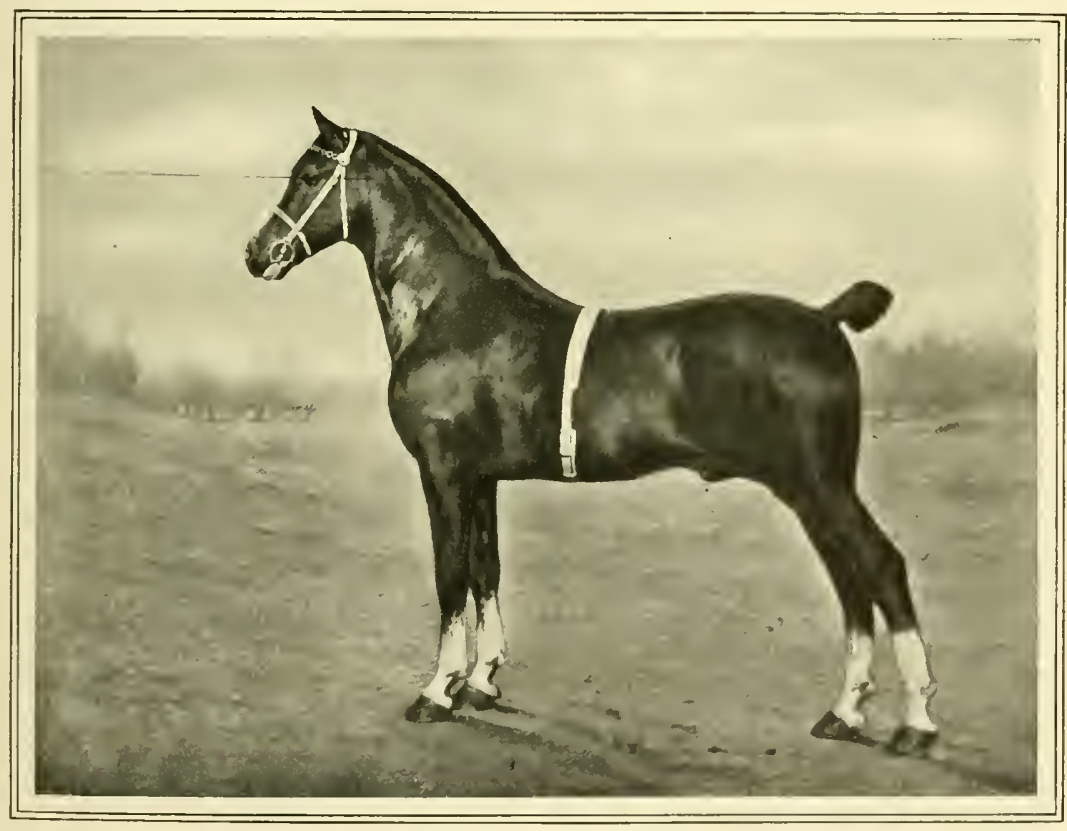

Photograph by G. H. Parsons, disaper 
associated with ponies, as his name appears in the pedigrees of many of the crack little

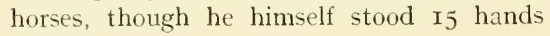
2 inches.

This allusion to the measurement of Doyley's Confidence affords an opportunity for referring to that much debated question -Hackney height. Upon this subject the ideas of breeders will be found to differ a great deal, and it may be added that until there arose, a few years ago, a desire to breed a taller, bigger horse, the rules of the Royal Agricultural Society prohibited any Hackney from exhibition at their shows that exceeded I5 hands 2 inches in height.

\section{The Tall Hackney}

The influence of the Hackney Horse Society, however, soon succeeded in getting this rule rescinded, but there are plenty of men who are intimately associated with the breed who regret the encouragement that is being given to the taller horse. Their opponents, however, have precedent on their side, for there is no getting away from the fact that the Hackneys of the late eighteenth and early and middle nineteenth centuries were in many instances quite tall horses. The names of at least fifty stallions foaled during the first half of the last century which stood I6 hands and over are recorded in the pages of the Hackney Stud Book. These animals in many instances were nearly related to Marshland Shales, a grandson of Scot Shales, who was foaled in $\mathrm{I}^{802}$, but he appears to have only been a I 5 -hands horse. Bellfounder also stood only i 5 hands, and yet his name appears in the pedigrees of several of the big ones, so it is very possible that the mares of the period were sizable animals, and thereby assisted materially in raising the height of the breed. As the subject of heights is one of considerable interest to many breeders it may be observed that Fireaway and Denmark,

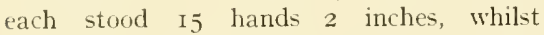
Great Gun reached the full I6 hands. The latter height is quite a common one nowadays, but it is in many instances associated with a diversity of type, as some of the big horses are tall and narrow-in short very far removed from the true Hackney character.

\section{Change of Type}

No doubt there have been changes of a more or less radical nature in the appearance of the Hackney from time to time, and these are not to be wondered at when it is remembered that the breed has been put to many purposes at different periods of its existence. In the old days beyond a doubt the heavier-built Hackneys were upon occasions put to farm work, and under any circumstances they must have been horses of a more powerful type than that at present favoured, for they had to carry heavier weights upon their backs, and the vehicles they were driven in were nothing like so light as the modern carriages; nor were the roads so good. It is not surprising. therefore, that when railways commenced to usurp the duties of the Hackney, and breeders discovered that the tastes of driving men had undergone a change, the raisers of Hackneys began to evolve a different type of horse to meet the altered conditions. There was plenty of excellent material at hand for them to exercise their abilities upon, and amongst the results of a carefully thought out series of crosses, were such stallions as Fireaway and Denmark. It is quite possible that the rule of the Royal Agricultural Society which prohibited the exhibition of Hackneys exceeding I5 $_{5}$ hands 2 inches was directed against the larger and coarser horses, which were no longer required; and it may have been thought that by discouraging them they would in due course disappear. If so, the anticipation proved to be correct, as for many years the medium sized horses were most in request.

\section{Thoroughbred Influence}

There can be no doubt at all that thoroughbred blood has been introdnced into the veins of many a modern Hackney, surreptitiously upon some occasions, and openly upon others. In some cases, too, the experiment has been accompanied by complete 
success, a notable instance being the very popular stallion His Mlajesty, whose maternal grandsire was a bloyd horse. It would probably be an exaggeration to suggest that His Majesty's success as a sire was entirely due to the infusion of thoroughbred blond in his reins, as in his show days his action was magnificent, the snap of the knee and flexing of his hocks showing no trace whatsoever of the blood horse, and he moreover almost invariably succeeded in transmitting his gift of going to his stock. On the other hand, His Majesty possessed a great deal of quality of the right sort, and this he likewise passed on to his foals, amongst which were some of the best looking and finest actioned Hackneys of their day. It is probable-highly probable - that a good deal of thoroughbred blood got introduced into some strains in the early days of the Hackney Horse Society, owing to a regulation that was passed with the object of recognising, to a qualified extent, the offspring of inspected mares which were regarded in the light of foundation stock. No doubt this rule was the means of encouraging a certain number of nondescript mares, though, of course, many good animals were also inspected and passed, but as was only natural, the feeling against these animals increased rapidly, and the obnoxious regulation was repealed at a special general meeting of the club, at which party feeling was very strongly displayed.

\section{Hackney Horse Society}

It may here be stated that, according to the articles of association, the objects of the Hackney Horse Society are as follows

(I) To improve the breed, and to promote the breeding of Hackneys, roadsters, cobs and ponies.

(2) To compile and publish a stud book of such horses.

(3) For the purposes of the Society, and subject to the provisions contained in Section 21 of the Companies Act, 1862 , to purchase, take on lease, hire, and otherwise acquire for the Society borses, lands, goods, chattels and effects; and to sell, let, or otherwise dispose of the same.
(4) To hold shows of such horses, to offer prizes, and to do all such other lawful things as may be incidental or conducive to the attaimment of the above objects or any of them.

The publication of the Hackney Horse Society's stud Book most indoubtedly la; proved to be the salvation of the breed, for it has effectively placed it beyond the power of a certain class of breeder to withhold correct infurmation regarding the pedigree of the animals he exhibits. It has made men more careful also in filling up their entry forms, as a mistake, even an innocent one, would lead to trusble, and hence the public are placed in a much sifer position than was formerly the case when purchasing a Hatkney.

\section{The Breeding Question}

There can be no doubt that the breed has become greatly increased in value through the existence of the Society's spring show in London; but opinions differ very considerably as to whether the type of animal that has of late been selected for prizes, and especially in the case of mares, is exactly the one which should be encouraged for breeding purposes. If this view is correct, the mistakes that are made can probably be traced to the fact that fewer breeders of eminence, and more persons who are associated with the harness horse, are invited to judge. The Hackney Society's show is, or should be, a breeders' exhibition, and consequently the type of animal that is calculated to produce the sort of hamess horse that is required is the one to be encouraged. It does not necessarily follow that the best animal in leather is the one that will breed stock as good as itself, and consequently, as the tendency of the age is all in favour of that mysterious entity known as quality, it not infrequently follows that a competitor is accorded high honours, though not one experienced breeder in a hundred would ever expect it to produce anything as good as itself. This is especially so in the case of the brood mare classes, some of the highest winners of recent years having been deficient in bone 
and crimped in their middles, though they were elegant to a degree and brilliant movers; in short, just the class of animal for harness work, but useless for breeding purposes. At least one champion stallion - it would be invidious to identify him by name-has proved a dire failure at the stud, and for the simple reason that the judges were led away by his quality and action, and forgot to attach the proper amount of importance to other very essentia] points.

It may be suggested, too, that the attribute of quality is one which is very imperfectly understood by horse breeders, many of whom are by far too much disposed to associate Hackney quality with thoroughbred quality, whereas the two are totally different. Quality in a horse may briefly be described as refmement, but the degree of refincment which would increase the beauty of a thoroughbred would simply appear effeminate in the case of a Hackney, which is built upon more substantial lines.

\section{Chestnut Hackneys}

Another and, possibly, as serious a danger to the position of the breed is the steadily increasing number of chestnut-coloured Hackneys which are met with on all sides. Indeed, if the breeders of this horse do not bestir themselves in earnest, and without delay, the variety is assuredly destined to develop into a chestnut breed, as the Suffoll horse has. No doubt the chestnut colour is an excellent one in many respects, and there can be no possible objection against the admirers of this shade indulging their taste to their heart's content ; but it becomes a totally different matter when one colour is practically absorbing an entire breed. The chestnuts, moreover, are not popular with the fashionable folk, who desire to possess big upstanding horses for use in their landaus and heary carriages ; in fact, they will not have horses of this colour, and consequently the Hacliney is placed at a distinct disadvantage when opposed to the Oldenburgs, Holsteins, and other varieties of foreign horses, which are all sizable and fine movers, whilst the prevailing colours amongst them are sound bays and browns. The encouragement that has been given to the chestnut Hackney has, in fact, caused many thousands of pounds to go into the pockets of other breeders; and as it has become the practice of many judges to be very tolerant of white splashes on the belly, white face's and lips, the Hackney has undoubtedly fallen into disrepute amongst an influential class of wealthy buyers. Unquestionably the craze for Denmark blood, and the amount of inbreeding that has been so prevalent of late, is in the main responsible for the increase in the number of chestnuts, as Denmark was of this colour, and it is the one of all others which appears to be the most prepotent. Hence increased regret may be expressed at the neglect of the Fireaway and Lord Derby II. blood which has been so prevalent of recent years, for both these horses sired a large number of bay and brown foals out of every crop.

Bay Hackneys are still to be met with in fairly large numbers - that is to say, their proportion to the chestnuts is somewhere about one in twenty - but browns are scarcer still, and roans are few and far between. The old-fashioned blacks which at one time were so popular are now practically extinct, as are the greys, whilst very seldom a skewbald may be seen, but when this is so the horse is generally a good one.

\section{Claims as a Riding Horse}

Although the Hackney has of late years come to be regarded as a harness horse, there are many of his supporters who cannot be brought to realise the fact, and they as a consequence insist upon his claims as a riding animal being brought before the public upon every possible occasion. The wisdom of this is, to say the least of it, open to doubt, for the Hackney action of the present is not of such a nature that it can be described as easy, and this is just what the riding men of the present day require. It is, of course, a fact that some Hackneys are smoother movers than others, but a good Hackney should use his knees and hocks in a style which cannot possibly conduce to easy artion, 
and if he is not a high and free mover he cannot be regarded as a typical specimen of the breed, in which case he cannot be a credit to it in any capacity.

As a harness horse, on the other hand, the Hackney knows no superior, and his merits are recognised in every part of the world, but his friends have often had to any means represent the number of important prizes won by horses of this breed.

It is in South America, however, that the merits of the British Hackney are more fully appreciated than in any country but his own, and the breeders of the Argentine have spared no money in procuring the very best blood they could for the purposes of crossing

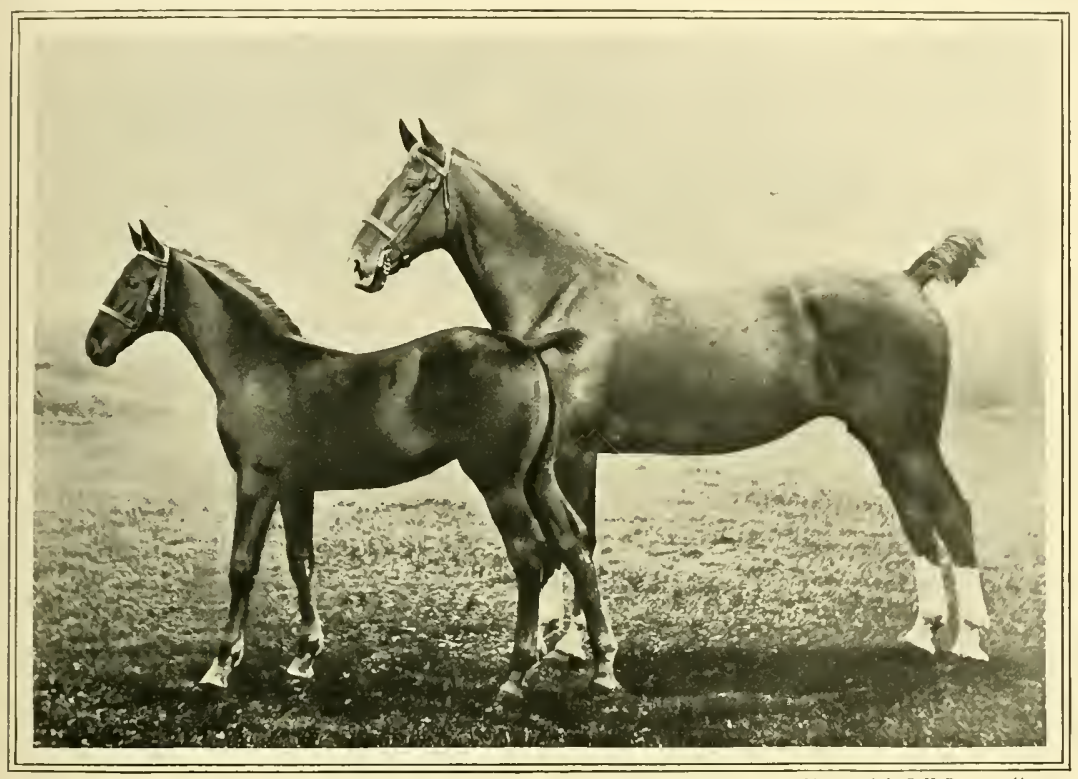

MR. R. WHITWORTH'S HACKNEY MARE, TOWTHORPE IRIS AND FOAL.

fight a hard battle on his behalf, as popular prejudices have to be overcome. In no country has the opposition to the breed been more powerful than in America, and this is only reasonable, for the Hackney could only succeed at the expense of the trotter. which may be regarded as the national horse of the United States. Yet the English breed has surely but steadily gained ground on the other side of the Atlantic, and a larger share of the prize money offered at the most important shows has annually been his share. The famous gelding Forest King by His Majesty literally farmed the championships at the New York show for several years, but his successes did not by with native stock. Immense success has attended the efforts of many of these gentlemen, conspicuous amongst whom are Señor Martinez de $\mathrm{Hoz}$, and Señor Augustin de Elia. The former of these enthusiasts ran a public stage-coach from London to Guildford during the season of I908, and horsed it as far as possible with animals he had bred on his estate in South America. The horses in question were full blooded Hackneys, and they sold at the end of the season far better than the American-bred trotters which had been in Mr. Alfred G. Vanderbilt's Brighton coach. Señor de Elia is now the owner of the mare Hawsker Rosina, a champion at the London show, and exhibited 
at the Hackney Society's show of Iojog, a five-year-old mare of most superb quality and action, which was second in a very strung class, and at one time appeared very likely to gain the highest honours. It is necessary that performances such as these should be alluded to, as they prove the atdaptability possessed by the Hackney for thriving under climatic conditions which might affect the constitutions of many breeds. The Hackney, however, appears capable of thriving everywhere, and were this not the case foreign govermments would not send agents to attend each successive exhibition in London, for the purpose of buying suitable stallions for service in their national studs. The fact that they do so effectually disposes of the misstatements of those opponents of the Hackney who declare that the breed is soft and lacking in courage; were their allegations correct it is impossible to believe for a moment that foreign governments, who have experience of the horse, would continue year after year to expend very considerable sums of money upon the purchase of stallions with the object of breeding remounts for their artilleries.

\section{The Hackney as Sire}

The Hacknev, it may be here observed, is a most impressive sire, and he succeeds in imparting his action, to a greater or less extent, upon all his stock, no matter how porr a mover the mare may be. At the gallop or canter the breed is certainly not seen to advantage, but every Hackney is a born trotter, and even foals, if they momentarily break into a canter when at play, at once return to their natural gait. It has been said, and truthfully, of many horses of this breed that they can trot faster than they can gallop, and a good one usually retains his form to the last, no matter how tired he may be. The perfect trotting movement so characteristic of the Hackney consists not merely of exceptionally high knee action, but of a remarkable ability to make use of the shoulders and to flex the hocks. An animal which fails in these two essentials is never a mover, as the free use of the shoulders provides lim with that freedom and power of "getting away" in front which is one of the chief beanties of the trot. C'nless, too, a horse tucks his hocks well under him when he is set going, it is obvious that he must be deficient in propelling power, and hence what merit is attached to his front action is materially lessened; in short, a Hackney which drags his legs behind him is guilty of a very bad fault. In referring to the fore action it may be mentioned that some horses, the Yorkshire-bred ones in particular, used to display a momentary poise of the front feet when extended before putting them down on the ground. The movement was instantaneous, but it created a most beautiful effect, the entire limb from the toe to the shoulder being extended to its utmost length with the toe a few inches above the ground. This poise is not so often seen as was formerly the case, which is to be regretted, as it was invariably associated with very fine hock action; and unless a Hackney moves all round he is comparatively worthless. His form of moving differs entirely from the high-stepping round-actioned type of horse which practically only bends his knees and does not get away at all, and who after lifting his knees almost up to his bit smashes his feet down within a few inches of the place from which he lifted them up, and leaves his hind legs behind him. This sort of movement, which has been characteristically described as "all action and no go," is nothing at all like the true Hackney action, and although it may be admired in the park, is not one that deserves encouragement.

\section{Teaching to Trot}

There can be no doubt that trotting can be considerably improved by a judicious course of schooling, but in order that the best effects should be produced there must be good material to work upon at the commencement. The simplest and most common methods to adopt when it is desired to teach a horse to step is to trot him on a straw track, or upon one which is cuvered pretty thickly with furze. The horse has then to raise his knees in order that his feet can clear the 
straw or furze, and when he once gets into the habit of doing so the action is likely to continue. The application of weights to the lower part of the cammon bones just above the fetlocks is another and even better method for general use when a horse is being schooled, but it is the wiser course to adopt this after the pupil has been for some time taken over the straw track, and then both systems can be employed. The weights consist of leather or indiarubber tubes filled with shot, which are buckled or fastened by some other means into position on the legs, and it is a good plan to vary their weight from time to time. The advantages of heavy shoeing are so generally recugnised that it has come to be a general, but most undesirable, practice amongst exhibitors of stepping horses to shoe their animals with a considerable weight of iron, in order that they shall "go high" in the show ring. To such an extent had this evil extended that it was no uncommon occurrence to see a horse shod with a solid piece of iron which covered the whole sole of his foot, frogs and bars included, but happily the Hackney Horse Society has recognised the objections which attach to the practice of over-shoeing, and have passed a rule to the effect that at their shows no horse over If hands high can be exhibited which wears a shoe exceeding $2 \mathrm{lb}$. in weight, whilst in the case of animals not exceeding $\mathrm{I}_{+}$hands, and yearling colts and fillies the limit is $\mathrm{I}_{2} \mathrm{lb}$.

\section{Development of Action}

Returning to the question of schooling horses it may be added that some owners employ railway sleepers laid across the track for the purpose of accustoming their Hackneys to step. There are obvious objections to this, as the animals are liable to injure their legs; and therefore other trainers dig shallow trenches and throw up the earth in a sort of mound in order that the horse will be inconvenienced if he steps short. This plan is very useful in the way of developing back action, as it encourages the pupils to get their hind legs well under them in order to clear the shallow trenches and mounds; but, of course, the liorses should be taken over such tracks at a slow pace, in order to avoid accidents. A few years ago a most abominably cruel practice, known as "cording," was openly adopted by some exhibitors, whose object it was to compel their Hackneys to go high under the influence of excruciating pain. It consisted of fastening a strong cord-whip-cord was generally used for the purpose-round the tongue of the unfortunate victim, and tying the ends to the cheeks of the bit, in such a manner that when the leading rein was jerked, the cord would cut into the tongue, with the result that the horse would bend his knees in his suffering. To their infinite credit the Council of the Hackney Horse Society have declared the practice of " cording" horses to be illegal, and consequently, although it is to be feared that some trainers still indulge in this particular form of cruelty at home, the public who visit shows are spared the pain of seeing the mouths of horses running with blood in the show ring.

\section{The Good Walker}

Having thus considered the trotting action of the Hackney, a few lines may be devoted to the subject of the walk, which is, or ought to be, a subject of unly secondary importance. It is to be regretted, however, that very few judges appear to devote an adequate amount of appreciation to the walk, and hence it is no uncommon occurrence to see every horse in a class niggiing about and off his feet when he ought to be deliberately stepping out in a methodical one, two, three, four, gait. Not only is a good walker attractive to look npon, but in the case of a harness breed such as the Hackney, it is a great advantage for an animal to walk well, for, as every driving man knows, there is often an immense amount of time wasted upon a journey when long hills have to be negotiated. Therefore, as the walk is a natural form of gait in every horse, and as its development is a comparatively easy task for the trainer, it is greatly to be regretted that this indispensable form of action should not receive the encouragement it deserves. 
Before concluding these observations upon action, the opinion may be expressed that no matter how well a horse may use his legs, the show he gives will be depreciated almost to vanishing point if he does not carry his head and tail properly. An animal which wears himself well, and moves as though he enjoyed being extended, cannot fail to create a far more favourable impression than one which goes with his head poked out in front and his tail carried as though it were attached to his body by a string. On the other hand, a high stepper with plenty of freedom and hind action, which carries both ends up at once, attracts attention and fully justifies the admiration bestowed upon him. Lastly comes the allimportant question of manners, as a headstrong, evil dispositioned horse, no matter how well he may move upon occasion, will never create the impression that a good mannered one will. Of course, temperament has a great deal to do with the question of manners, as a nervous, irritable, highly strung animal will always be a difficult one to deal with, but it may confidently be added that the exercise of patience combined with firmness on the part of the breaker and trainer will overcome a natural tendency towards unsteadiness. Doubtless also improper bitting has very often a great deal to do with the bad manners displayed by some horses, for although there is a key to every horse's mouth, many a breaker is too neglectful of his duties to try to find it, the result being that every year hundreds of valuable young horses are ruined for life. The subject of breaking and making young horses does not, however, enter into the scope of this article, and hence it is unnecessary to allude to it further than offering the advice that no owner of a young horse should entrust it to a breaker unless he has absolutely satisfied himself regarding the man's ability, and feels confident that the equine babies committed to his charge will not be treated with harshness or cruelly over-bitted.

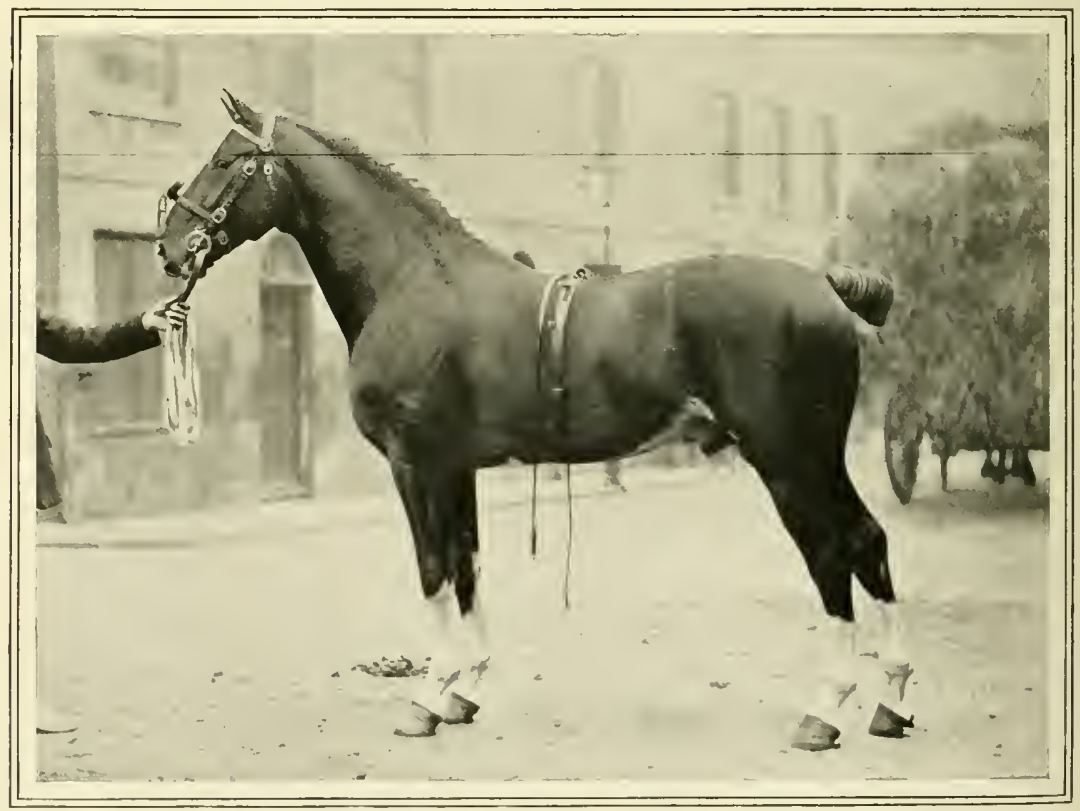

SIR WALTER GILBEY'S HACKNEY STALLION, ANTONIUS.

Phoing rath by Pictorial Agenc 


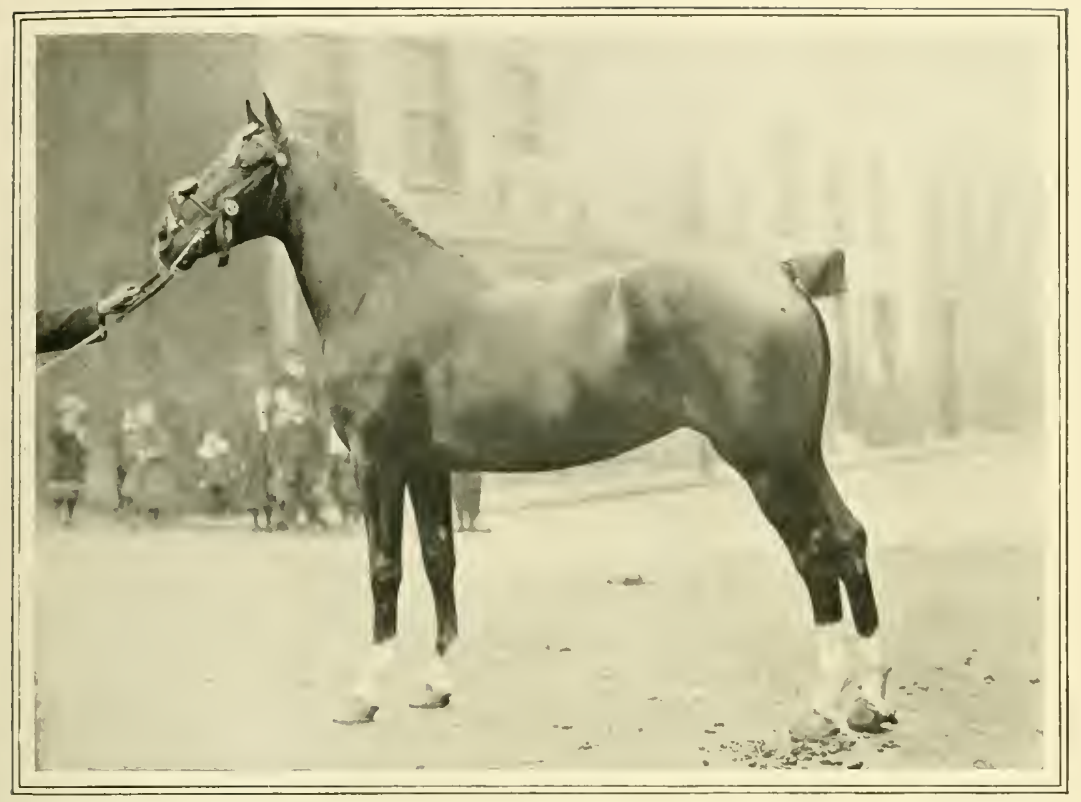

MR. A. W. HICKLING'S FOUR-YEAR-OLD HACKNEY MARE, ADBOLTON ST, MARY

\section{CHAPTER XX \\ THE HACKNEY (continued)}

$I^{\prime}$ $T$ is a remarkable thing that no official standard of excellence has been laid down by any of the great horse breeding societies whose members are pledged to the improvement of the variety they admire. Were there some such pronouncement in existence with respect to the Hackney, matters would be made far easier for breeders, and the public would not be indulged by the spectacle of some remarkable decisions in the show ring. As it is, every judge is a law unto himself, and consequently when it happens, as is usually the case, that two gentlemen officiate, it is by no means an uncommon occurrence to find horses of absolutely opposing types winning prizes in the same class. Of course, it could nct be expected that any standard $3^{n}$ of excellence would be applied exactly in the same manner by different judges, as each man would probably give effect to his own particular prejudices to the greatest extent possible; but at the same time some limit would be imposed upon the exercise of an extreme prejudice for or against certain points. At the present time the tendency of the age is all in favour of sensational action combined with quality. The former is well enough, but the attaching of undue importance to the latter attribute is calculated, as already has been pointed out, to injure the breed, for light-built, flashy animals are likely to produce stock even lighter than themselves. Hence, unless more encouragement is deroted to the oldfashioned, more powerfully built class of 
mare, the future of the Hackney as a harness horse for general use is not promising. No horse can possibly continue to hold a position in the estimation of the public unless he is capable of accomplishing something more than moving a few times round a show ring in front of a spider-wheeled conveyance, the weight of which can almost be calculated in ounces. This is not the sort of animal to be of use to a government desirous of breeding artillery and commissariat horses, and the public who require a horse for ordinary work upon the road will not find any use for such a Hackney. Unquestionably a sensational mover will always command a very high price for exhibition purposes, but when it is remembered how very few such animals there are, and the comparative worthlessness of the light-boned, weedy misfits of which there are so many, it must be acknowledged that the time has come for attaching more importance to substance in the Hackney of the future.

\section{Points of the Hackney}

According to the opinion of the writer, the head of the Hackney should be of a fair size, not heavy or cumbersome, but larger and squarer than that of the blood horse. The ears should be small and set wide apart, and the neck of good length, and powerful but by no means coarse. A short, thick-necked horse finds it difficult to save himself if he should stumble, and besides this he can never carry his head properly when fully extended. The shoulders ought to be of a good length, and lay back towards the withers, for although a straight shoulder is not so great a fault in a harness horse as it is in a hack, it is usually associated with a slowness and clumsiness of action which is most objectionable in a Hackney, whilst a very short, upright-shouldered animal never gets away properly. It is not necessary that the withers should be as high as they are required to be in a riding horse, as there is no saddle to be kept in its place; but the back should be short, level and powerful looking-a narrow back is a great eyesore-whilst the quarters are long and level, and the tail, usually docked short, set on high. The chest should be fairly wide; but a happy medium should be observed here, for if it is too wide the speed of the horse will be decreased, whereas if it is too narrow there is not sufficient room for the heart and lungs. In order to secure the latter demand the horse should be well let down behind the fore-arms and the ribs nicely sprung-a flat-sided Hackney is an abomination! The horse should be nicely coupled, the back ribs deep, and the loins very powerful. Mares should be longer casted than stallions, so as to render them capable of carrying their foals.

\section{Legs and Feet}

The fore-legs should be short and big, with plenty of muscle on the arms, large, well-formed knees, and short, flat cannon bones which measure well, for lightness below the knee is a very serious fault. The pasterns should be of medium length, not long and sloping enough to be weak, but if they are too short and straight they will increase the chances of concussion, and render the horse more liable to fall. The fore-feet ought to be large and round, and they must match in size; a contracted foot or a diseased one is a serious matter in a harness horse, and therefore the condition of the frog and bars should be a matter of concern to a buyer. The hoofs should be quite free from any suspicion of seedy toe, which often attacks a high stepper as a result of concussion. It is perhaps unnecessary to add that the feet should be set on straight, and not point inwards or outwards at the toes, though many good Hackneys of the past, including the sensational trotter Phenomenon, whose achievements we have recorded, displayed the latter fault. The hind-legs should show a good length from the stifles to the hocks, the latter being of a good size and clean.

\section{The Hocks}

Capped hocks are most unsightly, though not necessarily a proof of unsoundness. The hocks should not turn in or out, thougl some horses which are sent along faster than is natural to them move very wide 


\section{THE HACKNEY}

behind; they should not be set too far back, for if they fail to come sufficiently under the horse they are unable to sustain the weight of his body properly, and do not afford him the proper amount of propelling power. In short, sickle hocks of this description not merely detract from the appearance of a Hackney, but are a source of weakness and affect his power of drawing a conveyance. The hocks should be well let down, and the hind-legs well proportioned, the feet, of course, being longer than those in front.

With regard to the question of height, regret may here be expressed that less attention appears to be paid of late to the production of the $\mathrm{I}_{5}$ hand Hackney. The Cob, in fact, is being steadily merged into the horse on one side, and the pony on the other, and unless encouragement is forthcoming the sturdy little race of fineactioned weight carriers, for which no day was too long and few tasks too heavy, will become extinct. When this fate overtakes them the gravity of the mistake that has been committed will be recognised, with which opinion those who remember such great little horses of the past as Evolution, General Gordon, Winnal Fireaway, Cicely, Clarionet, Polonius, Lady Ulrica, and many others, will probably concur.

\section{Hackneys of the Past}

The names of the above very famous Cobs suggest the probability that a reference to some of the most prominent Hackneys of the past may be of interest to those interested in the breed at the present time. Of the original Shales there is not very much known, as may be supposed; indeed, there are two different sires assigned to him, one being Lord Godolphin's Blank, by the Godolphin Arabian out of the Little Hartley mare, which was full of Barb and Arab blood; the other being, as stated at the beginning of this article, Blaze by Flying Childers by the Darley Arabian. There is contemporary proof, however, that the latter is the correct pedigree, but the matter is not one of much moment to modern Hackney breeders, as in either case it is made evident that Shales went back to the Darley Arabian, whilst it may be added that by general consent he came out of " a strong, common-bred mare." His illustrious son Scot Shales, whose dam was a well-bred hunter, probably a halfbred, was foaled in $\mathbf{r} 762$, and was successively owned by one Thomas Jenkin, of Long Sutton, Lincolnshire, for whom he served at a one-guinea fee, and by a Mr. Saffery, of Downham Market, Norfolk. Old Shales's other famous son, Driver, foaled 1765 , who was reported to have been a very speedy horse, and to have trotted fifteen miles in the hour, carrying I5 stone, left behind him Fireaway, bred and owned by T. Jenkinson, of Long Sutton, who must not be confounded with the owner of Scot Shales, though their names are very similar, and place of residence the same. This bright chestnut horse is stated to have served in London, Norfolk, and elsewhere, at a fee of five guineas, and to have been sold for I,000 guineas, at which price he does not appear to have been dear, for the chronicles of his period state that he could trot two miles in five minutes. His son, Wroot's Pretender, was a black, and was foaled in $\mathrm{I} 788$; we have already alluded to his close inbreeding on the dam's side. He served in Norfolk, Lincolnshire, and Yorkshire, and when put up for sale by auction in 1806 , it was stated that in three seasons he had earned over $£ 760$ in stud fees, and that he had won a two hundred guineas match against a horse called Atlas, upon which occasion he trotted sixteen miles in the hour, carrying I6 stone. This horse in turn was the sire of Stevens's 15 liands 2 inches bav, Bellfounder, who was the sire of Jary's Bellfounder, a bay which stond I5 hands; his dam Velocity, a Yorkshire mare, is reported to have been one of the speediest trotting mares of her day. Bellfounder, however, was sold in Norfolk, and was exported to America in July, IS22, by Mr. James Booth, of Boston, who purchased him, it is said, at Winnold Fair. held at Downham Market, for $f_{3} 00$. The following is a description of this horse, by an American admirer: "A small head, full prominent eyes, and wide apart; neck medium length, set well from the withers; 
shoulders deep and oblique; deep girth and full chested; fore-legs well apart (not wide) ; short back, round ribbed, and very broad on the loin; hips wide and well gathered in ; long, full quarters to hocks, and short to fetlocks; limbs strong and well muscled, broad and flat below the knees and hocks;

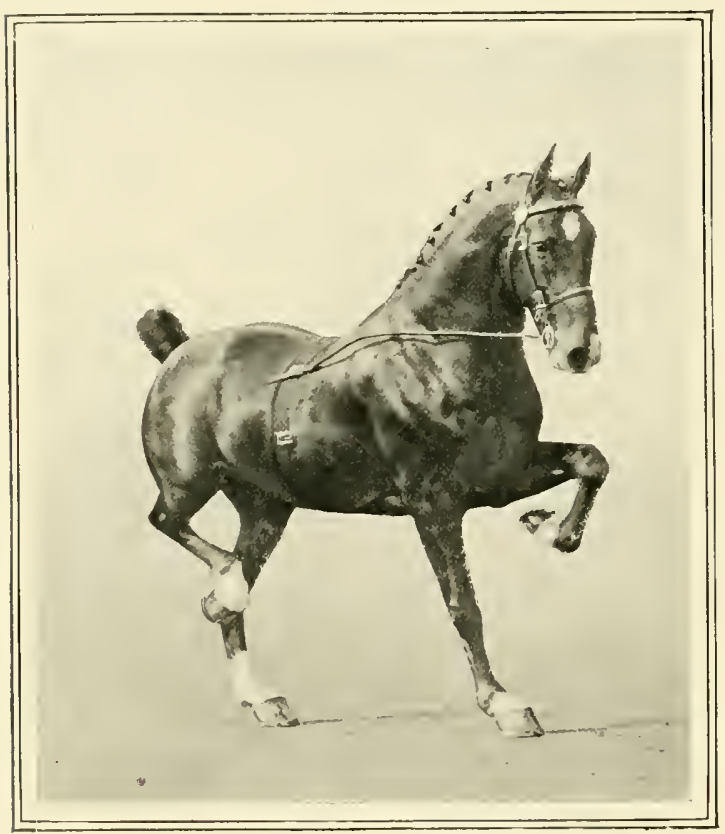

THE HACKNEY, EVANTHUS.

Photorrath by II: A. Rowch

pasterns rather short; concave hoofs and open heels; tail and mane full haired; had a large star on forehead, with a diamond shape on end of nose or lip ; one hind pastern white, and a little white on the opposite heel." His knee action was likewise described as very attractive and high, whilst an additional recommendation for him as a trotting sire was that he never got off his feet no matter how much he was pressed.

Scot Shales's two most famous sons were Hue and Cry-whose record was a mile well inside three minutes, and described as a bright bay with a little white about him, and standing about 15 hands 2 inches-and
Thistleton's Shales-a dark chestnut, who broke his back in the year I 820 at Wisbeach, when he was thirty-four years old, leaving behind him, amongst other sons and daughters, the famous Marshland Shales. whose dam was a granddaughter of Scot Shales. This was another chestnut, and his height was 15 hands, though some authorities state that he was only $I_{4}$ hands 3 inches. He was fraled in I 802 , and was disposed of as a yearling for twelve guineas, but in addition to proving himself a great sire, he was a very speedy horse; his best performance was trotting seventeen miles on the Lynn Road with I2 st. $2 \mathrm{lb}$. in the saddle. The name of Mlarshland Shales is to be found in many a modern pedigree, which is not surprising, as at one time or another he served in Lincolnshire, Norfolk, Suffolk, Essex, Cambridgeshire and London. Burgess's Fireaway was a grandson of Jenkinson's Fireaway, and was a 15 hands chestnut roan foaled in I8I5. At three years old he sired Norfolk Cob, who came out of a Marshland Shales mare, and in turn sired the great Norfolk Phenomenon. Norfolk Cob was a bay with black points, standing 15 hands I inch, and up to 20 stones, and is referred to as wonderfully good looking, and an extraordinary walker; when close on twenty years old he was exported to th: West Indies by his owner, Sir W. Codrington. His son, The Norfolk Phenomenon, was foaled in 1824 , and was a red roan with dark points, standing $\mathrm{I}_{5}$ hands 2 inches. His breeder was Mr. John Bond, of Cawston, Norfolk. He is described as a big-boned, short-legged horse, with first-rate legs and feet, and wonderful action. After serving for some years in Norfolk, Cambridgeshire, and Lincolnshire, he was purchased by 
Mr. Robert Ramsdale, of Market Weighton, and so found his way to Yorkshire, where he earned a great reputation as a coaching sire. He eventually died in Edinburgh.

\section{Lund's Merrylegs}

The last of the old Hackney stallions to be noticed here is Lund's Merrylegs, a dark chestnut, standing 15 hands 2 inches, who was bred by Mr. II. Lund, of Bielby, Vorkshire, in I830. On his sire's side he was a grands in of Wroot's Pretender, and on that of his dam by Sportsman, but which horse of that name it was is not recorded, excepting that he was bred by Captain Erle, of Beningbrough Hall, Sork. The mare, however, had earned a great reputation for herself, and when twenty-two years old she covered two miles two hundred and ninety yards in five minutes forty-eight seconds.

\section{Recent Celebrated Stallions}

Concerning the most successful stallions of the last generation, there is a very great deal that could be written did space permit, but though all cannot be noticed, a few words may be devoted to some of the most prominent winners at the Hackney Society's shows, the first of which was held in $\mathrm{I} 885$. At this Lord Derby II. was successful in his class, but he failed to gain the championship, which fell to Reality, by D'Oyley's Confidence, a Suffolk-bred horse, who repeated the victory at two other of the first four shows. At the second show the championship fell to the chestnut Confidence, bred in Yorkshire, whose sire was Denmark and his dam Poll III., the dam of old Empress, herself a great brood mare, which strained back to all the best horses of the past. Candidate was of a more rangy type than Reality, and he proved himself a successful sire; amongst his stock was the very breedy looking M.P., a dark chestnut out of Franchise, who distinguished himself by winning the championship twice.

The fifth show brought the Norfolk-bred chestnut Rufus to the fore, and he repeated his victory twelve months later; his sire, Vigorous, was placed reserve to him upon the first occasion. In the opinion of the writer, Rufus, who was got by Vigorous, when the latter was only two years old, out of the eighteen year old Ladv Kitty by Quicksilver (Jackson's), out of a thoroughbred mare, is entitled to the honour of being regarded as the best Hackney of modern times, for although his sire, Vigorous, was under $I_{5}$ hands 2 inches, he was a great strapping horse, brimful of Hackney character, and as perfect an all-round mover as man could wish to see. He was sold to go to Yorkshire, where he unfortunately died, not long after his second victory in London : but he lived long enough to leave some excellent stock behind him, including Cicely, the three year ofd filly which won the mare championship of the minth show, and Hedon Squire, the champion stallion of the twelfth. The next champion, Connaught, afforded another evidence of the value of the Denmark cross upon Fireaway mares, as he was bred that way, and then came the turn of another Norfolk horse, namely, M.P., and a very lucky horse he was. Then the star of Yorkshire again arose, the winner for two successive shows being the chestnut Ganymede, by the Denmark horse Danegelt. At the twelfth show, Hedon Squire was regarded by many as being lucky when he was placed over a number of first-rate horses, including Connaught and Rosador, for the championship, but the last-named great horse was rewarded by victories in the next two years, and concluded his triumphant show career by winning the honour again in I907.

Of Rosador, it may conscientiously be said that he has accomplished what no other Hackney stallion ever has, for although the feat of winning the championslip of the London show three times was equalled by Reality, Rosador has proved limself the most valuable sire of the day. As the sire of colts he has not shone to such adrantage as he has done as a sire of fillies, his successes in that direction having been simply wonderful; his daughters have won the mare championship for several years past, whilst his stock have invariably done well in the competition for groups of three Hackneys sired by the same horse. 


\section{CHAPTER XXI}

\section{THE HACKNEY PONY}

$\mathrm{T}$ HE Hackney Pony, which is quite a modern creation, is not by any means an easy animal to deal with in an article, as no one seems to know exactly whence he came, and leading authorities are bitterly at variance regarding the respective merits of some of the most successful specimens of the race. Of quite recent years, however, the breed has become firmly established, and hence the pedigrees of all the leading ponies of the day are well known, whilst the task of breeders has become simplified by the existence of records, such as the Stud Book of the Hackney Horse Society and the catalogues of the most important shows, which provide more useful assistance in working out their crosses.

It was, however, a very different matter five-and-twenty years ago, or thereabouts, when this class of pony began to assert its existence, as in those days the very best of the little horses were more or less goodlooking, fine actioned nondescripts, concerning whose breeding there was very little known beyond that they were sired by a Hackney stallion.

\section{Pony Character}

There still remains, morenver, a very serious difficulty for breeders to face, namely the ambiguity which exists regarding the definition of the word "pony." Jexicographers, of cuurse, inform us that a pony is a small horse, but this is exactly what those interested in his production declare that he is not. There is a mysterious attribute known as pony character, which must be possessed by any animal classed as a pony, and lacking this he cannot properly be included in the family at all. In short, a small horse need not necessarily be a pony, though a pony must be a small horse, in which sense the compilers of the dictionaries are correct, though they fall short of adding the saving clause " possessed of pony character." They would, however, be very clever men if they could define this to the satisfaction of the public. Pony character, in fact, is an almost indescribable attribute of miniature horseflesh, but to pony judges it is perceptible enough, though they may find it very difficult to explain what it is. It is a general tout ensemble which embodies facial expression, carriage, and character, with smallness of stature, and an indomitable spirit, which all true ponies possess to an extent quite out of proportion to the size of their bodies. A real lover of ponies will recognise pony character intuitively when he sees it, whilst the man who is not similarly gifted will, to the end of his days, be unable to distinguish an undersized horse from a real pony.

It is obvious, therefore, that the paths of those who set out to judge Hackney Ponies, having only an experience of the larger horses, are beset by many difficulties. Hence the very remarkable reversals of previous decisions which are provided at different shows, as it not infrequently occurs that a cup winner under one set of judges may be passed unnoticed a few days afterwards by another set, on the ground that he is deficient in pony character-which he very often is.

\section{Hackney Sires}

The Hackney stallion is undoubtedly the basis of this breed of ponies, and it is from him that the little horses have derived that action which has rendered them so attractive to the public, and has resulted in such high prices being secured for the best specimens.

Conspicuous among the sires who assisted in building up this race of Hacliney Ponies was D'Oyley's Confidence, a I5 hands 2 


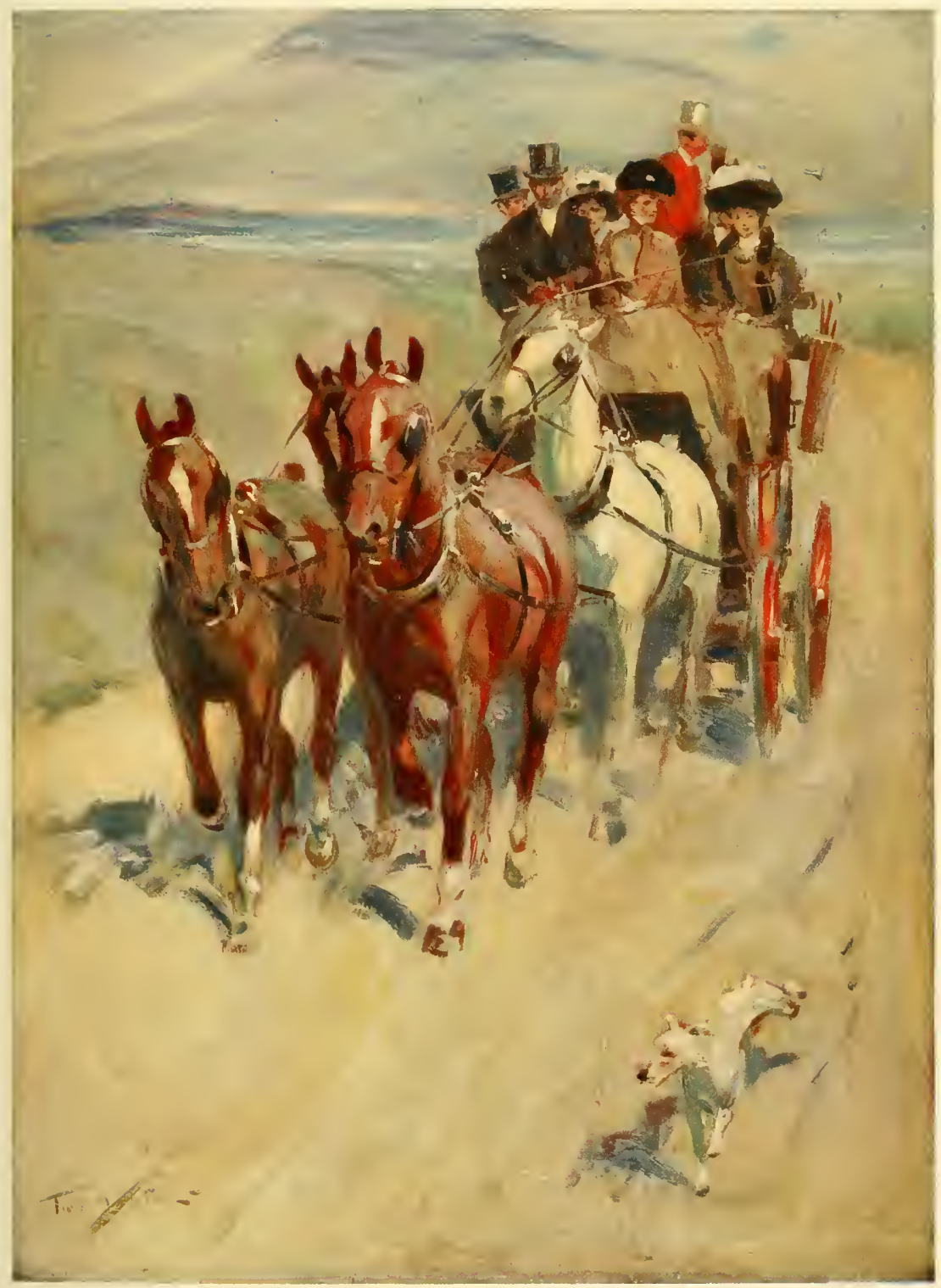

ON THE ROAD.

From the painting by $F$. Whiting. 

inches black brown, by Tice's Prickwillow, a great grandson on his sire's side of Norfolk Phenomenon, and on his dam's, of Brigham's Pretender, who was a son of Ramsdale's Performer, in addition to which he possessed a double cross of Jary's Bellfounder, the horse referred to in the Hackney article as having accomplished great things in America in the way of building up the Trotter. Confidence, however, was by no means the only full-sized Hackney that claimed the credit of contributing to the production of the pony, as amongst others who shared the honours with him were Cadet, by Lord Derby 1I., dam Princess, a London champion, and by Denmark, out of a Fireaway mare, whose son, Cassius, out of Belle, a Confidence mare, proved himself to be one of the most successful and impressive of pony sires. With such blood behind him as Lord Derby II., Denmark, Fireaway, and Confidence, it would be impossible to imagine a better local Hackney than Cassius, and as he came within the pony limit, probably owing to his Confidence lineage, it is not surprising that his services were in great demand.

\section{Pony Sires}

In addition to the horses named above, some remarkably impressive ponies were affording valuable co-operation in the good work of producing the miniature Hackney possessed of pony character. Included in the earliest category of these were such famous little sires as Tuck's Model by Little Wonder, and last, but by no means least, by Mr. Christopher W. Wilson's remarkable Yorkshire pony by Sportsman Harts, by Prickwillow Weatherhills, a grandsire of Ramsdale's Phenomenon. Sir George

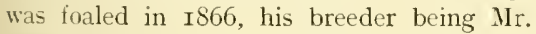
William Walker, of Shadwell, Leeds. He was a brown, standing well under It hands, and an extraordinarily good-looking pony, as may be imagined when it is stated that he was placed first at the Royal Agricultural Society's show eight years in succession.

\section{Sir George as a Sire}

But his claims upon the gratitude of posterity are based upon the fact that, on being selected by Mr. Wilson as the basis of a very close system of inbreeding, Sir George laid the foundation of a line of Hackney Pony mares the like of which had never been seen before. The method pursued by Mr. Wilson was to breed sire to daughter for several successive generations, so as to reduce the size of the foals, and to impress upon them as strongly as possible the action of their sire, which in the case of a mover like Sir George was something quite exceptional. As a further means to keep down size, and also with a view to ensure the survival of the fittest from a constitutional point of view, Mr. Wilson was in the habit of turning out the young ones on very poor land, so that there was no encouragement, in the way of over-feeding, for them to grow, whilst the weakly ones died off.

\section{Snorer's Romance}

This system proved most successful, and the first of a long line of magnificent little mares was the bay Snorer, by Sir George, out of a pony mare named The Pet. Snorer's name was the result of a peculiar noise she made when trotting; probably it was due to some malformation of the nostrils, as she was certainly not affected in her wind in any way. Moreover, she was the heroine of a mild sensation in her very early youth, for being a very puny and weakly foal, orders were issued that she should be destroyed. Mr. Wilson's stud groom, Moffatt, however, determined to try and save her if possible unknown to her owner, so Snorer was taken to his house, where, thanks to assiduous attention, her life was saved, to the great surprise and delight of her owner, who imagined that she was dead. Snorer in time threw Snorer II., another most successful pony of her day, to her own sire Sir George, and the excellence of this filly quite convinced Mr. Wilson that his views upon the subject of close inbreeding and subsequent treatment were correct.

Another conspicuous instance of a magnificent little mare was Mr. Willian Pope's piebald Magpie, by Confidence. Magpie 


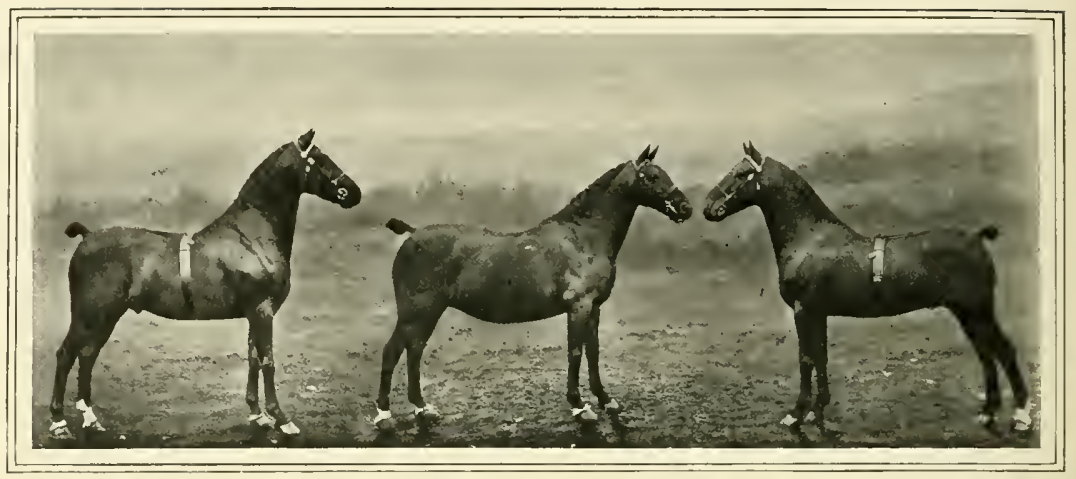

A GROUP OF HACKNEY PONIES, MARE, BERKELEY LILY IN CENTRE, AND HER SUNS (ON LEFT) TALKE WILDFIRE, (ON RIGHT) TALKE FIRE KING

unfortunately made no name for herself at the stud, but her merits may be gauged by the fact that she won over four hundred first prizes, including ten successive victories at the Royal, during her show career, and was, in addition, a perfect lady's hack.

Returning to the subject of the leading pony stallions of the early days, mention may be made of Winnal George, also known as Disappointment, a bay son of Sir George and Lady Polo by Sir George, who was bred by Mr. C. W. Wilson in 1878 , and who, in addition to winning several important prizes, left behind him some excellent pony stock. A still earlier foaled stallion was Lord Calthorpe's brown Don Carlos, by Prickwillow, the sire of D'Oyley's Confidence, out of Corinna, who was stated to have been a Welsh-bred mare. Don Carlos was a most beautiful pony, and was good enough to win premier honours at the first show of the Hackney Society, in spite of the fact that he was seventeen years old when it was held. Another capital pony, but of quite a different type from Don Carlos -as he showed a great deal more substance and less quality — was the bay Pick Up, by Tuck's Mlodel, who won as a five-year-old at the Hackney Society's Show in I886. He was a Norfolk-bred pony, and won again in I888, after which lie dropped out of the Hackney world, as he was sent into Hampshire to cross with New Forest ponies.

In the year 1887 , a very smart pony, and a most successful sire, was to the fore, in Pomfret Wonder, by Little Wonder, a famous son of D'Oyley's Confidence and a Welsh mare, the dam of Pomfret Wonder being by Sir George, and it may be added that he was a black, bred by Mr. Wright, of Doncaster, in I88I. Another extremely good-looking black stallion was Lord Nimrod, who took first prize in $\mathrm{I} 890$. He was a Norfolk-bred son of Dr. Syntax by D'Oyley's Confidence, who traced back on the dam's side to Jary's Bellfounder. As Lord Nimrod was bought by Mr. Burdett Coutts for 400 guineas at the show, he was provided with excellent opportunities for proving his value as a sire, and of these he availed himself well, whilst he further rewarded his purchaser by winning first prize at the Hackney Society's Show of I893. In the following year the highest position in the pony section of that show was awarded to a little horse which was destined to accomplish much as a Hackney Pony sire. This was the brown Berkeley Model, by Monarch, a son of Confidence, dam Peggy Sure, by Tuck's Model, whilst it may be further observed of him that he was bred in Norfolk in 1889 , and subsequently became a prominent member of Mr. A. S. Day's stud at Crewe.

The above were all undoubtedly most excellent Hackney sires, and each contributed in no small degree towards the good work of building up the breed; but there was yet to arrive upon the scene a little stallion which 
was destined to accomplish more for the race than any horse which had preceded him, unless it be Sir George, whose opportunities were far fewer. The pony in question was Sir Horace, who was foaled in $189 \mathrm{r}$, his sire being Little Wonder II., a brown, bred in $188_{3}$ by Mr. C. W. Wilson, and by Little Wonder, out of Snorer, by Sir George. Sir Horace's dam was the famous Dorothy Derby, by Lord Derby II., dam of Ware, br Danegelt, and he was bred by Mr. C. WV. Vilson. Sir Horace's first victory at the Hackney Society's Show was in I8g6, the performance being repeated upon seven subsequent occasions, whilst he has sired more pony winners during recent years than any other horse-either of the past or present-has produced in the whole of his career.

With the advent of Sir Horace it may be said that the type of the Hackney Pony has become fixed, as there has never existed a more impressive sire, great or small. In addition to stamping the strong family resemblance on all his stock, Sir Horace- who, for many years past, has belonged to Sir Gilbert Greenall-possesses a most invaluable faculty of imparting to his progeny the sensational action which he has himself inherited from his illustrious parents.

Meanwhile, whilst the Hackney Pony stallions were steadily improving as a body, a very satisfactory advance was also being made by the mares. At the outset breeders found themselves immensely hampered in their operations by the existing dearth of desirable dams, as most of the animals forthcoming which were good-looking enough to breed from, were either too large in size, or else so deficient in action that it was hopeless to expect satisfactory results from them. Nor was the difficulty in any way reduced by the fact that even the available stallions were either full-sized Hackneys, or else bred from such, there being, of course, a serious risk of throw-backs in the latter case. After a while the stallion difficulty began to be overcome, as experience taught breeders which horses and ponies were the most likely to get small stock, but the

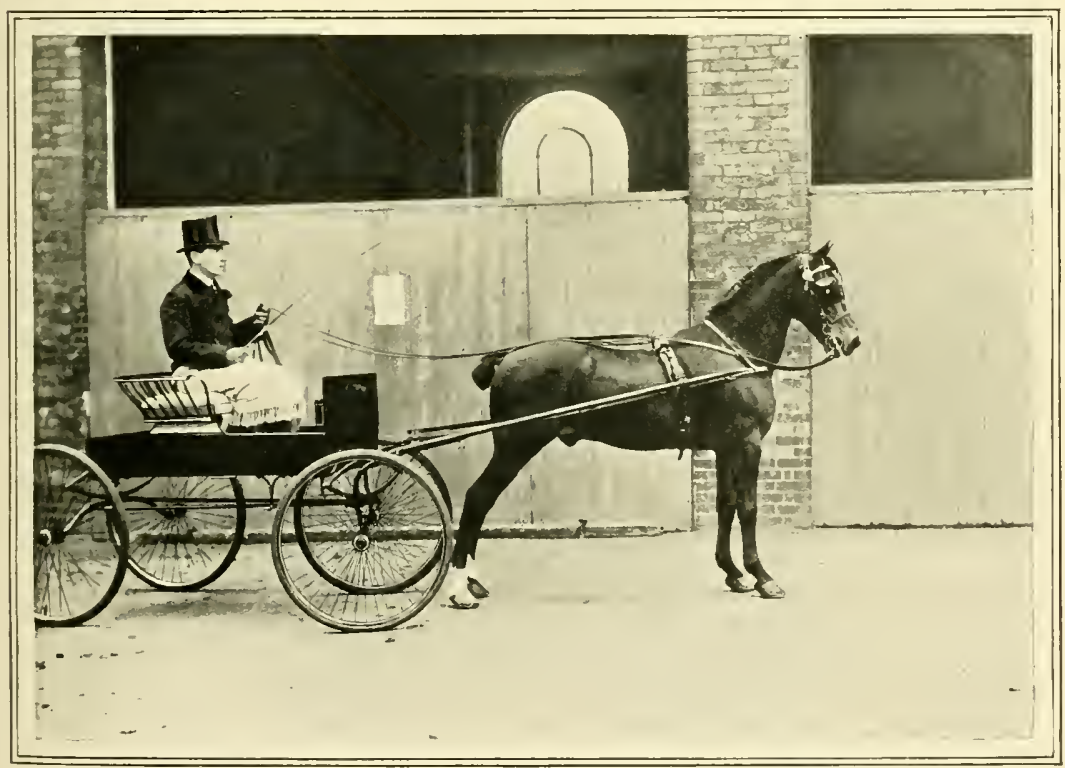

TEN.YEAR.OLD HACKNEY PONY GELDING, MEL VALLEY'S MASTER. 
paucity of desirable pony mares continued to exist. In time a supply of some sort -good, bad, or indifferent-was received from Wales, but as in those remote days the pedigrees of Welsh ponies were very badly kept, there was always a considerable uncertainty as to what sized stock a pony mare would throw, even though she was quite a small animal herself. Thanks, however, to the fortunate discovery that the stock of a stallion called Eidwen Flyer usually threw undersized foals, the position became better, and the daughters of this sire were soon in considerable request for the purpose of providing foundation stock. There was some controversy regarding the breeding of Eidwen Flyer, but there is no doubt that his breeding was Hackney, and hence the fillies got by him were bred the right way so far as the wants of the English pony breeders were concerned. Moreover, the success of Mr. C. W. Wilson's operations supplied some extremely valuable information, and many persons indulged in a quiet course of inbreeding without the knowledge of their friends, and thereby enjoyed a considerable start over the latter.

\section{Celebrated Mares}

The result of all that was going on was the production of a large number of very useful pony mares within the course of a few years, and naturally these contributed in no small measure to an increase in numbers of the Hackney Pony. Nevertheless, the most successful prize-winners were either bred, more or less by accident, from fullsized Hackneys, or from Mr. Wilson's Sir George's strain, and the latter, it may be added, alnıost invariably threw small stock.

Amongst the many good show mares of the earlier days, the majority of which have contributed to the excellence of the modern Hackney Pony, may be mentioned Snorer (already referred to), and her scarcely less famous daughter Snorer II. The latter was bred by Mr. Wilson in 1887 , her sire being also her dam's sire-Sir George-and she in her day was a noted prize-winner, and also bred some remarkably good stock. Another excellent little mare, Norfolk Model, was foaled in the same year as Snorer II., and this bay was likewise a beautifully bred one, as she was by Tuck's Model, dam by Little Wonder. The year 1887 , in slort, appears to have been prolific in high-class pony mares, as in it was also foaled the beautiful Dorothy Derby, to whom reference has already been made as the dam of Sir Gilbert Greenall's Sir Horace. This mare also threw a marvellously good bay filly, in Dorothy Derby II., to Little Wonder II., she being a full sister to Sir Horace, and, as will be seen presently in the remarks concerning the sensational sale of Sir Humphrey de Trafford's Hackney Ponies, she realised the great price of 700 guineas under the hammer. As a matter of fact the Snorer and Dorothy Derby blood monopolised the lion's share of the prizes at the Hackney Horse Society's shows a few years ago, and the value of the Wilson blood increased proportionately.

\section{Sir H. de Trafford's Sale}

At this point a reference may be made to the sensational prices received by Sir Humphrey de Trafford when he broke up the stud of Hackney Ponies which he had got together at Flordon, Norfolk, in I895. It is quite unnecessary to refer to all the animals disposed of upon the occasion, and therefore only the best prices are recorded. These should prove instructive, as proving the value of Mr. Wilson's theories in connection with pony breeding, and they likewise show the worth of first-rate Hackney Pony blood. The following were the principal lots disposed of :

Snorer II., I3 hands 3 inches, 8 years, by Sir George, out of Snorer, by Sir George, 600 guineas.

Georgina V., It hands, 6 years, by Sir George, out of Georgina II., by Sir George out of Georgina, by Sir George, 700 guineas.

Dorothy Derby, If hands, 8 years, by Lord Derby II., 600 guineas.

Dorothy Derby II., if hands, 6 years, by Little Wonder II., out of Dorothy Derby, 720 guineas.

Snorer III., bay filly, 2 years, by Cassius, out of Snorer II., 700 guineas. 


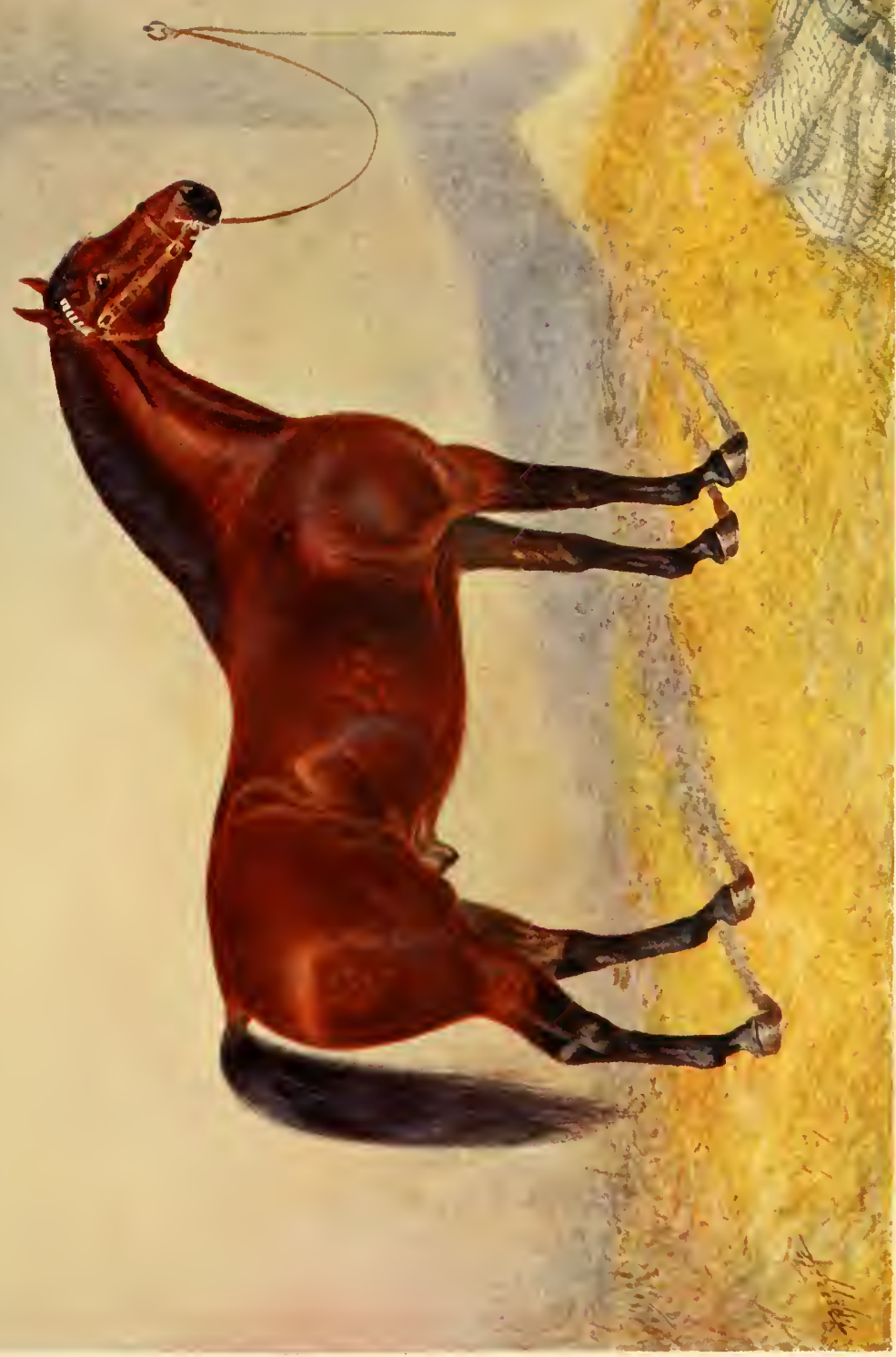

2.

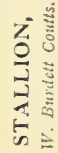

急

दे है

3

究 



\section{THE HACKNEY PONY}

Miss Sniff, bay yearling filly, by Cassius, out of Snorer II., goo guineas.

Such prices, needless to say, created a sensation in the horse world at the time, and doubtless encouraged many persons to embark in the undertaking of breeding Hackney Ponies, as the average of $£ 75^{6}$ for six mares, one of which was a two-year-old and another a yearling, must be accepted as approaching a record outside thoroughbred circles. It is not probable, therefore, that the tigures of Sir Humphrey de Trafford's sale will be repeated, but nevertheless the statement may be made with easy confidence that at the present time the Hackney Pony is as much in demand as any other breed of horse.

\section{Prices for Harness Ponies}

No doubt their qualifications as harness animals have accomplished much in the way of popularising these ponies, as the ring-side at every important show is always crowded whilst they are being judged. Some very high prices have also been realised by eligible Hackney harness ponies from time to time. It is generally believed that $f_{5} 5.000$ was the sum paid by Mr. Alfred G. Vanderbilt to, Mr. William Foster, of IIoseley, Warwickshire, for his extraordinary team of four bays which won the championships at the International Horse Show of Ino8. The sum, of course, included the miniature coach and harness, but even then the transaction must be accepted as constituting a record price for Hackney Ponies. The team in question consisted of Mel Valley's Wonder, + years, $I_{3}$ hands 2 inches; Ilel Valley's Wonderful, I3 hands 3 inches, both geldings by Whitegate Swell, by Cassius, dam Sarah Bernhardt, by Don Carlos; Wel Valley's Wonderful's dam was also by Cassius, so that he was closely inbred to Cadet, than which. as his breeding shows, no better bred Hackney has ever existed. The remaining members of the team were Ilel Valley's Wondrous, I3 hands 2 inches, by Sir Horace; and Mel Valley's Wonderland, I3 hands 2 inches, by Goldstone.

Another very famous Hackney harness pony of recent days was the brown Tissing- ton Kit Cat, by Sir Horace, dam Lady Kate, by Sir George; and most favourable notice may also be made of Westerham Pick 'Em Up, by Polonius, who was a very pretty gelding and a most brilliant mover. Admiration can likewise be expressed regarding the superb action and adherence to type displayed by Messrs. W. and F. Ferguson's District Sensation, a roan gelding, by Sir Horace, dam Dignity II., by Roan Danegelt, and Mr. William Foster's brown mare Tissington Belief, by Tissington Horace, dam Tissington Belle, by Sir Baldie, who fought out the battle for the pony championships in harness at the Igog show of the Hackney Horse Society.

\section{Colour}

Before concluding, attention may be directed to the fact that although they are in almost every instance directly descended in tail male from large-sized Hackney stallions, the vast majority of the Hackney Ponies which appear in public are either bays or browns. Chestnuts are rarely seen, but there are a few roans and greys to be met with occasionally. It is an exceedingly difficult matter to account for this condition of affairs; indeed, it appears a hopeless task to attempt to do so, in the face of the combined facts that some eighty per cent. of the large-sized Hackneys that are exhibited are chestnuts, and that the number of animals of this colour is steadily increasing. The adherence of the ponies to the bay and brown shade of coat is indeed most remarkable.

\section{"What is Pony Character?"}

Finally the opinion may be expressed that, great as the position of the Hackney Pony is at present, he has not by any means reached the zenith of his popularity with the public. His claims upon the latter are based upon the fact that he is as a rule an exceptionally fine mover, docile, handsome and extremely hardy. He costs but little to keep, and is always - provided that he is a pony and not a sinall horse-prepared to set to work just when many a big horse is beginning to shut up. This brings us back 
once more to the point where we began, namely, the existence of that indescribable something known as "pony character." Without possessing this it may be repeated that no animal can properly be called a pony, nor is he likely to behave as one. $\mathrm{He}$ will lack the strenuousness and spirit of determination which is so essentially characteristic of the pony, no matter to what breed he belongs, and he may in consequence be regarded as falling very considerably short of the high level of pony perfection. When the public begin to appreciate the value of pony character at its proper worth-as they cannot fail to do, even if they may not recognise it at first--as their associations with the race become closer, the popularity of the dwarf Hackney will assuredly subside, and the true pony will reign supreme. Action, of course, will always be a matter of the very greatest importance, but the existence of such ponies as those alluded to, and miny others which exigencies of space render it impossible to mention, prove that a magnificent goer can include character amongst his other excellent points. In other respects, the Hackney Pony is similar in his formation to the larger type, and therefore the suggestion given in the Hackney chapter for judging the latter may be applied to him.

\section{Hints to Breeders}

There still remains, however, an ever present danger of an excellent young pony growing beyond the limit of heightIf hands 2 inches - which is prescribed by the comcil of the Hackney Society as the maximum. This danger is not merely a result of an inherent liability to throw back to the larger horse, which is likely to be present for many years yet to come, but it is liable to be increased by the high feeding, good housing, and, generally speaking, luxurious lives which the best specimens enjoy: Consequently, Mr. C. W. Wilson's example should be imitated by those who have charge of the young stock; the latter must be turned out on poor land, and generally experience a hard time of it if they appear likely to grow too big. This course may appear a relentless one to adopt, but the laws of nature bear no contradiction, therefore a course of high feeding must infallibly lead to an increase of size. More especially must this be so where animals which descend from large horses are concerned, and therefore three golden rules may be suggested for the instruction of would-be Hackney Pony breeders. These are :-

I. Do not overlook the satisfactory results which can be derived from a judicious course of inbreeding.

2. Arrange that the foals are dropped late, in order that they and their dams do not enjoy all the best of the grass, as the better the keep the bigger the foal.

3. When foals are weaned put them on poor land, and do not over pamper them by warm housing.

If these rules are attended to size will be kept down; and although a few foals may be lost, they will be those of weak constitution, which, had they grown up, would always have been a source of anxiety to their owner, and no doubt the cause of a delicacy of constitution amongst their stock. All the best of the ponies which have made the history of their race have been reared under a rigorous course of treatment, and hence their hardiness and also that of their descendants. Should the time ever arrive when the latter are indulged with luxuries, not merely will size commence to go up, but the hardiness of the Hackney Pony will be seriously impaired. 


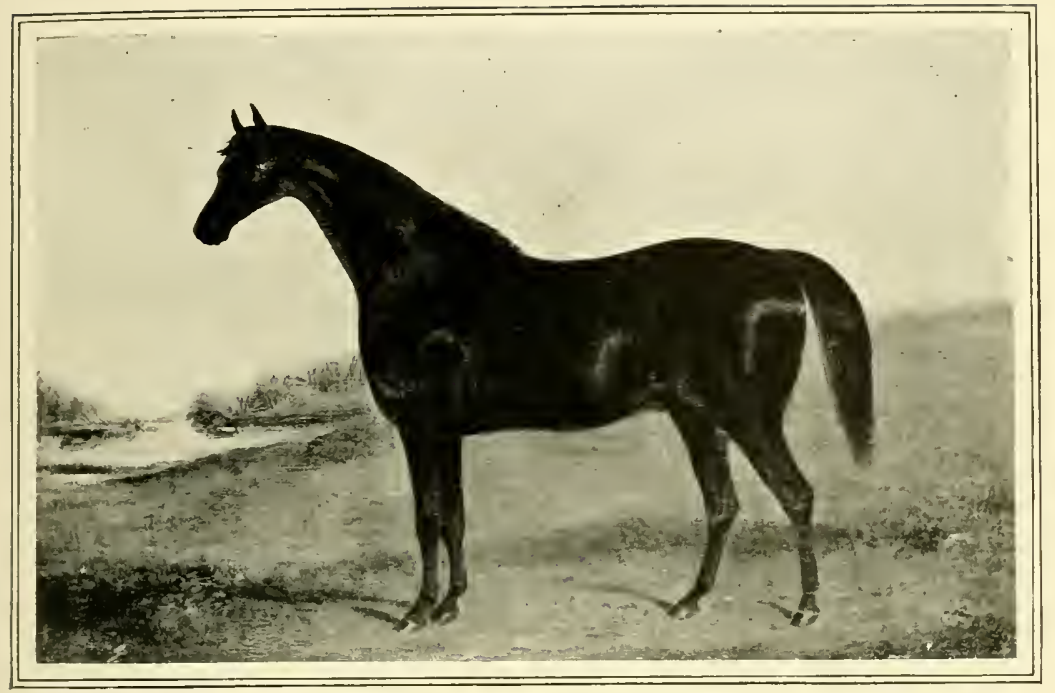

CLEVELAND BAY STALLION, ROSEBERRY.

From an old painting in the possession of $M r . F . G$. C. Dobson, Stokesley.

\section{CHAPTER XXII}

\section{THE CLEVELAND BAY}

$\mathrm{T}$ THE historian of the Cleveland Bay, when he sees the vast mass of valuable information which has been gathered together respecting the thoroughbred, cannot help regretting that so little has been done to preserve the early history of a breed which is possibly older than the modern English race-horse. For the Cleveland Bay had undoubtedly a great influence on the national life, and the history of his early development, which is so lamentably deficient, would have been likely to afford some good lessons in the science of breeding.

As it is, nothing is known but what may be described as "broad outlines" ; but happily those broad outlines are clearly defined and capable of proof.

In $188_{4}$, the present writer, in the Introduction to the first volume of the "Cleveland Bay Stud Book," advanced the theory that the Cleveland Bay was descended from the horses of ancient Britain; the horses which drew the war chariots of the Iceni and other prominent British tribes, and which cast confusion into the legions of Cresar. The theory was passed by with the remark that at any rate no one could say it was not correct.

But during the last twenty-four years much light has been thrown upon the early history and prehistoric annals of horses, and what was practically a theory formed from historic probabilities is now an established scientific fact. Professor Cossar Ewart, whose researches on many subjects connected with horses and horse-breeding have been of inestimable benefit, points out that it is at any rate highly probable that as there were several species of wild dogs in prehistoric times, so there were several species of wild horses. Darwin held that the 
domestic horse was descended from a duncoloured horse with a dorsal stripe. Cossar Ewart points out that if this were the case "crossing members of the different breeds ought sooner or later to result in duncoloured striped offspring." But this, he goes on to tell us, never happens unless one or other of the parents or grandparents is din-coloured and striped.

\section{The Forest Horse}

It would certainly seem, in the light of modern investigations, that the horses of the present day had not one common origin, but that they have improved and developed from several originally wild species. Of these the forest horse is regarded by Professor Cossar Ewart as the original foundation of the Cleveland Bay. What he has to say abont the forest horse is worth a moment's consideration: "A typical forest horse, like a steppe horse, is of a dark yellow dun colour with black points, but in the forest variety the vellow tends to become hight brown or bay rather than red-hence, whilst intensification of the colour of a steppe horse would probably result in a chestnut, a like change in the forest horse would be more likely to produce a bay. Unlike the steppe horse, the forest horse has many zebra-like stripes. There are frequently stripes on the face, neck, and shoulders; along the back runs a dorsal band which has a width of over two inches as it crosses the croup, and at right angles to this 'eel mark' or 'list' remnants of cross stripes are sometimes present as far as the flank feather, beyond which in some cases there are rows of spots. Bars, often as distinct as in zebras, are frequent on the fore-arm; sometimes they extend below the knee, and are well marked above and below the hock."

These markings are very similar to the "black points" which were at one time a distinguishing feature of Cleveland Bays, and which were appealed to as an infallible sign that they were of pure descent. Later on the writer will have something further to say respecting these "black points."

It is not worth while entering into any details respecting the conformation of the forest horse. The conformation of the horse has undergone such great changes since the days when he roamed at will in unpopulated wastes, that no practical benefit could result from any comparison between him and his successor as exemplified in the modem Cleveland Bay. But the colour is decidedly of interest. It unly remains to add that the forest type was very widely distributed, and was in all probability found in great numbers in this island.

\section{The Steppe Horse}

But another of the old "wild species" had something to do with the formation of the Cleveland Bay breed as well as the forest horse. This is the steppe horse, from which our thoroughbred is descended. The combination of the two made something from which the Cleveland Bay may be said to trace direct descent.

A theory as to the origin of the breed which seems to be a feasible one is that there was in Britain a breed of horses descended from the old forest horses, improved by such means of special selection as the Britons were capable of, which was probably much greater than we are at present disposed to admit; and further improved by the introduction of Barbs some time before Cæsar's invasion.

\section{Introduction of the Barb}

It has been held by recent writers that the story of Carthaginian merchants trading with Cornwall and Devonshire for the 200 years before the Christian era is a myth, but whether the Barb was introduced by Carthaginian merchants - which is likely enough if they ever did trade with Britain-there is the strongest presumptive evidence that the Barb was introduced about this time.

Professor Cossar Ewart's interesting Introduction to "The Horses of the British Empire" may be cited as evidence of this. Says he: "The large size of the cranium, the well-marked muscular ridges for the attachment of the galloping muscles, and the density and form of the limb bones, indicate that the ancient British horses were, as the Romans noticed, alike remarkable 
for their speed, strength, intelligence, and docility" ; and farther on he states that "one of the skulls from the Roman fort at Newstead would fit very accurately a Cleveland Bay'standing fifteen hands at the withers. This skull undoubtedly belonged to a tall, long-headed horse saturated with Libyan blood." Libyan is the same as Barb blood, and this skeleton is evidence of the existence of the ancestor of the Cleveland Bay at the time of the Roman occupation.

\section{Romans and the Cleveland}

It is possible that the Roman occupation of Britain did much to establish the Cleveland Bay breed on a sure foundation. The Crispinian Legion was quartered at Danum, the modern Doncaster, for a considerable period - we believe, upwards of a couple of centuries-and they were mounted on Barb stallions. The crossing of these stallions with the native mares of the "forest" type would result in the Cleveland Bay, or in something which was the foundation of the breed which became known as the Cleveland Bay in the middle or towards the end of the eighteenth century. It is noteworthy that there was in the south a breed corresponding in many particulars with the Cleveland Bay of north Yorkshire. This was the Devonshire packhorse, a breed which is now practically extinct, but of which there were a few specimens to be found a few years ago. With the exceptions that there were no black markings, and that white markings were frequently to be met with, the Devonshire packhorse was in many respects similar to the Cleveland Bay. He was not quite so tall, nor did he stand over so much ground, but in his hardy character, his activity, his pluck, and his clean flinty bone he resembled the Cleveland Bay. And his origin was very probably the same-the Barb or Libyan cross on the original forest horses. Professor Cossar Ewart has a theory that possibly the original founders of the Cleveland Bay breed were imported from Spain, whence many good horses came early in our history. It is quite feasible on the grounds that Spain had a great trade with Carthage, and that the Barb and forest horse cross could easily originate there. But against it we have the fact that when Casar came to Britain he found horses so good that he sent some to Rome, and it is very improbable that such a breed of horses as Ciesar describes would be made from inportations when the means of transit were so scanty. So we are brought back, after all, to the conclusion that the war-horses of the Iceni and the Brigantes - of which they had a sufficiency-were descended from the forest horses, with a strong infusion of Libyan or Barb blood, and that they in their turn became the foundation of our modern Cleveland Bays, and of nearly every other British variety of the horse.

\section{Other Theories}

One or two other theories which have been formed respecting the origin of the Cleveland breed may be briefly glanced at. Professor Low, who seems to have taken things very much for granted, held that the breed originated from a cross between the cart-horse and the thoroughbred, a theory which will not hold good for a moment. For it should scarcely be necessary to say that the Cleveland Bay does not resemble the cart-horse in any particular; and especially behind the saddle he has a distinct character of his own which neither the cart-horse nor the thoroughbred possesses. It is, however, needless to continue the argument, since the question of colour puts the theory out of court altogether.

\section{Claims of the "Great Horse"}

Martin Doyle, who is a careful writer, holds that the Cleveland Bay is the survival of the great horse, and in this he is possibly right. It may be objected that Sir Walter Gilbey has made out a strong case for the Shire horse in this direction. This is readily granted, but it is quite possible to make out as strong a case for the Cleveland Bay. For when the great horse-the horse whose rider with his "furniture" weighed something approaching + cwt.-fell into desuetude: when the mobility of Cromwell's Ironsides showed that there was 
another use for cavalry than the heavy shock of heavily-armed men, horse-breeding was, and had been for some centuries, pursued on scientific lines. The horse-breeders of the Middle Ages knew what they wanted and made a very good attempt at getting it; and so, whilst the breed was developed in one direction in the South and Midlands and Eastern Comnties, it might easily have been developed in another and widely different one in the Nurth.

That at the time when lighter horses began to be used for war the great horse was practically relegated to farm work is almost certain. And it was about this time-towards the end of the seventeenth century, that is - that better roads began to be made, and that carriages of sorts came into use amongst men of position and means.

\section{Attempts at a Lighter Breed}

So we find Sir Walter Calverley writing, under date January I5, I670, that when he wanted to use his coach he horsed it with the "lighter mears from the farm." What Sir Walter Calverley did, other Yorkshire gentlemen would also do. And what more likely than that these Yorkshire gentlemen would breed from these "lighter mears from the farm," and that, having an eye to future requirements, they would select light sires, and sometimes even thoroughbred or Eastern-bred sires?

In this direction, then, may the theory which Professors Ridgeway and Cossar Ewart hold-viz. that the Cleveland Bay is a result of a cross between the Yorkshire cart-horse and the Barb--be admitted as correct. But it must always be borne in mind that in Yorkshire the cart-horse, as we know him in these days, is of very recent introduction. The writer can remember the time when anything approaching a Shire lorse in type was a rarity indeed in north Yorkshire, or, indeed, anywhere in the county. The Holderness black cart-horse was a light horse compared with the modern Clydesdale or Shire ; he was, comparatively speaking, clean legged, and he was remarkably active. And as much may be written of the Yorkshire cart-horse all over the county. Indeed, in north Yorkshire the Cleveland Bay was almost exclusively the agricultural horse of the district. Some further introduction of blood-by which is meant thoroughbred blood--undoubtedly took place during the eighteenth century, though it is difficult to trace it directly.

But that it was introduced cannot be denied. In the first place, we have the evidence of that keen observer and famous agriculturist, William Marshall, who, writing some hundred years after Sir Walter Calverley, speaks of chapmen's horses (the old name of the Cleveland Bay) or coach-horses, as " tall, strong, over-sized hunters." Indeed, in the latter end of the eighteenth and during the first half of the nineteenth centuries it was by no means unusual to see Cleveland Bays hunted-and going well too-in some provincial countries in the north. One horse that had a real Cleveland Bay pedigree did well in Leicestershire. He was by that good horse Baylock 372 , and was probably an own brother to the stallion Baylock 30 . His sire was by Baylock 37I, dam by the thoroughbred Brutandorf, and if he was a brother of Baylock 30 , he strained back to Rainbow 2.46 , by Dart 84 , so that there was some more thoronglibred blood on the dam's side. He was bred by Mr. Lofthouse, of Gunnergate, some time in the late 'forties, and was sold to a famous London dealer, who gave a good price for him but stipulated that his pedigree should be changed.

\section{Thoroughbred Influence}

There is, however, direct evidence of a considerable infusion of thoroughbred blood in the middle of the eighteenth century. One horse that made a great mark on the Cleveland Bay was Traveller, by Partner, dam by Almanzor. He was bred by Mr. Osbaldeston, the father of the "Squire," and was a good race-horse in his time. Then somehow-how, history does not say -he drifted to Yarm-on-Tees, where he served mares at the low fee of Ios. And at Yarm he would undoubtedly have ended his days in obscurity had not the Duke of Cleveland noticed some good hunting stock 


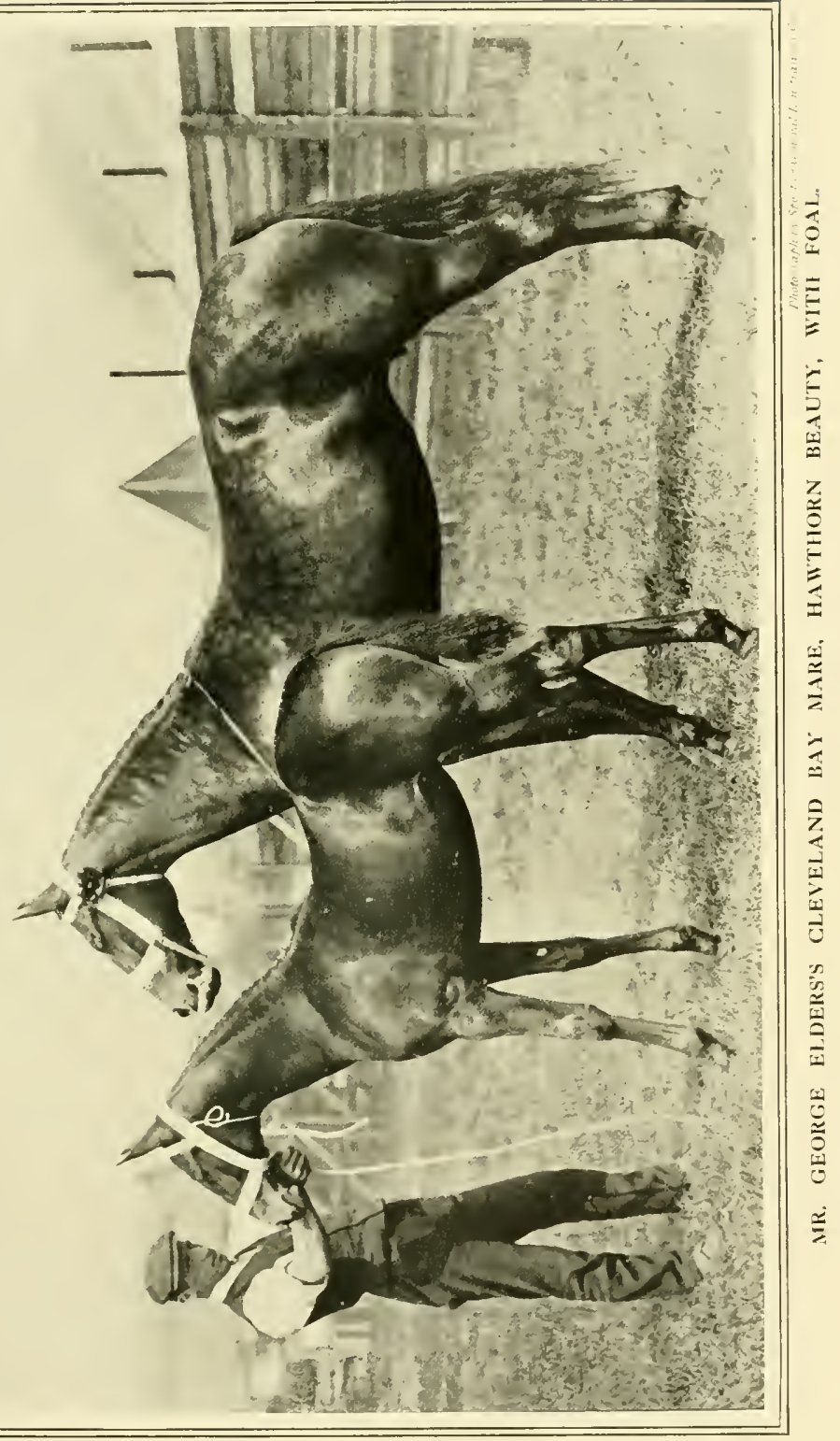


by lim, when hunting on the Yorkshire side. He sent Sleighted by All to him, and the result was Dainty Dary, the best horse of his year. Then Traveller was bought for a good sum, notwithstanding that he was twenty years old. But he had done an immense service before he left Yarm, and several of the best of the old Cleveland Bay stallions strain back to him. It is a curious fact, and one that is worth recording, that Traveller's name appears on the cards of several stallions. I do not remember coming across one that gave his pedigree, which wonld show that at the time these horses were travelling, breeders were regarding Cleveland Bays as a pure breed, and were jealous of any introduction of foreign blood, whatever the source.

\section{Is it a Pure Breed?}

The late Mr. Lumley Hodgson, who was a fine judge and who possessed a wide knowledge of horses, used to say that the Cleveland Bay was acknowledged as a pure breed in the East Iloor Dales before the days of the Darley Arabian and the Godolphin Barb, and this may well have been the case, for the sturdy dalesmen were proud of the breed, and if their written records were scanty they had plenty of oral tradition to fall back upon. "A pure breed without blood or black," the old men nsed to tell Mr. Hodgson, and no doubt such a breed did exist. But it is equally true that in the eighteenth century, and even later, a thoroughbred cross was occasionally introduced. Curiously enough, though, the Traveller cross is the only one that can be directly traced, and even here it has been in most instances obscured, either by accident or design.

Dirt $8+$, Barley Harvest $4+7$, and Farmer's Glory 316 (the Hob Hill Horse) fill, in the Cleveland Bay breed, similar positions to the Darley Arabian, the Godolphin Barb, and the Byerley Turk. Of Dart's pedigree nothing is known except that he was by a horse named Rainbow $2+4$, who was by an older Dart (83). Rainbow was the property of Mr. Agar, of Bempton, in the East Riding of Yorkshire. In his day Mr. Agar was a prominent breeder of Cleveland Bays, and he had more than one horse named Rainbow. Indeed, the way in which the changes were rung on Rainbow, Dart, Victory, Volunteer, and a few other names, in the early days of the registration of Cleveland Bay pedigrees is most confusing. Of the good horses descended from Dart perhaps the most famous was King George the Fourth, who for the first seventeen years of his life was known as Agar's Rainbow. When seventeen years old he was purchased by Mr. K. Thomas, of Eryholme Farm, near Darlington, who changed his name, and by so doing caused nearly endless confusion. The records only tell of King George the Fourth being shown once-riz. at Bishop Auckland, in I828, when he won in a class of coaching stallions. He was an old horse then, probably considerably over twenty, but there are no dates of the birth of any of Mr. Agar's or Mr. Dunsley's (who owned Dart $S_{4}$ ) horses ubtainable.

\section{The Dart Family}

The Dart family made a very great mark on the Cleveland Bay during the first half of the nineteenth century, but the line gradually died out, and there are few representatives of it left now-perhaps none in direct tail male. The last of the family to make a great mark was Master George 203. His sire was King George 160 , one of the many King Georges sired by or directly descended from King George the Fourth. His dam was by Barnaby 15, a grandson of the Hob Hill Horse, his grand-dam being by Forester IoS, and his great-grand-dam by the Hob Hill Horse. It would be well nigh impossible to find a better pedigree than this in the Cleveland Bay Stud Book. Barnaby's sire was Golden Hero I23, a rery famous horse of his dily. Of Forester, who belonged to Mr. Ralph Jackson, of Eston, no records are to be found, but his name appears in many pedigrees, and is notably at the foundation of the pedigree of another famous horse in Mr. Dennis's Forester I I2, a good winner in his day, and also of Mr. John Welford's No. 39 Depper, who was the founder of a famous family. 


\section{Master George}

IIaster George was a short-legged, wide horse, with very good shoulders, and he was as conspicuous for his quality as his substance. He was also a very fine mover. He was very dark in colour-he has been described to the writer as almost a brownand he must have been a remarkably fine horse, as well as a well-bred one, to have been used so extensively as he was, for during his life the prejudice against all colours except a bright bay was very strong, and there were plenty of stallions to choose from in those days. He appears in the Stud Book as the sire of twenty-three stallions and the sire of the dam of twenty, and he seems to have been one of those horses whose stallions and mares were alike good. Of the stallions the two which made the greitest mark were undoubtedly Richmond Lad 357 and Roseberry 260. The former was the property of Mr. W. Hansell, of Castleton, a famous lorse owner of his day, but who bred him does not appear. He was one of the earliest of Master George's stock-he was only four vears younger than his sire -and he was widely used in the Castleton and Whitby district for several years. Indeed, "Auld Richmond Lad" was a name to conjure with, and many famous modern horses trace their descent back to him on the dam's side, notably Mr. Welford's Depper family and the late Mr. James Hindson's Star, who was the dam of a great horse in Sportsman 290.

Roseberry 260 was bred by, and for a long time owned by, Mr. H. WV. Thomas, of Pinchingthorpe House. He was six years younger than Richmond Lad. A big fine horse, he was a great sire in his day, and a prize-winner as well.

\section{Barley Harvest}

Barley Harvest is a horse whose pedigree is wanting, all that is known of him being that he was the property of Mr. Luke Walmsley, an East Riding man, who had two or three stallions that had a rogue in their day, but about which there are no particulars forthcoming. Barley Harvest only appears in one pedigree, that of Victory
$43^{8}$, a horse owned by Mr. Lamplugh, of Prokthorpe. He was the direct ancestor in either the first or second generation of several horses named Victory or Volunteer, the changes being rung on the name in most confusing fashion. Indeed, it is quite possible that there were seven or eight horses of the latter name travelling the country at the same time. The most famous of the horses of this name were Ratsey's Volunteer $34 \mathrm{I}$ and his son Pomfret's Volunteer $3+5$. Volumteer 34 I was a grandson of Lamplugh's Victory 438 , and was the winner in a class of twenty-one at Beverley in 1835 . As Pomfret's Volunteer was foaled in I824, Volunteer $3+\mathrm{I}$ must have been thirteen years old at least when he won at Beverley, and probably he was fourteen years old or more.

Pomfret's Volunteer, who was perhaps the best of the line, was bred by Mr. Petch, of Goodmanham. He was successively the property of Mr. C. Pomfret, of Wolvertor, Mr. John Fawcett, of Stokesley, and Mr. Darley Welburn, of Kirby Moorside. He made a great mark on the breed, as indeed any horse must do that has the record he has, and travelling the same district for eleven seasons. He was a prizewinner at Guistorough four years rumningviz. from 1836 to 1839 inclusive-and in the following year he won at Whitby when he was sixteen years old. Few horses liave had the opportunities he had of making a name, for he travelled in the three districts in which the best mares of the day were to be found-viz. in the south part of Durham, in Cleveland between Stokesley and Whitby, and in the dales marching on Kirby Moorside. There is a good bit of his blood still to the fore on the female side, and Mr. John Gill's fine mares are all descended from him.

\section{The Hob Hill Horse}

About the Hob Hill Horse there is little known except tradition, but he lived long in the memories of Cleveland Bay breeders, and men used to love to dwell on his many excellences long after he and his sons had ceased to exist. He had no pedigree-at 
any rate, there is no pedigree of him forthcoming, but it is scarcely likely that his owner, Mr. John Weatherill, of Hob Hill, would buy a stallion without knowing how he was bred. It is said that he was bought without a pedigree I do not credit, because in the first place it was at any rate unusual for coaching or Cleveland Bay stallions to be shown in droves at fairs. Then, as has already been suggested, it was unlikely that

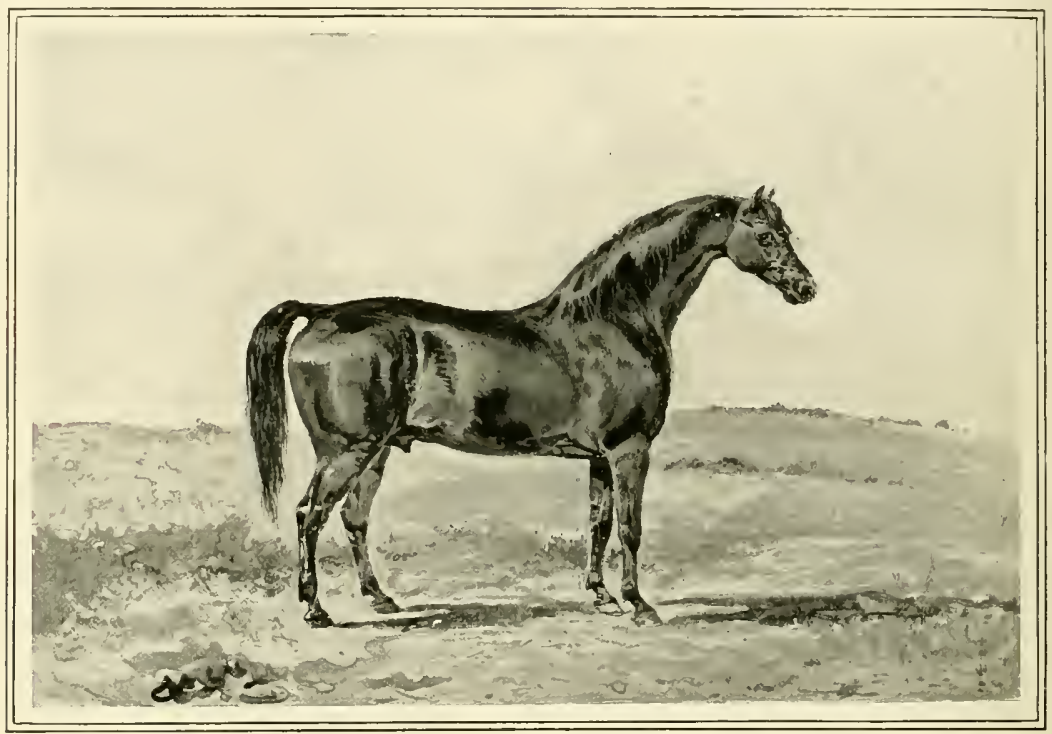

CLEVELAND BAY, FAVOURITE.

Winner of the First Prize at the Royal Agricultural Society's Shou, 1898.

as a yearling at Yarm Fair, and probably he was foaled in the last decade of the eighteenth century, for a grandson of his, Barnaby 15 , was foaled about I8o8. That he was a great horse there is not the least doubt. And one of the strongest proofs of this is, that though he was named Farmer's Giory, he was ahways known as "t'auld Hob Hill horse," and many of his staunchest admirers did not know his real name. There is, so far as I know, no card of him extant, and but three of his sons appear in the Stud Book-viz. Golden Hero I23, Ranter 249 , and Charley 380 . Tradition tells that John Weatherill once showed him and six of his sons at Guisborough, and offered to bet that a white hair could not be found in any of them.

The old tradition that the Hob Hill Horse was bought out of a drove at Yarm Fair an experienced breeder would buy a horse for a stallion without inquiring into his pedigree. A far more likely thing to occur would be for his friends and neighbours to accept his judgment on the score of pedigree and trouble themselves no more about the matter. The Hob Hill Horse lived to a good old age, and his blood is still to be found in the modern Cleveland Bay to a considerable extent.

One word more may be said respecting his pedigree. He came from Yarm, and therefore the suggestion that he descended from Traveller by Partner presents itself. It is, of course, only conjecture, and there is not the slightest evidence in support of it, but it is at any rate possible when we come to consider the great number of mares Traveller left in the country.

There are a few more horses of the long 
ago who should be mentioned, though, so far as can be gathered from the materials available, none of them founded a family in the same way as the three horses that have just been under consideration. Curiously enough, there is no pedigree forthcoming of any of them, and the dates when they flourished are likewise in most cases wanting. But most of then were contemporaries of the Hob Hill Horse, Volunteer, and King George the Fourth - that is, they most of them lived in the early part of the nineteenth century. Foremost amongst these was Masterman's Skyrocket. "Tommy" Masterman was a farmer who lived near Nunthorpe, a small hamlet between Ayton and Middlesbrough. He was a famous horse-breeder, and had several good horses in his possession, amongst which may be mentioned Forester, Summercock, as a mark of appreciation of his services to horse-breeding, it was with Skyrocket that his name was particularly associated, and Skyrocket was depicted on a glass, as was the fashion (f the times, with his owner standing at his head. Skyrucket was also the sign of the inn at Nunthorpe as long as the inn existed, and when the licence was taken away the old sign was lying about the blacksmith's yard at Nunthorpe till it fell to pieces. From the portrait of him on the glass Skyrocket seems to have been a horse of exceptional quality and a little light below the knee.

Summercock was another horse that made a great mark, and he was probably the horse that won eighteen first prizes. He was the sire of another Summercock owned by Mr. Thomas At'rinson, of Viewly Hill, Thorntonle-Street, who made a great mark in the

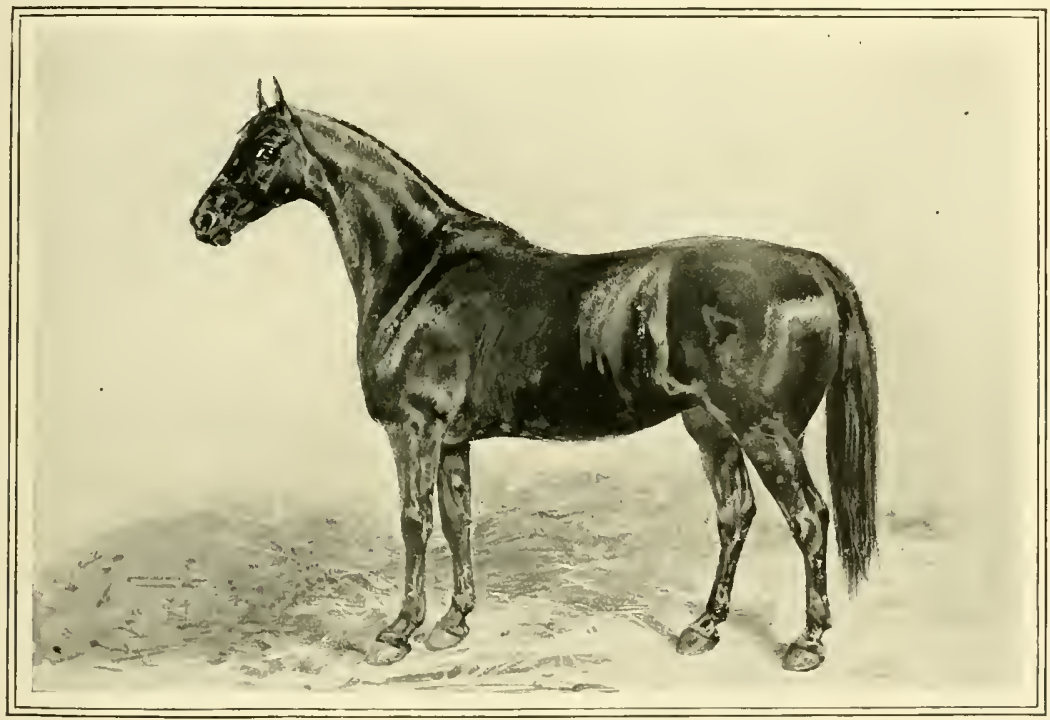

CleVElAND BAY MARE, WONDERFul LASS (1856),

Scrafton or Scrafter (for the name is spelt in both ways), and Tom. Skyrocket was probably the best horse he ever had, for when he was presented with a silver cup of the value of ten guineas by his neighbours
Thirsk district. With respect to Mr. Masterman's Summercock it may be added that there was a horse named Summercock by Skyrocket 280 (Masterman's), that was owned by Mr. John Jordeson, of Tollesby 
Farm, near Marton. In the Cleveland Bay Stud Book he is given a separate number to Masterman's Summercock, and notwithstanding the fact that there is but a distance of some three miles between Tollesby Farm and Nunthorpe, it is quite likely that they were two different horses. Indeed, the repetition of names of fanious horses was so common at that time that it seems more probable that they were two different horses than that they were the same horse in two different ownerships. Even though there was another Summercock at the same time, the changes do not appear to have been so frequently rung on the name as they were on Victory and Volunteer. Summercock 304 was a great horse, and his name is to be found in several pedigrees.

\section{Cleveland Lad and Wonderful Lad}

It is necessary to mention two more famous stallions, but they are of a much more recent date than those we have hitherto considered. These are Cleveland Lad and his son Wonderful Iad. Cleveland Lad was foaled in 1847 and was by Cleveland 6o, dam by Shortlegs 276 , grand-dam by Nailor, great-grand-dam Sister to Barnaby I5, by Golden Hero 123. There is no record of who bred him, but his first owner seems to have been Mr. John Robinson, of Hutton Rudby, a well known horse dealer and breeder in the middle of the nineteenth century. He then went into the hands of Mr. Rubert Emmerson, of Stokesley, and when last we hear of him he was in the hands of Mr. Peter Henderson, of Windlestone. He was the sire of some good stallions, and his name is also to be found in the pedigrees of some high-class mares that were flourishing not so very many years ago; but considering the excellent districts in which he travelled and the great reputation he had, there is but little mention of his name in the Stud Book. The best horses by him were Master Thomas, who was sold at a good price to go into Belgitum, and Wonderful Lad, who was bred by Mr. Harry York, of Worsall, a man who had a fine stud of Cleveland Bays, and who was one of the most famous breeders of his time. Wonderful Lad 361 was foaled in 1857 . His dam was by Wonderful 357, a celebrated horse that won a hundred-guirea prize at Ripon, dam by Luck's All i 78 , grand-dam by Summercock $30+$ (Jordeson's). When he was a rearling he knocked a hip off, and that was enough to prevent his sale to Germany, which was then the country with which the principal foreign trade was done. It did not, however, prevent his being shown, and he was a frequent winner in the north, winning, amongst other places, at stokesley and at the Cleveland show at Middlesbrongh. He was a horse that was remarkable for his quality, and there was a prevalent rmmour that he was by at thoroughbred sire and not by Cleveland Lad. An objection, followed by a lawsuit, however, put this question at rest for ever. As a sire he was very successful, and many famous sires were by him, amongst which may be mentioned Captain Cook 4, Lucky Lad I00, Roseberry 264, Sportsman 297, Yatton Lad 364, and Whalebone 355. He was also the sire of some very good mares.

\section{Fidius Duis}

Perhaps the most famous of his line in tail male was Fidius Duis ro7, whose nistory is worth relating.

Fidius Duis was bred by Mr. John Purritt - whose unhappy fate a few years after was at nine-day's wonder in Cleveland*-at Guisborough Park, and was the last colt foal the old Buck Rush mare bred. When Mr. Porritt left the farm the horse was bought by the late Sir Charles Lowther, who had some good Cleveland mares. Cleveland Bays, however, soon went out of fashion; there was little patronage of Fidius Duis, and he had to take part in the estate work. He was quite equal to taking a ton and a half of bricks as his load, and was never put

* Ifr. Porritt left home to buy a cow. He bought the cow but never returned. Some months afterwards, as the Eslidale Hounds were drawing, they came across his body in a very decomposed state in a covert. He had undoubtedly been the vict:m of foul play. 
out with it. The late Mr. James Lowther, always an admirer of the breed, had got a few useful mares together and bred from them, frequently using his own horse, and when the boom came in the early 'eighties he was ready for it. Luckily also he had Fidius Duis, who became the sire of many good horses, and whose blood is still to be found in the country, though it is questionable whether he has a descendant in tail male in England at the present time. The Master George mares were much sought after, and many of them were notable breeders, but it would be impossible to trace the careers even of a few of them. They will, however, be alluded to later, when some of the "mothers of the breed" are discussed.

\section{Famous Mares}

Though it would be too much to say that Cleveland Bay breeders trace the pedigree of their horses through the dams as the Arabs do, ret it is quite within the mark to say that they make decidedly more of their mares, and talk more about their mares, than do horse-breeders in England as a rule. When old breeders assembled and got talking on their favourite subject, it was not so much on Cleveland Lad or skyrocket that they loved to dwell as on the old Buck Rush mare, Pearl's Damsel and Darling, Hindson's Star, Codling's Bonnie, and Welford's Depper. They also not infrequently adopted the plan of inbreeding to the mare instead of to the sire, and though I have never heard any theorising on the subject-Cleveland Bay breeders, on the whole, are practical men, not given to discussing theories-I have seen some notable and very successful instances of it. One instance is in the case of Sportsman 297, a high-class horse in whose pedigree the name of Sister to Barnaby occurs twice in the first four crosses. Other instances conld be given, but it is unnecessary to multiply them.

One of the tamous mares in the middle of the nineteenth century was Mr. Porritt's old Buck Rush mare. Whether she ever had any name given her it is impossible to say : if she had it certainly does not appear in any of the catalogues which have been searched. She was one of the best brood mares of her day, and won in her turn, and she was a very successful breeder. Fidius Duis, who has alieady been referred to, if not the best of her sons, was the best known, and had the best chance in England to make himself a name. She bred an own sister to him, which also went to the Wilton Stud and which bred some useful horses.

\section{Mr. Thomas Peart's Mares}

Mr. Thomas Peart had a famous strain of mares. The tap-root was Jolly, a darkcoloured mare by Admiral 3 , dam by Barnaby 15, through whom comes the Hob Hill Horse strain, of which there was another cross through the dam of Admiral 3. Drainer 89 , the sire of Admiral, was one of the Barley Harvest family, being by Victory, and he also had a cross of Masterman's Skyrocket. Jolly was a good mare for her owner, for she bred him fourteen foals, one of which was kept for a stallion and sent abroad. But it is on her two daughters, Damsel and Darling, that her fame as a brood mare rests. Damsel was sold to Mr. John Robinson, the dealer of Hutton Rudby, for whom he bred some very high-class hunters, and at least one good Cleveland Bay, Mr. Robinson Watson's Sunflower, of whom something will have to be said later on. Darling, however, was the pick of the basket, and she certainly stands out as one of the best brood mares of her breed. To begin with, she was very successful in the show ring, and only once in the course of a long career was she overlooked altogether. She was second as a yearling, and won as a two-year-old at the Cleveland Show, where the opposition in her day was always strong. She was first shown as a brood mare when four years old. This was at Guistorough, where she won in a class of twenty. Two years later she won at Stokesley and at the Cleveland Show at Yarm, and a rear later she was second in the Cleveland Bay brood mare class, and first in the coaching brood mare class at Stokesley. She won other prizes, but the list is incomplete, and sufficient has been 
said to establish her position as one of the best of her time.

\section{The Famed Darling}

l)arling was a mare with great quality as well as substance. She had good shoulders, was near the ground, and was a fine mover. And she was a typical brood mare, breeding equally well to the thoroughbred and to the Cleveland Bay. There were many like her -indeed, this is one of the great attributes of the breed; but as there has not been preserved so complete a history of a great mare at the stud, it may prove interesting to give particulars. Her first foal was a colt by Perion, a thoroughbred, she having missed to Cleveland Lad, to whom she was mated as a two-year-old. Consequently she was sent to Perion, and the colt foal grew into a very good horse that eventually found his way into the stables of a big Londun dealer at a good price. She bred six stallions -viz. Master Thomas, by Cleveland Lad 60, sold at three years old to go to Belgium for $f$ Ioo; Lord of the Manor, by Wonderful Lad, who was sold at three years old to Mr. George Holmes for f200; Brilliant, by Wonderful Lad, sold as a yearling to Earl Fitzwilliam for froo; Brilliant 42 , by Yatton Lad, who displaced his hip joint, so was perforce kept at home, where he became the sire of Sportsman 299 and many great horses ; Captain Cook, by Wonderful Lad, a very successful colt in the show ring, and a useful sire, sold when young to go abroad; and Roseberry, by Wonderful Lad, subsequently sold to go to America. There was one pure-bred filly of which record remains -Duchess of Cleveland, by Wonderful Lad. She was a useful brood mare, and was the dam of two good stallions in Duke of Cleveland 97 and Roseberry 580 , and grard-dam to another in Duke of Rredale gs.

\section{Darling's Offspring}

Darling bred nine other foals, many of them to thoroughbred horses. One of these, a filly by Perion. had an interesting history. she was only shown once as a foal-viz. at Stokeslev, where she won in a class of colts or fillies, beating seven colts. Mr.
II. Dale, of Prissick House, bought her for fi5-a good price for a filly foal in those days-and he sold her to Mr. H. W. Thomas, the owner of Dictator and other well-known race-horses, for t60 when three years old. She had been stinted to Newport, but carried her foal so lightly that slue was deemed not to be in foal. She was consequently luunted during the end of the season. Notwithstanding appearances, she eventually dropped a fine filly foal, which Mr. Thomas sold to his brother-in-law, Mr. Henry Wilson. He hunted her a season or two, and then showed her in the open hunter class at Redcar, where she won, beating several good horses. She was then sold for ifoo to the late Mr. John Harrey, then Master of the Durham County Hounds, whom she carried for many seasons. It says something for a mare, and something also for the breed to which she belongs, that she should breed seventeen foals, amongst them some of the best stallions * of her breed, and some high-class hunters.

\section{Sunflower}

Sunflower. who has been previously mentioned, was by Wonderful Lad from Damsel, an own sister of Darling. She was bred by Mr. John Robinson, of Hutton Rudby, and purchased by Mr. Robinson Watson, of Stainton Vale, near Stockton-on-Tees. She had a very successful show-yard career, but was not shown till she was six years old, and she was always shown as a brood mare. Her score for I 868 was four first prizes and one second; in I869 three firsts and one second; in I87o five firsts and two seconds ; in $I S-I$. eight firsts and one second and a champion cup at Whitby. In 1872 she took six first prizes, one second, and one champinin (at Durham County) ; and in 1873 she won eight first prizes, one second prize (at the Royal), and two champions (at the Durham County and Whitby). Her total of thirtyfour first prizes, seven seconds, and four champion cups-all as a brood mare-is a very excellent one, especially when the fact

* MIr. George Holmes, who was a fair judge, said Lorl of the Manor was the finest coachn horse he ever saw. He went to India. 
is taken into consideration that in the 'sixties and 'seventies show's were not an everyday occurrence as they are now. Her principal battle grounds were the Cleveland -then an important show, only taking rank below the very best county shows--the Durham County, and the Yorkshire. It nust also be remembered that when she was like a chapter of romance. Mr. Smith, of

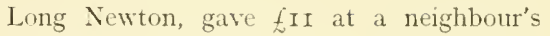
sale for a filly three and a half years old by Golden Forester I22, dam by Richmond Lad 157 or Grand Turk, who must not be confounded with Hindson's Grand Turk, as the latter was not foaled till I857, many years after the Grand Turk of this pedigree

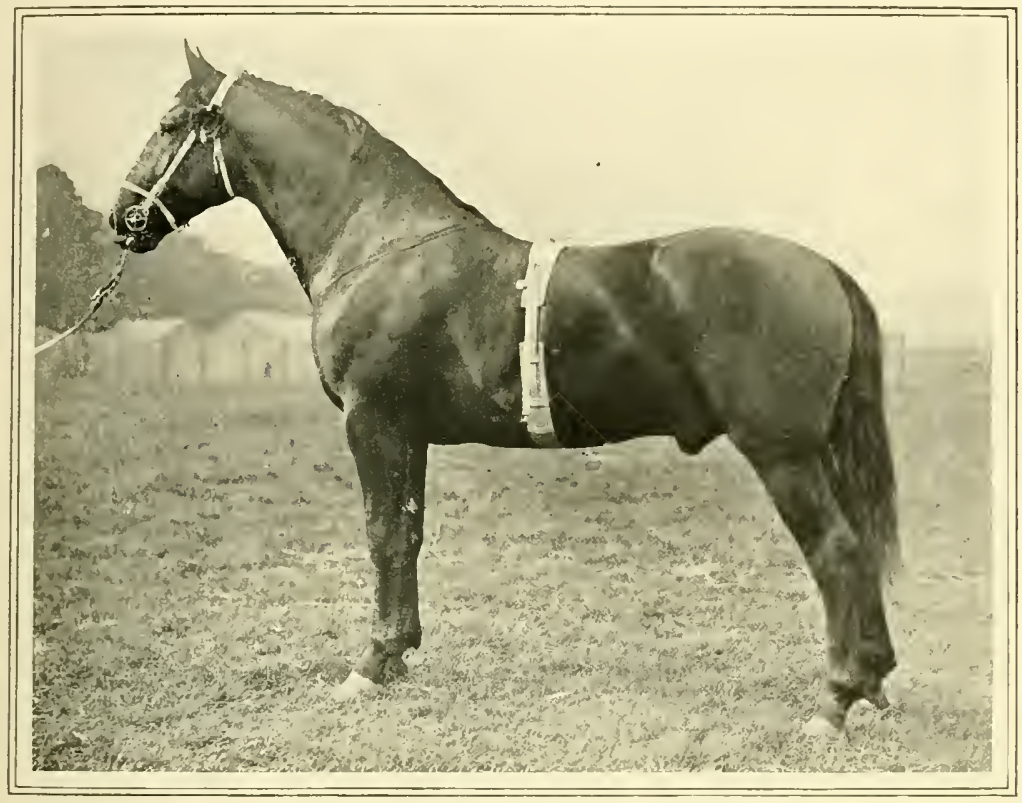

CLEVELAND BAY STALLION, BEADLAM.

shown at the Yorkshire and the Royal it was as a coaching brood mare, and not as a Cleveland Bay, and that she consequently had the worst of the handicap. The Royal was at Hull in 1873 , and right in the district which was then famous for coaching horses.

Sunflower was not lucky as a brood mare. She never bred anything to perpetuate the line of which she was a distinguished member. She was principally mated with thoroughbred horses, but she bred, at any rate, one high-class hunter. A half-sister to Sunflower, but a little older, was Mr. John Smith's Wonderful Lass, whose career reads was in existence. This is, in all probability, a horse of which no pedigree exists; at any rate, he cannot be traced. Mr. Smith broke his new purchase in and mated her with Wonderful Lad. The result Was Wonderful Lass, the only foal she ever bred, so far as can be traced, for a Newcastle gentleman named Bigge saw her on the plough soon after she had foaled, took a fancy to her, and bought her for $£_{50}$. Some year or two afterwards Mr. Bigge's establishment was broken up, and the mare sold. In the meantime, Wonderful Lass had grown into a remarkibly fine mare, and Mr. Smith was anxious to get her dam back. Then 
began a search for her which calls to mind the late Mr. l'Anson's search for Queen Mary, but unfortunately not with the same result. Wonderful Lass commenced by winning two first prizes als a toal,* and she was also to the fore three times as a yearling. As a two-year-old the was first five times, and as a three-rear-old she won four times, was second twice, and won a champion cup. In the following year as a brood mare she was nine times first and once second, the latter at the Cleveland show, when one of the strongest classes of Cleveland mares that was ever seen in a show ring was to the fore. In IS6I, when five years old, she was sold,

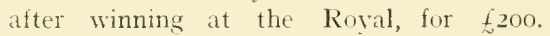
Twenty-four first prizes, three seconds, and a champion cup in five years was a great record for those days.

\section{Mr. Staintisorpe's Star}

It was only indirectly that $\mathrm{Mr}$. Stainthorpe's stal made a strong mark on the breed of which she was such a distinguished member. She was by Grand Turk I38, dam by Bay Thornton 35. She stood a trifle over sixteen hands, was built on excellent lines, and was a fine mover, and had plenty of substance as well as quality. She won upwards of thirty first prizes, principally at local shows, such as Castleton, Loftus, Hinderwell, Whitby, and the Cleveland Agricultural Society's shows, and once at Whitby she beat Mr. Robinson Watson's Sunflower. She was only mated with a Cleveland horse once-the more is the pity-and the result was Wonderful Lady.

\section{Wonderful Lady}

Wonderful Lady was by Wonderful 359 , and was, perhaps, the most successful show mare of her day. At any rate, she was quite in the front rank, as her excellent record shows. She was a late foal-foaled May I8, I870-and on this account she

* In Vol. I. of the Cleveland Bay Stud Book two more first prizes are given, but these are evidentiy a repetition. Mr. Snith, speaking from memory, told the writer the mare was foaled in 1855. She was foaled a year later, as shown by the Cleveland Agricultural Society's Catalogues of I 859 and I 860 . had to put up with a highly commended card the first twice she was shown. But notwithstanding this, she won three first prizes as a foal, only being shown five times. As a yearling she was shown four times, winning twice and taking second prize twice. As a two-year-old she won six times, and was second once out of the seven times she was shown, and as a three-year-old she won seven times and was second twice out of the nine times she was shown. When four years old she was shown ten times as a brood mare, and won eight first prizes and was second once. At Castleton in this year she had a novel experience, as, for the first time in her life, she did not receive any recognition at the hands of the judges. She was to be left out in the cold twice again in the following year, probably because she had been very hard worked when her owner was changing farms, but she made up for this disappointment by winning on the other five occasions of her being shown. In is76 she was shown ten times, won nine times, and was second once; and in 1877 she was shown seven times, taking six first prizes and one second. She was beaten by Mr. John Kirby's famous old mare Flora, at Darlington, and was subsequently sold to Mr. Kirby for 1126 -and very cheap she was. She had a few show engagements, however, and was not delivered till after she had fulfilled them, and between sale and delivery she picked up $f_{3} 8$ for Mr. Stainthorpe. Mr. Kirby showed her twice in $\Sigma_{7} 8$, and she won both times. Altogether, she was shown fitty-nine times, won forty-eight firsts, eight seconds, and was three times unnoticed. Her cult foal at foot when Mr. Kirby bought her went amiss, and her filly foal by Bay splendour, which she bred when Mr. Kirby had her, was drowned in the River Derwent. So she was not very successful as a brood mare in England, and the only one of her direct descendints that can be traced is 405 Lucy, by Barnaby is.

\section{Lucy and Her Offspring}

Lucr, by Barnaby, was bred by Mr. Francis Stainthorpe, and she was, we believe, the only one left of the old Star family when her dam 
Wonderful Lady was butght by Mr. Olde for the Belgian markit. She was the dam uf 402 Lovely and of tis Lady stainthorpe, and Lovely, who was by Lord Cleveland 627, wals the dam of $7 I_{3}$ Lady Hillingdon, who was by Lord Hillingdon, a son of Newton 216. Lord Hillingdon was also the sire of Lady Stainthorpe, and was one of the famous 39 l)epper family, under which he will come in for deseription. Lady Stainthorpe and Lady Hillingdon really form the foundation of the small but choice stud which Mr. George Elders has formed at Aislaby, for Aislaby Lass, his first purchase, did not do much in the way of establishing it, and may be regarded as a comparative failure. Lidy Stainthorpe has been a famous mare, both at the stnd and in the show ring. She has twice won at the Royal and fon times at the Yorkshire as a brood mare, and she won the Cleveland Bay Horse society's challenge plate at the Cleveland Show right out. Besides these, she has scored many other famous victories, and one of her latest - at Stokesley in ryos was not the least remarkable. She was eighteen years old, and had Mr. Elders not shown her great-granddaughter 1293 Hawthorn Beauty, she would also have won the champion cup. This would have been a fitting event, for Lady Stainthorpe won a special cup at Stokesley some ten or eleven years earlier. Mr. Elders has adopted a wise policy. He would never part with a mare or filly until he had another mare or filly of the same family. So when 949 Hetty, Lady stainthorpe's first foal, was a foal, he refused what was considerably more than a market price for her. And wise he was, for Hetty had bred him in6n. Aislaby Beauty, and one or two more, before her dam bred another filly! Mr. G. Allison, of Hawsker, and Mr. J. H. Trreman, of Hinderweil, also have some very good mares descended from Frank Stainthorpe's Star, and bred by Mr. Elders, who is one of the most successful living breeders.

\section{The Depper Family}

Amongst those who have stuck consistently to breeding Cleveland Bays, and who have never been led away by any of the passing whims of fashion, is Mr. Jolun Welford of Luttus frange, whose strain has for many rears lad a world-wide reputation. The original tap-root of the Depper fanily which has made Mr. Welford's name famous in the horse-breeding world was bred by Mr. John Wood, of Skelton Green, and sold by him to Mr. Heslop, of Norton, near Stocktonon-Tees. The original Depper proved too light for the brewer's wagon-or Mr. Heslop and his men thought her so, for it is difficult to balieve, when me crmes to inspect her powerful descendants or remembers Fidius Duis and his ton and a half of bricks for a load. It may easily have been, however, that she was too keen, and took more than her share of work. However, Mr. Heslop made up his mind to part with her, and he exchanged with Mr. Welford's father for a horse which was more to his liking, and well it was that $=0$ good a mare got into such good hands.

\section{"The Old Ottonburgh Mare"}

she was a rarely-bred mare, being by Ottonburgh 222 (she is frequently spoken of as "the old ()ttonburgh mare"), dim by Nimrod 218, grand-dam by Victory 337. great-grand-dam by Rulph Jackson's Forester IoS. It will be seen that she combined the blood of Barley Harrest and the Hob Hill Horse, of the latter of whom there were three direct crosses. One could scarcely have chosen a better bred one to make the foundation of a family, even when Cleveland Bays were plentiful, as they were in her day. She was never shown till she was fifteen vears old, and three firsts and three seconds out of six attempts make her excellent record. She left fifteen foals, most of which were sold at remunerative prices to London dealers. Four of her offspring have a record in the Cleveland Bay Stud Buok-viz. three mares and one stallion, Newton 216, by Sportsman 2y9. The old mare was awenty-four years old when he i. as foaled.

It is, however, on the fem:le side that we have to trace "the old Ottonburgh mare's" descendints. Three mares from her are 
found recorded in the Stud Book, all of them named Trimmer. The first Trimmer was by Lovely $\mathbf{1 7 2}$, a son of Barnaby 18 . She was shown five times, and succeeded in taking two first prizes and three seconds. She was then sold to go abroad, but left a filly behind her to carry on the it impossible to show her any more. This happened when she was four years old. She was a great success as a brood mare, and bred a useful horse in Conqueror 78 , by Wonderful 359.

The third Trimmer was by Fidius Duis I07, who, it should be said, was the sire of

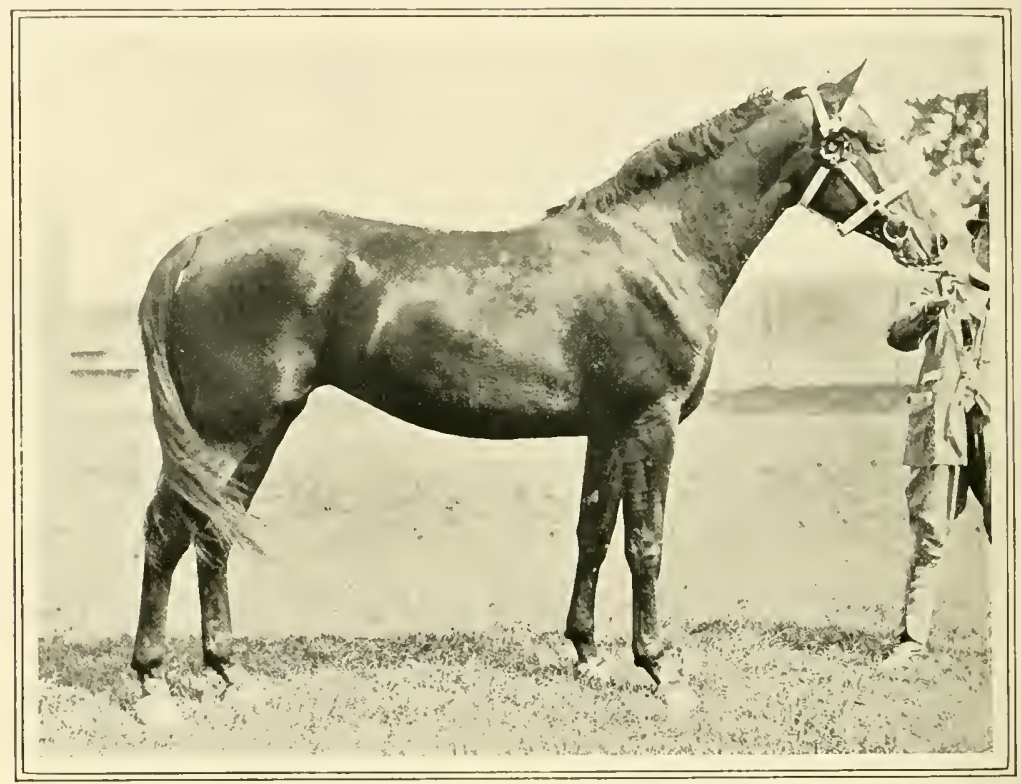

CLEVELAND BAY FILLY, CHOLDERTON BLOSSOM.

line. This was 30 Daisy, by Wonderful 359 , who was a useful mare and won her share of prizes, but was not so prominent in the show yard as some of her family. She was, however, a very good brood mare, and many high-class horses trace their descent back to her. The famous brood mare Madam, whose successes in the show yard a quarter of a century ago were so numerous, was a granddaughter of hers, and from her descend Madam II. and Madeline, the latter a mare that was bred by Mr. John Lett, for whom she has won several prizes.

The second Trimmer was by Barnaby i8. She looked like eclipsing all her sisters in the show ring, where she was remarkably successful, until an unlucky accident made
Madam. Of her it may be said, as of others of her family, that she was a very successful show mare, for she won all over the country, and she fully maintained the credit of her family as a brood mare as well as in the show yard. She was the dam, amongst others, of Lord Hillingdon 986.

It may be noticed here that Mr. Welford has been in the habit of inbreeding closely to the mares, and Lord Hillingdon, who was a very successful sire, was an instance of this. He was by Newton, whose dam was 39 Depper, from I05 Trimmer, whose dam was also 39 Depper. The plan has answered well with Mr. Welford's stock, which, it should be unnecessary to say, are of the purest bloud, and very rarely is to be found 
nowadays such a combination of quality and substance as in the 39 Depper family, which, happily, is a pretty numerous one.

\section{Mr. J. Gill's Stud}

It would be impossibie, and if it were possible it would be tedious, to give a history of every mare that has more or less founded a line, but no history of Cleveland Bays would be complete without a short account of Mr. John Gill's stud and its foundation. Mr. Gill is an instance of a farmer who has taken pains to preserve the pedigrees of his stock, and he still has descendants of the mares with which he worked his farm three decades ago or more. Mr. Gill's sort are scarcely so powerful as Mr. Welford's, yet they are by no means wanting in substance, are rare pullers, and have exceptionally fine quality. Tommy IIasterman's horses are very much at the foundation of the family, sirafton $7_{2} 8$, Forester 108A, and Skyrocket 280, all being found in the pedigrees of MIr. Gill's mares. There is also a cross of Volunteer 345 . One of Mr. Gill's best mares was I I 7 Zcë, a remarkably well-bred mare by Barnaby. She was the dam of several good mares, and from a sister of hers Ir. George Nlortimer, of Westerdale, has bred some good stock. Some of the family found its way into Hampshire, but unfortunately had no chance there, on account of the lack of stallions. Others, again, went into Cumberland and bred some good hunters. Mr. Gill does not show much, but at Stokesley and some of the local shows within reach he shows a few fillies, and he is always in the running. His strain is unique, as it is the only one in which Tommy Masterman's horses figure largely.

\section{Further History of the Breed}

Sufficient has been said of Cleveland Bay families, though much could be added did space permit. The more important of the families have been discussed, and it now remains to tell the history of the breed with relation to the country in general. $\mathrm{L}_{\mathrm{p}} \mathrm{p}$ to the end of the eighteenth century the Cleveland Bay flourished exceedingly, and was highly esteemed all over the north of
England, at any rate. Indeed, in the North Riding of Yorkshire, but chiefly on the eastern side, the dranght-horse is we now know him was not to be found. The work of the farm was all done by Cleveland Bays-much of it by mares, who bred hunters as well as pure-bred clevelands. For the more stylish of the geldings, those that had some quality and that could move, there was a ready market, both in the provinces and in London, to draw the heavy coaches which were then so common. Even in those days, though, it is very questionable whether any systematic attempt was made to keep the breed together, or whether, notwithstanding the eagerness with which men would dilate on the excellences of their " auld mears," those same mares were estimated at their proper value.

\section{Decline of the Cleveland}

The Regency days brought in a change of fashion, and the cabriolet, with its tall, flash-looking horse and its diminutive tiger, became all the rage with the bucks who fluttered round Carlton House. For the flashlooking horse standing some seventeen hands high - the higher the better-the Cleveland Bay mare was a famous foundation. She was crossed with a tall, not to say leggy, thoroughbred, and so, it may be said incidentally, the Coach Horse breed began.

Of course, this wholesale crossing in order to produce the fashionable harness horse of the day had a serious effect on the purity of the breed. Half-bred mares, especially if they were tall enough and flash enough, were bred from, and gradually the pure-breds became fewer and fewer in number.

So rapidly, indeed, did the breed decrease that by $\mathrm{I} S 20$ it was in danger of becoming extinct, and it owes its survival to the exertions of a few individuals in the north and east of Yorkshire and on the edge of the moors, who, recognising its great value, left no stone unturned to keep it pure.

\section{Its Revival}

Then the value of the breed for agricultural purposes became recognised, not only in its native dales and the surrounding 
districts, but also in the north and west of England. A stallion or two were imported into Scotland, and a Mr. J. B. Lloyd, who farmed in ciloucestershire, wrote a few years later in the Royal Agricultural Society's Joumal abont the Cleveland Bay stallion he had purchased and the good he had done on the farm. Then undoubtedly about this time there was a certain-perhaps a considerable-trade done with Germany and other Continental countries, so that there was a continuous drain upon what, after all, were limited resources. Worse than this, it was alway's the best that went; for the best, as it is needless to insist, always bring a little more than market price if anyone is anxious to have them; and it is to be feared that there was but scanty encouragement meted out to the few who endearoured to keep good horses in the country:

So that when the slump came it was not long before a pure-bred Cleveland Bay was a very scarce animal indeed. The cause of the slump this time was in quite a different direction from that which had taken place some forty years or more earlier in the century. Then it was the demand for a lighter horse for harness; now it was a demand for a heavier horse for draught. The increase in Cleveland mining had 110 doubt something to do with this; perhaps the increased prices paid for heavy horses for railway and town work had more. At any rate, the slump came, and if it had not been for the singleness of purpose and far-sightedness of the late Mr. James Hindson, Mr. John Welford, the late Mr. G. Codling, and a few of their friends and neighbours, there would have been few Cleveland Bays indeed to supply the demand which came suddenly in the later 'seventies.

\section{American Demands}

The last revival of the interest in CleveJand Bay breeding was due, in a great measure, to the opening up of the Western States of America, when the country had settled down after the great Civil II:Ir, and a general purpose horse of the Cleveland Buy type was greatly wanted. Buyers came over in increasing numbers, and even the commercial smartness of the American failed to disguise the fact that they were eager-nay, anxious-purchasers.

At first the horses were difficult to find; many mares were hidden away on remote farms, and many horses that should have been stallions were geldings. This, however, was made up for when the boom was at its height by many horses being kept for stallions. In those days a Cleveland Bay gelding was unknown.

\section{Clereland Bay Horse Society}

The American demand naturally drew the attention of English breeders and dealers to the breed, and when, as the result of a meeting between Sir A. E. Pease, Mr. J. P. Sowerby, Mr. F. E. C. Dobson, and the writer, at West Noor House, Marton, the Cleveland Bay Horse Society was ultimately formed, the time was ripe for it.

There is no necessity to enter into details respecting the history of that society or of the breed since its formation. It is sufficient to say that too narrow a policy was adopted, and many horses that should have been admitted into the Stud Book were rejected. Lnfortunately, the expediency of the moment was more considered than a broad and definite policy. Hence came divided counsels where there should have been practical unanimity, and though this did not bring about the decrease in the demand which set in a few vears ago, and which has had its effect in diminishing the number of pure-bred mares, it certainly helped to make matters worse when the drop did come.

\section{Points of the Breed}

The Cleveland Bay should stand on a short leg, and should cover a lot of ground. It has been said that good shoulders are not essential, but that long, level quarters are. Good shoulders are, however, as important in a Cleveland Bay, or in any horse, as they are in a hunter or saddle horse, for it is good shoulders which enable a horse to put his foot out and so save a fall when he steps on a stone whilst going down hill; indeed, many Cleveland Bays 
have very good shoulders, though not necessarily high and narrow withers. The back should be short and muscular, and the quarters should be long and level. It is these long level quarters which is a distinguishing characteristic and which gives the Cleveland Bay the stately appearance in harness for which he is famous.

Many Cleveland Bays are undoubtedly light in the back rib, but this is not a necessary attribute of the breed. Lengthy they must be, and stand over a great deal of ground, but it is needless to point out that though deficient back ribs do occasionally and even frequently accompany length, they are not necessary to it. The head is rather large, and in the head the modern Cleveland would seem to resemble to a considerable extent his remote ancestor, the forest horse. But the head is well set on and well carried, though the neck is not extravagantly arched. The set-on of the tail is an important point in the Cleveland Bay. A low set-on, "rulgar" tail is an eyesore, and an almost certain indication of alien blood. The bone is clean and flat, and there is plenty of it ; the cannon bone is short, the pasterns slope sufficiently, and the feet are well shaped and hard.

\section{Dimensions of Mr. Lloyd's Horse}

The dimensions of Mr. Lloyd's horse may prove of interest. When full grown " he measured 16 hands $I_{2} \frac{1}{2}$ inches high, $9 \frac{3}{8}$ inches round the pastern, io inches round below the knee, 21 inches round the arm, $15 \frac{5}{8}$ inches round the knee, and 6 feet ro inches round the girth. When measured he was in good condition, but not what you would call full of flesh, his legs as clean as a race-horse." It would be difficult-perhaps impossible-to find a horse with such measurements now.

\section{Treatment of Mares}

One thing which has brought about the scarcity of high-class Cleveland Bays which now exists is the haphazard way in which men have parted with mares of good family and undoubted merit, without first having some females of the blood left in their studs. The men who have stuck steadily to their mares-never having been tempted to part with them until they had at least one daughter left - may be counted on the fingers of one hand. Had the owners of some of the high-class mares which were sold out of the country or to breed linters adopted the same policy the breed would have been in a much better position at this day.

\section{Breeding to Colour}

It has been claimed for the Cleveland Bay-and with justice-that his long descent has thoroughly "established" his colour, and that a Cleveland Bay will sire bav's from mures of all colours-even greys. It is also claimed that a Cleveland Bay mare will breed bay foals no matter what the colour of the sire. In the case of horses and mares of long pedigree this is doubtless true, though, of course, there are plenty of instances to the contrary. Still, if a man wishes to breed a bay or brown from a Cleveland Bay mare, he would act wisely if he did not mate her with a gaudily-marked chestnut.

\section{A Chestnut Example}

An instance of Cleveland Bay mares breeding true to colour may be given. This is Colonel Scoby's Lady Cranford. Lady Cranford is by the King's Premium horse Wales, from Mrs. Hobground, a well-bred Cleveland Bay mare that has probably a good deal longer pedigree than is given her in the Stud Buok, as she was bred by a man who was associated with the breed all his life, as was his father before him.

Now, in the first thirty quarterings of Wales's pedigree there are seven chestnut horses or mares. Estella, his grand-dam, was a chestnut by a chestnut horse (Citadel) ard from a chestnut mare (Andorra). Citadel was by that impressive sire Stockwell, a chestnut, as was his sire, The Baron; and there is a Stockwell cross on the sire's side. It is, of course, impossible to say with any degree of certainty how many of IVales's stock are chestmut in colour, but it would be pretty safe to say that at least half of them are-and probably more than half.

But neither in colour nor shape does Lady 
Cranford show any thoroughbred ancestry. Her shoulders, perhaps, are better than the shoulders of the average Cleveland Bay, but in all other respects she is entirely of the Cleveland Bay type.

\section{The Wonderful Lad Cross}

It is the very excellence of the Cleveland Bay that has done much to bring about its scarcity. When there was a big foreign trade it will be noticed that the best mares and the best stallions were parted with in a reckless fashion, which could only have one result. Indeed, if we look back over the history of the past half-century or longer we will find that with one or two notable exceptions the horses that made the greatest mark upon the breed were kept in the country only because they met with some accident which unfitted them for the foreign market. Of this fact Wonderful Lad and Newton are notable instances. The value of the Wonderful Lad cross has already been insisted on, but two mares by him were allowed to go out of the country in spite of -or perhaps because of-their great excellence as demonstrated in the show yard. Allusion is made to Wonderful Lass, who, for any good she did the breed, might as well have left the country; and Wonderful Lady, whose value as a brood mare has been sufficiently demonstrated by her descendants in the hands of Mr. George Elders and others. Yet it was only by a fluke that any of her descendants are found in this country. Her daughter, Lucy, by a lucky accident was in existence when she was sold, and the great mark made by her descendants shows pretty plainly what would have resulted had Wonderful Lady been kept in England.

\section{Breeding with Thoroughbreds}

The Cleveland Bay makes an excellent foundation for any kind of light horse, and hunters and harness horses of high class have been bred from Cleveland mares mated with thoroughbred sires. A big, lengthy thoroughbred, however, is not desirable, especially if a hunter is the objert aimed at. The class of stallion to be selected is a rather small, compact horse, with very good shoulders - that rleveland mares are not always quite what they should be in this respect needs impressing on the man who would breed a hunter-and a short back and a good barrel and back ribs. Above everything, he should be a high-couraged horse, and he is all the better for being a little under rather than a little over fifteen hands two inches. Perion, who was under fifteen hands, was the sire of many highclass hunters, and the best hunter in Sir Harry Goodricke's stable was by a horse of similar type from a pure Cleveland Bay mare.

\section{Adaptability of the Cleveland}

It is obvious that a breed would have to be numerically strong to stand such a strain, but of late years there has been another strain on the breed--that of crossing with hackneys to get the "snap of the knee" which fashionable people demand.

The adaptability of the Cleveland Bay for crossing has led many men to breed hunters and other horses from their Cleveland mares when there has been a depression in the foreign market. This is natural enough, but many of them seem to have lost sight of the fact that unless the breed is kept pure it will not be there to cross from, and will not be there when it is wanted for a revived foreign trade.

lt seems curious that horses which are so eminently fitted for farm work, and so valuable for breeding purposes, should not be more extensively bred. The reason, perhaps, is that they get over too much ground in a day, and that they are tou active for the present generation of farm labourers. At any rate, a well-known Cleveland Bay breeder said to the writer that he should have to sell some of his Cleveland Bays at some price, for he could not get men to work with them.

And so, though there is material enough left to re-establish the breed if an attempt were made on sound lines, it would seem that, from one reason or another, one of our most valuable breeds will go by the board. Should this happen it will be little short of a national calamity! 


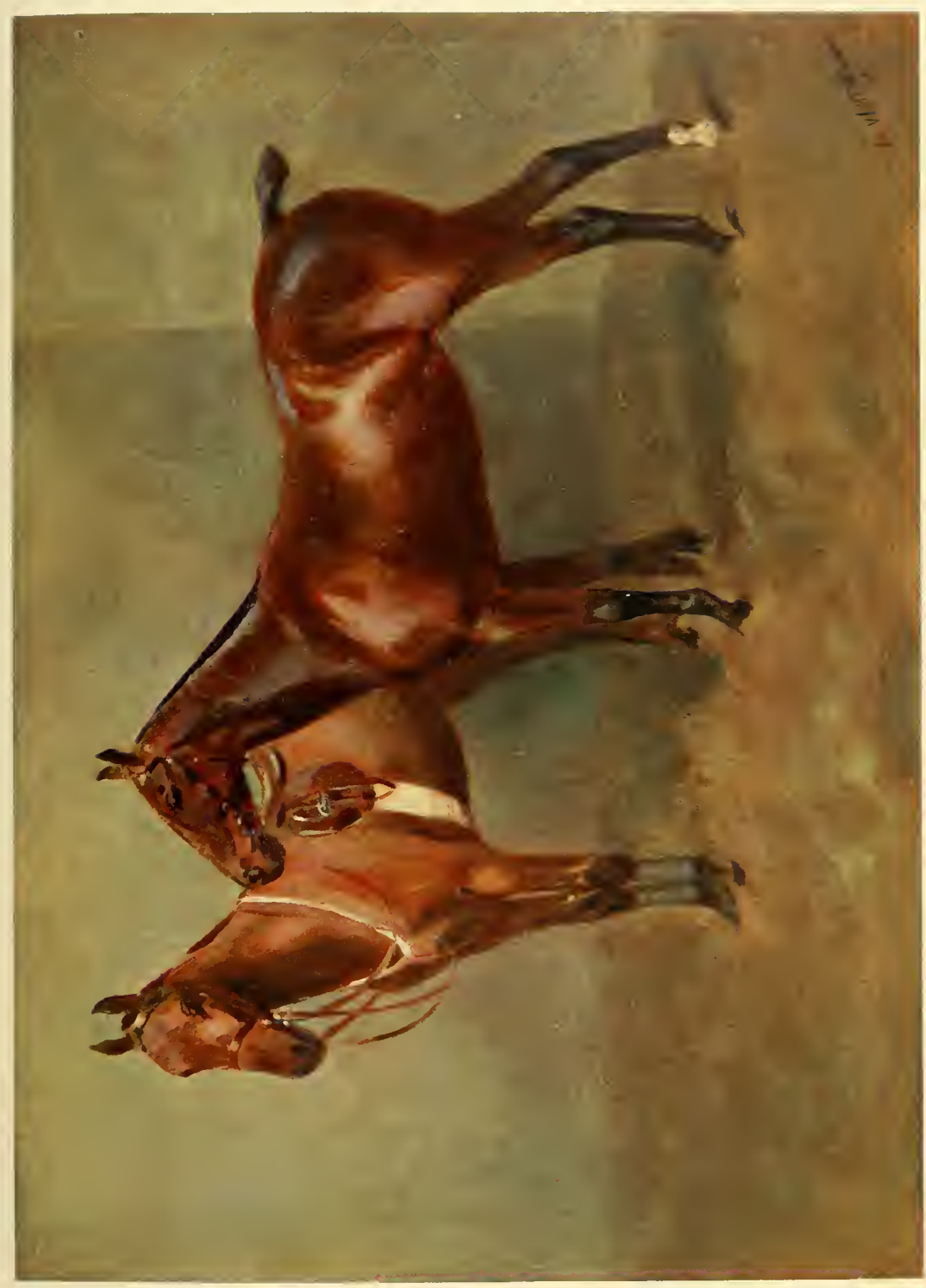

존

$\rightarrow$

का

2

鱼

$E$

ㄴ.

$<$ च

5

递

0
0
0
0
0 



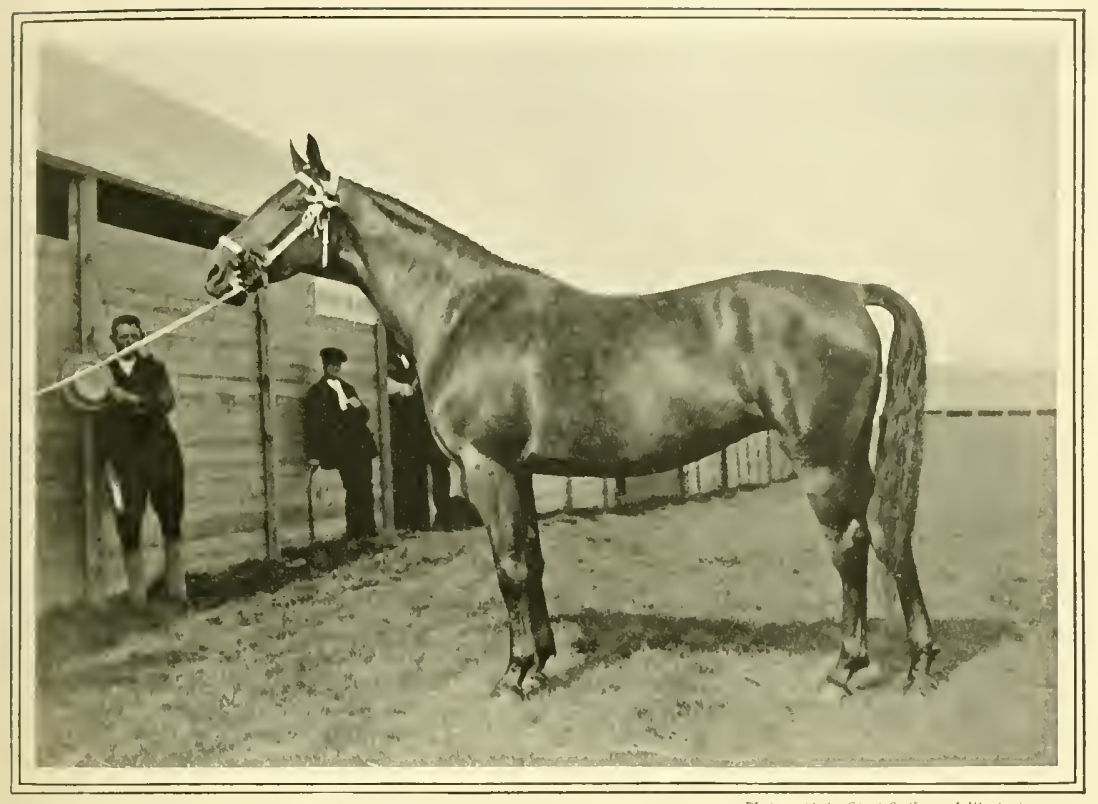

YORKSHIRE COACHING MARE, JOSEPHINE.

\section{CHAPTER XXIII}

\section{THE YORKSHIRE COACH HORSE}

T

WE Yorkshire Coach Horse is so nearly allied to the Cleveland Bay that much that has been written about the one breed necessarily applies to the other. The Yorkshire Coach Horse owes its origin as a breed to the demand for a lighter and "flasher" kind of carriage horse which came with the improvement in the roads, for though the tall, flash horse of the cabriolet called it into being, that was only a passing fashion. The demand for light and stylish harness horses continued until quite recent times, when the Hackney, instead of a riding horse, began to be looked upon as the fashionable harness horse. "The Druid" gave the Yorkshire Coach Horse the happy name of the Howdenshire Cleveland, and he said that the nearer they got to York and the south-eastern part of the East Riding, the more "blood" they got- "for every so many miles another cross of blood."

Broadly speaking, this is no doubt correct, though it is scarcely so literally. But it must be remembered that at the time when the Yorkshire Coach Horse was springing into existence many high-class thoroughbred horses were serving at very small fees indeed, and that some were even travelling the country. So that the temptation to use an extra cross of blood was great. We have seen that even in the days when the Cleveland Bay was in its strongest position a cross of blood was occasionally introduced and nothing said about it, many descendants of Traveller figuring as Cleveland Bays, and 
there is no doubt that when the demand was for quality thoroughbred blood was likely to piedominate.

\section{Thoroughbred Influence}

Indeed, if we examine carefully the pedigrees in the early volume of the Coach Horse Stud Book, we shall find many horses in it who were only just removed from thoroughbred. Of these may be mentioned as instances the brothers Ebor 928 and Paulinus 947. They were owned by a famous Coach Horse breeder, Mr. Burton, of Water Fulford. Their pedigree is given as by Necromancer, dam by Woldsman, grand-dam by Screveton, great-grand-dam by Grog. Now all these horses were thoroughbred, and they are the only crosses given. The probability is that the fourth dam was a Cleveland Bay mare of Mr. Burton's-a mare whose sire in all likelihood had no name, or whose pedigree had never been asked for. It is unnecessary to enter minutely into the pedigree of these two horses, but it is worth mentioning that through one or other of the sires named above they descend from such good horses as Highflyer, Sir Peter, Matchem, Snap, and others, whose names appear close to the top of the pedigree. Of Woldsman, who figures in many of the early Coach Horse pedigrees, it may be said that his dam, Young Rachel, by Volunteer, ultimately found her way into Sir M. MI. Sykes' stud, where she became the dam of Lady Rachel, Rhadamanthus, and other good horses. From this it will be seen that it was a high class of thoroughbred that went to the formation of the Yorkshire Coach Horse.

\section{Grey Sires}

Whatever the reason, early breeders of Coach Horses were by no means particular about colour. Indeed, grey thoroughbreds were used freely in making the original crosses, and the names of Delpini, Young Camillus, Trojan, Grey Hautboy, and White Nose are frequently to be found in the old pedigrees, and some horses in which they occur were so freely used as to be entitled to rank amongst the patriarchs of the breed.
If the breeders of the early part of the nineteenth century did not like the grey cross in their stallions for any reason, they were adepts at hiding it; but it is probable that it was not till the century was well adranced that they became really particular about colour. At any rate, a grey horse named IIonarch was extensively used in the middle of the century. He was owned by Mr. T. Stamper, but there seems to be no record of him in the Stud Book-probably because he was a grey. Another grey horse that was much used in the 'fifties was Duncan Grey, and another was Robin Grey. Indeed, in 1856 , at the Cleveland Show at Stokesley, there were six greys shown in the coaching classes, in which there were twenty-eight entries; in connection witl seven of them the colour was not given. Two out of the five brood mares were of that colour, and, curiously enough, one of them was by Rainbow, dam by Nimrod, both of which horses were bays. Instances could be multiplied, but sufficient has been said to show that greys were numerous in the 'fifties. Then suddenly they ceased; a grey Coach Horse at a show was unknown, and the Yorkshire Coach Horse breeders were as careful about colour as their Cleveland Bay breeding friends and neighbours. Much curiosity has been exercised about the reason of this, and various theories have been advanced. One is the peculiar way in which the Cleveland Bay foundation breeds true to colour, a modern instance of which has already been given, and no doubt this did do much to prevent the colour being "swamped" by grey thoroughbred sires. In other words, when it became desirable to get rid of the greys it proved easier to do so on account of the colour inheritance from Cleveland Bay ancestors.

\section{Thoroughbred Progenitors}

The grey thoroughbreds and their descendants have only been touched upon; it now remains to say a few words about the most prominent of the thoroughbred horses, who may be looked upon as the progenitors of the modern Yorkshire Coach Horse. 
First amongst these is Bay President, than whom perhaps no lorse ever did more gond in his generation. Lnfortunately, there is 110 pedigree of him forthcoming, but everything that is known about him is good. He was the sire of Politician President, a very good horse, and through his son, President Junior, he was the grandsire of another good horse in Bay President 922.

\section{The Presidents}

In Volume $\mathrm{V}$. of the General Stud Book, page 128 , Bay President is naned as the sire of Sancho; and on page 295 of the same volume Politician is described as a bay or roan colt by President, dam by Soothsayer, her dam by Deceiver, grand-dam by Dragon. This wonld be the horse known as Poirtician President, and a careful examination of some of the old cards night have taken the matter out of the realm of surmise altogether. A horse named President-probably Bay President-was the sire of Sir Harry Goodricke's famous hunter, to which reference has been made. The Presidents were owned by a Mr. Foxton, of Waitwith, near Richmond, and it is worth noting that in the year following Sancho's birth a bay colt is registered as Waitwith by Bay President or Politician. Mr. William Carter, who used to live at Applegarth Farm, near Richmond, informed Mr. John Osborne that Bay President was a plain horse, on the powerful side, and very short of quality for a thoronghbred. He said he was by a horse called President, a very stylish horse with remarkable quality, and this was all he knew about his pedigree. And here the history of Bay President comes to an end. It is interesting as showing the difficulty which exists in tracing the history of the Yorkshire Coach Horse, and also because Bay President did so much towards the establishment of the Coach Horse as a breed.

\section{Runaway's Offspring}

Another horse that was undoubtedly thoroughbred was Runaway, whose name frequently occurs in the old pedigrees. Here is afforded another instance of the careless way in which the Coach Horse Stud Book was compiled. Runaway's pedigree appears as follows: Sire Escape, dam by Sweetbriar, grand-dam by Misfortune, great-granddam by Curiosity. Misfortune and Curiosity are, in the Coach Horse Stud Book, said to be thorotghbred stallions. But no stallions with those names can be found in the General Stud Book, and Runaway's pedigree should read: Sire Escape, dam by SweetbriarMiss Meredith by Cade, her dam Misfortune, by Dux out of Curiosity, by Snap. Runaway, like Bay President, exercised a strong influence on the breed, and was travelling the country when the thoroughbred was very extensively used. He belonged to $\mathbf{M r}$. Abraham Dunn, and travelled in the district of Pakington, in Holderness.

\section{The Harpham Turk}

The Harpham Turk is another horse that flourished about the same time as Runaway. A remarkably fine pedigree is given of him in the Coach Horse Stud Book. He is said to be by Bedalian, dam by Turk 968, grand-dam by Engineer, great-grand-dam by Whitenose, great-great-grand-dam by Grey Hautboy, great-great-great-grand-dam by Makeless, great-great-great-great-grand-dam by Brimmer, great-great-great-great-great - granddam by Diamond. All these crosses, except Turk 968, are thoroughbred. Now Turk 968 is said to have been owned by a Mr. Farthing, and 110 date is given. His sire is said to have been a horse named Turk, owned by a Mr. Hutchinson. His dam was by Young Cade, grand-dam by Forester, great-grand-dam by the Godolphin Arabian. It is highly improbable that a mare with such a pedigree as the dam of Turk 968 would have been mated with a half-bred horse, and if Mr. Hutchinson, of Skipton, the breeder of Overton Beningbrough, and other good horses, was the Mr. Hutchinson mentioned as the owner of Turk, it is certainly unlikely that the horse would be anything but thoroughbred. He might be Turk, by Regulus-Crab mare, her dan by Childers; and though this horse was foaled in $I 763$, it is quite possible that he might be the sire of Turk 968 withont stretching probabilities very far. The have not found any record of this horse 
coming into Mr. Hutchinson's possession, it is true, but this would require more research than the subject is worth.

We think it may be taken, therefore, that Harpham Turk was a thoroughbred horse, but part of his pedigree seems very open to question. To begin with his sire, there is only one Bedalian in the General Stud Book, by Beningbrough, foaled in ISof. This could hardly have been the sire of a horse that was travelling in I8II, as he was certainly running late in $I 808$, but he may have been trained again after having served mares. We are, nevertheless, confronted with a doubt as to the paternity of Harpham Turk. Then the pedigree may be all right up to Engineer, or even Grey Hautboy; but Makeless, Brimmer (who was out of one of the Royal mares), and Diamond may be regarded with suspicion.

\section{The Second Harpham Turk}

It is greatly to be regretted that no opportunity was taken to verify the pedigree of the Harpham Turks-for there were two of them-when material might have been available. The other Harpham Turk was by Ruler 954, whose pedigree reads by Ruler, dam by Bay Richmond, grand-dam by Hutton's Arabian, great-grand-dam by Blaze, and apparently from the same dam as the furst one. He was sold to the king of Prussia for a large sum, otherwise we should have been tempted to think there was only one Harpham Turk, that he was by Ruler, and was the sire of Bedalian, the Coach Horse, as he undoubtedly was. That the sire of Harpham Turk could not have been Bedalian by Beningbrough has been suggested. There may have been another Bedalian, but there is no record of him in the General Stud Book. Both these horses - especially the one who figures as by Bedalian-were much used, and many good Coach Horses trace their descent to the latter.

\section{Nineteenth Century Sires}

Some great horses that flourished after the middle of the nineteenth century were Inkerman Hero, Paulinus, and Candidate, all of whom call for a word here.
The oldest of them was Inkerman Hero 237, by Remus 396, dam by Severus 958, grand-dam by Paulinus 947, great-grand-dam by Volunteer 652 . He was foaled in 1852 , and was probably bred by Mr. W. Burton, of Water Fulford. He was a great Yorkshire wimner at Northallerton in 1858 , and was extensively patronised by breeders all over the country.

Paulinus was bred by Mr. Beckett, of Deighton. H: was foaled in 1857 , and was by Paulinus 947, to whom reference has already been made, dam by Lambkin (thoroughbred!, grand-dam by Rainbow 385 . Like Inkerman Hero, he was a Forkshire winner, and he also took a second prize at the Royal at Leeds. He was a very famous sire.

Candidate 64 was bred by Mr. John Sherbourne, of Newton-on-Derwent, and was foaled in 1872 . He was by Omar Pacha 326 , a horse that was second at the Yorkshire when two years old in a class for all ages, or by Omar Pacha 325, a Yorkshire wimmer in a class of a dozen at Hull; dam by Candidate $6_{3}$, a Yorkshire winner at South Stockton; grand-dam by Inkerman Hero. With so many of his immediate ancestors Yorkshire winners it is not to be wondered at that Candidate himself took Yorkshire honours. This he did when three years old, and nine years later he was sold to go to New South Wales. He did a great deal of good in England, though there was a strong prejudice against him in certain quarters.

\section{Yorkshire Coach Horse Society}

When the writer was compiling the first volume of the Cleveland Bay Stud Book he included the pedigrees of the three horses just named, and several more that were bred on similar lines. The Editing Committee, however, would not have Coaching blood, and some horses were rejected which had certainly more Cleveland Bay blood than others which were admitted. It was this action of the Editing Committee of the Cleveland Bay Horse Society which led erentually to the formation of the Yorkshire Coach Horse Society, which was incorporated 


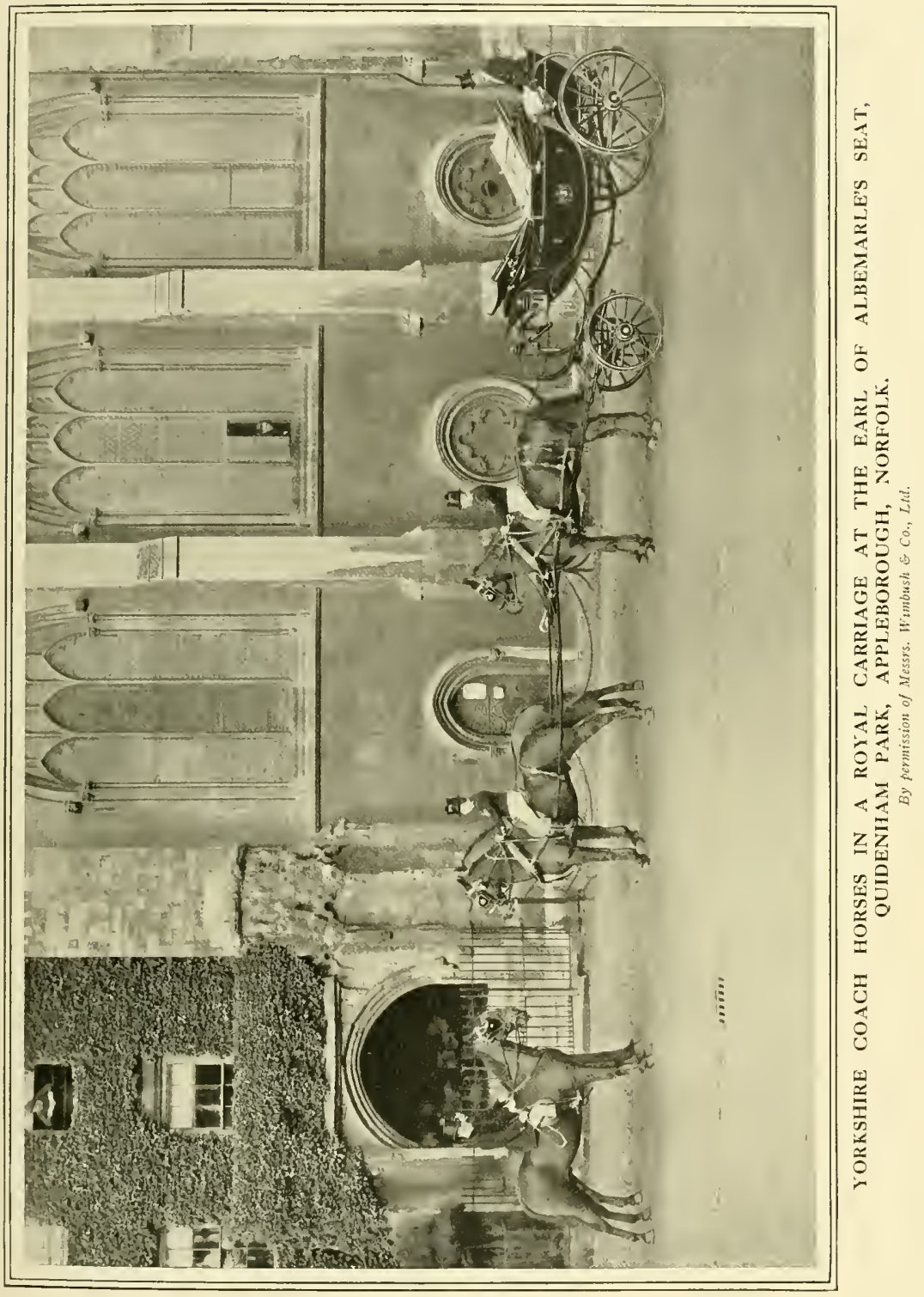


in I886, two years after the formation of the Cleveland Bay Horse Society.

There was no help for there being two sucieties, for the Editing Committee and Council of the Cleveland Bay Horse Society were obdurate, and there were many very excellent horses, for which there was a strong foreign demand at the time, which could not be registered in any Stud Book which was then in being. This registration difficulty, of course, had its effect upon trade. Some attempts were made to get horses admitted into the Cleveland Bay Stud Book under Cleveland Bay pedigrees, and some of these were successful.

But the great body of Coach Horse breeders stood aloof from these practices, and formed a society of their own.

So long as trade was really brisk no great harm was done; but when the reaction came the position of both breeds was decidedly weakened by divided counsels and divided interests. It is useless to go into details now or to criticise more particularly the action of the two societies; but it may be pointed out that a breed society should be something more than a mere trade protection society, and a Stud Book should be something more than a trade register. It was impossible to make the majority of those interested see this in the 'eighties, and the consequences have been serious.

\section{Attempts at Amalgamation}

It remains to say that two attempts have been made at an amalgamation of the two societies, but both failed. The first was made soon after the formation of the Yorkshire Coach Horse Society, and on the initiation of that society, and a special committee was appointed by each society to confer on the matter. The conference was held, but the committee appointed by the Cleveland Bay Horse Society adopted a policy of non possumus, and did not make a report. That was the time for an amalgamation, for then the breeds could have been kept distinct, and there would have been no difficulty in forming a powerful association to safeguard the best interests of both. When the second attempt was made a few years ago it was too late.

\section{Crosses with Yorkshires}

The Yorkshire Coach Horse, like the Cleveland Bay, is admirably adapted for crossing, and herein lies one of the great dangers to the breed. The Hackney cross has been incidentally referred to in connection with Cleveland Bays, and the Hackney cross is a very serious danger to the Coach Horse.

It was a principle with the early Coach Horse breeders that there should be no admission of any carting or Hackney blood under any circumstances, and the breeders of half a century ago would as soon have thought of mating their mares with a Shire Horse as with a Hackney. " Old-fashioned," " did not march with the times," say the men of the present day who are using the Hackney cross; but there was sound sense in the old policy.

It mav at once be admitted that there is a demand for the harness horses bred on the lines indicated, and that good geldings by Hackney sires from Coaching mares meet with a ready sale. But these half-breds should not be shown in Coaching classes, in which they usually win. The men who show them know it is unfair, and, with one or two exceptions, are careful not to give either name or pedigree.

\section{Dangers of Crossing}

Putting aside the unfairness, there is, however, a very serious danger. A gelding can do no harm, we know; but what is to come of the fillies bred on these lines? Nay, what does become of them? Do they by any chance find entry into the Stud Book? The writer can say that so far as he has seen this has never happened yet, but it is quite conceivable that it may happen. Indeed, it is conceivable that it may happen quite innocently, for some of the horses I have seen that are bred this way are shaped quite on Yorkshire Coach Horse lines, and the great-granddaughter of a Hackney sire might easily get into the Coach Horse Stud Book. It should not be necessary to insist 
upon the danger that would ensue if a system of cross breeding such as this were to become possible and were to be sheltered under il society, the ostensible object of which is to preserve the Yorkshire Coach Horse as a pure breed.

The greater number of breeders is strongly opposed to the state of things which prevails at some shows, but they seem to let grumbling suffice. At many shows the half-bred is shown as a Coach Horse as a matter of course; at some a Hackney is shown as a Coach Horse and no notice taken. The Hackney probably wins on action, and evervone sees his name in the paper, and his prize-card shown about; whilst if he is disqualified-which is by no means certain, for, especially at district shows, points are sometimes very much strained to prevent a disqualification-no one knows of it.

It seems that the breed societies ought to take this question up and deal with it in no half-hearted way. They have considerable power-quite sufficient power and influence, indeed, to make their protests respected by the executive of any show.

\section{Famous Mares}

Perhaps no history of the Yorkshire Coach Horse would be complete unless a few words were said about one or two of those famous mares of which the Yorkshire Coach Horse breed has had so many. For if these mares have not founded families as have some of the Cleveland mares, at any rate, so far as can be traced, there have been many mares whose individual form has ranked as high as Sunflower or Wonderful Lady, or any, indeed, of the great Cleveland Bay mares that have been treated of.

\section{Flora and Patience}

Mr. Kirby's Flora was one of the great mares of the breed. She was a big, fine mare, with remarkably good look-out and quality and a fine mover. She was bred by Mr. Bilton, of Snowthorpe, and was by The Earl 474 , a horse that strained back to the Hob Hill Horse on his sire's side, dam by the Aristocrat +72 , grand-dam by Hopeful, a Cleveland Bay. Flora was very in-bred to
Inkerman Hero, and the thoroughbred Necromancer-hence, no doubt, her exceptional quality. She was a great prize-winner all over the country, and amongst her long list of rictories are two firsts and a second at the Royal, and four firsts, a second, and a third at the Yorkshire. She was a good breeder, and had her eleventh foal running with her when she was eighteen years old. The two stallions she bred were sold young. The best of her mares was Lady Mary by the Clevelind Bay, Leverton. Lady Mary won as a yearling and two-year-old - the only times, we believe, that she was shown-and was the dam of three stallions that sold for good prices.

Mr. Kelsey's Patience was another great mare. She was five years younger than Flura, so that when she was in lier prime as a brood mare Mr. Kirby's mare was begimning to go back. She was Flora's only formidable rival, and in later years when they met she had all the best of the handicap. She was by Cyrus I I3, dam by Venture 5oI, grand-dam by Inkerman Hero 237, greatgrand-dam by Faithful, so that she had more Coaching and less Cleveland Bay blood than Flora. She was a very handsome mare, an aristocrat all over, and a fine mover. Her prize record was a remarkable one, as she won five times as a brood mare at the Royal and seven times at the Yorkshire, which is a record. She was a very good breeder, and lived to a ripe old age. Amongst her produce were some excellent stallions, and the last colt she bred-Partners-was a prize-taker at the Yorkshire.

\section{Bonny's Record}

The only other mare there is space to refer to is Mr. Reader's Bonny, and she merits special notice, inasmuch as she is the only one of the great mares by a thoroughbred horse. She was by Cawston, dam by Lord John 267 , grand-dam by Candidate 62 , greatgrand-dan by Necromancer, thoroughbred. She was full of thoroughbred blood, and looked like it. She was very successful in the show ring, taking i 5 first prizes. Slie was also a great brood mare, and bred for her owner nineteen living foals, which won 
at one time or another 300 prizes. She was twenty-nine years old when she died. Her grandson, Beacon Prince, by Prince Victor 376 was the best of the family, and the best Mr. Joseph Reader ever bred. He was not a very big horse, but was compact and full of quality, and had upwards of fifty prizes to his credit.

Two typical stallions of the present day, both of them Yorkshire winners, may be named incidentally. These are Mr. Stericker's Breaston Prince, and Mr. Sylvester Leaf's Star of Yorkshire. Both are big, fine horses, and typical of a breed that should not be allowed to die out. If activity, combined with power, is of any use as a foundation for breeding, the horse that is wanted and that will be wanted for general purposes - and they are and will be wanted, in spite of the motor-car-would seem to any unprejudiced man to be the breeds which produce such horses as those which have been mentioned. In Breaston Prince, who is quite the old-fashioned type of Coach Horse, there is a lot of Cleveland Bay blood; indeed, he is all Cleveland Bay except his dam's sire, who was by the thoroughbred Tynedale; and it should be remembered that to retain the size and power which are so essential, recourse must constantly be had to the Cleveland Bay.

With varying fortunes the Cleveland Bay and lorkshire Coach Horse have taken a leading part in light horse breeding during the last hundred and fifty years. Nor has this been confined to England alone. In Europe, America, Africa and Australia, the two breeds have done much in the way of improving the general utility horse. They have, indeed, been the foundation of half-bred horse-breeding. Whether their day is done is an open question. The breeds have been at as low an ebb before, and have recovered, and they may do so again. But if they do not, breeders of general utility light horses will, in a generation or two, be met by some problems that will not be easily solved.

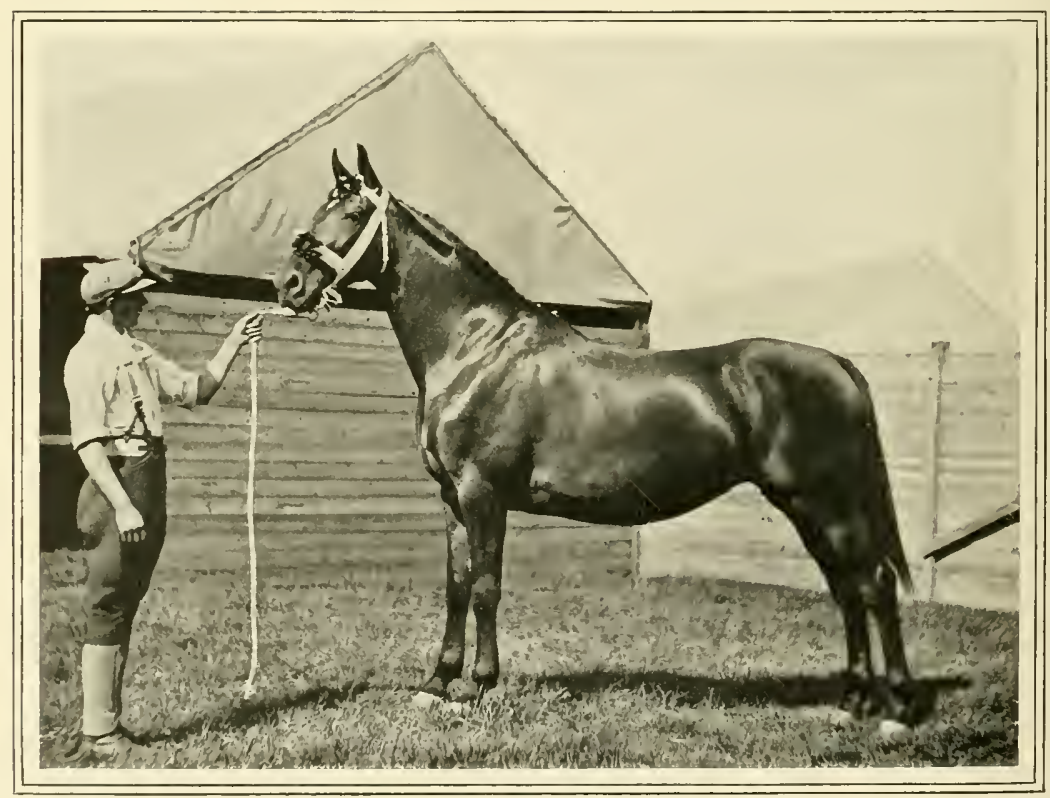

MR. W. G. GRANDAGE'S MARE, WOODLANDS BRION. 


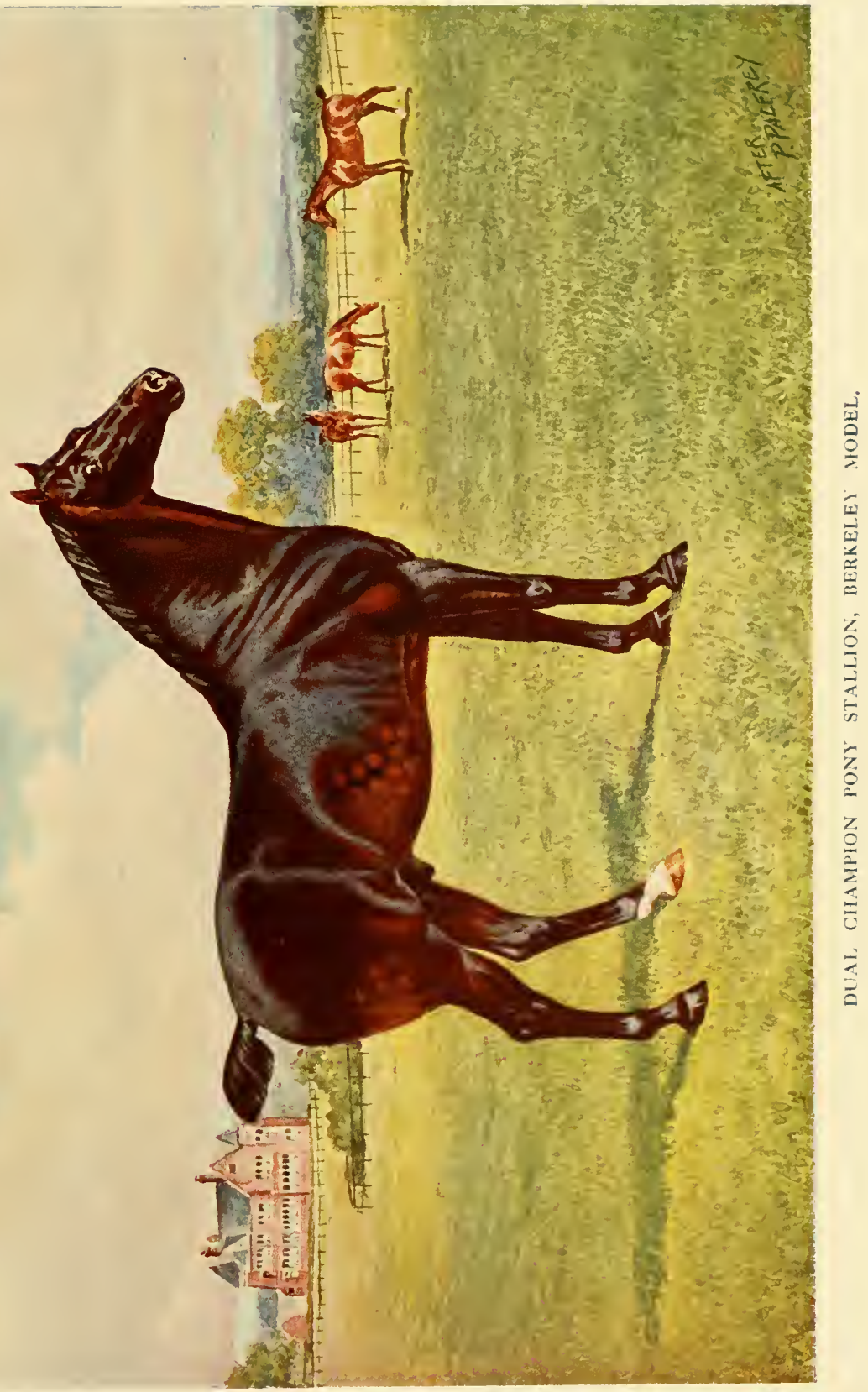





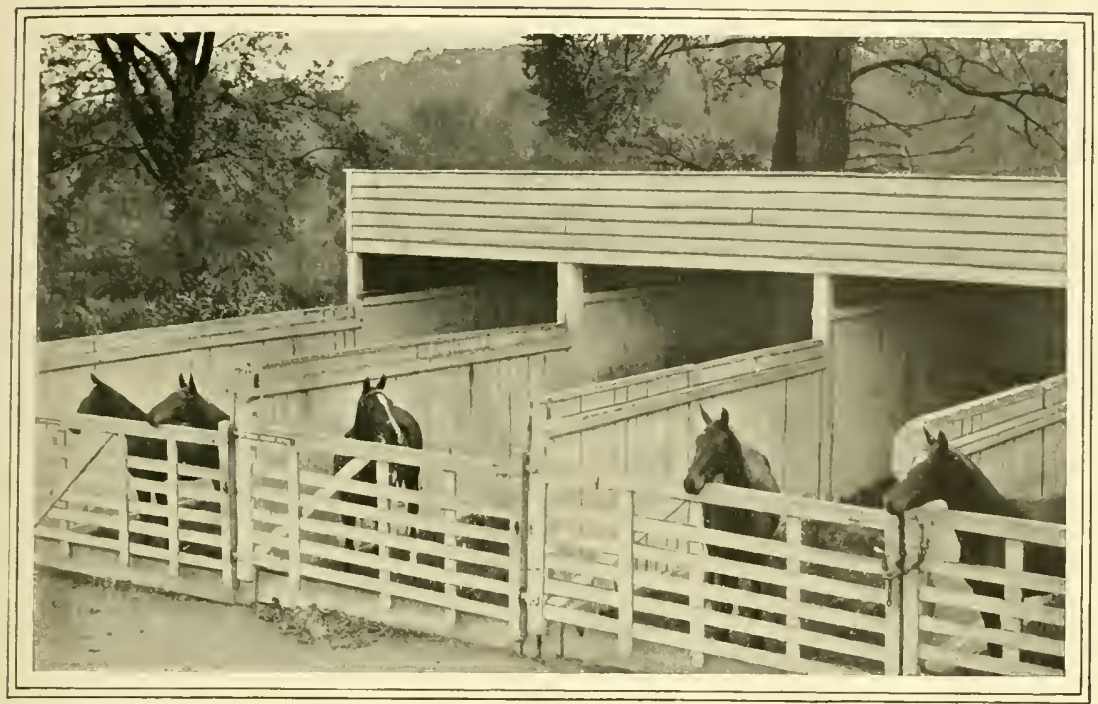

MR. TRESHAM GILBEY'S POLO PONY STABLES AT BISHOP'S STORTFORD.

\section{CHAPTER XXIV}

\section{POLO AND POLO PONIES}

CINCE polo became a fashionable game $S$ in the United Kingdom many volumes have been published, some of which treat of its early history, while practically all of them describe the game itself. Already the literature of polo has assumed goodly dimensions, and as the game has developed it has become more scientific, whilst its popularity has shown a rapid and continual increase. It now gives employment to thousands of little horses, which are commonly called Polo Ponies, and for this reason it is entitled to recognition in the present work.

The ponies used for the game concern us here more than the game itself, but brief mention of the latter must be made, and two important points to be noted are, firstly, that polo is probably the oldest game in the world, and, secondly, that it is the only game played in the kingdom in which the players are mounted. As to the age of polo it is difficult to speak with certainty, but the game was brought here from the East, and had undoubtedly been played there for nearly two thousand years before it was seized upon and copied by British players. Mr. T. F. Dale, who has written profusely on polo, stated in a book published some four or five years ago that polo was played about 600 B.C. by the Persians, while the late Mr. Moray Brown-one of the pioneers of polo in this country-wrote in the Badminton Library polo volume an account of the game as it was played in Persia more than a thousand years ago between Persian horsemen and Turks. There are in this same volume a copy of a Persian manuscript in the British Museum, showing incidents in a game of chaugan (the Persian name of polo), and a reproduction of a later 
drawing which depicts the Emperor Akbar pliying polo with his courtiers in the sixteenth century. This emperor reigned between 1555 and 1605 , and played chaugan. chiefly at a place called Garríwáli, abont four miles from Agra.

\section{Introduction of Polo to India}

Long before the date just given, polo, or a game which much resembled it, was played in China, and, indeed, there is evidence to the effect that it was popular in nearly all those Eastern countries in which there were suitable ponies, and where horsemanship was considered to be of the first importance. In $185+-55$ it was first played in British territory, by the tea planters of the Cachar district, being introduced to the British by the Manipuris, who luad settled there, bringing with them polo ponies. After the Indian Mutiny the game became so popular that steps were taken to form a club, and the first meeting was held in the bungalow of Captain R. Stcwart, Deputy Commissioner of Cachar in I859.

In the plains of India the game was first played in 1862 , between officers of the

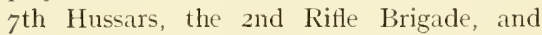
the 8oth Regiment of Umballa. It was then called "hockey on horseback," but shortly afterwards it was generally known as polo, the word being derived from the Thibetan word pulu, meaning a ball made from a knot of willow wood. In Calcutta polo was first played in 1864 , when Major Sherer, one of the original members and promoters of the first British polo club at Cachar, brought a team of Manipuris down from the country to show how the game should be played. Polo at once became a prominent pastime amongst Anglo-Indians, and Major Sherer, who has often been spoken of as "the father of polo," was entertained at a banquet, and presented with a handsome silver tankard and salver.

\section{Polo in England}

As to when polo was first played in England there has been some difference of opinion. It has been stated, and some- what widely believed, that it was brought from India by a certain cavalry regiment, which had recently come home from the East. As the game had been played a good deal in India during the late sixties, this idea was naturally adopted by those who considered the matter, but Mr. Moray Brown has asserted confidently that the initiators of the game in this country were certain young subalterns of the roth Hussars, who were quartered at Aldershot in 1869 . It is said that some of these gentlemen, having read an account of the game, as played by the Manipuris, at once decided to try it. They began on their chargers, using crooked sticks and a billiard ball, and quickly found out that chargers were too big, and a billiard ball too small and heavy. They were not disheartened, however, and having deputed one of their number to go to Ireland and buy ponies, they quickly formulated a game on the lines of that played by the Manipuris in India.

\section{First Polo Match}

The gth Lancers at once took the game up, and between this team and the Ioth Hussirs the first English polo match was played in I87I (?), there being eight on each side; a small ivory or bone ball was used, and ash sticks. According to Mr. Moray Brown, by the way, a game was played in Richmond Park by a mixed team of the Ist Life Guards and the Blues (Royal Horse Guards) against a mixed team of the gth Lancers and Ioth Hussars, which the Guards' team won by four goals. The date of the game, as given in the polo volume of the Badminton Library, is probably wrong, though it is quite certain that such a game did take place; and, in fact, the names of the players were all given. In I872, on July I6th, a much nore important game was played in the Home Park, Windsor, between officers of the Blues and officers of the gth Lancers, the then Prince and Princess of Wales, the Duke and Duchess of Teck, and a very fashionable attendance watching the play. This game was duly reported in the 
Ficld, and from this account we learn that Lord Horcester (now the Duke of Beaufort), Lord Arthur Somerset, Messrs. T. and C. Fitzwilliam, Lord Kilmarnock, and Ir. C. Egerton represented the Blues, and that Lord William Beresford, Captain Clayton, Captain Palairet, Messrs. Mowre, Green, and Wheeler did battle for the Lancers. The same account states that the competitors were mounted on strong, active ponies, and each man was armed witl a hockey stick about four feet long, the handle of which was of bamboo, with the head flat and fixed on at an angle. The ball was little larger than a cricket ball, and painted white to be easily distinguishable when rolling. The ground marked off was about 400 yards in length by 200 yards in width, and consisted of good level turf, a goal being placed at either end with Hlags. After this follows a graphic account of the game, and the writer concludes as follows: "It was certainly the general opinion that the inauguration of the Eastern game as a public spectacle had been a great success, and there can bc little doubt that we shall find polo ranking henceforth among established sports, at least among the officers of our cavalry, to whom it is especially suited. We did not observe that the animals ridden in the game of Tuesday were in any way distressed, although they were not changed during the game; but then . . . they were rested for a few minutes as opportunity offered."

\section{Early Clubs}

This is the first actual newspaper account of a polo match in this country, and in discussing it and other matches of about that date Mr. Moray Brown tells us that hard hitting was then unknown, the game, which was played almost at a walk, consisting mainly of dribbling and scrimmaging. Neither were the ponies trained to the pitch of perfection they now are, and anything was thought good enough to play on. The Ioth Hussars went to India shortly after this game, but the gth Lancers continued to bring polo into prominent notice, and in 1872 Captain F. Herbert, who bad just lett the regiment, founderl the Monmouthshire Polo Club, which was the first provincial clul to come into existence. Abont this time, or a little later, it polo club was formed at Lillie Bridge (in London) and many regiments took up the game, as did the horsy sets at Oxford and Cambridge. A very early provincial club was formed at Newcastle-on-Tyne also, their ground being on the Town Moor, which was then the local race-course as well. The Newcastle Club had a short life, and for many years polo was hardly played in the north, except at York and Edinburgh, where the soldiers quartered there were frequently imbued with the spirit of the game.

\section{Hurlingham and Polo}

The Lillie Pridge ground was soon found to be too small, and in $187+$ polo was played at Hurlingham, which place from that date onwards has been the headquarters of the game in this country. Fresh rules were drawn up, under the auspices of the Hurlingham Committee, and since I 876 the game has been played much more scientifically than it was during the first few years of its English life. Perhaps the most important changes were the reducing of the teams to four, the increase of pace, the substitution of hard hitting for dribbling, the improvement in balls and sticks, the organisation which gave to each member of a team his position in the field and distinct duties, the introduction of the back-hand stroke, and, last but not least, the fact that there was a gradual, but steady increase in the height of the ponies.

The changes which have been mentioned were very gradually brought about during the late 'seventies, and for many of them the brothers Peat, and the late Mr. John Watson-afterwards Master of the Meath Hounds-were responsible. These early players were mainly instrumental in bringing the game to its present state of perfection, and Mr. Watson not only did a great deal for polo in this country, but also in Ireland, where his father, the late Mr. 
Robert Watson-for fifty years Master of the Carlow and Island Hounds-was one of the earliest players, though well up in years when he first took to the game.

\section{Size of Ponies}

It must be understood that during the 'seventics very small ponies were used, many of them not exceeding thirteen hands, but it was being gradually found out that the bigger pony was faster and just as easy to play, and the height rose until the present limit of It.2 hands was reached. Meantime, civilian clubs were springing up all over the country, and at many of these the game was played in rather slipshod fashion for a year or two, probably because the players had seen little of the best polo then being played in London, and because of the difficulty there was in procuring suitable ponies. The fact is, that dealers were not very quick to recognise the demand, and at first there was little inclination on the part of players to pay the high prices which have since become quite common. At one country club the players got through a season (of sorts) by playing their hunters, and at other places there was at first no hard and fast rule as to height, and beginners took their lessons on any handy mount, whether he was horse, medium sized, or little pony. Then there was a rush for Argentines, Arabs, mustangs, and all sorts of foreign horses; but by this time it was being gradually discovered that the best English and Irish ponies, of the glorified cob type, made the most useful players, and all sorts of people were on the look-out for them.

\section{Growth of Polo}

In 1800 thirty clubs were registered at Hurlingham, of which three were metropolitan-Hurlingham, Ranelagh, and the Middlesex-one or two suburban, and all the others provincial. Only two military clubs were included in the list, but there must have been nearly as many of these as there were of civilian, and the two included were not regimental, but garrison clubsCanterbury and Aldershot, to wit.
In Inog the numbers were four metropolitan clubs, forty-five civilian provincial clubs, seven garrison clubs, six private Service clubs, three private civilian clubs, two private grounds, thirteen Irish county or civilian clubs, and one Irish garrison club, which gives a total of eighty-one. There were, in addition, the garrison clubs of Gibraltar and Malta, and twenty-one foreign clubs were also affiliated to Hurlinghan, so that the number had more than trebled in less than twenty years. This shows how rapid the growth of polo has been, and it may further be mentioned that during the period of less than thirty years in which it has been played in the United Kingdom there have been many other clubs which have come and gonein the natural order of things.

\section{An Expensive Game}

The greatest drawback to polo is that it is an expensive game. It has doubtless cost less in those regiments which have a regimental club with ponies of its own than it has to the individual player who has to provide his own ponies; but in any circumstances the expenses must be very great, for good ponies in these days are extremely valuable, and those which are short of pace, or awkward to play, are of little use in polo. There have been, and there still are, certain clubs where the standard is not very high and where it is possible for the man of medium means to play; but in good tournament company fast ponies are imperative, and no matter how well a man plays he cannot do himself justice if the pony he is riding is short of pace. In these days it is the fashion for a considerable number of the best country players to pass several weeks, if not the whole season, in London, and to play regularly at Hurlingham, Ranelagh, or Rochampton. It need hardly be said that such a programme is not within the reach of evervone, but there are many men who are wealthy enough to maintain a big stable of ponies, and, if they are good enough players, to take part in games all through the London polo season, which lasts from 


\section{POLO AND POLO PONIES}

the beginning of May until almost the end of July. Poor players who are not up to the form shown in the average London tournament soon dirop out, no matter how good their ponies may be, for nowadays there are so many spectators and so much give an instance, Lord Harrington was born in $\mathrm{I} 8+4$ and was playing in Igo8, when he was temporarily disabled by an accident. The late Mr. Robert Watson was well over sixty when he ceased to play, and many others could be mentioned

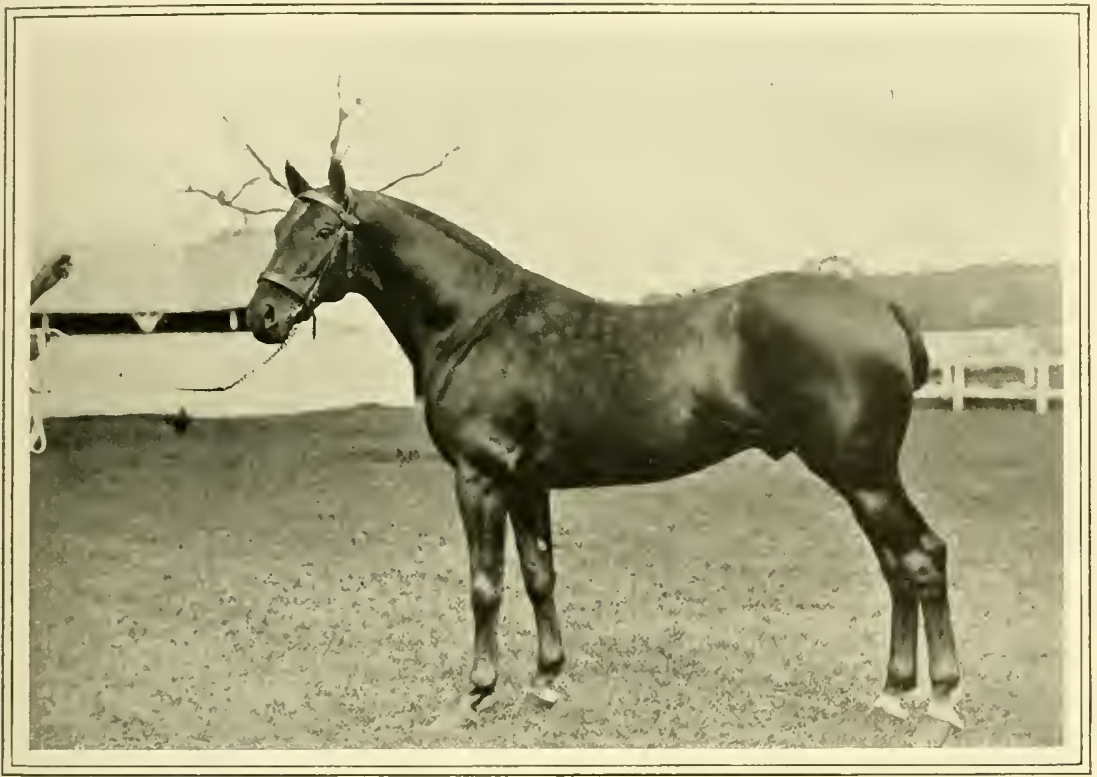

SIR J. BARKER'S POLO PONY, SANDIWAY.

criticism when any important match is played that mediocrity has little chance of escaping notice.

At the same time, there are many junior tournaments in which the novice has a chance to distinguish himself, and it is just as easy for polo talent to assert itself as it is for the promising young cricketer to obtain the notice of experts of the game. In fact, there is probably no game in which the youngster is given a better chance than in polo, and thus it is that there are always young players "coming on" to take the place of those who drop out. And in polo, if a man is light and active, and keeps himself in condition, his period of play can be a very long one. Fair players of sixty years of age are not uncommon, and, to who have played in first-class tournaments after they had passed their fiftieth year. Players of forty years of age and over are common on every polo ground, while, on the other hand, boys are seldom seen in a game, and probably a majority of players have their first lesson either at one of the Universities or as subalterns in the various polo-playing regiments.

Nor does the average player arrive at his best form very early in his playing days. Polo requires an immense amount of practice, especially in striking the ball. A clean, hard striker is always a valuable asset to a side; but clean striking is only arrived at after constant practice, and polo differs from golf in that the striking has to be instantaneous, and the ball is 
ofteis moving. The golfer can take as long as he likes for swing, and so forth, before he strikes at a stationary ball, but the polo player has to seize the vital moment and deliver his stroke at a ball which he nay he meeting, which may be going from him, or may possibly be lying still. He has, too, very often to race against another player for possession, and, in fact, all polo strokes are the work of a moment, and must be delivered at express speed. The average boy who is horsy and kcen on games has little chance of playing polo, and, as a rule, his chance does not come until he is fully grown up, and then only if he is possessed of means and has the leisure time in which to play.

All this goes to show that polo will never be a sport of the people; but, for all that, the game increases in popularity, and at the present day the tournaments at Hurlingham, Ranelagh, and Roehampton are watched by thousands of spectators.

\section{Principal Tournaments}

Some of the principal tournaments are the Hurlingham Champion Cup, the Ranelagh Open Challenge Cup, the Ranelagh Army Cup, the Ranelagh Points Challenge Cup, and the Roehampton Cup. There are also the Hurlingham Social Clubs Cup, the Ranelagh Hunt Challenge Cup and Hunt tournament, the Ranelagh Subaltern Challenge Cup, the Ranelagh Novices' Cup, and the Roehampton Junior Championship. These are all decided in London, as are such games as Oxford $\because$. Cambridge, Lords \%. Commons, and England \%. Americal.

Probably everyone knows that the America Challenge Cup is now in the possession of an American team, who won it in Igon. This Cup was first played for at Newport, Rhode Island, U.S.A., in I 886 , and was won by England, the players being the Hon. R. T. Lawley, Captains T. Horn and M. Little and the late Mr. John Watson. Two matches were played, both of which were won by England. In Igoo America sent a team over, but only one match was played, England winning by eight goals to two. Mr. John Watson again played "back," the other members of the team being Captain Beresford, and Messrs. Freake and Buckmaster. In IgO2 America again challenged, and three matches were played at Hurlingham, of which England won two and America one. It was the first of the three which went to the strangers by two goals to one, but the English victories in the second and third matches were most decisive, England winning by six goals to one, and seven goals to one.

There were no further international matches until rgog, and then the English were badly beaten twice, and at the moment the Cup remains in America. It may be here mentioned that in American polo there is 120 " off-side" rule, but otherwise the game is played on similar lines in both countries.

\section{The County Cup}

Another very important annual competition is the County Cup, which has had an existence of five-and-twenty years. The word "County" in this connection lardly signifies that the nembers of each team should belong to one and the same county, for as a matter of fact the contesting teans are drawn from the provincial polo clubs, and the signification of the contest would probably be better explained if the tomrnament was called the Provincial instead of the County Cup. The All-Ireland Open Cup, played in Dublin, also takes rank as one of the most important toumaments, and at many of the provincial clubs there are, most frequently in August, tourmaments which draw their players from among the best polo exponents of the day.

\section{Polo Associations}

Mention may also be made of the Polo Associations. There are three in the United Kingdom: the County Polo Association (Great Britain), the Army Polo Committee of Great Britain, and the Irish County Polo Club Union. There is also the Indian Polo Association, and the United States Polo Association, which is the governing 
body of all States except California. In the United Kingdom the Hurlingham Club Polo Committee is the governing body of the game; and to it are affiliated all the polo clubs of the kingdom. In fact, what the II.C.C. is to cricket, Hurlinghum is to polo, and it is from Hurlingham that the Recent Form List was, and the Goal Handicap now is, issued. The Recent Form List is a sort of first class of polo players, compiled by the Hurlingham Comnittee, to which only those who have greatly distinguished themselves in the best sort of toumaments belong. As a rule, there were some five-and-twenty to thirty players included in the Recent Form List, and in many matches played during the season only one, or perhaps two, of these players were allowed to compete on the same side, while in certain junior matches they were excluded altogether.

The Goal Handicap has lately been instituted, and takes the place of the Recent Form List.

\section{Polo Ponies}

As polo has become faster and more scientific, so has the Polo Pony advanced, until now the most perfect animals of their inches are used in the more important games. From an original height of some"here about $I_{3}$ hands, the size has been increased to If. 2 hands, and, according to the Hurlingham rules, no pony shall be played either in practice games or matches until it has been registered in accordance with the rules of measurement. These rules are very stringent indeed. They provide that all measurements shall be made by an official measurer under the supervision of the Polo Committee, that such official measurer shall be a duly qualified reterinary surgeon, and that he shall attend on certain days, both at Hurlingham and at such local centres as can be arranged for. A fee has to be paid for every pony measured, and ponies of five years and upwards can be registered for life, while ponies under five years can be registered for the current season only. The official measurer is empowered to determine the age of each pony brought before him, and there is a rule that no pony can be registered for life in the months of January, February, and March unless at least two permanent corner incisor terth are actually through the gum; and on and after April I5th a pony must have a complete mouth of permanent incisors to obtitin a life certificate.

This, it will be understood, makes it almost impossible for a four-year-old pony to secure a life register, though such things as "freak" nouths are not unknown. Apropos this point, there was, some twenty years ago, an awkward, angular thoroughbred at the now defunct Woodlands Stud, who defied the opinions of many veterinary surgeons. Towards the autumn of his yearling days he stood well over I6 hands, and though an ungainly beast. had great bone and size everywhere. His mouth was so forward that a stranger was always greatly puzzled to decide what his age was, but his general appearance suggested a three-year-old who had never been trained, or even broken. One day a foreign nobleman visited the stud, with a view to purchasing yearlings, and brought with him a well-known veterinary surgeon. Aiter the horses for sale had been inspected, the wergrown yearling was brought out, and the "ret." asked to say what his age was. The man looked the colt carefully over, and at last pronounced, "A backward four-year-old who has done no work, and with a two-year-old month." The colt at the time was just twenty months old, but had grown in such abnormal fashion that he deceived everyone. It may be added that in spite of his size he had no pace whatever, and he was eventually sold to a livery stable keeper for a few pounds.

\section{Rules for Measuring}

Going back to the Polo Ponies, it may be mentioned that the rules with regard to the actual measuring are of a most stringent kind. The standard used for nreasuring has to be approved by the Hurlingham Club, and a specially erected 


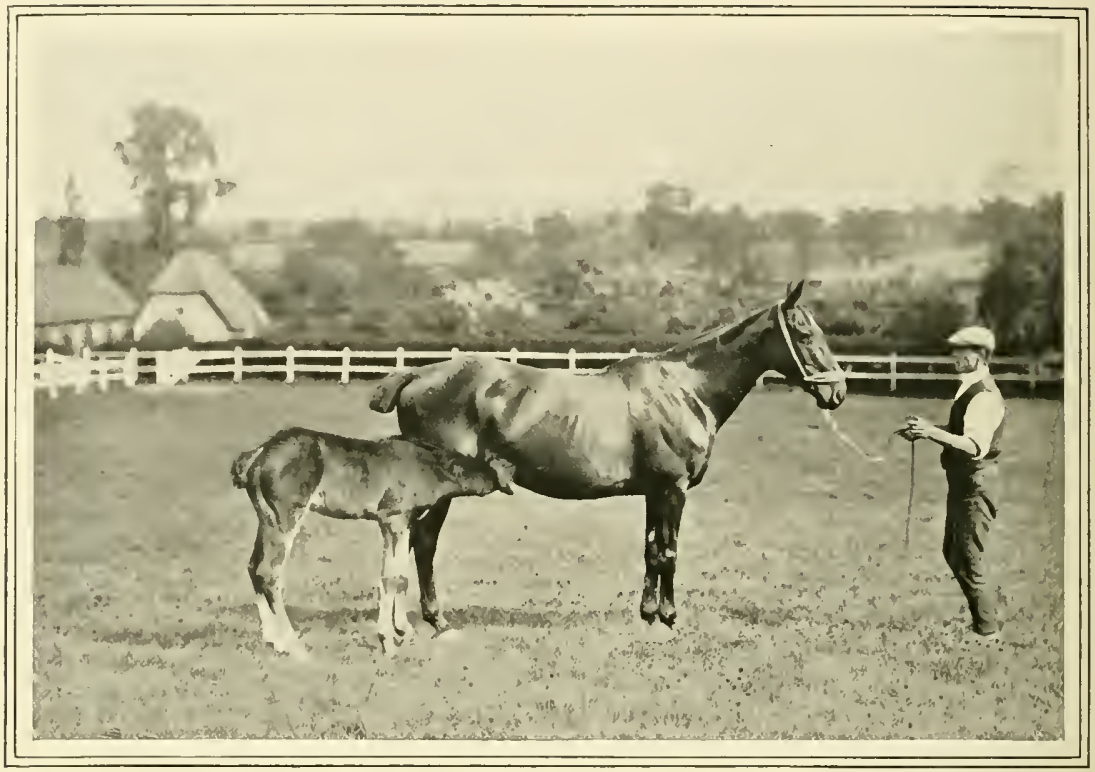

SIR JOHN BARKER'S POLO PONY MARE, SAPPHIRE, WITH FOAL, BY SANDIWAY,

box, with a level floor, is the scene of the operation. The pony must be held by a person deputed by the measurer, and not by his owner or groom. The head has to be held in a natural position, and the forelegs from the point of the shoulder, and the hind-legs, from the back downwards, have to be as perpendicular to the floor, and as parallel to each other, as the conformation of the pony will allow. And though the wither may be shaved, the mane must not be pulled down, nor the skin of the neck or wither in any way interfered with; ponies may be measured with or without shoes, but no allowance is made if the shoes are on when the measuring takes place. The owner and his servant are not allowed inside the box during the measuring process, and indeed no one except the measurer, his assistant or assistants, and members of the Polo Committeewho, by the way, cannot be present when their own ponies are being measured. It will be seen, then, that everything is done to keep the regulation height of 14.2 hands, and yet it is an open secret that many ponies are being played which, though they have been duly registered, are well over the regulation height. The fact is, that a fair number of ponies grow considerably after they are five year old, and, again, ponies of the right age are brought up to be measured which have spent most of their youth running out on poor, or poorish land, who have had little corn or good keep, and who are low in condition. Some of these ponies may first have been discovered in the wilder parts of Ireland or elsewhere, and they are genuine five-year-olds who are, nevertheless, so backward as to be an inch or two lower at the withers than they would have been had they been nurtured on a liberal diet. When properly cared for and well-fed these ponies continue their growth, and though, as a rule, they do not become much higher, some of them certainly go well over the polo height during the course of the next year. Quite lately a Master of Hounds bought " a 
registered Polo Pony" to carry one of his whippers-in-a 9-stone man who liked little horses to ride. The pony was sold at auction, and had been played for a couple of seasons, but with thin shoes on and iairly meas red he cannot be made less than I5. I $\frac{1}{2}$ hands. Probably his growth after five years of age was abnormal.

Polo Ponies, say from ten to twenty years ago, varied greatly in appearance. In an ordinary game would be seen the undersized thoroughbred, the strong cob, the Arab, the mustang, the Argentine (at times), the Syrian, the Indian country bred (very occasionally), and, in fact, any and every sort of horse who was of polo size and able to travel at a fair rate of speed. In these day's there is much more uniformity of type, as anyone who attends the annual shows of the Polo and Riding Pony Society at Islington in March is weil aware.
But some vears ago it was recognised that the English or Irish-bred pony, by a thoroughbred sire, and, if possible, with a strain of pure pony blood on the dam's side-either Welsh, Exmoor, Dartmoor, New Forest, or Connemara-was the best playing pony, and on these lines was formed the Polo and Riding Pony Society, with a Stud Book of its own and an annual show at Islington for the last ten years. So far, not a great deal has been done towards breeding this particular class of pony, but the fact is that no very great number of people interested in polo have taken up the idea, and though first-rate results have been obtained at one or two studs, the number of Stud Book bred ponies is at present ridiculously small compared with the number of ponies which is required to mount all the players in any one year. Nor can a distinct breed be

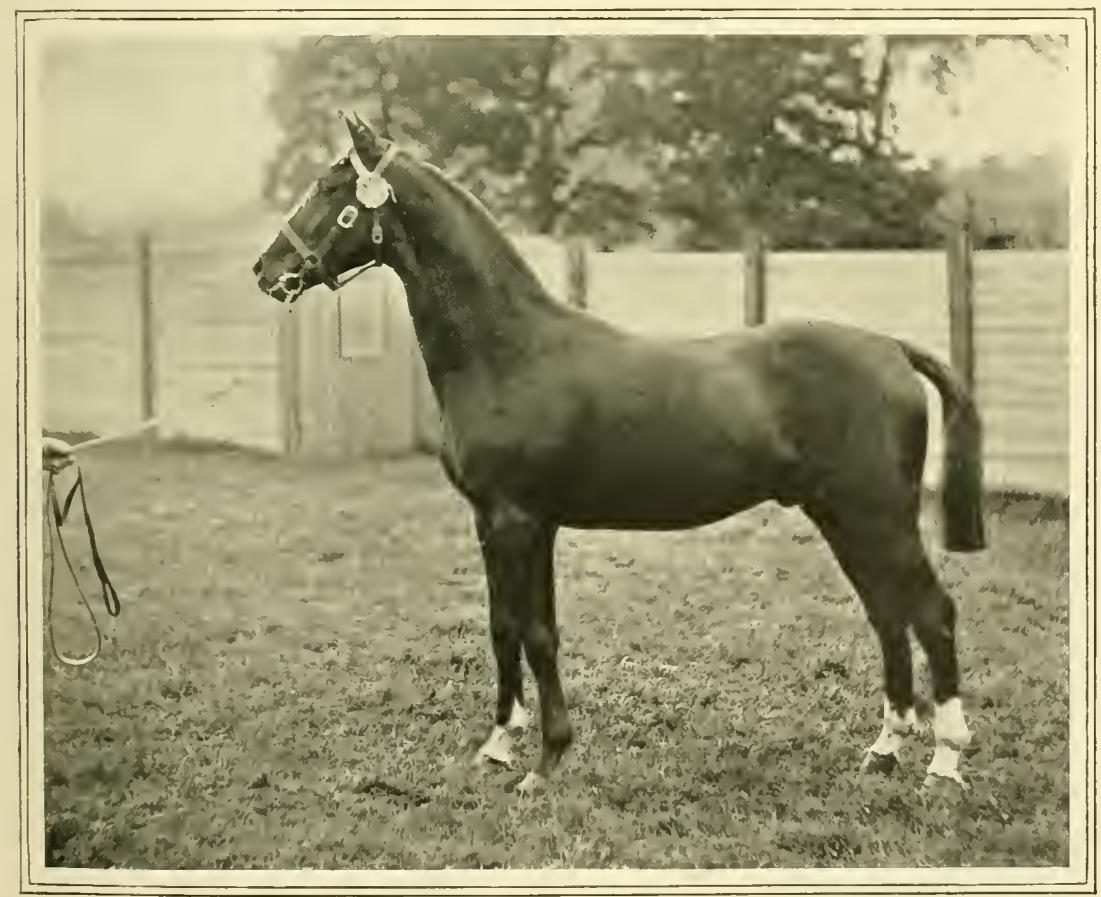

POLO PONY STALLION, WHITE WINGS, OWNED BY THE KEYNSHAM STUD CO. 
raised in a very short space of time. There nust be a certain number of foundation mares, if possible, of, or going back to, sume pure pony breed, and the produce of these must be mated, and their daughters mated again, with the small thoroughbred sire before the necessary height and size are forthcoming. The native ponies of distinct breed are, as a rule, much too small for polo, except perhaps the Comnemara ponies of Ireland, and very often the first cross is also far too small. It is, too, not a bad plan to cross the mative pony mare with the Arab first, and then to mate the female produce with the English thoroughbred. This gives a return of Eastern blood -the derivative of the English thoroughbred-and makes for strength, constitution, stamina, and other hereditary qualities of the best sort.

\section{Pony Characteristics}

Polo Ponies which are to hold their own in the best company must be fast, active, and strong, and must also be well broken, with perfect manners. They must be what is generally called handy, which moins that they can be pulled up in a stride or two, and can be quickly turned. A pony which is not clear in its pipes is not worth playing, and an impetuous pony, which always carries its rider several strides further than he wishe's to go, and which cannot be pulled up in a moment, is of little use in a game. Luckily, roaring is nothing like so common in ponies as it is among horses, but it must in Polo Ponics be avoided at all costs, and therefore one thinks that breeding from either sires or mares which "make a noise" is to be condemned altogether. It is true that many good racehorses, quite free from wind infirmity, have been bred from roaring sires and dams; but, on the other hand, roaring is undurbtedly hereditary, and though it may miss a generation, it of ten reappears in the produce of horses which have themselves been quite sound.

\section{Hunters for Polo}

A perfect hunter in miniature is perhaps the best definition of what a Polo Pony should be, but there must also be pronounced quality and pace. Many hunters there are who are well fitted for the duties they have to perform, who are good looking, fine stayers, and capital performers over a country; but all countries are not alike, and a horse may do wonderfully well in scores of provincial hunts which would be outpaced in a very quick thing over sound grass. So with the Polo Pony, many good-looking nags, who are strong enough to carry a fair weight, who can be turned and twisted at will, and whose manners leave nothing to be desired, are just without that dish of pace which would enable them to hold their own in a first-class game. As certain of the hunter tribe are perfect horses up to a certain point, so, too, are certain Polo Ponies. That is to say, numbers of the best-looking are quite good enough for an ordinary game, but comparatively few have the extra pace which is required, say, for an international game. To correct this fault, or rather to accelerate the pace, thoroughbred blond, and plenty of it, must be used, and pains should always be taken to use sires which had won races when in training. and thus proved thit they were not deficient in pace. It is perhaps not an easy matter to find such sires of the proper size; but ther are to be found, and one mav mention such well-known animals as Spanish Hero, Othrae, Trysting Tree, Jacko, and Right For'ard as examples of the thoroughbred suitable for siring Polo Ponies.

\section{Celebrated Pony Sires}

Spanish Hero, who hils won so many championships, is by the St. Leger winner Kilwarlin, out of Spanish Jaiden by the Derby winner Merry Hampton, her dam Castagnette by Mr. Winkle, out of Clarice by Paul Jones (second in the St. Leger), out of Laura by Lambton. Spanish Maiden was bred by Mr. C. Morbey, at one time a very successful jockey, and she died after breeding Spanish Hero, who was foaled in 1898. Curiously enough, Kilwarlin was a horse of fair size, and Merry Hampton was an upstanding thoroughbred, a good deal 
on the leg, even after he had been sent to the stud. He was not a great sire of racehorses, but he was responsible for Mlerry Wife, who in time became the dam of the Ascot Cup winner, Sintoi, and the Cireat Metropolitan winner, Laughing Mirror. Anyhow, in Spanish Hero there is not an atom of legginess, the horse being compact and small, and standing very near the ground. He won a race at Wolverhampton; but was, of course, too small to hold his own in the best company. Othrae is by Raebum, out of Othery by King Monmouth (in the last catalogue of the Polo and Riding Pony Society's show Othery was wrongly stated to have been by St. Simon), her dam Clarice by Charibert, out of Clarissima by Clarissimus. He (Othrae) was bred by Mr. W. E. Elsey, and ran twice as at twoyear-old, but was not a winner. $\mathrm{He}$ is a rather lengthier horse tham Spanish Hero, and his blood is undeniable, his sire having been one of the best of the earlier st. simons, and his dam by a very sterling performes in King IImmonth. Raeburn had beautiful quality, and was not a big horse; Othrae is very like him, but has square quarters, and the great quality of his sire. Already he has had winning stock, and if only they do not come too big they should make a mark in the polo world. Trysting Tree is polo bred by Mountain Ash, out of Confidential by Rosewater, out of The Secret; but Jacko is a thoroughbred, by Jaquemart, out of Mareca by Cherry Ripe, her dam The Widgeon by Uncas. This Jacko, who was bred in Ireland by MIr. J. Lonsdale, is a beautiful little horse, who ran a deald heat for the Lord Lieutenant's Plate at the Curragh as a two-year-old. Right For'ard is by Mark For'ard, out of Cuddle by Golden Garter, her dam Caress by Wanderer. The name of Cuddle, who was bred in America, is to be found in the General Stud Book; her son is verr well bred. Another fime stallion, shown at Islington in Igro, is White I'ings by White IIask, out of First Flight by Balquihidar, vut of Polly. He is polo bred, and not in the Greneral Stud Book, and is prettily turned, with much quality.

\section{Arabian Ponies}

Here it may be mentioned that for such breeders as wish to try the Eastern sire, one or two of the Arabs shown at Islington in IgIo are beautiful little horses. Lady Anne Blunt's Berk, a seven-year-old, who was bred at the Crabbet Arabian Stud, is a perfect picture of the high-class Arab, and in a rather different way quite as good-looking as Spanish Hero or Othrac. Indeed, when the three came in to bc judged for the Championship the judges must have been in a quandary, Berk being apparently quite as perfect a specimen of the Arab as the others are of the small English horse, bred from an Arab foundation. Berk is most beautifully turned, has a well placed shoulder, and the prettiest limbs; but what strikes one most is his wonderful carriage. He is an equine aristocrat all over, and bears himself as if he were fully iware of the circumstance.

\section{The Breeding Question}

Stallions for siring Polo Ponies can be found, but suitable mares are quite as necessary, and so far only some half-dozen breeders have been really successful in finding what is required, or rather in breeding Polo Ponies especially for the game. It has been mentioned that hitherto the best playing ponies have been hance-bred, picked up here, there, and everywheremisfits from thoroughbred or hunter breeding. There must, however, be an end to finding first-rate ponies that have not been specially bred for polo, and gradually it will come to pass that the "polo-bred pony" will include the greater part of the Polo Pony stock in use at any one time. The change will be very gradual indeed, and will only be brought about by the attention paid to breeding by those who recognise what the future is likely to have in store, but it is almost certain to come, and after a time one is likely to hear of many new studs, some the property of individuals, and others of syndicates, but all established with a view to preventing a failure in the supply of plating ponies. At the present day the most successful 
Polo l'ony breeding stud is that of Sir John Barker, Bart., which is situated in the valiey of the Stort, about a mile north of Bishop's Stortford. This is called the Grange Stud, and probably there is no better horse-rearing land in the kingdom than these rich and well-sheltered pastures, which are of great age, and are quite a month earlier with their young grass than are many of the higher lying areas of the same district. The Grange Stud is beautifully laid out. There is no crowding, and everything is managed on most approved principles, thanks to a very careful stud groom. On the farm every variety of polo breeding stock is kept, and when the writer paid a recent visit to the Grange Stud there were over Ioo head of ponits in the boxes and paddocks.

\section{Sir J. Barker's Success}

The numbers, of course, vary from time to time, but, broadly speaking, they were divided as follows: Three stallions, fortrthree brood mares, twenty-eight foals, twenty-two yearlings, and nine two-yearolds, besides a considerable number of older ponies, some in course of breaking, others ready for the breaker, and so forth. The ponies as they come to hand are sold when opportunity offers, and a fair price is forthcoming, and therefore it follows that there is always more young stock at the stud than ponies ready for play. The boxes are large and roomy, the saddleroom well arranged, large, and perfectly kept; but the great sight if one risit: the place in summer-time is the troops of well-shaped mares, travelling about the fields with their foals, or grouped under the big trees at midday. Look where you like, it is impossible to pick a badly shaped one, and one is lost in amazement, not only at the number of the beautifully shaped mares, but at the fact that so many have been gathered in one place. Indeed, a view of these pastures in the summertime suggests that Sir John Barker is firstly an enthusiast in Polo Pony breeding, and secondly a consummate judge of make and shape. Moreover, the mares are so even in size and height. You may look at a dozen and not be able to find a mare who looks to be It.3 or It. I hands. In fact, the correct height of $\mathrm{I}+.2$ hands seems to be about the average, though doubtless there are some snialler ponies. As far as is possible, too, the mares go back to pure pony stock, two or three generations away. All are mated with the small thoroughbreds, either the Grange Stud stallions, or suitable horses located elsewhere.

\section{Stallions at the Grange Stud}

Of the stallions at the Grange Stud, Othrae has been mentioned. There is also the beautiful Sandiway by Rosewater, out of Cuddington by Cucumber, who was bred by Sir Humphrey de Trafford, and has been a wonderfully successful sire. He is a dark bay, tight made and compact, with a strong back and well-sprung ribs, and is beautifully turned. What is most to the point, however, is that he moves like a Polo Pony, and is remarkably handy and active. Right For'ard, a rare stockgetter, has been mentioned; he has a beautiful shoulder, well laid back, and such manners that the head groom can ride him with a leading rein. There is also a three-year-old stallion named Belsire, who is by Right For'ard, out of Black Bella by Blackthorn, her dam by Tynedale, out of Bella Donna by Launcelot. This colt was bred by Sir John Barker, and is, of course, thoroughbred; he has fine quality, and considerable length, but is a little horse, and should sire stoek of the right size. His dam, though a thoroughbred, was played in a Champion Cup contest.

\section{Grange Stud Mares}

Of the Grange Stud mares there is no need to write at full length, but the names of a few of the best may be mentioned. Actress, of unknown breeding, was bought from Mr. Harry Rich, and was champion mare at Islington in Igo8. Then there is Sapphire, by Pet Fox, champion in Igo6, and Silver Star, champion in I g07. Sapphire had a foal by Sandiway at the time of 


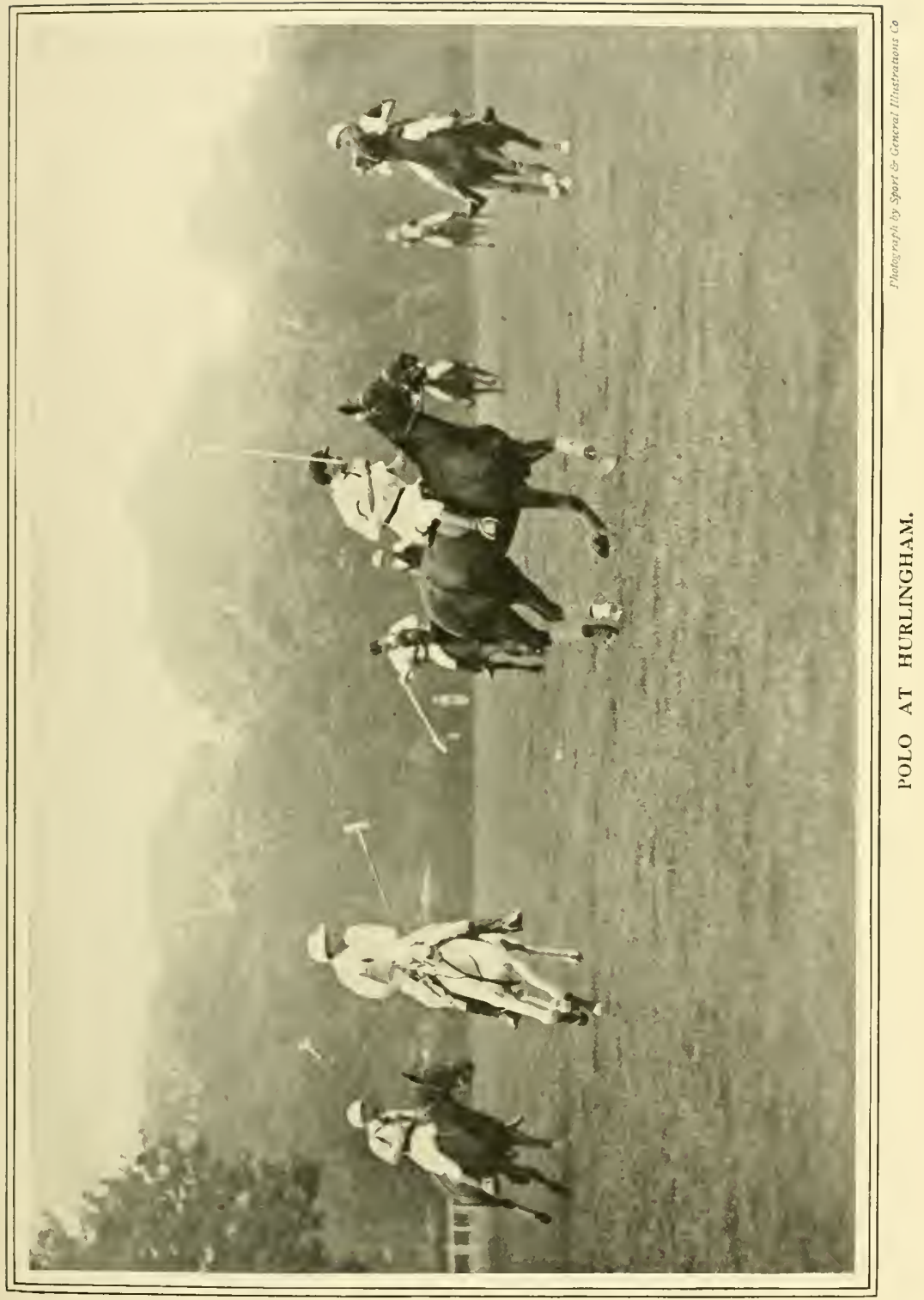


our visit, and beside her stood the already mentioned Black Bella, the dam of the three-year-old stallion, and herself not only one of the best ponies ever played, but the dam of a lot of prize-winners. Another beautiful pony is a mare by Buckinghum, who was bought from Mr. C. T. Garland and won in a light-weight class at Hurlingham; and Tipcat was not only it great player, but is a good breeder to boot. This mare was played by Mr. Walter Jones in the famous Rugby team, and she now has a yearling by Primrose Lad, a son if Ladas, out of Miss Primrose by Galopin, her dam Orontes II. by Ormonde. Here is the blood of one of the greatest horses of all time introduced into the polo world! Tipcat is smaller than some of the ponies, and her brecding we did not learn; but she has great pony character. Silk and Meath, of whom the last-named was played by Captain E. D. Niller; Greek Girl, by Xenophon, played by Mr. Tresham Gilbey; Florence, played by Captain Miller in Rugby tournaments; Surf Belle, by Southampton, out of Gazelle; Joy, whose breeding is unknown; Echo, a winner in the riding classes at Islington; and Sunshade and Rose Bracken. Lightning, who had her leg broken by lightning-and set by Professor Pritchard-may also be mentioned: and fr $m$ the above it will be seen that it has been Sir John Barker's object to breed from mares which have been played in good matches.

\section{Qualifications of Mares}

To sum up the position at the Grange Stud, it appears to us that thoroughbred stallions are almost entirely used, and mares which have one of these qualifications ; that is, they must either have been good players, prize-ring wimners, or thoroughbreds whose names can be found and pedigrees traced in the General Stud Book. Playing mares arte most numerous, and this qualification has evidently been held to be the best of the three, and, in fact, we saw few mares which had not been played, and when such a one was discovered it wals a prize-winner, and gener- ally a thoroughbred, or in the Polo Pony Stud Bouk as well. There is little doubt but that polo ability in a pony very quickly becomes hereditiry, and that mares which have been played are likely to breed better stock than ordinary mares is as certain as anything in breeding can be.

It may be added that the champion in the riding classes at Islington in I 910 was Mr. Tresham Gilbey's Animation, by Nootrub out of Spree, the last-named a thoroughbred, by Blue Green, her dam Signorina by Specific, bred by Sir John Barker at the Grange Stud. Mootrub was an Arab, so that here is a perfect specimen of what one takes to be almost a royal road to Poto Pony breeding-viz. the mating of small thoroughbred mares, which for choice have played polo, with the Arab sire. We may add that Animation is quite an exceptional pony, extraordinarily handy, with the most wonderful manners one ever saw in a show ring. She is strongly built and short backed, and has big limbs, with grand bone, and the Islington judges. Mlessrs. Buckmaster and R. N. Grenfell, stated after they had given her the championship that although only a five-year-old she was then fit to play in first-class polo. IIany other grand ponies have also been bred by Sir John Barker, and here, at all events, the secret of breeding ponies of the right height would appear to have been solved.

\section{Mr. Tresham Gilbey's Stud}

Mr. Tresham Gilbey's Whitehall Stud adjoins that of his father-in-law, Sir John Barker, but is at a slightly higher elevation, lying farther back from the valley of the Stort. The stud is not on so large a scale as its neighbour, but is excellently planned, and the boxes, which have a foundation of concrete, with boards above, are not only neat, but built on first-rate principles. There are at this stud, in addition to brood mares and young stock, a number of pories which are being trained for polo, which means that they are taught to twist and bend, to pull up sharp, start at a gallop, and broken to stick and ball. How 


\section{POLO AND POLO PONIES}

thoroughly this is carried out is proved by the wonderful form shown by Animation and several others at Islington, where Whitehall ponies were in I9Io successful in nearly all the bending and musical chair competitions. Kennington, by Amphion, out of Kienning by Kendal, and Redstone, who was champion in London in I909, may be mentioned as two of the best mares on the farm, and special mention may also be made of Patricia, whose pedigree is unknown, but who took the brood mare championship of Igro at Islington, and who has a wonderful combination of substance, bone, quality, and the length which all good brood mares should possess. At Whiteliall there are always many ponies which are still too young to be played, but which have been bred from the prizewinning stock, either on the place or at the Grange Stud. These are being gradually brought out and developed with a view to their becoming players, and when old enough are regularly trained for the game. In fact, at both studs everything is done with a view to turning out the finished pony, and towards the establishment of a pure breed of playing ponies. The grooms at either stud have expert knowledge of what is required in a Polo Pony, from the day of its birth until it appears in tournament at Hurlingham or Ranelagh, and progress on these lines is sure and steady. Iaster minds, possessing extraordinary knowledge as to what a Polo Pony should be like, govern the policy of the Grange and Whitehall Studs, and this being the case, it is small wonder that the two establishments carry off nearly all the honours at the most important shows.

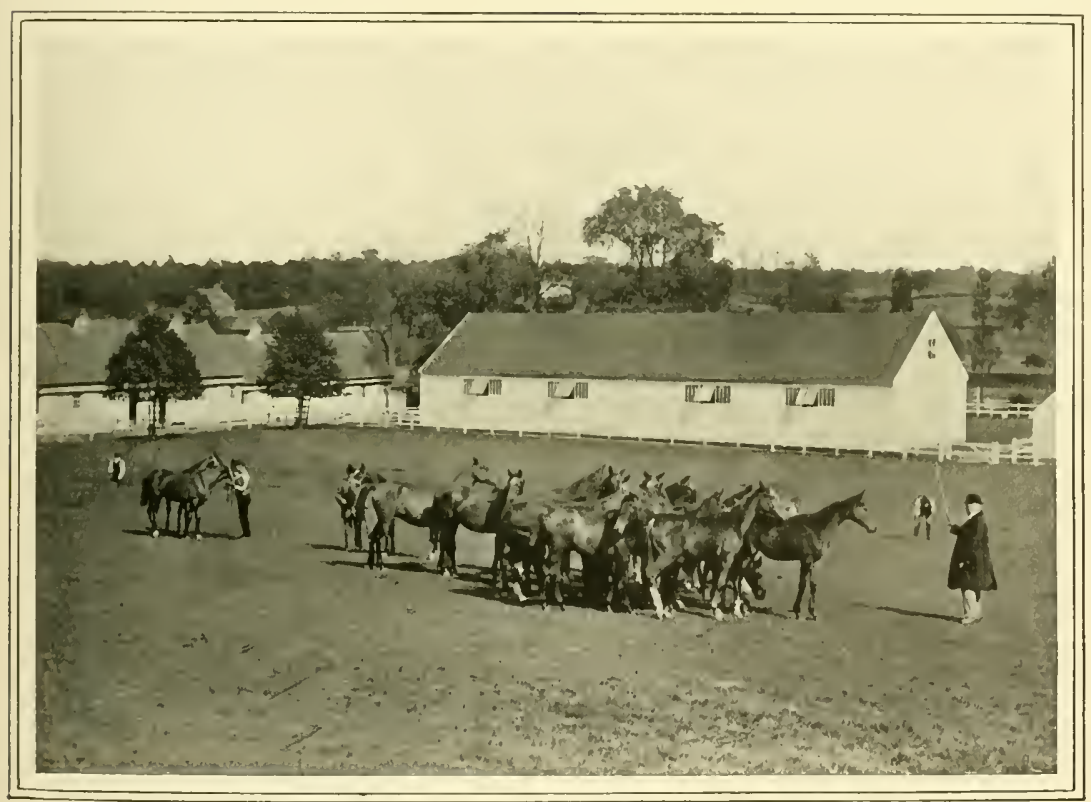

SIR J. BARKER'S POLO PONY STUD AT BISHOP'S STORTFORD. SOME OF THE YEARLINGS. 


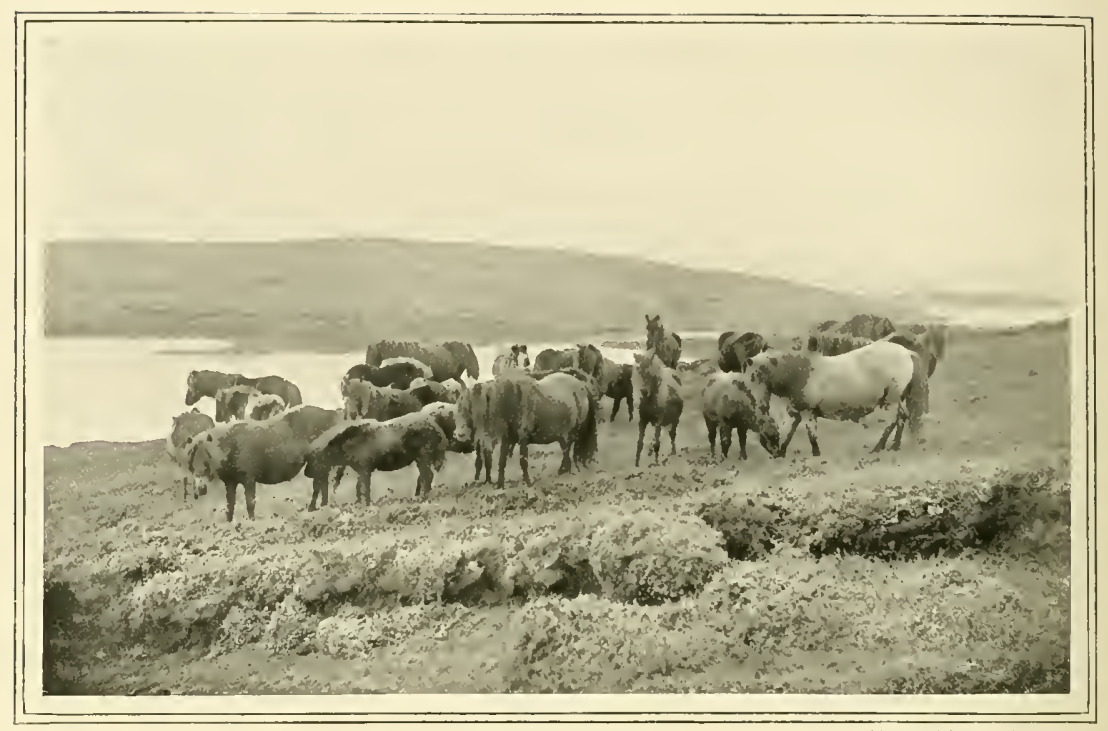

SHETLAND PONIES.

\section{CHAPTER XXV}

PONIES: SHETLAND, HIGHLAND, AND NEW FOREST

T HE term pony is a wide one, and different men will give widely different answers to the question, "What is a pony?" "Nimrod," in his well-known book "The Horse and the Hound," probably comes nearest to the mark when he says "A horse is called a pony when under the height of 13 hands, four inches to the hand." Then he goes on to say: "It is difficult to account for this diminutive breed, unless we believe it to be imported from countries farther north than Great Britain, which appears probable, from the fact of ponies being found in greater abundance in Scotland and Wales than in any other part of the island; the cffect, no doubt, of climate." William Day, in "The Horse and How to Breed Him," tells us that "the origin of some of the small and even diminutive breeds has often been ascribed to the poverty of their food, the poorness of the hill pastures on which they are reared, and the damp and biting cold of the climates which prevail in the districts they inhabit." That the weather and the quality of the pasturage have a marked effect on the fauna of any country is, of course, not to be disputed, but one would have thought that practical men like "Nimrod" and William Day would have recognised the fact that no amount of roughing it would reduce the hunter or the race-horse to the size of a Shetland or an Exmoor, and their experience should lave taught them that no Sheltie or Exmoor, however inuch he may have been pampered, increased more than an inch or two, and that even then the character was retained.

Much progress has been made in equine research, even since William Day wrote 
sume nineteen years ago, and thanks to l'rofessor Cossar Ewart, the multiple urigin of horses is now thoroughly recognised, and does awaly with the necessity for these vague speculations in which writers of a br-gone dar loved to indulge.

It is worth noticing that all the old writers have a word to say in praise of the pony, and his surefortedness, soundness, hardy character, and stamina. There is scarcely a writer that las not some story to tell of the speed and endurance of the pony, and he is continually being compared with the horse-not to the advantage of the latter.

Yet it has only been of late years that the value of the pony breeds as a national asset has been recognised, and it is at any rate within the range of possibility that this tardy recognition would not have come when it did had it not been for the popularity of polo, and the establishment of the Polo Pony society. Our pony breeds make a rare foundation for crossing, a fact which becomes more emphasised every day. It is also recognised that in order to get the best out of them the breeds must be maintained in their original purity, and not improved out of all knowledge, as has sometimes been the case with our old breeds.

\section{The Shetland Pony}

Of all our pony breeds the best known, and perhaps the most popular, is the Shetland. His sagacity and his docility are proverbial, and it would not be too much to say that inch for inch lie is the most powerful of the equine race.

It is only a hardy pony that could live and thrive in the Shetland Isles, where, as a rule, regetation is scanty, and the grass of poor quality. The spring is a terrible season in the islands, and though in winter the average temperature is higher than on the mainland of scotland, in summer it is lower. There was a theory that the Shetland pony is descended from Norwegian ponies brought over by the Norsemen from Norway at the end of the ninth century, but this theory is exploded, for there is evidence that there wore ponies in the shetlands long prior to the Norse invasion.

The first mention of the Shetland pony as such dates back to I700, when Brand, the historian, writing of the Shetland Islands, saly' "They have a sort of little horses, called shelties, than which no other are to be had, if not brought hither and from other places. They are of a less size than the Orkney horses, for some will be but nine, others ten handsbrcadths high, and they will be thought big horses there if eleven, and although so small, yet they are full of rigour and life, and some, not so strong as oithers, often prove to be the strongest. let there are some whom an able man can lift in his arms, yet will carry him, and a woman behind him, eight miles forward and as many back! summer and winter they never come into a house, but run upon the mountains in some places in Hocks."

With the mares running in herds on their mative hills, and with the rough and ready system of management which prevailed amongst the crofters, it would be unavailing to look for any historical events of importance in connection with the breed; and if it be true of breeds of horses as it is true of nations, that the breed without a history is happy - a position, by the way, the accuracy of which is at least open to question -the Shetland pony had a happy existence till the nineteenth century was well-nigh half gone by, for it was not until I $8+7$ that he was extensively used in coal mines, and it was twenty-three years later than that before the history of the breed in the modern sense of the term can be said to have begun.

\section{Crofters as Breeders}

Previous to the earlier date, with but few exceptions, the crofters of the islands were the breeders of Shetland ponies; and their system as might naturally be expected, was a rough and ready one, scarcely meriting the name of a system at all. But it demands a few words, more especially as about fourfifths of the shelties bred on the islands are now bred by the crofters. One or two mares 
is the number generally owned by a crofter, though some of them will have as many as half-a-dozen. These are used for carrying peat home in summer as well as for breeding, and it may be as well to bear in mind that the straw baskets slung over the ponv's back, one at each side, were once-and that not so very many years ago-the only means of conveying merchandise in the islands on the north-eastern coast of Scotland.

The ponies are run out both in winter and summer; in the latter on the commonlands, and in the former on the towuship lands, and when pasture gets scarce they will follow the ebb of the tide and live upon sea drift. Very rarely does ice or snow trouble the islands, and it is only on these rare occasions that the hardy Sheltie gets a bit of hay or a bit of oat sheaf. So it is not to be wondered at that by the time the long, bitter spring has drawn to a close the ponies are thin and somewhat feeble. The plentiful pasturage of the summer, however, soon restores their vigour and their condition, and by autumn they are in capital case again.

\section{Methods of Breeding}

The breeding is managed on the same happy-go-lucky system. The mare-; as a rule have only a foal every other year, as the foal is allowed to run with its dam all through its first winter, a plan which the crofter doubtless finds convenient, but which is economically false. In some places stallions are turned loose amongst the mares, and under those circumstances it is said there is a larger percentige of foals than there is when the mares are brought to the stallions for service. The latter plan, however, is the more frequently adopted now, when high prices rule, and when the principles of scientific breeding are every day receiving more attention.

\section{A Great Shetland}

It may be interesting to refer for a brief space to a Shetland pony which made for herself a great name in the early part of the nineteenth century. This was a piebald pony named Beauty, the property of MIr. Richard Lacy, a Yorkshire gentleman. She was eleven hands high, and was imported from the islands in 1824 , though at what age, Mr. Robert Brydon, who tells the story, dnes not specify. She was not broken until she was six years old, and in $183 \mathrm{r}$, when she would probably be eight years old, her owner challenged anything her own height to trot ten miles for froo a side. No one accepted the challenge, so Beauty trotted over the distance alone, to show what she coild do. Driven by a man weighing I I st. 4 lb., she trotted ten miles on the Leaming Lane road in 39 minutes 30 seconds. It is on record that she several times covered a mile in 3 minutes $4+$ seconds, and on August 3rd, I832, she trotted If miles on the $\mathrm{B}$ rronghbridge road in 55 minutes 45 seconds; and would undoubtedly have trotted fifteen miles within the hour had not a rein broken. Her driver, the same man that drove her on the Leaming Lane road, weighed on this occasion II st. $7 \mathrm{lb}$.

\section{The Modern Shetland}

The modern histury of the Shetland pony may be said to have commenced with the foundation of the Marquis of Londonderry's famous stud at Bressay. This took place in 1873 , and was practically the outcome of the high price of coal which prevailed in the 'seventics. This caused the thin seams to be worked, and it was only the very small pony that could work in those parts of the mines.

Lord Londonderry purchased stock all over the islands, and it is needless to insist upon the fact that he bought the best that could be found in Lnst, the West of Yell, Whalsay, Bressay, Northmavon, and the District of Walls, which were the principal places to which he resorted for his foundation stock.

Notwithstanding the care which had been taken, the mares were not a very even lot. At the same time as they were purchased two hundred colts were also bought, and from these in the following year six stallions were carefully selected. Each stallion was placed in an enclosure, and mares which 
were chosen to suit each particular pony were placed with him. This is the first instance on record of careful mating of the Shetland peny, and the result was highly siltisfactory.

Amongst other things, it showed that the stock of two ponies named Jack and Prince of Thule was much superior to that of any of the others. Jack was a black pony, Io hands high, full of character, and with big bone. He was especially famous as a sire of stallions, amongst those which have spread his blood all over the country being Lord of the 1sles, Odur, Giant, Laird of Moss, and the Marquis, all of them famous sires and notable prize winners.

Prince of Thule was a brown, standing a hand less than his stable companion, and he was most successful as a sire of mares. Those celebrated brood mares Fra, Princess, and Nesta, all of them well-known in the show-yard, were by him.

It is needless to point out that Lord Londonderry's management differed in essentials from that of the crofters. The foals were weaned in November, and put on good pasture, and were also hand-fed with hay when necessary. They were also provided with shelter sheds. The mares were also hand-fed when there was snow on the ground, and even when the weather was open in February and March.

Lord Londonderry's aim was to reduce height as much as possible, without any loss of power; to improve the quality of the head and shoulders, and to increase the bone, and in these objects he succeeded. Indeed, so great was his success as a breeder of Shetland ponies during the years his stud was in existence, that it is no exaggeration to say that there is scarcely a great prize-winner in the country that has not been bred by him, or that is not descended from one of his famous ponies.

\section{Other Eminent Breeders}

Other eminent breeders in late years are Mr. R. W. R. Mackenzie, whose Earlshall Stud dates from I89I, and is full of Lord Londonderry's blood; Mr. George A. Miller, at the head of whose stud at Lawmuir is Nultum in Parro, by Lord of the Isles;
Dr. Charles Douglas, whose principal sire is Thor, by Odin, a well-known prize-winner ; Mr. Munzall, of Transy, Dunfermline; Mr. William Chapman, of Helensburgh; the Ladies E. and D. Hope, whose purchase of Prince of Thule, and subsequently of Oman and Odin, placed therr stud amongst the most important in the country; and Mrs. IV. H. Hope Johnstone, whose ponies have been frequent winners south of the Border.

The Shetland pony has been well described as a miniature Clydesdale. He stands on a short leg, has wonderful bone, and a remarkably good back and ribs. His shoulders are not quite so good as they might be, but they have improved considerably of late years, and his head has also lost much of its coarseness. That he makes an excellent pony for children goes without saying, and the objection which some critics make to his back being too broad for this purpuse has really little in it. In colour he is principally black, brown, or bay. Dun, chestnut, and piebald ponies are also found, but these colours are easily bred out.

In height the Shetland rums from g hand: to I I hands, the average height being about Io hands 2 inches. As for various economic reasons the thin seams of coal are no longer worked, there is no longer that care taken to breed exceptionally small ponies as was the case when Lord Londonderry's stud was founded at Bressay, in the early 'se'venties.

The Shetland Pony Stud Book Society was established in I 890 , and the first stud book was published in ISyI.

\section{The Highland Pony}

The Highland pony is of very different type from the Shetland, and is put to il very different purpose. Unlike the pony of the North Eastern islands, he varies considerably in size, some specimens being as smail as II hands 3 inches, whilst others again are to be found as high as It hands I inch, or higher.

The habitat of the Highland pony is the north-west of the country. There are few of the islands on the north-west of Scotland in which the Highland pony in one of its 


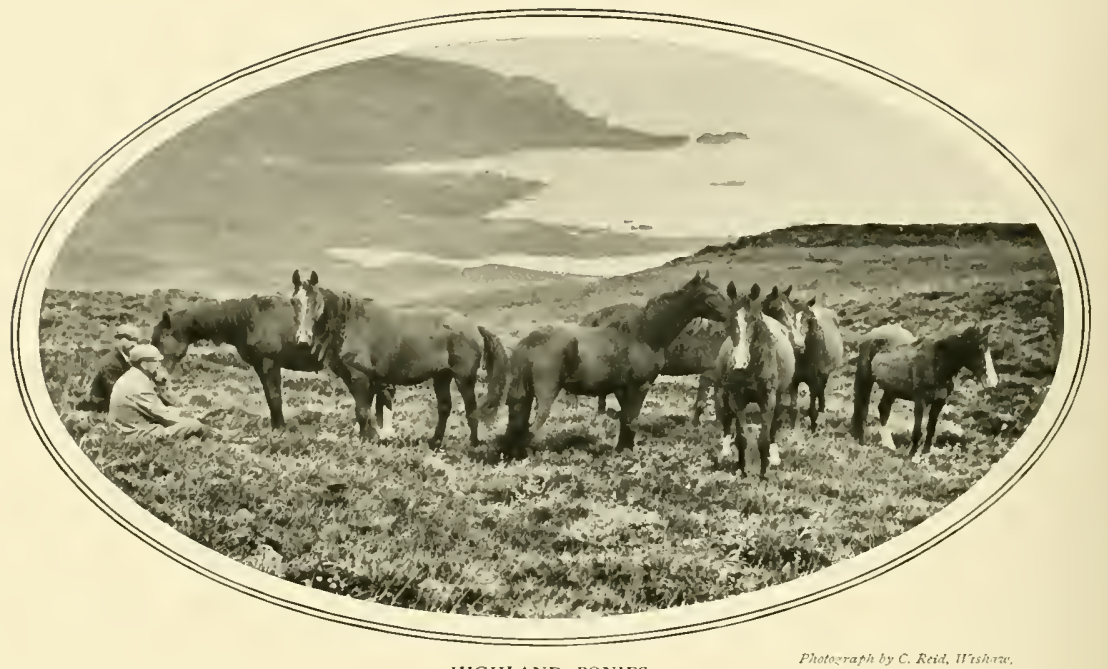

HIGHLAND PONIES.

variants does not flourish. From Lewis to Barra, from the north of the Isle of Skye to the Ross of Mull, amongst the islands; from Cape Wrath to the Mull of Kintyre on the mainland the Highland pony flourishes. At the southernmost point Lord Arthur Cecil-than whom there is probably no greater authority on ponies and pony breeding-is of opinion that the Highland pony became merged in the Galloway, a useful breed which has been practically extinct for many years, and which was not improbably a further development of the Highland pony.

One of the principal sub-divisions of the Highland pony is known as the Barra pony, whose principal home is in Lewis, Harris and $\mathrm{Uist}$. He is the smallest of the varieties of the Highland ponies, and is regarded as the survival of the most ancient breed of ponies. Ranging in height from II hands 3 inches to 12 hands 3 inches, and occasionally up to 13 hands, the Barra pony is certainly more distinguished for his utility than his beauty. He is of all colours, but a dun ranging from yellow to mouse colour is the most popular amongst the crofters who, as in Shetland, are the principal breeders. There is no little resemblance between the Barra pony and the Iceland or Celtic pony, and it is probable that it is directly descended from the latter. Lord Arthur Cecil describes it as a connecting link between the Celtic and the Norwegian ponies. Barra ponies are remarkably hardy in character, are very sure-footed, and take heavy loads up the mountain paths which abound in their native island.

The Uist ponies are of two types, one a development of the Barra pony, the other a pony of an altogether bigger and stronger character. The latter are in some respects not unlike a small Clydesdale, but there seems to be no direct evidence of a Clydesdale cross having been introduced, and it is possible that the Clydesdale foundation may have had a common origin with these stronger ponies. There is also in the Isle of Uist a breed of ponies, chestnut, with a white mane, which is not common elsewhere in Scotland. They stand about I 4 hands I inch, are very powerful and active, and are capable of drawing three quarters of a ton on the rough island roads-no mean performance for ponies of their inches. Like the Barra pony they are goose-rumped and cow hocked, but to use the words of Lord Arthur Cecil, " they form a distinct step 
towards what is known to deer-stalkers as the hill pony."

The history of the Skye pony is somewhat involved and difficult to trace. Crossing has been considerably resorted to, and it is perhaps more due to the inherent prepotency of the original foundation than to any systematic attempt to keep the breed pure, that the main characteristics of the Skye pony owe their survival, at any rate in parts of the island. But the tough old breed is difficult to breed out, and in the southern part of the island are to be found hill ponies of a class that is difficult to beat -sure-footed, powerful, and active. The average height of the Skye pony is 13 hands 3 inches.

The mainland hill-pony or Garron is the development of the above sub-divisions or one of them, for almost every stud of the Highland Garron breed, and nearly, if not quite every horse of note, can be traced back to one or other of the sub-divisions which have been described. They are an invaluable breed, and as their value comes to be more generally recognised there will be the danger from which so many breeds have suffered - viz. that the breed will be neglected in the interests of the crosses of which it will make such an excellent foundation.

The Highland pony, as developed on the mainland, is excellent for mounted infantry purposes, and even for Yeomanry, whilst suitably crossed the mares breed cavalry horses of a high class. Indeed, good hunters have been known to result from the cross between a thoroughbred sire and a Highland pony mare.

Short-legged, and remarkably powerful for his inches, it has been said that there may be a far-away suspicion of carting blood in remote times. The writer, however, scarcely agrees with that theory, and favours the idea that the type-which, whatever his origin, has been thoroughly fixed for many generations-is an original one-an active, powerful pony, peculiarly fitted for draught or saddle purposes, amongst his native hills.

There are several important studs of Highland ponies in existence, amongst which may be mentioned those of Lord Middleton at Applecross, of Lord Ports-

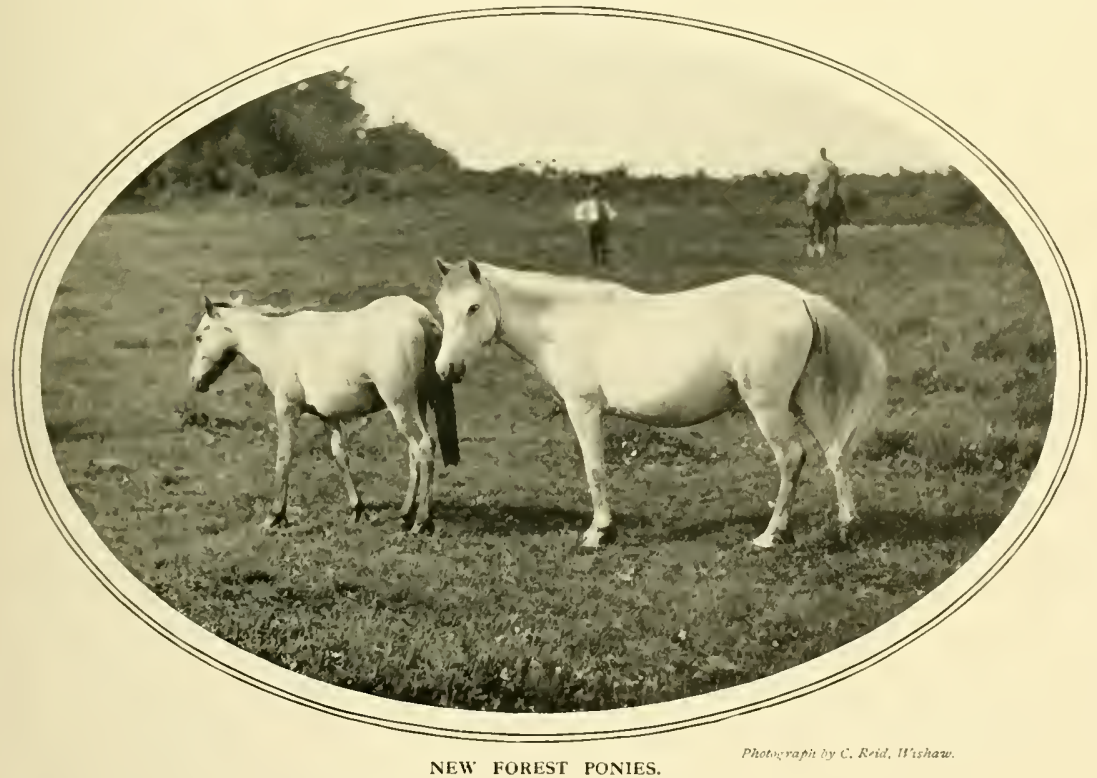


mouth, and Lord Tweedmouth at Guisachan, anci uf Mr. Donald Stewart, at Drumchory, Pitlochry:

\section{Highland Studs}

The latter stud has been remarkably successful in the show ring, and in recent years has carried off many a prize at the Highland and Agricultural Society's show. It is principally descended from a north Uist stock, and strains back to a stallion named Tom, owned by the late Mr. Macdonald, of Balranald, a winner at Glasgow in 1882 , and at Inverness in I883. A couple of Mr. Donald Stewart's ponies are described as affording a good idea of what the breed is like at its best.

The first is Hoss Crop, the gold medal winner at Dumfries. Hc is a very powerful pony, as may be gathered from his measurements. He stands If hands 2 inches high, has $8 \frac{1}{2}$ inches of bone below the knee, and his width between the forelegs is Io $\frac{1}{2}$ inches. The mare Highland Nancy, better known in the North perhaps as "Donald Stewart's grey mare," stands It hands I inch, and measures $7 \frac{1}{2}$ inches below the linee. It should be unnecessary to dwell upon the value of such ponies as these as a foundation for hardy troopers, but the writer is afraid that it is necessary to insist upon the importance of improving such a breed on its omn lines and paying strict attention to its purity.

\section{The New Forest Pony}

The New Forest, with its romantic history, and its curious survival of ancient English customs, has an intercst peculiarly its own. In the words of Mr. W. J. C. ILens-who has made of the New Forest and its antiquities a life-long study- in it there is $t o$ be found "the last piece of the Forest primeral in England-the very last bit of older England-the England of the outlaw, of the singer of ballads, of the lover wf life in the grenwiod."

It would, perhaps, not be too much to say that the common rights of the lioresters are the oldest rights belonging to a corporate body in England. They date back to Earl
Godwin, to Canute the Great, and probably even to an earlier date, and so firmly were they cstablished that neither William the Conqueror nor any of his successors have ever been able to abolish them. Naturally the Foresters are tenacious of their rights, and the forest is practically ruled now, as it was in the long ago, by a Court of Verderers, elected by the Foresters themselves. Under the Court of Verderers there are four Agisters or Marksmen, under whose management the Forest is placed. The Forest is divided into four districts, one of which is allotted to each Agister, and the ponies grazing in each district are distinguished by a tail mark which makes them easily recognisable at a distance. The tail mark for the northern district is the right side of the tail squared; the mark for the southern district is the near side of the tail squared; the mark for the eastern district is one ring round the tail, and the mark for the western district is two rings round the tail. The knowledge which these Ag.sters or Marksmen have of the forest and the forest ponies is phenomenal, and they can tell almost at a moment's notice where every pony is to be found.

\section{Colt-Hunting}

The Agister is in his element when colthunting, which is sometimes rendered necessary by a shy pony that will stray from his or her proper pasture. At the annual rounds up, too, the Agisters are men in authority and are responsible for the necessary arrangements. The tail-marking is done by them, the fee of eighteenpence for which goes to the Court of Verderers, who pay the Agisters their wages.

That the New Forest pony is a survival of Saxon times, and perhaps of a much carlier period, seems pretty certain, and it nay well be that even in Saxon times attempts were made to improve the pony; which it would scarcely be too much to insist is indigenous to the Forest. These attempts have been made more recently, and the proximity of the Forest to the Royal Stud; at Clarendon has perhaps been one 
cause of a systematic attempt to improve the breed.

\section{Traditional Origin}

There is a tradition to the effect that some horses escaped from the Spanish Annada, swim ashore, and found a home in the New Forest, where they much improved the native breed. It is curious how this tradition of the Spanish Armada and the animals which have "escaped" from it is to be found all over the country. In Devonshire, in Cumberland, in the islands of North Eastern and North Western Scotland there are similar traditions, and similar surmises, and probably with as little real foundation. At any rate, the tradition, as far as the New Forest is concerned, may be summarily dismissed. For it is perfectly obrious that the comparatively delicately reared horses of the Spanish cavaliers would not have been able to stand one winter of the exposure and scanty food of the Forest.

It is quite within the range of possibility that, in the middle of the sixteenth century, when there was a considerable impurtation of fresh blood into the country from Turkey, Spain, Naples, and Flanders, some effort may have been made to improve the Forest pony. The Royal stud at Clarendon was. as has been already indicated, within easy reach, and the managers of that stud would naturally have an ambition to improve the horses of the neighbourhood, especially when legislation on horse-breeding spoke in no uncertain tone.

\section{Duke of Cumberland and Forest Ponies}

These infusions of fresh blood, however, rest on surmise rather than on any reliable evidence, and we have to pass over a period of two hundred years before we get to thoroughly reliable evidence of an attempt to raise the character of the New Forest pony. William Augustus, Duke of Cumberland, was Warden of the New Forest in the middle of the eighteenth century. He was, as is well-known, an ardent agriculturist and sportsman, and amongst the many horses he owned was Marske, by Squirt. IIarske, like many another good horse at the stud, was a comparative failure as a race-horse, and also after he was first put to the stud. Snap had beaten him in three matches. On the dispersal of the Duke of Cumberland's stud at his death, Mirske was purchased for a small sum by a New Forest farmer, and he served mares in the Forest at a small fee, till the fame of Eclipse brought him to the front amongst thoroughbreds. It is on record that when in possession of the Duke of Cumberland he corered mares in the New Forest at the low fee of half-a-guinea, and half-a-crown the groom. It is therefore pretty clearly established that the blood of the sire of Eclipse still survives amongst the New Forest ponies: and this, of itself, is sufficient to account for the courage and stamina which are so notable in the breed.

\section{Arab Influence}

The late Prince Consort, too, was greatly interested in the New Forest pony, and sent a grey Arab to the Forest which did great service to the breed. Her late Majesty also lent a couple of Arab stallions-Abeyan (a fine Arab which was the gift of the lmaun of Muscat) and Yirassaw, both of which did a great deal of good, and were the sires of colts used in the Forest as stallions.

When the writer visited the New Forest in IS97, it was estimated that there were over 3,000 ponies in the Forest, and that the great majority-well on to 2,000-of these were brood mares. For these about a hundred stallions were required, and they ran wild in the Forest with the mares. This happy-go-lucky system-or want of system, rather-had the usual results, and ponies began to lose size, and, what was of more importance, constitution.

Attempts were then made to improve the breed, and various crosses were tried. Anrongst them the Norwegian, Welsh, and Exmoors may be put down as failures. The Norwegian cross, indeed, was conspicuously so; nor was the Welsh much better; whilst the Exmoor cross was certainly disappointing. Excellent results, however, were obtained from the Arab and English 
thoroughbred crosses, though, curiously enough, the Barb cross was only a qualified success, a fact which raises some knotty points respecting pony origins, and the multiple origins of breeds.

About this time the Forest Pony Association was formed, and under its auspices the New Forest pony has flourished, and perhaps he was never quite so good as he is now.

The New Forest pony stands from II lands 2 inches to 13 hands 2 inches, but not many are to be found of the latter height, and perhaps the fewer the better. It is the opinion of Lord Arthur Cecil that ponies much over $\mathrm{I}_{3}$ hands cannot stand winter in the Forest, and in this he is undoubtedly correct.* They are generally bay or brown with tan muzzle, and a little white under the eyes, but there is really no restriction on the question of colour, and ponies of all colours are to be found, duns being the least frequent. There are some very good

*In his article on New Forest Ponies in Sir Humphrey de Trafford's "Horses of the British Empire," Lord Arthur Cecil gives the height as from 12 to 13 hands. When the writer visited the New Forest the above were given to him as the extreme heights. We should say few ponies are so small as I I hands 2 inches. greys, said to be descendants of the Prince Consort's grey Arab stallion, to which attention has already been directed. They have lean, game-looking heads, deep, wellplaced shoulders, and muscular backs, and they have plenty of clean flat bone. They are rather short on the quarters, but are not so cow-hocked as some of the hill breeds, a fact possibly due in some respects to their habitat. They are wonderful weight carriers for their size, and make excellent single harness ponies, many of them being well capable of ten miles an hour in a light twowheeled conveyance.

There are numerous places in and near the Forest where pony fairs are held, Lyndhurst, Eling, Romsey, Ringwood, Martins Town, and Bretford being amongst the principal. Prices range for foals from about $f t$ to $E 7$. and useful yearlings will bring $f \mathbf{I 2}$. The prices, though not large, are very remunerative, being practically all profit; for the New Forest pony runs out all winter, and it is only in exceptionally severe weather that recourse is had to hand feeding, even on the most limited scale. This hardiness of character is of the utmost importance, and it must be kept prominently in view in any scheme for the improvement of the breed.

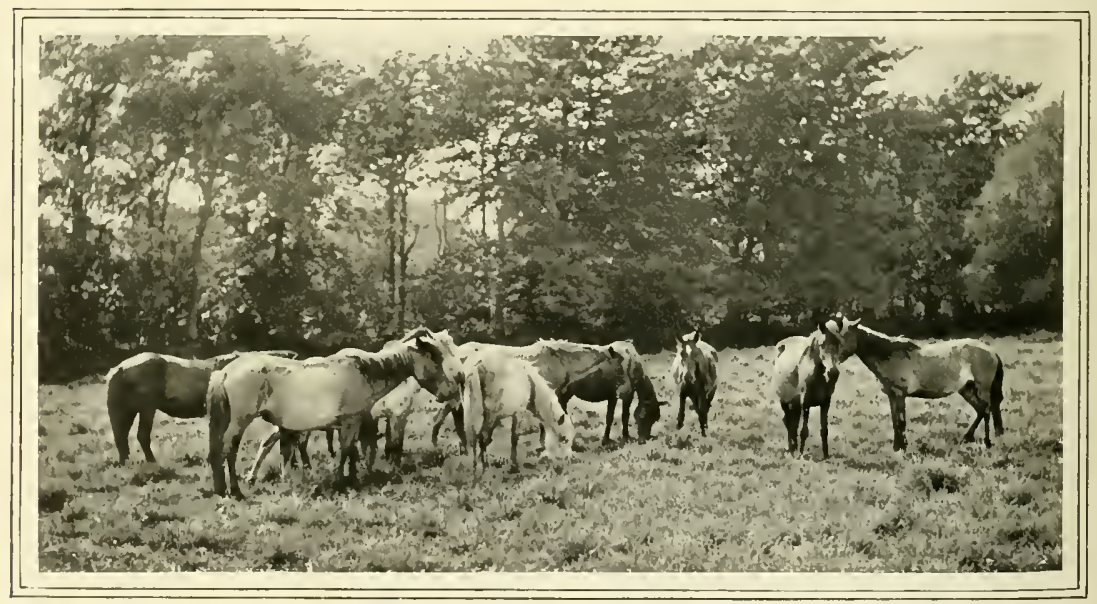

IN THE NEW FOREST 


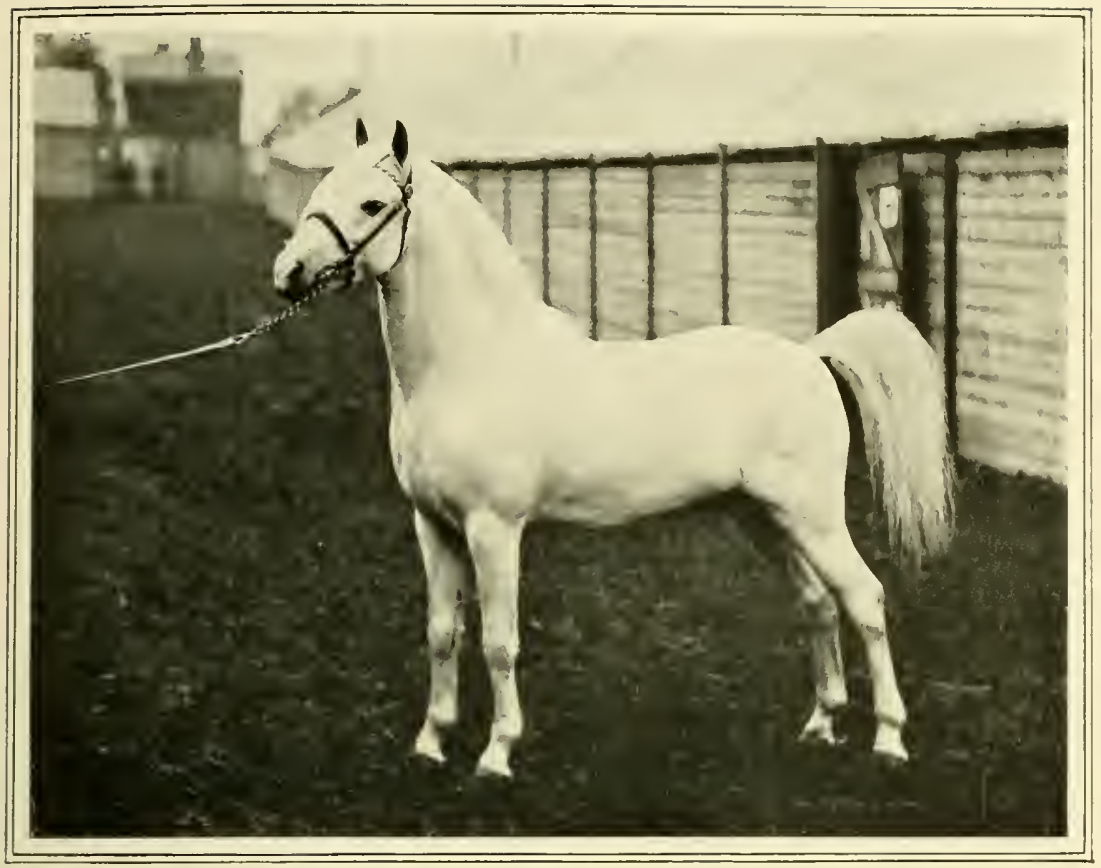

WELSH PONY STALLION, GREYLIGHT.

\section{CHAPTER XXVI}

\section{PONIES: WELSH, DARTMOOR, AND EXMOOR}

$\mathrm{I}^{\mathrm{r}}$ F the Shetland pony has been not inaptly described as the miniature Clydesdale, so the Welsh pony-the Welsh pony that is, that is clear of Hackney blood-has been adequately defined as a miniature Hunter. Their good shoulders, muscular baclis and quarters, and weight-carrying properties, combined with their remarkable activity, make them wonderful animals in a hill country, and, like the Highland pony of the north, the ivelsh pony makes a capital foundation for hunter-breeding.

There is, perhaps, none of the British breeds of ponies which has been so much crossed as the Welsh pony, and, it may be added, to such good purpose. The Hackney and the thoroughbred-even the Yorkshire Coach Horse-have all been used, and with excellent results.

The Welsh pony and his near relative the Welsh cob cover a wide ground between, or rather amongst them, for according to the classification of the Welsh Pony and Cob Stud Book they range in height from I 2 hands 2 inches to 15 hands 2 inches. They are divided into three classes, as follows: The first, which may be described as Welsh mountain ponies proper, are I2 hands 2 inches high, and under. The second class, which may be described as Welsh ponies, run from 12 hands 2 inches to $\mathrm{I}_{3}$ hands 2 inches, and the third class, which are known 
as Welsh Cobs, has two sub-divisions, one for cobs not exceeding It hands 2 inches, and one for cobs exceeding that height, and not exceeding $I_{5}$ hands 2 inches. Though, no doubt, those who drew up the regulations for the Stud Book may have been presumed to understand the work they took in hand, it may perhaps be permitted for others to lint that anything over I5 hands can scarcely be looked upon as a cob.

With the Welsh mountain ponies must be elassed the ponies which are to be found in the Shropshire Hills, and the hills of the Marches, for they are, to all intents and purposes, the same breed, though they are sometimes known by local names, such for instance as the Long IIynd ponies, which inhabit the Long Mynd Hills, to the west of Church Stretton.

\section{Neglect of the Breed}

Hardier than the New Forest ponies the Welsh mountain ponies praetically ran wild for years, and were neglected in a most regrettable manner. Not the slightest attempt was made to prevent the presence of bad or unsound stallions on the hills, and there is even now no provision for excluding undesirable stallions. Nor was this all. The very excellence of the breed and the increasing demand for it proved a danger, and it is not a little curious that the very thing which brought about a change for the better with shetland ponies brought about a change for the worse with Welsh ponies. This was the increasing use of the ponies in coal mines. When Shetlands were used in increasing numbers in the North, Lord Londonderry and other enthusiastic breeders laid themselves uut to improve the breed. But there was no one in Wales to adopt the policy of the great Northern breeders. The punies were " rounded up" every year for sale purposes, and naturally the buyers for the mines took the best, with the result that only moderate statlions were left on the hills to breed from.

\section{Pony Associations}

This fatal policy soon began to have its effect, and several pony assuciations were formed and did excellent work. Of these the Gower Union Pony Association may be given as a typical one. Gower is a peninsula eighteen nilles long and nine miles wide, which lies to the west of Swansea. One of its peculiarities is that ponies never come down to it from the mainland. When the Association was formed the ponies of Gower were very bad indeed, principally through inbreeding. Sir Walter Gilbey, in an interesting paper on Welsh ponies in the Bath and West of England Society's Journal, sar's: "Here, then, exists what is practically a self contained area, carrying its own droves of ponies, free from danger of invasion by others from without; an excellent opportunity for conducting such operations as the Gower Lnion Pony Assuciation has had in hand for the last four years. The Association when the Members' Roll was closed in Nay, Igof, numbered seventy commoners, who owned among them one hundred and one mares and twelve stallions; the scheme of the Association, broadly speaking, is the appointment of an inspection committee to examine the ponies of members once a year, and the exclusion from the commons of any entire pony which has not been passed by the committee. The task of clearing the commons of bad stallions has been vigorously prosecuted, for about the end of the year, Ino5, Mr. Vivian stated his belief that the lands were then freed from such undesirables."

\section{The Church Stretton Society}

Another private society which has done, and is doing, an immense amount of good is the Church Stretton Society, with which that well-known pony breeder and judge, Mr. John Hill, of Marshland House, Church stretton, has been so closely associated since its establishment in r 890 . For seven vears it continued its good work, and then lincal support grew slack, and the society "fell through." In a very few years the results of this mistaken policy began to show themselves, and on pony owners pledging themselves to support it lovally, the society was re-established in Igof, since when it has done excellent work. 
An attempt has been made to obtain legislative control of the commons and hills on which Melsh ponies run, so that unsound and bad stallions shall not be allowed to run at large. Nothing, however, has been done as ret, though it was in Igo7 that the Minister of Agriculture was approached on the subject.

\section{Welsh Pony Points}

IIe cannot do better than gire the description of the Welsh pony taken almost word for word from the Welsh Pony Stud Brok. In general character he is hardy, spirited and "pony tike." He must not exceed 12 hands 2 inches. There are no restrictions as to colour. The head must be small, clean cut, well set on, wide between the eves, and tapering to the muzzle. The ears must be well-placed, small, and pointed ; the eres full and bright; the nostrils prominent and open, and the throat and jaws finely cut. The neck must be fairly lengthy and moderately lean, with a stronger crest in the case of a stallion. The shoulders must be long and sloping well back, and fine at the points, and the girth must be deep; the back and loins muscular, strong and short coupled; the hind-quarters lengthy and fine, the tail well set on, and carried gaily. So much for the shape. The legs are distinguished by short, tlat bone, muscular forearm and well developed knees and hocks. The action straight, with wall flexed hocks. Such is the Welsh mountain pony, and such is the Welsh pony, save that he stands a hand higher.

\section{The Welsh Cob}

The Welsh cob may perhaps be principally regarded as a harness cob-at any rate, it is the Welsh cob of the harness type that we principally see in the show ring. The smaller Hackney has had much to do with his development and the names of many well-known Hackney sires are found in his pedigree. Iany famous Welsh cobs trare their descent to Old Trotting comet (Hackney Stud Book, 834 ), through his son Old Welsh Flyer, and his grandson Trotting Flyer. Another famous sire at the foundation of the Wclsh cob wais Smetticote Shales, who was a grandson of Alonzo the Brave, and had some of the blood of the Darley Arabian in his veins. The well-known Danegelt also finds his way into the Welsh Cob stud Book ats the sire of Rattler 232, and grandsire of John of Gaunt 5I, horses that have both made their mark.

Another famous sire in the first half of the nineteenth century was True Briton. This horse, Sir Walter Gilbey tells us, was by Ruler, a Yorkshire Coach Horse, and his dam was said to have been an Irab mare. At any rate, he was a horse of doubtful pedigree, but he was an exceedingly valuable st.llion, and had a very beneficial interest on the breed.

It may be put down as one of the qualities of the Velsh pony and his deseendants that he crosses well with any breed. At any rate, we have found the thoroughbred, the Hackney, the Yorkshire Coach Horse, and the Arab all crossing well with him, and it must not be forgotten that many of our high-class Polo ponies trace their descent from Welsh blood.

\section{The Dartmoor Pony}

Amongst the several ancient varieties of British ponies which frequent the moors and mountains of this country there are few, if any, that are entitled to greater respect than the Dartmoor. At the same time a very considerable amount of obscurity is associated with his origin, some authorities, lucal and otherwise, declaring that he is a survival of the horses of the ancient Britons improved by the Romans, whilst others express the opinion that he owes his existence to animals which escaped from the destruction of the Armada. There are still others who hold that the Dartmoor pony as lie still exists is indigenous to this country, and that, provided a pure bred specimen could be procured, his pedigree would trace back to time immemorial. There is, however, a great deal attaching to that saving clause " could be," for it is to be feared that the breeders of this pony, both in the past and present, have not been as careful as they ought to have been in attending to the 
purity of their strains. Consequently it is safer to assume that the origin of the race is lost in obscurity, and to admit that ponies belonging to the present race have inhabited the time-honoured moor for many centuries past.

There can be no doubt, however, that the Dartmoor pony, like other breeds of horses, has suffered a great deal by the died out. Some of the half-bred Exmoors, too, have experienced a similar fate, for the climate of Dartmoor is extremely trying, and keep is scarce, excepting in the late spring and summer. Crosses with the Pack Horse have thriven, and some very useful ponies have been bred in this way at the convict prison at Princetown, where the Exmoor cross was also attempted with less

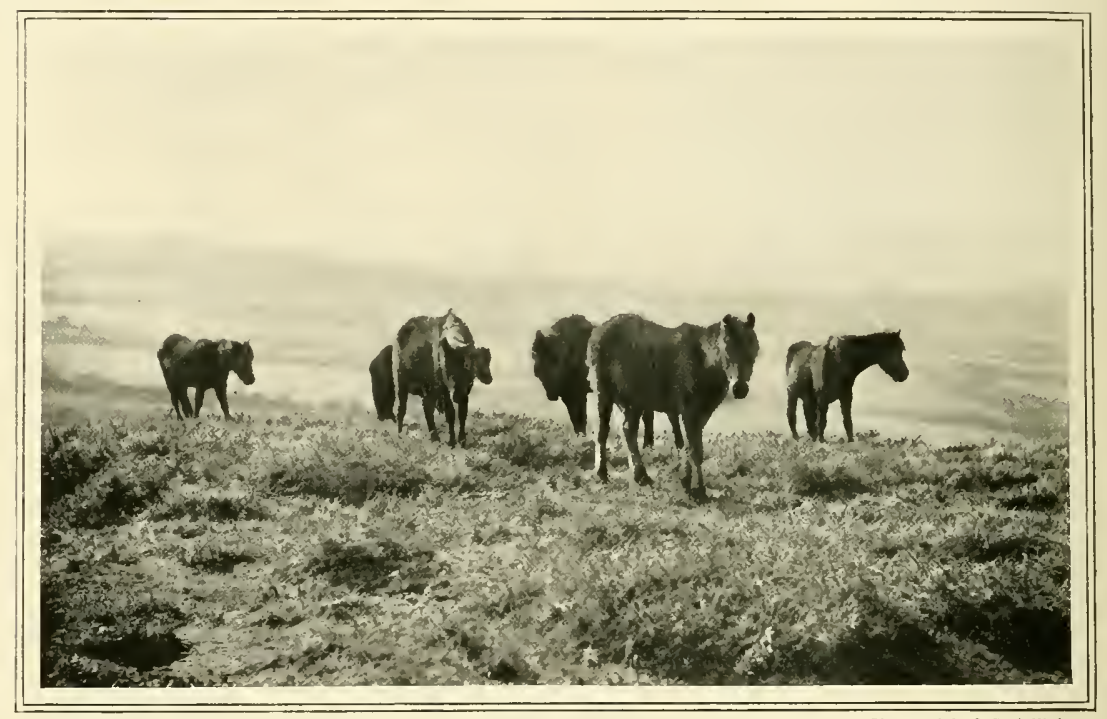

DARTMOOR PONIES

ill-judged crosses which have been introduced into the breed by well-intentioned but thoughtless people under the guise of improvements; nor can there be any denial of the fact that the purity of the stock running on the moor has been affected through their association with under-bred cart and other stallions, whose owners possess common rights. Of late years in particular efforts have been made on all sides to improve this ancient breed of ponies by attempting all sorts of crosses, but without much success. The progeny of the Arab stallion which was located at Buckfastleigh on the south-east corner of the moor were too weak to stand the privations of winter in this inclement region, and satisfactory results. That the Dartmoor pony is capable of improvement, like every other breed of horse, cannot be denied, but he is a remarkably good pony as he is if he strains back closely to the old breed, of which undoubtedly a few specimens still remain upon the moor.

Whether the height of these ponies-n which may be taken to be a full I2 hands 3 inches, or 13 hands at most-is likely to be increased in process of time by good feeding and removal to a more genial climate is at least problematical; and even so, the progress is likely to be slow. At all events, the experiment that was tried a few years ago of putting some extra good Dartmoors on rich land in Hertfordshire did not lead 
to very satisfactory results; the ponies did not increase much in height, though the young stock were thicker, and less active than their sires and dams. Possibly the most satisfactory cross would be that of a small thoroughbred sire, with the re-crosing of his stock with the ponies; but there is so much individuality about the Dartmoor that anyone who got together a good lot of selected ponies of the old-fashioned type, and bred them together judiciously, would not have much reason for regretting the outlay of his money, provided that the land he ran them on was cheap, and the soil and climate suitable for the ponies.

\section{Merits of the Dartmoor}

It cannot be claimed for the Dartmoor that he possesses anything in the way of extravagant action to commend him to the attention of the public, nor is his appearance so striking as to extract expressions of admiration from strangers. On the other hand, it can conscientiously be argued in his favour that he is capable of getting throngh an immense amount of hard work, that he is a fast pony for his inches, and that his constitution is as hard as iron. With so much to recommend the race it is surprising that its immense merits should not be more widely recognised, and doubtless they would have been had a Whyte Melville condescended to weave a romance around the breed, similar to "Katerfelto." In the absence of any such outside influence the Dartmoor pony must rest content to base his claims for recognition upon his own intrinsic merits, which are great. If they were only better known, few breeds would be in greater demand in England for harness purposes, or for children's riding ponies.

\section{The Moormen and Ponies}

The famous moor, over which these ponies roam in the company of other horses and cattle turned out by inhabitants of the district possessing common rights, is some 200,000 acres in extent, and belongs for the most part to the Duchy of Cornwall. The best ponies - that is to say, those which most closely adhere to the old type-are to be found on the southern side of the moor in the neighbourhood of Sonth Brent, Ivybridge, and Buckfastleigh, and these are annually disposed of in large numbers at Brent Fair, which is held on the last Tuesday in September. Whilst at liberty the herds of different owners keep pretty well together under the leadership of an old stallion, but, of course, mésalliances occasionally occur between some of the mares and the unattached stallions which roam the moor. The presence of the latter is calculated to cause much loss to pony breeders, and it is to be regretted that there is no law in force to prevent the owners of bad stallions permitting them to associate with valuable stock. The moor is under the superintendence of moormen, whose office is practically hereditary, as the duties in each district are usually handed over from father to son, but in reality they are the tenants of the Lord of the Manor, to whom they pay an annual sum, recouping themselves by levying a charge of half a crown for each animal on their part of the moor. In return for this they keep their eyes on the stock, and assist the owners of the ponies in bringing them in on the occasion of the annual drives, or rounding up, for the purpose of marking the foals, and selecting the animals to be sent to Brent Fair, or otherwise disposed of. In the course of an inclement winter, too, the moormen bring the ponies into enclosures and provide them with hay -they will not touch oats, and seem to be afraid of grain of any kind-and attend to the safety of the stock as far as they can.

\section{Disposal of the Ponies}

A large number of the ponies disposed of find their way into coal mines, where their superior strength renders them under certain conditions more serviceable than shetlands; whilst others are sent over to lreland, whence they return, when matured, as Irish bred animals; the choicest specimens fall into private hands. Prices vary from $f_{s} 6$ to $f \mathrm{I} S$ for adult ponies, down to about 30 s. for "suckers," by which name the foals are known, and considering the amount of work ther are capable of performing, their surefootedness, fine constitutions and longevity, 
it cannot be said that the selected specimens are otherwise than very cheap.

\section{Northern Dartmoor Breed}

Excellent ponies are also to be met with in the northern part of Dartmoor, in the neighbourhood of Tavistock. Many of these are taller than those bred in the Brent district, owing to the breeders of the north side favouring an extra half inch or so in height. This departure from the old traditions of the breed is probably a result of judicious crossing, but it is questionable whether the bigger ponies are an improvement upon the smaller ones, even though in some cases they may command slightly increased prices.

\section{Dartmoor Pony Points}

The head of a Dartmoor pony is large for the size of the animal, which, in the eyes of some people, may constitute an objection against him, but it is essentially a clever looking head and one that attracts the students of equine physiognomy. It is possible, too, that the size of the ears-which in the case of a true bred Dartmoor should be very small and pointed at the tips-may cause the head to appear larger than it actually is, but unquestionably the fact remains that it is heavier than that of any other breed of pony. The neck is of a good length, powerful and well set on sloping shoulders; the back is rather long, but very level; whilst the chest is well let down, and the quarters nicely ribbed up; the breed is very powerfully built and up to carrying heavy weights. The fore-legs are usually very good, carrying plenty of bone for the size of the pony, and the feet are as hard as iron, but they are sometimes not perfect in shape, which is probably a result of the ponies having to travel about over damp ground all the winter of their first year. The quarters and second thighs are excellent, as a rule, the former being level, and the latter carrying a good amount of muscle, but there is a tendency to cow-hock, and occasionally to goose-rump, which may be due to the privations endured upon the moor, or, as some local breeders maintain, to the habit the ponies have of crouching in a crowd with their heads together for hours at a time, during the prevalence of the storms which frequently sweep over the moor.

\section{Colour and Character}

The chief colours of the Dartmoor pony are brown, bay and black; chestnut and grey, though met with, are regarded, and rightly so, with extreme disfavour, as being indicative of impurity of blood, whilst duns, skewbalds, piebalds and other odd colours are never seen.

A word of praise must be bestowed upon the extreme intelligence and docility of the Dartmoor pony. When once his confidence in those about him has been establishedand it must be admitted that his life on the moor has rendered him suspicious of mankind - no better-mannered pony can possibly be found, but he requires to be carefully broken if the best results are to be obtained. Such an observation applies to every breed of horse, but more particularly to this pony, as he has a will of his own, which it is only possible to control by careful breaking in the first instance-in which case he will be a good-mannered little horse for life - or by sheer brutality in the form of thrashings afterwards. It is to be feared that some owners adopt the latter course, but if they do they may rest assured that they have succeeded in ruining a good pony.

The annual show of Dartmoors, which is held in the summer at Brent, is the means of bringing together all the best ponies of the district, and may be referred to as the most interesting and instructive event of its kind. It is held under the auspices of a local society, which is supported by all the leading breeders of the neighbourhood, and is well worth a visit from all who are interested in a most valuable and ancient breed of British pony.

\section{The Exmoor Pony}

The Exmoor Pony undoubtedly occupies a very high position on the list of popular British breeds, and of him it may justly be said that he is well entitled by his merits to all the eulogies bestowed upon him. At the 
same time it cannot be denied that the Exmoor is greatly indebted to the novelist, Whyte llelville, for bringing him so prominently before the public in the pages of "Katerfelto." It will be remembered that a leading character in the story was the mvsterious stallion of that name which roamed Exmoor somewhere about a hundred vears ago. There can be no doubt, noreorer, that a sentimental interest attached to the memory of Katerfelto long before he was immortalised by Whyte Melville, as no one connected with Exmoor was able to account for his presence there. The most probable of the many stories associated with his appearance is that which suggests that he was a survivor of a wreck upon the Devonshire coast, and thus found his way to the forest of Exmoor. That such a horse as Katerfelto existed is beyond all doubt, and there can be no question that he exercised a great deal of influence upon the mares in the forest. He was the first dun-coloured stallion to serve there, but duns with dark lists or stripes along their backs are stil] plentiful in the district, and all trace their origin to the mysterious Katerfelto, who was eventually captured and kept in confrnement at East Anstey until he died.

\section{Experiments with the Breed}

Romantic as was the history of Katerfelto, and great as were the services he rendered to the Exmoor ponies during the three years he enjoyed his freedom amongst them, the present value of the breed, however, must not be attributed entirely to him. As far back as the commencement of the last century Sir Thomas Acland was breeding these ponies on Exmoor, and when the Simon's Bath land came into the possession of the Knight family he removed his herd to Winsford Hill, near Dulverton, where he continued to breed the ancient type of animal. Neanwhile Mr. John Knight and his son, Sir Frederick Kinight, were de. roting their attention at Simon's Bath to ponies and other varieties of livestock. The herd of ponies was considerably reduced in the time of the latter, though their value was increased by judicious crosses of thoroughbred blood. This was not by any means the only outside cross that was experimented with, as previously to using the blood horse, both P'ick Horse sires and Dongola stallions, imported from Egypt, had been tried-with pretty good results in the first case, but disastrous ones in the latter. Sir Thomas Acland, on the other hand, adhered to the old blood, and the result was that his herd was the only one in the district which possessed it in the pure state.

Some fifty years ago Mr. Robert Sinith devoted a good deal of time to experimenting upon his Exmoor mares with a pony stillion got by a thoroughbred out of an Arab dam, and produced some saleable animals, though they could not by any stretch of imagination be described as Exmoors.

The object of all the crosses which were made was obviously the production of a taller pony, which would realise more money than the animals standing the legitimate I3 hands-which is the limit of height of the true Exmoor. There could have been no other reason for such attempts to improve a pony which for his inches was, and probably still is, the finest saddle animal of anything near his height in the world, and consequently unsusceptible of improvement except in the direction of greater stature.

\section{Exmoors v. Dartmoors}

In one respect the Exmoor pony possesses a great advantage over his near neighbour, the Dartmoor, inasmuch as the climate of north Devon is far more genial than that of the south; indeed, the Exmoors which have been subjected to the rigors of a severe winter on Dartmoor have generally succumbed to the privations they have endured. Beyond all doubt, however, the infusion of a little of the Exmoor blood into the Dartmoors would add to the beauty of the latter's heads. Very probably, too, the cross-breds would be an improvement upon the Exmoor in respect of the adaptability of the breed to work in leather, as the latter is essentially a riding pony, and possesses more quality than does the south Devon pony. As boys' hunters they can scarcely. 
be surpassed, if the country is not too big, and many stories are told, some of them doubtless true, of the marvellous crosscountry performances of Exmoor ponies with full-grown men on their backs, and under welter weights. Possibly the majority of these tales are exaggerated, but divested of all hyperbole the accounts of strangers to the breed who have seen members of it out with the Devon and Somerset Staghounds are most flattering to the courage, staying power and jumping ability of the Exmoor pony. Of course, there are Exmoors and Exmoors--some good and some bad; and it is unfortunately the case that the old breed has almost been "improved" off the face of the earth. Probably in their ignorance persons who devote themselves to the improvement of an ancient breed forget to follow the advice of the old poet Horace (himself an agriculturist) to "hasten slowly," and proceed to work in such a hurry that they have ruined all their foundation stock before they realise the gravity of the mistakes they have committed.

\section{Exmoor Characteristics}

In spite, however, of the crosses which have been inflicted upon them there is no gainsaying the fact that the ponies of Exmoor are most attractive-looking and valnable little horses. They are, moreover, a wonderfully even lot, always excepting the chestnuts, which appear amongst them in pretty large numbers and spoil the effect which would otherwise be created. No doubt these chestnuts are as closely related to the old strain as are many of the bays and other recognised pony colours with which they are associated, but there is no getting away from the impression which their appearance causes, namely that they possess more of the Arab and thoroughbred character than do the others. Possibly this may be the effect of imagination on the part of those who are aware of the circumstances of these breeds having been crossed with the Exmoor, but when one is supposed to be inspecting an ancient breed, which some people contend is indigenous to a district, it is better to try and disillusionise oneself as much as possible; hence the regrets which old-fashioned pony breeders must often feel when meeting with chestnuts in a herd of Exmoors. The fact that the chestnut colour was not to be found in Sir Thomas Acland's herd at Dulverton, which up to very recently had not been subjected to outside crosses, goes a long way towards showing that this shade of colour is not inherent to the breed; the most common are blacks, browns, and bays, with mealy-coloured noses, and duns with black lists or eel marks along their backs. The mealy-coloured nose is a great characteristic of the Exmoor pony; whence it is derived is not known, but the fact remains that many persons, erroneously, no doubt, are disposed to regard no pony as being of the old blood unless he has it.

\section{Points of the Exmoor}

With regard to the question of height it is pretty generally agreed that no Exmoor slould exceed 13 hands, or be less than I2; but many, if not most, of the improved ones, especially those evolved from recent crosses, are taller than $I_{3}$ hands. This is only what can be expected, as the main object of crossing the old stock was to increase the size of the pony. The head of the Exmoor is very neat and frequently bloodlike, the forehead being wide, the eyes full, and the ears small and pointed. There should be plenty of length of neck, and this should not be coarse and thick, but quite the reverse, and it should be neatly set on long, sloping shoulders, otherwise the riding properties of the pony will be depreciated. The back ought to be short and flat, and the quarters level; the chest moderately wide with the body let down well behind the forearms. Any tendency towards tucking up at the loins must be regarded as a fault in the case of a pony which, like the Exmoor, is used for saddle work and carrying weight. The fore-legs are short, with good arms and plenty of flat bone for the size of the animal, whilst cow-hocks are not so commonly seen as they are amongst the Dartmoors.

The question of action is important, as it always must be in the case of any horse that is used for riding, for if it is rough and 


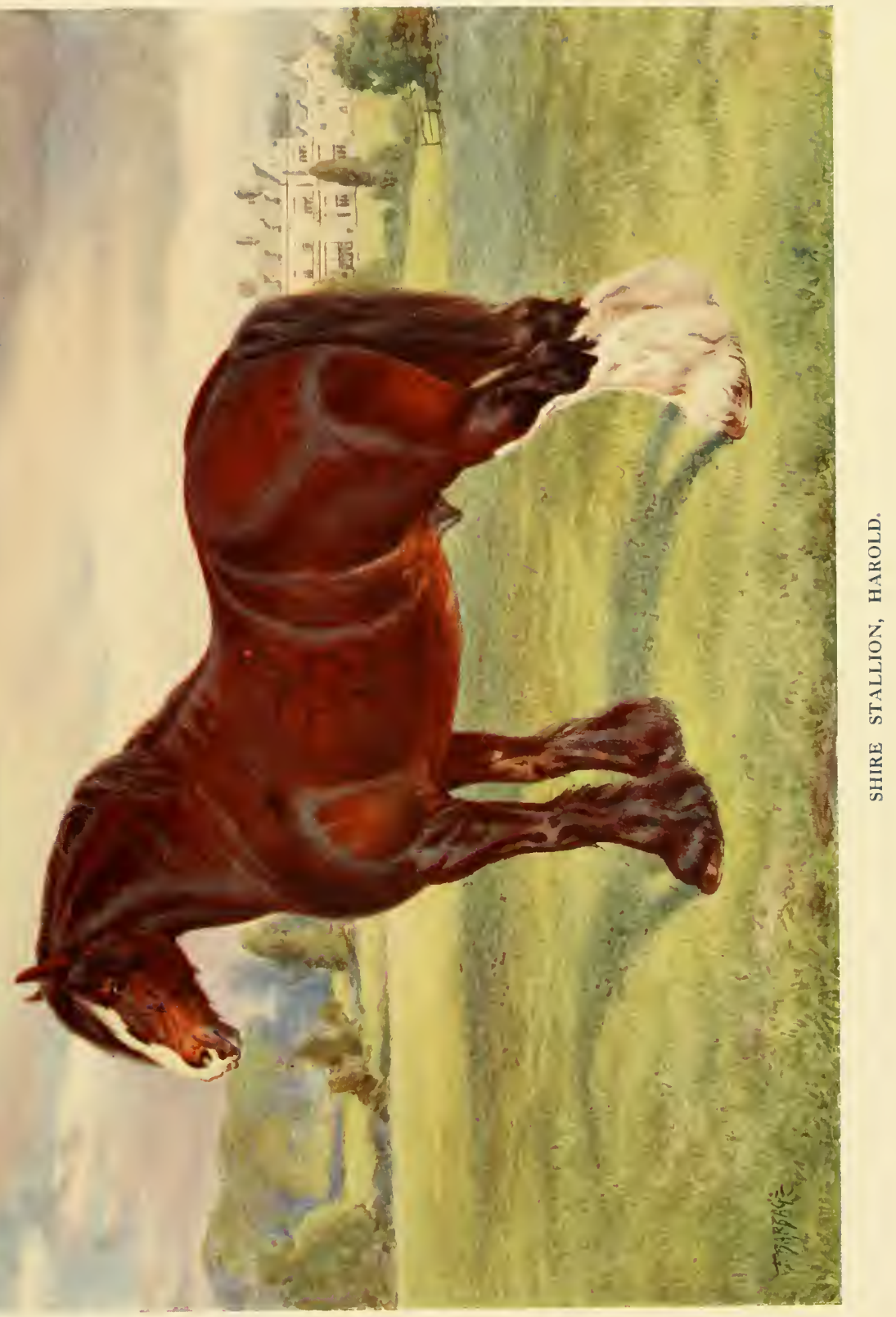



uneven the man in the saddle is sure to be uncomfortable, and very possibly the pony will suffer from a sore back through the saddle galling it. A few ponies found on Exmoor appear to possess a natural gift of stepping, not that their action is particularly high, but from the manner in which they shape, and it may be inferred that there is a Hackney cross somewhere far back in their pedigrees. A short time ago some experiments upon a small scale were tried by a well-known exhibitor of harness ponies to produce some high-actioned little ones of about 12 hands 2 inches - such as are always saleable-by introducing a direct cross of Hackney blood upon some Exmoor mares of the old type. The results, however, were not sufficiently encouraging to justify a continuation of the cross, from which it may be inferred that this mixture of harness and riding blood succeeds better in the case of the Dartmoor than with his neighbour in the north.

An Exmoor stallion, possessed, it was stated, of Arab blood, was tried by the directors of the Dartmoor prison stud at Princetown some years ago in order to im- prove the looks of the ponies bred at that establishment. Although this cross to some extent accomplished the purpose for which it was made, it was not upon the whole considered satisfactory and it is said that the constitutions of the ponies were weakened. If this is correct it would be serions, as Princetown is one of the bleakest districts on Dartmoor, the climate of which at all times is very trying to Exmoor ponies.

White markings are regarded with the utmost dislike by breeders of these, and indeed of all moor ponies, and consequently an animal possessing them should at once be rejected. From force of circumstances, however, as there was no competition, a pony thus disfigured has won at the London show of the Polo and Riding Pony Society in the Exmoor mare class.

In conclusion it may be stated that the great medium for the sale of these ponies is Bampton Fair, which is held on the last Thursday in October every year, and here very good adult specimens of the breed can be purchased at prices ranging from $f_{8}$ to $f_{\mathrm{I}} 2$, according to quality, whilst young animals may be bought for much less.

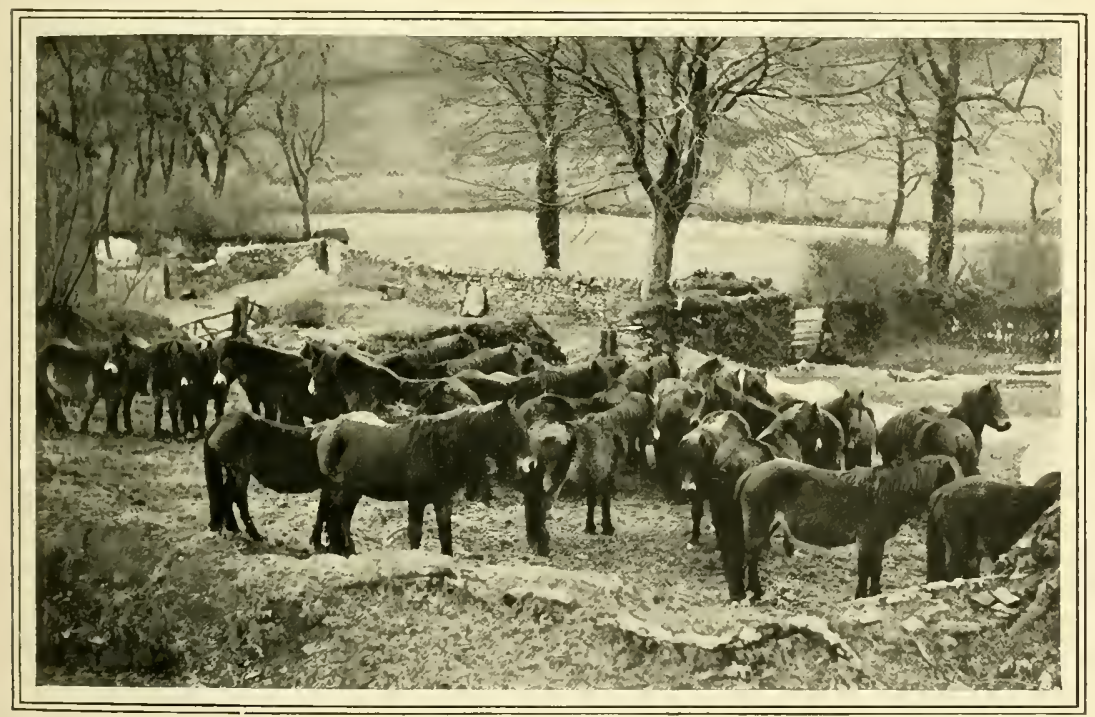




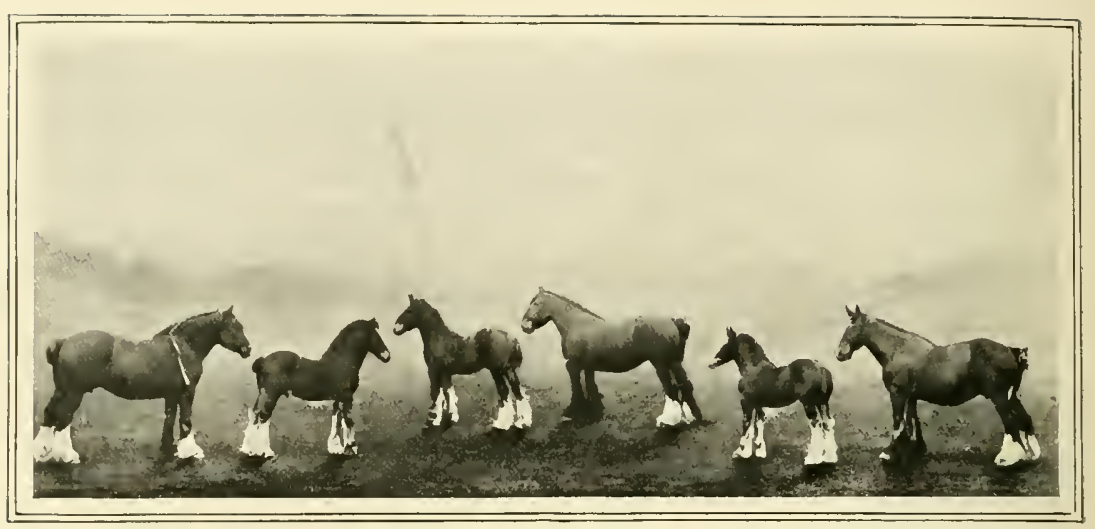

A GROUP OF CHAMPION SHIRES AT THE PERDLEY MANOR STUD, TRING. ON THE LEFT: ROSE, HITH FOAL BY LOCKINGE FOREST KING. IN THE CENTRE: DOROTHY OF WARSLEY, WITH FOAL BY HOE FOREST KING. ON THE RIGHT: TATTON MAY QUEEN, WITH FOAL BY DANESFIELD STONEWALL.

\section{CHAPTER XXVII}

\section{THE SHIRE HORSE}

T HE Shire horse is the chief draught breed in this country. It is bred in every county in England and Wales, and has a small following in Ireland. The reason why the heavy horse is so popular throughout the country is because it is capable of earning a living at an early age on the farm. The Hackney and the Hunter do not become serviceable until they are four or five years old, and as it is reckoned that the cost of keeping a horse in a growing state for a year is fIo, the advantages of breeding heavy horses is at once apparent.

The early history of the Shire horse is decidedly obscure. From the literature handed down to us a few suggestive facts emerge, upon which a mountain of theory has been constructed. History by inference is never satisfactory. It is an entrancing study, but immediately we enter the region of speculative belief we can cloak the progenitors of the present-day Shire in an atmosphere to agree with one's most cherished theories in heavy horse breeding. To take a case in point. The early Iincolnshire type, which is a distinctly hairy-heeled, even moustached, horse, could not have been subject to the same influences as those which dominated the breeding of Clydesdales at the same period. If we accept the historical fact in its nakedness, that during the reign of Henry II., in $1 \mathrm{I} 60$, an importation of breeding animals was made from abroad, and that these importations were continued at different periods subsequently, obviously the type of Continental draught horse must have greatly changed in the course of centuries. Flemish horses we know are notable for their lack of hair, and their influence in this respect can be seen in the Clydesdale of to-day. If the same influence worked as potently in the production of the Lincolnshire Shire, how can we account for the Lincolnshire Lads, and horses of that type?

We have here a problem which can only be worked out by analogy, and even then the result is not convincing. We know; for instance, that certain of the lands in the Midlands and on the East Coast are capable 326 
of growing great strength of bone, and a that size and substance so pronounced in plenitude of hair. Is it not possible that the Shire horse of to-day, it is more than in the original type introduced there was likely that under favourable conditions the

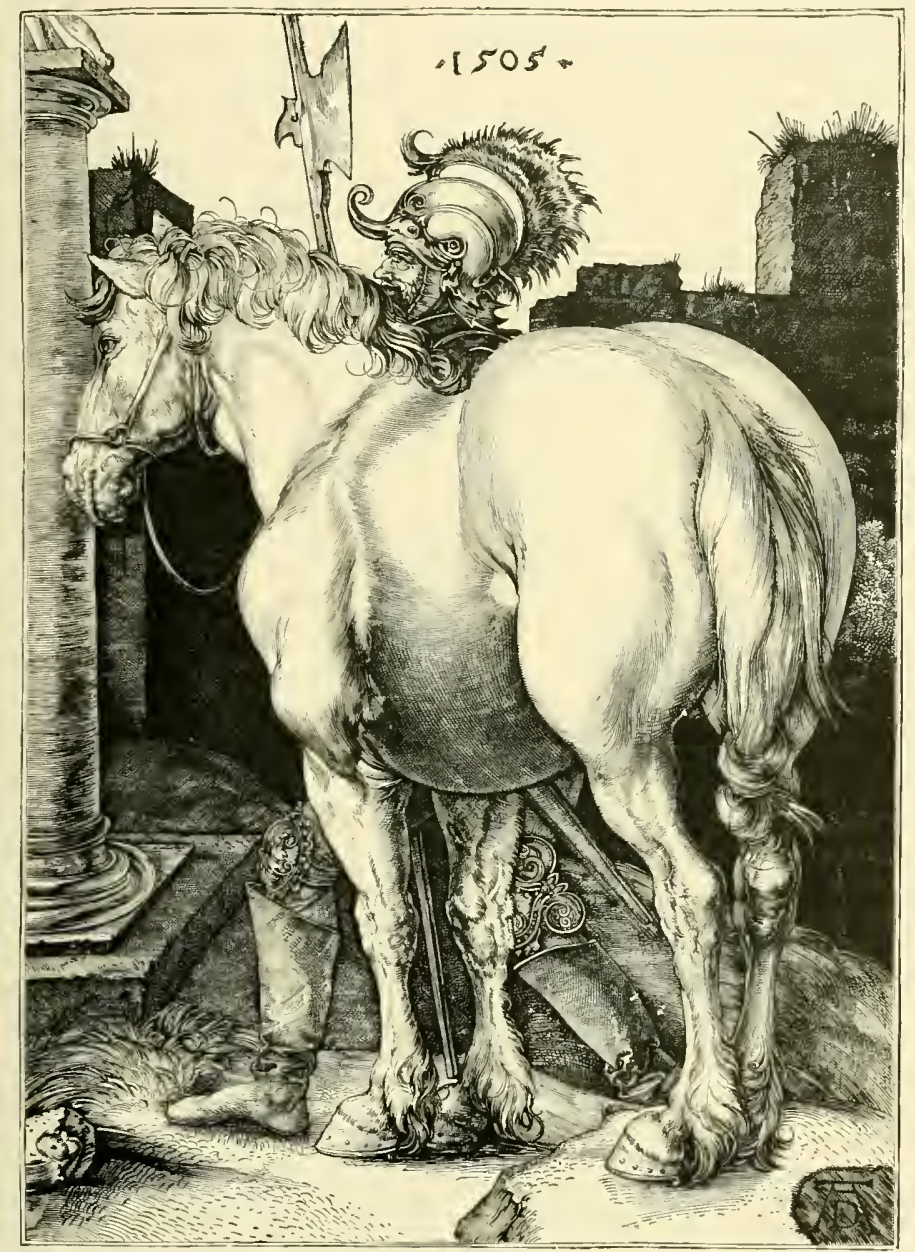

THE WAR HORSE.

By Albrecht Durer.

more hair than is commonly noted in the draught horses of the Continent to-day, the selections being made more in accord with the ideas of English than Continental breeders? Even assuming that we are partly indebted to alien blood for some of
Lincolnshire Fen-lands modified a prevalent type and produced one of their own. This probably accounts for the difference in the class of Shire horse kept in the early days on the East Coast and in the Nidlands, compared with further west, north and south. All 
modern experience of heavy horse breeding goes to prove that the influences of soil and climate are predominant in moulding type and character. We know, for instance, that Clydesdales bred in England do not altogether please breeders in the far north, for the reason that they are said to grow coarse. From a Shire horse breeder's point of view we should be more inclined to pass the opinion that they had improved in substance. But here again the point of view is all-important.

\section{Romans and British Horses}

Let us glance at material facts in history. At the time of the Roman invasion, some two thousand rears ago, the influence of Continental horse-breeding must have been very great in these islands, unsettled and warlike though their inhabitants were. Heavy horses must have been required to carry well armed men, and the chariot, to be dragged over rough country and through the thick of the fight, must have been hauled by a heavier type of horse than appears to have existed in these islands at that time. Strength and substance were then no doubt imparted to the native stock of Britain by the horses that the Romans brought over, for they were a skilful agricultural race. Moreover, in a wild state the tendency of equine races is to degenerate in size and constitution, and emerging from a barbaric period there can be no dombt that the original horses native to this country were small of stature. Some colour is lent to this view by that interesting volume from the pen of Sir Walter Gilbey entitled the "Old English War Horse." The first of the earlier drawings reproduced therein is by Albrecht Dürer, and is dated $1_{505}$. It depicts a horse of the period, beside which stands an armed soldier. The artist must either have had a liberal conception of the stature of warriors in those days, or his imagination or idea concerning a war-horse was somewhat vague, for the horse is a pigny in proportion to the height of the soldier. It is probable that the war-horse was a good hand smaller than the modern Shire. But what interests us most is that the outlines of the war-horse depicted by Dürer agree to a considerable extent with many of the conceptions of a draught horse. There is the hair of the mane, which the hirsute dogma says indicates strength. There are the wide, powerful loins and hips, the well developed muscle, strong shoulders, and big feet. Obviously in a horse bred for strength and endurance as well as fleetness there would be characteristics of the latter which we have lost sight of in more prosaic days, when "harness" of a different nature is carried. Still there appears to be the dominating influence of weight in the old war-horse, and most people who study the matter will agree in tracing a distinct connection between the war-horse which carried our forefathers and the dray-horse of our own time.

\section{Blundeville's Evidence}

Sir Walter Gilbey makes a good point in support of his contention by quoting from a book written by Sir Thomas Blundeville. This writer remarks of a time ante-dating about 500 years:

" Some men have a breed of great horses meete for the war, and to serve in the field: others tried ambling horses of a meane stature for to journey and travel by the way. Some again have a race of swift rumners to run for wagers or to gallop the backe; but plane country men have a breed only for draughts or burden."

This extract affords more than presumptive evidence that horses of distinctive character were then bred, and that the heavier knights rode out in the full panoply of war upon horses built more for strength than speed. As a matter of common sense it must appear that a $I \frac{1}{2}$ to 16 hands charger loaded with a portly knight clad in mail, which also included protective " harness" for the horse, must have been a very sturdy steed. He could not have had the speed of a modern Hunter, otherwise the knights who ran their courses could not have withstood the shock, and even allowing for the shivering of an ashen lance, the impact would have been so great as to hurl each combatant from his steed. 


\section{THE SHIRE HORSE}

\section{Further Foreign Importations}

Reference has been made to the time of Henry II., and the importation of breeding animils from abroad in ir6o. Following this, a few years later, another consignment was brought over from the Continent in the reign of king John, from which fact we may assume that the earlier introductions had proved successful. A lundred stallions of large stature, we are told, were bronght over from Holland, Flanders, and the neighbourhood of the Elbe. In the time of Henry VIII. considerable attention was paid to horse-breeding; we judge so from the regulations made to govem the production, control, and export of horses. For instance, there were stringent laws enacted against running inferior sires at large. So severe were they that in certain counties powers were conferred empowering their destruction. 1t was evident that size, uniformity and weight were points to be carefully cultivated, even to the extent of compulsion. It was likewise contrary to the law to export horses, and scotland was one of the countries under the ban of this prohibitive Act. In 1535 a law was enacted which provided that all owners or farmers of enclosed grounds of the extent of one mile compass should keep two mares, being not spayed, apt and able to bear foals of the height of "thirteen handfuls." A penalty was imposed upon those who permitted them willingly to be covered by any entire horse under the stature of "fourteen handfuls." The Act made law in I54I was, no doubt, a natural sequel to that passed six years earlier, for no person was permitted to put in forest, chase, moor, heath, common, or waste, where mares and fillies are used to be kept, any stoned horse above the age of two years not being fifteen hands high, within the shires and territories of Norfolk, Suffolk, Cambridge, Buckingham, Huntingdon, Essex, Kient, South Hampshire, North Wiltshire, Oxford, Berkshire, Worcester, Gloncester, Somerset, South Wales, Bedford, Warwick, Northampton, Yorkshire, Cheshire, Stafford, Lancashire, Salop, Leicester, Hereford, and Lincoln.

\section{7th Century Horses}

Coning to more recent times-within the past three centuries we have many references to heary horses. Thus, in 1620 , the Privy Council Minute of an estimate for horsing an expedition values the "strong or great " horses at $\mathrm{fI}_{5}$, and ordinary horses at $f 9$. This may have had reference to a superior class of horse, but probably it was intended to draw a distinction between an ordinary baggage horse and the heavier and more valuable draught type. In 5658 the Duke of Newcastle published a work which contained many allusions to the horses of his time, and likewise many plates depicting their character. Queen Anne, in I7I3, was a supporter of the draught horses for her equipage, but gradually there was modelled a coach horse of a distinct type, probably arising from a cross of the blood type on the draught animal.

Sir Walter Gilbey's conclusion of a wide historical survev is interesting.

"No doubt," he says, "these statutes helped to build up the shire horse and to establish a breed which mav now be accepted as national, for the counties enumerated in the statute of Henry VIII, sufficiently tell through what a wide area that breed existed six centuries ago, and since that date it has extended rather than diminished the area which it occupies. As the horses of this caste have been mated together for so many generations, their character has become permanent, and what must be termed a distinct breed has been produced."

He then refers to the necessity of careful mating, and the value of pedigree as a guide to the breeder.

\section{Shire Horse Society}

The Shire Horse Society is now a wealthy institution. Its formation was directly due to a suggestion made by Mr. Fred Street, of Somersham, when lecturing before the London Farmers' Club, in the year I 878 . His lecture dealt with the draught horse, and the proposal that a breed society should be formed was taken up with considerable enthusiasm. For a time he acted as secre. tary, when the initial meetings were being 
held, and a society formed, so to speak, out of the nebulous suggestion. Probably none of those who attached themselves to the society in these early days dreamt that it would ever attain to its present proportions, wield so much influence, and disburse so much money in the interests of the breed. From a small beginning it has gone on to great prosperity.

Originally the society was known as the English Cart Horse Society. After the reading of Mr. Street's paper a special meeting was convened under the chairmanship of Mr. John Brown, then chairman of the Farmers' Club, when the resolution "That it is desirable to form an association to publish a Stud Book of Shire-bred horses " was carried. The Earl of Ellesmere was the first President, and the first official secretary after the temporary services of Mr. Street was the late Mr. G. M. Sexton, who was then a partner in the firm of Messrs. Sexton and Grimwade, auctioneers. It was not until IS80, however, that the first show of the society was held at the Agricultural Hall, Islington.

It is scarcely necessary to dwell at length on the phenomenal growth of the society. Suffice it to say that in Igro the membership numbered 3,956 . The number of affiliated societies was 29I. From its inception the society was a success. Its influence is not alone confined to the improvement of the breed, but to a considerable extent regulates its aftairs. Its chief work is undoubtedly the holding of an annual show and the issue of a Stud Book. It has also an excellent scheme of gold and silver medal distribution at affiliated shows, whereby during the summer months it keeps in touch with the breed and with breeders.

\section{Veterinary Inspection}

The Shire show is dealt with elsewhere. Here we would only refer to the admirable system of veterinary inspection instituted in the year I892. At first every animal exhibited was required to pass through the veterinary yard. In the year mentioned, of +87 animals submitted to the judgment of the veterinary bench, 93 were rejected for hereditary unsoundnesses. since then the system has been modified, and now only the animals chosen in the preliminary drafting of the class must undergo the ordeal of the veterinary paddock. In I9Io 283 animals were placed before the veterinary inspectors, and only $\mathrm{I}_{5}$ rejected. We may therefore assume two things: (I) that the Shire is a sounder breed than it was, (2) that breeders are more careful of the soundness of the stock they send up. Not a little of the benefit of this strong stand made by the society in favour of a sound breed has been derived from what may be termed its moral effect. Breeders themselves are more careful of what they purchase, and in the case of a high-priced animal they usually insist on seeing the dam, or at all events having an adequate knowledge of her character and soundness.

The medal scheme enables breeders to exhibit for medals at summer shows, the gold medals being exchangeable for $t$ io in cash if desired.

The Stud Book is a very bulky volume. It has grown from comparatively insignificant proportions. Thirty-one volumes have already been published. The first thirteen of these contain the registration ntumbers of $\mathrm{I}_{3}, \mathrm{Sog}$ stallions, and $\mathrm{I}_{3}, 859$ mares. The second index to Volumes I4 to 25 contains the entries of $8,2+6$ stallions and 30,042 mares.

\section{Popularity of the Shire}

The Shire is supported alike by the aristocracy and the democracy. Many of the small farmers of the Midlands, especially in the Derbyshire neighbourhood, find that with one or two pedigree mares they can readily earn their rent if they are careful in the choice of a sire. It used to be a saying that many a small farmer sold a foal to pay the rent. The support of moneyed men and the landed aristocracy has been invaluable. To their appreciation of the finer points of a draught horse and to their practical support at many a sale-ring much of the improsement of the breed is due. If famers only had had the breed in hand, 


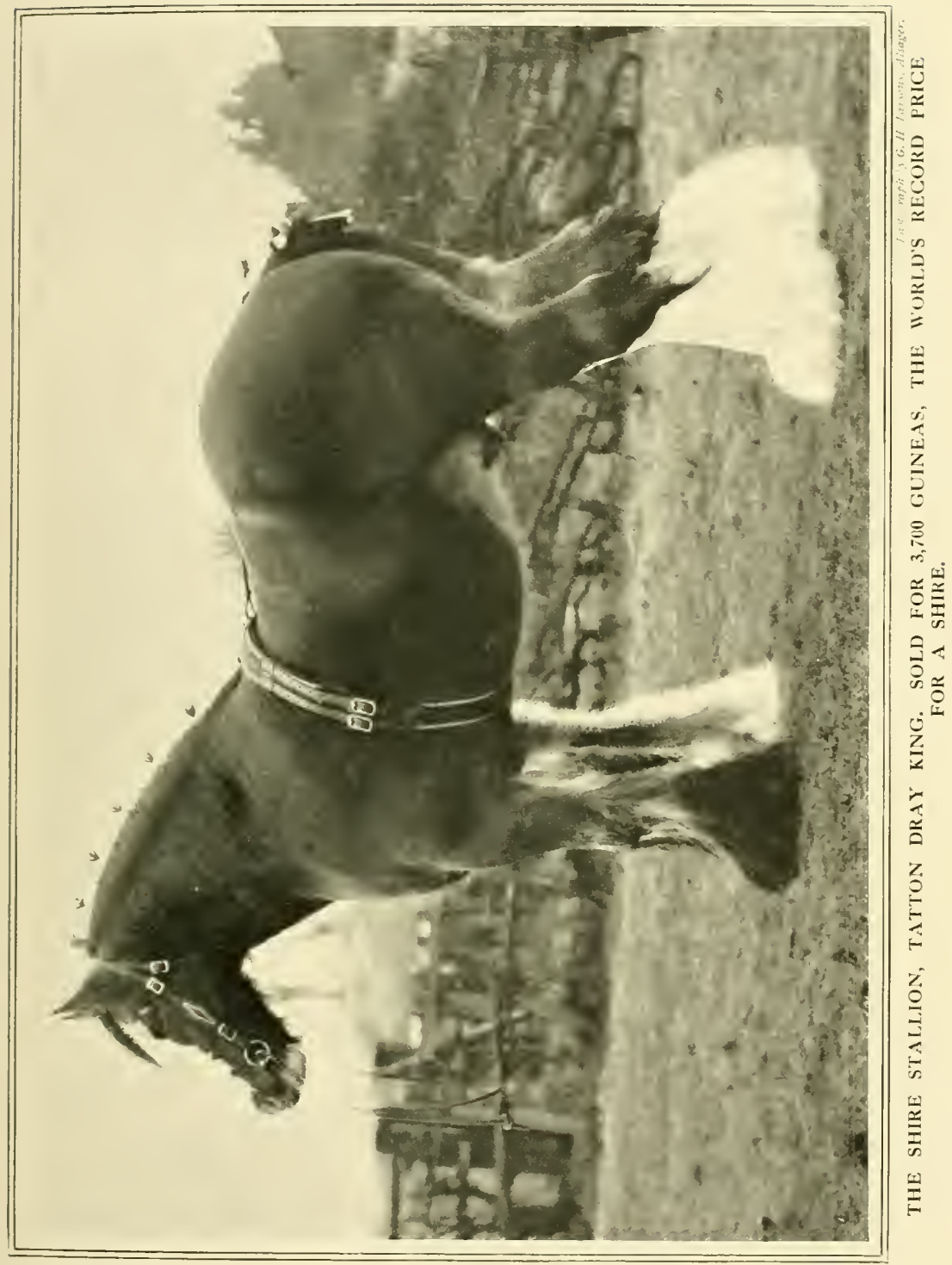


it is safe to assume that the realisation of high prices would not have advertised the pedigree Shire so much as has been the case in the past. Pedigree has appealed in the first plice to the moneyed man who has taken up horse-breeding as a hobby, and secondly to the farmer, who has been brought to realise that few more profitable investments can be made than the purchase of a good pedigree shire mare.

\section{Advantage of Pedigree}

It may appear to border on the absurd to ask wherein the advantage of pedigree to the farmer lies? But the fact that a higher price is paid for a good pedigree foal than for an equally good non-pedigree youngster is in itself a potent argument. Apparently, however, it does not strike everyone alike, for an infinitely greater number of non-pedigree than pedigree mares exist on the farms of England. A well-known owner of stud horses once estimated that nearly go per cent. of the mares covered by his horses in the season had no pedigree. This estimate is probably very liberal, for it is doubtful if there are ten per cent. of mares eligible for entry in the Stud Book.

\section{A Simple Problem}

It has always appeared to be a curious anomaly that the farmer who keeps unregistered stock should be so careful to choose a pedigree sire, but it is a hopeful angury of the time when pedigree shall be no longer considered a barrier to the breeder, but a means to his advancement. Let us propound a simple problem in figures which any farmer can check and construe for himself. Suppose a farmer has two mares of equally good character, one segistered, the other without a pedigree. The market value of each is respectively fso and $f_{5} \mathrm{O}$. The service fee of a first grade stallion is, say, seven guineas, the former being put to a good horse at that figure (usually ten guineas to others than tenant farmers). For the latter an ordinary three- or four-guinea horse may be chosen. The resultant foal, assuming it to be worth, if a male (with the gelding market in view), fI5 to f20 in the ordinary market, might with a pedigree bring anything from froo to $f_{2} 200$. It requires no scholastic skill in the lower branches of mathematics to understand that a gross outlay of $£ 30$ extra in capital, and four guineas extra in fees, under these conditions-a comparatively common experience-are not to be weighed in the balance. The cost of making farm mares pedigree instead of non-pedigree might be as much as fio or f 15 per head, but he must indeed be an inordinately unlucky breeder who cannot turn his additional capital over in two foaling seasons.

\section{The Packington Blind Horse}

The earlier volumes of the Shire Horse Society's Stud Book provide information concerning the foundation stock of the modern shire. Research has branded as the first Shire stallion of which we have any definite information the black Packington Blind Horse. The date associated with his travels is 1755 , and he was on the scene for some filteen years. He is supposed to have been a horse of about $I 6 \frac{1}{2}$ hands, with a white face and markings. His forehand was low set, his shoulders thick, his ribs well hooped, his legs short, and his feet and pasterns good. He was in active service in the Midlands, but his stock has been traced only in the three counties of Leicester, Warwick, and Derby. Seven generations have been outlined, and in the year IS3t the number of his direct descendants was stated to be upwards of I5o. We find one of his descendants travelling at a fee of three guineas, which seemed to imply that the necessity of paying a good price for the hire of a good horse was appreciated then as now. In Bakewell's time, of course, high service fees were common. We are so accustomed to associate this great master-hand in stockbreeding with the improvenent of the Leicester sheep that the fact may not be known that he was a heavy horse breeder of some eminence. Thus we have Artluir Young's testimony, in 177 I and I 786 , that Bakewell's horses were let at 25 guineas to I50 guineas for the season. 
"Mr. Bakewell's breed of horses," he sars, " is a great heary black and his stallions are $\mathrm{by}$ far the finest I have ever seen of that breed. Nothing can be more compactly. formed. . . Mr. Bakewell's exertions appear to be as successful in this line as in any other."

\section{Other Celebrated Stallions}

There are several other stallions which no doubt exercised a more potent influence on the carly times of heavy horse breeding, of which we have no authenticated record, so that it behoves us chiefly to consider the equine giants of our own time, and those strains of blood which have made the shire horse the power it is to-day in agricultural England. Amongst these we might mention Blaze as a particularly prolific sire, foaled in I770; the Derbyshire horse Ruler, which came into existence three years later; and the Leicestershire horses G 890 and Bald Horse 93, foaled in 1775 and 1778 respectively: These were all of Midland origin.

Coming to more recent times we are confronted with an array of famous sires. To mention a few of them, there are Lincolnshire Lad II. I365, Dack's Matchless I500, Royal Albert I885. What's Wanted 2332, William the Conqueror 2343, Bar None 2388, Harold 3703, Premier 26 46 , Hitchin Conqueror $4+58$, Menestrel I +180 , Bury Victor Chief II 05 , and more recently still Dunsmore Jameson I7972, Lockinge Forest King I8567, and Birdsall IIenestrel I9337.

\section{Lincolnshire Lad II.}

It is impossible in a review, which has its limitations, to do justice to the ramification of pedigree stock breeding. Our object may perhaps be best served if we consider one or two of the chief strains. First and foremost comes Lincolnshire Lad II. 1365, in whose back breeding appears a plethora of Honest Toms. A grey horse standing $I_{7}$ hands, he was bred by $\mathrm{Ir}$. Fred Ford, Locko Park, Derbyshire, in 1872. His sire was Lincolnshire Lad I Ig6, and his dam Madam, by Matchless I 506 . He passed through several hands. In his early career he went to Mr. W. Harriman, Wilsthorpe,
Derbyshire; IIr. William Clark, Locko, Derbyshire; and Mr. Kivte, of Derby, from whom he was purchased by Captain Heaton in I8SI. In 1885 he was transferred from the Earl of Ellesmere's service to the ownership of Mr. Walter Johnson, of Hatfield, Doncaster. Hewas, however, poorly patronised in that locality, and the IVelshpool Society hired him on four occasions at a rising fee. He finished his career in the stud of the late Mr. Fred Crisp, at Southgate, in 1895 , living to the ripe age of 23 years. He was a horse very full of hair, with a fine wealth of bone, rather a narrow type, but most breeders prefer a light middled, narrow horse for stock-getting. Lincolnshire Lad II. earned most fame through his still greater son Harold, unquestionably the most impressive sire of his time. He also sired, in addition to numberless fine mares, Eastoft Lad, Famous Lad, Lincolnshire Boy, Carbon, Lancashire Lad II., and Potentate.

\section{Harold}

Harold was admittedly a great horse. He was the progenitor of the triple London champion Rokeby Harold I53 I3, and Markeaton Royal Harold, always a famous show horse, but only once champion at London. Buscot Harold 16576 , which attained to the distinction of thrice champion at the Agricultural Hall, was a grandson of Harold, through Markeaton Roval Harold. The champion Bearwardcote Blaze is another grandson of the old horse. Amongst the mare champions, 20686 Queen of the Shires and $I_{4} 655$ Dunsmore Gloaming are credited to him, and such mares he was wont to sire! Big, roomy, weighty dams they proved, nnexcelled as breeders, especially when put to the Premier cross. There were others directly descended in the male line from him, such as 2976I Princess Beryl, +4795 Desford Countess, and t+ogI Belle Cole. This in itself is a magnificent record. He headed the list of winning sires at London in eight successive vears.

The two most notable breeding horses of the new century, Dunsmore Jameson and Lockinge Forest King, the former through Moor's Zealot and Potentate, and so to 
Lincolnshire Lad II., and the latter through Lockinge Manners and Prince Harold, are closely linked with the Harold blood. And yet it was an accident that Harold was retained in tlis country! Bred by Mr. Potter, of Spondon, near Derby, he was bought by Mr. C. J. Douglas to go to America. He did not make his name as a show horse

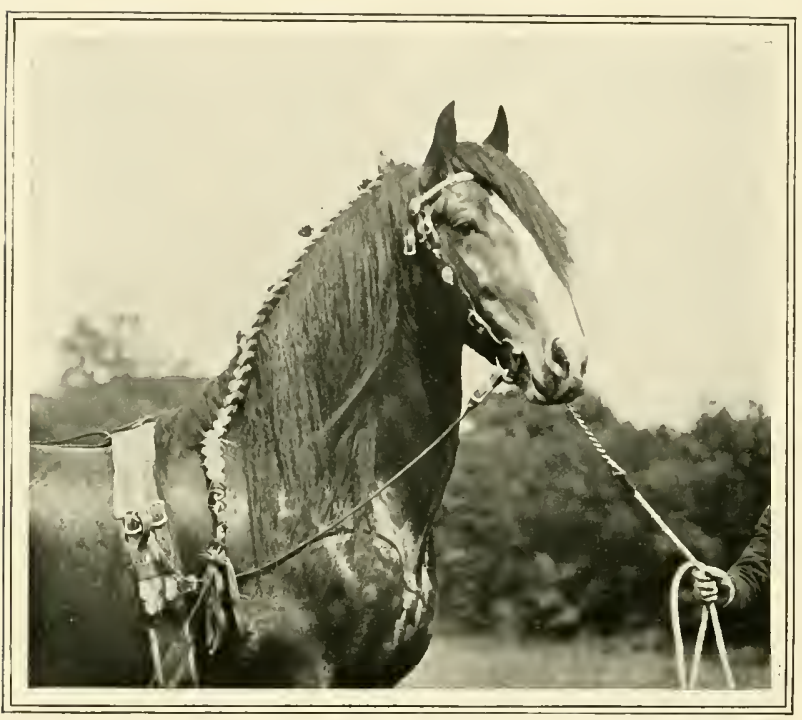

LOCKINGE FOREST K1NG.

leaving you, and impresses one with the idea of never failing courage and fire."

Royal Albert has a fine reputation in the IIidlands, having done great service in Derbyshire particularly. He was a brown horse, standing I7 hands I inch, bred by Mr. C. Marsden, of Hatfield, Doncaster. As a foal he was owned by Mr. Walter Johnson, of Hatfield. Mr. Johnson describes him as "an upstanding, leggy, narrow horse, but had wonderful limbs, particularly the hind legs." The Royal Albert type of hind leg is no tradition, and possibly we may trace this influence in Lockinge Forest King, whose dam was by this noted horse. We may further revert to Mr. Johnson's opinions of this horse, which he epitomised in a letter thus :

"Young John Bull II 83 was sire of Royal Albert I885. Royal Albert's dam was a mare of great size and

in London in his early years. Lord Hindlip fancied him as a horse for his tenantry, and so he went to his estate for a year or two. Eventually he was acquired by Mr. John Green for Mr. A. C. Duncombe, of Calwich Abbey, Derbyshire, for whom he won the championship in London in I887. His subsequent history was a long series of siccesses as a breeding horse in the Calwich stud. In a volume dealing with "Heary Horses," issued by Messrs. Vinton, the writer thus summarises Harold's strong points: "First and foremost, he is a thorough stallion all through, and there is no possibility of mistaking him for any of the weaker sex at any point; secondly, his commanding size and tremendous bone ; thirdly, in action he is especially good when weight, with the broadest, flattest and most correct hind legs I ever met with. I bought Royal Albert as a foal in $\mathrm{I} S 72$, and kept and travelled him in this district till he was eleven years old. I sold him in 1883 to a Mr. Geo. Naylor, of Newhaven, Derbyshire. I think he only travelled him in that part one season, after which time he became the property of Mr. Cecil Salt, of Willington, Derbyshire. He stood at Willington several seasons, where I believe he died.

"No one else ever owned him. He was a very big horse, $I 7$ hands 2 inches, rather narrow, but with wonderful legs, particularly his hind legs, which were the most correct I ever saw.

" He left some good mares in this part of Yorkshire, but he seems to have done better 
among the old-fashioned Derbyshire mares, which, with his great size and fine quality, he seemed to suit exactly. I should think King Charming 3166, a horse which I sold to Captain Heaton, was one of the best stallions he ever sired. He got better mares thim stallions."

What's Wanted 2332, was bred by Mr. J. Ashmore, of Darlton, Nottingham, in I 873 . He was a bay horse, standing $I 7$ hands. He was chiefly known in connection with Mr. James Forshaw's stud at Carlton-onTrent, Newark, and was sired by Bold Lincoln 23I. He sired many noted horses, the most famous of which was Premier 2646. What's Wanted only lived nine years.

\section{William the Conqueror}

William the Conqueror 2343 was the progenitor of a line of blood which became very famous. The double champion Prince William was the first to take that supreme distinction as a two-year-old. The dam of Prince William was the famous mare Lockington Beanty. A very masculine type of horse he was, with a splendid equipment of bone and feather. In all probability through Hitchin Conqueror this strain became most famous, for he was the sire of that supremely massive horse Menestrel, which in turn sired Lord Rothschild's champion, Birdsall Menestrel, a double champion in London. Birdsall Menestrel is a real Hitchin Conqueror type, full of quality, and a splendid show horse that is making his mark in the stud.

\section{Bar None}

Bar None 2388 was a famous prize-winner, and won the first champion Cup for the late Mr. Forshaw in London. He was more celebrated as a sire of mares than stallions. He did not leave them quite as big and weighty as could be wished, but for quality there was nothing further to be desired. He was in the hands of Mr. Malter Johnson, of Hatfield, Doncaster, who describes him as " a real Clydesdale sort, very full of hair-quite a big upstanding horse." He bought him out of the plough, but only kept him for one season prior to passing him on to Mr. Forshaw.

\section{Dunsmore Jameson}

Dunsmore Jameson was foaled in $I \& y \delta$, sired by Moor's Zealot I5731, dam 22192 Moor's Bonny by Regent II. During his lifetime he stood at the Dunsmore stud of the late Sir P. Albert Muntz. He was only once shown at London, where he won as a yearling. He made his mark as the leading sire of winners at the Shire show for several successive years. He was very full of hair when shown as a yearling, and gave promise of finishing a horse of great bone and substance. Even in mature years he was a light middled horse, and his success as a sire fits in with the dictum that a stallion with a heavy middle-piece is not the type of sire to make his mark. He sired amongst others the London champion, Dunsmore Fuchsia. Dunsmore Jameson died in Igo8.

\section{Lockinge Forest King}

Lockinge Forest King has come greatly to the front, his stock making very high prices. He is the sensational horse of the new century, creating a distinctive type in his progeny which are chiefly remarkable for their fine limbs and joints, compact form, and true close action. He was sired by Lockinge Manners 167 So, dam $477^{\circ}$ The Forest Queen, by Royal Albert 1885. Bred by the late Lord Wantage, he was owned for many years by the late Mr. Cross, of Cathorpe, Rugby, for whom he did all the prize winning. He was afterwards transferred to the ownership of Mr. W. T. Everard, of Bardon Hall, Leicester. He has been a remarkable success as a sire. In rgos he sired no fewer than five successive winners in one class, and twenty-two money card bearers were credited to him. He is a horse built on fine lines, not quite so masculine in appearance as many that have made their mark, but his fine flat limbs and quality are points which he transmits to his stock, As a colt he was narrow and very full of hair; as a mature horse he is light in his middlepiece, but very gay and full of vigour.

Following is a list of London champions :- 


\section{CHAWPIONS AT THE SHIRE SHOW}

Year. Name of Alimal.

Name of Sire.

Exhibilor.

\begin{tabular}{|c|c|c|c|c|}
\hline 1880 & Admiral $7 \mathrm{I}$ & .. & .. Honest Tom I IO5 & .. Ear] of Ellesmere. \\
\hline $8 \mathrm{I}$ & Spark $2407 \quad \ldots$ & $\cdots$ & .. The Colonel 2 InI & .. Mr. Wr. R. Rowland. \\
\hline & Bar None 238s.. & . & .. Lincoln 1348 & .. Mr. James Forshaw. \\
\hline & Spark $2497 \quad \ldots$ & - & .. The Colonel zior & .. Mr, MT, R. Rowland. \\
\hline & Enterprise of Cannock & $2 \pi 72$ & .. Heart of Oak 1009 & .. Cannock Agrl. Co. \\
\hline & Prince William 3956 & $\cdots$ & .. William the Conqueror $23+3$ & ... Mr. John Rowell. \\
\hline & Staunton Hero 2918 & $\cdots$ & .. William the Conqueror $23+3$. & .. Sir Walter Gilbey, Bart. \\
\hline & Harold $370_{3} \quad \ldots$ & $\cdots$ & .. Lincolnshire Lad II. I 365 & .. Mr. A. C. Duncombe. \\
\hline & Prince William 3956 . & $\cdots$ & .. William the Conqueror 2343 . & .. Lord Wantage, K.C.B. \\
\hline & Vulcan 4 I45 $\quad$. . & $\cdots$ & . Cardinal $2407 \quad \ldots \quad$. & .. Earl of Ellesmere. \\
\hline & $\begin{array}{l}\text { Hitchin Conqueror } 4+58 \\
\text { Iog } 82 \text { Starlight .. }\end{array}$ & & $\begin{array}{l}\text {.. William the Conqueror } 23+3 \\
\ldots \text { Sir Colin } 2022 \quad \ldots \quad \ldots\end{array}$ & $\begin{array}{l}\text {.. Lord Redesdale. } \\
\text {.. Mr. R. N. Sutton-Neithorpe. }\end{array}$ \\
\hline & $\begin{array}{c}\text { *Tulcan }+1+5 \quad \ldots \\
\text { I0982 Starlight } \ldots\end{array}$ & $\cdots$ & $\begin{array}{l}\text {. Cardinal } 2407 \quad \ldots \\
\ldots \text { Sir Colin } 2022 \quad \ldots\end{array}$ & $\begin{array}{l}\text {.. Earl of El\}esmere. } \\
\text {.. Mr. Fred Crisp. }\end{array}$ \\
\hline & $\begin{array}{l}\text { Bury Victor Chief I I IO } \\
*_{10982} \text { Starlight.. }\end{array}$ & & $\begin{array}{l}\text {.. Prince Victor } 5287 \\
\text {.. Sir Colin } 2022 \ldots\end{array}$ & $\begin{array}{l}\text {.. Mr. J. Wainwriglıt } \\
\text {.. Mr. Fred Crisp. }\end{array}$ \\
\hline & $\begin{array}{l}\text { Rokeby Harold I } 53 \text { I } 3 \text {. } \\
\text { I } 5507 \text { Rokeby Fuchsia. }\end{array}$ & $\begin{array}{l}\cdots \\
\cdots\end{array}$ & $\begin{array}{l}\text {.. Harold } 3703 \text {. } \\
\text {.. Lincolnshire Boy } 3188 \ldots\end{array}$ & $\begin{array}{l}\text {.. Lord Belper. } \\
\text {.. Mr. John Parnell. }\end{array}$ \\
\hline & 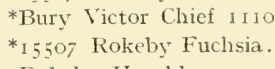 & & $\begin{array}{l}\text {.. Prince Victor } 5287 \\
\text {.. Lincolnshire Boy } 3188 \ldots\end{array}$ & $\begin{array}{l}\text {. Mr. J. Wainwright. } \\
\text {.. Mr. John Parnell. }\end{array}$ \\
\hline & $\begin{array}{l}\text { Rokeby Harold I5313. } \\
\text { I2989 Minnehaha }\end{array}$ & & $\begin{array}{lll}\text {. Harold } 3703 & \ldots & \ldots \\
\text {. Laughing Stock }+516 & \ldots\end{array}$ & $\begin{array}{l}\text {.. Lord Belper. } \\
\text {.. Lord Redesdale. }\end{array}$ \\
\hline & $\begin{array}{l}\text { *Rokeby Harold I5313. } \\
\text { I9593 Catthorpe Naxos }\end{array}$ & & $\begin{array}{lll}\text {.. Harold } 3703 & \ldots & \ldots \\
\text {.. Blagdon Victor } 0755 & \text {.. }\end{array}$ & $\begin{array}{l}\text {.. Lord Belper. } \\
\text {.. Mr. J. P. Cross. }\end{array}$ \\
\hline 7 & $\begin{array}{l}\text { Markeaton Royal Harol } \\
20686 \text { Queen of the Sh }\end{array}$ & & 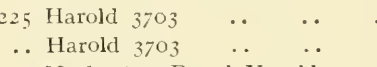 & $\begin{array}{l}\text {.. Sir A. Henderson, Bart. } \\
\text {.. Mr. A. Grandage. }\end{array}$ \\
\hline 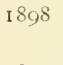 & $\begin{array}{l}\text { *Buscot Harold } 16576 . \\
\text { I395 I Aurea } .\end{array}$ & $\begin{array}{l}\cdots \\
\cdots\end{array}$ & $\begin{array}{l}\text {.. Narkeaton Royal Harold I } \\
\text {.. Thornton Premier I255I }\end{array}$ & $\begin{array}{l}225 \text { Sir A. Henderson, Bart. } \\
\text {.. Sir A. Henderson, Bart. }\end{array}$ \\
\hline & $\begin{array}{l}\text { Buscot Harold I6576. } \\
1+655 \text { Dunsmore Gloam }\end{array}$ & & $\begin{array}{l}\text {.. Markeaton Royal Harold } 152 \\
\text {. Harold } 3703 \text {.. }\end{array}$ & $\begin{array}{l}225 \text { Sir A. Henderson, Bart. } \\
\text {.. Sir J. Blundell Maple. }\end{array}$ \\
\hline & $\begin{array}{l}\text { *Buscot Harold } 16576 . \\
*_{1+655} \text { Dunsmore Gloam }\end{array}$ & ming & $\begin{array}{l}\text {.. Markeaton Royal Harold is } \\
\text {.. Harold } 370_{3} \text {. . .. }\end{array}$ & $\begin{array}{l}25 \text { Sir A. Henderson, Bart. } \\
\text {.. Sir J. Blundell Maple. }\end{array}$ \\
\hline & $\begin{array}{l}\text { Bearwardcote Blaze is } \\
21218 \text { Alston Rose }\end{array}$ & $\begin{array}{l}8501 \\
\cdots\end{array}$ & $\begin{array}{l}\text {.. Calwich Blaze I } 45+4 \\
\text {.. Vulcan VII. } 1+400\end{array}$ & $\begin{array}{l}\text {.. Messrs. J. and M. Wralwyn. } \\
\text {.. Lord Rothschild. }\end{array}$ \\
\hline 2 & $\begin{array}{l}\text { Stroxton Tom I } 5871 . \\
21218 \text { Alston Rose. }\end{array}$ & $\begin{array}{l}\cdots \\
\cdots\end{array}$ & $\begin{array}{l}\text {.. Honest Tom } 5123 \\
\ldots \text { Vulcan VII. I+400 }\end{array}$ & $\begin{array}{l}\text {.. Messrs, J. Forshaw and Sons. } \\
\text {.. Mr. R. W. Hudson. }\end{array}$ \\
\hline 3 & $\begin{array}{l}* \text { Stroxton Tom I } 587 \text { I } \\
*_{24787 \text { Solace }} \ldots\end{array}$ & $\begin{array}{l}\cdots \\
\cdots\end{array}$ & $\begin{array}{l}\ldots \text { Honest Tom } 5123 \\
\text {.. Lord Arthur 9834 }\end{array}$ & $\begin{array}{l}\text {.. Messrs. J. Forshaw and Sons. } \\
\text {.. Lord Rothschild. }\end{array}$ \\
\hline 1904 & $\begin{array}{l}\text { Birdsall Menestrel } 1933 \\
447 \text { Io Desford Countess }\end{array}$ & & $\begin{array}{l}\text {.. Menestrel Ifiso .. } \\
\ldots \text { Bardon Harold I } 5+63 \ldots\end{array}$ & $\begin{array}{l}\text {.. Lord Rothschild. } \\
\text {.. Messrs. WV. and J. Thompson. }\end{array}$ \\
\hline 5 & $\begin{array}{l}\text { *Cirton Charmer } 20515 \\
4+795 \text { Dunsmore Flichs }\end{array}$ & & $\begin{array}{l}\text {.. Normaer of Batsford } 15242 \\
\text {.. Dunsmore Jameson I } 7972\end{array}$ & $\begin{array}{l}\text {. Lord Rothschild. } \\
\text {. Sir P. A. Muntz, Bart. }\end{array}$ \\
\hline 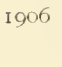 & $\begin{array}{l}\text { Present King II. I994 } \\
2976 \text { I Princess Beryl }\end{array}$ & & $\begin{array}{l}\text {.. Coming Prince } 17268 \quad \ldots \\
\text {.. Prince Harold } 1+228 \quad \ldots\end{array}$ & $\begin{array}{l}\text {.. Messrs. J. Forshaw and Sons. } \\
\text {.. Lord Rothschild. }\end{array}$ \\
\hline 1907 & $\begin{array}{l}\text { Birdsall Menestrel } 1933 \\
52340 \text { Stolen Duchess }\end{array}$ & & $\begin{array}{l}\text {.. Menestrel I+180.. . } \\
\text {.. Southgate Honest Iom i69 }\end{array}$ & $\begin{array}{l}\text {.. Lord Rothschild. } \\
\text { 4. Messrs. J. Forshaw and Sons. }\end{array}$ \\
\hline 08 & $\begin{array}{l}\text { Tatton Dray Kiing } 237 \\
\text { *4+09 I Bclle Cole }\end{array}$ & & $\begin{array}{l}\text {.. Drayman XXili. } 19551 \\
\text {.. Crossmoor Carbon } 19525\end{array}$ & $\begin{array}{l}\text {.. Earl Egerton. } \\
\text {.. Lord Rothschild. }\end{array}$ \\
\hline 0 & $\begin{array}{l}\text { * Halstead Royal Duke } \\
50678 \text { Chiltern Maid }\end{array}$ & $\begin{array}{l}25255 \\
\cdots\end{array}$ & $\begin{array}{l}\text {.. Lockinge Forest King I } 8867 \\
\text {.. Lockinge Forest King I } 8867\end{array}$ & $\begin{array}{l}\text {. Lord Rothschild. } \\
\text {.. Lord Rothschild. }\end{array}$ \\
\hline & $\begin{array}{l}\text { Gaer Conqueror } 25218 \\
53825 \text { Eureka }\end{array}$ & $\begin{array}{l}\cdots \\
\cdots\end{array}$ & $\begin{array}{l}\text {.. MontIord Jupiter } 18940 \\
\text {. Hereford I8o86 . . . }\end{array}$ & $\begin{array}{l}\text {.. Mr. A. Grandage. } \\
\text {.. Sir Walpole Greenwell, Bart. }\end{array}$ \\
\hline
\end{tabular}

* Won the Challenge Cnp ontright. 
In the early days of heary horse breeding the fen-lands of Lincolnshire and the valleys of Derbyshire were recognised as the main sources of supply. It was from these districts that the heaviest horses were sent out, and both contributed materially to the early history of the pedigree movement as applied to Shire horses. The Honest Toms and Lincolnshire Lads were amongst the earliest of the well-known sires, and their memory keeps green the position held by fen-land in Shire horse breeding.

\section{The Homes of the Breed}

It is difficult to say in these days which part of England has attained most fame in its association with the Shire. As a matter of fact pre-eminence in this respect is no fixed honour, for it is apt to vary with a notable stud horse's influence in a neighbourhood. Perhaps, territorially considered, Lancashire stands as high as any in the production of first-class prize winning Shires. In the days of Harold, Derbyshire was wont to claim this distinction. But farmers have grown less conservative in that they are now more willing to mate their mares away from home than formerly. The Midlands of England are the home proper of the breed. There are more enthusiastic breeders there than in either the North or the South. One of the chief and most convincing reasons that can be advanced for this is, that it is convenient for good stud horses and the land is capable of growing horses of great weight without the use of stimulating food. Indeed, it is a matter of remark that on many of the strong soils of the Midlands the difficulty is to keep the horns of horned stock of reasonable size. The fenlands of Cambridge and Lincolnshire and the Peterborough neighbourhood carry a large number of Shires, and foal shows flourish there in considerable numbers. In the grass counties-Warwick and Leicester -the Shire has made great progress amongst farmers, although the Hunter is supposed to be equally as much at home in that fast country. Northampton, Notts, Staffs, Cheshire, Shropshire, and Derbyshire have all strong contingents of breeders, although the soils vary from limestone to gravels and clays. On the borkers of Wales, and in the cheese county of Cheshire, of late years the pedigree Shire has been exceptionally vigorous, the type of horse kept varying from the smaller mare of the lills to the big 16 hand 3 inch mare of the strong gelding sort. The Fylde of Lancashire continues the chain of successful breeding, which mav be said to finish with the northern portion of that county on the West Coast. On the East Coast, however, Yorkshire has its devotees of the Shire, although the conflicting interests of the Coach Horse, the Hackney, and the Hunter, no doubt deprive it of much support it might otherwise have.

The extreme north of England has for many years been wedded to the Clydesdale type. The shire has made encroachments in Northumberland and Durham, but it will be many years ere breeders in these counties give up the Clydesdale, their first love in heavy horse breeding.

\section{Shires in the South}

It has been remarked that the south of England is a poor country for the draught horse. The statement is not devoid of truth, for the Shire does not flourish where the land bakes hard, and where cattle and sheep are in almost entire possession. The red sandstone of Devonshire, however, can grow very big bullocks and sheep of great scale. Why, therefore, should it not excel in the same degree as a Shire horse county? The argument seems hard to refute on paper, but the fact remains that horses bred in the south of England as a general rule lack weight. Sussex, with its stiff clays and its stratum of chalk, provides no exception to this observation, while Kentish breeders declare that they can more easily produce quality than substance. This explains why deputations, when hiring horses for the south of England, look for very weighty sires.

The Shire is admirably distributed over England, from Land's End to Lancashire and Yorkshire in the north. The most remarkable feature of the extension of its influence within the past ten years has been 
the firm hold which it has established south of the Thames. No doubt the wonderful surcess of Lord Redesdale is in a great degree accountable for this, but Mr. Freeman Mitford's and Sir Alexander Henderson's studs in Gloucestershire and Berkshire respectively have been largely instrumental in establishing the pedigree Shire on a firmer basis in the South. Breeders labour under certain disadvantages there, but the progress of the breed is as yet unchecked. It is a growing custom with large stud owners in the South to take Midland grazings for their young stock in summer. They thus avoid the heat, grow steadily, and are more easily kept on their joints than when running about on dry, sun-baked pasture lands.

\section{Points of the Shire}

The typical Shire horse represents the perfection of symmetry. In the breeding of all classes of animals that is the primary aim. In the olden days, we are inclined to think, balance of form was too much studied to the detriment of other very important points. To the show yard must be credited the recognition and appreciation of the finer points in draught horse breeding. At one time the predominant characteristic of the draught horse was his wonderfully massive top, his finely sprung rib, deep shoulders and quarters. Good as these points are, the views which to-day prevail undoubtedly place more importance upon the equipment of a horse at the ground than the rearing of a fine superstructure upon indifferent legs, joints, and feet. The analysis of a perfect Shire must therefore begin at the foundation.

\section{The Foot}

The old maxim, "No foot, no horse," is truer in its application to-day than ever it was. The foot must be well spread. The wall of the hoof should not be upright, nor slould it be too sloping. In the one case it implies a small foot, and in the other a weak, thin hoof, with no depth at the heels. It is a common condition arising from fevered feet. The hoof heads should be open. Opinions will differ as to the width of a perfect coronet. The Shire breeder is inclined to be a little more conservative in his estimate than he who has imbibed his knowledge of draught horses from a Clydesdale source. A wide, but not too wide, coronet is favoured, so that the superstructure is well supported and the horse will not literally go through his hoof. The colour preferred is blue, which wears better than white, but some concession has to be made to the craze for white legs and fetlocks for show purposes. The old blue foot is the ideal wearing hoof.

\section{The Points}

The joints should be long, but not to the point of weakness. In the olden days it used to be a commonly heard recommendation: "a good short-jointed horse." To-day, however, the pasterns are cultivated to give the requisite elasticity of movement and to break the jar resulting from causewayed roads. Thick pasterns are a fanlt commonly seen in old horses. The cleaner the pastern the more quality is there in the animal, and the smaller the chance of a high-set ringbone.

\section{Cannon Bones}

The cannon bones should be short and flat. Flat bone is always deceptive to the eye, but comes out well under the inch tape. The tendons should be strong and clearly defined. A common fault is lack of bone below the knee, frequently accentuated by the absence of a sufficiency of hair. The Shire breeder likes a profusion of hair, colloquially known as "feather." It should be devoid of the suspicion of a curl, being silky to the touch. Curly hair is freely associated with soft round bone, which is often found in a greasy leg, therefore the breeder looks to the quality of the hair as a good indication of the class of limbs on which it grows.

\section{The Knees}

The knees should be broad and not elliptical. Iuch of the strength comes from the knee and the hock joints, and if 
they are ample the muscular development is sure to be there. The arms should be well developed, the muscle standing out as in the well developed forearm of an athlete.

The stallion should be short in the back, the ribs well spread, the hind-quarters masculine appearance, the number of quality horses with gelding necks being on the increase. A good bold head and neck are therefore a fine and appreciable offset to a horse.

In the mare there is rather at longer middle-piece than in the stallion, less sub-

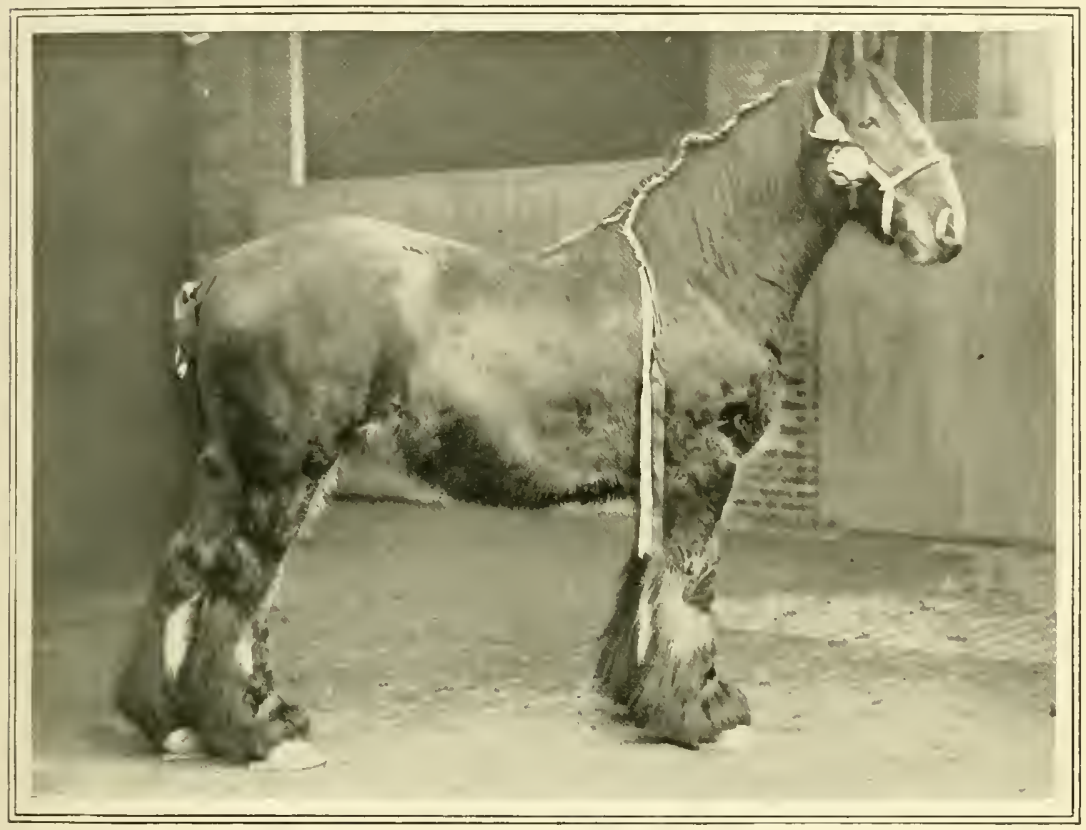

SHIRE MARE, BARNFIELD'S FOREST UUEEN,

slightly higher than the back, the first and second thighs well-filled. The typical Shire is a very broad and deep animal, showing a strong constitution by the robustness of his proportions. He should girth well, particularly round the heart, be deep in his back rib; in fact, his middle-piece should be almost square. The shoulder is deep and sloping.

In the stallion the neck and head should be well-defined. A strong crest is favoured, and a slightly Roman head is an attraction rather than otherwise. Close breeding, and the fining down of the breed through careful mating, has a tendency to rob a stallion of stance, and a longer, leaner, and more feminine outlook.

Great attention is paid to the action. In the ideal Shire the knees should be well snapped, the hocks bent, and the tout cnsemble on parade vigorous and full of life. A shuffling gait and open hock action are deprecated. In the latter respect a very great improvement is noticeable. Hitherto one of the most notable defects, to-day close action is a common attribute of the well-bred Shire.

When drawn up the horse should stand squarely on his limbs. The knee joints should be slightly accentuated. A horse 
that is "back at the knee" is weak in his foreleg. There should be no twist in the joints. The hind legs should not be far away, but well under the body, the line of the point of the hock, and the extreme outside of the quarters being perpendicular. Sickle hocks, a sign of weakness, are unsightly, but they are not so freely met with as in former times.

\section{Shire Types}

Broadly speaking there are two types of the modern Shire-the quality, and the rough. The former is the choice of the show yard and nearly every breeder. The latter has abundant weight, curly hair, and certain grossness of bone which belongs to a former age. The argument is frequently put forward that with the large number of quality mares to be found throughout the country it is an advantage to use a sour stallion. The idea of thus keeping the weight through the rough stallion. and inheriting in the offspring the quality of the dam, has supporters, but it is to be feared that other undesirable characteristics are perpetuated as well. There can be no doubt that stallions are less masculine in appearance than hitherto, but it has not been demonstrated that the breed has lost anything by the steady advance of the quality type. Weight is essential, and never lost sight of, for without weight it would not be possible to start the heavy dray on the insecure footlold of flat paved streets. Therefore the amount of avoirdupois that a horse puts into the collar is always kept in riew as one of the invaluable assets of the Shire.

\section{Measurements of Great Shires}

It is interesting to have as a standard of comparison the measurements of leading horses. The fact must not be forgotten that the Shire horse is much the heaviest draught breed in the universe, and that it measures more bone than any other. The following measurements of the London champions, father and son, Markeaton Royal Harold and Buscot Harold, are supplied by Mr. Walter Crosland, agent for
Sir Alexander Henderson, Bart., of Buscot Park, Faringdon :-

Markeaton Buscot
Royal Harold. Harold.

\begin{tabular}{|c|c|c|c|c|c|}
\hline Height & & . & . & I 7 hands $\frac{1}{2}$ in. & I 7 hands \\
\hline Girth & .. & . & $\ldots$ & $\mathrm{s} \mathrm{ft} . \mathrm{I}$ in. & $7 \mathrm{ft}$. I I in \\
\hline Knee & . & . & . & 20 in. & $18 \frac{1}{2}$ in. \\
\hline Below & knee & . & . & $13 \frac{1}{4}$ in. & $12 \frac{1}{2}$ in. \\
\hline Round & coronet & t. & . & $20_{4}^{3}$ in. & $20 \frac{3}{4}$ in. \\
\hline Hock & . & . & . & 23 in. & 22 in. \\
\hline Below & hock & . & .. & I4 in. & $13 \frac{3}{4}$ in. \\
\hline Across & foot $(\mathrm{f}$ & ore) & . & $7 \frac{1}{2}$ in. & $z^{3} \mathrm{in}$. \\
\hline Length & of hea & & .. & 30 & 33 \\
\hline Middle & of kne & to & ind & 21 & $2 \mathrm{O}_{4}^{3} \mathrm{i}$ \\
\hline
\end{tabular}

Markeaton Royal Harold was five years old, and Buscot Harold three years, when these measurements were made, and no doubt the latter improved upon these figures as a fully matured horse.

Following are the dimensions of the London champion horse Birdsall Menestrel, owned by Lord Rothschild :-

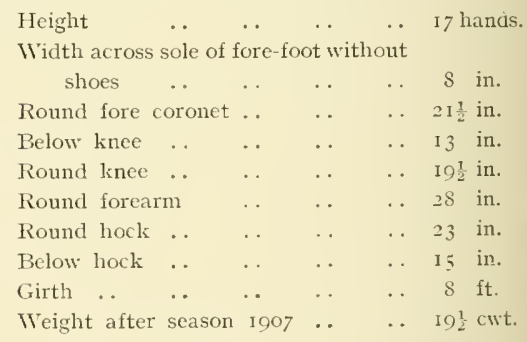

\section{Colour}

The colours most commonly met with are bay, brown, black, grey and roan. The first three colours are the most popular, bays especially. Grey is a very old Shire horse colour, and roans-blue, red, and strawberry-are often associated with horses of very hardy constitution. Roan stallions are few in number. They are generally converted into geldings. Grey mares are more frequently met with than grey stallions. There are studs, like that of Earl Beauchamp, which are solely composed of grey horses. Of late years there has been an increase of chestnut-hued horses. The colour is not liked, and being one of the fastest of hues it is specially to be aroided in the stallion. 


\section{Shire Shows}

The Shire horse breeder has no reason to complain of lack of opportunity to exhibit. It is a characteristic of the modern show secretary that he leaves no stone unturned to attract the exhibitor from a distance. Whatever argument may be advanced against the so-called "professional" exhibitor, he is at least a persona grata with the showgoing public. We have only to picture the show yard without our best specimens of the different breeds to realise how imperfectly the show ring would be supported, and how much each individual breed would lose without the "professional" showman. We prefer the term "expert" rather than "professional," for it is not reasonable to suppose that moneyed men would exhibit so freely as they do if the mere pecuniary reward were all that could be gained. The Shire horse is a fine show animal. The chief exhibition is held every year in the Agricultural Hall, at Islington. It comprises all ages, from yearlings upwards. The contention is frequently put forward that, as a matter of policy, the breeder greatly errs when he shows his young stock in a fleshy and more or less forced condition. Mlany breeders, it is true, do not look upon it with favour, knowing the risks which must necessarily be taken. Use and wont, however, exercise a strong and often a deciding influence. The young foal that is assisted by other means than the mother's milk may achieve a temporary success at the foal shows, but how frequently under the forced system of training now universal do they break down utterly before they are two years old!

\section{Overloading Young Stock}

A famous breeder, the lite Mr. James Forshaw, was wont to describe a certain type of Shire horse as " soon ripe and soon rotten." The tendency in loading youmg draught stock with flesh is distinctly in this direction. The breeder contends that the biggest invariably win in the young stock classes, and considering the importance of weight in the cart horse he feels that he must use every means to get his young stock big enough to compete on an even footing with others. Anyone who makes a consistent study of the show yard must recognise that as yearlings and two-year-olds there is a greater difference between the Shire and any other heavy breed than at any other age in their existence. Whatever views may be held on this question, the reader has the best opportunity of judging for himself by a prudent study of the Shire Horse Show held in the closing week of February. This show is unique. At one time, over 800 exhibits were sent forward, but of later years the number has been limited to about 650 , owing to restrictions of the London County Council in respect of fire prevention. The manner in which the entries are distributed is explained in the following comparative statement :-

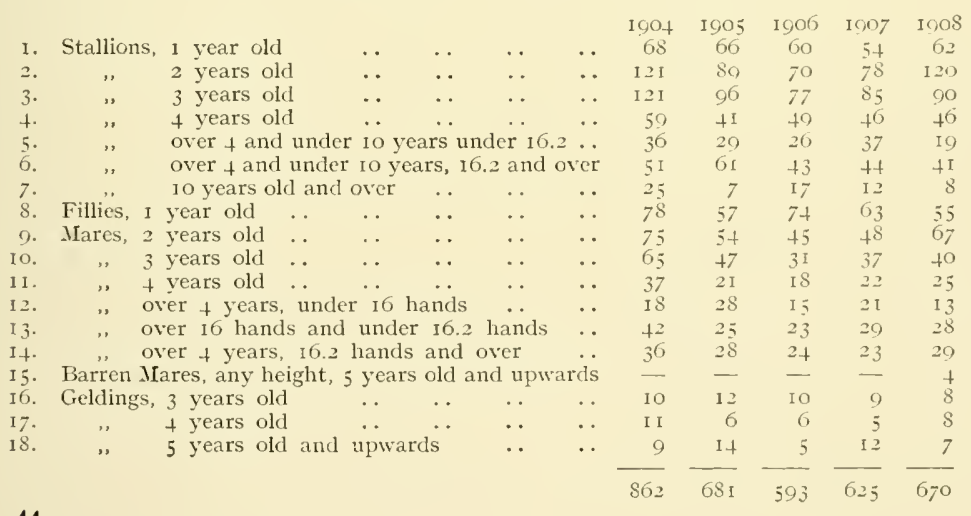


The best summer shows are undoubtedly those taking place in the Midlands. The Peterborough Agricultural Society has a very fine entry at its exhibition, usually held early in July. The Nottinghamshire Agricultural Society holds its meeting rather earlier in the season, generally the two days considerable extent dependent upon the location of the meeting. The Bath and West and Southern Counties Society, the Staffordshire, the Lincolnshire, the Warwickshire, the Yorkshire, the Shropshire and West Midland, the Herefordshire and Worcestershire, and, not least in importance, the

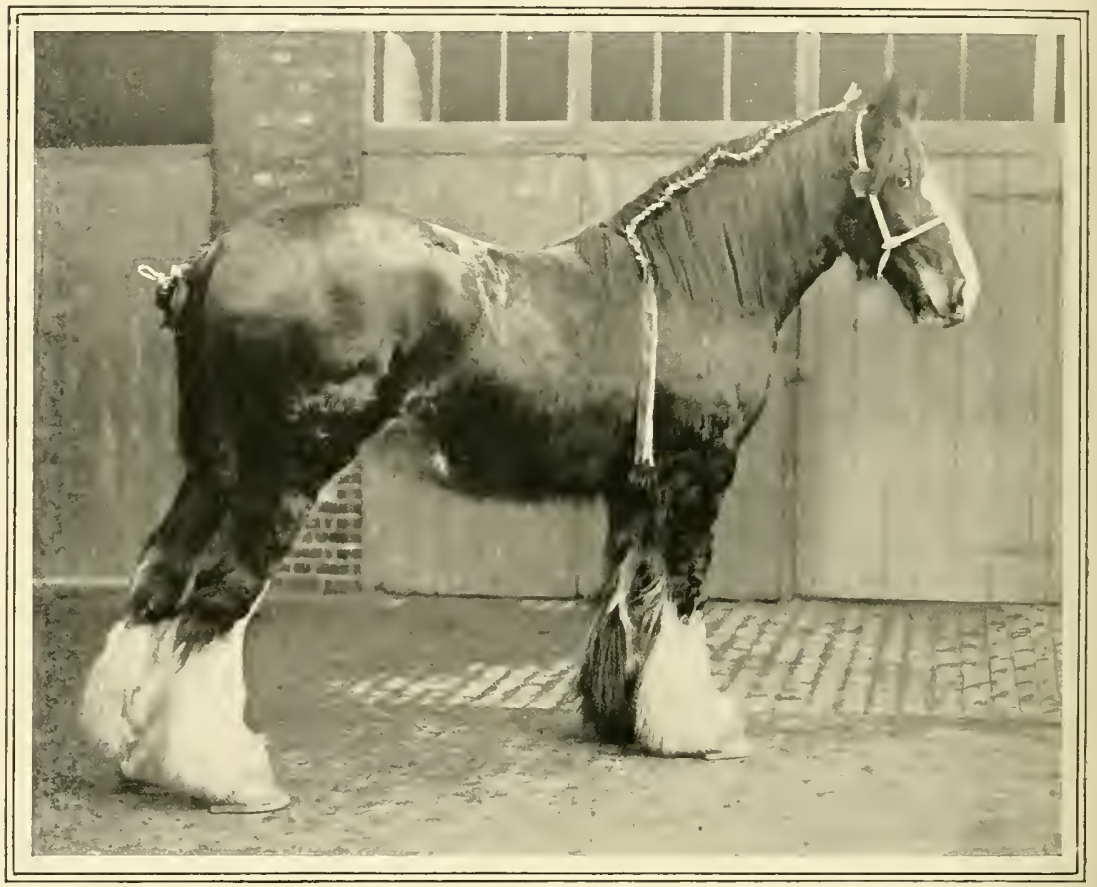

SHIRE MARE, BARDON FOREST PRINCESS

following the Whitsun Bank Holiday. These two shows, along with the Leicestershire Agricultural Society's fixture, may be said to present the Shire in the largest numbers during the summer months. In August the Royal Lancashire Agricultural Society's show usually attracts a fine entry, and in September the Ashbourne Shire Horse Show is the chief exhibition of foals and young stock.

There are, of course, other shows of great importance, amongst which is that of the Royal Agricultural Society. The strength of the Shire section there, however, is to a
Oxfordshire, societies, have all very good displays of the breed, which may be said to be supported at every exhibition of importance in England.

The classification adopted at English shows is governed by the time of the year at which the fixture is held. In the spring, when the stallion shows take place, a full classification can be made, with, of course, the exception that foals are either too young to be entered separately or the number of early foals is too small to be considered separately. The brood mare classes are interpreted as for mares in foal or with foal at foot. The 
point deserves to be considered whether the mere statement of date of service should qualify for this class, as suspicion has sometimes been raised that a late service was provided merely to enable an animal to qualify for competition for the higher trophies. Although they are not actually awarded till a mare has foaled, and duly qualified, still the honour lies with the temporary, and not the actual victor. At most of the large shows only breeding animals are allowed to compete for the higher honours, so that the question is one of importance.

Separate classification is usually provided for barren mares. It is obviously an advantage from an exhibitor's point of view to run a mare barren for a season to win prizes, although the loss of a foal has to be put against the prize winnings. The best mares, however, will have their times of infertility, so that it is right to afford the purchaser of a high-priced mare the opportunity of wimning honours. The Shire Horse Society, however, only allows its medals to be won by fillies and brood mares.

The fillies are usually graded into three ages up to three-year-olds, separate classes being provided for foals from midsummer onwards.

\section{The Stallion Shows}

The stallions are chiefly shown before the service season begins. The stallion shows are provided partly to enable exhibitors to compete with each other, partly to assist farmers in a district to select suitable horses, and partly to advertise local horses. At the summer shows, with very few exceptions (including the Lincolnshire and Royal Lancashire meetings), the age limit does not exceed three years old, so that exhibitors are not debarred from showing promising colts. Obviously it would be impossible to fill a class for mature horses which were meeting other engigements of a more important character.

Classification at the foal shows is usually for fillies and colts. Enterprising stud horse owners also offer premiums for the progeny of their horses.

At these, as well as other important county shows, the interests of the local exhibitor are generally safeguarded by the provision of local classes.

Mention should be made of a series of breeders' prizes given at the shire show varying from $f_{\mathrm{I}} \mathrm{I}$ to $\mathrm{f} \mathrm{I}$. Even the breeders of Highly Commended and Commended animals receive $f_{2}$ and $f_{I}$ respectively.

\section{Breeding Societies}

Horse-breeding societies, which have as their chief aim the hiring of suitable stud horses, flourish in England. It is true that proportionately there are not so many as in Scotland, but the necessity is not so apparent. There are more large studs with a full equipment of good horses south of the Border than north. They are better spread over the country than in Scotland, and tap the leading districts where pedigree and nonpedigree Shires are kept. It would be difficult to compute what heary horse breeding owes to these institutions. By combining together and soliciting the assistance of local landowners farmers are enabled to introduce sound first-class sires. Their value is most apparent in comparatively isolated districts like Devonshire, and the south and west of England generally. It is the usual custom to provide a guarantee of the number of mares to be served, and a low service fee is fixed, varying with the cost of the horse. It may range from two guineas to five guineas -generally about three guineas. The retainer for the best class of sire is likewise on a sliding scale. Societies like the Welshpool Association pay as much as one thousand guineas for the exclusive use of a horse, with, of course, a limit of mares. The society frequently makes itself responsible for the collection of service fees, which is by far the most satisfactory system. When this is so the terms of hire are a lump sum. Many good horses are hired at from $£_{500}$ to $\_600$. When the stallion owner collects the fees a good stallion can be hired with a retainer of $t$ So to fioo.

The method commonly in rogue at one time-indeed, it is still kept up in some districts-is to advertise the selection of a horse on a certain day. The stallion owner sends 
whatever horse he thinks most suitable, and from the entries thus made judges select what they consider to be the best horse. The principle governing this method of choice is not good. The judges appointed are not always local men. They may have no knowledge of the class of mare most commonly met with in the district, and their choice of a stallion is thus not influenced by local requirements. Moreover, no particulars are given of the capacity of the various horses entered for competition to beget foals, and it is not surprising that in many cases failure and disappointment follow.

\section{The Ideal System}

The ideal system, and that usually in force, is to hire by deputation. Men, with a good knowledge of the district's requirements, and an equally sound appreciation of the chief lines of blood, visit selected studs, and make their choice of a horse after consultation. They are guided in their work by the successes at the many foal shows, and by the reputation which horses have acquired in other districts. The Shire Horse Show might be more used for this purpose than it is, but many societies prefer to fix up their engagements at an earlier date than February. Indeed, there is a tendency to hire horses at the close of a season for the succeeding year.

From the stud owner's point of view the more popular the horse-breeding societies become the better. They provide an outlet for many very good horses, scund and weighty, which might otherwise beg a season on a private round.

Looked at from the broad point of view of the advancement of heary horse breeding, the horse-breeding society is invaluable if for no other reason than that it makes the living of the guinea "screw" insecure.

The basis of the Shire horse's prosperity is essentially commercial. Pedigree horse breeding as a "fancy" could not endure a succession of scasons of high prices without the backing of the commercial market. The gelding trade is the keynote to the many high figures publicly and privately realised.
When good geldings bring from $f 70$ to $£ 90-$ and these figures have been cheerfully given for horses of exceptional power-it is easy to understand how foo guineas can be made for a good pedigree mare in the sale ring. In the early 'nineties the boom in pedigree circles slackened, but it came again into unexampled prices towards the close of the century. In the earlier days most of the high prices were by private bargain. Thus we had Prince William 3956 making I,500 guineas as a two-year-old; Enterprise of Cannock 2772 making I,OOO guineas; Hitchin Conqueror 4458 making $\mathrm{I}, \mathrm{OoO}$ guineas ; Marmion 9885 , over I, ooo guineas ; Bury Victor Chief, 2,500 guineas; Bearwardcote Blaze, 2,000 guineas as a two-yearold; 5,000 guineas refused for Buscot Harold when he won his first championship in London, and so un.

\section{The Shire and Prices}

When we come to the tally of the sale ring we are confronted with a plethora of notable figures. The champion mare Starlight made 925 guineas under the hammer at the Scawby sale. The famous mare Hendre Crown Princess made I, Ioo guineas at one of the late Lord Wantage's sales, this being one of the highest prices publicly paid for a mare, although the mare Seabreeze was sold at one of His late Majesty's sales at Sandringham for I, I 50 guineas. The Premier horse Chancellor drew I, Ioo guineas at a Calwich sale; Hendre Champion fetched at the late Mr. Fred Crisp's sale I, 450 guineas, but Tatton Dray King eclipsed all these at 3,700 guineas.

The highest average was made at Lord Rothschild's sensational sale at Tring Park in Igo8, when thirty-five head made on an average $£ 266$ I 4 s. each. A yearling colt made goo guineas. Previously Lord Llangattock's fine average of $£ 226$ for forty-four head was for many years unapproached, save by that of $f 22+7 \mathrm{~s}$. gd. at the Sandringham sale of $\mathrm{I} S \mathrm{~g} 8$.

The trade for Shire geldings, mares, and fillies is very steady. At one time weight was the major consideration, but whether it be that railway companies and the large 
contractors take more out of their horses than they used to, or whether the advent of the motor has accelerated the pace of living all round is hard to say, the active horse is more in demand than ever. The sluggard, even if he has weight, is practically neglected. The brewer's dray and the railway wagon must be capable of travelling under stress at six miles an hour, and averaging over four.

The home demand for pedigree stock is liable to fluctuation. It is, however, on a very secure basis. The foreign trade has not been cultivated on the proper lines. This is not altogether the fault of the home breeder. The foreign buyer, perhaps through his own parsimony, perhaps because he was never properly educated up to paying a good price for a good animal, rarely robbed us of our best. The class of horse that was sent abroad in the 'eighties and 'nineties was a poor advertisement for English horsebreeding. Indeed, the foreign market was too often considered the refuge of stock which could not find purchasers at moderate figures at home. Consequently the number of export certificates issued was small, breeders mainly relying on a fine demand at home. In I905 a notable step was taken when King Edward VII. and Lord Rothschild sent for exhibition to the chief fairs of the United States and Canada a representative lot of Shires, which included the two champions, Girton Charmer and Guelder Rose. All were eventually retained in the former country, but Guelder Rose unfortunately died there. No doubt the effect of this object lesson in the type of Shires which England is capable of producing will be felt in the years to come.

The class of Shire chiefly in demand in North America is the one that is full of quality - with blue feet, if possible, as they are less liable to shock-and with little hair or feather. The Argentine Republic also takes a number, while the Continent, chiefly Germany, is a useful market. The latter country prefers short-legged, thick horses up to 16 hands, at moderate prices.

The number of pedigree export certificates issued by the Shire Horse Society in 1907 was 658 , in 1906543 , and 1905,333 .

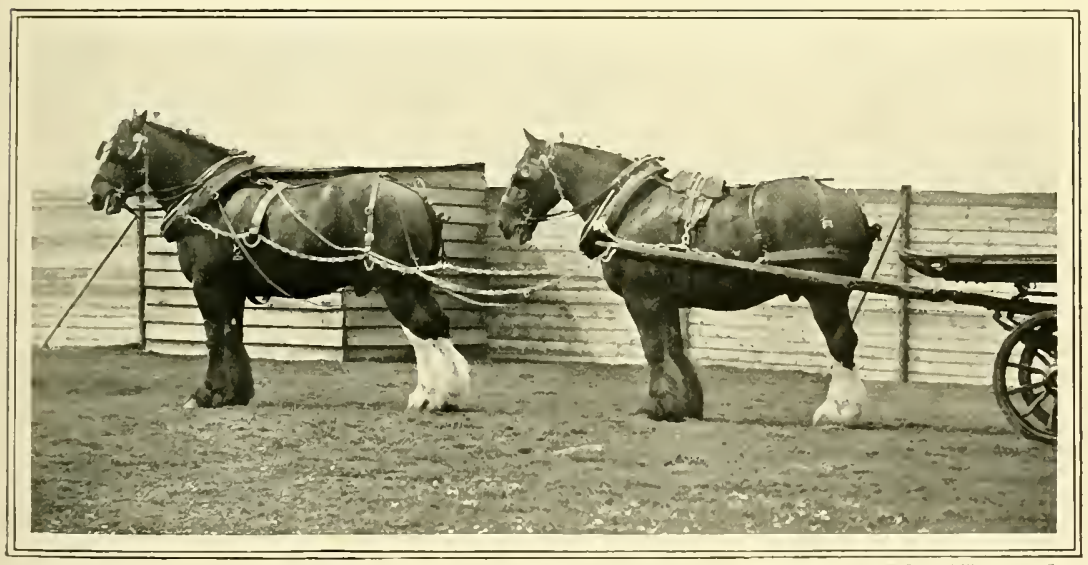

A FINE TEAM OF SHIRES. 


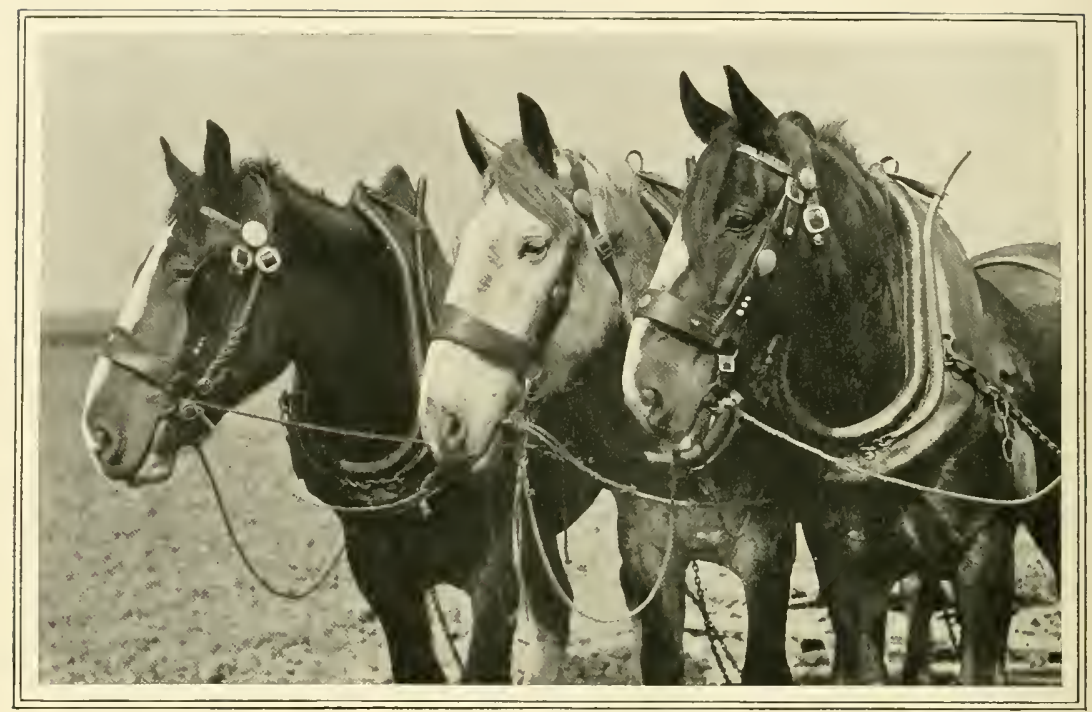

A GROUP OF CLYDESDALES.

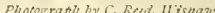

\section{CHAPTER XXVIII}

\section{THE CLYDESDALE HORSE}

T HE history of the Clydesdale horse forms an interesting study. It has been carefully analysed, and many interesting facts have been brought to light. The Clydesdale has a corresponding status in Scotland to the Shire in England. It is, perhaps, more truly national than the Shire, for the latter breed is opposed in East Anglia by the Suffolk, whereas the Clydesdale brooks no opposition whatever in Scotland. It differs in many respects from the Shire, but there can be no doubt that it is to a considerable extent indebted to southern blood, as at one time some of the best mares in the Midlands of England were taken to Scotland by men prominently associated with the Clydesdale. Amongst those who made periodical excursions into Lincolnshire and Derbyshire were the late Mrr. Lawrence Drew and Mr. David Riddell.
An examination of the early history of the breed leaves little doubt that it owes a good deal to Flemish blood. There is much that is still obscure, but when the moving events in the history of the country are considered, the close intimacy which existed during the Stuart dynasty with the Continent must almost inevitably have led to the introduction of foreign blood in the domain of horse-breeding. At what date Flemish horses were first introduced we know not, but that there was commercial intercourse with horses we may judge from the statute permitting, in the reign of James I., all horses over three years old to be sold for export, but during the Regency of the Earl of Moray this was rescinded. Naturally the type of horse aimed at was dependent upon the state of the country. In a warlike age the idea was to carry an armour-clad warrior, and when the sword was beaten 
into the ploughshare, the salient objects of agricultural work would be studied. It is not material, and can serve no particular purpose, to investigate the origin of the Clidesdale before the eighteenth century. It was then that the importation of Flemish horses had most bearing upon the prevalent type of liorse to-day.

Incidentally, one wonders why the name Clydesdale was bestowed on the breed. It points to at least one inference-that the vale of the Clyde was a prominent horse-breeding district in Scotland in early times. Its eminence apparently was incontestable, for the breed of horse cultivated within the watershed of Scotland's most important river has spread to the remote regions of the country.

\section{Introduction of the Flemish Horse}

It appears that the introduction of the Flemish horses in the seventeenth and eighteenth centuries may be ascribed to two sources in particular. One of these was the then Duke of Hamilton, and the other a certain John Paterson, of Lochlyoch, in the Upper Ward of Lanarkshire. Whethes the six black stallions from Flanders which were stated to be at Strathaven Castle came at the period indicated or not cannot be settled beyond dispute, but it is accepted as correct by most writers. The late Mr. Lawrence Drew, of Merryton, was inclined to hold the belief that James, sixth Duke of Hamilton, had a dark brown Flemish stallion set apart for the use of his tenantry in the middle of the eighteenth century. In the earlier part of the same century, John Paterson aforementioned, of the parish of Carmichael, was credited with introducing a Flemish stallion. In 1836 an Edinburgh newspaper mentioned that a certain person named Paterson was given a day's ploughing, and he was a grandson of the brother of Paterson who brought the notable stallion from England to Lanarkshire, and this stallion was the foundation of the famous Clydesdale breed.

From the region of speculation we descend to that of fact. The establishment of the Clydesdale Stud Book, and the subsequent compilation of such facts as breeders were aware of, puts us in possession of some interesting information concerning the earlier sires. A black horse named Blaze was acquired as a two-year-old in Ayrshire by Mr. Scott, of Broomlill, Carstairs. This horse did yeoman service in the county. Nothing was known of his pedigree, but he was considered to have a dash of coaching blood.

\section{Early Sires}

The first sire of which we have definite knowledge, and back to which most of the present-day Clydesdales trace, was Glauce: 335, known otherwise as Thomson's Black Horse. He became the property of Mr. James Thomson, Germiston, Tollcross, and, following a common custom in Scotland, the name of the owner and the animal became associated. It is assumed that this sire was descended from the Paterson strain, and probably from the Lochlyoch stallion already referred to. The two very famous horses, Darnley 222 and Prince of Wales 673 , were both branches of the same stock, which trace back to Thomson's Black Horse; and considering how those two stallions have impregnated the Clydesdale breed, the important part played by Glaucer 335 can well be understood. The date of the foaling of this sire is said to be 18 Io.

Another sire of eminence was Broomfield Champion 95, which begat one noted horse, Clyde, otherwise Glaucer 153. He was also known as Fulton's Ruptured Horse. Bred by Mr. Forrest, The Hole, Lanark, he was one of the first of the well-defined Clydesdale breed. In the early Victorian era the produce of this sire won many honours in the show-yard, his sons being most successful. Great horses in their time were many, amongst which may be mentioned Prince of Wales I55, Sproulston or Farmer 290, Juircock 550, and Barr's Prince Royal 647, the last-named being distinguished as the sire of many animals of outstanding merit.

The two great horses of more recent times were Darnley 222 and Prince of Wales 673. Both, as has been mentioned, come down 
from Glaucer 335, the latter through Samson, or Logan's Twin 7fI, which sired Darrley's dam and likewise Prince of Wales's; while the former on the male side also comes from Glaucer through Conqueror, Lochfergus Champion, and Salmond's Champion. Prince of Wales was bred by Mr. J. Nicol Fleming, of Drumburle, Ayrshire, being sired by General 322. Mr. David Riddell, of Kilbowie, was his next owner, but he attained his greatest fame in the possession of Mr. Lawrence Drew, after whose death in $188_{4}$ he was re-purchased at the Merryton sale by Mr. David Riddell. Opinion is much divided as to the breeding of Prince of Wales. Whether his grand-dam and great-grand-dam were English mares or not is not likely to be settled; but considering the large number of English mares that were taken north at one time or another, we have every reason to assume that the Clydesdale greatly benefited by the infusion of "alien" blood. Mr. Lawrence Drew was the great apostle of a fusion of the two races, which he held to have a common origin. He showed the stock procured by this cross, and they admittedly proved the contention that very good horses can thus be bred. In fact, the idea is not purely of Scottish origin, for it is held, though not practised, by many experienced men south of the Border. Prince of Wales 673 was foaled in I866 and died in I888. In his time he was unrivalled as a show horse. His limbs were furnished with clean flat bone, and he was a model horse at the ground. His greatest attraction, however, was his marvellous action. He was rather straight in the hind leg according to modern ideas, and perhaps strong in the head, but that is not measured as a fault in these days of effeminate looking sires.

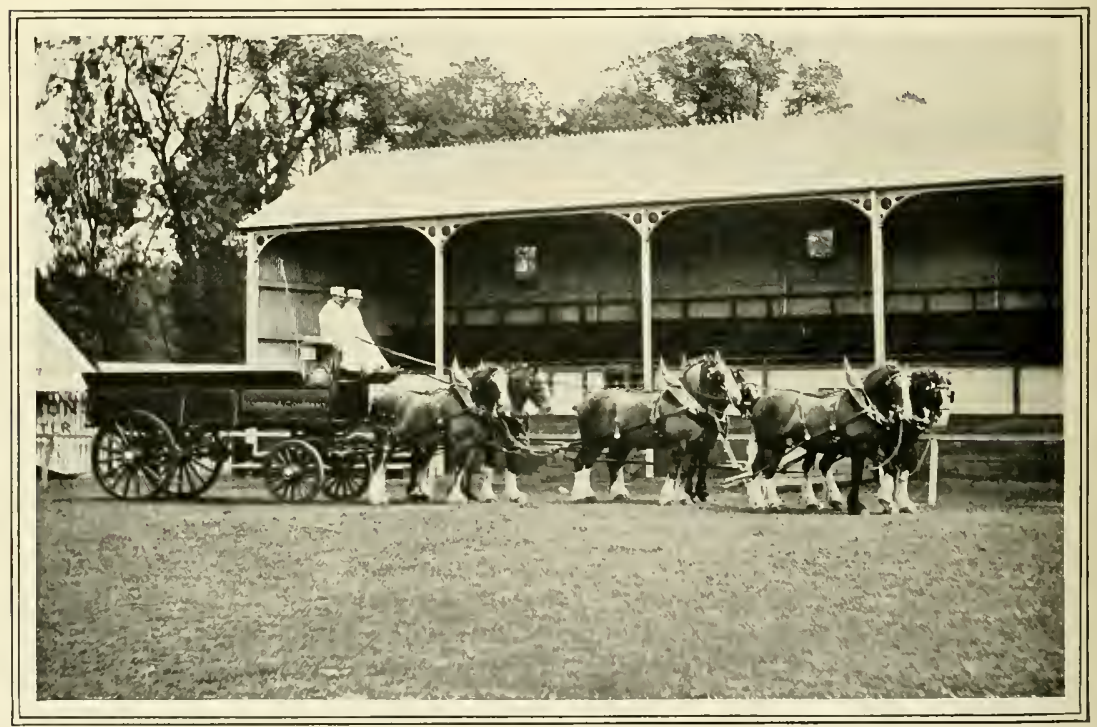

THE FAMOUS MORRIS TEAM OF CLYDESDALES. 


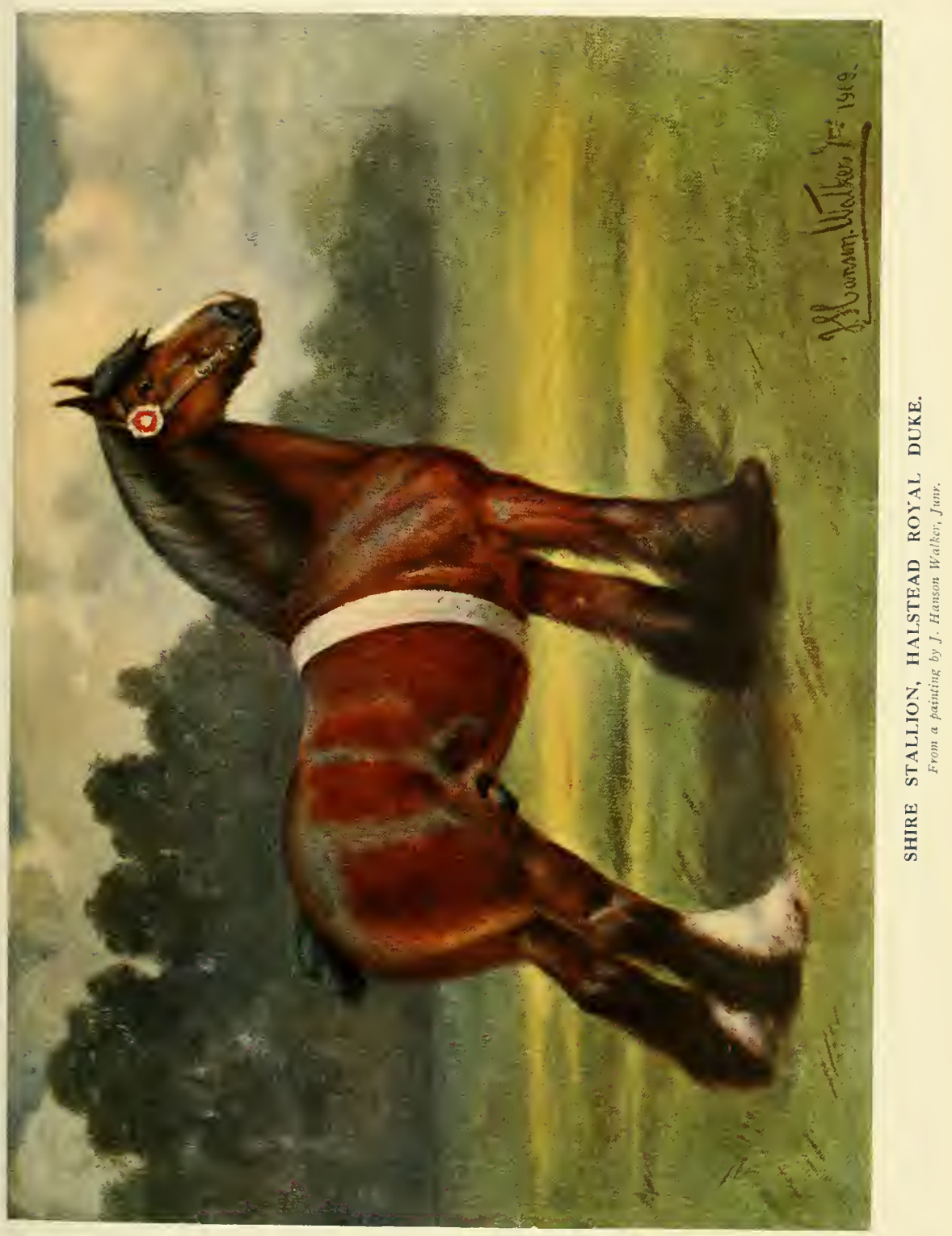





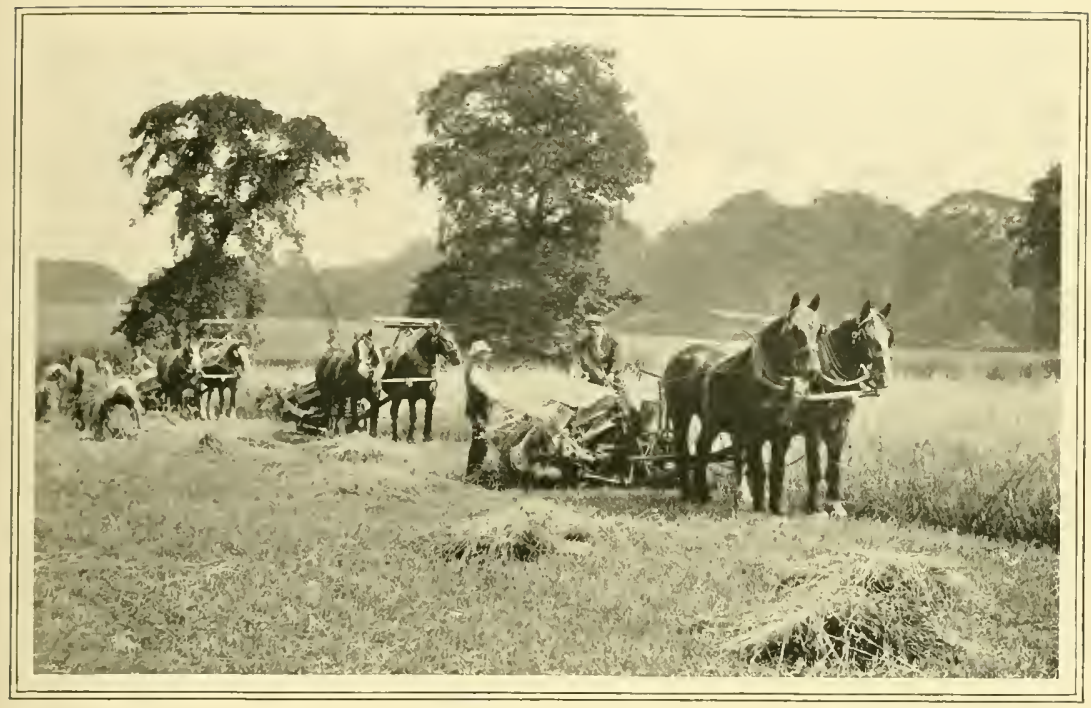

CLYDESDALES AT WORK.

\section{CHAPTER XXIX}

\section{THE CLYDESDALE HORSE (continued)}

D ARNLEI 222 was bred by $11 \mathrm{r}$. Stirling, of Keir, got by Conqueror 199 out of Keir Peggy by Samson. There is an element of romance in the breeding of this famous stallion. His dam had not been stinted, so she was sent as a sort of last resort to Conqueror, Darnley being the result. Had this happy afterthought not been put into execution, the modern history of the Clydesdale would have been different. Darnley attained his greatest distinction in the hands of Mr. David Riddell. “ Darnley for mares " is an apt summary of this horse's influence at the stud. The cross between Prince of Wales and Darnley's progeny was one of the striking features of their mutual success. One of the most notable results of this cross was Prince of Albion, bought by Sir John Gilmour for 3,000 guineas. The union of this horse and the ever famous
Moss Rose brought the thousand-guinea mare Queen of the Roses. Moss Rose, besides being a champion mare herself, kept these honours in the family with her daughters Montrave Maud and Queen of the Roses.

Darnley's three great sons were Macgregor $I_{4} 87$, Flashwood 1604 , and Topgallant I850. Mr. Andrew Montgomery, of Netherhall, and his brother Mr. William Montgomery, of Banks, owned Hacgregor at the height of his fame. Flashwood was bred by Mr. Craig, of Flashwood, Ayr, and was a full brother to Macgregor. Mr. John Pollock, of Paper Mills Farm, Girvan, owned him, and he became famous as a prize-winner. Messrs. Montgomery later on acquired him. Topgallant was bred by Mr. Smellie, Carluke, in I877, and was much shown by Mr. David Riddell. He eventually found his way into the hands of Sir Michael R. Shaw 
Stewart, Bart., by whom he was kept as a stud horse at Ardgowan, where he died in his eleventh year in I888. He left much good stock, including the famous Sir Everard 5352, bred by Mrs. Lamont, Killellan, Argyllshire, and owned by Mr. William Taylor, Park Mains, Paisley. He died in I $89 \mathrm{~s}$ in his thirteenth year. He sired the famous Barons Pride 9122, the greatest sire of his day. Barons l'ride was foaled in 1890 , and was bred by Messrs. R. and J. Findlay, springhill, near Glasgow. He was acquired by Messrs. Montgomery as a four-year-old, and won at that age the championship at Aberdeen Highland show. He has had a marvellous run of success as a stud horse, partly attributable to the policy of putting him to approved mares at a twenty-pound fee, but chiefly to his own inherent qualities. His greatest son is the famous Everlasting II33I, champion at one, two, and three years at the Highland Society's shows.

Probably the other most notable horse in modern times is Hiawatha 10067 by Prince Robert 7I35 out of Darling, bred by Mr. Hunter, of Garthland Mains, Stranraer, in I892. Amongst the more notable of this champion horse's progeny are Marcellus IIIIO and Labori IO79I.

\section{The Clydesdale Ideal}

When we write of the Clydesdale type we deal with a very advanced draught horse ideal. It is not easy to reconcile Scotch and English ideas concerning the best class of heavy horse for breeding purposes. English breeders who have attended the Glasgow stallion show declare that the most useful and weighty type of horses are seldom in their opinion given preference.

To understand the ideal towards which the Clydesdale breeder works, it is necessary to recognise that he does not believe in forcing his young stack unduly. We see yearlings in the show-yard which are not as big as Shire foals, and three-year-old Clydesdales no bigger than Shire yearlings; yet the fact must not be overlooked that a shire seldom grows after three to four years old, whereas a Clydesdale will keep on growing till six years of age.
Many believe with the late Lawrence Drew that the ideal animal is to be found in a cross between the Shire and the Clydesdale-preferably the Clydesdale stallion and the Shiremare. The defects of the Clydesdale - a weak, short head, lack of bone below the knee, and sometimes a lightness of " arms," thighs, and middle-piece-would be partly corrected by a union such as has been suggested. The Clydesdale as we see him to-day is essentially a good, open-footed horse. The feet are his foundations in more ways than one. Open coronets are favoured - too open some people think-but so long as the hoof is deep and open at the heels it implies a good, useful wearing foot. It is undoubtedly a disadvantage to have a very open coronet. Shire men consider it a source of weakness, and when colts are herded together, or horses are turning in the plough or chains, and a misplaced hoof tramples its neighbour, the bruised coronet, being more open, is more liable to injury and sidebone. The colour of the foot in the modern Clydesdale is usually white, owing to the favour which white legs meet with for show purposes. The late Colonel Holloway, one of America's most enthusiastic Clydesdale men, was a strong critic of the modern spongy white hoof, which did not stand the trying conditions prevail ing in hot countries.

\section{Clydesdale Points}

The finest point about a Clydesdale is the sweetness and cleanness of its pasterns. Length of joint is favoured rather than a short joint. At one time the term "a fine long pastern" was a point of recommendation, but moderation in all things, even in pasterns, is a creed worth keeping in mind. The limbs are beautifully fine, with a tendency to lightness below the knee. They are clean, well cut, and full of quality. The knee and hock joints are not orer-big, while the hair is of beautiful yuality, and very much less profuse than in the Shire.

The head is not so long, or, as some Clydesdale men think, so "sour," as in the Shire, and in some cases is too short even for Clydesdale tastes. The fore-hand is. 
lengthy and thick and statlion-like in the male. The shoulders are well laid, the back and ribs fairly well developed, though both are often deficient in young stock. The hind-quarters should be well developed, and the hocks nicely angled and free from a suspicion of straightness.

In action there is no closer or more correct moving breed. In the use of its hocks the Clydesdale is supposed to be a pattern to others. A good free walker, what it lacks in weight-breeders are freely heard to declare it makes up for in activity and pluck. In height 16.3 hands to 17 hands are good measurements. Sir Everard stood I 7 . I hands, and had II inches of bone below the knee, and weighed $20 \frac{3}{4}$ cwt. A good girth is from 7 feet 6 inches to 8 feet.

\section{The Stud Book}

The Clydesdale Stud Book was started in 1876 with 11 . Thomas Dykes, who has written much on the breed, as its first editor. It was undoubtedly a popular movement to introduce registration, although the rules governing it were the subject of a long and keen controversy. The first volume and the history of the breed were brought out at the expense of the late Lord Dunmore. The root idea of registration was to open the Book to animals having four crosses of registered Clydesdales. These four crosses, however, were stoutly opposed by several breeders, headed by the late Lawrence Drew. Mr. Drew was a regular visitor at Mlidland fairs, from which he took back across the Border many mares of great merit, from which the "Clydesdale" thus bred undoubtedly inherited considerable substance. Accordingly Mr. Drew, backed by sereral others of the same way of thinking. established the "Select Clydesdale Stud Book," registering horses after inspection. The fight between the supporters of the two books lasted for several years, but MIr. Drew's death in $188_{+}$practically killed the movement. The original Clydesdale Stud Book was left alone in the field, the "Select" rohme not surviving three issues. On the well established grounds of breeding, the theory of the production of a first-class horse by the Clydesdale Shire cross was excellent, but when we come to deal with a pedigree movement, breeders look for something more than individual merit in an animal to recommend it. They look for "back breeding." whence impressiveness is derived. Clydesdale breeders were, therefore, quite right in seeking to keep as large an element of purity as possible in the breed, otherwise registration was liable to miss the chief object it was intended to serve.

\section{Exportation of Clydesdales}

The export trade is not in many hands. In some way's this is a decided advantage, as the more attention devoted to it by at specialist few; the more do they feel inclined to develop it. It must be admitted that the export trade in Clydesdales far exceeds that of Shires. This is not necessarily due to the alleged fact that one breed is superior to the other, but to the ascertained fact that Clydesdale breeders were earlier ative to the importance of the foreign market. Many of the best colonists in North America are Scotsmen, and they carry with them their notions of what a draught horse is by taking the Clydesdate as their model. Mloreover, the Clydesdale suits Western tastes better than the Shire of fifteen years ago did. To-day the Shire is more modelled on Clydesdale lines, but with much greater substance and weight. America, which is the chief customer for exported horses, prefers draught stock with little feather, active, and not over weighty. Hence the Clydesdate and the Percheron are more hikely to satisfy the needs of breeders than the heary and more massive draught horse of England.

The United States and Canada are the chief buyers. A few go to South America, New Zealand, Australia, and the northern parts of Europe. It is worthy of note, as indicative of the activity of the trade, that I,049 pedigree certificates were issned to exporters by the Clydesdale Horse Suciety in 1906 .

The home trade has been liable to fluctuation: at one time very good, at the next 
moderate. A number of notable sales of late years have been recorded. The Blacon Point draught sale in the year I 905 averaged firs2 3s. 7d., the highest figure being 500 guineas for a mare. The final dispersion sale of Mr. Smith's stud took place in the year following, when $75^{\circ}$ guineas was made for the stud horse British Chief, and an average of $\$ 2 \mathrm{I} 6$ Ios. od, was recorded. As indicative of the "life" in trade within the past few years another sale, held at Perth in September, ino7, may be quoted. Seventeen animals from the stud of $\mathbf{M}_{\mathrm{r}}$. J. Ernest Kerr, of Harviestoun, Dollir, averaged fitg Ios. 6d. This is particularly good when it is remembered that of the stock offered five were foals and three rearling fillies.

\section{The Clydesdale in England}

The Clydesdale of later years has been gradually edged out of the south of Englind. An excellent horse in its own country, the difficulty which every English breeder encountered was to find appreciation of his sires in the neighbourhood. Before the Shire horse became the power he is, the Scottish breed had established itself in the northern comties, in Staffordshire, in Essex and Kent, and in South Wales. Even at the Windsor Royal Farms a Clydesdale stallion was kept for many years. Ciradually, however, the Shire has pushed the other breed out, this being particularly marked in Essex and Kent, where at one time the Lords Arthur and Lionel Cecil maintained a pure stud, which was usually represented at the Tumbridge Wells show-where, indeed, classes are still provided for " agricultural horses." In Cheshire a very vigorous stud was formed by Mr. Smith, of Blacon Point, the sale of which on the occasion of the owner's death has been referred to. In the north of England the hold of the breed is more secure, particularly in Cumberland, Northumberland, and Durham. It is a fact worthy of notice that the largest Clydesdale breeding stud is situate in Durham, where the Seaham Harbour Stud, Ltd, is established.

The charge has been made against studs removed some distance south of the Border that the type of horse grown is liable to become strong and cuarse. The north of England is very like the south of Scotland, so that the stock bred there is exrmpt from the tendency to deteriorate in quality: On the stronger horse-breeding soils of England, however, the transplanted Clydesdale has the best opportunity of developing bone and muscle, but apparently that little touch of extra quality so dearly beloved of the true-blue Clydesdale man is lacking. It is a significant tribute to the power the Clydesdale enjoyed in its earlier days that Shire breeders like the late Mr. Hart, of Cannock, first entered into the horsebreeding business with a Clydesdale stallion.

\section{Breeding in Scotland}

Horse-breeding societies flourish greatly in Scotland. What the Clydesdale and the Clydesdale stud owner owe to those admirable institutions it would be difficult to compute. The facts that Clydesdale horsebreeding is practically in the hands of tenant farmers, and that large studs are mostly grouped in the south-west of the country; and, therefore, not conveniently placed for breeders farther north, have no doubt influenced the progress of the horse-hiring society in the north.

Horse-hirings take place very early, sometimes two to three years before the horse is due to travel, so keen are farmers to secure the best sires. The fees and retainers vary. The premiums open for competition at the Glasgow stallion show run to $t 80$ and fees. The fees obtained for stud horses standing at home usually vary from five guineas upwards. As much as $\underset{\sim}{20}$, foal or no foal, is demanded and readily paid for service of the best stallions, the owner exercising the right of approving the mares. It must be said that the small breeder is more particular with reference to the choice of a sire in Scotland than he is in England.

The leading show is undoubtedly that of the Highland and Agricultural Society, which risits a different centre every year. It provides ample classification, and the awards there made are recognised as of the greatest importance. The Glasgow Agricultural 


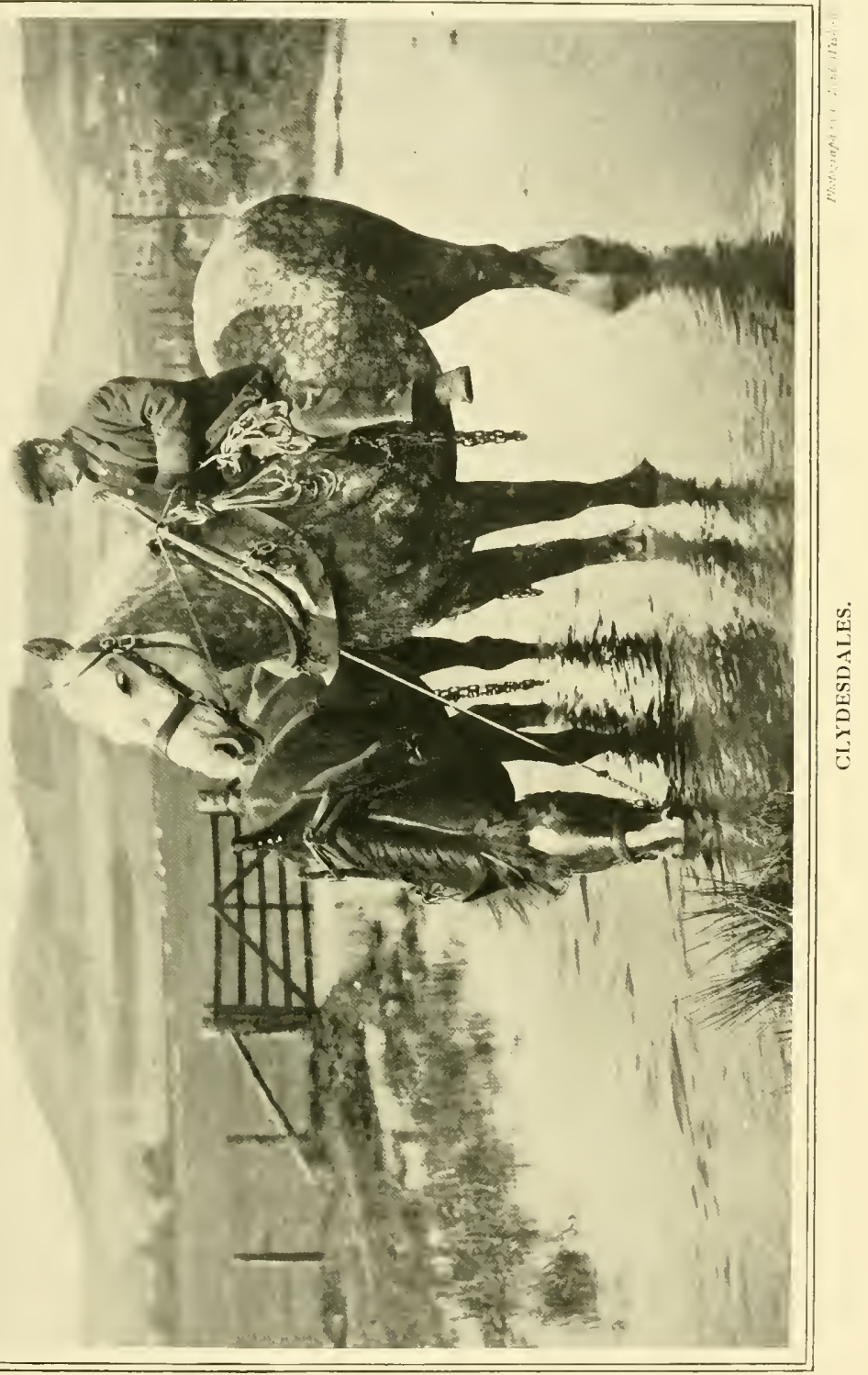


Society holds a spring stallion show, which is the chief event early in the season, and the most important ineeting for stallions. Particular attention is given to deputations from horse-hiring societies who attend to choose a stallion. There is no fixture, however, which corresponds in completeness to the Shire Horse Show at Islington.

The chief summer shows, in addition to the Highland, at which the breed is found in strength are Glasgow, Ayr, Kilmarnock, and Edinburgh.

\section{Clydesdale Stud Management}

The management of a Clydesdale stud does not differ very materially from the management of any other stud where stallions are kept. The arrangement of the buildings, the loose boxes, the stallion yards and paddocks, is governed to some extent by the liberality or parsimony of the landlord and the amount of money the stud owner is willing to disburse from his own privy purse. The well equipped modern stud has ample horse-box room, stallion houses-some of which lead into high partitioned yards - a good service shed, and, in the paddocks, shelters in which to feed the stallions and to permit them to take refuge from storms. It is generally found in experience that young stock prefer, after partaking of their meals in the sheds, to come out into the upen and sleep there.

Foaling is most convenient when it takes place in March or April. The very early foal is often a source of trouble and anxiety. If intended for exhibition it is difficult to keep on its legs through having to spend its early days in confinement. The extra size, owing to increased age, is not worth striving for, as freshness is of as much importance in a foal as size and substance. It is a good thing, therefore, to try to get the foal out to pasture as soon as possible, and to regulate the foaling date accordingly. The foal may run with the mare for five months before weaning, learning to feed by itself before being taken off the dam. It will readily take to the corn ration with which it is advisable to assist the mare from time to time. Good mother's milk, and plenty of it, will bring the young foal on, staving off as long as possible the day when grain is first given.

Good foals which are intended to be shown as yearlings should have special attention. They are all the better, if rumning out, with a little corn and hay feed. It is very difficult indeed to keep young animals thriving when brought up in the confinement of a box or even in a yard. They are better at pasture with a shelter which they can take advantage of in stormy weather.

The legs of all show stock running out should be periodically dressed to keep the hair right and prevent the evil efforts of rubbing and gnawing. For this purpose equal parts of train oil, paraffin, and sulphur, well rubbed into the skin, may be recommended. Next day the legs may be well sawdusted.

\section{Preparation for Showing}

In the large stud, where showing is an important matter, immediate preparation for the ring is important. Stock should be taken in a few weeks prior to the time of exhibition and handled well. They should be regularly exercised, drilled in their paces, and the feeding slightly increaser. It is not the practice in Scotland to show young stock so highly conditioned as in the English ring. The plan of growing animals chiefly on oats is therefore to be recommended. To get bloom on the coat nothing excels linseed or linseed cake, of which a little should be included in the ration.

The feet, too, require attention. L'nless the hoof is breaking badly, even tips should be avoided. When run unshod at pasture the tendency of the hoof to wear down at one side should be corrected with the rasp.

The stallion is all the better for outwintering, conditioning food being given to enable him to go through the season well. A very fat stallion is not the surest of foal getters, so that it is better to err on the safe side in respect of feeding. 


\section{CHAPTER XXX}

\section{THE SUFFOLK HORSE}

I I the Suffolk Punch we have the clearest and most incontestable evidence of purity of breeding. The Shire may be indebted to Flemish parentage partly for its strength of bone, the Clydesdale may have drawn upon the Shire and upon Continental resources, but the Suffolk Punch has been chiefly dependent upon British stuck. No doubt the distinctly Flemish and Norman appearance of the typical Punch has been responsible for the suggestion that its parentage was largely Continental. We know that in Henry VIII.'s time, and in the reign of uther kings of the Middle Ages, there were horses brought over from the Continent which no doubt influenced the entire horse-breeding of this country. But Mr. Herman J. Biddell, upon whom has fallen the mantle of breed historian, emphatically refutes the assertion that the modern Suffolk is the product of a Continental cross. In the course of a lecture delivered before the Framlingham Club in 1907 he said: "I have searched every available source from which this statement was likely to have emanated. I have been unable to find the slightest foundation for this mythological origin of the Suffolk horse. Those who have made the assertion have never offered to supply the source of their statement. There was a strain of Suffolks fifty years ago which came from a mare imported into this country from abroad. But the horse which had this strain in his pedigree could only have had an eighth of his parentage of this doubtful origin. This is the only instance of authentic introduction of foreign blood that I could discover."

IVe may accept it, therefore, in the absence of proof to the contrary, that the Suffolk horse is a comparatively pure pro- duct of native blood. There is abundint evidence in favour of the belief. No breed, be it light or heavy, reproduces itself with such constancy of colour and character as the Punch. That, as every breeder knows, is the most searching of all tests to apply to pedigree or pure-bred stock. On this point we have the further testimony of Mr. WI. J. Moscrop, of Loftus, Yorkshire, who, writing of the prize farms of Norfolk and Suffolk in 1886 in the Royal Agricultural Society's Journal, says: "If purity of blood is indicated by uniformity of colour, the Suffolk undoubtedly stands as the only unmixed breed of horses in the Britisl Isles. In no other can the colour be predicted with certainty before birth, the inference being that there can have been no crossing or mixing of blood for a period dating back to the mist of ages; and to produce any colour but a chestnut from a suffolk sire and dam is not within the power of the moderns, and would probably tax skill equal to that possessed by the patriarchs of old."

In the old files of East Anglian newspapers interesting links with the past are provided in the advertisements of horses standing for service and the reports of agricultural functions. Every scrap of information has been carefully preserved, so that there is no breed of heavy horses of which we have a fuller or more intelligible account than this. The points of the modern Suffolk horse are not of vesterday's creation. Even I50 years ago the purity of the breed was the subject of advertisement. No doubt the statement that a sire was "the truest bred cart horse in Suffolk" was as persuasively untrue then as it might be nowadays, but the fact remains that it proves to us that the particular lines on which breeders of the eighteenth century worked 
were precisely similar to those which animate one and all to-day.

There is no definite evidence to prove the actual antiquity of the Suffolk horse as represented by dates. Whether it came over with the Danes or Saxons or Romans, whether it was a product of these Isles we read of Sir John Cullum using Suffolk horses in his carriage. Some years after this Sir Thomas Jery Cullum mentions that " clean legs and well-formed shoulders are criterions of the true Suffolk breed; points which enable them to be good movers." Further light is thrown on the early type

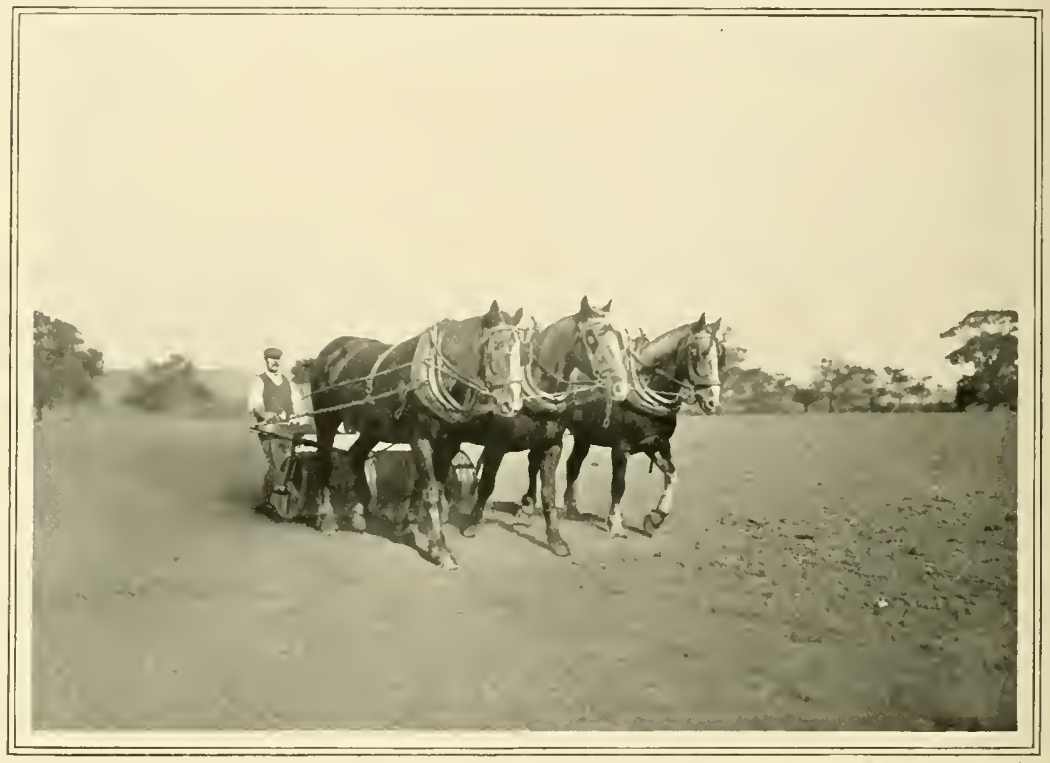

SUFFOLKS AT AGRICULTURAL WORK.

improved by imported stallions in the distant past, there is no documentary evidence to establish. We know that Arthur Young, the historian of the Board of Agriculture, recorded his impressions of the breed as he did of everything else pertaining to English agriculture and stock-breeding. Evidently he was either not acquainted with the best type of Suffolk Punch, or the horses of that period were sadly degenerate specimens, for he speaks of them as follows: "Sorrel colour; very low at the fore end; a large ill-shaped head with slouching heavy ears; a great carcase and short legs; an uglier horse could hardly be viewed. The old breed could only walk and draw; they could trot no better than a cow."

About the same time, in the year 1780 , in vogue in the "History and Antiquities of the County of Suffolk," by Suckling, who records that Suffolk horses " are middlesized, very short made, and though low in the fore-hand are active in their paces, and on the lighter lands of the county will draw a plough at the rate of three miles an hour." In the early part of the nineteenth century (I8I2), at Sir Robert Harland's sale, good prices were recorded. The best team made over $f$ Izo each; twelve others averaged fSo. A stallion made $£ \mathbf{I} 70$, a mare $£ \mathbf{I} 40$, and a foal $E \neq 6$.

It is a curious fact, and worthy of putting on record, that at a time antecedent to shows one of the methods adopted to test the courage and stamina of animals was to institute pulling tests. Sir Thomas Cullum 


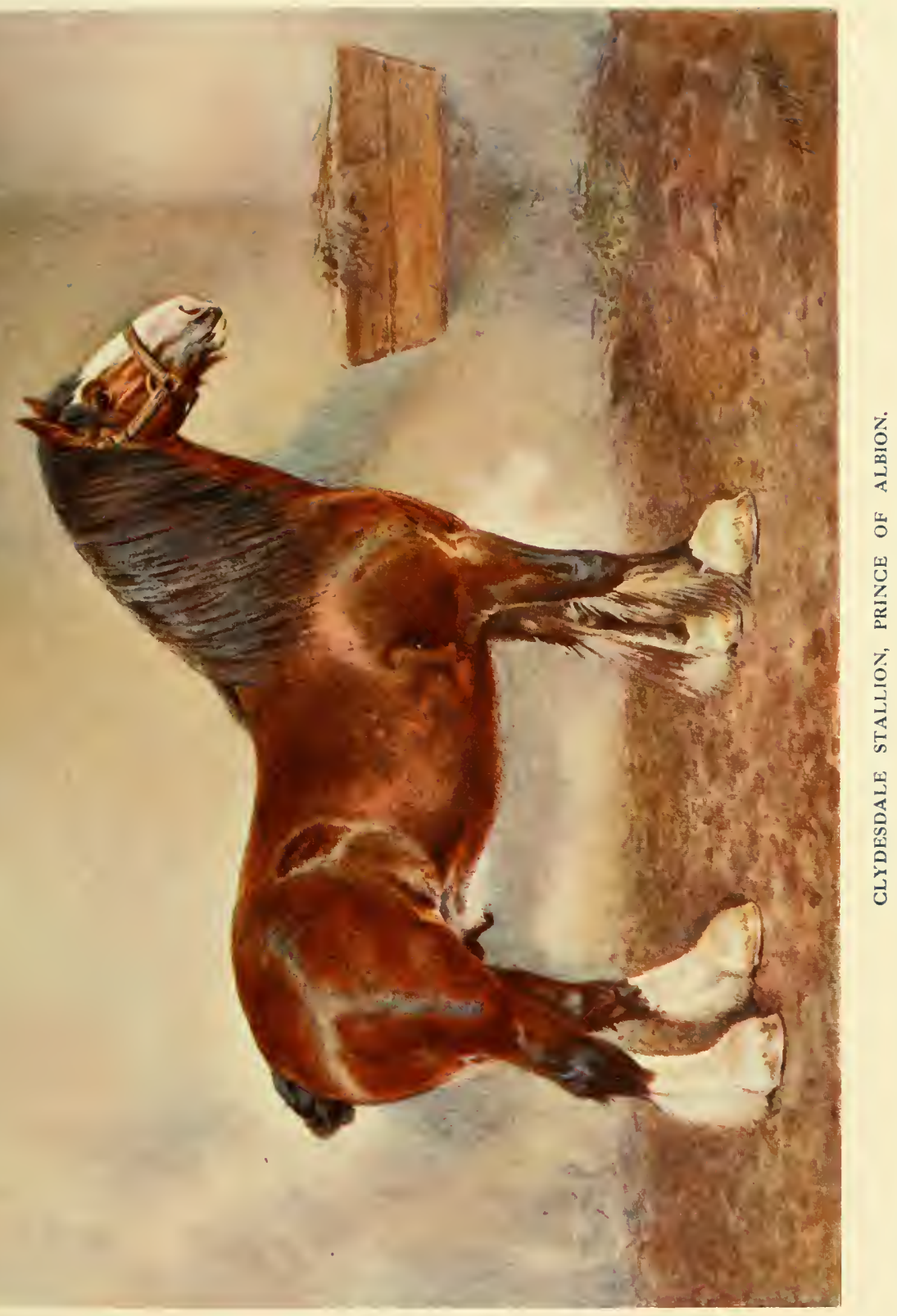



thus describes them: "The trial is made with a wagon loaded with sand, the wheels sunk a little in the ground with blocks of wood laid before them to increase the difficulty. The first efforts are made, as usual, with reins fastened to the collars, but the animals cannot, when so confined, put out their full strength; the reins are thereforc afterwards thrown loose on their necks, when they can exert their utmost powers, which they usually do by falling on their knees and drawing in that attitude. That they may not break their knees by this operation, the area on which they draw is strewn with soft sand." The announcement of a "drawing" in I724 states that a prize of a 45 s. piece of plate will be offered.
No doubt these early trials, although modern humanity might condemn the barbaric notion which they embody, have instilled into the breed its wonderful powers of haulage, testified to by Youatt and others. Youatt remarks that " the Suffolk would tug at a dead pull until he dropped."

The parent sire of the breed, so far as history relates, was a nameless horse owned by Mr. Crisp, of Ufford, a village three miles from Woodbridge. He is said to have been a $15 \frac{1}{2}$-hand horse, a bright chestnut in colour, and "fit to get good stock for coach and road." It is a rare thing to say of any breed, but practically every Suffolk horse traces back to this one. As a matter of curiosity, it is interesting to note that in

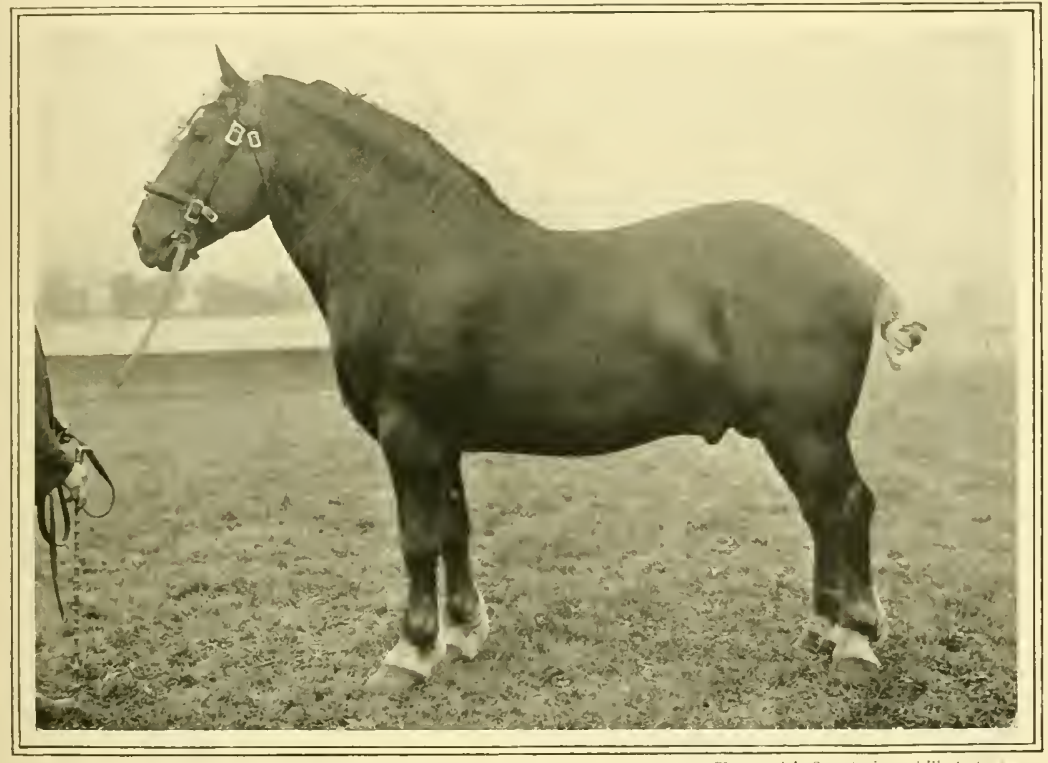

MIR. A. J. SMITH'S SUFFOLK STALLION, RENDLESHAM SORCERER,

Those bringing five horses and five mares were allowed to enter, " and ther that draw twenty the best and fairest pulls with their reins up, and then they can carry the greatest weight over the block with fewest lifts and fewest pulls shall have the said plate." a second season's advertisement the owner of this old horse mentions that those who were unsuccessful with him "last year" can have "the use of him this season for five shillings."

There have been external crosses, of course. These would of necessity creep into 
every breed which was not run under the wholesome influence of a Stud Book. Probably the cross about which most is known was that of a horse belonging to Mr. Blake, of St. Margaret's, near Ipswich. From him sprang what is colloquially known as the Blake strain. This sire appears to have been vaguely described as a "trotting horse," but his descendants were called Suffolks. He was probably somewhere in the neighbourhood of 15 hands high, and appears to have been highly popular. Farmer, as this horse was called, was evidently a success too, for Blake himself advertised that many of his horse foals " out of cart mares" were sold for from twenty-five to thirty guineas. Four generations were in the hands of Blake, so that the progeny were gradually becoming saturated with Suffolk blood, and amongst the produce of the fourth generation was Young Briton, foaled in 1796 , and for which his owner refused the sum of foo guincas. Mr. Biddell attributes to this introduction of Blake's trotting-horse blood "the handsome crest, the sloping shoulders, the well turned hind-quarters, and the improved action." These desirable qualities were, so to speak, hitched on to other characteristics which belonged to the breed from the dim ages - the fast colour, the fine constitution, the short leg, and the grim determination between the shafts.

\section{Attleborough Farmer's Glory}

Yet another introduction is mentioned about the beginning of the nineteenth century. Attleborough Farmer's Glory, advertised by John Wright, a dealer who lived at Attleborough, in Norfolk, although it hailed from Lincolnshire, had more substance than Blake's horse to which we have already referred, and the suggestion that he had Suffolk blood in his pedigree may have been true. Apparently he had not much hair, which may have justified the suspicion that his legs had been "drawn" a little. It all events, Mr. Biddell does not think he improved the breed as Blake's horses did. One of his descendants in the sonth-west of the county was stated to stand IS hands high and weigh a ton. The Farmer's
Glories were a numerous family. As late as the 'forties there were twenty-five of the old horse's descendants advertised in Essex, Norfolk, and Suffolk. The strain, however, gradually died out, the last horse traceable by Mr. Biddell being one belonging to $\mathrm{Mr}$. Sawyer, of Thwaite, foaled in $186_{4}$, another in Essex in 1878 , and Lewis's Duke, champion prize winner in 1806 , at Ipswich. The belief that the strain is extinct is regarded as another instance of casting off an "extraneous infusion."

\section{The Shadingfield Stock}

Amongst other experiments tried was the introduction about the cluse of the eighteenth century of the Shadingfield stock known as "Otley Bottom Proctors," and the "Barker's Proctors." These came from a riding horse. They were all dark chestnuts. Mr. Biddell describes them as "well whited in the legs." To the last they were high spirited and never tiring, light below the hock, fine in their shoulders, smart heads, and fast walkers, carrying out their distinguishing characteristics till the time the blood became extinct.

\section{Colour of the Suffolk}

What is the true colour of a Suffolk horse? The answer to this question is to be found in the word chestnut. It is correct to assume that chestnut may be of many hues and shades, but it is a singular fact that bays and the many other colours found in Shires and other brceds are unknown in the Punch. The only variation permitted is the presence of a few grey hairs. Some fifty or sixty years have elapsed since a bay Suffolk horse was known to be upon the road. In the early days of the Suffolk Stud Book the idea prevalent was to maintain the old Suffolk colour, and excluding from entry those animals that did not conform to it. No shade, so long as it was a chestnut, was objected to. Thus we have hues varying from the light sorrel to the dark chestnut, the coppery shade so prominently associated with Old Cupbearer. The really' dark chestnut, however, is hard to find to-day, and doubtless to Smith's Horse of Packam is due the fine similarity of colour which 
prevails in the modern type, the absence of white on the lieels and the white blaze on the face. Breeders are more cosmopolitan in their taste in respect to colour than they ured to be, but a bright chestnut has still command of the sale ring, although a really good chestnut of another hue would find as great support if the other attributes of a good horse were present.

\section{Shades of Chestnut}

It requires the discriminating feminine ere to do full justice to the varying shades of chestnut, but so far as mere man may uffer an opinion they may be thus distinguished: The dark chestnut, cherry red tint, almost implying a bay ancestry; the true red chestnut; bright chestnut, the best of all colours, with mane and tail of the same hue; silver-haired chestnut; the lemon-coloured chestnut, and the sorrel. One must not forget the mealy chestnut, but it is objected to as probably the worst of all hues which pass a horse into the Book. Whetlier this hue is associated with constitutional decline one hesitates to say, but the fact remains that many breeders are inclined to regard it as such. In the silverhaired chestnut, a few hairs of that hue are not objected to, but anything approaching a roan is considered outside of the pale of the true Suffolk shade. Reference has already been made to the manner in which the breed perpetuates its colour. It should be noted that experience of the chestnut hue in other walks of stock-breeding convinces one that it is the fastest of all colours. Thus in the Hackney it has proved itself the uvermastering shade, and many fine thoroughbreds and hunters are distinctly chestrut in tint. A notion prevails that in the Shire and other breeds it is associated with a softness of constitution such as is not found in good roans and gress. Probably the theory has been founded on unfortunate individual experience, but in the majority of cases it is based on prejudice.

\section{Points of the Suffolk}

The real Suffolk Punch is a finely-built horse. He is very thick and wide, and to those accustomed to the Shire, with his hirsute appearance, the Punch might look light of bone. To some extent the charge is true that he lacks substance, but on the other hand the rare pluck, endurance, and activity, coupled with quality of bone, enable a good Suffolk gelding to accomplish wonders in the way of pulling heary weights. A good Suffolk stallion will measure IO $_{2}^{1}$ inclies of bone below the knee; and that is considerable testimony in itself, for there is no hair to add to the verdict of the inch tape. The balance of the horse should be good. Width of top and quarters, strong loin and full thighs, are suggestive of power. The weak-hearted horse, short of rib behind the shoulder, is not often met with. The shoulders should be well laid, and the neck thick and cresty in the stallion, and leaner and longer in the mare. The head of the suffolk is a point upon which the fire of criticism has been levelled, as some of the best stallions have undoubtediy been short and lacking in masculine character in the face. The "ponified" head we should regret to see much introduced, and no doubt its appearance has partly led to the suggestion of Continental origin.

\section{Legs and Feet}

If the body is wide it stands to reason that the legs should be well placed outside of it. This explains why so many Suffolks are so wide in front. A horse that requires an expansive collar cannot tread so closely as one much narrower in the shoulders. The legs should be clean and muscular, the kneejoints broad and not oval. A narrow knee-joint does not suggest a strong fore-timb. The fetlocks should be clean and the pasterns sloping. The feet, some forty years ago, were much criticised, but they have greatly improved, and sidebones particularly are much less frequent than they used to be. In the show-rard one sometimes meets with the narrow coronet. Its attendant evils are well known to breeders. The gond work of veterinary inspection should be recognised, for it relieves the judge of a responsibility which should never have been placed upon him. To-dily the suffolk 
stands on as good a footing, metaphorically and otherwise, as other draught breeds.

The hind-legs should be nicely angled, the hocks bold without being coarse, and firmished with plenty of bone.

\section{Action and Height}

In point of action close movement is cultivated, but one must interpret what is close movement a little more liberally with this breed than with the narrower built Clydesdale. Free action is necessary with good use of the joints. It is the misfortune of the suffolk horse that his faults are easily seen. Any little twist of the joint is not obscured by a kindly lock of hair. Officially described, "the Suffolk horse is an excellent mover, with a smart, quick step, a true balance all round at the trot, and a capital walker."

In point of height the Suffolk runs from I5.2 to I6.2 hands, and a horse over that is viewed by good authorities with suspicion unless he be extremely well built. Mr. Hume Webster mentions that Mr. 1. J. Smith's Wedgwood as a frve-year-old measured 7 feet II inches in girth ( 8 feet 7 inches in condition), and $\mathrm{I}_{1}^{3}$ inches below the knee, $27 \frac{1}{4}$ inches round the forearm, and $7 \frac{1}{1}$ inches across the sole of the foot.

\section{Suffolk Characteristics}

The longevity of the suffolk is another point in his favour, and amongst the earlier exhibitions of the Suffolk Agricultural Society there was a mare entered for competition aged 37 years, and she was suckling a foal.

Docility is likewise a strong point of the breed, which those accustomed to work with horses will appreciate.

The Suffolk horse is primarily for agricultural work. It may be said without hesitation that it is an excellent farm horse. He never fails to do a good day's work, feeds economically, walks quickly; and is very handy in chains and cart. The absence of harry legs is an advantage rather than otherwise on heavy land. Indeed, it is difficult to keep the hair on a shire of the old type when in bad weather the soil adheres, to cake when dry.

\section{The Suffolk's Pluck}

The statement has been made that the breed is not suitable for the heary dray work of London streets. That may or may not be. If size and weight are the primary considerations, there can be no doubt that the Shire has first call. But those who have used Suffolks agree that there is no pluckier horse to be found. It is, indeed, singular testimony to this aspect of the character of the breed that Suffolks should be so largely used in railway vards for shunting. The chief difficulty is to find a horse that will throw himself well into the collar, and the fact that the Suffolk should be so popular for this heavy work-involving a great strainbears out the reputation which it has established in this direction. If the Suffolk were as big as the Shire his limbs would require to be fuller of bone, and purely by virtue of the fact that he lacks weight is the breed edged out of the heavy dray market. For the lighter draught work there is no horse that excels him.

The craze for very active dray horses has led one commentator to remark that the spectacle of a horse weighing a ton bending his knee up to his throat latch and striking the granite with his feet like a sledge-hammer is not an exhibition which appeals to a Suffolk farmer.

A considerable export trade is done, the Continent being the chief market.

\section{The Suffolk Horse Society}

The Suffolk Horse Society has done much useful work to encourage the breed. Its most notable scheme was that of hiring out mares to farmers. In October, I897, a scheme was adopted empowering the purchase of thirty nominations to approved sires. Owners from whom nominations were purchased were required to give a guarantee that the stallions employed would be restricted to the service of eighty mares during the season. Applications had to be made in response to advertisement or otherwise from tenants whose occupation did not 
exceed 200 acres. These nominations were to be granted to approved mares practically sound, the recipient being required to sign an agreement to deliver the foal unweaned free of cost, and to accept the sum of $f_{1} \mathrm{~T} 5$ from the Society. An appointed day of delivery was fixed, when the foals were put up for sale, the breeders being allowed to bid on the same terms as the general public.

Thirty nominations were taken up the first year at a cost of $£ 2$ each, and in September, r899, fifteen foals came under the hammer. These realised, after the deduction of the auctioneer's charges, $£ \mathbf{I} 7$ each. The Society, after paying farmers $£ \mathrm{I} 5$ and deducting the cost of nominations, costing f3 6s. Sd. per live foal, had a loss. The chief difficulty was to find suitable mares, as only twenty-five of the thirty were put to the horse. This led to a more extended scheme, whereby farmers were enabled to buy approved mares at the Society's sales. The farmer was required to pay 25 per cent. of the purchase money, the Society finding the remainder. The money advanced was charged at + per cent. interest. In the event of a Society's mare proving barren for two years, or in case of accident, or if in the opinion of the Breeding Scheme Committee such mare should be deemed best sold, the Society retained the power of sending her to auction, dividing the proceeds with the tenant farmer, in like proportion as the mare stood indebted to the two parties. The purchase of foals was agreed upon, conditionally that they were in good health, and the tenant accepted $£$ I6 IOS. on the delivery of the foal. In three years the farmer became the absolute owner of the mare, which was practically paid for by the sale of the foals.

The Suffolk Horse Society has now a membership of 239, and holds three sales yearly. It was founded in 1876 .

The chief shows at which the breed is exhibited are Woodbridge, and the Essex and Suffolk county meetings. In I 908 classification was introduced at the Norfolk county show: The Royal Agricultural Society's meeting is also well supported.

Medals are given at the London Cart Horse Parade by the breed society, while the teams of Suffolk geldings shown by Sir Cuthbert Quilter at the International Horse Show will doubtless bear fruit in advertising the breed.

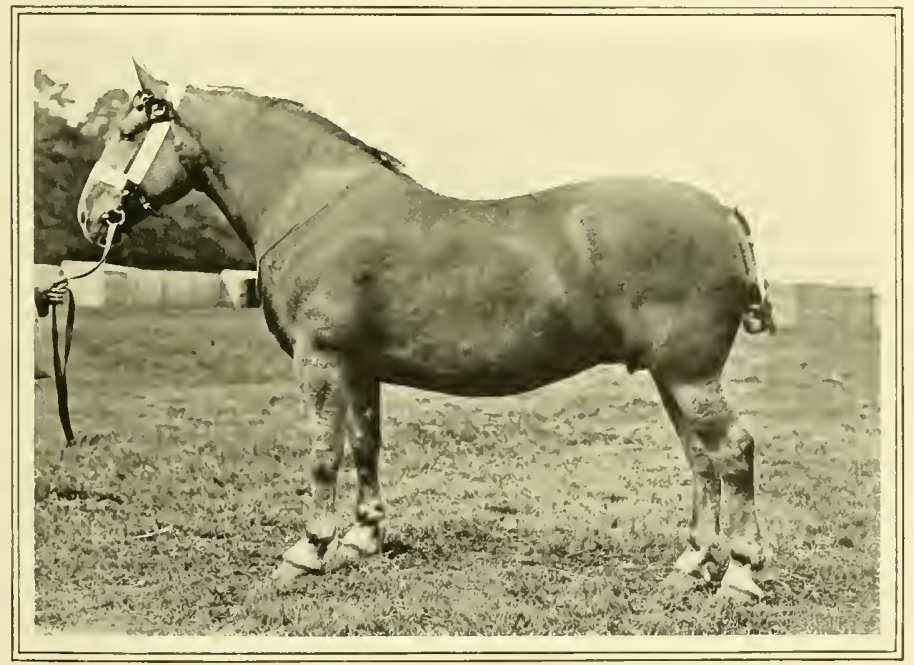

MR. R. C. WHITE'S SUFFOLK MARE, BOULGE MAID. 


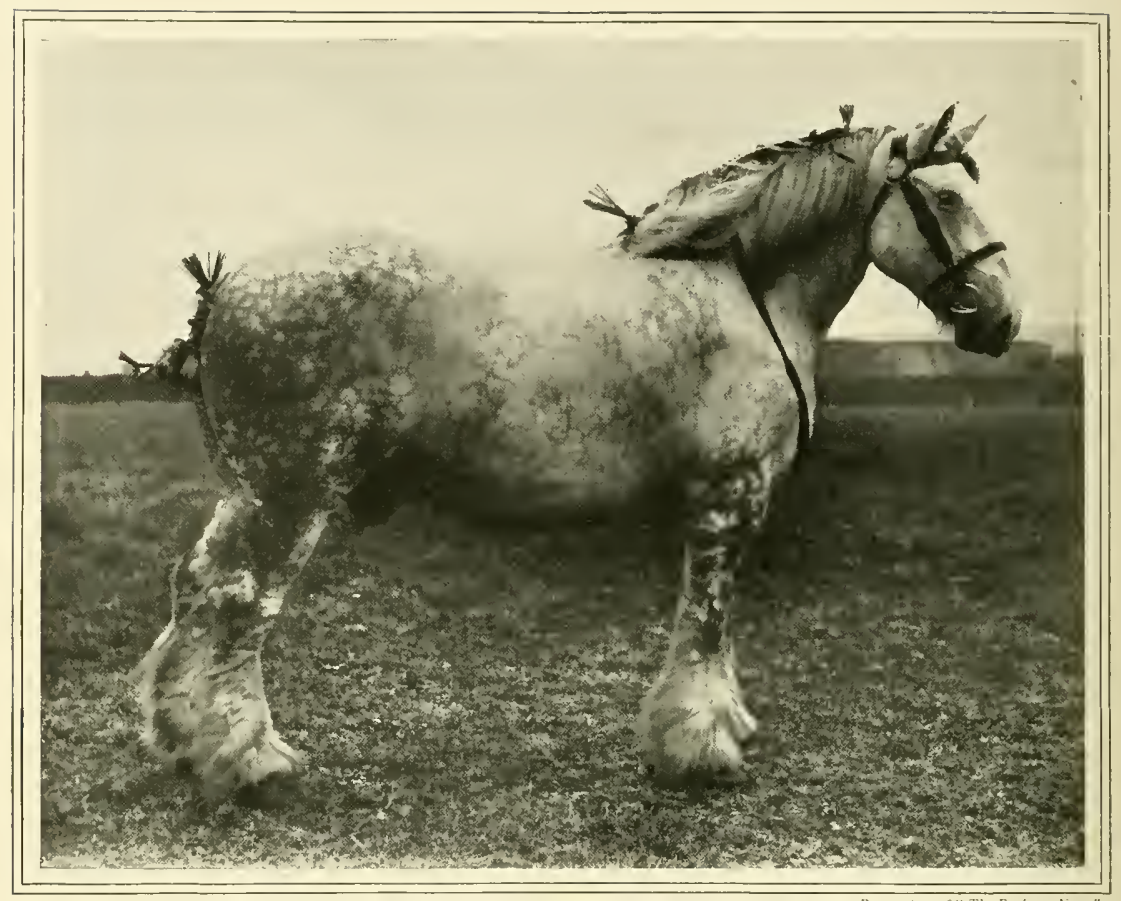

A MIDLAND RAILWAY HORSE (17 HANDS I IN. HIGH: WEIGHT, I TON).

\section{CHAPTER XXXI}

\section{MANAGEMENT OF HEAVY HORSES}

$\mathrm{T}$

THE management of the heavy horse is a big subject. It is capable of expansion to cover almost every subsidiary branch of horse-breeding. Properly speaking, the work of the veterinary surgeon is so closely allied to successful stud management that even the ailments to which horses are subject might be included in this chapter. For convenience, however, it may be taken that the main points to be considered in stnd management are the daily life of the brood mare, feeding and treatment, rearing of young stock, and their cquipment for show purposes.
In large studs the method of management naturally differs from that pursued in small establishments. The idle mare and her working sister are brought into sharp contrast, so that the working of an in-foal mare and a mare suckling her foal are to a large extent determined by necessity. In every stud, however, one of the first problems that faces the horse-breeder is when to mate his mares. As affecting the management of the stud it is unnecessary to enter very deeply into the matter, but the views entertained by breeders may be set forth as briefly as possible.

The main idea appears to be to mate 
opposites-a rough stallion on a quality mare, and vice versa, though truth to tell, there are so many mares nowadays of more quality than substance, that a reversion to the rough stallion would not be a misfortume to heary horse breeding. The era of stud books has brought with it certain defects, and one of these is the difficulty of finding stillions sufficiently masculine in character. By too many small stud owners the question is allowed to settle itself, and the handiest and cheapest horse is employed. With the facilities that now exist for sending mares by rail to horses of repute, the growth of horse-hiring societies, and the number of good horses privately travelled, there is no excuse for the choice of an unsuitable horse. The main things to look for are size, substance, quality of bone, good joints, and feet, and what is of paramount importance, soundness. If a certificate of soundness were demanded as the preliminary to negotiations for the use of a horse, draught horse breeding in this country would gain thereby.

\section{Foaling Time}

Assuming, however, that a suitable mate has been found, the next question that arises is the best time for foaling. In the large stud kept solely for breeding purposes, this is often left to regulate itself. We find mares due to foal as early as January and February, and others with services which indicate a late July foal. The best foaling months in England are April and May, and with the addition of June these are the most common. The definite choice of a foaling period is often that of Nature's, and a late service is frequently given rather than slip a year and wait for a more convenient period. Yet another factor influences choice of the time of parturition. In the case of the working stud the owner prefers his foals to arrive at a time when they are of the least inconvenience. It may be assumed, therefore, if the matter becomes one of choice, that it will unfailingly fall on the month of May after the spring sowing has been completed, and before the hay harvest is likely to demand all the horse labour towards the end of June. Early foalings entail a certain amount of trouble, and if a foal is good enough to go on for show in September it is often a matter of considerable difficulty to prevent it going stale. It is not desirable to keep young foals tor much under cover, so that a May foaling has the particular advantage of introducing the sucker to the fresh young grass at the earliest possible moment.

Assuming that before we can have a stud it is essential to have the mare in a brood state, a little attention may first of all be directed to the management of the dam. It may be supposed that the breeder has settled in his own mind at what age a filly may be put to the horse. As a rule this takes place when rising three, but the determining factor will be the state of development rather than slavish adherence to a common time. If the filly is out of condition and backward in size, frequently the result of being a late foal, it is as well to defer service another year. A young, growing animal cannot nurture a foal unless at some cost to herself, and it is desirable that she should have made the most of her growth before entering upon the duties of maternity.

\section{The In-Foal Mare}

In the treatment of the in-foal mare common sense should play the largest part. The period of gestation is as near as possible eleven calendar months. The best and surest way of keeping the mare in good health and giving the foal every chance to do well is to provide regular work and supply nourishing rather than fattening rations. Mares at work in an ordinary farm stud keep in good condition on a daily feed of oats, varied with a little bran and linseed, a run at grass, and such hay as the rick can afford. During the summer and early. autumn nothing is more appreciated than an occasional feed of tares, but a large allowance of this class of food must be aroided, as it has a distinctly softening tendency apparent in profuse perspiration when set to the hard tasks of the harvesting season. There is an unlimited choice of food, all the cereals save maize, as well as 
linseed and bran. As the in-foal mare wears on towards her time the work may be reduced to service between the chains, avoiding during the last three months of pregnancy the shafts of the cart. Nothing is more likely to be productive of abortion than backing with a load. There are other causes, such as over-exertion, fright, and serious illness.

It is the custom to watch the mare at foaling time so that assistance may be rendered if necessary. There are various kinds of foaling boxes in modern stud buildings, some more elaborate than others. The circular type of foaling box is not often met with, but in nearly every one all sharp corners are pared off so that the mare by no mischance may do herself an injury. Quite a good and convenient arrangement can be made by converting three ordinary loose boxes into two foaling boxes, and an observation chamber in which a fire may be kept burning, and a medicine cupboard installed. Two sliding panels enable the attendant to keep a close oversight on the mares on either side Young mares are usually shy of attention as foaling approaches, and the minimum of interference and disturbance frequently proves most satisfactory.

\section{Symptoms of Parturition}

The ordinary symptoms of the near approach of foaling are well known to every breeder. The udder becomes distended, and the waxy coating which oozes out of the teats is a sure sign that parturition will not long be delayed. When the dark, sticky liquid changes to a white colour the arrival of the foal may be expected within twenty-four hours. In cases of protracted labour assistance may be required. The first thing to determine is the position of the foal. It is not advisable to allow the amateur to deliver a mare when the foal is not naturally presented, and we may thus leave this branch of the subject to be dealt with by a veterinary pen.

Very often when the foal arrives the mare is exhausted, and a reviving drink is necessary. Oatmeal gruel to which a little brandy has been added will prove as serviceable as anything. When the case is a difficult one it may be necessary to repeat the stimulant at intervals. It is as well to remore the hind shoes from the mare to prevent serious injury to the foal, should the mare stamp on it.

\section{Treatment of the Foal}

So far as the foal is concemed it requires attention from the moment it is born. It is as well to clear the youngster's nose, and should the navel string not have snapped in the act of parturition, tear it asunder and dress the foal's navel with an antiseptic or whisky. Allow the mare to lick the foal, and throw a sack over the mare's loins, permitting both to lie quiet before attempting to put the foal to suck. A bran mash and a little hay will not come amiss to the mare, which for the next three days should have chilled water and sealded oat and bran mashes, and a little hay.

Weakly foals are at all times a trouble, but the best must be made of them. When the respiration is very weak or fitful a wet sponge should be passed over the head, especially the mouth and nostrils, the body vigorously rubbed, and the sides and chest smacked witls a cloth. When the breathing becomes regular the foal may be rubbed down and dried with a woollen cloth.

\section{Mare and Foal}

IIares are sometimes backward in taking to a foal, and require to be coaxed. Usually they will begin to lick the foal at the first opportunity, failing which the offspring may be sprinkled with a light-coloured substance such as flour, and the mare become thus induced to fondle it. A little coaxing invariably prevails. The foal will speedily find its way to the maternal font. It does not generally require assistance to find its first meal. The mother's milk may be gently drawn to wet the teats, and however unpractised the foal may be it will easily procure enough to satisfy its wants. If the mare is obstinate, and refuses to acknowledge her offspring kindly, the foal should be induced to suck. In extreme cases, where the mare rebels and attempts 


\section{MANAGEMENT OF HEAVY HORSES}

to kick the foal, she may be tied up, and the forefoot lifted to prevent free play with the heels.

\section{Rearing of the Foal}

The rearing of the foal is one of the most important branches of stud management. A good nurse will save the stock owner a great deal of trouble, for Nature's way is always best. After the first three days the mare may return to harder food, consisting of an equal mixture of dry oats and bran, say Io lb. or I2 lb., a few carrots, and the addition of chaff. This quantity may be reduced to a single feed per day when the mare and foal have the run at pasture. Confinement to the house for a few days should be followed by a run in a yard, and when the warm days may be depended on there is not likely to be a short supply of milk when the grass is young and sweet.

\section{Feeding by Hand}

The motherless foal may sometimes be fostered, and so may a twin foal of a mare that has not milk enough for two. When hand rearing has to be adopted the result is never so satisfactory as when the mare nourishes her own offspring. Next to mother's milk, cow's milk is the best. There are calf feeders on the market on the teat principle, and nothing could be better adapted for the rearing of a foal by artificial means. In the early stages the milk may be given out of a spouted can to the foal, the spout being wrapped round with a soft substance, such as cloth. The milk should be poured gently, the foal sucking the while. In a short time the foal will be able to take the milk from a pail. Warm milk is best, and the foal should be fed five or six times a day. If the milk cannot conveniently be got from the cow for each meal it is better to warm it before feeding, by adding a little hot water. There is a certain element of risk in feeding whole milk to a foal. Some of them thrive on it amazingly, while it appears to be too rich for others. Accordingly as it affects the foal, the milk may be reduced by the addition of water and sweetened with a little sugar.
But cow's milk will not entirely sustain the foal. Nor is it advisable that it should. The chief difficulty with young foals is to keep them growing and at the same time right at their joints. It is not difficult to detect a foal that has had an overdose of cow's milk, whether supplementary to the mother's nourishment or otherwise. It shows it in its forelegs and joints, and when it begins to feel the effects of overfeeding at an early age it often suffers for it in years to come. Every foal should be taught in its youth to eat from the manger. In the case of hand-reared foals this is indispensable. If the cow's milk is not an agreeable food and the young foal is not thriving, a change must speedily be made, for a check in foalhood is very difficult to recover. Trial may be made of linseed and beans, given in the form of an emulsion. Thus the beans are boiled and the pulp squeezed through a fine sieve, the straining being added to the milk. Probably the best mixture that can be used is linseed and bean meal, a quart of boiled linseed and 3 lb. of bean meal added to a gallon and a half of skim milk.

On many farms the nurse mare is given light work. There is little to object to in the working of mares suckling foals prosided they are not put to arduous tasks. If the mare returns to the foal in a profusion of sweat it is obvious that the milk will have a tendency to upset the foal. When necessity demands that the mare should be worked. provision should be made for supplementary food. The first warning sign of a foal going back in condition is slipping the hair.

\section{Weaning}

Weaning usually takes place when the foal is about five months old. It is generally accomplished piecemeal. The foal should have the company of others, and may be admitted for a day or two to the dam twice daily. Care should be taken to prevent it emptying the bag entirely, as the surest way to dry off the milk supply is inefficient milking. The mare may be put on dry food, and have a dose or two of mild aperient medicine. If the separation is immediateiy 
effected it will be necessary to draw a little of the mare's milk off by hand, but usually the supply will dry up in a week, when the food is not of a kind calculated to stimulate lactation. If the mare is hard at work, and the feeding dry and spare, there is not likely to be inflammatory udder trouble. Extra food will be provided for the foal in the form of oats and bran mixed, or a mash eomposed of oats, bran, beans and linseed, the last named boiled. It is unnefessary to elaborate the ration too much, as often the simpler the food the more satisfactory the progress. Oats alone will do well if the bowels keep regular. Costiveness may be prevented by the use of linseed.

One important point in the early life of the foal is to handle it freely. Ere it is many davs old it should have a leather haiter put on the head, so that it may early be aecustomed to the training which should begin when it is still young. It may be interesting to note the system practised with the breeding mares and foals at Dunsmore, in the stud owned by the late Sir P. Albert Muntz, as related by Mr. T. Ewart.

\section{Methods at Dunsmore}

"The brood mares," he says, "have to do the work of the farm when not suckling, as no geldings are kept. I do not as a rule work mares when suckling, but many of them work up to the time of foaling. . . . When mares are due to foal they are always provicled with boxes paved with grooved blue bricks laid on concrete. These are always well cleaned out, and every groove scraped out, washed with disinfectant, then sprinkled with hot lime a day or so before the mare is put in. There should be no drain opening into the box, which should drain to the outside. This is the surest prevention of joint-evil that I know of; in fact, I cannot remember any case occurring when this has been carried out. In addition I always adopt the system of disinfecting the navel the moment the foal is dropped, but I think this is of no use without the previous precaution. Neither do I believe in turning out early foals on to the damp ground, and exposed to the cold winds, as many foals are thus lost by chills which develop into other ailments. They are perfectly well and happy in well-ventilated boxes, and do not get delicate, as some suggest, if care and judgment are used in only turning them out for an hour or so the first day and about two hours the second day, and so on, when the weather is favourable. They can always lie out night and day on moderately good pasture, and do without artificial feeding. But I always advocate giving them food a fortnight or three weeks before weaning, so that they will take to their corn, and thus do not sink the first few weeks after the dams are taken away. Some people have an idea that when foals are weaned, and the grass is luxurious and good, they do not require any food until the grass has gone, and the weather gets colder. This is a mistaken notion, as there is no time in a horse's life when artificial feeding is more necessary than when it is just taken from its mothe1 and loses the milk which has practically no substitute."

\section{Feet Troubles of Colts}

There is really very little to say eoncerning the subsequent management of the yearling and two-year-old. An indolent life is the natural course, and beyond giving extra food in winter and spring, and if the pasture is poor a smaller quantity of supplementary rations in summer, the breeder must needs possess himself in patience. It is a mistake to crowd young colts into yards in winter, as they become mischierous, and are sure to kick each other, although only in a playful way. They are also very liable to trample on each others' coronets, bruising the top of the hoof, which bruise has a tendency to ossify in later years.

The feet of young horses always require strict attention. On strong land it is a good plan to turn the young animal loose without sloes, especially in a wet year, moist land being favourable to the development of the structure of the hoof. The two dangers to be guarded against are narrow eoronets and broken feet. Land that is liable to bake under the influence of a 


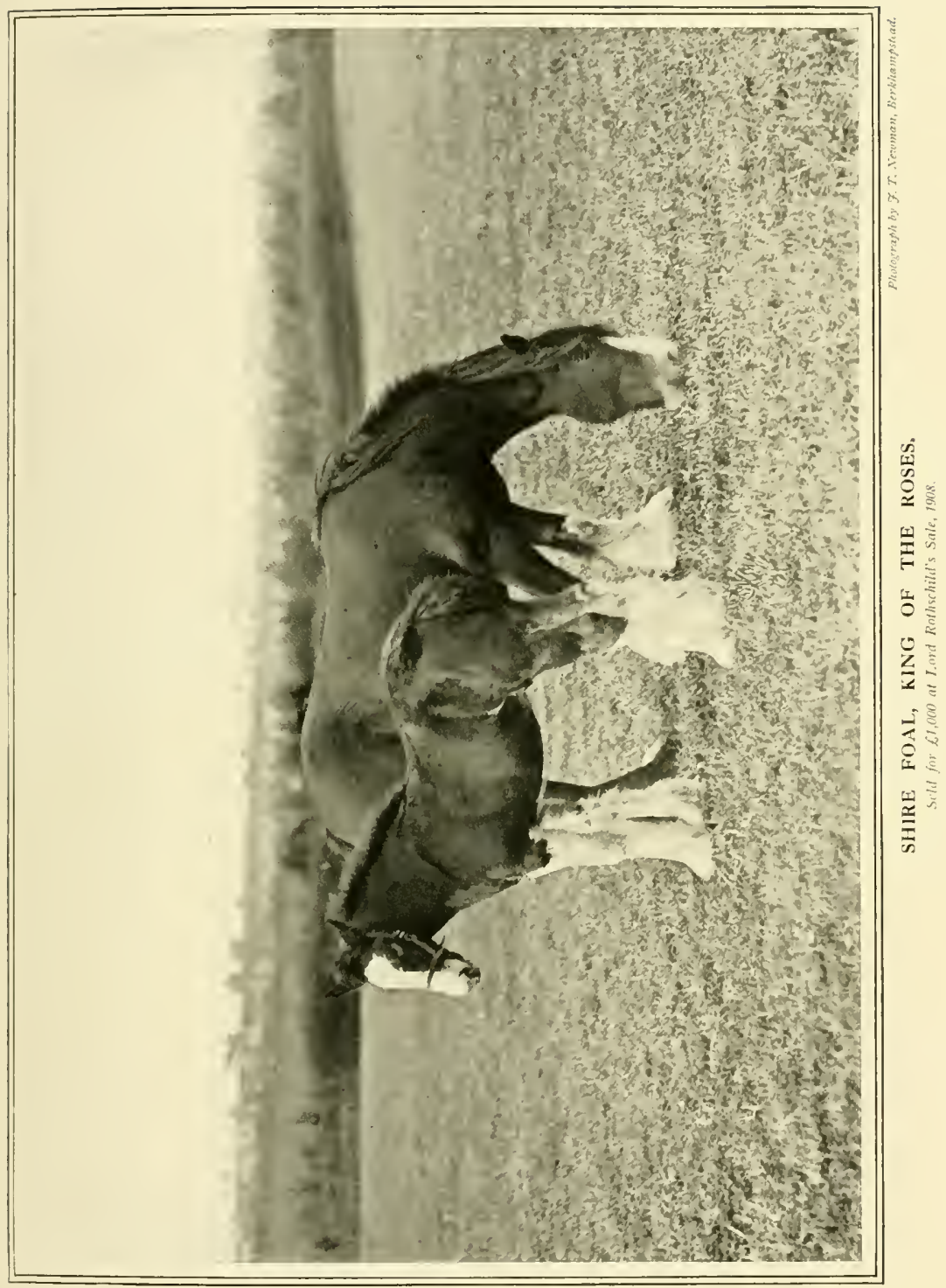


drying wind and a hot sun is not the best kind of soil to turn shoeless colts on. Plates may be put on, but only of the lightest description. The feet should be kept pared well down, and if the coronets are late in developing, wet swabs are of material assistance, as the foot has a tendency to expand under the influence of a continued application of moisture. The white feet which nowadays adorn white legs, so much appreciated in the show ring, are not nearly so tough as the old blue hoof, which is less liable to crack and does not break so readily.

At the age of three the young horse may be broken to work and begin to earn his living. If a filly, she should bear a foal at this age if her development as a two-year-old is sufficient to justify early mating.

\section{Preparing for the Show}

One distinct branch of stud management is the preparation of a horse for show purposes. In the main, the methods adopted are the same all over the country, except in the case of the Clydesdale breeder, who does not hasten his young stock to that state of high condition and early maturity which seems to find favour with Shire and Suffolk breeders. It must be acknowledged that the art of showing has been carried to a very high degree of perfection. The chief fault is a tendency to exhibit stock with too much adipose tissue, although it must be said that there are fewer overfed Shires in the show-yard to-day than was the case ten or fifteen vears ago. No doubt the difficulty of getting mares in foal was the stallion owners' warning beacon, but more faith may be attached to the Shire Horse Society's refusal to grant representative honours to any but mares in profit, or allow barren mares to win its medals.

Perhaps the purpose of this chapter may best be served by briefly outlining the method usually followed in fitting a young Shire animal for the show-yard. The first thing that the breeder has to settle in his own mind is the choice of type. Look well to the ground. If the feet, joints and limbs are built the right way, and there be a fair quantity of hair, prosided the foal is not too late, it may be chosen and put through the preparatory course with the object of coming out at the spring horse shows. In a Shire, look for plenty of hair about the fetlocks, and in front and behind the knee. Quality counts for much, and coarse fuzzy hair inclined to curl is strongly resented by judges nowadays. The youngster should move well, and when drawn up stand squarely on its legs. The Suffolk foal should be keenly examined about the hoofs, the knees, and the tendons of the foreleg. It must be remembered that in a breed like the East Anglian Punch the absence of hair magnifies the faults. The foal should be pushed along on corn if not quite big enough, but if the stature is satisfactory the longer corn feeding can be delayed the better. A very good mixture to give is crushed oats, bran, and chaff. At weaning the rations will require to be increased. After the mother has been forgotten the foal may be turned with others for company into a paddock, which has the convenience of a shelter. The chief advantage of a shed is that they can be fed in comfort, for it is rather curious the aversion the average young colt or filly has to take shelter even in very stormy weather.

The food may still consist of the ground oats, bran, and hay, but a little linseed or linseed cake may be added, and a few sliced or grated carrots given as well. It is better to keep young stock on hard muscle-forming food than to trust to an excess of cow's milk, too much sugar, or an over-dose of heatmaking grains like maize. It is quite true that milk may make a fine yearling, but there are many instances to show that it is almost fatal to two-year-olds.

\section{Treatment of Legs}

Some few weeks prior to exhibition-if the Agricultural Hall is contemplated-it is advisable to bring show stock under cover in order that they may become thoroughly accustomed to the confinement. Attention will now be turned to grooming, and chiefly to the legs and feet. Throughout they have been the object of careful supervision, to see that the young animal is treading 
them level. If there is any unequal wearing of the hoof it may affect the action, therefore the rasp must be freely used. One of the great difficulties is to keep the hair on the legs of young Shire stock when they are caked with mud; if the mud is allowed to dry and an itchiness manifest itself, it is certain that in self-defence the colt or filly will begin rubbing and gnawing, and then good-bye to a neatly befringed leg when it is most wanted. It is well, therefore, to dress the legs with sulphur, train oil and paraffin, as described in the preceding chapter.

\section{Practice in Action}

Meanwhile the training to walk, trot, and stand should be proceeding daily. The great thing to ascertain before showing an animal is the pace at which it exhibits itself to most advantage. Instances have been known where young animals going out of their proper pace have shown a tendency to fight for their heads, and even go wide. Therefore it is well to start on the basis that every colt or filly has a pace to be cultivated. They should be kept with the whip if necessary well up to the halter, when their best show parade has been discovered. Nothing is more detrimental to the chances of a young animal than to see the attendant two yards in front when the judges call for a trot.

One of the most important points to study is action. Good free shoulder play, and the use of knees and hocks are greatly studied. The plan usually adopted by the breeder to facilitate the use of the limbs is to shoe light in preparatory practice, and when the heavy show shoes are put on the extra weight on the hoofs induces an assumed freedom in the use of the limbs which is really artificially produced. To such an extent has the "ironing " of heary horses been carried that it might be advisable to fix a limit to weight according to age.

The trimming of the hair round the hoof beads and the bandaging of the ankles with wet cloths to keep the hair in the right position and show off the pastern formation complete the preparation of a young animal for show. The use of resin, soap, and other artificial aids to the appearance is forbidden, and so is the fashion of throwing sawdust over the back before entering the ring.

\section{Cost of Food}

The estimated cost of feeding a full-grown horse all the year round varies from $8 \mathrm{~s}$. to Ios. per week. Mr. Spooner, in his essay on " Management of Farm Horses," estimates that the average cost per week is Ios. $2 \frac{1}{2} \mathrm{~d}$. Thus from November to March, consuming per week $I_{2}^{\frac{1}{2}}$ bushels of oats, $\mathrm{I}_{4}^{3}$ cwt. of straw, and $t_{2} \mathrm{lb}$. swedes, and later on, in spring, 2 bushels oats, I $\frac{1}{2}$ pecks peas, and I cwt. hay, the bill varies from $8 \mathrm{~s}$. fd, to I2s. $3 \mathrm{~d}$. In the summer a bushel of oats may be given weekly, and green food ad lib., costing 8s. a week. A big draught horse will require, when in full work, from $16 \mathrm{lb}$. to $\mathrm{I} 8 \mathrm{lb}$. of grain, and an equal weight of hay daily. In city studs maize is more largely used in the ration than it was at one time. It is fed up to $I_{3} \mathrm{lb}$. daily, but as a rule farmers and breeders do not care for much maize feeding.

\section{Scottish Food Systems}

As typical Scottish systems of feeding, we may quote particulars given in a lecture by Mr. Archibald MacHulage, the Secretary of the Clydesdale Horse Society. He mentions that the use of boiled food is dying out in the west of Scotland, and on many farms it is never used. Horses winter better, and are less liable to colic without it. In Ayrshire the morning feed at 5.30 is $3 \frac{1}{2} \mathrm{lb}$. bruised oats, $3 \frac{1}{2} \mathrm{lb}$. maize, $3 \mathrm{lb}$. chopped hay, mixed. At noon this is repeated, and at 6.30 p.m. $3 \frac{1}{2} \mathrm{lb}$. bean meal, $3 \frac{1}{2} \mathrm{lb}$. chopped hay, mixed together and saturated with boiling water five hours before feeding. At all times the rack in front of the horses is full of hav. In the morth-east of Scotland the horses are fed six times daily. The following may be described as the timetable:- -5 a.m., a mash of $2 \frac{1}{2} \mathrm{lb}$. oats and $3^{\frac{1}{2}} \mathrm{lb}$. bran ; 5.45 a.m., 2 lb. oats ; I I a.m., $2 \frac{1}{2}$ lb. vats; noon, $2 \frac{1}{2}$ lb. oats; 6 p.m., $2 \frac{1}{2} \mathrm{lb}$. oats, and $3 \frac{1}{2} \mathrm{lb}$. bran in mash; 8 p.m., 8 lb. raw turnips. Uncut hay is supplied unstintedly, and the oats are bruised.

The feeding of a stallion is an important matter in view of the heavy season which 
he is expected to undergo. It is the custom in a great many studs to allow the stallions to " rough it " during the summer, autumn, and winter. They keep their health much better under these conditions than when shut up in a loose box. A small quantity of oats daily will maintain them in good hard condition. As the season approaches it is usual to try to put a little more condition on stallions than they carry through the autumn. A mixture commonly employed is oats, bran, peas or beans, with a few carrots. Others pin their faith to boiled barley as an acceptable addition to the ration, while a few of the more successful put the finishing touches on with molasses, in the form of a meal. To get the coat right the mash is useful, and so is a little linseed or linseed cake. It is really better to have a stallion in lean store condition than carrying adipose tissue, but farmers will choose the bettermade up horse and therefore breeders require to see to it that their horses are well topped off. In the middle of the season food is given more frequently, and when a horse is much in demand beans and eggs are relied on to replace lost stamina. A good horse will serve three or four mares in one day, and it is on record that as many as seven have been covered.

Concerning the treatment of the stallion, Mr. T. Ewart, Dunsmore, says:

" At the end of the season the majority of horses having finished their rounds, are turned out into the fields and paddocks, where they remain until the autumn, and some of them until early in the following year, generally without cover or shelter. They come up better than those that have been confined to the box. Further, they are infinitely better for stock purposes, although they may sometimes lack in outward appcarance in their tops (in comparison with those kept up), in the eyes of some people who are not expert judges of feet, legs, and unmadeup horses."

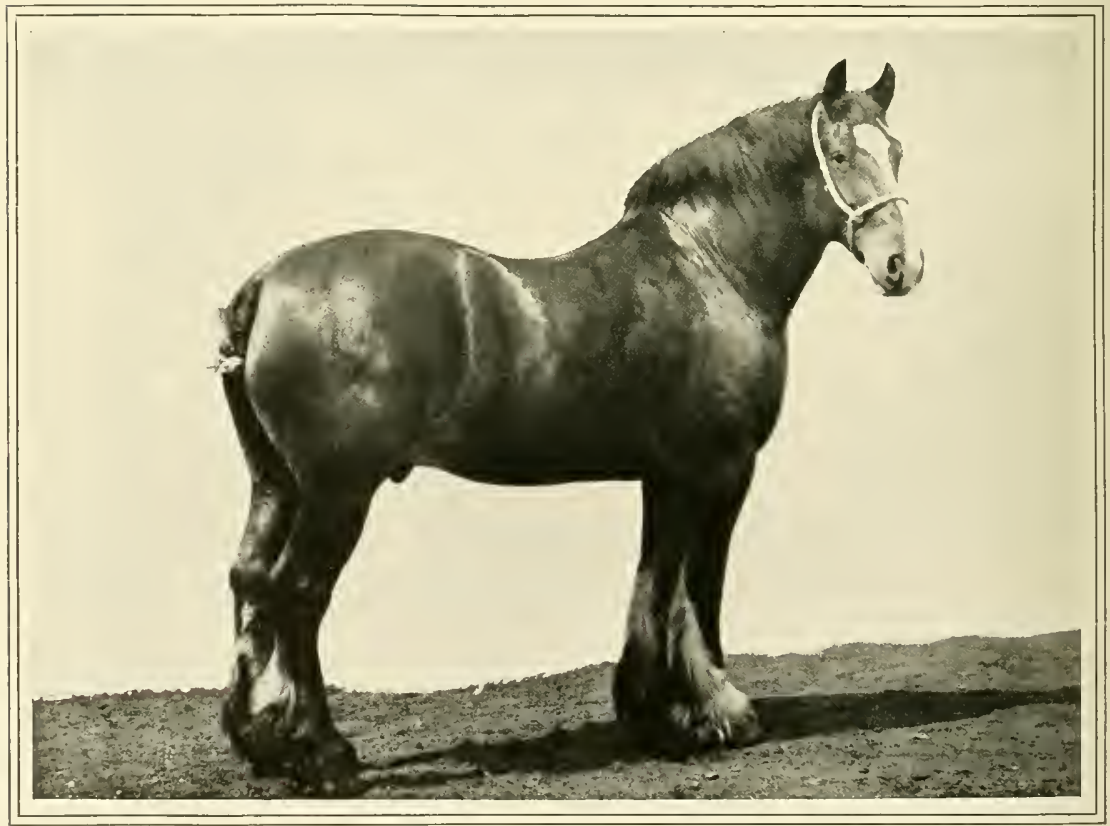




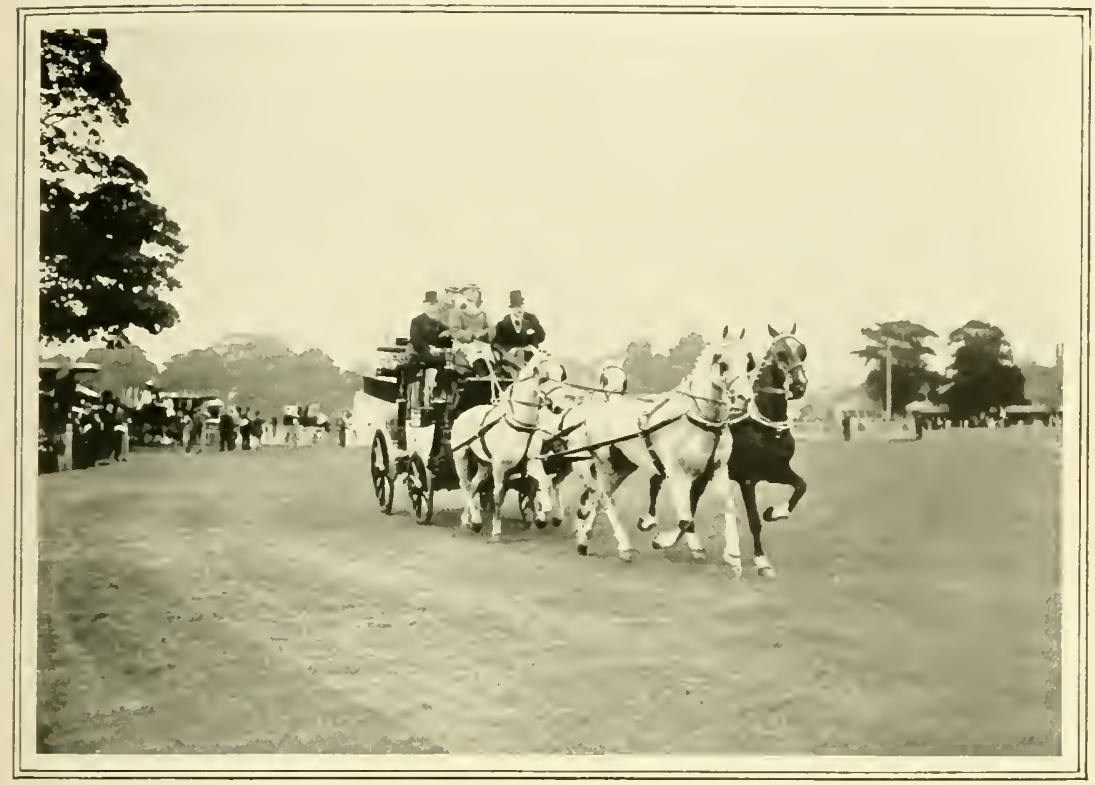

MR. W. A. BARRON'S ROAD.COACH, "THE VENTURE."

\section{CHAPTER XXXII}

\section{COACHING}

I will be easily understood that at the present day, when the driving of horses has been greatly superseded by mechanical traction, the subject is not of such interest as it was before the motor-car was invented, but nevertheless there are still thousands of people all over the world, but perhaps more particularly in the United Kingdom, who still take great delight not only in driving, but in the style of carriage and the class of horse they use. As a matter of fact there has in the last few years been a considerable revival in smart carriages and high-class harness horses, due in a great measure to the excellence of the modern Hackney, and due also, perhaps, in lesser degree, to the fact that a vast number of Englishmen are still possessed of horsy instincts.
The great horse show, held in June at Olympia, is to some extent responsible for a revival of four-in-hand driving. With its Coaching Marathon in Igog it struck the right note, and during I9I0 the interest in this and other similar contests has been more than maintained. It is perhaps a little singular, but nevertheless a fact, that in these days, when coaching is no longer a necessity, but purely a pastime, it has, probably reached a greater pitch of perfection than it ever knew in what are generally called its palmy days. Horses are, on the whole, better, and roads are so much superior to those of seventy years ago, that there can be no comparison; but the greatest improvement is in the vehicles themselves. Time was when all coaches were much heavier and more lumbering 
than the modern vehicle, but there has been steady and continuous reform in carriage building, and this can be seen at a glance by comparing the pictures and prints of the coaching era with the drags now seen in Hyde Park when either of the driving clubs is holding a meet, or by inspection of any of the road coaches now in work. As regards improvement in driving, it is no easy matter to give an opinion. Certain it is that there were scores of first-rate coachmen, both professional and amateur, in the old days; and that these men had far more practice than the modern coachman is also quite true. But, on the otler hand, there are now fifty rehicles of one sort and another on the road, where there was formerly one, and the old coachman had not to contend with the crowded traffic of London, the tram-cars, the motors, or the trains of wagons drawn by a road steam engine. The road in these days is in a very different state from what it was in the coaching period, and the difficulties of driving in London, or in any large town, have been enormously increased.

\section{Coach v. Motor-Car}

Not so long ago it was all plain sailing for the coach out in the country roads. The guard's horn cleared what little traffic there was so systematically that the coach pursued the even temor of its way from stage to stage without any slackening of speed, except such as was due to natural causes - a steep hill to be surmounted or a sharp descent to be negotiated. Now all this is altered, and on a recent coach journey of forty miles in Yorkshire-on a wet day, too-a motor-car was met at the rate of five to every two miles, while once in every mile the coach was passed by one. This was in August of Igog, on a country road near the sea crast, where the motor traffic is nothing like so heary as it is in some of the southern counties. But the motor-cars are not the only difficulties with which the modern four-in-hand driver has to contend. The steam trains of wagons are far more disconcerting to horses, and it is a curious fact that some horses which are used regu- larly for station work, and which will take no notice of a train if they are driven alongside or near a line of railway, are greatly frightened of a road locomotive. Hundreds of nags can be found which take no notice of the motor, but object to steam when it is on the road. We have been behind a team which acted perfectly through half a dozen miles of motors, and then showed signs of great fright at a steam roller and had to be coaxed past after the machine had been driven to the side of the road, and the steam turned off. This is a peculiar idiosyncrasy of horseflesh, and it keeps cropping up in the most unlikely horses. Only in the winter of Igog-ro, two hunters, both as steady as a rock with motors, met on their way home after a very hard day a threshing machine drawn by a road engine. Both horses pulled up sharp, quite two hundred yards in front of the engine, and refused to go on. The riders, both experienced horsemen, tried for quite ten minutes to get them near the engine, but at last took them into a field and went round, being anxious to get home. It was nearly dark at the time, and flame was coming from the chimney of the engine when the horses first saw it, and this probably increased their fright.

\section{Story of the Coach}

The coaching era is too far behind us to be discussed at length in a work which deals principally with the horse as he is now, and not as he was once used, but it may be briefly touched upon, and first it may be said that road wagons, drawn by a team of horses, and travelling hardly over three miles an hour, were the predecessors of the coach as a means of locomotion. There were no great numbers of these, and their progress was very slow, for in their day the whole nation rode, and all the important journeys were performed on horseback. The roads were too bad for quick travelling on wheels, and "springs" for carriages had not been invented. So-called coaches, which were really wagons, first made their appearance towards the end of the seventeenth century, and it is recorded that in $\mathbf{1 6 6 2}$ 
there were only half a dozen on the road. A little later it used to take six days to travel between London and York, and during the carly part of the eighteenth century two whole days were taken up by the journey between London and Oxford, a distance of less than sixty miles. The coach left London at seven in the morning, reached Uxbridge at midday, and arrived at High Wycombe at five in the erening, having travelled twentyseven miles in ten hours. At Wycombe it remained all night, and on the following evening reached Oxford. after twenty hours of actual travelling, and thirty-four hours all told. To show what extraordinary improvement was made the London to York jommey was reduced from six days to twenty hours, and the Oxford journey to less than a third of that time. About the same period it took a fortnight to travel between London and Exeter, whereas the mail coach, towards the end of the coaching era, did the distance in serenteen hours, while at about the same period the "Telegraph" occupied only one hour longer for the journey between London and IIanchester.

\section{The Coach and the Railway}

As will be readily understood, the service of coaches was at its very best just when railways came into existence and knocked the coaches off the road. It is true that there were no great number of coaches even in the 'thirties and 'forties of last century, but the cost of travelling was high, and only the well-to-do, and those who had urgent business at a distance from home, ever thought of patronising the coach. The Universities and the big public schools gave the coaches a good deal of trade at certain periods of the year, and a graphic description of a coach drive to Rugby is to be found in "Tom Brown's School Days," by T. Hughes, this being written at a period just previous to the setting in of the railway era. Charles Dickens, too, wrote at length of coach journeys, notably of the Salisbury coach in "Nartin Chuzzlewit," of the Dover mail in "The Tale of Two Cities," of coaching to Rochester, Bury St. Edmunds, and elsewhere in
"Pickwick," and in the same book he gave a perhaps exaggerated, but intensely interesting account of the professimal cuachman of the day. Thackeray described a journey by coach in "Vanity Fair," and Surtees, in "Ask Mama," wrote of some of the many disagreeable things which coach travellers had to put up with. Hundreds of other references to coach travelling could be quoted, for the novelists and other writers of the first half of the nireteenth century drew largety upon the coach journey for their descriptive writing, but Dickens stands out as the most vivid portrayer of both the bright and less pleasant side of "the road," and what he wrote from his own personal experience is much more trustworthy than what can be compiled by the modern author.

What is certain is that a long coach journey was a terrible ordeal, more particularly in winter time, and of this sort of thing there is plenty to be found in "Saddle and Sirloin," by "The Druid "- who has a long chapter dealing with the miseries of Shap Fell, in Westmorland, in times of heavy snow.

\section{The Country Coach}

The present writer is old enough to renember a period when many so-called coaches were still at work. Though the principal main lines of railway out of London are from sixty to seventy years old, scores of branch lines, in various parts of the country, are hardly half that age, and for many years after the advent of railways the more remote country towns and villages were served by coaches, or vehicles of the covered wagonette type. The road coach proper was cheap enough, for there were hundreds of second-hand coaches on the market, but they were, as a rule, too heary for the small town traffic, and too expensive to horse. The upshot was that a compromise was made, and a vehicle like a station bus put on, and even now there are certain districts that are served in this manner. From thirty to forty years ago they were common all over the country, but branch lines and light railways have for the most part taken their place, for far more people 


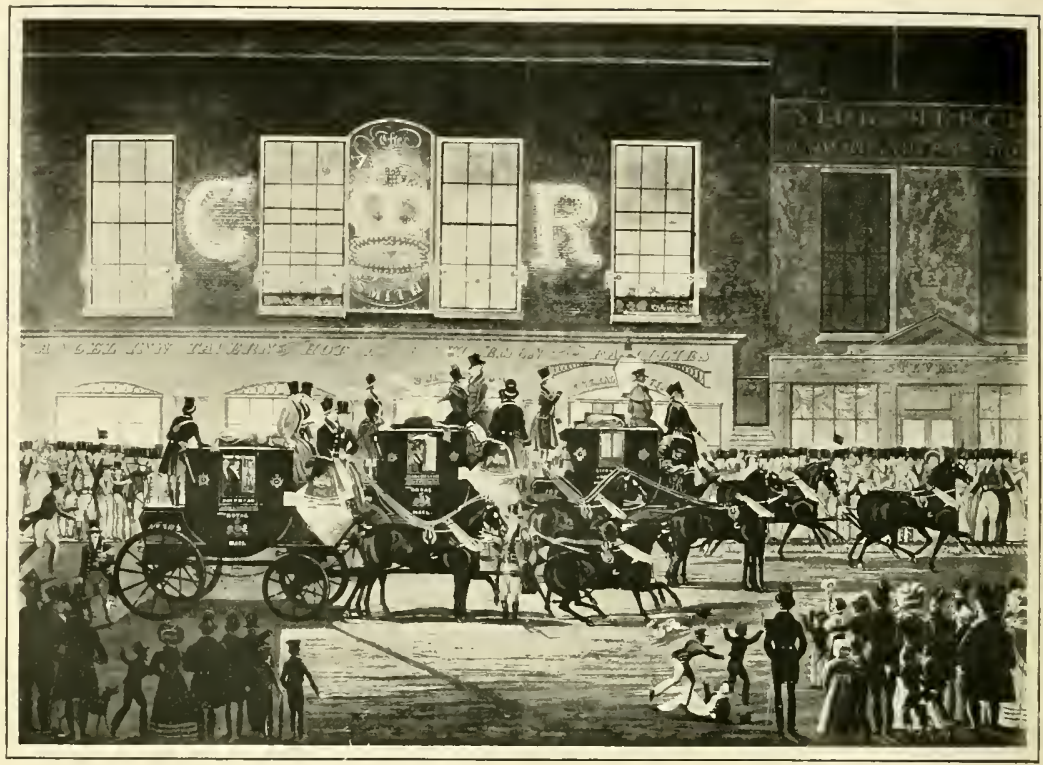

ROYAL MAIL COACHES AT THE "ANGEL," ISLINGTON.

From the engrating by R. G. Reete, after the painting by J. Pollard.

travel in these days than was formerly the case, and few travellers on business can spare the time which these buses take over their journeys.

When coaches first attempted to accelerate their pace, about 150 years ago, the four-inhand team was unknown; where four horses were used for the wagons the wagoner walked alongside. In $\mathrm{I} 774$ it is recorded that Mr. John Palmer tried a four-in-hand team instead of the unicorn (two wheelers and one leader) on the Bath road. How long the unicorn had been used is not very easily discovered, but Mr. Palmer's was the first four-in-hand team on a public vehicle of which there is certain evidence, and it did the journey between London and Bath at the rate of nearly seven miles an hour. Moreover, it was so successful that all the coach masters followed Mr. Palmer's lead, and about twenty years later, according to the Sporting Magazine of June, ISo7, one of the coaches on the North road ran from London to Stamford, a distance of ninety miles, in 9 hours and 4 minutes. The passengers ate and drank on the coach, and it will be seen that the average rate of speed was just under ten miles an hour.

Here it may be stated that ten miles an hour, including stoppages, is capital going for any coach, unless, indeed, the stages are so short that the team can be kept at the fullest pressure all the way. In the old days there were many bits of galloping ground, where the horses were "sprung" for half a mile or even more, but the modern coachman likes his team to trot, and the modern coach horse-or rather the horse which is driven in the modern coach-can, as a rule, trot a good twelve miles an hour on the level. If he cannot do this he is cast from the team and a quicker-actioned horse put in his place; but, after all, there is now only one coach-road or privatewhere there was a hundred, and the enthu. siasts who keep coaching alive at the present day can generally afford to pay a fair sum for their horses.

During the coaching era, when enormous numbers of horses were in daily use, no 
doubt the all-round quality was not very grand; but smart teams were almost invariably seen in and out of London and the big provincial towns, while certain coaches, such as the "Brighton Age," the " Mlanchester Telegraph," and others, were well horsed all through. But many of the country stages were worked by horses of small value, though of sufficient pace to allow of the coach keeping time. "The Druid " tells us that on the Glasgow mail the average price for a leader was $£ 17$, and for a good wheeler from $£ 22$ to $£ 25$, but never more than $£ 30$. The mail contractors were, in the last years of coaching, responsible, and the chief thing they insisted upon was condition. No horses under five years old were purchased, and the average of service was three years, after whichif still capable of doing work-they were sold to the farmers for something like $£_{5}$, and many worked on farms for many years. Two-year-old hay, the best oats which could be procured, and occasionally beans, was the usual diet, and when the condition had once been secured it would remain for years, unless the legs gave way. Coachmen were " tipped" by passengers, usually at the rate of $2 \mathrm{~s}$. for fifty miles, and some of the most popular drivers made two or three hundred a year in this manner. Still, it was a hard life, and a dangerous one, and so the money was well earned. There were - perhaps naturally-many accidents, and these in the earliest days of coaching were chiefly due to defective harness, badlyconstructed vehicles, and the shocking state of the roads. In later days many were due to the pace, which was necessitated by the frequent racing which took place between opposition coaches. The newspapers of the early part of last century give the particulars of scores of accidents, some very serious indeed, and attended with great loss of life. There is no need to go further in this direction, but in the St. James's Chronicle of July 15,1815 , an account is given of an accident which took place

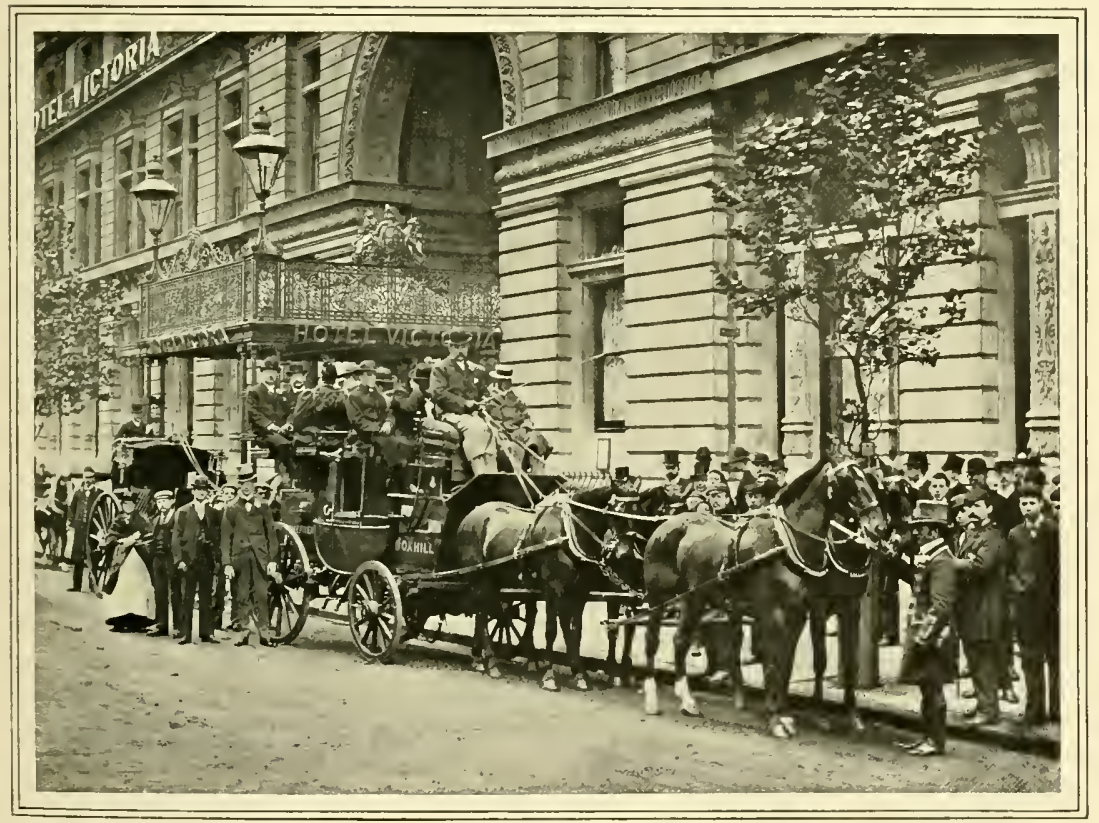

A MODERN ROAD-COACII. 
between Hinckley and Leicester, when the coach charged the post of a turnpike gate and was split in two. Three persons were killed instantaneously, two others survived but a few hours, and four more had fractured limbs and other injuries.

\section{Coach Racing}

Apropos coach racing, memory takes the writer back to a certain Aylesbury Steeplechase day in the early 'seventies, when he was one of a party of Oxford undergraduates who had hired a coach from James Higgs, a well-known livery stable keeper and whip, of Long Wall Street, Oxford. The drive to the course in the morning was got through in orderly fashion, but there was a second Oxford coach at the steeplechases and the two commenced the home journey almost together. As far as Thame things went quietly enough, the coach which had started first keeping its lead of a quarter of a mile or so. If memory can be trusted, there was a change of horses at Thame; anyhow, the journey was broken, and when a fresh start was made there appeared to be instantaneous rivalry between the two Jchus. For several miles it was a good race, but nearing Oxford Higgs's coach had got a good lead and seemed certain to be in first. As the top of Headington Hill (if memory serves) was reached, one of the leaders showed signs of being done. The team was pullcd up, and the other coach went sailing by with an ironical cheer from the load. Our leader was only blown, and soon came round; but just as we were about to start again a man came up the road to warn us that the other coach had been caught by the proctors, who had taken the names and colleges of all the load. Our coach was promptly abandoned -taken to a farmhouse, in fact-and overcoats, race-glasses, and so forth left with it, while the party broke up and by circuitous routes slipped into Oxford singly or in pairs, on foot. We lost the race and some small wager as to which coach should be first over Magdalen Bridge, but we escaped the proctors, who waited for hours knowing that a second coach was on the road.

\section{The Early Driving Clubs}

After the railway era had firmly set in, four-in-hand driving met with a serious check, but it was still practised by amateurs, both in London and the country, and various driving clubs were in existence during periods of the last century, two of which are going strongly at the present day. The first driving club was the Bensington (commonly called the Benson), founded in 1807 , and consisting of five-and-twenty members. The rules provided that members should drive twice a year to the White Horse, Bensington, in Oxfordshire, and twice to the Black Dog at Bedfont, near Hounslow. This arrangement lasted sixteen years, when the Bensington drives were given up, and Bedfont became the headquarters of the club. Then there was the Benevolent Whip Club, founded a year later than the Benson, and after that the Four Horse Club, in which landaus were used instead of coaches. The Whip Club was a very smart affair, and although there was a rule that the teams had to be bay, Sir Henry Peyton drove greys and Mr. Annesley roans. For several years the Benson and Four Horse Clubs flourished in friendly rivalry; but the first-named lasted the longer, and was still going in I838, when the Richmond Driving Club was founded by Lord Chesterfield, the Castle Hotel at Richmond being its dining place. It enjoyed a most aristocratic membership, but only lasted some six or seven seasons, whereas the Benson went on until I853. or the following year, when it was dissolved.

\section{The Four-in-Hand Club}

The next few years was the worst period which four-in-hand driving cver knew. Only the yellow coach and the grey team of Sir Henry Peyton was seen in the Park, but in 1856 the Four-in-Hand Driving Club was established, to take the place of the now defunct Benson Club. Its first members were the late Duke of Beaufort, Lords Stafford, Londonderry, Edward Thymne, Henry Thymne, Sir Watkin Williams Wynn, Mr. Morritt, of Rokeby, Captain Smith Baillie, and Messrs. Cooper, W. Craven, 
Thornlill, and Inglis Jones. This is the same club which now has two annual meets at the Magazine in Hyde Park; but the original nembers are no longer living, and the membership has been greatly increased.

\section{The Coaching Club}

In I870 the Coaching Club was founded, with an even larger membership, and, like the senior club, is a flourishing affair, which also holds two annual meets in Hyde Park, and has lately been a good deal in evidence at the Olympia and Richnond Horse shows. There have also been one or two country cuaching clubs, but all were shortlived and none is now in existence. There was one in Monmouthshire nearly forty vears ago, and after that one in Lanarkshire for a short time, while the last was in Northumberland in the early 'nineties, its headguarters being at Newcastle-onTyne. To this it may be added that in the period between $I 860$ and $I 890$ there were a fair number of country gentlemen who were not members of eitler club, but who ret drove a coach pretty regularly in the neighbourhood of their residence.

\section{Coaching in the North}

In the North of England the well-turnedout private drag was frequently seen, and the writer, when a schoolboy, went twice on a coaching tour of three or four weeks. In one case the Lake District and parts of Dumfriesshire were the chosen ground, and some particulars of the journey may be given, if only to show what big things goud horses, carefully driven and in first-rate condition, can accomplish. It must be understood that three of the team had been regularly hunted during the previous scason. while the fourth had been used as a covert hack, and had done a few odd days with hounds. The wheelers, a brown and a grey, were biggish horses, over I6 hands high, and strongly made; while the leaders, both bays, though standing about the same height, were rather smaller made. One of these was an extraordinary horse, very good-looking and a wonderful hunter. He had been bought for $f f^{\circ}$ when a four-year- old, having been fired on both hocks; but the firing had only been done as a precautionary measure and, as a matter of fact, he was never lame on his hocks throughout a long life. Still, the firing made his price far smaller than it would have been, and doubtless the farmer who bred him had no idea what a wonder he was parting with. He was by Homeopathist, a grandson of Blacklock, out of a well-bred mare, and though he never looked up to much weight, he carried a man who rode sixteen stones for eleven seasons and a half, and for nine summers he was driven as a coach leader. What is more to the point is that his owner was a bruising rider, who never shirked a fence, and who on this particular horse did many things that were talked about for years. At times, too, he was offered $t 300$, and then $f_{f}$,oo, for the nag, and this was a very big price for the North of England more than forty years ago. The horse had peculiarities, too. It was a most difficult matter to get him along the road when being exercised, and even when being taken to a meet of hounds he was at times very awkward, unless his owner was riding him. But he was a simply perfect hunter, fast, and an extraordinary fencer, and could come out fresh after the hardest day. He was also a grand coach leader, going always with his head up, and doing, if allowed, far more than his share of work. The other leader was a capital hack, and though too lightly built for his owner to hunt, did after this coach journey a great amount of hunting, ridden by a thirteen-stone man.

\section{A Long Drive}

The team were driven short distances daily for about a fortnight before their Iong journey began, and all had the condition given by the past hunting season to start with. They left Shotley Bridge, in the County of Durham, with six passengers and two grooms on the coach, and the inside full of travelling bags, horse rugs, and so forth. Roads in those days were much inferior to what they are now (the year was I868), and the first nine miles to Riding Mill, in the Tyne Valley, was over a broken road 
of loose stones, with a hill of almost a thousand feet to sumount. The route was then up the Tyne Valley, by Hexham and Haydon Bridge, to Haltwhistle, and here the roads were much better; but between Haltwhistle and Brampton in Cumberland much bad road was encountered again, and the writer has a distinct recollection of the team being trotted quietly along a grass edging of the road for quite a considerable distance. The month was July, and owing to the dry weather there were loose stones everywhere. Brampton, somewhere between forty and fifty miles from the starting place, ended the first day's journey, and the team were rested the following day, which was a Sunday. On Monday they were driven to Langholme, across the Scottish border, and a visit paid to Mr. Patterson, of Terrona, then master of the Eskdale hounds. Here the afternoon was spent, and in the cool of the evening the twenty odd miles to Carlisle were covered. This was altogether another fortymile journey, but the horses were now in grand going condition, and on the following day were driven from Carlisle to Derwentwater, which was the heaviest journey of the trip; for not only were the roads hilly and bad in many places, but a wrong turning was taken somewhere near lrby, where there was no finger-post, and this involved a detour of at least five miles in rough and narrow country lanes.

\section{The Return Journey}

There is no need to particularise, nor does the writer remember exactly how many were the journeys of the next fortnight in the Lake district, but on leaving Windermere we were driven over liirkstone Pass, no one leaving the coach to walk up, and then, starting on the following morning from the Patterdale Hotel at Ullswater, we reached Shotley Bridge in two days, the first day's journey being by Pooley Bridge and Penrith up to Alston, the highest lying town in the kingdom, and the second over Kilhope Law, 2,000 feet, into Weardale, and thence by Stanhope and Edmundbyers Cross where the road is $I, 700$ feet at the sum- mit - to Shotley Bridge. Maps give the distance from Patterdale to Shotley Bridge as between sixty and seventy miles in a straight line; but doubtless by road it is not less than eighty miles, and only those who know the district can appreciate what the hills are like. The town of Alston is I, 300 feet above sea level, and between Penrith and Shotley Bridge there is practically no level road, except a mile or two in the Wear Valley, between St. John's Chapel and Stanhope. The point, however, is that at the end of these long journeys the horses had lost very little condition. To one who had seen them every day they were a trifle thinner over the flanks and quarters; but they were all sound and hearty, and after a few days of rest, were driven on short coach journeys for at least another month. For careful handling of a team, and getting big distances out of them on rough and hilly roads, this trip stands out as the biggest coaching feat the writer has personal experience of, and as such is worthy of mention here.

\section{Modern Coaching}

The roads, more especially in the North of England, were very bad in the 'sixties and even later, more particularly perhaps in the hilly countries. On the drive which has just been described loose stones and sandy ruts were to be found half a dozen times is day, and often extended for a mile or two. The macadim road, though of earlier date, was in existence for many years before it became general, and when an attempt was made to macadamise an existing road, as a rule only a main road was chosen. In the early 'eighties, before the county councils took the roads over, the country lanes in many counties were in a deplorable state. Loose metal was occasionally shaken down out of carts and the stones rolled over, and, as a rule, the wrong time of year was chosen for the job. There were no steam-rollers, and the stones, where the traffic was light, took years to work in. The writer had at that time some experience of over three hundred miles of road in one large country district, and has no hesitation in stating that 


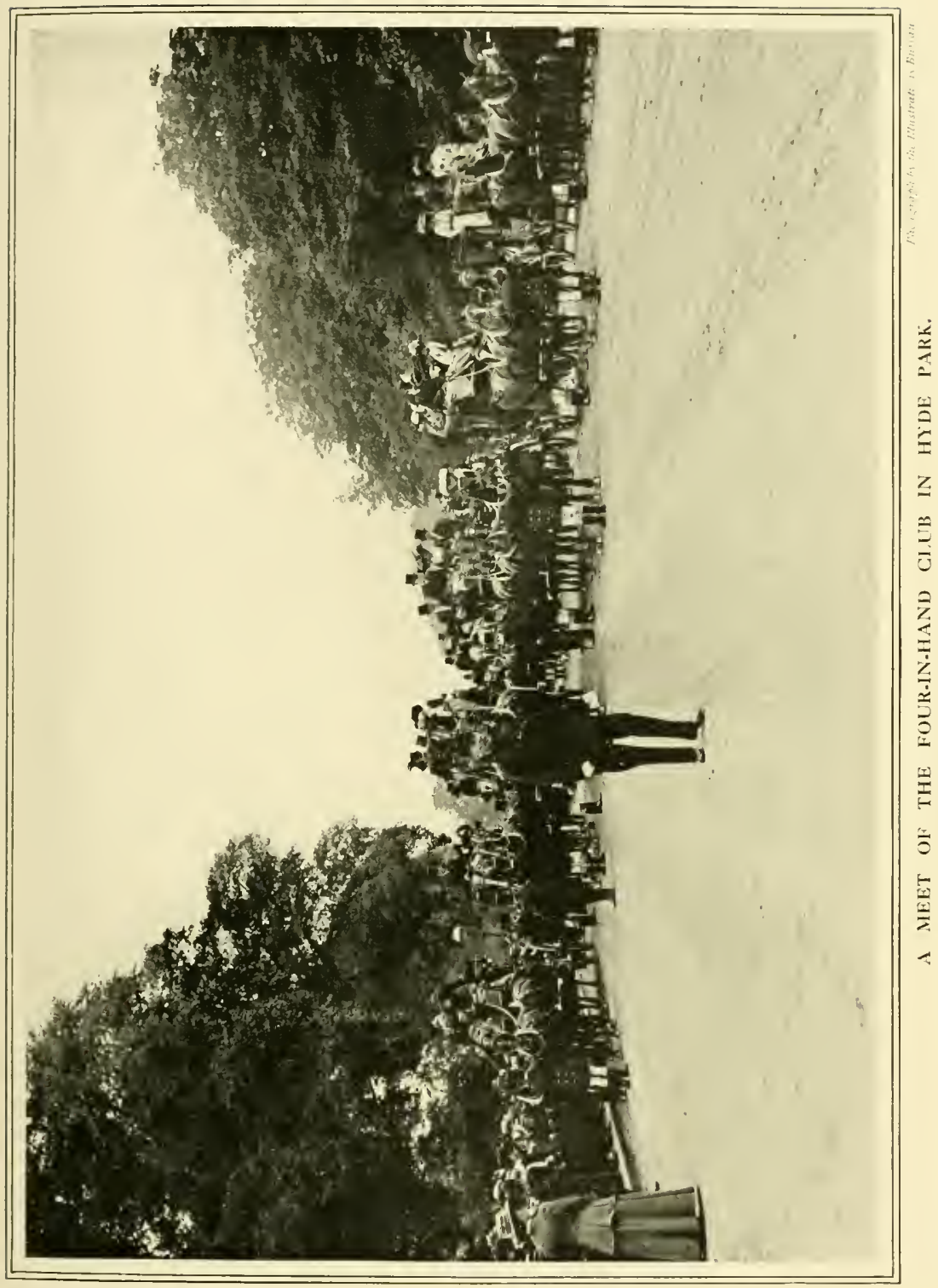


with the exception of two main roads, each of about twenty-five miles in length, and which crossed each other in the centre of the district, there was no road fit for coaching. It is probable that when railways disposed of the stage coaches the roads were to a considerable extent neglected, especially in remote districts where the carriage traffic was not heavy. The improvement which set in after county councils came into being is simply extraordinary to those who are old enough to remember what the roads were like before, and now we have in many places tar on macadam, and this gives an even better result, though if the tar is not very carefully laid it is ruinous to carriage wheels and panels.

The love of four-in-hand driving was not very many years in abeyance, and in I862 the "Brighton Age" was again at work; but this coach, which was a sort of link between the real coaching period and the modern revival, was not long in existence, though there were at that time several country coaches running where the railway had not penetrated. They were, for the most part, clumsy, badly turned-out affairs, such as have been described a few pages back, and there is no necessity to refer further to them. In I866 a Brighton coach, named the "Old Times," was at work for a few weeks, with such patrons as the late Duke of Beaufort, Lord H. Thynne, Messrs. Chandos Pole and B. J. Angell; but coach, horses, and harness were sold at Tattersall's during the autumn. In the following year (I867) the Brighton road was again used, the Duke of Beaufort, Mr. Chandos Pole, and Mr. Angell putting on a double service, much as Mr. Vanderbilt did in Igo8. The " White Horse " Cellar in Piccadilly, and the Albion Hotel on the Brighton front were the points of departure and arrival, and the partners shared the horsing of the road.

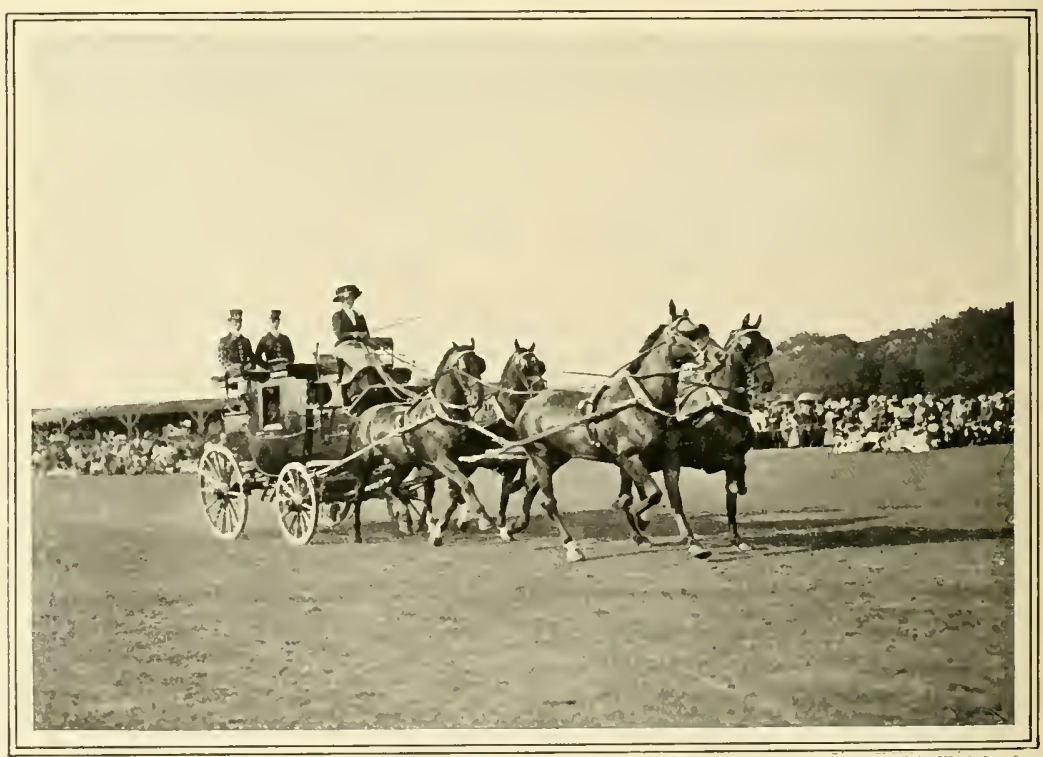

MISS BROCKLEBANK'S COACH. 


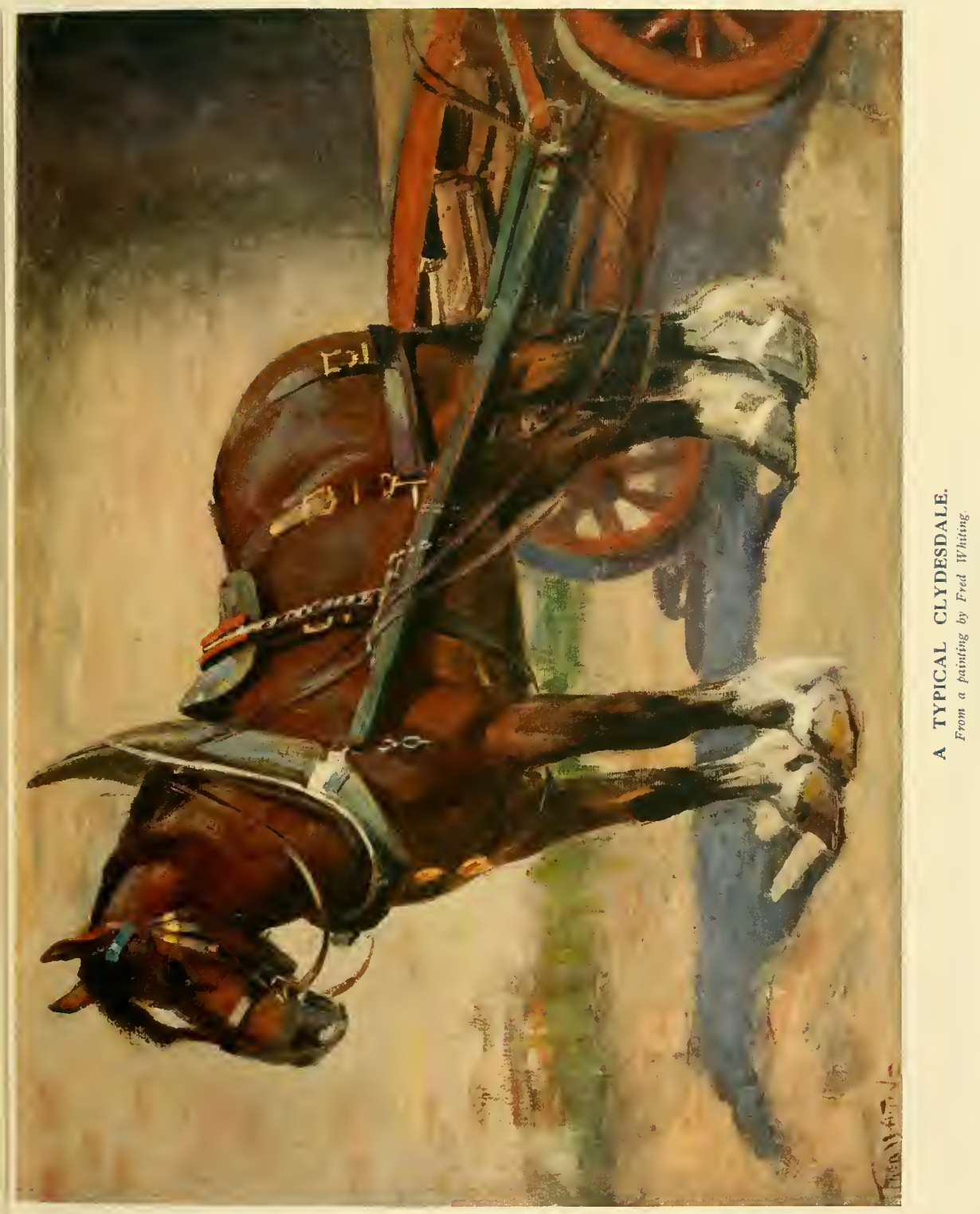





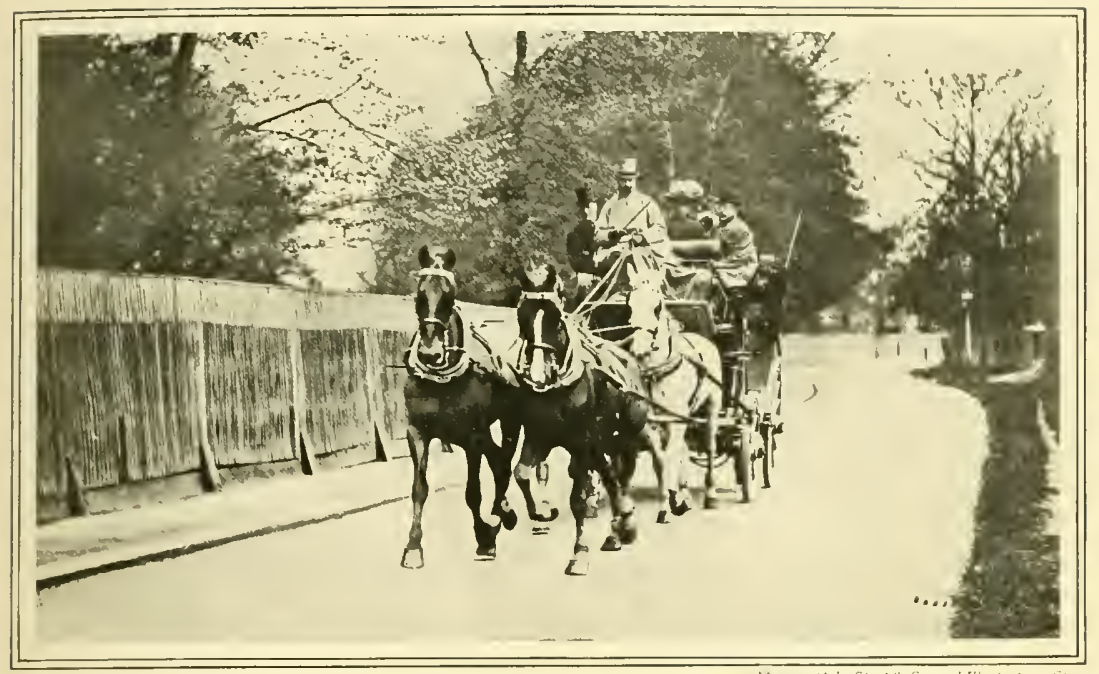

THE "RELIANCE " (LONDON TO GUILDFORD) IN ROEHAMPTON LANE.

\section{CHAPTER XXXIII}

\section{COACHING (continued)}

I I867, too, the late Mr. Charles Hoare started a coach between Beckenham and Sevenoaks, which was horsed by the late Edward Fownes. This coach was put on in the autumn, and in 1868 both it and the Brighton coach were again on the road. This year, however, Mr. Hoare's coach went on to Sevenoaks, and our first experience of road coaching was gained on it. Though only a schoolboy at the time, we were keeping a grace term, owing to an accident, and were lucky enough to come in for several drives on this coach. MIoreover, we have very vivid recollections of one or two of the drives. On one occasion Mr. Hoare entrusted a team to a friend, and they got out of hand going down the long hill which terminates near Dunton Green, and raced into a pond at the bottom. Everyone sat tight, and as the coach was not overturned no harm was done. Another day we re- nember that Mr. Hoare made a small bet with someone on the coach that he would not take longer than six minutes between Westminster Bridge and the " White Horse" Cellar, and he won his bet, thanks greatly to the fact that the hom and the police cleared the road for him all the way. Mr. Hoare was a powerful, dashing whip, but too much given to running risks. He was full of chaff, too; but one day we remember he was well scored off by the driver of a coster cart. If memory serves, the Sevenoaks coach went in those days, not down the old Kent Road, but by Dulwich and Sydenham, or somewhere near there. On the occasion we have in mind, about three miles south of Westminster Bridge a coster, driving a sharp pony, was in front of the coach, and every time Mr. Hoare attempted to pass, the coster would shoot away and gain a little. He then slowed down, keeping right in front of the coach, and making 
it impossible to pass. After a while our Jehu became angry, and a certain amount of tall language was interchanged; but we came to a side turning, and into this Mr. Hoare turned, observing that the road was up a little farther on, and we should have to make a detour. As a matter of fact, we travelled along a side road for a mile or two, and then reached the high road again, just in time to see the coster disappear round a corner in front. Five minutes later we caught him up, but he was now trotting quietly close to the kerb, on the near side, and as the coach swung past he looked up and said: "'Cllo, governor! Where ave you been spending your morning ?" Mr. Hoare, by the way, used one of the old mail coaches, altered to suit modern requirements.

\section{Other Road Coaches}

In 1869 the Brighton coach was still going, and Mr. Hoare extended his journey to Tunbridge Wells, a route undertaken some twenty seasons later by Mr. Charles Webling. A Windsor coach, too, was commissioned by Lord Carrington and Mr. Angell, and a fourth coach was on the road to High Wycombe, of which Lord Aveland and Vr. John Eden were the proprietors. In 1870 a coach was running to Virginia Water, of which General Dickson and Captain Candy were the owners; and in the following year the Dorking road was worked, with the late Sir Henry de Bathe and Col. Withington as partners. It is not necessary to particularise all the coaches which have been worked out of London since; but about the middle of the 'nineties no fewer than sixteen coaches were running daily. The Brighton, Dorking, Windsor, Oatlands Park (or Virginia Water), and Guildford roads have been the most popular, but at times some of these modern coaches have gone much farther afield, and in $\mathrm{I} \delta 79 \mathrm{Mr}$. Carleton Blyth ran the "Defiance" from Oxford to Cambridge, by way of London, a journey involving a period of twelve hours on the coach and fifteen changes of horses. There was also a coach between London and Portsmouth, going and return- ing on alternate days, in 1877 ; but it was found that the shorter journeys suited the average passenger best, and except with regard to the Brighton and Oxford roads, travelling down on one day and back to town on the next has never been much appreciated.

From time to time during the last thirty years or so there have also been wellappointed road coaches in various parts of the country. Lord Shrewsbury, in the Western Midlands, ran coaches for several years; but, long before, Mr. Platt had a coach going between Rotherham and Doncaster, and the late Mr. George Lowther worked the Scarborough and Bridlington road for ten or twelve years. Between Brighton and Eastbourne, Dover and Canterbury, Bath and Devizes, Reading and Windsor, Maidenhead and Oxford, Brecon and Abergavenny, Malvern and Ross, Chester and Shrewsbury, Leamington and Stratford-on-Avon, Buxton and Matlock, Hampton Court and Brighton, York and Liverpool, Rhyl and Bettws-y-Coed, and Barmouth and Dolgelly well-appointed coaches lave had their periods of success, but even now nothing like all the roads have been named.

\section{Provincial Coaching}

Provincial coaching has apparently suffered more from the arrival of motor-cars than coaching in London, and this is somewhat curious, because the cars are far more numerous near town than they are in the country, and no matter whit ronte out of London is chosen, there is always a great deal of traffic to contend with, while on many roads the tram lines are a difficnlty. Of the provincial coaching centres Brighton and Scarborough remain faithful. At the first-named place there is always a London coach at some period of the year, generally in the spring and early summer; while a little later there is always one rumning from Eastbourne, which arrives at Brighton at luncheon time, and goes back during the afternoon. There are frequently aftemoon coaches to Bramber and Steyning, and to Hassocks, and two or three years ago a 
pair of well-appointed and magnificently horsed coaches were working the road between Brighton and Tunbridge Wells. It Scarborough the late Mr. George Lowther was succeeded on the Bridlington road by Mr. Lewis Priestman, some seventeen or cighteen years ago, and Mr. Priestman's coach has only missed one year since, and is still to the fore. The Bridlington roada three-stage journey of twenty-one miles -is uscd, but some eight or ten years ago this coach ran from Scarborough to Harrogate and back on alternate days, the sixtyfour mile journey being divided into eight stages. On one occasion the writer was on this coach when it left Scarborough at the usual time, reached Harrogate in time for dinner, and starting again at ten o'clock in the evening, travelled back to Scarborough during the night. There was one supper at York and a second at MIalton, and the experience was a novel one for the present day, and gave one some idea of what the all-night travelling on the roof of a coach must have been when coaclies were the only means of transport for those who could not afford the heavy charges for posting.

\section{London Coaching}

In London during the season of IgIo the coaches barely reached half a dozen; but this is not at all bad when one considers the counter attractions of motoring and the driving difficulties there are to contend with. Still, as has been stated, there is a good deal of life in coaching yet. Mr. Vanderbilt's "Venture," on the Brighton road, is the most important coach of the moment, because it does the longest journey and uses most horses. The old road via Reigate (or Redhill) and Crawley has been changed for the longer route by way of Leatherhead, Dorking, and Horshanı, and as the stages are short ones, no fewer than ten teams are used, whilst as all are American horses bred from trotting stock the journey is a most interesting one to the horse-lover.

\section{The Horse for the Coach}

Even now, with modern coaching in its present state, it is not an easy matter to say which sort of horse is most at home in a coach. The Yorkshire Coach Horse and the Clereland Bay are State coach-liorses-too big all over and too lengthy, either for the private drag or the road coach. They are seen at their best in a State coach, or the big landau of a generation ago; but many of them would hardly go under the tailboard of a modern coach, and few of them have the necessary trotting pace, even if the height is right. Hackneys with a good deal of action look well in the Park, and can hardly be beaten for driving about town; but the hackney teams which one sees at the Club meets have, as a rule, far too much action for country coaching -unless, indeed, they are only required for short journeys on a level road.

The type of horse which suits the coaching man best is more of a hunter than anything else to look at. A long-backed, or a rather long-backed wheeler will pass nuster, but a long-backed leader is an eyesore. It is no easy matter to differentiate between types of half-bred horses, and though we know exactly what type of horse goes best it is difficult to describe the nag we have in mind. He should not be what is known in the trade as a carriage horse, nor yet what is understood as a "Paris" horse, but rather a quick-actioned, sloping-shouldered, compact animal, who should be able to carry a saddle in the right place. Perhaps medium-weight hunters, with a fair amount of substance, look best in a coach.

\section{Matching the Team}

The great thing, however, is to have the horses matched, and in matching colour is of really less importance than size, general appearance, and pace. A team which trots together at ten miles an hour, and swings along evenly, is far more desirable than a team of valuable horses which are not properly matched. The last sort of team may include four horses which are individually worth EI5o apiece; but if one or two are faster than the others, if the leaders camnot get out of the way of the wheelers, or if some of the team have knee action and the others none, the general effect is entirely spoilt. 
It is well, when it is possible, to have every team matched as to colour, and drivers of private drags are very often exceedingly particular on this point; but if a number of teams are required for a road coach, horses of similar type and action, whose pace is equal, are much the best.

If great pains are taken, it is, of course, possible to lave even the teams of a road white markings on the legs; but this sort of horse is essentially of the right pattern for a Park drag, and often a trifle too small for a road coach. Mr. Vanderbilt had sixty horses at work on the Brighton road during the summer of 1910 , and his grey teams, which work the London stages and have figured in the Marathon races, are wonderfully quick and handy. On some of the country stages of the "Venture" colour-

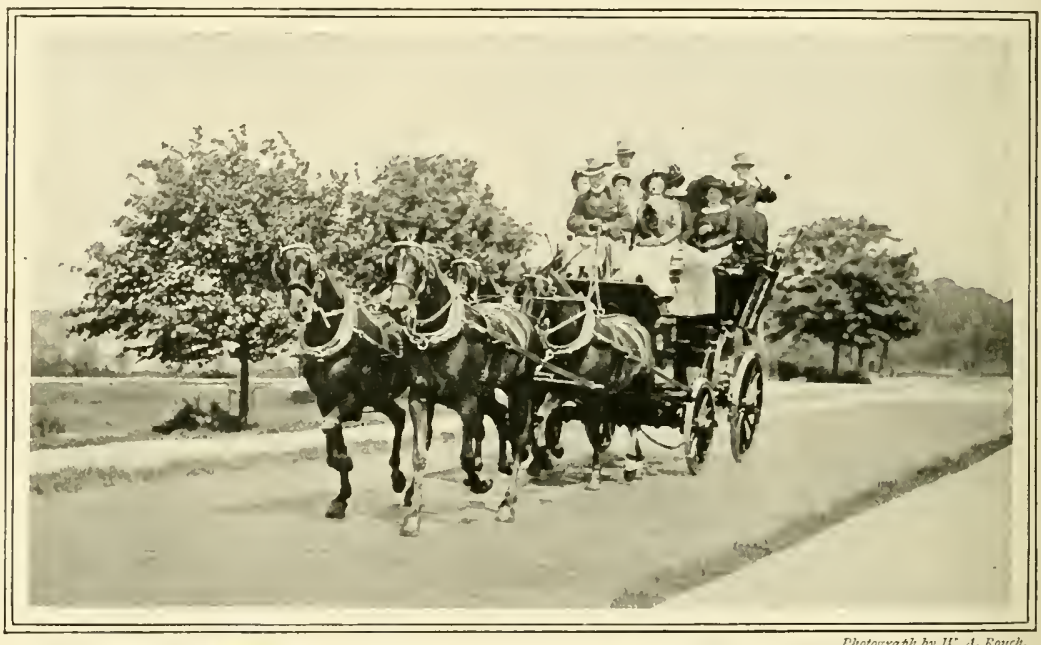

MR. R. CRAIG MCKERROW'S "REYNARD" (LONDON TO WINDSOR) ON BARNES COMMON.

coach colour-matched, and during the present season Mr. R. Craig MICKerrow has had seven teams at work in the Windsor coach, the matching of which has been extraordinary, both as to colour and general style and appearance. Five of these teams were bays, one black, and one chestnut, and all the horses were supplied by Messrs. Wimbush and Sons, Ltd., of Halkin Street. A black team is not very common in these days, and for that matter black race-horses, black hunters, and black polo ponies are by no means numerous, while a huge majority of the best hackneys are chestnut. The hackney teams one sees in the Park are most frequently chestnut, with plentiful matching has not been adhered to, but probably there were never ten teams in one stable which were better together as regards general conformation and pace and action. In road coaching there must always be at least one spare horse to every team, for it is only natural that every now and then a horse or two may go temporarily amiss or become lame. Mr. Vanderbilt allows six horses for each team, having a total of sixty for ten daily stages, but this is a higher number than most modern coachmasters use. At the same time, for a road corach it is absolutely necessary that there slould be a strong reserve which can be called upon at a moment's notice. 


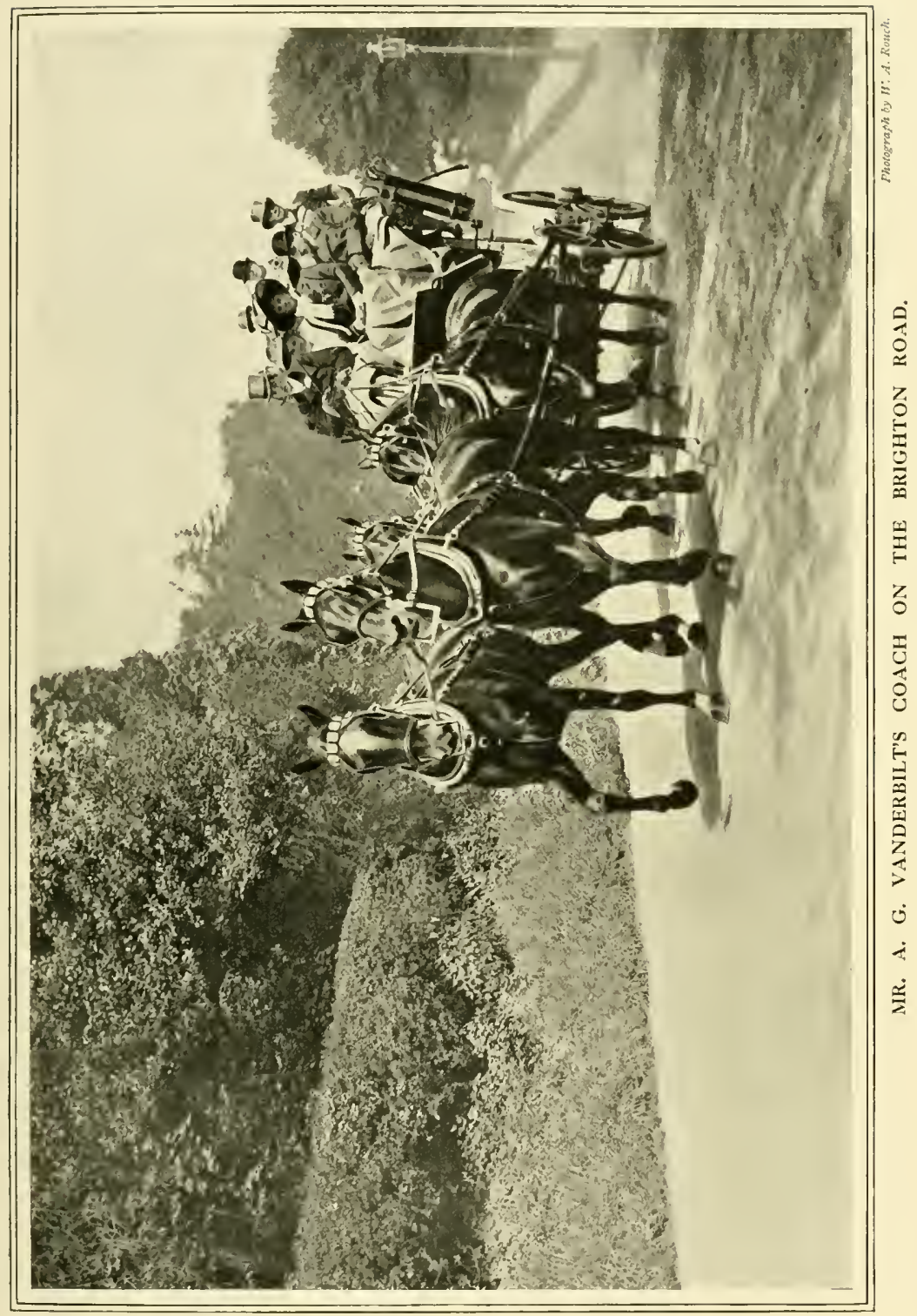




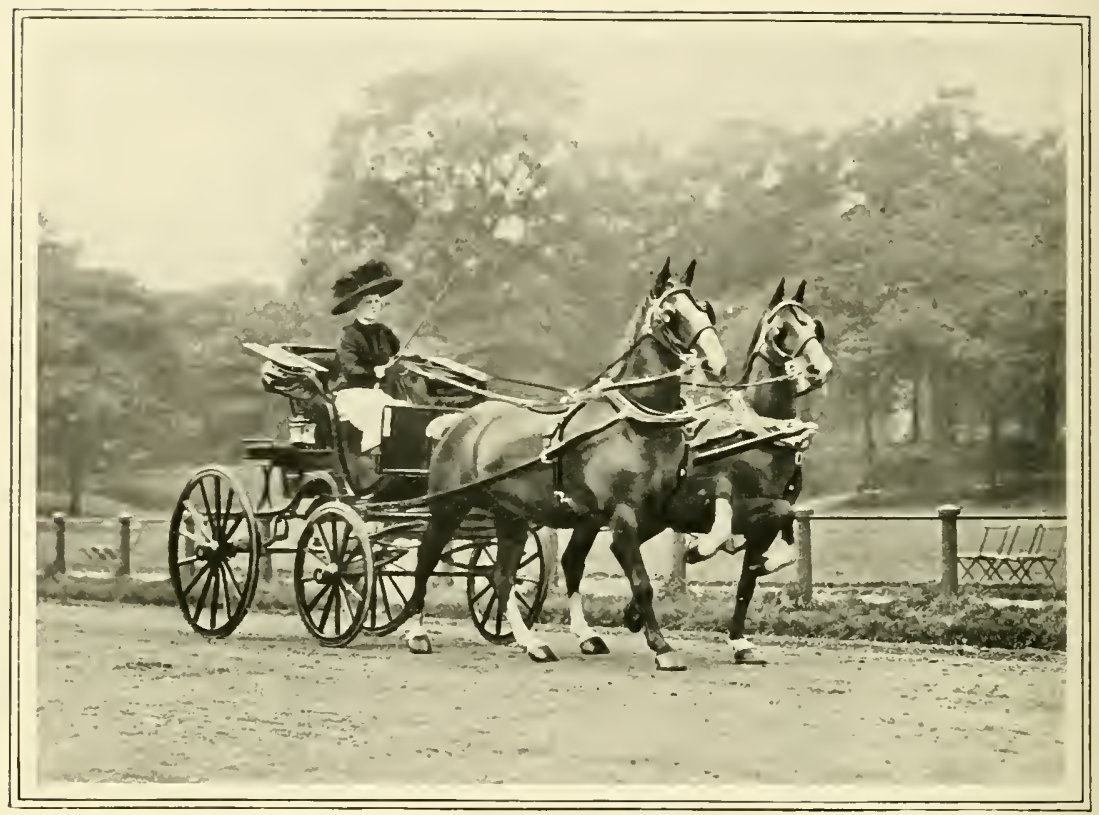

MRS. LEOPOLD ALBU DRIVING MY LADY AND ANNE OF AUSTRIA.

\section{CHAPTER XXXIV \\ DRIVING AND CARRIAGES}

I $T$ is matter for regret that since the motor-car came into use the number of horse owners who drive themselves has greatly decreased, and this applies to London far more than to the country districts. Not many years ago dozens of men, and almost as many ladies, could be seen driving their own horses during the afternoon, but now such sights are exceedingly rare. Some time in or about I 898 we counted over two hundred amateur drivers in Hyde Park one afternoon. It was at the time when motors were a good deal talked about, but very rarely seen. According to the notes we took, nearly so per cent. of these drivers had before them small horses or ponies in Ralli cars; about I5 per cent. were driving Stanhope or park phaetons; there were three private drags, one mail phaeton, and one pair-horse wagonette. Outside the Park on the same day we saw three private drags - not the same that were seen in the Park-and one four-horse char-àbanc. We may have counted some of the Ralli cars more than once, but we were very careful to notice those which had passed us and leave them out when we saw them again. This was at the time when the Ralli car was the most fashionable trap of the day and was seen everywhere, both in town and country. For the purpose of comparison we again took a note of what private carriages there were during the summer of Igog. In all, eleven were seen between half-past three and five o'clock. One coach there was, driven by a member of the Four36 
in-Hand Club; two park phaetons, one with a lady driver; one long brake with a team, a young man driving and liveried servants on the seats next the door; three governess cars; and four nondescript "traps" of considerable age. There were, of course, a fair number of landaus, victorias, broughams, and so fortl, driven by liveried coachmen ; and after four o'clock no motor-cars, according to rule.

\section{Driving in the Park}

Carriages, carriage horses, and general turn-outs are always a curious study in Hyde Park to those who have known the place for many years, and who have been sufficiently interested to observe the changes which are constantly occurring. One thing which must always strike the spectator is the number of what appear to be very old carriages that are invariably to be seen. These are chiefly landaus and broughams, big lumbering carriages, of a pattern which no good carriage builder has turned out for a generation. These carriages, however, are so well built and well kept, that they make a good show even now; but they are mostly drawn by heary, rather common horses, who are short of quality, and who, because it is their business to creep slowly round the Park two or three times every afternoon, have lost whatever action they may have once possessed. The modern carriage-generally a canoe-shaped victoria or a light brougham-is apparently about half the weight of the old timers; it is generally drawn by smaller horses of the hackney type, and the coachman takes good care that his nags do not dawdle, but sends them along as if there was a train to catch. Many of the smartest carriages one sees in the Park on any fine afternoon during the London season are only being driven through on their road to Hurlingham, Ranelagh, or elsewhere.

\section{Styles of Carriages}

"Other times, other manners." It is little use deploring the decrease of private carriages in London, but it is to be noted that in the Park itself there has been no falling off for several years. It is the exclusion of motors between + and 7 p.m. which causes the numbers to be well maintained, for there are still a great number of people who prefer the horse-drawn vehicle, and such know that for three hours they have a good road to themselves. It is said that the rule with regard to motors is to be revoked, but that the speed limit will be strictly enforced.

Let us now glance briefly at the carriages which are oftenest seen, first in London, and then in the country. State coaches are in these days seldom used for anything but State functions, and though the Lord Mayor's coach is frequently seen in the City, it is not a common object of the West-End streets. A propos this same Lord Mayor's coach, a certain Lord Mayor paid a semiState visit to Scarborough not many years ago, taking with him the coach and all the paraphernalia of State. When going anywhere officially (in Scarborough) a mounted policeman used to ride in front and stop the traffic, or clear it out of some of the narrower streets. One afternoon this functionary turned into a street named Huntress Row, and drove all the vehicles before him. But there was a single cab drawn up at the post office, and the driver refused to move. An interchange of compliments between the constable and the cabman was anusing a huge crowd of pedestrians, when the Lord Mayor's coach shot round the corner and just shaved the cab. There was silence for a moment as the coach passed, and the cabnian, standing up in his cab, addressed the crowd in the broadest Yorkshire, as follows: "Lads, ar think nowt o' t' Lord Mayor's corrch. I'd t' sooner gan i' t' charibang!" The speech was received with roars of laughter, and the cabman drove off amidst resounding cheers. The char-à-banc, it may be explained, is a favourite vehicle of Scarborough trippers.

\section{The Omnibus}

After the State coach and the semi-State carriage, such as is used by royalties in the less important processions, the biggest 
vehicles in regular use are the omnibus, and the char-à-banc. We are speaking now of private carriages only, and at many large country houses a private omnibus is usually kept. Such carriages require big, upstanding horses, for at times there may be eight or ten passengers using the vehicle for station work, going to a country ball, and so forth. No doubt the motor has interfered with the use of these omnibuses in some degree, but not altogether, because of the carrying capacity of the latter being so much greater. In London there is little demand for the private bus, but a char-àbanc, with a tean in front, is seen at times. When four horses are driven regularly in one of these vehicles - which are built like a coach, but lower, and with no inside seats -they should not be too large, or they make the carriage look insignificant. The usual char-à-banc for private work runs about I 7 or $\mathrm{I} S \mathrm{cwt}$, and hackneys of $\mathrm{I}_{5} .2$ or thereabouts suit them admirably. Wagonettes are not often used in London, but are common in the country, being shortcoupled, and therefore not so difficult to pull up a steep hill as the longer coupled carriage.

\section{London Carriages}

The commonest London carriages are now the rictoria and the brougham, but thirty years ago the closed carriage, to seat four inside, the landau, and the barouche were ta be counted by scores in the West End. The barouche is seldom seen now, but plenty of landaus are left, and on the whole the landan is still the most popular four-wheeler, because of the inside seats being of equal size, and also because the top can be opened and shut at will. It is, however, a long-coupled carriage, and in a hilly country half a dozen miles of landau work will tire a pair of horses more than double the distance when driven in a short-coupled and much lighter wagonette. The barouche is perhaps the most comfortable of all the carriages, but it is heavy, long-coupled, and requires big, powerful horses almost of the Yorkshire Coach Horse stamp; and barouche horses should be not only big, but fine, showy horses, the barouche being a very important carriage to look at.

\section{The Victoria}

Victorias have been made in several shapes during the last quarter of a century. At one time they were cut out under the back seat, but more recently they have had a rounded back, of what is called canoe shape. A smart, well-built victoria demands good-looking horses with a certain amount of knee action, and they should not be too big, but of course this depends upon the size of the carriage, some victorias being high enough and large enough to call for a I6-hands pair. For the average carriage of this build horses of about an inch and a half lower are the right size.

\section{The Brougham}

With regard to broughams, much the same thing may be written. Occasionally one sees a brougham quite large enough to require a really big carriage horse, but the average brougham, like the average victoria, will be properly horsed by animals not very much over $\mathrm{I}_{5} \frac{1}{2}$ hands, if a pair are driven, and by a I6-hands horse if single harness is adopted. Bronghams date from I838, at which time, and for many years afterwards, what was generally called a "close carriage" was also in rogue. This was an improved type of the "four-wheel cabriolet," and held four inside comfortably. It was like a bigger and bettermade four-wheeled cab, did not open like the landau, and was not cut away like the brougham, and at times there was glass all round above the inside seats which had their backs to the coachman. This heary and rather awkward carriage quickly disappeared when the landau came into fashion, and whilst some of the biggest were converted into mourning coaches, others were used as station cabs in the country towns, and at the present moment many are still to be seen outside the railway stations in the provinces. The brougham was named after Lord Brougham, and the original one, built by Mfessrs. Robinson and Cook, of Mount Street, was 


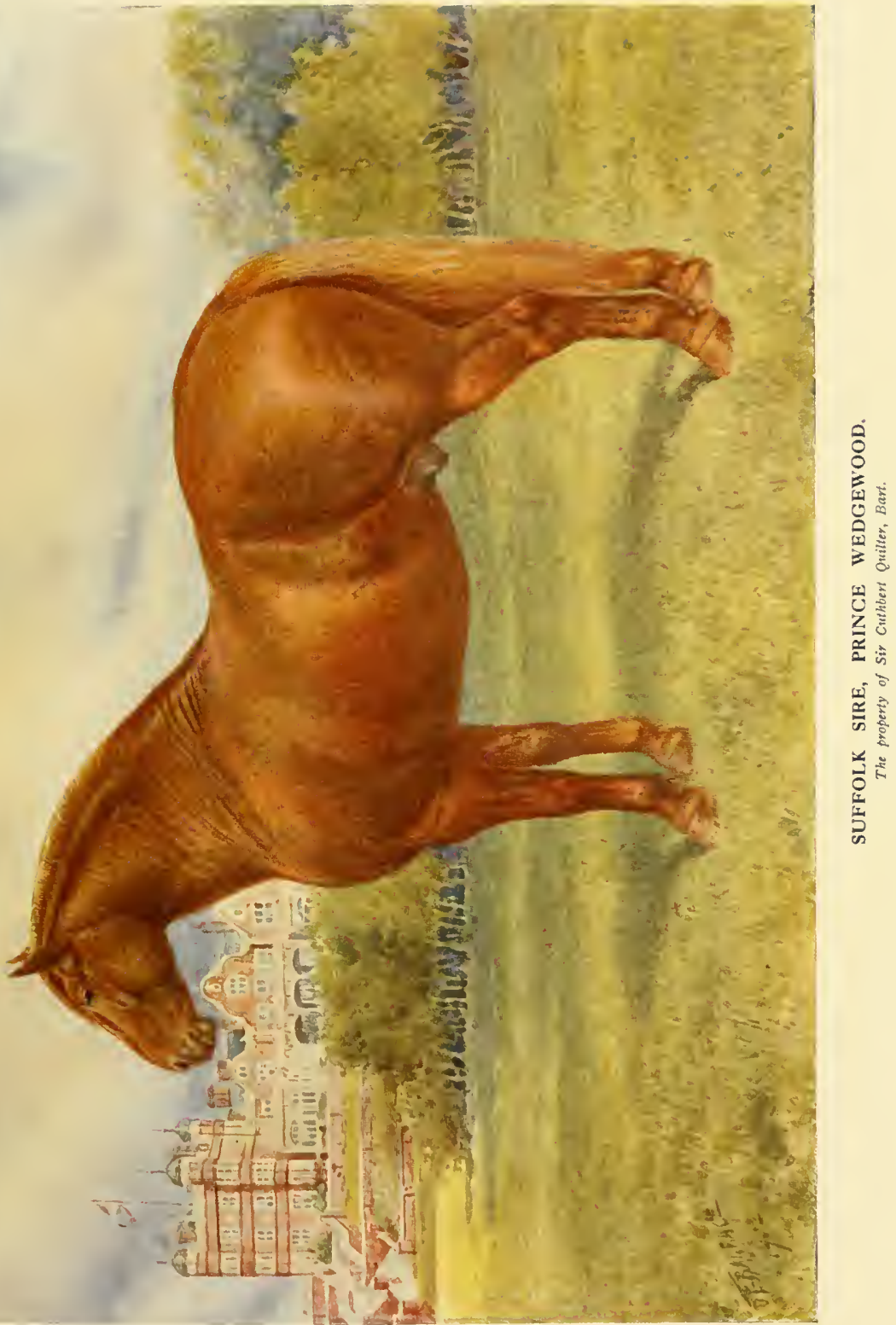





\section{DRIVING AND CARRIAGES}

not long ago, and probably still is, to be seen in the Sonth Kensington Museum. C-spring broughams quickly followed those of the original pattern, and from time to time there have been various improvements tending towards lightness.

Broughams were, and still are, made chiefly in three shapes-the single, double, and circular-fronted, and these carriages matter of course, interfered with the balance of the carriage. The modern hansom followed in due course, Mr. Evans, of Liverpool, and Mr. Marston, of Birmingham, having much to do with its construction, while later the Messrs. Forder, of Wolverhampton, made a great name for themselves by introducing the best materials and workmanship and reducing the weight.

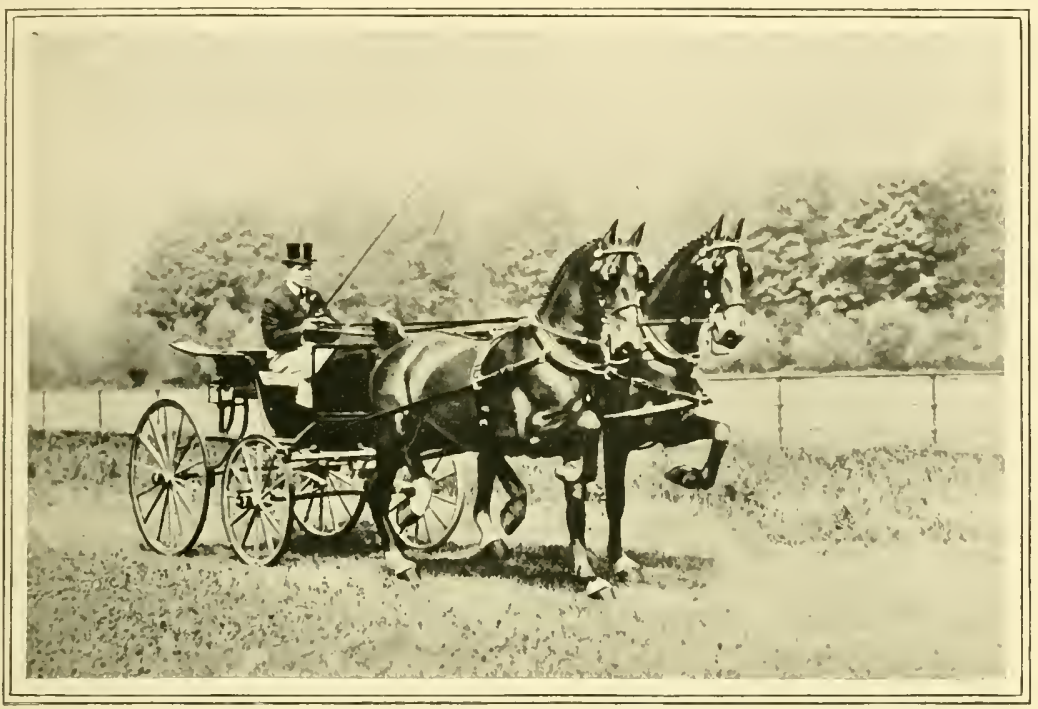

MR. JOHN KERR'S LOUDWATER ROB ROY AND DIANA VERNON

are not really comfortable with more than two people inside, the back seat, both in the "double" and " the circular-fronted" brougham, being too small, except for children. The single brougham of the present day is the lightest closed carriage which can be drawn by one horse, and it still retains great popularity amongst those who are not wholly given over to motorcars.

The hansom cab had extraordinary popularity as a street vehicle, and only began to lose ground when the much faster taxicab became general. The first was invented by Mr. J. A. Hansom, from whom the name was derived; but the driver's seat was at the off side, over the wheel, and this, as a 50
Four-wheeler hansoms appeared some fiveand-twenty years ago, and for a few years were fairly common on the London streets; but they never became really popular, in spite of the fact that they appeared to be much safer than the regular hansom. In all probability, their want of success was due to their being no faster than an ordinary four-wheeled cab, whereas the hansom proper, unless very badly horsed, is immensely faster than the cab which is commonly known as a "growler."

Phaetons have been made in many shapes, but three have been really popular and far better known than the others. These are the mail phaeton, the Stanhope phaeton, and the park phaeton. The mail phaeton proper 


\section{THE NEW BOOK OF THE HORSE}

should be built with a perch and the undercarriage of a coach, and should not lock. It is a sporting, but a heavy vehicle, requiring a strong pair of horses to pull it, and is seldom seen in these days. The Stanhope phaton is to the ordinary undiscriminating eye just like a mail phaeton. It has the same front and back seats, and should have a hood, but it has no coach under-carriage, and can be turned in its own length. Except that it is not such a sporting carriage to look at, it beats the mail phaeton altogether. It is much lighter, can be drawn by one or a pair, and being a short-coupled carriage is much more easily taken up a steep hill than the ordinary four-wheeled carriage. We are inclined to think that a pair of horses in good condition will do a bigger and longer diy's work in a Stanhope than in any other sort of carriage, and on one occasion we travelled a distance of $\mathrm{I} 20$ miles, over hilly roads, with the same pair of horses in three days. They were, as a matter of course, quietly driven, and in first-rate condition to start with, and the load was a light one-the writer, a friend, and a groom, and the smallest possible amount of luggage. For a mail phaeton half the distance, with a single pair of horses, in the same time, would have been fair travelling; but we know of a pair of horses having taken a mail phaeton from London to Canterbury in a couple of days, and the distance is well over sixty miles, but there are fewer hills and much better roads than those which were used in the Stanhope phaeton journey which has been alluded to.

\section{The "Spider" Phaeton}

What is generally called a park phaeton used to be known in the trade as a "spide: " phaeton. It is rather like a Stanhope in front, but has a striped body, like a fourwheeled Tilbury, and has a small seat behind, hung on turned irons, for the groom. With ladies who drive it was, not many years ago, very popular, and a fair number are seen at the present day, driven by men as well as by ladies. Stanhopes and spider phaetons are hung on elliptical springs ; but the spider is perhaps hardly of sufficient strength of build for heavy country roads, and is essentially a vehicle for the town. From time to time other four-wheeled phaetons have been seen, and the writer, when a boy, frequently travelled in one which had a doubled back seat, so that it could hold six instead of four. There were deep panels on the principle of the four-wheeled dog-cart, and either side of the back seat could be shut down. It was, indeed, like a modified char-à-banc, with narrower seats, and three instead of four. Being short-coupled and rather highly hung, it was a most useful carriage in the hilly country where its owner resided.

\section{The Four-Wheeled Dog-Cart}

The four-wheeled dog-cart is very like a Stanhope phaeton with the seats back to back, instead of facing the same way; but it should have an interior for holding a couple of dogs, and at one time it was greatly used by shooting parties. For long enough it has been very common in the country, but the inside space has in recent years been chiefly used for luggage, the carrying of dogs being no longer necessary in these days of game driving, when sportsmen do not go to visit their neighbours, taking with them a brace of pointers or setters. Retrievers and spaniels, which have almost entirely superseded the old style of shouting dog, are kept on the premises, so to speak, and the dog-cart may contain lunch and cartridges, but is seldom used as it originally was.

\section{Other Four-Wheeled Carriages}

The sociable, which is probably the oldest four-wheeled carriage, was like a victoria; but seats of equal size faced each other inside, and to all intents and purposes it was very like a barouche, but lighter, and cut out on rather different lines. It is now rarely seen. Low phaetons on the same lines, but without a driving seat, were at one time very common, and in the country are still seen. They are especially well adapted for elderly people and invalids, being so near the ground that they are easy to get into and out of; but as they are 
driven from the back seat they are not exactly comfortable, unless the seat opposite the driver is vacant. The reins rest on il turned piece of iron, which is fixed on a rud and comes up from behind the centre of the seat opposite the driver.

Wagonettes and brakes have been made in all shapes and sizes, from the station bus to the little jumped-up affair which is a very tight fit for four inside. Their great advantage over other carriages lies in the fact that they will carry more passengers than the ordinary carriage, while they are at the same time much lighter. They are, however, nothing like so comfortable to sit in, the seats, as a rule, being narrow, with rails to lean against. Certain varieties of this carriage there have been, and the late Mr. Harry IIcCalmont used to bring one to the Newmarket race-course which had a landau hood at either side, so that it could be closed in a moment if rain came on. This carriage was deep-seated, well padded, and comfortable, and, in fact, quite unlike the ordinary wagonette; but it was heavy, and required a powerful pair of high-class carriage horses.

\section{The Buggy}

The buggy is more generally used in America than in this country, and one often hears much difference of opinion as to what an English buggy really is. The fourwheeled buggy was never common in England, and is, in fact, a carriage of extreme lightness which is generally used for showing horses, for trotting races, and any sort of driving when remarkably fast time is aimed at. Lord Lonsdale used a buggy in his famous match against time, which was decided on a part of the Brighton road, between Reigate and Crawley.

This match was made between Lords Lonsdale and Shrewsbury, who backed themselves to drive a single horse, a pair, a team, and a pair riding postilion fashion, in an hour-he who did the fastest time to win. Lord Shrevisbury scratched at the eleventh hour. Lord Lonsdale walked over, and in doing so accomplished the feat with something to spare. The exact time in which
Ihe did it has been matter for some dispute, and in "Fifty Leaders of British Sport," compiled by Mr. F. G. Aflalo, 55 mizutes 35.5 seconds are given, while in Sir Walter Gilbey's "Modern Carriages" the full time is stated to have been 56 minutes 55.5 seconds. Sir Walter gives a tabulated statement of the drive, showing how long was occupied over each stage, and probably this record, though it is over a minute longer than the other, is the more trustworthy. It will be easily understood that it was not a particularly simple matter to time four heats of five miles each on a country road.

\section{Warpaint's Record}

A propos this famous drive, the horse which was driven in single harness was a thoroughbred, who galloped his five miles, and not a trotter. The horse in question was Warpaint, a well-named gelding by Uncas out of Toilette, by Speculum, her dam Vanity by Touchstone out of Garland, by Langar. Warpaint was bred by the once famous gentleman rider, Mr. G. S. Thompson, and did not distinguish himself in his early days. When about four years old he was bought by Mr. Robert Jefferson, of Whitehaven, who was then joint master with the late Mr. Anthony Dixon of the Whitehaven Harriers. Mr. Jefferson bought the horse for a hunter, but he was not big enough to carry him, and he was broken to harness and driven in a gig. On one occasion of the writer's visiting Whitehaven he was driven some six or seven miles to the harrier kennels at Rheda behind Warpaint, and was struck with the extraordinary pace at which he could travel with a gig and two fairly heary men behind him. Some months later he was sent to a North Country trainer, and schooled for steeplechasing, and at the Cartmel Hunt meeting, on June Io, I889, he won two little races on the same afternoon, Mr. Jefferson having the mount in the second event, which was a Selling Hunters' Flat Race. In the following season he ran four times unsuccessfully, and passed into Lord Dudley's hands, and, ridden by him, won two hunters' flat races at the Salisbury meeting 
of ISno. After that he was not so successful, but he always ran prominently, and hearing that he had been regularly driven before he became a cross-country horse, Lord Lonsdale bought him for the match. He did his five miles in 13 minutes $42 \frac{1}{5}$ seconds, which, it will be admitted, is rattling good time for a thoroughbred on an ordinary English road which was in bad order owing to half-melted snow.

\section{The Brighton Coach Record}

It is said that James Selby, the famous whip of the "Old Times," in his wonderful drive to Brighton and back, on July I3, I888, travelled part of the distance between Earlswood and Horley at the rate of twenty miles an hour, and it is just possible that such a pace may have been reached for a very short portion of the journey. The Brighton drive occupied 7 hours $5^{\circ}$ minutes, the coach leaving the "White Horse" Cellar, Piccadilly, at ro a.m., and arriving at the Old Ship, Brighton, at I.56 p.m. Here it was turned, and starting again immediately, reached the original starting point at $5.5^{\circ}$ p.m. This, of course, was a great performance, which meant galloping practically all the way, and was up and down hill, whereas Lord Lonsdale's drive was over a fairly flat piece of road. Still, the average pace was very much faster in the latter feat, for twenty miles were actually. covered in less than an hour. while the London to Brighton and back trip was ten minutes under eight hours for about 104 miles.

\section{Two-Wheeled Carriages}

Going back to the carriages, the principal four-wheeled ones have been dealt with, and perhaps it is not necessary to go into detail with regard to the many experiments which have been made and failed, or to describe the convertible carriages, none of which have ever really "caught on "with the public. Of two-wheelers there are probably more in use than there are fourwheeled carriages-first, because they are cheaper, and secondly because, if the whole country is taken into consideration, it will be found that a huge majority of the tradesmen's carts are two-wheeled. In London the two-wheeler has at times had great spells of popularity, and some twenty years ago a new pattern of " cart" would appear about every second year, and be much used, especially in the Park and W'est End, until something else became the fancy of the moment. High dog-carts were in vogue through all the middle period of the last century, and tandem-driving was popular amongst young men, perhaps more especially at Oxford. There was for a time a tandem club, and tandems were frequently, and are still occasionally, seen in town; but in these days horses driven in this fashion can be best seen at the more important shows, where some three or four men can turn and twist them about at will. Why tandem driving never became general is easily explained. In the first place, it was difficult and dangerous for an inexperienced whip, and in the second place the tandem driver who was a close observer became aware of the fact that the leader was to some extent a useless addition. Down hill he could not help to hold the trap back, and along the level he only assisted in pulling what was well within the powers of the leader. Up a steepish hill he certainly allowed of a better pace being maintained, and a really good leader no doubt eases the wheeler in some degree, and thus with two horses in hard condition a few more miles may be covered with a tandem than with a single horse.

\section{Tandem Driving}

But skill in driving tandem is very effective, and thus it has always had its votaries. At the Olympia, Richmond, and other shows of recent years there have been some wonderful exhibitions of tandem driving, and it is worthy of note that the celebrated show-ring drivers prefer a long trace, and seldom bring a tandem into the ring which has the leader's traces fastened to a bar, as was usually the case when tandems were used for work in the country. Nany years ago the writer went on a tandem tour through parts of Somerset, Devon, and Cornwall, the 


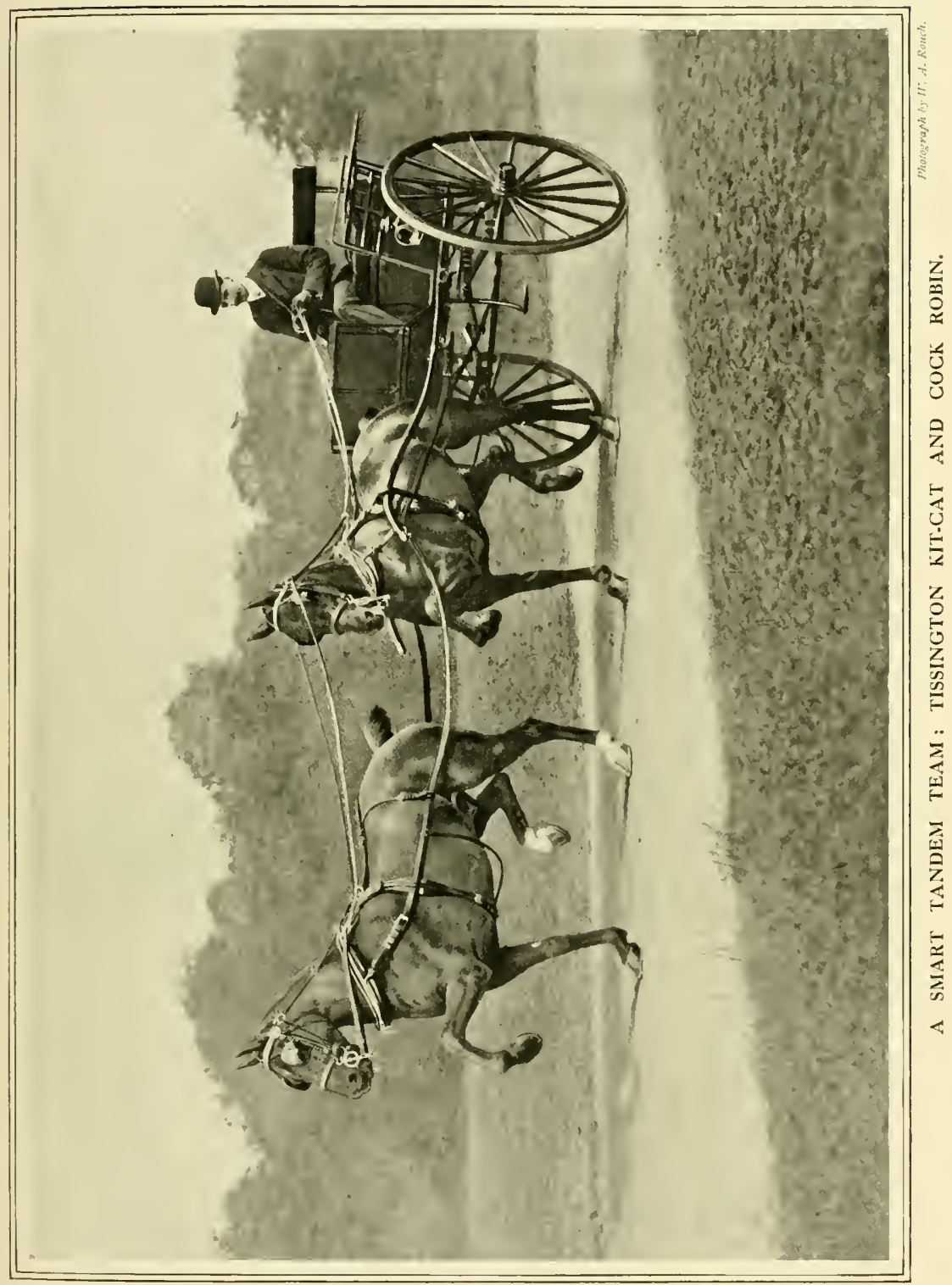


team beng light-weight hunters-a grey and a brown, the last-named a thoroughbred whose name appeared in the Stud Book. These horses were in good condition when they started, and thrived on their work, at times doing thirty to forty miles a day for several days consecutively. They both did their share of work, and though the brown was more often driven in the lead, they were changed at times, so that the work should be equalised. In these days of motor traffic and tramways, tandem driving should not be attempted in or about the large towns, except by an expert of great experience, but in quieter country districts the case is, of course, different. At the same time, there are good four-in-hand drivers who are unable to make a tandem leader go straight, and good coach leaders have occasionally been found that went very badly when driven tandem fashion. The fact is, that in a four-in-hand the leaders quickly realise that they have to work, and each gains confidence from the horse alongside him. The tandem leader, on the other hand, has only himself to depend on, and unless his trotting pace is just equal to that of the wheeler behind him he will shirk his work. A good driver of a four-inhand never allows the wheelers to pull the whole coach while the leaders trot in front, but in tandem driving this is not so easily done if there is any inequality of pace. To have the wheeler of a tandem faster than the leader is fatal, for then the horse in front cannot get out of the way of the horse behind, and if he is an honest worker he is forced to canter; if not, the wheeler is trotting over him all the time and he is loafing in front, just managing to get out of the leader's way, but doing no work. It used to be customary to drive tandem in a high cart, but the high cart is almost a thing of the past, and now gigs or dog-carts of ordinary size are used and the driver is much on a level with his horses, instead of being above them.

\section{The Dog-Cart}

The greatest thing to be said in favour of the one-horse carriage is that it costs less to maintain than when a pair is used, and thus it happens that thousands of people keep a carriage or cart of sorts, and a single horse or pony, where there are hundreds who drive a pair. With regard to dog-carts, the great difficulty is to get them well hung. We have seen carts that were beautifully made, on very sporting lines, and which looked perfect when standing bright and clean in a coach-builder's shop, and yet which, when a horse was harnessed to them, and two or three passengers got up, could not be properly balanced at any price, no matter how much sliding space had been given to the seats. If four passengers of about equal weight got up, and the front seat was placed as far forward as possible, the fore part of the cart would be a long way higher than the back, and if there were two in front and one behind the reverse would be the case, the back part being too much in the air. It is, perhaps, unnecessary to state that there are coach-builders and coach-builders, and while some firms will turn out a cart that can be properly balanced with one, two, three, or even four passengers, this cannot be said of all coachbuilders, and at some of the recent shows horses have been driven round the ring in carts that were jerking forward with a slight downward movement all the time they were going round. It requires a genius to build a dog-cart with a perfect balance, and another genius to detect whether the cart exhibited for sale will "hang" right when there is a horse in front of it.

\section{The Ralli and other Cars}

It can be easily understood that with the Ralli car and the panel car the question of balance is a much simpler one, and how rarely does one see any cart of what may be termed square build that is badly hung. In the governess car and the Battlesden car the idea is for the passengers to be near the ground. In the first-named they enter at the back, and the balance can be obtained by the sitters, who, if the car is not full, can alter their seats until they are on an even keel. The Battlesden car was more like a very low-hung dog-cart than anything 
else, but there was no "boot," or place for dogs, and the vehicle, which has gone quite out of fashion, was a very ugly one. The governess car is handy and useful, but it is not exactly elegant, and the passengers sit sidewars, facing the inside. The Irish, or jamnting car, has one advantage over all varieties of the English cart, in that if there is a driver's seat it will hold five instead of four-two on either side and the driver on a sort of perch in front. Common as these cars are in Ireland, they have never been popular in this country, and occasional users of them are quite likely to be thrown off when going fast round a comer, or travelling on a rough road. They would be impossible in the London streets, amidst the traffic of the present day, and very dangerous to the legs of the passengers.

\section{Touring Hints}

The writer has done many driving tours in a two-wheeler, and the best vehicles he ever used were a low-made dog-cart, and a hooded buggy. Both were very smooth-running vehicles, and the dog-cart was so well made that when sold by auction at Aldridge's after ten years' constant service it made within $f_{\mathrm{J}} \mathrm{o}$ of its original cost. In it there was sufficient room for travelling bags, horse-rug, and so forth, and it frequently travelled long distances day after day, and never went wrong. Moreover, it was an easy cart for a cob to pull, being perfectly balanced, with the "draught" exactly where it should be. The buggy, being canoe-shaped, had no real place for luggage, but a couple of leather cases were made to fit under the seat, and thus the difficulty was solved. In these days one hears of few people who tour the country with a pony and cart, but if one takes a little trouble to avoid the main roads there is no pleasanter way of taking a holiday.

The pony (or small horse) must be a good one, and in good condition-that is absolutely essential; and it is better to hire an animal that has been in regular work for some time, even if it belongs to a livery stable, than to buy a horse for the drive that is short of condition, or in the least awkward to drive. The animal should be a hardy beast, a willing worker, not too slow, and capable of covering long distances without unduly tiring himself. The driver, too, should have knowledge of horses and of driving, should know when to ease his nag and when to go along, and should on no account make the stages too long. A rest of a quarter of an hour and a draught of meal and water in the middle of a journey will enable a horse to do a sixteen-mile stage as easily as he would do a twelve-mile one without a break in the middle of it.

Then, too, if it is summer time the heat of the day should be avoided. It is better to make an early start, and do fourteen or fifteen miles before eleven o'cluck in very hot weather, and then to rest the horse in a cool stable until quite late in the afternoon. In the early morning, too, motors are much scarcer, and there is in consequence far less dust than will be encountered later in the day. Horses in hot weather work better in the morning and evening than they do in the middle of the day; but, of course, if the weather is ordinary, not very hot and not very cold. all times are alike. It is a good plan to have a little paraffin handy in case the flies are troublesome; we have tried all sorts of things for the fly nuisance, and have found paraffin the best. It should be rubbed over the horse's neck and ears, and over the harness also-collar, reins, and saddle. Flies do not like it, and a smearing of paraffin will drive away a cloud of these pests, but nothing that we have ever discovered will prevent a few inquisitive ones from annoying horses which are hot. A shoe-pick for loose stones is also useful, and a spare shoe or two may well be taken, for even if one cannot fix up a loose shoe oneself, the spare one will save the time the blacksmith would take in making one to fit. A small bag, or even a packet, of oatmeal, which can be added to chilled water at any public-house, or even at a road cottage, will be found necessary now, because there are few travelling carriages, and therefore a small demand, which means that at many baiting places they have to send to the village shop for the meal. In 
these days one of the most important things for the driving tourist is to know the country he is going through. He should study the map very thoroughly if he is in a new locality, so that he may be able to avoid the high roads if the dust happens to be thick. In the summer of 1909 the writer drove a cob from Molesey to Horsham, and on and Westmorland, are, to our mind, the best driving ground for the tourist ; but August is now a very bad month, because so many motor parties are also touring, and accommodation at the hotels, unless engaged before hand, is not always procurable.

This reminds us of an experience of a coaching party some fifteen years ago. A

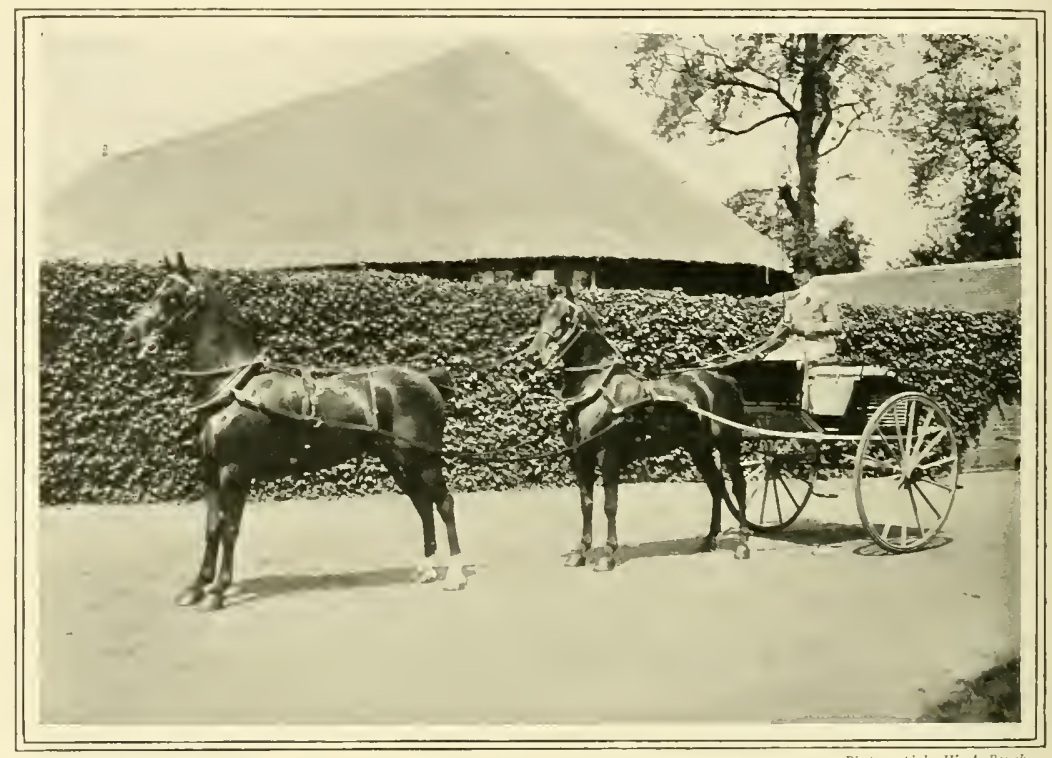

A TANDEM DOG.CART : MR. LOUIS WINANS HOLYPORT HORACE AND TISSINGTON COCK ROBIN.

to Hassocks the next morning, without ever being on main roads for more than an odd mile or so. We went by Oxshott and Ranmore Common to Box Hill, and leaving Dorking on the right, travelled by Leigh and Newdigate to Horsham, going two or three miles round, but avoiding the dust, of which great clouds could be seen whenever we were near the high road. At the present day the country lanes in many parts of the country are so good that it matters little if one leaves the high road, and here we are reminded that we have had little use for the shoe-pick during the last few years, though at one time such an article was frequently wanted. The Yorkshire dales, and those of Cumberland friend was about to put a road coach on between Scarborough and Bridlington, and arranged during the previous week to take the coach and horses from Newcastle-on-Tyne to Scarborough. There were twenty horses in all, and a party of half a dozen were asked to go on the coach, the idea being that the extra horses should trot on a stage or two in front. Darlington was the stopping-place for the first night, and Helmsley was chosen for the second, the party being due at Scarborough on the third evening. The stud groom had been instructed to write for rooms at the hotels and stabling for twenty horses. Everything was in order at Darlington, where there is a large hotel, 
but on arrival at Helmsley we were taken down the yard and shown into a great barrack of a place, with a huge dormitory above. One of the party instantly aslied why proper rooms had not been reserved, and the landlady answered: "Why, when I got the letter and saw that you wanted twenty horses put up I thought you were a circus, and we always put circuses and such like down the yard."

\section{Coach Touring}

Touring with a coach is in some ways a simpler matter than touring with a single horse, for there are grooms with the coach, while the single-horse driver has to depend upon the ostler or look after his own nag. The old race of ostlers who understood how to treat a horse which had done a big day's work is quickly dying out, and now at many inns there are men who know something of a motor-car, but are incompetent where horses are concerned. It is, therefore, of the greatest importance that the tourist should see for himself that his horse is properly groomed and fed, that he should know whether the nag has "eaten up" or gone off his feed, and here it is that a little knowledge of horseflesh is most desirable. If one sees that the so-called ostler does not understand his business it is far better for the tourist to groom and feed the horse himself than to leave him to the tender cares of an incapable man. It should be seen, too, that the stable is dry and the hay and corn of good quality; and that the horse is well littered up with clean straw. These little things make all the difference between the success or the collapse of a driving tour, and are of far greater importance now than they were when commercial travellers and many others were using the road with horses which were accustomed to long and heary journeys. We once knew a bay cob which a certain innkeeper used to let out to commercial travellers for long tours. The man was so fond of his horse that he would not sell it; but he would allow one or two travellers whom he knew well to hire it for journeys of six weeks or more, and it was the owner's boast-after some years of ownership-that the horse had travelled on English roads the distance between John o' Groats and Land's End twenty times over. No doubt this was true, for the horse went many long journeys in the course of a year, and he was doing this work for many years, and carrying his owner with the local pack of hounds in the winter. The best performance we ever got through was ros miles in two days, with a I 32 -hands pony in a light trap, with two people in it; but we have known of much longer journeys, and some years ago we remember a friend driving an even smaller pony from Newmarket to Lichfield in a day. The great thing in touring is not to overdrive the horse. Let him settle down to his work and go his own pace, whatever it may happen to be. To attempt to get ten miles an hour ont of a lurse whose natural trotting pace is between eight and nine is to court disaster, and to hurry a horse up a hill, unless he is terribly lazy, is also very bad policy. A lazy horse, by the way, should never be taken on tour, for even if he is capable of doing the long journey the effort of driving him will take away all the driver's pleasure. Neither is a hard puller a good horse for touring, as he will probably take far too much out of himself at the first stage of the day, and be slack and unwilling all the afternoon. 


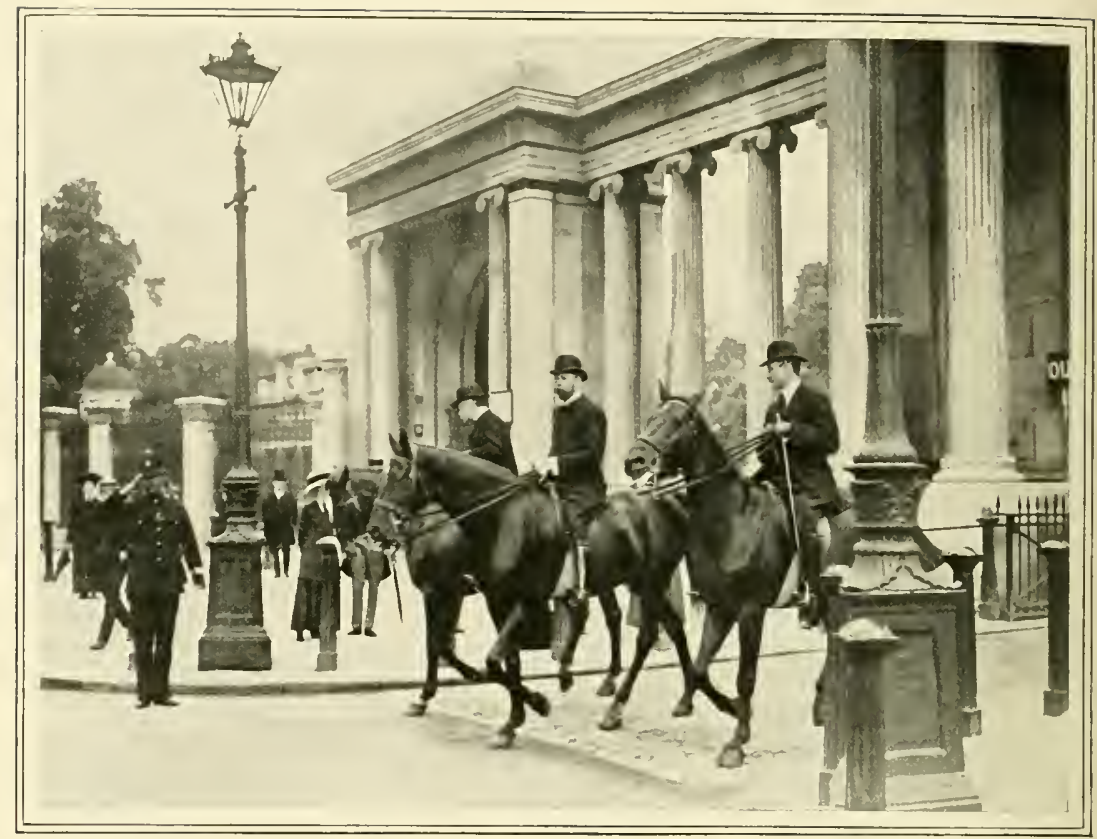

H.M. THE KING LEAVING THE PARK.

\section{CHAPTER XXXV \\ RIDING AND HORSE SHOWS}

I $T$ has already been stated that the number of riders in this country is not so large as it once was, this being due to the fact that the necessity for riding has in a great measure disappeared. But, after all, if there are fewer equestrians to be seen on the high roads and lanes of the country, the ranks of foxhunters have been enormously swelled, and the increase is at present continuous. Polo, too, has brought into being a new section of horsemen, and here, too, there is a steady increase in numbers. What is lacking are the old-fashioned riding parties of the summer time and the hundreds of people all over the country who rode daily, as a fair number of people still do in Rotten Row. No doubt there are many good reasons for the decline, and it is hardly necessary to mention the fact that the motor-car, and the dust which it raises, are serious difficulties in the way of the would-be equestrian; but it is a fact that long before motors were invented there was a serious falling off, due principally to railways having opened out the country sufficiently to allow of many journeys being made by train that were formerly undertaken on horseback.

The wish to ride a horse is, nevertheless, very deeply ingrained in the average man or woman of British or Irish birth, and even at the present day there are few country residents of position who have not ridden 


\section{RIDING AND HORSE SHOWS}

regularly at some period of their existence, even if they have never hunted. Probably a majority of the children of well-to-do parents, living in the country, are taught to ride; but many of them do not go on with it, not because they do not like it, but because there are so many other recreations to claim their attention.

The Boer War revealed the fact that great numbers of athletic young men who had been brought up in the country did not know how to ride and were in a state of complete ignorance as to the management of horses. Since that time there has been some reaction, and at present a great effort is being made in many quarters to have men properly taught to ride. That every young man who is in a position to learn should do so is, one thinks, imperative; but this is hardly the place for any discussion on the needs of the nation, or the future of cavalry, and it need only be stated that the lessons of the South African War point out very strongly how necessary it is to have a strong force of mounted soldiers, no matter of what branch of the service they may be a part. suldiers for horse artillery, cavalry, and even for mounted infantry, can, in times of peace, receive their instruction at the various depots, but when war is suddenly proclaimed and an extra force of what are, practically, rolunteers is required, then it is that the lack of knowledge of riding and horses makes itself so strongly felt, and this can be, and should be, guarded against.

\section{The Decline of Horse-Riding}

As things are now, a certain proportion of the upper and the upper middle classes know how to ride; also past and present officers and men who have served in cavalry, horse artillery, or yeomanry; a fair number of farmers, some farm servants, a very large number of grooms, and also a limited number of working men who have been engaged with horses, but have left them to follow sume other occupation. Time was when nine out of every ten countrymen knew how to ride and manage a horse, while the number of townspeople who rode was very considerable. Now one may stand in the principal street of a country town all day long and not see a ridden horse, out of the hunting season, except a few carriage horses being exercised in the early morning. At Brighton, Scarborough, Harrogate, and others of the more important seaside watering places, there is still a little hacking done, but not a fiftieth part of what there was, say, thirty years ago, and the average townsman never gets on to a horse in the whole course of his life.

\section{The Need for Riding-schools}

It is a somewhat sad state of affairs for what is supposed to be a horsy nation, and yet there are two or three million horses in the country, and, as a natural consequence, a quite important percentage of the population must be constantly employed in driving, riding, or looking after horses. About the country children learning to ride, the conditions are as they always were, and those children who incline to horses will quickly learn, and will go on riding, while youngsters who do not appreciate the chances they have will turn to something else. In the towns, and especially in London, the case is different, and now it is almost impossible for any town bred beginner, whether child or adult, to acquire the rudiments of horsemanship unless he goes to a ridingschool. Luckily, there are many first-rate riding-schools in London, where instruction of the fullest kind is given by experts, and an apt pupil can quickly become a fairly accomplished horseman. At one time the riding-sehool was rather held in derision by the country folk, who strongly faroured a rough-and-ready style of learning; but as a nation grows older it learns many things, and of late years even accomplished cross-country riders have admitted that "school tuition" is an extraordinary help to finished horsemanship.

\section{The "International"}

Great evidence of what the schools can teach has been afforded at the Olympia exhibitions of the International Horse Show. The show in question was inaugu- 
rated in 1907 , and during that year and the three succeeding ones there were a considerable number of competitions in which the school-taught rider was seen to far greater advantage than the man whose practice had been almost entirely confined to riding across country behind a pack of homnds in the Inited Fingdom. It is, perhaps, hardly necessary to state that these school-taught riders were for the most part foreigners-Frenchmen, Belgians, Italians, and so forth-and that their particular kind of horsemanship is regularly practised on the Continent, while it is comparatively new in this country. Iet the fact remains that though a small handful of English horsemen did hold their own with the large number of foreign officers and the few foreign civilians who visit Olympia, a majority of our show-ring riders were quite outclassed.

\section{Jumping Competitions}

It must be understood that the English division was not wanting in pluck; but two things were apparent during the four years of the show; first, that the English riders had had-we are speaking of the majority and not of the "handful " referred to above-little or no experience of this particular kind of riding; and, secondly, that a big majority of the English horses were quite unaccustomed to the jumps they had to negotiate in the covered and somewhat confined arena at Olympia. It is the case that in most of the European countries show-ring jumping is a serious business, whereas in this country it has until quite lately been looked rupon as an episude, instituted chiefly as a draw for the crowd. I3efore the advent of the International there were jumping classes at a majority of the important shows, and at all the smaller country exhibitions of horses. But these competitions were held towards the end of the day, when the more serious business of the show was over, and in many instances only took place so that the "gate" might profit by them. The horses were, for the most part, broken-down screws of small value, who could jump the usual fences, but had no pretensions to go through a long run with hounds. Many were bad roarers, and one very successful horse some years ago had so weak a back that he was invariably ridden by a six-stone boy, who dismounted as soon as his round was over and was never on the horse's back for more than a few minutes at a time. Yet this horse was a fine fencer and a very frequent winner.

\section{A Tricky Jump}

Jumping competitions at English shows are by no means a new thing, and the writer was very fond of taking part in them more than thirty years ago. At that date there was in some localities a natural course to be jumped, and occasionally good class hunters would be entered. The same sort of thing still takes place at Lord Tredegar's show in Wales, and from time to time attempts have been made to make jumping a fence or two imperative with regard to hunter classes-much as the "qualified hunter" classes are arranged at Olympia. We remember riding at one show in 1873 , at Bellingham in Northumberland, when the hunters had to jump an artificial fence in front of the stand, and then go out of the show field over a natural fence, jump one or two more natural fences, and then return to the slow ground. How many of these fences there were we cannot exactly remember, but one was an old thorn fence, which had been strengthened by a post and rails, and had a narrow occupation road beyond, and grass beyond that. The road had been laid with ashes, and was quite black, and two or three of the performers treated it as they might have done a water jump, and flew the whole obstacle, landing on the grass at the far side. Jumping contests, however, never appealed to the exhibitors of valuable show hunters, and for many years - except at Lord Tredegar's show-the jumping classes were confined to what may be called the professional show jumper.

\section{Improvement in English Jumping}

At the same time, it is evident that the lessons of Olympia have gone home to a 


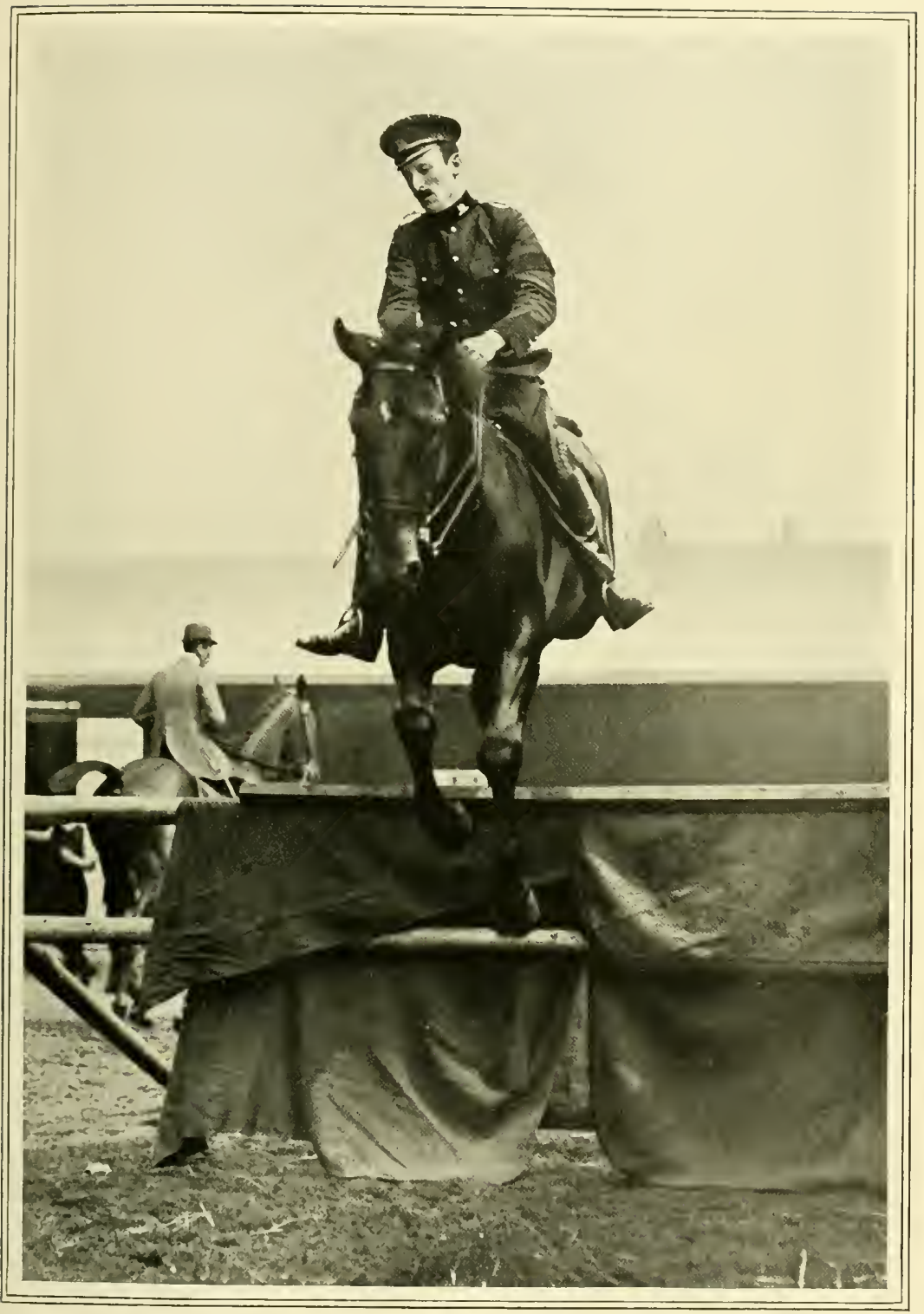

LIEUT. GODFREY BROOKS ON HARRIET. 
large section of the horsy world, for there has been, during the last two or three years, a marked improvenent in the jumping at the more important shows. Not only have the fences been better arranged, but a better class of horse has been entered, and at the Richmond Show of IoIo the performances were for the most part capital, and in the class for officers, jumping in pairs, very little fault could be found.

\section{The Olympia Jumps}

The show jumps at Olympia are all of them high, but as all are frequently cleared it cannot be said that they are unfair. It is the unaccustomed surroundings which cause so many English horses to do badly. Horses which can jump a steeplechase course, or are capable of getting over a really "big" country with hounds, will often fail lamentably when brought into a crowded enclosure, where a band is playing and where there is a continuous buzz of conversation. Some of them are frightened by the brightly painted obstacles and the wings thereof; others, again, do not like the noise and the crowd; but the chief thing is that horses which have only been jumped in the open cannot, without a great deal of practice, accuston themselves to the nearness of the jumps to each other, and often miscalculate their take-off. One year a horse with a big reputation as a hunter in the Midlands knocked down every jump at Olympia. As a rule, he got far too near the obstacles and hit them in rising; but this same horse jumped beantifully at Richmond a few days later, when on turf and with the fences a long way apart. We do not intend in any way to disparage the Olympia jumping contests, but merely to point out that it is absolutely useless to take the finest natural jumpers there unless they are thoroughly at home amid the noise of a crowd.

\section{Mr. Walter Winans's Jumpers}

Mr. Walter Winans, whose horses have won very many of the Olympia jumping prizes, has at Surrenden Park a school in which his Olympia candidates are preparcd.
Here he brings the village band, and introduces a score of stable lads, who shout, sing, and make a terrible noise while the horse is going through his instruction. The place is lit up by electricity and the jumps placed so that the horse can accustom himself to their frequent recurrence, and get into the way of taking off at the right moment.

\section{Foreign Methods}

All the foreign horses which one sees at Olympia have been schooled in some similar fashion, and no horses are sent over here which are likely to be frightened by their surroundings or to misbehave in any way while they are in the ring. With the horse which is only jumped at the outdoor show this school teaching is not so necessary for the horse, but the school-taught rider is at an advantage in any jumping competition, for through long practice he has come to understand how to help his mount and how to act when anything out of the ordinary occurs. Those who have watched the best of the foreign officers going round will understand what is meant; but it is rather difficult to explain. It is the case, though, that many of the best riders among the foreign contingent sit and grip their horses in different manner from the average English rider. The style of the last-named may be-probably is - the better for riding to hounds, where no two fences are alike; but in show jumping the foreigners appear to extraordinary advantage, and this not because they have better horses, but because these animals have been more thoronghly schooled, and because the riders have made a business of what in this country is merely a passing amusement.

\section{Necessity for School Training}

School riding among Continental nations plays a far larger and more important part in military training than it does in Great Britain, and the most successful school riders represent the French, Italian, Belgian, and other armies at Olympia. They are opposed by Englishmen who are fine horsemen, but who have had very little school training - at times none at all —and thus our 
officers have not in the past been seen to great advantage. But certain cavalry regiments have taken the matter up, and in recent vears officers of the 16 th Lancers and one or two from the caralry school at Netheraron have fairly held their own. It is entirely a question of practice; but practice of this sort makes great inroads on time, and if men are playing polo all the summer, they have no great amount of time to derote to the school training of jumpers.

\section{The Olympia Fences}

The Olympia fences are, on the whole, fairly natural for an enclosure; but some are distinctly artificial. The "piano" jumpas it was frequently called-was not seen in I9Io, nor the line of dummy soldiers; but the bank is a silly kind of obstacle, and the wattle hurdle totally unlike anything one sees in the hunting field. The ordinary bushed hurdle, the gate, the double, and the wall are, on the other hand, fairly natural, and all of them are to be met with in the hunting field. Neither can fault be found with the poles, for though such a jump is never seen, it teaches a horse to spread himself. The double is supposed to have a line of rails between the two jumps, and such obstacles are constantly seen in hunting. But they are very seldom jumped, though there are one or two well-known instances of horses getting over them all right.

Few of the Olympia jumps are really new, and many of them have been in use at the country shows for several generations. In the late 'serenties we had the laying out of a jumping course, on grass, where the fences included a bushed hurdle, a swinging gate-not so high as that used at Olympia, but less readily knocked over-a wall built of dry stones-not wooden blocks -an in-and-out (the fences of which were rails about 3 feet high, and which necessitated a horse only making one step between the two jumps, which were about 12 feet apart), a water jump, and a bank. This particular in-and-out was modelled on what was frequently seen in that country-riz. two sets of posts and rails on either side of a young, growing hedge. The bank was also of the pattern to be found in the district, some + to 5 feet high, with a rail on the top and just sufficient room for a horse to land with his fore feet on the bank and go over the rail with a second jump. This bank is very common in the big grazing grounds of the Tynedale and Morpeth hunts, and horses quickly become accustomed to them. At times these banks are stone-faced, and afford very little foothold at the top; but they are regularly jumped by hunting people-unless the rail has been replaced by a strand or two of barbed wire, and this one is obliged to admit is now verv common.

Besides the jumping at Olympia, the hack classes offer a premium to good schoo] horsemanship, for many of the hacks which are shown, and all the competing officers' chargers, have been taught a certain amount of high-school business, and at times the performances are remarkably pretty. And in the charger classes English officers more than hold their own with Continental officers, which is evidence that they would also do so in the "round the course" competitions if only they devoted more time and attention to the special schooling which is necessary, both for them and their horses.

\section{The Horse Shows}

Horse-showing has become a real business in recent years, and now during the summer months a great number of people are working in connection with it all day long. Every variety of British and Irish horse is shown, and only during the three winter months is the "business," or pastime - it is not easy to find a suitable descriptive title-in abeyance. The season may be said to commence at Islington in March, and to continue right on until November, when certain shows in South Wales are held. The Islington shows are four in number, and are what may be called breed shows. The first, which occupies four days, is of Shire Horses, and this is succeeded in the following week by the Hackney Show, which also extends over four days. Then comes the show of the Hunters' Improvement Society, with which the show of the 


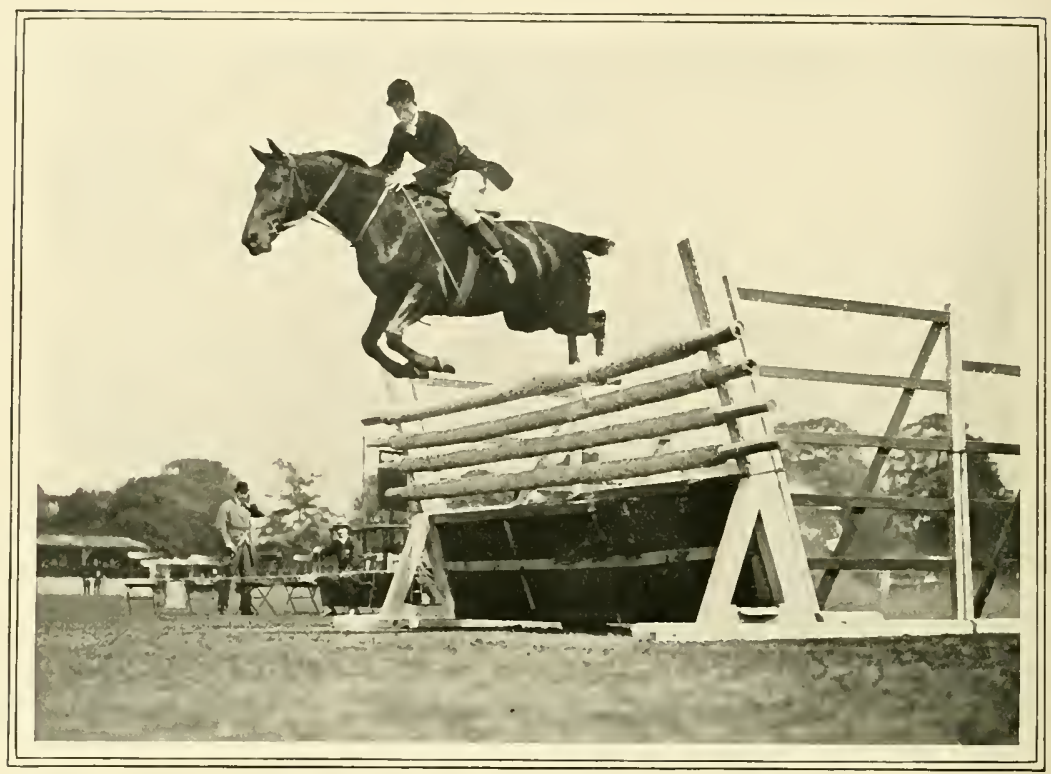

CONFIDENCE TAKING A HIGH JUMP AT RICHMOND.

King's Premium sires is affiliated, and this occupies three days. Last of all is the two days' show of the Polo and Riding Pony Society, making thirteen days of horse shows held during a period of three weeks. At these shows stallions, brood mares, foals, rearlings, and two- and three-year-olds are shown in hand, and as a rule the forenoons are occupied with these classes, while later in the day the finished article appears, and is seen in all its glory. Possibly the magnificent Shire horses are the most popular with the London crowd, but the Agricultural Hall at the beginning of March is not an ideal show ground, for it is draughty, and sometimes very cold. The tan from the ring, too, rises into the air, and troubles the eyes and nostrils; but everything is atoned for by the grand quality of the exhibits, and economy must be studied, for the public do not visit the place in such numbers as are to be seen at Olympia three months later.

The show of the Hackney Society is wonderfully well organised, and, when the time of year is considered, particularly attractive. It must be understood that for breed shows the dates are imperative, for sires begin their annual labours immediately after the spring shows, and would not be available at any other time. Besides hackneys hackney ponies are shown in great numbers at Islington; but the attractive features of the spring show are the hackneys in harness, and the championships for stallions and brood mares. It lias been explained that all hackney breeders have the show ring in view when making their breeding arrangements, just as all breeders of thoroughbreds attempt to breed a Derby winner. The hackney being a horse for which there is a special, but somewhat limited, market, must, if he is a good horse, be brought to the notice of breeders, and also of likely buyers, and this is best done by sending him to Islington in the first place, and later in the year to other important shows. We may take it that unless they are temporarily amiss, a majority of the best-looking young hackneys in the country are sent to Islington. 
There is a small handful of breeders who do not show, but they are so well known as to need little advertising, and as the names of the breeders appear in the catalogues it is a fairly simple matter to know whether the studs of men who do not exhibit are doing well or the reverse. One most successful breeder who does not show in these days is Mr. Burdett Coutts, but the number of great harness prize-winners which have been brought up in his paddocks is extraordinary, and this can be seen by a very cursory glance at the catalogues of the more important shows of the last few years. Harness classes at Islington seem to please the crowd, but the ring is too small for some horses, and a notable instance is Mr. Colman's Authority, who at two or three Islington shows would not settle down to trot, and yet at Richmond in IgIO, in a ring four times the size of that at Islington, he gave one of the grandest exhibitions ever seen at a horse show.

The first day of the Hunter Show is almost given over to the King's Premium sires. Twenty-eight of these King's premiums are given, each of $f_{150}$, and the horses which win them are required to stand or travel in certain districts appointed by the Royal Commission on Horse Breeding, and to serve not fewer than fifty half-bred mares at a fee of $f 2$ and $2 s .6 \mathrm{~d}$. to the groom. Twenty-eight premiums at $£ \mathrm{I} 5^{\circ}$ means $f t, 200$, and at the moment this magnificent sum is all that is given by the Government towards the horse-breeding industry. The question has, however, roused much discussion of late, and many schemes have been prepared. What the outcome of the agitation may be it is impossible to say, but we think it necessary to state plainly that hitherto the small horse-breeder has had practically no help from the State, whereas in France, and all other Continental countries, huge sums are granted each year and so cleverly distributed that the small breeder profits very largely. But if the sum of $£ 4,200$ is a very small one-it should be

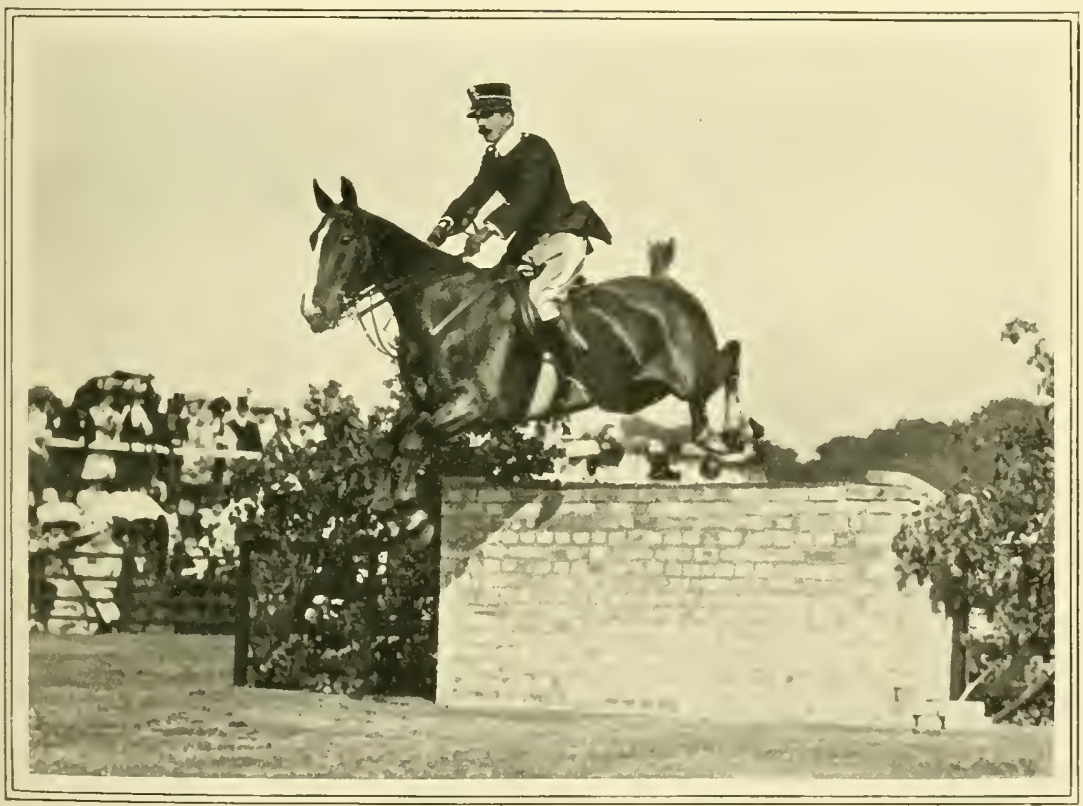


mentioned that there is also a grant of about $f 2.000$ to Ireland, which takes the form of racing prizes, called King's Plates - it is very wisely distributed by the members of the Royal Commission.

The twenty-eight sires are most carefully chosen from a very much larger number. As a general thing, there are upwards of a hundred sent to Islington to choose from. and they are judged by men who are experienced not only in thoroughbreds, but in hinter breeding. The prizes are given for thoroughbred stallions only, so that no "hunter bred" horse is eligible. This is a very wise rule, for, as has been stated in an earlier part of this work. the mating of a half-bred sire with a half-bred mare is a very risky business, and thoroughbred mares are very seldom to be found at the farms or holdings of those who avail themselves of the services of the Premium horses.

\section{Selection in Mating}

The idea of the King's Premium sires is to improve the half-bred stock of the country, and this can be done in no other way than by introducing pure blood. The man who puts a mare to a King's Premium horse in nineteen cases ont of twenty is attempting to breed a hunter, for he knows that if success attends his mating there is the chance of his obtaining a fair price for the produce. It is little use mating very common nags with a thoroughbred, or very undersized ones. A well-made cob mare may breed a hunter, but the alliance of a thoroughbred and a real pony (that is to say, a pony with some real pony blood in it) will probably produce an animal that is too small to be of much value. The Dales ponies in the north-western district of Yorkshire and the western part of Durham were a generation or two ago greatly improved as to size and strength by a mixture of pure blood, derived from The spy and other horses from the Streatlam stud of the late Mr. John Bowes; but even then they did not change their appearance after a single cross of pure blood, and are now thicker and stronger than ever, but still very short of quality.

\section{Soundness of Premium Sires}

The above is, however, a digression, and, to return to the Premium sires, every horse which is sent to the annual show at Islington has to undergo a rigorous veterinary examination. Roaring, whistling, ring-bone, unsound feet, navicular disease, bone spavin, and cataract all disqualify a horse, and the board of examiners includes some of the greatest celebrities of the veterinary profession. In fact, it is practically impossible for an unsound horse to win one of the preminus, and thus it is absolutely certain that in a limited way-because of the small number of Premium stallionsgreat benefit must accrue to the country breeder.

Moreover, the racing performances of all the candidates are taken into consideration. In the catalogue a brief memorandum of these performances must be set out, and though full particulars are not given, the judges, even if they do not remember the horses and their form when on the turf, have something to go by. It would be better, no doubt, if these performances were tabulated more elaborately than they are, for, as a rule, the descriptive matter is very vague, as, for example: "In training two years. As a two-year-old placed once; as a three-year old won once, and placed four times. On the Flat." Or: "As a four-yearold placed second twice; as a five-year-old won five races and placed 3rd twice. Over hurdles and across country. In training for four years." This style of description gives little information as to what the horse's class was in his running days, and it would be better if it were indicated what races had been won by each horse. At times some very smart performers are among the competitors: horses which have won good handicaps, or important weight for age events; and Curio, who won the Newmarket Stakes in 1892 , and was placed in the Two Thousand of the same year, may be quoted as a high-class race-horse which afterwards won King's Premiums, and has 


\section{RIDING AND HORSE SHOWS}

been a very successful sire of hunters; but vear after year the list is very incomplete in this direction, there being nothing to show which of the competitors was a good class performer and which a very moderate selling plater. At times horses are shown which have never won a race of any sort, and the catalogue always includes a fair number of animals which have never been in training, but of late years the judges have shown marked preference for the good, or fairly good, performers, and a horse which has not been trained must be rery goodlooking and exceedingly well-bred before he can secure a prize. It is, of course, quite possible that a horse which could not be trained, or was too slow to be a winner, may ret be able to sire good half-bred stock; but there have at times been great faihures among the good-looking horses which had not been raced, and most certainly the chances are that better stock will be bred from a racer of some note than from a horse which was never trained. With thoroughbred mares the case is different, many great horses having been bred from the poorest of platers, and a fair number from animals which had not been trained.

\section{Uncertainty of Breeding Results}

To the small breeder in many districts the ling's Premium sire is a great boon, and all over the country high-class hunters have been bred from these horses. There are, as a matter of course, many failures, but these are always occurring in every sort of stock breeding, and the produce of a sire and dam who hase both won the Derby may be a complete failure from a racing point of riew. On the other hand, the thoroughbed who is mated with half-bred stock at times sires a fair percentage of smart animals; but much depends upon the district in which he is located, for in one neighbourhood the mares may be of much better stamp than those in another. King's Premium sires perhaps do best in the Midlands and the North and East Ridings of Yorkshire, for hunter breeding has always been carried on in those parts, and the farmer and others know exactly what sort of mare to breed from. In other localities we have known of a King's Premium sire being mated with rather common mares, used for gig work or tradesmen's carts, with cobs, light-cart mares, and, in fact, with all sorts of animals which had no pretensions to brood mare status. Not one in ten of the mares sent to a certain horse we have in mind looked like breeding a hunter, and yet the sire in question was responsible for a fair number of hunter-like animals, the best of which were rery good indeed. In many districts the average farmer who tries to breed a foal or two every year will use any horse that comes to hand. We once knew the owner of at I5hand mare, who was driven in harness, ridden at times, and who did a lot of light carting. She was a good breeder, and in four following years her owner put her to a hackney pony, to a cart-horse, to a thoroughbred, and then to a half-bred cob. She foaled to each of them, and when all four were grown up the heights took a range of nearly 4 hands, the animal by the carthorse being just on $I 7$ hands, while the produce of the hackney pony was only a fraction over 13 hands. The last-named was a capital harness pony, however, and what he lacked in height he made up for in strength and constitution. The filly by the half-bred cob was a useless, under-bred brute; the animal by the cart-horse had not sufficient bone to carry his big frame; but the produce of the thoroughbred was a useful hunter for two or three seasons, when he went wrong in his wind. He wals a big jumper, and was ridden by a huntsman for a couple of seasons. By the time the breeder had gained a little experience he lost his mare through an accident; but from that day until quite lately he bred liunters with a fair amount of success.

\section{Where the Premium Sires Go}

The King's Premium sires are sent all over the country. Three are in the Home and Eastern Counties, the district (A) including Bedfordshire, Bucks, Cambs, Essex, Herts, Huntingdon, Middlesex, Oxford, Norfolk, and suffolk. Cumberland, Durham, Northumberland, and Westmorland also 
have three horses amongst them, this being District B ; while the Midlands (District C) also have three, for the counties of Derby, Leicester, Lincolnshire, Northants, Nottingham, and Rutland. District $D$ is a very large one in area, extending all along the southern seaboard. It includes Surrey, Berks, and also Kent, Sussex, Hants, Dorset, Devon, and Cornwall, as well as the county of Wilts. For this big district five horses are allowed, and it will easily be understood that four times the number would not be too many. District $\mathrm{E}$ includes the whole of Yorkshire, and has four horses allotted to it ; and 1)istrict $\mathrm{F}$, which also has four horses, means the Western Midlands and Sonth Wales, Gloucestershire, Herefordshire, Shropshire, Staffordshire, Narwickshire, Worcestershire, Monmouth, and half a dozen Welsh counties as well. District G-Cheshire, Lancashire, and Nortl Wales-has three horses; and District H-Ruxburgh, Berwickshire and district-one; while Fifeshire also has one and Forfarshire one. No doubt the scheme is wonderfully well mapped out, and is excellent so far as it goes; but it is not comprehensive enough, for twenty-eight horses cannot possibly travel all over the kingdom, and cannot possibly serve more than a very limited number of mares. It is to be hoped that when a Government grant is forthcoming an increase in the number of thorvughbred sires will be made.

\section{The Hunter Show}

The second and third days of the Hunter Show (at 1slington) are given over to the hunter in embryo, and the finished article which is ridden before the judges. There are no brood mare classes at this show; but there is always a class for hunter sires registered in the Hunter Stud Book, and lately these clisses have been better supported than they once were. The registered hunter sire, who is not exactly a thoroughbred, but has three or four crosses of pure blood, has made some headway of late, and there are those who think that for many mares he is an improvement on the thorotighbred horse. It is a matter which causes great difference of opinion, and there are hundreds of hunting people in all parts of the kingdom who object very strongly to the idea of using any other sire than a thoronghbred. This is not the place to thresh out the question; but we may point out that such sires should do well when mated with mares which are really thoroughbred, or very nearly so, but not with those which have only one cross or two of pure blood. The idea of the hunter sire is to give additional size, bone, ind strength; but thoroughbred bone, thongh smaller than half-bred bone, is much stronger, and thoroughbred vitality is almost essential for horses which have to do eight or nine hours in the hunting field without a rest or a feed. There is no need to pursue the subject farther, but we think it very improbable that the half-bred sire will ever depose the thoroughbred where the breeding of hunters is concerned.

\section{The Produce Class for Hunters}

A class with which we are much more in sympathy is the produce class for the best group of young horses - one, two, or three years old-by the same thoronghbred or registered hunter sire; for this always brings out some very smart young stock and gives hunter breeders the chance of comparing the produce of different sires. In this class in I9ro groups sired by eleven different horses were shown, and the class was a very fine one. Hunter-bred colts, two and three years old; yearlings of either sex; two- and three-year-old geldings and fillies; and, in fact, yomng hunters of every age are shown, and nearly all are bred in England. Indeed, great country as Ireland is for hunter-breeding, it does not send young stock to the annual show at Islington. In all probabitity the distance is too far and the expense too great. Anyhow, Irish breeders are hardly represented at all in the breeding classes; but, on the other hand, a fair share of the prizes in the riding classes go to horses which were foaled on the other side of the Irish Chann and have since been sent over to this country. The riding classes for hinters at Islington are more 


\section{RIDING AND HORSE SHOWS}

comprehensive than those at many of the shows which come later in the year, and because the Islington show is the leading show of hunters in the kingdom, therefore its lead is as far as possible followed by other shows. Four-year-old mares have a class to themselves, and so also have four-year-old geldings, and there is, chief object of the society in its prizes for ready-made hunters is to encourage the showing of young stock. Four-year-olds have, for example, three classes to themselves. There is a class in which five-yearold mares can compete, and three classes, divided as to weight, but in which no horse older than seven years is eligible. The

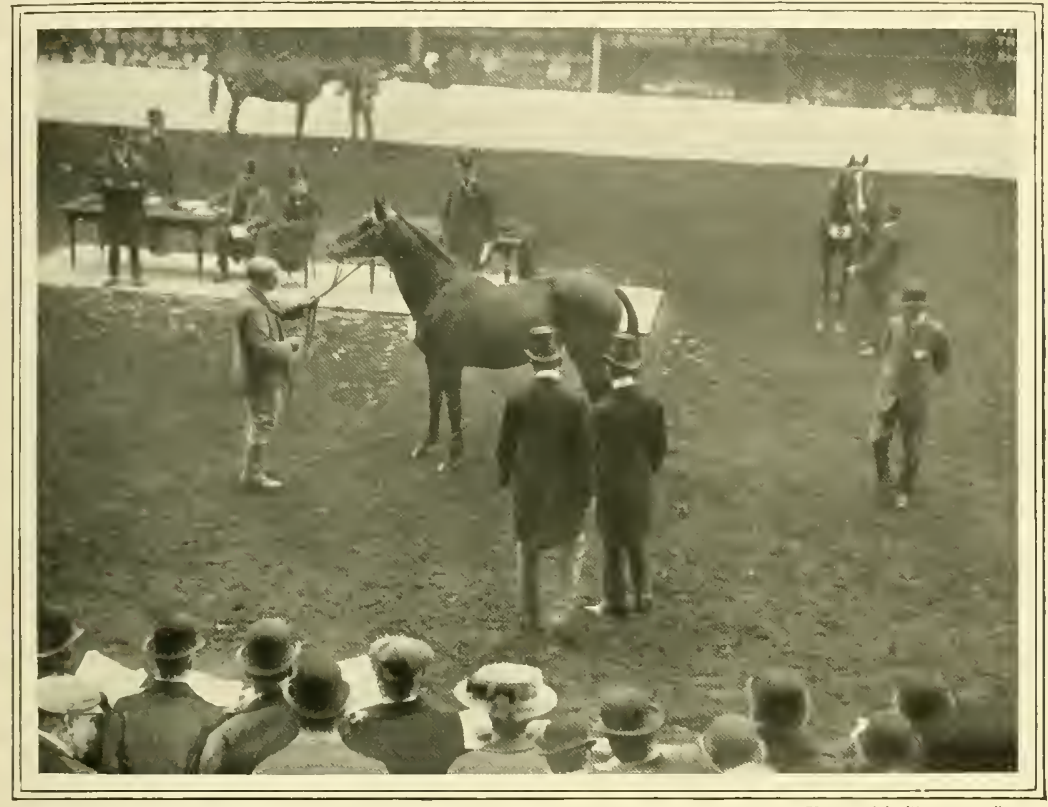

JUDGING HUNTERS AT THE AGRICULTURAL HALL SHOW.

in addition, a class for four-year-olds of either sex. Then there is a class for mares five years old and upwards, and a class for mares or geldings, five, six, or seven years old, not to carry more than 13 stone 7 pounds. This is folowed by a class for mares or geldings, five, six, or seven years old, to carry over 13 stone 7 pounds, and under $\mathrm{r}_{5}$ stone. Lastly comes a class with the same conditions as to age, but for horses up to I 5 stone and upwards. There is also a Champion prize for the best hunter in all the classes which have been enumerated.

It will be seen from the above that the veteran show hunter is thus debarred, so that young horses may have a chance of distinguishing themselyes, and this is distinct encouragement to breeders. It has often happened that many of the prize-winners at this show have been the property of Midland dealers, but these people take the trouble to find the really good-looking and well-bred horses, and doubtless have often to pay the breeder a fairly long price. They have also to school and make the nags, get them into show condition, and, in fact, convert the raw material into the finished article. They are therefore fully entitled to any success they may achieve. Study of 
an Islington catalogue shows that a considerable number of the horses exhibited in any one year hase been bred in Ireland; in a majority of instances the pedigrees are given, but the majority is not a very large one, and quite a big number of horses are shown about which no particulars as to breeding are fortheoming. Most of these "unknowns" have come from Ireland, and there would appear to be great carelessness on the part of Irish breeders in the matter of pedigree, or such ragueness that the purchaser will not accept what is given, and prefers to show without particulars of breeding rather than to put forward a pedigree which he knows to be doubtful.

\section{Hunters at Islington}

These hunters are only shown for appearance and manners. No other test is afforded at Islington, and capability to go over a country has to be taken as a matter of course. Not that there is any reason for doubt, as, if properly ridden, ninety-nine horses out of a hundred, of hunter type, will go over a country well enough. What the Islington show does is to set the type, so that breeders and owners who wish to exhibit can see for themselves the style of horse which is capable of winning. As a rule, the judges ride all the best in each class, and this is the very best way to test a horse, especially with regard to his shoulders. As a rule, the standard at this Islington show is very high, and the horses which win the prizes generally follow up their successes at the later shows. Horses with really bad manners are seldom shown at Islington-though common enough at the country shows-and really plain horses are never seen, for the man who is inexperienced in showing, but ignorant of the class of his horses, chooses another place. There was a time when horse-showing was not the business it has gradually become, when lorses of every description were shown. A hunter class would include half a dozen horses of hunter cut, and as many more plain, three-cornered, underbred brutes, who had absolutely no pretensions to be seen at even a village show; but those days are over, and only good-looking, good-mannered nags can get into the prize list at any show of importance. At one time at some of the local shows local men were asked to judge, and very often judges were chosen not because they had great knowledge of horses, but because they were the important personages of a district. We have a distinct recollection of a hunter class judged by two of these worthies, and of a first prize being given to a horse which spent all its life pulling an old lady's brougham. The horse was not a hunter, had never been intended for a lunter, but had been driven for several years. Its owner was abroad, and her cuachman entered it for the show and won first prize, beating at least four valuable hunters, which were not only previous winners, but were known to be first-rate performers acruss country.

\section{The Polo Pony Show}

Immediately after the Hunter Show comes that of the Polo and Riding Pony Society, to which some reference has been made in the chapter which deals with polo ponies. Breeding classes are again rery numerous, and brood mares, with foals, are shown, as well as stallions and young stock of every description. There is also a produce class, classes for Welsh mountain pony stallions and mares, and for Shetland stallions, mares, colts, and fillies. There is also a class for Eastern sires and for polo ponies bred on Stud Book lines; while the open classes for ponies fit to be played are divided into light weights and heary weights. This show is a comparatively roung one, having only been established in I8ny; but it has done an enormous amount of good, and invariably brings out the best breeding stock in the kingdom. It has special significance, too, because it is far the most important polo pony show of the year, and this is due to the fact that when the summer shows are in full swing polo ponies are hard at work playing polo. Hunters, on the other hand, have nothing to do in the summer, and if an owner cares to get them up for showing there is no interference with their work. Polo ponies, how- 
ever, can be got fit for the Islington show; which is held early in March, many weeks before polo is due to begin, and can afterwards go into training with a view to being plased. The classes of ponies ridden in the ring, and which have to bend, twist, turn, pull up short, and so forth, are ahways strong, whereas later in the year there is some difficulty in filling such classes except at the annual shows at the Hurlingham, Raneligh, and Roehampton clubs. Buth at the Hunter and at the Polo Pony shows at Islington there are jumping classes to finish the diy ; but these are in a great measure put on the programmes with a view to helping the "gate," and the horses and ponies which take part in then are not the same animals which have competed in the ordinary classes. At the polo show there are also turning competitions, musical chairs, and other games, such as are to be seen at a gymkhana; but here again it is the "gate," and not altogether the interests of the breed, which is being considered.

\section{The Olympia Show}

Besides the three breed shows at Islington, Londoners now have the International Show at Olympia, and the Richmond Show inmediately afterwards. The first-named has outlived the criticism to which it was at first subjected. It is, in truth, a wonderful exhibition of horses; but its chief aim is to show the very best animals in their most attractive guise. Thus it caters for the finished article rather than the horse in embryo, and its success has been extraordinary. It has many things in its farour, and notably the setting of the picture is so beautifully carried out that the eye of the visitor is charmed at once. There were at first many horse lovers who strongly objected to horses being shown in a garden, but their opinions have been changed entirely, and now one hears nothing but approval of the Olympia methods; and truly the charming surroundings are vastly more comfortable than the bare and draughty Agricultural Hall, where the spring shows are held. At the lastnamed place it is often bitterly cold in early March, whereas the Olympia show is held in June, and thus has a big advantage. The huge hall is decorated with great taste, all unsightliness is concealed behind gorgeous scenic effects, and the place is thoroughly comfortable. But the one great point which Olympia has made-and which is impossible at Istington-is that it las taught the public to enjor an indoor show. Day after day they come in their thousands, pay high prices for comfortable seats, and go away delighted with what they have seen. It has taught the public, too, that horses of every breed were never better than they are just now, and it gives not only Londoners, but thrusands of country people, a chance of seeing the very best. It appeals also to horsy people of a lower social standing, for it includes many clisses for vanners, for cabs (both fourwheelers and hansoms), and for costers' donkeys. It is also, to some extent, a military display, and mounted policemen are not forgotten. Every variety of horse and every class of visitor is catered for, and - which is perhaps most important of alladmirable time is kept. At many English shows the judging is terribly spun out, but at Olympia there is a time table, which is strictly adhered to, and yet the judging is, on the whole, just as good as it is elsewhere. The plan of having three judges for each class is adopted, so that if two of them disagree as to the merits of any particular horse there is always a deciding rote. In other words, there is always an umpire, and this does away with the frequent necessity - which obtilins at other shows - of a man being callect in from outside.

\section{The Driving Classes}

Barring the jumping competitions, of which mention has already been made, perhaps the driving classes are the most attractive of any seen at the International. In these are exhibited the very best of English and American show horses, and the competitions are stoutly fought amidst great excitement. No such collections of harness horses are ever got together elsewhere, and probably no better built or 


\section{OF THE HORSE}

smarter carriages are seen at any other show-in this country, at all events. It happens, as a matter of course, that many of the best horses come into the ring day after day, now in single, now in double harness; at times driven tandem fashion, and again in the appointment classes. But this is really a good thing, for there are two distinct crowds-one in the afternoon and another in the evening of each day-and this great variety of classes affords the chance of many lots of visitors seeing the greatest prize-winners of the show. Probably the four-in-hand competitions command the best attendance; but no matter how the show is looked at, the broad fact remains that it has now become one of the great attractions of the London season, and that it draws all sorts and conditions of country people to the metropolis, just as the Dublin show attracts men and women from every corner of Ireland to the capital.

Breeding classes were pretty numerous at the first two shows of the International; but it was soon discovered that they did not attract, and they have gradually disappeared from the programmes. There has been, on the other hand, a marked increase in the number of riding classes, and this encouragement of the park hack has almost certainly been productive of an increase in the number of regular riders in Rotten Row. The classes for children's ponies have been increased, too, and are now strong numerically, excellent in quality, and very popular with the crowd. Indeed, the popularity of Olympia is beyond question, and year after year new features are forthcoming, which seldom fail to " catch on." To Lord Lonsdale, Sir Gilbert Greenall, and to other members of the Olympia executive, the horsy public owes a deep debt of gratitude, and perhaps most of all to Mr. Frank Euren, who is the secretary of the show and also of the Hackney Horse Society. It was Mr. Euren and the council of the Hackney Horse Society who first conceived the idea of the International, and Mr. Euren has visited all the best Continental and American shows with a view to enlarging the scope of Olympia by adopting all the best features of the foreign executives.

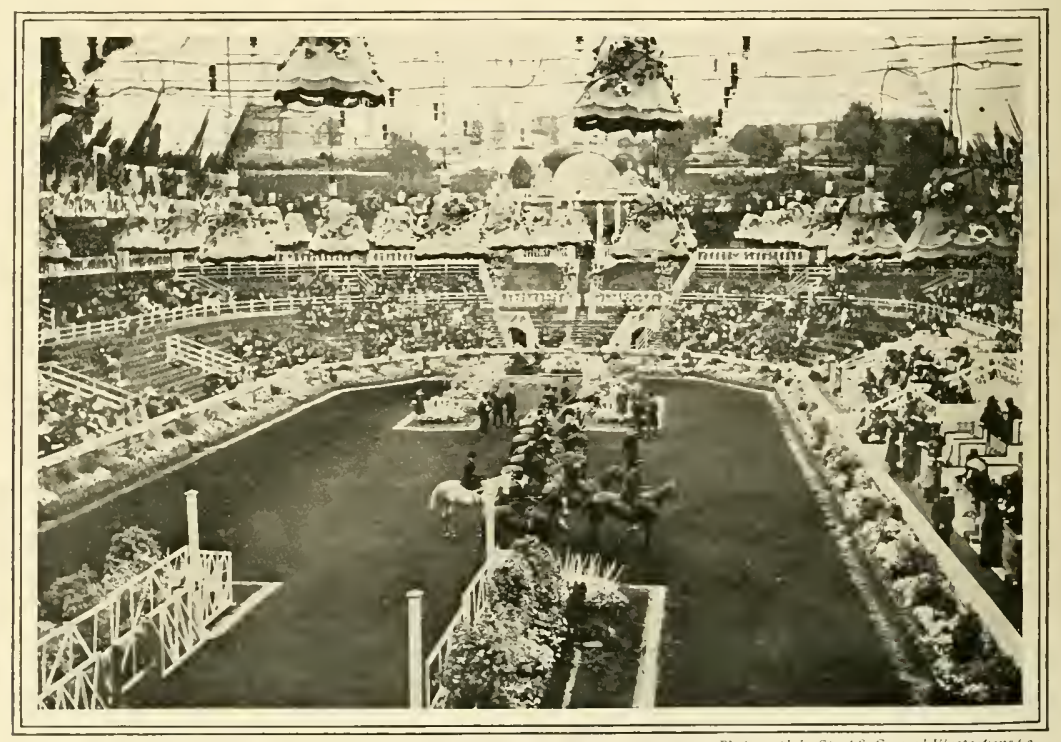

JUDGING RIDING HORSES AT OLYMPIA. 


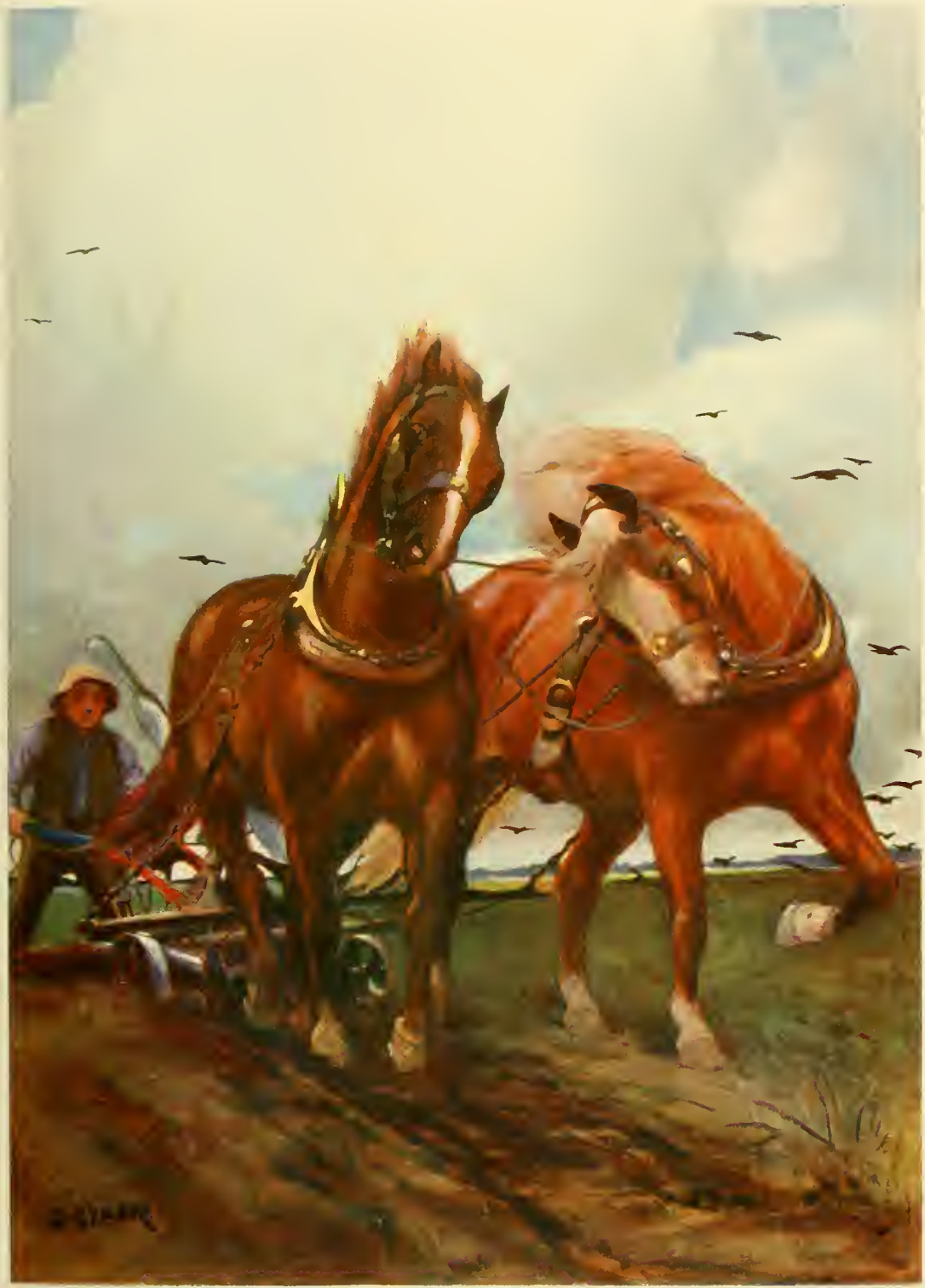

SUFFOLK HORSFS.

Frum a pountug bi c hilewpher c latk, $R I$ 



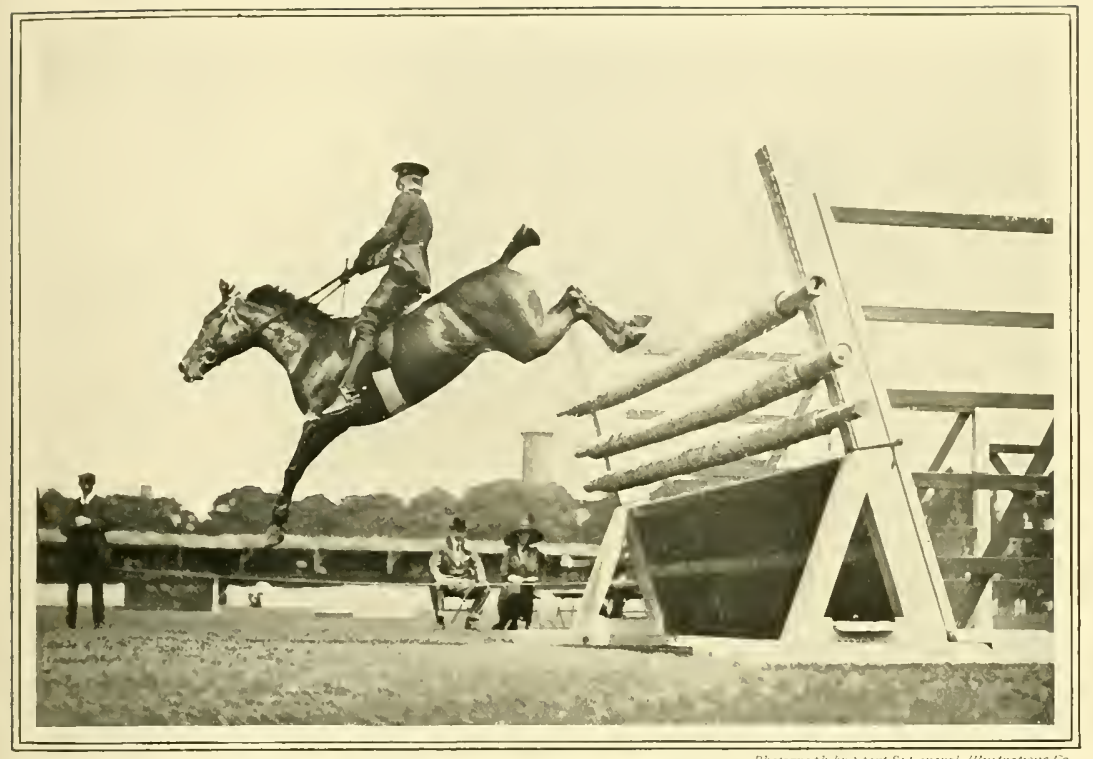

JUMPING AT RICHMOND: LIEUT, W. MAGNEILL ON KITTEN.

\section{CHAPTER XXXVI \\ RIDING AND HORSE SHOWS (continued)}

$\mathrm{R}$

ICHMOND show, in a manner, holds a unique position amongst English horse shows. It is a two days' affair, held in the Old Deer Park, and it possesses the largest and best natural show ring in the kingdom. Whether it is actually larger than the ring at the ill-fated Park Royal, where "The Royal" pitched its tents for two or three seasons, we do not know. The ring at Park Royal was a large one, but we always thought the Richmond ring superior, both in form and in affording a better view to a great number of people. As at Olympia, the finished article is the great card at Richmond, and special features of the show are the hunter and hack classes. Of these there is a great variety. In the big ring hunters can be galloped at a rate of speed which is impossible at Islington or Olympia.
Thus it happens at times-but not very frequently-that horses which have been beaten at the shows held indoors will turn the tables on their former conquerors, merely because they have more room to gallop in and are able to show their powers better than in the more confined area of the metropolitan exhibitions. At Richmond a judge of hunters, who rides the best of each class, can find out much more about the animals he rides than he can do in a small, tan-laid ring, and for this reason the Richmond hunter classes are immensely popular with exhibitors. In a hack great pace is not a necessity, trotting and cantering-especially the latter-being chiefly taken into account; but the hacks at Richmond can be better apprised by the public than they can indoors, and year 
after year a very grand collection of these hurses is forthcoming. During the afternoon harness classes, coaching competitions, and jumping ofcupy the time, and the same argument which has been set forth about the hunters holds good with the harness classes, perhaps more especially in the pace and action class. Even among hackneys, however, the big ring at times alters previous judgments, and in rgro there was a notable instance, when Mr. Nigel Colman's Authority won the championship for single-harness horses. Authority at the London shows had "broken" so frequently in his trot for two or three seasons that he had won practically nothing. though a great performer in leather when he first came out. At Richmond, driven by $\mathrm{Mr}$. Butcher, of Bristol, he went in totally different form, laying himself out on the grass track in a style which many of his admirers thought he had lost, and taking all the single-harness honours.

\section{Other Shows}

Besides the shows which have been mentioned, there are many others within easy reach of London; but it is not necessary to mention them all. Reigate has a good ring, and attracts the best hunters and carriage horses; and there is always plenty of quality at the East Berks show at Hawthorn Hill. But not many outdoor horse shows stand on the same plane as Richmond, the three most notable ones being the Royal, Peterborough, and the Yorkshire. At these three shows the quality is excellent, and all three have much greater scope than Richmond, having breeding classes, both of hunters and Hackneys, as well as competitions for older horses. The Royal, it need hardly be said, is an agricultural show, which, as far as the stock classes are concerned, extends over four days. It is, perhaps, a better show of breeding animals than of made hunters, though the best of the year are generally taken there. But many owners object to having their horses so long away from home, and some even miss the Royal, while showing at Olympia, Richmond, and other places where the show is of shorter duration. As regards cattle, sheep, pigs, and so forth, the Royal show is far the greatest and most important of the year; but in the classes for horses Peterborough and the Yorkshire are probably quite as good. Peterborough is a three days' affair, and here are seen every year wonderful classes of hunter brood mares and young stock of every age, as well as all the best show hunters. Islington, Olympia, and Richmond champions almost invariably attempt to add to their honours at Peterborough, and this applies not only to hunters, but to Hackneys also. Hack classes there are, too, but not so many as at Richmond and Olympia, which shows undoubtedly stand first as far as hacks are concerned. Shire horses also are a great feature of Peterborough, and the show is much on a par with the Yorkshire, which, like the Royal, is also a movable affair, but confined to the county of broad acres. The Lancashire is another good show, especially of Shire horses, and some of the county fixtures take a high place; but most of them are agricultural as well as horse shows. Of the latter there are a fair number of oneday affairs scattered all over the country, and one of the best is held at Bath in the early autumn; while late in the year there is an excellent show at Cardiff. But only those shows which are strong financially, and situated in a breeding district, can cater for breeding classes, which only interest a small proportion of the visitors and do not greatly attract the general public.

\section{District Shows}

There are also in many parts of the country shows of mares and foals, and at times of entire horses-generally the heavy breeds. These district shows are entirely organised with a view to improving the breed, and are exceedingly useful. They are small, local, and conducted at little or no expense, and very often are not reported in the newspapers. In I909 we were present at two of them. At one a local cart-horse society, of which nearly all the members were tenant farmers, offered a prize of froo for the 
services of a Clydesdale stallion to travel their districts, and the horses had to be paraded and one chosen on a certain day. Some seven or eight horses were sent, and duly judged, in the presence of perhaps $15^{\circ}$ people. The whole thing was perfectly simple, but nevertheless very significant, for it meant that a certain group of temant farmers were determined to use a good horse, and by combining were able to command the services of one. The other little show was in comnection with a hunt, and the prizes were nearly all offered by a master of hounds. Here there were two classes of brood mares, and two classes of foals-cart mares in one class and light mares in the other. There was no pomp and circumstance in this show, and no expense except that of the prize-giver; but sume sixty animals were brought from the immediate district, and a great success was achieved. Year by year this class of show is gaining in numbers, and it may be said to form a sort of groundwork of horse showing, for it involves no expense on the part of the exhibitor and yet must do much to improve each particular breed of horse. Hunt shows of many varieties are now quite common and do great good in every district where they are held, and if a new beginner is successful at one of them he is encouraged to take his animal to a more important fixture.

\section{Importance of Shows}

We have thought it necessary to write at some length on horse shows, because at the present day they piay a very important part in the world of horses. Showing horses is not only a business, but a pastime, and year by year it is making grcat headway all over the country. At certain studs of Shire horses the show ring is the chief objective with every young animal that is bred. To breeders of Hackneys the same thing applies, and, indeed, it is probable that if there were no horse shows pedigree Hackneys would soon cease to exist. Hackney ponies, too, are bred in the first place for the show ring, and scores of well-bred hacks would not be so carefully lorked for, and trained when found, if it were not for their chance of winning valuable prizes.

\section{Record Winnings}

Enormous prices are now secured for the best of every breed, whether it be shires, Hackneys, hunters or ponies, and clever men who make a real business of showing can win considerable sums of money at it. Mr. Walter Winans was credited with over $f_{1}, 365$ at the I0ro Olympia show, and at the same show Judge Iloore, of New York. won prizes amounting to $£_{1}, 332$ Ios. On the same occasion Lieut. Godfrey Brooks, of the r6th Lancers, took $f 500$ with his jumpers; Nlessrs. Crow and Murray, of Toronto, won $£ 325$ I6s. Sd., with jumpers: Mr. W. Foster, $£ 37^{\circ}$, with his Hackney ponies; Lieut. Le Clerc (France), £202 I0s.; Mr. Loewenstein (Belgium), f230 I 7s. 2d., both aggregates being won in jumping prizes; M. Riant (France), $f_{3} 4_{0}$, also won with jumpers; and Lieut. Ripet, $£_{2} 89$ I6s. 8d.

\section{Broadwood's Winnings}

At the Peterborough show in I9Io we were told that the champion hunter, Broadwood, whose owner lives at Harrogate, had been sent to London for the fortnight which covers the Olympia and Richmond shows, and that during that time he won f.too in money and cups. Of course, Broadwood is an exceptional horse, but he is quoted in order to prove that if an exhibitor is lucky enough to get hold of a really good one he is sure of a fair return for his money. At the moment we have no hesitation in writing that Broadwood has won over $f_{1}, 000$, and he is still only seven years old. Such Hackneys as Cokers Rosador and Proserpine have also won an enormous sum in prize money, and some of the winning jumpers at Olympia have big amounts to their credit. As a matter of course, prizes vary very greatly in value, and where one show can afford to give a froo for a champion prize another gives $f_{20}$, or even less, but very many of the prize lists have been increased in recent years, for the fact is the public are taking 
far more interest in horse showing than they used to do, and " gates " are bigger than they formerly were. Where horses are part of an agricultural show the prizes must be regulated with those given for agricultural stock, but a show which is only for horses can go on adding to its prize list as long as public support continues to in- achieved by Lieut. Brooks, who took four prizes only, but won a total of $f 500$. This would pay better than running horses in the average steeplechase, and would cost very much less. It can be readily understood that now when jumping prizes are of great value at many shows the training of jumpers is becoming a regular business

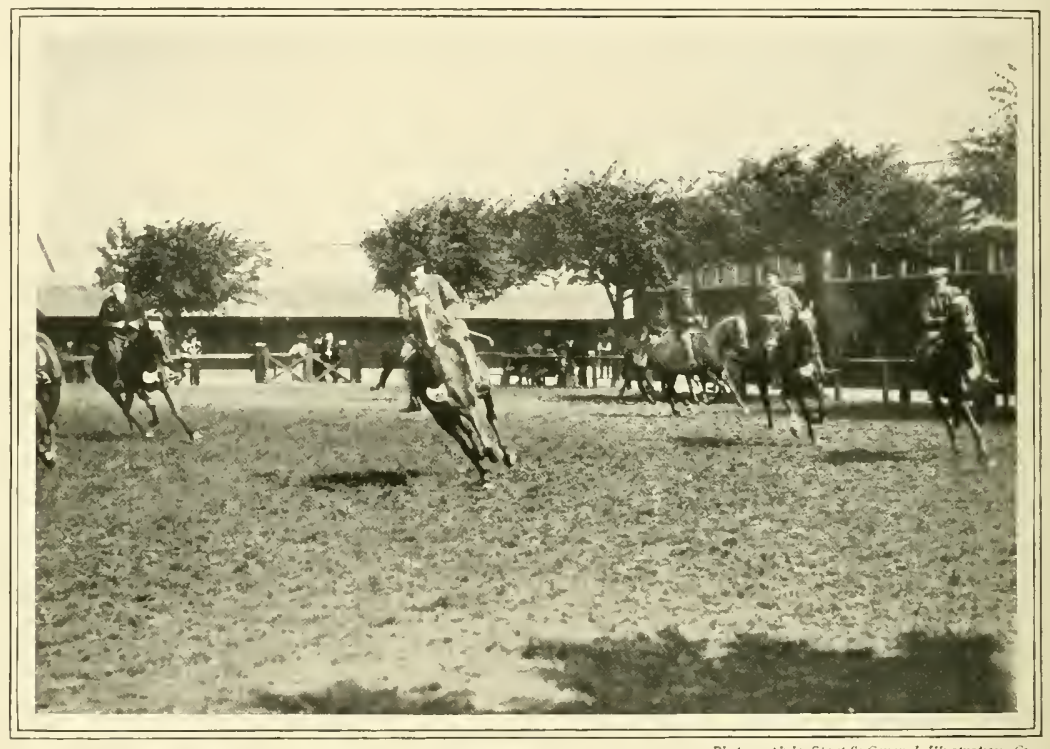

JUDGING HUNTER GELDINGS AT DUBLIN.

crease, though, of course, much depends upon the weather.

The figures given above as regards Olympia are very instructive. Olympia is, it need hardly be said, the richest show of the year, and naturally far larger amounts can be won there than at the country shows. Indeed, besides the winners which have been given, there were nineteen other exhibitors who took over floo apiece, and two exhibitions of four-in-hands were included among them-viz. Mr. E. H. Brown, of Roehampton, who for many years ran the Dorking "Perseverance" coach, and Mr. Alfred Vanderbilt. Mr. Brown won $£ 280$ in three prizes, and Mr. Vanderbilt $f_{160}$ in two prizes. Perhaps the most wonderful total was that among certain exhibitors-just as it has been for many years among certain of the Continental nations. And doubtless in time to come there will be an increase of the best sort of English show jumpers, schooled on what may be termed Continental lines. It present this particular business is in this country confined to a handful of military officers, and to an even smaller handful of civilians. But it is making steady and distinct progress, ard as time goes on valuable horses will be apprenticed to it, and, if the results are satisfactory, brought out at Olympia and other important shows. It is certain, too, that the fancy for exhibiting high-class harness horses is steadily increasing. As a rule, the exhibitors of 


\section{RIDING AND HORSE SHOWS}

these animals are possessed of ample means. or are dealers of high standing, who are wishful of obtaining good prices for horses with strle and action. But the amateur exhibitor of harness horses is at present in a majority, and he it is who is likely to increase numerically, there being a great deal of fascination not only in showing grand trappers, but in the preliminary work of matching and training.

We must not leave the subject of horse shows without making mention of the great slow which is held at Dublin towards the end of August. This is in many respects the greatest horse show of the year, for in the matter of numbers it exceeds all the English shows. But very often it is a case of quantity rather than of quality, a big majority of the entries being sent to the show for sale rather than because they are likely to win a prize. Hundreds of young hunters are brought before the public, and practically all of them are on sale.

\section{Classes at Dublin}

Some of the classes are enormous, so that the work of the judges is at times very hard, though a quick judge can soon pick ont horses which are not up to the mark, and have them sent out of the judging ring. There are at this show various classes for thoroughbreds, and a fair number of harness horses are shown; but it is more a show of the ready-made hunter than of any other sort of horse, and a great number of these are always bought by the English dealers, and a certain smaller number by amateurs who are inclined to trust their own judgment. Fouryear-olds and five-year-olds are generally better than the older horses, and much more freely sold; the fact is that the agents of English buyers of hunters visit all the Irish fairs, no matter at what time of year they are held, and buy whenever they can. There is, in consequence, a constant drain on young Irish stock, and it is surmised that many of the older hunters sent to Dublin have been submitted to English buyers before, and have failed to change hands. There is some truth in this, and it is a fact that winners of hunter prizes at the Dublin show, if bought by English buyers, frequently do not win much at the best English shows of the following year. Many of them, naturally, go into the hands of men who buy the horses to hunt them, and who do not care about showing. Many, indeed, never see the inside of a show ring again, but others which have been successful have in the following year occasionally been unable to hold their own, and are frequently beaten by Irish-bred horses which had never been to Dublin, but had been bought out of the country by English dealers as four-year-olds.

\section{Bargains at Dublin}

At times, however, great bargains are secured at the Dublin show. A horse may be hunter-like and yet not quite good-looking enough to win a prize. Some of the best, too, may be wanting in manners, and yet having great galloping and jumping capability, and will settle down into first-rate hunters when they have had more practice. On the earlier days of the show large sums are often asked for horses which hardly appear to be first rate; but as the week wears on prices come down and an instance of a hucky deal for the buyer may be given. The buver in question was an English hunting man, a very daring horseman, and very powerful. Early in the show he took a fancy to a horse which had shown temper in the ring, and after several days of bargaining he bought it on the last day for the very low figure of $f 36$. The owner had sold two others pretty well, and was doubtless glad to get rid of a horse which was evidently difficult to ride. During the following season the horse's new owner gave the nag about three days a fortnight with hounds; but even then he was hardly tamed, and a course of training made him pull harder than ever. In the spring he won a confined point to point, an open point to point, and thirdly a hunt steeplechase, all within the space of three weeks. Offers to buy him came in, and at $f 500$ he changed hands. His new owner had a lot of trouble 
with him, however, and finding he could not hold lim, passed him on at a big loss to certain hunt stables, and here for two or three seasons he did the work of two horses. He was a great performer in the hands of a man who could hold him, and though not altogether a satisfactory horse, a wonderful Dublin show bargain. Jumping classes are a great feature of the Dublin shows, and in I9Io competitions for military officers were well supported.

\section{The Question of Judges}

One of the difficulties which promoters of horse shows have to contend with is the securing of competent judges. This is by no means a simple matter, for there are no professional judges, and many of the greatest experts of horseflesh do not care about the job. It is not diplomatic to ask horse dealers to judge, and many exhibitors object to veterinary surgeons as judges. In fact, to ensure public respect, the judge must be an amateur who is not likely to be influenced by the surroundings he may find himself in. At all the big shows, or at least at a majority of them, judges who live in a distant part of the cuuntry are preferred, and in local shows a strange judge is also chosen when possible; it is not that local judges are distrusted, but because exhibitors prefer their animals to be judged by a man who has probably seen none of them before, rather than a neighbour, who may be acquainted with every horse in a class. As hunter judges, masters of hounds are in great demand, but it does not follow that a man must be a good judge of horses because he is a master of a pack of hounds, and there have been cases in which this class of judge has signally failed. The plan of having one or three judges perhaps works better than when there are two judges for each class. The single judge must, of course, have a big reputation, and when this is conceded he has only to please himself. Where there are two judges there are, at times, frequent disagreements of opinion, with the result that an umpire has to be called in ; but when there is a bench of three the third man can give a casting vote. In the judging of hacks and hunters it is customarybut not actually necessary-for one or both of the judges to ride a fair proportion of the horses which they consider to be the best in each class, and when this is done a much firmer opinion can be formed as to what a horse's mouth, shoulders, and action are like. Many horses have won prizes after being ridden which would hardly otherwise have done so, and, on the whole, the custom is one which meets with approval.

\section{Why Young Judges are Chosen}

But when judges are being chosen the elderly man of ripe experience is often passed over, just because it is thought that he may not care to ride strange horses in a public ring; and thus it happens that the average judge of hunters and hacks is, as a rule, a youngish man, and very often a light weight. When there is more than one judge at a hunter show one of the judges should be a big man and the other a light weight, because in judging hunters nine men out of ten are inclined-quite unwittingly-to go for the horse which they think would carry them best. In a mixed class light-weight judges frequently ignore the bigger, heavy-weight horses, and on one occasion, when two middle-aged, big men were judging a large class of hunters, in which there were no conditions as to weight, all the prizes went to weight carriers, in spite of the fact that there was a horse in the class which had won innumerable light-weight prizes.

\section{Judges in Harness Classes}

In breeding classes older men often officiate as judges, and, when possible, those who have had a good deal of experience in breeding are chosen. Judges of harness horses are most frequently amateurs who have distinguished themselves by wimning prizes. Such men must necessarily have the eye that picks out the best, and it is their own success in the ring that causes them to be aslied to judge. But only very seldom do we see judges in harness clisses who drive the best of the exhibits. At times a judge will take a horse or two round, but 


\section{RIDING AND HORSE SHOWS}

it is seldom done, and thus it happens that in these classes some three or four very excellent whips show horses which find their way into the prize list time after time. There is a great art in showing horses, and a nuvice, no matter how good a rider or driver he may be in an ordinary way, is often beaten merely because he cannot get the best possible out of the animal he is exhibiting. Many horses have been shown with great success by lady riders, and in the hunter and hack classes at all the great shows the same men and women will be seen showing horses all day long. These riders are experts at showing. Very often they own no horses which are at the show, but they get chances of plenty of riding, and the very fact of their coming in on someone else's horse shows that a good opinion has been formed about that horse, for the expert show rider will not take every chance mount that is offered, and will frequently decline to ride a strange horse who appears to have no chance of getting in to the money. At times a famous show-ring winner-either in harness or saddle - will be ignored by the judges; but, on the whole, there is wonderful unanimity of opinion, and a horse which wins one week in the South will win in the following week up North under an entirely different bench of judges. The fact is, that nineteen judges out of twenty have the same idea of type in their minds. Quality, combined with make and shape and the right sort of action, is what they look for, and in a huge majority of instances the verdicts given inside the ring are endorsed by the public outside. Moreover, those who are outside, or even in the boxes or stands above, are not in a position to see so well as the judge, who is on the same level with the horse he is judging. The public cannot see whether a horse is a true walker as the judge whom the horse approaches or leaves can, neither can they see much of his feet. Those outside can see whether a horse trots with action or gallops out freely; but some of the minutix of the show ring can only be known to those who are on a level with and close to the exhibits, and this is a matter which should be borne in mind by all would-be competitors at horse shows.

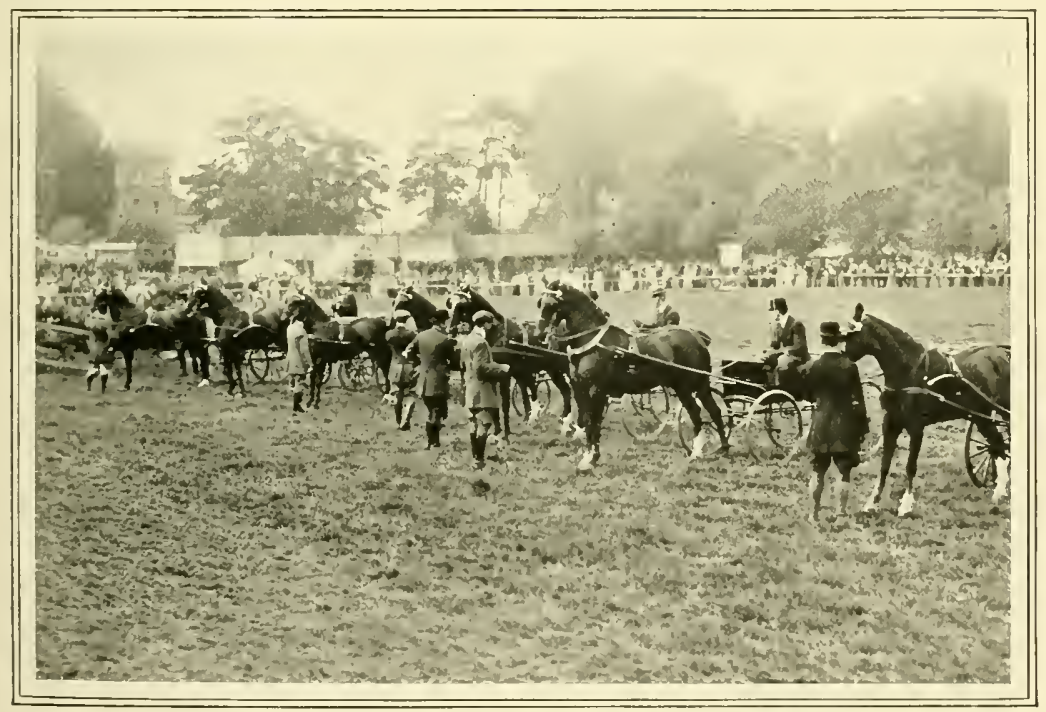

BATH HORSE SHOW: JUDGING SINGLE HARNESS CLASS. 


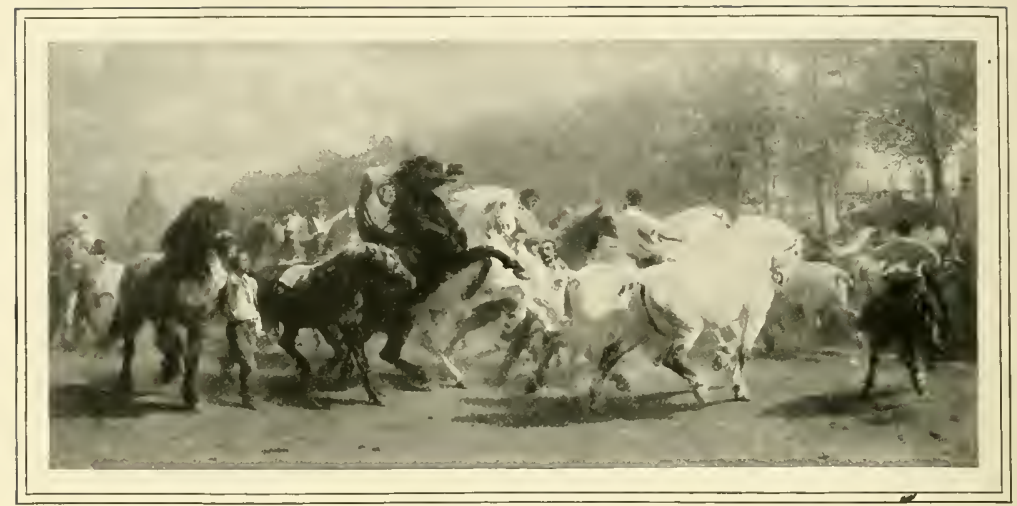

THE HORSE FAIR.

From the painting by Rosa Bonheur.

\section{CHAPTER XXXVII}

\section{HORSE-BREEDING AND BREEDS ON THE CONTINENT}

$I^{N}$ a survey of the present condition of the breeding of horses by Continental nations, it may be appropriate to deal first of all with the thoroughbreds. Every foreign Government which concerns itself closely with the efficient mounting of its army-and nearly all Continental countries possess excellent organisations for the encouragement of the breeding of army horses-recognises the value of the British thoroughbred. For at least one hundred years the policy of importing high-class English thoroughbred stallions has proved a paying one. They have been placed at the disposal of farmers and other breeders at purely nominal covering fees, and apparently foreign Governments have been well satisfied with the results, as they have never ceased to come to these islands whenever their studs were in need of replenishment. It may well be asked, why have not foreigners during all these years been able to establish their own race of thoroughbred stallions which would make them independent of English blood in breeding military horses? It cannot be because England has any monopoly of good racing, by which the merits of thoroughbreds can alone be properly tested. Racing flourishes in France, and to a lesser extent in Germany, AustriaHungary, and elsewhere on the Continent. How is it, then, that our neighbours have not made themselves free of any further obligation to the thoroughbreds of this country? That question has worried the best authorities on the Continent, most of whom have been forced to the conclusion that nowhere in Europe is soil and climate so remarkably well adapted for the breeding and rearing of thoroughbreds as those of the British Isles.

One wonders how often British breeders of blood-stock have been solemnly warned not to go on selling their good horses to the foreigners. A thousand and one times they have been assured that they will bitterly repent having allowed so much valued blood to pass out of the country. But have British breeders had cause for regret so far? We think not. On the contrary, the presence every December of Continental buyers at the great Newmarket sales cheers the heart of 
the British breeder who has mares and other stock to sell. He knows that the marketable value of thoroughbred horses here would decline very appreciably if foreign competition were to be withdrawn. In other words, blood-stock breeding in England under prevailing conditions is helped and not retarded by the lucrative foreign market. Now and again our Continental neighbours secure a prize with which we are very sorry to part. Flying Fox, for example, proved to be a great loss to the British stud, and a more recent case is that of Cyllene. But occasional gems of that kind apparently serve merely to whet the foreign breeder's appetite, and back he comes for more of a similar sort, bringing with him the gold that helps to place our horse-breeding industry upon a profitable basis. We still have alarmists who view the expatriation of every thoroughbred with concern, but their anxiety for the future of our stock is to a great extent misplaced. The country is rich enough in thoroughbred horses to continue to stand the strain.

\section{A Grave Warning}

As far back as I 22 I Mr. Charles Weatherby considered it his duty to utter a grave warning on the subject of the exportation of British stock. "If any proof were wanting," he wrote in one of the early volumes of the "General Stud Book," " of the superiority of the English breed of horses over that of every other country, it might be found in the avidity with which they are sought by foreigners. The exportation of them to Russia, France, Germany, ètc., for the last five years has been so considerable as to render it an object of some importance from a commercial point of view: But this adrantage, some of our Continental neighbours are of opinion, will not long remain with us. They are fully aware of the source whence we derive our superiority; and are, in consequence, endeavouring to establish races on the English plan, which, together with a more careful selection of stallions and mares than they observe in England, will very soon, they say, enable them to excel us, and they anticipate a day, not very distant, when the English must send to the Continent, if not for speedy at least for sound horses." since that was earnestly written by Mr. Charles Weatherby ninety rears have elapsed. And what changes in the situation are to be observed? Our neighbours, in truth, have managed to "establish races on the English plan"; they have, too, mated their sires and mares witl all the knowledge and judgment derived from a study of the scientific side of breeding. Yet still they do not "excel us," nor have we to go to them for either speed or soundness. Mr. Weatherby wound up with a note of optimism, as though he feared that he had drawn too dismal a picture. "The hint about soundness," he said, " may be worth attention, but for the rest, with the advantages this country already possesses, and so long as horse-racing continues to be followed up with spirit by her men of rank and opulence, there can be little to apprehend,"

\section{The Pari-Mutuel}

One of the most important innovations of modern times on the Continental Turf was the introduction of pari-mutuel betting under Government auspices. A small percentage of the profits have been devoted to the encouragement of horse-breeding, and in France especially the funds have been used to excellent purpose. However, there are now unmistakable signs that the parimutud, which by a recent law has practically ousted the bookmaker from French race-courses, is not at all popular with many owners in that country. Several, indeed, have already given up their racing interests and breeding establishments. It would be strange if the pari-mutucl, expected to be of much value to the breeding industry, should in the long rum prove detrimental to it.

Of all Continental nations the French have approached nearest to England in their racing. They have, too, been more successful than Germany and adjoining countries in breeding for the Turf. At BadenBaden and other Continental race meetings where international rivalry finds a vent, the 


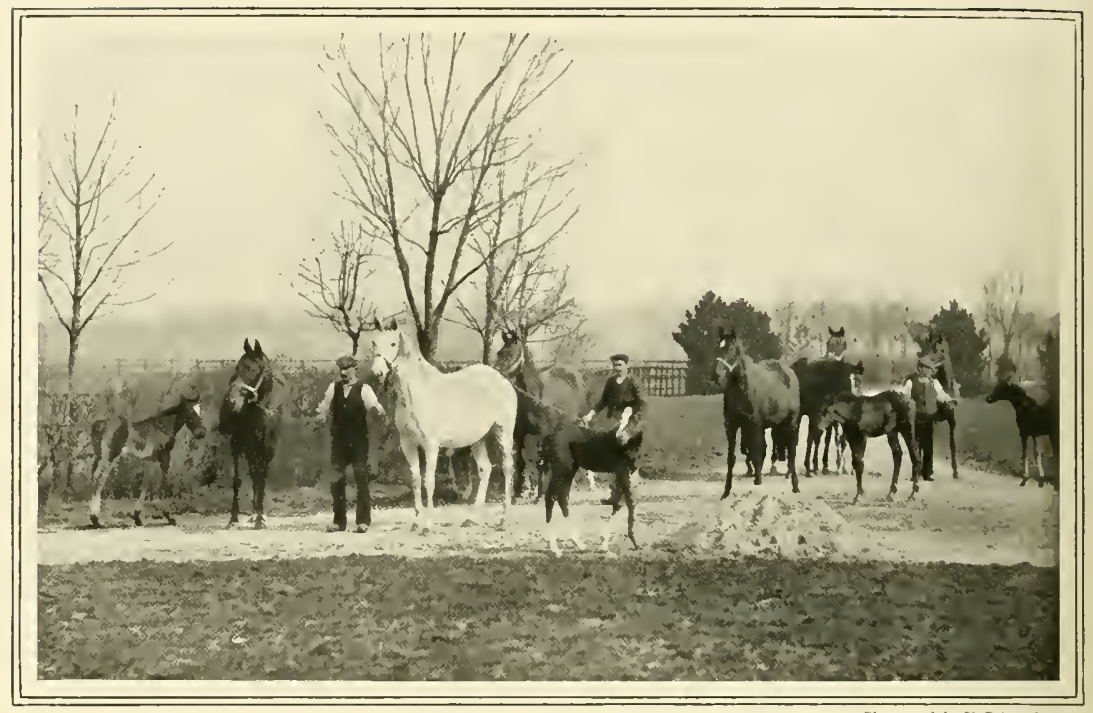

AT THE HARAS DE JARDY : COMING BACK FROM THE PADDOCKS IN THE EVENING.

French have consistently done well. Further, from time to time they have sent good horses to take part in English races, and here again their success has not been inconsiderable. In one or two cases English owners have found it not unprofitable to visit the annual yearling sales at Deauville; while France has had the satisfaction of exporting two $f 30,000$ young stallions to the Argentine, thus encroaching, almost for the first time, upon a sphere of commercial activity which English breeders have regarded strictly as their own. It should, however, be noted that both the stallions in question-Val d'Or and Jardy-were sons of Flying Fox, and practically English in pedigree. France enjoyed yet another triumph when Lutteur III. so brilliantly carried off the Grand National Steeplechase at Liverpool in 1909 ; but again the sire of the winner was an English horseSt. Damien, son of St. Simon.

There are breeders of blood-stock in France who may be worthily compared with the leading breeders of England, both in regard to the exceedingly keen interest they evince in their studs and the whole-hearted support they give to the Turf. MI. Edmond Blanc may be regarded as the foremost blood-stock breeder in France. He is the owner of the best and largest private stud in Europe. Early in the present century his successes were phenomenal. On one occasion his horses, Quo Vadis, Cains, and Vinicius, filled the three leading places in the Grand Prix de Paris; and when the first stock of Flying Fox appeared on the Turf all things went his way. Suddenly the tide of success was checked by the outbreak of a malignant type of influenza in his stables. His horses lost their form, and to this day MI. Blanc has not fully recovered that place of supremacy among the leading owners which he held previously to the extremely unlucky setback at La Fouilleuse. In IgIo 11. Blanc had three stallions at the Haras de Jardynamely; Flying Fox (I 896 ), by Orme out of Vampire by Galopin; Chaleureux (I89t), by Goodfellow out of L'Eté by John Davis; and Ajax (I $90 \mathrm{I}$ ), by Flying Fox out of Amie by Clamart.

Flying Fox was purchased on the death of the Duke of Westminster in I 900 for 37,500 guineas, and the man who was 


\section{HORSE-BREEDING ON THE CONTINENT}

courageous enough to give that vast sum for a four-year-old horse is surely deserving of all the profit the speculation may produce. And it may be said at once that II. Blanc found Flying Fox to be a sound bargain from the first, and he has never had cause to lament his purchase. Chaleureux, on the other hand, was picked up for the price of "an old song." Once more M. Blanc's lucky star was in the ascendant, as no sooner had Chaleureux become the French breeder's property than the horse's daughter, Signorinetta, reflected glory on her sire by winning the Derby and the Oaks. M. Blanc's other stallion, Ajax, is of his own breeding, and one of the grandest thoroughbreds it has been the writer's pleasure to look over. True, Flying Fox is a sire whose strong lines and beauty of conformation would compel admiration; but Ajax is lengthier, more raking, and has, in addition, all the extreme quality of his sire. The Haras de Jardy is a model establishment of its kind, and we treasure the memory of a visit which M. Blanc kindly allowed us to make when Flying Fox was in the heydey of his success. From the radiance of Paris, overflowing with life in its gay and crowded boulevards, a journey of less than ten miles brings one to the quiet seclusion of the Jardy paddocks, bounded by leafy lanes and sheltered by thick belts of young trees. To walk through those paddocks and find such mares as the Oaks winner Airs and Graces: the noted La Camargo, and others equally famous, is a sheer delight to the lover of thoroughbreds.

An American sportsman, MIr. IV. K. Vanderbilt, is one of the largest and most successful breeders of blood-stock in France. In I 1908 his horses won $\{52,563$ in stake money, and in the following season $f \downarrow 6,127$. He has a good deal of English and American blood at the De Villebon Stud, but his three stallions are French, comprising Maintenon, who won the French Derby of 1906 and $£_{31,826}$ in stakes during that season; Prestige, who was almost as good as

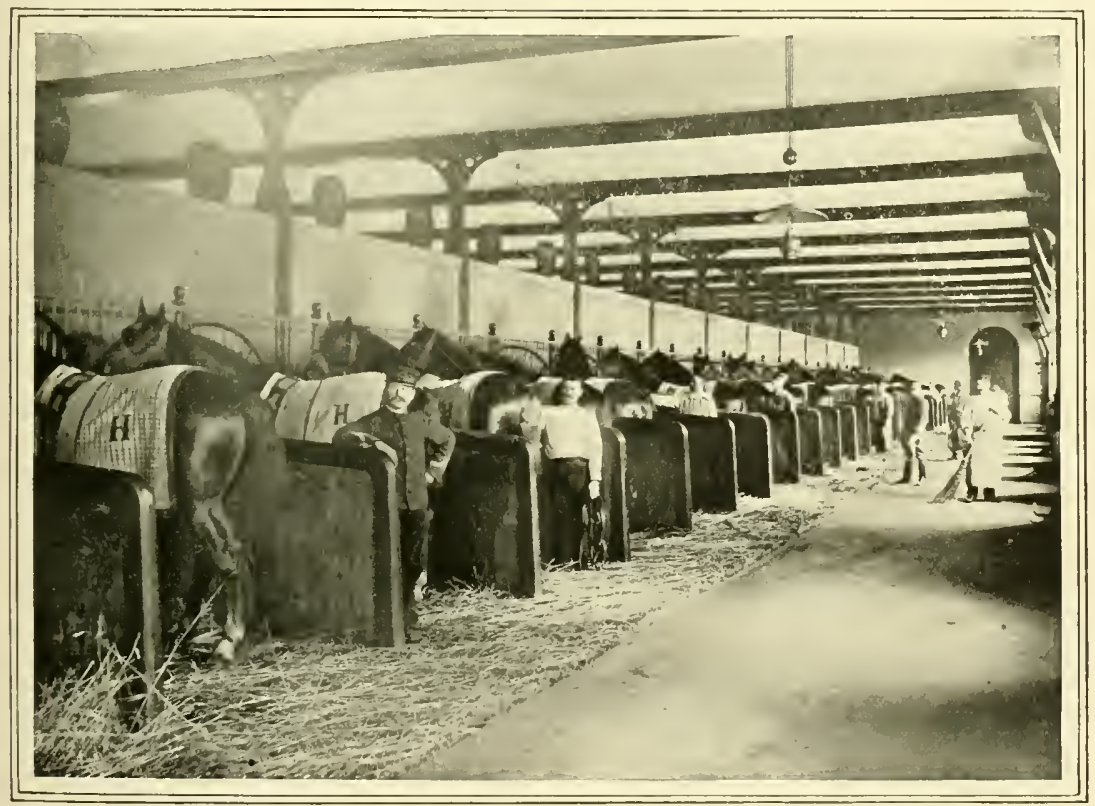

STABIES AT THE FRENCH MLITARY STALLION DEPOT OF ST. LÓ 
Maintenon; and Turenne, a son of Le Hardy. Baron E. de Rothschild's stud at Meautry, near Deauville, is equal in strength to Mr. Vanderbilt's, and very little inferior, indeed, to M. Blanc's. Here many English brood mares are also to be seen, but the five stallions were all bred at home. Another particularly fine stud is that of M. Maurice Caillanlt, at Nonant-le-Pin, where the visitor will meet such high-class horses as Chéri, Macdonald II., and the Chester Cup winner, Querido. M. E. Veil-Picard, too, has a notable stud at Neaufles, including the handsome Orme horse Cupbearer, purchased in Igog from Ireland for 8,000 guineas; while Mine. Lemaire de Villers, who has bought freely at the Newmarket December Siles, has a valuable haras at Saint Lucien. These are just a few of the leading French thoroughbred studs. They may be said to exist entirely for the Turf, and they owe their prosperity to the excellent sporting instincts of their respective owners.

\section{The French Military System}

The organisation of the breeding of military horses in France is particularly thorough, and the question has been asked: "What could not be done in England with a system like that in France?" Without being in the strict sense a horse-loving nation, France produces probably the finest military horses in the world, and it is all mainly due to the enormous organisation which makes it profitable for every farmer to assist in the vast breeding industry. In Germany the organisation is also remarkably good, but the results in France are better, as that country has the advantage of possessing a variety of breeds suitable for all the different requirements of the army; from light cavalry remounts to heavy artillery and wagon horses; whereas in Germany draught horses are not abundant. One cannot but admire most sincerely the energy and perseverance which have been displayed in France in breeding under Government directions. Remember the devastating effects of the Franco-German conflict, and imagine the utter annihilation of the horse-breeding industry that ensued in many provinces of
France. Yet it has been possible to reconstitute the elements lost in $1870-7 I$, to improve the breeds indigenous to the country to introduce blood from England and America with much advantage, and finally to increase the production to limits which were not dreamed of in days before the great war.

\section{National French Expenditure}

Money has never been stinted since the National Assembly first put the breeding machinery into motion. Each year the sum expended on horse-breeding by the French Government has increased, until in Igog it reached in round figures the colossal total of $f 8,0,000$, of which about $f 80,000$ was derived from the pari-mutud. In I 885 the annual grant amounted to $£ 325,520$, so within fourteen years the sum has almost trebled itself. The bulk of the money goes in the maintenance of twenty-two stallion depots, containing in Ioog no fewer than 3,425 sires of various breeds. These horses stand during the covering season in the country districts in twos and threes, and their services are reserved-at a very small covering fee-for mares belonging to farmers and other private breeders. Thanks to this system, the production of horses in France is now believed to be amply sufficient for the requirements of the army and trade. The prices paid by the Government for troop saddle horses in Igog was from $£_{3} 8$ to $£ 5 \mathrm{I}$; $£$ to for artillery horses ; $£_{5} 6$ to $£_{72}$ for horses for the riding schools; and $£ 54$ to $£>I$ for officers' chargers.

\section{French National Breeding Estab- lishments}

Apart from these stallion depots, the only regular Government breeding stud is the Haras de Pompadour, in the Department of Corrèze. Sixty thoroughbred mares are kept here, which are intended solely for the production of Arab and Anglo-Arab horses. The largest of the stallion depots is that of St. Lô, in Normandy, from whence over foo sires are sent out for service. Another big establishment is the Haras le Pin, in the department of Orne, established in the reign 
of Lonis XIV. "The beauty of the place is striking," says a writer in the "Live Stock Journal Almanac" for Ioro ; "its gardens and gates compare with those of Hampton Court, and the stables are even nore elegant, albeit they are older, than those which the late Duke of Westminster erected at Eaton... There are 300 stallions within its walls." In discussing the metloods of the Government, he continues: "The authorities have no objection to paying as much as $f I, 000$ or even $f_{2}, 000$ for a halfbred carriage stallion, with a tinge of hackney blood in him most probably, or $£ 5,000$ to f6,000 for a thoroughbred. If found at any time afterwards to be defective or suffering from any hereditary disease, the stallion is castrated, put aside, and twice a year there are public siles at which such a horse might go for a few pounds. No horse goes out of a stud entire if there is a doubt about its soundness. Old horses, though sound, are killed rather than sold." The same writer reports that at the Haras le Pin there are twenty-two thoroughbred stallions for the use of the farmer-breeder. If the latter has a thoroughbred mare he pays for the sire a service fee of $f_{t}$; and it should be remembered that for this he gets the use of a horse like Prince William (who all but won the Doncaster St. Leger, and was bought by the French Government for $\left.f_{5}, 000\right)$, or Frontier, who was bred by the late Duke of IVestminster's stud, and cost $f 6,000$. Halfbred mares are served by these fine thoroughbred horses for a nominal fee, while the services of a Norman Hackney or other halfbred stallion may be commanded at a fee as small as three shillings.

\section{French Government Supervision}

In addition to the elaborate system of providing sound Government stallions for the use of breeders, a strict surveillance is exercised in France over all stallions, the property of private owners, whose services are open to the public. These are examined by Government inspectors, whose duty is to determine whether or not they are afflicted with roaring or intermittent ophthalmia. Only stallions that have been passed free of these blemishes are allowed to cover public mares. Such stallions are registered as " accepted," and between 7,000 and 8,000 of them are passed for service annually. Then there are two other classes of private stallions, namely :-

(a) "Approved" stallions, which are recognised as capable of improving the breed of horses, and which receive an annual premium from the Government, varying from $f_{12}$ to $f 80$. A stallion standing at a higher covering fee than too francs $(f t)$ is not entitled to a premium, though accorded a certificate of approbation.

(b) "Authorised" stallions, which are judged good enough to maintain the breed of horses, though incapable of improving it. These horses do not receive premiums, but they have an official status which enables their progeny to take part in the shows subrentioned by the State.

\section{Government Premiums}

The premiuns to private stallions referred to above constitute a formidable item in France's expenditure on horse-breeding, but it is exceeded by the total of preminms given to brood mares, which includes special premiums to thoroughbred mares devoted to the production of Arab or Anglo-Arab horses. The latter are applied to certain districts of the Pyrenees, where the mares are too scattered about for it to be possible to assemble them in a show yard. The premiums in this instance are given on the recommendation of the Grovernment stud officials. The ordinary brood mare premiums are awarded at the various shows throughout the country.

The show system enters very largely into the French Government organisation, and the most interesting show of the year is that promoted at Paris by the Minister of Agriculture. Here the finest examples of the best breeds in France may be seen. In I Io the show was held at the Champ de Mars in the middle of June, when prizes to the value of $f 8,368$ were awarded by the State. The horses were divided into five sections. First in the catalogue came the thoroughbreds, comprising English, Arabs, 
and Anglo-Arabs. Section II., the largest in the catalogue, was devoted to half-bred stock; this included half-bred Arabs (possessing at least 25 per cent. of Arab blood), trotters, Normans (within the limits of the stallion depots of Le Pin and Saint Lô), Vendéens and Charentais horses (within the limits of the stallion depots of
Ardennais, Boulonnais, Breton, Nivernais, Percheron, and Mulassière breeds. Finally, there were sections at the show for asses and mules.

Thus it will be observed that the whole breeding strength of France was represented at the Champ de Mars, and no more instructive spectacle could have been pro-

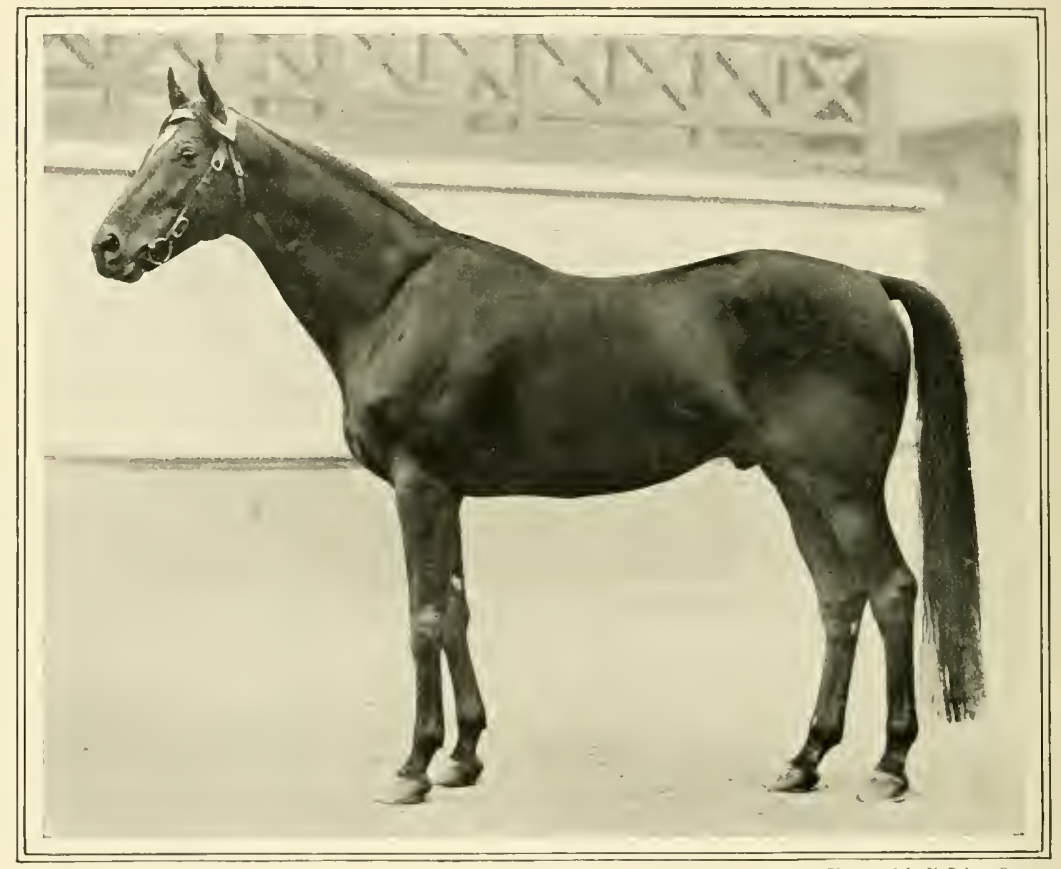

11. BLANC'S AJAX.

Hennebont, Lamballe, La Roche-sur-Yon, and Saintes); horses from the midland district of the country (stallion depots of Angers, Blois, Cluny, and Annecy) : and horses from the northern. eastern, southern, and south-eastern districts (stallion depots of Libourne, Villeneuve-sur-Lot, Pau, Tarbes, Aurillac, Rodez, Perpignan, Pompadour, Besançon, Compiègne, Montier-en-Der, and Rosières).

Section III. was a small one allotted to the Postier breed from Brittany. Section IV. was for draught horses, comprising the vided for anyone interested in the breeds of the country.

One must fully recognise the importance of the heavy draught horses of France, which flourish most in the northern provinces. But for military purposes the chief breeds are the Anglo-Norman, large, robust, and very active, which is found in the north and north-east, and the lighter Tarbes breed in the south, which, in the opinion of some French military authorities, constitutes the saddle horse par excellence. They are from If hands 2 inches to 15 hands in height. 


\section{HORSE-BREEDING ON THE CONTINENT}

Accurding to one authority, the horses of the Anglo-Norman type were originally created by the fusion of pure English blood and that blood which is indigenous to the northern and north-eastern districts of France. The proportion of English blood in the Anglo-Norman is reckoned at 5o per cent. for harness horses, and 75 per cent., and even more, for saddle horses. Horses of the Tarbes type are created by the mingling of three bloods-the Arab, the benefit to Irish horses is problematical, but this much is certain: the breed is highly appreciated by the authorities of Italy, Germany, Russia, Austria-Hungary, Switzerland, etc., for the production of cavalry horses. No Englishman knew more of Norman horses than the late Mr. John Hetherington, and when he gave evidence in 1897 before the commissioners appointed to inquire into the horse-breeding industry in Ireland, he was asked whether any foreign

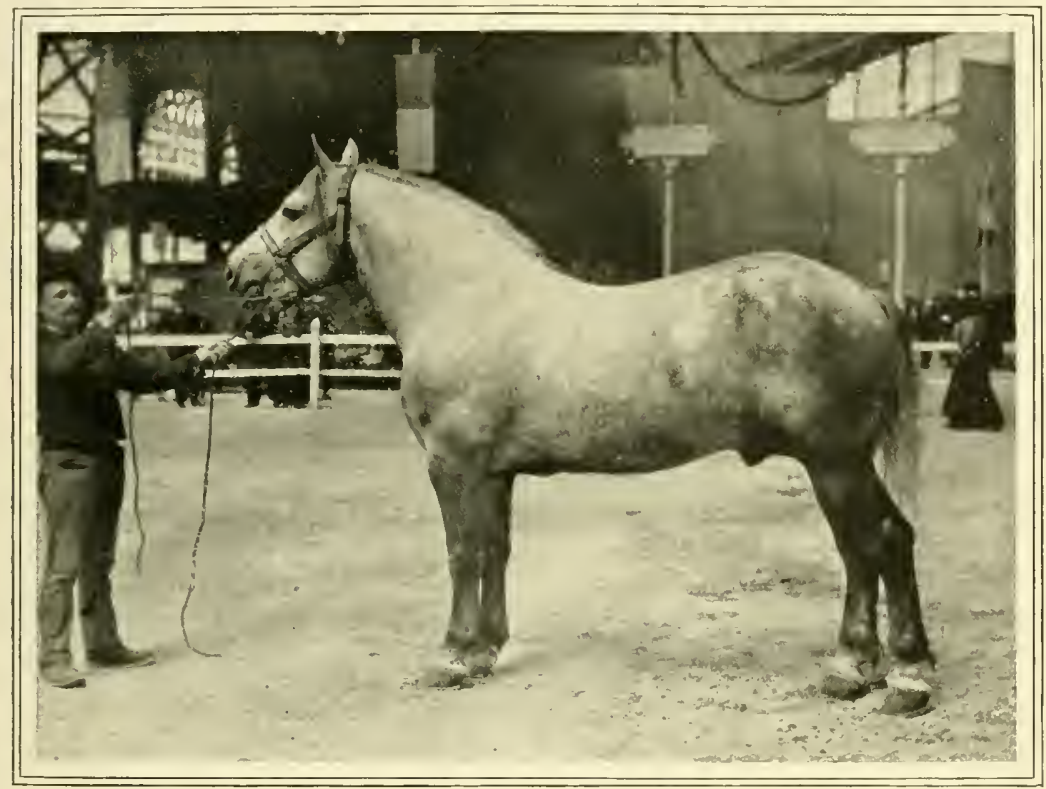

RAVISSANT: A TYPICAL PERCHERON STALLION.

English, and that indigenous to the south of France, itself of eastern origin. According to Comte Imbart de la Tour, the normal height for light cavalry in France is $\mathrm{I} \mathrm{m}$. 47 to I m. 50, for cavalry of the line from I $\mathrm{m}$. 50 to I m. 54, for the reserve cavalry from I m. 54 to I m. 6o, for artillery horses from I m. $4^{8}$ to $I \mathrm{~m} .54$, and for gendarmerie horses I m. 52 .

A proposition in rgog to introduce some Normandy sires into Ireland met with much disapproval from the breeders of the green isle. Whether the Norman blood would be of any
Government bought sires from Normandy farmers. "Every Government in Europe buys out of Normandy," was Mr. Hetherington's emphatic reply. No doubt the objection of Irish breeders to receiving the Norman blood is based on the fear that it would introduce Hackney characteristics. This fear is undoubtedly well founded, for the Hackney blood flows freely in the veins of the modern Norman horse, having been used to give him action. He was formerly a rather heavy but very good-looking horse, yet lacked something in activity. And so the French 
breeders had recourse to the Hackney, with the idea of imparting greater life and action to him.

\section{The Norman Breed}

The Norman breed makes its influence felt over so extensive an area nowadays that it may be well to examine his ancestry. Commandant Cousté, in his "Stud Book" of the Norman breed, states that the horse is a "half-bred" (un métis), originally resulting from the cross of the English thoroughbred horse or his derivatives with the native mares of Normandy. In tracing the pedigrees of sires formerly used or still being used for covering in Normandy one always gets back to the three great English sires-Matchen, Herod, and Eclipse. The descendants of these horses, many of them half-bred, undoubtedly created the AngloNorman breed from the native mares. Then came the introduction of other foreign blood for the purpose of securing superior action and swiftness. From 1836 to i 8 to the principal towns of Normandy began cautiously to organise their first trotting races. In I85t was imported The Norfolk Phenomenon, and that famous Hackney seems to have had a greater influence on the Norman breed than any other horse. The blood of Herod is no longer represented in the great trotting families of Normandy, at least in the stallions, and the blood of Eclipse is sustained only by the powerful family of Phaeton and his sons. On the other hand, the descendants of Matchem are more and more sought for by the breeders of Normandy, while the descendants of The Norfolk Phenomenon number almost a third of the effective force of Norman stallions. At the present time there are not more than five strains of sought-for blood, viz. :-

FAmLy of Matchem.

The blood of Conquérant.

The blood of Normand.

$$
\text { FAMILY OF ECLIPSE. }
$$

The blood of Phaeton.

Famly of The Norfolk Phenomenon.

The blood of Tigris.

The blood of Niger.

Commandant Cousté states: "The Norman breed has become one of the most remarkable trotting breeds of the world. In twenty-five years one may say that its speed has improved by one second a year. The energy and power of the sires are largely spread abroad, and have helped to make of the Norman horse what one calls a horse of qualities."

\section{The Limousin}

Among the riding horses of France the Limousin, which came from Saracen ancestors, once held a great reputation, and his decadence, dating from the time of the Revolution, shows that the love of riding to hounds, never so strongly developed in France as in England, goes hand in hand with the improvement and development of the breed of superior light horses. The Guvernment has made attempts to revive the Limousin breed, but with little success. Other old French breeds which for one reason or another have lagged behind in the march of progress are the Camargue, a hardy race of ponies, generally of a light grey colour, which formerly flourished in the Rhone country near the Mediterranean ; and the Lorraine breed, which used to display unmistakable tokens of an eastern ancestry. Having been badly affected by the wars of France, this animal has lost a great deal of his former quality, and is now just a plain harness horse on the heavy side. In Brittany there is a stout race which, crossed with the Percherons, make extremely serviceable draught borses; but the bidet and the doublcs-bidet are perhaps the most trpical breeds in Brittany. These are the active cobs and ponies, very powerful for their size, which the Breton men and women ride to market and use for all general work.

\section{The Percheron}

Undoubtedly the best-known breed of France outside that country is the Percheron. The name is derived from the province of Perche. He is probably the most active of all heavy draught horses; certainly his superior action justities the description often applied to him-" a grey trotting carthorse." Long before the Government of France elaborated their present gigantic 
system of fostering horse-breeding, the peasants of Normandy knew the value of the Percheron. They bred him for his supreme utility for all manner of draught work. He could do his twenty-five or thirty miles on the road; he could put in a good day's work on the land. In the old days he stood from $I_{5}$ hands 2 inches to 16 hands, and a typical Percheron of that time has been described as a " blood animal with beautiful limbs and beautiful neck, the tail set on well, and the body as round as a beer barrel." In modern times the Percheron has increased in weight; he is less of a sharp harness horse than a heavy draught horse. In height he stands from I6 hands to 16 hands 2 inches. Nevertheless, the clean limbs and neat head which always distinguisled him are retained. Years before the motor-bus was dreamed of, the Percheron breed supplied London with many of its best omnibus horses. But for heavier work the Shire horse, the Clydesdale, and the Suffolk have held this Frenchman at bay in England.

\section{The Percheron in America}

In America and Canada the Percheron has met his greatest popularity. In the United States especially the breed has successfully rivalled the Clydesdale. The American Percheron Stud Book was founded in 1876 , and this blood was mainly responsible for the magnificent team of six greys sent over to England by Mr. Ogden Armour for the International Show at Olympia of I907, where many Englishmen for the first time saw the remarkable agility and handiness of these tremendous horses, including the special favourite of the team, Big Jim. American Percherons show how greatly the breed has changed since the time when the Percherons were the post-horses of France. The breed is nowadays frequently the victim of misdescription, the term "Percheron" being applied to horses possessing few: of the best characteristics of the race. It should be borne in mind, therefore, that Percheron horses include only the horses recorded in the Percheron Stud Books of France, Canada, and the United States. The
General Draught Horse Stud Book of France embraces Percherons and the various other draught breeds of the country, some of which are considerably intermixed; but only purebred Percherons may be recorded as Percherons. In the United States no draught horse is more appreciated than the gros Percheron, and the premier horse of the breed in America in Igon was Hoche, a son of the famous sire Etudiant. Weighing 2,000 lb., he was described as the "sensation" of the Pennsylvania Live Stock Breeders' Association's show at Philadelphia. During the Chicago International show in the same year the Percheron stallion Carnot sold for $f 2,000$ - an indication of the high value placed on the old French breed on the other side of the Atlantic. In Canada Clydesdales are the dominant breed of heary horses in the prairie provinces, and Percherons come next, followed by Shires, Suffolks, and Belgians. A French writer has stated that the Percheron was originally bay or sorrel in colour, but was turned grey because the postmasters, the chief purchasers of the breed, gave better price for grey horses. Now there are signs that the Normandy breeders will eventually revert to a darker shade, in obedience to the dictates of American fashion. A coarser type of carthorse than the Percheron is the Boulonnais, extensively bred in France for agricultural and heary van work. He is a very powerful horse, standing from $x 6$ to $I 7$ hands. Then there are the Ardennais and Nivernais, both good draught breeds; while a profitable industry is the breeding of mules from the big heavy mares of Poitou, known as Poitevin mulassières.

\section{The German System}

From France to Germany is a natural transition when the question of horsebreeding is being considered. Both nations are equally alive to the necessity of encouraging the industry by all possible means. There is one noticeable difference in the methods pursued in the two countries; whereas France prefers the stallion depot system, planting sires in different villages and agricultural districts, Germany believes 
in the system of maintaining big stud-farms, with many brood mares at each. Prussia has always held her own as a horse-breeding land, and the cavalry of Frederick the Great was unsurpassed. In recent years good progress has been made in other parts of the German Empire.

\section{Influence of the Thoroughbred}

The original stock of horses in Prussia appears to have benefited largely by the infusion of eastern blood at the time of the Saracen invasion of Europe, and towards the end of the eighteenth century the English thoroughbred began to do his share towards improving the quality of Prussian horses. This same thoroughbred still plays what is seemingly an indispensable part in the breeding industry of Germany. Sir Walter Gilbey has told us that during the nineteenth century the Hackney blood was widely diffused orer the horse-breeding districts, particularly Hanover, Oldenburg, Holstein, Mecklenburg, and East Friesland. But previously to the introduction of fineactioned steppers from Norfolk and Yorkshire, Oldenburg was noted throughout the Continent for its handsome coach-horses, and it is stated that Oliver Cromwell, at the time of his Protectorate, received as a gift a team of coach-horses from the Duke of Oldenburg. Thus the Oldenburg horses may be reckoned among the national breeds of Germany, and the Hanoverians-those handsome creams so often used in English State processionsand the Mecklenburgs may also be included. A writer in the Cornhill Magazine points ont the coincidence that Germany has the distinction of supplying both the cream Hanoverians for our State coaches and the black Drenthe horses for our funerals, the latter being chiefly bred near Osnabruck, in Hanover.

\section{German Light Horses}

Germany's most typical breeds are comparatively light horses. According $t 0$ "Les Haras et les Remontes" (Conte de la Tour) Eastern Prussia is chiefly responsible for producing the best caralry remounts. Western Prussia breeds the same type, but to a less important extent. On the shores of the Baltic Sea the horses are of a more substantial stamp, but in Posen again the breed is light.

\section{Breeding in Hanover}

Saxony is now producing a good powerful horse, but the Bavarian and Saxon cavalry for many years have been almost exclusively remounted from East Prussia. In the industrial districts on the shores of the Rhine there is little important breeding, and heary and powerful horses are in chief demand. Hanover is of great importance from the breeding standpoint, and it is suggested that British influence and British taste for good blood are most noticeable there. The depot of Celle has contributed largely to the prosperity of Hanoverian breeding since its forndation in 1735. The most important Hanoverian breeding centre lies between the Elbe and the Weser, and Comte de la Tour asserts that breeders here have happily known how to remedy "the excessive and too continuous use of English thoroughbred sires, which tends to lessen the size of the horses" by having recourse to the fairly weighty stallions of the country. As a rule, the proprietors of small farms in Hanover keep four or five mares, which are employed in agricultural work, and, thanks to this division, a large percentage of foals are produced in this part of Germany. The use of English thoroughbred sires in Schleswig and Holstein, dating from about I820, has had satisfactory results in improving the breed, but the choice of stallions has not always been irreproachable. In Holstein, as in Hanover, the brood mares are used in agricultural work. In the so-called "Remount Provinces "-namely, East and IVest Prussia, Posen, Hanover, and Brandenburgall forms of State aid for the encouragement of horse-breeding-prizes at horse shows, etc.-are given only for the type of horse required for military purposes.

\section{The Prussian Trakehnen}

In Prussia the dominating type is the Trakehnen, which is composed of about 50 per cent. of English thoroughbred blood, 25 per cent. of Arabian, and 25 per cent. of 


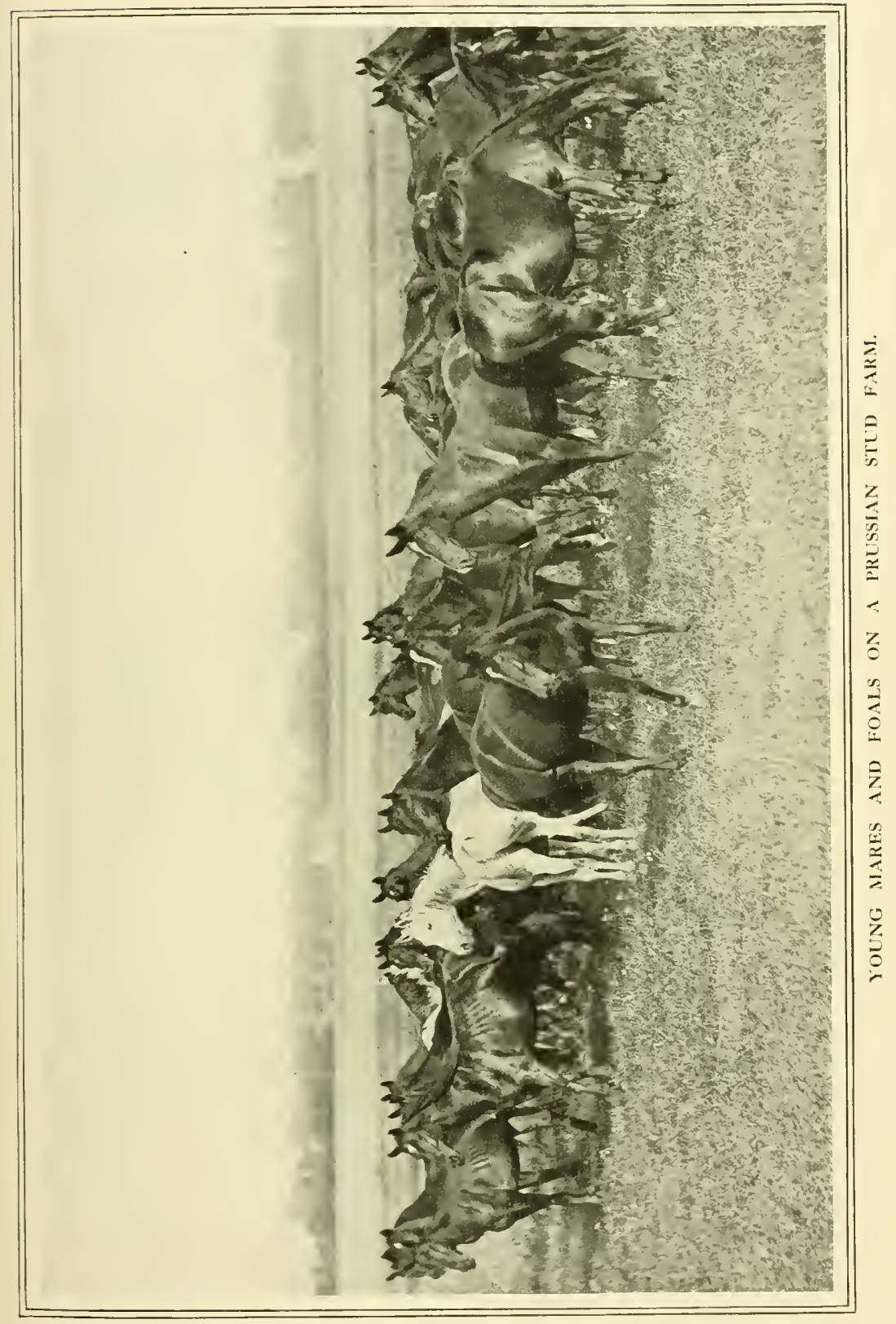


native Lithuanian blood, which originally came from the east. French authorities declare that this type resembles the Tarbes breed in the South of France rather than the Anglo-Norman. Certainly it makes an excellent remount. The Prussian light horse has a delicate head, excellent neck and shoulders, and good quality, clearly indicating his superior breeding. Oldenburg, as has already been noted, produces a special breed of large draught horses (which have many serious defects, according to Count Wrangel), and Wurtemberg is distinguished for the high calibre of its pure-bred and half-bred horses. Many of the great landed proprietors in Germany concern themselves with horse-breeding, and turn out high-class horses adapted to military service. One private stud, Herrenhauser, is famons for its white and dun coloured horses.

\section{Prussian Government Establishments}

In spite of the existence of numerous and important private studs, the Prussian Govermment is obliged to intervene so as to foster and direct the breeding operations of the country, and above all to secure an ample supply of remounts for the army. In 1893 it was written: "The Prussian Govern. ment takes most elaborate means to encourage horse-breeding, but contrives to combine efficiency with economy in a manner which appears impossible with English, French, or American officials." In view of this statement the most recent statistics of German horse-breeding are interesting, because they prove that, while the expenses of the Government studs in Igos were as high as $f 35^{2}, 7 \mathrm{I} 9$, that amount was reduced to less than one half by the receipts, leaving a deficit of $f_{1} 68,128$, which in the circumstances is by no means an excessive burden on the taxpayers. The chief sources of revenue are $(a)$ from the principal stud farms-horses and cattle sold, and farming receipts; (b) from the rural stud farmscovering fees and foal money. In the five principal studs in 1908 there were thirtyeight first-class thoroughbred stallions, 740 brood mares, and 2,460 colts and fillies. At the rural studs (Landgestiite), eighteen in number, there were 3,438 stallions. These sires were composed of the following types, the list being arranged approximately in order of numbers kept at the rural studs :-

I. Heavy riding or light draught horses.

2. Heavy draught horses.

3. Light riding horses.

4. German farm horse type.

5. Belgian and Ardennes horses.

6. Shire horses.

7. Clydesdales.

8. French farm horses.

9. Normandy horses.

Io. Percherons.

II. Shire horse and Belgian cross.

Here is the financial statement of the German studs :-

\begin{tabular}{|c|c|c|c|c|c|}
\hline \multicolumn{3}{|c|}{ Principal Stuts. } & $\begin{array}{l}\text { Receipts. } \\
\text { Marks. } \\
459.370\end{array}$ & $\begin{array}{c}\text { Expenses. } \\
\text { Harks. } \\
1,041.550\end{array}$ & $\begin{array}{l}\text { Deficit. } \\
\text { Marks. } \\
582,180\end{array}$ \\
\hline Graditz & $\ldots$ & .. & 486.926 & $855,8 \mathrm{I} 7$ & 368,591 \\
\hline Beberbeck & . & $\cdots$ & 103,900 & 354,870 & 250,970 \\
\hline \multicolumn{3}{|c|}{ Neustadt a. Dosse } & 49.610 & I 39.555 & $89,9+5$ \\
\hline \multicolumn{3}{|c|}{ Zwion-Georgenburg } & $I+1,530$ & 237,720 & 96. I 90 \\
\hline \multicolumn{6}{|c|}{$\begin{array}{c}\text { Rural Studs (Landge- } \\
\text { stiute). }\end{array}$} \\
\hline \multicolumn{2}{|c|}{ Rastenburg... } & $\cdots$ & 114,540 & 210,330 & 95,790 \\
\hline \multirow{2}{*}{\multicolumn{2}{|c|}{$\begin{array}{l}\text { Braunsberg... } \\
\text { fieorgenburg }\end{array}$}} & $\cdots$ & 88,500 & I 89, I 50 & 100,650 \\
\hline & & -. & 197,380 & 998 & 26.618 \\
\hline \multicolumn{2}{|c|}{ Gudwallen .. } & $\cdots$ & 281,760 & 325,3 I 8 & 43,558 \\
\hline \multicolumn{2}{|c|}{ Marienwerder } & $\cdots$ & 87,550 & 193,453 & ro5,903 \\
\hline \multirow{2}{*}{\multicolumn{3}{|c|}{$\begin{array}{l}\text { Pr.-Stargard } \\
\text { Friedr. Wilh. Stud }\end{array}$}} & 82,230 & $20+370$ & $122,1+0$ \\
\hline & & & $124,6+0$ & $268,3+3$ & $16 \mathrm{r}, 700$ \\
\hline Labes & . & $\cdots$ & 107,180 & 060 & I 20,880 \\
\hline Zirke & $\cdots$ & $\cdots$ & 134,410 & .824 & 70,414 \\
\hline Gresen & $\cdots$ & $\cdots$ & 700 & .640 & 69.940 \\
\hline Leubus & $\cdots$ & $\cdots$ & 123.360 & $3+2$ & 90,982 \\
\hline Cosel & $\cdots$ & $\cdots$ & I 53,410 & 254 & I $13,8+4$ \\
\hline Kreuz & . & $\cdots$ & 88,990 & 710 & I 28,720 \\
\hline Traven thal & . & $\cdots$ & $8+, 320$ & 265.537 & 81.217 \\
\hline Celle .. & $\cdots$ & $\cdots$ & 330,200 & 467.914 & I 37,714 \\
\hline Warendorf & .. & $\cdots$ & $98,6 \mathbf{z} 0$ & $268,0.40$ & 169,420 \\
\hline Dillenburg & $\ldots$ & $\cdots$ & 71,250 & 213,440 & 142,190 \\
\hline \multirow[t]{2}{*}{ Wickrath } & .. & $\cdots$ & $124,44^{\circ}$ & 317,152 & 192,712 \\
\hline & & & $2,450,480$ & $4.424,872$ & $1,97+, 392$ \\
\hline \multicolumn{2}{|c|}{ Totals } & $\cdots$ & $3,691,816$ & 7.054 .384 & $3,362,568$ \\
\hline English & quiva & ent & $E I 8+59^{\circ}$ & $\{352,719$ & $t \leq 68,1$ \\
\hline
\end{tabular}

\section{"Country Stallions"}

At the five principal studs the chief duty is to breed " country stallions," and horses for the Emperor's stables and for the army. The "country stallions " then find their way into the eighteen rural studs mentioned in the above list. A number of English and French thoronghbred sires, as well as Germanbred race winners, are also located in the rural studs, and during the covering season they are sent to stations in different parts of the district, each station being set apart for two, three, or four sires, according to local demands. Thus it happens, according 
to a writer in the Sporting Lifc, that the country studs themselves are empty during the covering months. Here one observes a system very similar to that obtaining in France, only the latter country has but one small stud with brood mares (Pompadour) as against five big establishments of that description in Germany.

\section{The Trakehnen Stud}

The stud at Trakehnen dates from 1732 , and covers an area of 10,855 acres. It is under the management of Baron von Oettingen, a breeder of wide experience, whose notable work, "Horse Breeding in Theory and Practice," was translated into English in 1909 , and was most favourably received br breeders who study the scientific side of the production of horses. Baron von Oettingen has over $I$, joo head of horses under his direction at Trakehnen, and the stock reared there is mainly of the hunter type, up to weight, and showing plenty of bone. Of the twenty-one stallions at this stud in Ioog thirteen were thoroughbreds, one an Anglo-Arab, and the rest half-breds reared at Trakehnen, they having a distinct preponderance of pure blood. A fair example of the thoroughbred sires here is Red Prince II., a son of Kendal out of the Grand National winner Empress. In Ireland Red Prince II. met with great success as the sire of steeplechase stock. He was an old horse when the Germans bought him, but they valued his blood so much that they did not hesitate to pay $\underset{\sim}{3}, 000$ for him.

\section{The Graditz Stud}

At the Imperial Graditz stud attention is almost entirely confined to the breeding of race-horses, and the latter perform on the Turf in the name of the stud. This, by the way, is a sore point with private owners of race-horses in Germany, who complain that they are forced to compete against the taxpayers' money, which subsidises the Graditz stud. "The contention," says one writer, " is that if Graditz and the other Government studs want the colts they breed to be subjected to the race-course test, they should be raced for that purpose only, and not for the purpose of winning stake money." of the forty-five horses in training belonging to the Graditz stud in Igog, thirty-two were got by English sires and eight by Frenchbred stallions.

\section{Derby Winners in Germany}

The most notable thoroughbred sires in Germany are undoubtedly Ard Patrick, who stands at Graditz, and Galtee More, who is at Romerhof. Each of these Derby winners is at the command of private breeders at the modest service fee of $f_{\mathrm{L}} \mathrm{I} 5$. To appreciate the good fortune of German breeders in regard to these stallions it should be recalled that Ard Patrick cost the German Government f20,000, having been purchased by that high authority on the thoroughbred race, Count Lehndorff. Galtee More was sold to the Russians for the same amount, but subsequently found a new home in Germany at $f_{1} 4,000$. The most successful Germanbred thoroughbred is Hannibal, by Trachenberg out of Zama, by Hermit out of Sonsie Queen by Musket. He stands at the Graditz stud at the same fee as Ard Patrick. Since I 906 Hannibal has supplied three winners of the German Derby-namely, Herr Weinberg's Fels (Ino6), Prince Ed, von Oppenheim's Seiger (Igo8), and the Graditz stud's Arnfried (Inog). Recent census statements show that horse-breeding is on the increase in Germany. Horses, including those of the army, were returned at $4,345,000$ head for I 907 , as compared with $3,836,000$ in 1892 .

\section{Swiss Breeding Methods}

Although operating, of course, on a smaller scale than their neighbours, the Swiss Govermment gives every encouragement to breeders, and the army remount of the cantons is a well-bred, hardy, muscular horse, who for stamina will compare well with any remount on the Continent. The Swiss Government* undertakes to purchase suitable stallions on behalf of the cantons and pay one-half of the purchase money. The cantons lease these stallions to breeders, and are required to supervise their use under proper conditions for breeding purposes * Journal of the Board of Agriculture. 
during at least six years. After six years the Government may repurchase an animal or declare it unfit for breeding purposes, either with or without compensation, or may grant the breeder an annual subsidy of five per cent. upon its estimated value. In addition, stallions are lent to cantons for short periods from the State stud. In the case of brood mares and fillies, premiums are awarded to animals chosen anmually by very young horses was forbidden. But the first great impulse to horse-breeding in Austria was given by a decree drawn up by the Empress Maria Theresa in 1763 , and since then the State has continued to encourage horse-breeding as far as possible. The still existing State studs at Radautz and Piber were established in $\mathrm{I} 792$ and $\mathrm{I} 798$. These facts are inentioned by Mr. Mansfeldt de C. Findlay in the course of a wholly

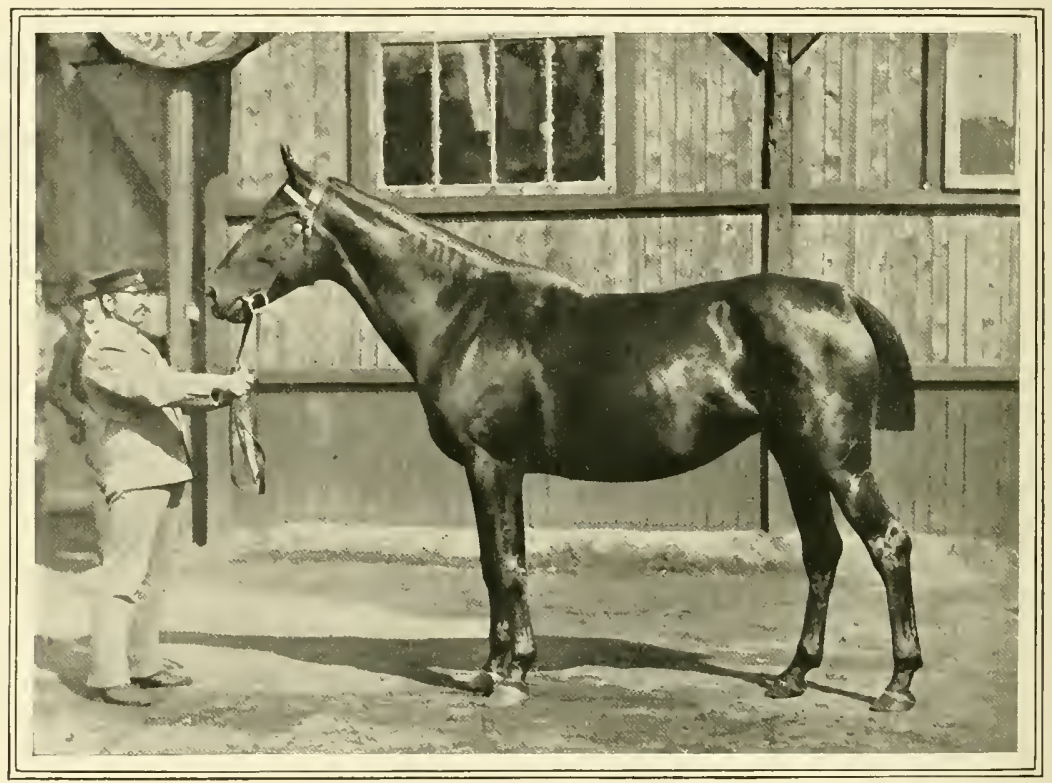

WALKURE: A PRUSSIAN PONY.

judges appointed for the purpose by the Government. The premiums amount to f2 8s. for fillies from two to three years old, and $f 8$ I6s. for mares from three to five years old.

Records go to show that the Austrian Government has long had in view the general development and improvement of the various breeds of the country. Its active interest in horse-breeding seems to date from the reign of the Emperor Charles VI. By a decree of 1736 the provincial authorities were directed to provide stallions suitable for getting remounts, and the working of admirable report on horse-breeding in Austria which he wrote during his diplomatic appointment at Vienna. Count Heinrich zir Hardegg, who took the direction of horsebreeding after the conclusion of peace in I8I5, was the first to work on scientific lines. He imported at various times a number of pure-bred Arab stallions, as well as English thoroughbreds, and within thirty years he had the satisfaction of finding his native land for the first time independent of other countries in regard to the supply of remounts for the army. The object of the two State studs in Austria (Radautz and Piber) is to 
provicke sound stallions for use throughout the country. These stallions are first sent to the central depots, and then distributed to the various stations in the country-a precisely similar system to that described in the account of German horse-breeding earlier in this chapter.

\section{The Austrian Pinzgauer}

There are five clearly-defined horse-breeding districts in Austria, and the Government takes special care to distribute their stallions so as to suit the existing local conditions. The Pinzgauer is nne of the best and most trpical of Austrian breeds. It is found chiefly in the Alpine district, which includes Týrol, Salzburg, Styria, Upper Austria, and a part of Carinthia. The Pinzgater is an ideal horse for draught work in hill districts. Curiously coloured, being white or very light dun with dark spots, he is powerful, hardy, free-actioned. The lighter type trot quite well enough, says Mr. Findlily, for heary carriage work over bad roads. Pinzganer stallions are used to cross with the heavy Noric breed, which thrives in Zell, st. Johann, and the vicinity. In the mountain districts of Bohemia, Moravia, Silesia, and Lower Austria various types lighter than the Pinzgauer are bred, and to mate with them the Government chooses strong weighty stallions, suitable for the production of a heary cart breed. Gillicia and Bukowina, where great estates abound, are important centres for the production of cavalry horses. These horses, as a rule, are good-tempered, strong, and more shapely than the cavalry horses of Hungary. In Galicia especially there are many private studs, whose animals, while usually on the small side, are yet thickset, hardy, and good troop horses.

\section{The Lippizaner Stallions}

Then in Dalmatia, parts of Carinthia, and the coast district of Austria are found small hardy horses, largely nsed as pack animals. To assist in breeding this useful class of animal the State supplies Lippizaner stallions. These horses are from the ancient Imperial stud at Lippiza, near Trieste. They have a marked character, and are the result of careful crossing of Spanish, Italian, and Arab stock. Mr. Findlay describes the Lippizaners as long-bodied, short-legged, with good quarters, legs, and feet; usually grey or bay, with good action, excellent constitutions, and in height from I5 to $_{5} 6$ hands. Handsome, tough, and fast, they make first-class carriage horses. There is a bigger breed of harness horses at the Krladrub Imperial Stud, also descended from Spanish and Italian stock. In colour either black or white, they are upstanding horses of about I 7 hands 2 inches, with Roman noses, arched necks, and heary crests. They are chiefly used in State processions, being very showr, fine actioned, commanding-looking horses. An effort was made to cross this breed with the thoroughbred, but it was not a success.

\section{Breeding in Hungary}

Under the beneficent rule of the Emperor Francis Joseph the horse-breeding interests of Hungary have been practically identical with those of the sister State. There is the same system of stallion depots and covering stations, and the service fees paid for the sires vary from one shilling to fifteen shillings. Committees are formed in different parts of the country with a view to encourage the industry by making the farmers acquainted with the object and principles of horse-breeding. This forms a connecting link between the breeding establishments of the Government and the farmers and other private breeders. The income from the parimutuel, as in several other Continental lands, helps to provide the Govermment with the money devoted to horse-breeding. Subsidies are granted for the creation of "common pastures" in the poorer communities of Hungary, and the Goremment has other equally interesting methods of encouraging private breeders.

\section{The Kisber Stud}

Hungary produces thoroughbred stock in her State studs-viz. Kisber, Babolna, Mezöhegyes, and Fogoras. The Kisber stud is one of the best-known and certainly one of the finest establishments of its kind in the 
world. Here is a list of the thoroughbred sires advertised to serve at Kisber in Igog:-...

1. Admiral Breeze (bred in England) by Velasquez-Seabreeze.

2. Bona Vista (bred in England by Bend OrVista.

3. Dunure (bred in England) by St. Simon-Sunrise.

4. Fenek 1. (native-bred) by Fenek-Filon.

5. History (bred in England) by HamptonIsabella.

6. Horkay (native-bred) by Match-box-See Me.

7. Kozma (native-bred) by Balvany-Kishoske.

8. Pardon (native-bred) by Morgan-Petroleuse.

9. Rocketter (bred in Ireland) by GallinuleVolant.

ro. Rother Stadl (native-bred) by PardonAranyka.

11. Royal Lancer (bred in England) by Royal Hampton-Lightfoot.

12. Slieve Gallion (bred in Jreland) by Gallinule -Reclusion.

13. William Rufus (bred in England) by MeltonSimena.

Many of the above names will be perfectly familiar to British race-goers. As a means of conveying to the reader the value at which the best of these sires are appraised by the Kisber stud authorities, it may be stated that Pardon and Slieve Gallion were advertised to cover native mares at $\mathrm{I}, 000$ kronen, Bona Vista at 800 kronen, Dunure and William Rufus each at 500 kronen, and Rocketter, Rother Stadl, and Royal Lancer at 300 kronen. William Rufus was leased by the Kisber stud from Mr. J. Musker, to whom he has since been returned.

\section{Horse-Breeding in Italy}

We have seen at recent International horse shows at Olympia that the Italian army produces remarkably fine horsemen. The jumpers they brought to compete in the competitions were wonderfully well-schooled animals of the hunter type. Indeed, it would not be surprising to know that some of those fine jumpers were bred in England or Ireland. In any case, it was obvious that they all possessed good thoroughbred and hunter blood. Breeding in Italy has made undoubted progress during the past thirty years. The Government has supplied good stallions, and has spent money freely in endeavouring to improve the native breeds. It has also adopted that system of "approving" private stallions which has been of value in France. According to Colunel Charles Needham, who for a number of years was military attaché at Rome, and visited the remount establishments and the stallion depot at Pisa, the great fault of Italian horse-breeding appears to be the tendency to use too much Arab blood. " The native mares," said that authority, "are stout, active, wiry animals, but they have bad shoulders, narrow quarters, and are deficient in substance, all of which defects are predominant in the Arab, except in the very best, and of these there seem to be few, if any, in Italy. The one special attribute of the Arab-power of endurance-is already possessed by the native Italian race and it would appear unnecessary to reproduce it in excess."

\section{Italian Government Depots}

On January Ist, Igo8, there were 677 stallions in the Government Horse Depots, this comparing with 582 in $\mathrm{I} 895$. For breeding purposes they were divided as follows :-

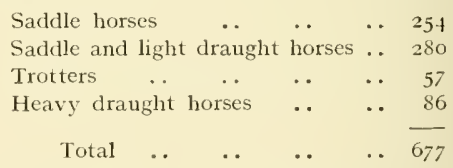

In I 008 there were 686 stallions posted at 498 different stations. They covered in all $35,35+$ mares, an average of $5 \mathrm{I} .53$ mares to each stallion. The following shows the different horse-breeding districts, with the number of stations, stallions, and mares in each :-

\begin{tabular}{|c|c|c|c|c|}
\hline \multicolumn{2}{|c|}{ Name of District. } & $\begin{array}{l}\text { No. of } \\
\text { Stations. }\end{array}$ & $\begin{array}{l}\text { No. of } \\
\text { Stallions. }\end{array}$ & $\begin{array}{l}\text { No. of } \\
\text { Mares } \\
\text { Served. }\end{array}$ \\
\hline Crema & . & .. 70 & I 45 & 8,425 \\
\hline Reggio Emil & & .. $4^{8}$ & 76 & 4,488 \\
\hline Ferrara & .. & .. $6_{5}$ & 99 & $5,45^{2}$ \\
\hline Pisa .. & . & . & 100 & 4.116 \\
\hline Santa Maria & Capua & 89 & 103 & 5,538 \\
\hline Catania & .. & .. $7+$ & 78 & 3,300 \\
\hline Ozieri & . & . $5^{8}$ & 79 & 3,945 \\
\hline Total & .. & . 198 & 686 & 35.354 \\
\hline
\end{tabular}

Efforts are made in the above districts to maintain a decided uniform character in 
breeding. Care is taken, therefore, to choose stallions which are suitable for the mares of certain localities, and no stallion is removed from his station, unless for special reasons, until he has served there for at least three or four seasons.

In most Italian districts the condition of lyorse-breeding is fairly satisfactory, though in the southern Mediterranean and Adriatic provinces many farmers neglect the breeding of horses for that of mules, which is more profitable. A mule at twelve months old, reports Colonel Needham, is worth from $f 6$ to $f s$, whereas a foal of the same age will rarely fetch more than $f_{t}$. A three-year-old mule is worth more than f2o, whereas a horse of the same age can seldom be sold for that amount in the place where it is bred. The breeding of mules is also of great importance in Sicily, where a quiet and hardy beast of burden is a necessity.

\section{Use of the Arab in Italy}

According to the Director at Pisa there is an annually increasing traffic in light draught or saddle horses, which are purclased by French dealers, and this trade is obviously of benefit to owners who for various reasons have been unable to sell their horses to the Government. In Lombardy stock got by stallions from heary Brabant and Ardenne breeds make the best prices. For the district of Crema and the greater part of Ferrara, especially along the River Po, the best stallion would probably be the Hackney -stout, strong-limbed, and well-shaped, though private breeders have not acquired many of this breed so far. The most popular type of stallion for Sardinia is the Arab, either pure-bred or cross-bred, and the eastern sires do very well there. In Sicily the Arab is also recommended by the Government as a suitable sire, but breeders consider them too small, and prefer a larger animal, whose produce realise better prices. The Anglo-Eastern cross, which is somewhat larger than the Arab, is the favourite in Sicily. In Pisa and Emilia the English thoroughbred increases in popularity, and such good sires as Melton, Andred, Melanion, and Workington have done much to improve the breed. Dming the few years he lived in Italy, Melton did extremely well. His stock won the majority of the best races, and his sons have made successful stallions. More recently signorino has been imported into Italy, and this son of Best Man and Signorina promises well.

In addition to the 686 Government stallions in 1008 , already referred to, there were 716 approved sires serving public mares in 1taly in that year. These were of the following breeds : 35 English thoroughbreds, I Arab, 3 Anglo-Arabs, $48+$ half and threequarter bred sires, I 30 trotters, and $6_{3}$ heary draught stallions. Belgian draught horses would seem to be most popular among the Italian breeders of heavy stock, as there were 43 stallions of that breed among the private approved sires, as against 6 Boulonnais, 6 Ardennes, 5 Brabants, 2 Clydesdales, and only I Percheron. There is no mention of the use of the Shire horse by private Italian breeders, and only one Hackney was registered in I908. On the other hand, there were 20 Russian trotters and Io American trotters. As showing the advance in numbers which the breeding industry has made, the results of the census of horses, asses, and mules in all parts of the kingdom for the years I88I and Igos is appended :-

$\begin{array}{rrrrrr}\text { Horses } & \ldots & \ldots & 207,507 & \ldots & 955,031 \\ \text { Asses } & \ldots & \ldots & 174,742 & \ldots & 848,988 \\ \text { Mules } & \ldots & \ldots & 94,493 & \ldots & 388,361\end{array}$

\section{Italian Remount Establishments}

The largest of the remount establishments in Italy is at Grosseto, situated on the RomePisa railway, about I20 miles from Rome. The estate, which belongs to the Government, consists of about I8,000 acres of pasture and arable land almost entirely reclaimed from the marshes, which extended to the sea. The remount horses are purchased between the months of April and June by a committee composed of the officer commanding the depot, the captain attached, the veterinary captain, and a cavalry officer detailed by the Ministry of War. Notices are previously issued to all towns in the district informing breeders of the date and 
place at which horses may be brought for inspection. As a rule, only three- and fouryear-olds are purchased, and the price, fixed by the Ministry of War, depends on the amount available in the army budget for the purpose. When Colonel Needham made his excellent report on Italian horsebreeding, the average price was $£ 2 t$ for three-year-olds and $f 32$ for four-year-olds. It is calculated that a colt from the age of carrying substantial burdens and covering long marches.

No recent statistics regarding horse-breeding in Spain are available. The typical light horse of the country shows plenty of quality, and no doubt owes it to his Arab and Barb ancestry. When Arabian horses were originally brought to Europe the first place they halted at was Spain, and their influence has never been lost. In medieval wars the

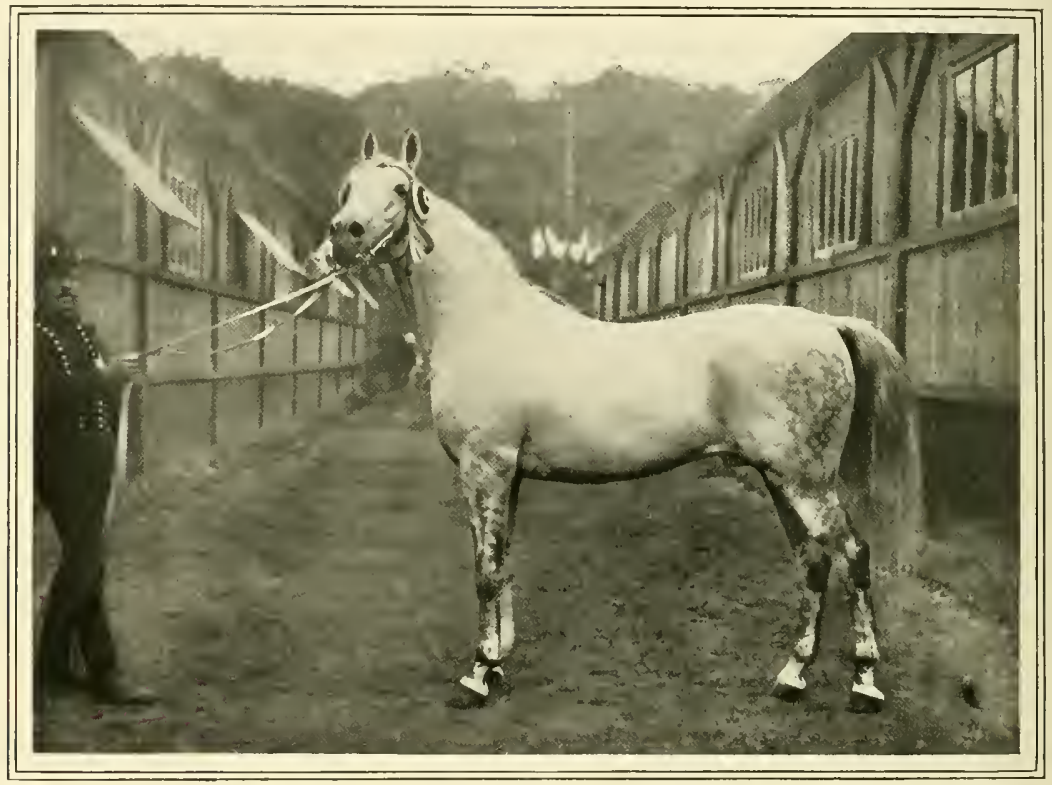

KOHEILAN 1.: A HALF.BRED ARABIAN.HUNGARIAN.

three to four years costs $£ 6$ for his keep, including all expenses. The maximum number of horses kept at Grosseto is 3,000, and at the end of December, by which time those considered fit have been drafted to their regiments, the number is reduced to $I, 200$. The ninimum size for three-year-olds is I4 hands $\frac{1}{2}$ inch ; for four-year-olds It hands $2 \frac{1}{2}$ inches. Colonel Needham points out that the great defect is want of size and substance, while the heavier horses show distinct want of breeding. Nevertheless, the Italian cavalry horses have undoubtedly great powers of endurance when
Spanish jennet breed played a prominent part. "I have heard some of the Spaniards," said an old-time English writer, " to set such praise on their jennets' courage, as they have not letted to report that they have carried their riders out of the field, I cannot tell how manie miles, after the jennets themselves have been shot clean through the bodies with Harquebushes." A heavier breed, the old Spanish war-horse, was the right sort to carry a man in armour, as one may judge by the paintings of Velasquez and other artists of the country. For ages the virtues of the Andalusian horse 
have been extolled, and one authority asserts that the breed was acknowledged to be the best in Europe until the English produced the thoroughbred.

Mlany of the wealthy landed proprietors of Spain still possess beautiful specimens of the ancient breed, which do not differ very materially from the horses which Mlarkham and the authorities of the seventeenth century eulogised for their value in war and their accomplishments in the mantigc. Here is a description of the Spanish horse of the best type, written some years ago by an English veterinary surgeon in Madrid: "The Spanish horse stands generally from ${ }^{5} 5$ to I6 hands, with rather a large, bony head, in shape like the Merino sheep; with full eve and large expanding nostrils, which denote his remarkable vigour and power; a shortish, muscular neck, strong shoulders, rather narrow in the back, but with magnificent quarters-thighs, hocks, and hindlegs placed well under them ; the arms, forelegs, and feet are as good generally as can be, feet well formed, short cannon-bones, and back tendons strong and standing well out. All elasticity and action in walk, trot, canter-faster than this they should not be asked to go, as at a forced pace they lose their beauty of motion, and appear to be disconcerted from the extravagance of their action. . . In my opinion no horse is superior, either in the park or on parade, to a well-bred and broken Spanish horse of the best breed."

\section{Horse-Breeding in Spain}

Such is the aristocrat among modern Spanish horses, but he is exclusively bred by and used among the higher classes of the country. Some fine examples of the breed may still be seen at the Imperial stud at kladrub in Austria, as has already been noted. The horse usually employed for riding and pack work in those parts of Spain where the mule does not supplant him is a wiry, good-constitutioned animal, who has been likened to the rapidly disappearing pack-horse of Devonshire. However, modern Spaniards can hardly be considered a horse-breeding nation. Apparently mule- breeding is found more profitable in the country provinces. With good reason has Spain been described " the stronghold of the mule," as it was estimated in Igon that the country had only 451,000 horses as against 810,000 mules, or as many as all the other countries of Europe put together. It has been remarked that until one has seen a good Spanish mule, with his skin "like black velvet," one has no idea to what perfection the animal may be brought.

\section{The Russian Orloff}

The most distinctive of the native Russian breeds is undoubtedly the Orloff trotter, whose good action and sound qualities are widely appreciated throughout Europe, as may be noted by the presence of Russian trotters in the stallion depots of Italy and other countries. An Eastern horse, called Smetanka, whose skeleton is still preserved in the Orloff museum, is generally reckoned to have been the great progenitor of the Orloff breed. He came to St. Petersburg as a gift from a Grecian breeder, and was passed on by Catherine the Great to Count Alexis Orloff. Crossed with the Friesland breed, whose pace Blunderville described as a "good comely trot," Smetanka sired some remarkable trotters. English blood was used in developing the breed, the classic winners Tartar (St. Leger) and Dadalus (Derby) being imported into Russia. Within thirty years the race of trotters became a distinct type, thanks to the very careful methods of the Orloff family, whose stud was eventually taken over by the Government (1845), at a cost of $8,000,000$ roubles.

\section{Russian Horse-Breeding}

Russian landed proprietors have always regarded horse-breeding as a duty as much as a pleasure, and in the last quarter of the nineteenth century it was calculated that there were $I, 600$ private studs in Russia, with nearly 6,000 stallions, and more than 50,000 mares, mostly of the Orloff strain. This breed has certainly not been improved by crossing it with cart blood, but the typical light Orloff horses have still a good deal of the Arab about them, though their 


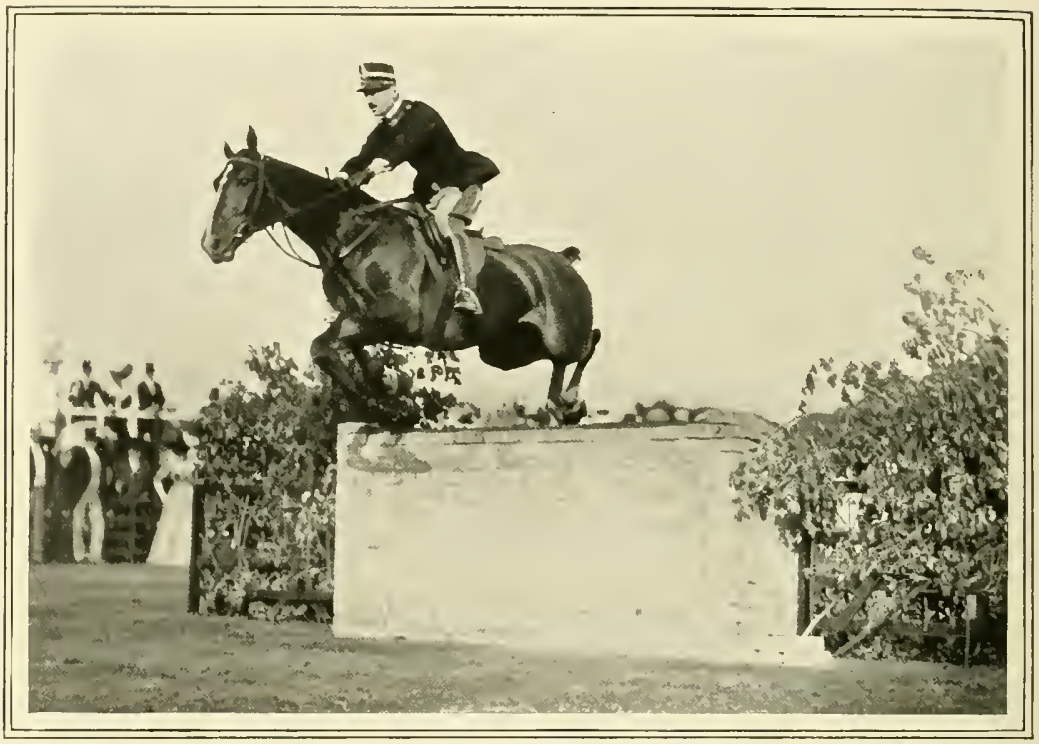

JUMPING DISPLAY BY LIEUT, BOLLA, OF THE ITALIAN ARMY

action is quite distinctive. They have great pace and powers of endurance, though the American trotter would probably beat them on the trotting track. Russian sleigh and troika horses are extremely hardy, a harsh climate having doubtless made them comparatively impervious to rough weather, but after having been driven hard for a couple of years along cobbled streets they naturally show signs of wear. The horses of the Cossack cavalry are famous for their toughness and stamina; it was once said of them that they will keep in good condition when they can get no more substantial sustenance than the twigs of trees! In the Caucasus a tough race of ponies is bred.

Russia is not less alive than other great Continental nations to the necessity of encouraging horse-breeding, and the expenses of the Department of State Studs, as presented in the estimates for I908, amounted to $f_{196,076}$, of which $£ 79,300$ was devoted to the maintenance of State horse-breeding establishments. That there is no relaxation on the part of the Russian authorities in their efforts to foster the horse-breeding industry may be gathered from the following extract from the Official Messenger of January, I9Io: "A new Government horse-breeding farm has been established in the Kamytskaia Steppe (Government of Astrachan), with an establishment of roo stud stallions. The Duma and the Council of the Empire have sanctioned an expenditure of 3,300 roubles in 1910 for salaries of the chief officials; I0,000 roubles for building (50,000 roubles was granted for this purpose in 1909$)$; 40,000 roubles for the purchase of to stallions $(35,000$ roubles were granted in Igog for the purchase of 35 stallions); 800 roubles for the purchase of stable necessaries, and foo roubles for the supply of stallions."

At the present time there are six horsebreeding establishments (jumentaries) under the control of the Russian Department of State Studs, and for interesting particulars of these establishments we are indebted to an official report which our Board of Agriculture and Fisheries has courteously allowed us to see. Of the six studs four are situated in the Starobiel district of the Government 
of Kharkoff, and at all of them saddle horses are bred. At the Strieletsky farm the horses are of a light type, their origin being eastern, with a strain of English blood. At the Limarevsky farm they produce lialfbreds, English and Orloff strain; while the Derkulsky farm is used for breeding English thoroughibreds, and English and Arab halfbreds. At the remaining stud in this district, the Novo-Alexandrovsky farm, the horses are English half-breds. There is one establishment in the Bobrovsky district of the Government of Voronesh-namely the Khrienovsky farm-which is intended for the breeding of trotters and draught horses. The sires used here comprise Orloff trotters, Ardennes, Brabants, Clydesdales, Percherons, and Suffolks. Finally, in the Konstantinovsky district of the Government of Siedlice there is the Yanovsky farm for the breeding of saddle horses from thoroughbred and English half-bred sires. The following horses were in these six establishments in January, Igo8 :- $\begin{array}{lcccr}\text { Stallions } & \ldots & \ldots & \ldots & 99 \\ \text { Brood mares } & \ldots & \ldots & \ldots & 878 \\ \text { Progeny of various ages } & \ldots & \mathbf{r}, 35^{\circ}\end{array}$

In addition, there are thirty-eight stud depots under the control of the State Department. On the same date these held 5,4 I2 stallions, of which 4,406 , maintained at the expense of the State, are devoted to the public use at temporary stations ; whilst the remaining $I, 006$ sires are distributed amongst the estates of private individuals, and are entirely maintained by the latter. Precise regulations are drawn up for the control of the temporary stations, which are arranged annually in towns, villages, or localities where there is proper accommodation for the stallions with their attendants. Requests for the supply of stallions have to be made not later than November in each year to the nearest Government State farm, the covering season usually extending from February to the end of June. Regulations have also been drawn up for the leasing of

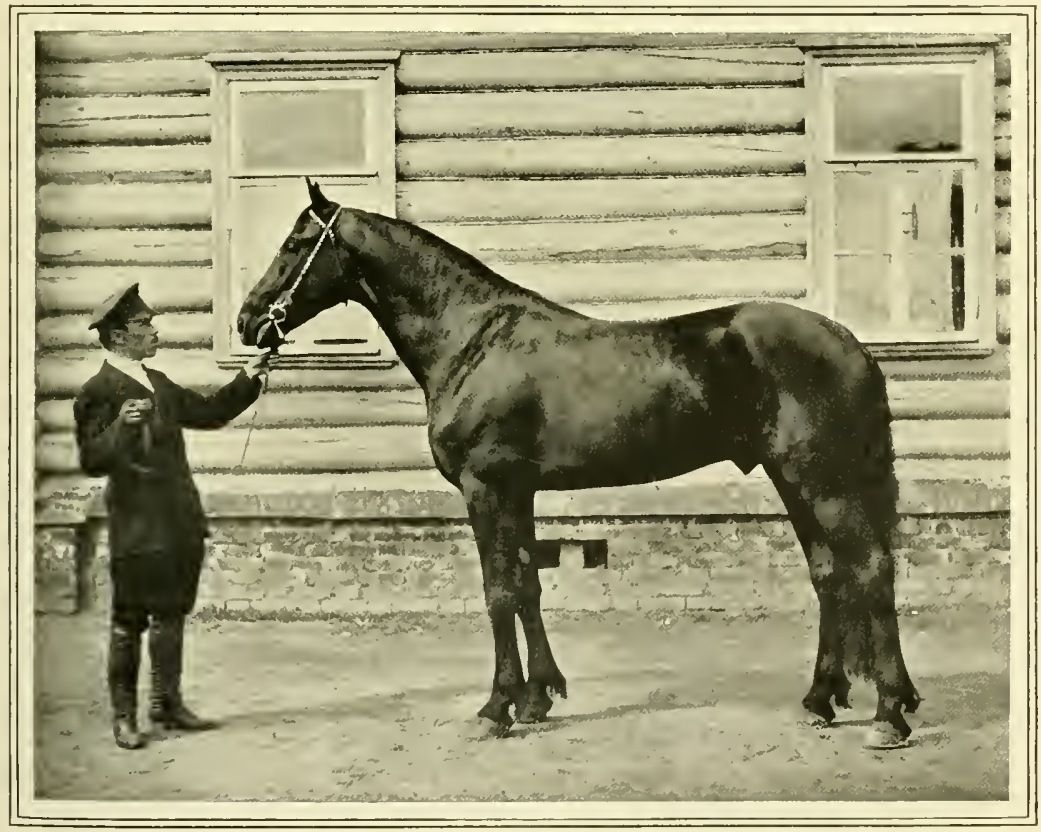

A TYPICAL RUSSIAN HORSE OF THE ORLOFF STRAIN. 
Govermment stallions for use at permanent stations. When the applicant is a private breeder he must forward a proper certificate to the effect that he possesses not less than ten brood mares. If the application is made by a peasant society a duly signed certificate has to be forwarded, to the effect that the society applying is in a position to maintain both grooms and stallions.

\section{Breeding in Holland}

The Kingdom of the Netherlands* (called Holland, as a rule, in foreign countries, although only two provinces have that name) contained about 300,000 horses in Igog, of which 63,376 mares and 6 40 stallions were used for breeding purposes. About 45,000 foals are born every year. Horsebreeding is practised in all the eleven provinces on the following scale in rgog:-

\begin{tabular}{|c|c|c|c|c|}
\hline 1. North Bra & bant & . & .. 7.501 & mares. \\
\hline 2. Zeeland & .. & .. & .. II,9II & "r \\
\hline 3. Limburg & . & . & 2,766 & , \\
\hline 4. South Holl & and & .. & 8,002 & ", \\
\hline 5. Gelderland & . & . & 9.770 & ", \\
\hline o. North Holl & land & . & 4,263 & , \\
\hline 7. Utrecht & .. & . & 2,192 & , \\
\hline 8. Overyssel & .. & $\cdots$ & 2,008 & ", \\
\hline o. Drenthe & .. & $\cdots$ & $3.72 \mathrm{I}$ & ", \\
\hline o. Groningen & .. & $\cdots$ & 7,132 & ", \\
\hline II. Friesland & . & . & 4.110 & , \\
\hline
\end{tabular}

Excepting a few thoroughbreds, the Nethcrlands produce nothing but hamess horses of two quite different types-riz. (a) Light harness horses with much quality and highstepping action in all the provinces except Zeeland and Limburg; (b) Cart-horses of the Belgian type, the greater part clean-bred Belgian horses, in the southem provinces at the Belgian frontiers. To improve the breed of light harness horses, stallions and mares have been imported in great numbers from Oldenburg. The Dutch horses from this cross get the stateliness and strength without losing their high action, their quality, or their manners in harness. At the same time, some Hackney and Noman stallions have been and are still being used to get more dash and still more quality. For

* Much of the account of horse-breeding in the Netherlands was written by Colonel K. D. Punt, the Director of the Iemount Department of the Dutch Army, and is published by the courtesy of the Department of Agriculture, Industry, and Trade in the Netherlands. improving the cart-horses the best of Belgian stallions and some good young mares are imported every year from Belgium.

Nearly all the breeding horses belong to farmers, who own one to eight brood mares. Hardly any large cultivated properties exist. All horses, brood mares, and the greater part of the stallions included, are used for farm work from the age of two and a half years. That is the reason why Dutch horses are so strong, and show such good manners. Foreign dealers very seldom see a horse in harness before buying; they know by experience that there is never any difficulty in putting a Dutch horse to harness. The prevailing colours are bay, brown, and black, with few white markings. This facilitates the matching of pairs. Some chestnuts are to be found also, but very few greys and mans. Although many Dutch horses can be used as riding-horses, those of the real, good, blood type are very scarce. All the riding horses for the army (about 450 a year) have been bought in Ireland since about IS84, the artillery draught horses being bred in the Netherlands.

All the stallions belong to private breeders or to societies of brecders. The State does not own stallions.

\section{Dutch Government Methods}

Since $I 807$ the Government has bought twenty colt foals every year. They are brouglit up in the proper way, on the grass during the summer, and in open sheds with paddocks in the winter time at Bergen $\mathrm{Op}$ Zoom. The colts that develop well are sold at the age of three years old under the condition that they must be used as stallions in the country. Every man is allowed to breed whatever he likes, but all the stallions that are used for public service must have a State licence according to the law of Igor. Before that time every province had its special different rules, and every stallion required a provincial licence. Since Igor the three-year-old stallions have been examined in the months of February and Narch, the older ones in September and October. Three judiges examine the stallions as to their value as stud horses according to their 
special breed, and if thought good enough they are examined as to soundness of wind and eyes by three veterinary surgeons. For the examination of wind the horses are galloped (lunged) both sides every year in suitable covered places, made in about thirty districts all over the country. Stallions over seven years who have proved to be good breeders, are allowed for public service even if they make a noise, if they have been perfectly sound before that time. The result used is left entirely to provincial commissions and three Government members for the eleven provinces. Each province has to send in its premium-scheme for the coming year in due time to enable the Government to make necessary alterations. Horses of three years old and older must be entered into one of the stud-books to be eligible to compete for the premiums; all the horses are examined before they are entered into a stud-book at the age of three years old.

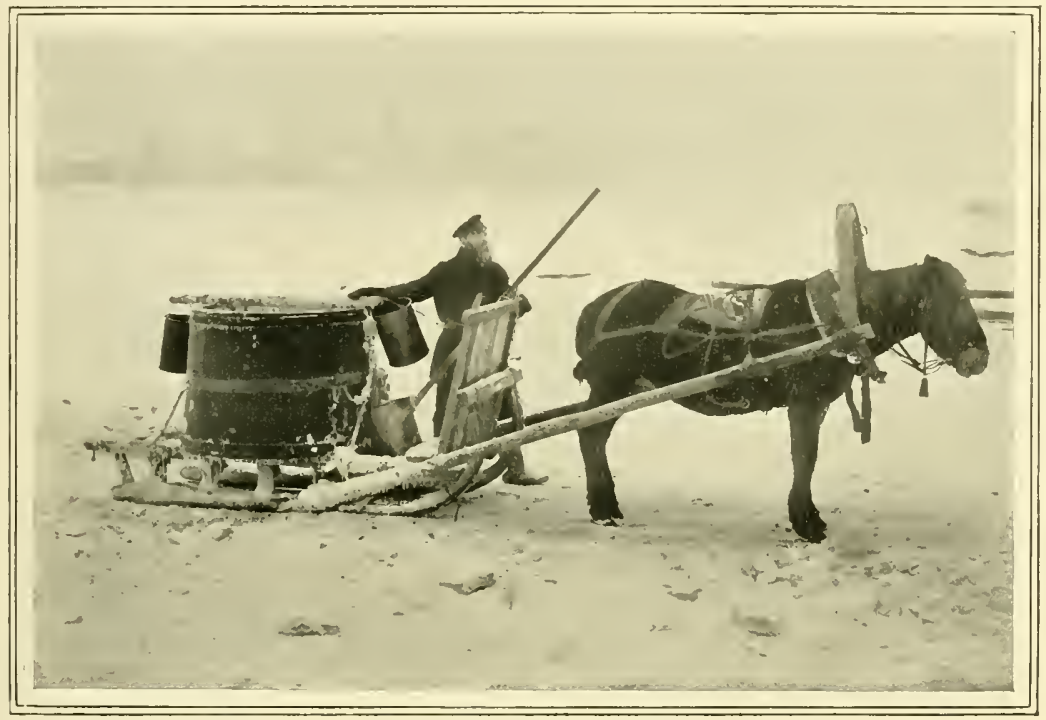

A RUSSIAN TROIKA HORSE.

of this severe yearly examination of all the stallions is that unsound horses are a great exception. Since I90I Colonel Punt, Director of the Remount Department of the Dutch army, has been appointed by the Government to be president of the commission of examination of all the stallions. About $\mathrm{I}, 000$ stallions are examined every year, of which about 640 get a licence. All the expenses are paid by the Government.

The sum of 120,000 florins $(£ 10,000)$ is spent every year in premiums for breeding horses of different ages; 75,000 florins from the Government and 45,000 florins from the provinces. The way in which this money is
The Government money is divided according to the number of mares served in the year past in every province.

In 1908,646 stallions were serving in the country, comprising 27 I cart-horses and 375 of other breeds (322 Oldenburgs and their crosses, I5 Normans and their crosses, 7 Hackneys, ro Frisians, \& thoroughbreds, and I7 trotters).

The breeding of American trotting horses and French-Norman trotters is increasing in the Netherlands. It is estimated that about roo mixed galloping and trotting race-meetings take place every year on four race-courses. Breeders have a good oppor- 
tunity to show their horses in hand, ridden, or in harness every year at the International Hague Horse Show, and every five years at the National Agricultural Show. Horses are bred to a considerable extent for exportation, about II,0oo horses going to Germany every year, over 7,000 to Belgium, and several thousands more to England, France, Spain, Italy, Switzerland, and Austria.

A good climate and splendid grass in the greater part of the Netherlands have made it a notable horse-breeding country from times immemorial. Even in the ancient times of the Bataviers, the Gelderland and Friesland cavalry were renowned, and it has already been noted in this chapter that the Russian Orloff trotter breed was built up with a great many imported Dutch-Frisian mares.

These Frisian horses, jet-black, without any white, with nice small head, good neck, very long mane and tail, high-stepping action in front, and pretty fast in short distances, could be found until twenty years ago in the four northern provinces on the German frontiers, but are likely to disappear altogether. They are the original breed in this part of the country, but are now only bred in a part of the province of Friesland, where ten clean-bred stallions are still serving. Their particular shape, with low back and dropping hind-quarters, has made it difficult to find a ready market for them. The specimens still bred now go to England, Spain, and Italy for funerals, if they do not remain in the country. The second original breed, the Gelderland horse, was found in the province of Gelderland. He was a sharp, good trotting harness horse, rather like the Oldenburg and Norman, but not so strong. He did not step so high as the Frisian horse, but went better behind; these horses were bred in the provinces of the middle of the country. The third original breed was the Zeeland horse, a light cart-horse, much like the Flemish horse, and found in the southern provinces.

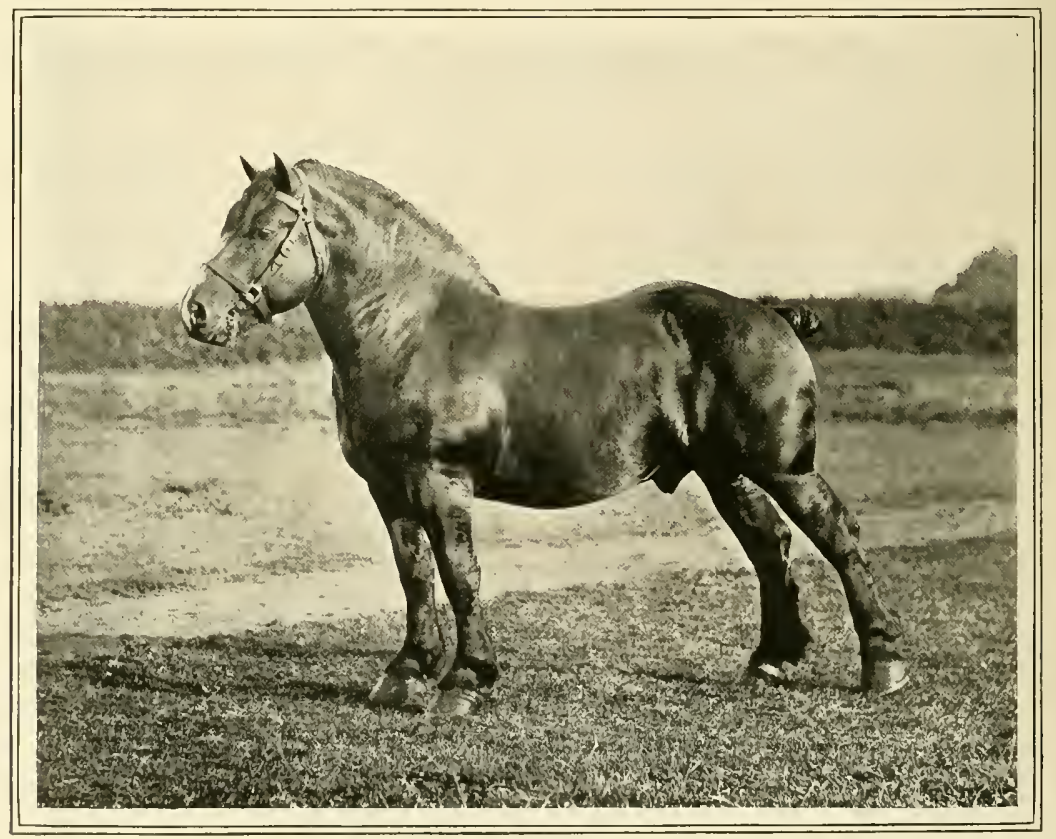

MAJOR DE BACHANT: A TYPICAL ARDENNAIS STALLION. 


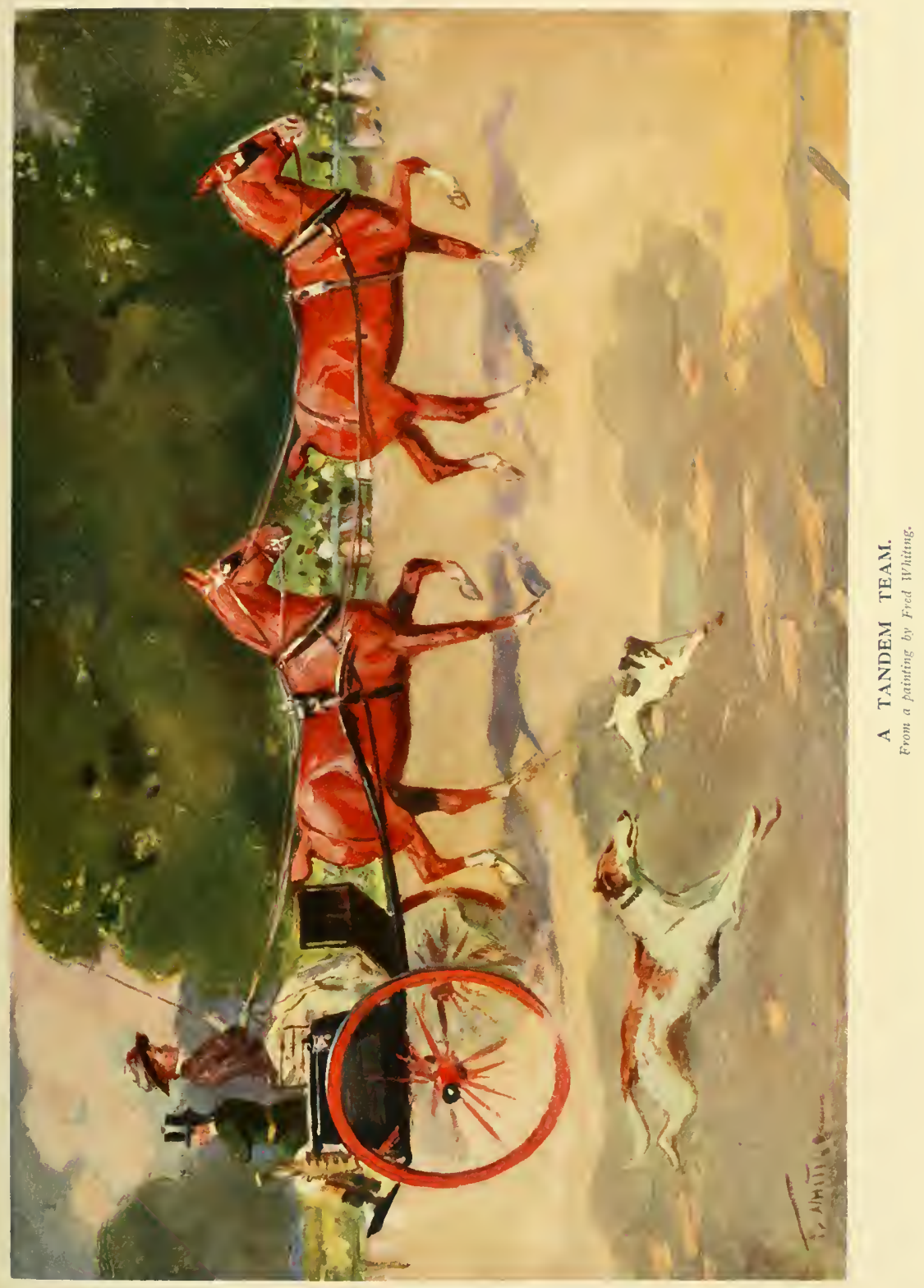





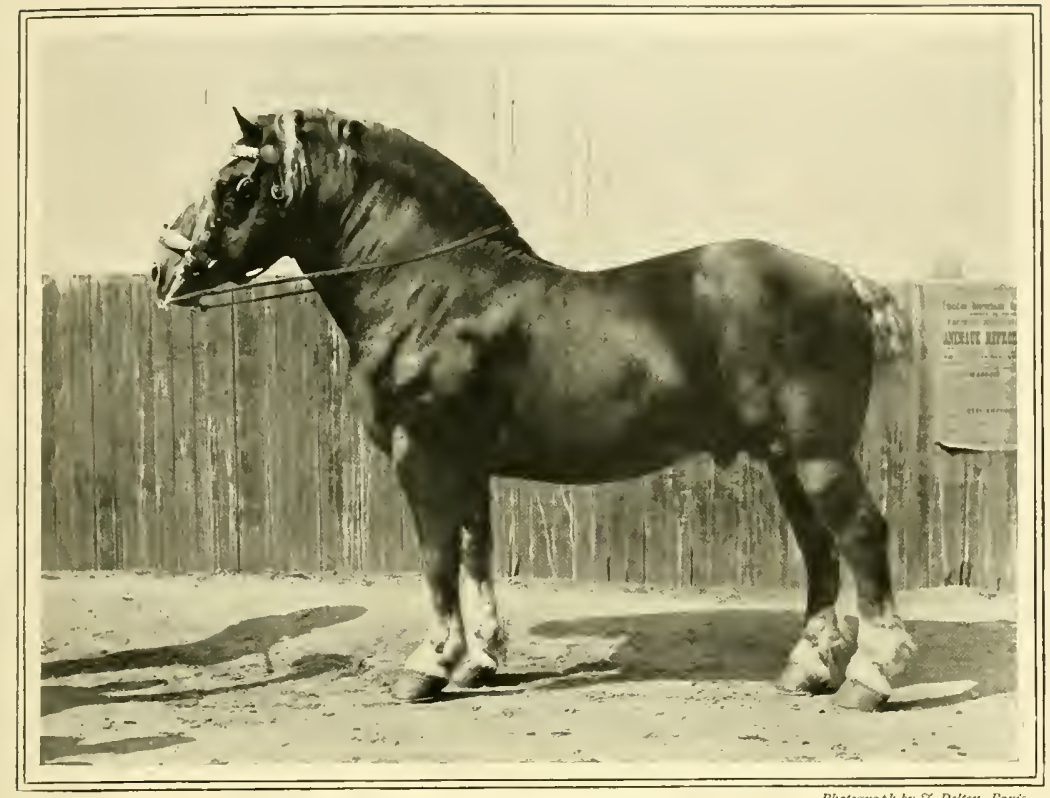

RÊVE D'OR: A TYPICAL HAINAULT STALLION.

\section{CHAPTER XXXVIII}

\section{HORSE-BREEDING AND BREEDS ON THE CONTINENT (continued)}

$\mathrm{A}^{\mathrm{L}}$ THOUGH horse-breeders in the Netherlands have been left a pretty free hand in the choice of their breeds, the Government has been responsible for several rules in this respect.

Even in the seventeenth century stallions had to be examined in most of the provinces, and in 1799 a law regulated this matter for the whole country. Amongst other rules, this law ordered that Government judges had to examine the stallions and only pass the best. A man who owned only one stallion had to have a black or a bay with black points. He who owned more than two stallions was obliged to have two jet-blacks or one black and one bay. The heiglit had

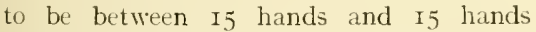
2 inches, and sires had to be bred in the country. At the same time premiums were given to the best horses and mares. This law lasted until 1803 , and the above mentioned rules were left after that time in the hands of the different departments. During the Napoleonic wars horses in the Netherlands became very scarce. This decided the Govermment to establish two stallion depots, one in Gelderland at Borculo, and one in Luxemburg. For Borculo were bought a good number of brood mares, and stallions were imported from Mecklenburg, Pommeren, Lithauen, and Hungary. Farmers did not quite like these under-sized horses, and so in $\mathbf{I} 825$ and 1827 stallions were imported from Holstein (ten of which were English bred), and also twenty-five Russian horses of good breeding. Later, in 1837 and 
I838, twenty-three English thoroughbred horses were added to the Dutch stud. For finincial and other reasons this Govermment establishment was given up in $18+\mathrm{I}$, and the improvement of horse-breeding left to each province.

The Brabant or Brabançon horse, undoubtedly the lineal descendant of the great Flemish war-horse of the Middle Ages, is the most widely distributed, the most valuable, and the most numerous of any breed in Belgium. Light horse breeding in Belgim is insignificant compared with the breeding of heavy draught horses. Possibly it was to some extent from the old Flemish stock that the breed of English Shire horses was built up, and Belgimm's massive stallions are still in demand in all parts of the world. The Brabant breed flourishes in nearly every part of Belgium, Luxemburg being the only province in which it is not met with. Belgian statistics estimate the number of Brabant horses (Brabançons and Condruziens) at 225,000, and the Ardenne horses, a rather smaller breed, at 25,000 .

\section{Points of the Brabant Horse}

The Brabant has a well-modelled head, rather light in comparison with the size of the body, with full lower jaw. His strong neck is slightly short, matching his thick-set trunk, and his withers are thick and fleshy. His back is short and wide, his chest full and round, and his massive croup, well but not deeply cleft, is furnished with thick, muscular pads which sometimes make it appear too high in comparison with the loins. The limbs are powerful, with wide joints, short but elastic pasterns, and wide, well-made hoofs. This splendid beast of burden draws loads of three tons without any apparent effort, and four tons and even five tons on the flat pavements of the quays of Antwerp. The district for the breeding of the Brabant horse is mainly composed of clay soil, highly fertile. Indeed, he does not do well in less fertile zones.

In Germany and elsewhere, the name of Ardenne is popularly applied to all Belgian horses, even to the most weighty Brabants. But, as we have already mentioned, the Ardeme or Ardenuais breed is numerically small compared with the heavier Belgian horse, and, what is more, the geographical area he covers comprises merely the province of Luxemburg and some cantons in the provinee of Namur and Liége. He is also bred on the French side of the frontier. The essential differences of form between the Ardenne and the Brabant horse are gradually disappearing, and often it is only by their dimensions that one can distinguish between the two. It amounts to this, that the light Ardennais of the "good old times" is metamorphosing itself into a Brabançon of small size, and is now simply the lightest form of the Belgian draught horse.* His height is from I m. $4^{8}$ to $\mathrm{I} \mathrm{m} .5^{8}$, his temper good, his endurance extreme. He makes the hardiest of horses for omnibus and tramway work, and it is from the light animals of this breed that the Belgian artillery secures its vigorous, agile, and docile harness horses.

\section{Belgian Government and Breeding}

Some of the regulations concerning the improvement of the native breeds of draught horses in Belgium go back to the eighteenth century, but the system of subsidising the provinces began in I8fo. The objects of the provincial councils, acting in conjunction with the Mlinister of Agriculture, are (a) to discard from use the stallions not possessing the qualities desired for the improvement of the breed to which they belong; and $(b)$ to encourage, by means of premiums, the preservation of the best animals, sires as well as mares, of the original breed. Each year, in the month of October or November, there is an examination of stallions of the native breed (Belgian draught horses) designed for the public service of the year. For the purposes of this survey the provinces are split up into departments, making forty-five in all-viz. three in the province of Antwerp, six in Brabant, six in West Flanders, five in East Flanders, six in Hainault, five in Liége, two in Limburg, * "Le Cheval Belge," by J. Leyder. 
five in Luxemburg, and seven in Namur. "It is to this process of selection, carried out for many years in some of our provinces, that Belgium is indebted for the most part for the possession of a breed of draught horses of quite the premier order," said the Belgian NIinister of Agriculture in an interesting brochure issued in connection with the exhibition at Liége. In I 886 the Society of the Belgian Draught Horse was founded, and has done a great deal of good for horsebreeding by means of its premiums at shows and its Stud Book. The Government allows the society an annual subsidy of 30,000 francs, this being in addition to premiums to breeders given directly by the State.

Danish horses at one time were of high repute, and had some share towards the making of the Orloff breed of Russia, but when Schleswig-Holstein came under German rule, Denmark was deprived of its most valuable pasture land. A useful cart-horse is bred now in Jutland. Danish horses, however, are mainly on the small side, but very strong and hardy, and on the sea-coast a sturdy race of ponies is bred, somewhat similar to those of Iceland. In the course of travels in Norway, and particularly in the neighbourhood of the northern fiords, we have been struck with the excellent breed of ponies produced in those parts. They are from I4 hands to $\mathrm{I}_{4}$ hands 2 inches, and in colour nearly all dun, or what we should call a washy chestnut. These little ponies do splendid service in the mountainous district, and it is a pleasure to ride behind them either in carriole, or stole carrje. Botli in Norway and Sweden horse-breeding is mainly in the hands of small farmers. In the latter kingdom there are some good thoroughbred and English half-bred sires, but Sweden imports a good many horses for military purposes, going as far as the Argentine in recent years for this purpose.

In closing this chapter the writer desires to express his thanks to the directors of those foreign Departments of Agriculture who have courteously supplied him with information for this section of "The Book of the Horse." He is also deeply indebted to our own Board of Agriculture and Fisheries. The authorities of this ably-managed department at Whitehall Place have been most kind in placing their library at his disposal, and in assisting him in other ways.

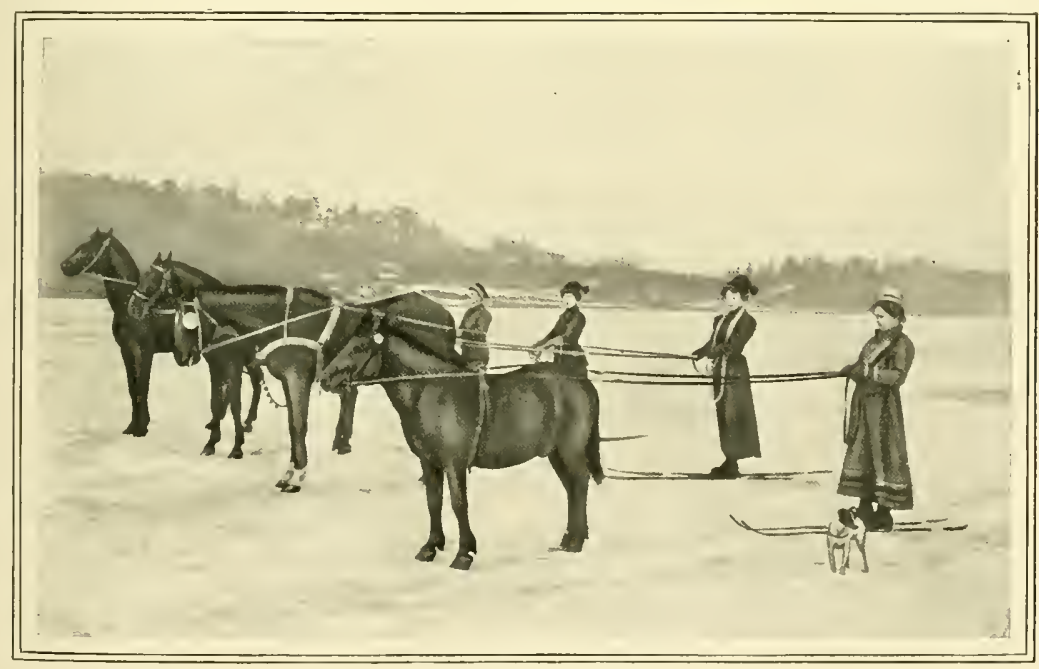

NORWEGLAN PONIES. 


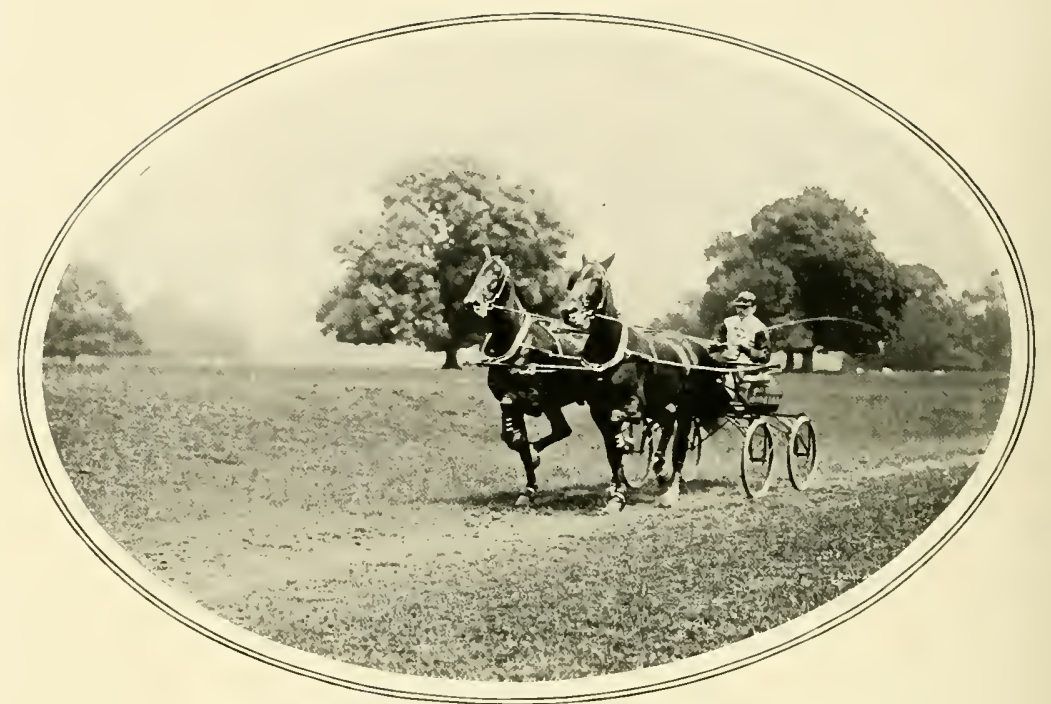

MR. WALTER WINANS'S TROTTERS. PRINCELL AND LAKE ERIE.

\section{CHAPTER XXXIX}

\section{AMERICAN HORSES}

\section{$\mathrm{S}_{\mathrm{S}}$ in the popular idea in this country, A the American horse is the trotter,}

There are all sorts of curions fancies and conventionalities connected with the American trotter in England, and they are very hard to eradicate. For instance, if one talks with the "man in the street" about the trotter, the conversation almost invariably is as follows: Man in the Street: "How many miles an hour can your horse trot?" (never "What is his record?"). It takes a little calculation for a trotting man to be able to answer this question, as he is so used to calling a horse, for instance, a 2.20 horse or even "a twenty horse" without the "two," that it takes some calculation to reduce " a mile in two minutes twenty seconds" into "about $25_{4}^{3}$ miles an hour."

Then invariably comes the remark, with a smile: "Quite so; but how long can he keep it up ?" (as if a horse were a motorcar, and as if anyone asked how long a Derby horse can keep up his gallop). The next invariable question is: "The harder you pull at him the faster he goes, and when you drop the reins he stops, is that not so ?"

The following two remarks are assertions, not questions; they are: "An American trotter cannot pull weight," and "An American trotter cannot trot fairly-he shuffles." Now this last remark is the result of the so-called trotting races in England. In all other countries trotting races are naturally confined to trotters, but in this country "pacers" are allowed to compete in trotting races. As a pacer, price for price, is a very much cheaper horse than a trotter of the same speed (a trotter with a speed of two minutes fifteen 
seconds for a mile is a fast horse, whereas a pacer of that speed is quite a third rater), it follows that most of the horses " trotting !" in English races are pacing, and the public get to think that paeing is "American trotting."

As to the doubts concerning the weightpulling capacity of the American trotter, the Coaching Narathons at the International Horse Shows of Igon and IgIo have dispelled them for ever. Mr. Vanderbilt and Judge Iloore, driving American trotters with a full load in a coach, out-trotted all the other horses, both hackneys and lunter bred, and in the former year Mr. Vanderbilt won the cup.

As to the idea that you must pull hard at a trotter, the fact is that the modern trotter has a very light mouth. Lou Dillon, the ITorld's Champion (mile in one minute fiftyeight and a half seconds), used to go with a loose rein, and most of my horses can be "speeded" with the reins in one hand and stopped at the word "Woa!"

\section{The Question of Docking}

In my opinion, the idea of docking a harness horse also is wrong. There seem to be two reasons offered for docking horses, the first of which is that if a horse carries his tail tucked in, he is improved by docking. Now, as an American trotter does not tuck his tail, nor need a "spoon" under his dock like a hackney, but carries it like a flag, there is no necessity to dock him, but if a short tail is preferred he can be "banged." The second is the exploded idea that a long-tailed horse is dangerous to drive, especially in a low carriage, on account of his getting his tail over the reins.

Now I have driven since I was ten years old, and have had trouble several times with horses getting their tails over the reins, and in every case it has been with a short-tailed English horse.

The American road and speed wagons, "runabouts," etc., are all much lower than English carriages, so if the idea of a long tail being dangerous were correct, it would be most evident in American carriages; but the exact reverse is the case. A docked horse, who switches his tail and grabs the reins when he gets his tail over them, is dangerous, but the reason he is so is bcause he has been docked. A horse, if treated kindly, does not mind his tail being touched, or if he happens to switch it over the reins takes it off again, just the same as if he happens to switch it over the dashboard or the shafts. But if he has been docked, he connects, in his mind, the idea of his tail being touched with the agony of being docked, so the moment he feels the reins under his tail he says to himself: "The brute is going to ehop another bit off my tail," and naturally kicks for all he is worth, or holds tight to the reins with his mutilated dock, and runs away.

I was driving a man with one of my trotters, and he seemed very nervous and at last said: "What would happen if the horse got his tail over the reins?" I said: "This," and leaning forward took hold of the horse's tail and put it over the reins. The horse kept on jogging, and after going a few hundred yards, I, holding the reins still slack in the left hand, swung them to the left, throwing the horse's tail clear of the reins.

\section{Description of the Trotter}

Now to come to the description of the trotter. As trotting races are not looked on seriously in England I will confine myself to the use of trotters in harness on the road. There are two types of trotter; one the light well-bred horse, full of quality, and looking like a light-weight hunter or almost a thoroughbred. This horse is an ideal one for driving to cover or for pleasure driving, either singly or in pairs, at any speed from six to twenty-four miles an hour. Most of them have perfect manners (as in fact the rast majority of American horses have). If there is a smash the horse does not begin " milling," but stands still till the damage is repaired. This is owing chiefly to the horse having been taught to rely on limself during breaking, not being driven beside a "break horse" in a heary break witls a dozen stablemen hanging on or running beside him. This type of trotter has 
no more action than a thoroughbred, and does not bang his legs. He can be kept on all day at sixteen miles an hour without being hurt.

\section{The Morgan Type of Trotter}

Another type of trotter is the Morgan type, which corresponds to the hackney, but has much more quality, a small bloodlike head, high action with great speed, and although very quiet, much more courage and stamina than any hackney. This is the type of horse which won the Marathon coaching race, and with which Messrs. Watson, Vanderbilt, and Judge Moore have won so many first prizes at the International Horse Show each year, against hackneys.

This, in my opinion, is the coming carriage horse of the world; he can do everything, and do it better, than any carriage horse of any breed can do. He can step, he can pull weight, he can catch a train, and he can be trusted for the owner's wife to drive, or to take the nurse and children out for a drive. He can be driven till he drops dead, without using the whip.

\section{The Kentucky Saddle-Horse}

A type of horse not generally known in England is the Kentucky saddle-horse, but it is one which would not be much cared for in England. It is rather "harnessy" in English eyes, with too much crest. It is what is called "gaited"; that is to say, that, besides walk, trot, and canter, it can do the rack, single foot, pace, fox trot, and other gaits. "Single foot" is the term given to the action when all the feet are moving independently. Like an extremely fast walk, single foot is like pacing only slightly disconnected, and so on. All these gaits are easy to sit on, no rising in the stirrups being necessary. The horses need a special training on the part of the rider, as anyone using the ordinary "aids" could not make the horse understand them. Polo ponies broken in Anerica do not generally get on with European riders, because, whilst in Europe the horse is turned and stopped by the use of the legs in con- nection with the reins ("school riding "), in America the turning is done entirely with the reins, and this is the reason American ponies are sometimes condemned as unhandy.

The above remarks were written by Mr. Walter Winans, who is the best-known owner of American horses in this country, and whose experience of all sorts of breeds -American, British, and Continental-is probably unique. Mr. Winans has experimented to an extraordinary extent both with harness horses and jumpers, but his chief fancy appears to be for trotters, and at English shows he has for many years carried all before him with horses, either bred by himself, or imported from America. The best of his trotters are kept in V'ienna, where they win a very big proportion of the most important Austrian trotting events, but as, already explained, American trotters are not popular in this country, and few of the best--except those owned by Mr. Winans -are ever seen at the English shows.

\section{Horse-Breeding in the States}

Brief reference must now be made to American horses generally. And first it may be said that in the United States horse-breeding has for the last hundred and fifty years been carried on in very whole-hearted fashion, and with the very best results. Probably the United States is the greatest rival which Great Britain has in horse production, and in several ways it takes the lead of this country. It is not exactly easy to make a comparison, and it must be stated that all the best breeds in the United States have been built up on a British foundation, but the fact remains that while they have in the States thoroughbreds of which the best are as good as our English thoroughbreds, they have also the trotters and pacers, and an enormous number of light horses both for riding and driving. These last-named nags are not strictly thoroughbreds, but they are not far removed from it, and one is inclined to think that there has, in a measure, been more attention paid to the breeding of 


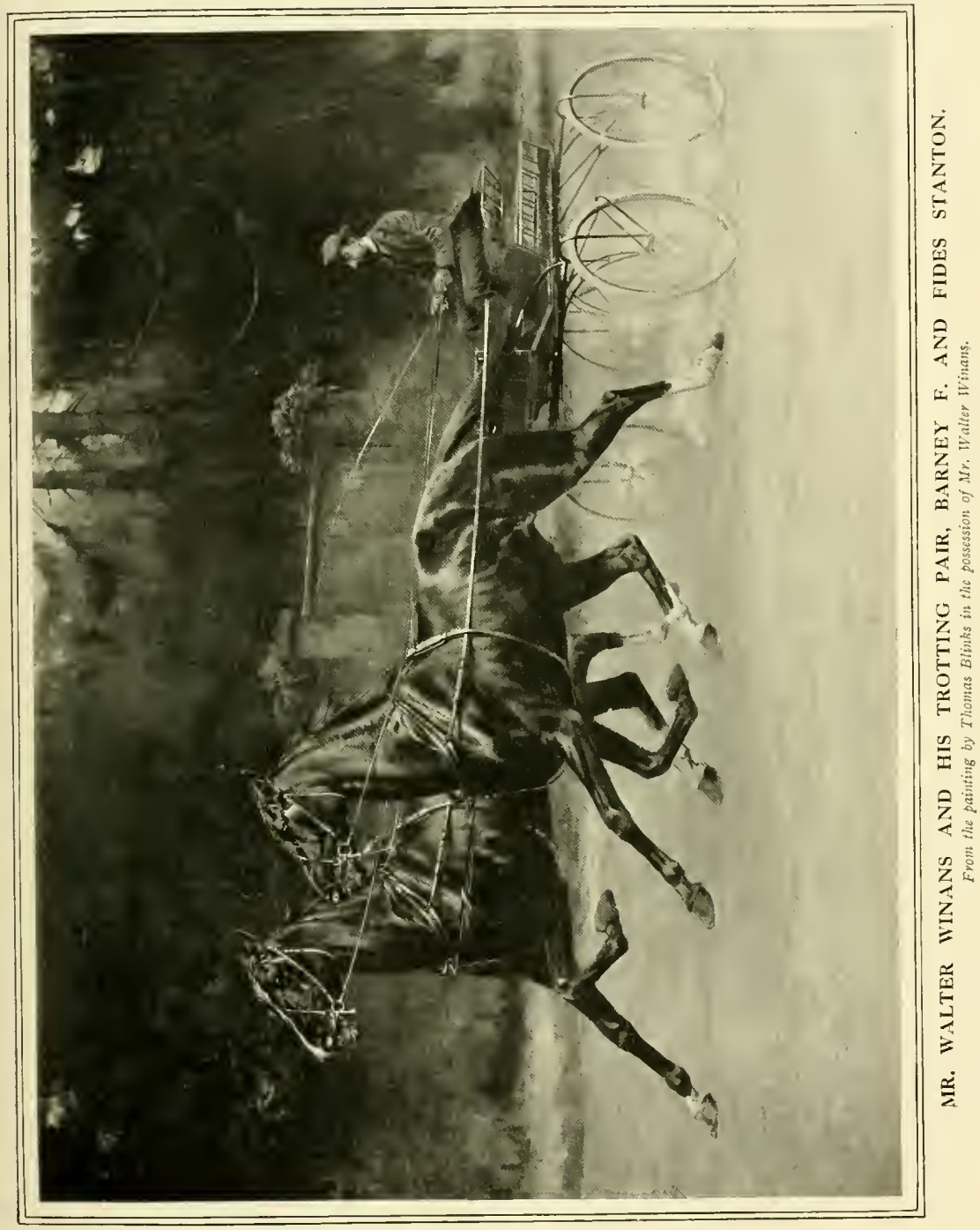


ordinary light horses in the States than there has in this country.

\section{American Horses in England}

Some ten or twelve years ago large consiguments of these horses were sent to Liverpool, and sold by auction every week. We have no statistics on the subject, but from personal knowledge should say that about $f_{50}$ was the average price paid for these nags. They were mostly bought by dealers, and were sent all over the country; the more heavily built ones were used for light van work, the lighter and better bred ones as harness horses, hunters, and hacks. Scores of them appeared in the huntingfields about that time, many being reputed to be British. They could gallop and jump, and could stand a long day, when they became acclimatised, while they made good coach horses, and were, for the most part, very hard. We have seen one or two that were difficult to ride in the huntingfield, but this was due to the fact that they were high couraged horses, and this was proof that they were well bred. It was said that many of these horses had been reared in Kentucky, but be that as it may there was a big demand for them for a time, and probably the demand only came to an end because of the rapid advance of mechanical traction.

\section{Whence Did the American Come?}

Professor William Ridgway, in his "Origin and Influence of the Thoronghbred Horse," tells us that at the time of the Spanish conquest of America no horses, either wild or domesticated, existed in any part of the country, and that all the thousands of horses now ranging the Pampas of South America are descended from seven stallions and five mares introduced by the Spaniards. Yet it has been proved that in pre-glacial times North America possessed at least nine perfectly distinct wild species of cquide, which varied in size, and so forth. It is not our concern now to discuss the prehistoric horse, but to show how the modern species has been bred in America, and, beginning wilh the thoroughbred, it may be said that the American breed owes its origin to a horse named Bulle Rock, which is said to have been foaled in England in 1718 , and imported to Virginia in 1830 . The first volume of the general Stud Book makes no mention of this horse, but from advertisements in very early Virginian papers it appears that he was by the Darley Arabian, dam by the Byerly Turk. There are three Byerly Turk mares in the Stud Book, one of which is credited with having bred a filly to the Darley Arabian in a year not given, but probably in $1706-7$ or 8 , but no trace of a colt bred in this way is forthcoming. Bulle Rock was owned by Messrs. Samuel Patton and Samuel Girt, of Virginia, and was spoken of in the prints of the day as being a horse of the best English (or Arabian) racing family. Though Bulle Rock was the first race-horse-so far as is knownto reach America, horses had been imported from the earliest days of the discovery of the country. Columbus took horses with him on the occasion of his second voyage to the new country, and it is on record that in 1527 Gabeza de Vaca turned loose certain Spanish horses and mares-these being the animals to which allusion has already been made.

\section{Virginia and Horse-Racing}

In 1609 a stallion and six mares were sent to Virginia from England; in 1625 certain horses were shipped from Holland to New York, and four years later there was a consignment of English horses to Boston. All this maybe read in "The American Thoroughbred," by Charles Trevathan, a most excellent book, which treats of American racing from its earliest days, and to whom the present writer is much indebted for information which has been sadly scamped elsewhere. Virginia was the earliest home of American racing, and until quite recent times took the lead in a sport which has since become general all over the Lnited States. In 1763 a horse named Protector was bred by Mr. Vernon, in England, which was by Shepherd's Crab (a son of the Grey Crab by the Alcock Arabian) out of Crazy, by Lath (a son of the Godolphin Arabian), 
and was sent to America, and there renamed Lath. This horse is said to have made it great impression on the stock of his time, and it would be interesting to know if his line still exists in tail male. He was sent to New York rather more than I fo years ago, and by this time, both in the Northern and southern States, a breed of thoroughbreds, or as nearly thoroughbred as could be obtained, was being erolved, just as the same process was going on in this country.

\section{Early Races in America}

The first actual American racing organisation was formed at Charleston, South Carolina, in 1760 , the course and club. house being constructed by Mr. T. Nightingale, a Yorkshireman by birth. Virginia speedily followed with a Newmarket, a Tree Hill, a Broadrock, and a Fairview course, and before 1776 racing in the Southern States was in full swing, while after the Revolution racing stables were established in Ularyland, as well as in Virginia and South Carolina. Long Island was the scene of the first racing in the North, but the Southerners kept the lead in all racing matters until the nineteenth century was well advanced.

\section{Diomed's Influence}

The horse which did the greatest good to the American turf was Diomed, by Florizel, the first winner of the English Derby in I7So. This horse was by a son of Herod, and Herod was fourth in male descent from the Byerly Turk. He (Diomed) was out of a mare by Spectator, and was bred by Sir Charles Bunbury in Suffolk, or by Mr. Vernon. The last-named owned the mare before Sir Charles did, but the Stud Book states that the Spectator mare was in Sir Charles Bunbury's possession when Diomed was foaled. It is a matter of little consequence now, but after Diomed had won, and been beaten in many races, he commenced stud life in England at a five guinea fee, which was afterwards doubled. Somehow he did not catch on with breeders, and was sold for fifty guineas to go to America. He was taken to Virginia, and there resold for upwards of I,0oo guineas, and stood for nine seasons in the new country. Ieantime, curiously enough, his stock succeeded in England after he had come to be regarded as a failure, and notably his son Grey Diomed was a great runner and a. successful stallion. Young Giantess, by Diomed out of Giantess, bred, among others, Eleanor, who won the Derby in ISoI, and Sorcerer, who sired a Derby winner in Smolensko, and whose name appears in the direct line from the Godolphin Barb to West Australian, Barcaldine, Marco, and Neil Guw, the Two Thousand winner of Igro. This proves that Dioned was sent ont of this country before his stud value was really known, and it is a curious and exceedingly interesting fact that he should have been as successful in one country as he was in the other. In America he sired a host of winners, but there is no space at our command wherein to mention them at length, and we shall merely refer to Sir Archy, by whom the line, which exists to the present day, was carried on. Diomed was a chestnut of 15.3 hands, and he died in 1808 , aged thirty-one years, having been taken to America when he was twentytwo years of age.

\section{Diomed's Descendants}

From his earliest arrival in Virginia Diomed became the leading stallion of the day. His son, Sir Archy, though bred in America, was of English parentage, being out of Castianira by Rockingham, and bred by $11 \mathrm{r}$. Popham, in 1796 . There is a note in Vol. I. of the Stud Book to the effect that the mare was the dam (by old Diomed) of a celebrated American horse, "Sir Archie." Castianira was out of Tabitha, by Trentham out of Bosphorus. Trentham was by Sweepstakes, but there were several horses of that name, and presumably this Sweepstakes was by an earlier horse of the same name, who was by the Oxford Bloody Arabian.

Sir Archy was a big thoroughbred for that day, standing fully sixteen hands. He did not at first assert his supremacy, but after a while he won many important events of 
the day in Virginia, and came to be justly recognised as a champion. As in England at the same time, four-mile races were common in Virginia, and Sir Archy proved himself to be a great stayer. At the stud his successes were great, and in fact he did an enormous great was his reputation that in some quarters the possibility of opening races to the world, bar Boston, was discussed. Among many other winners sired by Boston, Lexington and Lecompte stand out, and these two were said to be far the best animals

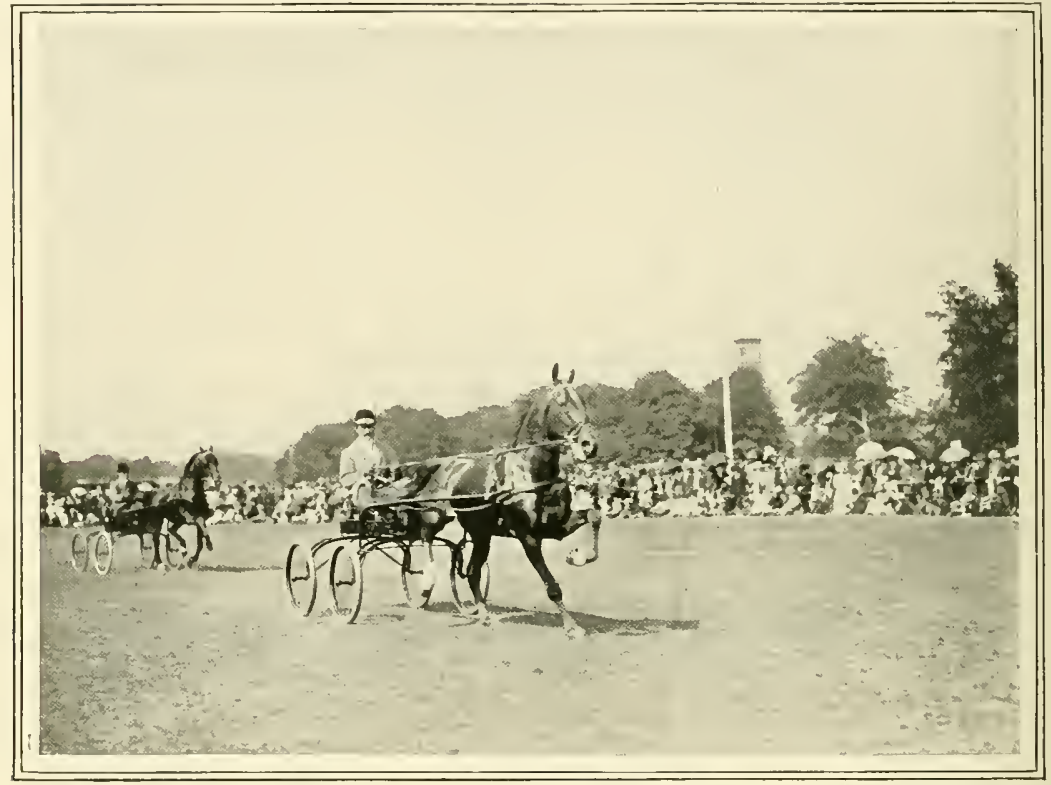

MR. WAITER WINANS'S CHAMPION ROADSTER. BONNIE VIEW.

amount of good to the American turf, especially in Kentucky, where after a time his descendants were exceptionally numerons. His son Timoleon was the sire of a great American race-horse named Boston, who was foaled in $\mathrm{I}_{3} 33$, and who being a small colt was not put into training until he was three years old. As a two-year-old he had been bonght for $\$ 800$, and his first efforts in the following year were not altogether satisfactory. He won an extraordinary trial, however, and after that came to wonderful form, winning race after race at two, three, and four miles. Many of his victories were gained in the Northern States, and at one period of his career he won in succession eight races, seven of which were four-mile heat events, and so in training in the United States in 1854 . They ran a great four-mile heat match at New Orleans on April 8, 1854, which Lecompte won, but the line of Lexington has been handed down, and is at the present day very familiar to those who study the pedigrees of the American horses which run in this country. Lexington was out of Alice Carneal, by the English horse Sarpedon, and Lecompte out of Peel by imported Glencoe, and was controlled by Mr. Richard Ten Broek, who a few years later was well known on the English Turf. Lecompte only ran seven times, and won six races worth $\$ 56,000$. Lexington was a bay, standing I5 hands 3 inches, and at the stud he sired the winners of $\$ \$_{1,159,321}$. He had twenty-one seasons of stud life, siring some six hundred 
horses, of which two hundred and thirty-six were winners. He may indeed be called the Stockwell of America, for he was not only by far the greatest winner of his day, but his progeny were the best runners of the next generation.

\section{Lexington's Progeny}

Among his early successes was the mare Idlewild, who was the best performer of her day, and from Glencoe mares he sired three famous horses, named Kentucky, Norfolk, and Asteroid, all of whom were big winners in the early 'sixties. Another great son of Lexington was Harry Bassett, who was not a great stud success. Nevertheless a majority of the American horses which win in England at the present day have the blood of Lexington in their veins, and yet according to our standard this blood is not altogether pure, for the dam of Timoleon traced to unknown sources, while the dam of Ball's Florizel, who was the sire of Boston's dam, was also from an impure source. Boston, by the way, was inbred to Diomed, and Lexington had also the Diomed blood through his dam Alice Carneal, who was out of a mare by Sumpter, a son of Sir Archy. The curious blot in Lexington's pedigree is that referred to in connection with Ball's Florizel. This horse's dam was by imported Shark-who was by Marske-the sire of Eclipse, out of the Snap mare, who goes back to a natural Barb mare, who did not found a family in this country, but whose name is in nearly every American pedigree of the present day. The name of Shark is to be found in Vol. I. of the English Stud Book, and no doubt his blood was quite as valuable as that from which a majority of the British female thoroughbred families were founded. In the case of Timoleon's dam the case is different, and she traces to purely American sources.

It will be seen from the above that the American thoroughbred has its origin in the English thoroughbred, but to this it must be added that there have been constant importations of British blood to America since Diomed went there. For example, Diomed was imported in I799, and Lexington was foaled in $185^{\circ}$, and in the pedigree of the last-named there are the names of eleven other imported horses and mares in addition to that of Diomed.

\section{The American Race-Horse}

As to whether English or American racehorses are the better there is no need to argue, but of late years the majority of the latter which have run in England have been more remarkable for speed than stamina, and this is rather curious, because the system of rumning four-mile heats was maintained far longer in America than it was in the United Kingdom. From America a small proportion of stayers have been sent to run in this country, and among them were Parole, who won the Great Metropolitan in I879, Foxhall, who won the Cesarewitch as a threeyear old under 7 stone 12 lbs. in I88I, King's Courier, who won the Doncaster Cup in Ig0o, and David Garrick, who won the Chester Cup in rgor. These four horses all stayed well, but a majority of the best American winners in England have been milers-such as Caiman or Democrat-or short distance runners, such as Americus Girl-a direct descendant in tail male of Lexington-or many of the best of Mr. Whitney's present-day runners. Americus Girl was bred in Ireland, and was by an American-bred sire out of an Irish-bred mare.

In the matter of looks there is not a pin to choose between American and British thoronghbreds. The former have just as much size, and, to our thinking, more quality than the average Colonial horse; but when compared with the very best English horses they are perhaps just a little lacking in this respect. Their bone appears to be as good as ours, and, horse for horse, the best that one sees over here would compare well in the matter of measurement; but it is possible that the best Americans have not been sent to England, and it is quite likely that in races of not more than a mile their best might beat our best. This is merely conjecture, however, and there can be no real means of comparing the best of one country with the best of another, when thousands of miles 
separate them and the question of acclimatisation comes into the argument. During Igro there were many successes in this country on the part of American bred horses.

\section{American Racing Methods}

American methods of training are somewhat different to ours; but, on the whole, there is little reason for supposing that they are better than those in rogue in this country. In the matter of jockeyship, we have, however, copied the American for something like ten years, and both for and ayainst the now universally adopted American style there is something to be said. Its one great advantage is that races are run from beginning to end at a high rate of speed. Time was when, in many long distance events, especially weight for age races, half a dozen horses would wait on each other for a mile and a half, and only really race for the last three or four furlongs of a two-mile race. This was not often the case in handicaps, where light weights were, naturally, ordered to make running; but it was exceedingly common in other races, and perhaps most of all in cup contests and in the old races for King's or Queen's Plates. The advent of American jockeys to this country altered all this, for they dashed away in front, compelling their opponents to come after them; and now that the fashion of coming along all the way has become established the average race of a mile and upwards is much more truly run than it was. On the other hand, it is by no means certain that the American forward seat is an advantage. It probably eases the horse in some degree, and it most certainly neutralises the pressure of a heavy head wind; but before it became the vogue jockeys used to throw their weight forward by standing up in their stirrups in the early part of a race and were only sitting down when the "riding" began in the last furlong or two. The jockeys had, when the old style was customary, far more command of their horses than they have to-day, when the forward seat is universal, and most certainly under the present conditions swerving is mucl more conmon than it formerly was. And when a horse swerves, a jockey, perched forward on its withers, has nothing like so much power over his mount as the jockey who is sitting down in the saddle. The upshot is that swerves are now not only more frequent, but are of longer duration than they once were, and at times one sees the best horses, ridden by the foremost jockeys of the day, deviate from the straight line at the exact moment when ever so little deviation means the difference between victory and defeat.

\section{Condition of Racing in America}

As we write, racing is in a bad way in America, owing to the action of a certain section of the people. It is not within our province to go into the politics of the matter, but that the sport of racing can be carried on in honest fashion we are firmly convinced, and the average English racecourse of the present day affords a scene of enjoyment for thousands of horse lovers, and it seems a pity that in America this should not be recognised, as it is here. We have not sufficient knowledge of American racing to understand thoroughly the questions which are at issue on the other side of the Atlantic, but we may state with confidence that the American nation has built up a breed of race-horses which is probably equal to the breed of any other country in the world, and that therefore it is matter for great regret that the horse lovers of some portions of the United States are at present unable to carry out their favourite pastine. There are just now a fair number of American horses racing in this country and in France, and in addition American yearlings are frequently sent to this comntry to be sold. During the last season or two many of these have been sold cheaply, and have turned out great bargains to their purchasers. Colts and fillies by Watercress, Heddler, Hamburg, and one or two other sires, have won a great number of races in this country, and in 1908 the Grand National Stecplechase at Liverpool was won by Rubio, an American-bred gelding, who had been sold at Newmarket when a yearling, ten years before he scored his 
memorable victory at Aintree, for the ridiculous price of fifteen guineas.

\section{The American Trotter}

Probably to the average Englishman who does not happen to be an expert in turf matters the idea of the American horse is usually associated with trotters, and as regards this particular breed America stands alone, in spite of the fact that trotting at the high rate of speed which the best American horses arrive at is altogether artificial. It is probable also that even now the trotting horse appeals to the average American more than the thoroughbred does, and this is only natural, for trotting is an especially American sport, while the racing of thoroughbreds is only a sport copied from another country. The horse to whom the American trotter owes his origin is Messenger, who was by Mambrino out of a daughter of Turf, and a mare by Regulus. Mambrino was by Engineer, Engineer by Sampson, Sampson by Blaze, and Blaze by Childers, a son of the Darley Arabian. Thus as the present lines of American thoroughbred blood go back to the Byerly Turk through Diomed, so do the best lines of trotting blood go back to the Darley Arabian through Messenger. Of the horse first named the Stud Book says Messenger was sent to the United States; but the date of his being foaled is not given, and we only know that his dam was born in I774. He arrived in Philadelphia in I788, and according to American authorities he was four years old at the time. He had won races in England, and was a very good-looking grey horse, and he had twenty years of stud life in the Northern States, and was held in such great estimation that at his funeral military honours were paid him and a volley of musketry fired over his grave.

\section{Great Trotting Matches}

As can be readily understood, his immediate offspring were raced on the turf, and as a matter of fact trotting races of the kind now in rogue are of comparatively modern date, the first public race of the kind only having taken place in I8I5. This race was the outcome of a bet that no horse could trot a mile in three minutes. According to Porter's " Spirit of the Times," the horse about whom the wager was made was a rat-tailed, iron-grey gelding named Boston Blue. About his pedigree nothing was known, but he aceomplished his task and was afterwards taken to England, where he trotted eight miles in 28 minutes 55 seconds, winning a wager of $f_{1} \mathrm{OOO}$. In I 825 the New York Trotting Club was organised, and in I828 the Hunting Park Association, in Philadelphia, was formed "for the encouragement of the breed of pure horses, especially that most valuable one known as the trotter." In I 829 Topgallant, by Hambletonian, a son of Mlessenger, trotted twelve miles in larness in 38 minutes, and three miles under saddle in 8 minutes 3 I seconds, and it was stated that when nineteen years of age this horse could trot a mile under $150 \mathrm{lb}$. in 2 minutes +5 seconds. About the same time a mare, named Betsy Baker, by Mambrino, like Hambletonian a son of Nessenger, beat Topgallant under saddle, carrying $\mathrm{I}_{50} \mathrm{lb}$. over a three-mile course in 8 minutes $3 \mathbf{I}$ seconds. It is said that this mare could trot twenty miles within the hour.

Here it may be stated that there has been a great want of originality in the naming of these early American trotters. The student of pedigree will find constant repetitions of the names of Nambrino, Messenger, Hambletonian, and others, and though some of these have a prefix it is not always easy to ascertain which of two or three horses of the same name is meant.

\section{"The Emperor of Horses"}

Trouble, by Hambletonian, trotted two miles in 5 minutes 25 seconds, and Sir Peter, by the same horse, three miles in harness in 8 minutes 16 seconds, while about the same time Screwdriver, by Mount Holly (another son of Messenger), trotted two three-mile heats in 8 minutes 2 seconds and 8 minutes to seconds. This horse was another great farourite, whose obituary was as follows: "The Emperor of Horses is no more: Screwdriver is dead." He died in 
I828 at Philadelphia, and was probably the best trotter which had appeared up to that time. Fron I830 onwards trotting was the most popular horse sport of America, but there is a table of statistics which dates from a much earlier period. This applies to the time in which a mile has been covered, and it begins with a horse named Yankee, who trotted a mile in 2 minutes 59 seconds in 1806 , and brings the record down to Lou Dillon, who trotted a mile in less than 2 minutes, nearly a luundred years later. This table emphasises the fact that it has taken a hundred years to reduce the time for the mile from 3 to 2 minutes, but it may be stated that very few of the very best trotters can do level time, and yet that there are scores of $2.10,2.15$, and 2.20 horses in every trotting community. The famous Mland S., who held the record for several years, did the mile in 2 minutes $8_{4}^{3}$ seconds. Her record was beaten by Nancy Hanks who cut off $t_{4}^{\frac{3}{4}}$ seconds, and this mare in turn had her record lowered by a quarter of a second, when Alix did the mile in 2 minutes $33_{4}^{3}$ seconds. This was in 1894 , and six years later half a second less for the mile was credited to The Abbot, who in IgoI lost his record to Crescens, the lastnamed doing it in 2 minutes $2 \frac{1}{2}$ seconds. Lou Dillon brought the figures down to 2 minutes in $\mathrm{I} 903$, and since to I minute 581 seconds, a record which seems likely to stand.

\section{Lou Dillon}

Lou Dillon is directly descended from Messenger through Sydney Dillon, Sydney, Santa Claus, Strathmore, Hambletonian, Abdallah, and Mambrino, the last-named a son of Messenger. The blood also comes from the Charles Kent mare, who was by the imported English Hackney, Bellfounder, out of One Eye by Hambletonian, the son of llessenger. The Hambletonian first mentioned in this pedigree was Rysdyk's Hambletonian, who was by Abdallah out of the Charles Kent mare; and it may be added that the pedigree of the mare just referred to has been questioned, but is nevertheless senerally accepted. Besides the line of blood we have mentioned there are many others, and as a matter of fact the best trotters of the present day are almost as well bred and of as long pedigree as the thoroughbreds. They are almost thoroughbreds to look at also, but perhaps a trifle longer in the body. Nost of them carry great quality when they are in training, and a majority are wonderfully docile and well-behaved.

\section{The Staying Power of the Trotter}

No doubt the fast times have been greatly helped in recent years by the light tackle and the excellence of the tracks; but the general result has been that a breed of horses has been evolved of which the best can trot at the rate of twenty-five miles an hour. And that they can keep up their pace in wonderful fashion is also a fact, though in this country little is known as to their ability to cover a distance of ground. The horses used by Mr. A. G. Vanderbilt and Judge Moore, of New York, in the IIarathon competitions, certainly travelled over sixteen miles an hour with a heavy coach and a load behind them, and a few years ago we sat in a light gig behind quite an ordinary American lrorse, who covered seventeen miles of country roads in Cheshire in a few seconds under the hour. There were milestones on the road, and these he passed at intervals of from three to four minutes, according to the nature of the road. He needed no whip on the journey, and pulled up at the end quite fresh. There were no steep hills on the road, but plenty of undulation, and the horse pulled steadily all the time, increasing his pace when the ground was in his favour, and slowing up just a little when there was an ascent. This horse had been trotted at the trotting ground near the Liverpool race-course, and though his pace was not great enough to put him in the front rank of such trotters as are seen on the English tracks, he could stay for ever, and was very powerfully built.

There are great numbers of good riding lorses in the States which are not exactly thoroughbred in the English sense of the word, but whose breeding has nevertheless been carefully attended to for many 
generations. These horses have been bred for saddle work, and in this country would probably be hunted, or used as hacks. There is a breed called the Mlorgan horse, to which Mr. Winans has referred, and another descended from a horse named Denmark, the latter chiefly located in Kentucky. Denmark was introduced into Kentucky some sixty or seventy years ago; he had been raced, and was by an imported horse named Hedgford-probably Hedgford by Filho da Puta out of Miss Craigie, by Orville, who was foaled in 1825 . About the breeding of the dam of Denmark there seems to be some doubt; but Denmark's son, known as Gaines' Denmark, was a great stock-getter, who was mainly responsible for founding the breed of riding horses which is known as the Denmark. True Morgan horses have capital action, great constitution, and are very neatly turned. The breed has, perhaps, not been so well maintained as it should have been, but it still exists, and, according to Mr. Winans, is used by the coaching men of the United States. Morgan horses are not very big, but have a wonderful combination of activity and power and a great deal of pace. As regards the purely American paces, the running walk, the rack, the fox trot, and so forth, it is urged that teaching these gaits has had a beneficial effect on the Kentucky saddle-horse, and that the discipline in training which the teaching involves has had a wonderful effect on the disposition and temper of the pupils.

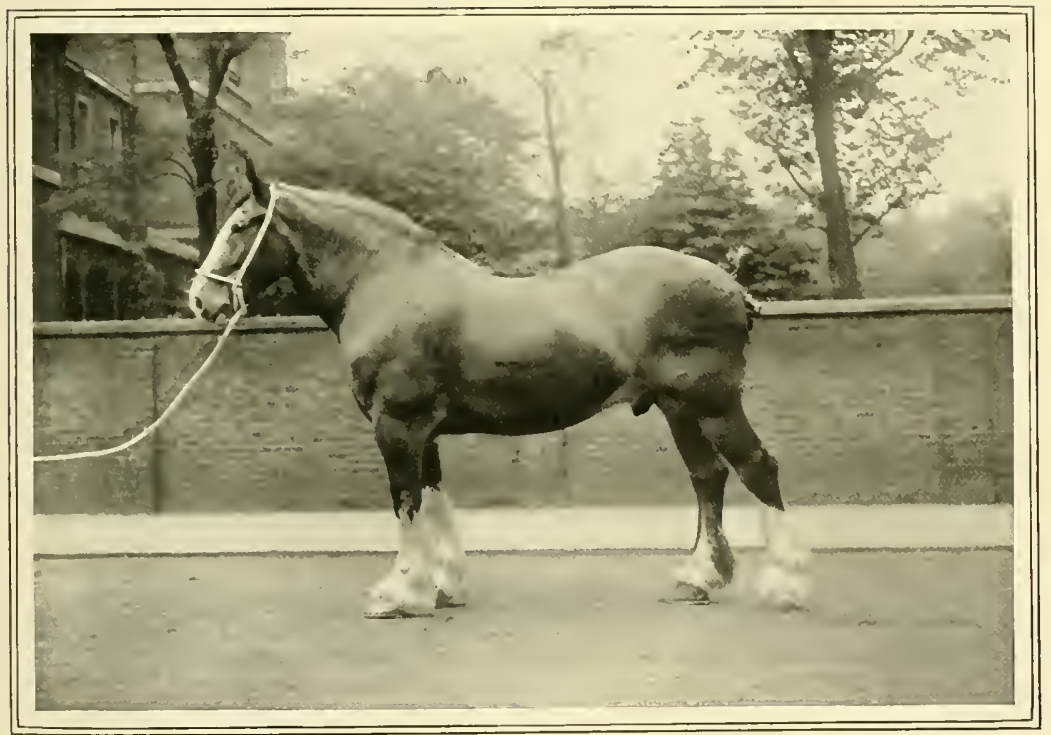

DREW ONE OF THE FAMOUS MORRIS CLYDESDALE TEAM.

Plotograph by W. A. Rouch 


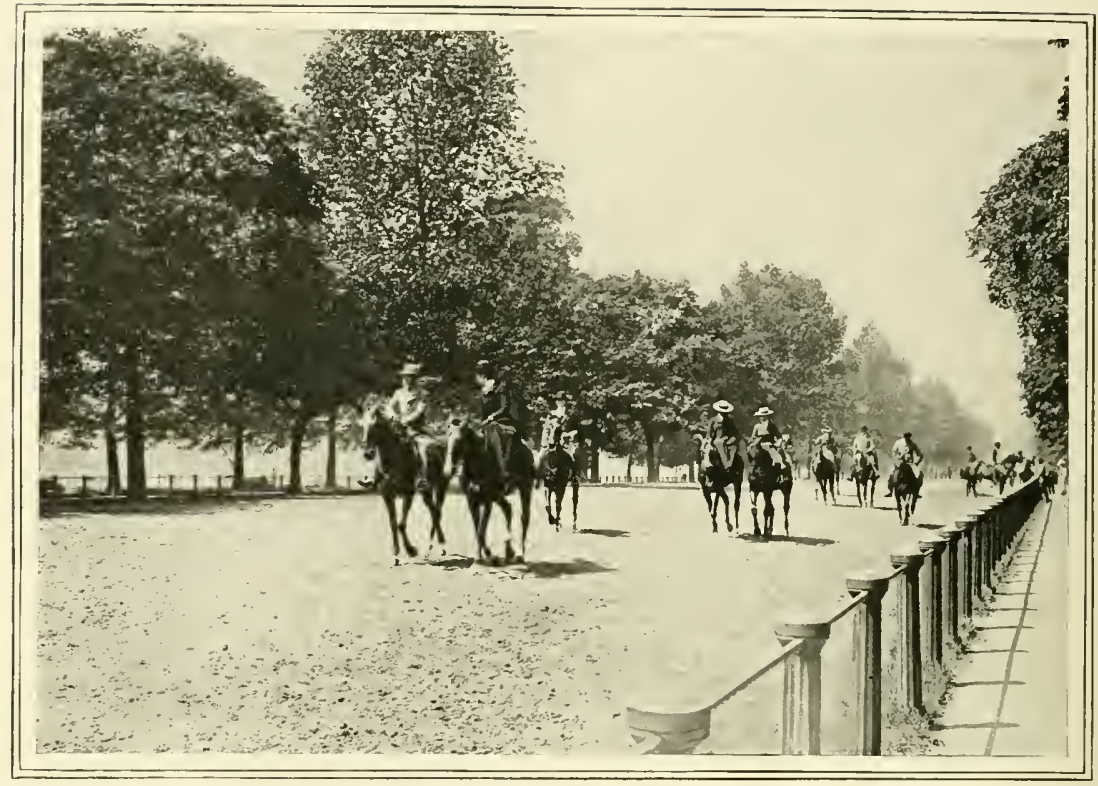

ROTTEN ROW:

Plotegraph by Stort of General Hllustrations Co.

\section{CHAPTER XL}

\section{THE LAW AS REGARDS HORSES AND THEIR USES}

I NTRODUCTORY.-Much of the law relating to transactions in which horses are concerned is generic, and is not specifically confined to those chattels; the broad principles which dictate it could, mutatis mutandis, be analogously applied to transactions relating to other animals and also to inanimate goods. There are, on the other hand, situations which, for all practical purposes, relate only to horses and the uses to which they are put, such as livery stabling and the principles which govern it, horse sales and horse warranties, and the rule of the road (pace, motor traction as a latter-day rival to the horse). Carriage by rail is not exclusively confined to horseflesh; at the same time, it is probable that the law would not have intervened so readily, if at all, to limit carriers' liability in this line but for the fancy values which attach to some horses, especially race-horses, coupled with the practice of invoking the aid of the rail to convey them to various sporting destinations. Then there are rules of the road and of traction and of general responsibility of owners for their horses' performances ; and, lastly, comes a class of situations to which, though not exclusively confined to transactions resulting from the use of horses, may be said to be due to the bulk of those leading cases from superior courts that deal with such contingencies to the existence of horseflesh; to wit, disputes and claims which arise out of gaming transactions. By far the majority of these have the ir origin in matters relating to the Turf.

For practical purposes, as regards the 


\section{THE LAIW AS REGARDS HORSES AND THEIR USES +6I}

normal lity reader, the more important departments of law relating to horses will be, firstly, that which deals with sales of such animals (and thence frequently with questions of waranty as to their condition and (jualities when sold); and, secondly, thit which relates to responsibilities on either side when a horse is on hire, or on trial with a view to possible bargain and sale thereafter; and, thirdly, the general duties of owners of horses towards fellow men.

\section{Sales}

11 hat is a Salc? - A sale of a horse is governed by the 1893 Sale of Goods Act, and especially by section + thereof, which requires, if the price is fIo or more, certain conditions to make the bargain binding. These can be :-

I. Acceptance of the animal by buter.

2. Acceptance by seller of purchase money or part parment as "earnest" money.

3. Sume written memorandum signed by the parties.

t. Signature of $(a)$ the buyer or seller, or $(b)$ agent thereof.

Lnder the statute there can be two classes of contract of this nature: the one a sale, the other an " agreement to sell." Action can be maintained upon either.

An Agrcement to Sell.-An agreement to sell (and hence also to buy) occurs when, by the terms of the bargain, delivery of the horse does not take place off-hand, but is arranged to take place at or before a certain date.

When, in such a case, the respective date arrives, and all conditions requisite have been fulfilled by the party claiming under the agreement, the precedent "agreement" becomes a "sale," conferring on the one party the property in the article sold and on the other the title to the purchase money.

The Statute of Frands requires written memoranda of any contract of sale which has more than a year to run before completion; but for all practical purposes this provision does not affect nomal horse- dealing. It would only be operative under the rarer situations of contract to supply horses (as for army or other purposes) at certain prices and for prolonged periods.

I deal for less than fro does not require the above technicalities. It is sufficient if the parties say " Done!" in effect, and each shows that he is ready (by tender, direct or indirect) to hand over, respectirely, horse or cash.

Accoptance and Earncst Moncy.-As to "acceptance" in deals higher than fIo, "earnest money," as part payment, accepted, binds the seller: one halfpenny earnest money may suffice! *

The buver, on the other hand, binds hin self by "cons ructive" as well as by actuil icceptance of the horse.

Constructive acceptance would be illustrated by situations such as the buyer saying, seeing the horse: "All right; I will send my man to fetch him on that day or on a later day?" The vendor in such case would become the agent for buyer, to take care of the animal till sent for; and, as agent, would be in possession on behalf of lis principal, the buyer. $\dagger$

On the other hand, if a wrong horse, resembling the intended purchase, were delivered to the buyer and unwittingly received as the true article, that would not bind a deal for the substituted animal ; but, on the issue of fact, much would depend upon how soon, after discovering error, the buyer claimed redress.

(The old-fashioned market and fairs practice in many rural districts of a shake of hands to bind a deal is not technically binding under the Sale of Goods Act as regards deals of fro and more.)

Memoranda of Deal.-As to written memoranda or signatures, as required by Sale of Goods Act.

Letters, signed respectively by the parties, will operate; so will a brief memorandum, merely initialled. So long as it mmistakably refers to the deal alleged, as expounded by other (possibly oral) evidence, an invoice, bill-head, with description of the article

* Bach v. Oreen. 5 T.R. fog.

$\dagger$ Elonore v. Stone, I Taunt. 458. 
sold, can be effective; still more so a specific joint memorandum, initialled on both sides.

As to auction sales, see later.

There must be clear evidence as to who are the parties dealing-e.g. a document purporting to bind a deal between $\mathrm{A}$ and $\mathrm{B}$ cannot be saddled upon C. But even if the document does not specify the parties, their identity may be proved from extraneous surrounding circumstances.

Special Conditions to be Recorded.-If there are any special conditions attached to the deal, any written memoranda to bind the bargain must specify them, as instance :-

I. Dite of delivery if deferred.

2. Date of payment if deferred.

3. Contingencies, such as on future wins, if any, in racing.

4. Trial allowed, and for how long.

5. Veterinary certificate.

6. Warranty generally.

Terbal Explanation.-Where such or analogous conditions are attached to a deal, no verbal evidence, to import others not thus in writing, is allowable; but verbal evidence is admissible to explain the reference of a condition; as instance, A sells to $\mathrm{B}$ a " brood mare, also a hunter subject to veterinary certificate of soundness." Oral evidence is admissible to show that the veterinary qualification refers only to the hunter.

Correspondence after a Deal.-Correspondence which has taken place after the deal is admissible to bind the deal, or to explain and to be read in conjunction with prior memoranda that were contemporaneous with the bargain; as instance: $C$, as agent, bought a horse for $B$ from $A$, and wrote later to $\mathrm{B}$, mentioning the sale and asking for the money to pay with. B replied to $C$, promising to remit. Later, $B$ tried to repudiate the deal. B's letter to C was evidence against $B$ 's contention that there had been no sale.*

Efject of an Amending Condition.-If correspondence discloses on one side or other an introduction of some further con-

* Gibson v. Holland, L.R. I C.B. I. dition, any offer contained in a preceding letter can be waived and withdrawn. As instance: A offers $f_{0} 60 . \quad B$ replies: "Make it guineas." A's offer is absolved, and can be withdrawn.

Similarly, if stipulation for trial, warranty, or other condition is made in reply to an offer to sell at a given price. But if the reply to an offer is, in effect: "Done!" " I agree," the bargain is clinched.

Again, A offers to sell at a price, giving till Tuesday for reply. Tuesday passes: no reply. A is no longer bound by his offer.

Postage Evidence.-Postage of a letter, proved, is evidence of delivery of the letter to its destination, in absence of specific evidence to contrary-e.g. destruction or spoliation of mail cn route.

If a would-be buyer writes an offer and says: "If I hear nothing further I shall consider that the horse is mine at so much," this binds him, but not the owner of the horse, who is under no obligation to reply "Yes" or "No" to the bid.*

Signature to Mcmoranda.-In order to make either of the parties chargeable under the Sale of Goods Act, his signature to the statutory memorandum (or its equivalent) is necessary. The authorised signature of an agent will also bind a principal, and such agent need not have his authority in writing from his principal. (See also hereto as regards sales by auction, later.)

It was ruled in Swect v. Lce (3 II. \& Gr. +52) that mere initials, not setting forth the surmame of the party implicated, would not suffice. But it would perhaps appear that this old ruling was based on the possible contingency of initials only not being fully understood by the person addressed. If there were evidence that $A$ or $B$ had been in the habit of initialling only communications to each other, and that the handwriting and initials were respectively well known from one to other, it would seem that such abbreviated signature would bind.

"John Smith, his mark $\mathrm{X}$ " is binding if duly identified. Also a printed stamp or usual (rubber) signature of a firm or other party holds good. Where only one party 


\section{THE LAW AS REGARDS HORSES AND THEIR USES 463}

thus signs the document upon which a claim is based, that document should, on the face of it, clearly express the individual to whom it is addressed. Mere allusions to "vou" or to "Dear Sir," deficient in personal identification of an addressee, are inadequate for the purpose.

Sunday Deals. - Sunday trading, in the "calling" of a subject, is forbidden by the almost obsolete statute of Charles II. But it has been held by the Courts that this statute still has force to vitiate any Sunday horse-trading contract by a horse-dealer, so far as the latter may be seeking to enforce that contract. This, because horse-dealing is his "calling" and "business." Also, if a non-horse dealer knowingly deals with a horse-dealer on a Sunday, he cannot enforce the contract, but otherwise if he is not aware at the time that he is dealing with a professional.

If neither party is a horse-dealer, their Sunday deal holds good.*

Auction Sales. - When horses are sold by auction, the auctioneer is the agent of the seller until the hammer falls. He thus becomes the agent for the buyer so soon as the latter has admitted (by himself or his representative) that the final bid was his; and, as such agent for the purchaser, the signature of the auctioneer to the catalogue and to conditions of sale bind the buyer to the deal.

Also, where conditions of sale entitle a buyer to return a horse within a specified period-in event of some misdescription or breach of warranty-and meantime the purchase-money has been paid, the auctioneer holds the deposit as agent for the buyer subject to the sale conditions being fulfilled, and must not part with it to the seller until the buyer's period of grace has expired.

Conditions of Sale.-An auctioneer has no " implied" authority to warrant. If a seller tenders a warranty in his instructions for sale, and the auctioneer embodies it in his catalogue, he does so as agent. MLreover, at the bulk of horse repositories

\footnotetext{
* Iennell v. Ridler. 5 B. \& C. 4068.

* Bloxsone v. Williams, I Taunt. I 35.
}

auctioneers are in the habit of wisely abstaining from inserting allegations of warranty further than such statistics as may at once be verified from official publications, such as age of horses in the Stud Book, engagements, or records of races won.

Conditions of sale which figure on the catalogue of the day are binding on parties. Where conditions, instead of appearing in the catalogue, are posted up for public reference in the auctioncer's' premises, it becomes a question of fact whether the notice of a buyer was reasonably drawn to those conditions before he made his bid.*

II ilful Misdescription by Sellor.-If a seller wilfully and fraudulently misrepresents his property to enhance its value at auction, and the auctioneer, deceived thereby, reproduces the misrepresentations in catalogue or rostrum, and a deluded buyer discovers the fraud before the seller is paid, the auctioneer should annul the sale; the fraudulent seller has no claim on him. $\dagger$

Rescric at Sales.-Sales without reserve are now specifically regulated and controlled by the Sale of Goods Act, sec. 58, sub-secs. 3 and 4 , which enacts that, unless conditions of sale stipulate that there is a reserve, or that a seller shall be privileged to bid for his own goods, he may not so bid, nor may the auctioneer bid for him. All such bidding to raise prices then becomes fraudulent and is actionable. This enactment, in effect, makes statutable the earlier Exchequer ruling in Warlow v. Harrison (20 L.J. Q.B. I4), which laid down that in a sale without reserve the last genuine bidder is entitled to the property at the price, and if after announcing sale without reserve the auctioneer accepts a bid from the seller, and especially a final bid which outbids the genuine buyer, he is liable to the latter for damages.

Later there was a case-Rainbow v. Hawkins (9I L.T. I 49, and 73 L.J. K.B. 641)before Mr. Justice Kennedy. The auctioneer had reserve orders, but forgot them and announced sale without reseric. A buyer bid, and the lot was knocked down to him 
(a pony for 15 guineas). No sooner had the hammer fallen than the auctioneer discovered his oversight, put up the lot again for sale, and it was bought in for 17 guineas. The genume bidder sued the auctioneer for the pony, or damages for breach of conditions of sale. The learned judge decided against plaintiff, on the ground that there was no "signed memorandum" of the sale to satisfy the Act, and that the auctioneer had "refused" plaintiff's bid, and therefore had not created any contract between buyer and seller.

It would seem therefrom that the judge held that the fall of the hammer did not " accept the bid," and that written entry of the sale in office books was further required in order to constitute "accptancc" by the auctioneer of the bid. It looks as if here there was equitably a miscarriage of justice. The auctioneer became buvcr's agent so soon as the hammer fell; he failed in his duty as agent by omitting to book the sale and so to satisfy the statute. Had he been sued for negligence as the agent, he might have been held to be liable. Still more so if, so soon as the sale was reopened, the buyer had formally demanded to be allowed to sign the book or catalogue, as buyer at I5 guineas, on refusal of the auctioneer to book the sale to lim. It would, in our opinion, be risky for auctioneers to rely too much on this ruling, if they conceal orders to sell with reserve and thereby delude genuine bidders and oust them after the hammer has fallen.

Oancrs' Names in Catalogucs.-A statement in a catalogue that a horse is the property of $\mathbf{X}$ is a representation that may affect the price bicl. If at the hour of sale, even if $\mathrm{X}$ was the true owner when the catalogue was compiled, there is another owner whose repute might not have enhanced the price so much as the repute of $\mathrm{X}$, a buyer can, on discovery of the misrepresentation, repudiate the sale if he desires. This was ruled by Lord Arerstone in 11 hur $v$. Derenish.* The doctrine is important. It acts as a check upon a previous not uncommon practice of putting in third parties' * 20 T.L.R. 385. horses into a sale by an owner of repute, in order to enhance their value. The dispersal of a noted stud carries a prestige; but animals not belonging to the stud should not be allowed to cruise under its colours.

Market Oicrt.- It is a general rule that a seller cannot convey to a buyer the property in a chattel which he professes to sell unless he is the lawful owner thereof. Therefore the owner of a stolen horse can recover it from an innocent purchaser. But there is the exception of "market overt."

In the City of London market overt extends all the year round as regards goods perfectly exposed for sale by a person who trades in goods of this nature, and who exposes them openly in his "shop" and not in a back room or yard in the rear of his premises. In the country, market overt only exists on specitied days in the year, and at certain places authorised for such class of market, either by charter or by long usage which presumes the furmer existence of a charter. Sales at such markets pass the property to a genuine (not to a collusive) buyer. Not all "Fairs" are market-overt; they depend upon their history, titles, and usages.

\section{Innkeepers and Horses}

An innkeeper is liable for the safe custudy of a horse entrusted to him hy a guest. The $\mathrm{IS6}_{3} \mathrm{Act}$, which limits liability for valuables of a guest at an inn, exempts his animals, and specifies horses as being still under the old law.

The innkeeper is bound to take in a traveller's liorse, so long as he has stable accommodation for it (or even pasture), and le has a "lien" upon it to detain it until charges incurred are paid up. It is an undecided question whether a traveller's horse can be thus detained for more than its stable expenses, or can be the subject of lien for the guest's board and lodging also : but judicial opinion indirectly farours the view that all property of the glest, in stables and in dwelling-rooms of the inn, is subject to lien for all food and shelter supplied to lim. 


\section{THE LAW AS REGARDS HORSES AND THEIR USES}

If an innkeeper trades also as a liverystable keeper, and horses come under his care in the latter capacity, and not as guests' beasts of burden, no lien exists, and the custody is only that of livery stabling (which see, infra).

Rights of Sale.-By the IS-8 Innkeepers' Act the quondam lien of an innkeeper is extended. Previously he could detain, but not sell or use, a horse for unpaid stabling and forage. Now he can, under certain conditions as to notification of sale (one month) and subject to holding the surplus, if any, to the credit of the defaulting wwiner.

Innkccpers' Rights. - If an unauthorised person brings a horse to an inn and the owner traces and claims it, he must repay the innkeeper the interim cost of its foragc.* It is doubtful whether in such a case a further charge for shelter can be maintained. The principle is sound: otherwise $\mathrm{A}$, by collusion with $\mathrm{B}$, might get his horse foraged ineantime, gratis, at the expense of $\mathrm{C}$, the innkeeper. Lien of an innkeeper extends to rehicles stabled with him as well as to the horses which draw them; and right of sale, under the 1878 Act, supra, includes carriages and other effects.

\section{Farriers and Livery-Stable Keepers}

A furrier has a lien for cost of shoeing a horse; but if he shoes the horse, say in March, and gives credit, and shoes it again later, the March score remaining unpaid, his lien is limited to the price of the later shreing: he abandoned his March lien.

A farrier has no statutory power of sale for unpaid lien such as conferred on innkeepers by the I 878 Act.

A farrier is, prima facie, liable for damages for injury from faulty or negligent shoeing ; but if an employer presses the shoeing smith to take on a job out of hours and in a bad light, it becomes a question for a jury $\dagger$ whether the unreasonable demand of the owner does not absolve the farricr.

A livery-stable keeper has no lien for unpaid stabling, as the very essence of the contract between him and the owner of the horse is a right to take the horse out for daily use if wanted.

Similarly, a trainer of race-horses, delivered to him to train generally for prospective races, has no lien on the like principle. But supposing a race-horse, with no cngagements, were delivered to a trainer to see if any good could be made out of the animale.g. a yearling unbacked, or a horse unsclooled at fencing, to be taught steeplechasing-it would seem that the principle of lien as regards such education of the animal and expenses incidental thereto might be held to be applicable.*

\section{Liability of Railways}

Railways are common carriers of horses, but are further regulated by the ${ }^{2} 854$ Railway and Canal Traffic Act, which enables a court to override, as " unreasonable," any too onerous conditions which their practical monopoly of such locomotives might otherwise enable them tyrannically to impose to the public detriment. By statute, railway companies enjoy limited liability for damages for injury to any horse that may be entrusted to them for conveyance. That limit is $f 50$. If the owner consigns a horse of greater value, he must insure it for such sum in excess of this $f 50$ als he considers will represent its value to him. Whether the prenium per cent. which the company charge for insurance is "reasonable" is a question for the court in which a claim, if any, is made. Up to date the opinion of the bench appears to be that a percentage of $2 \frac{1}{2}$ is reasonable, as such the figure usually stands in railway traffic.

Autocratic conditions, such as declarations by the company that they will not hold themselves liable unless a claimant can prove "wilful misconduct" on the part of their employees, are practically bruta fulmina, and any court will override them as "unreasonable."

Where a horse is consigned, and the consignor, whether owner or agent, signs the consignment note, it is assumed that he has

* Fonth v. Simpson, is L.J.Q.B. 260. 
consented to the terms in it ; but, as aforesaid, any unreasonable condition dictated by the autocracy of the rail and its monopoly is subject to rerision and rejection by the court.

Railway Ncgligence.-Railway companies are responsible for injuries which are the outcome of defective repair of their trucks or horse-boxes,* or from defect in other apparatus of their carrying machinery, as a bridge to a landing-stage, $\uparrow$ or for failure to provide horse-boxes contracted for to complete a journey to an anction sale. $\$$

Railway Fonces.-Railway companies are by statute required to fence their lines securely against the live stock of owners and occupiers of adjoining lands and against stock on highways abutting on the line. Where horses escaped from their owner's land, and got on to a highway crossed by a railway, or level crossing, and one of the level-crossing gates was open, and the horses thereby reaching the line, got killed, the company was liable. $\S$ But where stray horses entered a station yard, and thence got on the line, and were killed, the company was not responsible. $\|$

\section{Rule of the Road}

Owners and users of horses have duties and responsibilities as regards public safety on highways.

They must observe the "rule of the road," as expounded in the I 835 Highway Act, sec. 78 , which applies to saddle and harness horses alike.

Each party, meeting, has to keep to the left ("near") side; when overtaking, the slower mover keeps to the left and the overtaker passes on the right (" off") side, provided there is traffic room for so doing at the moment; but if another horse $(\mathrm{C})$ or vehicle be approaching, to meet the overtaken (A) and overtaker (B), and is in possession of the road-in that $C$ would arrive abreast

\footnotetext{
* Comle v. London \& S.II.R., $3 \mathrm{I}$ L.T. 6I3.

+ Willoughby v. Horrulge, 22 L.J.C.P. 90.

+ Waller v. Milland Great II estern Raileay, L.R. 4 (1. Irish) 376 .

\$Fau'cett v. York \& North Midland Kailway, 20 L.J. Q.B.

1 Manchester, Shefild \& Lincolnshre Railway v. Wallis, 14 C.13. 213.
} 222 . of $\mathrm{A}$ sooner than $\mathrm{B}$ would pass $\mathrm{A}$-then $\mathrm{A}$ should wait and defer to C, till C's passing has left space for B to orertake $\mathrm{A}$.

Negligent Drivers. - If an acciclent occurs when one of two parties (A) is on the wrong side and the other (B) on the right, such sitution is prima facie evidence of the wrongside passenger being the negligent cause of damage. But this may be rebutted by specific evidence of the circumstances, especially of those immediately prior to collision. If it appears that B conld have avoided contact by giving up his rightful berth and crossing to the other side, A may be exonerated as regards damages to $\mathrm{B}$, while at the same time, independently, he may be open to conviction under the Highway Act for violating the road rule or for furious or dangerous driving (sec. 78 ).

Led Horse.-It is under this interpretation that the led horse is allowed to take passage on the wrong side, where exigency requires it.

Pcdcstrian's Rights. - The pedestrian is not bound by sec. 78 of the Highway Act. He has as much right in the main (carriage) road as the horseman. Drivers are liable, civilly, if they injure him, unless he contributes by his own gross negligence to catastrophe; and as regards criminal proceedings for injury to a subject of the Crown, it is no defence that the injured pedestrian was obstructive or drunk, so long as the rider or driver could have aroided him.

Unsound Gear.-It is no defence to urge that reins were rotten, brakes ineffective, or horse restive or hard-mouthed, mnless it can be shown that the person implicated had no possible or reasonable opportunity of being aware of such defects till the hour of collision revealed them.

Ricstive Dispositions.-Chief Justice Erle said * that the "mere fact of restiveness is not even prima facie evidence of negligence." But this should be taken as implying that the person using the horse had no prior knowledge of such disposition in the animal, and that this ignorance of the horse's temper must be specifically in evidence.

If a man has lately bonglit a strange horse, * Hammack v. White, I I C.B. N.S. 588 . 
with no information as to its antecedents, and without any preliminary trial of it in a safe region, proceeds, offhand, to use it, and in a crowded thoroughfare, such recklessness might warrant any jury in finding that he was " negligent."

(It is doubtful whether the modern bench would accept Chief Justice Erle's dictum, without some qualification as suggested herein.)

Caution.-The nder or driver of a strange and new purchase may be willing to take risks for himself, but is not $c x$ officio justified in saddling those risks on his fellow-men.

Contributory Negligence.- "Contributory negligence" puts an injured party out of court. A plaintiff must come into court with clean hands.

Pure Accident. - If A injures B by "pure accident," $\mathrm{A}$ is not liable, as when a lady holds a pony, and a travelling-show alarms it and the pony bolts, causing damage.* That is, if a jury believe the defence (which they did not in the case referred to).

Cnsound Highreay.-If a highway is left in a dangerous condition, and a traveller, using all reasonable circumspection, is injured thereby, the highway authority is responsible.

I'icious Horses. - An owner must not place a vicious animal that has propensities to attack people in a field where there is right of highway.

Straying Horses.- So, if his horse strays into another field, he is responsible for damage if it attacks persons or other animals, even though in the invaded field there is no highway, and even if he was not aware of ferocity in the horse; and, as all owners of stock are responsible for restraining them (by fence or tether), he is responsible if his horse kicks or bites a neighbour's stock, through an imperfect fence, though not actually passing through the fence to the next field. $\dagger$

But where a horse strayed on the highway and kicked a child, and there was no evidence of any knowledge by the owner of

* Goodman v. Taylor, 5 C. \& P. 4 ro.

+ Fllis v. Lofias Iron Co., L.R. Io, C.B. Io. vice in the horse, it was held that the owner was not liable.*

\section{Riding to Hounds}

There is no common law for the right to ride to hounds. Formerly, in forest days, and when the land was infested by " noxious beasts," it was held that to chase and slay a beast of prey justified the trespass. Even then it did not warrant intrusion by mere spectators of the chase (the modern "field " with hounds), but only exculpated huntsman, hounds, and hunt servants.

This old theory may now be considered to be obsolete with the advance of civilisation, and any occupier of land may warn off a hunt and its field, and may obtain injunction if the warning is disregarded.

A Ml.F.H., thus warned off, would be liable for injury done by his "field," as having tempted them to follow and copy his trespass.

Individual Liabilities (Hunting).-Individual members of a field, if identified, can be sued for damages, such as for gates left open or broken by them, especially if thereby stock becomes injuriously mixed or sent astray. As a rule, sporting tact and purse obviates such causes of social friction in hunting countries, but, for form's sake, the letter of the law is here recited.

\section{Warranty}

The matter of warranty is one which is constantly involved with transactions in horseflesh, and is perhaps more productive than any other concomitant of litigation and misunderstandings.

The subject may be examined from two standpoints-the one, the abstract legal principles which constitute warranty, or its avoidance; the other, those veterinary and stable doctrines as to what is or is not unsoundness or vice in a warranted animal-which have obtained official recognition in courts of law, and which may be accepted as orthodox creed in such matters.

Warranty as regards a horse may be given verbally as well as by writing.

Warranty, however given, must be

* Cox v. Burbidge, 32 L.J.C.B. 89. 
specific as to the qualities or capacities thereby guaranteed by the seller (or his agent). The bare expression: "I warrant the horse," is meaningless, unless in conjunction with that utterance other remarks have passed between the parties which throw light on what is supposed to be warranted. As, for instance, if a buyer inquires: " Is he sound? " or " quiet in harness?" and then the reply as above would constitute warranty as regards the matter inquired.

"Puff" not Irarranty.-Mere "puff" is not warranty. To say: "I never saw a better horse," "He's as clever as a cat," "I'd back him to, etc.," are empty phrases, and do not affect a contract of sale. They may be dishonestly conceived and uttered, but they do not constitute legal fraud or misrepresentations to void a bargain.

"Carcat cmptor" is the principle which must guide all purchasers in the absence first, of warranty, second, of reliance that the seller, if he warrants and the warranty fails, is a man to be trusted to make good.

Implicd J arranty.-- Warranty can be implied, though not specified, in certain situations; as instance, in all sales, save market overt, there is implied warranty that the seller has the property in the right to sell. If it should turn out that the seller has been himself rictimised by dealing with a stolen horse, that does not exonerate him as regards the purchase from him. The same principle would apply if the seller were in unlawful possession of the horse, as per an illegal distress, or by erroneous delivery to him from an auction of a wrong lot.

Breach of J arranty.-When a buyer, under a warranty, has accepted and paid for his purchase, it is too late to repudiate the sale as roid.

The remedy then is to claim damages for breach of warranty, if any. Financially, this should be equivalent to annulment of the deal, if the seller is not insolvent or a fugitive from law.

It the seller disputes the breach, the usmal and soundest resource is to re-sell the animal at the earliest reasonable opportunity, by auction, and if it fetches less than the sale price, to credit the contuma- cions seller with that amount and to sue for the balance as damages.

Limit of Claim.-The burer in thus claiming compensation is limited to recovery of his purchase money and any minor consequential expenses, which would be evident and in contemplation of the parties at the time of the deal (as keep and rail transit to and from buyer's abode). But he is not entitled to special consequential damages for loss of a profit on the bargain which would have accrued if the warranty had been good-e.g. A buys under warranty from $\mathrm{B}$; re-sells to $\mathrm{C}$ under warranty and at a profit; $\mathrm{C}$ discovers unsoundness and returns the horse to $\mathrm{A}$, who loses his profit on the deal; he cannot claim that profit from B, but only the original purchase price.* However, judging from judicial dictum (Lord Denman) in Cox v. IJalker (which was settled and did not reach appeal), it would seem that if some or all of the enhanced price at which A sold to $C$ could be ear-marked to care and skill bestowed by A on the horse in the interim, A would then be entitled to claim that amount of lost profit from $B$.

Since, statistically, the prospect of improved value through skilful treatment developing during the period of non-discovery of unsoundness would be extremely remote, Lord Denman's contingency does not seem very material.

Repository Conditions.-In most horse repositories and anction yards the terms of sale usually fix a limit of time within which any claim that a purchase does not conform to warranty must be lodged.

Limits of Time to Notify Breach of 11 arranty.-Usually such sale conditions further require return of the misdescribed animal by a specified date. However, if the return of the animal is physically impossible within the defined period, it will suffice to notify the breach of warranty and to mention the inability to move the horse. Such disability may arise from interim injury to the horse with no negligence of buyer, or ilhess of the animal, or $(\mathrm{scmblc})$ stress of weather. In such cases the buyer must, till

$$
\text { * Clare v. Maynard, } 6 \text { A. \& E. } 524 \text {. }
$$




\section{THE LAW AS REGARDS HORSES AND THEIR USES}

removil is practicable, take the same care of the holse that a reasonable min would of his own property.**

11 ritusn Harranty Best.-It is alwatys adrisable for a buyer who relies on it warranty to require the same to be rcduced to writing. Alleged verbal warranty may be productive of contradictory hard-swearing. A seller who shirks writing his verbal warranty should be aroided.

11 riting v. Parol.-If written warranty be giren parol evidence to qualify or extend it is not admissible, but may be admitted to explain references in the warranty; is instance, "Warranted sound for one month" may be explained as referring to the period of grace during which purchaser was free to discover unsoundness, if any, which had cxisted at the date of salc, but not to any guarantee that the horse would remain sound for that period.

kicprescntation v. 11 uranty--Representation and description need not amount to warranty, especially if the term "warranty" is applied (and in writing) to some details of description and not to others-e.g. : "Sold for f-, a bay mare, six years old, warranted sound in wind and limb." This sale note does not warrant the age: only the sumdness. As to age, purchaser, if he doubts, can call in a "vet." to examine the mouth.

A warranty may be implied and construed from correspondence passing between the parties, and if that correspondence is ambiguous, parol evidence may explain its context and references.

A waranty may be coupled with a condition, such as right of return in event of discovery of breach within a specified date.

Iritten Torms Over-ride I crbal Warranty. -If a seller makes verbal statements which, if left alone, would constitute warranty or bargain, but, later, buyer and seller agree in criting as to sale and terms, and the writing does not embody some or all of those prior statements, it is assumed that they have been waived and eliminated from the conditions of sale. The like as to any prior verbal stipulations by buyer.

* Chapman v. Withers, 57 L.J.Q.B. 457.

60
Duration of II arranty. I warranty, as to vice, does not iast for ever. If a liorse is sold as quiet in harness, and confirms to this for several weeks, and then discloses restiveness, it is open to a jury to belicve that the animal's temper mas have been affected in the interim by the manner in which it has been driven or harnessed or groomed, and so on.

Similarly as to warranty against cribbiting and wind-sucking: such vices may develop after sale.

Agcht's Ilarranty.-When ar agent warrants, in principal's absence, and there is no evidence to show that the principal was aware of the agent's allegations, the question then arises whether such agent, as viewed from general principles, or from past dealings with the same parties, had authority to warrant.

A groom's assurance behind his master's back would ordinarily be worthless in this line; whereas a foreman who had been in the habit of conducting sales for a dealer in the latter's absence might be reasonably assumed to speak in his master's name and with authorit:

Groom at a Fair.-But if a groom is entrusted to take a horse to a fair, and to sell for his master, and to accept the cash and give receipt, it may be reasonably assumed that such agency by a groom would include authority to warrant this or that quality in the horse. If, on the other hand, the groom is simply sent to show a horse to a prospective buyer, there being time for buyer to communicate with seller, it will not be reasonable to assume that the groom has authority to warrant, or even to make abatements in price, in the absence of clear information on the subject from the employer.

Votcrinary Certificatc.- Where conditions of sale agree that some paid reterinary surgeon is to report as to soundness, and the report to be accepted by both parties is truly descriptive, that report operates as warranty.

I'ctcinary and a Bribc.--Provided that it is bona fidc, for where there was evidence that a "vet." thus employed had accepted a 
donceur from the seller (independent of any fees earned by the examination),* the buyer was held to be justified in stopping his cheque and declining to ratify the sale. The court held that it was immaterial to consider whether or not the veterinary surgeon's mind had been prejudiced by the briber. The mere acceptance of it disqualified him as an impartial arbiter.

Patent $x$. Latent Defects. - Warranty applies to qualities which are not patent to the eye, especially of a non-expert. It does not guarantee against patent defects, which cannot reasonably be unobserved under the circumstances of the deal. As instance, if a horse has an eye visibly removed at the time of sale, no breach of warranty will lie as to unsoundness in sight, though otherwise loss of any eyesight constitutes unsoundness when not within buyer's means of cognisance (as in a sale contract by letter).

Sale "With all Faults" Safest.-If a seiler sells "with all faults" he exonerates himself from any imputation of warranty. This is the wisest course for the unwary to pursue, in default of consent to abide by a specific veterinary certificate.

Misrepresentation and Its Effects.-Misrepresentation is not of itself warranty; but if it is fraudulent it may vitiate a deal. It is fraudulent if $(a)$ it is knowingly false, or $(b)$ is made at random and without grounds.

Mere "puff," as already stated, is no warranty; but if an owner of a horse that is presently going to be sold by auction elects falsely to describe the horse's qualities and thereby induces the auditor to buy where otherwise he would not have done so, he is liable for damages. $\dagger$

If a misrepresentation of such nature is made, but is bona fide, and not wilfully false, damages will not lie; but the burden of proof of bona fides rests with the storyteller.

Fraud entitles a party hoaxed by it to void a contract, but does not of itself void the bargain if the hoaxed buyer is, after all, content with it.

\footnotetext{
* Shipway v. Broadwood, I Q.B. 373.
}

$\dagger$ Bardell v. Spinks, 2 C. \& K. 646 .

\section{Bad Cheques}

Where payment is by cheque, and the cheque is bad, the buyer does not obtain property in the horse he has professed to buy. The seller need not sue on the bad cheque; he can claim restoration of the horse.

A deal with an imbecile or a hopelessly drunken person can be set aside in Equity.

\section{Hiring or Borrowing}

He who hires (or borrows) a horse for horse vehicle) is responsible for damage thereto if injury accrues to the chattels, through any neglect of duty, either in omission or commission on his part. He would not be responsible if the horse were struck by lightning, or attacked in the road by a mad dog; but he would be liable if he put a hired saddle-horse into harness, or put a hack to hunting duty, and thereby the animal got injured.

He also is responsible to the hirer for injury done by his servant to the hired article, even though that servant may be acting in actual contravention of his duties. On the other hand, if the same coachman had done mischief with a horse belonging to his cmployer, and under circumstances disclosing distinct violation of duty, the owner would not be responsible. To illustrate: A hires horse and vehicle from $B$ for a period. A's coachman, in disobedience of standing rules, takes out horse and trap for a spree of his own. He collides, injuring the hired property, also injuring what he collides with; and there is no doubt that in the collision he was solely to blame. Here there are two parties injured by A's coachman's wrong-doing. But A is liable only to the man from whom he hired. He is not responsible for the mischief done, in disobedience, by his coachman to the other party in the collision.*

If a horse is hired (or borrowed) for a specific purpose or journey, and is used without owner's consent for another, and is injured, it becomes a question of fact for the court whether the deviation from the original agreed intent of use in hiring is

* Coupe Co. V. Maddick, 2 Q.B. 413, and Samnderran v. Collans, 9 L.T. 243 . 


\section{THE LAW AS REGARDS HORSES AND THEIR USES}

sufficiently "material" to account for the mishap.

Serious over-driving, as to distance or reasonable speed, would be actionable; also al hiring to drive from $\mathrm{X}$ to $\mathrm{Y}$ along a good country road, and a deviation into a rough road or moorland, breaking a spring. But to meet with an accident involving no negligence by hirer, while deviating half a mile on good road to call on A cu passant, though not arranged for in the original hiring, would not be likely to be interpreted as "material," and as making the hirer liable.

The lessor of hired horses or rehicles is responsible that they are fit for the class of work contemplated by the hiring. If the vehicle breaks down the lessor is responsible, and if the horse goes amiss, from no fault of hirer, the cost of curing him and bringing him home falls on the owner.

Stealing Hired Horses. - To sell and fraudulently convert to hirer's or borrower's use the proceeds of a hired article is "larceny as a bailee." A coachman's livery is presumed to notify him, in reasonable situations, as his master's agent. Therefore, if the coachman runs up an unauthorised forage bill, a jury may hold the employer liable, even though the coachman has meantime been convicted of stealing and selling his master's surplus forage.

An owner of horse, harness, and carriage hires a driver from a livery stable, where he keeps his horse. He puts that driver into his own livery. The driver is negligent, and causes injury to third parties. A jury is justified on such facts in treating the driver as servant to the owner of horse and vehicle, and as such saddling the last-named with the damages. It is a pure question of fact, interpreted from all surrounding circumstances.*

Borrowing and Hiring.-Borrowing and hiring are on much the same footing, on broad principles. One allows the use of the property for goodwill, the other for money. The former must deal with the property as any reasonable person would and should deal, under such circumstances; and the lender alike must not lend a dangerous

* Jones v. Sculard, 79 L.T. 386. article without clearly informing the borrower of the defect or other quality which is an element of peril.

\section{Warranty and Unsoundness}

In relition to warranty, where soundness, absence of rice, or capacity for specified equine duties are guaranteed, a category of recognised breaches of such warranties may be useful.

Unsoundness exists where there is any disease or alteration of natural structure which at the time impairs, or is prospectively capable of subsequently impairing, the usefulness of the animal.

Vice is a tendency, not natural in the horse, to commit acts which render him less fit for his duties.

To catalogue recognised unsoundnesses :-

Any disease of the eye or injury to it which is calculated to impair vision-cataract, inflammation to wit, whether arising from innate disease or from some external injury.

Broken knees are not an unsoundness, though they are a blemish.

Blood-spavin and bog-spavin are blemishes only, unless lameness accompanies them, or they are attended with evidences of inflammation which may in time produce lameness; but it is risky to certify as sound when thus afflicted, and special warranty is wisest.

But bone sparin is at all times unsoundness.

Broken wind also, and all wind diseases, as roaring, whistling.

A cough is unsoundness, while it lasts. It may vanish and leave the animal sound, but till cured it is unsoundness.

A capped hock may be mere blemish, and may be unsoundness. If there is no lameness, no evidence of pain at the touch, the animal may be sound with it; but in any certificate it is advisable to specify its existence and to state the opinion formed as to its effects, present and prospective.

Contracted foot is on a like basis. It may or may not be unsoundness at the moment. It is always suspicious of future 
disease. It is best to be specified in any reterinary certificate for buyers' edification and jurgment, even where there is no heat or apparent lameness. (Such specifications are called special warranty.)

Corns are unsoundness.

Carb is unsoundness. At the same time, it need not produce lameness. It should, in such case, be subject to special warranty in any certificate, like capped hock and contracted foot.

Cutting, or specdicut, is not of itself unsoundness, but is the result of malformation; it may, by injuries from cutting, produce eventual unsoundness. It is advisable to have it specified if there are evidences of the tendency.

Dropsy is, of course, unsoundness, whether of skin or heart.

Glandular culargement, enlarged hock, lampas, fistula, laminitis, and navicular are all unsoundness.

A " ncred" horse that has been operated on by neurotomy may go sound for the rest of his days; but such a horse and his operations should always be described therein under special warranty, if any.

Grease and Cracked Heels are unsoundness, while extant.

Thrombosis, evinced by premature exhaustion, is unsomndness.

Sand-crack is unsoundness, but as it may spring up at an hour's notice its first appearance very soon after a deal does not vitiate warranty.

Stringhalt is an unsoundness, for though not producing lameness per sc, it tends to wear out the system, and may develop to excruciating convulsion of action at starting.

Quittor is unsoundness.

Puniced Fect also.

Ringbonc also, when once in evidence or incipient.

Thrush is controversial, but it is best to specify it, if existent, in any warranty.
Nine veterinaries out of ten would, we think, rank it unsound.

Splint is a question of fact, whether or not it chafes a tendon, or is likely to do so. IIany horses go sound ad lib. with a splint, but special warranty, if any, is best adopted where there is splint.

Any disease of internal organs is unsoundness. If not detected at date of warranty, it becomes an issue of fact whether the evil, though latent, existed at date of sale.

Suspensory Ligamcuts, if weakened or ruptured, are, of course, unsoundness, though a fired horse may work sound ad lib.

Thickened Since is suspicious, but not absolute proof of unsoundness; a contusion may have caused it, and it may subside. Special warranty, specifying, is best in such a case.

Oerreach is analogous to speedicut; it is an outcome of faulty construction and action, but not unsoundness per se.

Inflamed Gums and faulty tcething are unsoundness, whilc they last.

rices.-Crib-biting, wind-sucking, and kicking in stable are vices which are well calculated to produce unsoundness, but need not absolutely produce such effect by date of sale.

Jibbing, backing, bolting, and rearing are vices. Ferocity generally is a vice; also restiveness under shoeing or grooming.

As to warranties of quiet in harness, or saddle, disputes hereon are mainly issues of fact; it is always possible that, if some reasonable time has elapsed after sale before discovery of restiveness, the fault may have meantime developed under injudicious treatment or from natural causes.

"Quidaing" the food is a vice, but not per se an unsoundness.

The writer desires to acknowledg: the valuable asststance which he has derived, in compiling this brief cpitome. from the latest ctition of "Oliphant on Horses." as cditud and revised by .Ir. C. Flphnstone-Lloyd. Barri-ter. in the matter of chapter and icrse for veferince to leating cases to illustrate the principles onnuncuted. 


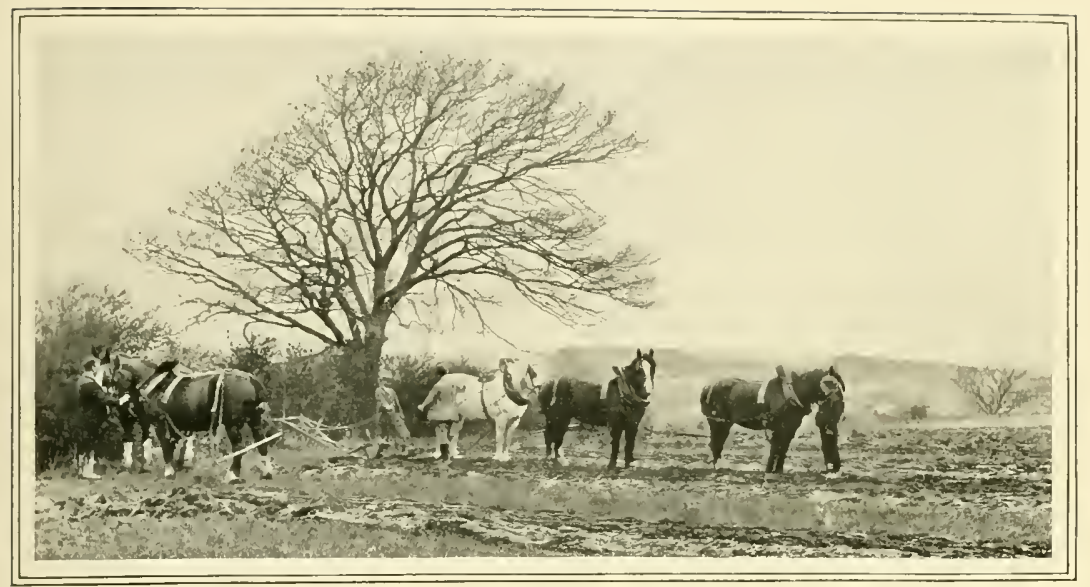

\title{
VETERINARY SECTION
}

\author{
CHAPTER I \\ DISEASES OF THE BREATHING ORGANS
}

1

ATARRH.-Many horses die through ignorance on the part of owners who continue to work them when suff ring from catarrh. "Only a cold," they say, and expect a horse to get well while pursuing his ordinary business, just as the man himself does. They think that he ought to get well, and not have to lay up for such a trifle as "a bit of a cold" and running at the nose, which is chiefly objectionable because the animal cannot use a handkerchief. We would strongly urge upon the owner the need for rest and nursing, because horses are peculiarly liable to rapid and serious complications which may end fatally in a few days, or leave the patient permanently unsound and depreciated in value. Among the after consequences of neglected cold, when fatal complications do not ensue, may be mentioned roaring, thick wind, whistling, broken wind, and other sequele which will be alluded to in their respective places.

The symptoms of catarrh or common cold in man are so familiar that they would need no description in the horse were it not for the importance of early diagnosis, before the discharge from eyes and nose has declared to the novice what is the matter. It is through working the animal in the early congestive stage that many cases of pneumonia, pleurisy, and congestion of the lungs occur, which would have been avoided had the owner or attendant recognised the rigor or shivering fit which ushers in any inflammatory disease. Before a cold is developed, the horse will show what is called a "staring " coat, which means that the hairs stand up and feel harsh, when they should lie flat and feel silky. This is equivalent to the cutis anserinus, or "goose flesh," of the shivering bather who has stayed in the water too long, and whose skin more or less resembles that of a plucked bird. The horse may arch his back somewhat, and stand upon less ground, by the approach of hind and fore feet, and shake or shiver. This condition -which, we have said, is called rigors-is one the horse-keeper should never disrogard, as it 
may wricate a cold or a more scrious illness approashing, and then is the time to endcavour to restore circulation. If at this time the oldfashioned "fever drink" is given it may make the whole difference between a moderate degree of catarrh and a fatal case of pneumonia. There will be veterinary agnostics, who have imbibed many theories but seen little practice, who will give this statement but a grudging or qualified endorsement: but the amateur will do wcll to lay it to heart. If the temperature is taken by introducing a clinical thermometer into the rectum (or the vagina of a mare) during the shivering, it will be found to register from two to six, or even more, degrees of fever. It is when a man or horse shivers or " shudders down the back" with cold, that his temperature is up ; not when he complains of a burning skin and generally hot surface. The temperature should be 98.5 to $99 \mathrm{deg}$. F. in a horse in health, but inmediately after severe or sustained exertion it often runs up without illness. Then, however, the rigors will be absent, and the animal will not have refused his food, as he will have done during the feverish fit or rigor. The ears and legs are apt to be cold or variable

Treatment.-Clothe the body and bandage the legs. Pull the ears and wisp the neck and other uncovered parts to promote surface warmth, and withdraw blood from the central vital organs where congestion is to be feared. Give a stimulant, such as an ounce or more of sweet spirit of nitre, with half an onnce of tincture of ginger; or an ounce of compound tincture of cardamoms ; or, failing the advantage of a drug store within casy distance, give a gill of whisky in a quart of water, and prepare a hot bran mash, to be offered a little later. Such early measures may turn the scale and save a serious illness. If the early symptoms have escaped notice-they may occur in the night, or when no one is present to obscrve them-the congestive stage of the membranes will have given place to a discharge of watery fluid from the eyes and nose, or perhaps from the nose only. when the tear ducts permit of rapid running off of the fluid from the conjunctival membrane. Good hygienic conditions rather than medicaments are then chiefly to be sought. Pure cold air is better than warm, apart from the difficulty of getting it warmed withont vitiating it, and in this connection it may be mentioned that many dealers in the cheaper kinds of horses turn them out to grass in weather that is not warm, as they find by experience that the pure cold air is a tonic to the respiratory membranes, and that feeding from the ground favours drainage of matter which is soon thick and tenacious, and unlike the watery fluid which was first noticed. Better than turning out, is the airy loose box and moistened food in a receptacle placed on the floor. The return of health and ability to resume work will soon follow when the nasal discharge diminishes in quantity and becomes ycllow, only being occasionally observed when the animal snorts or blows it away, as he experiences tickling in the passages. As a cold produces debility, the convalescent should not be asked to do a full measure of work at first.

\section{Nasal Gleet}

Following on catarrh, influenza, strangles, and, as a result of debility, a lasting discharge varying in quantity, in character, and in its offensive odour as it issues from one or both nostrils, is the disease known by the above title, or as chronic nasal catarrh or ozona. High up in the nasal passage the membrane has become permanently inflamed, and reacted upon by its own products: a chronic low form of inflammation ensues. It is recognised by its long endurance; by its smell ; and the somewhat different nature of the discharge from that present at any stage of a common cold which runs its course in a jormal manner. So long as it is confined to the lining membranes of the nasal chambers or passages, curative measures are hopeful, but when it extends into the cavities of the face, the so-called sinuses, then it is beyond the reach of topical remedies, and usually incurable.

Treatment.-Tonics of the mineral class, as iron, copper, antimony, arsenic, and such segetable ones as quinine, gentian, calumba, and other barks and roots; fumigation by means of hot bran mash in a nosebag with carbolic acid, sulphurous acid, turpentine, eucalyptus, and other germicides and antiseptics. Syringing with solutions of zinc, iron, and copper sulphate often prove beneficial, and insufflation with powders of iodoform, chinosol, alum, and the sulphates previously mentioned, made less caustic by dilution with innocuous powders like starch, flour, and fuller's carth. Pure air, fceding from the ground to promote the discharge, and nutritions food of a kind easily assimilated, and only moderate labour are adrised. 


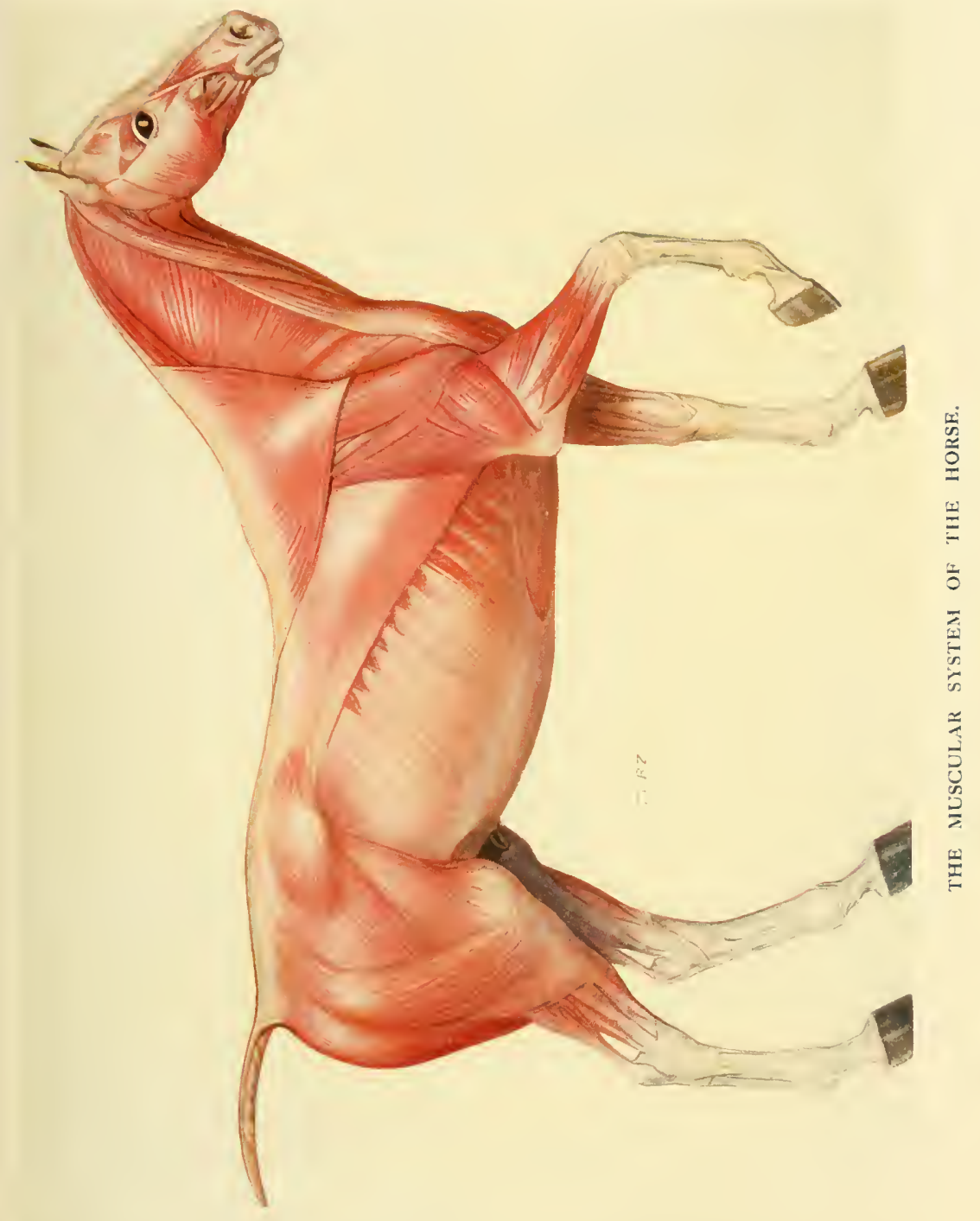





\section{Bleeding from the Nose}

Much alarm is felt when a horse bleeds even moderately from the nostrils, and it may indicate a very serious condition of the lungs or a merely local relief to congested membranes in the face or sinuses, as often witnessecl in children, and followed by no evil consequences. Whether the membranes, the lungs, or the stonach bleed, the escape will be from the nostrils. Without perplexing the amateur with the technical terms by which these hemorrhages are distinguished, we may describe their chief differences.

If the bleeding is from the membranes of the nasal tract, the blood is rather dark in colour (venous) and unmixed with any great amount of mucus; it trickles quietly away, or is blown out from the nostrils and soon clotted. No distress is exhibited by the animal.

If from the lungs, where vessels have given way, the blood is bright red and mixed with froth and air bubbles, and disposed to come away in little jerks or spurts; and if from a large ressel, as when a race-horse breaks a blood ressel while galloping, the pumping out of blood will be synchronous with the contractions of the heart, and soon prove fatal from the loss of blood and from the flooding of the lungs, and suffocation. If the hæmorrhage is from the stomach, fron the rupture ot a vessel, or a morbid growth, the blood will be mixed with more or less partly digested food in a fluid condition, or contain finely comminuted portions of the last meal. From the foregoing remarks it will be gathered that blecding from the nose is not necessarily a disease of the respiratory tract, but that it is important to note these differences in order that suitable mezsures may be taken.

Treatmont.-This is directed to arresting the flox by cold douches to the head, by a bag of powdered ice over the part affected, by the injection up the nostrils of astringent solutions, as alum, tannic acid, acetate of lead, or sulphate of iron ; where one nostril only is affected, plugging with cotton wool may be cautiously attempted. Solutions of gallic acid, of lead, and of iron given internally have the effect of arresting hæmorrhage where topical applications are inadmissible: as where the lungs or stomach are the seat of the mischief. Perfect rest and absolute quiet should be imposed, and when the patient has apparently recovered, caution should be used in putting him to work again. Horses subject to hæmorrhage from the nose should never be worked with a full stomach, or overfed.

\section{Coughs.}

In dealing with catarrh or common cold the reader was asked to consider such a condition as always dangerous because of its sequelce, or possible after consequences. This remark applies with equal force in regard to coughs and sore throats: at the head of which stands laryngitis. Anyone who has but the remotest acquaintance with racing will know that, when a "favourite" is reported to be "coughing," there will be persons more concerned than if they had read of an earthquake-anywhere beyond their own premises. Any cough, any irritation of the larynx, may result in thickening of its membrane, in whistling. roaring, wheczing, thick wind, or other permanent damage to the parts which will reduce the horse's value from a thousand pounds to a thousand or a fewer number of shillings. An ordinary cold may be followed by a cough as the inflamed nasal membranes extend their condition to the region of the larynx, and set up variable degrees of irritation. Whether the discomfort is in the throat, in the lungs, or their coverings (the pleuræ). or a stomach derangement is reflected to the nerves common to the respiratory and digestive systems (pneumogastric nerve with many branches), the desire to cough is felt in the throat, and coughing is done to relieve it. A tickling, stringy mucus within the larynx may be coughed up and imrnediate relief obtained, but the animal will cough if he has minute parasites deep down in his small bronchial tubes, a yard distant from the larynx. Irritation of any portion of the respiratory tract is more or less felt in the larynx, just as hunger is assigned to and felt in the stomach, although the tissues generally are in need-not less but more than the stomach, which will be ready to do work as soon as something is put into it. It is the muscles, or the brain, according to the work done, which cause the feeling of hunger (resulting from waste of tissue), but until the trembling or faint stage is reached, hunger is felt in the stomach. So is any condition of the breathing tract felt in the larynx, although pain may be experienced in other parts in addition. This rather long preamble, or preliminary canter, as our sporting readers might call it, is given for the purpose of leading up to such a simple description of conghs as will enable the horse owner to distinguish between the cough 
in the throat and that arising from the lungs or the stomacil, as it will be obvious that putting mustard on the throat will not influence broken wind due to indigestion, nor will the application of medicaments to the sides of the chest have any bencficial action on a cough due to laryngitis. Do not seck for a mistura mirabilis under cover of a hybrid Greek name, but endeavour to understand the cause of cough and remove it.

Sore Throat.-The back of the palate, the top of the gullct, and the area around the larynx which is closed by the little trap door called the glottis (except when we get a crumb the wrong way and discover its extreme sensibility) is commonly called the throat, and this when inflamed makes a horse swallow his food with difficuity, nod his head frequently, and cough with more or less evidence of pain when he does so. This sore throat is to be distinguished from laryngitis, and is of common occurrence. It may be the sequel of catarrh or a symptom common to other respiratory diseases. There is more or less tenderness to the touch from outside.

Treatment is generally successful if prompt, and consists in counter-irritation to the skin by mustard and vinegar, which need not blind the operator by being mixed with hot water, or reduced in potency by employing water that actually boils at the time, as it will act just as well if used cold. A rapid diversion is usually effected, and there is swelling between the skin and throat which gives relief to the more sensitive parts within. Whatever medicaments are chosen, they should never be given in the form of balls, as these may induce spasm, or be coughed up into the nasal chamber. What are known as electuaries are best for sore throats, as they have first a local soothing action, and afterwards produce their effects through the medium of the circulation. A dram of chlorate of potash; a dram of nitre; a dram of extract of belladonna, and sufficient honey or glycerine to make a soft paste to be spread upon the arch of the tongue, is a favourite formula for a sore throat, and may be repeated every six or eight hours during the acute stage. A horse with a sore throat should be offered no dry or dusty food, but encouraged to take linseed mashes, hay tea, scalded bran, and crushed oats, and if soon disgusted with these things he should be tried with carrots, apples, or green meat, or whatever of the kind is to be had. The ammoniacal atmosphere of a badly ventilated stable will frequently cause sore throat, and always retard recovery, and a loose bos with pure, if cold, air is preferable, making up with clothing of the body and a hood over the head and neck.

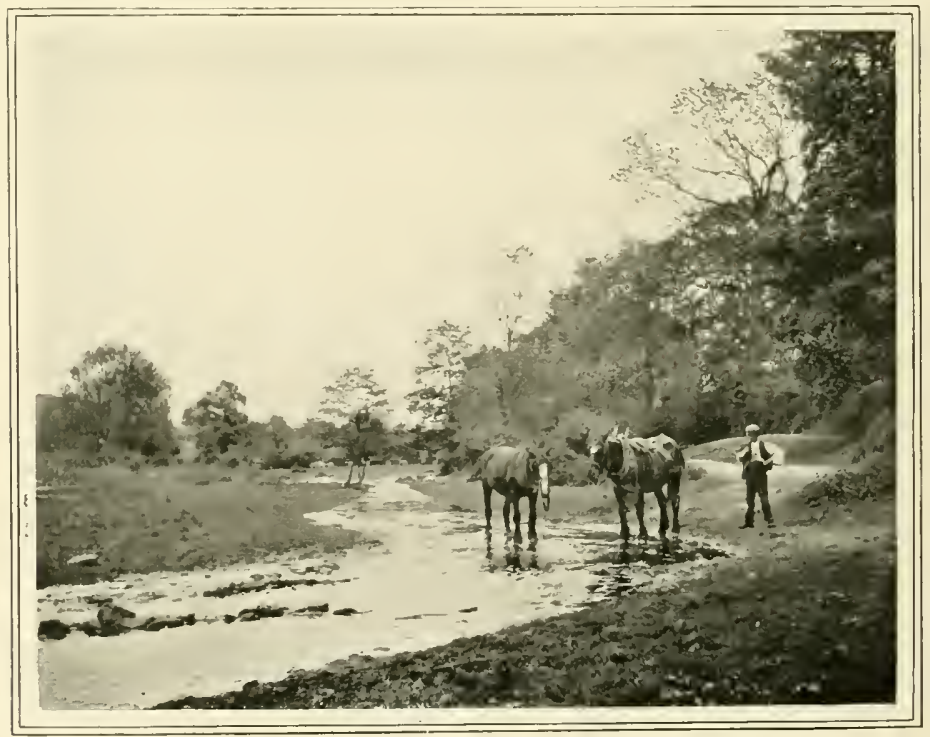




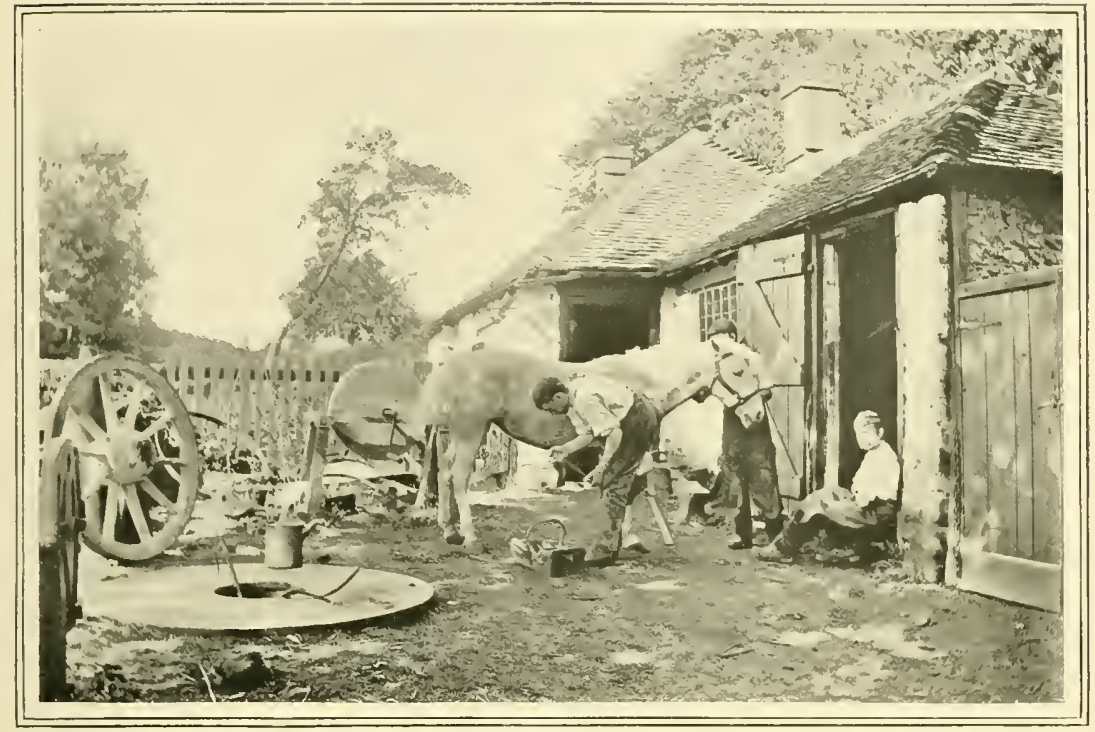

\section{CHAPTER II}

\section{DISEASES OF THE BREATHING ORGANS (continued)}

$\mathrm{L}^{\mathrm{Ant}}$

ARYNGITIS. - This is inflammation of the larynx, chiefly its lining membrane, but involving decper tissues in some cases, and presumably in most chronic ones, where permanent defects are left. This malady may be so acute and the swelling so great as to suffocate the animal by narrowing the aperture, or it may subside into a chronic form, leaving a settled irritation, chronic cough, and difficulty of breathing. The same causes which lead to catarrh and sore throat induce laryngitis, and country horses brought up from grass and compelled to breathe the bad air of close town stables are the most subject to it. It may be a sequel to influenza, strangles, or that disease of the blood called purpura hæmorrhagica, or big head. In rare instances it has been caused by lodgment of foreign bodics.

The early symptoms are not very dissimilar from ordinary sore throat and cold, but with the development of the disease there is heightened temperature, quickened pulse, and the most painful paroxysmal cough follows which it is possible for a horse to endure, or a horse lover to listen to. The cough is so extremely painful, so hard and ineffectual yet compelling, that the poor beast makes every effort to suppress it, and labours under great excitement and distress; he gets no relief, but only aggravates the soreness each time he yiclds to the tickling sensation which makes him cough. The difficulty of swallowing referred to in connection with ordinary sore throat is intensified in laryngitis, and food is altogether refused, or dropped from the mouth when the effort has been made to eat it. The nose is poked out, as breathing in this attitude is less painful; a roaring or hissing sound is emitted which may often be heard at a considerable distance. But for short intervals of relief the patient must dic of distress, and during these short periods a few moments' sleep are snatched while the horse is standing. The imperfect aeration of the blood when breathing is so shallow that it reacts upon the system, and 
the membranes of the eye and nostril are a dark red or livid colour, the pulse full and hard, and the legs cold. During the paroxysms of pain the more irritable temperaments shake the head and paw the ground and break out into patches of sweat, as horses do when suffering from certain forms of colic.

Treatment.-It is of the utmost importance to have pure air and a stable free from dust, therefore we should forbid moss litter and sawdust as bedding, and if the straw is not bright and

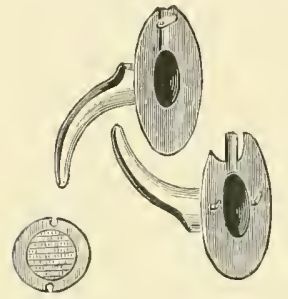
TUBE.
ARNOLD'S TRACHEOTOMY good, the water-pot with rose should be employed to sprinkle the surface. If the animal can be led into another stable while the floor is cleansed he will avoid the bad smell, so injurious in this complaint, when the litter is taken up. Nustaro or a mild cantharides blister is used by some, but greater advantage is claimed by others for the practice of continuous poulticing with linseed meal and bran, suspended by means of the leather head-collar. A bronchitis kettle, so arranged that the patient cannot interfere with it, will afford much relief, or, failing this, buckets of boiling water may be introduced in order to disseminate steam in the apartment. If inhalations are attempted they should be given on scalding hot bran at the bottom of a nosebag, strapped a long way from the muzzle, or the animal's difficulty in breathing may be aggravated. Friar's balsam is a soothing remedy which may be poured over the bran. Where this form of treatment is adopted a person should remain in charge of the animal until the bag or apparatus is removed, lest he should get into trouble during a paroxysm of coughing. The agony of laryngitis may be so speedily abated by making an opening in the windpipe that the practice is frequently resorted to, and we have known bold amateurs to succeed, and rarely induce any bad results, if they observe the rule to make their incision about half-way down the neck, where the trachea has least muscular covering.

In emergencies, an incision in the skin two inches long may be made; the cartilage should be cut in the same way, and the opening maintained by stitching back the tissues. When the crisis has passed, the wound heals without difficulty, and need not leave any serious blemish if properly treated. Colonials, and others far from professional aid, may save the animal's life by operating in the manner described, but no one would undertake it if a veterinary surgeon were available.

It is the after consequences of laryngitis that are most dreaded by the horse owner, as ulceration, or one of the "wind" troubles previously mentioned is so apt to follow even a mild attack of this malady. Some of the worst consequences may be avoided by a course of iodide of potassium and mineral tonics, commenced after the acute symptoms have subsided. The electuary advised for sore throat is the most suitable form of medication so long as the irritation remains.

\section{Bronchitis}

Inflammation of the membrane lining of the bronchial tubes is known as bronchitis, whether acute or chronic. It may occur as a primary disorder, or as a sequel or complication of other diseases, such as neglected cold, debility, old
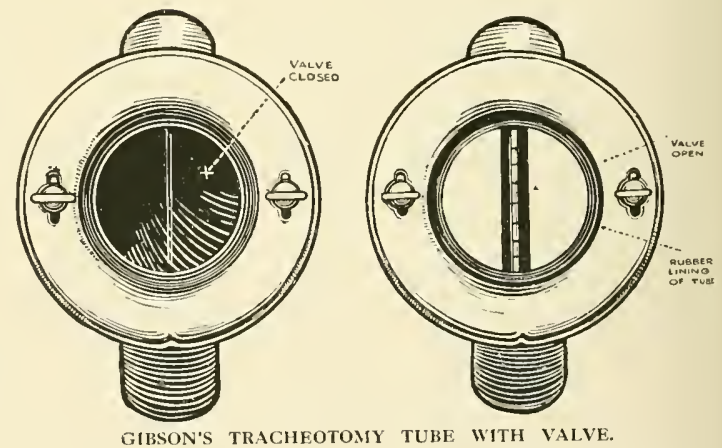

GIBSON'S TRACHEOTOMY TUBE WITH VALVE.

age, or previous attacks. The usual causes are those mentioned in connection with catarrh, sore throat, and laryngitis.

The early symptoms are those of catarrh or common cold, and the distinction is not obvious 


\section{DISEASES OF THE BREATHING ORGANS}

until the peculiar cough and rattling sound mirlis the seat of the trouble. When the larger tubes are involved the sound emitted is much louder than where the lesser ones are chiefly concerned, but there is always a rattling sound, as of air passing over a roughened surface, and later, through much mucus, which is diagnostic, and probably familiar to most persons in the liuman subject. The horse suffering from bronchitis is reluctant to move, the ears and legs are of variable temperature, or cold. The cough is spasmodic, and shakes the animal severely during the early congestive stage, but later, when the mucus is secreted in abundance, he suffers from its accumulation in just the same way as his master, but fails of as much relief for want of expectoration, which some chronic human subjects reduce to a fine art, only excelled by American tobacco-chewers. Horses do, of course, expectorate in a way, but it consists only in coughing up the phlegm and either swallowing it, or allowing it to drop from the nose, into which it is coughed through the back passage (posterior nares). By placing one's ear against the trachea and at the sides of the chest a good deal of information is to be gained as to the extent of the malady: a practice (auscultation) which will be alluded to in connection with other chest affections.

Treatment.-Besides those hygienic conditions prescribed for all respiratory troubles (see C.ATARRH, etc, page +74 ), the treatment in bronchitis is more particularly directed to relieving the distress by promoting the flow of mucus, or reducing its viscidity by expectorants. If the diseasc is early recognised, the attack may be cut short by bold doses of chloral and iodide of potassium, together with stimulants. When established, no cutting short can be hoped for. Mustard may be applied to the throat all down the course of the windpipe to the chest, and again on the sides immediately behind the elbows. Clothing, including a hood, and bandages to the legs, should be employed to keep the surface warmth up. anci tne vapour of hot water from a kettle, or ressels containing boiling water, should be utilised to soothe the air passages. Inhalations of cucalyptus, of camphor, and of friar's balsam are also of service. Expectoration, or the casting off of nucus, is promoted by tartarised antimony, camphor, ipecacuanha, squills, nitrate, and chlorate of potash, but we are somewhat restricted in our choice of drugs, because we can give no very volatile substances or administer balls or drenches -our medication is necessarily in the form of electuaries, for the reason previously given (see Sore Throst, page 476). The soft and laxative foods, such as linseed and bran mashes, carrots, and green-meat, should also have the effect of preventing constipation, to which animals are prone when suffering from any disease accompanied by high temperatures long maintained. No purgative more drastic than linseed oil should be administered, and this will very likely be accepted with a feed of crushed oats, without having to elevate the head or give it forcibly as a draught. The convalescent must not be exposed to draughts or hardship, and his return to work should be gradual and progressive, or a relapse may be feared.

\section{Chronic Bronchitis}

As a sequel to the acute form, rather than as a senile disease, such as men and dogs suffer from, the chronic thickening of the tubes and tenacious secretion of the membranes give rise to cough of a

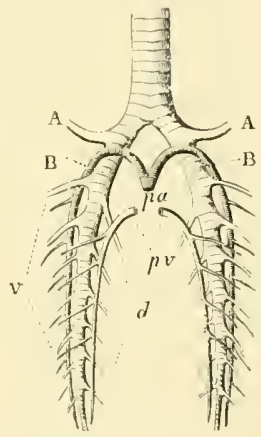

BRONCHIAL TREE OF HORSE.

A. Eparterial. B. Hyparterial ventral (v); d, hyparterial dorsal bronchí ; p a, j v, pulmonary artery and vein (after Aeby). less severe but more persistent variety than that already described. Atmospheric changes aggravate it, and dusty fodder gives rise to coughing fits. The subjects of chronic bronchitis are bad thrivers, and casily fatigued, and, therefore, of little value, although in the hands of a careful and considerate person they may be made to yield useful service for years. Much benefit is experienced by the administration of powders in the damped evening meal, consisting of nitre, antimony, guaiacun, and arscnic. Stockholm tar and linseed oil are found to give relief, but there is some little difficulty in getting horses to take it in food, and the ball or drench may be resorted to in chronic cases where these forms of medication would be quite inadmissible in 
the acute disease. Very much may be done by dicting (see Broken Wind, page 483 ).

\section{Congestion of the Lungs}

There is a very great distinction to be made between horses and men in the use of this term. The public, or their medical attendants, speak of congestion of the lungs as of some condition just falling short of inflammation of the substance of parenchymatous tissue of the organs. In the case of horses it means engorgement of the lungs with blood sent there for aeration, but stagnating in the great pulmonary vessels and unable to make the circuit.

Our meaning will be clearer if we take the example of a hunter indifferently conditioned, or prepared by regular and increasing exercise, taking part in a prolonged chase, and coming to a standstill, pumped out, with heaving flanks and dilated nostrils, and evincing great distress. This horse was in perfect health a few minutes previously, but owing to want of heart power (due to the absence of preparation before mentioned) the excessive quantity of blood brought to the lungs for aeration has congested. The pump (heart) has failed to send it through. If the rider has pulled up in time and turned the animal's head to the wind and administered the contents of his pocket flask, it is quite possible for the heart to get just enough energy to overcome the stagnation ; otherwise the animal is smitten with a congestion which is extremely likely to prove fatal in a couple or three days. The good horseman knows the value of condition or training, as the animal so prepared will accomplish with a light heart the task that proves fatal to such an one as we have above imagined. Any other sort of work in an unprepared state, such as harness or quite moderate riding, may bring on congestion of the lungs. A cold, or the period of incubation of one, as a sequel to influenza, strangles, or any other debilitating malady, may result in congestion of the lungs; and besides these predisposing causes (see CATARRH and Comuow Cold, page 473), there is a peculiarity about horses known as metastasis, or sudden transference of disease from one organ, or set of organs, to another. Suffice it to mention one or two examples. A horse with fever in the feet may be found one morning much relieved in the feet, but blowing, and in great distress, from congestion of the lungs. A mare after foaling will show symptoms of congestion of the Jungs, and then in the course of a night perhaps have the trouble "drop into her feet," as it is said.

The symptoms are such as to call urgently for attention, even to the untrained eye, which will detect something very seriously wrong, as it notes the blowing or rapid but shallow breathing, the bloodshot eyes, and distended nostrils, the hanging head, and icy-cold extremities. The animal generally stands all the while, poking his head into a corner where the air is worst, while we should desire him to breathe the purest and coolest. Occasionally the pain which accompanies the disease prompts the horse to go down, as one with colic, but the position is soon found to be even less tolerable than standing, and he rises again with a groan. A torpidity gradually overtakes him as his self-poisoned blood fails to afford vitality to the brain and other organs. The labouring heart can be heard by pressing the ear to the side of the chest, and a crepitating sound, as of one crumpling tissue-paper, may be distinguished from the harsh bronchial noise which accompanies it. Unless the stagnation is overcome, there is rapid decomposition, and the animal dies with lungs found to be absolutely impervious, and black with congealed blood.

Treatment.-From what was said in describing the nature of the ailment, and the case of the hunter, the main line of treatment has already been indicated: at least for first aid. The nearest stable should be sought, or, in the case of passive congestion following on some other malady, an airy loose box chosen. Bleeding from the jugular vein has doubtless saved many a life when undertaken at the right moment, which is early, and a few minutes after giving a rousing stimulant, as half a pint of whisky, or two ounces of sal volatile in water, or sweet spirit of nitre for choice; but any alcoholic stimulant will call forth the latent energy in the heart and assist in making the blood flow. There is then less rolume of blood for the heart to deal with, and smaller doses of ammonia, of ether, or the popular forms of alcohol, may be given at intervals, to avoid reaction after the first big dose. Digitalis and anmonia are given in this discase with a view to increase the force, and diminish the number of the heart's contractions. Some difference of opinion exists among veterinary surgeons as to 


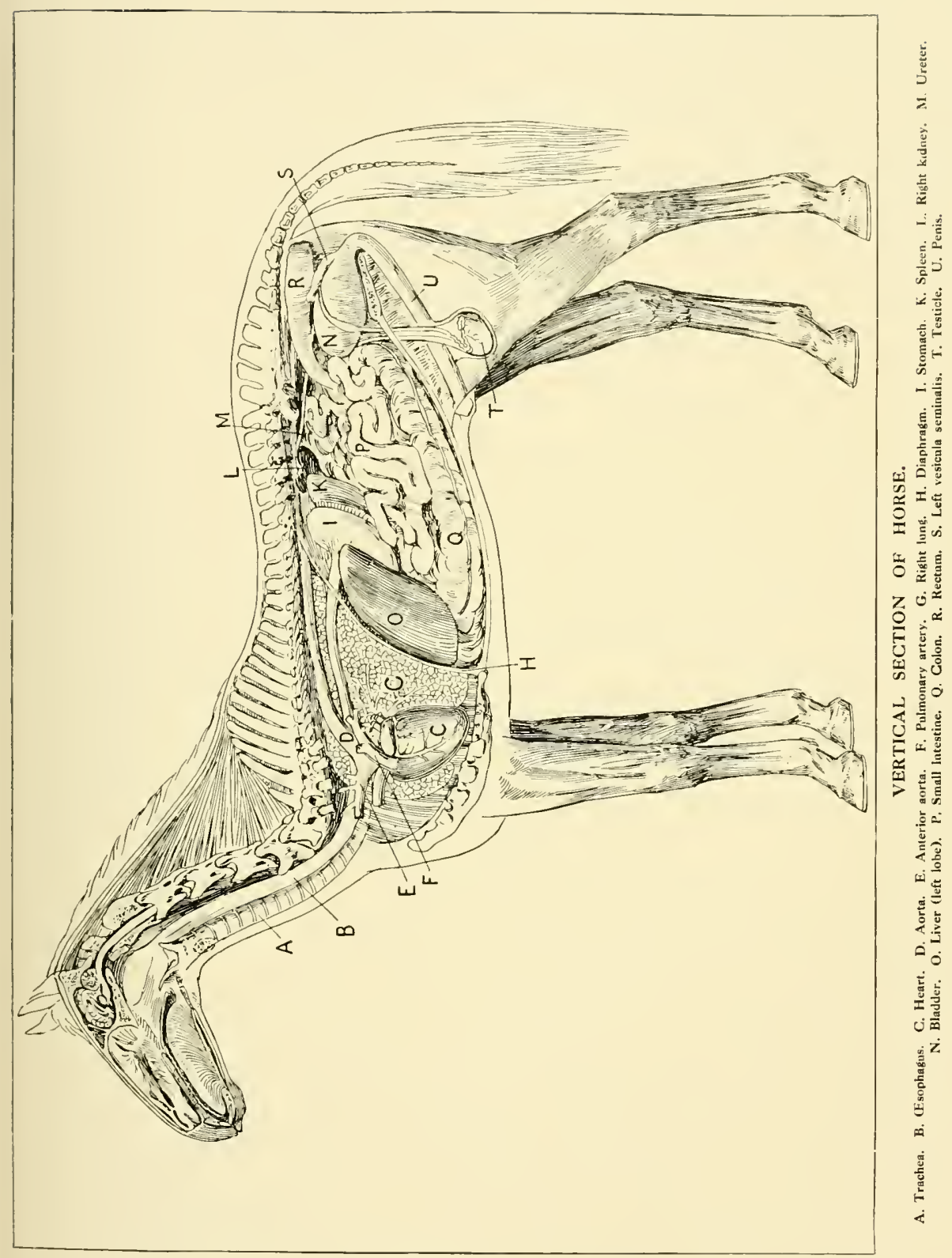


the utility of blecding, and as to counter irritants applied to the sicles of the chest ; but the majority of expcrienced practitioners are in favour of the latter, if the samc cannot be said of taking blood. The application of mustard to the walls of the chest is often followed by great relief in a very short time, and is the turning point in the case. If the animal does not respond to the sting of the mustard lis prospects are dark indeed. Strong liniments or hot packs are preferred by some, their object bcing the same-namely, to bring blood to the surface and withdraw it from the lungs. Grood nursing and unremitting care are necessary for the convalescent, who is morc likcly to make an absolute recovery from the point of death, without any bad effect remaining permanently, than is the horse with a simple sore throat or common cold.

If constipation be guarded against by oil and sufficient laxative food, we are permitted a wider range and choice of eatables in congestion of the lungs than in those other discases of the respiratory system already described. Plenty of time should be allowed for absorption, and complete restoration of deep breathing powcr before asking a paticnt to work : indeed, a run at grass will repay the owner in the end and ronew the legs as well as the lungs, if the subject happens to be a "stale" one.

\section{Inflammation of the Lungs}

If the reader has not already perused the section on congestion of the lungs (page 480 ), he is advised to do so before considcring what is said here on inflammation. Inflammation of the lung substance may arise from sudden chills, east winds, and other climatic conditions, or be associated with bronchitis, when it is called bronchopneumonia; or with plcurisy, when the name given to it is pleuro-pncumonia. Neglected colds, influcnza, strangles, and other debilitating diseases predispose to it, and in badly ventilated stables and horse-ships a septic or infectious form causes the death of many horses. Foals suffering from joint ill sometimes develop a septic pneumonia.

The symptoms of preumonia are not so defined as those of congestion of the lungs, and it is not easy to tell the exact time of the invasion, because it is more often a secondary diseasc or scquel to a common cold (see page
473). The membrancs of the eyc and nostril do not display the dark congestive appearance described in connection with true congestion of the lungs, nor are the respirations so distressfuI at the beginning. A dull brick-red colour of the eye and nose is more cliaracteristic of pneumonia. and the skin and extremities are colder than normal, but do not impart that icy coldness to the touch which has been described in pulmonary congestion in the over-ridden hunter (see page 480). There is constipation, loss of appetite, high-coloured urine, cough of the kind associated with bronchitis in its looser stage (see BRoNchiris, pages 478-9), with a discharge from the nostrils less copious than in common catarrh, and becoming stained later with a reddish substance suggestive of brick-dust, and accompanied with a very disagreeable odour. The chest sounds (detected by pressing the ear to the animal's sides) arc at first louder, but the consolidation, or filling up of the air cells with the products of inflammation, reduce these to little crepitations, which only the expert can be expected to distinguish from those other sounds described in connection with bronchitis and congestion. It is not, however, difficult for the horseman to diagnose, if he will bear in mind the rapidity with which congestion of the lungs declares itself, and the noise made in laryngitis, and the rattling in bronchitis, and if in doubt up to the time of the red tinged discharge, he can be so no longer.

It comes on more slowly, and does not reach an early crisis : moreover, it takes a much longer time for the animal to recover from. Relapses are not infrequent, and too often fatal. Just when the animal seems to be picking up he falls into a feeble state, and appears to be self-poisoned by the absorption into the circulation of the morbid material in the lungs.

Treatment.- No hard and fast linc of treatment can be laid down, as the condition of the animal at the time may vary from the weakened invalid brought low by influenza to the full-blooded young horsc fresh from pasture and necding depletion. Blccding from the jugular vein may be cxcclient practice as regards the lattcr, but calculated to devitalise the former. The best liygicnic conditions arc of the furst importance: pure, if cold, air ; and the bodily warmth must be conscrved by clothing which is to include bandaging tro legs. The sides of the chest may loc stimulated with mustard, or a strong liniment, or con- 
tinuously poulticed or steamed by means of a wet pack frequently renewed. I plan that can le put into operation anywhere is that of applying first a slect wrung out in hot water, with a rug placed over it, and then ironing over all with the domestic flat-iron.

\section{Asthma}

The sudden paroxysms and distressful breathing which denote this malady, and its equally sudden diseppearance, point to a nervous origin. and it is believed to be due to spasmodic contraction of the bronchial tubes. Its causes are rather obscure, but it is known as a sequel to bronchitis, and is observed to occur in badly sentilated stables, and where there are irritating gases from ch mical factories; also as a result of prolonged digestire disturbances: in the latter respect haring an analogy to broken wind, which is refered to in the next column. The cough may best be described as a choking one, in which the paticnt secms overwhelmed with difficultics, and at the point of suffocation: the wet of expiration is more difficult than that of inspiration, and the mucus, or matter expectorated, is uncertain, the paroxysm often returning when it seems to be almost gone. The temperature runs up, and the expression is anxious. These symptoms by their acuteness distinguish it from broken wind, which it somewhat resembles.

Treatment.-The success attending the administration of sedatives is one of the arguments in farour of the discase being of nervous origin, but an aperient of oil, preferably linsecd. should be gren first. We may choose between chloral and the bromides of potassium, sodium, and ammonium, and such drugs as camphor and belladonna, and the combination known as chlorodyne. To obtain the best results we may ring the changes, not persisting in any one too long, although it may give the desired result, hecause all sedatives have a tendency to "wear out." If the periods of freedom from attack are lengthy, and medicines are not given contınuously, it will not matter if the same remedy is resorted to on each occasion. It is important to aroid all dusty food; during the illness food should only be given wet. Linseed, boiled or scalded, or in other forms, is the food par excellence, as it possesses medicinal as wcll as nutritive value. Kibbled oats with bran scalded, and small quantities of carrots, or other "roots" and green-meat, may be given, but it is important to kcep down bulk, as any distension is provocative of spasm, and a return of the paroxysms. The inhalation of warm vapoux is helpful in some cases, but not all, it being noted that some asthmatic horses are best in damp weather, when the air is loaded with moisture, and others when it is dry.

\section{Broken Wind, or Emphysema of the Lungs}

A dilated condition of the air cells of the lungs, with consequent enlargement of the lungs themselves, and impaired elasticity, which gives rise to difficulty of breathing. It was formerly sadd that the cclls were actually ruptured into one another, but this does not appear to be the case, or only in exceptional instances.

The causes are not very clear-the proximate causes, that is to say; but the contributory oncs are well known. That it is strongly hereditary is agreed, and broken-rrinded mares should therefore be objected to for brecling purposes. Nature herself interferes in this matter, rendering the majority of such animals sterile, but the popular tradition that all are barren is not consistent with the facts. That it is intimately associated with the digestive system is agreed, also that the majority of cases occur where bulky and innutritious food has been long provided, or where damaged fodder has been supplied, such as over-heated hay or musty oat or barley straw, foxy oats, and those which have been kiln-dried after suffering from rain in the stook. That farmers' horses should he more often brokenwinded than others is reasomable to expect, having regard to the fact that farmers camnot sell badly got hay, and must needs use it on the holding.

Symploins.-The cough "gives away" a brokenwinded animal directly, as it is different from all others in its prolongation. If the flank be watched it will be seen, in a pronounced case, to contract twice where it should act but once in the expulsion of the breath-a double act of expiration, in other words. In less dercloped cases the rapid movements of the flank are only such as are commonly associated with exertion or excitcment. When the animal is at rest he may not cough or show any distress, but on taking a drink of water, or commencing to eat, he will be likely to do so. As time goes on the chest grows rounder and the abdomen becomes more distended, and there is frequent flatus from the rectum. The capacity for work is diminished. 
Treatment.-It may lee said at once that a broken-winded horse will be useful or not, according to the man who looks after him. If the food is given damp, and linseed forms a considerable part of the ration, if water is sparingly offered and never given within two hours of going to work, and bulk generally kept down in favour of nutritive value, the animal may continue to do good service for years. The nonobservance of these rules will soon render it practically useless. If space permitted, one might tell many funny stories in comnection with this subject. It is a fact that the wind may be "set"-that is to say", the symptoms of broken wind may be temporarily removed so as to deceive the very elect. It is also a fact that the secret of doing it has been lept, and that among a class of persons often to be seen in their cups. The most potent libations have never proved effective in drawing it from the few men, chiefly of the gipsy breed, who are masters of this accomplishment. Many a young veterinary surgeon has been deceived, if he has not made the suspect cough by pinching his larynx - a performance which the low-class dealer is on his guard against, and which is none too safe to perform in the fair or market, where the veterinary examiner is anything but a first favourite. Horses have been purchased and slaughtered in order to find out what remedies have been used, and large quantities of tallow and gun-shot have been found in the stomach, but these things do not constitute the whole secret, and the veterinary surgeon is still in ignorance of the method of setting the wind. If it wcre due to sedatives in large doses we should expect a depressed creature, with hanging liead and listless manner, but, on the contrary, he appears to have indulged in a genuine cock-tail.

\section{Pleurisy, or Pleuritis}

Inflammation of the membrane which covers the lungs and lines the chest is called by the above names. One side only may be affected, or both, and the disease may be a distinct one, or complicated with pncumonia, when it is called pleuro-pncumonia. The causes are the same as those enumerated in connection with common cold (see page 473), but a cutting wind against the side of a heated animal when kept standing is perhaps a more frequent cause than any other, especially in the unilateral form.
Symptoms.-Shivering and elevated temperature: quick, short, painful breathing, accentuated at the moment when the lungs are most distended, and causing the animal to give vent to a sharp grunt or groan, as if stabbed in the side -a feeling described by persons who have similarly suffercd. Pressure of the knuckles against the ribs, or between them, shows that the horse is intensely sensitive. If made to turn, the patient groans with acute pain. "Too sore to cough " is the common verdict, and this opinion is confirmed when the patient is compelled to do so. It is a short, suppressed cough, differing in the extreme from broken wind, and the more acute coughs which have been described under other respiratory diseases, and to which the reader is again referred for comparison. After a variable period, the tense congested serous membranes become moist, and the sound as of rubbing pieces of paper together, which might have been heard at first when listening at the side of the chest, gives place to others not less diagnostic, such as dropping of water, or splashing, bell-like tinklings in the distance, due to the fluid which is being rapidly secreted from the serons surfaces of the pleuræ. The hard and frequent pulse which characterises the attack undergoes a softening, and feels less in volume as the moist period is entered upon and the pain is less severe. In pleurisy alone among the chest diseases or respiratory troubles is the peculiar symptom present of a tucked-up line along the belly, or ridge extending from behind the ribs. This occurs in the act of expiration more particularly, and is more and more marked as the "water on the chest" accumulates, or the cavity fills with a fluid of variable quality. Flocks of lymph appear later and attach the lungs to the sides of the cliest, and are often to be observed as old adhesions in the knackerman's yard. If the filling up of the chest goes on the animal usually dies, despite the surgeon's efforts to relieve pressure by puncturing the chest and withdrawing large quantities of fluid-a practicc which gives immediate but only temporary comfort, the disposition to secrete more fluid seeming to be excited in some instances. I successful result now and again is perhaps sufficient justification for performing the operation, but it should be regarded as an off-chance.

Treatment.-In no other disease of the chest may we expect such good results from counter- 


\section{DISEASES OF THE BREATHING ORGANS}

irritation, since the membranes affected are so near to the outer surface as to be vesicated by mustard or strong liniments. A marked chane for the better is often observed in half an houl. or as suon as the distress of the application itself has passed off. If the patient is fat and fullHooded, bleeding from the jugular vein is advised,

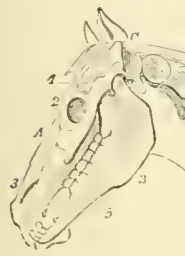

to airl in chisorption of the effused fluid, and to builil up the elements of the blood.

\section{Roaring and Whistling}

In the articlc on common cold (catarrh) and other diseases of the respiratory apparatus, 
them. the choice depending much upon whether the rendor, or some less interested person, is speaking of the particular horse in question. A little thickening from a cold may result in a slight whistling sound when the animal is pushed at a hill, and be scarcely audible in harness, although neticeable when ridden. So slight an impediment will not seriously interfere with the usefulness of the animal, but will predispose him to further thickening and increased trouble whenerer he may get a chill. If an otherwisc desirable horse is to be sold, the buyer should not be tempted by a record of his past performances, but give no more than a "screw" price, on the chance of his getting worse. It is true that some horses will remain about the same for several seasons, but the tendency is to get worse, and should be discounted in purchasing. Every degree of thickening is possible, and roughened eminences give a rasping sound. When the trouble is in the larynx the noise is greatest; it is literally "roaring," and easily distinguishable from the "thick wind" noticed as a sequel to bronchitis. It must not, however, be supposed that roaring is never encountered save as a consequence of some illness, such as we have mentioned; on the contrary, it is well known to be hereditary, and more so in race-horses than others. Had this fact been recognised earlier, the horses of to-day, both thoroughbred and others, would have been much less subject to this form of unsoundness. Roarers whose performanees have brought them fame have been put to the stud regardless of the probability of transmitting the trouble to their progeny, and it is difficult at the present time to find a thorough. bred whose ancestors were free from the defect, or whose progeny have wholly escaped. The preliminary symptoms of respiratory trouble may be so slight as to go unobserved, and a rested horse, or one put away for a time, may come up a roarer if the disease is hereditary. The market is instantly depressed when a horse in training is reported to be "coughing," as the cognoscenti expect to hear next that he has been "scratched," or his engagements cancelled. When roaring has existed for some length of timeor become chronic, that is there is wasting of the dilator muscles of the larywx, and this is belicreal to be caused by failure of nerve supply, but the most careful microscopic examination of the suspected branch has hitherto failed to afford any information. The left recurrent branch of the pneumogastric nerve in some way fails to innervate the muscles on the left side of the larynx, and they waste away. That no pathological changes slronld be observed is only consistent with our gencral ignorance of nerves, it being usual to find nothing, although fits and paralysis in man and beast are obviously due to imperfect current.

The symptoms of roaring would need only to be described to a deaf man, but what we wish to know when the animal is still is, if he will make a noise when put to his paces. If we can see the lunter extended, or the chaser galloped, we shall probably hear quite enough ; but vendors do not always invite such exammations, and if, as previously stated, the rules of auction marts compel the seller to armit "a noise" on the part of his lorse, the buyer must endeavour to ascertain by such symptons as are here given to what extent the animal suffers, and the auctioncer whether he is offering as sound an animal that is a roarer.

In a restricted space, where the above tests cannot be applied, it should be noticed if a horse grunts when a feint is made at his flank with the fist, or a stick such as dealers carry. Cute dealers may be seen with a suspect against a wall, threatening him with blows which never descend, but which cause a groan or grunt from the frightened horse, and if permitted they will "cough" him, which means, pinch the throat over the larynx with finger and thumb, whereby the animal is made to emit the characteristic cough which accompanies roaring, more or less. at other times. This is but a rough and imperfect test, the symptom being absent in many subjects of roaring when not much advanced, and some horses would seem to have been pinched so many times that they have learned to set the muscles of the neck, and resist the pressure that woukd otherwise provoke coughing. They are not old rogues conspiring with the seller to get a better situation, as has been suggested, but have learned the noble art of self-defenceor shall we call it passive resistance? The stick and the coughing trick are not reliable for another reason, and that is that some highly nervous horses, which are quite sound in wind, will grunt or groan when so treated. There is a form of roaring which comes on very suddenly, is extremely loud, and evidently painful. It is lue to spasm of the larynx, and, as might 
be supposed, passes off again with the subsidence of the spasm. An opposite form of roaring to that last mentioned is paralytic. It is gradual and progressive.

Treatment. - This is not very hopeful, as the reader will have gathered from studying the chief causes, because irremovable; but we need not despair of all alike, and in the early stages it will be worth while to attempt remedial measures, if they do but palliate or retard the malady. Blistering the skin outside the throat will often excitc considcrable absorption of the thickened depositcd substances which give rise to whistling or wheezing. Repeated mild applications of iodine, in one form or another, appear greatly to bencfit other cases. The administration of iodide of potassium and iron has a marked influence, and in the paralytic variety good results are believed to attend the use of nux vomica, or its alkaloid, strychnia. The dieting which has been advised for broken wind (see page ${ }_{4}{ }_{4}$ ) proves helpful in other respiratory troubles, and roarers restricted to the best of oats and sifted chaff, carefully damped, with a portion of linseed in each fecd, will be capable often times of leaving sound horses " pounded" in a difficult country. In the hands of an unskilled person they will rapidly grow worse; mow-burnt or dusty forage is as poison to them. There is a poison $w^{c}$ may mention that is remarkably beneficial to roarers and to broken-winded horses, and it is arsenic. In what way it acts is not clcar, but that it does lend wind power, and cause the animal to thrive, is beyond doubt; but, as in the case of the Styrian miners and the mountaineers of South-Eastern Europe, the drug habit once acquired must be continued, or rapid loss of condition follows. The dose is from three to ten grains daily, and is best given in combination with an alkali, as bicarbonate of soda, which facilitates its solution and entrance into the body. Roarers should not be turned out, or let down in condition, as any distension of the digestive organs immediately affects the wind prejudicially.

\section{High Blowing}

Some horses make a peculiar sound with their nostrils - a vibrating or fluttering sound, which is not cxactly a snort, but a preparation for greater effort and wider expansion. Animals with thin skins and casily compressed false nostrils, as the wings or ala are called, often make this noise during a prehiminary canter, but nothing of the kind is observed in the gallop indeed. it has been remarked by so great an authority as Professor Axe, that "ligh blowers are conspicuous for the soundness of their breathing organs and endurance under excrtion." This peculiarity then must not be mistaken for roaring ; nor should the incxperienced be led to believe that a roarer is merely a high blower. The roarer will make a different sound, and even the man who does not recognise it will be able to remember that the high-blower ceases to blow when the roarer's difficulties increase.

\section{Tube in the Neck-Tracheotomy Tube}

When from any cause in the upper portion of the respiratory tract obstruction or difficulty of breathing exists to a dangerous extent, or from the excessive and distressing noise made the horse is decmed too bad for service, resort is had to the tube as an immediatc and effective means of stopping it, and rendering respiration perfectly free and easy, through the artificial opening. It is a simple opcration, and horsemen who are not veterinary surgcons have performed it successfully in cases of cmergency (see L.ARY:NGitis, page 478). The good surgeon will incise the skin, cut out a circular piece of the windpipe the exact size to accommodate the selected instrument, and excite so little hæmorrhage or irritation that the subject of operation will be allowed to work in a day or two. As a rule, one docs not find a man ride more than one or two seasons with a tube in his horse's throat; not that that instrument fails of its purpose, but bccause he cannot stand the attention it excites, and, worst of all, the impertinence of ignorant persons who declaim against the "cruelty" of a merciful provision for the animal's comfort and usefulness. This interference from elderly ladies - for the most part " unappropriated blessings " who have no knowledge of the subject but who succeed in collecting a little crowd round a carriage horse with a tube in his throat -is too much for most folks' tempers, and they sell out. Thickening from granulations around the orifice of the wound naturally results from the presence of the tube and the blind cfforts of Nature to repair what we wish left undone, but these may be easily suppressed where it is desired to keep on a horse upon which tracheotomy has been performed. 


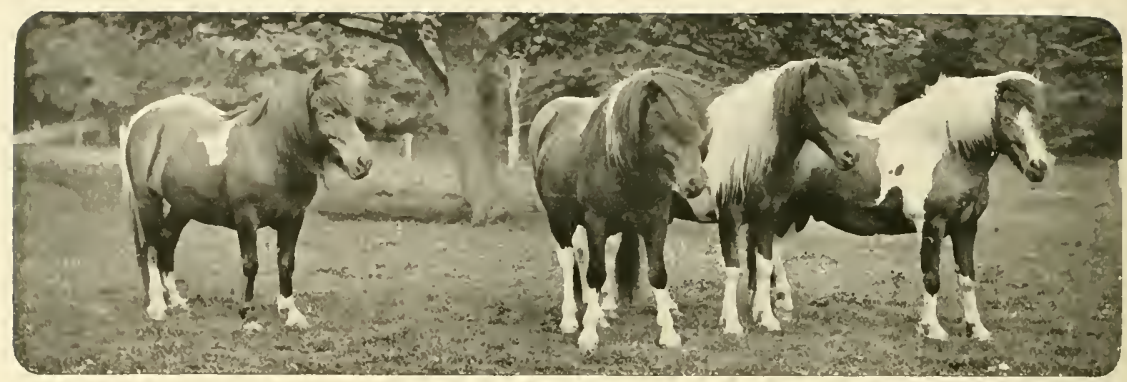

Protinath by C. Nezl, Wishazo

\section{CHAPTER III}

\section{DISEASES OF THE DIGESTIVE SYSTEM}

\section{$\mathrm{T}$}

HERE is no portion of the digestive system immune from disease, from the lips, with which the horse prehends his food, to the terminal portion of the canal from which he extrudes unprofitable waste. It should never be forgotten that horses seize their food by means of their mobile lips, operated, however, by powerful muscles, and that when these are injured the animal is liable to starve, unless suitable aliment is provided. Hunger teaches him to suck up liquid or soft moist foods such as gruel, milk, beaten-up cggs, and other foods, which are more fully described in the chapter on invalid foods and nursing.

\section{The Lips}

Whether a disease of the lips is local, or arises from some constitutional disorder, as stomatitis, it should receive careful attention. Abrasions from rough objects and eruptions from within, thorns, prickles of dried thistle in hay, and vesicles from " nosing" a limb that has been blistered, are among the lip troubles from which horses suffer. Sometimes nasty cracks follow on injuries from nibbling mangers that have previously amused crib bitcrs. The angles of the mouth may be irritated by rusty bits, or by an ignorant breaker using a vesicant to a hard mouth, and making it harder, as a consequence, when the soreness has passed. Inside, too, the mem- brane and deeper tissues may be injured from falls or blows without, and be cut against the teeth.

Treatment.-Is usually easy and successful, as the patient assists us if he has not an aversion to moist foods-a very trying peculiarity met with in individuals, who will show disgust when a couple of bran mashes have been taken, and $r$ fuse linseed in every form. No dry food whatever should be given, but scalded and crushed oats, bran, linseed, carrots, green-meat, or roots in winter. So far as medicaments are concerned we have almost a specific in alum for the inside of the mouth, a strong solution of which may be sponged daily over the sore places. The natural dryness of the skin outside makes us prefer a five per cent. glycerine lotion with three or four per cent. of boric acid, which hinders cracking and is not objectionable if licked by the pationt. A few indolent sores (ulcers) may need sharper remedies, such as a touch of lunar caustic, or a crystal of sulphate of copper.

\section{Inflammation of the Mouth (Stomatitis)}

An inflamed mouth, in which the tongue and cheeks participate with the lips, is often due to an acute digestive disturbance of the stomach, and is reflected, or secondary, to that trouble. It is known as stomatitis. Similar troubles are expcrienced as the result of mistaken adminis- 

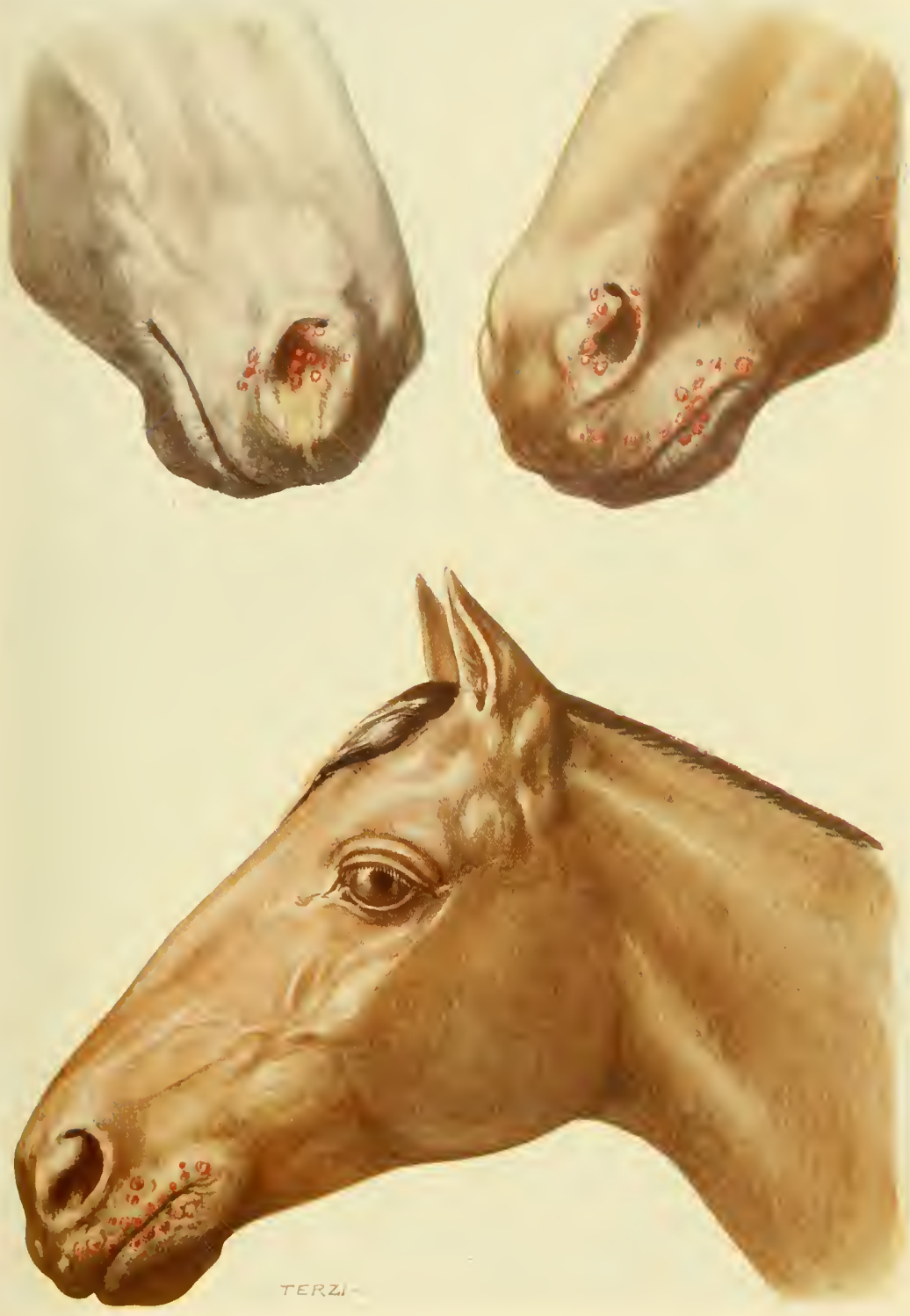

STOMATITIS ERUPTIONS. 

tration of liniments, or of medicaments improperly prepared, the stings of wasps inadvertently taken into the mouth; from changes in the teeth of the young, and sharp edges in those of the old.

The symptoms should attract the merest tyro in horse management, as there is a slimy mouth, filled to overflowing with ropy saliva, having a very ill odour. When opened, the mouth is found to be swollen, tender, and reddened, and soon after disposed to peel. When drinking, the animal dwells with his muzzle under water, as this affords him temporary relief. His cautious manner with food, turning his "quid" from side to side and very likely dropping it, may be the first indication to the unobservant horse-keeper, and then he is reported as " quidding," this being an accepted stable name for it. If it extends backwards there is cough.

Treatment.-This will depend much upon the cause, which should be ascertained; or, failing a definite diagnosis, emollients and astringents, such as have been mentioned in treatment of the lips; or if the stomach is the seat of the mischief, as will be ascertained by signs of indigestion, constipation, diarrhœea, or bad-smelling dejections, a course of bicarbonate of soda or potash with calumba, as powdered root, damped and mixed with the food, or as an infusion, will be given. The mouth sores may be soothed by an electuary composed of a dram of extract of belladonna, and an ounce each of glycerine and treacle, with which the parts should be mopped two or three times daily. The teeth should always be examined in cases of inflamed mouth, as rasping or removal may be necessary.

\section{Aptha}

Resembling the mouth troubles already described is the aptha of young foals, but distinguished from it, if observed early enough, by white patches upon the tongue and other parts. The monthly nurse would recognise it as thrush, which infantile malady it exactly resembles, and is probably due to a similar microscopic fungus (Oidim albicans). As with the human infant so with the equine, thrush may pass backwards down the alimentary tract. Generally, however, it passes away without producing much tronble.

Treatment.- If a foal is observed to shake his head and drop his ears in disappointment while seizing the teat, he should at once reccive attention, and the greyish white spots upon the membranes be dressed with borax and glycerine, than which no dressing is better calculated to destroy it without risk to the patient. The teats of the mare should be sponged with a five per cent. lotion of carbolic acid, or re-infection may ensue when the foal sucks, atthough his own mouth may have been cured. It is a good plan to give a dose of castor oil, and follow it with a few tca-spoon doses of fluid magnesia diluted with water.

\section{Inflammation of the Tongue}

Hitherto we have spoken of the surface troubles of the tongue, in which only its covering membrane, or at least the tissues immediately underneath, are involved, but there is a dangerous disease of the substance of the tongue itself, which the reader is doubtless aware is composed of muscles arranged to give it great mobility an<l in every direction. Inflammation of the tongue may be caused by infection of a triting wound, or result from serious injury from the bit, or by biting it when falling on the muzzle ("pecking," it is called by hunting men). Diseased teeth, or food retained for lack of a toothpick between them, undergoes decomposition, and produces the septic material with which the tongue may be poisoned if there is an abrasion, although the intact membranes will permanently resist such deleterious influences. This immunity on the part of sound mucous membranes explains why the world has not been depopulated by tuberculosis, if, indeed, it is proved that the bacillus in milk enters the system through such abrasions. The writer has seen savages gorging with the flesh of animals that have died, and without any subsequent inconvenience to themselves; but the man who gets a splintered bone in his hand, or a breach in his mucous membrane, will be easily poisoned by what would be innocuous over sound surfaces. If his companions note without indifference his inability to follow the tribe, they are more likely to credit his illness to having failed in making a suitable present to the local fetish than to a custom they have practised from time immemorial.

The symptoms of inflammation of the tongue are increased size of the organ, the extent of the swelling sometimes threatening suffocation 
by involving the throat. At first red, it soon becomes purple, is lot, hard, and very sensitive to the touch, and is unable to deal with food. A foul-smelling thick saliva falls from the angles of a mouth which is held forward as the least painful attitude.

Treatment.-This should begin with an apcricnt, but a ball of aloes may be difficult to give after the first stage, and the animal may be then induced to take sulphate of magnesia (Epsom salts) dissolved in water. This drug, the bitterness of which precludes its more general use in domestic medicine, is not much objected to by horses when given with their food, and this may be accounted for by the vegetable bitters in their natural aliment. All the ranunculacere are intensely bitter, and the most careful feeder will be in the habit of taking more or less buttercup in his hay if he feeds all round the coarse stems when at pasture. When a horse has inflammation of the tongue his sense of taste is so debanched that he will aid us in this form of medication. as he is eager for drink. Punctures made in the tongue with a clean lancet give relief to the extreme tension by blood-letting, and the mouth should be syringed with an antiseptic, such as permanganate of potash, boric acid, carbolic acid (thrce or four per cent.), and, later, with chloratc of potash and alum, when some subsidence of the swelling has taken place. Nourishment should be offered in the form of eggs beaten up in milk, and if it cannot be taken it may be given per rectum with a syringc. The use of meat essences is now adopted in such cases, and they arc found to afford temporary sustenance of much value, although very few graminivorous animals can be persuaded to take them voluntarily. From milk and eggs to fine oatmeal gruel, haytea, and sloppy mashes and boiled roots, therc is an casy transition, but all dry food must be withheld until convalescence is fully cstablished. Recovery is usually complete and permanent, and it is quite remarkable from what very serious injuries the tongue may be restored. There is another disease of the tonguc of an anthracoid nature which will be considered under specific or constitutional discases.

\section{Inflammation of the Throat}

In the list of discases of the respiratory system (page ${ }^{476)}$ will be found an account of sore throat as it gencrally manifests itsclf from chills or catarrh, and the invasion or spreading of maladics connected with the breathing organs, but there is an inflamed throat (pharyngitis) connected with fevers and tcething, and foul air acting upon this sensitive portion of the organism. Sore throat may be caused by strangles (see Strangles, Chapter VIII.), or by infective organisms and abscesses formed in the guttural pouches. For this type of sore pharynx or throat, weak solutions of chlorine, of permanganate of potash, of chlorate, and nitrate of potash are employed, together with glycerine, honey, and other softening agents, calculated to soothe irritability and relieve coughing.

\section{Abscess in the Throat}

The lodgment of a splinter or thorn, and occasionally a ncedlc, has been known to cause abscess in the throat. The rapid swelling and formation of matter is a natural cure, for, as a rule, the discharge carrics away the offending body. It may happen that the unfortunate animal is choked while this is proceeding, and we should endeavour to discover the cause of sudden distress and outward swelling and tenderness, which point to such accidents, when we may be able to gag the patient and remove with fingers or forceps the cause of the troublc. It is rather remarkable that such cases are not more frequent, having regard to the forage consumed in scmi-dark stables, and in mangers where the horse trusts cntircly to the senses of smell and touch, and not to vision.

\section{Salivation, or Ptyalism}

Excessive secretion of saliva of a morbid character is known as salivation, and the symptoms have been frequently referred to in connection with mouth and tongue troubles. Any irritant may set up salivation, or bad tecth or irritation of the stomach from nests of worms in its lining membrane. Salivation as understood in human medicine, and arising from mercurial poisoning, is very rare in horses, and need not be considered in this connection.

\section{Inflammation of the Parotid Glands (Parotitis)}

In its outward appearance this rescmbles "the mumps" in human beings, but is not, 
like that disease, a specific contagion communicable from one subject to another. The parotid gland. which occupies so lirge a space under the ear of the horse, may be injured by the throat lash, or through the strup being too tight, or ther forms of extcrnal violence, which result in inflammation, but the conmonest cause is by the extension of strangles or influenza. It short and preventing suppuration or abscess : or the application of a strong liniment may arrest the disposition to form pus. Failing this we continue to poultice, in orcler to bring the abscess to a point and release the pent-up matter by the use of a clean lancet or sterilised knife. Linseed gruel and moist foods should be offered. Rorring sometimes follows on parotitis.

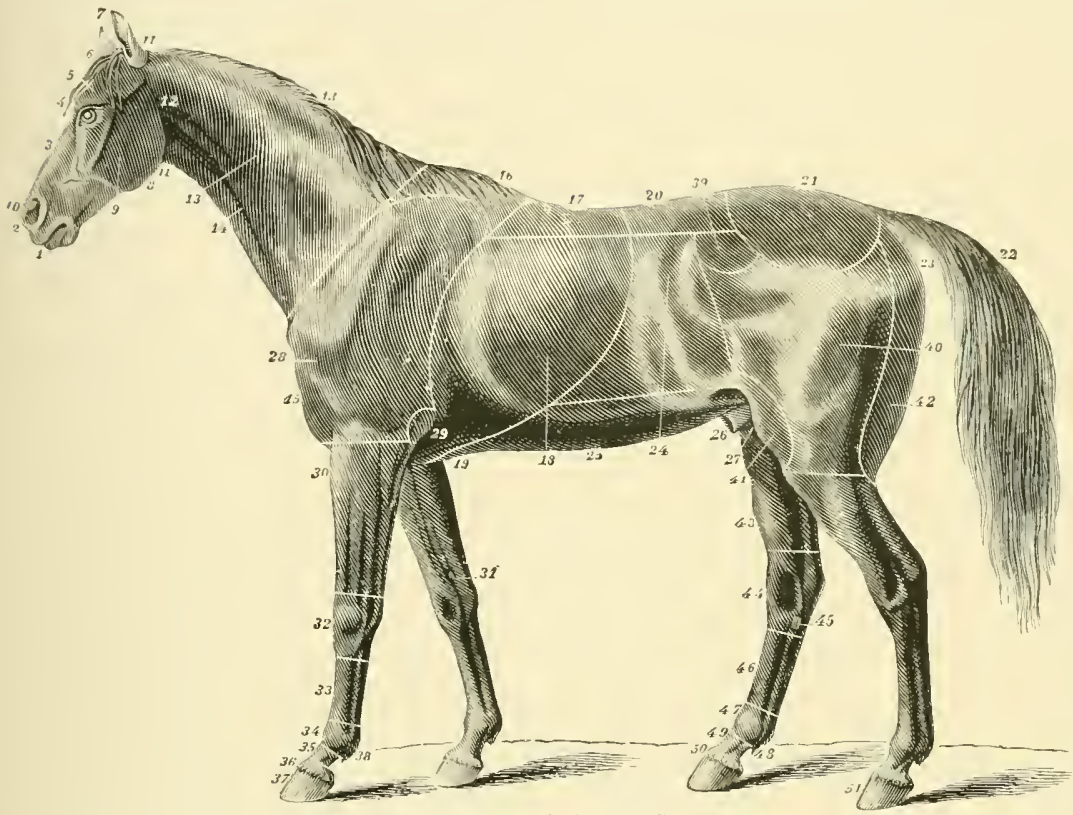

POINTS OF A HORSE.

1. Lips. 2. EnJ of nose. 3. Nose. 4. Forehead. 5. Hollow abnve the eye. 6. Forelock. 7. Ears. 8. Lower jaw. 9. Cheek. 10. Nostril, 11. Upper part of neck, or poll. 11'. Neck. 12. Parotid gland. 13. Ridge of neck. 14. Hollow of neck, or jugular furrow. 15. Breast. 16. Withers. 17. Back. 18. Side, or ribs. 19. Girth. 20. Loins. 21. Croup. 22. Tail. 23. Anus and deck. 24. Flank. 25. Belly. 26. Sheath. 27. Testicles. 2K. Shoulder and arm. 29. Elbow. 30. Fore-arm. 31. Ergo\%, nr chestnut. 32. Kiee. 33. Cannon, nr les brine. 34. Fetlock joint. 35. Pastern, 36. Cor net. 37. Foot. 38. Foot, or fetlnck. 39. Ha nch. 40. Thigh, or hind-quarter. 41, S ifle, 42, Battock, or point of hip. 43. Leg. H. Hock. 45. Chestnut. 46. Cann:n bone. 47. Fe lock joint. 48, Fetlock. 49. Pastern. 50. Coronet. 51. Foot.

may take an acute course resulting in abscesswhich eventually breaks and relieres itself-or become chronic, and leave permanent enlargement, and more or less diminished functional activity. There is little difficulty in diagnosing a case. The horse pokes out his head and makes short nodding movements with more or less snoring or noisy breathing, and shows difficulty in eating and drinking. If the abscess breaks inside, a whitish matter will come down the nostrils and relief immediately be experienced.

Treatment.-Continuous poulticing is advised. This has often the effect of cutting the inflammation

\section{Fistula of the Parotid Duct}

An opening in the cheek giving rise to a watery. discharge near the lower border of the jaw may generally be traced to an injury of the parotid duct, which allows the escape of the salivary fluid intended to be discharged into the mouth to aid digestion. It is a state of things calling for the assistance of the skilled veterinary surgeon. and not to be trifled with or its treatment delayed.

\section{Salivary Calculi}

Calculi, or stones, somctimes form in the salivary ducts, notably in the one above referred 
to. A surgeon should be consulted in such case. They are recoguised by a bulging of the lower border of the jaw: the substance feels hard, thougl surrounded by the salivary fluid it has dammed.

This is a comparatively rare accident in the horse, but is attended with greater risk than with cattle, as the gullet is small in proportion to the size of the animal, and his nervous temperament throws him into a state of alarm, which adds to the difficulties of treatment. Whole apples that have slipped past the grinders and got beyond control of the tongue, portions of carrots or other roots, and, strange as it may appear to the novice, onions and Ihen's eggs are

\section{Choking}

saliva and anxious countenance, sweating and trembling and, of course, refusal of food, mark the choked horse, and if water is bottled down him some of it may go the wrong way and bring on a burst of ungovernable coughing. A bulge may often be seen and felt when the obstruction occupics a site between the pharynx and half way down the neck, but the gullet winds over the windpipe at the latter place, and the substance may be lodged in a position from which no assistance can be given by pressure outside. If relief is not obtained, the tissues of the neck first swell witl gases and later the whole body, and the animal dies.

Treatment.- Where there is doubt as to the position of the obstacle, the mouth should be opened and the back of it explored, as the object may be within reach and removable. If ascertained to be in the neck, small quantities of linseed oil should be given from a bottle, and then quict

the chicf things by which horses get choked. All but the last two articles are eaten voluntarily, and if the former are given in unsuitable form the patient is at least guilty of what lawyers call contributory negligence. Perhaps this charge ought not now to be made, since no such disqualification exists in regard to servants credited with more intelligence, even if they do not always display it. Whether the horse gets choked with an apple or the two-legged ass with his artificial teeth, the master is equally liable. Whole eggs and onions are credited by some grooms with producing a fine glossy coat, with less demand upon the sudorific glands of the attendant, and their cost can be charged to the master. Among other causes of choking may be mentioned imperfectly masticated hay, swallowed by greedy individuals, and pieces of stick anu wire. The obstruction may be anywhere between the throat and the last inch of the gullet, before it reaches the stomach (cardiac orifice).

The symptoms are modified somewhat according to the position of the obstacie. The nose is poked out as in sore throat, but repeated, painful, and spasmodic efforts to swallow distinguish it. There is a peculiar convulsive movement of the muscles of the neck and depression of the chin at the same time, when the "choke" is in the neck. Dribbling of efforts made to move the body up or down the gullet. Movement either way may result in riddance, as the substance is often no bigger than could be swallowed, but its lodgment has paralysed the muscular tube at the part wherc it has been pressed for so long a timc. Manipulation that is carricd on without "flurry" will often result in breaking up the obstacle and so enabling the horse to gulp it down, or render it pervious to further doses of oil, which will so soften the mass that it will prescntly be swallowed. When these methods have failcd, resort must be had to the probang, or choke rope, which is passed rapidly over the tongue and gently down until it reaches the obstruction, and from thence, with but moderate force, continuously pushed until it reaches the stomach. Too much force is likely to rupture the gullet and end disastrously. If the object cannot be moved at all with moderate pressurc from the choke rope, it is better to withdraw the latter; the canal should then be oilcd again and an interval allowed to elapse before a further attempt is made. The second is often successiul, as the first has enabled the oil to get further round the obstacle, and success rewards the man who will " hasten slowly" or adopt the motto of the Drummonds and "gang warily." A fast of fifteen hours or so. save for a little thin, warm gruel, is desirable after choking, that the cesophagus may regain 


\section{DISEASES OF THE DIGESTIVE SYSTEM}

its normal tone and the lining menbranc recover from the local irritation.

\section{Vomiting}

The majority of "horsy" men believe that horses never vomit, but this is not the case. When they do, it is too often due to ruptured stomach or midriff (diaphragm), and a fatal termination may be looked for. Some few cases of vomiting are due to distension with indigestible food and the presence of gas, and are relieved by the act. The writer had an old mare that used to get choked with hay and relieve herself by romiting, after which she went on very well for a month or so, and did it again. Not wishing to keep a record breaker, she was sold.

\section{Acute Indigestion}

The acute forms of indigestion in the horse, such as result from engorgement with unsuitable food, produce effects upon the brain which, in stable language, are not inaptly described as stomach staggers, sleepy staggers, and mad staggers. Mountain and moorland ponies, and such horses as endeavour to make up in bulk what is lacking in quality, are the special subjects of this malady. Idle and gluttonous animals, and those which sink to the level of their masters, and eat merely for the sake of eating and not to appease hunger, are also to be counted among the victims, as unlike the biped glutton they cannot resort to somebody's family pills to mitigatc the consequences of excessive indulgence at the manger. Restricted in their choice also, they must continue to eat constipating food, if the groom does not observe the necessity for a laxative, and this adds to the risks of acute indigestion. Familiarity with the sour dyspeptic who has " an eye to which all order festers, all things here seem out of joint," would lead the novice in horse-flesh to suppose that some earlier sign would be observed prior to the head symptoms. but, such as they are, they frequently fail to attract notice. The symptoms depend somewhat upon the degree of distension and paralysis of the stomach and duration of the trouble, which may not be known with horses at pasture away from observation. The stabled animal may bc observed to show some little uneasiness in the belly, looking round dreamily at his side and pawing slightly, and presently lying down in a 63 manner much less excited than in colic (see page 496). These eridences of abdominal pain may either precede or follow on the brain symptoms of sleepiness, during which the horse stands with his hearl pushed against the wall in front of him, or hangs it down as if too heary to be lifted. In horses at grass we hase sccil them walk with the head down between the krees-a most comical attitude, and once scen can never be mistaken to indicate any other cliseasc. The belly enlarges by the accumulating gases, caused by decomposition of food. Bclching of gas and the bringing up of some digested food, scarcely amounting to romiting but suggestive of it, will give slight relief, very much more being afforded where wind is broken off behind; but this relief is rare. Trembling of the limbs, patches of sweat, unsteady or rolling movements, will perhaps precede rupture of the stomach, or Aelirium, which is what is meant by mad staggers. "Nature cures" occur by reason of abstinence from further food, and by the resulting irritation and gases evolved acting as a purge. In these cases the comatose condition may cndure for several days, the lips hanging pendulous, the ears drooping, and the animal standing aslecp - a sleep from which it is difficult to arouse him by ordinary means, and if shaken up he lapses into the same condition inmediately. The breathing is slow and accompanied by nore or less snoring. Little or no fæces are passed, and these are covered with a shiny coating. The urine is highly coloured, and its yellow tinge indicates a disordered liver.

Treatment.-A bold dose of aloes should be given at once, and this is one of the few diseases in which it acts better in solution than as a ball, for its rapid diffusion over the stomach is secured, instead of having to wait for the bolus first to dissolve in an organ incapable of dealing with solids. An ounce may be given with ginger and peppermint, or dill water, and if the colicky pains mentioncd are present, an ounce of sal volatite will be a desirable addition. As much water as the creature will drink should be allowed. The rectum should be "back raked," as the operation of unloading it with the greased hand is called. The resistance of the sphincter muscle controlling the anus is considerable at first, but soon tires, and gives way to the pressure a man can exert with his fingers; followed up with hand and arm until the object is attained. Solutions 
of salt, syringed up the bowel every three or four hours, assist in rejeasing the contents. For the brain symptoms, whether "sleepy" or "mad," there is no remedy so prompt as bleeding from the jugular wein, from which a large quantity of blood may be safely talsen. Powdered ice in lags applied to the back of the head (poll) also ameliorates the excitement of delirium. Unless there is a repetition of the causes a permanent restoration to health may be expected.

\section{Chronic Indigestion}

Errors of diet, of course, account for indigestion in horses as in men, but there are individuals who from conformation and heredity are prone to dyspepsia, besides those whose livers have become impaired by town life and continuous feeding upon stimulating food, without an occasional return to grass and natural conditions. Hard water and changes from one district to another sometimes account for indigestion in horses.

Symploms.-The less observant among stable attendants fail to see anything wrong until a loss of condition makes itself apparent, as an unthrifty or staring coat, hide-bound, grinding of the teeth, licking the walls, variable appetite, an occasional short cough, sour smelling ordure, constipation, or diarrhoea. Brittle feet are frcquently due to chronic indigestion, but this is not generally known to horse-keepers. Slight pains, sufficient to cause the animal suddenly to cease f: eding and look round, attract attention; especially is this the case where the subject does not resume his meal. This may be a habit with some horses, but they will be found to be of the "washy" or badly conformed type which never thrive and carry a good barrel, and of whom it may be said that their digestions are never really good

Treatment.-An examination of the teeth and condition of the tongue and oral cavity generally, of the evacuations both solid and fiuid, and a full consideration of the food supply, must precede any prescription for the cure of indigestion. In the young, dentition troubles may be the hinIrance; in the old, ragged edges of the grinders, or interdental spaces in an unhealthy condition from accumulations of food, which have decomposed and set up inflammation of the gums, and possibly of the bone. The presence of worms in large numbers, hard water and badly harvested food, must be eliminated before resorting to those restorative remedies which, in certain circumstances, seem to lend digestive power. The greedy feeder may need to have more dry short chaff with his corn. from which he cannot pick out the oats or swallow in the mass without more insalivation than he has been giving. As a matter of experience this suggestion has more often to be made than any other in cases of in digestion; the opposite but seldom, and then only do we prescribe crushed oats and soft food not needing much grinding for the old, or those who cannot use their own "mill stones." The reason for this will be obvious to the reader who remembers that digestion begins in the mouth, and that the ferment (ptyalin) contained in the salivary fluids must be introduced into the food during slow mastication. The more quickly food is swallowed the less digestion takes place in the mouth, and the more labour is thrown upon the glands of the small intestine. Indigestion should be cured chiefly by judicions dieting. We can, however, give considerable assistance, and reduce the time required by first an aloetic purge, then a course of alkaline bicarbonates and calumba root, or of acids and gentian and nux vomica (see TABLE of Doses).

The water question is one of greater importance than is generally recognised. Some animals never learn to take sufficient when the bucket is offered them, and exception should be made in their case, a receptacle being kept always supplied by their side. The writer was called upon to arbitrate between two liunting friends who had fallen out over a horse lent by the one to the other, and rapidly reduced to a " disgracetul" condition. The borrower had treated the animal well, but had not discovered that he was a sipper who would only take about half a gallon at a time and then turn his head away. With a bucket of water placed beside him he was always found to have emptied it on each return visit to the stable, and in a few days dropped his belly and recovered his condition. A reconciliation was casily effected. Watering before feeding is now recognised as the best method.

\section{Gastritis}

Gastritis is inflammation of the lining membrane of the stomach, varying in intensity according to the cause. This may be engorgement (see 
Actie Ixdigestiox, page +93), lodgment of foreign bodies, the swallowing of irritant poisons, the presence of worms, or a result of specific fevers, etc. Since weed-killers have been generally employed more accidental cases of gastritis have occurred, the arsenic in such preparations finding its way into forage by being upset over it. Arsenical sheep-dips, too, have caused gastritis and death, for they are mixed with alkalics and have a fatal attraction for horses and other live-stock.

The symptoms are tlose of continuous abdominal pain, without the intermissions usually associated with colic. The breathing is hurricd, and the facial expression very anxious, the white of the eye and lining membrane of the nose being greatly reddened, the animal looking round with a half angry expression at the seat of pain. In the case of arsenical poisoning, frothing and dribbling of saliva from much swollen lips occur. If caused by eating yew, collapse and nervous prostration accompany the other symptoms of gastritis.

Treatment.- If known to be caused by an irritant poison the recognised antidotes should be obtained with the least possible delay. If from the other causes mentioned. demulcent foods, as milk and barley water, linsced tea (see Foods FOR THE SICK, Chapter VIII.). The evident pain in the belly may be more or less relieved by warm compresses or sheets dipped in hot water (see Pleurisy, page 48.4 ) and applied over the region involved. The most valuable drugs are those given to "stale drunks," or those persons who have indulged in an alcoholic debauch and failed to partake of food-the most frequent cause of acute gastritis in the horse's master. These are bismuth, bicarbonate of soda, and hydrocyanic acid. The two latter are chemical incompatibles, but their medicinal effect is entircly satisfactory (as part cyanide of sodium). Great care in diet is necessary until the injured organ recovers its digestive power.

\section{Chronic Gastritis}

This is more common than the acute, and shows the same symptoms, but in less aggravated form - occasional attacks of colicky pain and

a clisposition to climrhoea, to weakness, and loss of flesh. A variable and unsatisfactory appetite accompanies this chronic stomach trouble. Treatment on the lines suggested for the acute form and careful dieting offer the best hopes for recovery and, if the season be favourable, a turn out in good pasture.

\section{Ruptured Stomach}

A ruptured or burst stomach is rarely the result of external violence, but is not altogether unknown, nor is it an accident that often occurs in the young, but as a result of chronic distension and weakencl walls brought on by habitual indulgence in too much food. Horscs with stomachs

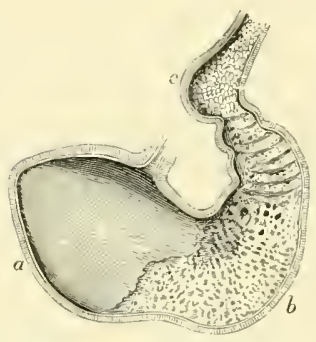

INNER FACE OF THE WALL OF THE STOMACH OF THE HORSE.

a. Cardiac; b, Pyloric sac; c. duodenal dilatation (after Chauveau). so weakened undoubtedly go on in apparent health for a long time, the climax being reached when a hearty meal is followed by a d e e p draught of water and excessive exerticn.

\section{Symptoms.-}

There is no one diagnostic symptom of broken stomach, although vomiting, as mentioned clsewhere, has been observed in connection with it. This symptom, however, is rare. The acute abdominal pan is indistinguishable from that of colic (see page 496), but is followed by a quict period in which the paticnt stands with anxious countenance and his extremities become increasingly cold. The pulse is what is known as a "rumning-down" one, becoming imperceptible after a while. The shallow breathing is succeeded by staggering, and presently the animal falls, never to rise again ; some horses appear actually to die on their feet. Before the cnd comes, sighing and sweating may occur. These, however, are not invariable symptoms, and none of them distinguishes ruptured stomach from ruptured diaphragm or bowel. They all point to the giving way of some abdominal organ and a fatal ending. Nothing could, of course, be done if a positive diagnosis could be made. 
The only thing that remains is to destroy the animal when the fatal collapse is definitely shown.

\section{Colic, Gripes, Fret}

Modern veterinarians recognise quite a variety of colics, but the chief distinctions still hold good, and for our present purpose it will be sufficient to describe spasmodic and flatulent colic as the chief types. Spasmodic colic is the result of sudden and intense contraction of the muscular structure of the bowel. Flatulent colic is induced by distension with gases eliminated by the undigested contents of the gut. The tradition still lingers among stablemen that colic is "in the water," and nothing but post-

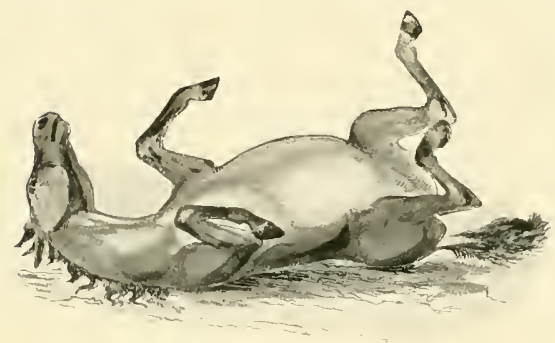

HORSE ATTACKED WITH COLIC.

mortem evidence will convince many of them. With the relaxation of spasm, urine is gencrally passed, and effect is mistaken for cause. "Only get him to stale and he will be better," says the groom. Both kinds of colic have their chief cause in indigestion. Because deep draughts of well water, or water below the temperature of the atmosphere, will bring on spasmodic colic, an erroneous view of watering horses was held for a century or more, and not until watering before fecding was adopted in the Army and in some large privatc studs, with a great reduction in the number of colic cases, was a rational system generally accepted. A fair draught of water when a horse is hot and tired is now found rapidly to restore him and promote appetite by providing the necessary saliva witl which to chew his food; moreover, slaughter a few minutes after drinking proves that the fluid taken passes rapidly out of the stomach and into the cæcum or water-gut, and does not dilute the gastric juices and hinder digestion, as was supposed when it was not known that digestion is only to be provoked by the presence of somcthing to digest, and that if the juices were always being secreted in the intervals of feeding the stomach would dissolve itself. The tired and hungry horse compelled to choke down his food with no more than a mouthful, or single "godown," of water, and then given a bucketful when digestion has commenced in earnest is more liable to colic than even the excessively watered one. Certain springs and wells have a reputation for producing colic, and particulas ponds may be drunk from ad libitum, as "there isn't a colic in the whole pond," the people will tell you who have lived by it all their lives. Stones and other concretions, worms and "oddments," such as wire nails and other things which find their way into chaff and corn, and ar a taken even at pasture, may give rise to colic.

Symptoms.-Colicky pains are frequently referred to in connection with the different diseases of the digestive organs, and even show themselves when pleurisy and lung troubles afflict the horse, but the downright attack of spasmodic colic cannot well be mistaken; the other colicky pains are but mild imitations, and are referred to merely as having a resemblance. Spasmodic colic comes on quite suddenly. The acute pain with which the animal is seized causes him to trample and stamp the ground, paw with one foot and then another, strike at his belly with a hind foot, sweat, lay back his ears as when angry, crouch, throw himself down, roll to one side, then to the other; then on to his back, shake his head, half rise and go down again, get up and down almost instantly, or enjoy a short remission of pain, during which he scems quite well, and perhaps returns to an unfinished meal. While the food is in his mouth he will be seized once more with agony, and go through all the performance described, but with variations. With the first symptoms of pain the dung in the rectum will often be expelled, and this deceives the unobservant attendant, who will assure the veterinary surgeon that the horse's bowels are acting well, whereas he has but emptied the small round shiny balls that were in the terminal portion of the gut and is constipated the while. There may be quite a sharp line between some dry undigested food in the bowel which is causing the trouble and some soft green-meat or mash since taken, so that the evacuations should be watched and a judg- 
ment should not be formed upon a single mass expelled. During the paroxysms of pain the breathing is accelerated and the pulse quickened, but the temperature is not increased unless the malady continues for some time. It is a favourable sign when intervals of case are of longer duration and the return of pain less severe. The converse conditions portend danger.

Treatment.-For spasms, anti-spasmodics. Alcoholic stimulants of great variety are employed and with more or less success, but if one could choose from a well-stocked pharmacy, essence of ginger, aromatic spirit of ammonia, spirit of nitrous ether, and peppermint or dill water woul] he preferred for a first dose. If the case proves more scrious, chlorodyne, or tincture of opium, or other direct modynes or narcotics, are prescribed at intervals. Turpentine in linseed oil is a simple and often valuable medicine. There is some difference between town and country practice with regard to treatment of colic The carriage horse or the cart-horse, where good management is the rule and mashing regulariy carried ont, is not so likely to have colic from impaction of dry and inferior forage, as the farm horse, to whom hay and corn are given which are not quite up to the standard of the corn merchant; besides which there is not that individual attention and careful observation that we look for in the best studs and in establishments boasting of a horsekeeper On the whole, then, we commend the old practice of first giving an aloetic or "plyysic" ball, and proceeding with anti-spasmodies without regard to the ball; but where it is given the linsced oil must not be added or too much subsequent purging may be set up (see SupEr-purgaTIox, page 499). The aloes will be getting to work and will remove an impaction which the spirituous drenches would not affect, although allaying pain. Many bowel concretions and hard stones are passed as the result of a "pliysic" ball, whose presence has not been suspected (see SToxes AxD Coxcretrons, page 50r). Without a laxative of some kind, the repeated doses of opium often preseribed have resulted in obstinate constipation and even defeated the object of the prescriber.

Flatulent Colic.-In this form of the malady the large bowel is distended by gas resulting from decomposition of the food. It may follow on spasmodic colic, or arise from obstrutions in some other portion of the eanal.

The causes are unsuitable food, too long abstinence, gluttonous fecding, imperfect mastication because of bad teeth, or failure of the digestive organs to do their part. Stones, concretions, and growths interfering with the free passage of the ingesta are also responsiblc for cases of flatulent colic. Horses that have been long accustomed to dry feeding and then turned out into sucenlent grasses are apt to eat too fast, and fermentation quickly takes place, with the result above described.

Symptoms.-The diagnostic feature of this form of colic is the tympany or drum-like distension of the abdomen. Pain comes on less suddenly and is continuous (it is intermittent in spasmodic colic). Horses suffering from this discase vary greatly in their behaviour, some being deeply depressed and only pawing feebly and looking round uneasily at the flank, while others show the violence described in comnection with the spasmodic form, but without the disposition to throw themselves down upon the ground, rather choosing to wander round a loose box or enclosure. When weary and desiring to lie down, the manner of doing so is careful, and the animal stretches out on its side at full length, with only an occasional glance backwards. The pressure on the under-side naturally distends the upper one, and the blown appearance is aggravated, although there is good reason to believe that this pressure enables the patient to break off wind and so obtain a measure of relief. Flatulent colic may endure for an hour or two, or even two or three days, but is always to be considered dangerous on account of liability to rupture of the bowel.

Treatment is directed to breaking up or forcing out the gas. Massage over the abdomen, straw wisping, kneading with the knuckles, moving the horse at a walk, also disposes to breaking off wind. The most prompt method of releasing the gas is to puncture the flank with a trocar and canula (see PLEurisr, page $f \$ f$ ), a practice of comparatively recent years, as veterinary surgeons had an exaggerated fear of peritonitis following. If the instrument be sterilised by boiling, or other means, there is scarcely any risk. The gas rushes out and the belly goes down like a pricked balloon; immediate case being c sperieneed. Medicinal agents calculated to decompose the gas already present and prevent 
the elimination of more are to be chosen. Among those best suited for the purpose are aromatic spirit of ammonia (sal volatile), carbonate of ammonia, ginger, cardamoms, and other aromatics which assist to restore the contractile power of the orer-distended gut. Linseed or olive oil has the effect of masking gases and of preventing their development, and many cases of colic are cured with no other treatment. Sweet spirit of nitre or tincture of ginger are better given with oil than ammoniacal preparations, as the latter, to some extent, saponify the oil. It is not possible in all cases to say what the composition of the gases may be, but carbonic acid and sulphuretted hydrogen predomirate, the latter being easily recognised in the flatus. Small doses of carbolic acid, as fifty to one hundred drops in linseed oil, or a dram of chlorinated lime (so-called chloride of lime) in a pint of water, form suitable draughts where decomposition is manifest. Turpentine and laudanum given with linseed or olive oil have also been found beneficial. A very helpful performance is that known as back-raking, and proviously referred to (page 493). The oiled hand should be inserted in the rectum at intervals, both to remove accumulations of solid matter, and to aid the escape of gases during its artificia] distension. If death does not take place from rupture of the bowel or of the diaphragm (midriff, an abatement of the symptoms and recovery is usual, and great care must be taken in diet for a few days, small meals of easily digested food only being given until tone has been restored to the parts affected.

\section{Constipation}

When the undigested remains of the food are unduly retained, are too hard, or expelled with difficulty, we describe the condition as constipaticn.

Camses.-In the new-born foal, accumulations of meconium plugging the rectum, and needing to be removed by an oiled finger or soap enema. In working horses, continued dry fodder and insufficient attention to mashing with bran or other laxatives at stated intervals. In forest ponies and other horses seeking a living upon rough, poor pasture, the consumption of much innutritious woody fibre. Besides these common causes, there are animals whose secretion of bile and other digestive fluids is imperfect, and either constipation or diarrhoea is habitual.
The symptoms of straining will attract the attention of the most careless, but a groom who is worth his salt will observe the state of the evacuations daily, and if disposed to be small in size, hard, or having a surface at all glazed, will give laxative foods before any greater constipation follows. The behaviour of the young foal is somewhat different, for even the act of defecation has to be learned, and he does not know how best to posture for the purpose, but arches his back and strains in a way that leads the inexperienced in such matters to think that he is unable to pass urine.

Treatment.-This will be modified to suit the case; the young foal as already suggested, by mechanical relief, the corn-fed, sluggish-livered horse by an aloetic ball, and the habitually dry and inoperative with linseed oil over the food, and by small and frequent doses of sulphate of magnesium (Epsom salts) in the drinking water, or mixed with the manger food. It is important in all cases of constipation to trace the cause and remove it, rather than have resort to medicines which after a while fail of thcir purpose unless increased in quantity. The debility, or loss of contractile power, in the bowels of old horses, is often best treated by a course of nux vomica and gentian or calumba, to restore function.

\section{Diarrhoea}

Should not be considered as a disease in itself, to be stopped as one would staunch blood or plug a leak in a boat, but, as Professor Axe say"s, as "the expression of an irritable condition of the alinentary canal, sometimes resulting from an excess or deficiency or impaired quality of one or other of the digestive secretions." It is often Nature's plan of ridding the canal of materials prejudicial to the animal's welfare, as when colts scour on unsuitable food or cow's milk when left orphans, or are too early weaned and compelled by hunger to take more solid food than their digestive organs can deal with. Nature then sets up diarrhoea as a curative measure, and the good practitioner takes the hint and assists with a small warm dose of castor oil, after which he selects remedies calculated to soothe irritated membranes and restore them to health. Of these bismuth and chalk, and opium. catechu, kino and alum, are drugs with a reputtation. Some horses scour from nerrous excitability. Some of the most famous trotters have had this disability, and many horses famous for 


\section{DISEASES OF THE DIGESTIVE SYSTEM}

nothing else will begin to purge as soon as the harness is put on them, continuing throughout a journey and needing intervals of two or more days before they can be used again with safety. The causes of diarrhoea, then, being so many and diverse, no single line of treatment can be advised but a careful inquiry into all likely causes and their removal.

\section{Super-purgation}

This is quite distinct from diarrhoe, which has already been considered. It is an artificially induced diarrhoea by the administration of too much aperient medicine. It most often occurs by giving a second aloetic ball too soon after the failure to opcrate on the part of one previously administered. When a "physic" ball is given on top of dry foorl, and without any preparation in the way of bran mashes, its action is often delayed, but it is quite unsafe to give another within a week, lest superpurgation should be set up. The symptoms need not be described beyond saying that the purging is more severe than in a natura! diarrhcea, and that pain and collapse and a fatal termination are not by any means a rare sequel. It will sometimes happen, when the purging ceases on account of emptiness, that fever in the feet will follow (see Congestion of the Lungs, page 480, and reference to Metastasis, page +80).

Treatment.-The exhaustion, loss of temperature, and running down of the pulse, indicate the need of surface warmth being maintained by clothing, hoods, bandages, and hand wisping, pulling the ears, and the administration of stimulants. A quarter pint of brandy beaten up with eggs and milk and horned down may give a turn to a bad case if taken in time. Chlorodyne, with further small quantities of alcohol, should be given to sustain the animal, and when he has rallied from the worst point of threatened collapse he should be offered boiled rice with white of egg in it, cornflour and arrowroot, and from such simple astringents pass on by degrees to a normal diet. A good deal of time must be allowed before asking a horse to work which has suffered from super-purgation.

\section{Dysentery}

This disease differs from those purged conditions of the bowels previously described in that the lining nembrane undergoes a destructive inflammation, with general illness or constitutional disturbance, It has some resemblance to typhoid in the human subject. and will probably be traced to an organism of similar type, if not infective, in the sense of being communicated from one animal to another. It may follow on other bowel troubles, and is noticed when the drinking water is bad from the presence of decaying animal matter, and where factorics discharge waste into streams.

The symptoms at first resemble diarrhos, but remain and grow worse, and are relected in the animal's condition. Hide-bound, wasting of flesh, colicky pains, a dejected countenance, an irritable pulse and indifference to food, the passing of jelly-like masses of blood-stained mucus and shreds of membrane are common, and long bands or easts of howel mucus come away and are mistaken for worms. The smell of the evacuations is well nigh intolerable to any undisciplined nose. Thirst, exhaustion, increasing pains, and collapse, with temperature subnormal, indicate the end. It is generally a long-drawn agony, lasting over weeks, and therein differing from all other bowel affections in horses, which conmonly terminate fatally in a short time unless restored to health.

Treatment.-Not very much is to be looked for from the administration of drugs. If a specific organism had been identified as the cause, a phagocyte might be bred to fight it. At present we know not what we are trying to neutralise, and can only ameliorate symptoms. Most hope is to be found in good hygienic conditions, such foods as have been suggested for cases of diarrhoa and super-purgation, and the use of the astringent and anodyne remedies which are found to alleviate the acute conditions.

\section{Enteritis}

Inflammation of the bowcls. This is the most latal of all the bowel troubles of the horse, and affects either the large or small bowel -frequently both. The large intestine is its most frequent situation, commencing in the lining membrane and extending to the other tissues of which the bowel is composed.

Causes.-Very many have been suggested, but the most careful investigations have failed to account for so many cases in the common experience of veterinary surgeons that we can only regard them as speculations with a degree 
of probability, or perhaps as contributory or favouring the elimination of a toxin or the production of bacilli. Colic, impaction of the bowels, swimming when heated, sudden changes of temperature, cxhaustion after hunting or excessive labour, these and other exciting causes have been suggested as possible.

Symptoms.-It is probable that fewer fatal cases would occur if the symptoms did not resemble a mild attack of colic, and to some extent disarm the suspicions of the groom, who postpones sending for the veterinary surgeon, whose services should be sought immediately in a disease so serious. There will have been rigors or slight shiverings, with some standing up of the coat, although it may not have been observed. Loss of appetite is succeeded by depression of spirits, accelerated breathing, small evacuations of dung, and a pulse small and wiry and quite different from the pulse of colic, which is only quickened during the paroxysms of pain. In this disease the membranc of the eye and nostril is reddened, the little vessels standing out and showing quite a different state of things from that of colic, where these febrile symptoms are not present at first, nor is the rise of temperature that which charactcrises enteritis. The hot and clammy mouth in itsclf distinguishes it from colic, although a peculiar condition of the belly sometimes deceives the tyro. It is not distended or blown out as in the flatulent colic described elsewhere, but is flattened from below and pushed outwards. A variable period of extreme depression and languor and refusal of all food is followed in most, but not all, cases by stamping and pawing the ground, and looking round as in spasmodic colic, but there are no intervals of ease, or restoration to a cheerful countenance. Despitc the high tempcrature persistently maintained, and evidence of thirst found in the sticky mouth, the animal does not drink; but animals in a state of fever do not drinli copiously like men. Throughout the illness the patient will often lie down, but it is with caution, and unlike the passionate abandonment which is seen in spasmodic colic, and the attitude of extreme extension described in connection with flatulent colic is not adopted in enteritis. "I am very ill and in much pain," the animal seems to say, and only when the stage of delirium is reached does he throw himself down or bccome violent. He is then near the end. Hot and cold patches of skin, cold ears, legs alternately cold, and finally imparting to the touch a sensation of being dead-not such coldness as exposure or other causes can bring about, but a deathlike sensation. With ears lopping and a hopeless stare which sees nothing, the trembling animal finally staggers and falls, death putting an end to its sufferings.

Treatment.-Although the proportion of fatal cases is so great there is sufficient encouragement in the number of recoveries to cause us to persevere in treatment while any hope remains. The application of warm compresses (see PLEURISY, page $4_{4}$ ) to the belly, the administration of bold doses of opium and belladonna, or of morphine by the hypodermic syringe, control the pain, and give the patient a better chance of weathering the storm. Some vetcrinary surgeons give half an ounce of calomel with an ounce of opium, believing that the calomel does not in this case act as a purgative, but, conjoined with opium, has a specially sedative effect, and later on prevents obstinate constipation. Warm glycerine per rectum is soothing and gently laxative. Doctors and nurses both have often stumbled over the continued constipation, and in convalescents have caused a fatal relapse by giving an aperient. It is better to wait for the natural peristaltic movements of the bowels to come back than to give anything that excites them. Bread and milk and other soft foods should be offered in small quantities, and time allowed for the invalid to be fully restored to his normal condition before calling upon him to do anything.

\section{Rupture of the Intestine or Broken Bowel}

The term rupture here is not that commonly understood by persons who describe hernia in their own persons as rupture, but means broken, burst, or rent, as was said of ruptured stomacls (see page 495). The causes are much the same -namely, distension by gas, by habitual overloading, by chronic disease, and by falls and outward violence. If not previously weakened by disease, the bowel is capable of great strain without a rent resulting-the form in which rupture all but invariably occurs.

The giving way or rupture of the bowel is ccrtainly fatal, and our interest in it ceases if known to exist, but herc is the difficulty, even with the most experienced practitioners. 
The symploms are not definite; there is nothing to enable us to differentiate between rupture of bowel, of miclriff, or of stomach with certainty, although there are a number of signs which, taken together, point to the one or the other. The rent may come on suddenly, as when a horse with full stomach makes a supreme effort to start a heavy load uphill, or it may follow on colic, impaction, or a fall. When it occurs suddenly and from strain or concussion from without, there are signs of extreme anxietyan expression of countenance which men quite ignorant of surgery and medicine know and rightly describe as "marked for death." It is a peculiar haggard look, impossible to describe, but denoting any fatal breach of a vital organ and, therefore, distinguishable from the mere cxpression of pain as seen in its acutest form in spasmodic colic. If it follows on a bout of colic of either variety. the exact moment when the rent takes place cannot be told ; indeed, there is often a giving way stitch by stitch, so to speak, as cvidenced by post-mortem examination; therc are to be seen, also, partial breaches which have healed, for it is possible for the outer envelope to break without a fatal termination, so long as the contents of the bovel never escape (see RuPTURE OF THE Liver, page 505). Rupture of the bowel is distinguished from mere colic by the continuity of the pain, by the pulse running down and failing to respond to stimulants. The subject of this accident is more likely to display resignation to his fate than to be violent, and to remain on his feet until he drops and dies. This period of calm has often deceived the novice, who reports the patient as "much better, only that he won't eat and doesn't take much notice." In a few cases delirium comes on before the animal succumbs.

\section{Obstruction of the Bowels}

Besides those causes which interfere with the proper functions of the bowcls alrcady described, there are to be reckoned twists during spasm, concretions or balls which form in the canal, and stones built up on a nucleus and referred to in another place. The symptoms are not distinguishable from those of acute and persistent colic in its worst forms, and a twist is always in the mind of the ret. when colic does not yield to treatment (see Colic, page 496). The reader who has perused the article on impaction and distension of the stomach, etc., will understand that there are many causes of obstruction of the bowcls which are capable of removal, and it is, therefore, advisable to treat all obstructions as hopeful until any dung ccases to be passed, and the running-down pulse and indications of collapse described in conncetion with ruptured stomach and bowel place the case beyond hope. Some owners will hesitate to slaughter cven then, as "while there is life" there is said to be "hope," and the vet. will not urge slaughter lest the owner might afterwards think that a sporting chance was thrown away.

Treatment.-Consists in giving laxative medicines and frequent injections per rectum, of salt dissolved in tepid water, and mixed with olive or linseed oil, altermated by introducing neat glycerine. Some dread of aloes was formerly held, but where one horse is killed by too early resort to a bold dose of this drug, a dozen probably die for need of it. Frequent small doses of linseed oil, or of sulphate of magnesium in large volumes of water, are also calculated to remove obstructions. Pain is controlled by chlorodyne, laudanum, and other anodynes as advised in colic (see page 497). When an obstruction has been successfully treated, a careful diet table should be adopted, and the animal's evacutions habitually watched.

\section{Calculi, or Stones and Concretions}

Incidentally, we have referred to stoncs and concretions as causes of colic, obstruction, and other intestinal troubles. They often exist without being suspected and pass out in considerable numbers as the result of an aloetic purge. The hard ones are called "stones" quite fairly, for they are not less tough than many kinds of stone. When sawn through they show a nucleusperhaps of nothing harder than an oat-hair or little bit of grit, or maybe a splinter of wood, a broken nail, or other object in itself hard. Around this a deposit takes place of ammonio-phosphate of magnesium, phosphate of lime, animal matter, soluble salts, fatty substances, etc., and show in concentric circles like a section of a trce of the exogenous division.

These stoncs take the shape of the bowel as they repose in saculations of it, and presumably remain for long periods making steady growth until some disturbance occurs from worms or ferments in the food when their shifting is liable 
to culanger the bearer. It is always in the large gut that they are discovered, and with facets quite polished from contact when a number exist together, as is more usual than to find a single large stone. They sometimes attain to enormous proportions and weigh over half a hundredweight. The horses of millers and bakers were more frequently the victims of stones in days prior to the use of improved machinery by which all that is forcign is now removed from offal and meals. Millers' horses are quite commonly more sleek than their neighbours, and presumably through fecling more upon meals and bran, and "sweepings," which might find their way to the pigtub more properly. Fragments of metal are now scldom found in the forage of good establishments, and calculi are decreasingly rare in such stables.

Concretions of great size and often playing the same fatal role as stones (calculi) are distinguished by their external rough and irregular surfaces, by being more nearly spherical, and relatirely soft. They consist of vegetable and carthy matter agglomerated together, and differ in density as well as composition. When mixed concretions are soft and of but recent formation, they are known as dung balls, and contain the same salts as calculi, only loosely held together with chaff, straw, husks of oats, etc. They are much darker in colour than stones or than oathair concretions, which more nearly resemble stoncs, in many cases by having a smooth onter coating of the same material, but easily distinguished by their lightness and softness when cut through. They are composed for the most part of the fine downy hairs that invest the oat kernels, and not the beards as commonly stated. Why these things sliould form in some horses and not in others is not known, nor is there any breed or type predisposed to them, or, on the other hand, immune or exempt. When they become wedged in the bowel and cause impaction or obstruction, a fatal ending is frequent, but there is abundant evidence of their dislodgment in numerous instances, great numbers being passed when the treatment recommended for obstruction has been successfully carried out.

\section{Inversion of the Rectum, or Eversion of the Rectum}

This alarming accident occurs as the result of straining, some portion of the bowel, from a few inches to two feet or more, being cxtruded with the mucous lining on the outside. In the violence of labour pains this happens to mares, but is not unknown to other horses when enfeebled by age or habitual constipation (see Coxstipatios, page 498), or in the agony of colic and obstruction of some other portion of the gut, or inability to pass urine. The great mass sometimes everted offers cvery opportunity of injury in the excitement and fear which the accident induces, and while the animal is going round the box. It first of a pink colour, it rapidly passes to a deep red or purple, by engorgement of the vessels, much swelling takes place, and the gut later appears black from infiltration under the membrane.

Treatment.-If the accident is observed, the animal may be secured and prevented from doing irremediable damage; the extruded gut should be carefully bathed with a warm antiseptic, and with a hand similarly prepared be reposed with as little delay as possible. If, as frequently happens, the gut has come out in the night and suffered in the manner referred to above, it cannot be replaced in its engorged state, and it should be pricked at several points with a clean lancet to permit some of the serum to escape and reduce the volume to be dealt with. A flannel soaked in a warm disinfectant may then be used as a gentlc compress before attempting to return the gut with the hand. This is an operation less difficult than it appears, provided the individual is neither fearful nor rash, and the subject not vicious. The hand, anointed with carbolised oil, is to be pushed slowly but continuously, and with moderate force, until the object is attained. Getting it back is not so difficult as kecping it there when returned. During the effort to repose it, the animal invariably strains against the operator, and adds to his difficulties, and, when it is returned, immediately makes expulsive efforts. The hand should be retained within the rectum for a short time, the tail held down forcibly, and as soon as possible a large dose of morphia subcutancously injected, or, failing such appliances as hypodermic syringes, a bold dose given by the mouth. The patient shoukl not be left a moment for at least twclve hours, and only small quantities of laxative food, as bran mashes or carrots, allowed until there 
is reason to suppose that the danger of a recurrence is past.

\section{Diseases of the Liver}

The artificial lives of stabled horses and the iabitual stimulation with highly nitrogenous food with a view to obtaining the greatest amount of muscular force, give rise to liver troubles unknown to the grass-fed animal, and is of less frequent occurrence among the animals cmployed in agriculture and more generally kept under natural conditions.

Congestion of the Liver.-A superabundance of blood in the vessels of the organ is known as congestion. More than is needed for its own nutrition and for bile formation constitutes excess.

Causes.-The most general are too high living, impure air in the stable, and, in the case of horses kept for pleasure, too long spells of idleness without corresponding regulation of the diet. Diseases of the heart and lungs also induce congestion of the liver by interrupting the outflow of the blood. As a result of strangles and influenza we often meet with liver congestion.

Symptoms.-These are not so marked in mild cases as to make diagnosis easy to the horseman, but he is likely to have observed certain signs of indigestion by which the true cause may be sought. These are impaired appetite, sour breath furred tongue, constipation or diarrhoa, accompanied by a very unpleasant smell. In more severe cascs the visible membranes undergo a yellow discoloration akin to jaundice. There may be tenderness on the right side when the knuckles are pressed against the animal, and flatulence distending the belly, or frequently expelled as flatus from the rectum. Lameness of the right fore limb has apparently becn due in some cases to liver disturbance.

Treatment.-Better results are obtained from the continuous administration of small doses of salines than from a ball of calomel and aloes, which is sometimes prescribed in the more urgent cases, for horses whose owners are too anxious to get them to work again. One to three ounces of sulphate of magnesium and an ounce of bicarbonate of potash daily in the drinking water, or mixed with food, is found a useful combination, and this may be changed for sulphate of soda a little later. On no account should linseed, croton, or other oily aperients be given. The acute cases which give signs of tenderness over the region of the liver may with advantage receive a dressing of mustard and water, or a strong limiment to produce counter-irritation. Surface warmth should be kept up by clothing, and the food should consist of green-meat and carrots, bran and hay, with very little corn, and no linseed or fatty foods. Convalescents may be heiped by daily doses of nux romica.

Jaundice, Yellows, Icterus.-An accumulation of biliary matter in the blood gives rise to the yellow staining of the membranes which is called by the above names.

Causes.-These are not very clearly understood, as many disorganised livers from struc. tural changes, tumours, parasitism, and other interferences with its functions do not result in staining with bile, and, on the other hand, comparatively slight disturbances may give rise to jaundice.

Symptoms.-The prominent one of yellowness is well known, but may be easily overlooked if the horse-keeper has not learned to turn up the eyelid and note the colour whenever anything is amiss. The urine, too, is often stained a saffron colour with the passing of bile products. The diversion of bile into wrong channels leaves the dung pale and ill-smelling, as it is one of the functions of bile in the intestinal canal to act as an antiseptic as well as to stimulate the peristaltic movements by which the ingesta is carried on through its course. The evacuations are always pale, often coated with mucus, and at intervals watery or thin. Headache, shown by hanging the head down : nausea, by curling the lip and indisposition to feed; a mouth dry and clanmy, bad breath, harsh feeling of the skin, and "staring" coat are among the general symptoms noted in any but light cases of jaundice.

Treatment.-An aloetic ball, followed by salines, as adrised for congestion of the liver. The absence of biliary fluid and its ill consequences may in a measure be supplied by mixing ox gall with dry linseed meal, and giving in the form of balls until the natural secretion has been induced to enter the canal again. Small doses of nitre and gentian with calumba, or dilute 
mincral acids with gentian, particularly phosphoric and nitro-hydrochloric acids, prove beneficial.

Inflammation of the Liver, Hepatitis.-Acute inflammation of the liver is rare outside the tropical beit and in those regions is thought to be due to some infective organism similar to ycllow fever in man, which is introduced by the bite of an infected mosquito. The cases which occur in our own country are due to falls and other forms of violence, exception being made in the case of foals whose livers suffer acute infective inflammation through the open navel. Abscesses are disposed to form as a result of septic poisoning.

Symptoms.-The symptoms described in con nection with congestion of the liver are aggravated in the case of acute inflammation. A very dark coloured, offensive urine is passed, which precipitates a dirty deposit on cooling.

The causes are generally remote rather than lirect, such as the infection by ulcerated bowels or stomach

Treament.-A blister over the right side, frequent administration of saline aperients and ipecacuantia, which promotes the action of the skin and removal of bile from the liver. A period of abstinence from all food for a day and night is advised, after which a soft but restricted diet only should be allowed.

Chronic Inflammation of the Liver, Cirrhosis. - I his is the liver trouble most common and only diagnosed with certainty when it is too late -namely, when the animal is examined after deatl. We may make a very good guess as to cirrhosis during life, as the sufferer has indigestion which we fail to cure, or only temporarily relieve. Constipation at times and diarrhca at others, with many of those symptoms described in connection with congestion of the liver and jaundice (see page 503), indicate functional derangement, without showing us the actual degeneration which luas been going on, as in a drunkard's liver, for this is the special discase of the organ which afflicts the rictims of habitual alcoholic cxcess, and is known as "gin liver." Its true nature will be understood when the reader is reminded that the liver cells whose office is the making of bile are held together by a network of connective tissue, and that this latter takes to growing thicker and thicker, until it squeczes out of existence the true liver substance; it follows, then, that the liver may be cnormously cnlarged and at the same time less efficient. The fact that horses get cirrhosis is proof enough that alcoholism is not the only cause of it in human beings, as horses do not often acquire the alcohol habit, although the writer once had a pony that would not pass a particular public-house, wherc she had been accustomed to take a glass of beer in her teetl, and, raising it slowly, drain the last drop and "hand" the glass back. She always did a sprint. too, on the strength of that "liquor up." Out of respect to her memory, it should be said that she formerly belonged to a sporting publican who had enabled her to acquire the taste for excisable liquors. In horses the disease may generally be attributed to long indulgence in rich food and lack of work.

Treatment.-As with men, so with horses, life may be sustained and work carried on with but the remnants of a liver in action, and as we cannot gauge the extent of the degeneration, we use remedies and think we prolong the useful life of the patient. These are salines (see Congestion and JAUNDICE, page 503), followed by mineral acids and regetable tonics, and, if the season of the year permits, the Naturc cure ("Dr. Green" and "Dr. Time") often does wonders for horses with cirrhotic livers, apparently arresting the degenerative process, or at least retarding it, while giving special activity to the unimpaired portion, so that they come up again from grass greatly improved in health and able to resume work.

Fatty Liver.-There is always fat in the liver, but the discase to which we refer is an infiltration of fat in cxcessive quantity, or else an actual conversion of tissue into fat (fatty degeneration). The distinction is important, as will be seen in conncction with the heart and other organs when circulatory diseases are considered. Fatty liver is not the result of hard work and poor fare. but of idleness, indulgence in high living, and the use of condiments. Fatty liver often precedes rupture of the organ. There are no early diagnostic symptoms of a positive kind, but a plethoric condition with a disposition to flatulence, distension of the abdomen. and the evacuation 
of pale-coloured fæces are suggestive of this condition, as of those other disorders previously referred to, and the same depletive measures are recommended if this infiltration with fat is suspected.

Rupture of the Liver.-I burst or ruptured liver is a frequent cause of death in pampered animals (see FAtTr LIVER, page 504), and the symptoms at first are those of colic (see page 496), followed by collapse, blanching of the membranes of the eye and nostril, sighing, trembling, cold extremities, perhaps patches of sweat about the body, a "running down" or imperceptible pulse, and some degree of tympany or distension of the belly. The facial expression of horses when the liver or intestine is ruptured is peculiarly painful and haggard, and persons with no acquaintance with disease in horses will often say that the animal is "marked for death" or "doomed to die," as this indescribable look is noted. When, however, a horse is eollapsing from a ruptured bowel there has gencrally been some previous pain and colic, heightened pulse and respiration, and in sympathy with these things a more or less injected or reddened mucous membrane, which has been often referred to in the veterinary section of this work as indicating fever and serves for a "com. plexion" in animals whose faces are hairy, but afford the expert quite as much information as the human physiognomy. In the case of sudden rupture of the liver while at work, the symptoms are those of internal hæmorrhage and deadly fear, such as we have mentioned. The patient usually tries to keep on his feet until he falls and dies. There are other cases, more nearly resembling colic, in which the capsule of the liver is not broken, and the hamorrhage is presently arrested and the breach repaired. Many such cases are treated as colic and recover, but on post-mortem examination show the scars resulting from former breaches in the substance of the organ. When the capsule itself is broken, the hæmorrhage into the abdominal cavity is always fatal.

Treatment.-If the symptoms of internal bleeding are associated with yellow tinged membranes, and the liver is suspected, it may be worth trying to arrest the hæmorrhage by dram doses of gallic acid, or half drams of sugar of lead, or ounce doses of spirit of turpentine or of tincture of iron.

\section{Dropsy, Abdominal Ascites}

An accumulation of the watery portion of the blood or of straw-coloured fluid within the abdominal cavity is known as dropsy or ascites, and is found in animals of all ages and arising from various eauses. In the young, on poor pastures and exposed to inclement winters, tlicre is a disproportion between the ituid and solit elements in the herbage, and dropsy may then be regarded as a disease of poverty. A so-callerl pot-bellied colt may be expected to recover on good food. and the excess of fluid will be absorbed. The constant pressurc of the gravid uterus of brood mares upon the great reins is another cause of dropsy of the abdomen, which, if it does not wholly disappear with a cessation from foal-bearing, is gencrally so decreased as to have no ill effect, albeit the perfect "figure," as ladies would call it, is never again resumed. More serious, and often fatal, is the filling up of the belly with fluid as the consequence of heart disease, of liver degencration, or obstruction and interference with the portal circulation. Derangements of the liver account for much the largest proportion of cases of abdominal dropsy in horses. other than those already mentioned.

The symptoms do not at first differ from ordinary distension by bulky food, but are followed by loss of animation, a staring coat, hidebound, weakness, and wasting of the loin and neck muscles, with a more and more pendulous and enlarged belly. Palpitation of the heart is noticeable when weakness follows on dropsy, and a startled colt will have it so badly that the heart can be heard at some distance for a few seconds. All the symptoms of indigestion may be present, and the reader is more particularly referred to those mentioned in connection with liver diseases (see preceeding pages). Splashing may be heard when the ear is pressed against the flank, and tapping with the knuckles fails to yield the ordinary sounds.

Treatment.- When merely due to porerty, c course of good feednng and tonies, as iron and gentian in dram and four-dram doses respectively, will do much to restore the patient. If the liver is suspect, calomel and aloes may be given first and followed up by salines (see Coxgestox or 
THE LIVER, page 503). Above all, it is necessary to place the animal under good hygienic conditions, and stabled horses will gain by turning out to grass. Even those with degenerate livers will for a time profit by a return to natural life in the field.

\section{Spasm of the Diaphragm}

The expansion of muscle and tendinous material which separates the chest cavity from that of the abdomen, and called by anatomists by the
Foals are liable to what is called congenital hernia, when a knuckle of intestine protrudes through the umbilical opening, or into the scrotum. Adults may suffer from accidental or acquired hernia as the result of straining to pull a load, or in the case of hunters when jumping. Simple ruptures or extrusions may often be reposed, but the strangulated kind are commonly fatal. These occur within the abdomen as the result of spasmodic colic (see Colic, page 496), or from external injury; the gut may protrude and by swelling become irreplaceable. The latter form of rupture is a common result of goring by bullocks when horned stock are turned out with horses.

Treatment.-The veterinary surgeon should be asked to treat such subjects, if possible, but the circumstances in which many horse owners are placed render first aid essential, or the patient will acquire fatal lesions before professional aid can be obtained.

Exomphalus or umbilical hernia is not usually an urgent matter, and often disappears spon- above name, is subject to spasm, which shakes the entire animal, and is commonly mistaken for violent palpitation of the heart. It may easily be distinguished by the pulse, there being no common time, as is necessarily the case when the heart is irregular. It seems to be due to some disturbance in the current of the pneumogastric nerve, and is quickly subdued by the administration of alcoholic stimulants, as a gill of whisky in a pint or more of water.

\section{Hernia or Rupture}

Surgeons speak of any protrusion of an organ or part of it from its proper place as hernia, and they use the word rupture to meas a rent or breach, as when the liver is ruptured (rent), or the bowel broken by distension. The lay public more often understands the term rupture to apply to such things as protrusions of the gut. taneously about weaning time, when the small intestine leaves its position on the floor of the abdomen and passes to its permanent place in the flank. For this reason it is well to wait, and if operation is necessary, any time during the first year will be soon enough.

Treatment.-The application of a blister often effects a cure by the swelling of the adjacent parts causing a pressure in the least line of resistance, by which the soft bowel is pressed into the cavity. Some plastic material is thrown out. and this forms a binding or plug by which the gut is permanently retained inside the belly. If this fails it may be necessary to cast the foal upon his back (see MIEthods of Restraint, Chapter XIX.), and put on a clamp. The animal is fasted by way of preparation, and it is found easy then to push back the soft parts within, while taking up a bunch of skin and applying the wooden 


\section{DISEASES OF THE DIGESTIVE SYSTEM}

or metal clans with such pressure as will kecp back the gut while exciting sufficient inflammatory action in the parts above the instrument as will produce plastic matter and seal the opening; the pinched-up-skin will presently slough off, and a strong scar or dense fibrous tissue result, which adds strength to the binding material produced within. It looks a clumsy performance, but is really a very good operation, needing judgment as to the degree of pressure to be put on, as too little will fail of its purpose, and too much may slough off the skin before the desired effect has been gained, and then the bowel will escape and a fatal result follow. Ranchers and others in out-of-the-way situations venture on these operations with a large amount of siccess and, of course, acquire the knowledge of how much "squeeze" to employ. Another plan is to run metal or wooklen skewers through the uplifted skin, and wind round a figure of eight of string, but the principle is the same.

Inguinal hernia, similar to the form from which men most often suffer, is comparatively rare in the horse, although stallions are not exempt.

Trealment.-Efforts should be made to release the imprisoned portion of gut. After unloading the rectum with a greased hand, the arm should be inserted until the hand can grasp more or less of the bowel under it, and gentle traction will not infrequently reduce the rupture. Failing this, the patient should be cast and chloroformed. With the animal placed on his back, the position favours the return of the gut. While one man presses upon it from the outside, the hand of the more experienced performer is employed within the rectum. The hand will reluce the amount of ingesta and release gas and thus facilitate the return of the escaped portion of bowel. If valuable time has been lost, these methods will not succeed, and the skin must be cut through and the connective tissucs, and the protruding bowel be pushed through the opening with gentle but firm and continuous pressure. The patient must he kept under the influence of chloroform for some time after the operation is complete. It is in the act of rising that most danger is feared, the disposition on the part of the gut to come out again being great. If antiseptics are cmployed throughout and stitches put into the skin with a good "hold," the case will probably go on well. Subsequent swelling outside is to be wel- comed as forming a pad and giving needed compression.

Hernia into the scrotum is treated by traction as recommended in inguinal hernia, but the disposition to return in old stallions gencrally necessitates castration, which is a permanent cure.

Ventral hernia. When the abdominal wall is rent from violence of any lind whatever, and the gut obtrudes, it is called ventral hernia. The majority of such cases are fatal, and if the animal is to be saved it will be by carly attention, first, to the securing of the patient and prevention of further injury by his struggles; next to the cleansing witl antiseptics in warm water; and thirdly, to the return of the bowel before inflammatory changes make it impossible or invite peritonitis. A sheet soaked in carbolised oil or witer or other suitable antiseptic sliould be placed round the body, while preparations are made for throwing the animal and getting him on his back. Chloroform will greatly aid the operator by reducing the straining against him. In its absence he may still attempt the reposition of the gut, keeping his finger steadily pressing the bowel back, bit by bit, avoiding injuring it and never yielding to the outward expulsive cfforts which are involuntary on the part of the poor beast. A surgeon will sometimes take the risk of enlarging the orifice, but if it is possible to return the viscus without this it should be done.

Once returned, there will be leisure to review the situation and consider how best to suture up the wound and bind and bandage it over, before the horse is allowed to rise. The longer he is kept down the better, as subsequent swelling will be in favour of retention of the gut. Where a large volume has escaped, or any injury to the gut has taken place, the prospects of recovery are very small, the animal almost always succumbing to peritonitis or other complications.

From the sketch we have given of discases and accidents which interfere with digestion, it will be seen that there are many causes, and these may be in the mouth, or in any of the organs concerned in the complicated process of conversion of food into living animal tissues.

\section{Irregularities of the Teeth and their Diseases}

In Chapter XX. the reader will see how the changes in the teeth which take place with age 
enable the horseman to judge of the youth or adranced period of lite to which the animal has attained, and in this section of the work therefore it will only be necessary to refer to some of the diseases and equine disabilities which accompany them.

Shedding of Molars.-Fcbrile disturbances occur during the shedding of the grinders or molar teeth, especially between the second and third year, and there are sometimes difficulties in feeding, owing to the temporary tooth or the crown of it being wedged and sticking up above the level of the others, thereby making it wellnigh impossible to

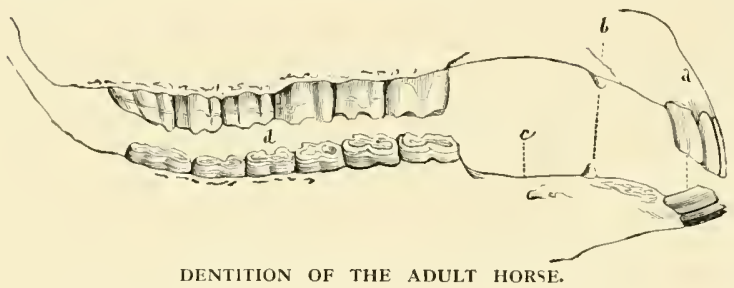

(a) 1ncisors. (b) Tushes, or canines. (c) Interval called the bar.

(d) Molars. flamed, and the lancet may be employed to make a few pricks in the most prominent and spongy places, but the horsc-owner should set his face against the barbarous and illegal practice of "burning the lampas," as practised by ignorant farriers. Broken teeth need to be extracted, or the fissure admits food which ferments and causes disease of the alveolus, or socket, and this is the common origin of caries of the bone, giving rise to an offensive odour and when occurring in the upper jaw may lead to ozæna, the worst form of nasal gleet. The absence of a tooth in the upper jaw permits excessive growth of the corresponding tooth in the lower one, and cases have been known in which the growth of the latter has continticd until the bones of the face have been pierced. This continuous growth of the teeth is an important factor in maintaining them as grinding stones, and one that is not so generally known as it should be. Decayed teeth in horses are not so common as in their masters. The disease most often commences at the neck and through some of those putrid conditions of the gum alluded to already.

Parrot Mouth.-By this is meant the projection of the upper row of incisor tceth beyond the level of the lower ones. It is disfiguring and objectionable when exaggerated, as a horse so formed cannot graze properly, although he may feed well enough at the manger, using his lips for prehension and his grinders for the real work of mastication.

Crib Biting (see Stable Tricks and VicesChapter V.).- This practice has the cffect of wear ing down the tables of the incisor tecth and bevelling them in a manner which "gives away" the horse to the expert.

Wolves' Teeth.-These are small supernumcrary molars or pre-molars, supposed to be a reversion in part to the time when horses had seren molars.

These vestigial remains are credited witl causing horses to shy, and their removal is said to effect a cure. As they are quite uscless and easily extracted, they may well be removed in deference to the superstition of the attendant. the gums are not infrequently swollen and in- 


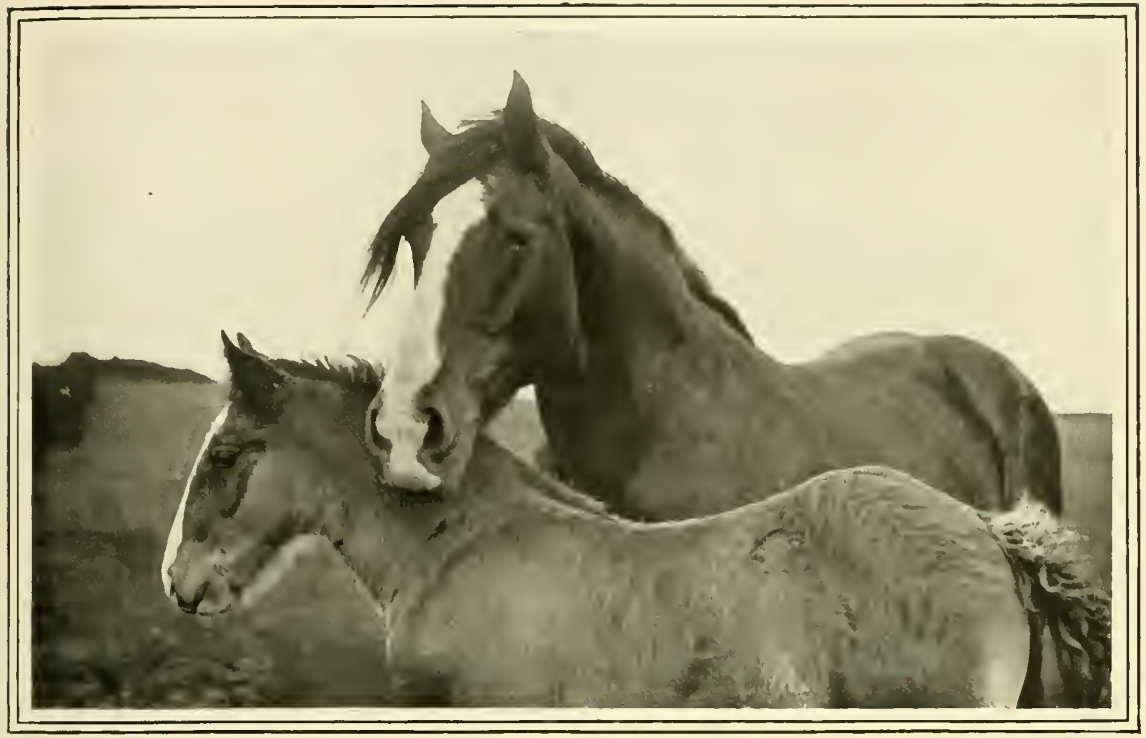

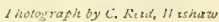

\section{CHAPTER IV}

\section{DISEASES OF THE URINARY AND GENITAL APPARATUS}

$\mathrm{I}^{1}$

$F$ we were to aceept the dictum of the average groom, we should credit the urinary organs with more than half the troubles to which horses are subject, for no sooner does an animal show pain or fail to thrive tlian his kidneys are suspected, or there is said to be "something wrong with his water" (see CoL1c, page 496).

As a matter of fact, urinary troubles are not very common, although the kidneys are frequently appealed to in efforts to relieve a variety of maladies. One reason of this is their willingness to act vicariously for the skin, and when the latter is chilled and fails to do its work, thick urine is often passed. In like manner, bilestained urine is caused by failure of the liver to perform its task, and again the kidneys are called upon to pass out waste products which should have been eliminated by other channels. Thick or discoloured urine does not indicate diseased kidney or bladder so often as their ability to aid other organs which have temporarily failed in their work. It is important for the horseowner to bear this in mind, as no other class of medicines is so much abused as diuretics or kidney stimulants, and the cause of thick urine should be sought and removed rather than medicines given to act directly upon emunctories already overtaxed.

Upon the efficient discharge of their function the health of the horse largely depends, the chief office of the kidneys being to carry away worn-out tissues. Urine differs greatly according to the food consumed, and may be healthy although thick and profuse in quantity when a horse is put on green-meat, or comparatively high-coloured and leaving a sediment on the stable floor when corn-fed. An excessive quantity voided at short intervals and colourless is much more indicative of discase than the other states which we have alluded to, and which concern the average groom and induce him to administer nitre, sulphur, resin, or other diuretics. The presence of albumen, 
of mucus, of casts of the uriniferous tubes, of pus, or of blood may indicate grave disorders.

\section{Diabetes, Polyuria, or excessive staling}

Popularly called diabetes, but not containing sugar, which constitutes true diabetes, an irritable condition of the kidneys, with an excessive amount of fluid of low specific gravity, is frequently met with in lrorses, and is accompanied with thirst, rapid loss of flesh, staring coat and general debility. It is often associated with indigestion and chilling of the surface of the body in freshlyclipped animals, but is more often traceable to some unsuitable food, which acts as a nerve irritant to the branches supplying these organs, such as hay that has been fired in the rick-mow-burnt, as it is called-" foxy" oats which have been badly harvested or kiln-dried, an excess of roots, or other improper feeding. In addition to the symptoms already mentioned, there are a weak pulse, small and frequent, a hidebound condition, the membranes are pale and the appetite impaired; the animal easily sweats and is quiclily tired with less than his usual task.

Treatment. - The so-called diuretics, or kidney stimulants, should on no account be given, but a small aloctic dose: a half to two-thirds of the amount usually prescribed as a purge, and followed up with daily doses of one dram of iodine crystals with the like amount of iodide of potassium for a few days, after which similar quantities of iodide of iron and half-drams of nux romica and quinine may be helpful. If rapid progress is not made, a change to half-ounce doses of dilnce nitro-hydrochloric acid and half pints of infusion of calumba may be tried. If the cause is removed and the animal given demulcent foods, such as linseed tea and the best oats scalded, witin broad bran, and placed under good hygienic conditions, he will in almost every case recover. Those animals which continue to waste away despite such treatment are generally found, after death, to have other complications.

\section{Bloody Urine or Hæmaturia}

It is not always possible to ascertain the cause or the exact seat of the mischief, but there are three principal ways of locating the trouble. If hemorrhage is from the kidney, the blood and urine are uniformly mixed. If from the blaclder, it romes last, by the final expulsive effort, blood being heavier than urine. If the canal leading from the bladder is the seat of mischief, the blood will come when the first portion is passed.

The causes are various, violence being the chicf, as from falls in the hunting-field or in the shafts. Calculi or stones in the kidney itself, in the bladder, or in the urethral canal, where they become lodged and lacerate the walls, form another cause, and in a few cases structural changes in the organs lead to hæmorrhage.

Treatment.-When due to falls, or other forms of violence, the loins may be poulticed with a pillow of steeped hops or bran, or, in the absence of such things, pulped turnips or mangels. WTarm enemata may be injected into the rectum, and contain a dram or more of extract of belladonna and five per cent. of glycerine in water. The bowels should be kept lax with linseed and bran mashes, carrots, or green-meat if in season, and absolute rest imposed. If the bleeding is the result of kidney disease, cold cloths applied to the loins and small doses of nux romica, as half drams of the powder, and like doses of gallic acid are advised. If caused by stones (calculi), a surgical operation is necessary, and this is quite beyond the amateur horse-doctor, who must be content to wait until a good surgeon is available. Sometimes, when a stone has passed down the canal, and the poor animal cannot pass urine except in dribbles, the horse-owner may fee! it in the penis from the outside, and if the situation seems desperate had better cut down npon it, choosing the upper surface so that urine will not subsequently prevent it from healing by constantly passing through the wound and irritating it. The smallest wound that will enable the operator to pass the stone through should be made, and the incision shonld be cut by a single stroke of the knife, held in one hand, while the suffering member is held by the other and the stone pressed against the surface to be incised. After any operation of the kind, only the smallest quantity of water should be allowed for a few days, but all food in the meantime may be supplied in a moist condition.

\section{Inflammation of the Kidneys (Nephritis)}

This is not such a frequent malady in the horse as his master, and for the reason that horses are all teetotallers and that alcoholism is the 


\section{DISEASES OF URINARY AND GENITAL APPARATUS 5II}

most frequent cause of kidney trouble. The chief causes in horses are exposure to inclement weather when heated, as when the clipped horse, made warm by fast work, stands still while my lady is shopping, or the hunter hangs around the covert side when a check occurs. It has also to be stated that cases of inflammation of the kidneys are brought about by the foolish practice of giving cantharides to wearied stallions or barren mares to provoke sexual appetite. The abuse of that class of remedies which promote the secretion of urine, and previously spoken of as diuretics, is also an occasional cause of inflammation. Cantharides (Spanish Fly) blisters are sometimes absorbed and cause kidney inflammation, and this is one of the reasons why it has given place to other agents (see BLISTJzs axd Blisterixg, Lamexess, etc., Chapter Xix.). Iares blistered during the period of cestrum are more susceptible than others.

The symptoms are frequent ineffectual attempts to urinate, or but very small quantities of highcoloured and scalding fluid escapes. The penis is frequently protruded and withdrawn, and the clitoris of the mare exposed as when at oestrum, and ineffectual posturing as if in expectation of passing water. Thick, muddy urine or stained with blood (see Bloody URINE, page 510), or containing pus, or broken-down tissues, is expelled when the effort is successful. Great tenderness over the loins is evinced when the hand is pressed upon the region, the pulse is quickened, and in the later stages of the disease the temperature is high, the mouth hot and clammy, the membranes much reddened and the facial expression pained and anxious.

Treafment is best commenced with a purgative of aloes, as this is found to make a diversion, as well as to reduce the temperature, relieve pressure and influence the character of the scalding urine. Opjum and belladomna in small but repeated doses (see TABLE of Doses, Chapter XXII.) tend to

relieve the acute pain, and large poultices over the loin afford comtort to the sufferer; as do enemata of beiladonna, glycerine and warm water, alternated with linseed tea strained free from seeds. Stallions and geldings may receive these enemata per rectum, as the anatomical arrangement permits of much soothing influence from such treatment. Bran as a mash with some linseed tea is the most suitable food. The poultices may, in certain unavoidable circumstances, be replaced by ammonia liniments, but no turpentine or Spanish fly should be employed, for the reason already given.

\section{Inflammation of the Bladder (Cystitis)}

The lining membrane is the usual structure affected, but it may extend to the other layers.

Causes.-The abuse of diuretic medicines, the administration of cantharides, or the absorption of that drug, or of turpentine when employed externally, the presence of stone (calculus), and urine long-retained, or obstructed. Mares may have inflammation of the bladder as a result of straining with a big fotus during parturition. Invasion from the kidney or contignous structures may cause it, and it has followed on influenza and other diseases.

The symptoms are much the same as in intlammation of the kidney (see page 510). In mares the vulva is everted by spasn, horses extrude and withdraw the penis frequently and straddle as if to micturate. A hand passed into the rectum and pressed against the bladder provokes pain, which is shown by the animal looking anxiously round at the flank. The urine is thick and perliaps blood-stained and contains detached mucus from the lining of the viscus. A small quick pulse, rapid shallow breathing, and lirick-red membranes mark the progress of the disease, and the countenance wears an anxious cxpression.

Treatment is directed to the reduction of pain, the alteration of the character of the urine in the first instance and restoration of function. Removal of the contents of the bladder by means of the catheter will be undertaken by the veterinary 
injections of warm soap and water, of glycerine and belladonna cxtract, etc., may be syringed into the bowel (see INFLAMMATION OF THE KIDNEYS, page $5 \mathrm{ro}$ ), and demulcent foods, as white of eggs beaten up with milk, and Jinsecd tea, given in small quantities and at short intervals. Warm poultices over the loin soothe the pain, and dram doses of extract of belladonna and opium by an inconsiderate person compelling an animal to continue his course when desirous of an opportunity to discharge the contents of the bladder. This lack of knowledge or "horse-mastership" in our raw levies in the South African war led to many losses. The young fellow from a big city would be cluttered up with loot and never realise that his horse's falterings were mute

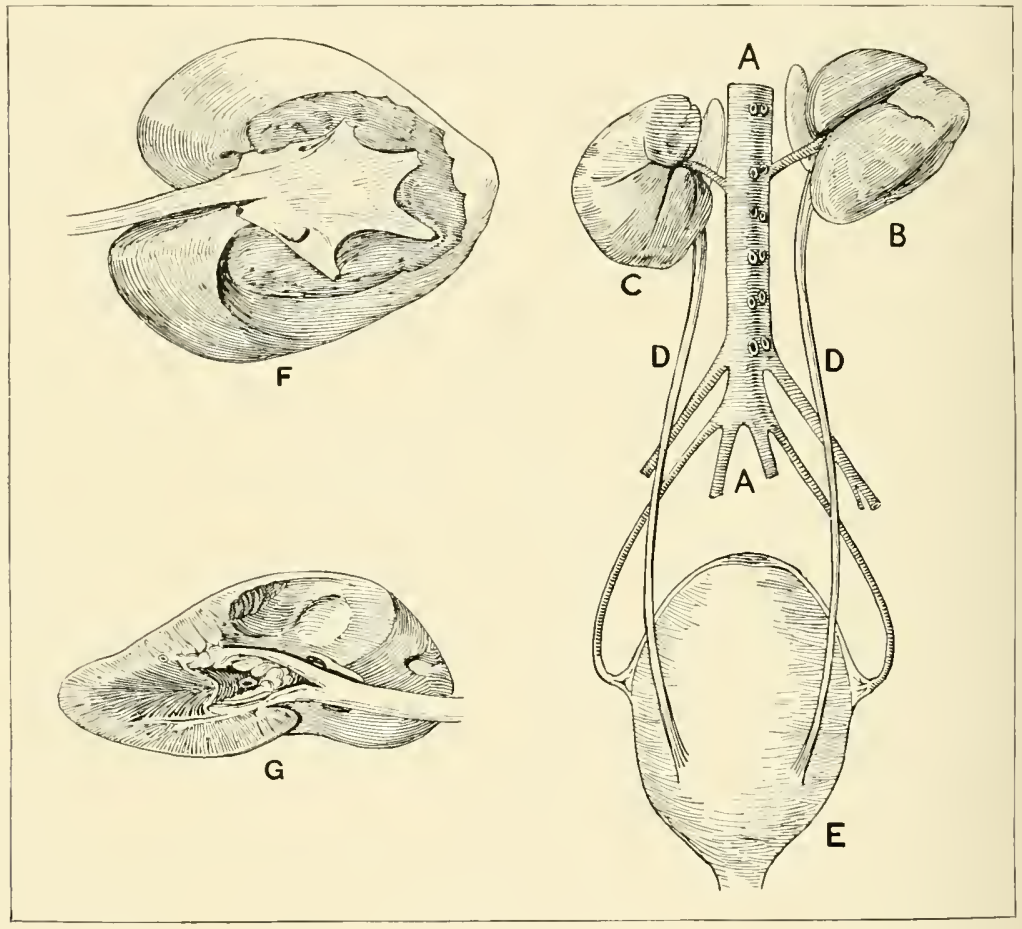

URINARY ORGANS.

A A. Abdominal aorta and brancbes. B. Right kidney. D D. Ureters. E. Bladder. F and G. Sections of right kidney.

may be given as balls or drenches during the acute stage. There is a disposition to a return of the malady in those horses which for any reason retain their water unduly.

\section{Retention of Urine}

Inability to pass water is a distressing condition, whether partial or complete, and one the horseowner should be ever on his guard against, as it is not infrequently caused, in the first instance, appeals to stop and stale, and finally, when the opportunity came, the poor beast could not relieve himself. Long retention causes paralysis of the muscular coat of the bladder, and it becomes necessary to pass a catheter and draw off the fluid. Enlargements of the prostate gland in old stallions and the descent of small stones into the canal are other causes of retention, and spasm of the ncck of the bladder in connection with foaling, and where there has been difficult parturition, is another. 
The symptoms of retention are those of other urine troubles already described-namely, straddling to urinate and inability to do so ; grunting or groaning while making the effort ; some arching of the back and leaking involuntarily of a few drops at a time rather than successful clischarge of fluid. As this straining sometimes occurs when an injured bladder is empty, it may be well to unload the rectum and pass in a greased hand, when the distended organ can be distinctly felt if retention is the trouble.

Treatment.-In the absence of a cathcter and the knowledge of how to use it if at hand, a gentle pressure may be exerted upon the bladder by the hand within the rectum, as the resistance is often but small, and such pressure may succed in starting the stream. Pain and excitement should be kept down, and for this purpose a dose of two to four drams of camphor may be given as a ball, or as camphorated oil further diluted with linseed oil. Dram doses of extract of belladonna rubbed down with hot water and given as drenclies have a soothing effect upon the parts distressed, as do fomentations to the loins, or bags of hops moistened with hot water.

The will is not wanting, although repeated efforts have failed, and every induccment shoull be offered in the way of deep straw bedding, a loose-box witl the door shut, and no person near enongh to excite the patient, while whisting, to encourage the animal with the familiar sound he has learned to associate with freedom from interruption at such times. Some horses will not urinate in harness or " ask" for an opportunity, while others will come to a standstill and almost insist on relieving themselves. This shoult be made clear to beginners in horse-keeping and its importance pressed home.

\section{Incontinence of Urine}

An opposite condition to that previously described is the leakage of urine or inability to control it. Paralysis of the neck of the bladder, the presence of stones, growths or injuries, are among the clief causes.

Treatment may be successful when the cause is a calculus, which can be removed by operation, or pushed back into the bladder by means of a catheter, or powerful syringe containing warm water. Nux romica will sometimes have a beneficial effect where paralysis exists, but such cases are not very hopelul, and protection from scalding by means of lanoline, or other suitable unguent, may be all that can be done to render the animai useful in some humble sphere of employment.

\section{Stone in the Bladder}

In considering the other diseases of the urinary organs frequent reference has becn made to the stones, or calculi, which may form in the kidney itself, in the bladder, or be found as escaping from the latter and lodged in the passage (urethral canal). They are composed chiefly of caicic carbonate, and in order to understand their formation we may for a minute consider the variable composition of urine from which they crystallise or deposit upon a nucleus. The horse's urine varies from a pale, almost colourless fluid, to a brownish ycllow. It is of specific gravity between 1.015 and 1.50 , and contains besides mucus, urea, hippuric acid, uric acid, soluble and insoluble salts. The sediment consists of 80.9 to 87.5 of carbonate of lime, 8.5 to 12.1 of carbonate of magnesia, and 4.3 to 7.0 of organic matter. These varying constituents are loosely held in solution at the temperature of the body, and separate when cooled outside. The abnormal conditions which excite the formation of calculi are not very well understood, but an excess of solids may easily afford a nucleus of crystalline matter, mixed with mucus from an irritable surface, and, as in the borrels (sce Concretioxs, page 501), when a beginning is made there is a disposition to accumulations both of saits and of other matters. In certain forms of indigestion an excess of oxalate of lime is found in horses' urine, and some of the stones taken from the bladder have been found to consist almost wholly of that substance. It would be supposed that limestone districts would be more fruitful of stone than others, but such does not appear to be the case.

The symptoms of stone in the bladder are not uniform and are often mistaken for slight colicky pains in the bowel, but in more advanced cases rifficulties in urination lead to a suspicion of their presence-intermittent discharges of urine, some grunting and evident pain, which is more marked after rapid movements, as if the stone caused irritation by rolling. While at work, 
horses affected with stone are disposed to stop and cxtend themselves as if desirous of passing water, Lut often without result, or but a small trickle. There is also a disposition in males to extrude the penis, and allow it to remain ontside the sheatl. Perbajs one of the most diagnostic symptoms is the sudden cessation during uriration, just as a full stream is issuing. This is caused by the stone getting over the outlet. Contrution of the anus after passing water is also a symptom of stone in the bladder. Diagnosis is attempted by exploring with a hand passed into the rectum, but only an expert veterinary surgeon is likely to distinguish between a stone and any morbid growth which may be present; $1100^{\circ}$ will anyone else attempt an operation for its removal if discovered. What the lorse owner may do in a case of emergency is to pass a catheter, previously dressed with carbolic oil, and push aside a stone that is stopping the niouth of the urethral canal, or in the absence of an instrument, forcibly inject warm water with a syringe. Stones of small size sometimes descend into the canal, and straining and bloodstains, with much swelling of the penis, follow. The urgency of the case may compel a bold horseman to operate in the manner advised under the title of bloody urine and its causes (see page 5IO).

Treatment of stone, as before mentioned, is a matter for the surgeon as a rule, but there are acids which have a tendency to dissolve the stones or check their accretion, according to old treatises upon the subject, but it is very doubtful if such uction takes place. If dilute acids can be injected into the bladder then direct contact of acids with alkaline carbonates will result in more or less decomposition and dissolution of the calculus. This is done sometimes where operation is forbidden by circumstances, such as when a damaged spine precludes casting the animel in preparation. The owner of a horse which he knows to have stone in the bladder need not discard him, as there is always the possibility of the calculus getting pouched or forming a depression on the floor of the viscus, and being retained there by fibrous material which is the result of temporary inflammation. The other aids mentioned may serve to put off the evil day, but it has to be confessed that an early sale commends itself to the conscience made lax by many horse transactions. These stones do not always begin in the bladder, but pass into it from the pelvis of the kidney when they have attained to any size.

\section{Inversion or Eversion of the Bladder}

This accident sometimes occurs to mares in the violent expulsive efforts of foaling. It would hardly seem necessary to describe the "symptoms" of such a case, if we did not know that defective knowledge of anatomy has led to persons mistaking the bladder for the fotal envelopes or placental membranes, and cutting it open with the idea of aiding delivery of the foal. It is much thicker than the fotal envelopes and fleshy-looking; a pale red until it has been exposed for some little time and circulation in its walls interrupted, when it becones blue, purple, or nearly black. The little orifices of the ureters should be sought if any doubt exists, as their presence affords absolute proof. A rent in the vaginal wall will sometimes let the bladder pass through without the latter being inverted, or the muscular layer may be broken and the coverings intact. It can then be felt through the membranous covering.

Treatment.-Avoiding all excitement and liaste, the mare should be first secured and the intending operator's hands washed and rendered aseptic by immersion in a suitable disinfectant. The extruded organ may then be carefully sponged to free it from extraneous matters, which arc prone to collect. Carbolised oil upon the hands is a good preparation for the gentle but continuous pressure to be exerted in reposing the organ. When pushed back within the vagina one must feel for the opening, or meatus, and, having found it, proceed with the fingers to push it through a little at a time, but never releasing it, or the whole is immediately returned. $\mathrm{A}$ four per cent. warm solution of cocaine is of great service in keeping down straining, by the local insensibility it produces. The danger is not over when the bladder has been replaced, and the animal should be watched to administer cocaine if necessary, or prevent mechanically a return of the trouble. Perfect repose, very little food, and that of a moist kind, should be given, and water almost entirely withheld until all symptoms of pain and inclination to strain have passed off. The subject of this accirlent will be liable to its recurrence if she should bear another foal. 


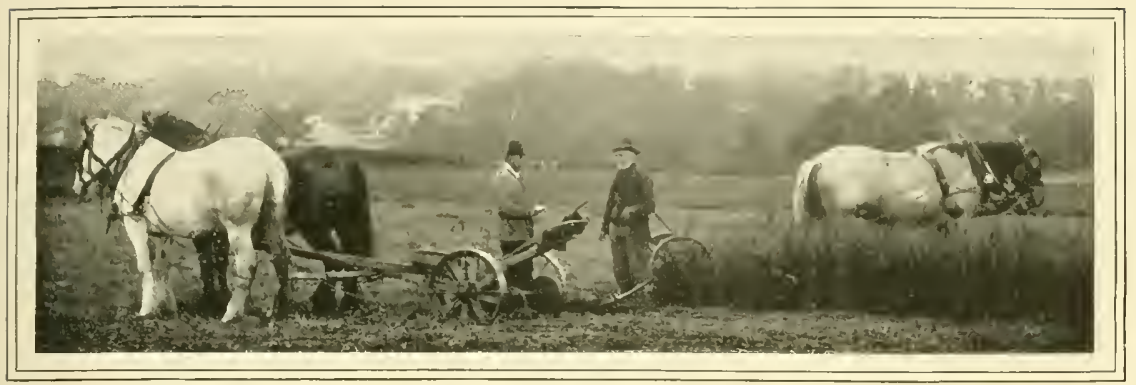

\section{CHAPTER V}

\section{DISEASES OF THE NERVOUS SYSTEM}

I

$\mathrm{N}$ considering diseases of the nervous system we have to bear in mind the cerebro-spinal and the sympathetic. The former responds to outward impressions through the organs of special sense, sight, touch, taste, sound, smell, as conveyed by nerves whose special office it is to carry them to the brain, where memory plays a part, as well as inherited instinct, and decides the animal as to what course to pursue: what to fear, what to eat or avoid. Space forbids us to enter upon the very interesting topic of animal intelligence and the possession, or not, of reason. The sympathetic system regulates the functions, as in the governance of the blood-vessels, permitting a greater or less flow of blood as the nerves relax or contract the canals. When food reaches the stomach, the blood supply is bountiful in its walls and the mucus surface is rose red. When the viscus is empty, the supply is so regulated by the sympathetic nerves that only enough blood circulates for the maintenance of the tissues and the lining membrane is quite pallid. It is from the blood circulating in the walls of the stomach that the gastric secretions are produced, and this, of course, applies to all other organs. The sympathetic system, then, is a very important one, and has much to do with the health of the animal.

Any derangement of the cerebro-spinal system is of grave import, and perverted, or interrupted, brain or spinal cord functions are liable to make a powerful animal uncontrollable and dangerous. Delirium on the one hand and stupor on the other are common results of brain disturbance, and inability to co-ordinate the movements when the cerebellum, or little brain, is the seat of imperfect function.

\section{Inflammation of the Brain (Cerebritis)}

Congestion or inflammation of the brain occurs in the horse as a result of injuries, and as a consequence of certain digestive troubles (see Stomach Staggers, Mad Staggers, etc., under AcutF INDIGESTION, page 493), from morbid growths (brain tumours), and rarely from the intrusion of parasites or pressure of bony growths. There is at great distinction to be made between cerebritis and meningitis. In the former the substance of the brain itself is involved, and carries with it the symptoms of coma or pressure, with drooping eyelids and sleepiness, with a disposition to rest the muzzle on some convenient object or press it against the wall. Sometimes delirium supervenes, but this symptom practically distinguishes meningitis, or inflammation of the covering membranes, from that condition of the substance of the brain.

So far as treatment is concerned, the horseowner need not accurately differentiate between the two, as the chief thing to do is to get the bowels to respond to an active purge. Not waiting for a ball of aloes, we may give six ounces of the solution, and as soon as this begins to divert blood to the intestines the head trouble usually 
diminishes. There are individuals in which prompt bleeding from the jugular vein gives immediate relief, but the generality of cases are much better treated by purgatives. So much is this the case that bleeding for brain troubles has almost fallen into desuetude. After an aperient it is sometimes advisable to rouse the patient from his stupor by two-ounce doses of impairment of the functions of digestion, the gorged stomach and congested liver contributing more than other disorders to such a condition. A tight collar, hindering the return of blood from the head, or standing in the sunshine at a hot bend of the road, may induce giddiness. It has often been stated that so-called sunstroke is due to the direct rays of the sun, but the writer is

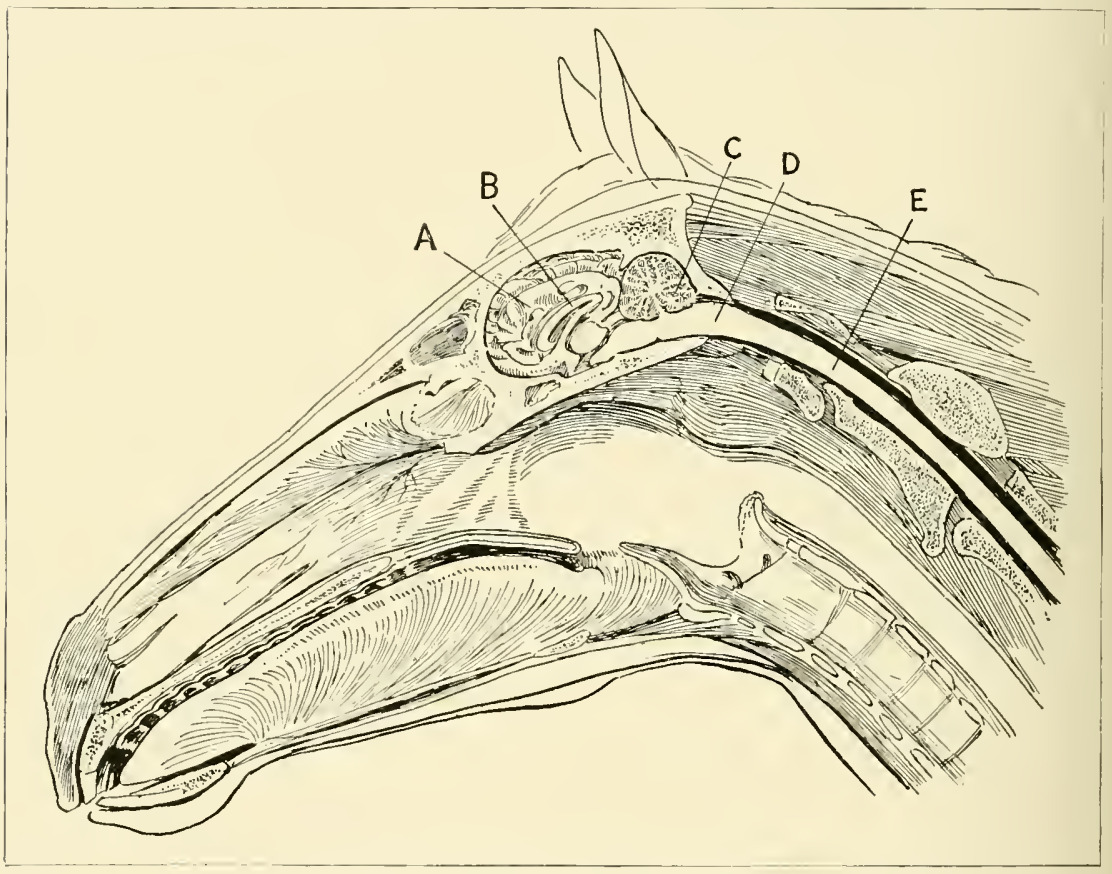

SECTION OF SKULL, SHOWING BRAIN.

A. Cerebrum B Corpus callosum. C. Gerebellum. D. Medulla oblongata. E. Spinal cord.

sal volatile in a pint or more of water, at intervals of two or three hours. Cold sponging of the head, or ice-bags on the poll, have a marked effect when the meninges are chicfly affected. A horse that has once suffered from brain pressure should ever afterwards be carefully dieted to prevent constipation, a slightly lax condition of the bowels being obtained by linseed and bran mashes rather than by resort to drugs.

\section{Megrims, Vertigo, Giddiness}

As with brain troubles already mentioned, giddiness, megrims, or vertigo may be due to in a position to contradict this, and to say that in the open, where there may be a certain amount of wind and where there will certainly be fresh air, a horse is not so likely to go down with heat stroke as in the bottom hold of a horse-ship. where no sun's rays penetrate. But the heat in the Tropics is, of course, terrible and the atmosphere vitiated, despite wind-sails and scoops, and other contrivances for ventilation or the withdrawal of bad air. This form of vertigo begins with depression and dullness, hanging the head, dropping the ears, and increasing insensibility; the animal's efforts to remair on his feet finally fail, and down he goes like a person 
helplessly drunk. (Inly in a hot bit of a road, where the heat is great and the air still, has the writer seen horses sink dow'll with heat stroke, but a score a day have needed his services in ships crossing the Equator. If the water is cold enough and the hose promptly turned on, recosery is the rule, but just in the tropical beit the water temperature runs up to $s_{7} \mathrm{cleg}$. F. or morc, and is of very little help save by the cold that evaporation produces from an animal still hotter. Balls containing four drams of ammonia carbonate help to rouse the heart and overcome the stagnation of blood in the brain in heat stroke, which is a preferable term for what can hardly be describerl correctly by its old name of sunstroke.

Vertigo includes this special form, as it does megrims, hut the latter is a peculiar malady, and its cause not often to be found upon careful post-mortem examination. In some cases, granular bodies, and even tumours of the size of a walnnt, are found, but more often there will be no lesion recognised by pathologists.

It may be that megrims is due to liver conditions, which we have already shown have much to do with other forms of brain pressure. Megrims, however, are of brief duration, recovery, temporary at icast, taking place without any treatment, while the other conditions described under staggers, stomach staggers, and cerebritis are not escaped from without a diversion of blood by blecding or purging, or both. Megrims is a dangerous malady, which may land the driver into difficulties if he does not recognise the first symptom of shaking the head as if distresserl by the briclle, or trying to shake off the attentions of a tly, or something ir the ear. If the animal is at once stopped and the collar pressure relieved, the fit may pass off, and the driver be deceived into thinking it was after all caused by some external worry. Continuance uphill "against the ccllar" will icad to more violent shaking of the head and twitching of the cars, rolling and bloodshot eyes, swaying aside and falling down in convulsions, which seldom continue long after a recumbent position is assumed. Somewhat dazed, the animal rises after a few minutes and resumes his journey if asked, and provided the carriage has not come to grief. Ridden horses are not exempt from fits of vertigo, but are less subject, as they have a frecr circulation in the veins of the nock.

Treatment.-A carcful man may continue to get good service from a subject of megrins by 66 using what is called a pjped collar-e.g. one that is shaped to the windpipe, and bears least upon the vessels of the neck - by taking hills with care, and allowing of stoppages at intervals, particularly in hotweather; hy feeding on laxative substances, and aroiding any disposition to hardened feces or to abdominal distcusion with bulky food. A periodical ball of aloes is an excellent thing to prevent the attacks, and some horses will go on for months without a sign of vertigo when so treated.

\section{Abscess in the Brain}

Either as the result of external violence, or from the pus of an abscess in another part of the body getting into the blood, matter may form in the brain, or under its covering membrancs. This accident happens when a ressel is punctured at the time of lancing and bloodpoisoning follows, known as pyæmia or pus poisoning. It may occur anywhere as a consequence of this accident, but in the brain it proves fatal, as no means of treatment are possible.

The symptoms are those of increasing clrowsiness, passing to complete coma and death.

\section{Epilepsy}

Horses are not so subject to epileptic, cataleptic. or other fits, as either mankind or dogs, nor from those reflex nerve troubles which tecthing difficultics give rise to in both dogs and pigs, and it is not necessary for us to consider here the technical distinctions between them. Negrims, already described, most nearly approaches to the fit observed in dogs and pigs, and-if we may put babies last-very young children. Occasionally in an underfed mare suckling a colt and doing hard work at the same time, there is a convulsive spasm or repeated spasms of the extensor muscles, with some trembling and sweating, and in this respect resembling what is known as eclampsia in other quadrupeds, but there being no loss of sense or mental disturbance it can hardly be classed with that malady in other specics.

\section{Chorea, or St. Vitus's Dance}

This spinal cord disease, which causes much loss in the kennel, is scldom seen in the horse, 
but certain revrous twitchings are obscrved in what are known as shiverers. It is probable that some spinal tronble occurs in coits at grass and passes unobserved, but icads to unequal pressure of the fluid between the covering membranes and the cord itself. Dogs suffering from this complaint in a bad form are found, after death, to have a red softening of the substance of the cord.

\section{Stringhalt}

This, too, is a ncrvous affection, in which certain muscles of the hind-leg are involuntarily flexed, or excessively flexed, so that the hind foot is jerked up towards the belly, when the animal intended perhaps to lift it no higher than necessary to walk. One or both hind-iegs may be affected, and, in rare instances, the front limbs are involved. Nothing is seen of stringhalt when the animal is at rest, and this casily distinguishes it from chorea, the subject of the latter malady being unable to keep still even to sleep. It is generally slow and progressive, but in a few cases intermittent, and cures have been claimed when horses turned out to grass have for a time been comparatively free from it. It varies, too, in the same animal, and may be very pronounced after a hard day's hunting, or a long journey in harness: or may be most conspicuous in a rested animai standing too long in the stable. All sorts of theories have been entertained as to its origin, but the most careful post-mortem examination of the nerves governing the muscles affected have failed to discover any changes of structure.

\section{Apoplexy}

From excessive exertion in an unprepared state or when fat and out of condition, from degeneration of blood ressels, and in extremely hot weather, horses are liable to excess of blood in the brain, and rupture of some ressel followed by hæmorrhage into its substance. Mfore often it takes the form of congestion and not actual rupture, or may be of serous apoplexy, when the watery portion of the blood passes through the walls of the vessels and causes pressure, and those brain symptoms which have been described under vertigo, megrims, and suustroke or heat stroke (see page 516). If rupture of a vessel is followed by anything but very slight hæmorrhage, a fatal ending may be expected; but slight escapes of blood into the brain-substance may only cause drowsiness, and after a while the little clot undergoes changes (fatty degeneration) and absorption, or it may furst of all diminish and reduce pressure so that normal function is restored, but eventually form the nucleus of those brain tumours referred to elscwhere (page 520). According to the situation of the hemorrhage in the brain will be the effect upon the animal's conduct and movements. If in that part from which the optic nerves have their deep-seated origin, the horse may be the victim of so-called glass eye, the organ remaining perfectly trans. parent but sightless. If at the back of the brain (cerebellum), there will be failure to coordinate the voluntary muscles and a staggering gait. If at the base of the brain, from whence nerves of special sense pass out through holes in the skull, the pressurc upon them may induce loss of smell, of taste, or other failurc. Any appearance of brain pressure may be of apoplectic origin, and most veterinary practitioners belicve in a diversion to the bowels and kidneys as the most rational treatment and the most successful in their cxperience, but there is difference of opinion among high authorities. Perhaps the best advice we can give to the horse-owner in the circumstances is to give the aperient dose advocated by the "G. P." (general practitioner) first, and then the stimulants to rouse the flagging heart adrocated by others. Icebags to the poll give relief to some cases. Professor Axc says: "In all cases where the power to swallow exists, a strong dose of physic should be promptly administered."

\section{Crib-biting, Wind-sucking, and Weaving}

These objectionable practices are generally spoken of as "vices," but are really nervous disorders, or a nervous cxcitability already exists before the habit is copicd from another horse, or developed in solitude. Continental authorities have given much study to the above tricks, or evidences of nerrous disturbance, and many pages of learned matter have been written, but it is not possible to pick out any information from them that is of any practical utility. Observers in this country are agreed that horses with much time on their hands are like men so situated, in that they are apt to fall into mischief, and the old adage is confirmed that "one fool 


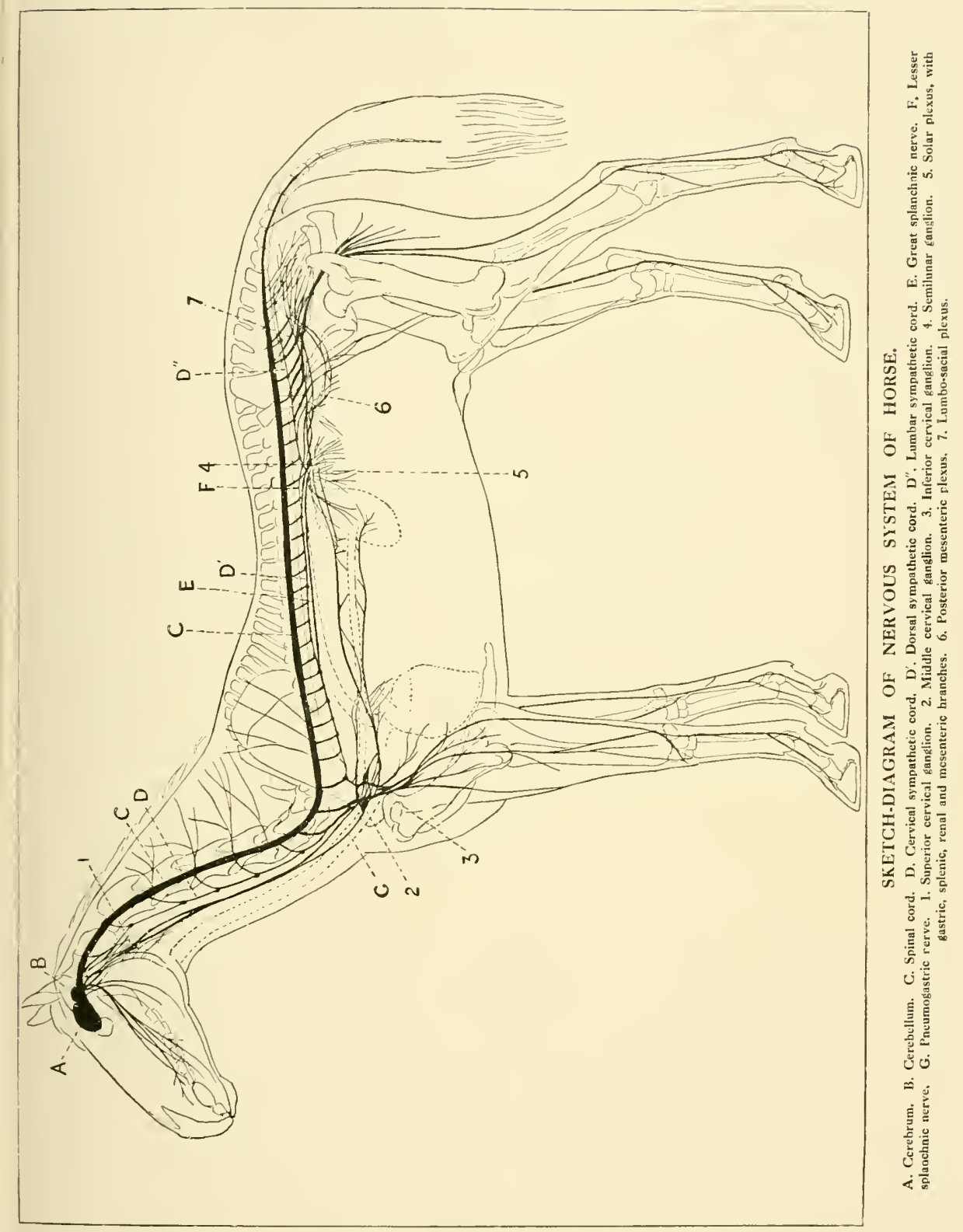


makes many:" With nothing to look forward to but meal-times, the well-fed and lonely animal may begin with nibbling the manger or other objects, and end in confirmed crib-biting and wind-sucking, or pass much time and relieve enmui by weaving. To those who do not know by mournful experience the annoyance of these tricks, or vices, or whatever we may choose to call them, it may be said that crib-biting, when developed, consists in laying loold of the manger with the teeth, and stiffening the muscles of the neck, repeating the operation at irregular intervals, and for various periods. It commonly develops into sucking air into the stomacl while holding on with the teeth, and may become so confirmed that an olject to lay hold upon is no longer necessary; old subjects of the trick being able to nod the head and suck wind until the flanlis are distended. Young horses coming into a stable where a "cribber" stands will frequently pick up the trick very quickly, but, on the other hand, association does not invariabiy result in imitation, and the older the liorse the less likely is he to acquire the habit from another. The beginning of it may be traced, in some cases, to a hyper-sensitive skin, roughly-groomed or curry-combed by a hard-fisted groom ; the animal venting his irritation on the manger. In such cases the horse should be turned round in the stall and secured by pillar reins, while the groom should be admonished as to the use of the comb, and made to employ straw wisps instead. Cribbers should be placed where other horses cannot see them. In the early stages a horse may sometimes be broken of the habit by being fed from a manger on the ground of a loose-box, with no partitions or "furniture" upon which he can lay hold with his teeth. The most effectual restraint against crib-biting and wind-sucking is the provision of a broad strap round the throat, which must always be worn in the stable, and the mark of which upon the neck always "gives him away" to a would-be purchaser.

Weaving is the constant swaying of the head and forepart of the body from side $\mathrm{t}(\mathrm{s}$ side, like a caged bear. It is most distressing to witness, and as the practice quickly wears through any rope, a chain has to be substituted, and this makes much noise, and apparently affords the weaver the greatest satisfaction. A loose-box without any head attachment will cause some horses to forget the trick, or perlaps find no pleasure in it when no sound is created, but there are confirmed weavers who will stand clear of cverything, and continue to sway rhythmically to their own satisfaction, whether in a box or out in an open field.

\section{Brain Tumours}

Abnormal growths within the cavities of the brain, varying in size from a pin's head to a hen's egg, are occasional causes of pressure, of coma, or sleepiness, of the opposite condition of cerebral excitement, of fits of insensibility, falling on the ground with staring or rolling eyes and loss of power over the muscles. Running away, or other conduct inconsistent with the manners of a well-trained horse, may be due to tumour on, or in, the brain or from pressure of a bone tumour inwards from some portion of the cranium. There is no one special diagnostic sign of brain tumour, although it is often suspected, and post-nortem examination reveals it, but there are some of the symptoms described in connection with diseases of the nervous system, and they can be assigned to the brain by one or more such prominent symptoms as recurrent drowsiness, and the failure of purges and other treatment. They are composed of a mesh-work of fibrous tissue in wlich granules of earthy material and particles of fat are mixed with glistening plates of cholesterine. They commence from the membrane known as the choroid plexus, and not in the brain substance, unless as the result of an apoplectic cffusion (see APOPLEXY, page 519). A brain tumour may suddenly increase and lead to paralysis and death, or remain chronic, with a certain amount of accommodation of the contiguous structure, but a horse believed to have a cerebral tumour should be regarded as dangeious and destroyed. Few persons are willing to make the sacrifice, and, as there is nothing that even the expert veterinary examiner is likely to discover at an auction sale, they conmonly pass on from one unlucky purchaser to another. Being sold without warranty, the purchaser must licep such a horse "with all faults and errors of description" until he can plant the wretched creature on someone else, and compose himself to sleep with a good conscience, if he has not lost too heavily on the transaction and " got out of him" fairly well. It is a fact. also, that horses with all the appearances of brain tumour sometimes recover completely, 
and this is because the pressure was causcd by œdema of the choroid plexus, which has becn subsequently absorbed. There is no doubt, also, that shrinkage rather than growth follows in some cases, and we have seen many brains of sheep and other animals which have wasted around the tumour and so afforded room for what is practically a forcign body and crentually harmless. But this off-chance is not good enough for a prudent man to gamble on ; he had better be rid of the horse.

\section{Diseases of the Spinal Cord}

These can hardly be considered apart from those of the brain and its coverings which we have previously named, but there are disorders in which the cord alone suffers, and others, like cerebro-spinal meningitis, in which both are in volved.

Acute Spinal Meningitis-Inflammation of the Membranes of the Cord.-From injuries without and from sudden and extreme changes of temperature, from east winds, and as a consequence of excessive fatigue after hunting or fast trotting in harness, or heavy draught, a state of inflammation of the two softer membrancs of the spinal cord (pia mater and arachnoid) is sometimes discovered next morning in the acute form, or it may come on slowly and be progressive in intensity.

Symptoms.- Shivering fits (rigors) and an expression of pain when made to nove. Spasms of the muscles of the limbs, giving them an upward jerk and letting them down again upon the ground with loss of control, inability to walk in a straight line, a rolling gait, knuckling over at the fetlocks and final inability to stand, precedes complete paralysis. On the ground the animal struggles to rise again and the muscles of the neck and limbs are thrown into violent spasm. The facial expression is haggard, breathing hurried, the animal gives vent to groans and the body is bedewed with sweat. Slight remissions of the spasms only lead to further weakness and loss of sensation as well as motion. If the animal does not die during these attacks he is a hopeless cripple and had better be destroyed.

Acute myelitis or inflammation of the cord itself is generally associated with the discase of the covering membranes above described. The symptoms are those of meningitis, but more hopeless from the first. An end to the case comes in most instances by some pulmonary complication, and only slight cases afford any hope of recovery by medical treatment. The administration of salicylate of sodium in large and repeated doses, during the first two days, and of small doses of the bromides on succeeding days for a wcek, appear to do good, and later on a course of nux vomica and iron is calculated to restore nervepower, and cxcite absorption of fluid between the spinal cord and its membranes.

\section{Paralysis}

Loss of power or of control over the voluntary muscles is frequently referred to as paralysis in other sections of this work. It is not a disease per se, but a symptom of some disorder of the brain, the spinal cord, or some nerves connecting the parts affected. There may be paralysis of motion, or of sensation, or both. The brain is the central office from which instructions are conveyed to the muscles capable of obedience to the will, and the spinal cord the main avenue, and if for any reason the brain fails to give orders or gives uncertain oncs, there will be stoppage or irregular movements wanting in control. The ncrves being conductors, or conduits, of the will, must also be capable of receiving and transmitting instructions to the motors (muscles). or there will be failure to contract, although the brain and spinal cord may be functionally perfect.

Some of the causes of paralysis have been mentioned in connection with the pressure of apoplexy, of brain tumours, and of reflex action of the pneumogastric nerves (see Stomach Sraggers, etc., page 493). There are still other causes, as poverty, when by starvation the nerves, like all other structures dependent on the blood for nutrition, are weakened and become incfficient. Lead and other poisons taken into the system cause paralysis, or poisons developed within the animal may induce auto-intoxication, as when urca is taken into the circulation through failure of the kidneys (see INFLAMadion of THE KrDNers, page 5IO), or in so-called milk fever, when in cattle paralysis follows after calving through absorption of some toxic substance developed in the udder. These are the chicf caluses of 
paralysis, but there are others more or less obscure which it would not be worth while to discuss at length, neither would a classification of the various forms be of profit in a work of this kind. Suffice it to say that paralysis of one lateral half (right or left) is known as hemiplegia, and that paralysis of the posterior half of the body, with failure of the hind limbs, is known as paraplegia, and that when muscles are paralysed which are supplied by a particular nerve it is known as peripheral, as, for example, when the lower lip hangs down helpless, or the face is held awry or an ear dropped.

\section{Cerebro-spinal Meningitis}

A disease in which the membranes of the brain as well as spinal cord are concerned appears from time to time among horses, and was believed to have been imported, like bad weather, from the American continent, until Professor Axe, with that painstaking investigation which characterises all his undertakings, discovered isolated accounts of the disease contributed by the few veterinarians who carefully recorded cases occurring in their practice. It does not appear to be influenced by climatic conditions, as it has appeared in hot and dry, wet and cold seasons. The blood of an affected horse caused paralysis in sparrows, in pigs, and in a dog partaking of it. This infection by ingestion naturally leads to the conclusion that the malady is infectious, but by what means conveyed, whether aerial or by contamination of food, is not clear. That a number of cases occur in a district, and that the disease dies out again, is about all that we know of its invasions and retirements.

Symptoms.-In the majority of cases paralysis comes on suddenly, the animal stumbling and failing to go straight, or falling down behind, because the muscles of the hind parts are most early influenced. Stabled horses may be found prone without any preliminary symptoms being observed. Some have the muscles of deglutition specially affected, and have a difficulty in swallow- ing ; in others, a progressive failure of the voluntary muscles is noted. As the malady progresses great excitcment is succeeded by complete loss of consciousness, or by frenzy known as mad staggers (see StAgGers, etc., page 493). The frenzied period commonly ends in death. The pulse and temperature are not much influenced by the disease. After death the membranes are found gorged with blood, and there are extravasations of blood and sermm on the brain and spinal cord.

Treatment.-Regarding the disease as infectious, our first precaution will be to remove the sick horse and disinfect the stable. Ice-bags to the poll and cold applications along the spine, laxative food and salines, as small doses of salts, and salicylate of sodium, appear to offer most hope. Spasms may be subdued by chloral and the hypodermic injection of morphine. If by such means a measure of control is obtained over the acute symptoms, time is gained for Nature to fight it out, and our treatment, if not heroic, may turn the scale in the patient's favour.

A disease resembling cercbro-spinal menin gitis has been caused by feeding horses with so called Indian peas or vetches (Lathyrus satirus) which does not immediately produce its effects, but has a cumulative influence after a variable period. These "peas" now seldom find their way into the British market for horse-food, but there is good reason for supposing that they constitute some portion of the cheap poultry mixtures commoniy sold, as symptoms much resembling those in horses appear from time to time in well-managed flocks. A very important action was brought by a tramway company against the vendors of these vetches and damages awarded. The horses appeared well, but so many fell in harness that careless driving could no longer be supposed to be the cause. The falling was followed by more pronounced paralysis, and investigation followed and resulted in the discovery of a toxic effect from the article mentioned above. 


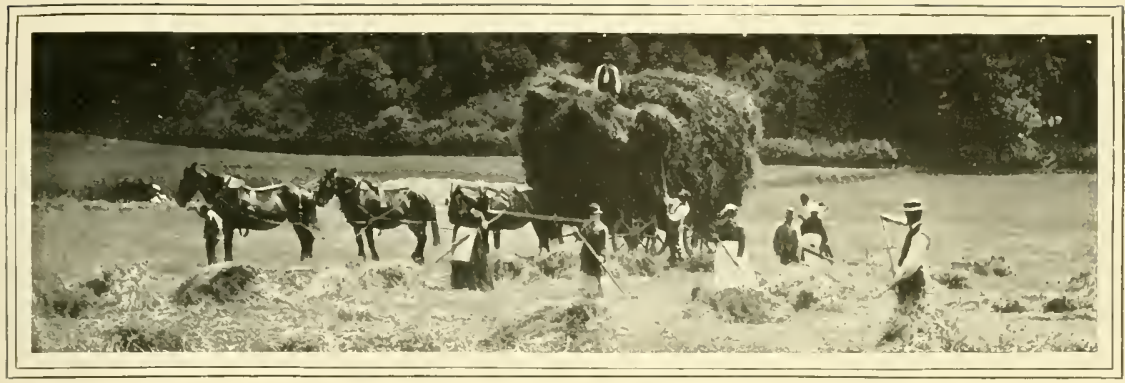

\section{CHAPTER VI}

\section{DISEASES OF THE HEART AND BLOOD-IESSELS}

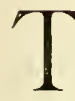

HAT horses fall dead in the street, or on the course, from heart affections most people are aware, and the majority of persons, at some time or other, have seen animals drop in this way, but it is. nevertheless, a fact that horses are much less subject to fatal heart diseases than man, despite the subjugation of their wills and the compulsory performance of tasks beyond their strength. It is certain, however, that they do not injure themselves by alcohol sm or fall victims to the passions of love or ambition which influence the central organ of circulation in their masters. Horses' hearts acquire power early in life by the full development of muscular strength, and an organ thus tuned for its life-work is less liable to derangement than that of man obeying a wayward will and taxing an organ which may never have had the benefit of systematic physical training. Expert veterinarians often find it diffcult to diagnose heart diseases, and it cannot therefore be expected that the amateur will learn to auscultate and differentiate between the various disturbances of the organ which indicate structural or other disease. We may glance at a few of the chief disorders and point to a few prominent symptoms which may enable the horse owner to cry "whoa!" and afford the probable sufferer from heart trouble the necessary rest or changed conditions of life best calculated to restore the organ to efficiency.

\section{Pericarditis}

Inflammation of the heart sac, or covering membrane, seldom exists alone, but as a complication of lung diseases, unless it is caused by the lodgment of a foreign body, such as a needle or piece of wire, taken in the food and passing from the stomach to be lodged in the pericardium. In the first case, the heart sounds will be muffled by the more or less solidified lung, and in the second the normal "lub-dub" will be altogether obscured by the effusion of fluid between the pericardium and the heart itself-indeed, this absence of sound is more diagnostic than anything else, and the horse-owner who desires to study the subject should make a practice of listening with his ear pressed against the side of a healthy horse, if he would attempt comparison. A peculiarity connected with heart troubles is the alternate coldness of different limbs; one or more feeling normal and others chilly. This has been specially noticed when fencing wire and other bodies have lodged in the covering membrane, and set up pericardi'is. Usually before any such pronounced sy'mptoms appear there have been fits of indigestion and distension of the belly, and more or less colicky pains which could not be assigned to the bowels. With almost any heart trouble there may be loud palpitations, but these, on the other hand, may arise from indigestion or fright and are not reliable signs of a diseased heart.

Treatment.-In the case of the lodgment of a 
foreign body, it is obvious that no treatment will avail, and it is only after death that the diagnosis is confirmed. The administration of aperients, of belladonna plasters over the region and of digitalis to regulate the impulse, is often followed by improvement. Perfect rest, and a return to

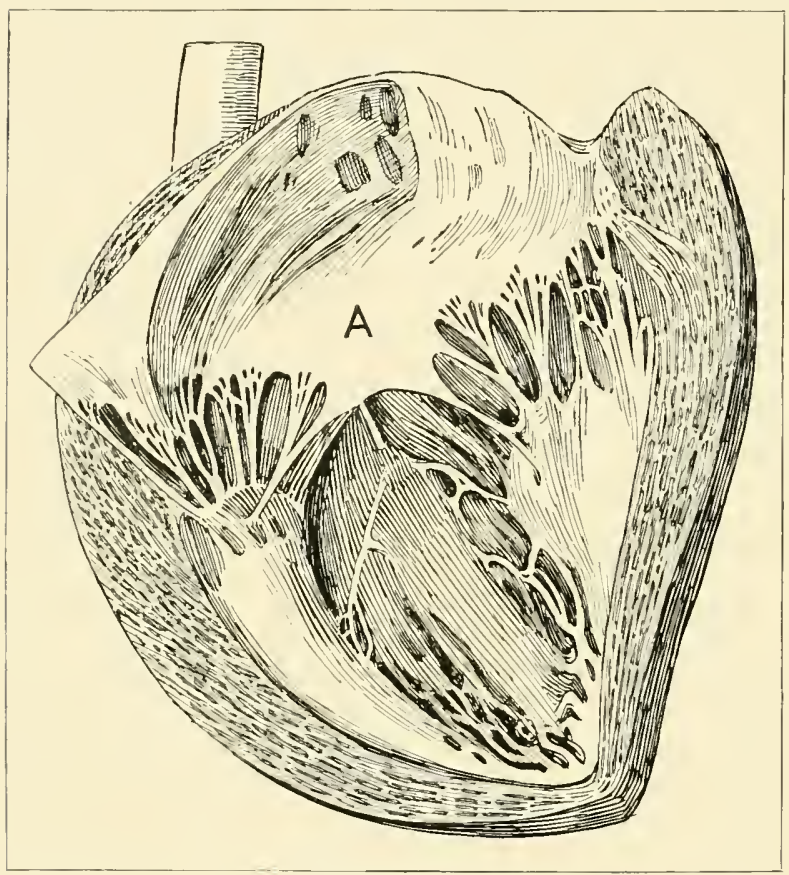

HORSE'S HEART.

Section through left auricle and ventricle. A. Mitral or bicuspid valve. leave the heart impaired, as in the subjects of rheumatic fever of man. Detached portions of fibrinous matter may get into the circulation and be arrested in the lungs, or other parts, and act as foci of disease in their new situations. Abscesses may even result in the brain (see ABScESS $1 \mathrm{~N}$ THE BraIn, page 520).

Treatment.-Saline purgatives to keep the bowels soft, combined with salicylate of sodium, which has the best possible effect of keeping fibrin in solution and preventing valvular incompetence afterwards. Weakness, or disposition to faintness, as displayed by deep sighs and listlessness, may be combated by ammonia and digitalis.

\section{Myocarditis}

Inflammation of the heart substance is called myocarditis and is usually caused by invasion of the last-named trouble. It is scarcely possible to distinguish between this form of heart disease and those already mentioned, but it leads to degenerative processes, such as enlargement, softening and inefficiency, capricious appenatural conditions of life in the field, may complete the restoration of the animal.

\section{Endocarditis}

Inflammation of the lining membrane of the heart is commonly accompanied by excited action of the organ, and murmurs, without the friction sounds which are sometimes observable in pericarditis. Not so much pain is felt in this malady as might be expected ; the pulse, at first frequent and full in tone, becomes weak and irregular later on. A high temperature, too, may be noted at first, but it becomes lower and persistent as the disease makes progress. The subsequent formation of clots, which adhere to the valves, tite, giddiness, inability to work, sweating with but slight exertion and not infrequently to falling in the shafts to die.

\section{Enlarged Heart, Hypertrophy, Dilated Heart}

All these are results of disease and are seldom amenable to medical treatment. As they often lead to fits of giddiness a horse so affected is dangerous and should be destroyed.

\section{Atrophy of the Heart}

Wasting of this vital organ is followed by feeble circulation and passive congestions in 
various organs, emaciation and general wealsness, for which there is no renedy.

\section{Fatty Heart}

What is known as fatty degeneration of the heart is not often seen in the horse. An accumulation of fat upon the organ and infiltration of fat globules between the muscular fibres is not conversion into fat, which is intended by the term fatty degeneration, and which often overtakes human athletes when they quit sport and take a "pub." Fatty infiltration is apt to enfeeble and impair the animal's usefulness, making him short-winded and easily fatigued. Properly regulated exercise and feeding will, in most cases, restore the subject of fatty heart, but a long time and gradual conditioning alone will succeed.

\section{Rupture of, or Broken, Heart}

This may follow on degenerations arising out of the diseases already mentioned. An indifferent heart may serve for moderate labour until some excitement, or fall, or distension of the stomach, obstructs the passage of blood in the larger vessels.

\section{Diseases of the Arteries and Veins}

Blood-vessels undergo structural change as a result of inflammatory diseases and from the presence of parasites which make their homes in them, notably the Strongylus armatus, which seeks a junction where vessels branch off and forms, as it were, a nest. The presence of worms induces changes in the artery wall, which dilates to form an aneurism or pouch which may undergo such further changes as to cause it to break when the heart's action is more than usually forcible,

Thrombosis.-Blood-vessels, whether carrying blood from the heart (arteries) or conveying it back for renewal (veins), are liable to be blocked by a clot, otherwise a thrombus. Thrombosis, as this condition is called, was frequent when bleeding by amateurs with fleams and bloodsticks was general, but is now only rarely met with. It may occur in lancing an abscess, or other wounding of a ressel by accident, bruising from outside and as a result of castration, or 67 parturition in the mare, or falling spread-eagle fashion while in harness, or stretching the limbs in other ways. Plugging of this kind occurs most often in the iliac arteries, and stiffness on rising from his bed or when first brought out of the stable is a common symptom in the horse. With exercise the patient improves, but not permanently. The trouble recurs in a more marked form and the legs swell and impart a feeling of coldness to the touch, while the large veins become distended on the outside. Exercise reduces the swelling of the veins, but it returns after rest. An uncertain and more or less rolling gait marks the advance of the disease. A quivering of the muscles, profuse sweating, hurried pulse and respiration, may be followed by paralysis. From all these symptoms horses will apparently recover until put to work, when the trouble returns. Of such are the habitues of the auction mart, and many of them are quite well known to dealers who resort to such places. There are still a few men who make a business of selling such horses both by auction and privately, and depute a "friend" to buy them back again at their own price, until another unwary purchaser can be found. No treatment is practicable. Thrombosis, or inflammation of the jugular vein resulting in thrombosis, is among the disappearing troubles of the horse-keeper, as the chief cause is bleeding with unclean instruments or unnecessary violence with the blood-stick. The wound appears inflamed, swollen and painful to the touch. Above it may be felt a liard cord plugging the vein, which undergoes changes, becomes solidified and makes the channel impervious. The corresponding vein takes up the additional work imposed on it of carrying away blood from the head, and accommodation is soon reached, but the subjects of this accident should never be turned out or be fed from the ground. It sometimes happens that instead of becoming organised the clot softens and matter is formed and breaks out at different points in the ehannel of the ncck, or enters the general circulation to cause pyamia or abscesses in distant parts.

Treatment.-A cooling dose of aloes, warm fomentations, soft, wet food and irrigation with weak carbolic lotion. The old practitioners, who were certainly not wanting in experience of this trouble, placed implicit reliance on a blister down the course of the vein, which "set" it, to use their own term. 


\section{THE NEW BOOK OF THE HORSE}

\section{Ancmia}

An insuffi iency of iron in the blood, and consequent diminution of red blood corpuscles, causes pallor of the membranes of the conjunctiva, the nostril and the mouth, which constitute the "complexion" of hair-covered animals, and this state of the blood is known as anæmia, and results in wcakness and general malaise. Too often in horses it must be confessed that the cause is insufficient food and too much work. But there are many other causes, such as unsuitable food-although not wanting in amountas when horses are turned out on rough hillsides and bare pastures to find a scant living or starve ; the robbery of internal parasites, the loss of blood by hæmorrhage and chronic discharges, confinement in close stables and unventilated buildings, and as a sequel to debilitating diseases. Besides the pallor of the visible membranes there is a Faccid tongue, a dry, harsh, or hidebound skin, and a tendency to dropsical swellings of the legs or belly. There is another form of anæmia called "pernicious," which probably owes its origin to some micro-organism, which attacks anci destroys the red corpuscles and does not yicld to ordinary or, indeed, to any treatment, as a rule; loss of spirit, hanging head, depressed expression of countenance, palpitation of the heart, casily provoked by slight disturbances and suppression of the periods of œestrum in mares. An irregular, intermittent and fecble pulse, weak digestion and occasional colicky pains mark the progress of pernicious anæmia.

Treatmont.-If the cause is known, suitable remedics will be prescribed, but with such a variety we necd scek for the particular one and rcmove it. Good hygienic conditions certainly will be advised, the expulsion of worms, the building up of the animal by nutritious food and access to pure water, and moderate and increasing exercise as the animal gains strength. Digestion is often so impaired that only small quantities of food can be assimilated, and small meals and often are recommended of such things as crushed linsecd, malt flour and treacle, or Molassine meal, until the patient is able to deal effectively with hard corn mixed with chaff. Iron is an invaluable substance for the rebuilding process, and may be given in combination with quinine and gentian or nux vomica, in small but increasing doses.

\section{Plethora}

A sudden attack of excitement, "blowing," and trembling, followed by dullness, with an injected state of the visible membranes, is often mistaken for congestion of the lungs and many other acute diseases, but is really an exact opposite condition to arzmia. The over-fed and underworked animal has accumulated rich blood and the pulse is full and hard, indicating brain pressure, and at other times quick and irritable, as pointing to congestion of other organs. If there is ever a need for blood-letting it is in plethora, and the abstraction of anything from a quart to a gallon of blood from the jugular vein will be followed by immediate relief. Purging or starvation will effect the purpose, but much longer time will be occupied, besides running a risk of congestion of the lungs.

\section{Septicremia}

Blood-poisoning caused by the entrance into the circulation of malignant bacteria or their products is known by the above name, or if due to known infectious diseases, it is called specific infection or septicæmia. Pyæmia, already referred to in connection with circulatory diseases, is distinguished by the production of abscesses in other situations. Wounds that have appeared to do well for a time may develop poisonous matter, and this, becoming absorbed into the general circulation, may produce a high degree of fever, commencing with a shivering fit (rigors) and recurring at intervals. The pulse is feeble and quick, the breathing hurried, appetite lost and excessive prostration, with muscular pain and frequent shifting of the weight from one limb to another. The visible membranes acquire a peculiar yellowish-red colour. The mouth is clammy and the tongue furred.

Treatment consists in fortifying the animal with stimulants and tonics, such as brandy. whisky and quinine, large doses of the latter seeming to inhibit the powers of the bacteria. Vegetable bitters, as gentian and chiretta, are best calculated to repair appetite, and the animal's strength may be upheld by eggs and milk "bottled " down him like medicines. If an unhealthy wound is the causc, it must be well and frequently irrigated with a disinfectant, such as a four or five per cent. carbolic wash, and covered in the intervais with boric wool, bandaged over. 


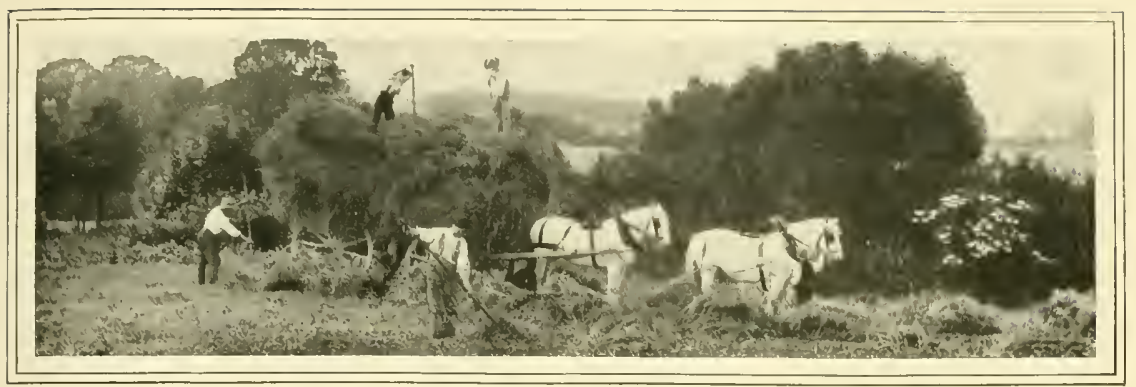

\section{CHAPTER VII}

\section{CONSTITUTIONAL DISEASES}

$\mathrm{R}$ HEUMAT ISM. - If rheumatism were caused by exposure to inclement weather alone, we should meet with a great many cases in horses wintered in the fields, but such is seldom the case. Nore often, indeed, is this distressing malady developed in the old and stabled animal protected from the vicissitudes of the climate, but inhaling bad air and unable to rid himself of the effete material in his blood. Damp and ill-drained stables cont ibute to the number of rheumatic victims, and debility from any cause, as well as hereditary predisposition, account for others. It has been observed that rheumatism is prone to attack convalescents from influenza and strangles, as also from pulmonary affections.

Symptoms of rheumatism may be acute and amounting to rhenmatic fever, as seen in men and dogs, or chronic and affecting the joints, or intermittent and strangely transient and movable, from one limb to another. With the febrile form there is usually some one joint or limb swollen, painful and wanting in mobility. A quick and irritable pulse and persistently high temperature. together with rapid respiration, loss of appetite, constipation, dry, hot skin and high coloured membranes, distinguish the acute or feverish attack from the chronic and the intermittent. Chronic rheumatism may follow on an acute attack and accounts for many of the enlarged joints one sees in horses in the streets of our towns. The sheaths of tendons also suffer, and remain permanently swollen in somc cases. When the muscles of the loins are involved, all the symptoms of lumbago are present and the patient has a difficulty in getting up from his bed, which he expresses first by reluctance to rise, and next by groaning when made to do so, and moving "all of a piece" when walking the first few steps. Intermittent attacks, which suddenly jump from one limb to another, have given rise to many peculiar situations between the owner and the veterinary practitioner. The writer has been one of thrce to be called a fool for diagnosing the lameness in the wrong limb, but the fact was simply this, that each veterinary surgeon, called in at different times, found the lameness in a different limb.

Treatment of rheumatism, except of the chronic form, may be said to be more generally successful in horses than in men, but this may be accounted for, to some extent, by the doctor's orders being better observed, since the horse has none of those temptations to toast his friends in unsuitable drinks. Rhenmatic fever is subdued by doses of half-an-ounce to an ounce of salicylate ct sodium two or three times a day, and the tempes ature lowered and arterial pressure reduced by repeated saline doses, as ounces of bicarbonate of potassium and two to three ounces of sulphate of magnesium. By these means the fibrin in the blood is kept from depositing upon the valves of the heart, and leaving it inefficien's when the rhoumatic attack has passcd away. It is the 
discovery of salicine that has so greatly reduced the number of cases of valvular disease in man during the last generation; those who had rheumatic fever two or three times almost certainly suffered from incurable heart disease for the remainder of their lives before this drug was employed. "Vets." were not slow to make use of it, and with the greatest benefit to the patient. Occasional or recurrent rheumatism partakes somewhat of the nature of gout, especially that form of it which attacks tendons and their sheaths, and for this form the salicylates may be combined with colchicum, and an appeal made to the kidneys to carry off waste material by stimulating them with small doses of nitrate of potash and sulphate of magnesium. What is called a half-dose of physic- " physic " always meaning an aloetic purge in the language of the stable-is frequently given when a joint is inflamed by rheumatism but the symptoms of constitutional fever are absent, and then a mild blister, or ammonia liniment, applied to the affected part. This appears to "draw out the poison," as the old farriers would say; anyhow, the practice is very successful and commonly resorted to. A good, dry, well-aired box should be given to the subject of rheumatism, whether of the acute or chronic type.

\section{Lymphangitis, Weed, "Monday Morning" Disease}

This is a constitutional illness with a local manifestation. The lymphatic glands and vessels of a limb or limbs, preferably one hind but occasionally the front legs, are suddenly attacked, more often during rest and, therefore, unobserved in the initial stage, when rigors or shivering might be looked for. The cart-horse is most prone to it, and those of heavy or lymphatic temperament among the lighter breeds. It is unknown among colts at grass, and seldom makes its appearance until horses have been for some time stabled and stimulated by high feeding. That it is due to somc retention in the blood of waste material is probable, and its method of attack during periods of respite from work point in this direction. Its frequency in the draught stable after a Sunday in has led to the popular term of "Monday morning leg."

Symptoms. - On entering the stable, or asking the subject of this trouble to "get over" in the stall, the carter discovers a swelled leg and inability to obey the command, which, if insisted on, is carried out by jerking the leg high in the air and hopping over on the other. So painful is the movement in a bad case that the animal seems likely to fall over in making the attempt to get across the stall. Extremely tender to the touch, and hot and tense in the skin, the patient may be heard to groan when the suffering member is approached. The swelling is often well defined

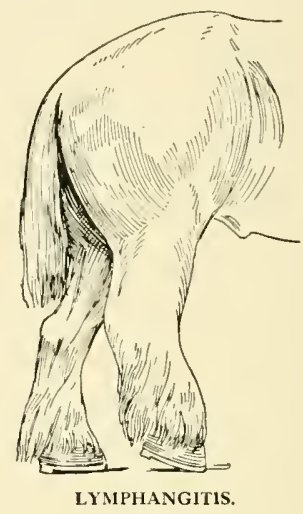

and terminates above, as if a cord had been drawn tightly around the limb in a slanting direction. If the groin is examined, the glands will te found swollen, and in some severe cases a reddish fluid oozes through the skin. The thermometer shows an increase of two or three degrees of temperature and the mouth gives the usual indications of a febrile state by a clammy tongue. More or less constipation accompanies the malady.

Treatment.- In all but the old and debilitated. a bold aloetic purge is desirable, and while the ball is dissolving within, outward relief may be afforded by warm fomentations, a lotion of one part Goulard's extract and seven or eight parts of linseed oil, applied when the skin is again dry. A smear of cxtract of belladonna rubbed together in a mortar with glycerine and diluted with water wiil help to relieve the pain and tension of the skin. Doses of nitre, one to six drams, twice daily, may be given with ounce doses of salts. Of all diseases most bencfited by diuretic medicines, this is perhaps the greatest, and their employment at intervals with a known subject of the malady may prove his salvation. 
An ounce of nitre, two ounces of sulphur, and three ounces of salts, may be considered a preventive if given in a bran mash once a week. The abuse of diuretic medicine has elsewhere been referred to. IIovement, so painful at first, reduces the swelling, and is to be recommended after the first two days, but when insisted on during the early period of the attack, appears to be prejudicial, as the swelling is stiii greater after a short rest. The loss of appetite is not to be regretted, as a low diet favours recovery, and a bundle of green-meat, or a couple of bran and linseed mashes, for the first two or three days will be sufficient. Nor should appetite be indulged when the patient again desires food, short commons being desirable until he is able to take a good deal of exercise or do light work, gradually resuming the ordinary fare. NIore or less thickening of the limb and depreciation of value is the result of a single attack and a still greater deformity after each succeeding one. It is a good plan to give the suhjects of this disease a purge of aloes about three times a year and, when possible, a run at grass.

\section{Purpura Hamorrhagica, or Big-head}

This is another of the systemic or constitutional diseases which affect the entire body, the blood undergoing some change which results in rupture of small vessels and the production of spots and patches of blood in the skin; this is best seen in the mucous membranes of the eye, the nose and the mouth. The red blood corpuscles breali up as in the discase of red water in cattle, and are found by microscopic examination adhcring together instead of in rouleaux or like heaped-up coins, which is usual in health. The white cells are in excess of their usual number, and often broken. The exact canse is not known, but it is probably dne to some attack by a similar micro-organisn to that which produces red water and pernicious anæmia, or " an organic ferment," which finds a favourable field in the blood of an animal after debilitating diseases, such as strangles, influenza and lung troubles. Its sudden appearance in apparently healthy and fat animals is unaccountable, but in their case it has been observed that the stables have a north aspect and are damp and ill-drained, from which the earlier observers were led to associate it with some form of malaria. The writer has, however, seen it on open forests where no such conditions apply, and it may, therefore, be conveyed by insect puictures, in like manner to red water, by ticks who are themselves infected, or act as purveyors, and even transmit it to their offspring.

The symptoms are unmistakable when fully developed, but commence with swollen lips and drops of blood-stained fluid coming from the nostrils. The swelling extends until the lead resembles that of a rhinoceros rather than that of a horse. It is this, of course, which gives the discase the popular name of big-head. Sometimes the limbs, rather than the head, swell to cnormous size, or the belly maly appear dropsicai. No mistake will be made as to the leg swellings, as they are very insensitive and unlike lympliangitis or "Monday morning leg." Bloocl-stained urine is a symptom in many cases, and there is always great prostration, more or less inseased temperature and, if of long duration, patches of skin slough from the lips and hecls.

Treatment.-A roomy, light loose-box with plenty of good straw on top of a. flow sprinkled with carbolic acid, or Sanitas suwdust, it there is no proper drain; clothing aut bandages to keep up surface warmth; alcoholic stimulants ; cggs and milk beaten up, and all the succulent foods the animal can be induced to tiske. Medicines are very helpful if juliciously employed, and of these tincture of iron and turpentine, in doses of half-an-ounce of the former to one ounce of the latter, twice a day, in a little linseed oil, are recommended, the amount of oil to be regulated by the disposition to constipation or otherwise. There is no treatment so effertual as that of injecting into tlie windpipe, by means of a stont hypodermic syringe, a solution of four grains of iodine and eight grains of iodide of potassium in one onnce of water, once or even twice a day.

\section{Hæmoglobinuria, or "Hysteria"}

This disease was furst observed in mares, and the nane of hysteria erroneously applied, and subsequently retained-which must serve as the reason for employing it here and because the proper name may not convey its meaning to some horse-keepers. It is a bloxl dyscr tsia which attacks horses very suddenly that lave to all appearance been perfectly well a few minutes before. The rested horse coming out of the stable after a few days of good living and 
idleness suddenly falls so "dead lame" as to make the man using him think the poor beast has broken a bone, or dislocated a joint, in a hind limls; more or less general paralysis follows and very dark, coffee-coloured urine is passed. It is by testing this fluid that we know the real nature of the malady. Albumen exists in large proportion and broken-up red corpuscles. In some cases the animal cannot urinate and a catheter has to be used. Falling down and unable to rise, the horse suffering from a severe attack of this disease fights with his fore-limbs in a convulsive way and throws his head round to the side, as animals do when suffering the pains of colic. The visible membranes are intensely red; there is a full and rapid pulse and increased temperature.

Treatment.-Prompt bleeding and a bold dose of aloes saves many a life. Slings should be improvised if proper ones are not available (they very seldom are to be got in emergencies of the kind). A large, warm bran poultice along the loins should be provided, such as a pillow-case or loose polke in which chaff is sent out, as this gives relief to pain and relaxes the cramped muscles. Further ease may be afforded by syringing warm water up the rectum from time to time, and when the aperient has acted the kidneys may be kept up to their best efforts by ounce dcses of sweet spirit of nitre night and morning. If muscular convulsions continue, an ounce dose of chloral in solution may be given as a draught. While the poultices are being renewed the loins should be well rubbed with soap liniment. A laxative diet, and that sparing in quantity, should be given. Recovery is facilitated by turning out to grass, but there often remains more or less loss of power and wasting of the muscles principally concerned.

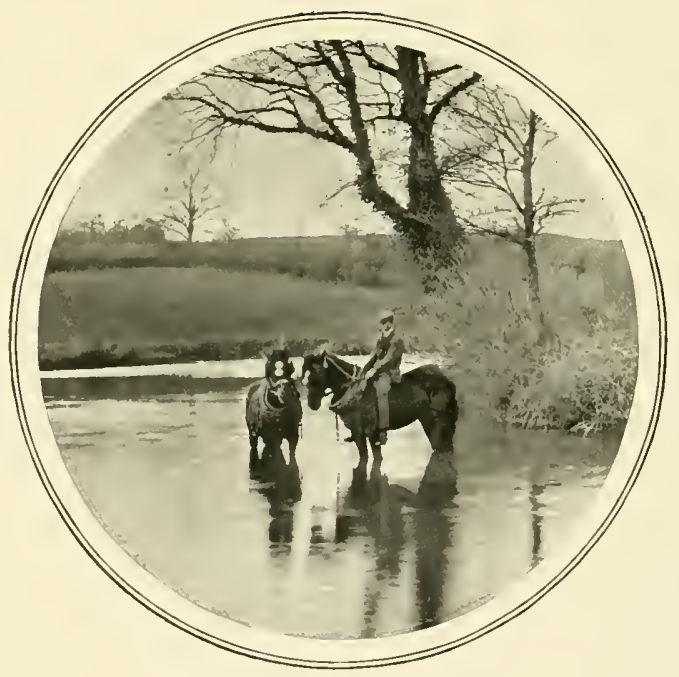




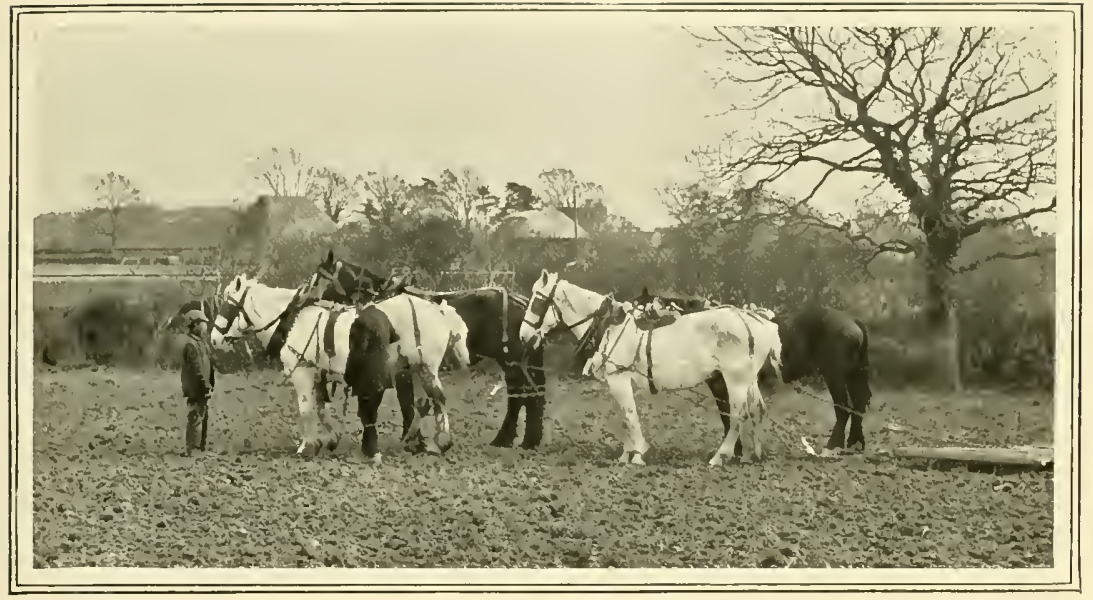

\section{CHAPTER VIII}

\section{CONTAGIOUS DISEASES}

I NFLUEN Z A.-This is a catarrhal disease of low type, and ealled in America "pink-eye," on account of the highly reddened conjunetival membrane which is a prominent symptom. It makes periodical visits to this country in the spring of the year, reappearing in autumn, and varying greatly in its intensity, and, like its congener in the human subject, displaying new symptoms, or attacking fresh organs, from time to time. Like the "flu" of human beings, also, it is ehicfly dangerous when the early symptoms are neglected, and work continued, and from the after effects, or sequelæ, when resumption of labour is undertaken too soon. Horse-keepers are agreed as to its infectivity, although it is not always eonveyed by association with diseased animals in the stable. Doubtless various degrees of resistance exist in different individuals, but a large stable in which an influenza case is introduced will almost certainly have a good many victims, and it is therefore dcsirable to isolate suspects without delay.

Symptoms. - The great distinguishing symptom of influenza is the sudden and extreme prostration, which is not present in ordinary catarrh, or even more serious pulmonary troubles. The system seems to be suffering from shock. The temperature riscs, the appetite is bad, the pulse feeble and quick, the eyelids are swollen, and the conjunctival membrane intensely reddened; tears run over the face, and sometimes, but not always, there is a running at the nose. Swellings of the head and limbs and muscular pains simulating rheumatism are often present, or the malady may affect th internal organs, attacking the liver and showing discoloured membranes, tinged yellow with bile, and hardened fæces, covered with shining mueus. A defluxion of mucus from the nose and general eatarrhal symptoms are rather to be welcomed as affording a drain, for when these are absent the lungs may take on a form of pneumonia, ending in gangrene and death. Exaggerated accounts of the losscs sustained have been published, and given rise to much unneeessary alarm. In Ameriea some seven per cent. of deaths appear to have oceurred in the great outbreak of 1872 , but this was owing to the general ignorance at that time concerning the malady, and the sending to work of animals only fit for the sick bay and the attentions of the veterinary surgeon. 
Treatment.--The essentiai thing is to place the subject of influcnza in a comfortable, light, welldrained loose-box, with good straw to encourage repose, where he will have pure air but not be subjected to draughts. He should be clothed - a hood should not be forgotten-and bandaged. Kecping up surface warmth is the way to prevent internal congestions, and it is probably for this reason that so many horse-owners have acquired great faith in whisky and other forms of alcohol. Quinine and bitters-as gentian tincture, compound tincture of cardamoms, and quassia- given two or three times a day, help to sustain the patient during the early period of shock, and probably hasten recovery. Eggs beaten up with milk, and any demulcent foods the animal can be persuaded to take, should be offered, and in some cases horned down with the stimulant selected. Where any doubt exists as to the destination of whisky or other forms of alcoliol, the owner may save his men from temptation by prescribing one to two ounces of spirit of nitrous ether, or aromatic spirit of ammonia, diluted with ten times its bulk of water. In those cases where the liver is affected, it may be desirable to give ounce doses of bicarbonate of potash, with two ounces of sulphate of magnesium, or other salines; but the horse-owner should in all complicated cases obtain the assistance of a qualified veterinary surgeon.

\section{Contagious Pneumonia}

In confined spaces, as on horse-ships and in underground stables, a form of pneumonia breaks out which is extremely infectious and frequently fatal. It has been traced to an ovoid bacterium. The conditions most likely to contribute to recovery are too often unattainable-namely, pure fresly air and good nursing. Many horses died of this disease on the ships sent to South Africa, and as a sequel to influenza and strangles, which were rife during the Bocr War. No specific can be found, and every effort must be made to sustain the animal's strength by stimulants, tonics, and suitable foods. No amateur would undertake its treatment if professional aid could be had.

\section{Glanders and Farcy}

[nti] comparatively recent years these diseases were not known to originate from a common cause, but were separately considered. Farcy is a local manifestation. It is now known that glanders and farcy are both duc to the Bacillus mallei. If this organism is cultivated on boiled potatoes, or in sterilised serum, it can be communicated to other animals. Wuch of the confusion of the past arose from the variable period of incubation and the apparent resistance of stable companions. It is also a fact that glanders may be conveyed to another horse and remain latent for a very long time. Animals, to all appearance perfectly healthy, are found when tested by mallein to react, or give evidence of the disease somewhere in the system, and such animals slaughtered and carefully cxamined after death, invariably prove to have lesions from which the bacillus can be obtained. An inoculated animal, gencrally "takes," and the period is so short in asses that they were formerly sacrificed as test animals before the discovery of mallein, subjects with "three legs and a swinger" being bought up for the purpose thirty years ago.

In this country a horse suspected of glanders will be examined by experts as soon as notice of suspicion has been given to a constable, so that the poorest owner need not remain in doubt or have to pay for advice. But there are horseowners in other parts of the world who will rcad these notes who may have to rely on their own skill and judgment to detect and climinate infected cases, or disaster may not be averted.

The svmptoms of glanders when advanced are not difficult of recognition, and consist in ulceration of the lining membrane of the nostrils, with discharge, more often from the left, but occasionally from both. It is an adhesive semitransparent matter in the beginning, but later partakes more or less of the character of pus. Under the jaw of the discharging nostril will be felt an enlarged gland, popularly known as a "jug." The discharge may exist without the corresponding enlargement of the gland, or only a bluish and suspicious membrane may indicate the disease in connection with the glandular swelling. So variable are the symptoms in the less pronounced cases that no one should decide without cither professional advice or after employing the mallein test. The horse-owner thrown upon his own resources as to diagnosis of glanders should be specially warned to avoid an error, often made for lack of anatomical knowledgenamely, that of mistaking the opening of the 
lachrymal duct on the floor of the nasal chamber for an ulcer. If the reader will examine the nostril of the first healthy horse he handles he will never forget its appearance, or fall into such a mistake. Glanders may be acute, and the sufferer in that case rapidly wastes away; or it may be chronic, when he will not be a good thriver, but may continue to perform his work and be thought to have a chronic cold or nasal gleet (see CAtarrh, page 773 ; also NASAL GLEET, page 474$)$, and these are the dangerous subjects which pass on the disease from place to flace.

Farcy shows itself most commonly in swelling of the lynuphatic vessels of the skin, in which the limb participates, and so-called "farcy buds" form and break. These "buds" in the skin are of the same nature as the ulcers upon the membrane in the better defined forms of glanders already mentioned. Ifuch confusion has arisen with regard to farcy, as the old-time farriers called lymphangitis "water farcy," and some of them failed to distinguish between true farcy and this inflammatory odema, which is dealt with in another place and called, among other names, "Monday morning leg" (page 528). The same practitioners in coaching days saw but little connection between farcy and glanders, although recognising the fact that glanders often followed, in the same way that we now recognise many diseases invading a constitution already debilitated and ultra-susceptible. References will be seen in many parts of this work to sequelæe of strangles and influenza, which are not symptoms, or even aftermaths, of those specific diseases, but whose germs find prepared soil in the weakened animal. It was thus that the old practitioners regarded glanders when it followed on farcy. Their success in controlling both farcy and chronic glanders also hindered them from a true perception of the fact that farcy and glanders are one. Glandered and farcied teams were kept on the road by administration of mineral tonics, which for a time have a powerful influence upon the lymphatics, and even appear to effect a cure, but these practices are now done with, and no one is allowed to treat. but must declare the presence of either form of the disease, whether glanders or farcy, and we need not occupy further space beyond such as will enable us to deal with the mallein test.

The Mallein Test for Glanders. - In a broth, with five per cent, of glycerine, the bacillus of glanders (Bacillus mallei) is cultivated at a temperature of $100 \mathrm{deg}$. F. for three to six weeks, then sterilised by steam, and filtered through unglazed earthenware, in order to separate the bacilli. Only their products remain in the pale sherrycoloured fluid, but the effect of injecting them into the blood of a horse already glandered is such as to raise the temperature and produce a swelling around the puncture, with characteristic lines leading out from the diffused tumefaction. It must be seen to appreciate its exact meaning, but there is all the difference between an ordinary little puff or lump such as would follow a prick from an unclean needle, and the typical enlargement which follows on mallein injection. Ordinarily a needle puneture from a sterilised hypodermic syringe will show no mark a dozen hours afterwards, and if sterilised water or other innocuous fluid is injected, it will have disappeared twenty or thirty hours later-probably very much sooner; but a mallein swelling persists and increases for a varying period of twenty to forty hours before gradually diminishing. The type of swelling, taken together with a rise of temperature of two or more degrees, enables the operator to decide whether or no the animal is a subject of latent glanders. It may be here stated that there is no comparison between the tuberculin test for cattle and the mallein test for horses. liany beasts give a doubtful reaction, or fail to indicate the true condition, but mallein is so nearly certain that veterinary surgeons advise slaughter of valuable animals on its evidence. It is most desirable that the animal's temperature should be taken two or three times before testing, and that he should be free from other disease; but mallein is so reliable that the characteristic reaction can only be induced when glanders is in the system. Trials have been made with the subjects of pleurisy, nasal catarrh, and gleet, without producing the typical swelling.

\section{Strangles}

An infectious disease of horses, chiefly affecting the young, and characterised by symptoms of fever, discharge from the nose, sore throat, cough, and a swelling of the glands and tissues under the jaw, commonly resulting in abscess. Twoand three-year-olds are particularly susceptible, and in some seasons the disease is very infectious. In infectivity it varies so much that some doubt was entertained at one time as to its transmissi- 
bility at all, but this has been settled by Sihutz's discovery of a streptococcus which, when cultivated, produces strangles in inoculated horses. Horses, asses, and mules are al! subject to strangies, and the discase may occur in colts a few weeks old, or in aged horses, when it is called bastard strangles, and does not often take so acute a course as in the youngster at grass, with the additional trouble of changing his teeth. During the formation of pus under the jaw the animal is often very ill, a high temperature depriving him of appetite, if he is not prevented from eating by the pain and pressure against the floor of the mouth. The colt pokes his head out to relieve the tension, and unless relieved stands for hours together in an attitude of tame resignation to fate.

The abscess ripens in time, points, and breaks; a large quantity of pus escaping and affording immediate relief, after which recovery is the rule and in a comparatively short time. So rapidly do colts put on flesh after strangles that horsebreeders may be heard to say that it does them good to have the malady. There are exceptions to this rule, and it sometimes happens that pus gets into the circulation and causes pyæmia (see page 5I ), leading to other abscesses in distant parts, and occasionally in the brain (see StAGgERs and MIA Staggers, page 493). Blood discases, and purpura hremorrhagica, may follow on strangles which for a short time leaves the animal highly susceptible to many constitutiona? discases.

Treatment.-The disease has to run its course, and good healthful surroundings are the chief matters to be attended to. There can be no doubt, however, that efficient poulticing cuts short the period of pain and inability to eat, and thereby saves some of the subsequent prostration, as the abscess will ripen, and may be lanced much sooner for such treatment. The abscess of strangles, although due to a specific disease, runs the same course as other abscesses, and it may be worth while here to say that premature lancing of such swellings is worse treatment than non-interference. Abscesses "point" or show more prominence at one place than over the general swelling, and if felt at this part are found to have wasted the skin underncath, and yickl to pressure, the matter fluctuating under such pressure. Here it is that the lancet may be judiciously plunged. The operator should be bold. and do all that is required at one stroke. thereby causing less pain, effectually letting out the mattcr, and leaving the least possible blemish afterwards. Syringing out the cavity left wirh a weak carbolic lotion favours recovery, but the continuance of poultices is not desirable. If flies are about it is better to smear the parts with an ointment composed of one part Stockholm tar and three parts lard. Colts recovering from strangles profit by iron and gentian, given as a powder in the food, previously made damp

\section{Anthrax}

This disease is unfortunately of greater frequency in this country than formerly, and may be attributed to the importation of hides from the Persian Gulf and from Soutl American countries, where it is prevalent and ineradicable. It is due to a specific organism (Bacillus anthracis), which may be conveyed in forage as well as in animal products. It comes on very suddenly, the animal showing the ordinary symptoms of fever, quick breathing, higil temperature, rapid pulse, a staggering gait, and sometimes colicky pains, swelling of the throat, and, later, of the chest, and breaking out into a sweat. Death takes place in a few hours, never extending over thirty, and oftener in less than half that time. No treatment is of use, and our efforts must be directed entirely to prevention. In outbreaks of anthrax a very thorough investigation should be made of all possible sources of infection, and if foreign corn or hay has been purchased samples should be examined microscopically and inoculations made of guinca-pigs and rabbits, for which a virisection licence is necessary. An affected animal should be immediately removed, and the carcase burned or deeply buried in quicklime, but this must not be done in England without notice to the police, who undertake to see that the various regulations are carried out. The animal must not be skimned, but buricd wholea very wise precaution, as it prevents the infected blood from being spilled, and the risk of human infection if the slinner happens to get a scratch, anthrax being extremely infectious to human beings and frequently fatal.

\section{Horse-Pox}

Ar eruptive discase, occurring about the pasterns, and sometimes upon the nose and lips, 
and characterised by the formation of resicles, or little bladders, which soon break and coalesce, forming a serous scab. It is a comparatively benign disease and of rare occurrence. Its interest to the pathologist consists in its relation to cowpox, human small-pox, and the raceine disease intentionally induced as a preventive of smallpox. It was asserted by some of the early opponents of vaccination that the virus employed by Jenner was from the horse-pox, and by others that it was from the greasy heels of horses suflering from the malary known as grease. It is still thought by some that inoculation with horse-pox gives immunity to man from small-pox.

\section{Rabies}

Rabies, miscalled hydrophobia in animals, is occasionally met with in horses as the result of a bite by a rabid dog. So far as Britain is concerned we may say it is no longer met with, for, thanks to Mr. Long's ability to bear abuse and persist in the muzzling order, rabies has been stamped out in this country.

The symptoms in the horse are those of nervous irritability, biting the manger, or other objects within reach, and sometimes attacking the attendant; swallowing pieces of wood, or bones, and anything lying around; perhaps biting the skin where inoculation took place; great thirst (the dread of water or the sound of it is peculiar to man suffering from hydrophobia); muscular spasms, resulting in a fall, have been observed in a rabid horse when making an attempt to bite a whip held out towards it. After remaining on the ground a few minutes the spasm passes off, and the animal gets up apparently recovered from the fit. The recurrence of spasms of the throat and neck ultimately cause death, or general paralysis may supervene before the end comes. Horses with rabies have been known to live a week, but four days or less is more common. As the discase must prove fatal the right thing to do is to shoot the sufferer as soon as diagnosis is confirmed.

\section{Tetanus, or Lock-Jaw}

The frequency of spasmodic contraction of the muscles of the jaw and inability to open the mouth to any extent gave this disease the name of lock-jaw, or locked jaw, and it was known to follow wounds, especially the punctured variety, and such as occurred about the feet (sce Nounds, Ch.upter XI1.), and a raricty of theories wre entertitined. We now know, however, that it is due to the entry into the tissues of a micro-organism. the Bacillus tetani. Idiopathic or self-developed tetinus was believed in, as there are cases in which it is weli-nigh impossible to trace to some tiny prick or abrasion an entrance gate, but medical authorities are agreed that withont the organism tetanus is not produced. The organism belongs to the class of anaerobic bacilli, or such as cannot grow in the air, a fact of some importance in the treatment of wouncls, as will be seen later. In those cases where, after the minutest examination, it is impossible to find a wound or puncture, it may be conjectured that the bacillus has been taken in the food, and found its way into the blood, as do other malignant germsand as tubercle is now chiefly believed to gain access-but of this we have no positive proof. The writer remembers a little boy of the streetarab type who died of tetanus, and no wound or abrasion could be found until ane of the surgeons scraped off some thick skin on the boy's heel, underneath which was found one tiny drop of matter, and in that matter the specific organism. How much easier, then, for a thorn-prick to escape our observation in the hair-covered horse !

It is notable that the bacillus, when it has entered a wound, does not invade the whole animaj, but locates itself in the bottom layers of the wound. This has a particular bearing on broken knees, from which tetanus is more often dereloped than from other wounds, save those of the feet, and the discovery of this fact has led to the more thorough irrigation of wouncls of the knees with disinfectants; indeed, horses have been saved after tetanus has manifested itsolf by probing down to the bottom of the wound and removing the surface granulations and discharges, and destroying the bacilli in their home. It is not the organisms themselves that cause tetanus, but their products.

Symptoms.-Professor Axe, in his standard work on the horse, says that these are observable "from ten to sixteen days after the introduction of the infectious material," but the writer has seen it follow on pricks caused in shoeing, and in bulls, after castration, in five days. There is a peculiar stiffness in the muscles of the head and neck, and a difficulty in taking hold of food, and the legs are drawn nearer to each other under 
the body. The tail is cocked or held on one sirle (this symptom is often noticed before the others), and the drawing back of the cye into its socket, which causes the haw to protrude, or rum along the front of the globe, like that of a sleepy parrot or a sick cat. This is a common symptom of debility in felines and birds, but it is not performed in the spasmodic or jerky manner of tetanus. The appetite often remains, and eager attempts are made to take food until the advanced stages, when the whole muscular system is involved, and the entry of a person into the stable may prove sufficiently exciting to throw the animal into a fit, during which he falls upon the ground. The excited breathing and dilated nostrils add to the appearance of anguish, and many a humane man has prescribed a bullet without waitıng for further developments. Death generally results in a week, but a sufficient number of cases recover to make it worth while to use mcans. Some lapse into a somewhat chronic condition and gradually recover, while still subject to spasms of lesser violence.

Treatment.--Perfect quiet should be maintained, the animal being placed in a roomy box, of which the attendant alone has the key, and he should only make absolutcly necessary visits. Slings may be desirable in selected cases, but some horses are made worse by feeling themselves restrained. Soft foods, as gruel and green-meat chaffed, carrots and other "roots" can often be caten, as the mouth in the majority of cases is not shut like a vice, but with difficulty opened a short distance; morcover, horses soon learn to suck up sloppy foods as pigs do. Water should be kept near the patient in a position most easy of access. The body should be clothed and the limbs bandaged, but here, again, some horses are annoyed by bandages when not accustomed to them, and in such case they should not be employed. An anti-tetanus serum has been cmployed with doubtful success. The time to use it is before the discase is manifest, and it is of doubtful utility afterwards. Large doses of sedative medicine, as chloral and morphia, have a controlling influence, if they can be administered without provoking more excitement than they allity. They are most easily digested in the form of suppositories, introduced into the rectum. A large proportion of deaths may be looked for, despite the best of medical treatment and nursing.

\section{Stomatitis Pustulosa Contagiosa}

This long name is given to a disease which has no popular one. It is a specific infectious fever, characterised by an eruption in the mouth, on the lips, and sometimes the face and more distant parts of the skin. The period of incubation is about three days, and its duration from ten to twelve days. The young are most susceptible. Infected food and stable utensils are the means of propagation. Immunity from a second attack lasts an uncertain time. Much inconvenience is experienced, but it is seldom a fatal disease.

Symptoms,-Slight elevation of temperature, but no very marked fever, or greatly increased number of the pulse-beats. In a day or two the mouth is observed to be sore, a sticky saliva comes from it when feeding, and there is more or less difficulty in grinding the food. The bright red colour of the membrane of the mouth is interspersed with little pimples, these occurring on the inner surface of the lips, the tongue, and the gums, often in the order we have stated, or they may appear simultaneously, and extend to the skin around the angles of the jaw and upon the muzzle. The pimples have a character of their own, whether in clusters or scattered about the membrane and skin; each fills with matter, breaks, and leaves a sharply defined ulcer. When these extend to the inside of the nostril they must not be mistaken for the ulcers of glanders (see GLANDERS, page 532).

Treatment consists in the provision of soft foods, as bran mashes and roots, scalded hay, etc., and small doses of nitrate of potash in the drinking water. An ounce of bicarbonate of potassium daily, dissolved and mixed with food, is also recommended, and topical applications of chlorate of potash and alum as a weak iotion. If the ulcers prove languid they may be touched up with a crystal of alum, which soon promotes repair. Separation of the aftected animals is important to remember, and the disinfection of mangers and buckets used by them.

\section{Dourine, or Maladie du Coit}

This infectious disease is of such rare occur. rence as to call for no special notice beyond a warning to see that brood mares are not placed in danger of infection, and immediately to cancel any engagements by a stallion suffering from it. 
It does great damage on the Continent of Europe, but genuine cases of it in Britain can hardly be said to have occurred. The better sanitary regulations instituted abroad during the last few decades have nearly done away with a disease which is a disgrace to any country.

\section{South African Horse Sickness}

Of the infectious nature of this disease there can be no doubt, or of the grave losses it causes in what may be regarded as its home. Quite a staff of veterinary surgeons are employed in investigations on the spot, and a protective scrum will no doubt in time be obtained; indeed, claims have been made that such a "vaccine" has already been discovercd. Injections of iodine into the trachea appear to succeed in some cases. So generally fatal is the malady that a horse that has had it and becomc immune is known as a "salted" onc, and his value is very greatly enhanced, especially in the districts most subject to the disease.

\section{Epizootic Lymphangitis}

This is another of the South African infectious maladies which militate against the prosperity of the sub-continent, and after the Boer War some infected subjects were brought home. Isolated cases applucared from time to time, but it is now thought to have been stamped out by the measures instituted by the Board of Agriculture. Any sort of wound or abrasion over which an infected brush may be used will be sufficient to induce the discase. A large number of vetcrinary surgeons have never secn it, and it must not be expected, therefore, that the amateur in horse doctoring will recognise it. It is very unlikely that he will be troubled by it. If anyone is unfortunate enough to have a suspected case he slould report it to the nearest police officer.

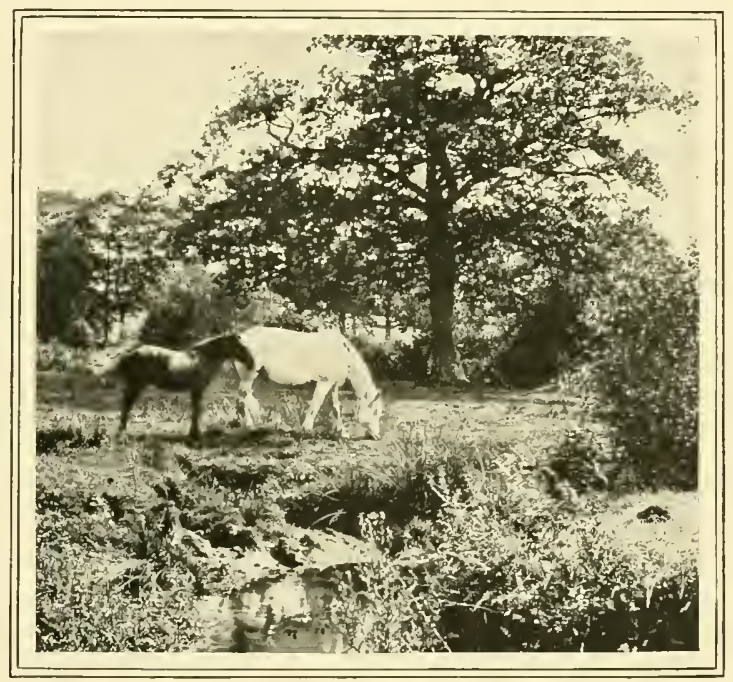




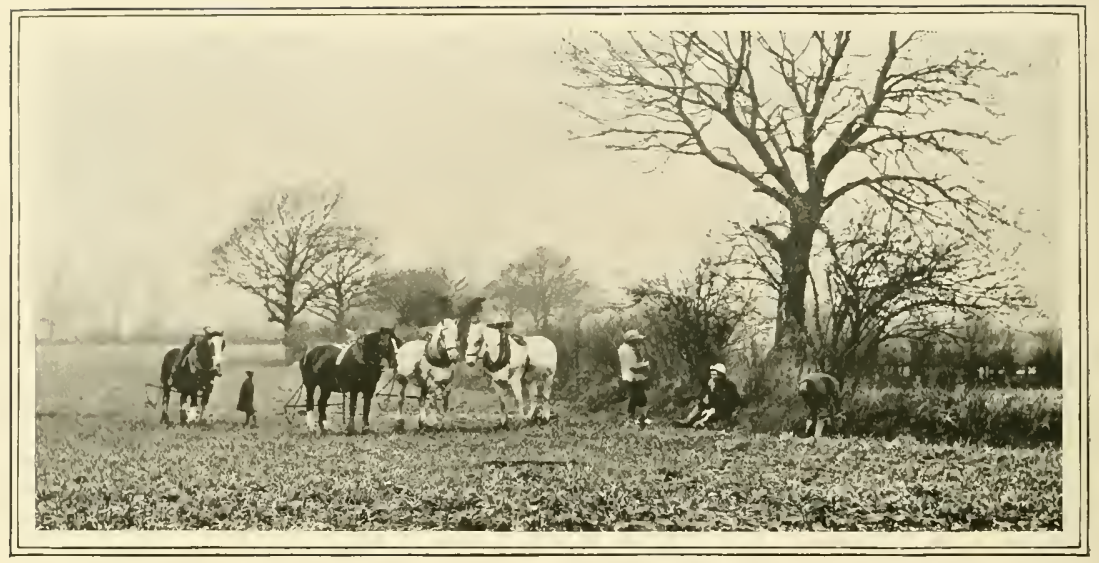

\section{CHAPTER IX}

\section{DISEASES OF THE REPRODUCTIVE ORGANS}

$\mathrm{P}$ HYMOSIS. - The day after birth this trouble is discovered in foals, from a very simple cause that is easily remedied. The inability to extrude the penis and pass urine is due to the folding back of the organ within the sheath, and all that is necessary is to introduce an oiled finger and release it. If not soon detected the young creature suffers from distension of the bladder, and postures as if to urinate, but fails to do so. Any difficulty of the kind should be promptly attended to, or it may prove fatal. The colt must be caught and thrown upon his side in order to carry out the instructions above given. Swelling of the part often seriously hinders an operation which we have described as simple if undertaken early. Phymosis in adults is caused by injuries in jumping, by kicks from other animals, by gores from bullocks at pasture, and as a sequel to castration, when great swelling follows and insufficient attention has bcen given to the cleansing of the sheath and lubrication of the penis with lard or other unguent. The gelding is much more liable to this trouble than the entire horse, as the sheath does not grow to the same extent after emasculation, and the secretion of unctuous matter, intended to facilitate the use of the organ in copulation, is altered in character in the gelding, often accumulating as a dark, thick, waxy substance, and at times proving irritating when it should be the reverse. This matter, which is vulgarly called "cod wax," and employed to fill up sandcracks and other defects of the hoof by horse-copers, occasionally causes phymosis, and the animal is observed to straddle and make frequent ineffectual attempts to pass urine. At grass, horses are sometimes stung by wasps or bees, and such swelling follows in the loose tissucs of the sheath that phymosis results. Stones lodged in the canal, low down, may also give rise to this condition. In all there is the symptom of swelling, which can scarcely fail to attract attention, and this usually precedes any serious difficulty in micturition.

Treatment may be commenced by warm fomentations, and followed by free inunction of lard to the skin outside. A greased hand should be introduced into the sheath, and the accumulations of sebaceous material patiently removed, pushing up more and more lard or vaseline to further soften what remains. If by this means the animal is able to urinate freely, the operation may be completed next day by syringing out 


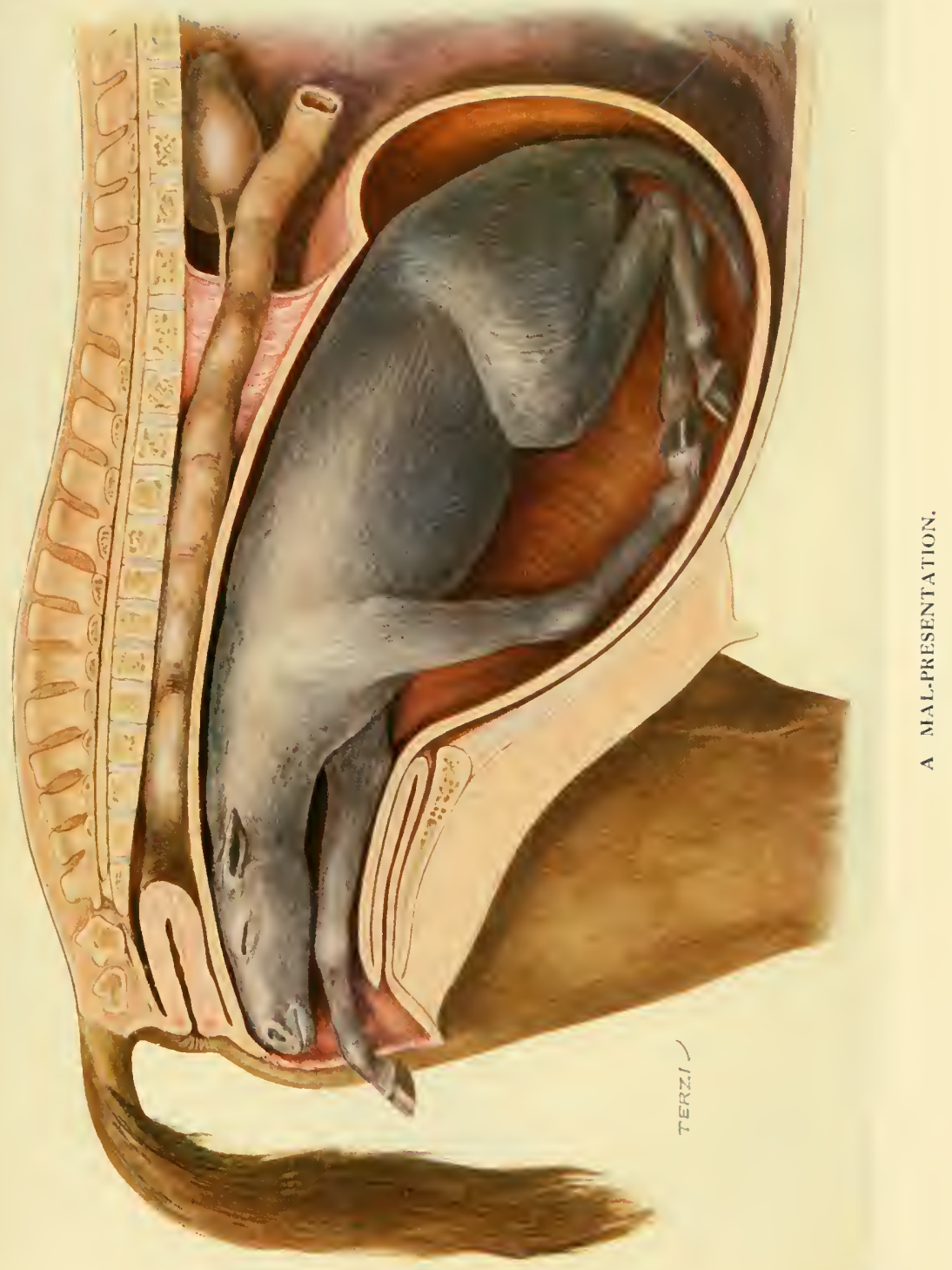





\section{DISEASES OF THE REPRODUCTIVE ORGANS}

with neutral soap and abundance of warm water, and finally introducing a little more lard, free of salt. It may be necessary to do this two or three times in a year in individual cases, but usually the trouble does not recur for a long time-perhaps not at all.

\section{Paraphymosis}

Inability to retract the penis when unsheathed is known as paraphymosis, and occurs as a result of debility, old age, swelling of the glans penis, the descent of calculi (see CALculr, page 5or), paralysis, and inflammation resulting from sexual relations in stallions. The symptoms are unmistakable and often alarming, as the swelling attains to the size of a man's head, and cren larger. The inflamed state of the organ, unless quickly relieved, is a cause of great pain, and from a red it passes to a purple colour, and mortification may follow strangulation. In the chronic paraphymosis of paralysis the enlargement is comparatively slight and unaccompanied by pain.

Treatment.-If from debility, good food and mineral tonics, as iron and nux vomica, but in every case efforts should be made to return the organ after careful lubrication and the removal of accumulations as recommended in connection with the opposite condition of phymosis. When returned, cold evaporating lotions assist in contracting the lax tissues. In severe cases the organ cannot be returned without previous reduction by scarification, or the making of numerous lancet punctures, whereby a quantity of serum and a little blood is withdrawn, and reposition faroured. A broad suspensory bandage passed under the sheath and over the back, supporting the weight of the swclled organ, will do much to relieve the strained ressels and restore circulation. Exercise farours absorption and better circulation, but must be given with judgnent, not forcing an animal with swinging and heavy penis to injure it by further strain. IIorbid growths must be operated upon and removed, and calculi extracted or cut down upon.

\section{Edema of the Sheath}

Great swelling of the sheath often takes place without any serious interference with urination, or resultant paraphymosis or phymosis. It is a simple infiltration of the watery constituents of the blood into the loose tissues which constitute this part of the animal. A local form of dropsy. and of common occurrence in heavy draught horses when standing idle. It may be a sign of age, of debility, of exhausting disease, of hcart failure, or imperfect action of the liver, of accidental injury, of the accumulation of wax (see PHrmosis, page 538 ), or poverty and bad living.

Treatment.-Exercise usually clcars it up in the simpler cases, but in others it persists. Cleansing with soap and warm water and generous and repeated lubrications with vaseline or lard are advised, and the administration of mineral tonics, together with diuretics. A ball, consisting of two drams of Venice turpentine, two drams of soap, two drams of nitre, a dram of sulphate of iron, and enough powdered gentian to make the bolus, is a very useful one for cases of the kind, or flowers of sulphur, and nitre and sulphate of magnesium, may be given in a bran mash, where the attendant is not expert in giving a ball.

\section{Paralysis of the Penis}

The causes are often difficult to ascertain, and treatment of little avail. If recovery does not take place spontaneously, it is usually bes: to amputate such a portion as may suit the particular case, leaving enough for micturition without the risk of scalding the sheath, which will follow if the penis is too much shortened. The operation is quite commonly successful.

\section{Orchitis or Inflammation of the Testicles}

The average horsc-owner is not likely to be troubled with cases of this kind, but those who breed horses, or keep entire animals, should know how to give first aid when injuries by the kicks of mares or bruising during the leap, or in other ways, sets up an inflammatory condition of the essential organs of reproduction in the horse. The symptoms are those of febrile disturbance and pain, straddling gait, and tenderness over the loins with swelling of the organs, and tensc shining slin of the scrotum. Abscesses may form when the injury is severe, or sloughing of a testicle and portion of the scrotum. Treatment is directed to reducing the temperature, by salines internally; fomentations and pouftices of the parts inflamed, affording support by cotton wool and bandages, and antiseptic lotions where the 
skin is broken. Unless these measures succeed it may be nccessary to castrate the animal in order to save his life. As entire horses are of great value for breeding purposes, this will only be entertained as $u n$ dernier ressort.

\section{DISEASES OF THE FEMALE ORGANS OF REPRODUCTION}

\section{Flooding, or Uterine Hæmorrhage}

This accident follows on premature labours or abortions ; after difficult parturitions, in which diate measures to cope with it. The womb cannot contract while the placental membranes, or afterbirth, are retained, and we must depart from the usual rule of non-interference where bleeding is evident, and seek, with a hand dressed with carbolised oil or other suitable antiseptic, to remove it by gentle traction, making sure that none is left behind. The removal of the placental membranes often secures the desired result, and blceding ceases. It may be necessary to inject cold water, or water hotter than is usual for other purposes-both have a styptic influence. We

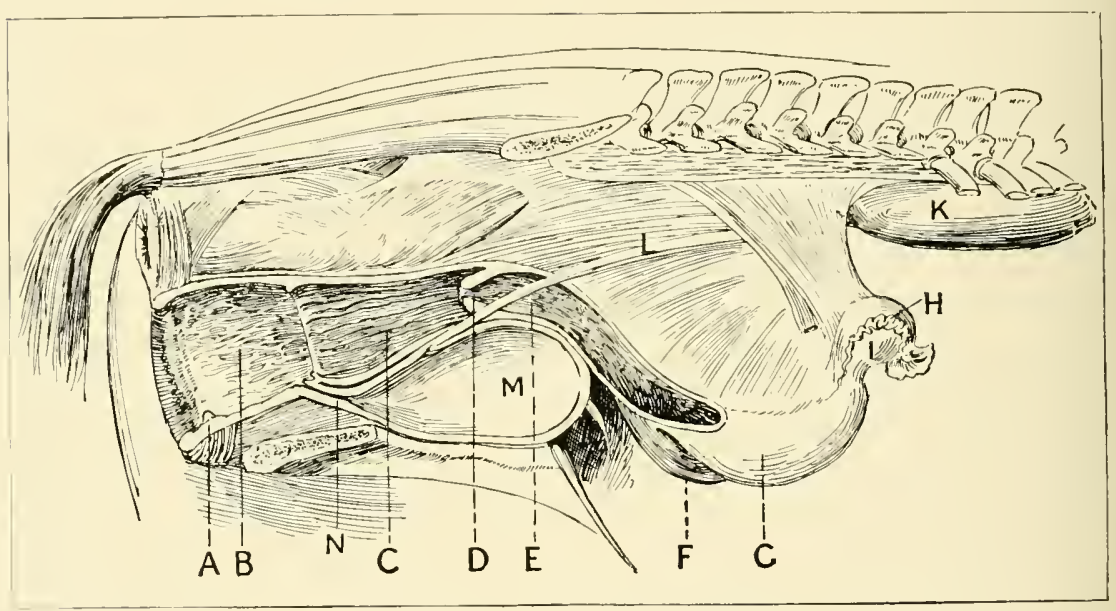

THE ORGANS OF GENERATION OF A MARE, PARTLY LAID OPEN.

A. Clitoris. B. Vulva. C. Vagina. D. Os uteri, E. Uterus. F. Left horn of uterus. G. Right horn of uterus. H. Fallopian tube. I. Ovary. K. Kidney. L. Ureter. M. Bladder. N. Urethra.

forceful delivery has bcen accomplished by the accoucheur, and probably in some cases from weakness or thinness of the uterine walls, as it occasionally follows on perfectly natural deliveries, and with no known cause of strain or excitement. The appearance of blood from the vulva is commonly preceded by cold shivering fits and trembling, pallor of the visible membranes of the eye and nostril, small quick pulse, and the symptoms described under hæmorrhage (see page 475). A large amount of blood may be loose in the cavity of the uterus before it overflows from the vulva, and inexperienced persons may not suspect the true state of affairs. They should be warned, then. that any of the signs of weakness and trembling alluded to may mean hæmorrhage, and take imme- are, however, confronted with a choice of evils. If we allow Nature to arrest hemorrhage by the formation of clots, we leave a secd bed for the multiplication of septic germs, which frequently cause the death of the mare. If we continue to wash out the nterus with antiseptics we retard closure of the bleeding vessels. Of the two evils we choose the latter as being the least, but employ such substances as tannic acid and glycerine, or tincture of iron diluted with water, or weak vinegar and water, and hold up the mare by giving alcoholic stimulants. The extract of witch hazel is a good remedy for this purpose. The administration of ergot, so effectual in human flooding, is practically useless in mares, the drug being inert in this connection. 


\section{Inflammation of the Womb (Metritis)}

Following on difficult labours, and often without any obvious cause, inflammation of the womb occurs in mares. Acute, sub-acute, and chronic forms of this discase are recognised. All may be going well with mare and foal, and the usual affectionate relations established, until the end of the second day, when a shivering fit and staring coat is followed by loss of milk, small and irritabie pulse, and increased temperature. Reddened membranes, pasty tongue, cold legs, and whisking of the tail indicate inflammation and some degree of pain. Some mares strike at the belly with a hind foot, as in colic (see CoL1c, page 496), are lame from muscular cramps, and indisposed to lie down, or fear to do so. The distension of the uterus with a thin yellow or reddish discharge may be felt in the flank, and seen to overflow from the passage. The labiæ are often tumefied in sympathy, or the swelling of the external genitals may have been caused in delivering the foal. The peritonemm is often infected (metro-peritonitis), with the result of abdominal distension, and roundness. Fever in the feet (laminitis) may supervene, when there is usually some relief caused by the diversion (see Peritoxitis, Pleurisy, etc, page $4^{8}$ ). If the acute form does not cause the death of the mare, a modification of the symptoms follows, and the malady persists in the sub-acute form, or becomes chronic, when the discharge continues, and there is no return of milk. Wrasting and debility and false appearances of ostrum characterise this condition of the mare.

Treatment.-Much may be done by copious injections of antiseptics, combined with emollients and anodynes, as two or three per cent. of pure carbolic acid, with four or five per cent. of glycerine, and two per cent. of aqueous extract of opium, or the extract of belladonna rubbed down and mixed with the water, at a little above the temperature of the body. Nutritious but laxative foods should be given, and constipation guarded against by mixing linseed oil with mashes.

\section{Vaginitis, or Inflammation of Vagina}

This commonly occurs in association with metritis, last described, but may be independent of it, and caused by difficulties in delivery, such as pressure long continued, and injudicious pulling at the foetus during a dry labour. If the 69 nombrane is wounded by the finger-nails, by the use of ropes or instruments, blood-poisoning may ensue.

The symptoms are swelling about the orifice, the niembrane showing red, constipation, feverishness, and groaning after passing water. The discharge becomes more like pus, and less like ordinary vaginal mucus, about the third day. This matter is apt to excoridte the skin, and cause the lair to come out, which should be guarded against by the use of a simple unguent.

Treatment.-The exposed parts may be carefully sponged with a soothing antiseptic, as carbolic acid and glycerine, diluted with water, and the interior treated by syringing, but great care is necessary in introducing the nozzle of the instrument to avoid hurting so sensitive a membrane when inflamed. In the simpler cases, recovery soon takes place, but in others patches of membrane slough away, or ulcers form, bloodpoisoning ensues, or a chronic discharge known as "whites" remains. Ulcerated conditions are best treated by solutions of ahm, which are most effective where mucous membranes are concerned, whether of the moutl or genital apparatus.

\section{Leucorrhœea, or "Whites"}

A chronic discharge from the vagina varying in consistence and odour. It may be quite a simple and inoffensive but viscid matter, or partake of the foetid and purulent character of decomposing animal substances. As a result of parturition difficulties, it has already been referred to, but in many debilitated old mares it is seen without any such previous history. A course of mineral tonics, as sulphates of iron and copper. together with quinine and gentian, will be found efficacious in many instances, and this treatment should be accompanied by daily syringing with some astringent, or a change of astringents, as three per cent. of alum in water for a week, then a similar solution of iron, of sulphate of zinc, and of carbolic acid. Occasionally chronic cases will yield to a mixture of the three sulphates, when they have failed singly. Good sound oats and hay, bran mashes and linseed, a comfortable home, and no more than moderate work, facilitate recovery, but despite all remedies a few cases persist, and only daily attention will 
keep the subject presentable in the public thoroughfares.

\section{Mammitis}

Inflammation of the udder is a serious matter, as it so frequently results in loss of the foal and permanent damage to the lacteal glands, which will interfere with the career of the animal as a brood mare. Over-distension with milk, chills from east winds, lying upon cold ground, standing of imperfectly formed milk Fomentation of the udder, and the inunction of camphorated oil and simple ointments, as spermaceti or marsh mallow, relieve the tension and help to restore function, and we can draw off the milk or degraded products of the bag with finger and thumb. Attention to the above details will restore the majority of indurated udders, but there are others in which an abscess will form, or death of " a quarter," as each separate compartment of the udder is called. It is a "quarter" in a cow, but in a mare it is "half." It is possible to retain the function of one side or half of the udder, although an abscess is forming in the corresponding portion, as they are quite separate compartments. If abscess is present it should be poulticed and fomented to encourage a "point," or thin place, where it may be lanced when ripe, the matter allowed to escape, and the in draughts, impervious teats, fear, and excitement, are among the causes, and possibly also obstructions in the great veins.

Symptoms of inflamed udder are shown in swelling, heat, extreme tenderness, a shining skin, fever, and loss of appetite. Before these are observed the probability is that the owner's attention has been called to the dam's unwillingness to allow the foal to suck. The manner of foals is to bunt the udder to make the milk flow, and this action is extremely painful in mares with any degree of inflammation of the gland. Some ticklish mares kill their foals when so approached, and the breeder of horses will at this critical period be watchful while there is any doubt of the mare's regard for her offspring. As to removal of the foal, much will depend upon circumstances. If the udder is merely overstocked or congested, or the teat does not draw properly, the foal may be our most valuable assistant, if protected from injury by the dam, while sucking the hardened organ. Nor is the foal very likely to suffer by taking a small amount cavity syringed ont with a disinfectant solution, after which it rapidly heals up, but is rarely of further service for milk production, and only in exceptional circumstances will the risk be taken of putting such a mare to horse again. In addition to the local measures already advised, cooling salines, or even a purgative dose of aloes, may be deemed desirable. The teat siphon, so useful in cows, is not easy of employment in mares, owing to the small size of the canals, bnt in Shires, and others of the larger breeds, it may sometimes be used with advantage.

\section{Parturient Fever}

This disease is caused by the absorption into the circulation of septic organisms in connection with the diseases already considered (which see). It is ushered in by rigors, or shivering fits, and a rise of temperature, loss of appetite, suspended milk secretion, decreased size of the udder, shallow respiration, pasty mouth, and coldness of the ears and legs, or variability in their temperature. 
Abdominal pain is shown by striking at the belly, looking round at the flank, whisking the tail, and the expulsive efforts which accompany the extrusion of the fotal envelopes. Swelling of the vulva and a variable discharge, pale yellow to chocolate in colour, arching of the back, and evident cramping pains in the hind limbs, are present in most cases. The mare usually succumbs inside a week. The prospects of recovery largely depend upon the industry and intelligence of the nurse, in repeatedly irrigating the womb with warm dilute antiseptics. Large doses of quinine and alcohol have an inhịbiting effect upon the septic germs. Breeders are advised to use every precaution to prevent this disease, by attention to detail, and removal of all causes, particularly to the antiseptic dressing of any abrasions of the genital canal incurred in delivery.

\section{Inversion of the Uterus}

During the straining efforts of foaling, the attachments of the uterus sometimes give way, and the birth of the foal is followed by eversion of the womb. It is an alarming accident, and the great volume of the viscus makes it somewhat difficult to deal with, and extremely liable to injury and septic invasion before it is possible to repose it ; moreover, the prospects of obtaining professional assistance in time are rather remote, and for this reason the owner should be able to afford first aid, while an urgent message is despatched to the veterinary surgeon stating the nature of the call. First the mare should be restrained from movements which may injure the exposed parts. A clean sheet should be obtained, and also some disinfectant and tepid water. Three or more men should be pressed into the service. One to the head and another at the side: one on either side of the rump supporting the viscus in the sheet while it is carefully sponged clear of any gathered straws or rubbish, and repeatedly moistened with the weak solution. Any of the recognised disinfectant fluids will do, but care must be taken to use them in the proportions recommended by the makers. If professional aid is soon forthcoming, it may be as well for the men to sustain the burden until more expert hands are ready to replace the uterus. If not, the womb should be held well up while the operator endeavours with both hands to return it by a continuous but gentle pressure, never yielding to the throes of the patient, only ceasing tor the moment to push against them. Needless to say, his hands will have been soaked in the disinfectant, or, better still, in carbolised oil, which will aid in the lubrication of the parts. The great obstacle to the return of the womb is its weight, and the necessity will be seen for the support by the shect, which will enable a handy man to get back the viscus by steady pressure. Those who have had experience of this task will agree that it is not so difficult to replace it as to retain it in position. The oiled hand should be allowed to remain a few minutes after all is put back, and one of the men should squecze the mare over the withers with his hand. In the absence of a proper clamp, large sutures may be passed through the lips of the vagina, taking plenty of hold so that the risk of tearing out is lessened. When this accident occurs in the absence of the attendant, it may be found so swollen that return is impossible without a few lancet punctures to let out the accumulated fluid. An ounce of chlorodyne or two ounces of laudanum may be given in water, and the animal should be made to stand lower in front than behind, and be watched for a few hours and prevented from straining by pressure over the withers, and, if need be, by a second dose of the anodyne. If the membranes have not been injured by the operator's finger-nails, or by contact with walls or floor, there is a fair chance of recovery, but metritis or parturient fever is liable to follow: In attempting the delivery of foals, and on all occasions when the hand has to be introduced into any of the passages, care should be taken to wash and trim the finger-nails - an operation particularly necessary with men accustomed to manual labour and having hard and insensitive hands and strong nails.

\section{Diseases of the Ovary}

Many mares which prove sterile are the subjects of ovarian cyst and show false symptoms of westrum at irregular intervals. In some, faults of temper follow, and it becomes necessary to operate for the removal of the growth. It is attended with some risk, but may be the only means of rendering the animal of service. 


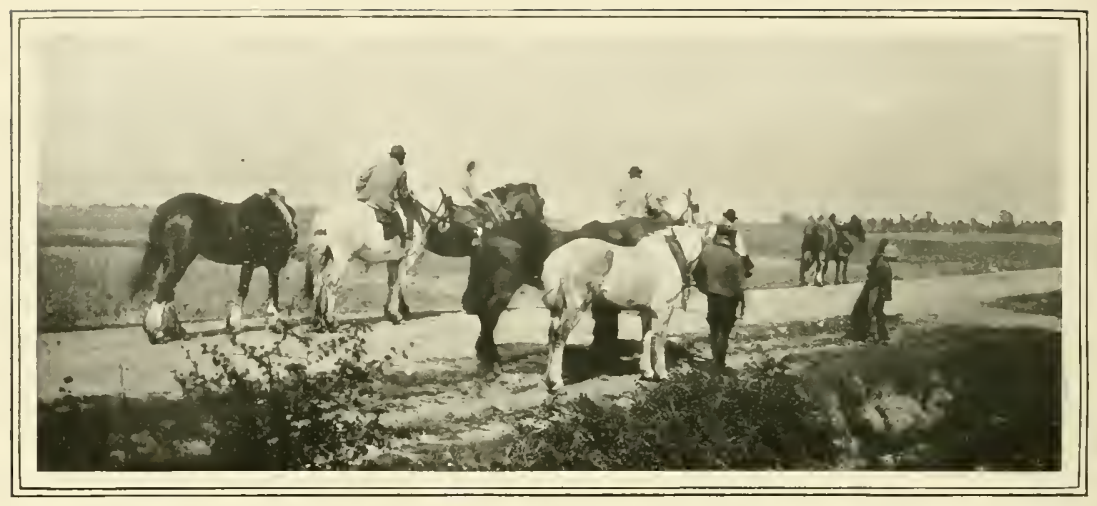

\section{CHAPTER X}

\section{DISEASES OF THE EYE}

$\mathrm{T}$

HE veterinary surgeon may be so expert in the examination of the eye as to detect very slight departures from the normal and the perfect, but he cannot correct astigmatism, myopia, or presbyopia, by prescribing suitable spectacles for any of the lower animals. Defects of vision are scarcely less important in horses than in men, and it is therefore advisable that we should reject a horse offered us if any imperfection is visible, or by any means discoverable. The most careful examination often fails to discover the reason for shying, and, on the other hand, serious lesions, as cataract, may exist without the animal indulging in this dangerous practice.

External injuries to the eye and its appendages are the most frequent troubles, and it may here be said that nails in the stable walls should on no account be allowed. The horse's focus is much longer than ours, and a large animal turning in a narrow stall may fail to see such an object as a rusty nail, although quite apparent to the man in charge.

\section{Torn or Lacerated Eyelids}

Since the advent of cocaine, injuries to the eye and its appendages are more easily dealt with, as a horse with a torn lid or a hay-seed in the eye is almost unapproachable for purposes of surgery or medication. With a five per cent. solution of this drug, one may syringe the injured member, and in a few minutes handle the parts, no twitch or other means of restraint equalling it in efficiency. With injuries to the eye, as with other wounds, the early employment of antiseptics is important, and the organ should be irrigated with a weak solution of chinosol or boracic acid, or pure carbolic acid, one or two per cent.; the resinous coal-tar preparations are less suitable than for wounds in the flesh (see Wounds, page 577). Having bathed a lacerated eyelid, the amateur in surgery will be tempted to cut away ragged or hanging portions. This must on no account be done. Every atom of skin should be conserved, and many fine stitches or sutures employed to make a neat "tailor-like" job of it. It is a matter of surprise, even to the young surgeon, how Nature will utilise every fragment of slin that is not utterly deprived of life, and "piece-up" a terribly torn lid, so that scarcely a pucker finally remains when it has healed. When by sutures a neat repair has been made, the operator will take care to protect the eye by a pad of lint soaked in such a simple antiseptic as boric acid, and softened by the addition of five per cent. of glycerine, or employ a very dilute carbolic oil, and over the pad 
contrive a light bandage attached to a head coller. Renewal from time to time, and careful sponging away of accumulated matter, should be practised, leaving the sutures in as long as possible, although slight suppuration is caused. When union appears to have taken place, these should be cut through with fincly-pointed scissors and removed corefully. If great pain is experienced the lotion may contain cocaine, and a watery solution of belladonna and morphine. It is wall to give conjunctival membrane may need interference. A slight operation upon the skin of the lid generally serves to overcome the deformity, and this should be performed by an expert. It is not a sudden emergency in which the horse-owner noed act for himself.

Diseases of the lachrymal glands or of the duct are so rare in the horse as to call for no description here.

a laxative dose of medicine in most cases, as it diverts blood from the head.

\section{Foreign Bodies in the Eye}

When hay-racks were placed above horses, many more cases of seeds falling into the eyes occurred than in the present day, when the arrangement is on a level with the manger. Flies or gnats also get caught betwcen the lids of horses' eyes, as they do with their masters. With the cocaine preparation advised above, one may proceed with a camel-hair pencil : open the lids with thumb and forefinger, and extract the offender, after which recovery commonly takes place in a few hours, unless some septic matter has been introduced by the insect, which may have been busy upon decaying carrion before his adventure. While under control by cocaine, it is therefore wise to flood the front of the erte with a boracic lotion. Thorns, and more solid objects than flies and seeds, occasionally enter the conjunctival membrane, and need removal by forceps, in which case the need for antiseptic treatment is still greater.

\section{Entropium and Ectropium}

Turning in or turning out of the lid so that lashes are brought into contact with the sensitive

\section{Diseases of the Conjunctiva and Cornea}

Simple ophthalmia, or an inflamed eye, is a rather frequent trouble in horses, and was still more so when they were stabled in close buildings, and the air was saturated with ammonia from their own waste. The common causes are dust, flies, and other foreign bodies, and as a symptom or conscquence of certain febrile discases as influcnza (pink eye). The symptoms are swelling of the lids, great redness of the membrane, tears flowing down the face and scalding the skin (if not prevented by the application of some unetuous material), sensitiveness to light and fear of being touched about the head. Later, the watery discharge changes to a muco-purulent matter, agglutinating the lids and excoriating the adjacent skin. 
Treatment. Warnı fomentations in which aqueous extract of opium and belladonna, have been dissolved. I mild aperient, and after a day or two a lotion of two grains to the ounce of sulphate of zinc in distilled water, applicd over the surface of the cornea daily. This corrects the disposition to pus-like matter, and hinders the formation of a cloud, which may often be seen to follow on a simple inflammation.

The lash of the whip is a frequent cause of inflamed eye, and then there is to be secn a rough line from which the epithelial layer has been torn, if carefully observed from the side of the animal. In the healing stage this is apt to form an irregular white cloud on the front of the eye, and is erroneously called cataract. If it does not clear up with the simple treatment just advised, it may be necessary to employ a lotion of nitrate of silver to excite the absorbents. If the injury is anything more than a very superficial one there will commonly be left a slight opacity or nebula which is really a scar (eschar). As in other inflamed conditions of the eye and its appendages, a cool and rather dark box should be preferred, or some sort of shade improrised.

\section{Inflammation of the Cornea}

An inflamed state of the conjunctival or thin superficial membrane may occur without involving the cornea, but the latter cannot suffer inflammation without affecting the covering membrane. When the cornea is inflamed, Jymph accumulates between its layers, or suppuration may follow, and rupture or ulcers result

The early treatment is that recommended for inflammation of the conjunctiva, but with the advent of pus a serious condition is set up, and more or less opacity nust be left. Irrigation with weak Chinosol lotions, and the application of a three-grain to the ounce solution of nitrate of silver daily, is best calculated to destroy the pyogenic organisms and heal the ulcers. Ulceration is comparatively infrequent in horses, although extremely common in dogs. Is a result of softening and giving way of the cornea, a protrusion-known as a grape or staphyloma-may be seen, though rarely in horses.

\section{Periodic, Constitutional, or Recurring Ophthalmia}

This is a much more serious trouble than the simple form of inflammation already described, and is of a constitutional nature, returning at uncertain intervals, and each time leaving some further structural change. The symptoms are not at first unlike that of the traumatic form, but later a peculiar pucker on the upper lid appears and remains, giving the opening between the lids a three-cornered look, and proclaiming to the veterinary examiner something of its history, although the eye may seem otherwise perfect. A peculiar amber tint pervades the eye in this disease, and after a week or more this concentrates in the lower portion of the chamber. A week later it may have cleared away, and in a month nothing may remain to show what has happened but that three-cornered aperture already mentioned. Unfortunately, the first attack is followed by others, and the iris grows to the lens through deposited lymph becoming organised; and the vitreous humour after a period of blucness gradually assumes the appearance of a hard-boiled egg, leaving no possibility of recovery of sight.

Treatment.-The administration of an aloetic ball, followed by half ounces or more of salicylate of sodium twice daily, is adrised, and as a local application a solution containing both atropine and morphine, two or three grains to the ounce of each. Atropine keeps the radiating fibres moving, and morphine causes the circular ones to contract after a longer time, so that the iris is less likely to be caught and fixed by the lymph resulting from the inflammatory process. Iodide of potassium in half-ounce doses twice a day may succed the salicylate, after the first three days, as this drug has a decided effect in promoting absorption of effused matters. Energetic treatment of the kind indicated may do much to mitigate the attack at the time, and therefore prolong the usefulness of the animal.

\section{Growths from the Cornea}

Growths closely resembling skin, and having distinct hairs upon them, are sometimes met with in horses. In cattle they are relatively common. There is no option but operation by a skilful surgeon.

\section{Cataract}

We have already alluded to the popular error of describing an opacity on the front of the eye 
as cataract, and would now explain that any cloud or opacity in the substance of the lens or its capsule is the lesion properly called catarict. If the lens itself is the seat of the disease, it is called lenticular cataract; if the covering membrane, capsular cataract; but these distinctions are of no great importance where horses are concerned, as operative interference is out of the question, for reasons stated at the beginning of this chapter. The site of the opacity may, however, have some bearing on the future of the eye, and influence the horse's conduct. If it obtrudes between his vision and the ground, he is more likely to make mistakes, such as treading upon a stone he fails to see. If higher I1p, it may not interfere with his work, or if on the outer lateral or inner border. A cataract may be small and dense, and with such a detined edge that the experienced surgeon may say that it will probably remain about the same size during the horse's life; or it may be diffused and tell the same experienced person to expect a gradual or eren rapid extension. Cataract in one cye is apt to be followed by a sinilar disability in the other. Cases of renewal or substitution of a fresh lens, when the diseased one has been removed, are reported by Dr. Randolph who operated on a dog, and it is possible that such a result might follow in the horse, but up to the time of writing no such occurrence is reported. No medical treatment appears to be of any use.

\section{Amaurosis, or "Glass Eye"}

A horse may be totally blind yet have a perfectly clear eye. Paralysis of the optic nerve or of its expansion (retina) over the posterior chamber is the cause. The transparency of such eyes is very umnatural looking and gave to the disease the horseman's term of "glass-eyce." The animal may be standing in a bright light, yet the pupil will remain widely dilated; or, being brought into a dark stable, will remain the same. The pupil of a healthy animal contracts in a strong light, and expands in a low modium of light, and by this simple test amaurosis may be detected without any deep knowledge of opties. The "glass-eyed" horse is generally shown upon familiar ground where he goes in good form, and the unwary purchaser loes not observe the constant movements of his ears, by which he seeks to obtain information which should come through his eyes.

The causes of amaurosis are several. Blows upon the head, falls producing similar results, the presence of parasites or of tumours, clots or other bodies which may press upon the deepseated origin of the optic nerves or their trunks. Cases have been known to recover at grass, when it may be assumed that the pressure of a clot was gradually removed by absorption, but no medicai treatment seems to be of service. The only advice we can give is not to buy such a horse, and if you are unfortunate enough to possess one, do not sell it to your maiden aunt.

\section{Glaucoma}

Common in the dog but extremely rare in the horse, glaucoma is "an increased tension within the eyeball in consequence of an excessive secretion of the aqueous and vitreous humours" (Professor Axe). An operation whereby a portion of the iris is removed is often attended with good results.

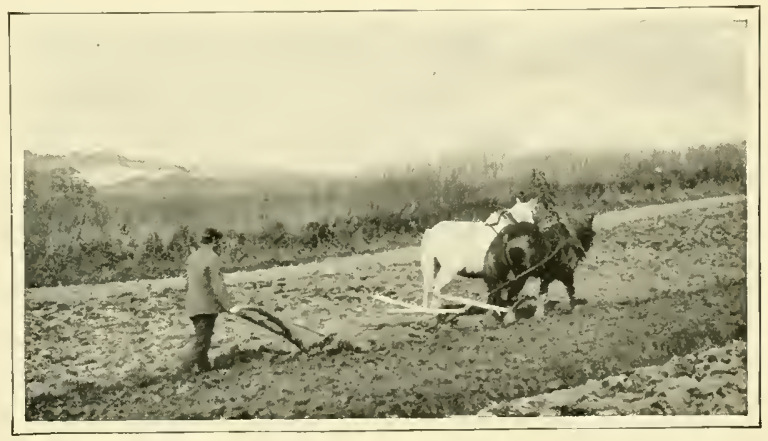




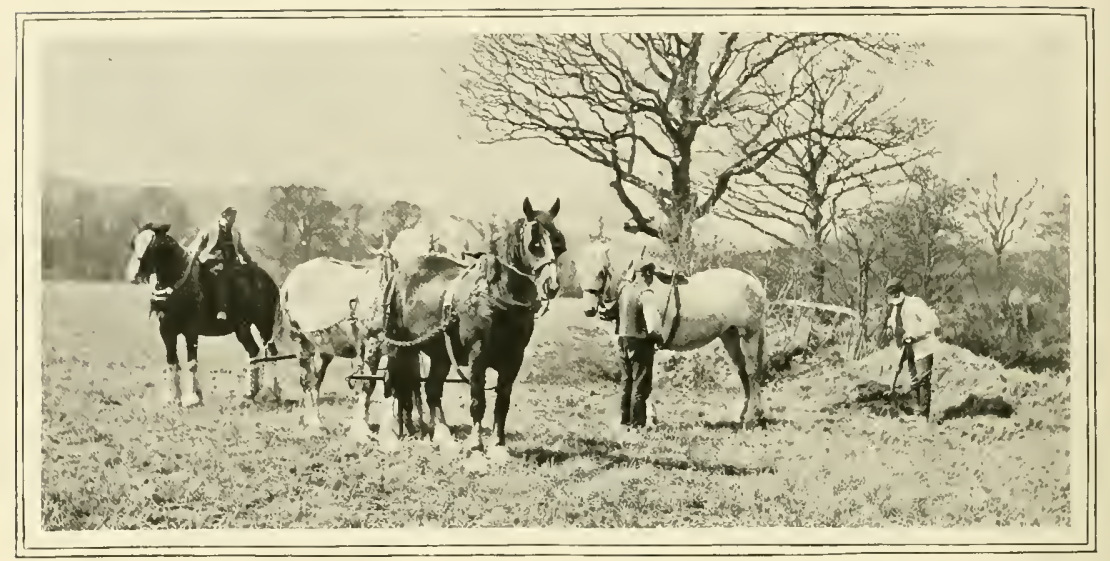

\section{CHAPTER XI}

\section{DISEASES OF THE SKIN}

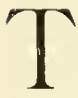
HE classification of diseases is always a difficult matter, and those of the skin are as frequently due to some systemic trouble as to any outward or intrinsic cause. Eruptions are caused by disordered stomach or specific discases, as stomatitis, farcy, epizootic lymphangitis, or horse-pox; while others are caused by injuries great or small, and from parasites, as mange. For cruptive diseases of the skin the reader is therefore referred to the chapters which deal with the above-named maladies.

\section{Erythema}

Any redness of the skin, whether caused by friction, dust, east wind, or other causes, is known by this name. A fat, unconditioned horse will sometimes display much redness between the arm and the brisket, and this is called crythema intertrigo. Mud fever is another example. The cause is to be songht and removed, and simple emollients, as one part of the strong solution of lead (Goulard's extract) to seven or eight of linseed oil applied. Any slight case of erythema neglected may lead to suppuration by the invasion of pyogenic organisms.

\section{Urticaria, or Nettle Rash}

The suddenness with which irregular lumps come upon the skin of an apparently healthy horse may perhaps have accounted for the name of nettle rash. Their disappearance is often as abrupt ; not always, however, and they are apt to leave the hair glands impaired when existing over a few days, white or light coloured spots following, and remaining permanent blemishes in some colours. Nettle-rash has often appeared a few minutes after a deep draught of cold water, when a horse has been heated by exertion, and it is these cascs which more frequently disappear when his journey is resumed. Sudden changes of diet account for most of these rashes, as when clover and vetches are suddenly substituted for hard corn or the reverse.

Treatment.-A saline laxative, as three or four ounces of salts with an ounce of nitrate of potash, should be given in mild cases, and an aloetic ball where there is a disposition for the disease to become chronic, followed by daily half-ounce doses of bicarbonate of soda and a desscrtspoonful of table salt in the food. Obstinate cases often yicld to ounce doses of the solution of arscnic known as Fowler's. Calumba, in combination with soda, or quinine, with a mineral acid, are worth a trial if the lumps persist.

\section{Eczema}

There are many theories as to the cause of eczema, and much ink has been used to describe 
its rarietics: the most probable explanation is that the skin endeavours to perform some of the work which the liver and kidneys should do in the climination of waste proelucts, and suffers irritation thercby. The appeal to those organs to do their best is often successful in getting rid of eczema, and this may perhaps be accepted as proof of their delinquency in the first instance. An irritation of the surface of the skin is followed by little vesicles or bladders which break if left alone, but are more frequently ruptured by the patient who rubs them to allay itching, and then a serous scab is formed by the exudation of many little vesicles combined. His rigorous rubbing may leave nothing to be scen but a sore place by the time the horse-owner's attention is drawn to the case.

Treatment.-An aloetic ball is often a good preliminary dose, as it clears the alimentary canal of fermented ingesta and wakes up the liver and kidneys to the performance of their duty. Simple alkaline washes, as an ounce of bicarbonate of potash in a quart of water, allay irritation of the skin, and in some cases it is desirable to add a dram of dilute hydrocyanic acid. In neglected cases, where crusts have formed, a carbolic oil will soften and assist in removing the scabs as well as soothe the irritated integument. Salines, as sulphate of magnesium, bicarbonate of potash, and sulphate of soda, in daily small doses, together with gentian and calumba, are given in chronic cases, and aiternated with arsenic and antimony. The treatment found to succeed in one case may quite fail in another, and a variety of remedies both topical and constitutional should be tried in obstinate forms of eczema, as well as changes of diet.

\section{Rat Tails, or Lichen}

This is a popular name for a form of cczema affecting the lower portions of horses' limbs, the exudation sticking the hairs together in the form of rat tails.

The treatment is the same as for other eczematous troubles, with the exception that it is advisable to use a stronger alkaline wash to prevent a permanent blemish.

\section{Prurigo}

An intolerable itching is often experienced by horses without much to be seen upon the skin, 70 but little hard lumps or papules can be felt. Through the animal rubbing or biting them little spots of blood or scrous scabs are formed. This disease is often called "surfeit" by stablemen, and an aloetic purge or alterative powders prescribed. When it arises from debility and bad hygiene the purgative dose will be dispensed with, and small doses of sulphate of magnesium given. Tonics, as iron sulphate and gentian, also bencfit such cases.

\section{Herpes}

Often called ringworm, because it occurs in patches or rings, but it really consists of clusters of vesicles which, if discrete, would be indistinguishable from some forms of eczema. It is due to some form of indigestion, and treatment is therefore directed to the digestive organs, not the least of which is a change of dict.

\section{Suppurative Inflammation}

Erythema.- An elevated patch of slin with numcrous pustules and intensely tender to the touch, is called by this name. It may be simple, and from some blood dyscrasia, or a similar area of eczema may have been rubbed and inoculated with the pus organism, as so often occurs with dogs. There is a contagious form known as "American horse disease" and as "Cerman boil." It is chiefly spread by infected clothing and harness. The application of carbolic lotion of ten per cent. strength is advised, and this should extend a little beyond the affected parts. All clothing and gear should be disinfected. It seldom induces any constitutional disturbance, and calls for no special treatment beyond that indicated.

\section{Squamous Inflammations}

Pityriasis.-This is a state of the skin in which scales, like bran, form in great quantity and discredit the best of grooms. It is generally ascribed to poverty, but we have seen it in the best caredfor animals, just as we have secn dandruff on the shoulders of the best groomed men. Change of food often cures it, and benefit is also derived from alteratives such as small daily doses of nitre, sulphur, and antimony or arsenic. A lotion of sulphurctted potash with glycerine cured a horse that the writer bought for a mere triflc, when all other remedies had been tried. 
Psoriasis.-Accumulated scales in raised patches and thickening of the under layers characterise this skin discase. Inside the ears, along the mane and ncck, and in the flexures of the joints it most often is found, and in the latter situation forms cracks that are difficult to cure. As it most frequently affects the overfed, and those stimulated with condiments for show purposes, the treatment must be a lowered as well as changed diet, with repcated applications of iodine ointment to cracks, and oxide of zinc ointment, or carbolised oil to other situations.

Ichthyosis.-This is a thickening or nypertrophied condition of the skin generally, with a disposition to outgrowth of the epidermis or outer layer. It is best removed by strong alkaline washes, as solutions of washing soda, or the powdered soaps so popular among women who do not patronise a laundress.

\section{Warts, Verucce}

All animals are subject to warts, more or less (frequently more), and the horse is by no means exempt, atthongh he cannot compete with cattle for the size of them. They are outgrowths of all the tissues of which the skin is constituted. Their presence where harness excites irritability of the slin can be understood, but why they come in parts free from any such compression or friction is no more known than their preference for little girls' hands; or their disappearance suddenly, after midnight incantations, or the execution of a black cat. That they do disappear suddenly and without remedies is as true of animals as of human subjects. If one had to provide a scientific reason for thcir disappearance one might attribute it to pressure and cutting off the blood supply caused by contraction of the parts most early developed.

Treatment.- Warts may be conveniently divided into the broad-based, the pedunculated, and the cncapsuled. The first-named must be disposed of by solvents: and of these we make choice according to the situation. Around the mouth or upon the eyelids no stronger application than salicylate collodion should be used, lest damage be done to sensitive structures. Daily painting with this substance soon reduces the wart, and picking off the surface every two or three days facilitates its solution. The pedunculated variety offer a neck we can strangle, and so deprive the body of life. Silk or thread twinc or stouter string may be desirable, and a waxed-end is very serviceable for some of the larger ones. The third variety arc little fatty fibrous tumours within a sac, necding only that the latter should be cut open at one clean stroke, when the solid body can be easily lifted out-if, indced, it does not jump out.

For those irregular masses which grow upon other parts of the body, various measures are neccssary. Some of them, or large portions, may be twisted off and the remainder treated with arsenical soap, made by mixing one part by weight of arsenjous acid with two parts soft soap. Care should be taken to avoid injury to the adjacent skin, and none of the paste should be dropped upon the ground, as animals are attracted bv it, and fowls frequently killed.

\section{Mallenders and Sallenders}

An eruptive disease of eczematous type, occurring behind the knee and in the bend of the hock, and producing cracks and chronic thickening with more or less swelling and unhealthy discharge, is known as mallenders in front and sallenders bchind. Both are precisely of the same nature. The heavier breeds are the most prone to it.

Treatment.-Occasional aloetic purges act as deterrents, and local applications mollify the inflamed tissues. It is seldom radically cured, but the following ointment appears to do very much in that direction. Finely triturated red oxide of mercury, twenty grains; exsiccated alum, one dram; lanoline ointment, seven drams. Applied every night. Diuretic medicines, such as rccommended for the subjects of swelled legs, arc also useful in this malady.

For skin diseases caused by acari and otlici external enemies, the reader is referred to the chapter which follows on Parasitic Diseases. 


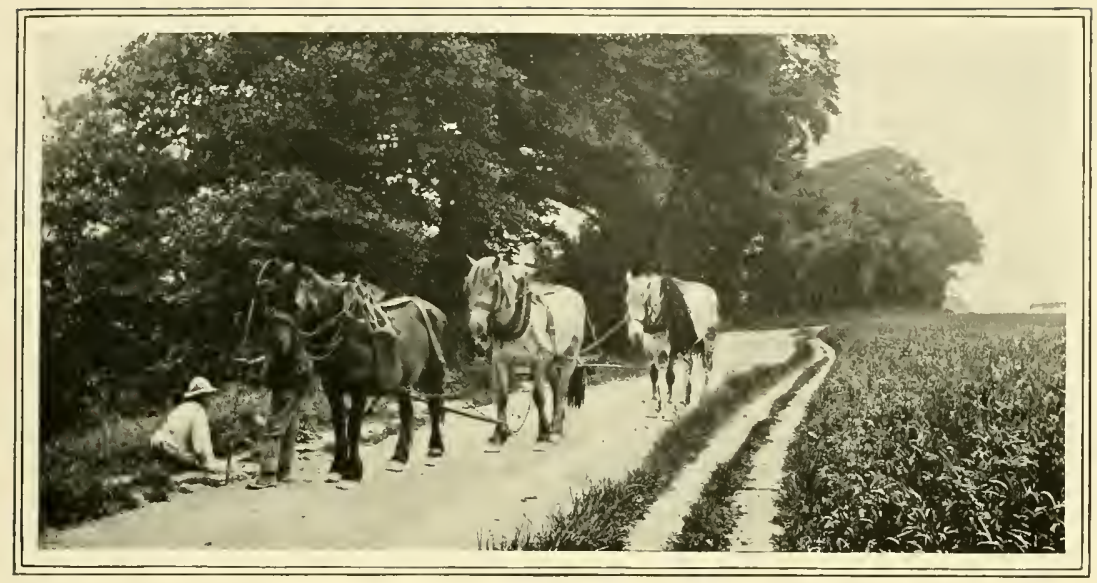

\section{CHAPTER XII}

\section{PARASITIC DISEASES}

I $\mathrm{T}$ is quite possible that every disease will be one day relegated to an organism of some kind, and in the broad sense in which parasitism is now employed our notions will have to be revised, and the general public will no longer restrict the meaning of the word parasite to that of worms inside the body (or to their own poor relations). Tuberculosis and glanders may be taken as examples of parasitism of the microscopic order. For the present, and in a work of this kind, it will be sufficient to call attention to the parasitic pests, whether residing within and classed as entozoa, or living upon the surface of the beast, and known as ectozoa. We shall also take the popular view of parasites as expressed in one word in America, "cusses," and make no exception to those whose presence is excused on the ground of their being merely "fellow-boarders," and not deriving their sustenance by robbery and violence to the structures of their host. Parasites belong to both the animal and regetable kingdoms. The large ascaris of the horse may be placed at one end of the list, and the little ray fungus, which causes actinomycosis, at the other. The damage to the bearer, or host, is not to be measured by the size but by the eonduct of the guests.
The worms which infest the horse may be roughly divided into the round and the flat. The round worms vary immensely in size, from the destructive little strongles of a quarter inch in length to the Ascaris megalocephala of a foot or mote. Round worms are found in the eye, the skin, the digestive canal, kidneys, the heart, and the blood-vessels. The flat worms include many varieties of tapeworm and some flukes which resemble miniature soles rather than worms. Round as well as flat worms produce eggs in which embryos develop, and these appear to require an intermediate host, or to undergo changes in other circumstances outside the original host before they reach their destination in the ultimate host. The life cycle of the round worms is not very well made out as regards many families, and the assertion that all have to reside outside the host for a period can hardly be accepted in view of Dr. Salmon's and other investigators' observations of the filiaria of birds and similar parasites which reside in the air passages of young animals, and there reproduce. The tife cycle of the tapeworms is well known. The egg, passing out of the host of the mature tapeworm is swallowed by another animal, in which it is hatched out, and the embryo, armed with cutting 
apparatus and hooks, bores through the tissucs and anchors by its hooks, as instinct dictates, in the one hundred and fifty varieties: some in the brain of the sheep (Cenurus cerebralis), until another host consumes the little bladder which develops, with future heads of tapeworms on its inner aspect. The giddy sheep, seen to spin round and fall, has such a cyst or hydatid in his brain, which came there by swallowing an egg passed by a dog on the grass. When the sheep but the true discase is caused by a fungus, Trichophyton, which gets into the hair follicles and into the shafts of the hairs themselves. Any doubt can be set at rest by microscopic examination of the bent hairs, mixed with solution of potash and glycerine, when the characteristic spores will be seen.

Treatment is invariably successful in horses, although often so difficult and prolonged in children. An ointment of one part mercurial ointment to six parts of lard or lanoline, or one part pure carbolic acid to nine parts glycerine, or a solution of one of perchloride of mercury in three hundred of water, destroys the fungus. All stable tools and harness used upon a horse suffering from ringworm should be thoroughly cleansed, as it is by such things the disease is commonly conveyed. It may be well to remember that moss litter as a bedding holds ringworm, and transfers it to other horses lying down upon it, and its employment should be discontinued where this skin trouble exists.

Lice. - These troublesome pests seldom gain foothold in the private is killed the butcher casts aside the bladder, which would spoil the salc of the brain (if exposed to view), and the passing dog picks up the unconsidered trifle. The heads then attach themselves to the intestine of the dog, and segment by segment a tapeworm is formed, and the whole business begins again. The flukes undergo quite a long series of changes, the last of which is the cercaria, which penetrates the body of a snail and there resides until sufficiently developed to seek its ultimate host and ascend the ducts of the liver of the sheep, ox, or horse, camel or elephant, or even the fox. These flukes which cause such havoc among sheep are seldom of serious conscquence in horses, but are by no means rare.

\section{Diseases Caused by Parasites}

Beginning on the outside of the horse, we may take

Ringworm.-We have said in the chapter on eczema that herpes is often miscalled ringworm, stable where good grooming is the rule, but on farms, and among horses lying rough in straw-yards - and especially where barley straw is used-they are frequent visitors, causing much irritation in the late winter and early spring months, when on a sunny morning they may be seen enjoying the weather. They are of two kinds, Hamatopinus, or those which puncture the skin, and Trichodectes, those which have no wounding apparatus, but seek a living among the loose cuticle and secretions of the skin. The irritation they cause usually leads to their detection, and then the question arises as to what is a safe, effectual, and not too expensive remedy to dispose of them.

Treatment.-Any fixed oil employed in sufficicnt quantity will block their breathing pores and cause their death, but the cheapest of seed oils, used by the gallon, are expensive, and a solution of one part carbolic acid, two parts soft soap, and forty-seven parts hot water, may be used with 
good effect. Tobacco water also destroys them, and the juice can be bought at a cheap rate, as it is not charged with the duty on the manufactured leaf. A decoction of staresacre seeds, one in thirty by weight, is also effectual, if the druggist has not had it in stock till the active principle is dissip:ted.

Mange-Acariasis. - The most common form of mange in liorses is due to the Psoroptes, who live upon the surface and are lisposed of with comparative ease. The other mange is due to Sarcoptes, whose habit is to burrow and bury themselves under the cuticle. Besides these hody mites, there are Symbiotes, whose depredations are usually confined to the pasterns, seldom travelling above the knee and hock, and whose presence and consequent itching is often attributed to incipient grease. Only by microscopic examination can the varieties of mange mites be certainly distinguished, but the intolerable itching used by them should direct the attention of the horseman to the pimples and raised portions of cuticle from which issue an exudation which scabs and forms crusts, and displays a raw surface if roughly removed.

Treatment-Once recognised, mange of the psoroptic variety, or the symbiotic, affecting the legs, is easily cured, but the psoroptic form, when neglected, sometimes proves incurable, and even causes the death of the host by the intolerable itching and loss of rest occasioned. Shetland ponies and others from time to time suffer in this way, and it has been found necessary to resort to the stamping-out system and clearance of the district for a season. Sulphur is one of the so-called specifics, and its employment is as old as the armies of Alexander the Great-probably older, although parasites were not suspected. To cure mange, the chief thing is to go about it in such a way that no remnant shall escape, none to play the part of the Noah family after the deluge of soft soap and warm water which should be the preliminary to "opening the skin," for remedies to reach the enemy in his entrenchments. Then a preparation of one part flowers of sulphur, one part paraffin, and seven or eight parts of liard, should be thoroughly inuncted into the whole area affected, and a little heyond. Various preparations of mercury, of turpentine, and of tobaceo are used, and the coal-tar series of disinfectants in the proportions recommended by the makers commonly answer the purpose: but nothing, in our experience, is equal to sulplur as an ointment, libcrally employed. The process should be repeated in a week, to overtake stragglers or new hatches, which may have kept in retire-

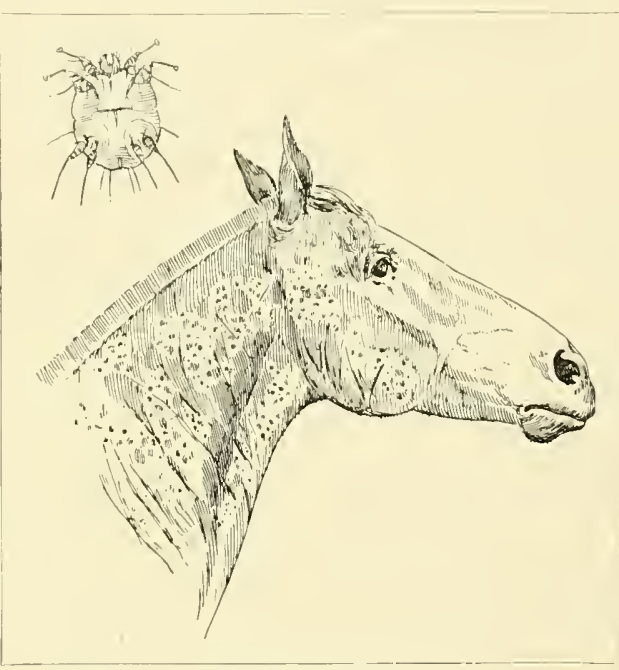

SARCOPTIC MANGE.

(The Parasite-considerably magnified-is shown at the top)

ment and emerged from their galleries when the first storm was over. All the varieties of mange are infectious, and it is an offence to lead a mangy horse upon the king's highway.

\section{Parasites of the Digestive System}

A minute strongle, named after Professor Axe, Strongylus Axei, is an occasional cause of trouble in the horse's stomach, and two varietics of spirotera have been discovered on the continent. They lead to the formation of small round tumours on the lining membrane. Bots in the stomach are familiar sights to the knacker and others who see the viscus opened. They are the larva of the bot fly, which lays its eggs about the shoulders, arms, and sides of the animal in the summer months, and are from thence licked into the mouth and swallowed ; they obey their instinct 
to fasten on to the membrane and there abicle until the next summer, when they let go their hold, pass out through the intestinal canal, and assume the chrysalis form until they get a rise in life and become bot flies. A second variety, known as the Estrus hemorrhoidalis, takes advantage of the moment during which the red membrane of the anus or first few inches of the lining membrane of the rectum is exposed in the act of defecation, and deposits its eggs in a few seconds at the most, before the orifice is closed. The resultant grubs are reddish in colour and cling to the situation where they were born until the following summer, unless removed by the hand of the stableman. Because Bracy Clarke deemed stomach bots harmless, successive writers have been content to acquit them of evil, but instances are on record where they have caused such damage to the walls of the stomach as to lead to its rupture. Many remedies have been tried to expel them, the last of which is bisulphide of carbon in a gelatine capsule. They have been proved to resist everything else, and it is very doubtful if a bad smell is considered by them as a notice of eviction. All the remedies we have seen succeed (?) have been given at a time of year when the tenants were willing to quit without notice.

The great Ascaris megalocephala is the commonest of worms in the horse, and varies in length from three or four inches to fifteen. In small numbers they do not appear to do harm, but a lot of them will so rob the host that he loses condition, his coat stands up, and his appetite is uncertain and variable, being voracious at times and indifferent at others. The foregoing are common symptoms of worms, and when a horse does not thrive on a fair ration and reasonable labour, worms should be suspected and looked for in the droppings. The whip worm (Oxymris curvula), two or three inches in length, and curving at the thick end and drawn out like a whiplash at the other, is a very common worm in horses, and difficult to get rid of entirely. Being a dung feeder it does not do so much damage as some others, which rob the host of the products of digestion when just ready to enter the circulation. The Strongylus armatus and tetracanthus are serious enemies, especially to young horses at grass, the latter causing many deaths and ruining by debility and arrested development many Shires bred on land that has become infested by then. They are tiny red or yellowish threads, often only a third of an inch long, but more mischievous than all the large worms together, and have rendered horse-breeding unprofitable where they have become established. They are bloodsuckers and commence their career within the intestine, as little cysts coiled up in the mucous membrane.

The tapeworms of the horse are remarkable for their small size, as compared with those of dogs and other smaller animals. The Tenia perfoliata is about three-eighths of an inch in width, and seldom two inches long. The $T$. plicata is about the same widtl, and attaining to three inches or more, and the $T$. mamillana no more than an inch in length and but an eighth in width. The fluke, Distoma hepaticum, found in the liver of the horse, is never hardly a cause of trouble, and unlikely to be diagnosed during life; nor could it be evicted if known to be lodged there. The liver of the horse may be more seriously affected by the intermediate or cystic form of the dog tapeworm, $T$. echinococcus. Wanderers are found on the serous membranes of the chest and abdomen, where they remain and finally degenerate if the animal's life is prolonged. Without another host, as was explained at the beginning of this chapter, no tapeworm can reach the final development.

Treatment.-The ascarides, the whip worms, and such of the larger strongles as are found free in the intestines, are generally expelled by a fair dose of aloes, a "physic" ball, proportioned to the age and breed of the animal-from three to eight drams of aloes in the ball. A preliminary dosing for three or four mornings with twenty to sixty grains of santonine, thirty to one hundred grains of sulphate of iron, and a teaspoonful or two of table salt in the first meal, will destroy or make sick great numbers: of which the ball will more easily dispose. Aloes has the effect of carrying out alike, in the intestinal storm, many worms which do not appear to be dead or even sick. Worm remedies are notorionsly uncertain, and if one remedy fails another should be tried. An ounce to three ounces of spirit of turpentine, in half a pint to one pint of linseed oil, following a fast of fifteen to eighteen hours, often results in the expulsion of many round worms, both ascarides and strongles, but the little tetracanthus already referred to is the most insistent of all. Doses of fifteen to twenty-five grains of thymol dissolved in spirit have proved successful in the 
hands of some, but were pronounced valueless at the Royal Veterinary College aiter anple experiment.

Many worms may be got ricl of by manual removal of the contents of the rectum, and syringing with tobacco decoction, infusions of quassia, dilute vinegar, carbolic acid, and warm water, as well as by occasional purges. We can seldom dispose entirely of the whip worıs, but by such means as we have set forth they may be kept down, as all weeds on a farm, without being able to boast of an absolutely clean field. The persistent administration of powdered sulphate of iron, with salt and gentian, undoubtedly makes the intestinal canal an undesirable habitat, and we have seen many worms converted into a species of white leather where these drugs have been continuously used.

The fermentation produced by the first few bundles of green-meat in May olten causes the expulsion of worms.

The tapeworms are seldom suspected. For them the oil of male-fern, with areca in a ball or gelatine capsule, is perhaps the best remedy we can employ. Worms in the aqueous chamber of the eye are removed by operation, but those residing in the blood-vessels cannot be reached, and only the keeping up of the general health and condition enables the host to submit to their presence without serious injury.

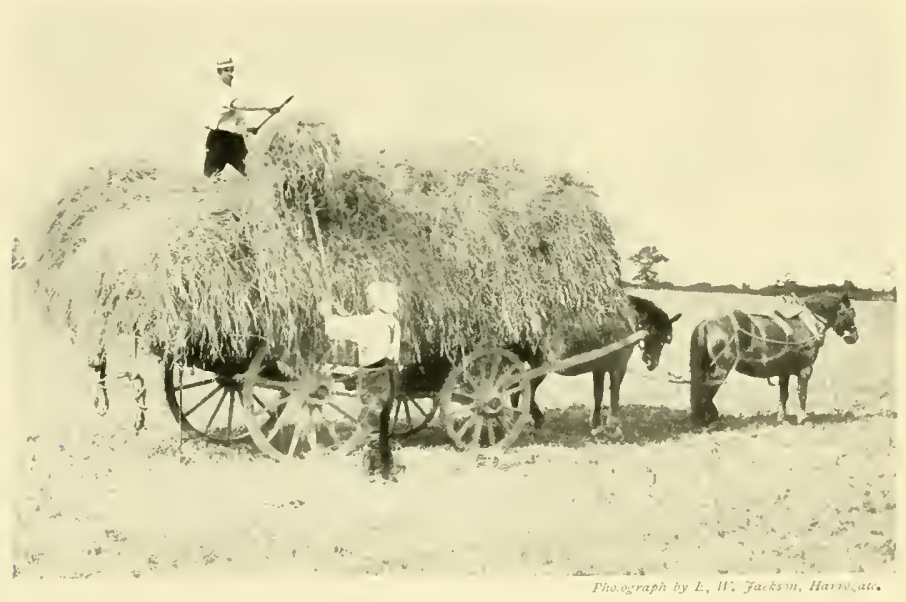




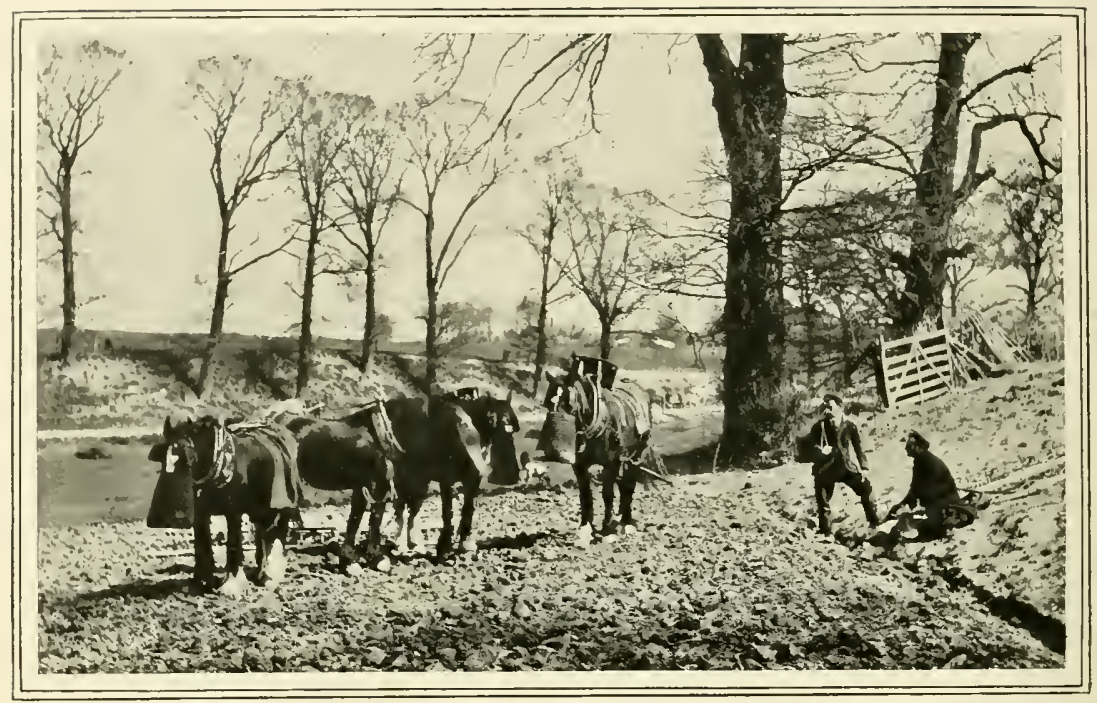

\section{CHAPTER XIII}

\section{DISEASES OF THE BONES AND JOINTS}

$\mathrm{R}^{\mathrm{m}}$ ING-BONE.-Often found as an extension around the pastern, this disease came by the above name. It as often does not take a circular form. Any ossific deposit upon the short or long pastern bones (corona, suffraginis) is called ring-bone. It mav be a very small deposit and cause lameness, or very large, and permit of movements of the joints without interference with their mobility. Ringbone is deemed unsoundness. The long and weak pastern, and the short, upright one, is more liable to ring-bone than that of moderate length and slope.

Heredity is counted among the causes, and mares should not be bred to sires that have this defect. Too early labour and shoeing with high heels contribute to the disease. Lameness is often the first indication, but many young horses put up ring-bones withont the knowledge of their owners, and the latter are much annoyed when the veterinary examiner discovers what they never suspected to exist. Ring-bone, splint, and spavin are all primarily caused by an inflamed condition of the covering membrane (periosteum), and the resultant growth of bone upon bone, is alike in character but differently named.

Treatment-An aloetic ball is given to cool the system, while rest is prescribed for the limb, and hot bathing and bandaging at first, to subdue inflammation and further deposit. This is followed by a blister or succession of blisters, with the object of provoking absorption, or at least preventing further growth of the offending material. Firing may have to be resorted to, and even this fails in the worst cases, and the only thing to be done is to cut off sensation, by division of the sensory nerve (see UNNERVing, page 587).

\section{Splint}

Splints, like ring-bones, are exostoses. They most frequently occur about a third of the way down the bone, from the knee, but may affect any part. Those close to the knee are the most 


\section{DISEASES OF THE BONES AND JOINTS}

serious, as the joint may be impinged upon and anchylosis follow. The round and forward splint is the least likely to prove injurious; the back-

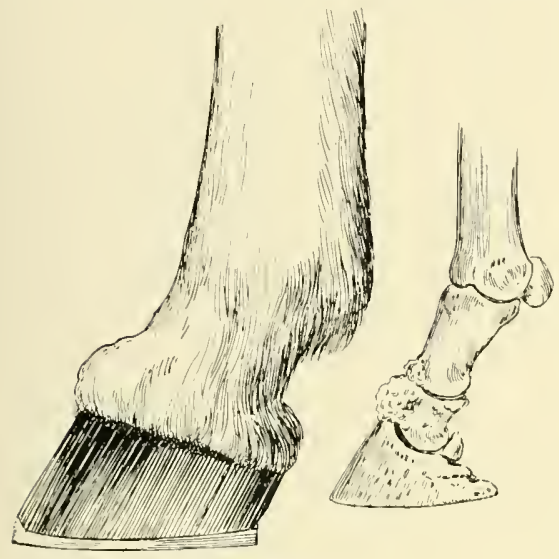

RING-BONE。

wardly situated may interfere with the tendons and ligaments. Lameness is frequently present during the early inflammatory stagc, and passes off when the splint has become callosed or ceased to grow. Splints are hercditary, and commonly appear in youngsters between two and five years old, but foals of a few months and yearlings are not infrequently found to have them. Twoyear-olds at the time of being broken in, and four-year-olds when first put to work, are particularly liable to throw out splints. External violence, as wcll as strain, may account for splint, as from striking with the shoe of the other limb, kicks, etc.

When not large enough to be easily scen or felt, splints may often be detected by manipulating the limb and pressing upon suspected parts, while the leg is held up. The animal winces when the sensitive splint is squeezed.

Treatment.-Rest is often sufficient to eure slight cases, but for others the same treatment as for ring-bone is advised.

\section{Periostitis, or Inflamed Bone}

In writing of ring-bone and splint, we have said that they are caused by inflammation of the periosteum or covering membrane, from which the outer and denser portion of bone is maintained.
Instcad of localised inflammatory spots, the periosteum may be suffering over the greater part of a bone, and the lining membrane (cndostium) may be involved at the same time. The symptoms are those of intense pain, and extreme tenderness to the touch, swelling, at first firm, and afterwards fluctuating under pressure. Abscess follows, breaks, and in the discharges the dead bony matter escapes in broken particles.

Treatment consists in carly incision, thereby allowing escape of matter and preventing scparation of periostcum from the bone. Syringing with antiseptics, good nursing, and tonics, and a long turn-out at grass, may complete the cure. In the chronic form it is known as "sore shins," and chicfly affects racers and chascrs, whose legs may be seen bandaged and booted in all sorts of ways to protect the enlargements from selfinflicted blows when performing. Some of the greatest performers over "the sticks" have deformities due to chronic ostitis, which the
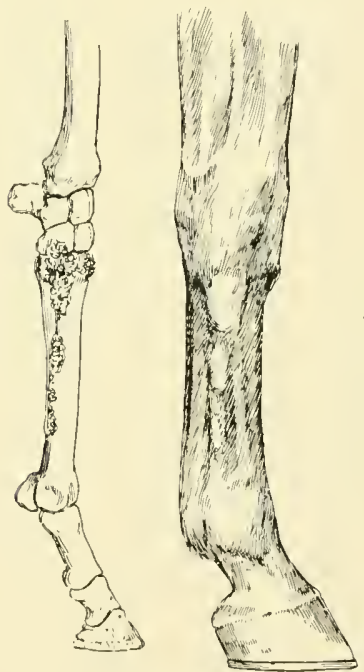

SPLINT.

norice might well suppose would incapacitate the animal.

\section{Necrosis and Caries}

These terms are employed to indicate different kinds of decay of bone. Injuries resulting in the 
death of bone are followed by swelling and tenderness, with much heat of the part, and lameness if affecting the bones of the limbs. Wherever bone is kilicd, if the portion is no bigger than a pin's head, an abscess will form, and if the dead material does not come away in the discharge a fistulous opening is established in order to drain it away (see Fistulous WITHER and QuitTor, page 580 and 572 ).

Treatment then will be dirceted to removal of the necrosed bone, be it large or small, after poulticing and irrigating with disinfectants. Nature detaches the dead material without our aid if given time, but we may shorten the period if we watch our opportunities.

\section{Osteo-Porosis, or Big-Head}

Another reference has been made to the popular name of big-head, when it is applied to the swelling due to purpura hæmorrhagica (see page 529). The form of big-head now under notice is due to a constitutional disease involving the whole skeleton, but attracting most attention to the head. The cause is not known, neither is any treatment of use, and it is commonly fatal. A case is on rccord of recovery after treatment with iodide of potassium and nux vomica. Many more might be put on record that derived no benefit from these or any other drugs.

\section{Spavin}

This term should be reserved for a bony growth on the inner and lower aspect of the hock joint, but is often used in connection with a distended capsule, and also known as " bog spavin." Spavins may be so small that the expert has some diffculty in finding them, or so large that the novice detects the deformity. In shape, too, they may be round, pointed, or irregular, and extend across the joint. One or both hocks may be spavined; it frequently happens that first one and then the other becomes affected. The small, weak, and ill-formed, more often than the good hock, develop sparin, but the best are by no means immune. The causes are hereditary predisposition, upright pasterns, and straight quarters, sprains, concussion, and over-fatigue. Lameness comes on at the first, but may pass off with rest, to return when the animal goes to work again. Old or "stale" sparins frequently cause much lameness when the liorse first comes out of the stable, and the latter passes off when warmed up with exercise. Many cripples are sold at fairs, going sound, and prove lame next morning.

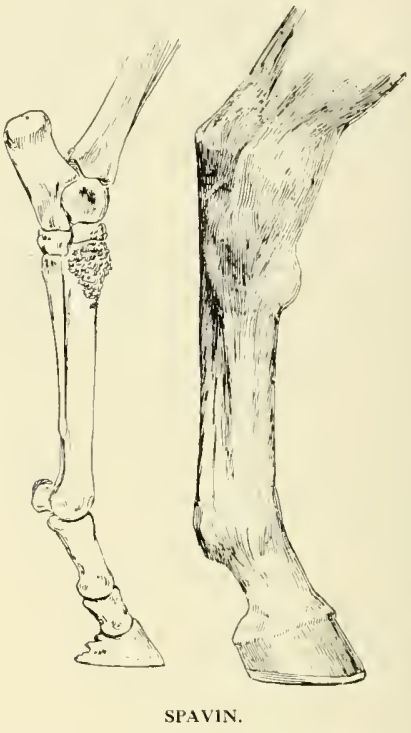

Treatment.-Rest, physic, and the same measures as advised for ring-bone (see page 556), and other exostoses.

\section{Fractures-Broken Bones}

There is a general belief that a horse's broken bones cannot be "set," or will not unite, but this is a popular error, founded on the fate usually assigned to those animals who break their legs. It is a matter of cold calculation in $t \mathrm{~s}$. d. The maintenance of a horse for months, to say nothing of his doctor's bill, amount to as much as many a poor beast is worth. Added to this, the owner will not be repaid by a union such as would satisfy the human surgeon, and his paticnt must be restored to absolute soundness if the treatment is to be a success. Many broken legs have been treated in the case of valuable brood mares, where soundness at fast paces is not required, and some have been perfectly restored to complete soundness at all paces, but the majority of fractured bones of the limb unite with such a large callous, or ring of bone, that the soft structures are injured by friction, or, maybe, a joint is united 
by anchylosis. Having regard, then, to all these risks, the horse which breaks his leg in the street is commoniy slaughtered, and not on account of any inlerent difficulty in setting it, as the term goes. There are broken bones which it is worth while to set, as in colts at grass, and in the case of bones other than the long round ones.

Fractures are conveniently classificd as partial or complete, simple when the bone is not connceted with a wound, or compound when it has such connection. If the bone is broken into more than two parts, it is described as a comminuted fracture, and may be in fifty pieces. A number of other distinctions are recognised by surgcons, but the above comprise the bulk of such accidents, and the nomenclature goes far to explain them.

The causes are outward violence, muscular contraction, and predisposition, due to inherent brittleness or faulty composition. In the act of casting horses (see MIETHods of Control, page 587 ) the violence of the muscular contractions sometimes causes fractures. The diagnosis of fracture is not always easy where it concerns the bones covered with flesh, as those of the femur or the pelvis, but the bones of the extromities when broken often show deformity not difficult of diagnosis. Even here, as in split pastern, the swelling is apt to obscure the true nature of the accident, so long as there is no acturl displacement.

Trcatment.-A fracture with wound will seldom be worth treatment, nor will a comminuted one, if a long bone is the subject; but where possible the owner should seek the opinion of a veterinary surgcon before signing the death warrant. Many simple fractures can be successfully dealt with by bringing the broken portions into apposition, and retaining them in position by simple appliances. Packs of tow or wadding, splints of wood or metal, and bandages over all, serve for split pasterns. A cradle can be improvised for a broken jaw, and soft foods provided which can be sucked up for the first few days. The principles need only be understood so that the horseowner unable to obtain professional assistance can apply them to the individual case. There is no need for haste. The parts should be examined for abrasions of the skin, and if any cxist they should be dressed with an antiseptic, preferably carbolised oil, because its softening influence is more lasting under appliances that may not be remored than is the case with aqueous preparations. A considerable thickness of soft material which will protect from friction and "bed sores"; an equable pressure suffirient to retain the bandages and splints in place; an avoidance of such pressure as will interfere with circulation, and watchfulness for undue swelling citler at the seat of fracture or as a consequence of it. In the course of a few days the blood clot which at first resulted from the injury undergoes changes and becomes organised, affording a soft temporary union to be by degrees changed into a substance much denser, and finally as hard as the bone itself. Provided care be taken to prevent a restive animal from undoing the work, it is better to remote and replace appliances which are provoking too much swelling.

\section{Diseases of the Joints}

During the first few years of life, horses are subject to joint troubles which often determine their value as well as usefulness. Sucking foals are frequently ruined-nay, killed-by an infectious joint, an ill which enters at the open umbílicus as a specific organism, and, gaining access to the joints of the limbs, sets up inflammation and suppuration.

Treatment is not very successful, but prevention is easy. As soon as the foal is born the navel string should be soaked in a five per cent. carbolic lotion and tied with silk, thread, or catgut, after which it may be dusted two or three times a day with a dry disinfectant, as boracic powder. From five days to three weeks is the critical period, but the guarding of this gate of entrance from the septic organism renders the youngster practically safe from the most disastrous of all joint evils. If these precautions are neglected, and the foal is infected, dullness and symptoms of fever follow, the joints-somc or all of them-sweil, are intensely painful, and the crippled animal can scarcely reach the teat if the desire to do so remains. Sustaining the patient in his fight against disease by frequent doses of quinine and ammonia, tincture of gentian, or brandy in milk, is the most likely treatment, and the application of iodine; in the form of glycerine of iodine, to the swollen joints. Some good results have followed the injection under the skin of the parts of a four per cent. formalin solution, thus bringing a powerful germicide into more or less direct contact with the septic material. A few foals 
survive and ultimately outgrow the trouble, but we would take the opportunity here of advising the utmost cleanliness in the foaling box, besides the procautions already stated to be so successful in preventing access through the open umbilicus.

Joint inflammations may be due to rheumatism (see page 527), or to external violence, the latter
Anchylosis.-As a result of inflammation in a joint the mobility may be lost or impaired. The morbid material uniting the bones may be fibrous or composed of ossific material, and no treatment is likcly to succeed. There are cases in which enormous ring-bones (see RiNG-BONE, page 557) envelop the pastern joint and completely anchylose it, but the animal can do slow work as he

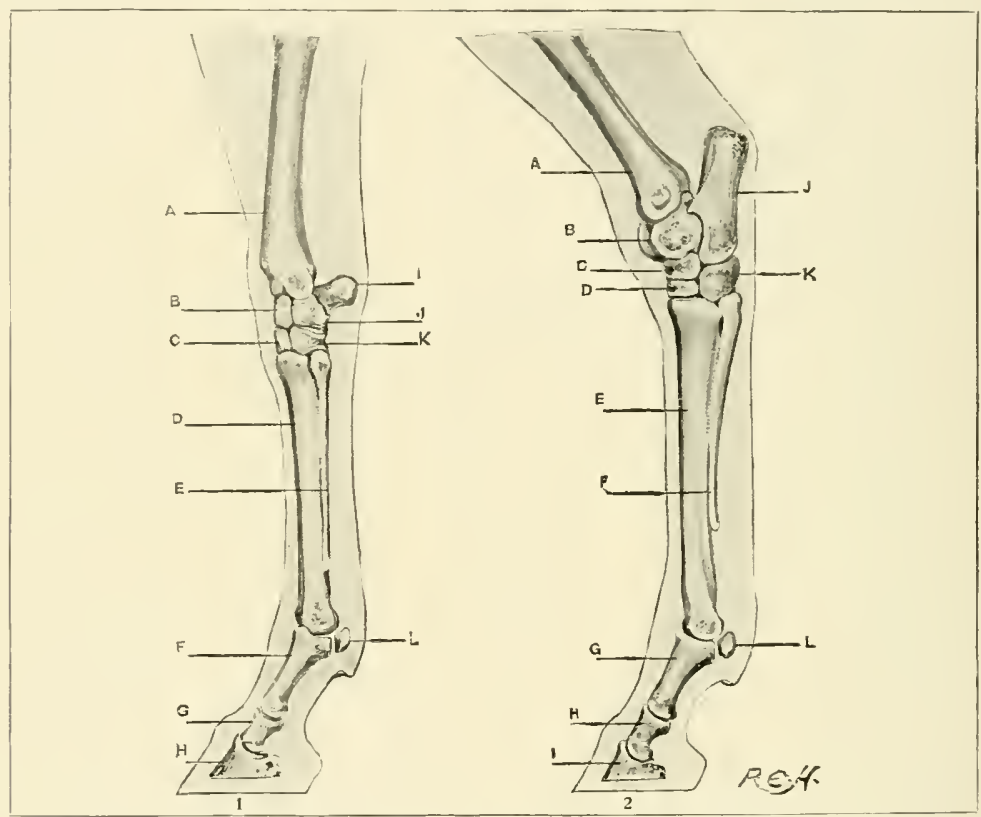

BONES OF THE HORSE'S FORE.LEG, (1): HIND-LEG. (2)

1. A, Radius: B. Lunare: C, Magnum; D and E, Metacarpals; F, Pastern: G. Coronet; H. Pedal bones;

1. Pesiform: J, Cuneiform: K, Unciform: L, Sesamoid. 2. A, Tibia ; B, Astragalus: C. Naviculare ;

D. Cuneilorm: $E$ and $F$, Metatarsals: J. Calcaneum. Other references as in 1.

being the most fruitful cause, whether in the horse at play in the field or at work on the road, in hunting, or racing. The symptoms common to inflammation of the joints are lameness, heat, tenderness, swelling.

Treatment.-Inflammation of a joint should always be deemed a serious matter calling for rest, a cooling dose of medicine, warm fomentations or poultices at first, and with the subsidence of swelling and acute pain, the irrigation of the joint with cold water or cold lotions. The final reparative process is facilitated by a blister and a run at grass, or further period of rest in a large loose-box. learns to use the limb without bending the joint.

Bog spavin, so called, is a joint trouble, and being caused by strain is placed among that list of equine troubles.

Open joint will be found under the title $\mathrm{cf}$ Wounds (page 580).

\section{Sprains or Strains}

Having regard to the character of the work exacted from horses, such as the drawing of heavy 
loaks and carrying of weights in hunting, it is no matter of surprise that strains are of frequent occurrence in all classes. Over-extension and excessive exertion at work or play account for many sprains, and some peculiarities of conformation predispose to such accidents. Joints, tendons, and ligaments are all subject to strain, and it is often difficult even for the anatomist to diagnose the exact nature of the accident, or state with precision what structures are involved.

The symptoms of sprain are not always manifest at the time, but there are cases affecting the tendons and liganents which attract the attention of the novice by the presence of lameness, tenderness, swelling, and evident pain, to a greater or less degree.

Bog Spavin.-This is an example of a strain that may not have been observed at the time, and commonly occurs in young horses poorly kept and soft in their structures. When associate? with strained hock its appearance as a soft swelling at the upper and inner part of the hock may be quite sudden, but more often it is gradual and progressive. It is a distension of the capsule of the hock which is overfilled with synovia. Without any known or likely cause of strain, it appears in overgrown youngsters of the Clydes. dale and other breeds, and would then appear to be no more than an irregular development and superfluous secretion of synovia, which later becomes absorbed. While weakness on the one hand predisposes to bog spavin, artificial forcing for the show-yard on the other has a like bad influence on the joint, and excites this excessive production and consequent bulging. Pain and lameness is experienced in the sudden and acute cases, but not in those of gradual invasion, which latter are more permanent and frequently assocrated with thoroughpin.

Treatment.-Reduction of the inflammation by fomentation with warm water at frequent intervals ; pressure from a truss, or by contracting and thickening the skin by blisters; an apericut dose of medicine and rest - a turn-out at grass being specially helpful when the effect of blistering has been fully seen.

Strain of the muscles may amount to no more than over-extension, or some of the filures may have been actually ruptured. They can generally be felt as tender and hot, and with nore or less visible swelling. Of strained tendons the same maty be said, but the cxcess of reparative material which is brought to the part is more easily removed from muscles than from tendon or liganent, which often remains permanently disfigured when restored to usefulness. This after thickening is always in the mind of the veterinary surgeon in treating leg sprains, and explains why he is apparently so fond of blisters. He knows that when warm fomentations have done their work blisters

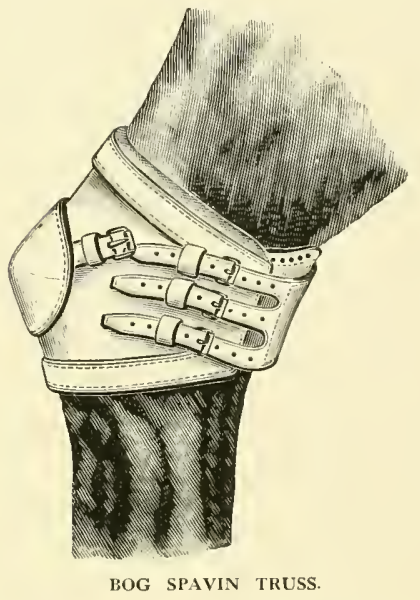

will carry off very much more building material (no longer wanted) than if left to the ordinary natural cure which would occupy very much longer time, and not result in so great refiring of the affected parts (see BLISTERING and FIRING, page 589). The anatomical knowledge of the professional man enables him to decide, in the majority of cases, what particular muscles, ligaments, or tendons are hurt, and his experience telts him the probable duration and prospects of recovery; so the horse-owner does well to take his advice where available. We need not in a work of this kind enter into a description of all the known strains so carefully classified by the expert, but be satisfied to know the general principles for the guidance of the unfortunate owner of a sprained horse, which are embraced in the foregoing remarks, but place especial emphasis on rest as the true cure.

Careful handling of a lame limb will often lead to the discovery of the strained portion, and 
the attitudes assumed to relieve it also point to the scat of trouble. If the horse-owner finds a difficulty in locating lameness he may be told that it is also the subject which most rexes the expert, and in no small number of cases altogether baftles him.

\section{Sprained Back}

This happens when a horse's hind-legs slip under him while kecping back a load, or when landing badly orer a jump, or struggling up a bank when he has come short in his efforts to reach the other side of a stream. He may be so badly strained that he cannot get up. and the onlooker may think his spine is broken, but there will be some degree of movement of the legs when sprained, however badly. In the case of a broken back there is none; besides which, he will not respond to the prick of a pin.

Treatment.-Even a bad sprain of the back need not be despaired of if the animal can be conveyed to a stable, or supported by slings out doors. Warm fomentations to the loins, and enemata per rectum, afford much relief, and if the progress is slow success usually rewards our efforts. Muscular power is more quickly restored in the convalescent stage if a mild blister is applied, and the horse is then turned out to grass.

\section{Curb}

This is the result of sprain, and followed by by thickening of the sheath of the flexor pedis perforans tendon. The calcaneo-cuboid ligament when sprained and enlarged is also called curb, and the swelling in either case appears at the same place at the back of the hock, and is best seen in slight cases from the side. Curb is hereditary in its tendency to appear upon comparatively slight strain. It may occur in any conformation, but is most frequent in straightlegged horses, who:e hock-points are not prominent because the os calcis bone is short. The degree of swelling varies greatly; as does the amount of pain, leat, and lameness ; in the slighter ones no lamencss may be observed.

Treatment of curb before the enlargement disfigures the animal is important, and almost invariably successful. A dose of physic (aloes), a blister, and rest with a high-heeled shoe, is usual. Time should be allowed for the consolidation of the parts sprung before any severe work is required of the horse.

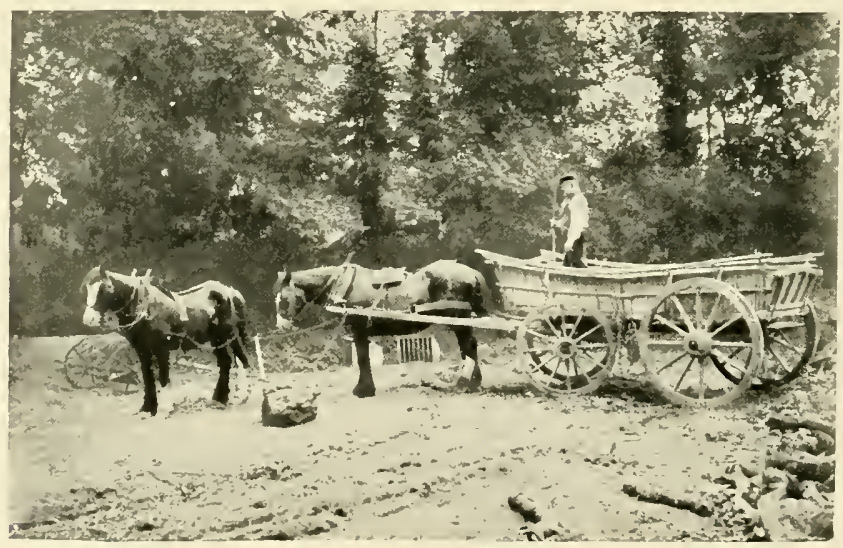




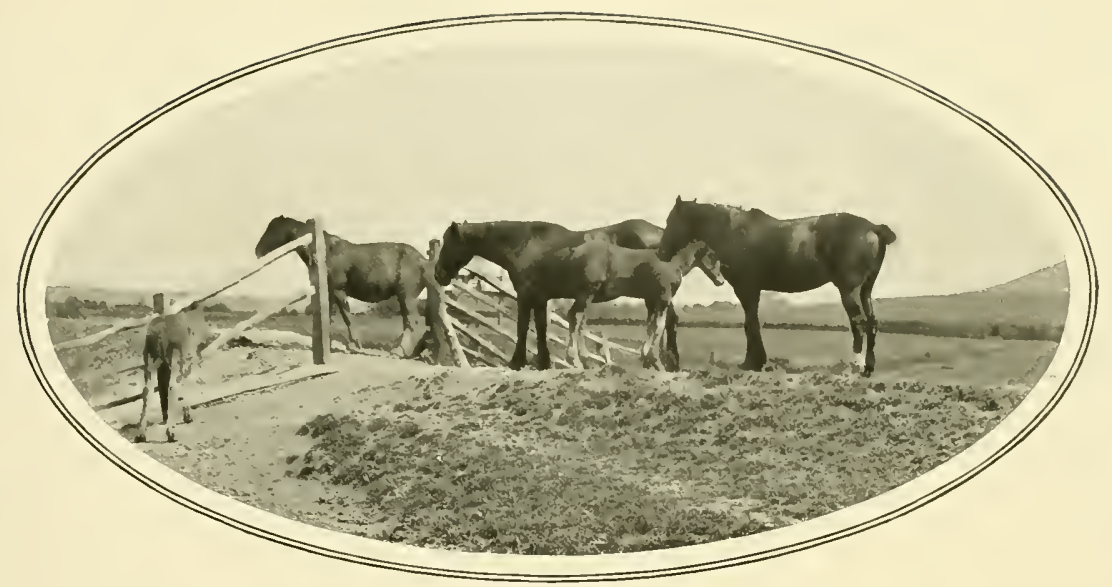

\section{CHAPTER XIV}

\section{DISLOCATIONS}

D) ISPLACEMIENT of the articular ends of bones may be partial or complete. It is with the partial cases that the horse-owner has most frequently to deal. With the complete he will seldom necd to prescribe anything softer than a bullet. There are just a few rare cases of complete dislocation, as of the shoulder, in which the courageous amateur has had a line put on the foot and traction exerted, while he, having divested himself of his boots, has jumped upon the shoulder at the critical moment, and the dislocation has been instantly reduced, the horse allowed to get up, and walls home, etc. Speaking as a veterinary surgeon of forty years' experience, we confess to not having seen this easy performance as described after the market ordinary, but the story is so venerable that it has our respect. A less sensational proceeding is to get the animal under chloroform, and all his muscles relaxed, and then induce the ends of the bones to resume their former relationship. These complete dislocations are so rare that we need only pay passing tribute to a post-prandial story, and call the reader's attention to those partial dislocations of the horse's fetlock and other joints where treatment may be of value.
The over-shot fetlock is a partial dislocation. In a front limb it is much more serious than in a hind one. It needs to be blistered scverely, or fired, a high-heeled shoe put on, and a long rest prescribed if the luxation is not to get rapidly worse, and end in such lengthening of the tendons that no subsequent treatment will cure. The hind fetlocks may go orer quitc half way, and the animal continue to be useful for years. The treatment advised for front limbs should be resorted to early, to prevent further deformity.

\section{Dislocation of the Patella or Stifle Joint}

The bone which corresponds to our knce-cap is a frequent source of trouble in weakly, overgrown, or malformed colts, or we should perhaps say that the lateral ligaments are often so weak as to be easily strained and permit of the dislocation or temporary luxation of the patella bonc. It may be heard in such cases to go back with a click or snap, coming out and going back at every few steps in some instances. Many youngsters outgrow it: some do not.

Treatment. - Besides the building-up of the young animal upon nutritious food, he should be 563 
placed in a small paddock or straw-yard on tevel ground. The stifle joint should be blistered two or three times at intervals of about two months, as by this means a cushion is first formed by which pressure is exercised betwcen the skin and the patella, and afterwards the thickening of the skin serves as a permanent bandage to the joint. During this process the stretched ligaments have been gaining strength.

In adults the dislocation of the patella is a scrious accident, and the bone must be quickly reposed if ulceration of the articular cartilage is not to follow on severe inflammation provoked by the dislocation. The leg is extended backwards and cannot be brought forward if the dislocation is complete. In the partial dislocations of the patella, the leg is made to swing in the arc of a circle, a movement, it may be remarked, which is more or less diagnostic of stifle lameness, and implied by those who speak of lameness in the "round bone." In this accident the modern veterinary surgeon with chloroform will subdue the muscular opposition easily, and bring forward the limb by a rope round the fetlock. The amateur will probably have to depend on the rope passed round the withers first as a collar, and then the free end round the fetlock will be pulled forward with such force as to overcome the obstacle to reposition. If done while the animal is standing an irritant can be immediately put on, and the horse prevented from lying down or moving until the desired swelling has had the effect already referred to. The cast animal is very liable to dislocate the bon again in the act of rising, and he should be prevented from doing so for a few hours.

\section{Thoroughpin}

A fluctuating swelling between the ham-strings and the lower end of the leg bone (tibia) shows as a bulge on either side of the hock. It is a distension with synovial fluid, of the sheath of the flexor pedis tendon, and save for its situation might be called a windgall, being of precisely the same nature (see Wrisdatls, page 566). It is often associated with bog spavin, the strain or over-work which brings on the one also causes the other (see Bog SPAvin, page 56I).

Treatment.- If of sudden origin and evidently inflammatory, it will be well to give an aloetic ball and rest, while fomenting the parts and applying warm bandages or packs frequently renewed, and later replaced by cold irrigations, and lastly by a blister, as advised in connection with many joint troubles. Chronic or slowly formed thoroughpins may need the firing iron

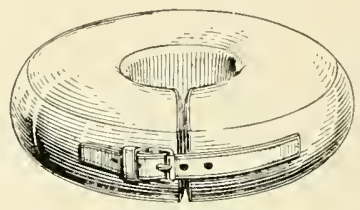

ELBOW PAD.

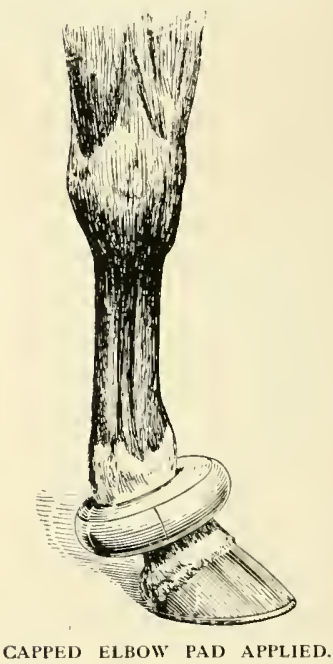

as well as the blister, to bind down the lax tissues and support the weakened and enlarged synovial sheath.

\section{Capped Elbow}

$A$ round or pear-shaped swelling on the point of the elbow is called a capped elbow. It may be almost entirely composed of straw-coloured fluid, as a result of a rather severe blow or injury by the heel of the shoe, or an irregular floor from which the bedding has becn scraped. In such case it answers to the American description of a "shoe boil." When neglected it may even contain pus. Instead of this rapid filling, more 

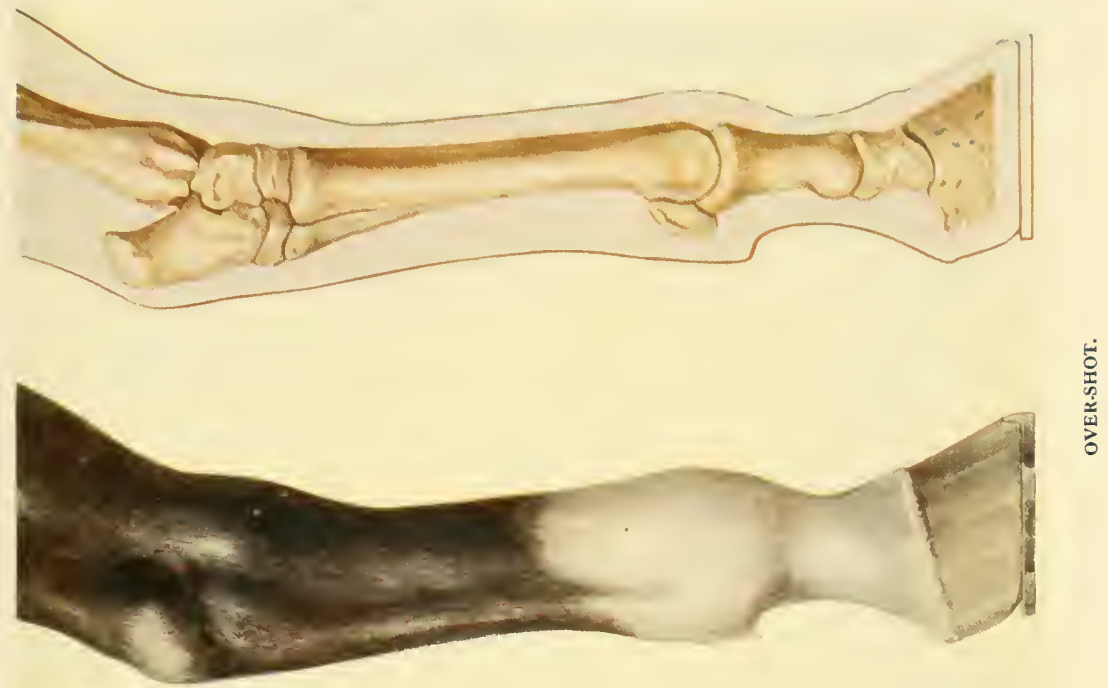

$\frac{1}{0}$
$\frac{1}{2}$
$\frac{1}{3}$
3
0

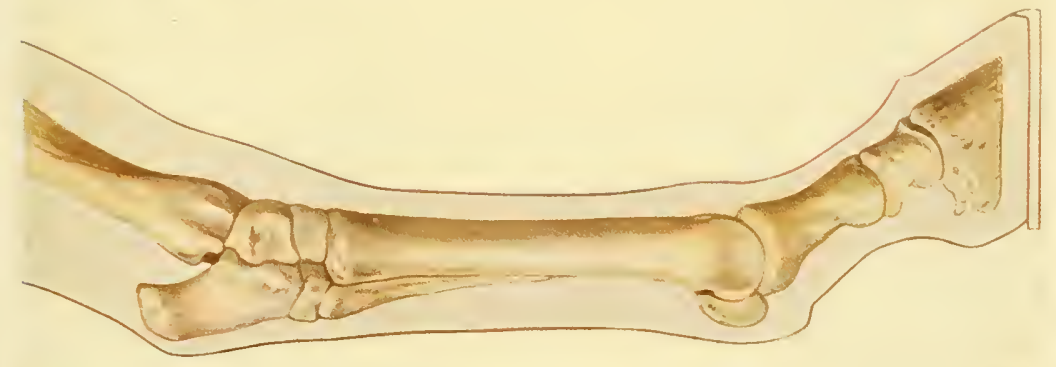

选

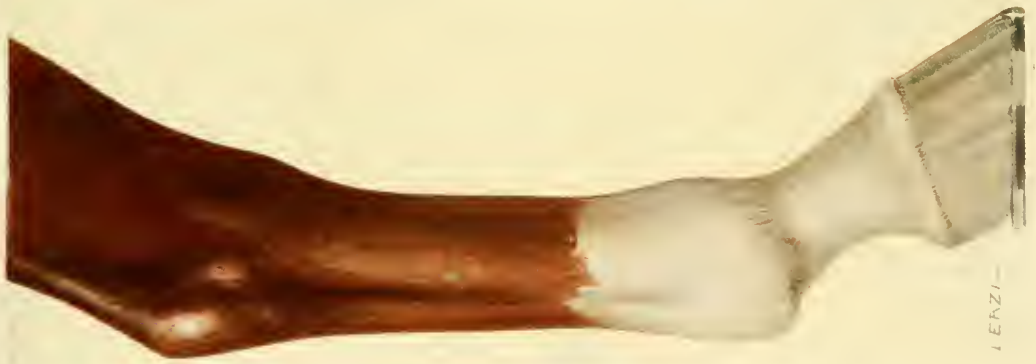



often there is a gradual cnlargement from repeated irritation, or resting on the shoe when recumbent, and then the thickening of the skin and subjacent tissues attains to great dimensions, while the fluid contents may be small or altogether converted into solids.

Treatment.- I tumour of such variable composition will necessarily call for different kinds of treatment. It may be that the first inflammatory swelling will yield to warm fomentations, and prevention of further contact with the shoe or the ground, or that equal parts of soap liniment and water will disperse the enlargement. Whiting mixed with vinegar is very much approved for for this purpose by some, as also for capped hocks. Failing to disperse the contents quickly, the lancet will be necessary. A bold stroke of the instrument, whereby a long ircision is made, and the fluid allowed freely to escape, is preferable to a puncture. Into the sac should be inserted daily some tincture of iodine, to prevent refilling and reforming of the secreting mem. brane, and later the sides of the skin should be blistered, as this is found to reduce the blemish which must inevitably follow to a greater or less extent. Prevention by care in shoeing, by the use of plenteous bedding, by rubber rings or pads worn above the fetlocks, or by Ufford's patent contrivances, should be adopted on the first appearance of capped elbow, in however slight a form.

\section{Capped Knee}

This is of the same nature as capped elbow just described, but is more disposed to solidify from the first and to become callous.

The causes are falls and contusions. Heary horses, somewhat clumsy, in narrow stalls, are the most frequent victims, as they bruise their knees upon the floor.

Treatment.-If fomented with warm water and then wrapped in a thick layer of cotton wool and bandaged over all with gentle pressure capped knee will commonly be cured quickly. If neglected, a permanent disfigurement will result, but rarely any interference with the mobility of the joint. Repeated applications of iodine, as glycerine of iodine, will often effect considerable reductions, but will not wholly remove the swelling if of long standing. In some cases, where the swelling is felt to consist chicfly of fluid, a sterilised instrument (aspirator) is inserted under the skin and the offending fluid drawn off : its reappearance or refilling being prevented by such pressure as we have before suggested.

\section{Capped Hock}

Causes.-Many valuable horses are disfigured by capped hocks. There are two causes, one of which is more or less remediable according

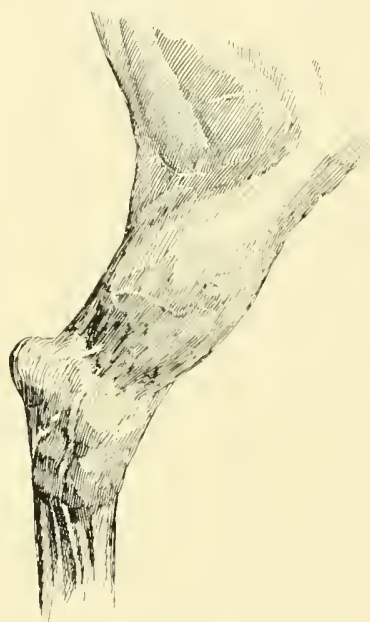

GAPPED HOCK.

to its duration and the other incurable. The simpler form is due to bruising of the skin and tissues immediately beneath it, and will yield to the treatment advised for capped elbow and knee. In the other variety of capped hock, the synovial membrane between the tendon and the bone is injured, and the bulging at the sides distinguishes it from simple capped hock, where the enlargement is on the point only.

The treatment advised for capped elbow and knce is suitable, unless the swelling acquires the character of a serous abscess, when it may be necessary to employ the aspirator, as for obstinate cases of capped knee. Exercise is desirable, and lameness rarely ensues, and there is always a 
disposition to reduction of the swelling if the exciting causes are removed, but permanent disfigurement to a greater or less extent commonly remains.

\section{Filled Legs, Edema}

Filled legs, more or less swelled or even distended with fluid, are quite common among horses debilitated either from poverty or disease, and are to be distinguished from inflammatory cedema, or "Monday morning leg," or weed (see page 528). The fluid consists of the watery portions of the blood which escapes through the sides of the vessels and usually passes away with exercise, only to refill when again at rest, unless the cause is sought and removed. In this connection there is a general abuse of diuretic medicines, as remedies which excite the kidneys to additional work are found quickly to fine the legs. They should not be used for such cases, but the general health should be built up by good food and tonics, daily dram doses of sulphate of iron, with half ounces of gentian being helpful, or half drams of sulphate of copper and quinine. Regular exercise, when not called upon to work, should be insisted on in those animals disposed to dropsical swellings of the legs and of the sheath.

\section{Windgalls}

These round or oval enlargements found about the fetlock joints, the hocks, and knees are due to distension of the capsular membrane of the joint with synovia (joint oil), or a like condition of the synovial sheath of the tendon. Some horses are predisposed to them by heredity, and others of the thick-skinned, coarse-haired type, with big bodies, early develop them without much work, but windgalts as commonly met with speak rather of hard labour performed, and a horse laxing them is said to show "use." They are soft to the touch, and contain fluid, not "wind," as their name suggests. They seldom cause lameness, unless associated with rheumatism.

Treatment of windgalls should be undertaken early, before thickening of their walls takes

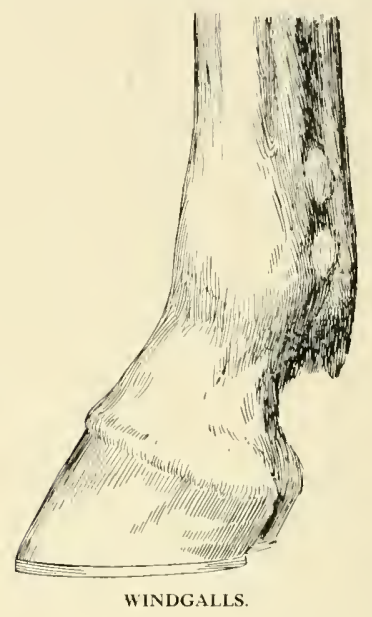

place. The pressure of a pitch plaster, from three or four inches above the fetlock, right down to the coronet, and a run at grass will cure them when first developed; or, when a little more advanced, a mitd blister may have the cffect, but when fully established these remedies only reduce them for a time. Bandaging at night certainly keeps down the swelling, and while at exercise they do not fully regain their size, but on again standing in the stable the distension is as great as ever if not supported by pressure from without. Removal of the fluid by the aspirator and the injection of iodine is sometimes resorted to, but good stable management and habitual bandaging is usually deemed sufficient for what amounts to no more than an eyesore if neglected. 


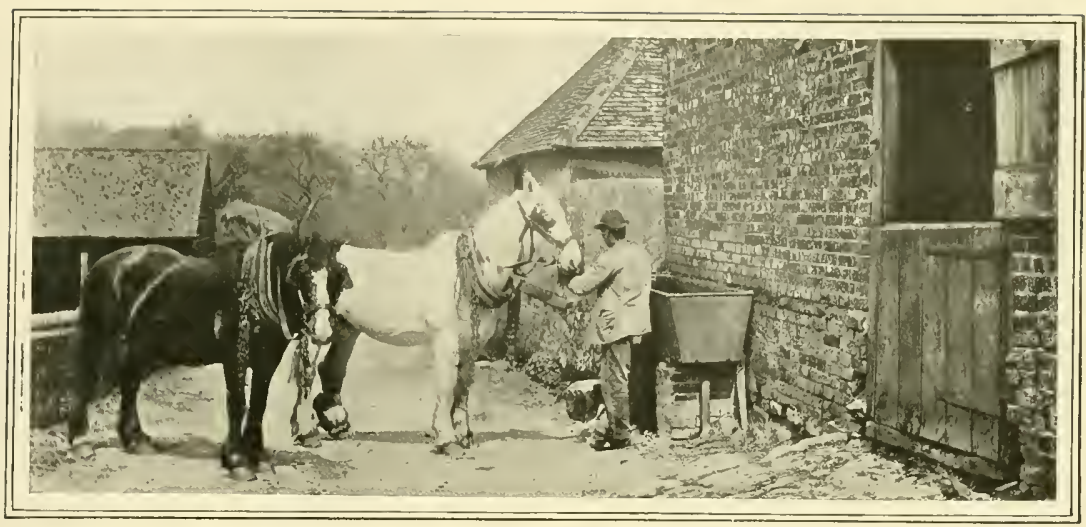

\section{CHAPTER XV}

\section{DISEASES OF THE FEET}

S

AND CRACK. - A fissure in the hoof has long been known by this name, and is most common on dry, sandy roads, but may occur anywhere and in horses of all types. Light horses have these rents most frequently on the inner side of the front feet, and heasy horses at the toe of the hind ones, but they may occur at any part. Directly opposite causes give rise to them; if the hoof is unusually thick and dense; or when it is thin and lax in the horn fibres of which hoof is composed. In dry summers the hoof becomes brittle, and certain chronic forms of indigestion predispose to cracks in the hoof, from absence of gelatine in proper proportion. The cracks commonly begin at the top and extend downwards, increasing In length and depth if not arrested. They may appear quite suddenly and with oozing of blood from the crack, or the separation may be gradual, and fail to attract sufficient attention. If the breach in the horn extends to the sensitive foot, lameness is marked; othcrwise it may be absent. Small superficial cracks sometimes grow out without causing any inconvenience.

Treatment.-Rest and antiseptic dressings to begin with, and a ball of aloes if the animal is at all gross. To prevent the crack from extending, a line is drawn with a hot iron just below the end of the fissure, and one on either side in the form of a $\mathrm{V}$ to divert concussion. There ate several means of drawing together the divided hoof. A fine horse-nail may be driven trarsversely from the sides and clinched on both sides; or holes may be drilled in the hoof and clamps inserted. Bindings of tarred cord, straps of leather, or tape answer the purpese, more cr less well, of keeping the fissure elosed until new horn grows down from the coronary band, which latter is stimulated by a mild blister. Most sand cracks can be thus grown out, but a few prove intractable, owing to injury to the coronet, which fails to secrete the requisite horn material to effect the necessary repairs.

\section{Shelly Feet}

When the horn-making structures fail in their function, as from chronic indigestion already mentioned, shelly or brittle hoofs result, and much difficulty is experienced in obtaining good nail-hold for the shoes.

This defective secretion is frequently hereditary, and is also caused by improper treatment of the feet by paring out the sole and fitting shoes too hot. Shelly fect have been observed to follow on febrile diseases, as laminitis and influenza. 
Treatment.- A good deal may be done to remedy this defect in the stabled horse, by stimulating the coronets periodically with ammonia and turpentine liniment, or a tery weak ointment of

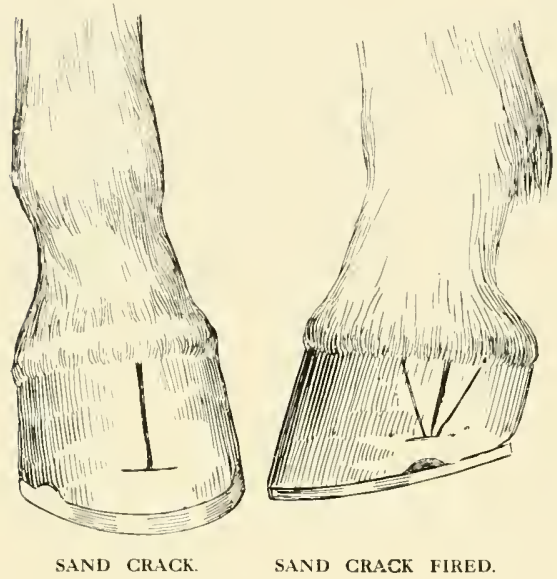

biniodide of mercury (one in sixteen), and the smearing of the hoofs with equal parts of Stockholm tar, fish oil, and glycerine. A radical cure may result from a blister, followed by a run out in a low-lying wet pasture for several months.

\section{Seedy Toe}

When the inner layer of horny laminze breaks away from the outer and denser one, the condition lnown as seedy toe results, and a quantity of decomposed grey or blackish matter is found to have destroyed the union. This material comes away and leaves a cavity which may often be detected without more examination than tapping the foot on the outside, and listening to the hollow sound emitted. The toe is the more frequent site of the disease, but it may occur at the quarters. Until the malady has made some progress it does not cause lameness. In attack of fever in the feet (laminitis) predisposes to it. Many theories have been offered in explanation of this disease, but none is altogether satisfactory. In the débris may sometimes be found a parasite named after Professor Axe, who was the first to discover it (Ptlodera Axei), and it is possible that this is the chief source of the trouble.
Treatment consists in scraping out all the diseased matter, dressing the cavity with a powerful disinfectant, as chloride of zinc, and filling up the space with Stockholm tar, which is both a parasiticide and a horn nourisher. At the same time, the coronary band is stimulated to secrete new material by mild and repeated blisters or liniments. Only in bad cases is rest prescribed, the secretion of new horn being favoured by use of the foot.

\section{Horn Tumour, Keratoma}

Blows and concussion are said to be the causes of growths on the inner surface of the hoof, for which very little can be done; operation for their removal is attended with but a small measure of success. Judicious shoeing relieres some cases.

\section{Thrush}

A low form of inflammation, or congestion, of the sensitive frog results in a discharge from the cleft, and a ragged decayed state of the visible frog, known as thrush. Some horses have a constitutional predisposition to it, and others appear to contract it from standing in urine and filth, or from habitual moisture, as borses at

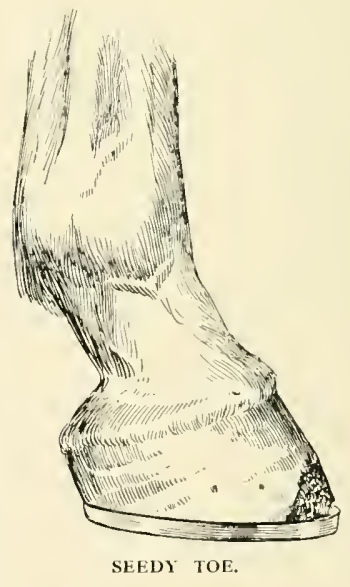

grass may contract it. High living in the stable and the lymphatic temperament also predispose to thrush. Paring away the horny frog and cutting out the sole and sloein $z_{2}$ in such a manner 
that the frog, bars, and sole get no pressure and share none of the animal's weight, is sufficient alone to cause thrush. Withont use of any structure, atrophy follows. When the frog is deprived of its natural function by being pared away and lifted off the ground, atrophy begins, and the waste products of imperfect horn come away as a disagreeable discharge, and the horny portion itself shrinks and grows ragged and shows dead patches or hollows.

Treatment.-Of all methods of treatment frog pressure is the most successful. If the shoes are removed and the horse made to stand on a hard level floor, the frogs flatten and grow hard, the heels expand, the bars are strengthened, and the foot reverts very much to the shape of the colt's. Next to throwing out of work, we may use the sunk shoes known as Charkier's. With quite the majority of cases we must needs work the animal, and in the shoes to which he has been accustomed. We are thus restricted in our operations, and must avoid drying up the frog too quickly with the powerful caustics so often employed, which cause further shrinking of the frog and falling in of the heels. A dose of aloes in a ball acts upon the feet in withdrawing blood or reducing pressure. The old farriers aptly called aloes a "derivative" in respect of the horse's feet, and there are dealers to-day who know how to use aloes in such a way as to patch up a cripple for sale. While giving such constitutional remedies as salts, and nitre, and sulphur, we may clean out the clefts and insert pledgets of tow mixed with one part of salt to three parts of Stockholm tar, making this an habitual dressing, but occasionally washing out with soda and warm water and afterwards pouring in a ten per cent. solution of chloride of zinc. Some horses suffer on peat moss; and others are helped by pine sawdust; but all thrushy horses should have dry bedding and receive constant attention to their fect, when the worst of cases may be controlled and ordinary ones cured.

\section{Corns}

Many terms used by horse-owners are puzzling to the beginner, and this is one of them. A corn in a horse is not a hard excrescence, but a bruise with more or less blood-staining, and perhaps suppuration, in the angle between the crust, and its inflection called the bar of the foot. Most frequently found on the inside of a fore-foot, but occasionally seen in both hind and front leet. Among the chief causes are defective fect and bad shoeing. The low, weak heel, as seen in Flemish and other horses bred on lowland, predispose to corn. Too much paring of the sole, lowering of the heels, shoes too short and narrow at the heels, and above all too long retention of the shoes, eause corns by the overgrowth of the foot, or, as is commonly said, the shoe growing in-by which is meant the altered position of the heel of the shoe by which it presses upon the angles or the bars, when its bearing should be upon the crust or outer wall. The presence of corn is too frequently overlooked by the smith, who is either forbidden to "rob" the foot, or else too busy to examine the scat of the corn when nothing has been said about the subject. If the angle is pared out, a red spot of variable size will be found-a staining of the horn, in fact, from the bruise in the sensitive part above it.

Treatment.-If neglected, corns become greatly inflamed and suppuration follows, extreme lameness calls attention to the foot; an exploration with the knife leads to the liberation of the matter confined in the hoof.

Other symptoms, as heat and tenderness in the hecl, point to corn as the cause of lameness, and no time should be lost in relieving it by removal of the shoe and paring out, poulticing, and rest. A dose of aloes should be given during the enforced idleness of the patient.

Many corns are at once relieved by removing the pressure of the shoe, putting it through the fire, and opening the heels, so that when replaced it has no bearing upon the seat of corn. When suppuration takes place, the matter must not only be drawn out, but time allowed for Nature to effect repairs. Neglected corns are liable to result in a breach in the coronet, as the matter takes the least line of resistance and comes out between hair and hoof. Even then it may be cured by prompt drainage from below. Failing proper treatment a quittor results (see page 572).

\section{Laminitis, Fever in the Feet}

Fever, or laminitis, has been referred to in connection with pulmonary and intestinal inflammations, and as following on difficult parturition or inflammation of the womb in mares, 
when its sudden appearance is known as metastasis, or transference from one part of the aninal to another. It consists in inflammation of all the soft vascular tissucs (laminæ) between the hoof and the bones within the foot. Shallow or weak fect, low in the heel and spreading, are specially prone to laminitis, but all sorts of feet are found to be affected. Heavy horses are more liable than the lighter breeds, or contract laminitis with less provocation. Concussion, whether from usually called; and this latter symptom is sometimes mistaken for congestion of the lungs in horses standing in stalls and not made to move. The membranes of the eye and nostril are very red as in other conditions of fover, and appetite more or less is in abeyance.

Treatment,-In other foot troubles the reader will have noted that a dose of aloes is prescribed. In this malady a full dose should be given imme-

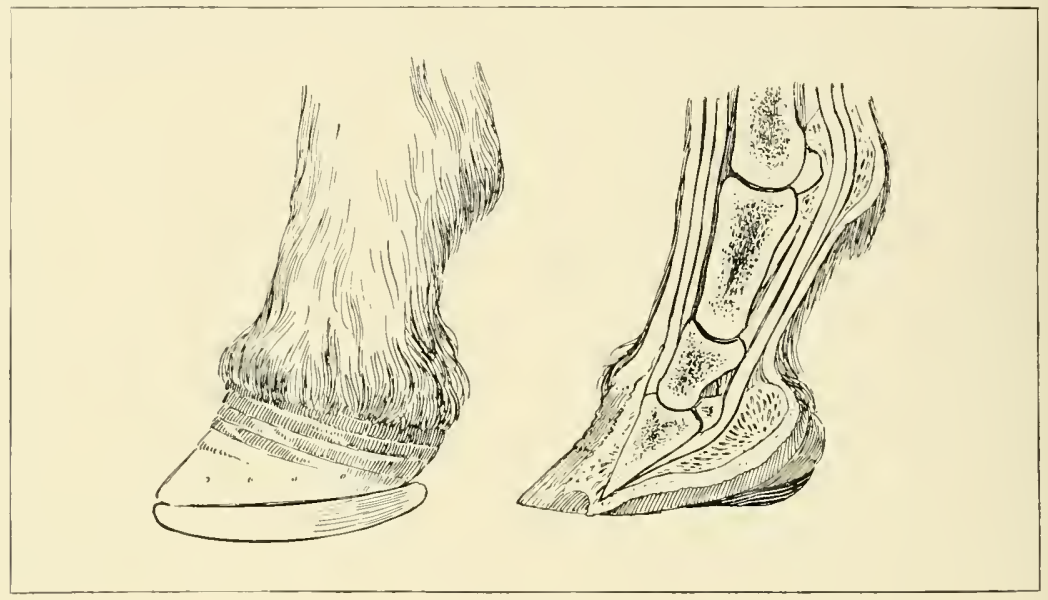

LAMINITIS.

high action, excessive labour, or jumping, accounts for the majority of cases. High feeding and want of exercise are frequent causes in the gentleman's stable, or spells of idlcness and bursts of spced, as with the sporting publican's pony. Too much feeding on wheat and maize are among the causes of laminitis in this climate, but do not have the same effect apparently on the American continent and in some other countries.

The symptoms of laminitis are, as a rule, sudden, and the fore-feet most often affected. The position which affords most relief to the pain is one in which the animal leans back upon his heels and appears rooted to the ground. If all four feet are affected, he assumes a crouching attitude. The feet are hot to the touch, and if lightly struck the poor beast shows pain. There is high temperature of the body, as indicated by the thermometer per rectum, an anxious expression of countenance, rapid breathing, or "blowing," as it is diately, and blood should be taken from the jugular vein. Slings afford a measure of relief to the feet, but should not be employed if there is a disposition to lie down. The shoes should be removed and the feet put into poultices of warm bran. In extreme cases, full doses of morphia, of chloral, of cannabis indica, or the bromides of potassium and ammonium may be given. When a horse obstinately stands and the smith cannot get the shoes off, an injection under the skin of the coronets at three or four places may be made of a seven per cent. solution of cocaine, when twenty minutes' relicf will be afforded, and the operation can be carricd out. With the subsidence of acute pain cold water may be substituted for poultices, allowing a stream to run over the feet, standing in a pond, or swabbing in the stable, according to circumstances. Slow walking exercise follows, then a blister round the coronets, and a turn-out in a wet pasture. Despite treatment, horses sometimes die of 
laminitis, and most acute cases leave an alteration of structure whereby a cheesy material is interposed between the sensitive foot and the hoof. and the front falls in, the heels grow larger, the sole drops, and rings form on the outside of the hoof. Where no other bad effect is readily seen, the rings upon the hoof should warn the intending purchaser, who will be told that they are only grass rings. They are, however, quite different from the healthy plump enlargement of the hoof that often follows on a run at grass in favourable weather.

\section{Quittor}

This is a fistulous wound at the top of the hoof, and is formed to drain away injurcd, dying, or dead tissues underneath. Mfany pipes communicating with each other are often found in bad cases. Any injury to the coronet, such as heavy horses inflict upon themselves in turning in shafts, or receive from their fellows in double harness, a prick from a nail, a neglected corn or bruised sole, may result in quittor (see CoRNs, page 569). Beginning with a hot and painful swelling caused by the formation of matter it presently breaks, discharges, and is less painful; but the cause remains, and fresh swellings in the direction of the toe are followed by sinilar breaches in the skin. The lameness is not so acute after the first outbreak, but persists.

Treatment of quittor is most successful when least scientific. According to surgical rules, the sinuses or pipes should be traced and cut through with a bistoury, and successive poultices should draw out the offending matter. We have seen horses so treated until their feet were as soft as jelly, and the animals have then been destroyed. We have seen a large number cured by the old farrier's method of rolling up some arsenic and corrosive sublimate in a little cone of tissue paper and pushing it down to the bottom of the wound, whereby a terrible inflammation is set up, great pain experienced for a couple of days or more, and then a slough or "core" has come out and a gaping wound left which has soon healed with poultices. When healed over, a light blister is applied all round the coronet, the swelling goes down, and the case recovers. It is never agreeable to recommend what are called "cruel" methods, but the question may be asked, is it eruel if successful, and when compared with the cutting operation which so often fails? As a result of quittor the coronary band is often injured, and what is known as false quarter remains.

\section{Canker}

This is the most offensive disease of the feet, and fills the stable with its persistent odour. It consists in a spongy growth of the frog, and extends to the sole and other parts if not arrested, and produces a discharge of cheesy-like matter. One or more feet may be affected, and the heavy breeds are more subject to it than light horses. It often follows thrush or other horn troubles.

Treatment.-Unless promptly attended to canker is incurable, save by a few specialists, who strip the sole and frog, which is a very painful operation and a long business. Preparation by a dose of aloes, short rations, and disinfection by immersion in a tub of ten per cent. solution of chloride of zinc, is advised, after which all diseased horn should be carefully scraped away, for as long as any particle remains it appears to act as seed for the growth of more fungoid excrescences. To the scraped surface a variety of caustics are applied, as arsenic, chłoride of zinc, sulphates of copper and iron, and liquids as nitric acid or sulphuric. Pressure is then brought to bear upon the parts by wedges under the shoe or by other means. and a cure is more likely to result if in this more or less painful state the animal is compelled to do moderate work.

\section{Pricks of the Foot}

Many horses are lamed by nails wrongly driven in shoeing, and not always from carelessness of the smith, as a restive animal snatches his foot just at the moment of striking the nail. Gathered nails, or such as are picked up on the roads, also account for pricked feet. The situation of the prick will generally determine the means by which it occurred. Fatal injuries have resulted from picked-up nails passing through the frog into the navicular bone. Pricks also carry into the sensitive foot the bacillus of tetanus, or the pyogenic organism which causes suppuration. These are sufficient reasons for considering every pricked or punctured wonnd of the foot as a serious matter, calling for immediate attention. As a rule, the injury is not detected until lameness results. Shoe-nails are sometimes driven so close to the quick as to cause pressure or bulging, and these give rise to some difficulty in discovery. 
Treatment.-Removal of the shoe and pinching round the various holes will often enable the smith to find the tender spot, cut it out, tack on the shoe without replacing the nail, and recovery

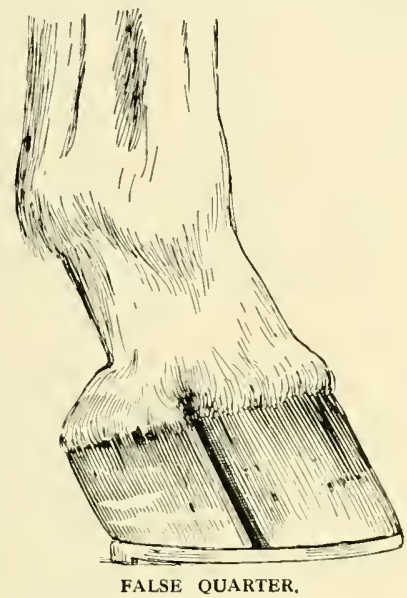

follows in a day or two. Not always docs this happy termination ensue, but the animal gets more lame, points the foot in the stable, and suffers much pain, and a green matter, like the sap of a tree, forms, and perhaps under-runs the sole.

If the matter consists of only a single drop the patient will be lame, very lame, as a rule-and the offending fluid must be got out by the knife and subsequent poultices. The common mistake made by amateurs and blacksmiths is that of making the orifice too small. They are afraid of a few drops of blood, and desist from cutting just at the time when they would do most good by getting free drainage. At the same time the wound should be saturated with a disinfectant, the fear of tetanus (lock-jaw) being always before the eyes of the operator (see TETAnus, page 535). Provided good drainage is effected. disinfection practised early in the case, poultices continued until the inflammation has subsided, and sufficient rest allowed, pricked foot generally makes a complete recovery, but any neglect may result in quittor (see page 572 ).

\section{Chronic Inflammation of the Coronet (Villitis)}

Horses may be seen with the hair round the top of the hoof standing on end "like the quills 73 on the back of the fretful porcupine." This is due to a lasting congestion of the papilla from which horn grows down, and a defective hoof results. A long rest in a wet pasture is the best treatment.

\section{Side-Bone}

At the sides of the foot and towards the heel may be felt in the normal foot a wing of cartilage which is a prolongation of the pedal bone, in the same sense as the cartilage at the top of the shoulder-blade bone, which every carver must have noticed in connection with a shoulder of mutton. This lateral cartilage is subject to a gradual change in its composition, beginning as deposits of bone in the cartilage cells, and ultimately resulting in transformation to bone, when it is known as side-bone. It often exists together with ring-bone (see page 556), and may involve the whole of the cartilage, or only a small part of it. Among the causes must be counted heredity; concussion and external violence, highheeled shoes, and calkins also contribute to the number of cases.

It is often difficult to diagnose, as the commencement of it may be in the part under the hoof, and until it is pronounced the cartilage continues to bend under the pressure of the thumb, which is a rough and ready tcst the horseowner may apply. Lameness does not necessarily

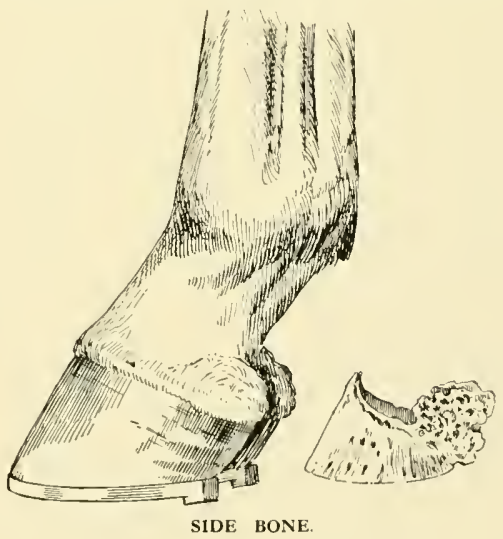

accompany side-bone, although it is frequently caused by it.

It is, however, a serious cause of unsoundness, as 
it is apt to go on growing and ultimately involve the joint, causing anchylosis. Heary horses are the principal subjects of it. Light horses are more frequently lame when side-hone is present.

Treatment.-At first an aloetic ball, cold swabs constantly applied, or a daily foot bath in a pond where available. Then a blister, repeated every three weeks on three successive occasions. Turning out in a wet pasture should follow. If these repeated blisterings fail to reduce or arrest the ossification, firing must be resorted to; and if firing fails, some period of usefuiness may result from division of the plantar nerve, whereby the parts are deprived of feeling. Continental veterinarians saw through the hoof on each side of the ossification, and exercise the animal during the reunion. This gives more room, and in some cases proves successful.

\section{Navicular Disease (Navicularthritis)}

This foot trouble was very much more prevalent in cities when stone sets and macadamised roads were the rule, and prior to the introduction of wood paving. A further diminution in the number of cases is due to the more general recognition of the hereditary character of the malady, farmers now seldom breeding from the subjects of navicular disease, which they formerly attributed to the shoulder. They were only at the wrong end of the limb, and thought that a "shoulder tied" mare should recover at grass, while bearing a foal to pay for her maintenance. The veterinary profession has only known the true nature of navicular disease for about a century, and technical information was not then published in penny agricultural papers: hence the long time occupied before the hereditary nature of the malady was realised by those whom it most concerned.

The symptoms vary, and the progress of the disease is often slow, sometimes rapid, at others the lameness is periodic or uncertain; at times the animal seems to be all right, and again after a day's hunting, or other labour, comes out stiff in the morning, but warms up with exercise and continues to go sound so long as kept moving. There are a number of conditions which pass under the name of navicular lameness. Some are due to inflamed joint, others to friction or congestion of the tendons close to the bone, or to the bone itself. There are also cases in which the wings of the pedal bone give rise to symptoms so much like navicular joint lameness that it is not easily distinguished from that malady. Pointing the foot, or extending the suffering member in advance of the other foot, is the most general and persistent symptom. At the same time the opposite diagonal is brought forward under the body, and weight thus removed from the discased foot. When both front feet are affected the animal frequently changes them. A near fore and an off hind are brought forward; then an off fore and a near hind. The symptom of point. ing will often precede any other, and owners will sometimes refuse to believe that pointing is anything more than a liabit. It is a habit. It is the habit of navicular disease, and if any cure is to be effected, then is the time. As the malady increases, the horse comes out increasingly. "shovey." His step is shortened and leg straightened, the lameness is more and more pronounced, and a longer time in exercise is needed before it is thrown off, and its return is observed if the animal only stands still a few minutes. This is specially noticeable in turning. Shortening of the step continues, and wasting of the shoulder muscles succeeds after a variable time. There is no sort of foot exempt, nor can it be said that any shape specially predisposes to the malady. It used to be thought that a contracted foot was a symptom of navicular disease. We would rather put it that heels that have fallen in, and feet that have contracted as the result of paring away frogs and cutting out soles, invite navicular disease.

Treatment.-If the symptom of pointing is accepted as evidence of this disease before any other presents itself, then a blister round the coronet and a long rest in a soft pasture may restore the animal; indeed, an apparent restoration follows this treatment in more advanced cases, but the lameness returns when work is resumed. Of such are the cases that ruin the reputation of the young vet., who passes them as sound. Repeated blisterings, and even firing through the coronet, and setons through the frog, have been used and are still employed, but to no good purpose. If a horse has navicular diseasr in any but the earliest stage he will yield the best service to his master if unnerved before structural changes have advanced. The little bone (navicular or shuttle bone) which gives its 
name to this larneness is found in all stages of congestion, ulceration, and disintegration in longstanding cases examined after death.

\section{Stringhalt}

This belongs to the diseases of the nervous system, and its pathology is not understood (see Diseases of the Nervous Sistem, page 515).

\section{Injuries Resulting from Defective Action}

Brushing is the term used to describe the defective action which results in bruising and wounding of the fetlock, or other portion of a

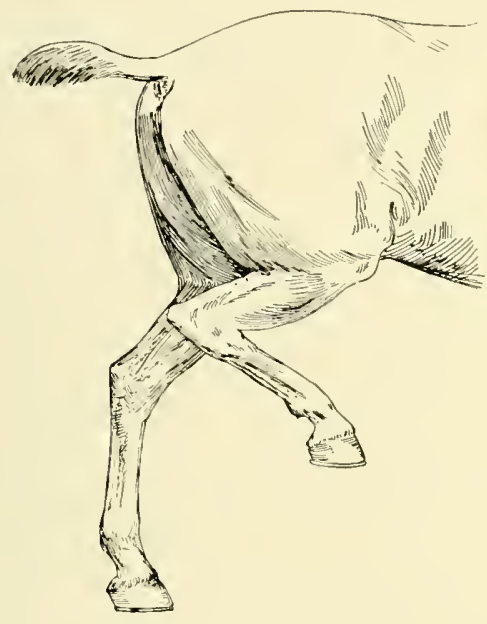

STRINGHALT.

limb, by the foot of its fellow. Soreness, swelling. and in some cases lamencss, follow when brushing is repeated. It is a common defect of youngsters when first broken in, or while still "green," as the word goes. Weakness and awhwardness under unaccustomed circumstances of having a weight on the back, or being confined within shafts and unable to turn in a natural manner, leads to these blows, and they should not be regarded as of little consequence, because the swelling increases and becomes callous, always afterwards offering an impediment, and increasing the risk of further injury. Warm fomentations, followed by pressure from a sheet of cotton wool, bandaged rather tightly, will often cure the trouble in a night. Prevention by a folded picce of rug strapped on the leg (a Yorkshire boot) is advised as preferable to the leather and rubber appliances sold for

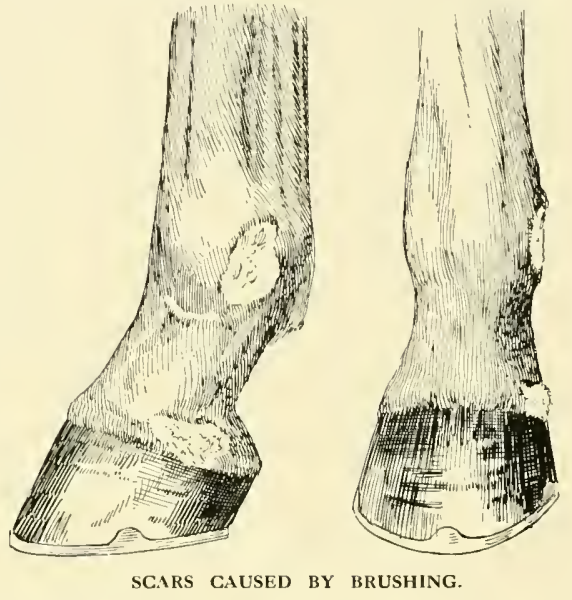

habitual brushers, as the piece of rug can be renewed as often as it gets hard. It is not elegant, but for temporary use is to be preferred.

Cutting.--The sharp edge of the shoe, or the force of the blow, very often inflicts a wound, as well as a bruise, when horses

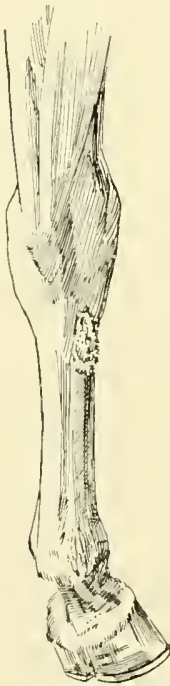

SPEEDY CUT. brush. These should be fomented with a five per cent. carbolic lotion, and some carbolised oil on a piece of lint retained on the wound by a bandage.

Speedy Cutting.-A very dan. gerous form of interfering through defective action is known by this term, and is to be distinguished from ordinary brushing and cutting of the fetlock and pastern. It is striking against the prominence at the lower and inner part of the knee or thereabouts, when the aninal is trotting or going at a faster pace. It is extremely dangerous in a saddle horse, as he is likely to come down. It is not so amenable to treatment as the previously mentioncd troubles, because it 
arises out of defective conformation. Horses with turned-out toes are the kind to brush, and if the chest is narrow and the legs close together, the danger of speedy cutting is greatly increased. Various kinds of boots or leggings are contrived to prevent, or reduce the violence of, a blow from the opposite foot, and a careful horse-owner will avoid these injuries by always keeping the animal under his best pace, and never allowing him to become careless in action through fatigue. When wounds occur as the result of specdy cut, it is even more important than in brushing injuries to do all that is possible to prevent permanent enlargement; the twelfth of an inch in thickness at this point or at the fetlock may make all the difference as to interfering or not.

Over-reach.-This happens to unconditioned and immature horses who have not learned the proper use of their limbs, like the growing youth wearing "nines" and kicking up against the furniture with feet whose changing length make him awkward. Some horses continue to "clackclick," forge, or over-reach, but their conformation is defective, and to that extent they are incurable; but much may be done by shoeing and the management of the feet to mitigate the evil. The loud noise made by some horses is duc to the toe of the hind foot striking the shoe of the front one. Others inflict injuries by wounding the coronct at the heel. The short body, "wellribled home," so much liked by riding men, is the confermation which naturally leads to this accident; but they look, too, for hind feet-or, rather, legs - so conformed that in the gallop the turned-out toe means the clearance of the front foot. Hind shoes shortened in front, "cowmouthed," and having side instead of toe clips, with foot rasped back almost to the white line in the hoof, and front shoes with short heels bevelled away, will overcome the defect in the majority of cases, or sunk shoes, known as Charlier's, may obviate the difficulty. No single remedy will answer for all cases of brushing, cutting, and interfering, but a careful consideration of each one on its merits, with the co-operation of an intelligent smith who knows his business, will in many cases enable the owner to find a way out. There are a number of rubber appliances faroured by owners of trotting horses.

\section{Grease}

This old name for a form of inflammation of the true skin of the heel and pastern denotes a common symptom in the carly stages, when an offensive fluid discharge follows on an itching and rubbing of one limb or foot against the other. Stamping at night, or when at rest, is also an early sign, but may be due to a species of mange mite which confines its attentions to the lower parts of the limbs. The pouring out of greasy fluid, of particularly unpleasant odour, is diagnostic of grease. Neglected cases run on to the formation of round eminences which are known as grapes. The heavy breeds of horses, with slow circulation, are the most prone, and among those with round rather than flat bones its attacks are particularly noticed. It has been called the curse of the cart stable, but the careful breedingout of the old-fashioned round-legged type, and the development of the Shire horse, has very greatly reduced the evil. It may, however, occur in almost any kind of horse, but the well-bred and the hackney types are comparatively immune, and its presence in the private stable is a reflection upon the groom or the owner.

Treatment.-Horses disposed to grease should not have their legs washed, but the mud should be allowed to dry, and be brushed out with a stiff dandy brush. Farm horses should not drink from ponds for this reason. Diuretic medicines have a very marked effect on horses subject to this malady, and a bran mash twice a week, containing an ounce of nitre, two ounces of sulphur, and four ounces or less of sulphate of magnesia (Epsom salts) will either cure or keep it in check, unless long neglected. Epsom salts may be regarded almost as a specific, if used when the first signs appear. Small doses of sulphate of copper and zinc and iron, given in the form of balls, or mixed with damped corn and chaff, are advised in advanced cases, and should be given over a considerable period, to have their best effect. A lotion of five to ten per cent. of chloride of zinc in water for established cases will be found to check the discharge, and prevent the formation of grapes, but when these have actually formed, the hot iron may have to be used, and a veterinary surgeon should undertake the task, which may then be considered to be rather beyond the powers of the amateur horse-doctor. 


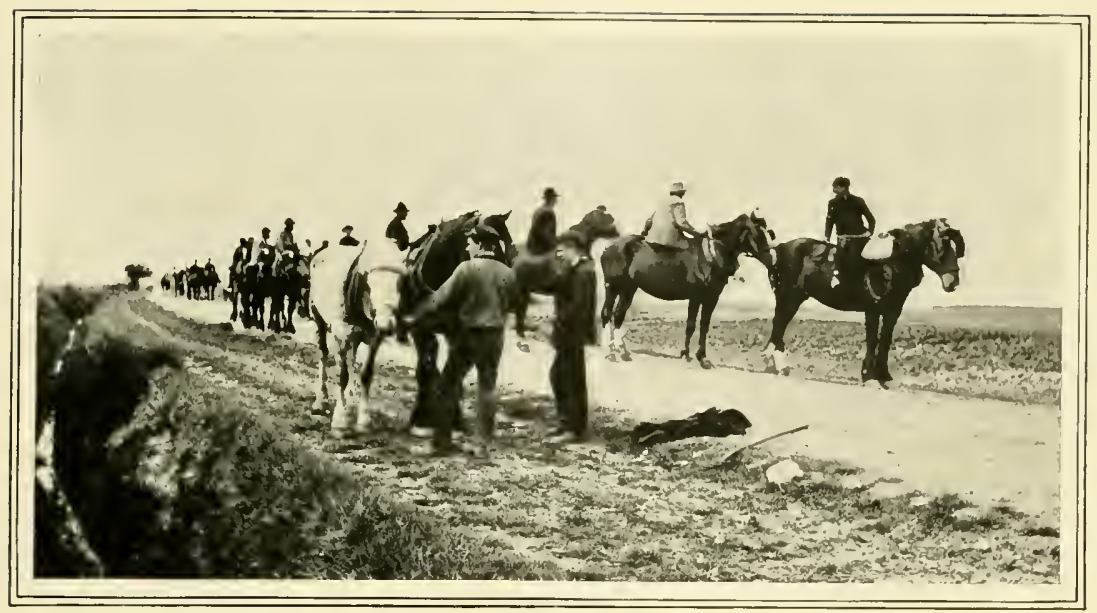

\section{CHAPTER XVI}

\section{WOUNDS}

$\mathrm{T}$ HERE are a variety of wounds encountered in connection with horses, and the owner should be in a position at least to give first aid, if not to carry through the treatment to the end. They are conveniently classified as incised, lacerated, punctured, contused, and poisoned.

\section{Incised Wounds}

Clean cuts-such as are made by knives - come within this category, and their treatment is simple. The principle to be remembered is that of bringing the edges into apposition at the earliest moment, while excluding germs which may be floating in the air or found upon the skin. A clean, incised wound from which blood comes freely, but not in spurts or in uncontrollable quantity (see HemorRHAGe, page 475), may be brought together without previous irrigation with an antiseptic, but any needles or suturing material employed should be sterilised in one or other of the popular disinfectants now so generally to be found in houses and stables. If wounds are stitched, a wide margin should be allowed to prevent tearing out. No more pain is inflicter by a needle quickly thrust through muscles as well as skin than is caused by superficial sutures. What are known as interrupted sutures are usually best, each stitch being fastened off separately. Repose is what is needed, while protection from germs is afforded by a simple dressing of carbolised oil, and a bandage or covering according to the situation of the injury. Simple incised wounds often heal by adhesive inflamma. tion or "first intention," as it was formerly called. No discharge is produced, but an adhesive material holds together the previously divided structures intil perfect repair is effected underneath, and unseen.

Lacerated wounds are such as result from blunt instruments, nail-hooks, and gear cmployed for harness horses, by falls, collisions, etc. The skin and structures beneath are then more or less torn, and hang in rags and tatters.

Treatment of these must be begun by thorough disinfection, as in almost all cases foreign matter has gained access. The amateur goes wrong in lacerated wounds by cutting away shreds of skin (see TORN EYELIDS, page 544), which should be 
conserved to the last. Every bit of skin should be dealt with as a piece of priceléss old lace, and fine nceules and suturing material used where coarser ones will only suit the greater portion of the wound. A pad of lint soaked in carbolised oil will suit the majority of cases for the first two or three days, but aqueous antiseptics will later on prevent undue softening of the tissues, which results from too persistent use of oil.

Contused wounds.-Bruising or crushing of the tissues, as well as laceration, is here meant, and followed by more inflammation and swelling and liability to tear out stitches, which should be deeply placed. Sloughs or dead material may come away, and should be encouraged to do so by antiseptic or disinfectant lotions applied warn, or syringed into the opening. Fistulas are the result of too rapid healing over (see Fistulous Withers, page 580; and QuitTor, page 572).

Punctured wounds are, of all others, to be feared (see PrICkEd Foor, page 572), as the bodies which cause them are apt to carry in septic matter perhaps the specific bacillus of tetanus (see TEtanus, page 535), and produce fatal results. Besides this, the punctured wound-say by a hay-fork or rusty nail-closes immediately, and when inflammation follows there is no drainage, the swelling occluding the passage made by the wounding substance; lience there is infiltration of the surrounding tissues, a disposition to form "pockets" of matter, as well as to afford every opportunity of absorption of morbid matter into the circulation, and cause septicæmia (see page 526).

Treatment.-Forcible syrunging out of the wound with a disinfectant and plugging with a tent of tow or other material soaked in it. A good dressing is found in equal parts of spirit of turpentine and olive oil, and if slight suppuration follows, so much the better.

Staked wounds-which are generally of the punctured variety-need especial attention to ascertain that no portion of foreign matter is left in, and if any doubt exists it is better to enlarge the wound. It is often said-and with much truth - that a big wound heals better than a little one, and this applies with greatest force to punctured wounds, which may generally be enlarged with safety and advantage.
Poisoned wounds.-From what has already been said the reader will be on his guard against wounds becoming poisoned, but there are some he will have gathered which are poisoned from the first, as those inflicted by venomous creatures, or introduced upon the wounding instrumentthe poison of rabies, of glanders, or from decomposing matter. The desire to close a wound must not over-ride the necessity for thorough disinfection. The simple process of healing under aseptic conditions, or in the absence of any complications, has already been referred to, but many wounds-nearly ail but the clean, incised onesheal by granulation. A variable amount of discharge precedes the growth of little red points of mushroom-like appearance (save for their colour), and these rapidly fill up the space-too rapidly in some cases, when what is called "proud flesh" extends beyond the level and needs repression (see BROKEN KNEE). The drying off and scabbing over of the wound is followed by the formation of cicatricial tissue or the production of an eschar which is not new skin-the latter, indeed, never forms, and the condition constitutes the chief reason for that conservative surgery we have advocated in dealing with the ragged portions depending from a wound, and inviting removal by any but the experienced surgeon.

\section{Broken Knee}

This name is given to any breach in the skin covering the knee, and does not necessarily imply any injury to the bones. The almost invariable cause is falling upon the ground, although other accidents occasionally give rise to it. The injury may be superficially small, but deep, and bruising may be severe, or fracture of one or more bones occur, or the joint may be so injured as to permit escape of the joint oil (synovia). Much swelling and pain, and consequent lameness, follow when the decper tissues are badly bruised or cut, but a large surface may be injured, and a corresponding amount of permanent blemish left without incapacitating the animal for more than a fortnight.

Treatment of broken knee should be begun by a thorough examination of the extent of damage done, and irrigation by a syringe repeatedly filled with a five per cent. lotion of carbolic acid, or one per cent. lysol; but any of the standard disinfectants may be used according to the directions 
scnt out with the ressels containing them. Grit is so apt to get into the knee at the monent it is open, and to be caught in the wound when the animal rises, that spccial care is needful to remove anything of the kind, by warm fomentations tollowed by a poultice of linseed meal and bran, enclosed in muslin. It is usually advisable to give a full dose of aloes, as this tends to kecp down inflammation and reduce swelling. Poulticing tor two or three days is enough as a rule, after which a wcak lotion-one per cent. or more of chlericle of zinc-will control granulation and retard the too rapid growth of large, soft, spongy material, which results in outgrow th and permanent lumps upon the knee after the wound has healed. It is during the final stage of broken knce that the amateur fails. He allows the granulations to get ahead of him, and fears to use a caustic soon enough. By touching over the most prominent spots of the new red growth, a level surface can be promoted, and when this has been accomplished he may minimisc the probable blemish by rubbing of the newly formed scab and cauterising afresh the raw surface. Repcating this operation every two or three days, he will pull the sound skin over the injury and approximate the original edges of the wound until only a very small portion of shiny cicatricial tissue is seen.

\section{Cracked Heels}

A crack across the skin of the heel or on one side or the other is often a troublesome matter, and leaves a scar that tells its own tale to the expert examiner. Being in a flexure, it is more difficult to heal than a skin wound elsewhere, The causes of cracked heel are various. Those animals of a lymphatic temperament with slow circulation, and their opposites with high courage and high feeding, and such as are subject to swelling of the limbs (see Filled Legs, page 566), are most prone to cracked heels, but other exciting causes produce chaps and cracks, as snow, salted roads, keen winter winds, and summer dust. Washing the legs and leaving them to dry is a fruitful cause of this trouble. The degree of lameness varies. On the first occasion the animal may be found in the morning as lame as if he had a broken bone, and is led out of the stable with great difficulty, until the crack is opened by movement and the imprisoned fluid released, when he is able to use the limb again in a few minutes with ordinary facility. Chronuc subjects are less lame, and the heels thicken. I good deal of sympathetic swelling may extend up the leg.

Treatment may well be commencel with at purging ball of aloes, and with poultices to the heel, the latter being frequently changed. Wheri the inflammation has subsided the wound should? be treated with a powder composed of one part boracic acid to three parts of flour, and a few clays later, with powdered alum in lieu of the boracic acid. The practice of applying sulphate of copper. or other strong styptic or caustic agcnts, is to be deprecated, as the union is too rapid and not lasting. I slower healing produces a hetter surface, and without so much of a ridge or scar. An application of oxide of zinc ointment daily tends to restore the softricss and flexibility of the impaired slin.

\section{Uicers}

Ileers may be simple or specific, as the uleer caused by a collar-gall, which leaves a ragged wound or hollow which is reluctant to heal, and the ulcer of glanders (see GLANDERs, page 532), brought about by a pathogenic organism. The common characteristic of the ulcer is its disposition to continue, and its reluctance to heal by ordinary treatment.

Treatment is first directed to removal of all possible causes (as frecdom from harness pressure or rubs), the cleansing of the sore, and next its stimulation. Sulphate of iron serves for the less obstinate cases, while cupric sulphate, silver nitrate, or a mixture of these, may be found necessary for the languid and indolent. The firing-iron is sometimes applied, destroying the surface of the ulcer, and appealing to the structures bencath to make a fresh effort at repair. Provided the patient is not old or weak, or suffering from specific disease, ulcers generally prove amenabie to such treatment as we have indicated.

\section{Fistula}

Fistulous wounds have been referred to in connection with quittor (page 572), and the description there given of pipes forming to drain away dead or dying tissue applies to other sinus or fistuious wounds. 
Poll Evil.-This is one of the most difficult of all fistulous wounds (not excepting quittor), and follows in the poll after a painful swetling or abscess has broken or been lanced. Bruises on the top of

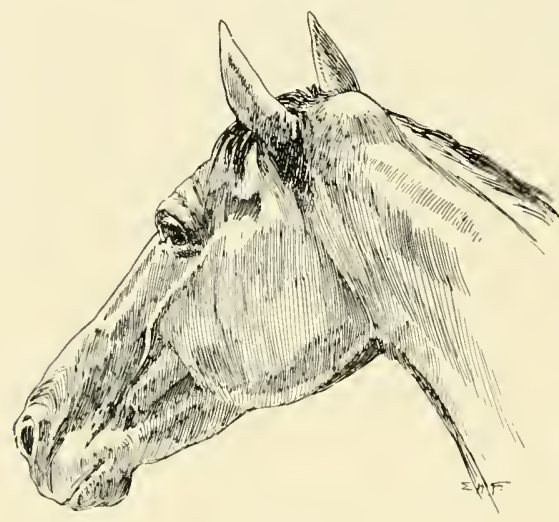

POLL EVIL.

the head, caused in going through low doorways and by heary collars, or other outward violence. are the causes.

The first symptom is a shyness about the head when the collar is passed over, or the bridle put on, and this is the time when warm fomentations may suffice to disperse the swelling. More often the injury is dcep-seated, and a considerable time may elapse between the blow or blows and the formation of matter; indeed, it would seem in most cases that the abscess forms because some portion of the denser tissues of the poll are dying, and Nature will not tolerate them; the abscess is then a means of getting rid of material that cannot be repaired, and must be encouraged to form, and when ripe be boldly lanced to afford the best drainage. Sinuses or pipes form as in fistulous withers and quittor, and have to be destroyed. Sloughing them out with corrosive substances, or by the aid of a tape or cord repeatedly dressed with an irritant, is the plan commonly adopted, or plugging with such substances (see Punctured Wounds, page 578; and QuitTor, page 572). The cure is always tedious, and often the healing-over is but temporary, and a further formation of pus takes place, perhaps after an interval of months, and the whole thing has to be gone over again. There are to be found in most of the counties of England men who make a speciality of curing fistulas, whether of the poll or the withers, and a contract with one of these is not likely to provoke jealousy on the part of the local vetcrinary surgeon, who can get but little honour or emolument from such cases.

Fistulous Withers.-Fistula of the withers is caused in the same way as poll evil, and, like quittor and other sinuous wounds, must be treated with a vicw to the removal of the offending material which gives rise to it (see Poll EviL; and QuitTor, page 572). The withers are more easily explored than the poll or the pipes within the hoof, and a picce of bone may somctimes be traced and removed. Failing to get away the diseased or dead tissues by operation, a drain must be established by setoning as advised for poll evil. It is not a discase the amateur should undertake to cure if he can get expert assistance, and he will need much paticnce if thrown upon his own resources and compelled to act on the lines suggested here and in connection with those other sinus wounds to which his attention is directed.

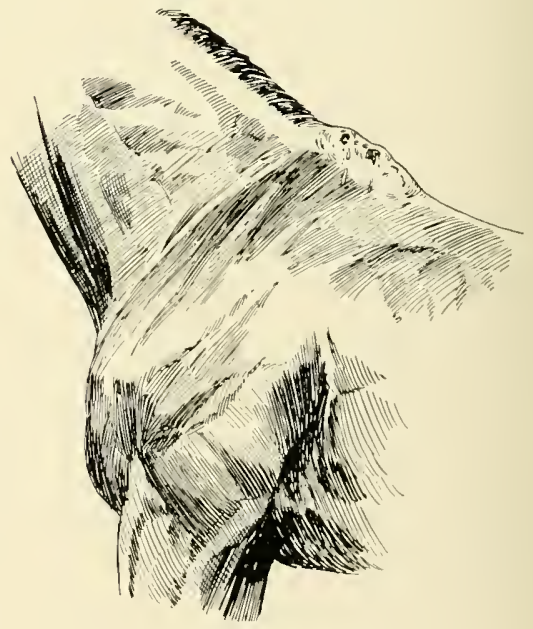

FISTULOUS WITHERS

\section{Open Joint}

No worse accident can befall a horse than to be wounded in a joint and admit air into the articulation. Any small punctured wound in the 
neighbourhood of a joint should be approached with the greatest care, and no probing done by any but an expert; better far to let a suspected thorn fester and make its way out later, as the swelling behind a foreign body will help to keep the joint intact. Pricks from the stable fork, kicks, blows, and other external violence may lead to an open joint, when synovia escapes from it and intense fever and pain follow, the joint-oil presently discharging as a saffron-coloured fluid, and the wound refusing to heal. Many a valuable horse is destroyed as soon as the case is proved to be one of open joint, as it is sure to be of long duration, nceding much care and doctoring, and probably leaving the animal with a stiff joint, or one much enlarged if not stiff. All the same, there are a good many horses which afterwards prove useful at slow work, or, in the case of mares, as breeding stock.

The primary treatment consists in injecting the wound with a disinfectant, and covering with layers of boric wool or antiseptically prepared lint, and protecting it from the ingress of malig- nant germs. An aloetic ball is given early, and from time to time cooling doses of salts and nitre to a!lay fever, and in extreme cases morphia is injected under the skin to allay the anguish which so often accompanies this trouble. All sorts of styptics are tried to stem the flow of joint-oil, such as whites of eggs and a paste made of chalk and methylated spirit, which are constantly applied until they dry on and cover the issue. It would seem like adding fuel to the fire to blister the part, but such treatment is often effectual in sealing the opening, as it causes the tissues under the skin to swell and occlude the orifice while drawing out the inflammatory trouble from the joint itself. An open joint is no case for the amateur horse doctor, but the professional will need all the assistance the tyro can give him, and an endless stock of patience besides. It is desirable in most cases to sling the patient, as he must needs stand for some weeks, during which he gets very weary, and may at last throw himself down and break open the joint again. A long run at grass should be given as soon as the animal can be safely turned out.

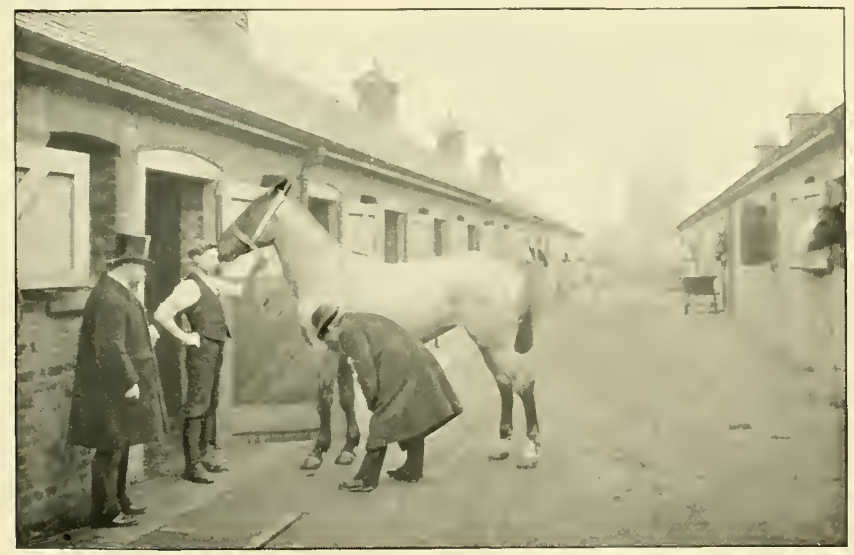




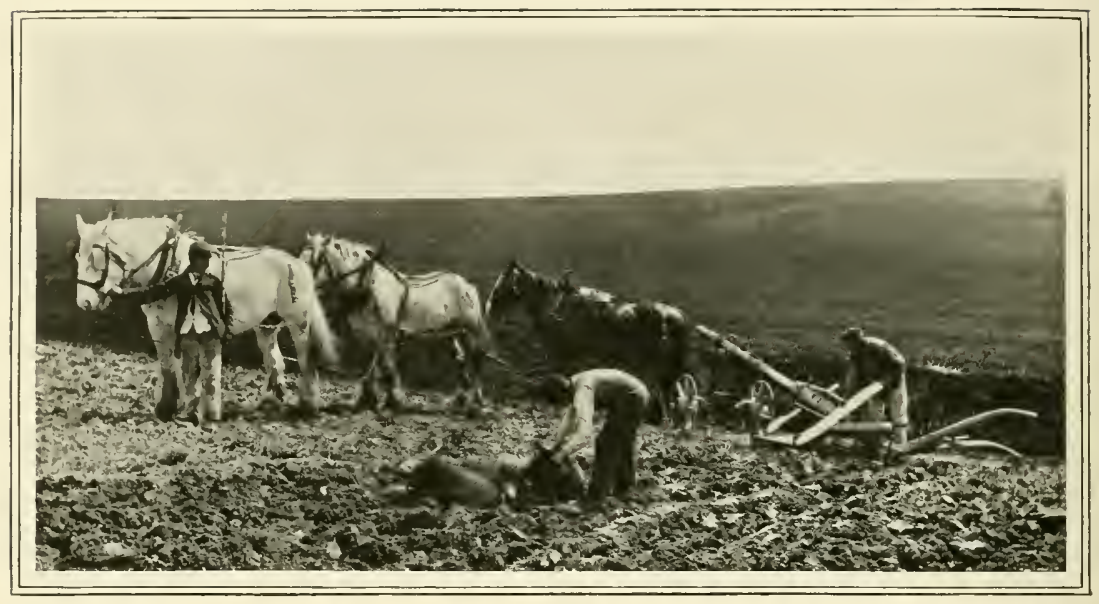

\section{CHAPTER XVII}

\section{FIRST-AID}

$\mathrm{A}^{\operatorname{con}}$

DENT or sudden illness should not find the horse-owner unprepared and incapable of rendering assistance, if it take no more active form than that of knowing how to wait while professional aid is forthcoming. It has been said that "all things come to him who knows how to wait," and $w$ may say here that injuries which need not prove fatal often do so because the impatient or excited amateur in surgery does no know how to wait. One should "hasten slowly," by a careful consideration of the circumstances before deciding to act. When a horse is found cast in the stable, for instance, we have to consider calmly in which direction he will need help, and how it can be most efficiently supplied-not shout or whip him to efforts beyond his power. It is at either end of him we have most power, and one man at his head and another at his tail can often pull him round into a position from which he can rise, when a stimulant has been given to revive him after the fruitless struggles of, perhaps, half a night. In this, as in most eases where firstaid is required, we are at the disadvantage of having a frightened animal of great weight, whose strength is more likely than not to be used in opposition to our own small powers, if, indeed, we are not injured in giving him succour. In the unaccustomed circumstances of an accident we are apt to forget the useful knowledge we possess, and a crowbar or stout wooden bar may be at hand, and a rope which, wound round the former and planted between bricks or into the ground, will give us the power of several men to move the helpless animal the few inches that may be all that is necessary. We may have only to lift one of his feet to the other side of a stallpost to enable him to get up, as he is to be regarded as temporarily stupid when he has failed to get up in the usual way, and will spend the remainder of his strength in utterly useless efforts until he dies of exhaustion if we do not relieve him. It may be said here that the will power of one man may save him while waiting for further assistance, as he will obey the voice and keep quiet, regaining some of his strength until such aid arrives.

\section{Hæmorrhage}

In the article on hæmorrhage (see page 475) the means of arresting blood flow are 82 
more particularly dealt with, and the reader is referred to such means as may be at hand and of which he has not thought; the handkerchief twisted round a stick, tlie hat-pin, scarf-pin, a skewer made of a faggot or hedge stake, and the coat-lining or other parts of a garment which may be easily rent and subsequently replaced. The hair from a horse's mane and tail makes a binding and stitehing material (when it has not been hogged and its tail deprived of any hair more than two or thrce inches long). In sueh a case, if the accident occurs to a lady's horse, her sympathy might be put to a severer test than a mere man dares even to mention.

There are injuries in situations where the advice here tendered cannot be put into practice, as when the head is cut and ressels cannot be ligatured. It will often be found possible to press the fingers upon the artery, or compress the lips of the wound until a clot is formed.

Any bleeding from the nostrils should be the sign for waiting. It may be a vein ruptured or quite a slight injury, and soon cease; or the spurting of an artery (see H.EMORRHAE, page 475), and be most desirable to remain where the aceident happened until vinegar or spirit or other stypties ean be obtained.

\section{Injury to Joints}

When joints are injured it is of all things important to restrain the animal-not walk him home because he is anxious to make the effort, but remembering that the exertion may just serve to break through the capsular ligament and let the oil escape (see OPEN JoInt, page 580). If any sort of antiseptic ean be begged, borrowed, or stolen from the nearest house or stable, it should be applied, and a bandage made of a split stocking or coat-lining to support and proteet the parts, until a float can be obtained in which to convey the animal home, or to the nearest stable where slings are available. The latter may be made of stout saeks and poles with a pulley and wagon rope; or a farm-cart may be utilised, by lowering the shafts over a fallen animal. The question of removal, or of detention, should receive the most careful consideration, because a horse ean easily walk to the nearest stable while the wound is fresh and be quite unable to do so a few hours later. If, then, it is not feared that a joint will break open and synovia escape, it will usually be best, when all fear of fatal hæmorrhage has passel, and after a stimulant has been given, very quietly to lead the animal to some safe asylum. In the meantime a veterinary surgeon will have been summoned. It should be deenced an essential of first-aid to send such a message to the "Vet." as will enable him to come prepared with what is most likely to be needed. "Come at oncehorse bad," may mean eolic or anything else, and the medicines hastily prepared will be useless. A few words on a leaf of a pocket-book will be better than a verbal message, which is liable to many mutations before reaching the recipient.

\section{Removal of Dirt from Wounds}

When dirt or foreign matter has entered a wound, it is most desirable to remove it if possible without waiting for the surgeon. To this we may perhaps make one exception in staked wounds, unless the amateur has fully realised the importance of ascertaining the direction, and withdrawing the offending body in such a manner as to leave no particle behind-no, not a fragment of bark ! or future trouble will result. Staked wounds should be stuffed with tow or a bit of sheep's wool, or liandkerchief, to prevent air being drawn in. This specially applies when the horse is moved.

\section{Horses in Holes}

When horses fall into pits or down areas, the bewildered amateur seldom thinks of sending for a load of straw or other substance by which he may fill up the pit while restraining the animal's fears. A few inches at a time, and in no very long lime either, the floor is thus raised, and the horse walks out. Horses get into ditches, and, forgetting how they got in, fail to get out again, and wander aimlessly up and down until exhausted, and may thus die in a few feet of water. At all other times a horse's bump of locality serves him, but in water he bccomes a fool if once lost. W'hen discovered, his fears must be ealmed until he can be reached by placing a ladder across the stream, and a halter put on him, when he may be led to the standing stage. If exhausted a stimulant may be given before asking him to make the neeessary effort.

There are cases, too, where risk of injury must be aecepted by placing a rope round the animal's head in order that another horse may drag him 
out of a hole. The powerful ligaments of the head and neck are not very likely to suffer, and it is a choice of evils.

\section{Water as Restorative}

Collapse or fainting and falling in harness or saddle should bid us wait and seek restoratives. In the absence of any of the popular forms of alcohol, it should not be forgotten that water is a restorative, and fills up the vessels quickly, and if a horse will not drink he can be drenched with bottles of water. Cold water thrown over the head also restores the faint.

\section{Falls in Harness}

When a horse falls in double harness he should be secured by the head by one man, while another undoes the hame strap, by which both traces are freed; then the pole piece. In single harness the breeching straps should be furst undone; then the hames, and the animal should be restrained while the cart is run back.

First-aid to the sick consists in the provision of suitable accommodation in the way of a comfortable loose-box, with good ventilation, ample bedding, clothing, bandages, and a supply of hot and cold water.

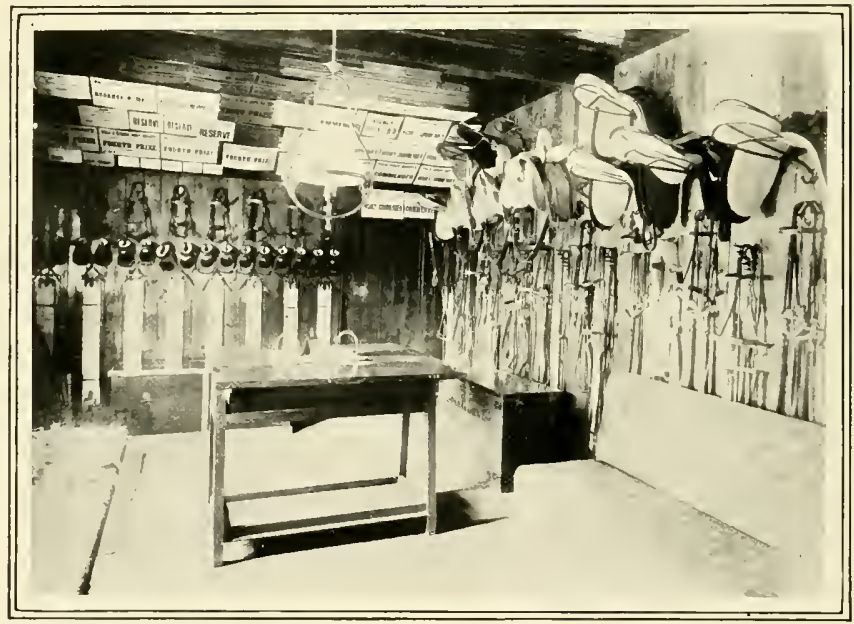

SADDLE ROOM AT MR. TRESHAM GILBEY'S POLO PONY STUD AT BISHOP'S STORTFORD. 


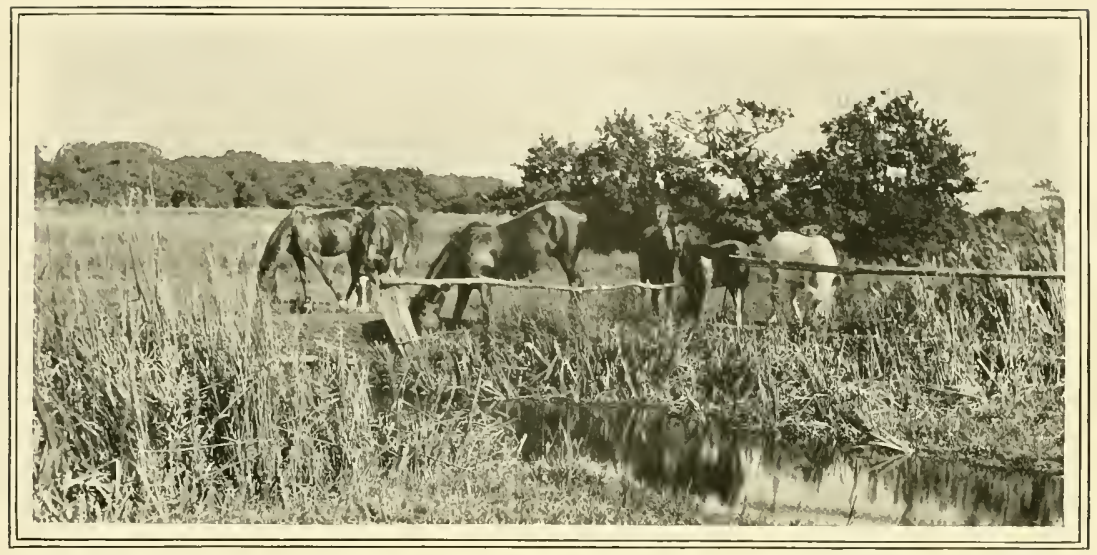

\section{CHAPTER XVIII \\ NURSING AND FOODS FOR THE SICK}

$\mathrm{A}$

SICI horse should be isolated in a loose-box of comfortable dimensions, well drained, with a good supply of fresh air, but free from direct draughts. For the sake of his fellows, and for fear of infection, it should be at a distance from others. If known to be other than infectious, removal is not always desirable, as the horse is a social animal, and, if he is not very ill, desires to see and hear other horses. This latter trait in his character should be more specially borne in mind with regard to convalescents, who will be helped by cheerful surroundings. Warmth should be sought rather by conserving the animal's own temperature than by artificial heating of his apartment; hence the recommendation to clothe warmly, and to remember that a hood and bandages are indispensable to a good suit of horseclothes. Removal of these at least once a day is desirable, when the skin should be wisped and a surface circulation encouraged in every way. Bedding may be varied to suit individuals, as peat moss or sawdust for some cases of lameness, but good wheat straw is in most cases of illness to be preferred. The sick should not be made an exhibition of to all callers, but their privacy respected and quiet obtained, not forgetting that
Nature's swcet restorative-sleep-is as necessary to horses as men, although the former rarely sleep longer than four hours at a time; but that is no reason why they should not choose that time, and be free from unnccessary interruption.

\section{Green Foods}

The same attendant should, if possible, be engaged throughout the illness, as the patient will feel confidence in him and perhaps be persuaded to take food from his hand when he would turn away from a large quantity thrown into the manger. Small quantities of various foods should be offered at short intervals, and nothing should be left that is not consumed quickly. In a large proportion of cases, laxative foods are required. They tend to keep the bowels open and reduce temperature, promote the excretion of waste material, and give the kind of support most needed. In sumner we have a choice of green foods, even if we live in large cities, as such provender is carted into town daily. Grass, lucerne, clover, rye, and all of the cercals in the green state may be used. In winter we can fall back upon carrots, parsnips, beets, mangels, swedes, gruel, boiled barley, bran, 585 
linsced, hay tea, and linseed tea and oil, and in some cases molasses or common treacle. Greenmeat should not be given wet with rain or heavy dew, but slightly withered, or flatulent colic may result (see Colic, pagc 496). Salt should be given with boiled barley or other grain, and it should be cooked in only just enough water.

\section{How to make Bran Mash}

Bran mashes and gruel should be so made that not the slightest suspicion of burning at the bottom of the pan may put the sick horse off his fancy. For this reason, when a mash is made the bottom of the vessel should be first wetted, then some bran added; then the boiling water; more bran, and a further quantity of water, until the whole is saturated, not forgetting a tablespoonful of salt. The vessel should be covered over and allowed to stand an hour or more, and should not be thrown into the manger too hot to be eaten, or the invalid may be annoyed because he cannot eat it when he would, and will refuse to do so when he might. Sick horses, like sick children, are easily put out of temper, and should be humoured. Three pounds of bran to three pints of water is about the proportion for a mash. For a bran and linseed mash, we should first boil for two hours a pound of linsced in half a gallon of water, and then add a couple of pounds of bran, stirring the whole and adding an ounce of salt. Linseed tea may be made by boiling a pound of linseed in a gallon of water, adding another half-gallon to thin it when cooked.

\section{Gruel}

This term is now often applied to a handful of oatrieal in a bucket of water, given as a refreshing drink on the road, or to the hunter when first brought in ; but real gruel is made by boiling. If a pound of meal is mixed with a gallon of cold water and stirred over the fire until it boils, a fair sample of gruel is produced.

\section{Nourishing Foods}

The articles already mentioned are, of course, nourishing, but their primary object is to be relaxing. We have then to use in ccrtain cases of prostration the most nourishing-milk and eggs beaten up together will be drunk by many horses, or may have to be horned down as medicine in a few cases; bread and biscuits and all sorts of corn, as oats, barley, wheat, maize, and millet, which may be given cooked or crushed, or in meal, together with chaff or cut "roots," or other food the patient may fancy, and which may be offered only to induce him to take what will be more beneficial.

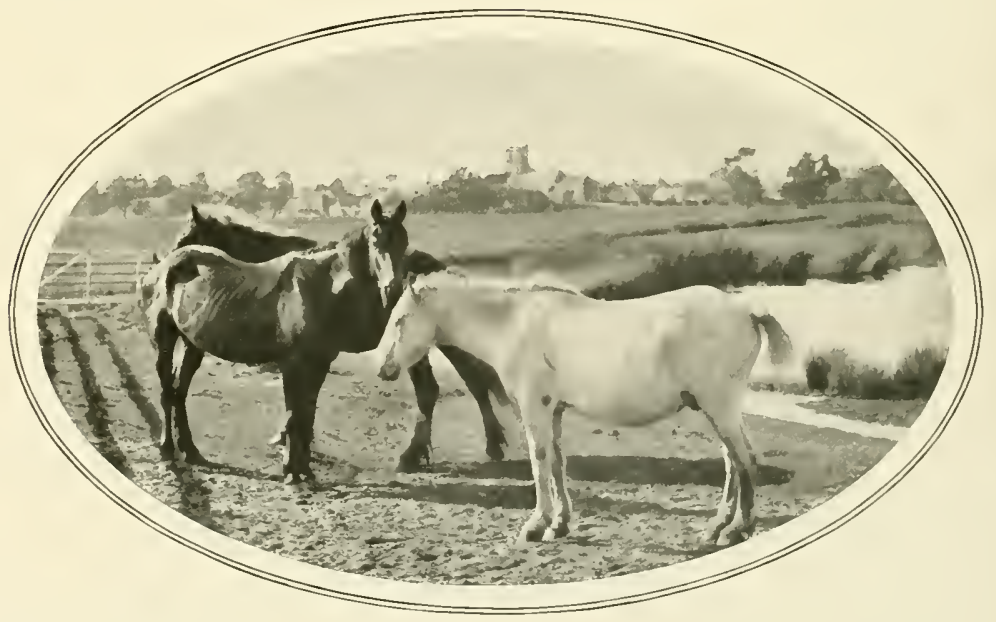




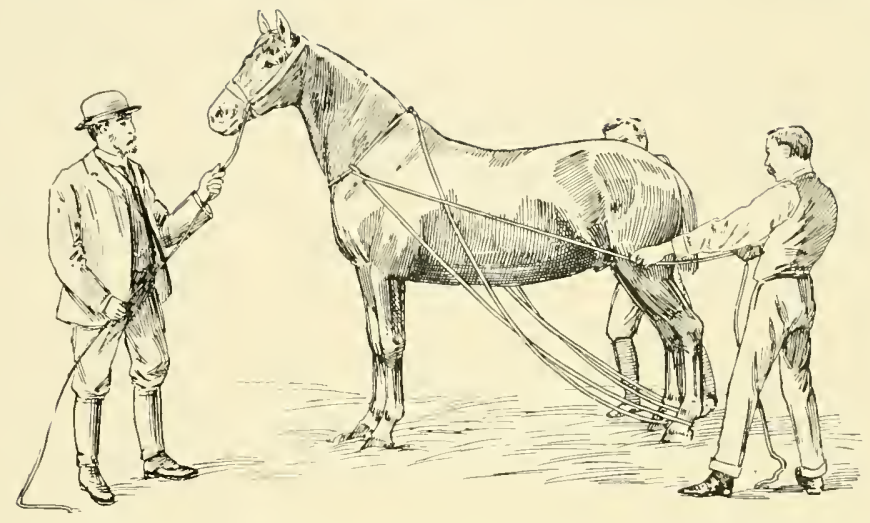

CASTING WITH A WAGON ROPE.

\section{CHAPTER XIX \\ METHODS OF RESTRAINT : FIRING AND BLISTERING}

$\mathrm{I}^{N}$ $\mathrm{N}$ order to perform operations, whether the simple one of drenching, or the sevcre one of firing, we have to resort to a variety of means of securing our patients, since their strength is greater than ours, and will be

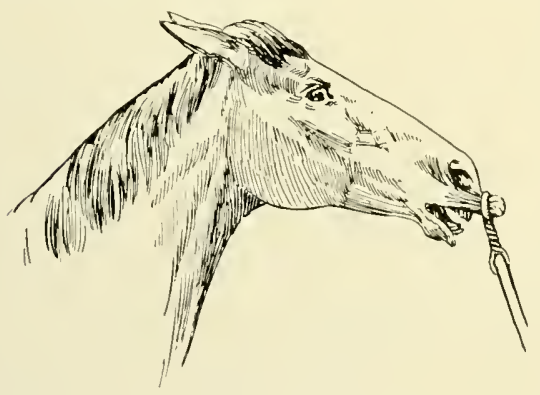

TWITCH APPLIED.

exercised to defeat our object unless we can outwit them.

The twitch is one of the commonest and most effectual means, and its simplicity makes it obtainable under all circumstances. Applicd to the upper lip, it compresses the plexus of nerves and causes pain. For one's own safety, and if not abused, its employment is justified. Many minor operations may be performed with no other means of restraint. Holding up a foot or strapping it up will often enable us to do something to the opposite limb, or remove the contents of the rectum, pass a catheter, lance a boil, or cauterise a wound. Cocaine is an aid in many cases, and has been specially referred to in conncction with torn eyelids and other troubles of the visual organs. General anæsthesia is a sccondary means of restraint in regard to horses, as we must first get them under control by mechanical means.

The side line is one of the oldest means of trammelling a horse, either for operation while on his feet, or when thrown upon the ground by its means. It is preferred by castrators to the more elaborate hobbles which are employed for such operations as firing and unnerving. As these performances belong to the veterinary surgeon, we need only direct the reader's attention 


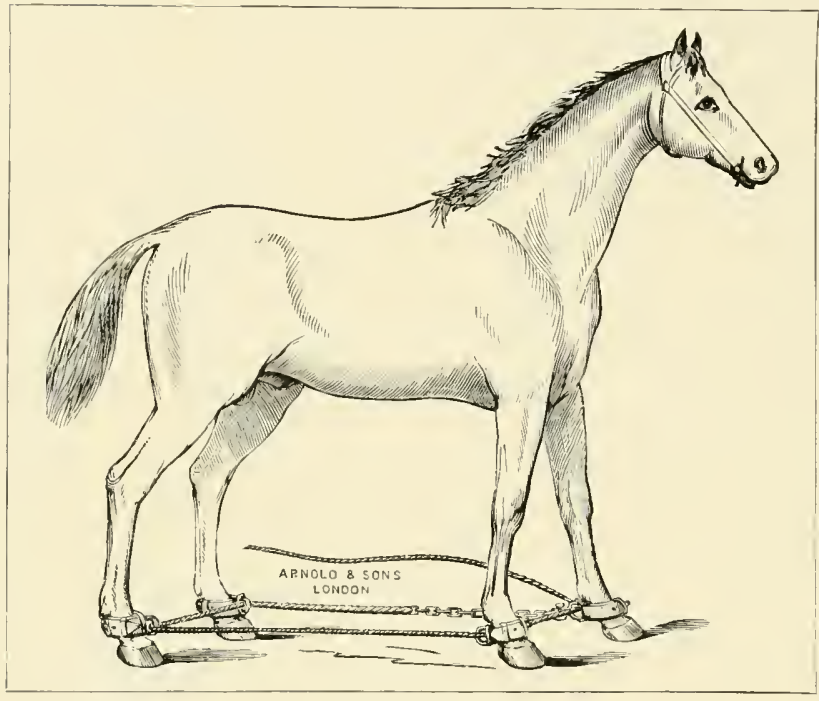

LEATHER HOBBLES.

The men should stard well back, as by such means they obtain most porver. When the animal is down, the most able man of the party should secure the head. Then the feet may be drawn together, and half hitches passed round them so that it is impossible for the animal to get loose or damage the men.

It is important when horses are cast, whether by hobbles or ropes, to keep the head back while on the ground, as it is not in the act of throwing that accidents occur to the spine, but when the animal gets his head to the illustrations by which he will be able under between his knees and struggles. The modern circumstances of difficulty to apply himself, as it hobbles of leather, with metal eyes, are easily occasionally happens that a colt has to be cast in order to be shod, or for some com. paratively small operation to be performed. An ordinary thirty-six foot wagon rope looped round the neck, with the knot on the withers, may answer the amateur's purpose. The ends are passed outside the fore-legs and round the heels of the hind ones, a man or two on each side being employed for this purpose. When both are in position in the heels, the free end of the rope is passed through the collar or neck portion first mentioned, and then all is ready for a backward pull to bring down the animal.

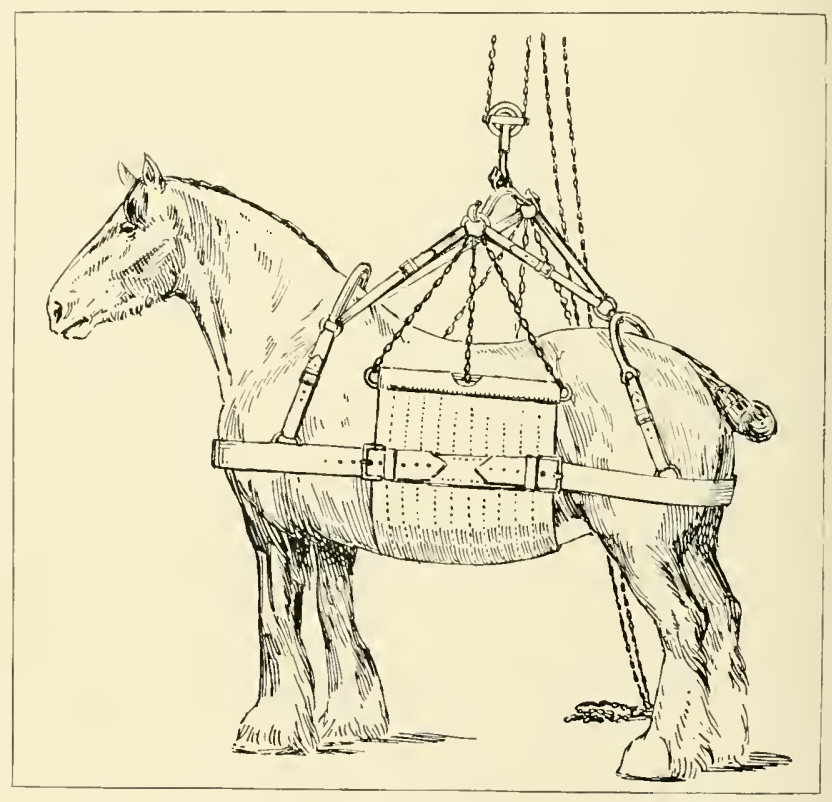

SLINGS. 


\section{ME'THODS OF RESTRAINT: FIRING AND BLISTERING 589}

adjusted, and as the rope runs through them, three or four men pulling at once, and if assisted by an over-rope under the shoulder or attached to a surcingle, can cart the horse exactly where it is desired.

\section{Firing}

The painful operation of firing is robbed of much of its objectionable character by the use of chloroform in the cast animal, or by subcutaneous injection of a ten per cent. solution of cocaine in the region to be operated upon; indeed, the latter is so helpful in minimising pain that very many horses are fired without casting.

Firing is practised for the cure of various forms of lameness, as spavin, curb, ring-bone, side-bone, splint, brokendown tendons, and sprains, where blistering is decmed inadequate or has already failed. The pattern made by the hot iron is not of any importance, whether lines, diamonds, or feathers. The effect is to cause inflammation, then absorption of inflammatory products, and lastly, to act as a permanent bandage and support by reason of the contraction of the skin over the part. The hair is first clipped, and careful operators have the skin washed, to prevent dirt and septic matter from entering the wounds. Restraint by double halters, one on each side of the head, and attached to the pillars of the stall, is necessary for a day or two, perhaps longer, or the sufferer may gnaw the leg or injure his face by rubbing. Before being released, the parts are anointed with raseline or other emollient, particular attention being given to the heels, which may erack if the discharges have run into it. The rest in a loose-box or the run at grass which follows is a compensation which the lumane man wishes he could communicate to his patient during his sufterings.

\section{Blistering}

Many references will be found to blisters as remedies for equine troubles, and there are certain little matters which the amateur goes wrong over in this connection. The animal should be prepared as advised for firing, and secured in like manner ; the heels should be carefully protected by lard, and the selected vesicant rubbed in equally over the whole surface to be blistered. The morning

rum at grass which follows is a compensation

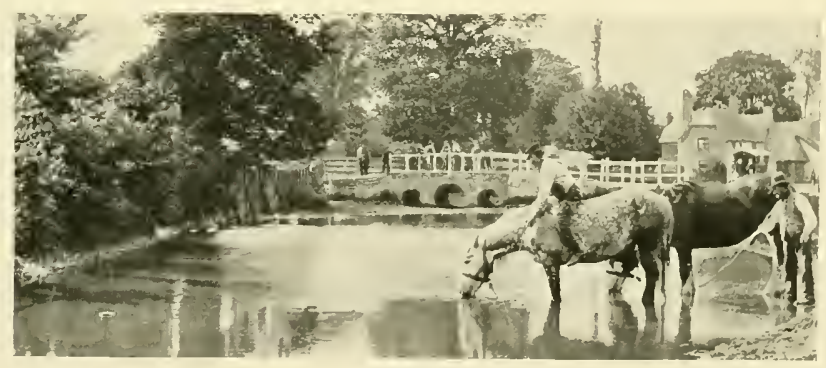




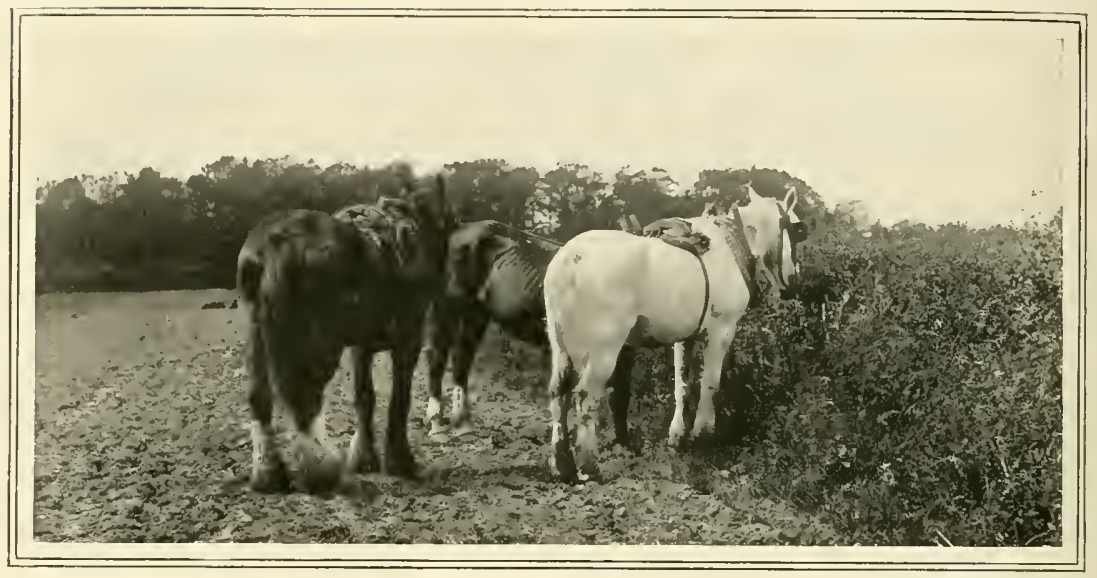

\section{CHAPTER XX}

\section{THE TEETH AND AGE OF HORSES}

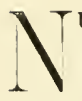

UMBER OF TEETH - The number, development, or wear of the horse's teeth enable us to tell his age with accuracy in the normal subject up to a certain period (seven), and aftenwards to form a fair estimate of his years. When mature the horse has twelve incisors or cutting teeth 'six in the upper and six in the lower jaw), and twenty-four grinders or molars (six above and below on either side). The male has four tusks or tushes, one above and one below on either side. These are sometimes present in the mare, but not so fully developed; tradition says that such mares are sterile, but such is not always the case. In front of the first upper molars we sometimes find small conical teeth-imperfect molars-known as wolves' teeth, and to their presence the habit of shying has been referred, but there is no proof of this popular helief. The age is usually judged by the incisor teeth, but experts are ahle to decide in doubtful cases by the assistance of the grinders prior to their full development. The first or temporary tecth are smaller, whiter, and distinguished by a more abrupt change of form between the crown and fang. The tables or upper surface of the milk tecth are never so indented or dark as those of the permanent set, and are replaced by the first pair of permanent ones of larger size, before the wear of the temporaries has led to any great resemblance to the permanent. During dentition the age is readily seen by the number of permanent as compared with temporary teeth, and after the full number of adult teeth are acquired the appearance of the tables enables us to say what age the animal is until they are worn down or "out of mark."

\section{One to Two Years Old}

Without examination of the teeth, the foal of the first year is easily distinguishable by his mane and tail and other signs. At birth the foal has two central incisors through the gum, and some indication of the next pair (one on either side) coming. In a fortnight the centrals are well up, and in six to eight weeks the laterals are grown. When a year old, the set of teeth has a general resemblance to that of the aduit horse, but his unfurnished and coltish appearance precindes the possibility of mistaking him for a "grown-up." At two years the teeth which came first have begun to show wear, and the outer ones have a less slelly, or unfinished, appearance. Mistakes have howerer, been made in the case of well-furnished 
two-year-olds, with manes trimmed close or "hogged" and tails doeked short, and the unwary have purchased such immature ereatures as adults, A little later, between two and three years old, the first pair of incisors are replaced by the permanent ones, which are so different in charater as to be easily recognised, and, with the probable foaling time kept in mind, the age of the animal can be estimated within a period of weeks or a few months at the outside. As, for instance, if one sees a colt at Christmas with two permanent teeth breaking the gum, he will know that the animal is rising three-that is to say, he will be three years old in the sping.

\section{Three to Four Years Old}

Two permanent incisors, then, are the special feature of the "coming-three" animal. These two new teeth will be a little more developed in appearance and in greater contrast to the remaining milk-teeth as the year advances, but not until the next autumn or winter, perhaps early spring, will he lose the temporaries on cither side, and have them replaced by the laterals of permanent type. He is then rising four years old, laving four permanent incisors, and a small temporary one at each corner. The next autumn or winter, perhaps early in the spring, he will lave these corner nippers replaced by permanent ones, and then he is rising five years old, and if a male the tushes will be coming.

\section{Five Years and upwards}

Up to this period we know his age by the relative number of temporary and permanent teeth, and custom calls him "rising" so many years from autumn to spring, and so many years "off" from spring to autumn. At five years, then, the horse has a full mouth ; all his incisors are up, but the corner ones have a shelly $\mathrm{er}$ incomplete appearance, which serves to distinguish him from an older horse. Next year, when he is six, these corner ones will be fully developed, and we look to the tables of the central pair, which, it will be remembered, were the first to come. These have begun to show wear in the centre of the tables; the black mark, or infundibulum, is not quite so large as in the laterals, and there is still more difference between them and the corner ones. The following year, when he is seven, the marks in the laterals will be diminished, and only the outer or corner nippers show a welldefined mark. This is the speeial feature of the seven-year-old. The following year these marks will be going, and the tables will look much like the others, although from the centre outwards it will not be difficult for an observant person to note the varying degrees of wear.

A horse at eight is said to be "ont of mark," and it is no longer possible to say with certainty what his age may be, and although the expert can form a very good judgment, he will no longer certify as to his age. The term "aged" applies to all horses when ont of mark, except with regard to race-horses, which are "aged" after they have passed their sixth year. If the buyer is able to distinguish between the well-developed two-year-old and the adult, he will not go far astray in the matter of ages if he will hear in mind what has been said about the successive changes in the teeth and their markings which are here given.

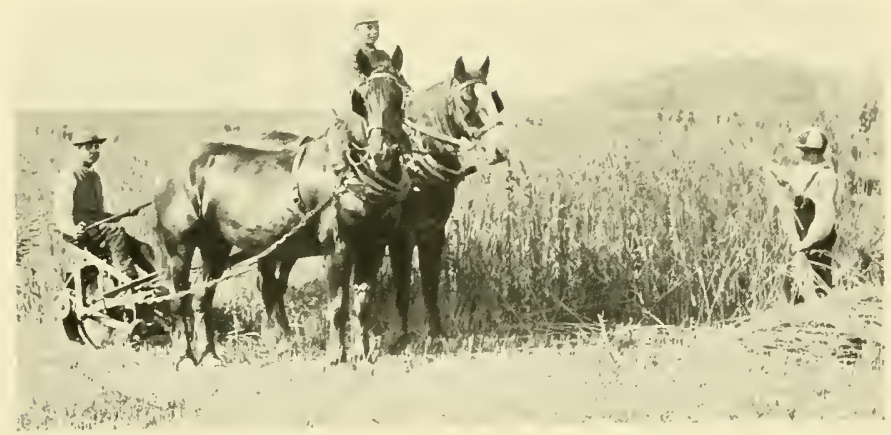




\section{TEETH OF THE HORSE AS AN INDICATION OF AGE}

A. Side View of Incisors of a Colt of a little under three years: the central incisors $(a)$ in upper and lower jaw are well grown, and all but tonch, and the edge of infolding enamel is not worn. The median and lateral incisors are the temporary or milk tceth.

B. Side View of Incisors of an eight-year-old Horse: the teeth, well grown, should meet; the canines, or "tushes," of only moderate length.

C. Side View of Incisors of an aged Horse: the angle very acute; the teeth projecting forward, grooved on the surface, and irregularly worn, the gums contracting in front, thus exposing a considerable length of the tooth.

D. Incisors of a Colt, showing temporary or milk series: the "table" or cutting surface showing a small mark; the lateral incisors not worn.

E. Incisors of a Colt at three years: the two central incisors, $a, a$, well grown, and showing a good "mark" ; the median and lateral incisors are milk teeth, well worn.

F. Incisors at four years : the central and median incisors, $b, b, b, b$, well grown, and show a wide mark, $x$; the lateral incisor is a milk tooth. The canines, $c$, appear about this time.

G. Incisors at five years: all the teeth are of the permanent or adult series; the mark is getting smaller in the central incisors, the canines or tushes a little more advanced.
H. Incisors at eight years: the mark in the central incisors reduced to a small circle of enamel. In the median incisors the mark is getting narrower; the lateral incisors still show a good mark, and the canines are well grown.

I. Incisors at twelve years : the mark worn out ; in the central and median incisors only a small vestige of it left, forming a yellowish spot; the mark in the later incisors long and narrow ; the canines longer.

J. Incisors of an aged Horse: the crown of the tooth now almost worn out; a smaller yellow spot indicating the last vestige of a mark ; the tables (or cutting surfaces) are irregular, furrowed and triangular ; the canines grow to a considerable length.

1i. An Adult Incisor in Profle and in Section :I. The enamel, thicker in front of the tooth and extending about three-quarters of the length of the tooth; on the inner side the enamel is thinner and does not extend so far. 2. The dentine or matrix. 3. The "pit" or " mark," an infolding of the enamel, as shown in the section of the milk tooth, the progressive wear cutting this fold, and so forming a mark. 4. The pulp cavity, with a bloodvessel passing into it.

L. Section and profile of a temporary or milk tooth: I. Shows the infolding of the enamel; the pulp cavity is always open.

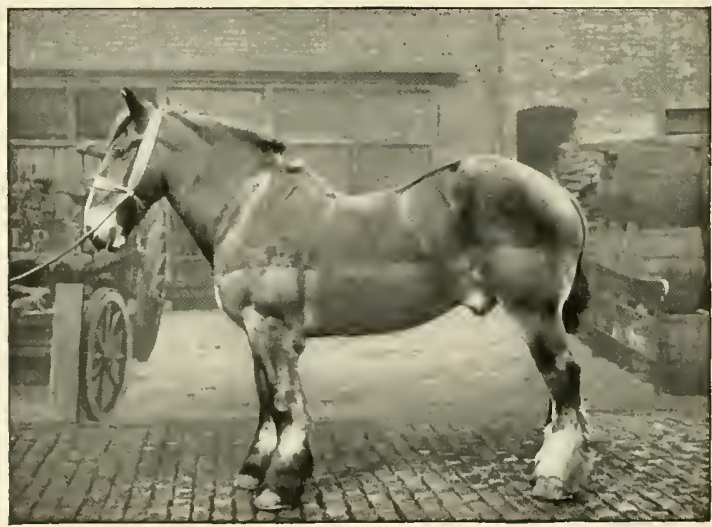




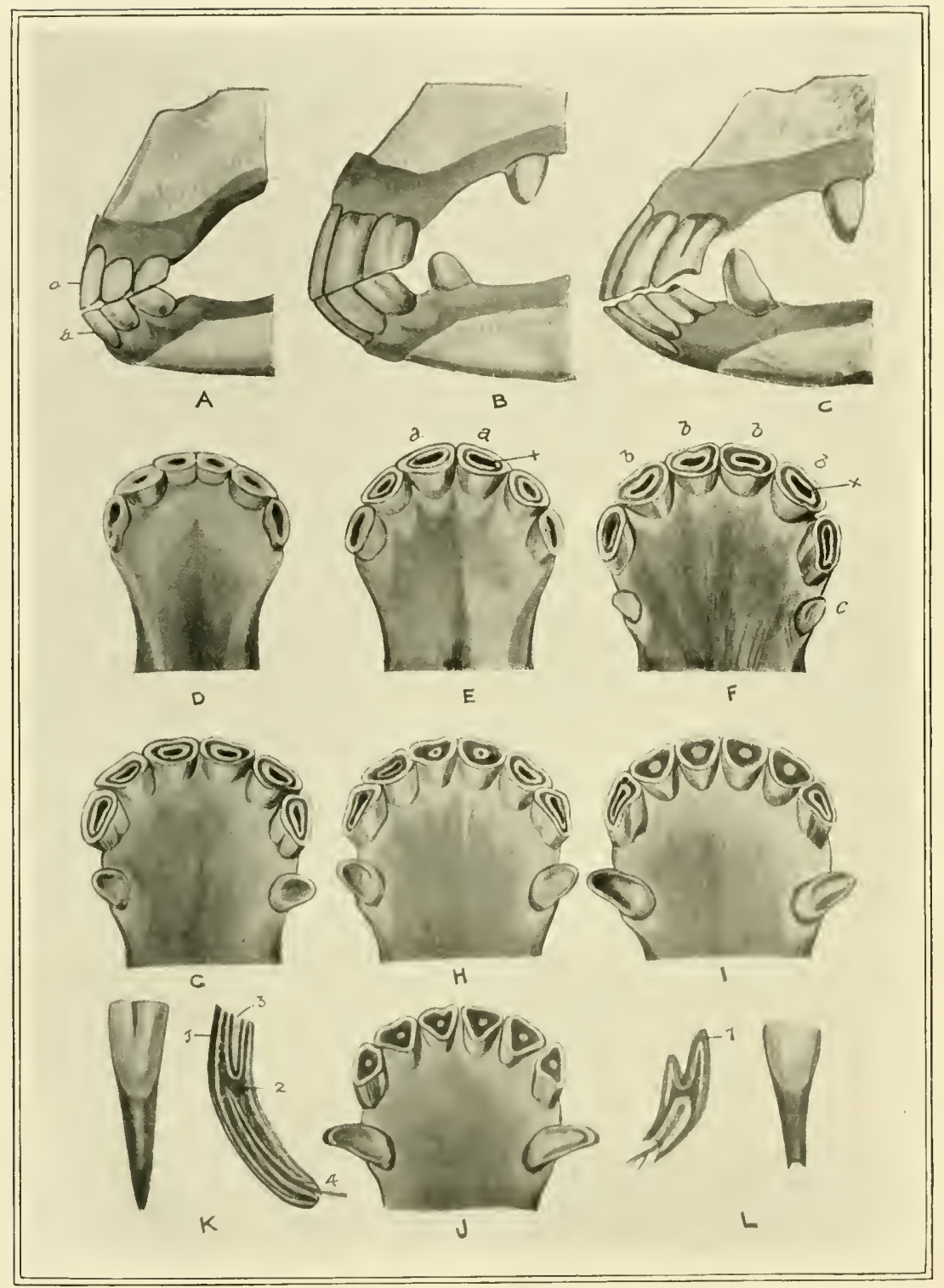

TEETH OF THE HORSE AS AN INDICATION OF AGE. 


\section{POISONS AND ANTIDOTES}

T THEN a case of poisoning occurs, nobody is prepared for it, and few persons will read up the subject in "cold blood." Having this in mind, we have prepared a short list of the commonest poisons and grouped them, at the same time indicating the most likcly means of neutralising them or inhibiting their effects.

\section{PoIsons}

Mincral acids, including nitric, sulphuric (oil of vitriol), hydrochloric (spirits of salts), and phosphoric acid.

Acetic acid, oxalic acid, salts of lemon, tartaric acid.

Prussic acid (hydrocyanic), and cyanide of potassium.

Canstic alkalies, as potash, soda, and ammonia.

\section{Aconite.}

Acorns, ferns, and ouk shoots.

Antimony,

Arsenic.

Belladonna, henbane, and hemlock.

Cantharides (Spanish fly).

Carbolic acid and creosote.

Croton oil.

Cocaine.

Colchicum (autumn crocus).

Insect stings.

Lead (salts of).

Copper,

\section{ANTIDOTES}

Ant-acids, as chalk, carbonate of soda, and potash, whiting or plaster scraped from walls, whites of eggs, milk, soap, olive, linsecd, or other fixed oils.

Carbonate of magnesia, lime, wall-scrapings, or chalk.

Lot and cold water alternately thrown over the spine. Hypodermic injections of cther, camphor, atropine, drenching with perchloride of iron dilute, sulphate of iron dissolved in much water, magnesium carbonate.

Any dilute acids, preferably vinegar, lime juice, or that of lemons, eggs and milk together or separatcly, salad or linseed oils. Alcoholie stimulants if collapsed.

Ammonia, atropine, alcohol, cligitalis.

linsecd oil and laxative foods, saline aperients.

Tannic or gallic acid in solution, followed by eggs and milk, mucilage of acacia (gum). and tragacanth and bismuth.

Wash out stomach by means of siphon and warm water. Give freshly precipitater ferric chloride.

Large doses of alcohol, strong coffee : move the patient about, and use electric currents.

Barley water and gruel, but not oil which dissolves the active principle.

Sulphates of soda and lime, saccharated line, stimulants. Do not give oil.

Gruel and barley water, stimulants.

Give chloral, inhale chloroform.

Tamnic and gallic acids, stimulants, barley water, and gruel.

Ammonium, oil, carbolic acid in oil.

Dilute sulphuric acid, Epsom salts, sulplute of soda (Glauber's salts), iodicle of potassium, castor oil.

Iron peroxide (moist), soap, magnesia, eggs, milk. Wash out stomach with siphon if possible. 


\section{POISONS AND ANTIDOTES}

\section{Porsoxs}

Morphia and opium preparations.

Phosphorus.

Savin.

Snake bites.

Strychuine and nux vomica.

Tobacco.

Turpentine

Yew.

Zinc salts.
A.xtmotes

Siphon off contents of stomach. Alcohol, ammonia. hot coffee, elcetric curtent, strychnine. or atropine by subcutaneous syringe. Keep patient awake by every means.

Sulphate of copper solution, turpentine, charcoal. No oils or fats.

Ethers, nitric or sulphuric, demulcents, Epsom salts.

Tight ligature, hot iron, cut out flesh. Large doses of ammonia and alcohol.

Tobacco internally, chloroform inhaled, chloral. bromines, tannic acid.

Strychnime, tannic acid, hot stimulants, iodino: in solution.

Demulcents, Epsom salts.

Alcohol and ammonia, demulcents, linseed oil.

White of eggs, milk, demulcents.

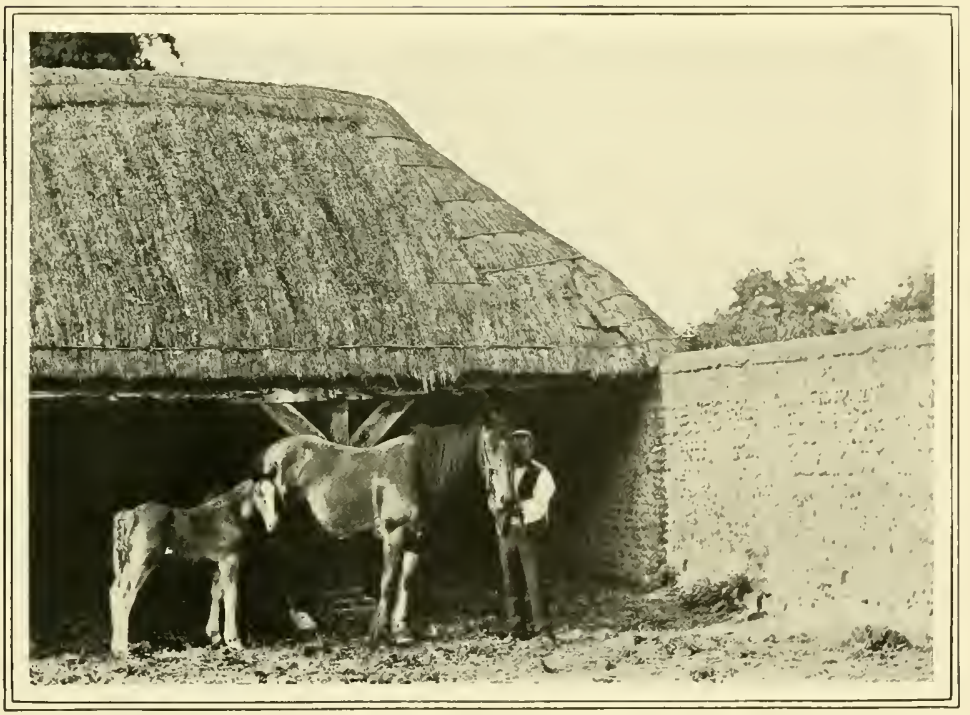




\section{TABLE OF DOSES}

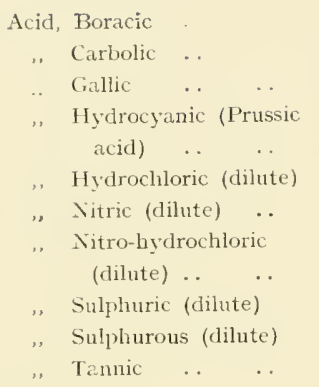

Alocs

Alum

Ammonium chloride .

Antimony oxide.. .

Tartarised.

Areea nut .. .

Arsenic .. .. .

\section{Belladonna, Extract of \\ Bicarbonate of potash .

$$
\text { , soda .. }
$$ \\ Bismuth .. . .}

Bisulphide of carbon ..

Bromide of potassium .

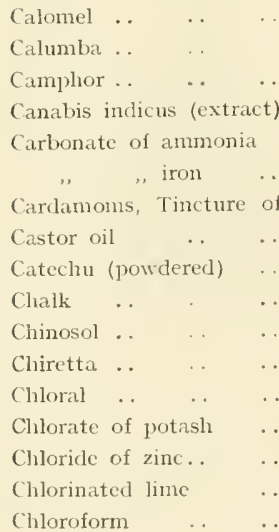

\author{
I to 3 drams. \\ $\frac{1}{2}$ to 2 drams. \\ $\frac{1}{2}$ to $1 \frac{1}{2}$ drams
}

$\frac{1}{3}$ to I drant.

1 to 3 drams. .. 1 to 3 drams.

- i to 3 drams.

. I to 3 drams.

.. $\frac{1}{2}$ to $I_{2}^{\frac{1}{2}}$ ounces.

.. $\frac{1}{2}$ to $1 \frac{1}{2}$ drams. 3 to 8 drams.

2 to 5 drams.

2 to 6 drams.

1 to 3 drams.

I to 3 drams.

${ }_{2}^{1}$ to $1 \frac{1}{2}$ ounces.

2 to 8 grains.

.. $\frac{1}{2}$ to 2 drams.

$\frac{1}{2}$ to 2 ounces.

2 drms. to $1 \mathrm{oz}$.

I to + drams.

I to 2 drams.

2 to 8 drams

I to 4 drams.

2 drams to $1 \mathrm{oz}$.

I to 3 drams.

I to + drams:

1 to 6 drams.

.. I to + drans.

.. $\frac{1}{2}$ to 2 ounces.

.. 5 to 20 ounces.

.. I to $S$ drams.

.. 2 to 8 drams,

.. $\frac{1}{2}$ to $I_{2}^{\frac{1}{2}}$ drams.

2 to 6 drams.

.o 8 drams.

.. $\frac{1}{2}$ to 3 drams.

.. 15 to 60 grains.

.. I $\frac{1}{2}$ to 5 drams.

. I to 2 drams.
Chlorodyne

I to 6 drams.

Cocaine ..

Colchicum (extract)

2 to Io grains.

r gro to jo grains.

Copper sulphate $\quad$. . . $\quad \frac{1}{2}$ to 2 drams.

Corrosive sublimate (Perchloride of mercury) .. .. 2 to 6 grains.

Digitalis .. $\quad \ldots \quad \quad \ldots \quad \quad \ldots \quad \frac{1}{2}$ to 2 drams.

Dill water $\quad \ldots \quad \ldots \quad \ldots \quad 5$ to 20 ounces.

Ether, Nitrous spirit of $\ldots \frac{1}{2}$ to 2 ounces. Eucalyptus oil .. $\quad \ldots \quad \quad \ldots \quad \frac{I}{2}$ to I dram.

Fluid magnesia... $\quad . \quad \ldots$ i to 3 ounces. Friar's balsam .. $\quad \ldots \quad$.. I to + drams.

Gentian .. $\quad \ldots \quad$. $\quad \ldots$ I to 6 drams.

,, Tincture of $\quad . \quad \ldots \quad \frac{1}{2} 10 \quad 2$ ounces.

$\begin{array}{llllllllll}\text { Ginger } & \ldots & \ldots & \ldots & \ldots & 1\end{array}$ to $\mathrm{I}$ ounce.

Glycerine $\quad \ldots \quad \ldots \quad \ldots 2$ to 5 ounces.

Guaiacum resin .. . . . 2 to 6 drams.

Iodide of potassium .. .. I to 4 drams.

, , iron .. . ... I to + drams.

lodine .. . . . \& 8 to 30 grains.

Iodoform $\quad \ldots \quad \ldots \quad \ldots \frac{1}{2}_{2}^{1}$ to I dram.

I recacuanha, Powdered $\quad \ldots \frac{1}{2}$ to $I_{\frac{i}{2}}$ drams.

Iron sulphate $\quad \ldots \quad \ldots \quad \ldots \quad \ldots$ to 3 drams.

, Tincture of $\quad . \quad \ldots \frac{1}{2}$ to 3 drams.

Kino $\quad \ldots \quad$.

Liudanum $\quad \ldots \quad \ldots \quad \ldots$ i to 6 drams.

Lead acetate .. $\quad$. $\quad$.. $\frac{1}{2}$ to $I_{2}^{\frac{1}{2}}$ drams.

Linseed oil $\quad \ldots \quad \ldots \quad \ldots \quad \ldots 5$ to 20 ounces.

Iale fern, Oil of $\quad . \quad \frac{1}{2}$ to 2 drams.

Morphine $\quad \ldots \quad \ldots \quad \ldots$ t to Io grains.

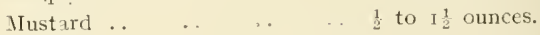

Nitrate of potash $\quad \ldots \quad \ldots 2$ to 8 drams. , ". silver .. .. 4 to 12 grains.

Nitre, Sweet, Spirit of.. . . $\frac{1}{2}$ to 2 ounces.

Nux romica $\quad$. $\quad \ldots . \quad \ldots 20$ to 60 grains. 
Oil of male fern

Opium .. .

Peppermint wate

Permanganate of potash

Prussic acid

Quassia .

Quinine.

Resin

$\frac{1}{2}$ to 2 drams.

1 to 6 drams.

Sulphate of soda

, " iron

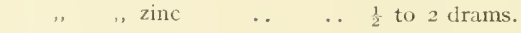

Sulphur .. $\quad \ldots \quad \ldots \quad \ldots \quad \frac{1}{2}$ to 2 ounces.

Sulphuric acid (dilute)..

Sulphurous acid (dilute)

. I to 3 drams.

. 15 to 30 grains.

-. $\frac{1}{2}$ to I dram.

.. 2 to 6 drams.

I 5 to 60 grains.

.. $\ldots$... 2 to 6 drams.

$\begin{array}{llllllll}\text { Salt } & \ldots & \ldots & \ldots & \ldots & \frac{1}{2} \text { to } 2 & \text { ounces. }\end{array}$

Salts $\quad \ldots \quad$. . $\quad \ldots$.. I to + ounces.

Sil volatile .. $\quad . \quad \ldots$ I to 6 drams.

Santonine $\quad \ldots \quad \ldots \quad \ldots \quad 15$ to 40 grains.

Soap $\quad \ldots \quad$. $\quad \ldots \quad \ldots \quad \ldots \quad \frac{1}{4}$ to $I_{\frac{1}{2}}^{\frac{1}{2} \text { ounces. }}$

Squills $\quad \ldots \quad \ldots \quad \ldots \quad \ldots \quad \ldots \quad \frac{1}{2}$ to $I_{2}^{\frac{1}{2}}$ drams.

Stockholm tar .. $\quad \ldots \quad \ldots$ I to 4 drams.

Strychnia $\quad \ldots \quad \ldots \quad \ldots \frac{1}{4}$ to 2 grains.

Sulphate of magnesium (Salts).. I to 4 ounces.

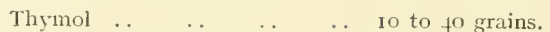

Tincture of cardamoms $\quad \ldots \quad \frac{1}{2}$ to 2 ounces.

," . gentian .. .. $\frac{1}{2}$ to 2 ounces.

$$
\text { . , ginger . . . . } \frac{1}{4} \text { to } 1 \text { ounce. }
$$

.. ., iron $\quad . \quad \ldots \frac{1}{2}$ to 3 drams.

$\begin{array}{lllllll}\text { Tobacco } & \ldots & \ldots & \ldots & \ldots & \text { I to } 3 \text { drams. }\end{array}$

Turpentine, Spirit of .. .. $\frac{7}{2}$ to 2 ounces.

$$
\text { , Venice . . . } \frac{1}{2} \text { to } 2 \text { ounces. }
$$

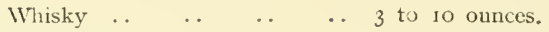

Witch hazel (extract) .. . . 2 to 4 drams.

Zinc sulphate $\quad \ldots \quad \ldots \quad \ldots \quad \ldots \frac{1}{2}$ to 2 drams.

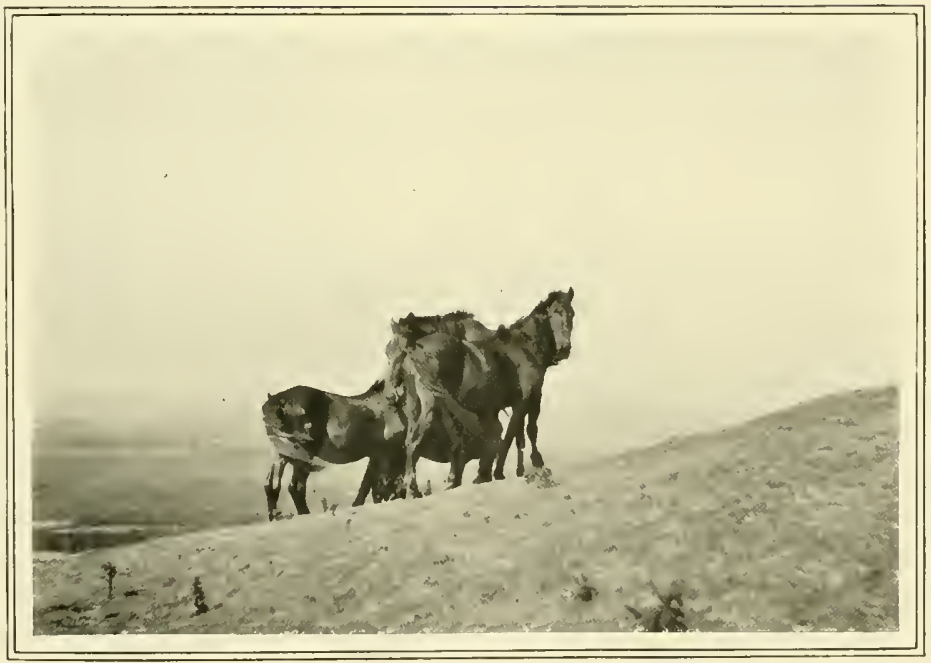




\section{APPENDIX I}

\section{LAWFUL STAKES, AND GAMING AND WAGERING IN RELATION TO HORSES}

I the time of George II. the Legislature sought to repress indiscriminate horseracing, and enacted a $£ 200$ penalty for racing other than at Newmarket and Hambledon, and for less than $f_{50}$. The same reign, later, witnessed a Statute against light-weight racing; welter weight for age races were ordained.

\section{Lawful Racing Stakes}

The Victorian Gaming Act of I $8+5$ specifically exempts from the category of gaming all subscriptions or contributions or agreements to subscribe for a plate, purse, or prize for winner or wimners of any lawful game or sport.

This enables a winner to sue for stakes in such contests.

Otherwise, all gaming contracts are roid by this Statute; and money cannot be recovered in relation to them, either for unpaid wagers, or for wagers paid and repented of.

\section{Stakeholder's Responsibility}

But where a stakeholder to a bet holds stakes, and has not yet parted with them to an accredited winner, either party may enjoy locus panitentia, and back out of his illicit contract to game, and demand his money back from the stakeholder.

This was ruled in Hampden $v$. Walsh; where the Editor of the Ficld was stake. holder and umpire between Messrs. Wallace and Hampden, in a wager whether the earth was flat or a globe. Experiments on straight water in the Fens proved the curvature. Hampden disputed the umpire's fiat, and demanded his money back. Walsh, the Editor, paid it to Wallace, disregarding
Hampden's demand. It was held that the deposit placed in Walsh's hands remained the property of Hampden so long as Walsh had it. (Walsh had to return the cash to Hampden.) (33 L.T. 852.)

\section{Match v. Time}

A bona-fide match between horses and men, for a deposited stake, is not a wager ; and is not affected by this ruling. But matches against time are held to be wagers; and not contests of skill or merit. (Whaley v Pigot, 2 Bos. V., P. 5I, and Batsonv. Newman, I.I. pd. 575.)

\section{Valid Trotting Match}

Otherwise, even a trotting match for f25 a side on a high road was held to be lawful as regards the gaming aspect of this matter (although not so as to the case of the high road for racing), and not even to infringe the spirit of the stringent George II. turf statutes. (Challand $i$. Bray, I I L. J. B. B. 204.) On the other hand, trotting against time on the high road was "wagering," and roid; though the nominal terms of the match sought to give this matter a semblance of bargain and sale; the terms being that if the horse trotted I 8 miles in the hour the price to be paid for him should be $£ 200$, and if the time limit was exceeded, it was to be a shilling. The court held this to be but colourable, and to be practical wagering, and roid as a bargain. (Brogden v. Marriott. 5 L.T. C. P. 307.)

\section{Stewards' Decisions and the Law}

When stewards of a race meeting have honestly adjudicated upon a disputed point, 
involving the winning or losing of racing stakes, and have decided in accordance with the rules under which the race has been run, their finding upon questions of mere fact will not be reversed nor questioned by a court of law, even though that court might otherwise have differently interpreted from the same evidence, as to credibility of witnesses, or balance of evidence as to fact.

\section{All Betting Void by Statute}

Betting contracts are prima facic void by the Gaming Act I 845 (supra). But for some little time after the ruling of Mr. Justice Hawkins (afterwards Lord Brampton)-in Read \%. Anderson-confirmed by the Court of Appeal, there seemed to be some chance of redress for any commission agent who made bona-fidc bets for a principal with the Ring, staking his own credit for his client; and then being compelled, through default of his client, to pay the Ring out of his own pocket, in order to save his own reputation, and to enable himself to continue his calling in such agency.

The court held that, on the facts of turf customs in evidence, the delegation of authority to an agent of this class, to make bets for a principal, carried with it implied authority to pay those bets if lost, and to debit them to the principal. Norally this was sound; if the practice could have been limited to bona-fide deals with the Ring-by a disinterested agent-for principals. But, so soon as this ruling became law, it was seen that under its agis a coach and four could be driven through the Gaming Act, and that lost bets could be sued for and recorered, by a stalking horse of alleged commission agency. Thus $\mathrm{A}$ and $\mathrm{B}$, being bookmakers, only agree to nominally credit each other with bets booked with C. A or $B$ 's agent, and vice versa. When action was brought, $\mathrm{A}$ and $\mathrm{B}$ could swear colourably to the alleged agency, and $\mathrm{C}$ could not disprove it, and had to pay.

\section{The Act of 1892}

Then in 1892 an amended Gaming Act was passed, to estop this resource. It lays down that money paid or lent for a gaming transaction is not recoverable. Hencenow-even if $\mathrm{A}$-at $B$ 's request-pays $B$ 's betting losses to $\mathrm{C}$, A has to trust solely to B's honour, and cannot maintain action against $\mathrm{C}$ for money paid to his use.

After this there seemed to be no prospect for a defrauded winner of a special wager to recover from a contumacious defaulter by any process of law. But, since that date, a series of cases have occurred in the Law Courts with fluctuating results, according to the facts in evidence, wherein claims for "real and valid considerations" have been urged by the creditor.

\section{New Considerations for Defaulters arising out of Betting}

They can arise as follows:-A loses wagers to $B$. The creditor can make matters unpleasant for the debtor in more than one direction. Socially he can injure him, for club repute, by proclaiming the default, publicly dunning him, and asking when he is going to pay.

The same tactics injure A commercially if he is in business, because the public may be inclined to infer that if he acts in a shady manner with regard to debts of honour he either is hard up, which damages his credit in trade, or else he is tricky in money matters, and as such to be more or less distrusted.

Lastly, if $A$ is a member of the same club as B, and still more so if they are members of Tattersall's, the Beaufort, Victoria, or other betting club, A can be forced to refer the Act to arbitrators, and to resign if he fails to abide by the arbitration.

Accordingly some such motive influences $A$, finding himself in B's power, to ask time to pay, or for some such arrangement.

If $\mathrm{B}$ assents, and it is clear that he assents on the faith of an undertaking by $\mathrm{E}$ to pay some or all of his debt, sooner or later, while $B$ on his part undertakes to refrain from putting on the screw by any of the resources above sketched, then a new and valid " consideration" for the debt is created, where, previously, under Gaming Acts, there had been no legal consideration; and thus, if 
A fails to pay up by the agreed date, while B lieeps to his share of the new bargain, $B$ can maintain an action for the recovers:

Each such case has to be judged upon its own individual merits, as will be seen from the following precedents. In Gordani i. Baker (98 L.T. and 24 T.L.R. 338),

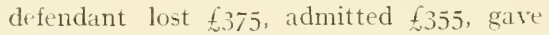
cheque for $\$ 355$. The cheque was dishonoured. Then defendant asked for fourteen dars further time to find the mones; to save himself from being reported at his club as a defaulter. The plaintiff agreed to wait for that time, and for that reason. He failed to pay, and was sued on the cheque. The learned judge (A. T. Lawrence) who tried the case held that these facts disclosed "good consideration" for the claim, and gave judgment for the claim, though defendant had pleaded the Gaming Act. A year later came Hyams v. Stuart King, before the Court of Appeal (99 L.T. 424). A cheque for losses was by arrangement held over by plaintiff at defendant's request, lest it should, by dishonour, prejudice him and his partners in business. The court, by two to one (Lord Justice Fletcher Moulton dissenting), held that his holding wer at request, under the circumstances, created new and valid consideration.

Lord Alverstone had recently two cases of this class before him.

In Ladbroke v. Buckland (25 L.T.R. 55) defendant asked for time; plaintiff replied asking now soon he might expect a remittance, if he meantime refrained from posting defendant as a defaulter.

To this question defendant made no reply. Plaintiff sued. The learned judge held that plaintiff's silence as to when he would pay absolved him from any specific promise to pay in consideration of forbearance from defendant, and therefore held that the Gaming Act was still a defence to the claim, as pleaded.

In another case, before the same Lord Chief Justice-Hodgkinson $\approx$. Simpson-his lordship found in favour of the plaintiff, as follows: Defendant lost $f 55^{\circ}$ in bets. He was interviewed and threatened with being posted as a defaulter. He did not belong to betting clubs; but none the less he seemed to object to being posted as a black sheep at any of them; he accordingly wrote and delivered a memorandum promising to pay fir $9 \mathrm{~s}$. ad. by July gth, and the balance in due course - to be arranged, "In consideration of your forbearing to sue me and of the fact that I shall not be registered as a defaulter either in the list compiled by the Turf Register or at Tattersall's or at any of the sporting clubs." Such was the text of his written undertaking. L'pon the face of this Lord Alverstone held that a new and valid consideration had been created, and gave judgment for the unpaid balance sued for. (The $\underset{\sim}{f} 7$ odd had been paid, and no more.) Again, in Coker $z^{\prime}$. Ulph (75 T.L.R. 5.5) Mr. Justice Bucknill similarly gave judgment for plaintiff ; the defendant having expressly promised to pay, provided that plaintiff would refrain from posting him at Tattersall's as a defaulter.

\section{Money Lent for Gaming}

Money lent for gaming in Britain, where gaming is unlawful, cannot be recovered: but if lent for gaming in another country where gaming is not unlawful, it can be recovered (Quarrier v. Colsten, also Saxby i. Fulton, 24 T.L.R. $S_{56}$; before Mr. Justice Bray). On the other hand, in Brown $:$ Bailey (24 T.L.R. 277) Mr. Justice Darling ruied that plaintiff could not recover on a dishonoured cheque for $£_{2}, 000$, given to pay if,joo betting losses in France, and for which plaintiff had actually given f2ro change to defendant! The cheque was post-dated and drawn upon an English bank. Plaintiff lost his case.

\section{Other Betting Legal Curiosities}

In Beyer v. Adams, $\mathrm{A}$ lost bets to $\mathrm{B}$, and gave $\mathrm{C}$ the money to pay $\mathrm{B}$. C died before he could hand the money to B. It was held that C's executors were not bound to make good the money either to $A$ or to $B$.

"Welshing" is now often dealt with as theft - "as larceny by artifice," if the jury are of opinion that the welsher ncicr intended to make a real bet, but 
intonded to appropnate the backer's money to his own use-from the outsct, win or lose,

See R. $\approx$. Buckmaster (20 Q.B.D., I82).

It is understood that "welshing " consists of posing as a bookmaker, offering to bet, asking for deposit of stakes from the backer, and then levanting if the bet is lost ; showing from the outsct no intention of paying. If the defaulter could show that he paid some such bets, and had simply overlaid his book, and could not pay all, that would be reasonable defence; but the burden would lie on him to satisfy the court that he had not the intent to appropriate the backer's stake from the outset. It took long years before the courts adopted this view. The Buckmaster case came from Ascot, and was tried at Reading, with case stated for opinion of superior court. Curiously, prior to this, the Reading police office seemed dispused actually to protect welshing. In I868 an old Oxonian got detectives to collar a weIsher on Reading racecourse, near the Palmer recreation ground; the welsher was taken to the Reading police office, and the charge was refused and derided by the police clerk in charge!

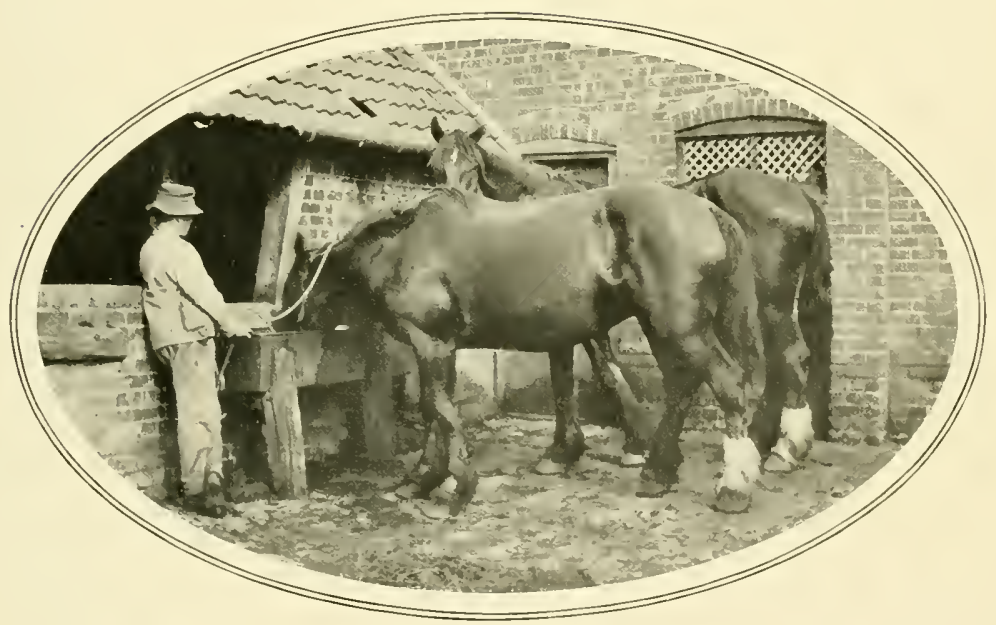




\section{APPENDIX II}

\section{CARE OF THE HORSE'S FOOT, AND SOME NOTES ON SHOEING}

Fis ROM a practical point of view it is a good thing to try and cultivate an eye for a good foot, and to be able to judge whether the foot, which at the moment may be quite sound, is likely to stand the work for which the animal is required.

Healthy feet are not so common as is beliered; it is undoubtedly true that "no foot " means " no horse," however perfect may be his conformation and action, and one is very apt to overlook this most important fact.

Without being unsound, or having had any serious disease in the feet, a horse may yet have feet so badly shaped or possessing such defects that, if used for the purpose required, it is merely a question of time before he becrmes unsound.

\section{Sound and Unsound Feet}

Iuch can be learned from books about the characteristics of the sound and the unsound foot, but it requires a great deal of practical application to acquire a working knowledge of what does constitute a good foot, for no two horses have feet alike.

To enter into details about good and bad feet is beyond the scope of this article, but horse-owners would be well advised to learn something about " weak heels," a condition of the foot that does not have sufficient importance attached to it when the evils resulting are taken into consideration.

But it is not sufficient to know what a good foot is like, it is essential to know how to look after it properly.

It is quite an extraordinary fact that so many horse-owners who are really good horse-masters should know so little about, and, what is more, take so little interest in, the vital question of how their horses are shod.

\section{The Rule as to Shoeing}

The rule that a horse must have his shoes taken off at the end of four weeks, his feet lowered and either new shoes put on or the old ones, if they will last another four weels, refitted and put back, is one that is more honoured in the breach than the observance.

It is considered by horse-owners quite legitimate for the visits of the horse to the forge to be regulited by the condition of the shoes. Should it so happen that the shoes last longer than four weeks, then the horse has to do his work with feet growing longer and longer, with additional strain on fetlock and tendons, running the risk of stumbling or strain.

The average growth of the wall of the foot is about four inches a year, or roughly onethird of an inch in four weeks. The longer the foot, the further the base of support is from the leg, and, consequently, the greater the strain on fetlock and tendons, so it can hardly be wondered at if the animal strains its tendons or breaks its knees if the feet are allowed to grow too long.

Yet the horse-owner never seems to bother, and is quite surprised if anything happens.

Cases have been known of shoes being left on farm horses for three or four months at a time :

\section{Horses Out at Grass}

The feet of animals turned out at grass are often very much neglected, owners thinking that the fact of being out at grass, under so-called natural conditions, does away with any necessity for looking after or lowering their feet. The unshod foot of an 
animal out at grass undergoes a certain amount of wear, the amount depending on local conditions and rarely being suffficient to keep the foot the proper length; the wall of the foot also is always liable to get broken away. Combined, these two facts render it absolutely necessary that the feet of the animal should be looked to by a farrier every four weeks or so.

\section{Effects of Early Neglect}

Nuch faulty conformation of the legs of young stock is due to the feet having been allowed to grow out of shape. Any departure from a level tread must react with great effect on the feet and limbs, for development is still going on, and the joints are not set.

It is worth noting here that this fact can be made use of to a certain very modified extent when attempting to correct faulty conformation of the legs of young stock or to prevent some defect from becoming greater. But any attempt of this nature must be carried out by means of a shoe, and not by having the sides of the foot of unequal heights. The foot, in such a case, must be kept in proportion, but the shoe can have one branch slightly thicker than the other, or the toe a little thicker than the heels, or vice versa-e.g. for a turned-out toe, the inner branch slightly thicker than the outer. A force, slight but constant, can thus be directed to counteract the tendency of a leg to develop an irregular conformation.

With a mature animal any attempt to correct faulty conformation by these means must only result in straining the ligaments of the joints above, for the animal is set, development having ceased.

It is quite an ordinary practice to turn ont horses to grass for a period of some months with their fore shoes on, and to pay no more attention to their feet until the animals are brought up from grass again. Comment is needless.

\section{Attention to Shoes}

Another important point seems to be so often overlooked by both horse-owner and stableman, it is the condition of the shoes, how they are wearing, whether they are loose or not.

A shoe worn too thin by exceptional wear or from having been kept on too long, not only is verv liable to be cast, for the nails have but slight hold on the shoe, or it may spread at the heels and cause more or less serions injury to the upposite leg, or bruiso. the foot it is fastened to.

A loose shoe can be casily pulled off in heavy going, as a rule causing damage to the wall ; before it can be replaced it sometimes happens that the foot is unduly worn away, and the shoeing-smith's task rendered very difficult.

A look at the shoe when the foot is being washed, the liand passed round the clinches to make sure that none of them are up, a pull at each heel to feel if the shoe is loose-that is all that is necessary; a matter of ordinary everyday routine. If a clinch has risen, the nail has worked loose, and must be replaced as soon as possible by a new one.

Care and attention bestowed on the feet not only directly benefit the animal, but also do much to help the farrier, just as inattention and neglect undoubtedly render his task more difficult.

\section{The Importance of the Farricr}

In some cases the choice of a farrier presents a problem of some difficulty, but every horse-owner should make it a rule to employ the best shoeing-smith obtainable.

It is to be feared that the vital importance of good shoeing is not generally recognised by horse-owners. There is no excuse for them. The farriers themselves have taken the matter up, and a scheme for the examination and registration of farriers inaugurated by the Worshipful Company of Farriers in 1890 , is receiving their cordial support.

Technical colleges and county councils are supporting the scheme, and examinations are held in all parts of the country, wherever sufficient candidates can be obtained, either by the Company alone or 
in conjunction with most of the principal agricultural societies at their annual shows.

Yet the majority of the people who will benefit most by any improvement in the standard of work-that is to say, the horseowners-know nothing of what is taking plice, and would very probably take but little interest in the movement if they did.

It is the custom with certain horse-owners to blame farriers as a class, but the boot is on the other leg, and the fault lies with horse-owners who, owing to their apathy or ignorance, are unable to discriminate between good and bad work. The really good shoeing-smith gains no advantage by reason of his superior skill over the indifferent or bad workman, who, in his turn, has no inducement to improve, for his customers are quite content with his work, bad as it is.

\section{Effects of Bad Shoeing}

When the foot is pricked or narl-bound, or when the shoe has been burnt on, the lameness resulting can at once be attributed to the right cause, but it so often happens that the harm being done to the foot by bad shoeing is unly shown by structural changes which take place slowly, but none the less surely. These changes are so gradual as to be hardly perceptible to the careless observer; therein lies the great danger. It may be months before the animal will show signs of there being anything wrong, and then, more often than not, any explanation but the right one will be forthcoming to account for the trouble.

\section{The Structure of the Foot}

Considering the extremely complex nature of the horse's foot, it is hardly to be wondered at that important structural changes do take place as a result of bad shoeing. The foot is most certainly not the solid block of horn some people must surely think it, to judge by the treatment they subject it to.

It would be well worth any horse-owner's while to study the illustritions of sections of the foot given on page 57I. The insight thus gained into the structure and relationship of the different parts would repay the trouble taken.

He would be able to form an idea of the provision Nature makes to meet concussion and prevent jarring by means of the elastic plantar cushion which fills up the back of the foot inside, and terminates outside on the ground surface in the tough resilient frog. The importance of this can be appreciated now photography has established the fact that the heels are the first part of the foot to meet the ground at all paces, except when the animal is in heavy draught.

Again, the horse-owner could not fail to see that the sensitive parts of the foot lie comparatively near the surface, that the insensitive covering protecting these parts does not provide a very big margin to work on. In this manner the dangers resulting from undue lowering of the foot-rasping the outside of the wall, paring ont the sole, cutting away the frog, etc.-would be forcibly brought home to him. The thickness of this insensitive covering varies, of course, in proportion to the size of the foot -take, for instance, the thickness of wall and sole in the foot of a $16 \frac{1}{2}$-hand Shire horse, and of an $8 \frac{1}{2}$-hand Shetland pony.

He would realise that Nature provided the foot with an insensitive wall, sole, and frog for the purpose of protection, and that, due reduction being made for growth, they must be left to fulfil their functions. But a great difference is to be found in the nature of the horn composing the wall, sole, and frog. The lorn of the wall is extremely hard and tough, growing to a great length if not subjected to wear; that of the sole is not so hard, and after reaching a certain thickness, flakes off in pieces, while the horn of the frog is soft, tougl, and elastic, and, moreover, is liable to contract and shrivel up unless subjected to pressure.

The fallacy of the theory advanced by Youatt and his school, that the hard, insensitive sole would hurt the sensitive structures above, and therefore must be pared away until it yielded to the pressure of the thumb, is self-evident. 


\section{Directions as to Shoeing}

The following brief summary will give a few essential points that should be observed in shoeing.

In preparing the foot a level-bearing surface must be obtained on which to fix the shoe. The rasp alone should be used to prepare this surface, the drawing-knife never, for it is impossible to get a perfectly level surface by cutting horn away, and it is also very difficult to regulate the amount removed. When the foot is very much overgrown the toeing-knife may be employed to remove some of the wall, but only in exceptional cases.

The sole must never be pared out smooth, otherwise it will not flake off as it ought to do.

The bars must never be cut away, for they act as buttresses to keep the heels from contracting.

The frog is needed at its full strength, so it must not be pared, only loose pieces removed.

When preparing the bearing surface, care must be taken not to reduce the foot unevenly, otherwise it is thrown out of relationship with pastern and leg. The relationship suitable to the particular conformation must be maintained, so it is clearly impossible to lay down any fixed angle for either fore or hind foot.

The surface of the shoe on which the foot rests must be perfectly level ; if it has any tendency to slope outwards or inwards great strain is thrown on the wall of the foot.

\section{Weight and Thickness of Shoe}

The shoe must not be too heavy, for an unnecessarily heary shoe means so much additional fatigue to the animal every time it is lifted from the ground, also greater concussion and jar to the foot when it meets the ground. Some horse-owners have the mistaken idea that a heavy shoe lasts longer, but this is not the case, as the additional weight only entails increased friction and consequent wear to the shoe. The shoe, therefore, should be as light as possible, consistent with it lasting four weeks without wearing too thin, due consideration being given to the nature of the work the animal has to do.

The shoe must be of an even thickness throughout, and not too thick.

The nail holes in a fore shoe must be in the front half of the shoe, in the two anterior thirds of a hind shoe.

The slope, or pitch, of the nails must correspond to a certain extent with the slope of the wall, so, where necessary, the nail holes must be punched at a slope to allow for this.

\section{Form of Shoe}

The form of shoe to be used depends on the work the horse has to do. Hunters, polo ponies, etc., naturally require lighter and narrower shoes than carriage, business, and agricultural horses; so the concave fullered shoe and the concave stamped shoe are used for the former, the plain or stamped shoe and the fullered shoe for the latter.

The concave fullered shoe, narrower on the ground than on the foot surface-hence concave-is fullered along the whole, or part, of the ground surface, which consequently consists of two ridges. This shoe is narrow and light, gets a good grip of the ground, but will not stand a great deal of wear on the roads.

The concave stamped shoe is very similar, but without the fullering, and therefore stands more wear. It is much used for hunter hind shoes.

The plain or stamped shoe, of equal width on both foot and ground surfaces, has a tlat ground surface, is wide and heavy, but capable of resisting great wear.

The fullered shoe is very similar to the last, but fullered the whole, or part, of the way round the ground surface, therefore it does not ware so long as the stamped shoe, but is rather lighter and less liable to slip.

One of the best of the variety of shoes made, with the idea of preventing slipping, is the Rodway shoe, much used for carriage horses. It is fullered on the ground surface and in addition has an inner groove running all the way round. 
In fitting the shoe to the foot it is essential that the surface of the shoe should fit the bearing surface of the foot very exactly. By applying the shoe hot to the foot, the farrier is able to see whether the two surfaces are in exact apposition or not, and can proceed accordingly.

It is impossible to obtain the exactness of fit necessary in surface fitting by means of " cold shoeing," whatever arguments may be advanced by the supporters of this practice. On service, or in places where no forge is within reach, cold shoeing is justified ; given a forge the raison d'etre of the practice disappears, a fact that some horseowners will not realise.

Although there are nowadays more farriers who know that a strong sole affords protection to the foot from bruises and injury, and that a well-developed frog prevents concussion and slipping, there still remain a good many of the old school, or of those brought up on its lines, who pare, cut away, and trim with the idea of making the foot look clean and smooth, of giving it the appearance of being a better shape, or even of providing for expansion.

It is very necessary for the welfare of the foot that such practices should not be tolerated by the horse-owner; it is equally essential that proper care and attention be given to the foot in the stable and elsewhere.

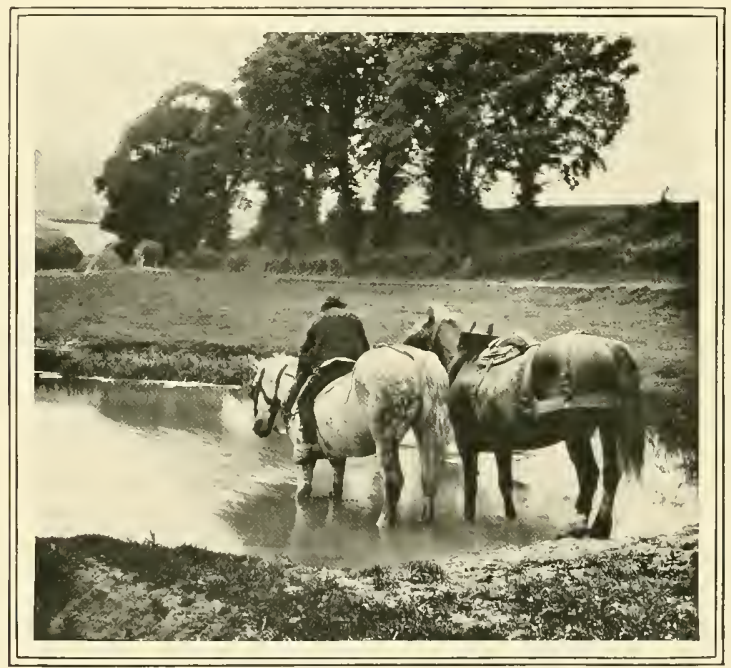




\section{APPENDIX III}

\section{HORSES FOR THE ARMY}

"I HE New Book of the Horse" goes finally to press at what may be distinctly called a critical period with regard to the future of the English horse. It is the case, and has been for some time past, that fewer light horses are being bred than formerly, and, truth to tell, there is no encouragement for small breeders to embark capital in the somewhat precarious experiment of producing stock which may or may not be of paying value when fit to be placed on the market. All this has been alluded to in the first chapter of this work, but events move quickly in these days, and there has been some considerable change in the position of affairs during the last twelve months. In the first place, it has gradually dawned upon a great number of different individuals residing in different parts of the country, and representing different interests, that the supply of army horses is in jeopardy. Much has been written on the subject, a great deal of which is of little value. But certain experts have informed the country that the supply is a decreasing one, and this is to some extent proved by what was written more than a year ago, on page $I_{3}$ of this book, to the effect that the number of foals bred annually shows a decrease.

It must be understood that the decline is not with the thoroughbred, nor with the highly bred cart-horse, whether he be of Shire, Clydesdale, or Suffolk breed. Nor, indeed, is it with the lighter not so wellbred cart-horse, which is reared on thousands of farms, chiefly with a view to being worked on those farms and not for show purposes. There are in this country an enormous number of cart-horses which would not qualify for the stud book of any special breed, but which are nevertheless good-looking horses, of great value to their owners. Of such are the horses of the average farm, and of such also cre the lighter and less valuable horses used for carting, both in town and country.

\section{Buying Hunters}

The question of hunter breeding has been treated of in Chapter XVIII. (p. 2I9) of this volume, and an estimate of the numbers required every year has been given. Here there is no change, but the price is still rising, especially for young horses, and there are many men of experience who are of opinion that it will continue to rise-unless more hunting men take to breeding horses for their own sport. Under any circumstances, good hunters are not very easily procured, and there are those who think that the present supply is not equal to the demand. "I do not know where to buy good hunters," said a master of hounds quite recently. But he added: "All the same, when I have any to sell no one seems to want them." The latter sentence is easy to understand, it being probable that the would-be buyer is often frightened that a cast-off from another stable may have something wrong with him. But even in buying hunters much depends upon the buyer. There are men who, knowing what they want, succeed in getting it at a reasonable price. There are others who hardly know what they want to begin with, and who always seem to think they are being asked too much. They hesitate so long when a horse is offered at a certain price that they end by missing him, and very often in despair they give 
more for a second-rate animal than they could have bonght a much better horse for.

Then, again, hunters of big reputationthose which have been known to distinguish themselves across country-often sell at fancy prices, more especially when they are sold by auction and two or three buyers are after the same horse. Hunters with no great reputation are, on the other hand, more cheaply bought, as also are those which the clever buyer can see at a glance have possibilities, but are not of the highest type. But what we have to explain is that the army horses-at all events, a great proportion of them-have been bought from the men who are trying to breed hunters and are, in point of fact, the misfits of hunter-breeding. At present, on its peace footing, the army is chiefly supplied from Ireland, and the supply required is - being very small indecd-forthcoming without any trouble. It was not so, however, during the Boer war, when, as all the world knows, we had to go to any and every market of the world and buy just what we could get. The fact is that hitherto the Government of this country has never concerned itself greatly with army horse supply, except when it has had to act on an emergency, as it had ten years ago. Other countries, more especially those of the European Continent, have for generations studied the horse question, and have given away large sums to breeders. They hare, in fact, not only bred thousands of horses for themselves on Government farms, but have offered sufficient bounties to breeders to make it worth their while to produce the exact article which is required.

\section{Variety of Type Required}

In this country we want for the army horses of varied type. The better sort of 'bus horses-those which are known as "light vammers"-are necessary for artillery; horses of about $\mathbf{1 5 . 2}$ hands, of fair hunter trpe, are required for the cavalry; and smaller horses, rather more of the cob cut, but very strong, for the mounted infantry. And it is a question whether an adequate supply of these horses would be forthcoming in the event of war breaking out. Indeed, recent experience shows that the supply would be very quickly exhausted, and that we should again be dependent on foreign nations, or possibly on our colonies, for what number we wanted.

\section{The Question of Price}

What is clearly evident is that the ordinary British land-holder, whether he be farmer, or the owner or occupier of a little grass land, will not deliberately set out to breed horses for the army, for it would not pay him to do so. He knows that the army buyer is restricted as to price, and that at present (it is possible this may be changed) he cannot sell the horse he has bred until it is four years old. Now, the average fouryear-old half-bred horse has probably cost as much, or within a few pounds of as much, as the army buyer will give, and therefore the small breeder tries first to sell his nag at a higher figure as a hunter or carriage horse. For four-year-olds of the cheap type there is some, but no great, demand as hunters. A horse expert may see virtue in a four-year-old for which 150 or less is asked; but, as a rule, the cheap humter is one whose exact capabilities are known, who has been humted, and who is within the means of the less wealthy hunting man or woman. It is not the status of the hunter misfit about which there is difficulty at present, but rather that, the market being cramped, because of motor traction having to a great extent superseded horse vehicles, the breeder has fewer opportunities of selling. When everyone used horses for road work there was a steady and ever-increasing demand for harness nags of every description and price. Now the very lest are still in fair demand. but for the rank and file there is very little market, except to draw tradesmen's light carts. The average tradesman does not give a very high price for what he buys, and, in fact, the remark which has just been made about breeders not setting out to breed an army horse applies also to tradesmen's nags. 
Whether in the days to come we shall have large Government stud farms, or whether we shall go to foreign countries for our army horses, are questions which cannot at present be answered; but lately a useful suggestion has been put forward, and is being acted upon successfully in at least two different parts of the country.

\section{A Matter of Complaint}

Before explaining this, it should be first stated that complaints have been made that the same horses have been used for duty with several distinct units of the Territorial force. It is understood that certain horses are hired for the annual training of one unit, and are passed on to another when the training of the first lot is done with, and so on, as long as a series of trainings are taking place. Whenever this plan is in vogue it is evident that the units which hire horses and pass them on have none of their own, and if required to be mobilised would have to procure horses from somewhere or other. The scheme which has for its object the securing of a permanent horse supply for the Territorial forces is to buy a certain ntmber and loan them out to tradesmen, farmers, and others, who will keep them (and work them), allowing them to be commandeered for the annual training and so many drills at other times.

This, in brief, is the idea which Colonel Mulliner has obtained leave from the War Office to put in execution in a part of Warwickshire, but into the details of which there is no need to enter. It is the idea of the Brood Mlare Society in another form, and if it can be worked all over the country it should go a long way towards solving a most difficult probiem.

\section{Other Sources of Supply}

As can be easily understood, other sources of supply, beyond the British Isles, have been discussed, and probably Canada would be the best place to buy horses from (if such a thing were necessary) if an adequate supply was forthcoming. Being one of our Colonies, Canada would be a more satisfactory place to buy from than the Continent. Such Canadian horses as have been sent to this country have met with general approval, and the freight is no very great matter. In Australia hundreds of thousands of horses are bred every year, and the Indian troops are for the most part supplied from that country; but the journey from Australia to England is a long and expensive one, and it seems extremely probable that army horses could be raised on stud farms in England and Ireland which at maturity would cost less than walers or other Australian nags. It seems to 11 , indeed, that Ireland is especially suited to breeding army horses of every kind. Throughout the country, and more particularly in the south and west, the land is probably the best in the world for horse breeding. The soil, or rather, all the best of it, is limestone, and this gives bone and strength, with sound feet. The climate is so mild that young horses can run out all the winter and be improved thereby, because they are all the time gaining hardness of constitution; and, lastly, the average Irishman would sooner breed a horse than anything else. A huge proportion of the best hunters come from Ireland, and many have been brought up on somewhat short commons; but the only effect of this is that they take rather a long time to come to their full strength and are seldom of much use for real work until they are rising six years old. If horses were bred in Ineland by the Government this lateness in maturing would disappear, as they would be better treated in their early days. It may, however, be added that many of the very best Irish hunters that have been sold to England owe a great deal of their excellence to the fact that they were not worked very early. Many are brought to this country which are of little value as far as work goes until something like a year has passed over their heads. They then come quickly to hand, and a very considerable number of them last far longer than the horse which has been put to hunting at four years oid, and, as a five-year-old, has done a full season.

In the meantime, it is understood that 
the Government has at last taken up the horse question, and it is announced that the premiums for King's Premium stallions will, at the March show of IgI , be increased from twenty-eight to fifty, with certain new regulations into which there is no space to enter, but which do not affect the main principle, which is to improve the breed of horses. It will be readily understood that a considerable increase in the number of
King's Premium sires is a distinct encouragement to the breeder, for nearly double the original number of horses, carefully chosen by expert authorities, will be available. No doubt further action will be taken shortly, for it is understood that at least $£ 50,000$ will be disposed of in furthering the interrests of light horses, and the twenty-two fresh premiums only mean an increased expenditure of $£ 3,300$, less sundry expenses.

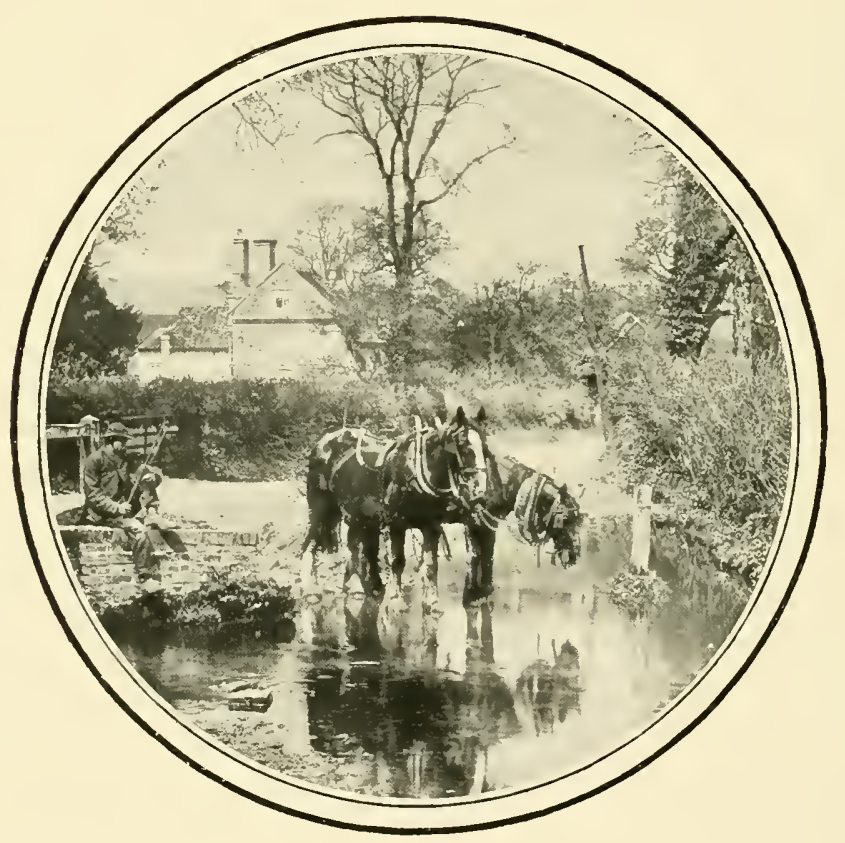




\section{EDITOR'S NO'TE}

I $T$ the Introduction to this volume we stated that consideration of the various horses of British breed would chiefly be given, and this idea has been carried out. The thoroughbred, who is used almost entirely for racing, is the most valuable, and in some ways the most important, of all hurses. His blood is the purest in the world, with the exception of that of some of the best Arabian strains, and from him all the best lines of race-horses, trotters, and light horses are descended, not only in this comntry, but in America, the British Colonies, and on many parts of the Continent. His numbers are comparatively small, not more than five or six thousand being bred in any year in the Britisl Isles; but his blood is in constant demand in every part of the world in which scientific horsebreeding is followed, and a huge majority of the countries which now have a breed of thoroughbreds of their own must constantly replenish their blood with a fresh infusion from British sources. On this account, then, and to some extent because of the great popularity of racing, a considerable anount of space has been giren to the thoroughbred. His history has been traced, and the greatest examples of his kind have been mentioned, with some account of their principal performances. In this the horses themselves, rather than their owners, trainers, and jockeys, have been made the subject of our theme, and we have further endeavoured to show which particular lines of bluod have survived, and are providing the great runners of the day. Some description of racing as it is at present conducted has also been given, and the various race-courses described, many of them with plans and photographs, in order that readers who are not acquainted with English racing may have an opportunity of acquiring knowledge as to where the sport flourishes most, and as to how the courses vary, and may know for themsclves on which courses the most important races are decided.

All this part of the book has been written by the Editor, as have also the chapters on hunting and hunters. So greatly does hunting flumish at the present day that it would have been an easy matter to have devoted more than double the space to it, but this was hardly possible, and we have had to content ourselves with a brief outline descriptive of the hunting which is followed on horseback, and with some description of the modern hunter.

The hackney has been treated of by Mr. Vero Shaw, an authority who has been familiar with the breed for more than thirty years, and who has hardly missed any notable show of hackneys during that period. Mr. Shaw has also written the chapter on hackney ponies, and of this breed he has seen the rise, from its beginning to the present day, when a team of hackney ponies can be sold for something like a thousand apiece. The hackney pony is, indeed, quite a modern creation, the most modern of every British breed, except the Stud Book polo pony; but he has made an extraordinary advance within the last few years, and all this has been described by Mr. Shaw. The chapter on Cleveland Bays is from the pen of Mr. IV. Scarth Dixon, who was born and brought up in Cleveland, who farned his own land, and bred Cleveland Bays, and who has been in touch with the breed all his life. Mr. Dixon was one of the earliest secretaries of the Cleveland Bay Association, and has done a great deal towards maintaining the integrity of the breed. He is also the author of the chapter on Yorkshire Coach-horses, a breed which 
was distinct enough until quite recently, but which is now being amalgamated with the breed of Cleveland Bays.

The various breeds of British ponies have also been described, and the chapters on polo and polo ponies are the work of the Editor, while those upon Shetland, Highland, New Forest, and Welsh ponies have been written by Mr. Mr. Scarth Dixon, and those upon Dartmoor and Exmoor ponies by Mr. Vero Shaw. These gentlemen have for years past made a study of the various breeds they have described, have visited many of the more important studs, have seen the ponies in their native wilds, and at all the principal shows to which they are sent.

The chapters on the Shire horse, the Clydesdale, the Suffolk horse, and the management of heavy breeds are the work of Mr. Charles Macdonald, the Farm Editor of thie Field and Times; and the chapters on coaching, driving and carriages, and riding and horse shows have been written by the Editor; while the chapter on horse-breeding and breeds of the Continent is the work of Mr. A. W. Coaten, who has made special study of the subject. In the section devoted to American horses, and which we should have liked to have made longer, Mr. Walter Winans has written the introduction and the Editor that part which deals briefly with American race-horses and trotters. The law chapters are from the pen of Mr. IV. B. Woodgate, an eminent barrister, who long ago became famous as an amateur oarsman. The veterinary parts of the book are the work of Mr. Harold Leeney, M.R.C.V.S., Veterinary Editor of the Field; and the appendix on horse-shoeing has been written by Captain Scratchley, of the Territorial forces, who has made a great study of the subject, having worked at it for years, both at the forge and in the study.

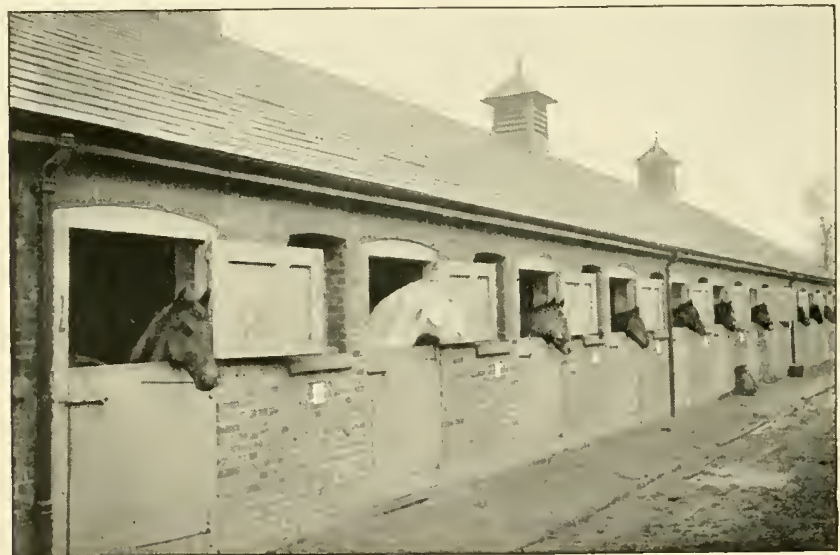




\section{INDEX}

A

Aberdeen Highland Show, $35^{\circ}$

Action, practice in, for shows, 369

Agricultual Hall, Hackney Show at, 26, 403

- Hunter Show at, 403, 408, 4 10

- - Polo Pony Show at, 25, 40S, 41 s

-_ Shire Show at, 354, 403

- horses, statistics of, 13

Show, National, 444

Agriculture and the horse, I7

Aintree, Becher's Brook at, 173

_- Steeplcchase course, $\mathbf{I} 7 \mathbf{2}$

-C Valentine's Brook at, 173

Alcibiade, 1,4

Amaurosis, 547

Ambush 11., 179

America, conditions of racing in, 456

- early races in, 453

- racing methods in, 456

- the Percheron breed in, 429

American demand for Cleveland Bays, $28 \mathbf{2}$

- horses, $44^{8}$ et seq.

- - in England, $45 \mathbf{I}$

polo, $45^{\circ}$

- ponies, $45^{\circ}$

- trotter, description of, 449

__ trotting horses in Holland, 443

Anæmia, 526

Anæsthesia, $5 S_{7}$

Anchylosis, 56r, 574

Andalusian horse, virtues of the, 438

Anglo-Saxons and racing, 96, 97

Anthrax, 534

Antidotes and poisons, 594, 595

Apoplexy, 519, 520

Aptha, 489

Alab, the, influence on English breeds, 33, 34

—— on New Forest pony, 315 use in ItaIy, 437

- in Spain, $43 \mathrm{~S}$

Ard Patrick, $S_{5}, S_{9}, \mathbf{1 6 2}, \mathbf{I} 63, \mathbf{I} 66$

Ardenne breed, the, $44^{6}$

Argentina, exportation of French horses to, 422

Army horses, 14,607

Ascites, abdominal, 505

Ascot, 116
Ascrit, best horses at, 116

- races at, $\mathbf{x} \$$

_ social side of, IIS

Ashbourne Shire Horse Show, 342

Asthma, ${ }_{4} \mathrm{~S}_{3}$

Atherstone Pack, $19 \mathrm{~S}$

Auction sales, the law with regard to, 463

Austria Hungary, appreciation of Irish horses in, 427

$\longrightarrow$ breeding in, 435

$\longrightarrow$ racing in, 420

Axe, l'rofessor, on apoplexy, 519

- on cerebro-spinal meningitis, $5^{22}$

- on diarrhoea, $49 \mathrm{~S}$

$\longrightarrow$ on glaucoma, 547

- - on high blowers, $43_{7}$

- - on seedy toe, $5^{69}$

- - on tetanus, 535

Ayr Show, 354

Azor, 94

\section{B}

Babolna stud, 435

Bachelor's Button, $79,8_{3}, \mathbf{1} 48$, r $\in_{2}$

Back, sprained, 562

Baden-13aden race meeting, $42 \mathbf{I}$

—- Steeplechase, $\mathbf{r} 75$

Badminton Pack, I9I

Badsworth Hint, 204

Bampton Fair, 325

Barcaldine, $47,72,77,79$, So, $\mathrm{S}_{1}, \mathrm{~S}_{2}, \mathrm{~S}_{3}, 88,94, \mathrm{r}_{3} 8$, $14^{8,}, 453$

Bard, the, 160

"Barker's I'roctors," 358

—, Sir J., polo pony stud, 306

Baron, the, 50, $94,28_{3}$

Barra pony, 3rz

Bath Horse Show, $4 \mathrm{I} 4$

Bartlett's (or Bleeding) Childers, $34,35,42,71,88$, 91, 93

Battlesden car, the, 394

Bayardo, 60, II6

Bedale Pack, 206

Beeswing, 85,138

BeIgian Draught Horse Society, 446

I3e] gium and breeding, 446 
Belgrade Turk, 93

Belvoir Pack, 190

l3endigo, 157, 167

Bend Or, 48, 51, 52, 54, 85, 87, 151, 154

Berkeley Il unt, 191

Berks Hunts, ios

Betting, 10n, 110

_ defaulters arising out of, 599

- legal curiosities, 600

- Tari-Mutuel, $42 \mathrm{I}$

Betty Leedes, 34, 35, 36, 42, SS

Pig-head, 477, 529

Birdcatcher, $48,66,68,70,75,82,90,92$

Birthrate, decline of, 13

Blacklock, $61,62,63,64,66,68,70,75,87,143,15^{2}$

Blackmore Vale 11 unt, 199

Bladder, eversion of the, 514

- inflammation of the, 511

- inversion of the, 514

- stone in the, 513,514

Blair Athol, 51, So, yo, 150, $15 \overline{1}$

Blink Bonny, So, go

Elistering, $5 \mathrm{~S}_{7}$

Blood sparin, law as regards, 472

Bloody urine, 510, $511,51+$

Blue Gown, ${ }_{5} 1$

Bog sparin, 501, 564

_- - the law as regards, $47 \mathrm{I}$

Bone, inflamed, 557

- spavin, the law as regards, $47 \mathrm{r}$

Bonny, 291

Borculo, stallion depót at, $7+5$

Borrowing, the law as regards, 470,471

Bowel, broken, 500, 501

- obstruction of the, 501

Brabant horse, points of the, 446

Brain, abscess in the, $51 \%, 524$

- inflammation of the, 515

- tumours, 520

Bran mash, how to make, 586

13reeding classes at International Horse Show, 412

— Cleveland lays with thoroughbreds, $2 S_{4}$

- Clydesdales in Scotland, 352

- difficulties of hunters, 222

- French national establishment, 424

- government supervision in France, 425

- hackneys, 24\%

- - in the seventeenth century, 235

- heavy horses, 362

- hints on hackney pontes, 264

- _ in Belgium, $44^{\circ}$

- influence of racing on, $\mathbf{2} 2 \mathbf{2}$

-.. in Hanover, 430

- in 1Jolland, 4.42

- in Hlungary, 435

- in laly, $43^{\text {t }}$

- in Spain, 430
Breeding in United States, $45^{\circ}$

- lrish method of, 223

- methods in Switzerland, 433

_ with Shetland ponies, zro

- national expenditure in France, 424

- on the Continent, 420 et seq.

— polo ponies, 26, 303

- progress in Charles I.'s reign, 30

_ race-horses, 19

— Royal Commission on, 17, 405

system in Germany, 420

- thoroughbred as sire, 223

lireeds, linglish, summary of, 2

lirent Fair, 321

"13righton Age," the, 375, 38o

— coach record, 302

- Race-course, 321

Bright's Roan, 46

British horses and Norman invasion, 2

—— and Roman invasion, I

- - origin of earliest, $\mathbf{I}$

Broadwood, 415

Brocklesby l'ack of Foxhounds, 190

Broken knees, the law as regards, 47

- wind, the law as regards, 471

Bronchitis, $4-\$-479,4 S_{2}$

- chronic, 479

Brooks, Lieutenant, 415,416

Broomfield Champion, 347

Brougnam, the, $3 \mathrm{SS}$

— the o spring, $3^{\mathrm{d}} \mathrm{g}$

- the circular-fronted, $3^{89}$

- the double, $3^{8}$ )

- the single, 38 g

Brownlow Turk, 46

Brushing, 5,5

Buck Rush, 275

liuggy, the, 391

Burton's Barb llare, S7

Buyers, effect of Continental, on prices, 420

Byerly Turk, 29, 31, 32, 36, 38, 39, 44, 46, 71, 73, 79, $S_{7}, 89,90,91,94,453,457$

C

Cab, the four-wheeler, $3^{89}$

- the hansom, $38 \mathrm{~s}$

Cade, 40, 79

Calculi, 491, 492, 501-2, 539

Caledonian Ilunt Cup, the, 141

Caller Ou, go, $13 \mathrm{~S}$

Camel, 56, 70

Canker, $57^{2}$

Canterbury Pilgrim, 87

Capped hock, 565 
Capped hock, the law as regards, $4 i x$

- knee, 565

(ardiff Ilorse snow, 414

Careless, 42

Caries, 557

Carriages, early travelling by, 4

- - in Queen Mary's reign, 7

- London, 388

- styles of, $3^{s_{7}}$

('ataract of the eye, 547

Catarrh, 473, 474, 478, 484, 533

('athedral cities, race-courses in, ro3

Catheter, use of, $5^{11}, 5^{12}, 5^{\mathrm{S}_{7}}$

Cattistock HIunt, Ig9

(avalry horses, normal height of, in France, 427

Cerebritis, 515

('hallacombe, 94, 95

Champions at Shire Show, list of, 336

(harles 1 , and racing, 30

- and stud book, 86

Chariton Hunt, isS

Cheques, the law as regards oad, 470

Chester Bell, the, gs

- cup, the, r 39,140

- Race-course, $\phi S$

Chestnut hackney, 248

('hilders mystery, the, 36

('hoking, 492

('horea, 517

i hurch stretton Society, 318

ficero, 4 S, 54, 162

('irrhosis, 504

Cleveland 13ay Horse Society, 282

- Bays, 2, 265

—- Adaptability of, $2 S_{4}$ - American demands for, $2 S_{2}$

- and the Romans, $26_{\overline{7}}$

- — as ccach horses, $3^{\$_{3}}$

— breeding with thoroughbreds, $28_{4}$

- colour of, $28_{3}$

- decline of, 28I

- - famous, 2,0 et seq.

—_ points of the breed, $2 \mathrm{~S}_{2}$

— revival of, $28 \mathrm{I}$

— thoroughbred influence on, 268

- treatment of mares, $28_{3}$

- Jad, 2/4, 275

Clinker, 79

Cloister, $58, \mathbf{1} 5 \mathbf{x}, \mathbf{1}-8, \mathbf{7} 79$

Clubs, early driving, 3,6

Clydesdale, the, 2

- breeding in Scotland, 352

—_ compared with Shire horse, 3,76

- early history of, 346

-- sires, 347
-- effect of Flemish horses on, 347
- exportation of, $35 \mathbf{r}$
Clychdale, the, llorse Society, 351

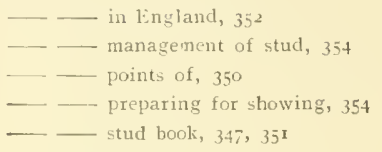

Coach and the railway, 373

- Brighton, record, 30)2

- improvement in building the, $3 \%^{2}$

- matching the tcan, $3 S_{3}$

- racing, $3 ; 6$

- speed of the, 374

— the country, 373

- the horse most used with the, $3^{S_{3}}$

-n the story of the, $3 \tau^{2}$

- touring, 397

- versus motor-car, 372

Cuaching Club, 2\$, 377

- in the Jorth, 377

—_ London, $3^{8} 3$

- modern, $37 \mathrm{~S}$

-.. number of horses necessary for, $3^{8} 4$

- provincial, ${ }_{3} \mathrm{~S}_{2}$

Cob, the Welsh, 319

Colic, 493, 495, 496, 497, 501, 506, $54 \mathrm{r}$

- flatulent, 497

Colonel, the 174

Colt hunting, $3^{\mathrm{I}} 4$

Colts, feet troubles of, 366

"Compleat Sportsman," 89

Conductor, 79

Coneyskins, $+2, \mathrm{Sg}, 9 \mathrm{I}$

Conjunctiva, diseases of the, 545

Con-tipation, $49 \mathrm{~S}, 502$

Continent, breeding on the, $+20 \mathrm{et}$ seq.

Contracted foot, the law as regards, $47 \mathrm{r}$

Cornea, growths from the, $5+6$

- inflammation of the, $54^{\circ}$

Corn Law, effect on hunting, $2 \mathrm{~s} 3$

Corns, $57^{\circ}, 572$

- the law as regards, 4,2

Coronation (up, 115

Coronet, chronic inflammation of the; 573

Coughs, +75

- the law as regards, $47^{\mathrm{I}}$

Cracked heels, $5 \% 9$

— - the law as regards, $47^{2}$

Cranborne Chase Ilunt, I 89

Crib-biting, 50\$, $5 \mathbf{1 9}$

— the law as regards, $47^{2}$

Crofters as breeders of Shetland ponies, 309

Cromwell and racing, $\mathbf{1 0 2}$

Crossing, dangers of, 200

- influence on Dartmoor Ponies, 320

Cub-hunting, 211

- as it was, 212

Curb, 562 
Curb, the law as regards, $4 \gamma^{2}$

"Curtal," 6

Cutting, 575

Cyllene, 162

Cystitis, 511

\section{D}

"Dale" pony, 8

Danish horses, 447

D'Arcy's White Turk, 44, 90

- Vellow Turk, 42, 44, 88, go

Darley Arabian, 29, $3^{\mathbf{r}}, 3^{2}, 34,35,3^{6}, 3^{8}, 42,46,4 \$, 63$, $7 \mathrm{r}, 73,87,94,234,236,255,270,319,457$

Darnley, 347,349

Dartmoor pony, 31 7 , 3 i9

—— and the moormen, $3^{21}$

— colour and character of, 322

— compared with the Exmoor pony, 323

- height of, 320

- influence of crossing on, 320

- merits of the, 320

- northern breed of the, 322

$\longrightarrow$ points of the, 322

Prison stud, 325

Derby, the, 155 , 156

— the first, 104

- winners in Germany, 433

Devon and Somerset Staghounds, 32:

Devonshire Junt, 199

Diabetes, 5 ro

Diamond, 145

- Jubilee, 60, 162, 179

Diaphragn, spasm of the, 506

Diarrhoea, 408

Diomed, S8, 453, 455, 457

District horse shows, $4 \mathrm{I} 4$

Disqualifications, early racing, 98

Docking, the question of, +49

Doctor Syntax, 146

Dodsworth, 42, 8-, 94

Dog-cart, the four-wheeled, 390

_ difficulties with the, 394

Doncaster, 4S, 51, $151,16-$

- and the St. Leger, I $3^{2}$

- as a rival of $\mathrm{Ascot}, 132$

_- Cup, 134

- fixtures, 134

— position of course, 134

_- Race-course, 99

Domovan, 1,58

Doricles, 93

Doses, table of, $59^{5-7}$

Dourine, 536

Drawing the covcrt, 215

Drivers, decrease of amateur, $3 \$ 6$
Driving, $3 \$ 6$

-.. at International Horse Show, 4II

- clubs, early, $3-6$

- in Hyde Park, 38 -

- tanden, 392

Dropsy, 505

$\longrightarrow$ the law as regards, 472

"Druid, The," on Blacklock, 62

- on Camel, 56

- - on Doctor Syntax, 146

—— on Eclipses and Herods, 62

—— on Gohanna, $7^{1}$

—— on Hambletonian, 62

—_ on Mlarske, $3^{6}$

- - on Sweetmeat, 75

_- on the Glasgow Mail, 375

- on the Jorkshire horse, 285

on Vedette, 66

on Walton's stock, 75

on Whalebone, 72

Dublin Horse Show, 10, $4 \mathbf{T}-$

- bargains at the, $4 \mathbf{1 7}$

Dysentery, 499

\section{E}

Ear] Fitzwilliam's IIunt, 203

Earnest money, the law as regards, 461

East Berks Horse Show, $4^{I} 4$

Eastern County Hunts, 202

- sires, importation of, $3 \mathrm{I}$

- - influence of, 34

- stailions, 7,20

Eclipse, 31, 37, 38, 39, 40, 41, 42, 46, 47, 4\$, 56, 6r, 62, $63,64,68,69,70,7 \mathrm{r}, 73,75,76,77,7 \mathrm{~S}, \mathrm{So}$, $S_{1}, 8_{3}, S_{5}, \delta_{9}, 91,106,144,145,147,154,455$

Ectropitim, 545

Eczema, 54 S, 549

Edinburgh Gold Cup, the, rar

- Show, 3.54

Edward III. and horses, 30

- V1. and horses, 6

Elbow, capped, 564, 565

Elizabeth, Queen, and horsebreeding, 6

—— and horses, 7

- - - and importation of foreign horses, 7

_— - and introduction of coaches, 7

—— at races at Croydon, 99

—_ racing stud of, 99

" Emperor of Horses," 457

"Emperor of Stallions," 51, I 49

Empress Maria Theresa and breeding in Austria, 434

Enclosures, club, Iro

Endocarditis, 524

English Cart Horse Society, $33^{\circ}$ 
English improrcment in jumping, 400

Enlarged hock, the law as regards, $47^{2}$

Enteritis, 499, 500

Entropium, 545

Epilepsy, 517

Epsom, Coronation Cup at, 115

-_ Race-course, 113

- - situation of, is 3

summer meeting at, i 15

— the Derby at, $I_{5}$

Erythema, 54s

Essex County Show, 36 I

Exmoor pony, $3^{1} 7,3^{22}$

- characteristics of the, 324

— Compared with the Dartmoor pony, $3^{23}$

_- experiments with the, 323

— points of the, 324

Exomphalus, 506

Exportation of horses stopped by Henry VIII., 4

- of Clydesdales, 351

Eye, cataract of the, 547

- of the, law as regards, $47 \mathrm{I}$

foreign bodies in the, $5+5$

Eyelids, torn or lacerated, $5+4$

F

Family packs, 190

Famous horses, 143 et seq.

Farcy, $53^{2}$

Farriers, the law with regard to, 465

- the Worshipful Company of, $6_{0} 3$

Favourite, 93

Feet, care of, and shoeing, 602

- diseases of, 56-

- troubles of colts, 366

Fences at Olympia, 403

Fetlock, orer-shot, 563

Fever, parturient, $5.42,543$

Fidius Duis, 274, 280

Filho-da-P'uta, 146

Firing, $5 \mathrm{Sg}$

Fistula, $5,-8,5,-9,580$

- the law as regards, $47^{2}$

Fistulous withers, 580

Fitzwilliam Hunt, $x_{96} 6$

Flemish horses, effect on Clydesdales, 347

Flooding, $5+0$

Flora, 93

Flying Childers, $34,35,39,46,73,88,144,147,234$, $23^{t}, 255,28 ;$

Dutchman, $64,72,88,1_{4} 7,1_{4} 8,1=1$

Fox, 10, $45,53,54,69,89,160,161,162,166$

Foal, feeding by hand, 365

- rearing of the, 365
Foal, treatment of the, $3^{6} 5$

Foaling, best time for, $3^{6}, 3$

logoras stud, 435

lood, cost of, 300

invalid, 585

- Scottish systems, 369

Foot, growth of the, 602

- pricks of the, $573,5, \mathrm{~S}$

Foreign hunts, 210

- jumping methods, 402

Forest horse, 260

Four-in-II and Club, 28, $3-6$

Foxes, haunts of, 210

- how secured, 2 II

- mange and, 207

Foxhall, 154

Foxhounds, family, 190

number of packs, 182
- subscription packs, increase of, 195

the Atherstone, ins

- the Badminton, rgo

— the Bedale, 206

— the Belroir, Igo

— the Brocklesby, Igo

- the 1ritzwilliam, 1,06

— the oldest pack of, 186,189

- the Penistone, IS 7

-. the Pytchley, I92

the Williams-Wynn, 19I

Fox hunting, 186

Fractures, 559

France, Government supervision of breeding in, 425

- national breeding establishments in, 424

- - expenditure on brecding in, 424

- racing in, 420

— the military breeding system in, 424

Fret, 4 , 40,497

Frisian horses, 444

G

Galopin, 61, 64, 66, 67, 68, $70,77,78,85,88, \mathbf{4} 47$,

$$
\mathrm{I} 5 \mathrm{I}, \mathrm{I} ₹ 2
$$

Galtee More, $85,88,160$

"Gambaldyn" horse, 6

Gaming $\mathrm{Act}$, the, 599

-_ money lent for, law as regards, 600

Gamos, 75

Garron pony, 3r3

Gastritis, 405

Crate money meeting, introduction of the, 107

- - increase of the, ros

Fatherley $\mathbf{l l o o r}$, racing at, $100, \mathrm{IO}_{3}$

Gatwick Race-course, 10S, I 23

Gelderland horse, 444 
Cieneral Stud Book, 30

Germany, appreciation of Irish horses, $\$ 27$

- breeding system in, 429

- Derby winners in, 433

- influence of throughbred in, 430

- light horses in, 430

- racing in, 420

Giddiness, 516,517

Gilbey, Sir Walter, on Cleveland Bays, 267

_ on the "Crambaldyn" horse, 6

on the Shire horse, 328,329

- on the sixteenth century stab?e, 6

-- on True Briton, 319

_- "Ponies Past and Present," 3, 30

(iimcrack, $>$ I, 135

Club, 136

Stakes, 136

Gladiator, 75, I 50

Glanders, 532, 536, 579

Glandular enlargement, the law as regards, $47^{2}$

flasgow Agricultural Society, 352, 354

-.. Stallion Show, 352

Glaucer, $347,34 \mathrm{~S}$

Glaucoma, 547

Godolphin Arab, 29, 31, 32, 40, 46, 71, 72, 73, 79, 255, $270,45^{2}, 453$

Gohanna, $71,7^{2}$

Goodwood, it 8

- - races at, 120

- situation of, 119

Governess car, the, 304

Gower Lnion Pony Association, 3IS

Graditz Stud, the, 433

Grand Mlilitary Steeplechase, ISo

- National Steeplechase, I3 $S$

- - age of winners of, $1 ; 9$

- French horse wins the, 422

- - recent, 179

- - the first, 172

(irease, $57^{-6}$

- the law as regards, $47^{2}$

Great Subscription Stakes, 106

Green foods, use of, $5^{8} 5$

Grey Grantham, 46

Gripes, 496, 497

Gruel, how to make, ${ }_{5} 86$

II ackney, as harness horse, 243, 249

- as riding horse, $237,24 \mathrm{~S}$

-... as sire, $250,25^{8}$

- as trotter, 230

- breeding, 247

-.. celebrated stallions, 257

Hackney, change of type of, 246

- chestnut. $2.4 \mathrm{~S}$

- defence of the, 23 y

- derivation of the, 234

- early history of the, 234

- Horse Society, 26, $246,+12$

- importance of the, 26

- in Scotland, 242

- influence of railways on the, 243

- its place at shows, 26

_ of the past, 255

- points of the, 254

- pony, 28,258

- colour of, 263

_- hints to breeders of, 264

- seventeenth century breeding of the, 235

Society, 28

- Stud Book, the, 26

- teaching trotting, 250

- the, 2

- the cult of the, 242

- the modern, 26

— the tall, 246

- thoroughbred influence on the, $\mathbf{I}, 246$

- triumph of the, 28

Hæmaturia, 5 Io

Hæmoglobinuria, 529, 530

Hæmorrhage, 475,540, $5^{82}$

- uterine, $54^{\circ}$

Ilague Horse Show, International, 444

11 ambletonian, $6 \mathbf{r}, 62,64, \mathbf{1} 43, \mathbf{1} 45,457,45 \mathrm{~S}$

Ifamptun, I 49

Hanover, breeding in, 430

Hansom cab, the, 389

Hants IIunts, 201

Hardegg, Count Heinrich zir, 4;

Harkaway, 69. 87, 159, 160

Harness classes, judges in, $4^{\text {I }} \mathrm{S}$

- horses, hackneys as, 243, 249

—- hunters as, 222

_ ponies, prices for, 263

Harold, 333

Harriers, $1 S_{2}$

Haunts of the fox, 2 to

Hautboy, 44, 8-, 90, 91, 94, 286, 288

Heart, atrophy of the, 524

- dilated, $5^{24}$

- enlarged, 524

fatty, 524

rupture of the, 525

Ileary horses, management of, 362

Ileels, cracked, $5 \% 9$

Height of cavalry horses in France, 427

- of race-horses, 7 o

II Imsley Turk, 30, 3r, 87, S9, 94

Henry 1I. and the Shire horse, 326

- II.'s reign, races at Smithfield in, 97 
Henry Vil, and horses, 3

- VIII. and horses, 3

- _ and stoppage of exportation of horses, 4

- as a race patron, 99

Hepatitis, 504

Jjermit, $58,149,151,167$

Hernia, 506

- inguinal, 50;

_- into the scrotum, 507

— umbilical, 506

- rentral, 50;

Herod (King IIerod), 38, 39, 40, 43, .47, 46, 47, 62, 64, $72,73,75,70,77,78, S_{1}, S_{5}, y 0,44,144,145$. 14,753

Herpes, 540

Highflyer, 6r, 62, $72,73,74,145,286$

Highlaud and Agricultural Society, 352

- pony, 308, 3I I

Hints for riders, 21-

Hired horses, law as regards stealing, $4 \nearrow \mathrm{I}$

lJiring, the law as regards, $4 ; 0,471$

"History of Richmond," Ico

— of the British Turf," 101

- of the TurI," c, 6

Hobbles, use of, $5_{5 S}$

"Hobby," the, :

Hob-hill Horse, 2,-r, 2,-5

Hock, capped, 565

"IJolding-up" cubs, $21 \mathrm{I}$

Holland, American trotting horses in, 443

breeding in, $4 t^{2}$

_ government breeding nethods in, $+\neq 2$

- laws regarding horses in the sercntenth century in, +45

Home Counties Hunts, 201

Horn tumour, $5^{\circ 9}$

Horse-pox, 534

Horse-riding, decline of, 399

Horse show, Aberdeen Highland, $35^{\circ}$

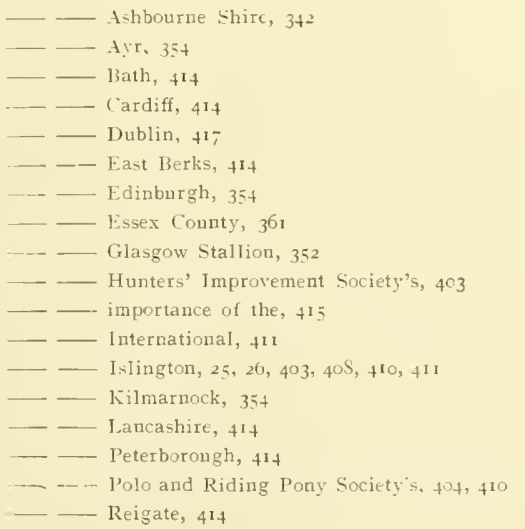

II orse Show, Richmond, $41 \mathrm{t},+13$

- Royal, 4It

- - Shire, 341

_- Shires at Islington, 354

_- South WaIcs, 403

—- Suffolk County, $3^{61}$

— Wharfedale Igricuitural Society's, $2 j^{8}$

—_ Woodbridge, 301

"Horses I'ast and P'resent," 30

IIours of meets, 212

II unt, liadsworth, 204

- Berkeley, ini, igs

- Berlis, 108

- Blackmore Vale, 199

Cattistock, I tyo

Charlton, isS

- Cranborne 1 hase, $\mathbf{I} \mathbf{9}$

- Devonshire, 199

__ Earl litzwilliam's, 203

- II ants, 201

- Lincolnshire, 202

- Midland, r94

— Norpeth, 207

__ Northumberland, 208

- Notts, 203

- Oxfurdshire, ig $\$$

- Quorn, iso

- Royal, 18;

_- smartening up of the, 196

_._ Stainton Dale, is

_- Tynedale, 20-

Iork and Ainsty, 204

II unters, amount of work done by, 23

- as harness horses, 222

_ as pleasure horses, 182

_- at coach work, 222

— at Islington, 410

best from Ireland, $1 \$_{2}$

brecding difficulties, 222

- English-bred, ${ }_{\text {I }} S_{3}$

— for polo, 302

- how to tach jumping, 226

_ Improvement Socity, $1 \$_{3}$

- Jrish method of breeding, 223

- number of, 21, 1,82

- points of, 231

- prizes for, $1 \$_{3}$

_- produce class for, tos

- question of height of, 23 I

- red ribbon, 227

_- schooling for, 224

- short-legged, 220

- speed necessary for, 20

_- thoroughbreds as, 220

- value of, 2 I

—working life of, 227 
II unting, change of horses while, I

- - colts in the New Forest, 3r4

- cubs, $2 \mathrm{II}$

- effect of Corn Law on, 213

-_ feminine majority, 22

- for Londoners, 20 I

— fox, I80

-_. incrcase of, 20

- increased popularity of, 195

- influence of Peterborough Show on, I95

Hlunts, Eastern County, 202

- foreign, 2 Io

- Home Counties, 201

- Irish, 208

- I'rovincial, 194

—_ Scottish, 208

1 Iurlingham and polo, 295

_- Polo Pony Show, 4 II

Hurst Park Race-course, 108, 128

Hutton's Royal Colt, 30

Hyde Park, driving in, $3^{8} 7$

IIypertrophy, $5^{24}$

"Hysteria," 529, 530

\section{I}

lchthyosis, $55^{\circ}$

lcterus, 503

Importation of foreign horses in Queen Elizabeth's reign, 7

- - of Normandy horses, 30

- of Virginian horses, 452

India, introduction of polo to, 294

Indigestion, acute, 493

- chronic, 494

Inflamed gums, the law as regards, 472

Influenza, 474, 531, 532

Innkeepers and horses, the Iaw with regard to, 464

- rights of, $\$ 65$

International Hague Ilorse Show, +44

- Horse Show, 399, 4ri

_- breeding classes at, 412

_- driving classes at, $4 \mathrm{II}$

- - jumping competition at, 400

__ - Suffolk horses at the, $3^{6} \mathrm{I}$

Intestine, rupture of the, 500, 501

lrish horses, Austria's appreciation of, 427

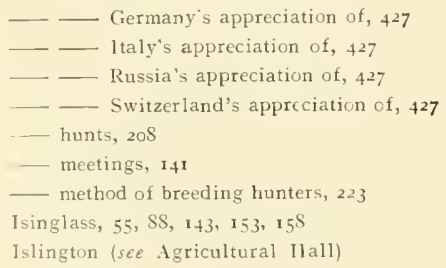

Isonomy, 55, 152

Italy, appreciation of Irish horses in, 427

- breeding in, +36

- government breeding depôts in, 436

- remount establishments in, 437

— use of the Arab in, 437

\section{J}

Jaundice, 503

Jaunting car, the, 395

James 1. and importation of foreign horses, 7

- and Markham Arabian, 30

- and racing, 30

- and steeplechasing, 169

Jockey Club and gate money, I07

—— and froo ruie, $107,108,109$

- - foundation of, $\mathrm{IO}_{2}$

— headquarters at Newmarket, 126

- racing rules, I6

Joint, open, 5so

Joints, diseases of the, 559

- inflammation of the, 560

- injury to, $5 \mathrm{~S}_{3}$

Judges in harness classes, 418

- the question of, $41 \mathrm{~S}$

- why young, are chosen, $4 \mathrm{I} \&$

Jumpers, Mr. Walter Winans's, 402

Jumping at International Horse Show, 399

— at Olympia, 402

- foreign methods, 402

— how to teach hunters, 226

_ improvement in English, 400

- necessity for school training, 402

\section{K}

Kempton Park Race-course, 109, 123

Kendal, r55

Kentucky saddle horse, 450

- _ - effect of the Morgan horse on, 459

Keratoma, 569

Keystone $11 ., 70,163,164$

Kidneys, inflammation of, $510,511,521$

Kilmarnock Show, 354

King Fergus, 6I, $1+5$

King's platers, 16

L'lates, Eclipse and, $3^{8}$

—_ Conductor and, 79

- premium sires, the, 405

- influence of, on half breds, 406

_- soundness of, 406

"Kingsclere," 55 
Kisber, 152

- Stud, +35

Knee, broken, $5-8$

— capped, $5 \mathrm{~b}_{5}$

L

Lachrymal glands, diseases of the, 545

Ladas, $\delta_{7}$

Ladies, increase of, at race meetings, no

La Flèche, $10,53,62,65,70,88,158,168$

Lamb, the, 174,175

Laminitis, $541,56 \%, 570$

the law as regards, $+7^{2}$

Lampas, the law as regards, $4-2$

Lancashire Horse Show, the, $4^{14}$

Lanercost, so

Laryngitis, $475,477,478,4 S_{2}, 4 \delta_{7}$

Layton Barb mare, $\$ S$

Leedes Arabian, 4.4, 46

Legs, filled, 566,$5 ; 9$

Leicestershire AgriculturaI Society, 342

Lemberg, 162

Lencorrhue, $54 \mathbf{r}$

Lewes Race-course, 121

Lexington, 455

Lice, 552

Lichen, 549

Lillie Rridge Polo Ground, 295

Limousin breed, the, $42 \mathrm{~S}$

Lincolnshire Hunts, 202

— Lad II., 333

Lingfield Race-conrse, Ios, 124

Lippizaner stallions, 435

Lips, dise sases of the, $4^{\mathrm{SS}}$

Lister Turk, 42, 44, 7 1, 93

L.iver, chronic inflammation of the, 504

- congestion of the, 503

- fatty, 504

- inflammation of the, $50_{4}$

- rupture of the, 505

Livery-stable keepers, the law with regard to, 465

Lockinge Forest King, 333, 334, 335

Lock-jaw, 535, 536, 573, 5,8

Lond: $\mathrm{n}$ carriages, $3 \mathrm{~S} 8$

- Cart Horse Parade, $36 \mathrm{r}$

- coaching, $3^{8} 3$

I.ondoners, hunting for, $2 \mathrm{cr}$

Lord Lyon, 5i, $\mathrm{t} 5 \mathrm{t}$

Lottery, $17 \mathbf{7}, \mathbf{1 7} 7.3$

Lou Dillon, the world's champion trotter, $449,45^{8}$

Lowe, Mr. Bruce, 84, 86, 87. S\$, 93, 94

Lungs, congestion of the, $473,480,499$

- emphysema of the, $4^{s_{3}}$

inflammation of the, $4 \mathrm{~S}_{2}$
Luxembourg, stallion depôt at, 445

Lymphangitis, 528

— epizootic, 537

\section{M}

Mail phaeton, the, ${ }_{3} \mathrm{~S} 9$

Makeless, $46,79,8-, 94,2 S S$

Maladie du coit, 536

Mallein test for glanders, 533

Mallenders, $55^{\circ}$

Mammitis, $5 . t^{2}$

Manchester meetings, $\mathbf{I}+\mathbf{r}$

- Telegraph, 375

Mange and foxes, 207

- psoroptic, 553

-_ sarcoptic, 553

Manifesto, $\mathbf{I}-8, \mathbf{I} 79$

Narco, $83,148,453$

Nares, first stud book, 86

Market overt, $46_{4}$

Markham Arabian, 30, $3 \mathrm{r}$

__ Gerrase, on English horses, 7

Narske, 31, 36, 37, 38, 39, 42, 63, S9, 455

Martagon, tS $^{\mathrm{S}}$

Mary, Queen, and suppression of horse stealing, 6

Nassey's Barb mare, SS

Match, driving, between Lords Lonsdale and Shrewsbury, 391

Matchem, 40, 45, 46, 47, $7 \mathrm{r}, 77,79,83,85,88,106,144$. $14^{6}, 286$

Matching the coach team, $3 \delta_{3}$

Mechanical traffic as a rival, I0, I7

Meets, hours of, 212

Negrims, 516, 517, 519

Melbourne, So

Meliora, 44

Melton, I 55

Memoir, 88

Mendicant, 56

Meningitis, acnte spinal, $5^{2} \mathbf{I}$

_- cerebro-spinal, 522

Merlin, 94

Merry Hampton, 93

Metritis, $54 \mathbf{r}$

Mezohegyes Stud, 435

Middleton, Lord, as breeder, 20

Midland Hunts, 194

- other, Io6 meetings, $13 \mathrm{I}$

Military breeding system in France, 424

Nimi, $s_{3}$

Ninoru, I $16,162,16$ -

Minting, 52, $143,156,157,160$

Misrepresentation and its effects, 460

11 iss D'Arcy's 1'et, 42, 44, 90 
Modern coaching, 378

"Monday Morning Leg," 528, 529, 533, 566

Noonah Barb mare, 9.3

Noore, Judge, and the Coaching Marathon, 449

- and his Marathon horses, $45 \mathrm{~S}$

— at International Horse Show, $45^{\circ}$

Moormen and Dartmoor pories, 321

Morgan breed, 459

trotter, the, 450

Morganette, $8_{5}$

Norpeth Hunt, 207

Motor-car versus coach, $37^{2}$

Notors versus horses, Io

Muscles, strained, 561

Myelitis, acute, 521

Myocarditis, 524

Nasal gleet, 474, 533

National Agricultural Show, 444

- Hunt Steeplechase, I $8 \mathbf{r}$ value of, isi

Navicular disease, the law as regards, 472

Navicularthritis, 574

Necrosis, $557,55^{8}$

Neil Crow, 83, 148, 453

Nephritis, 5 II

Nettle rash, 548

Newbury Race-course, 124

New Forest pony, 308, 314

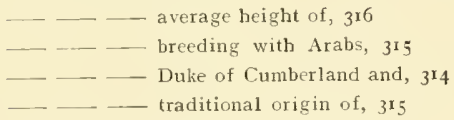

Newmarket as headquarters of the turf, 125

_- - of the Jockey Club, 126

- autumn season at, 130

_- early morning at, 131

_- Eclipse versus Bucephalus at, $3^{8}$

_ Flying Childers versus Almanzor at, 35

- meeting, II I

- number of meetings at, 126

- race-course at, 30, 100

- the rise of, roo

Newminster, $5 \mathrm{~S}, 68,70,77,8_{2}, 85, \mathbf{1 4} S, 149$

New York Trotting Club, 457

Norman invasion and horses, 2

breed, the, $42 \mathrm{~S}$

Normans and horse culture, 2

Normandy horses, importation of, 30

Northern meetings, $13 \mathbf{1}$

Northumberland, liarl of, sixteenth century stable of, 6

- Itunts, 208

-_late, 138
Norwegian horses, 447

Nose, bleeding of the, 475

Nottinghamshire Agricultural Society, $34^{2}$

Notts Hunts, 203

\section{o}

Oals, the first, 104

Oglethorpe Arabian, 46

Old Clubfoot mare, 42

- Ottonburgh mare, 279

— Partner," $38,39,46$

_._ Woodcock, 91, 92

Olympia Show, 10, $37 \mathrm{r}$

- rences at, 403 - jumping at, 402

One Thousand Guineas, institution of the, 106 Ophthalmia, constitutional, 546

- periodic, $54^{6}$

- recurring, 546

Orby, 53, 54, 165

Orchitis, 539

Ord, Mr. Richard, on value of hunters, 21

"Origin and Influence of the Thoroughbred Horse," 44

Orloff trotter, the Russian, 439

Orme, $48,53,54,81,90,156, \times 5^{8}$

mystery, the, r $5 \mathrm{~S}$

Ormonde, $48,5^{2}, 53,7^{2}$, So, $91,95,138,142,148,151$, $154,155,156,157,158,159,160,161$

Orvieto, 48

Osteo-porosis, 558

Ostler, the decline of the, 397

"Otley Bottom Proctors," $35^{8}$

Our Lassie, 93

Ovary, diseases of the, 543

Over-reach, 5,6

- the law as regards, $47^{2}$

Oxfordshire Hunts, igs

Pack horse, the, S

Packington Blind Horse, 332

l'aralysis, $5^{21}$

l'ari-mutuel betting, introduction of, 42 ?

l'ark phacton, the, $3{ }_{9}$

- Royal, the ill-fated, 4I 3

Farliament stops excessive racing, I02

Parotid duct, fistula of the, 4 (i)

- glands, inflammation of the, 490,491

Parotitis, 490, 491

Parrot mouth, $50 \mathrm{~S}$ 
Pattisan, 75

Parturition, symptoms of, 364

Patella, dislocation of the, 563

Pedestrians, the law as regards, 466

Pedigree, advantage to farmers of, $33^{2}$

- of Eclipse, 42, 48

- of Herod, +3

- of Mlatchem, 45

Penis, para!ysis of the, 539

Penistone flarrier l'ack, 187

Percheron breed, the, $42 \mathrm{~S}$

- in America, 429

Perdita 11., $\mathrm{S}_{5}$

Pericarditis, $\$ 23$

Periostitis, 55;

Persimmon, 60, 62, 67, 6S, $7^{0}, 8 \mathbf{1}, 82,86,89, \mathbf{I} 44$, 159,160

Peterborough Agricultural Socicty, 342

Horse Show, $+\mathrm{r}_{4}$ - influence of, on hunting, 195

Phaeton, Stanhope, compared with four-wheeled dogcart, $39^{\circ}$

- the mail, 380,390

- the park, $3 \mathrm{~S}$ )

- the "Spider," 390

- the Stanhope, 380,390

Phantom, i5

l'henomenon, 240, 254, 256, 259

l'hiladelphia Hunting Park Association, 457

Phymosis, $53^{\mathrm{S}}$

Piber Stud, the, 434

Pinzgauer breed, the, 435

"Pitman's Derby," r 38

I'lace's White Turk, 31, 8-, 94

"Platers," decline of, 16

$$
\text { King's, } 16
$$

Plenipotentiary, 147,151

Plethora, 526

Pleurisy, $473,4 \$_{4}, 4 S_{5}, 495,497$

P'Icuritis, $4 \$_{4}, 485$

Pneumonia, contagious, $4 ; 3,532$

l'oisons and antidotes, 594, 595

Poll evil, 58o

Polo, age of players, 297

- ancient, 293

- and Hurlingham, 295

- and Riding Pony Society, 25, 301

- associations, 298

- County Cup, $29^{8}$

- early clubs, 295

- - expense of, 296

- first match, 294

- growth of, 206

- hunters for, 302

- increased popularity of, 25

_._ in England, 294
Polo, introduction of, to lndia, 294

- ponies, American, $45^{\circ}$

- pony, the, 2

- breeding, 2ti, 303

…_ demand for the, 25

- increase of the, 25

- rules for measuring the, 209

- size of the, 296

$$
\text { Suciety, 309, } 325
$$

principal tournaments, 298

Polyuria, 510

Ponies, hackney, 28

- Past and Present," 3

- tribes of, 2

- wild, $\mathrm{S}$

Pcny, Barra, 312

- Celtic, 312

- character, 258,263

- Dartmoor, 319

- English, 2

- Exmoor, 308

- Highland, 31 r

- mares, 262

- New Forest, 314

- Norwegian, 312

- Scotch, 2

- Shetland, 308, 309

_- sires, 259

- Skye, 313

Cist, 312

- Welsh, 317

Pot-8.05, 47, 62, 85

Premium stallions, 16

President, 287

1'retty Polly, $8_{3}, 91,162,163,168$

Prices paid for horses, 9, 10, 21, 160, 166, 262, 263, 276, $316,321,325,329,344$

- effect of Continental buyers on, 420

Probang, use of, 492

Procopius on non-existence of horses in Britain, x

Provincial coaching, $3^{8} 3$

- Hunts, 194

Prurigo, 549

Prussian Government establishments, 432

—. Trakehnen, 430

Psoriasis, $55^{\circ}$

['tyalism, 490

Pumiced feet, the law as regards, 472

Purpura hemorrhagica, 477, 529, 534

Pytchley Pack, 192

"Quidding," $4^{89}$

- the law as regards, $47^{2}$ 
Quittor, 572, 573, 578, 5So

- the law as regards, $47^{2}$

Quiorn II unt, ISg

\section{R}

Rabies, 535

Race-course, Ascot, 116

- Brighton, 121

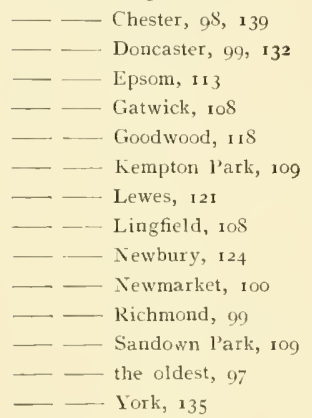

Race-courses in cathedral cities, Ic 3

- other early, 99

Race-horses, early, 30

— English and American compared, 455

— first big, 72

height of, 70

- speed in, 20

- the earliest, 97

Race meetings, betting at, ron-10

-_ - increase of, rot

- - of ladies at, 110

- modern, 107

Races, early, in America, 453

___ famous : Eclipse versus Bucephalus, $3^{8}$

-_ _- Filho-da-P'uta verszes Sir Joshua, 146

— Flying Childers versts Almanzor and Brown Betty, 35

_.... Hambletonian versus Diamond, 145

-_ Voltageur versus Flying Dutchman, 64, 147

— seventeenth century, at Salisbury, 7

— statistics of, ro4

- value of, rí

Racing and Anglo-Saxons, 96, 97

- and Oliver Cromsell, 102

- - and Parliament, roz

- calendar, ir5

- centralisation of, 106

- coach, 376

- condition of, in America, 456

- early disqualifications in, 08 - horse, 3. 30

- mfluence of railways on, 106
Racing, infuence on breeding, 122

-... in Austria Hungary, 420

- in France, 420

- in Germany, 720

- in Ireland, 141

- in Scotland, $\mathrm{I}+\mathrm{I}$

_ in the eighteenth century, 103

__ in the seventeenth century, ror

- methods, changes in, 104

- - in America, $45^{6}$

- popularity of, 20

- stud of Queen Elizabeth, 99

Radautz Stud, the, 434

Radium, $5^{2}$

Railways, influence on hackneys, 243

-_ on racing, 106

_- liability of, 465

_- negligence of, 466

_- special race trains on, $1 \mathbf{1}$

— the cuach and the, $3 \pi j$

Ralli cars, 356,394

Ranelagh Polo Pony Show, 411

Rat tails, 549

Record winnings, 4I 5

Rectum, eversion of, 502

- inversion of, 502

Red ribbon horse, 227

Reigate Ilorse Show, 4I4

Remount department of Dutch Army, 443

— establishments in Italy, 437

Representation versus Warranty, 469

Rêve d'Or, $8 S$

RheumatisnI, 527, 560

Richmond Horse Show, 4I I, 4I 3

- Race-course, 99

Ridgeway, Professor, on early British horses, 2

_ _ "Origin and Influence of the Thoroughbred

$$
\text { IIorse," 44, } 452
$$

Riding, decline of horse, 399

- horse, hackney as, 237,248

— need for, schools, 399

— to hounds, the law with regard to, 467

Ringbone, 556, 561, 573

- the law as regards, $47^{2}$

Ringworm, 552

Roaring, $486,4^{S_{7}}$

- the law as regards, 47 I

Robert the Devil, 154

Rock Sand, 56, 88, 162

Roehampton Polo Pony Show, 411

Roman invasion and borses, $\mathbf{I}$

Romans and the Cleveland Bay, 267

- and the Shire horse, 328

Roodeye Race Course, Chester, 97

Rosador, 245, 257

Roxana, $4^{6}$

Royal Agricultural Society's Show, $34^{2}$ 
Royal Commission on horse breeding and premiun stallions, $\overline{1}_{7}, 405$

- Horse show, the, 414

Hunt, the, 187

- Lancashire Agricultural Society, 342

- mares, $42, \% \mathrm{O}, 85,80, \mathrm{sy}$

— turf patrons, 30, 90

Kule of the road, the, $4^{60}$

Rupture, 500

Russia, appreciation of Irish horses in, 427

- breeding in, 439

Russian horse breeding, 439

_- Orloff trotters, 439

- state studs, $44^{\circ}$

troika horses, 440

\section{s}

Saddle horse, the Kentucky, 450

"Saddle and hirloin," 3-3

Sale, condition of, as accepted by law, $46_{3}$

Sales, reserve at, $4^{6} 3$

- the law as to, $q^{6} \mathbf{1}$

Salisbury, seventeenth century race at, 7

Salivation, 490

Sallenders, 550

Sampson, 71

Sand crack, 567

- the law as regards, $47^{2}$

Sandown Park Race Course, rog, 122

St. Albans Steeplechase, $\mathbf{I} ; \mathbf{I}$

- Blaise, 93

-_ Frusquin, $64,67,68,70,93,159,160$

- Gatien, 154, 155

- Ciris, 160

Leger, r 19

- the first, 104

Serf, to

Simon, 52, 61, 62, 63, 64, 65, 6- 6S, 77, 7 S, So, $S_{1}$, $S_{2}, 85,90,143,147,148,149,15^{2}, 154,157$, ${ }_{15} \mathrm{~S}, 159,162$

Vitus's dance, 517

Sceptre, 10, -0, 91, 95, 162, 163, 166, 168

Schools, necessity for training, toz

- the need for, 399

Scotland, breeding the Clydesdale in, $35^{2}$

- racing in, 141

- the hackney in, $24^{2}$

Scottish Hunts, 208

Seedy toe, 5oo

Sefton, 94

Septicæmia, 526

Sheath, œdenia of the, 539

Shelly feet, $5^{6}$;

Shetland pony, 308
Shet land pony, crofters as breeders of, 309

- methods of breeding, 310

- - the modern, 310

Shield's Galloway, 4

Shire horse and the Romans, ${ }_{2} \mathrm{~S}$

- Breeding Society, 343

- celebrated stallions, 333

- colour of the, $34^{\circ}$

- compared with ( lydesdale, 346

- early history of the, 326

- - home of the, 337

- in Henry 11.'s reigu, 326

- - in the sututh, 337

- - measurements of the, $34^{\circ}$

- - points $c_{2}^{\prime}$ the, $33^{8}$

- popularity of the, 330

-_ Show, lslington, 354

- -... shows, 341

- - Society, 329

- - Stud Book, 330, 3.32

- - the, 2, 326

- types of the, 340

- veterinary inspection of the, 330

Shivering, 473, 519

Shoeing, rules for, 602

— points to be observed in, 604

Shoes, types of, 605

Show (see Horse Show)

Side bone, 573

Side-line, use of the, 587

Signorina, ;o

Signorinetta, 32, 40, $83,94,95,148,166$

Silvio, $5 \mathrm{x}$

Sires, early Clydesdale, 347

Sir Hercules, 48, 50, 56, 7o, 87

Sir Joshua, 146

Sir Peter Teazle, 74, 145, 2 S6

Skye pony, 313

Smithfield, races in Henry 11.'s reign at, 97

Sociable, the, 3yo

Sorcerer, $72,70,80$

Sore throat, $4-6,4 \% 0$

South African horse sicliness, 537

- Wales Horse Shows, 403

Spain, Arab influence in, 438

$\longrightarrow$ breeding in, 439

Spanish horse, description of the, 439

Spanker, 34, 42, 44, 88, 89, 94

Spavin, $55 \mathrm{~S}$

bog, 56r, 564

Spearmint, 60, 163, 166

Speed in 1ace-horses, 20

- of the coach, 374

Speedicut, 573

- the law as regards, $47^{2}$

Spiletta, $3^{1}, 40$

Splint, 557 
Splint, the law as regards, $4 \tau^{2}$

" Sports and Pastimes of the English People," 96

Sportsman, 275

Sprains, $56 \mathrm{t}$

Squamous inflammaticns, $5+9$

Squirt, $36,7^{*}$

Stainton Dale Hunt, 187

Stable of the sixteenth century, 6

Staggers, mad, 493, 515, 522

— sleepy, 493

— stomach, 493,515, 521

Staghounds, packs of, I 82

Stakeholder's responsibility, $59 \mathrm{~S}$

Stakes, lawful racing, 598

Stallion, Shire, shows, 243

- depôt at Borculo, 445

— at Luxembourg, 445

Stallions, celebrated, 257

- - Shire, 333

famous, 237

Lippizaner, 435

- premium, 16

Stanhope phaeton, the, $3^{89}$

Statistics, racing, 104

Stealing hired horses, law as regards, $47 \mathbf{r}$

horse, capital offence, 3

Steeplechase course at Aintree, $\pi 72$

- - at St. Albans, I71

- Grand Military, ISo

- National Hunt, 181

- the first course, 171

the myth of the first, i 70

Steeplechasing, 169 et seq.

and James I., 169

early, I $\%$ I

Stephen, King, and the trotting horse, 234

Steppe horse, 266

Stewards' decisions, the law as regards, 5, 9

Stifle joint, dislocation of the, $5^{6} 3$

Stockwell, 75, 77, 85, 88, 91 $94,148,149,151$

Stomach, ruptured, 496

Stomatitis, ${ }_{4} 89$

- pustulosa contagiosa, 536

Stones and concretions, 497, 501, 502

Strains, 56t

Strangles, 474, 490, 533, 534

Straying horses, the law as to, 467

Stringha]t, 519, 575

- - the law as regards, $47^{2}$

Stud, Babolna, 435

- book, Clydesdale, 35 I

- general, $3^{\circ}$

- hunter, 2, 10, 408

- mares, first, 86

- Shire horse, 330

Fogoras, 435

Kisber, 435
Stud, Mezohegyes, 435

- - prices, 37 et seq.

- Russian State, $44^{\circ}$

- the Graditz, +33

- the Piber, 434

- $\rightarrow$ the Radautz, 434

- the Trakehnen, 433

Studs, list of German, $43^{2}$

Subscription packs, increase of, 195

Suffolk County Show, 361

- Punch, the, 2, 355 et seq.

- action of, 360

- Arthur Young's opinion of, $35^{5}$

- - characteristics of the, 360

- colour of the, $35^{8}$

- height of, 360

- Horse Society, 360

- - pluck of the, 360

$\longrightarrow$ points of the, 359

- prices paid for the, 356

- shades of chestrut of the, 359

Sunday deals, the law with regard to, 463

Super-purgation, $49 \bar{\gamma}, 499$

Suppurative inflammation, 549

Suspensory ligaments, the law as regards, 472

Sweatmeat, 75,93

Switzerland, appreciation of Irish horses in, 427

breeding methods in, 433

\section{$\mathrm{T}$}

Tandem driving, 392

Taunton's "Portraits of Celebrated Race-horses," 56

Teddington, $149, \mathbf{1} 49$

Teeth, number of, 590

- state of, in a one to two year old, 590

— of, in a three to four year old, $59 \mathrm{I}$

—— of, in a horse five years old or upwards, $59 \mathrm{I}$

Testicles, inflammation of the, 539

Tetanus, 535, 536, 573, 578

"The British Thoroughbred Horse," 7

Thickened sinew, the law as regards, $4 ; 2$

Thormanby, 76,150

Thoroughbred, eastern origin of the, 29

-_ influence of the, 430

- origin and influence of the, $x$

$\longrightarrow$ Stud 13ook, 30

Thoroughbreds and speed, 20

- as hunters, 220

- - as sires, 223

— breeding Cleveland Bays with, $28_{4}$

- - - of, 19

__ foreign stock of, 44

- influence on Cleveland Bay, 268

_- on hackneys, 246 
Thoroughbreds, influence on Lorkshire coach horse, 286 - record prices for, 9

Thoroughpin, $5^{6} 4$

Throat, abscess in the, 490

- inflammation of the, 490

Thrombosis, 525

- the law as regards, $47^{2}$

Thrush, 569

- - the law as regards, $47^{2}$

Tongue, inflammation of the, 489,490

Touchstone, $5^{6}$

Touring coach, 397

hints, 395

Tracheotomy tube, use of, $47 \mathrm{~S}, 4 \mathrm{~S} 7$

Trakehnen Stud, 433

the Prussian, $43^{\circ}$

Tramway versus horse, 12

Tristan, $\mathrm{S}_{2}$

Troika horses, Russian, 440

Trotter, description of the, 449

- the hackney as, 239

- the American, 445

- the Uorgan type of, $45^{\circ}$

Trotting matches, early, 240

-- - valid, $50 \mathrm{~S}$

--. reaching hackneys, 250

Troutbeck, 163 , I6.

True Blue, $8 S$

. Trumpator, 79, 9r

"Turf Annals," 103, 104

Twitch, the use of the, $5^{8} 7$

Two Thousand Guineas, institution of the, 106

Tynedale Hunt, 207

\section{U}

U ist pony, $3 \mathbf{r} \mathbf{2}$

Licers, 579

Linderhand, $13^{8}$

United States, breeding in, $45^{\circ}$

Unsound highway, the law with regard to, 467

Urine, bloody, 510, $5^{11}$

- incontinence of, $5^{1} 3$

- retention of, $5 \mathrm{r}_{3}$

Urticaria, $5+\mathrm{S}$

Uterus, inversion of the, 543

\section{V}

Vagina, inflammation of the, 54 I

Vaginit:s, $54^{1}$

Value of races, i 6

Vanderbilt, Mr., and his Brighton coach, $380,3 S_{4}$ - and his Marathon horses, $45^{8}$
Vanderbilt, Mr., and the Coaching Marathon, 449

- at International Horse Show, $45^{\circ}$

Vedette, 65,66

Velocity, 105, 166

Verderers, court of, 314

Vertigo, $516,51 \%, 519$

Verucce, $55^{\circ}$

Veterinary inspection of Shire horses, 330

Vicious horses, the law as regards, 467

- treatment of, 67

Victoria, the, $38 \mathrm{~s}$

Vienna, Mr. Winans's trotters in, $45^{\circ}$

Villitis, 573

Virago, 167

Virginia and horse racing, 452

Voltageur, $63,6_{4}, 65,72,75,87,147,148,151,15^{2}$

Voltaire, 63,64

Voluptuary, $177, \mathbf{1 7}$ S, 179

Vomiting, 493

\section{IV}

Walton, 75

Warning, a grave, 421

Warranty, advisability of written, 469

- and unsoundness, $47 \mathrm{I}$

- agents, 469

- breach of, $46 \mathrm{~S}$

- duration of, $q$ fig

- implied, 468

_ law as regards, $4 \boldsymbol{f}_{7}$

- limits of time for notice of breach of, 468

representation versus, $4^{69}$

Warts, $55^{\circ}$

Water, use of, as a restcrative, $5 \delta_{4}$

Waxy, 69, $7^{2}, 74,9^{2}, 1+4,1+6$

Weaning, age of, $36_{5}$

Weaving, 520

Wecd, $5^{28}$

Welsh cob, 319

- pony, $3^{\mathrm{I}} 7$

—_ compared with New Forest pony, 318

- neglect of breed of, 318

West Australian, So, Sx, S7, 144 $, 149,453$

Whalebone, $50,5^{6}, 72,85,92,145$

Wharfedale Agricultural Society's Show, 238

Whisker, 146

Whistling, $486,4 \mathrm{~S}_{7}$

the law as regards, $47 \mathrm{r}$

Whitelock, 62, $S_{-}, \mathbf{1} 43,144$

White Knight, the, $16_{3}, 16_{4}, 16_{5}, 166$

"Whites," $54 \mathrm{I}$

William 1I1., 162

Winans, Mlr. Walter, on American polo ponics, $45^{\circ}$ —_ - and the Mlorgan breed, 459

Wind, broken, $4 S_{3}, 4_{4}, 4 S_{7}$ 
Wind sucking, 5rg

-. - the law as regards, $47^{2}$

Windgalls, 564, 566

Winnings, record, 415

Withers, fistulous, $5^{\text {So }}$

Wolves' teeth, 508

Womb, inflammation of the, $54 \mathrm{I}$

Wonderful Lad, 2-7

Woodbridge Show, $36 \mathbf{r}$

Woodham Moor, racing at 1 co

Woodpecker, 73

Wounds, contused, $57^{-S}$

_... incised, $5 \pi 7$

- lacerated, 577

- method of remoring dirt from, ${ }_{5} \mathrm{~S}_{3}$

_ poisored, $5 ; 8$

- punctured, 578

- staked, 578
Yellows, 5 c3

Young True Blue, 88

York and Ainsty Hunt, 204

— Race-course, 134

Gimcrack Stakes at, 136

Yorkshire coach horse, the, 2

- - as coach horse, $3^{8} 3$

Society, $2 \delta 8$

suitability for crossing, 290

thoroughbred influence on, 286

- Horse show, the, 414

Z

Zeeland horse, the, 444

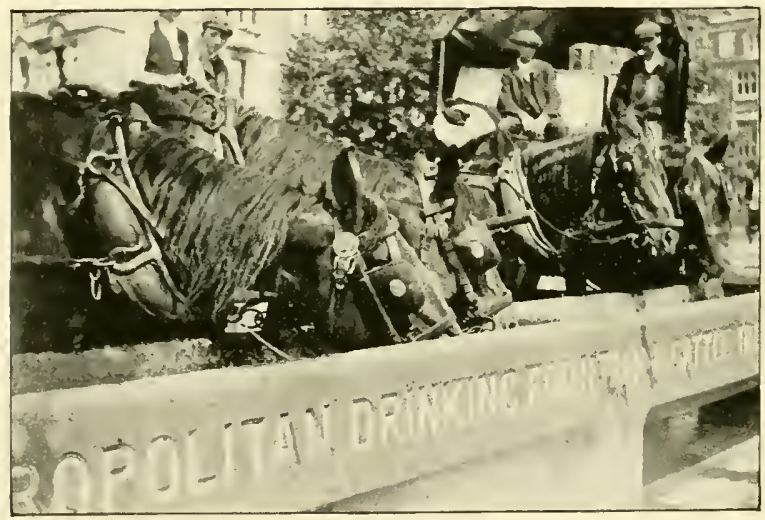

Printed by Cassell \& Company, Limited, La Belle Satvage, london, E.C. 





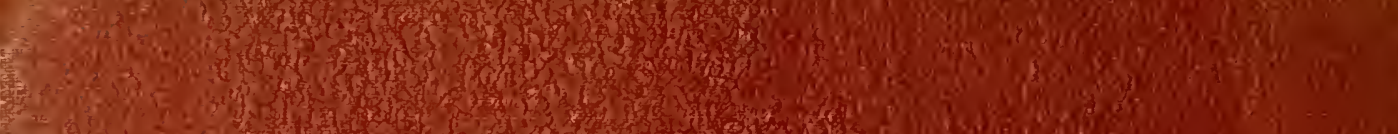
(2)

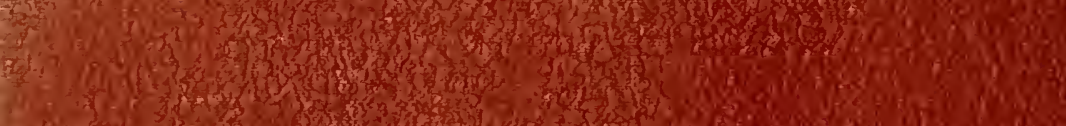

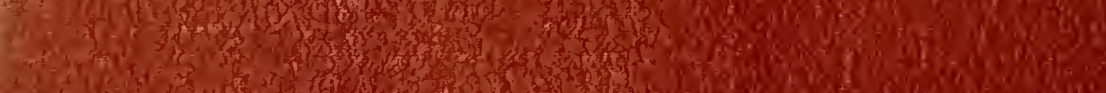
1
7 730 m.t.

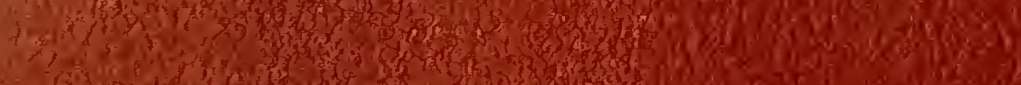
$\therefore$ 1) 20

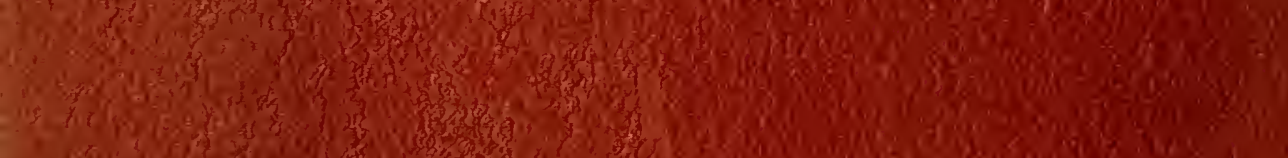
7.

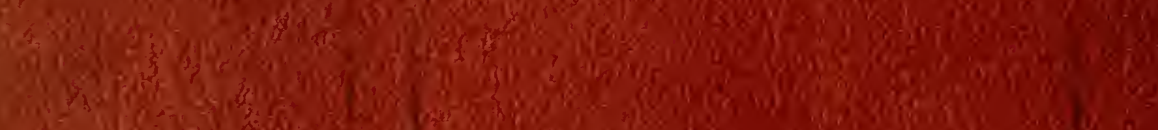

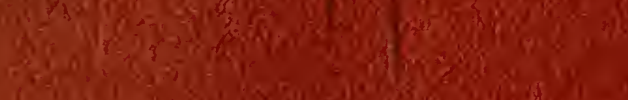

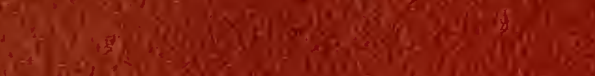

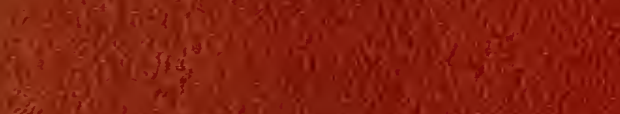

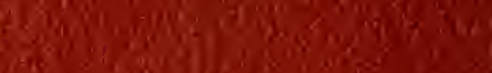

$\therefore$ (a)

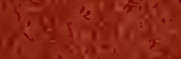

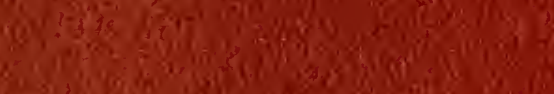

Sin a s.

War in

2 in.

Li. 30 ing

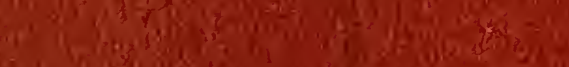

B.

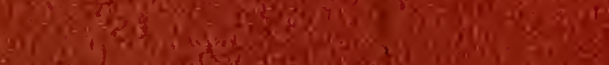

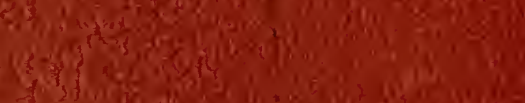

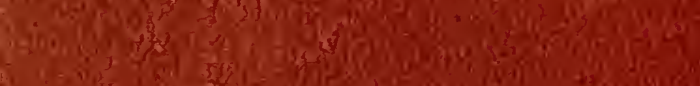

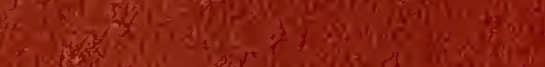

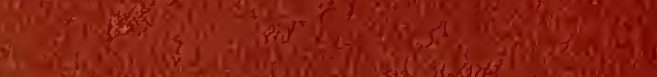

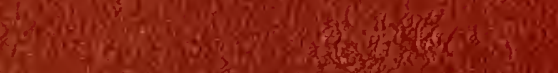

10. 